\title{
Studies of the Early Mesozoic Basins of the Eastern United States
}

\author{
uwce Library
}

DEC 061988

\section{6}

Depository Shipment

U.S. GEOLOGICAL SURVEY BULLETIN 1776 



\section{Studies of the Early Mesozoic Basins of the Eastern United States}

\section{ALBERT J. FROELICH and GILPIN R. ROBINSON, Jr., editors}

A summary of current research on early Mesozoic sedimentary and igneous rocks and related mineral resources and studies of geophysics, structure, and tectonics of the basins of the Eastern United States

\section{U.S. GEOLOGICAL SURVEY BULLETIN 1776}




\section{DEPARTMENT OF THE INTERIOR DONALD PAUL HODEL, Secretary \\ U.S. GEOLOGICAL SURVEY \\ Dallas L. Peck, Director}

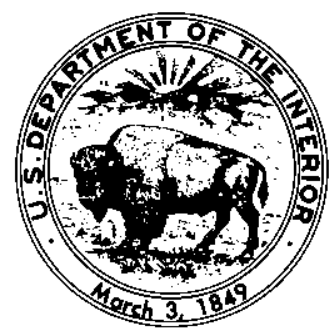

For sale by the Books and Open-File Reports Section, U.S. Geological Survey, Federal Center, Box 25425, Denver, CO 80225

\section{Library of Congress Cataloging in Publication Data}

Studies of the early Mesozoic Basins of the Eastern United States.

(U.S. Geological Survey bulletin : 1776)

Bibliography: p.

Supt. of Docs. No.: I 19.3:1776

1. Geology, Stratigraphic-Mesozoic-Congresses. 2. Geology-

Northeastern States-Congresses. 3. Geology-Middle Atlantic States-

Congresses. 4. Mines and mineral resources-Northeastern States-

Congresses. 5. Mines and mineral resources-Middle Atlantic States-

Congresses. I. Froelich, A.J. (Albert Joseph), 1929- II. Robinson,

Gilpin R. III. Series.

$\begin{array}{llll}\text { QE75.B9 no. } 1776 \quad 557.3 \mathrm{~s} & \text { [551.7'6'0974] 87-600494 }\end{array}$

[QE675]

The use of brand names is for descriptive purposes only and does not imply endorsement by the U.S. Geological Survey. 


\section{EDITORS' PREFACE}

For the past several years, the U.S. Geological Survey (USGS), in collaboration with several State Geological Surveys and scientists from academic institutions, private industry, and other government agencies, has been conducting extensive geologic investigations of the early Mesozoic basins in the Eastern United States. One goal of this research program is to develop a comprehensive understanding of the geologic character of these basins that can be used to evaluate their mineral and energy resource potential. Elsewhere, significant mineral and energy resources are associated with intracontinental basins developed in extensional and rift tectonic settings, and the potential for similar deposits in the early Mesozoic basins of the Eastern United States has not been adequately evaluated. An understanding of regional stratigraphy, environments of sediment deposition, sediment chemistry, igneous chemistry and petrogenesis, geophysical setting, structural geology, and tectonic history is considered essential for the evaluation of the mineral and energy resources of the region. Support for this research program has been provided jointly by the Strategic and Critical Minerals Program and the Geologic Framework and Synthesis Program at the USGS, with additional cooperatives with several Eastern States through the USGS COGEOMAP Program.

Investigations by the USGS began in 1982 with a workshop focused on assessing the status of current knowledge of early Mesozoic geology in the Eastern United States and on developing a regional overview preparatory to undertaking an integrated research program to investigate the basins. A second workshop, held in 1984, was a progress report of ongoing research efforts. One goal of this 1984 workshop was to improve communication between members of the various projects and outside scientists funded by the USGS program. The results of this workshop were published as a collection of research papers in USGS Circular 946. A third workshop, held in 1987, marked the culmination of the major phase of this interdisciplinary USGS research and was intended to present the results to the public in a timely manner. Although the main phase of this interdisciplinary research program is largely completed, many topical studies related to the early Mesozoic basins will continue. This volume presents the results of 36 of the 44 research projects that were described at this workshop and includes 2 fieldtrip guides to some aspects of the geology of the Culpeper basin of Virginia.

The editors are grateful to the authors, technical editors, and many other individuals who contributed to the completion of the scientific investigations reported here, the planning and organization of the workshops and fieldtrips, and to the preparation of this report. The papers benefited greatly from careful editorial review by John Watson of the USGS. The USGS is grateful to numerous individuals and private companies for access to their lands and materials in the course of these scientific studies. 



\section{CONTENTS}

Editors' preface III

Introduction $\mathbf{I X}$

SECTION 1: STUDIES RELATED TO EARLY MESOZOIC SEDIMENTARY ROCKS 1

Uniform symbols for the Newark Supergroup 1

By Joseph P. Smoot, Albert J. Froelich, and Gwendolyn W. Luttrell

Continuity of strata in the Newark and Hartford basins 6 By Paul E. Olsen

A cored stratigraphic section through the northern Newark basin, New Jersey 19 By Michael S. Fedosh and Joseph P. Smoot

Paleoenvironmental reconstruction of a fluvial-deltaic-lacustrine sequence, Lower Jurassic Portland Formation, Suffield, Connecticut 24 By Nicholas G. McDonald and Peter M. LeTourneau

Stratigraphic framework and distribution of early Mesozoic rocks of the northern Newark basin, New Jersey and New York 31 By R.A. Parker, H.F. Houghton, and R.C. McDowell

Preliminary analysis of unusual palynomorphs from the Taylorsville and Deep Run basins in the eastern Piedmont of Virginia $\mathbf{4 0}$ By Eleanora I. Robbins and Robert E. Weems

Thermal histories of the Hartford and Newark basins inferred from maturation indices of organic matter $\mathbf{5 8}$ By Lisa M. Pratt, C.A. Shaw, and Robert C. Burruss

Source of kerogen in black shales from the Hartford and Newark basins, Eastern United States 63

By E.C. Spiker, R.K. Kotra, P.G. Hatcher, R.M. Gottfried, M.F. Horan, and Paul E. Olsen

Chemical composition and thermal maturity of kerogen and phytoclasts of the Newark Supergroup in the Hartford basin 68

By R.K. Kotra, R.M. Gottfried, E.C. Spiker, L.A. Romankiw, and P.G. Hatcher

Evidence for petroleum generation and migration in the Hartford and Newark basins 74

By Lisa M. Pratt and Robert C. Burruss

Inorganic geochemistry of fine-grained sedimentary rocks and hornfels in the Newark Supergroup 79

By Walter E. Dean

Mineral-bound ammonium in black shales of the Triassic Cumnock Formation, Deep River basin, North Carolina 86

By M.D. Krohn, John Evans, and Gilpin R. Robinson, Jr.

Comparative mineralogy of clay-rich strata in selected early Mesozoic basins of the Eastern United States 99

By R.M. Gottfried and R.K. Kotra 
SECTION 2: STUDIES RELATED TO JURASSIC IGNEOUS ROCKS 105

Petrographic and major-element characteristics of Mesozoic basalts, Culpeper basin, Virginia 105

By Richard P. Tollo

Reinterpretation of the relationship of the western extension of the Palisades sill to the lava flows at Ladentown, New York, based on new core data 113 By Nicholas M. Ratcliffe

Effects of postcumulus fractionation in the Palisades sheet: Further evidence from Weehawken, New Jersey 135

By David N. Shirley

Significance of major- and trace-element variation trends in Mesozoic diabase, west-central New Jersey and eastern Pennsylvania 141

By Jonathan M. Husch

An overview of early Mesozoic intrusive rocks in the Culpeper basin, Virginia and Maryland 151

By Albert J. Froelich and David Gottfried

Element mobility during alteration of early Mesozoic diabase sheets, Culpeper basin, Virginia 165

By Paul C. Ragland and Jonathan D. Arthur

Structural analysis of the Furlong fault and the relation of mineralization to faulting and diabase intrusion, Newark basin, Pennsylvania 176

By Nicholas M. Ratcliffe and William C. Burton

Innovative approaches to the dating of igneous events in the early Mesozoic basins of the Eastern United States 194

By John F. Sutter

Magnetic and gravity fields of early Mesozoic diabase sheets in the northern Durham basin, North Carolina 200 By David L. Daniels

SECTION 3: STUDIES RELATED TO GEOPHYSICS, STRUCTURE, AND TECTONICS 21

Deep structure of rift basins from the continental margin around New England 211 By D.R. Hutchinson and K.D. Klitgord

Using balanced cross sections to understand early Mesozoic extensional faulting By Jean M. Crespi

A simple technique for analysis and migration of seismic reflection profiles from the Mesozoic basins of eastern North America 229

By John D. Unger

A geophysical study of the northern Hartford basin and vicinity, Massachusetts 235 By Jeffrey D. Phillips

Buried structures at the northern end of the early Mesozoic South Georgia basin, South Carolina, as interpreted from aeromagnetic data 248

By Jeffrey D. Phillips 
Aeromagnetic imagery with geologic correlations for some early Mesozoic basins of the Eastern United States 253

By Kevin R. Bond and Jeffrey D. Phillips

SECTION 4: STUDIES RELATED TO MINERAL RESOURCES 265

Inventory of metal mines and occurrences associated with the early Mesozoic basins of the Eastern United States-Summary tables 265

By Gilpin R. Robinson, Jr., and C.M. Sears

Base and precious metals associated with diabase in the Newark, Gettysburg, and Culpeper basins of the Eastern United States-A review 303

By Gilpin R. Robinson, Jr.

Locations and analyses of selected early Mesozoic copper occurrences in Pennsylvania $\mathbf{3 2 0}$

By R.C. Smith II, S.W. Berkheiser, Jr., and D.T. Hoff

Variations of palladium and platinum contents and ratios in selected early Mesozoic tholeiitic rock associations in the Eastern United States $\mathbf{3 3 2}$

By David Gottfried and Albert J. Froelich

The origin of copper occurrences in the Hartford basin 341 By Norman H. Gray

A comparison of uranium-bearing sequences in the Newark basin, Pennsylvania and New Jersey, and the San Juan basin, New Mexico 350

By Christine Turner-Peterson

Sedimentology of stratabound base-metal occurrences in the Newark Supergroup 356

By Joseph P. Smoot and Gilpin R. Robinson, Jr.

Characteristics of base-metal and barite vein deposits associated with rift basins, with examples from some early Mesozoic basins of eastern North America 377 By Gilpin R. Robinson, Jr., and Laurel G. Woodruff

SECTION 5: FIELDTRIP GUIDES TO THE CULPEPER BASIN, VIRGINLA 391

Field guide to the igneous rocks of the southern Culpeper basin, Virginia 391 By Richard P. Tollo, David Gottfried, and Albert J. Froelich

Base- and precious-metal occurrences in the Culpeper basin, northern Virginia 403 By Joseph P. Smoot and Gilpin R. Robinson, Jr. 



\section{INTRODUCTION}

The papers collected in this volume are extended versions selected from material given as oral and poster presentations at a workshop called "Geology of the Early Mesozoic Basins of Eastern North America," held at the National Center of the U.S. Geological Survey, May 11-14, 1987. The papers are grouped into one section containing fieldtrip guides and four sections covering themes focusing on concepts of interbasin and intrabasin sedimentation; stratigraphic, paleontologic, chemical, and thermal evolution; chemistry, character, age, and evolution of igneous rocks; the characteristics and distribution of mineral resources; and on the regional interrelationships of basin fill, geophysical character, and structural patterns throughout the Newark rift system. The section titles are (1) studies related to early Mesozoic sedimentary rocks, (2) studies related to Jurassic igneous rocks, (3) studies related to geophysics, structure, and tectonics, (4) studies related to mineral resources, and (5) fieldtrip guides to the Culpeper basin, Virginia.

\section{Section 1: Studies Related to Early Mesozoic Sedimentary Rocks}

Smoot and others present the rationale they have developed to relate similar sedimentary rocks of the Newark Supergroup throughout the exposed early Mesozoic basins. A systematic symbolic code is used to identify rocks according to lithologic character and sedimentological features. The great variety of stratigraphic nomenclature currently in use in the discrete basins of eastern North America tends to obscure important regional stratigraphic relations. Using common symbols facilitates interbasin and intrabasin comparisons of lithologic sequences and shows comparable features of formations in all of the basins.

The other papers that address sedimentology and stratigraphy concentrate on detailed studies in the Newark and Hartford basins. Olsen describes the lateral continuity of Van Houten cycles in the Newark and Hartford basins and emphasizes the necessity of correlating laterally continuous strata in deciphering regional stratigraphy, geochronology, paleoclimatology, and paleoecology. The principles he outlines are applicable to the entire Newark Supergroup. Precise stratigraphic correlations between core holes are one of the best means of studying the lateral continuity as well as the vertical variation of Newark Supergroup cycles. Fedosh and Smoot describe the lithologic variation in a series of core holes that provides a nearly continuous section of the fluvial and lacustrine Jurassic sequence in the Newark basin, New Jersey. McDonald and LeTourneau present a paleoenvironmental reconstruction based on a classic exposure of a fluvial-deltaic-lacustrine sequence in the Jurassic Portland Formation of the Hartford basin in Connecticut. They interpret this sequence as the shoaling western shoreline of an Early Jurassic lake, providing the counterpart to previously recognized shoreline deposits of lacustrine units in the Portland Formation along the abrupt eastern margin of the Hartford basin. Parker and others describe the results of new mapping of Triassic strata in the northern Newark basin of New York and New Jersey that provide the lithological basis for subdividing the Passaic Formation into four mappable units. They present a depositional model whereby a drainage system parallel to the basin axis produced a 
prograding coarse-grained sediment wedge over finer grained strata of the Passaic Formation. They also demonstrate that dark-gray shales and siltstones of the Lockatong Formation tongue out northward into arkosic sandstones of the Stockton Formation. Robbins and Weems describe unusual palynomorphs from the Deep Run and Taylorsville basins of Virginia that may be Permian in age. These pollen and spores are dark brown, in contrast to typical light-colored, middle Carnian assemblages from the Taylorsville and Richmond basins.

These presentations demonstrate that meticulous sedimentologic, palynologic, and paleontologic observations supported by careful detailed mapping are necessary to decipher the complex relationships between laterally correlative strata of diverse origin and lithology in the Newark Supergroup.

The organic geochemistry papers focus largely on the results of comparative studies of black, organic-matter-rich lacustrine shales in the Hartford and Newark basins. Pratt and others infer the thermal history from regional organic-matter maturation indices that show Triassic shales to be overmature with respect to petroleum generation but pass abruptly upward into mature and immature Jurassic shales. They ascribe these markedly contrasting levels of maturation over relatively small stratigraphic intervals to a pulse of high heat flow related to Early Jurassic intrusion and volcanism. Spiker and others demonstrate that the source of kerogen in these shales was a mixture of autochthonous lacustrine algae and allochthonous woody organic matter. Pratt and Burruss show that the basinwide continuity, thickness, and high organic-carbon content of shales indicate a petroleum source potential of commercial interest. Furthermore, the composition of hydrocarbons in bitumen from shales, solid bitumen from veins, and viscous bitumen from concretions is remarkably similar, implying a precursor-product relationship. In a study of the chemical composition and thermal maturity of kerogen in Lower Jurassic shales compared to phytoclasts, Kotra and others show that the organic matter was appropriate for generation of liquid hydrocarbons and that the kerogen was derived mostly from an algal source. Thermal maturity generally decreases from north to south across the Hartford basin, confirming the observation of Pratt and others that thermal anomalies are present in the northern part of the basin where igneous plugs are common and in the central basin where northeast-trending faults are abundant.

The use of fluid inclusion studies of vein minerals in black shales and a great variety of independent organic geochemical techniques (elemental ratios, Rock Eval pyrolysis, NMR, gas chromatography, organic carbon determination, stable isotope ratios) to evaluate the characteristics of black, organic-matter-rich Mesozoic shales and phytoclasts provides powerful support for the favorable conclusions about mixed source-rock characteristics and thermal maturity. They not only document a record of petroleum generation and migration but also reflect aqueous fluid migration, including types potentially capable of complexing and transporting metals.

A number of papers compare the mineralogy and inorganic geochemistry of dark-gray to black organic-matter-rich shales and siltstones of lacustrine origin in the Newark Supergroup. The mineralogy and element distribution in such rocks is controlled by both regional effects, such as climate, and local effects, such as provenance and geomorphology. Dean's regional reconnaissance study of black-shale chemistry shows no correlations between contents of organic matter and any metals, as has been observed in black shales elsewhere, but shows significant correlations between trace-element abundances and concentrations of iron and aluminum. This relation implies that the trace metals in these rocks are associated with inorganic clays rather than with the organic material. Krohn and others show that significant nitrogen concentrations are present in black shales of the Cumnock Formation of the Deep River basin. Ammonia $\left(\mathrm{NH}_{3}\right)$ is associated with organic-matter-rich phosphatic zones ("blackband"), but mineral-bound ammonium $\left(\mathrm{NH}_{4}{ }^{+}\right)$shows the highest concentration in illite-rich layers $60 \mathrm{~m}$ above the blackband intervals, suggesting that 
nitrogen transport took place in sediments of the Deep River basin and resulted in enrichment at mineralogically favorable sites. Gottfried and Kotra focused their study of comparative mineralogy on the distribution of clay polytypes in dark-colored lacustrine shales in the Hartford, Newark, Gettysburg, and Culpeper basins. Whereas illite and chlorite are widely distributed, smectites are common in the Hartford basin, and kaolinite is abundant in the Culpeper basin. The association of palygorskitesmectite and illite-smectite from the Hartford basin suggests arid depositional conditions there, whereas the abundance of kaolinite in several Culpeper basin samples suggests deposition in a more humid environment. These mineralogical differences may be related to regional variations in climate but could also result from differing paleohydrologic conditions.

\section{Section 2: Studies Related to Jurassic Igneous Rocks}

The presentations on Jurassic igneous rocks cover a broad range of subjects that include (1) petrographic and major-element characteristics of basalt flows, (2) element mobility during alteration of diabase sheets, (3) effects of postcumulus fractionation in diabase sheets, (4) major-, trace-, and rare-earth-element variation trends in diabase, (5) the relationship of diabase intrusives to flows, to mineralization, and to geologic structure, (6) new approaches to dating igneous events, and (7) gravity and magnetic fields associated with diabase.

Whereas the papers in USGS Circular 946 concentrated on recognition and classification of the principal types of tholeiitic magma characterizing Early Jurassic basalt flows and intrusive diabase dikes and sheets in eastern North America, the papers in this volume focus on rare-earth and trace-element trends, on details of basaltic-flow evolution, and on differentiation and alteration of diabase sheets. The petrographic and geochemical study of the three basaltic flow sequences in the Culpeper basin of Virginia described by Tollo show that each can be correlated along the length of its outcrop belt and that each can be distinguished from the others by use of chemical and petrographic characteristics. Whereas the lower two flow series and the lowest flow of the upper series show consistent chemical and petrographic properties, the upper flows and contained gabbroid segregations show differentiation trends of $\mathrm{Fe}$ and Ti enrichment. No simple scheme of differentiation can account for all the chemical variations in each flow series, and each may have had a separate source in the mantle. Ratcliffe has reinterpreted the relationship of the northwestern extension of the thinned Palisades sill near the Ramapo fault in Rockland County, New York, as an intrusion of fine-grained diabase into basalt flows on the basis of recent core holes and new chemical analyses. Conglomerates that contain basalt clasts underlie pillow basalt at Union Hill and are truncated by the intrusive Palisades sill. The Palisades magma may have surfaced and produced basalt flows equivalent to the Orange Mountain Basalt, but it is likely that a later phase of Palisades magma produced basalt flows at Ladentown that chemically resemble the Preakness Basalt.

Chemical variations within high-titanium, quartz-normative diabase sheets in the Culpeper (Froelich and Gottfried) and Newark (Shirley; Husch) basins are due to a combination of various types of silicate fractionation processes. Shirley describes the effects of postcumulus fractionation of the extensive, differentiated Palisades sheet in New Jersey. He shows that a granophyre-rich zone developed first at a "sandwich horizon," where the floor and roof converged and solidified together, and subsequently at another zone below the sandwich horizon where residual interstitial magma migrated upward to form a second granophyric ferrodiorite zone. In the case of the Lambertville sill and several nearby smaller diabase and granophyric intrusives in New Jersey and Pennsylvania, Husch describes major- and trace-element trends that indicated a common source. Compositional variability apparently resulted in part 
from in-situ crystal fractionation, with high-magnesium compositions resulting from early orthopyroxene and clinopyroxene accumulations, but with localized contamination from Triassic strata contributing to some of the observed compositional variability. Froelich and Gottfried discuss the regional distribution of major high-titanium, quartz-normative (HTQ) and low-titanium, quartz-normative (LTQ) sheets and dikes and minor olivine-normative (ON) dikes and plugs in the Culpeper basin of Virginia and Maryland. Whereas LTQ and ON diabases show little or no evidence of differentiation, many of the thick and extensive HTQ sheets display significant orthopyroxene accumulation, and others show late-stage differentiation into syenitic granophyre, pegmatite, ferrodiorite-ferrogabbro, and aplite. The large segregations of late-stage products of differentiation may be complementary fractions to the sheets with thick cumulate zones, and these chemical variations are best explained by wholesale lateral flow differentiation, modified locally by gravitational settling and by late-stage filter-pressing of granophyric differentiates. Ragland and Arthur present geochemical and petrographic data documenting element mobility during alteration of LTQ diabase sheets in the Culpeper basin. They show that diabase samples having loss-on-ignition values greater than 2 percent also exhibit moderate to extensive alteration of plagioclase and pyroxene. This alteration affected many elements, including some that are generally considered to be immobile. Ratcliffe and Burton describe the mineralogy and geochemistry of pervasively altered (albitized) Mesozoic granophyre, Triassic strata, and Paleozoic carbonate rocks from core holes through the Furlong fault in the Newark basin, Pennsylvania. Sodium metasomatism accompanied normal faulting and northwest-southeast extension, with albitizing fluids possibly being derived from low temperature $\left(200-300^{\circ} \mathrm{C}\right)$ connate brines in the underlying Triassic strata.

Innovative approaches to date igneous and other thermal events in early Mesozoic basins were described by Sutter, who uses ${ }^{40} \mathrm{Ar} /{ }^{39} \mathrm{Ar}$ plateau ages of minerals capable of acting as closed isotopic systems. Hornblende from a syenite in the Culpeper basin of Virginia yields a nearly concordant age spectrum having a well-defined plateau age of $200.3 \pm 1.2 \mathrm{Ma}$, supporting the $201.1 \pm 1.3 \mathrm{Ma}$ time of igneous crystallization established from a whole-rock sample of diabase elsewhere in the basin. In addition, biotite from a xenolith of Triassic arkose in diabase in the Newark basin, New Jersey, yields an age of $202.2 \pm 1.3 \mathrm{Ma}$, probably providing another reliable crystallization age. In contrast, $\mathrm{K}$-feldspars from a variety of settings record similar argon closure ages of 175 to $178 \mathrm{Ma}$ that are interpreted to reflect a heating event of approximately $200{ }^{\circ} \mathrm{C}$, possibly caused by hydrothermal fluids migrating in response to regional tilting and uplift. Daniels describes a new method for mapping diabase in early Mesozoic basins in which continuous ground magnetic intensity profiles from a truck-mounted fluxgate magnetometer are used. An example in the Durham basin, North Carolina, shows how the magnetic data and detailed gravity data can be used to model the shape, subsurface configuration, and thickness of a diabase sheet.

\section{Section 3: Studies Related to Geophysics, Structure, and Tectonics}

The geophysics, structure, and tectonics section presents new concepts on (1) deep structure of rift basins on the continental margin of New England, (2) crustal extension across the Georges Bank basin, (3) a technique for migration and analysis of seismic reflection profiles from early Mesozoic basins of eastern North America, (4) buried structures in the northern part of the South Georgia basin, (5) a geophysical study of the northern Hartford basin, Massachusetts, and (6) a comparison of new aeromagnetic imagery of some early Mesozoic basins with the known geology. 
Hutchinson and Klitgord present new geophysical data from the continental margin of New England that probably reflect brittle faulting and displacement along reactivated Paleozoic thrust faults. These include paired border faults that extend deep into the crust, a discontinuity in a buried detachment surface, and a low-angle detachment beneath the continental margin. A model for extensional faulting of the upper crust beneath the Georges Bank basin based on interpretation of seismic data and kinematic analysis of listric normal faults bounding early Mesozoic rift basins is presented by Crespi. Extension values of 25 to 30 percent and definition of fault structures at depth were determined by balancing cross sections of these rift basins and a synclinal basin seaward of the rifts. Unger demonstrates a microcomputerbased program that yields a simple and rapid technique for analysis and migration of seismic profiles of early Mesozoic basins.

Phillips presents illuminated and edge-enhanced aeromagnetic images of buried structures at the northern end of the early Mesozoic South Georgia basin beneath the South Carolina Coastal Plain. Mesozoic border faults, diabase sheets and dikes, and a large circular feature $50 \mathrm{~km}$ in diameter that may be a Paleozoic impact crater or a caldera are evident. Newly compiled digital aeromagnetic and gravity data for the Deerfield and northern Hartford basins and vicinity, Massachusetts, are presented as gray-tone images by Phillips, who interprets them in terms of known geology and inferred structure. Paired magnetic and gravity profiles were used to construct geophysical models that show good agreement with near-surface structure but show some discrepancies with published geologic interpretations of deeper structure. Bond and Phillips present five new aeromagnetic maps of parts of the Eastern United States that have exposed or partly buried early Mesozoic basins. They compare gray-tone images to the known geology and show that basalt flows and diabase sheets and dikes within the basins are evident, that some border faults are well defined, and that pre-Mesozoic plutons are prominent.

\section{Section 4: Studies Related to Mineral Resources}

The papers addressing mineral resources associated with the early Mesozoic basins focus on metallic mineral occurrences. Information and references on metal mines, prospects, and mineral occurrences are presented by Robinson and Sears, with summary information on site location, deposit type, size of occurrence, host-rock lithology and age, and metal associations. In general, the deposit types group into two categories: (1) those associated with a diabase intrusion or the adjacent thermal aureole and (2) those occurring as sediment-hosted, stratabound, or vein types spatially unrelated to igneous intrusion.

Robinson provides an overview of metal occurrences associated with igneous intrusions. Deposit types in this category include (1) magnetite skarn and replacement deposits that contain abundant magnetite and accessory sulfide minerals enriched in $\mathrm{Cu}, \mathrm{Co}, \mathrm{Ni}, \mathrm{Au}$, and $\mathrm{Ag}$ in marble bordering tholeiitic diabase sheets; (2) low-iron, copper-rich hornfels deposits that are locally enriched in $\mathrm{Au}, \mathrm{Ag}, \mathrm{Mo}, \mathrm{Bi}$, and other trace metals in metamorphosed calcareous siltstones bordering diabase and late-stage diabase differentiates; and (3) late-stage segregations and veins that are locally enriched in precious and other trace metals within and bordering diabase sheets. Smith and others provide representative analyses of sulfide concentrates from skarn and mineralized hornfels deposits in eastern Pennsylvania of the types described by Robinson.

Gottfried and Froelich report anomalous Pd enrichment from late-stage Fe-enriched zones in the York Haven diabase sheet at Reesers Summit, Pennsylvania, and in the Palisades diabase sheet in New Jersey. The Pt and Pd analyses of other diabase sheets indicate that tholeiitic differentiation is dominated by silicate fraction- 
ation in diabase sheets in Virginia, Maryland, Pennsylvania, New York, New Jersey, and Connecticut; thus, early sulfide accumulations are not likely there. However, these studies provide background information on the fractionation coefficients of $\mathbf{P t}$ and Pd under typical differentiation conditions. During silicate fractionation, $\mathrm{Pt}$ is enriched relative to $P d$ in the early cumulate stage, while $P d$ may be enriched relative to $\mathrm{Pt}$ in late-stage differentiates.

Stratabound mineral occurrences, in most cases, appear to be associated with depositional conditions that favor the preservation of woody organic material within permeable strata. Copper deposits occurring as stratabound disseminations in fluvial sandstone units are described by Gray and by Smoot and Robinson. The copper occurrences are associated with organic material concentrated at the base of trough cross-beds or in root structures penetrating shale-draped cross-beds within finingupward sequences. These $\mathrm{Cu}$ deposits are sometimes associated with $\mathrm{U}$ enrichment.

Turner-Peterson compares and contrasts the Triassic sandstone-hosted uranium-bearing sequences in the Newark basin of Pennsylvania and New Jersey to Jurassic uranium-bearing sequences in the San Juan basin of New Mexico. Similarities in the occurrence of uranium enrichment in these two areas include a close spatial association between uranium in sandstone and interbeds of gray lacustrine mudstone, the tendency of uranium concentrations to follow sedimentary scour surfaces marked by zones of clay rip-up clasts, and the presence of organic matter, pyrite, and chlorite enrichment in the uranium-bearing zones. Differences between the areas include basin geometry and size, tectonic setting, and uranium and sediment sources. However, it is likely that a similar model for uranium ore genesis applies to both basins, with uranium being mobilized in relatively oxygenated ground waters, which is subsequently precipitated under more reducing conditions.

Sediment-hosted, stratabound $\mathrm{Cu}$ and $\mathrm{Zn}$ sulfide enrichment in dark-gray to black lacustrine mudstones of the Culpeper basin, Virginia, are described by Smoot and Robinson. The enrichment appears to be largely restricted to black, rootdisrupted sandy mudstones that underlie laminated lacustrine shales. This sedimentary facies type occurs repetitively as part of sedimentary cycles, which may be controlled, in part, by climatic variation.

Epithermal base-metal and barite veins associated with the Hartford basin of Connecticut are described by Gray, and similar occurrences in other early Mesozoic basins by Robinson and Woodruff. Sulfide minerals in these veins typically have high silver content. Fluid inclusion, isotope, and other studies indicate that the veins are associated with the transport of moderate temperature $\left(100-250^{\circ} \mathrm{C}\right)$ and moderate salinity (10-16 weight percent $\mathrm{NaC1}$ equivalent) brines from within the basins and adjacent basement to shallow sites of mineral precipitation. Fluid migration may be due to a seismic pumping process that was produced by stresses developed during the separation of North America from Africa. Potassium feldspars from a variety of settings in the early Mesozoic basins record ${ }^{40} \mathrm{Ar} /{ }^{39} \mathrm{Ar}$ closure ages of 175 to $178 \mathrm{Ma}$ that are interpreted by Sutter as a regional heating event of approximately $200{ }^{\circ} \mathrm{C}$ caused by hydrothermal fluids. These $\sim 175$-Ma argon closure ages may reflect the formation age of some of the vein deposits.

The papers given herein represent significant progress toward understanding the geologic setting, tectonic history, and mineral and energy resource potential of the early Mesozoic basins of eastern North America.

\section{Section 5: Fieldtrip Guides to the Culpeper Basin, Virginia}

Two 1-day fieldtrips in the Culpeper basin of Virginia are given in this section. Smoot and Robinson present a fieldtrip guide to base- and precious-metal occurrences associated with Triassic sedimentary and thermally metamorphosed rocks; 
Tollo and others present a fieldtrip guide to stops that display igneous features of the suite of three Jurassic basalt flows and the high-titanium, quartz-normative Rapidan (early cumulus-orthopyroxene-enriched) and the related Germanna Bridge (latestage differentiate-bearing) diabase sheets. 



\title{
Studies of the Early Mesozoic Basins of the Eastern United States
}

\author{
Albert J. Froelich and Gilpin R. Robinson, Jr., editors \\ UNIFORM SYMBOLS FOR THE NEWARK SUPERGROUP
}

Joseph P. Smoot, Albert J. Froelich, and Gwendolyn W. Luttrell

\begin{abstract}
Uniform symbols are presented for the rocks of the Newark Supergroup in order to facilitate interbasin and intrabasin comparisons of lithologic sequences and to help in the recognition of regional depositional patterns. The lithologic designations are generalized for use with maps at $1: 125,000$ scale and reflect the detail of published data presently available for all of the basins.

The criteria for defining lithologic units are based upon characteristics believed to significantly reflect the deposition of the sediments. Sedimentary rocks are divided primarily by grain size, and igneous rocks are separated into basalt and diabase. The symbols for the major sedimentary rocks units are also combined to illustrate the relative abundance of two rock types; for instance, $s / c$ is pebbly sandstone with minor conglomerate beds and $\mathrm{s} / \mathrm{si}$ is sandstone with interbedded siltstone. Symbols are further discriminated by subscripts indicating characteristics such as major clast type of conglomerate, diabase chemistry, or the relative position of a basalt flow. Thermally metamorphosed rocks that form halos around intrusive diabase bodies are indicated.

The selection of bedrock units designated by the proposed symbols reflects not only common textural characteristics but also similar suites of sedimentary structures or chemical affiliations that are comparable in all of the basins. These characteristics are interpreted as indicators of common depositional environments of the sediments or chemical differentiation of the igneous intrusives. The generalized lithologic divisions do not represent the most detailed level of division possible in a basin or in a portion of a basin. The symbols focus on the principal lithologic similarities and differences of all of the Newark Supergroup basins. Comparisons then can be made between basins with less detailed coverage and those that have more detailed studies for the purpose of regional paleoenvironmental analysis, mineral resource or petroleum exploration, hydrologic studies, hazard assessments, and land-use planning.
\end{abstract}

\section{INTRODUCTION}

The U.S. Geological Survey is compiling a series of 1:125,000-scale bedrock lithologic maps of each of the
Triassic-Jurassic Newark Supergroup basins (Froelich and Olsen, 1984) in the Eastern United States. These maps will employ a set of common symbols for the rock types in all of the basins in order to facilitate interbasin and intrabasin comparisons and to help in the recognition of depositional relations. Existing maps of the Newark Supergroup basins are published at a variety of scales. Lithostratigraphic nomenclature used in these maps varies between basins and even within basins, and descriptions commonly include outdated terminology or different meanings for similar names. The lithostratigraphic boundaries also are commonly not coincident with lithologic changes that reflect changes in depositional conditions. The new maps are intended to illustrate the distribution of the dominant lithologies that reflect common depositional conditions or significant variations in character; these maps will be used in local and regional stratigraphic and structural interpretation, paleoenvironmental reconstruction, land management, and economic development.

\section{LITHOLOGIC SYMBOLS}

Sedimentary rocks are divided primarily by grain size (c-conglomerate, $\mathrm{s}$-sandstone, si-siltstone, $\mathrm{sh}$ shale), and igneous rocks are divided into basalt (b) and diabase (d). Thermally metamorphosed rocks (tm) form halos around intrusive diabase bodies. Sedimentary rock units that are composed of two major grain sizes are indicated by combined letters with the predominate lithology first; for instance, pebbly sandstone with conglomerate is designated $\mathrm{s} / \mathrm{c}$, and sandstone with subordinate siltstone is designated $\mathrm{s} / \mathrm{si}$. Further subdivision of lithologies is accomplished with subscripts, as in the dominant clast types of conglomerates $\left(c_{\mathrm{g}}\right.$-greenstone conglomerate, $c_{1}-$ limestone conglomerate, etc.). Siltstone that occurs in distinctive cyclic sequences with minor shale $\left(\mathrm{si}_{\mathrm{c}}\right)$ is further divided into predominately gray units containing thin black shales $\left(\mathrm{si}_{\mathrm{cg}}\right)$ and predom- 
inately red units $\left(\mathrm{si}_{\mathrm{cr}}\right)$. Basalt flows are numbered from oldest to youngest $\left(b_{1}, b_{2}, b_{3}\right)$, as are the interbedded sandstones and cyclic siltstones overlying them $\left(\mathrm{s} / \mathrm{si} \mathrm{s}_{\mathrm{c} 1}\right.$, $\left.\mathrm{s} / \mathrm{si} i_{c 2}, s / \mathrm{si}_{\mathrm{c} 3}\right)$. Letters are used to distinguish among diabases $\left(\mathrm{d}_{\mathrm{a}}\right.$-quartz-normative diabase with high $\mathrm{TiO}_{2}$, $\mathrm{d}_{\mathrm{b}}$-quartz-normative diabase with low $\mathrm{TiO}_{2}$, etc.). Thermally metamorphosed rocks are divided on the basis of their parent rock $\left(\mathrm{tm}_{\mathrm{a}}\right.$-arkosic sandstone altered to meta-arkose, $\mathrm{tm}_{\mathrm{m}}$-limestone conglomerate altered to marble, etc.). Lithologic types that are only broadly known are referred to as undifferentiated $\left(\mathrm{d}_{\mathrm{u}}\right.$ - undifferentiated diabase).

The lithologic divisions of the sedimentary rocks reflect more than their textural characteristics. The divisions chosen for representation on the maps also broadly represent differences in the sedimentary structures and packaging that are significant to interpreting the depositional environments. The division of diabases is based on the important chemical indicators of magma differentiation or source types.

Plate 1 (in pocket) is a correlation chart of the lithostratigraphic units in all of the Newark Supergroup basins in the United States. It illustrates the age relations and various geologic names used for the rocks that appear on published maps. Table 1 is a list of the lithologic symbols used for the stratigraphic units in each basin in our preliminary map subdivision. The rock types indicated by the symbols represent the characteristic lithologies mappable at the 1:125,000 scale but do not exclude other minor lithologies from those areas. Important local rock varieties, such as coal beds or limestones, are not shown separately because they are too thin or discontinuous to be mapped at this scale. Figure 1 is a small portion of the Newark basin in New Jersey illustrating the use of symbols on these maps.

\section{Lithologic Descriptions and Interpretations}

c Conglomerate-Poorly sorted conglomerate that either is massive or has crude or irregular bedding. Clast size varies from large boulders to pebbles, and fabric may be either matrix or clast supported. Internal stratification is generally poor, represented by flat lamination and rare cross-bedding. The major clast types are indicated by subscripts: greenstone clasts $\left(c_{g}\right)$, limestone/dolomite clasts $\left(c_{1}\right)$, quartz/quartzite clasts $\left(c_{q}\right)$, and mixed clasts $\left(c_{m}\right)$. This lithology is commonly referred to as "border fanglomerates" on some published maps (for instance, the Arendtsville Fanglomerate Lentil of the Gettysburg Formation in the Gettysburg basin, Berg and others, 1983). These deposits probably reflect deposition by debris flows and by flash floods on alluvial fans and in shallow, high-gradient streams.
Table 1. Lithologic symbols used in preliminary maps for

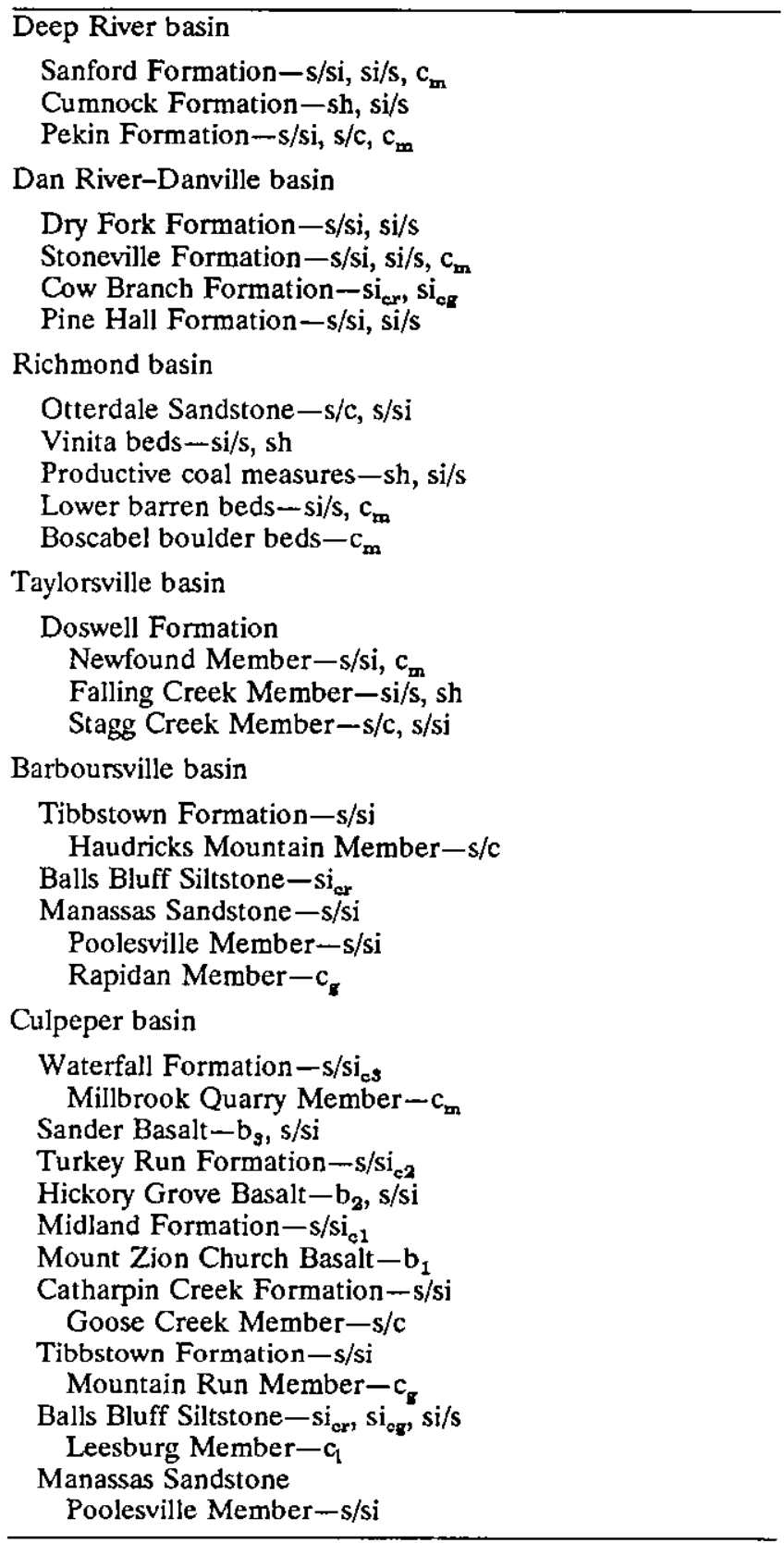

$\mathrm{s} / \mathrm{c}$ Pebbly sandstone-Pebbly sandstone that is interbedded with less abundant conglomerate. The sandstone is commonly arkosic with quartz pebbles being the most common clasts. The lithology is characteristically well stratified, commonly with trough or tabular crossbedding or flat lamination. Fining-upward sequences of conglomerate to sandstone are also common. The Hammer Creek Formation (Glaeser, 1963) in the Narrow Neck between the Newark and Gettysburg basins contains good examples of this lithologic type. The deposits of this lithology were formed mostly by braided streams. 
the stratigraphic units of the Newark Supergroup

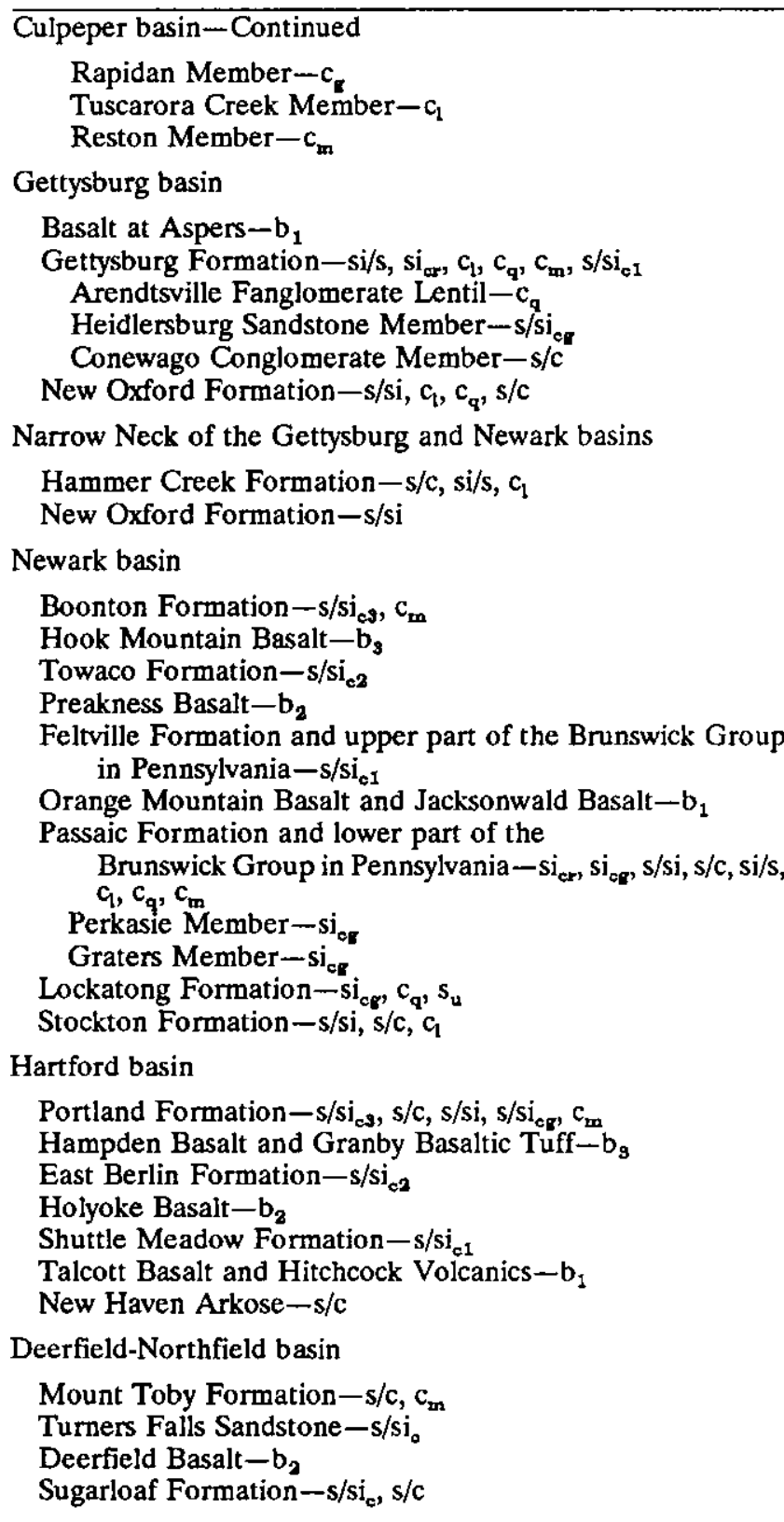

$\mathrm{s} / \mathrm{si}$ Sandstone/siltstone-Sandstone that is predominate with less abundant siltstone. The sandstone ranges from arkose to quartz arenite and commonly contains internal stratification ranging from dune-scale cross-beds to ripple-scale cross-lamination and flat lamination. Sandstone lacking internal stratification typically shows evidence of extensive bioturbation. The sandstone forms fining-upward sequences overlying erosional scour surfaces in siltstone and grading upward into siltstone or has gradational bases and forms coarsening-upward sequences from basal siltstone units. The Stockton Formation of the Newark basin is an example of a unit comprised mostly of this lithology (McLaughlin, 1945). Deposits of this lithology were probably sand deposited by meandering or braided rivers or in deltas. The associated siltstone represents fluvial overbank, deltaic, or lacustrine deposits.

si/s Siltstone/sandstone-Siltstone that is predominate with less abundant sandstones. The siltstone contains a wide variety of sedimentary structures including flat lamination, cross-lamination, burrow structures, root casts, and mudcracks. The siltstone may be very calcareous with abundant dolomite or calcite micritic nodules. The sandstone is typically lenticular, forming both finingupward and coarsening-upward sequences. Ripple crosslamination and bioturbation structures are common. The Sanford Formation in the Deep River basin (Reinemund, 1955) contains good examples of this lithology. The siltstone of this lithology probably represents distal flood plain or flood basin and shallow lake deposits, and the sandstone is probably channel-fill, crevasse, and sheet delta deposits.

$\mathrm{si}_{\mathrm{c}}$ Cyclic siltstone-Siltstone, mudstone, and shale that occur in pervasively rhythmic cycles 3 to $8 \mathrm{~m}$ thick. The cycles are equivalent to the "Van Houten" cycles described by Olsen (1985), consisting characteristically of thin-bedded to finely laminated siltstone or shale grading upward into a massive silty mudstone. The lower portions of the cycles have few or no desiccation features and may contain lacustrine fossils, whereas the upper portions contain abundant desiccation features or root casts (Smoot and Olsen, 1985). Predominately gray cyclic siltstone units with black basal laminites that are locally calcareous commonly occur in groups of three or four cycles. These groups of gray cycles are mappable and are designated $\mathrm{si}_{\mathrm{cg}}$. The Perkasie Member of the Passaic Formation in the Newark basin (Olsen, 1984) is a good example of this lithology. Cycles that are predominately red, containing only scattered gray or black beds, are designated $\mathrm{si}_{\mathrm{cr}}$. Most of the Passaic Formation and the lower part of the Brunswick Group (Lyttle and Epstein, 1987) in the Newark basin are composed of this lithology. The cyclic siltstone deposits are lacustrine and are interpreted as reflecting the rise and fall of lakes apparently in response to climatic variations (Olsen, 1986). Calcareous black laminites within cycles are interpreted as deep-lake deposits; red or gray thin-bedded siltstone and mudstone with mudcracks are interpreted as deposits of shallow or intermittent lakes; and massive siltstone or silty mudstone with mudcracks or root casts is interpreted as soils or playa mudllat, very shallow lake, or vegetated mudflat deposits.

sh Black shale-Thick black shale that is not obviously cyclic with gray mudstone and siltstone. These deposits contain sandstone that forms coarsening- 


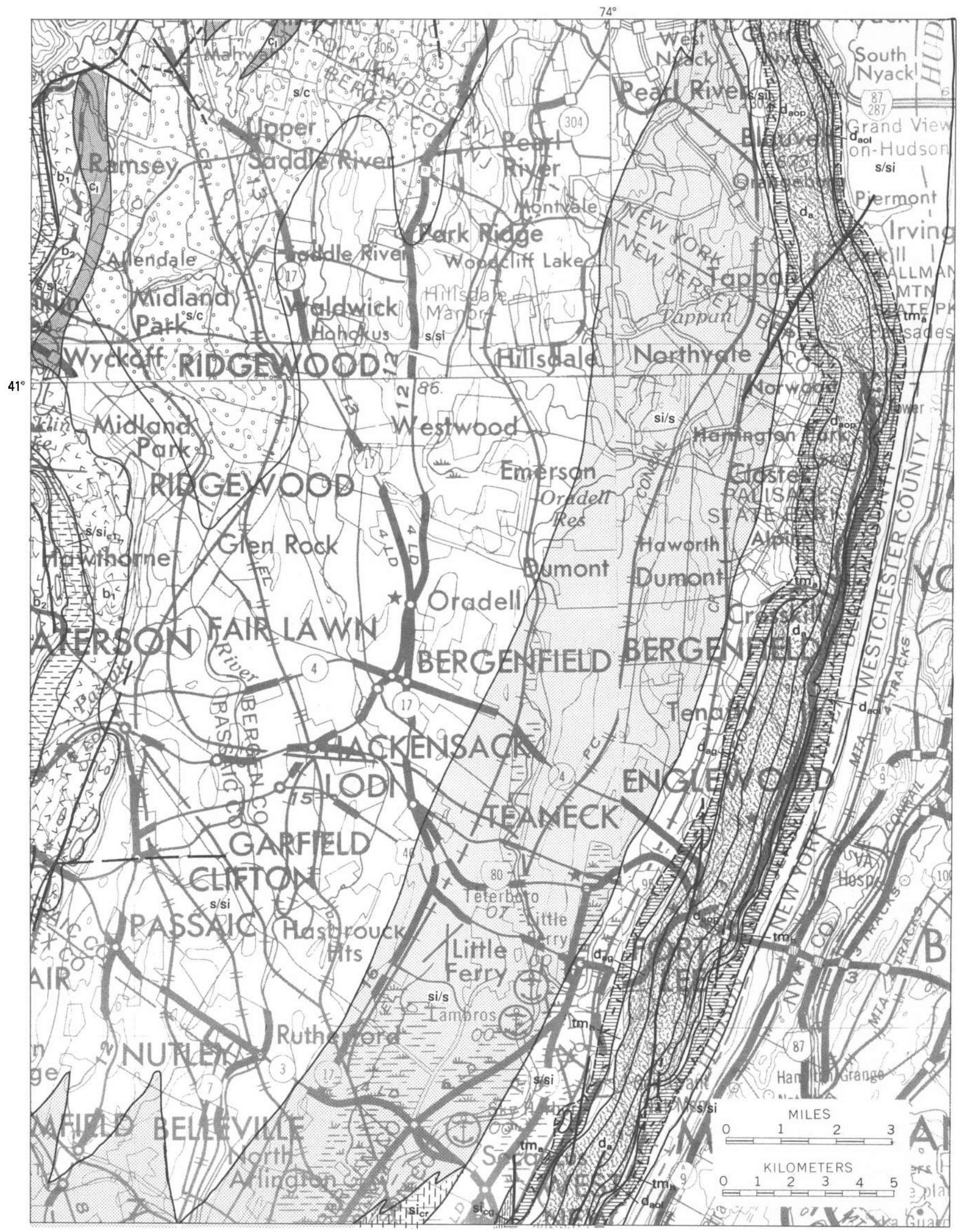

Figure 1. Lithologic map of a portion of the Newark basin in New Jersey illustrating the use of symbols described in the text. 
upward sequences in some places; elsewhere they may be fossiliferous and locally may contain coal beds. Phosphatic and sideritic layers called blackband beds (Reinemund, 1955) occur locally. The Cumnock Formation in the Deep River basin (Brown, 1985) is an example of this lithology. The black shale lithology reflects deposition either in deep lakes or in shallow swamps, possibly associated with deltas or crevasse splays.

$\mathrm{s} / \mathrm{si}_{\mathrm{c}} \quad$ Mixed cyclic sedimentary lithologies-This unit is predominately a mixture of deposits similar to $\mathrm{s} / \mathrm{si}$ and $\mathrm{si}_{\mathrm{c}}$ that commonly occur in narrow belts between basalts. The lithologic changes are laterally abrupt and difficult to show at the 1:125,000 map scale, and are therefore combined. The deposits that are interbedded with basalt flows are given numerical suffixes corresponding to the underlying basalt flows ( $\mathrm{s} / \mathrm{si}_{\mathrm{c} 1}$ oldest and $\mathrm{s} / \mathrm{si}_{\mathrm{c} 3}$ youngest). The East Berlin Formation of the Hartford basin (Hubert and others, 1978) is an example of this lithology. The mixed cyclic sedimentary lithology was deposited in fluvial and deltaic environments under lacustrine conditions that reflect the cyclic rise and fall of lake level.

b Basalt-One to several tholeiitic basalt flows that may have thin sedimentary rock intercalations. Each basalt flow unit has a numerical suffix indicating its relative age with respect to the other flows $\left(b_{1}\right.$ oldest and $b_{3}$ youngest). These basalts were deposited under both subaerial and subaqueous conditions as flood basalts. They are predominately quartz-normative, high- $\mathrm{TiO}_{2}$ tholeiites.

d Diabase-Dikes and sills of tholeiitic diabase intrude the layered Newark Supergroup and show chill margins against aureoles of thermally altered sedimentary rock. Some large sheets have cumulus zones rich in olivine or orthopyroxene. Diabase is subdivided into quartz-normative, high $\mathrm{TiO}_{2}\left(\mathrm{~d}_{\mathrm{n}}\right)$, quartz-normative, low $\mathrm{TiO}_{2}\left(\mathrm{~d}_{\mathrm{b}}\right)$, and olivine normative $\left(\mathrm{d}_{c}\right)$. Late-stage differentiates of $d_{a}$ include granophyre, ferrodiorite, ferrogabbro, and pegmatite $\left(\mathrm{d}_{\mathrm{ag}}\right)$, and early phases of $\mathrm{d}_{\mathrm{a}}$ contain orthopyroxene cumulus $\left(d_{\text {aop }}\right)$ and olivine cumulus $\left(d_{\text {aol }}\right)$. The diabase intrusives locally show cross-cutting relationships and apparently some served as feeders for the basalt lava flows.

tm Thermally metamorphosed rocks-This lithologic unit consists of the entire range of sedimentary lithologies that were metamorphosed as thermal aureoles enclosing diabase dikes and sheets.

\section{DISCUSSION}

The lithologic designations presented in this paper are an attempt to illustrate lithologic variations reflecting depositional conditions that can be compared in all of the Newark Supergroup basins. The level of detail shown by this subdivision reflects the 1:125,000 map scale and the detail of published data presently available for each basin. In certain areas of some basins the lithologies can be more finely divided, but these subdivisions can seldom be extended over an entire basin or directly compared to other basins. The divisions presented here allow comparison between areas with extensive outcrop and good subsurface control that are well understood and areas that have poor outcrop or less subsurface data and are consequently less well known. More detailed mapping is possible within this framework, and the common symbols may serve to highlight areas for intrabasin comparison, for mineral resource or petroleum exploration, for hydrologic studies, hazard assessments, land-use planning, and for paleoenvironmental analysis.

\section{REFERENCES CITED}

Berg, T.M., McInerney, M.K., Way, I.H., and MacLachlan, D.B., 1983, Stratigraphic correlation chart of Pennsylvania: Pennsylvania Geological Survey General Geology Report 75.

Brown, P.M., 1985, Geologic map of North Carolina: North Carolina Geological Survey, scale 1:500,000.

Froelich, A.J., and Olsen, P.E., 1984, Newark Supergroup, a revision of the Newark Group in eastern North America, in Stratigraphic notes, 1983: U.S. Geological Survey Bulletin $1537-A$, p. A55-A58.

Glaeser, J.D., 1963, Lithostratigraphic nomenclature of the Triassic Newark-Gettysburg basin: Pennsylvania Academy of Science, v. 37, p. 179-188.

Hubert, J.F., Reed, A.A., Dowdall, W.L., and Gilchrist, J.M., 1978, Guide to the redbeds of central Connecticut: 1978 ficld trip, Eastern Section of Society of Economic Paleontologists and Mineralogists: Department of Geology and Geography, Contribution No. 32, University of Massachusetts, Amherst, 129 p.

Lyttle, P.T., and Epstein, J.B., 1987, Bedrock geologic map of the Newark $1^{\circ} \times 2^{\circ}$ quadrangle, New Jersey, Pennsylvania, and New York: U.S. Geological Survey Miscellaneous Investigations Series Map I-1715, scale 1:250,000.

McLaughlin, D.B., 1945, Type sections of the Stockton and Lockatong Formations: Pennsylvania Academy of Science Proceedings, v. 19, p. 102-113.

Olsen, P.E., 1984, Comparative paleolimnology of the Newark Supergroup-A study of ecosystem evolution: New Haven, Connecticut, Yale University, unpublished Ph.D. thesis, $726 \mathrm{p}$.

-1985, Distribution of organic-matter-rich lacustrine rocks in the early Mesozoic Newark Supergroup, in Robinson, G.R., Jr., and Froelich, A.J., eds., Proceedings of the second U.S. Geological Survey workshop on the early Mesozoic basins of the Eastern United States: U.S. Geological Survey Circular 946, p. 61-64.

1986, A 40-million-year lake record of early Mesozoic orbital climate forcing: Science, v. 234 , p. $842-848$. 
Reinemund, J.A., 1955, Geology of the Deep River coal field, North Carolina: U.S. Geological Survey Professional Paper 246, 159 p.

Smoot, J.P., and Olsen, P.E., 1985, Massive mudstones in basin analysis and paleoclimatic interpretation of the Newark
Supergroup, in Robinson, G.R., Jr., and Froelich, A.J., eds., Proceedings of the second U.S. Geological Survey workshop on the early Mesozoic basins of the Eastern United States: U.S. Geological Survey Circular 946, p. 29-33.

\title{
CONTINUITY OF STRATA IN THE NEWARK AND HARTFORD BASINS
}

\author{
Paul E. Olsen ${ }^{1}$
}

\begin{abstract}
Trangressive-regressive lacustrine sedimentary sequences, called Van Houten cycles, can be traced over large areas of the Newark and Hartford basins by use of six independent means: (1) walking out the trace of the beds; (2) detailed matching of unique sequences of beds between isolated outcrops; (3) detailed ecostratigraphic correlation; (4) identification of key marker beds; (5) magnetostratigraphy; and (6) matching of microlaminae. By use of these methods, Van Houten cycles of the Lockatong and Passaic Formations in the Newark basin and the East Berlin Formation in the Hartford basin have been traced over most of the areas of their respective basins. Demonstration of the lateral continuity of Van Houten cycles is necessary for their use in stratigraphy, geochronology, paleoclimatology, and paleoecology in the Newark Supergroup.
\end{abstract}

\section{INTRODUCTION}

The title of this paper is tribute to the classic work of Dean B. McLaughlin, an astronomer at University of Michigan and later of Harvard University. In his spare time, McLaughlin doubled as one of the finest physical stratigraphers to work in the Newark Supergroup (Froelich and Olsen, 1984) of eastern North America. In McLaughlin's paper (1948) entitled "Continuity of Strata in the Newark Series," he showed how individual red and black members of the Lockatong and Passaic (lower Brunswick of Kummel (1897); Olsen, 1980a,b) Formations could be traced over much of the Newark basin (figs. 1 and 2). It is vital that the lateral continuity of small-scale lithologic units be understood, because only then can local effects be differentiated from regional ones. Further, it is these laterally continuous units that have the potential to provide very fine-scaled stratigraphic and geochronologic tools (Olsen, 1986). In this paper, I follow up on McLaughlin's work by describing

\footnotetext{
${ }^{1}$ Lamont-Doherty Geological Obsenvatory, Columbia University, Palisades, NY 10964.
}

(1) how individual components of his informal members can be traced over most of the Newark basin, (2) how this lateral continuity holds for the other parts of the Newark basin section, and (3) how the same pattern pertains to parts of the Hartford basin.

\section{VAN HOUTEN CYCLES-MODAL SEDIMENTARY SEQUENCES OF THE NEWARK SUPERGROUP}

The Lockatong and Passaic Formations of the Newark basin make up a natural facies package united by a common theme of repetitive transgressive-regressive lake-level sequences called Van Houten cycles (fig. 3, table 1) after their discoverer (Van Houten, 1964, 1969, 1980; Olsen, 1980a,b,c, 1984a,b, 1986). Van Houten cycles make up at least two orders of compound cycles, which as described by Olsen (1986), can be viewed either

Table 1. Divisions of the Van Houten cycle

[See figure 3 for illustration of cycle]

Division Description

1...... A calcareous claystone to siltstone with pinch and swell lamination with thin bedding, occasional desiccation cracks, burrowed or rooted horizons, stromatolites, and oolites. This represents a lacustrine transgressive sequence including shoreline deposits.

2...... A laminated to microlaminated calcareous claystone and siltstone, or limestone, with desiccation cracks rare to absent. This division has the highest organic content of the cycle, and fish and other animal fossils are sometimes abundant; it represents the lake's high-stand deposit.

3...... A calcareous claystone and siltstone, with abundant desiccation cracks, burrowed and rooted horizons, vesicular and crumb fabrics, and reptile footprints. Division 3 represents the sequence of the lake's regressive through lowstand deposit; the lake was at least occasionally dry, with incipient soil development. 


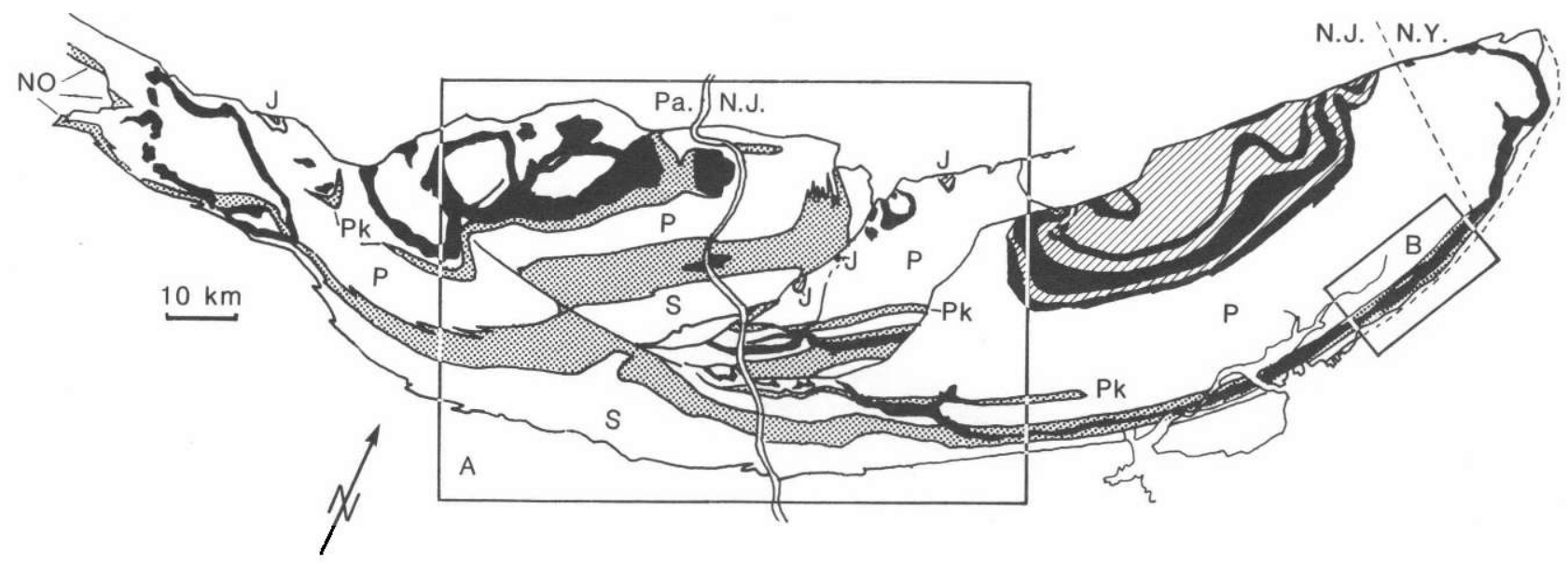

Figure 1. Simplified geologic map of the Newark basin showing the major areas discussed in text: $A$, Delaware Valley area; $B$, Weehawken area. Abbreviations and symbols for units are P, Passaic Formation; S, Stockton Formation; J, Jurassic extrusive basalts and interbedded sedimentary

typologically or by numerical means through Fourier analysis. These second- and third-order cycles (fig. 4) show up as modulation of the expression of Van Houten cycles. Van Houten cycles and the compound cycles similar to those in the Lockatong and Passaic Formations occur through the Jurassic portions of the Newark basin and through most of the rest of the Newark Supergroup (Olsen, 1984a, 1986) and span a total interval of more than 40 million years.

McLaughlin (1943, 1944, 1945, 1946, 1948, 1959) concentrated on tracing out the second-and third-order cycles across the largely continuous sequences comprising the northwestern fault block in the Newark basin (fig. 2 ). He did this during the 1930's and 1940's when central New Jersey and southeastern Pennsylvania were largely farmland and the gray and red members of the Lockatong and Passaic Formations could be walked out easily over plowed fields. Tracing individual Van Houten cycles and their compound cycles laterally in faulted, overgrown, or densely populated areas is now more difficult and inferential.

Where cycles cannot be walked out, lateral correlation of individual Van Houten cycles and the secondand third-order cycles is afforded by five independent means: (1) detailed matching of unique sequences of beds between isolated outcrops; (2) detailed ecostratigraphic correlation of fossils in stratigraphic sequences (Cisne and Rabe, 1978; Hoffman, 1981); (3) identification of key marker beds such as radioactive units or fluidized beds; (4) correlation of stratigraphic units and magnetozones (McIntosh and others, 1985); and (5) matching of microlaminae within division 2 of single, distinctive Van Houten cycles. Because the rocks are not rocks; NO, New Oxford Formation; Pk, Perkasie Member of Passaic Formation; stippled areas, Lockatong Formation, except where designated as Pk; diagonally ruled areas, Jurassic sedimentary rocks; black areas, diabase and basalt, extrusive where adjacent to Jurassic sedimentary rocks.

continuously exposed, these correlations are hypotheses that are only as good as the rigor of the tests they survive.

\section{LOCKATONG FORMATION, NEWARK BASIN}

\section{Middle Lockatong Formation, Hunterdon Plateau Fault Block}

The longest single outcrop of the Lockatong occurs in the northern fault block in Byram, New Jersey, along the west side of Route 29 and along a small brook (fig. 2, locality 1). More than $400 \mathrm{~m}$ of middle Lockatong Formation (fig. 5) crop out; this outcrop forms the main basis of Van Houten's original interpretations. The upper part of the section contains the important marker units called the "First Thin Red" (fig. 5) and "First Thick Red" units of McLaughlin (1946), which he mapped throughout the northwestern fault block. The surrounding $100 \mathrm{~m}$ of section contain a distinctive sequence of Van Houten cycles that include two Van Houten cycles in which division 2 is a microlaminated fish-bearing unit (SH1 and SH2, fig. 5). These two cycles contain the only two such units in this section.

About $25 \mathrm{~km}$ to the southwest of these outcrops, the Haines and Kibblehouse quarry exposes about $120 \mathrm{~m}$ of middle Lockatong Formation (fig. 5). McLaughlin (1946) mapped his "First Thin Red" unit through this area prior to the opening of the quarry in 1965 . The quarry now exposes all of the First Thin Red initially mapped by McLaughlin (fig. 2) and apparently replicates the entire pattern of Van Houten cycles and higher order 


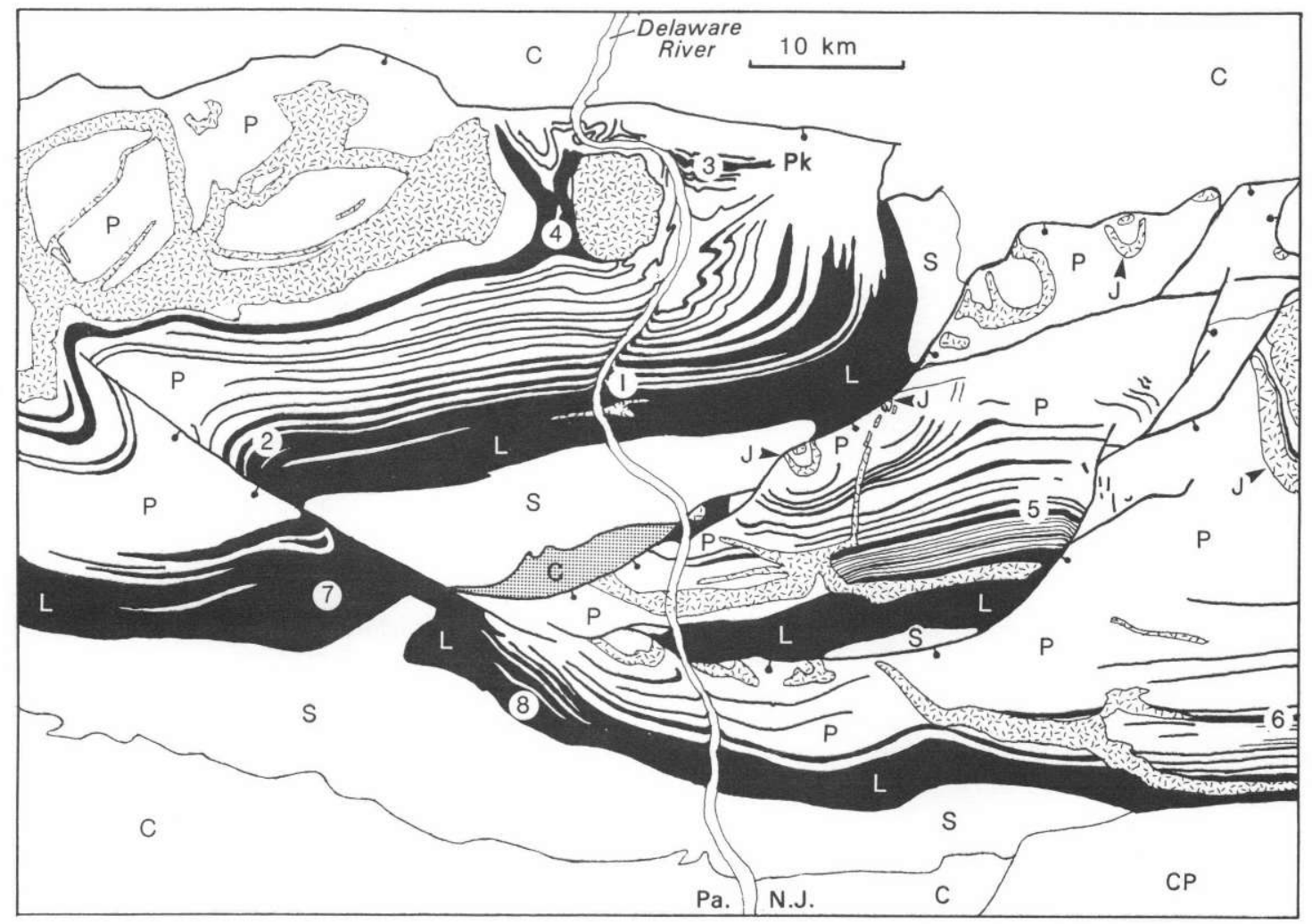

EXPLANATION

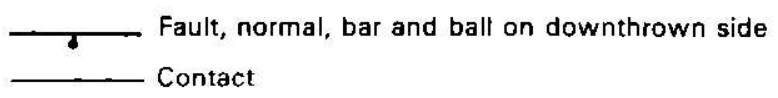

Figure 2. Simplified geologic map of the Delaware Valley area of the Newark basin showing positions of major localities: 1, middle Lockatong Formation, Route 29 exposures, Byram, New Jersey; 2, middle Lockatong Formation, Haines and Kibblehouse quarry, Chalfont, Pennsylvania; 3, Perkasie Member of Passaic Formation, Milford, New Jersey; 4, Perkasie Member of Passaic Formation, Harrow, Pennsylvania; 5, Perkasie Member of Passaic Formation, Furmans Corner, New Jersey; 6, Perkasie Member of Passaic Formation, New

cycles present along Route 29 . This includes the relative positions of the microlaminated fish-bearing units relative to the First Thin Red, thereby providing additional support to McLaughlin's original hypothesis.

The quarry section differs from that along Route 29 , however, in having much more sandstone and in lacking the common analcime- and carbonate-rich massive mudstones with breccia and crumb fabrics (Smoot and Katz, 1982). These mudstones are replaced by red massive mudstones with less dense breccia fabric, rooted and burrowed fabrics, beds of red ripple cross-laminated siltstone and sandstone (often with soft-sediment deformation and desiccation cracks), and rare tufa gravels. Some of these red units contain rare to abundant bones of the little reptile Tanytrachelos, larger bones of phyto-
Brunswick, New Jersey; 7, lower Lockatong Formation, Eureka, Pennsylvania; 8, lower Lockatong Formation, Rushland, Pennsylvania. Abbreviations and symbols for units are C, crystalline and Paleozoic basement, stippled within basin; $\mathrm{J}$, Jurassic extrusive basalts and sedimentary rocks; $L$, Lockatong Formation; P, Passaic Formation; Pk, Perkasie Member of Passaic Formation; S, Stockton Formation; irregular dashed pattern, tholeiitic igneous rocks, intrusive unless designated by $\mathrm{J}$; $\mathrm{CP}$, coastal plain sediments.

saurs, and reptile footprints (fig. 5) (Olsen and Flynn, in press). The massive gray mudstones of cycles above the First Thin Red are replaced by flaggy, oscillatory- and climbing-ripple bedded sandstones with reptile footprints. The features that Van Houten used to distinguish his chemical cycles from detrital cycles are absent in the quarry section, even though correlative cycles are present.

\section{Lower Lockatong Formation, Weehawken area}

The lower Lockatong and upper Stockton Formations are exposed in the northeastern Newark basin along 


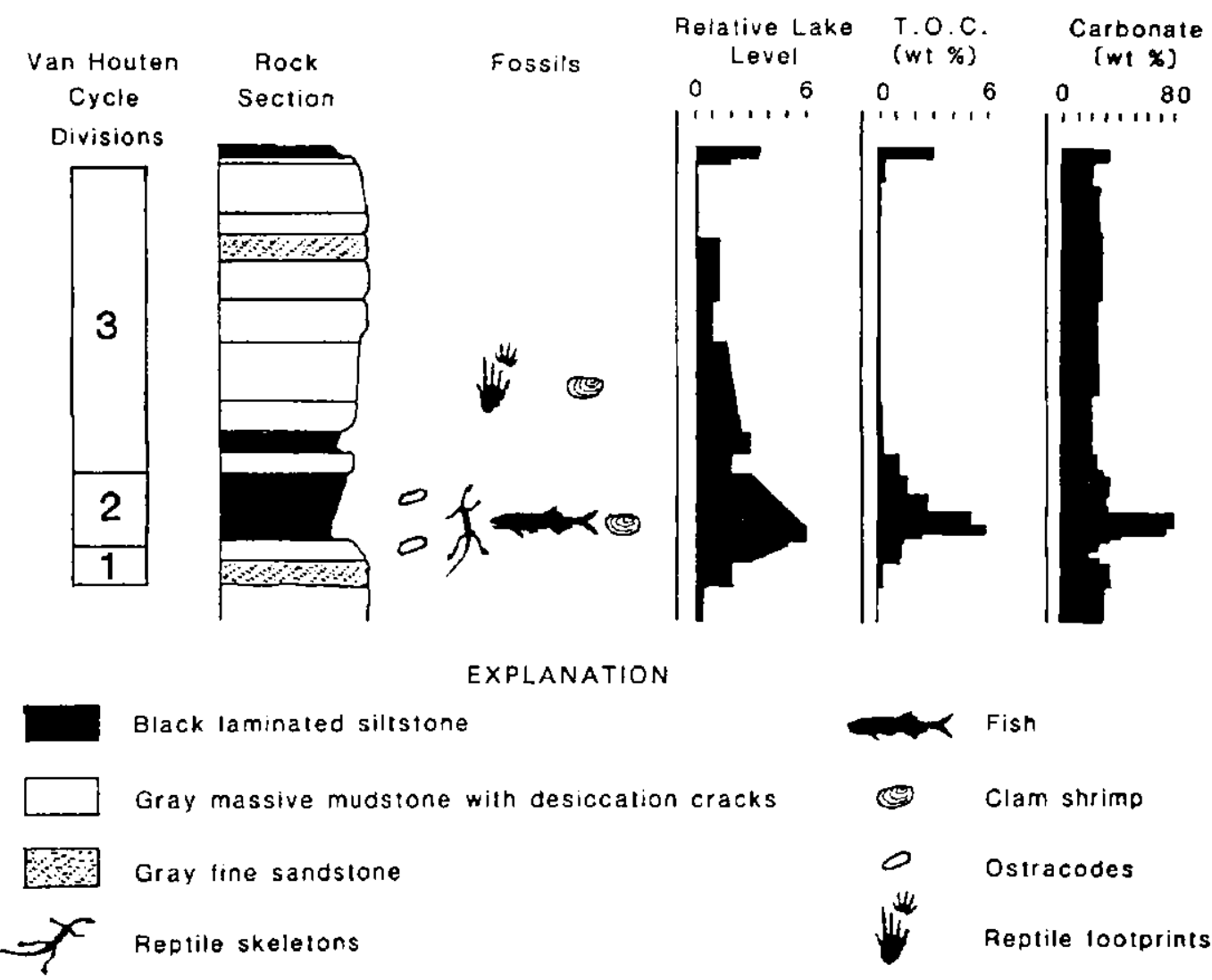

Figure 3. Sketch showing single Van Houten cycle (SH2 in fig. 5). Relative lake level increases from 0 to 6 (depth ranks of Olsen, 1984b, 1986). T.O.C., total organic carbon. See table 1 for explanation of cycle divisions.

the base of the Palisade sill in the Weehawken, New Jersey, area (Hoboken north to Alpine, fig. 1). Exposures are small, the area is densely populated, and there are no mappable units of different color. Fortunately, the Van Houten cycles of the lower Lockatong are richly fossiliferous and much thinner-an average of $1.5 \mathrm{~m}$ in this area (Olsen, 1980c) compared to $5.9 \mathrm{~m}$ in the Hunterdon Plateau Fault Block (Olsen, 1986). Small exposures therefore provide a disproportionally large amount of information.

Olsen (1980c, 1984a) used ecostratigraphic methods (Cisne and Rabe, 1978) to correlate a long series of cycles at five main exposures from Hoboken to Fort Lee, New Jersey. Ecostratigraphic correlation uses the partial vertical ranges of fossils as sensitive indicators of relatively subtle regional changes in environments rather than using the total vertical ranges of taxa as indicators of origination and extinction as in standard biostratigraphy. The taxa used by Olsen (1980c) have total ranges that span most of the Lockatong Formation, and these would be useless in using standard biostratigraphic melhods to correlate within the formation. There seems to be a correlation between pyrite sulfur content and the fish taxa that can be interpreted as a correlation with salinity
(Olsen, 1984a; 1987, unpub. data). The vertical distribution of taxa may thus reflect salinity changes in the Lockatong lakes.

By this approach in the Weehawken area, individual cycles and the compound cycles are correlated over a distance of about $12 \mathrm{~km}$. Additional outcrops near Alpine, New Jersey (still under study), extend this correlation another $4 \mathrm{~km}$.

\section{Correlation of Lower Lockatong Across Newark Basin}

The same ecostratigraphic method used in the Weehawken area allows the development of a reasonable hypothesis of correlation (fig. 6) from Weehawken southwest $140 \mathrm{~km}$ to the Eureka quarry (fig. 2), despite the large distances involved and the dramatic increase in the thickness of Van Houten cycles. This correlation involves much more significant lateral facies change and some lateral change in the distribution of fossils as well; hence, it is not as secure as that within the Weehawken area or within the middle Lockatong in the Hunterdon Plateau. However, it may be possible to test the correlation by 


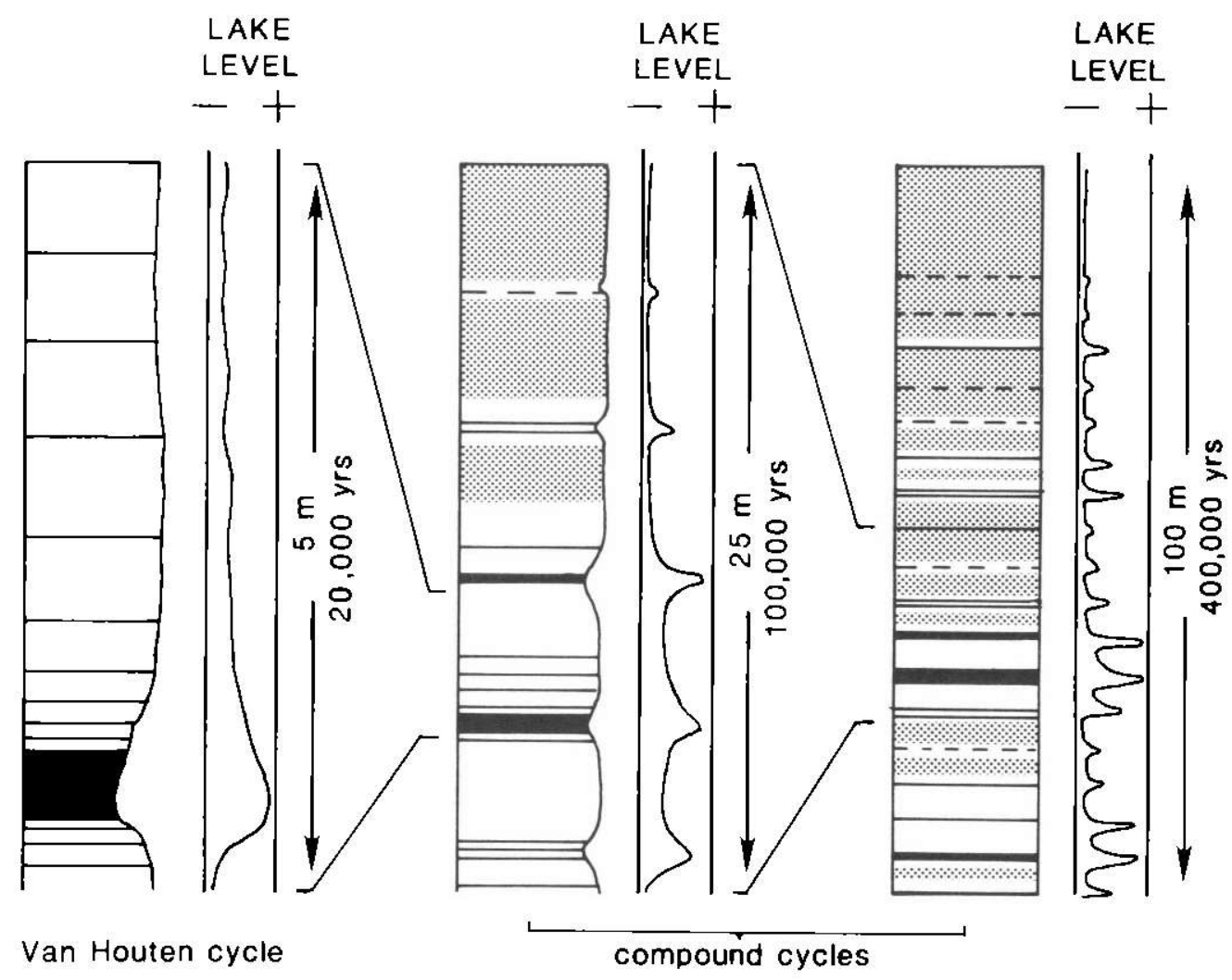

2nd order

3rd order

EXPLANATION

Black laminated siltstone

Gray massive mudstone with desiccation cracks

Red massive mudstone with desiccation cracks

Figure 4. Idealized Van Houten and compound cycles showing thickness for Lockatong Formation and general interpreted durations and relative lake levels.

magnetostratigraphy, because the lower Lockatong contains at least one reversed interval (W. Witte, personal commun.).

\section{PASSAIC FORMATION, NEWARK BASIN}

One of the most distinctive units mapped by McLaughlin $(1948,1959)$ in the lower Passaic Formation is the Perkasie Member (Johnson and McLaughlin, 1957). The Perkasie crops out extensively across the Hunterdon Plateau from a coarse-grained marginal facies at Milford, New Jersey, to a much finer grained facies exposed in Pennsylvania. In the Hunterdon Fault Block, the Perkasie Member consists of two second- order cycles, each containing two Van Houten cycles that have laminated black calcareous siltstones in division 2 . Exposures along strike of the mapped distribution of the Perkasie (figs. 1,2, and 7) show the same pattern of Van Houten cycles and compound cycles. One of the Van Houten cycles (shown in fig. 7) is unusually radioactive at all but the Milford outcrops.

A lithologically very similar sequence to the Perkasie Member occurs in the lower Passaic Formation at New Brunswick, New Jersey (fig. 7). The pattern of Van Houten cycles and compound cycles is the same as in the northwestern fault block. In addition, units lithologically similar to McLaughlin's members $\mathrm{K}, \mathrm{L}$, and $\mathrm{M}$ crop out within this New Brunswick section in the homotaxially 
Red / Gray Massive Mudstone

Red /Gray Sandstone

Fed / Gray Conglomerate

Red / Gray Poorly to WellBedded Siltstone

Red / Gray Platy to

Laminated Siltstone

Large Tilted Surfaces

i:3

Intraformational Conglomerate

Microlaminated Clay-Siltstone

Polded Beds

EFT Mud Cracks

侪 $\lambda$ Roots

Feptile Bones
A) Plams
(A) Follen Reptiles
(D) Fish Scraps
Clam Shrimp
Ostracodes

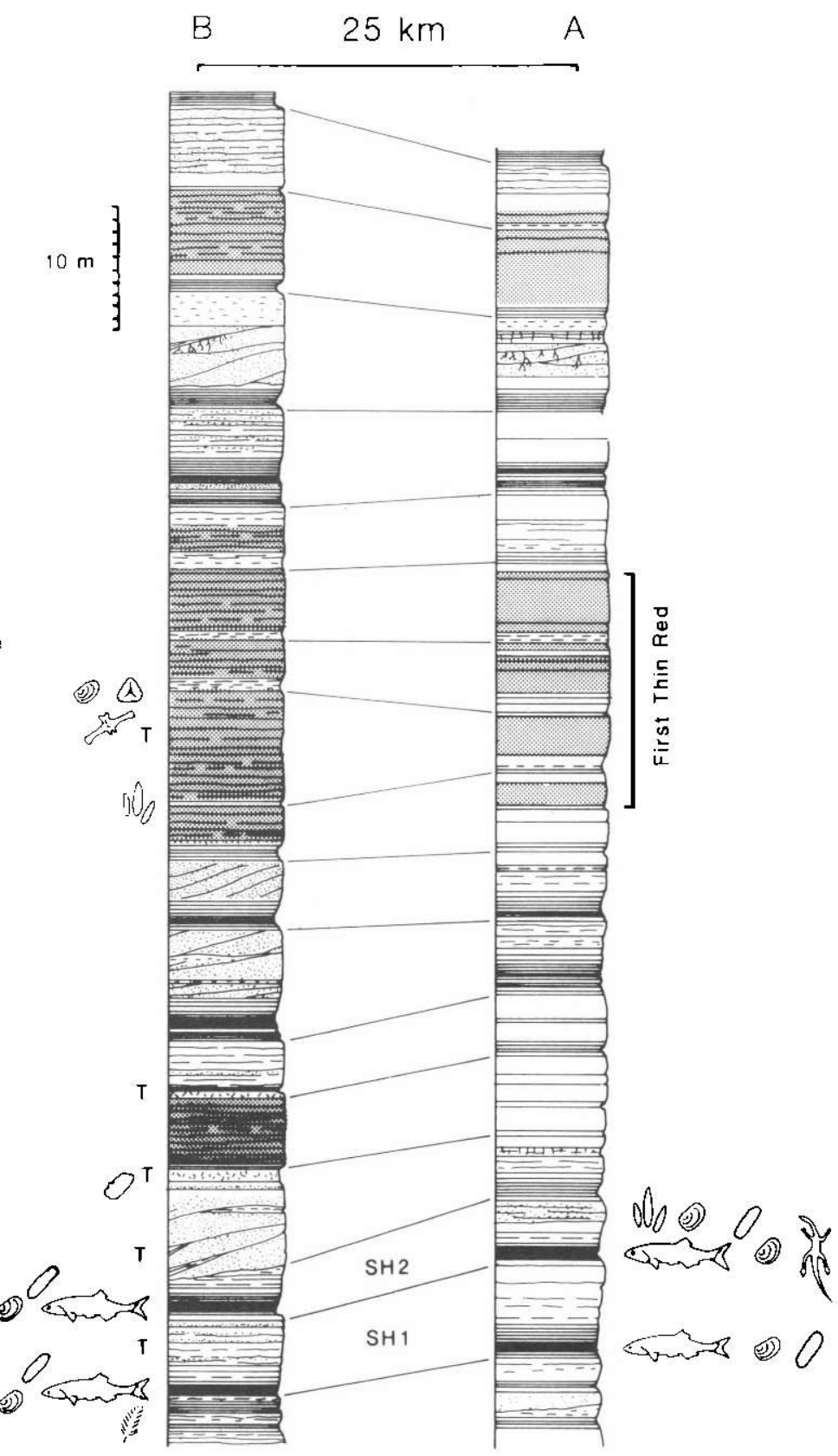

Figure 5. Comparison of sections of middle Lockatong Formation at Route 29 (A) and the Haines and Kibblehouse quarry (B) exposures. $\mathrm{SH} 1$ and $\mathrm{SH} 2$, two Van Houten cycles in which division 2 is a microlaminated fish-bearing unit; T, Turseodus.

appropriate section. McIntosh and others (1985) show the presence of a polarity boundary in the same relative position in both the New Brunswick outcrops and in the Perkasie Member. One black shale is strongly radioactive, and it occurs in the same relative position as well. In their 1985 paper, however, McIntosh and others do not correlate this New Brunswick unit with the Perkasie, as suggested by West (1980). Rather than accept their own magnetic data, they correlated this New Brunswick unit with McLaughlin's Graters Member of the northwestern fault block. This produced a mismatched magnetic stratigraphy. Correlated as in figure 7, both the magnetostratigraphy and the cycle stratigraphy match precisely over $60 \mathrm{~km}$ and provide a test of the match of cycles between three fault blocks that was first suggested by the lithologic pattern and stratigraphic position alone (Olsen, 1984a). This correlation is also consistent with all paleontologic data.

An outcrop near Furmans Corner in the central fault block lies geographically between the New Bruns- 


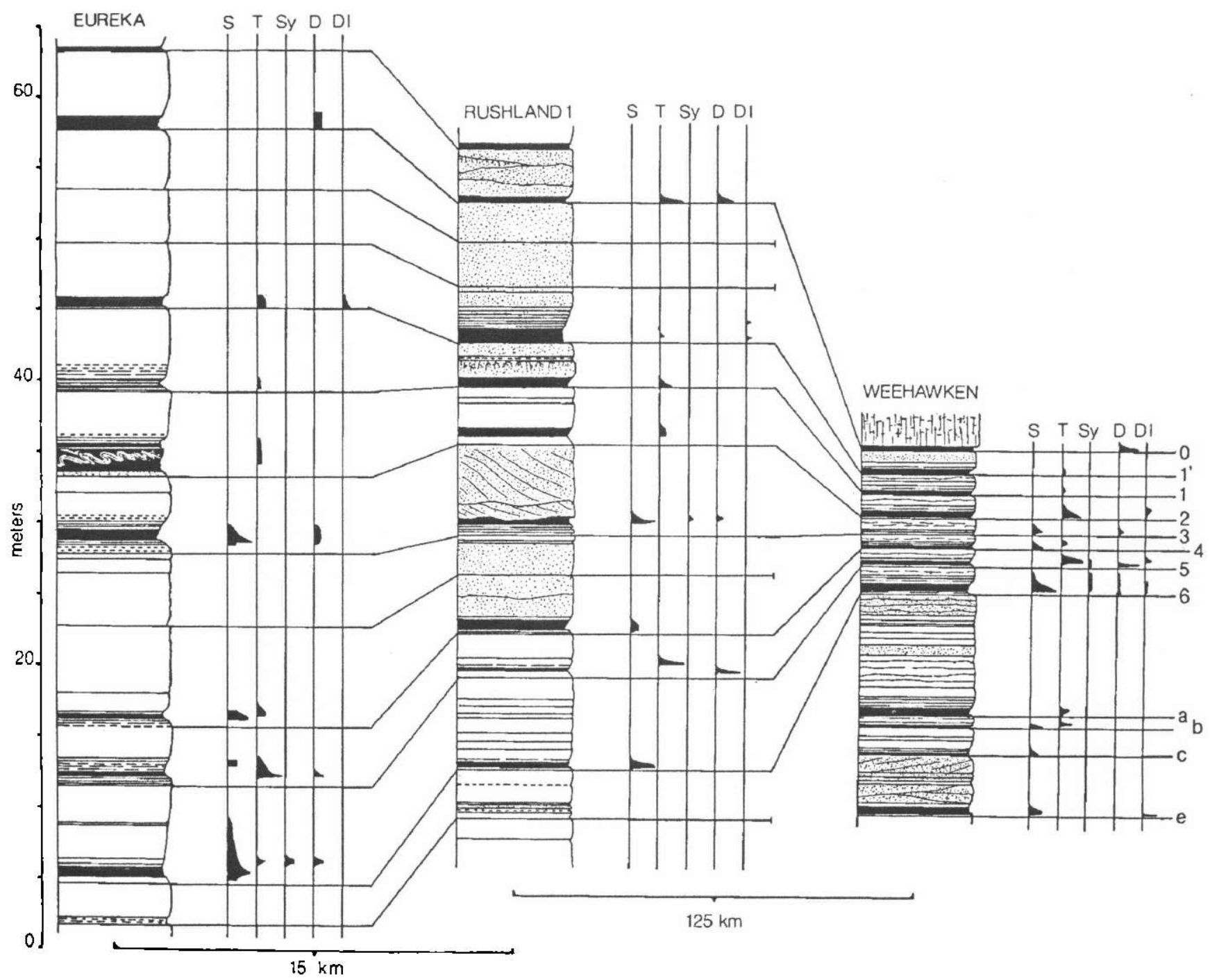

Figure 6. Correlation of Van Houten cycles, lower Lockatong Formation from Weehawken area across Newark basin. Cycle designations shown on right. Key to lithologic symbols in figure 5, and key to localities in figures 1 and 2 . Abbreviations of vertebrate taxa are D, Osteopleurus (Diplurus) newarki; DI, large coelacanth; S, Semionotus braunii; T, Turseodus, Sy, Synorichthys.

wick, New Jersey, area and the northwestern fault block (fig. 7). This outcrop shows the same pattern of Van Houten cycles and higher order cycles as seen in outcrops of the Perkasie Member and its hypothesized correlative in the New Brunswick area. Correlation of this unit with the Perkasie can now be tested by looking for the magnetostratigraphic boundary present in the other areas.

\section{EAST BERLIN FORMATION, HARTFORD BASIN}

The pattern of Van Houten cycles and higher order cycles in the Jurassic strata interbedded and overlying the extrusive basalt in the Newark basin (Olsen, 1986; 1987, unpub. data) corresponds with a nearly identical homotaxial pattern of cycles in the Jurassic syn- and postextrusive strata of the Hartford basin (Olsen and Fedosh, 1987, unpub. data). The East Berlin Formation (fig. 8) is the thicker and better exposed of the two syn-extrusive units in the Hartford basin.

Good outcrops of the East Berlin Formation occur in three areas in the Hartford basin (fig. 8). While no outcrops expose the entire formation, some do expose more than half the thickness, and it is possible to piece together adjacent outcrops and to build a local composite section by walking out single beds or matching beds over short, covered intervals. Analysis of the lateral continuity of cycles in the East Berlin Formation is aided by measuring down from the base of the Hampden Basalt and up from the top of the Holyoke Basalt (fig. 9). 

Milford N.J.
Harrow Pa.
Furmans
New Brunswick
Corner N.J.
N.J.
$16 \mathrm{~km}$
$35 \mathrm{~km}$
$20 \mathrm{~km}$

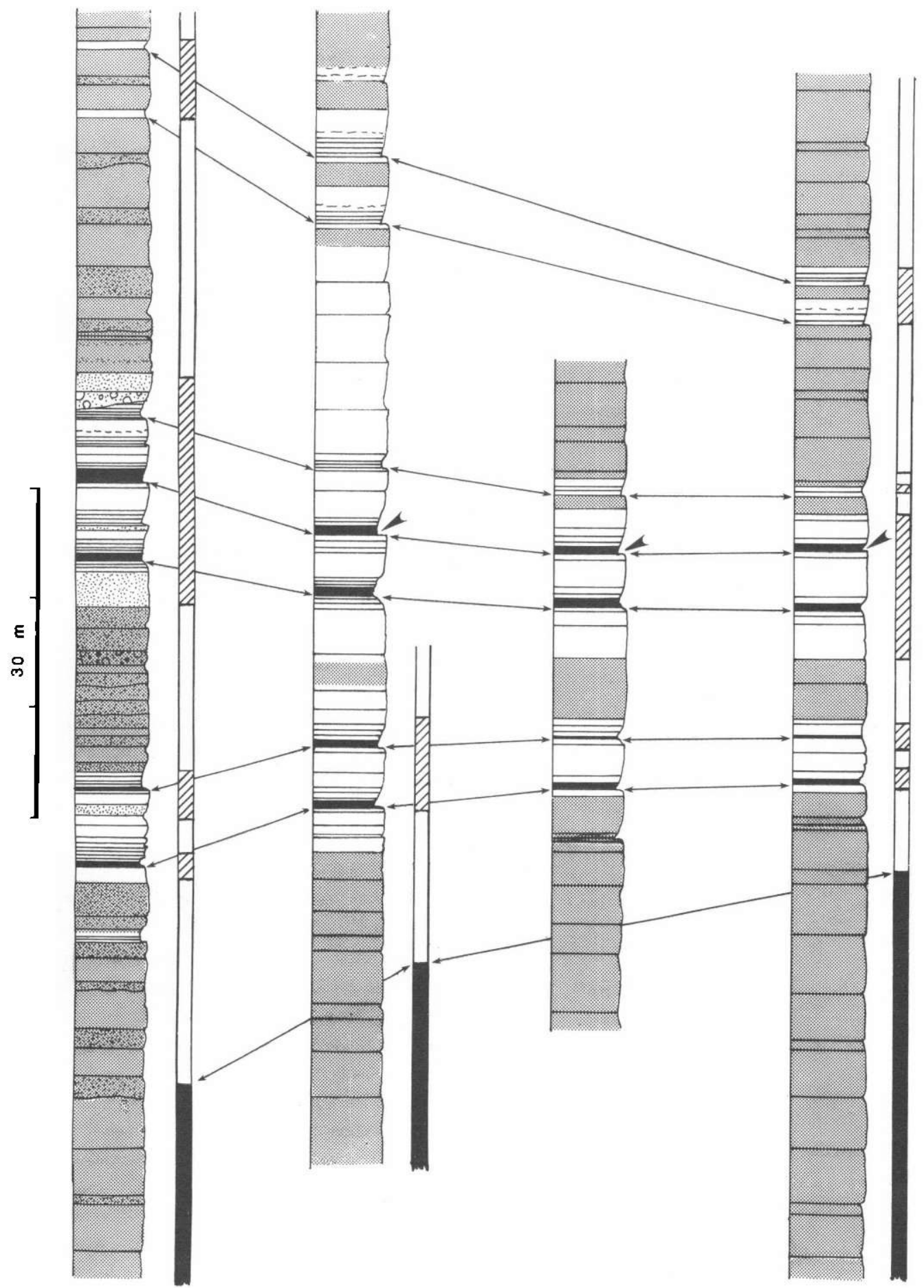

Figure 7. Lateral correlation of Perkasie Member of Passaic Formation across Newark basin and correlative magnetostratigraphy (magnetic polarity data from Mclntosh and others, 1985; Hargraves, personal commun.). Vertical black, white, and diagonally ruled bars represent normal, reversed, and uncertain polarity zones, respectively. Large chevrons denote unusually radioactive zones. Key to lithologic symbols in figure 5. 


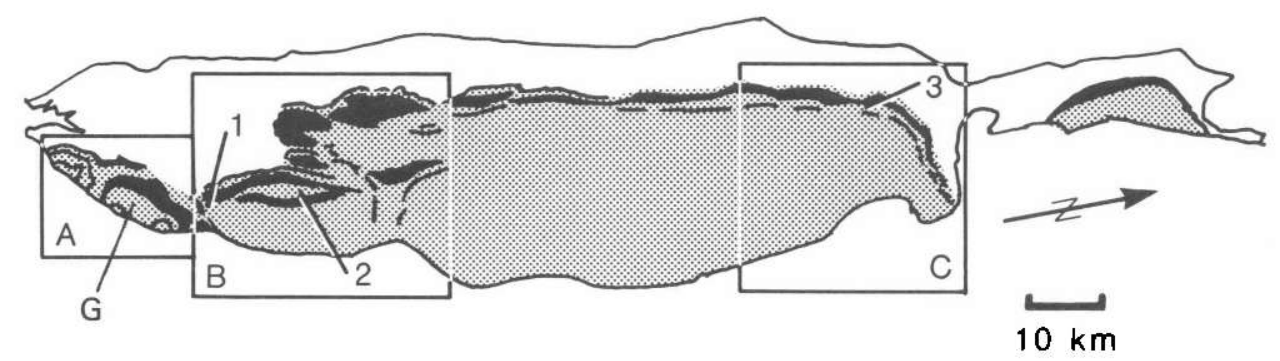

Figure 8. Map of the Hartford basin showing the main areas of exposure of the East Berlin Formation: $A$, southern area (Gaillard Syncline, labeled $G$ ); B, central area; $C$, northern area; 1, Parmele Brook exposures of Westfield Fish Bed, Durham, Connecticut; 2, Miner Brook exposures of Westfield

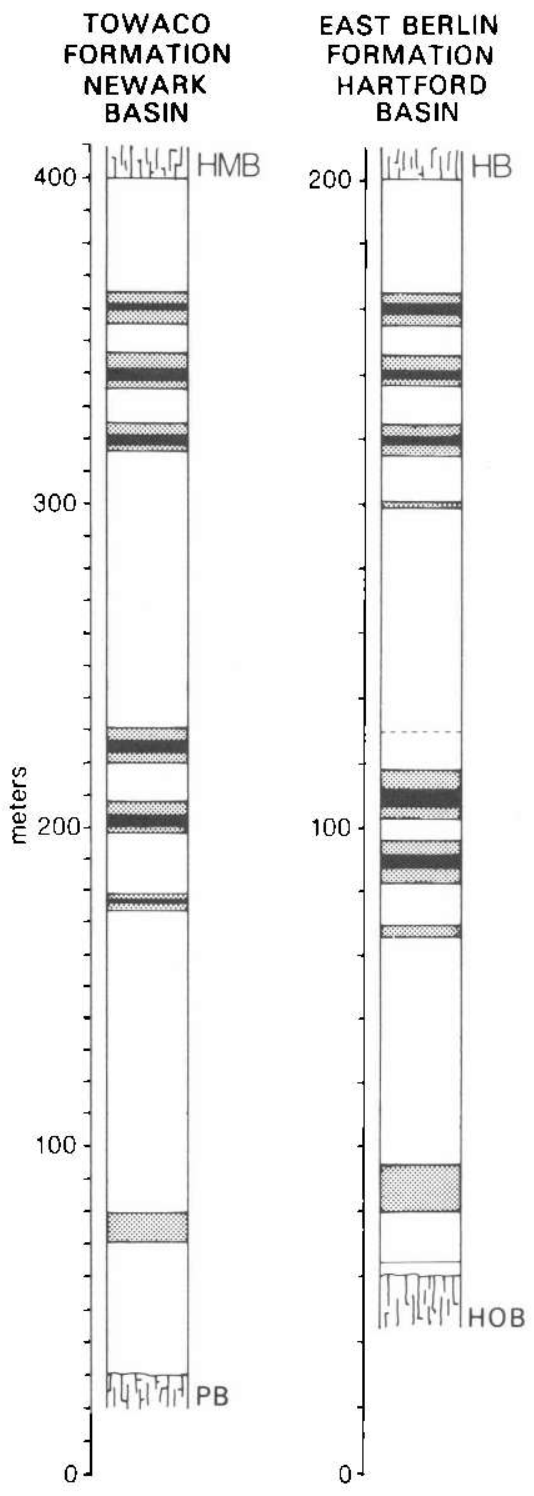

Fish Bed, Westfield Connecticut (Route 72 exposures are about $3.5 \mathrm{~km}$ northeast of this locality); 3, Mount Tom Area, Northampton, Massachusetts. Gray and black areas are Jurassic sedimentary rocks and extrusive basalts, respectively.

Figure 9. Composite sections of Towaco Formation of Newark basin and East Berlin Formation of Hartford basin showing homotaxial sequences of Van Houten cycles. Compare to figure 4. Key to lithologic symbols in figure 10 caption. Abbreviations: HMB, Hook Mountain Basalt; HB, Hampden Basalt; PB, Preakness Basalt; and HOB, Holyoke Basalt.

Klein (1968) was first to recognize the cyclic nature of the East Berlin. Transgressive-regressive cycles in the upper part of the East Berlin Formation were described by Hubert and others (1976), who proposed that the cycles could be traced basinwide. Additional descriptions have been supplied by Demicco and Kordesch (1986). The East Berlin cycles are Van Houten cycles. As is typical of the Newark Jurassic, the East Berlin cycles are generally 2 to 5 times thicker than the Triassic cycles in the Newark basin.

A cluster of three Van Houten cycles, each bearing a black microlaminated division 2 , occurs in good continuous outcrops at several localities in the central area of the Hartford basin and at one excellent exposure in the northern area (fig. 10) (Hubert and others, 1976). At the type section of the East Berlin Formation in the central area (Hubert and others, 1976), this cluster of cycles is underlain by about $45 \mathrm{~m}$ of red clastic strata (which in other areas show a vague cyclic pattern), which are in turn underlain by two Van Houten cycles, each having a microlaminated division 2 (fig. 11). These two cycles mark the middle of the East Berlin. Nearby, stream exposures show that the upper of these two Van Houten cycles is unique in the East Berlin by containing abundant whole fish (Semionotus, Redfieldius, and Diplurus) and abundant Cornia-type clam shrimp. This unit is traditionally termed the Westfield Fish Bed (Davis and Loper, 1898). Division 2 of the Westfield Fish Bed (figs. 11 and 12) has a distinctive graded bed interpreted as a lacustrine turbidite that, together with the microlaminae surrounding it, can be matched closely in outcrop over a distance of $18 \mathrm{~km}$ (fig. 12). The lower East Berlin 


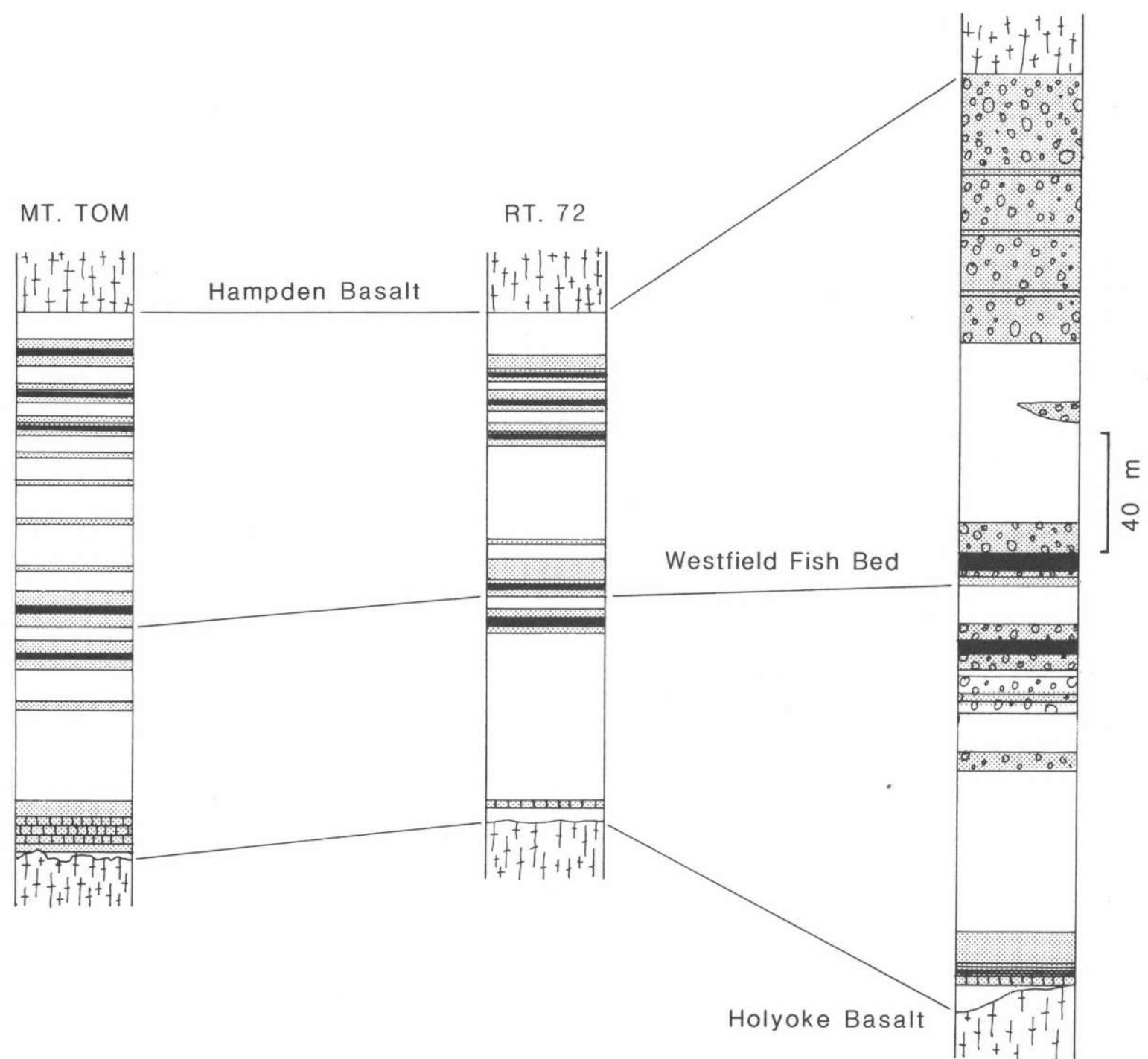

Figure 10. Correlation of Van Houten cycles of the East Berlin Formation from north (left) to south (right) across the Hartford basin. Lithologic symbols are: white, red clastics; black, microlaminated calcareous siltstone or limestone; gray, gray clastics; small circles, conglomerate; bricklike pattern, nonmicrolaminated limestone. Note that only Van Houten cycles having a black division 2 can be traced laterally with confidence.

Formation, in the central area, consists of a $60-\mathrm{m}$ red clastic sequence underlain by a limestone-rich Van Houten cycle that lacks a black, microlaminated division 2 . This limestone-rich cycle overlies a thin and variable sequence of red clastics overlying the Holyoke Basalt. These three clusters of Van Houten cycles define three second-order cycles, themselves demarcating threequarters of a third-order cycle (fig. 10).

In the northern area (fig. 8), the uppermost three Van Houten cycles and their match to the cycles in the central area have already been described by Hubert and others (1976). The two middle Van Houten cycles also have counterparts in the northern region with the upper cycle matching the Westfield Fish Bed in faunal content and details of lithology (figs. 10 and 12). Likewise, the basal limestone-bearing cycle is very well developed, locally serving as a source of cement during the last century (Hitchcock, 1858).

In the southern area, the thickness of the East Berlin Formation is about double that in the central area, and the constituent Van Houten cycles are roughly twice as thick. The units that are believed to be correlated to the upper three cycles consist of gray shales surrounded by coarse conglomerate. The middle two cycles are exposed in a number of areas, and the upper of these contains a fauna characteristic of the Westfield Fish Bed. 

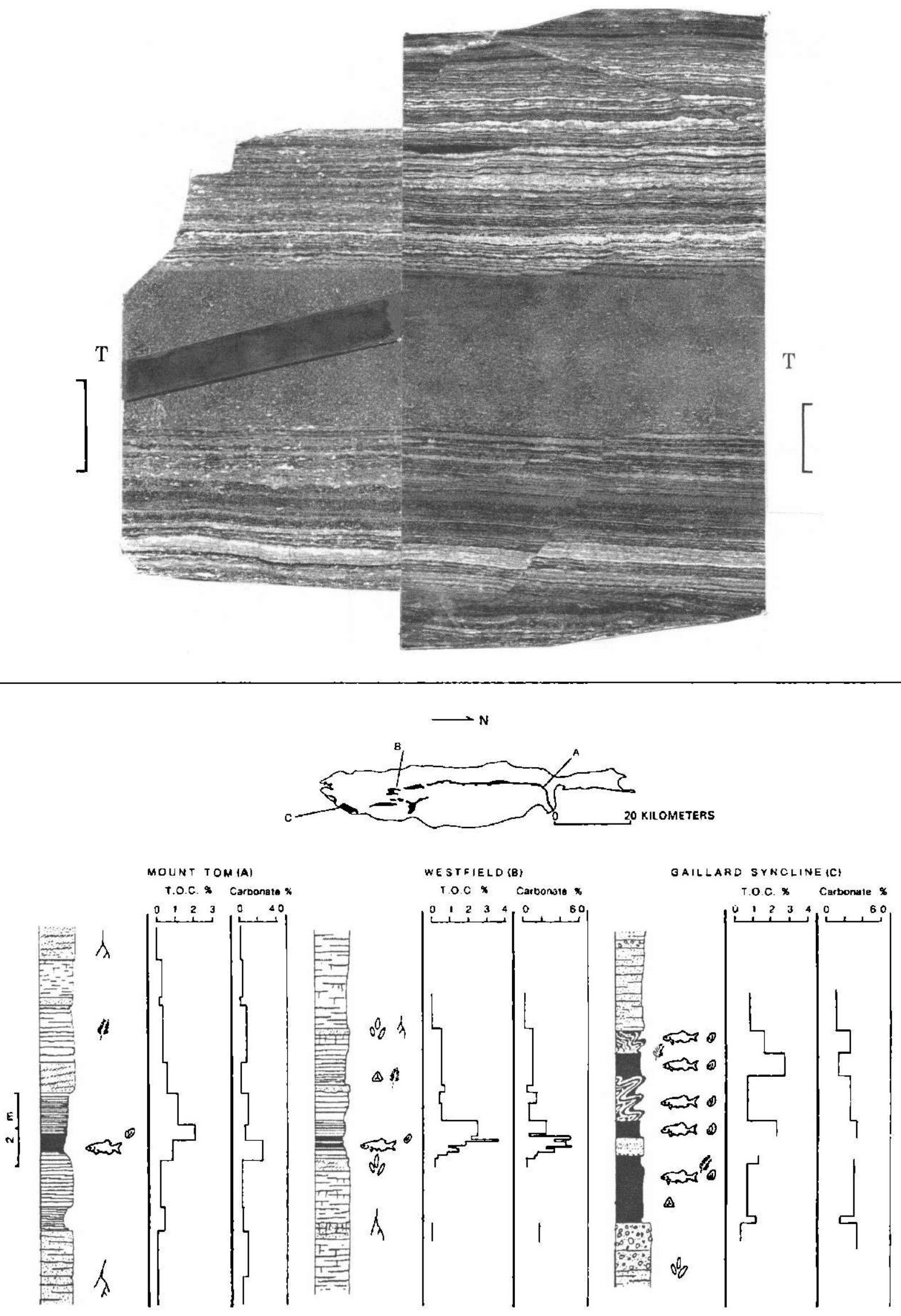
Figure 11. Comparison of portion of microlaminated units from the Westfield Fish Bed from Stevens locality on Parmele Brook, Durham, Connecticut (right), and Westfield locality on Miner Brook, Westfield, Connecticut (left). $T$ marks lacustrine turbidite. Scale bar is $1 \mathrm{~cm}$; note difference in magnification. Black diagonal bar in turbidite on left reflects amount turbidite must be expanded in order for the microlaminae to match. This reflects a greater amount of thinning of the turbidite relative to the microlaminae over the same distance. Localities shown in figure 8.

The microlaminated unit is, however, over eight times as thick as in the more northern exposures (fig. 12). This local expression of the Westfield Fish Bed is the unit described by Thorpe (1929). The lowest limestonedominated cycle is especially well exposed.

\section{LATERAL CONTINUITY BETWEEN THE NEWARK AND HARTFORD BASINS}

The remarkable match between the Van Houten cycles of the strata interbedded with the basalt flows of the Hartford and Newark basins does not necessarily imply former lateral continuity between the two basins as in the Broad Terrane Hypothesis of Russell (1880) and Sanders (1963). This is because the fish assemblages in homotaxial cycles are very different in the two basins (Olsen, 1983, 1984a). The lakes within the two basins were thus not connected, and the homotaxial Van Houten cycles could not have been physically continuous between the basins. This suggests a regional control of the cyclicity, such as periodic climate change, which has already been invoked as the cause of Van Houten cycles and the compound cycles (Van Houten, 1969; Olsen, 1984a,b; unpub. data, 1987), in accord with the orbital theory of climate change.

\section{IMPLICATIONS}

Understanding the lateral continuity of Van Houten cycles is vital to a number of major concepts including (1) the use of Van Houten cycles and compound cycles as time-stratigraphic markers for stratigraphic and structural studies (Olsen, 1985a), (2) the interpretation that these cycles represent basinwide lake-level cycles controlled by climatic cycles imposed by variations in the Earth's orbit, (3) the interpretations of the size and metabolism of Newark Supergroup lakes (Olsen, 1982, $1985 \mathrm{~b}, \mathrm{c})$, and (4) the use of the Newark Supergroup as a

Figure 12. Comparison of sections of the Westfield Fish Bed from the three major exposures (fig. 10) (from Olsen, 1984a). Key to lithologic and paleontologic symbols in figure 5. Scale bar in map inset is $20 \mathrm{~km}$; T.O.C., total organic carbon. standard for calibrating early Mesozoic time. Knowledge of the physical stratigraphy of the Newark sequences permits the development of higher order interpretations. No doubt, McLaughlin would have been pleased to see the developing connection between his two seemingly disparate areas of inquiry: physical stratigraphy and astronomy.

\section{REFERENCES CITED}

Cisne, J.L., and Rabe, B.D., 1978, Coenocorrelation: Gradient analysis of fossil communities and its applications in stratigraphy: Lethaia, v. 11, p. 341-364.

Davis, W.M., and Loper, S.W., 1898, Two belts of fossiliferous black shale in the Triassic formation of Connecticut: Geological Society of America Bulletin, v. 2, p. 415-430.

Demicco, R.V., and Kordesch, E.G., 1986, Facies sequences of a semi-arid closed basin: The Lower Jurassic East Berlin Formation of the Hartford basin, New England, U.S.A.: Sedimentology, v. 33, p. 107-118.

Froelich, A.J., and Olsen, P.E., 1984, Newark Supergroup, a revision of the Newark Group in eastern North America, in Stratigraphic notes, 1983: United States Geologica] Survey Bulletin 1537-A, p. A55-A58.

Hitchcock, E., 1858, Ichnology of New England, a report on the sandstone of the Connecticut Valley, especially its footmarks: Boston, Massachusetts, v. 1-4, 220 p.

Hoffman, A., 1981, The ecostratigraphic paradigm: Lethaia, v. 14 , no. 1, p. 1-7.

Hubert, J.H., Reed, A.A., and Carey, P.J., 1976, Paleogeography of the East Berlin Formation, Newark Group, Connecticut Valley: American Journal of Science, v. 276, p. 1183-1207.

Johnson, M.E., and McLaughlin, D.B., 1957, Triassic formations in the Delaware Valley, in Dorf, E., ed., Guidebook for field trips, Atlantic City meeting: Geological Society of America Guidebook Series, p. 31-56.

Klein, G. deV., 1968, Sedimentology of Triassic rocks in the lower Connecticut Valley, in Orville, P.M., ed., New England Intercollegiate Geological Conference, 60th Annual Meeting, New Haven, Connecticut, Oct. 25-27, 1968, Guidebook for field trips in Connecticut: Connecticut Geological and Natural History Survey, Guidebook 2, trip C-1, p. 1-19.

Kummel, H.E., 1897, The Newark System, report of progress: New Jersey State Geologist, Annual Report, 1896, p. 25-88.

McIntosh, W.C., Hargraves, R.B., and West, C.L., 1985, Paleomagnetism and oxide mineralogy of Upper Triassic to Lower Jurassic red beds and basalts in the Newark basin of New Jersey and Pennsylvania: Geological Society of America Bulletin, v. 96, p. 463-480.

McLaughlin, D.B., 1943, The Revere Well and Triassic stratigraphy: Proceedings of the Pennsylvania Academy of Science, v. 17 , p. 104-110. 
1944, Triassic stratigraphy in the Point Pleasant District, Pennsylvania: Proceedings of the Pennsylvania Academy of Science, v. 18, p. 62-69.

1945, The type sections of the Stockton and Lockatong formations: Proceedings of the Pennsylvania Academy of Science, v. 19, p. 102-113.

1946, The Triassic rocks of the Hunterdon Plateau, New Jersey: Proceedings of the Pennsylvania Academy of Science, v. 20, p. 89-93.

1948 , Continuity of strata in the Newark Series: Papers of the Michigan Academy of Science, 1946: Arts and Letters, v. 32, p. 295-303.

1959, Chapter IV: Mesozoic rocks, in Willard, Bradford, ed., Geology and Mineral Resources of Bucks County Pennsylvania: Pennsylvania Geological Survey Bulletin C9, p. 55-114.

Olsen, P.E., 1980a, The latest Triassic and Early Jurassic formations of the Newark basin (Eastern North America, Newark Supergroup): Stratigraphy, structure, and correlation: New Jersey Academy of Science Bulletin, v. 25, p. 25-51.

1980b, Triassic and Jurassic formations of the Newark basin, in Manspeizer, Warren, ed., Field studies in New Jersey geology and guide to field trips, 52d Annual Meeting of the New York State Geological Association, Newark College of Arts and Sciences: Newark, Rutgers University, p. 2-39.

1980c, Fossil great lakes of the Newark Supergroup in New Jersey, in Manspeizer, Warren, ed., Field studies in New Jersey geology and guide to field trips, 52d Annual Meeting of the New York State Geological Association, Newark College of Arts and Sciences: Newark, Rutgers University, p. 352-398.

1982, Lockatong Formation detrital cycles (Late Triassic, Newark basin, New Jersey and Pennsylvania), giant lakes, and ecosystem efficiency: Geological Society of America Abstracts with Programs, v. 14, no. 1-2, p. 70.

1983, On the non-correlation of Newark Supergroup by fossil fishes: Geological Society of America Abstracts with Programs, v. 15, no. 2, p. 121.

1984a, Comparative paleolimnology of the Newark Supergroup: A study of ecosystem evolution: unpublished Ph.D. thesis, Biology Department, Yale University, 726 p. 1984b, Periodicity of lake-level cycles in the Late Triassic Lockatong Formation of the Newark basin (Newark Supergroup, New Jersey and Pennsylvania), in Berger, A., and others, eds., Milankovitch and Climate, NATO Symposium: D. Reidel Publishing Co., pt.1, p. 129-146.

1985a, Significance of the great lateral extent of thin units in the Newark Supergroup (Early Mesozoic, Eastern North America) (abs.): American Association of Petroleum Geologists Bulletin, v. 69, p. 1444.
$-1985 \mathrm{~b}$, Constraints on the formation of lacustrine microlaminated sediments, in Robinson, G.R., Jr., and Froelich, A.J., Proceedings of the second U.S. Geological Survey workshop on the early Mesozoic basins of the Eastern United States: United States Geological Survey Circular 946 , p. 34-35.

-1985c, Distribution of organic-matter-rich lacustrine rocks in the early Mesozoic Newark Supergroup, in Robinson, G.R., Jr., and Froelich, A.J., Proceedings of the second U.S. Geological Survey workshop on the early Mesozoic basins of the Eastern United States: United States Geological Survey, Circular 946, p. 61-64.

-1986, A 40-million year lake record of orbital climatic forcing: Science, v. 234, p. 842-847.

Olsen, P.E., and Flynn, J., in press, Field guide to the vertebrate paleontology of Late Triassic rocks in the southwestern Newark basin (Newark Supergroup, New Jersey and Pennsylvania): The Mosasaur.

Russell, I.C., 1880, On the former extent of the Triassic formations of Atlantic States: American Naturalist, v. 14, p. 703-712.

Sanders, J.S., 1963, Late Triassic history of the northeastern United States: American Journal of Science, v. 261, p. 501-524.

Smoot, J.P., and Katz, S.B., 1982, Comparison of modern playa mudflat fabrics to cycles in the Triassic Lockatong Formation of New Jersey: Geological Society of America Abstracts with Programs, 1982 northeastern and southeastern combined section meetings, March 25-27: Washington, D.C., p. 83.

Thorpe, M.R., 1929, A new Triassic fossil field: American Journal of Science, 5 th ser., v. 18, p. 277-306.

Van Houten, F.B., 1964, Cyclic lacustrine sedimentation, Upper Triassic Lockatong Formation, central New Jersey and adjacent Pennsylvania: Geological Survey of Kansas Bulletin, no. 169 , p. 497-531.

1969, Late Triassic Newark Group, north-central New Jersey, and adjacent Pennsylvania and New York, in Subitzky, S.S., ed., Geology of selected areas in New Jersey and eastern Pennsylvania and guidebook of excursions, Geological Society of America and associated societies annual meeting, Atlantic City, New Jersey: New Brunswick, Rutgers University Press, p. 314-347.

1980, Late Triassic part of the Newark Supergroup, Delaware River Section, west-central New Jersey, in Manspeizer, Warren, ed., Field studies in New Jersey geology and guide to field trips, 52d Annual Meeting of the New York State Geological Association, Newark College of Arts and Sciences: Newark, Rutgers University, p. 264-276.

West, C., 1980, Paleomagnetic stratigraphy of the Brunswick formation near New Brunswick, New Jersey: Junior project, Geology Department, Princeton University, 42 p. 


\title{
A CORED STRATIGRAPHIC SECTION THROUGH THE NORTHERN NEWARK BASIN, NEW JERSEY
}

\author{
Michael S. Fedosh ${ }^{1}$ and Joseph P. Smoot
}

\begin{abstract}
A series of core holes recently drilled by the U.S. Army Corps of Engineers in northern New Jersey provides a nearly continuous section of the upper part of the Newark Supergroup. A total of $1,650 \mathrm{~m}$ of Late Triassic to Jurassic section were cored representing four sedimentary formations separated by three Jurassic tholeiitic basalt formations. The Orange Mountain Basalt, Preakness Basalt, and Hook Mountain Basalt are each made up of two or more subaerial flows that have possible paleosols at their upper boundaries. The Passaic Formation is predominately coarse sandstone and conglomerate comprising graded sequences indicative of deposition by shallow ephemeral streams or deep flash. flooding rivers. The Feltville, Towaco, and Boonton Formations are dominated by ripple cross-laminated sandstone and siltstone and have interbedded black shales and gray siltstones. These deposits reflect a fluctuation between fluvial and lacustrine depositional environments. The differences between the sedimentary formations may in part be due to changes in climate or tectonic adjustments to basin drainage or both.
\end{abstract}

\section{INTRODUCTION}

The U.S. Army Corps of Engineers has proposed a flood diversion tunnel for the Passaic River basin in northern New Jersey. This tunnel, about $22 \mathrm{~km}$ long, is to be entirely within nonmarine Mesozoic rocks of the Newark basin and will trend across the regional northeast strike (fig. 1). Continuous rock cores, ranging from 18 to $141 \mathrm{~m}$ long, were recovered from 27 vertical holes drilled in 1985 and 1986 and from 5 older holes scattered along the tunnel alignment. These holes were drilled primarily to examine the engineering qualities of the rock. The close spacing of the holes provides stratigraphic overlap of the gently northwest-dipping beds, enabling precise correlation of strata in adjacent holes in most instances. Geophysical logs provided by the U.S. Geological Survey support the stratigraphic correlation and were especially helpful where visual correlation was difficult. This correlation provides the first relatively complete stratigraphic section of the Jurassic rocks of the northern Newark basin.

The thickness of the Mesozoic succession in the northern Newark basin is approximately $5,000 \mathrm{~m}$ from the base of the Stockton Formation to the eroded top of the Boonton Formation (fig. 2). The proposed tunnel

\footnotetext{
${ }^{1}$ U.S. Army Corps of Engineers, 26 Federal Plaza, New York, NY 10278.
}

Table 1. Length of core recovered from each drill hole

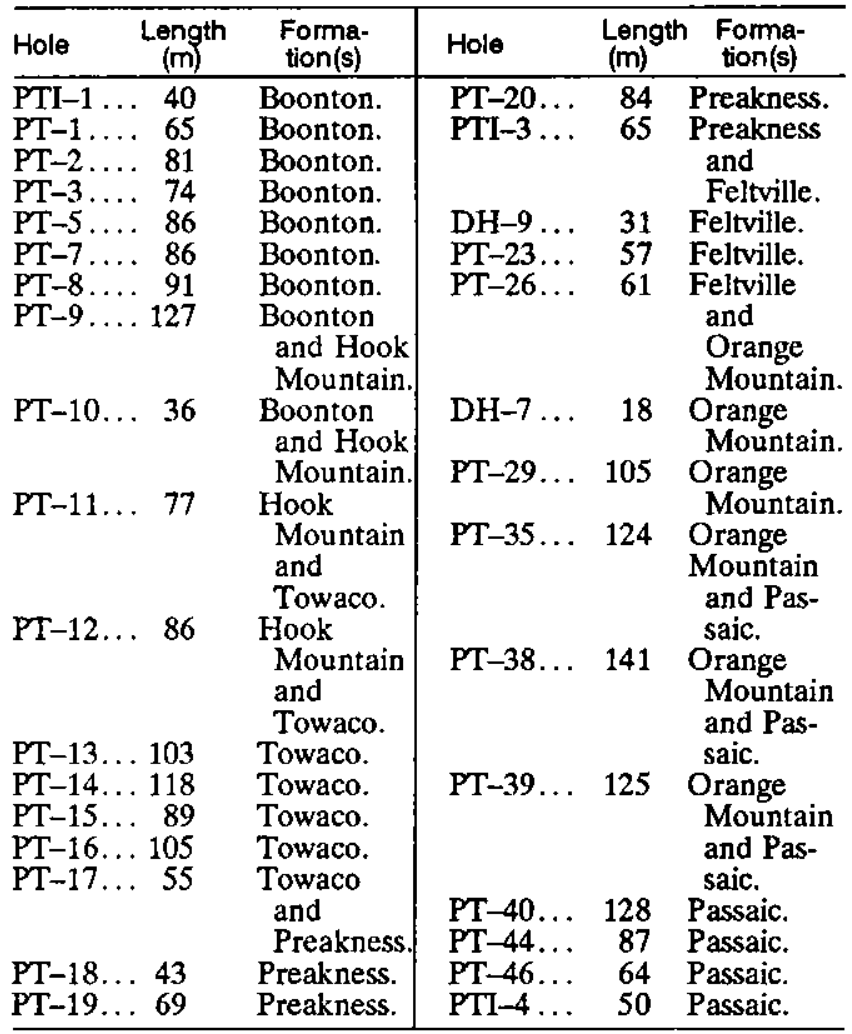

would cut through about $2,400 \mathrm{~m}$ of strata from the upper part of the Passaic Formation through the lower half of the Boonton Formation (fig. 2). Recovery of 2,571 $\mathrm{m}$ of rock core represents about $1,650 \mathrm{~m}$ of stratigraphic section (table 1), most of which is Lower Jurassic. Several cores that were taken along strike in the Boonton Formation show lateral facies changes in the same stratigraphic units. Older Passaic strata along the projected tunnel route will be cored in future programs.

Most of the sedimentary portions of the cores are red sandstone, a smaller component of red siltstone and mudstone, and minor amounts of black shale, gray mudstone, and red conglomerate. The portions of the Passaic Formation that were cored differ from the overlying strata by being more coarse grained, by having poorly preserved internal stratification, and by lacking black shale and gray mudstone. The Feltville, Towaco, and Boonton Formations are dominated by ripple crosslaminated sandstone and siltstone with distinct black shale and gray mudstone units at intervals of 12 to $60 \mathrm{~m}$. 


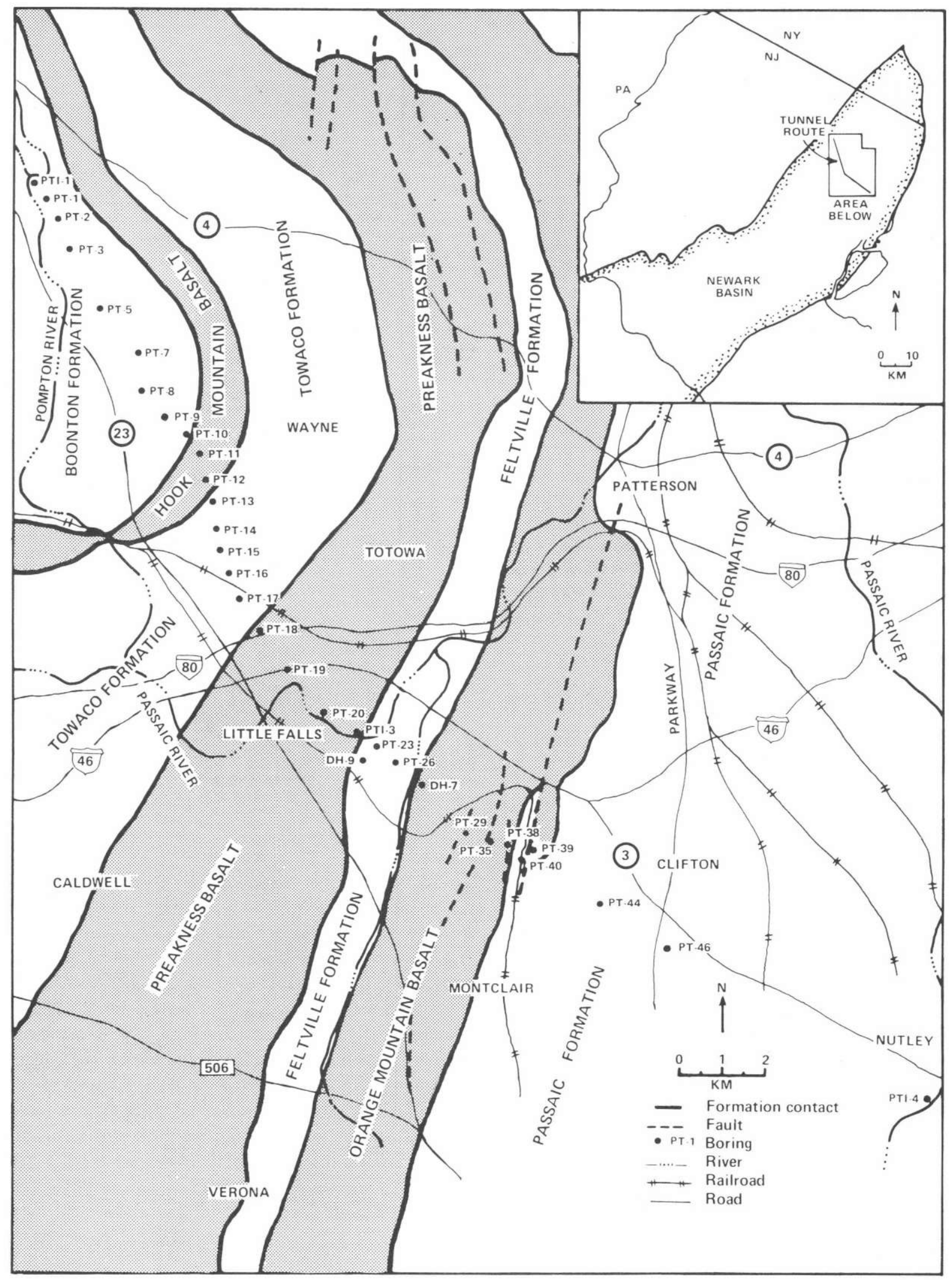

Figure 1. Geology along the proposed tunnel route (stratigraphy from Olsen, 1980a). 

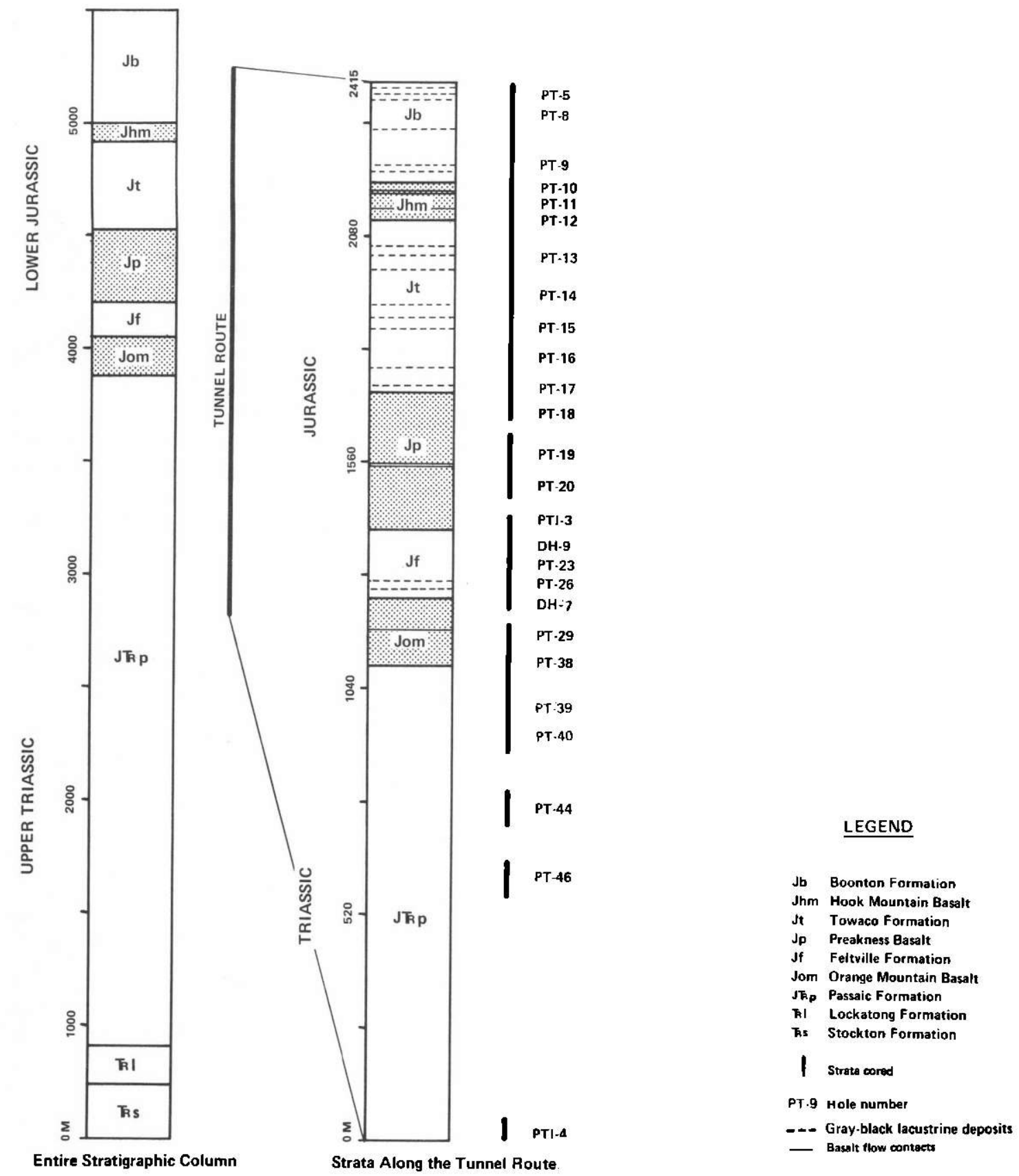

Figure 2. Stratigraphic column of the northern Newark basin showing strata cored (modified from Olsen, 1980a).

Although these formations are lithologically similar, each has characteristic sedimentary packages different from the others. Each of the basalt formations is composed of two or more extrusive flows whose tops are delineated by zones of vesicles and possible soil horizons. The basalts contain abundant zeolites along faults and minor fractures and within vesicles.

\section{CORE DESCRIPTIONS BY FORMATION}

\section{Passaic Formation}

The Passaic Formation was drilled discontinuously to a stratigraphic level about $1,100 \mathrm{~m}$ below the Orange 
Mountain Basalt (fig. 2). Only $430 \mathrm{~m}$ of core were collected, including $190 \mathrm{~m}$ of continuous section at the top of the formation. The general sedimentary style consists of irregularly spaced, 0.3 - to 5.0-m-thick, graded sequences. Each sequence ranges in grain size from pebbly sandstone that grades upward into mediumgrained sandstone to muddy sandstone that grades upward into muddy siltstone. Vertical successions of several of these graded sequences appear to define 15- to 25-m-thick fining-upward packages, consisting of sandstone beds with pebbles of limestone and quartz at the base, and muddy siltstones with carbonate nodules at the top. All of the strata are bioturbated and stratification is generally poorly preserved. Decimeter-scale cross-beds are visible in some sandstone beds, and a few thin beds of interlaminated mudstone and fine-grained sandstone occur near the tops of the large-scale fining-upward packages. The bioturbation includes root casts and burrows, in particular Scoyenia (Olsen, 1980b). Mudcracks and small scours are present in the laminated portions of the cores.

The Passaic deposits are probably fluvial in origin, but it is not clear whether the small-scale graded sequences represent channel deposits of small braided streams, or if they are sections through large trough cross-beds within 15- to 25 -m-thick channel-fill or point bar deposits of large rivers.

\section{Orange Mountain Basalt}

The lower $100 \mathrm{~m}$ and the upper $20 \mathrm{~m}$ of the 180-m-thick Orange Mountain Basalt were cored (fig. 2). At least two tholeiitic basalt flows are separated by a thick vesicular zone, with the lower flow being $71 \mathrm{~m}$ thick. The bottom meter of the lower flow exhibits pillow structures indicative of deposition into standing water, perhaps a shallow lake. The top of the second flow consists of vesicular basalt capped by a brown, weathered basalt, which may be a paleosol.

\section{Feltville Formation}

The entire $155 \mathrm{~m}$ of the Feltville Formation were cored (fig. 2). Two calcareous, black, laminated shales, each about $2 \mathrm{~m}$ thick, separated by about $20 \mathrm{~m}$ of predominately gray sandstone, siltstone, and mudstone, occur about $20 \mathrm{~m}$ above the basal contact. This sequence is equivalent to the informal Washington Valley member of Olsen (1980b). The bulk of the Feltville consists of alternations of red sandstone and muddy siltstone to silty mudstone. The sandstones form 1- to 4-m-thick finingupward sequences. The thickest sequences have crossbedded (10-20-cm-thick sets), coarse-grained sandstone overlying a sharp basal contact. The coarse-grained sand- stone grades upward into medium- to fine-grained sandstone with low-angle, climbing-ripple cross-lamination, which grades into rippled to flat-laminated siltstone. This, in turn, grades upward into bioturbated muddy siltstone, which may have claystone partings or, more typically, is massive. Thinner fining-upward sequences are composed of medium- to fine-grained sandstone with abundant low-angle, climbing-ripple cross-laminae. The muddy siltstone and silty mudstone layers are typically massive to poorly bedded with abundant root casts, burrows (although Scoyenia-like burrows occur only in a few zones), and carbonate nodules. Mud cracks are common in the upper portions of mudstone layers and mud clasts are common in the overlying sandstones. Coarsening-upward sequences 10 to $30 \mathrm{~m}$ thick are suggested by vertical changes from predominately mudstone and siltstone to increasingly thicker and more closely spaced fining-upward sandstone sequences.

The sedimentary structures in the Feltville indicate primarily fluvial deposition in low-gradient, meandering or anastomosing streams with crevasse-splay overbank deposits. The black shales of the Washington Valley member indicate relatively deep lake conditions and the gray siltstones were deposited in shallower water. The overlying rippled sandstones are probably deltaic. The lower portions of the coarsening-upward sequences may represent delta front or distributary deposits in shallow lakes.

\section{Preakness Basalt}

The Preakness Basalt was cored discontinuously, recovering $259 \mathrm{~m}$ of its $310-\mathrm{m}$ thickness (fig. 2). It contains at least five tholeiitic basalt flows, two of which are separated by $3 \mathrm{~m}$ of fine-grained sandstone and siltstone, the latter apparently defining a fluvial, finingupward sequence. The 145-m-thick basalt below the sedimentary layer has coarsely crystalline gabbroic layers as much as $11 \mathrm{~m}$ thick. The upper basalt unit also contains gabbroic layers, but they are less than $8 \mathrm{~cm}$ thick. The coarsely crystalline layers may represent pockets of slowly cooled lava, segregation veins, or intrusive layers.

\section{Towaco Formation}

The entire $380 \mathrm{~m}$ of the Towaco Formation were cored (fig. 2). The Towaco resembles the Feltville, except that it has eight black calcareous laminated shales, which are generally thicker (3-5 m) than those of the Feltville, and has sandstones that are typically more fine grained (medium- to fine-grained sandstone). The black laminites commonly grade both upward and downward into gray bioturbated silty mudstone and sandstone. Red sandstones form 1- to 3-m-thick fining-upward sequen- 
ces, typically consisting of a basal medium-grained sandstone with low-angle, climbing-ripple cross-lamination grading to fine-grained sandstone having high-angle, climbing-ripple cross-lamination. The top of each graded sequence consists of flat-laminated to massive bioturbated siltstone. Soft-sediment deformation structures are common in the sandstones, including load casts, pseudonodules, oversteepened cross-laminae, and small faults. Scoyenia-like burrows are present, but root casts and other small burrows are more abundant. Mud cracks occur irregularly throughout the section in red mudstones but are less common than soft-sediment deformation. Sandstones overlying mud-cracked mudstones are typically rich in mud clasts and fill irregular scour pockets.

The black laminites are interpreted as deep lake deposits which grade into bioturbated siltstones that were deposited in shallow water. The rise and fall of lake levels was apparently in response to cyclic climatic variations (Olsen, 1986). The climbing ripples in graded sandstone sequences suggest pulses of deposition in standing water. These features and the abundance of soft-sediment deformation structures are similar to the deposits of shallow water deltas described by Smoot and others (1985). Some of the sandstone packages represent small stream deposits, and the mud cracks indicate sporadic subaerial exposure.

\section{Hook Mountain Basalt}

The entire $85 \mathrm{~m}$ of the Hook Mountain Basalt were cored (fig. 2). It consists of at least four tholeiitic basalt flow units, which are, from base to top, 29, 35, 3, and 18 $m$ thick. The top of each flow unit has brown brecciated basalt grading down into a thin vesicular layer. The brown brecciated layers are interpreted as paleosols developed on the basalt flows.

\section{Boonton Formation}

Approximately $272 \mathrm{~m}$ of continuous section were cored in the lower part of the 500-m-thick Boonton Formation (fig. 2). Six 3- to 5-m-thick, black, laminated calcareous shales that grade into gray siltstones are rhythmically distributed through the dominant red sandstones and mudstones. The shale sequences are very similar to those of the Towaco Formation. The sandstone-mudstone red-bed units are more similar to those of the Feltville, although the bases of some finingupward sequences contain limestone pebble conglomerates. Evaporite crystal molds were observed in one shale unit near the base of the Boonton, and several red silty mudstone layers have possible sand-patch fabric (Smoot and Olsen, 1985).
The similarities to the Towaco Formation suggest that the Boonton had similar, climatically induced lake level fluctuations. The fluvial deposits, similar to those in the Feltville, may differ from the predominately deltaic Towaco sandstones because the area cored in the Boonton is closer to the basin margin or because channeled areas were not crossed in the Towaco core transect. It could also indicate that longer periods of dryness followed lake regressions in the Boonton, allowing stream channel systems to develop over the old lake bottom. Arid evaporitic conditions for at least part of the lower Boonton accumulation are suggested by the evaporite pseudomorphs and are supported by the possible sandpatch fabric, which is produced by sediment accumulation on an efflorescent salt-encrusted surface.

\section{CONCLUSIONS}

The cored section of the Passaic Formation indicates depositional conditions considerably different from the sections cored through the younger sedimentary deposits. The coarser grain size of the Passaic suggests that stream gradients were steeper than those during deposition of the Feltville, Towaco, and Boonton Formations. The Passaic was deposited either by a complex of small braided streams or by larger rivers than those that deposited the younger formations. The black shale and gray siltstone sequences in the Feltville, Towaco, and Boonton Formations were deposited in lakes whose levels fluctuated, apparently in response to cyclic climatic variations (Olsen, 1986). The cyclic nature of these lake sequences is not obvious, probably due to superimposed fluvial and deltaic aggradational sequences. The Feltville Formation may have fewer black shale sequences than the younger formations, because its period of accumulation was shorter, spanning only two climatic periods of high inflow. The red sandstones and siltstones in the Feltville, Towaco, and Boonton Formations were deposited by low-velocity streams or in deltas, as indicated by the abundance of ripple cross-laminae. The Feltville and Boonton cores indicate predominately fluvial channel sequences in the coarser sediments, while the Towaco Formation, dominated by graded ripple sequences, is probably mostly deltaic. The Feltville cored intervals are more coarse grained than those of the Towaco despite their location more basinward relative to the northern border fault. This suggests that the Feltville may have had steeper gradients or that the Towaco was more poorly drained. It is also possible that the Towaco cores failed to cross a channeled area and that regional depositional conditions were very similar. The presence of evaporite pseudomorphs in the lower Boonton Formation suggests more arid conditions than for the Feltville and Towaco. Overall, the cored sequence through the sedimentary 
formations in the northern Newark basin suggests a gradual increase in standing water from Passaic deposition to the Towaco and a decrease in depositional gradient. A trend to drier conditions from the Towaco Formation to the Boonton Formation is also indicated. These changes may be entirely due to climatic changes or changes in the basin drainage due to tectonic activity or both. Basalt deposition was largely subaerial, followed by periods of nondeposition long enough to allow soil development.

\section{REFERENCES CITED}

Olsen, P.E., 1980a, The latest Triassic and Early Jurassic formations of the Newark basin (eastern North America, Newark Supergroup): Stratigraphy, structure, and correlation: New Jersey Academy of Sciences Bulletin, v. 25, p. 25-51.
$1980 b$, Fossil great lakes of the Newark Supergroup in New Jersey, in Manspeizer, Warren, ed., Field studies in New Jersey geology and guide to field trips, 52d Annual Meeting, New York State Geological Association: Rutgers University, Newark, New Jersey, p. 352-398.

1986, A 40-million-year lake record of Early Mesozoic orbital climate forcing: Science, v. 234, p. 842-848.

Smoot, J.P., LeTourneau, P.M., Turner-Peterson, C.E., and Olsen, P.E., 1985, Sandstone and conglomerate shoreline deposits in the Triassic-Jurassic Newark and Hartford basins of the Newark Supergroup (abs.): American Association of Petroleum Geologists Bulletin, v. 69, p. 1448.

Smoot, J.P., and Olsen, P.E., 1985, Massive mudstones in basin analysis and paleoclimatic interpretation of the Newark Supergroup, in Robinson, G.R., Jr., and Froelich, A.J., eds., Proceedings of the second U.S. Geological Survey workshop on the early Mesozoic basins of the Eastern United States: U.S. Geological Survey Circular 946, p. 29-33.

\title{
PALEOENVIRONMENTAL RECONSTRUCTION OF A FLUVIAL-DELTAIC- LACUSTRINE SEQUENCE, LOWER JURASSIC PORTLAND FORMATION, SUFFIELD, CONNECTICUT
}

\author{
Nicholas G. McDonald ${ }^{1}$ and Peter M. LeTourneau'
}

\section{Abstract}

A noteworthy exposure of the lower Portland Formation displays interfingering coarse and fine, clastic and chemical, oxidized and reduced strata. These fluvial, deltaic, and nearshore deposits formed along the western shoaling margin of a large, perennial Portland lake, where small fluctuations in lake level produced broad, lateral shifts in depositional environments. Low-angle delta lobes built into the lake from the west and overlapped fine clastic and carbonate sediments. Reworked carbonate sediment (peloids, ooids, pisoids, oncolites, tufa crusts) accumulated on nearshore bars and later formed distinctive lenses of intraformational conglomerate. Associated fossils include fishes, in-situ bivalves, bivalve escape traces, conchostracans, ostracodes, and plants. Previously, lake margin deposits of the lower Portland have been recognized only along the eastern margin of the Hartford basin; identification of western shorelines allows the development of a comprehensive depositional model for Early Jurassic Portland lakes.

\footnotetext{
${ }^{1}$ Department of Earth and Environmental Sciences, Wesleyan University, Middletown, CT 06457.
}

\section{INTRODUCTION}

The Hartford basin, in central Connecticut and southern Massachusetts, is an east-dipping half-graben containing 4 to $7 \mathrm{~km}$ of Upper Triassic and Lower Jurassic continental sedimentary rocks and interbedded tholeiitic basalts. The uppermost stratigraphic unit in the basin, the Portland Formation, varies in thickness from 450 to over $3,000 \mathrm{~m}$ and occupies the eastern two-thirds of the basin from Middletown, Connecticut, north to the Holyoke Range in Massachusetts (fig. 1). Portland sedimentation began in the Hettangian, following the extrusion of the Hampden Basalt; the upper Portland strata are possibly Toarcian and are the youngest of all exposed Newark Supergroup deposits (Cornet and Traverse, 1975; Olsen and others, 1982).

Recent investigations (LeTourneau, 1985a,b; LeTourneau and McDonald, 1985) have outlined the character and distribution of major facies and subfacies in the Portland. More than half of the formation is made up of red-brown, medium- to coarse-grained fluvial sandstone. Along the eastern border of the basin, however, alluvial fan and fluvial conglomerate and pebbly sandstone predominate. In the central and western por- 


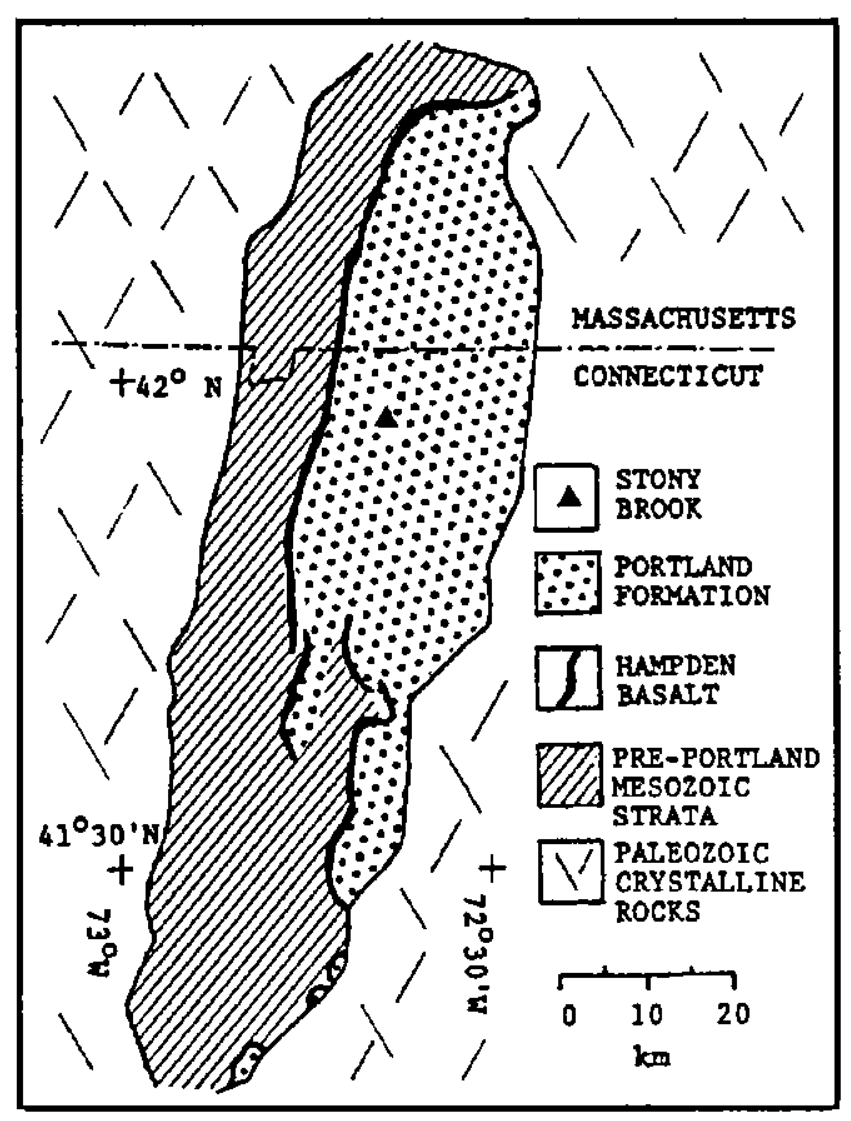

Figure 1. Index map of the Hartford basin showing the areal distribution of the Portland Formation in Connecticut and Massachusetts and the location of the Stony Brook site.

tions of the outcrop area, the formation consists primarily of red-brown and gray fluvial, lacustrine, and playamudflat sandstone, siltstone, and shale. Asymmetrical, nonred lacustrine depositional sequences, some of which are analogous to the "Van Houten cycles" of Olsen (1985), are common in the lower half of the Portland.

Portland Formation lacustrine strata interfinger with sandstone and conglomerate along the eastern margin of the basin but are interbedded with siltstone and shale in western and central portions. The geometry of eastward-thickening lacustrine sequences, in association with coarsening-up alluvial fan cycles, documents the asymmetrical syndepositional subsidence of the basin floor. Comparison of the thickness of varved black shale beds in eastern and western outcrop areas indicates that the deepest and longest-lived portions of Portland lakes were oriented along the eastern fault margin of the basin and that the lakes gradually shallowed toward the west (LeTourneau, 1985b). The gray-black lacustrine sequences are of paleontological importance and may also prove to be of economic value as hydrocarbon source beds.

This report describes the sedimentology and paleontology of a fluvial-deltaic-lacustrine sequence in north- central Connecticut. This sequence is interpreted as the western edge of a perennial lake in the lower Portland. Shoreline and lake margin deposits of the lower Portland Formation have only recently been recognized along the eastern margin of the Hartford basin in central Connecticut (LeTourneau and Smoot, 1985). The recognition of both eastern and western shorelines allows the development of a comprehensive depositional model for lakes in the lower Portland.

\section{SEDIMENTOLOGY}

More than $60 \mathrm{~m}$ of the lower Portland Formation are exposed along the near-vertical walls of the Stony Brook ravine, $3.4 \mathrm{~km}$ southeast of Suffield (Windsor Locks and Broad Brook 7.5-minute quadrangles). Most of the Stony Brook section is composed of thinly bedded to massive, red-brown sandstone, siltstone, and shale, interpreted as shallow stream channel, floodplain, and ephemeral lake deposits. Typically, these red beds are highly micaceous and intensely burrowed; oscillatory ripple marks, desiccation cracks, and reptile footprints are locally abundant on bedding surfaces. The succession of oxidized fluvial deposits is interrupted by at least two asymmetrical sequences of gray-black strata and a number of smaller nonred units.

A 6-m-thick sequence of interbedded sandstone, siltstone, and shale, located along the south bank of Stony Brook, $0.2 \mathrm{~km}$ west of the Route 159 bridge, is noteworthy because of its depositional geometry, unusual lithologies, and diverse fossils. At the western (up dip) side of the outcrop, gray sandstone lenses interbedded with fissile red siltstone and shale form prominent ledges. These meter-thick sandstone units display trough and tabular cross-stratification and ripple and megaripple cross-lamination, which indicate unidirectional flow toward the east and northeast. Down-dip to the east the gray sandstone units thin and interfinger with gray siltstone and black shale. Here, oscillatory ripple crosslamination occurs in the upper part of each sandstone lens, and climbing ripple cross-lamination is found in the lower part. These structures indicate rapid sedimentation from traction and suspension and subsequent wave reworking. In addition, the base of the lower sandstone unit contains elongate prod marks, groove casts, and linear scours oriented approximately N. $30^{\circ} \mathrm{E}$. to N. $50^{\circ} \mathrm{E}$., presumably formed by the transport of woody material and other debris in traction. Farther down-flow, the thinned edges of the gray sandstone units display oscillatory ripple cross-lamination overlying "ball and pillow" structures. This style of soft-sediment deformation resulted from the rapid inflow and loading of medium to coarse sand on silt and clay.

Gray, irregular- and wavy-laminated siltstone beds thicken in a down-flow direction (down dip) and pinch 


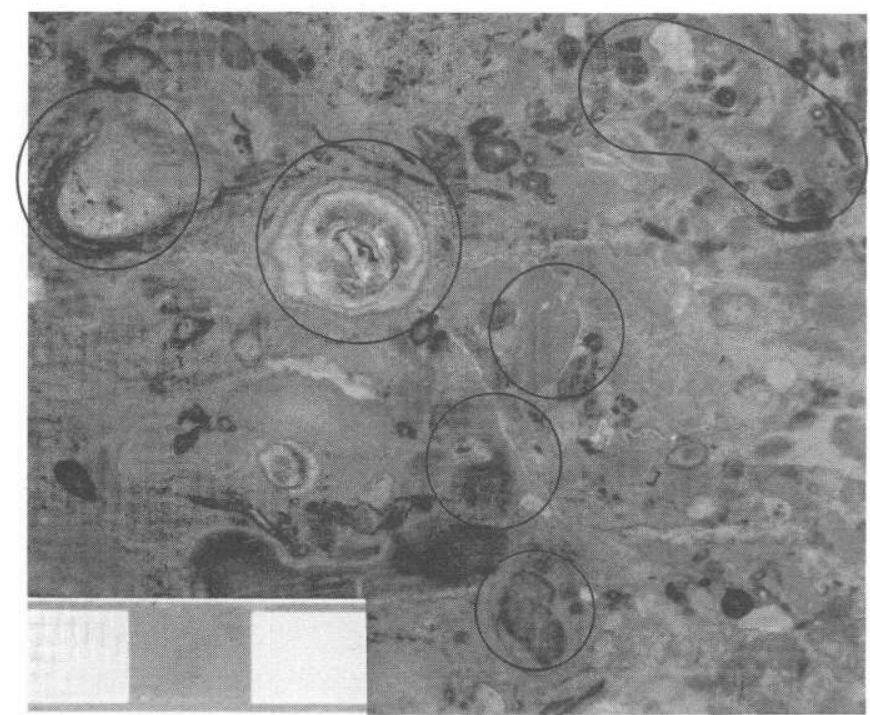

Figure 2. Photograph of cut slab of intraformational conglomerate (IFC) showing lunate, fragmented tufa crust (upper left), oncolite (center), ooids and pisoids (upper right), and rounded micrite clasts (lower right). Scale in centimeters.

out against sandstone units toward the west (up dip). Several of the siltstone beds contain mound- or pillowshaped micritic nodules up to $30 \mathrm{~cm}$ long and $20 \mathrm{~cm}$ thick. These structures are externally similar to the algal carbonate mounds described by Schäfer and Stapf (1978, fig. 3). Near the base of the sequence are two thin lenses of gray-black, microlaminated, silty limestone with well-defined "loop bedding" (see Bradley, 1931, p. 29). Underlying the limestone is a thin black shale bed that contains cubic crystal molds, possibly formed after halite.

Interbedded with the gray sandstone units are irregular, hummocky lenses of carbonate-rich intraformational conglomerate 0.5 to $25 \mathrm{~cm}$ thick. Typically, the intraformational conglomerate (IFC) is composed of a diverse assortment of the following: (1) angular to wellrounded, sand- to pebble-size limestone or dolomitic limestone peloids; (2) ooids, pisoids, and oncolites; (3) fragmented tufa crusts; (4) well-rounded gray siltstone and black shale rip-up clasts as large as $10 \mathrm{~cm}$ in diameter; (5) micrite clasts enclosing fish scales, bones, and coprolites; (6) cylindrical, tufa-coated, micrite-filled or hollow structures (probably plant stem or branch casts); and (7) large, complex intraclasts of any combination of the foregoing (fig. 2). In outcrop, the weathered rock develops a characteristic vesicular appearance due to selective dissolution of the carbonate clasts. The IFC clasts occur in both matrix-support and clast-support layers; tabular clasts are typically imbricated. The matrix of the IFC consists of stratified, micaceous, carbonaterich, fine-grained sandstone and siltstone. The IFC is found in three stratigraphic horizons in the Stony Brook section; the middle and upper units are normally graded and the lower unit is reverse graded. The upper and lower contacts of the IFC lenses with the enclosing sandstone and siltstone units are undulatory and sharp.

\section{PALEONTOLOGY}

Fossils are abundant in the lacustrine strata at Stony Brook. Carbonized plant stem, branch, and leaf fragments are found throughout the sequence and are particularly common in some of the gray sandstone and IFC units. Much of the plant material consists of finely macerated, taxonomically indeterminate debris; however, Brachyphyllum-like (conifer) leafy shoots and Equisetites (horsetail) remains can be recognized.

Networks of branching, smooth-walled, millimeterscale, horizontal and vertical burrows are common on many bedding surfaces; larger burrows of the Scoyenia type are confined to the fluvial red beds surrounding the Stony Brook lacustrine strata.

The lenses of IFC enclose square- or diamondshaped fish scales and isolated skull, shoulder girdle, and fin bones referable to some of the more robust species of Semionotus. Black, oval, scale-filled coprolites as long as $5 \mathrm{~cm}$ are present in some IFC lenses; these may indicate the presence of the coelacanth fish Diplurus longicaudatus or fish-eating reptiles.

Thin, calcareous, ooid-filled layers in the middle lens of IFC contain scarce, well-preserved darwinulid ostracodes and ovate conchostracan (clam shrimp) valves. The conchostracans, referable to Cyzicus sp., are as long as $4 \mathrm{~mm}$ and possess calcite-replaced shells having distinct concentric costae.

The most noteworthy fossils in the Stony Brook section are bivalved mollusks contained in the IFC lenses and associated gray sandstone (fig. 3). These pelecypods are the only known in-situ mollusks from the Portland Formation, and the locality is one of only three sites in the Hartford basin where mollusks have been found (McDonald, 1982, 1985). The bivalves occur as detailed internal and external molds and compare favorably with the previously described species of Unio (freshwater clams or mussels) found in a glacially transported boulder near Wilbraham, Massachusetts (Emerson, 1900; Troxell, 1914). The Stony Brook specimens are narrowly elliptical in outline, with a gently convex beak and long, well-defined lateral teeth; typical individuals are about 5 $\mathrm{cm}$ long and $2 \mathrm{~cm}$ wide. The concentric growth lines of the shell are preserved in several specimens. Nearly all the unionids are fully articulated with closed and unbro- 


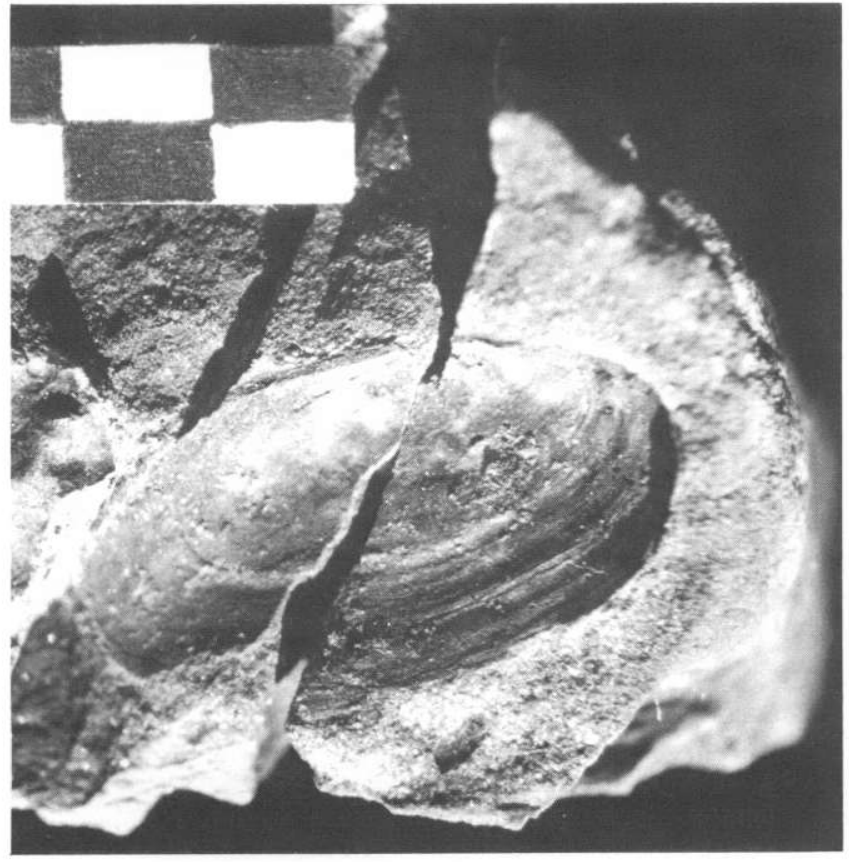

Figure 3. Internal mold of unionid bivalve from Stony Brook. Note concentric growth lines, hinge area, and dentition along outer edge of valve. Scale in centimeters.

ken valves. Individuals seen in cross section display minute dissolved shell voids about $0.2 \mathrm{~mm}$ in thickness.

The articulated and unabraded condition of the bivalved remains and their abundance in certain layers strongly imply that these fossils are autochthonous. This conclusion is further supported by the recognition of apparent mollusk-excavated dwelling/escape burrows in the uppermost IFC and the overlying sandstone (fig. 4). The larger burrows are straight, roughly cylindrical, unbranched, vertical to subvertical structures as long as $10 \mathrm{~cm}$ and as wide as $2.5 \mathrm{~cm}$. Along the edge of the burrows, the sediment laminae are bent downward, a diagnostic feature of escape traces (Reineck and Singh, 1980). The deepest portions of many burrows are excavated into the upper few centimeters of the IFC; most burrows terminate upward in ripple cross-laminated calcareous sandstone. Mollusks have not yet been found within the burrows, but they are common at the appropriate horizons. The present-day Unio is a filter-feeding bivalve having an incompletely fused mantle; it lives exposed on lake and stream channel floors, or it can burrow a short distance into the sediment (McKerrow, 1978). Evidence suggests that the Stony Brook bivalves were semi-infaunal, in-situ residents in the gravelly and sandy substrate.

\section{INTERPRETATION}

The strata exposed in the basal gray-black sequence at Stony Brook are interpreted as deltaic and

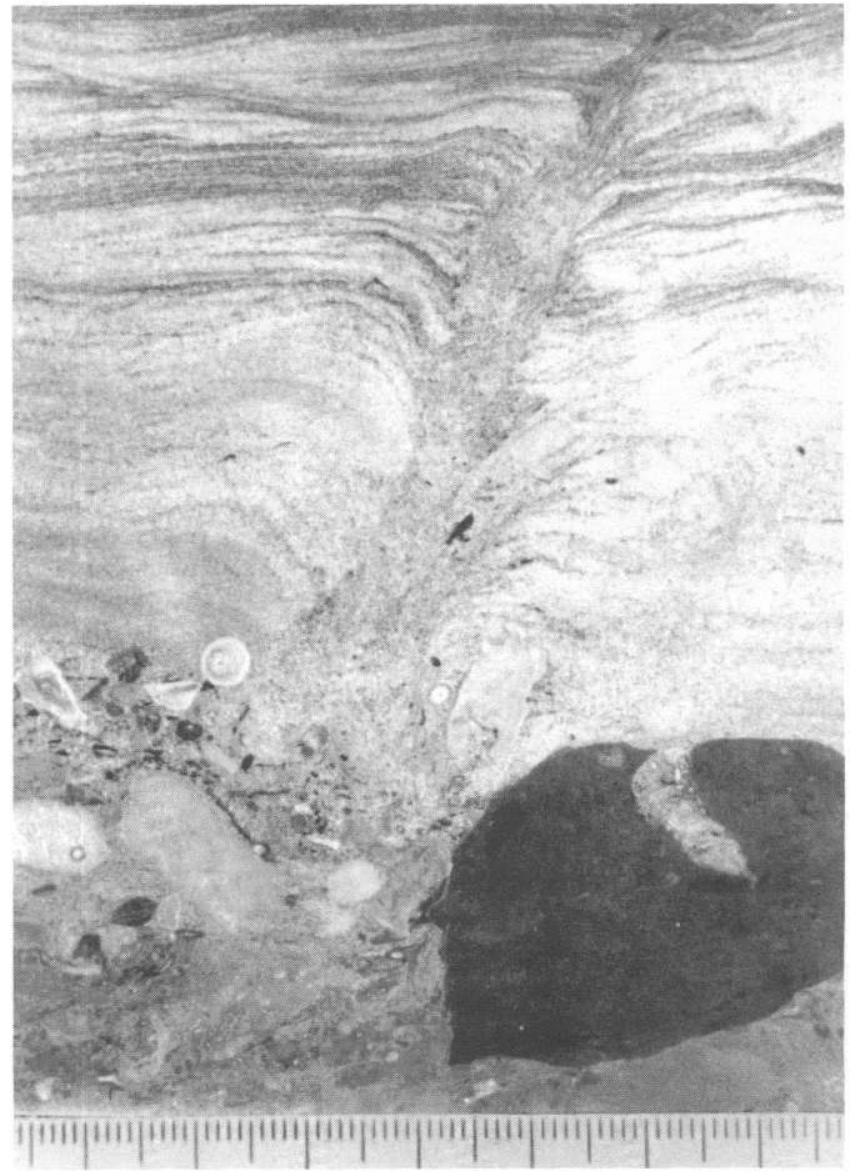

Figure 4. Escape burrow in gray, ripple cross-laminated sand, probably excavated by a unionid mollusk. Lower portion of photo shows intraformational conglomerate. Black shale clast and burrow at lower right. Scale in centimeters.

nearshore deposits that formed at the western margin of a large, perennial, Portland lake. Periodic fluctuations of lake level on a low-gradient basin floor account for the interfingering of coarse and fine, clastic and chemical, oxidized and reduced sediments. Small changes in lake depth corresponded to broad, lateral shifts in depositional environments. During deposition, the fluvialdeltaic and littoral-sublittoral depositional environments were alternately subjected to episodes of shoaling and subaerial exposure followed by periods of lake expansion and inundation.

The lenses of well-sorted gray sandstone that dominate the section represent prograding, low-angle delta lobes that built into the lake from the west. This interpretation is supported by (1) the geometry of the sandstone wedges that thicken westward and thin eastward, (2) the down-flow change in sedimentary structures from fluvial to wave-worked types, (3) the interbedded dark siltstone and shale units, (4) features indicative of rapid sedimentation, such as climbing ripple cross-lamination, basal load casts, groove casts, linear scours, reverse 


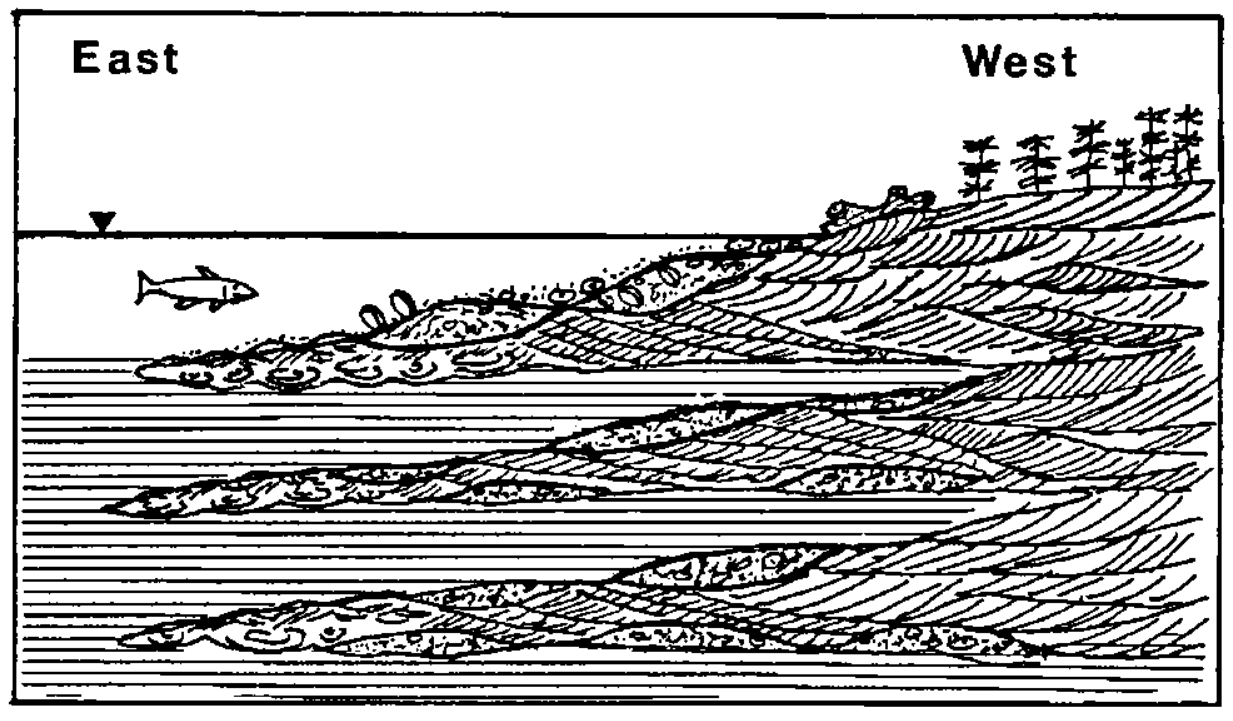

Figure 5. Schematic diagram and paleoenvironmental reconstruction of the Stony Brook section showing bedding geometry and down-flow changes in sedimentary structures of the sandstone units. Trough and tabular cross-stratification and ripple and megaripple cross-lamination indicate unidirectional flow from right (west) to left (east). The middle portion of each sandstone unit contains oscillatory ripple cross-lamination overlying climbing ripple cross-lamination. The thinned edges (left) of the units consist of oscillatory

grading, and escape burrows, and (5) the presence of lacustrine vertebrate and invertebrate fossils. Figure 5 summarizes the geometry and the down-flow changes in sedimentary structures of the sandstone units.

The abundant carbonate sediment originated from the inorganic precipitation of calcite and aragonite from alkaline lake waters. Carbonate precipitation perhaps was enhanced by the mixing of alkaline lake waters with stream water (Smoot, personal commun., 1985). The fragmented tufa crusts and tufa-coated branches contained in the IFC show little evidence of transport and presumably formed at or near the shoreline (Smoot, 1978). In addition, algal mats and mounds in the photic zone were a potential source of biogenically produced carbonate.

Wave agitation and local reworking of carbonate sediment produced peloids, ooids, pisoids, oncolites, and intraclasts that were later incorporated into the intraformational conglomerate. The presence of dark shale, siltstone, and carbonate rip-up clasts in the IFC suggests that the conglomerate may have formed during a transgressive phase when low-standing lake waters readvanced over previously deposited, partially lithified littoral and profundal sediment. The stratification and clast imbrication of the IFC are consistent with nearshore bar form deposition on a low-angle delta front during periods of increased wave activity, possibly during storms.

Poorly represented in the Stony Brook section is the sulfide- and organic-matter-rich, rhythmically lami- ripples overlying "ball and pillow" soft sediment deformation. Superimposed on, and interbedded with, the sandstone are distinct lenses of carbonate-rich intraformational conglomerate composed of peloids, ooids, pisoids, oncolites, and tufa crusts, and containing bivalve, fish, and plant fossils. Lined pattern indicates fine-grained lacustrine deposits. Shown on the lake shoreline and delta top are typical plants (Equisetites sp.) and woody debris. Approximate vertical scale equals 4 $\mathrm{m}$ and approximate horizontal scale equals $30 \mathrm{~m}$.

nated, fossiliferous black shale that characterizes many other Hartford basin lacustrine deposits, particularly along the eastern margin. However, rounded clasts of pyrite-rich black shale occur in the IFC layers, so this facies presumably existed offshore of the Stony Brook deposits.

The abundance and diversity of the flora and fauna and the rarity of evaporite minerals imply that saline conditions did not persist in the Stony Brook lake. Although the large amounts of carbonate sediment suggest that the lake was alkaline, throughout much of its history the lake was ecologically hospitable and possessed well-developed food webs. If the Stony Brook lake extended to the eastern margin of the Hartford basin, the width of the lake at that time may have approached 15 $\mathrm{km}$.

\section{CONCLUSIONS}

During the approximately 15 million years of Portland sedimentation, southern New England was positioned $15^{\circ}$ to $20^{\circ}$ north of the paleoequator (Olsen, 1984). The lateral and vertical distribution and variable character of the rocks and fossils of the Portland Formation suggest that the regional Early Jurassic climate was characterized by oscillations between humid and semiarid conditions (Thomson, 1983; Olsen, 1984; LeTourneau, 1985b). 


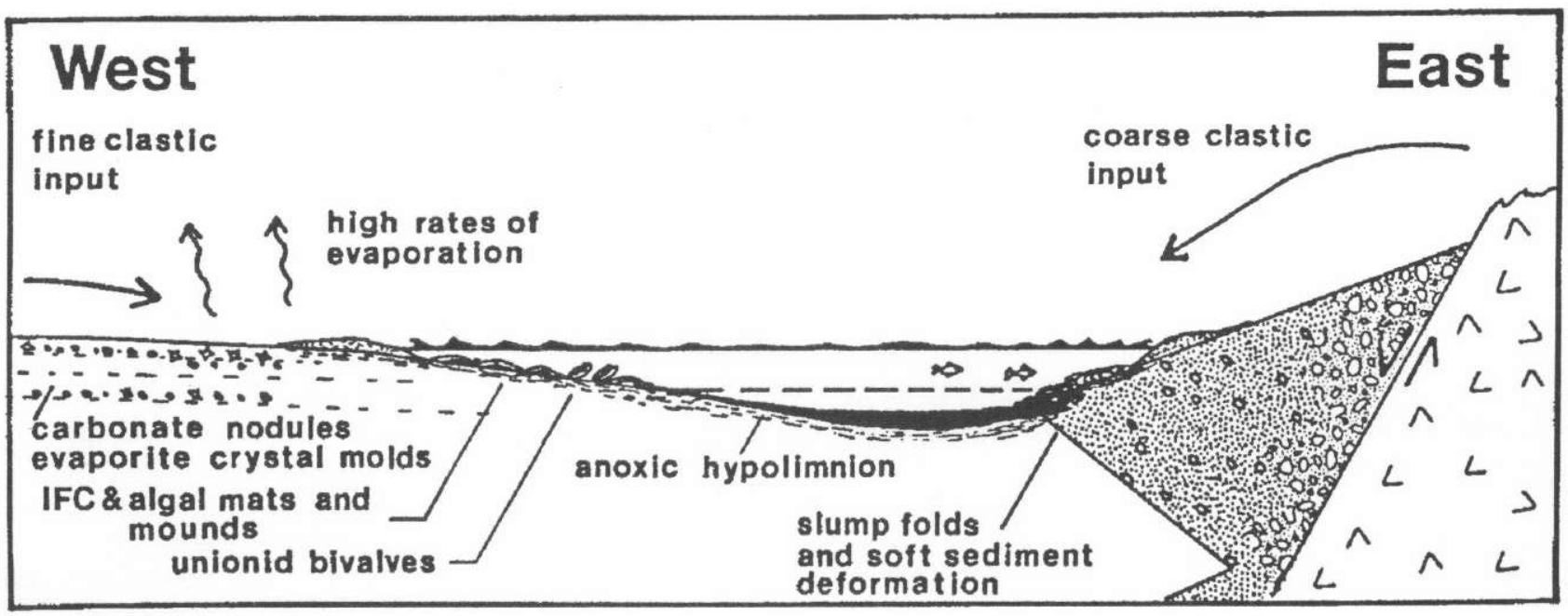

Figure 6. Schematic, west-east cross section (not to scale) through the Hartford basin during Portland time, showing an asymmetric lake basin and contrasting styles of sedimentation at its eastern and western margins. IFC, intraformational conglomerate.

In Portland time, perennial and ephemeral streams flowed from both the eastern and western highlands toward the central parts of the basin. Along the eastern margin, alluvial fan debris accumulated against fault escarpments. The basin floor contained sand-filled, braided and meandering stream channels and broad, silty floodplains. During dry intervals, limited areas of the basin floor were occupied by ephemeral lakes or playamudflats. During more humid climatic periods, the internal (closed basin) drainage system produced areally extensive, perennial, stratified lakes.

Figure 6 summarizes the depositional system proposed for the Lower Jurassic rocks of the Portland Formation during a hypothetical period of maximum lake expansion.

Asymmetric subsidence tilted the basin floor to the east, so that the lakes were deepest and longest-lived adjacent to the eastern margin of the basin. Coarse clastic deposition and high rates of sedimentation predominated in the eastern parts of the basin. The easternmost black shales are the thickest and have the best preserved fossil fishes -in part a result of well-developed stratification of the lake waters (McDonald, 1975, 1982; LeTourneau, 1985b). Episodic high influxes of sediment, due to the proximity of alluvial fans, may have contributed to the rapid burial and excellent preservation of the aquatic life. Lacustrine shorelines were formed on the distal margins of discrete alluvial fans (LeTourneau, 1985a,b; LeTourneau and Smoot, 1985).

In contrast, deposition in the central and western portions of the basin took place on a broad, low-gradient basin floor. Here, inorganic and organic carbonate sedimentation occurred in shallow, alkaline lake waters. Relatively low sedimentation rates encouraged the growth of algal mats and stromatolitic mounds in the photic zone. Periods of lake regression and the evaporative concentration of lake waters resulted in the precipitation of evaporites, mainly gypsum and halite (Parnell, 1983). At Stony Brook, littoral zone deposits of a perennial lake contain abundant micritic intraformational conglomerate, unionid mollusks, and plant debris. Wedgeshaped, low-angle delta lobes built into the lake from the west and locally encroached on fine-grained sublittoral deposits.

The recognition of Portland-age shoreline and deltaic paleoenvironments in the western and central portions of the Hartford basin further supports the hypothesis that the basin was recurrently internally drained and closed (as Demicco and Gierlowski-Kordesch (1986) have concluded for the underlying East Berlin Formation). The identification of shoreline and deltaic deposits is important for the paleoenvironmental reconstruction of the Hartford basin and other early Mesozoic basins because it allows the delineation of facies "edges" and, subsequently, outlines the distribution of depositional environments. In addition, the deltaic and well-sorted shoreline sandstone units, where buried in the subsurface, may have economic value as hydrocarbon reservoirs.

\section{REFERENCES CITED}

Bradley, W.H., 1931, Origin and microfossils of the oil shale of the Green River Formation of Colorado and Utah: U.S. Geological Survey Professional Paper 168, 58 p. 
Cornet, B., and Traverse, A., 1975, Palynological contributions to the chronology and stratigraphy of the Hartford basin in Connecticut and Massachusetts: Geoscience and Man, v. 11, p. 1-33.

Demicco, R.V., and Gierlowski-Kordesch, E., 1986, Facies sequences of a semi-arid closed basin: The Lower Jurassic East Berlin Formation of the Hartford basin, New England, U.S.A.: Sedimentology, v. 33, p. 107-118.

Emerson, B.K., 1900, A new bivalve from the Connecticut River Trias: American Journal of Science, 4 th series, v. 10, p. 58.

LeTourneau, P.M., 1985a, The sedimentology and stratigraplyy of the Lower Jurassic Portland Formation, central Connecticut: Middletown, Connecticut, unpublished M.A. thesis, Wesleyan University, $247 \mathrm{p}$.

1985b, Alluvial fan development in the Lower Jurassic Portland Formation, central Connecticut-Implications for tectonics and climate, in Robinson, G.R., Jr., and Froelich, A.J., eds., Proceedings of the second USGS workshop on the early Mesozoic basins of the Eastern United States: U.S. Geological Survey Circular 946, p. 17-26.

LeToumeau, P.M., and McDonald, N.G., 1985, The sedimentology, stratigraphy and paleontology of the Lower Jurassic Portland Formation, Hartford basin, central Connecticut, in Tracy, R.J., ed., New England Intercollegiate Geological

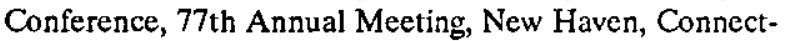
icut, October 4-6, 1985, Guidebook for fieldtrips in Connecticut and adjacent areas of New York and Rhode Island: Connecticut Geological and Natural History Survey Guidebook 6, p. 353-391.

LeTourneau, P.M., and Smoot, J.P., 1985, Comparison of ancient and modern lake margin deposits from the Lower Jurassic Portland Formation, Connecticut, and Walker Lake, Nevada: Geological Society of America Abstracts with Programs, v. 17, no. 1 , p. 31.

McDonald, N.G., 1975, Fossil fishes from the Newark Group of the Connecticut Valley: Middletown, Connecticut, unpublished M.A thesis, Wesleyan University, $230 \mathrm{p}$.

1982, Paleontology of the Mesozoic rocks of the Connecticut Valley, in Joesten, Raymond, and Quarrier, S.S., eds., New England Intercollegiate Geological Conference, 74th Annual Meeting, Storrs, Connecticut, October 2-3, 1982, Guidebook for fieldtrips in Connecticut and southcentral Massachusetts: Connecticut Geological and Natural History Survey Guidebook 5, p. 143-172.
1985, New discoveries of Jurassic invertebrates in the Connecticut Valley: Implications for lacustrine paleoecology: Geological Society of America Abstracts with Programs, v. 17, no. 1, p. 53-54.

McKerrow, W.S., ed., 1978, The ecology of fossils: Cambridge, Massachusetts, The MIT Press, 384 p.

Olsen, P.E., 1984, Periodicity of lake-level cycles in the Late Triassic Lockatong Formation of the Newark basin (Newark Supergroup, New Jersey and Pennsylvania), in Berger, A.L., and others, eds., Milankovitch and climateUnderstanding the response to astronomical forcing: Dordrecht, Holland, D. Reidel Publishing Co., pt. 1, p. 129-146.

1985, Distribution of organic-matter-rich lacustrine rocks in the early Mesozoic Newark Supergroup, in Robinson, G.R., Jr., and Froelich, A.J., eds., Proceedings of the second USGS workshop on the early Mesozoic basins of the Eastern United States: U.S. Geological Survey Circular 946, p. 61-64.

Olsen, P.E., McCune, A.R., and Thomson, K.S., 1982, Correlation of the early Mesozoic Newark Supergroup by vertebrates, principally fishes: American Journal of Science, $v$. 282 , p. $1-44$.

Parnell, J., 1983, Skeletal halites from the Jurassic of Massachusetts, and their significance: Sedimentology, v. 30, p. 711-715.

Reineck, H.-E., and Singh, I.B., 1980, Depositional sedimentary environments: New York City, New York, SpringerVerlag, 549 p.

Schäfer, A., and Stapf, K.R.G., 1978, Permian Saar-Nahe basin and Recent Lake Constance (Germany): Two environments of lacustrine algal carbonates, in Matter, Albert, and Tucker, M.E., eds., Modern and ancient lake sediments: International Association of Sedimentologists Special Publication No. 2, p. 83-107.

Smoot, J.P., 1978, Origin of the carbonate sediments in the Wilkins Peak Member of the lacustrine Green River Formation (Eocene), Wyoming, U.S.A., in Matter, Albert, and Tucker, M.E., eds., Modern and ancient lake sediments: International Association of Sedimentologists Special Publication No. 2, p. 109-127.

Thomson, K.S., 1983, Scale structure and growth in fossil semionotid fishes: Geological Society of America Abstracts with Programs, v. 15, no. 3, p. 121.

Troxell, E.L., 1914, Unios in the Triassic of Massachusetts: American Journal of Science, 4th series, v. 38, p. 460-462. 


\title{
STRATIGRAPHIC FRAMEWORK AND DISTRIBUTION OF EARLY MESOZOIC ROCKS OF THE NORTHERN NEWARK BASIN, NEW JERSEY AND NEW YORK
}

\author{
R.A. Parker, H.F. Houghton, ${ }^{1}$ and R.C. McDowell
}

\begin{abstract}
Sedimentary rocks below the Early Jurassic Orange Mountain Basalt in the Newark basin in New Jersey and New York are divided into three formations: the Stockton and Lockatong Formations of Late Triassic age and the overlying Passaic Formation (herein adopted) of Late Triassic and Early Jurassic age. Field mapping in the northern part of the basin has shown that dark-gray shale and siltstone of the Lockatong Formation tongue out into arkosic sandstone of the upper Stockton. The Passaic Formation can be subdivided into four informal, mappable lithofacies units, largely on the basis of their stratigraphic position, areal distribution, color, and grain size. Paleocurrent indicators and the distribution of lithofacies in the Passaic suggest a strongly southsouthwest-oriented axial paleoflow in the northern Newark basin. The composition and areal distribution of the stratigraphic units in the basin should prove useful in deciphering the geologic history of the area.
\end{abstract}

\section{INTRODUCTION}

Sedimentary rocks below the Orange Mountain Basalt (the first Watchung Basalt of earlier workers) in the northern Newark basin in New Jersey and New York are subdivided into three formations of early Mesozoic age: arkosic sandstone and red siltstone and sandstone of the Stockton Formation, cycles of gray and black argillite and siltstone of the Lockatong Formation, and red-brown mudstone, siltstone, sandstone, and conglomerate of the Passaic For mation (table 1). Existing geologic maps show various interpretations of stratigraphic relations among the three formations in the northern part of the Newark basin. Difficulties are encountered where criteria used to establish boundaries between the formations elsewhere in the basin are applied in the northern part because of lateral changes in the formations and interfingering. A number of maps and measured sections (U.S. Geological Survey, 1967; Savage, 1968; Sanders, 1974; Olsen, 1980a) indicate that the Passaic Formation (herein adopted; lower part of the Brunswick Formation of earlier workers) becomes significantly coarser grained northward, and north of the pinchout of the Lockatong, the Passaic directly overlies the Stockton. Field work for this study was initiated with three principal objectives: (1) to examine stratigraphic relations among these early Mesozoic formations, (2) to determine whether the lithologic sub-

\footnotetext{
${ }^{1}$ New Jersey Geological Survey, CN 029, Trenton, NJ 08625.
}

division of the Passaic Formation used by Savage (1967, 1968 ) in Rockland County, New York, could be extended southward into New Jersey, and (3) to ascertain whether gray siltstones in the Passaic Formation in the central part of the basin could be traced into the northern part.

Our mapping in the northern part of Newark basin has shown Stockton lithology both above and below the Lockatong Formation and has confirmed that the Lockatong Formation intertongues with the Stockton Formation near their intrusion by the Palisade Diabase as noted by Van Houten (1969, p. 342) and later demonstrated by Olsen (1980c) (fig. 1). The Passaic Formation has been shown to directly overlie the Stockton Formation everywhere in the mapped area and has been divided into four lithologic units somewhat modified from those of Savage (1968) (fig. 1).

The geologic map (fig. 1) shows what we consider to be mappable units within the early Mesozoic rocks of the northern Newark basin, on the basis of the results of previous workers and our own field observations and examination of core samples and logs. Positions of lithologic contacts are interpretive in many places not only because of the gradational nature of the contacts but also because of extensive glacial or urban cover.

\section{STRATIGRAPHIC UNITS}

\section{Stockton Formation}

At the composite type section on the Delaware River, the Stockton Formation is approximately $1,500 \mathrm{~m}$ thick (McLaughlin, 1959). The dominant lithologies are gray and buff-colored arkose and arkosic conglomerate and red siltstone and arkosic sandstone. The formation generally is more fine grained near the top, and the proportion of red shale and siltstone is greater. The top of the Stockton is placed at the base of the lowest continuous black siltstone unit of the overlying Lockatong Formation (Olsen, 1980c). In the northern Newark basin the Stockton sequence below the Lockatong thins to less than $250 \mathrm{~m}$ (Olsen, 1980c). Examination of approximately $62 \mathrm{ft}$ of core from 11 different holes in the Secaucus, New Jersey, area indicated that Stockton-like lithology occurs in stratigraphic positions as much as $\mathbf{3 0 0}$ $\mathrm{m}$ above the Lockatong Formation. The total core consisted of about 64 percent white to tan arkose, 27 percent 


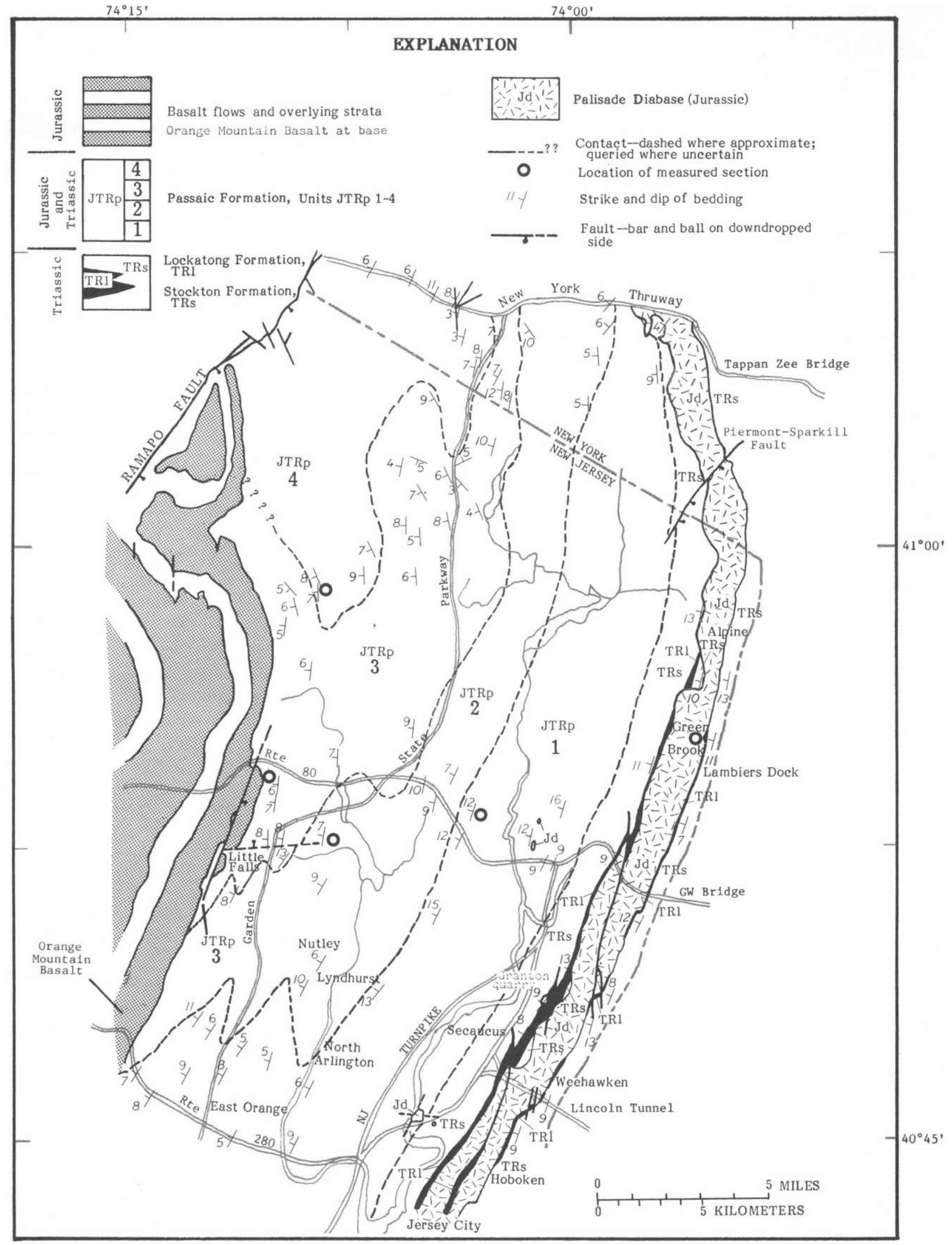

Figure 1. Geologic map showing outcrop localities and distribution of lithofacies of the Passaic Formation, and the Lockatong and Stockton Formations. Locations of measured sections in figures 2 and 3 are shown on map. 
Table 1. Nomenclature used in this report

\begin{tabular}{|c|c|c|c|}
\hline \multicolumn{2}{|c|}{ NEWARK BASIN } & \multirow{2}{*}{\multicolumn{2}{|c|}{$\begin{array}{c}\text { NORTHERN NEWARK } \\
\text { BASIN } \\
\text { (This Paper) }\end{array}$}} \\
\hline $\begin{array}{l}\text { Darton (1890), } \\
\text { Kummel (1897) }\end{array}$ & Olsen (1980a) & & \\
\hline "lst" Watchung Basalt & Orange Mountain Basalt & Orange Mount & n Basalt \\
\hline \multirow{2}{*}{ BRUNSWICK } & \multirow{2}{*}{ PASSAIC } & \multirow{2}{*}{ PASSAIC } & UNIT 4 \\
\hline & & & UNIT 3 \\
\hline \multirow[t]{2}{*}{ FORMATION } & \multirow[t]{2}{*}{ FORMATION } & \multirow[t]{2}{*}{ FORMATION } & UNIT 2 \\
\hline & & & UNIT 1 \\
\hline $\begin{array}{l}\text { LOCKATONG } \\
\text { FORMATION }\end{array}$ & $\begin{array}{l}\text { LOCKATONG } \\
\text { FORMATION }\end{array}$ & \multicolumn{2}{|l|}{$\begin{array}{l}\text { LOCKATONG } \\
\text { FORMATION } \\
\end{array}$} \\
\hline STOCKTON & STOCKTON & \multirow{2}{*}{\multicolumn{2}{|c|}{$\begin{array}{l}\text { STOCKTON } \\
\text { FORMATION }\end{array}$}} \\
\hline FORMATION & FORMATION & & \\
\hline
\end{tabular}

gray to pinkish-gray sandstone and sandy siltstone, and 9 percent red to red-brown siltstone and sandstone. These data suggest that the dominant lithology underlying the Secaucus area is more typical of the Stockton Formation than of the Passaic.

The Stockton Formation in the northern Newark basin consists mostly of coarse- to medium-grained arkosic sandstone. The sedimentary architecture is predominantly stacked channel-fill sequences 2 to $5 \mathrm{~m}$ thick. The sandstone contains about 15 to 45 percent feldspar, is generally matrix free, and is moderately sorted. Except for minor occurrences of reddish-brown sandstone and red silty and shaly mudstone, Stockton sandstone lacks the hematite and clay matrix of the red Passaic siltstone, sandstone, and conglomerate beds, and is thus predominantly gray, pinkish-gray, white, and tan. Some arkosic beds were altered, but other arkoses only a few feet from the Palisades sill do not appear to be altered, suggesting that the coloration of all the sandstone was not due to metamorphic effects.

Where shown above the Lockatong Formation in figure 1, the Stockton Formation contains 2- to 4-mthick beds of light-tan to white, coarse- to mediumgrained, arkosic sandstone interbedded with gray, finegrained sequences less than a meter thick consisting of laminated or thin-bedded argillite and cross-laminated fine-grained sandstone. The gray, fine-grained, laminated sequences are interpreted as lake deposits, and other gray, fine-grained, cross-bedded and flat-bedded sandstone that contains scoured surfaces is interpreted as fluvial in origin.

Red-brown siltstone and sandstone and red mudstone are interbedded with light-tan to white arkosic sandstone in portions of the upper Stockton beds. In New York, Savage (1967, p. 55) suggested that the Stockton and Brunswick (Passaic) lithologies were distinguishable on the basis of heavy mineral and lithic fragments. In this gradational zone of Stockton and Passaic lithologies, we found no workable field method for allocating the various light-colored arkosic sandstones. Our preliminary results show similarities in bedding style and no significant variations in the percentage of feldspar in the arkosic sandstones. We suggest that in the northern part of the basin, where the Lockatong pinches out or is overlain by an upper tongue of the Stockton, the boundary between the Stockton and Passaic Formations can be operationally defined to separate dominantly light-tan to white arkosic sandstone below from dominantly red sandstone and siltstone. This definition, which generally follows the criteria of Stose (1925) for a similar lithologic succession in the Gettysburg basin, includes in the Stockton Formation about $300 \mathrm{~m}$ of beds mapped as lower Brunswick (Passaic) Formation by Savage (1967, 1968, p. 53), who does not extend the Stockton Formation north 


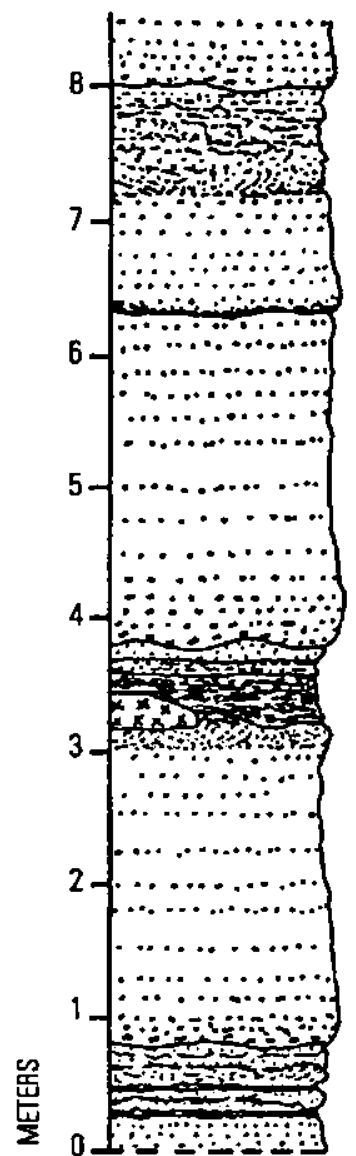

Sandstone, coarse to very coarse, arkosic; channeled base

Sandstone, fine to very fine, gray; flat, wavy, and trough cross-laminated; base cross-laminated

Sandstone, medium to coarse, gray, arkosic

Scoured bedding at base; weathered nodules at base

Sandstone, coarse, light pinkish-gray, arkosic; 30 percent feldspar

Sandstone, medium, light gray, arkosic

Siltstone, clayey, dark gray; flat to wavy lamination

Sandstone, fine to medium, arkosic; trough cross-laminated

Fining-upward channel-fill sequence: coarse to medium sandstone; 25 percent white feldspar; massive bedding, faint horizontal lamination

Sandstone, medium, light brown to pinkish-gray; coarsens upward

Sandstone, muddy, greenish-gray; upper part cross-laminated; two thin beds dark-gray argillite interbedded with medium to fine arkosic sandstone

Figure 2. Measured section of arkosic sandstone facies of the Lockatong Formation, Green Brook, New Jersey (see fig. 1). Small diabase body at $3.3 \mathrm{~m}$.

of the Piermont-Sparkill fault; she considers arkosic sandstone and interbedded red mudstone of that area as transitional between Stockton and Brunswick (Passaic) lithologies or as part of the lower Passaic Formation. Displacement on the Piermont-Sparkill fault is insufficient to cause the abrupt termination of the Stockton Formation, and we extend the Stockton belt several kilometers northward (fig. 1).

\section{Lockatong Formation}

The Lockatong Formation conformably overlies the Stockton Formation throughout most of the Newark basin in New Jersey and Pennsylvania. In the northern part of the basin, however, the Lockatong beds interfinger with Stockton-like lithology, eventually pinching out northeast of Alpine, New Jersey (figs. 1 and 2). The Lockatong Formation thins from about $1,150 \mathrm{~m}$ at its type section to less than $150 \mathrm{~m}$ near Weehawken, New Jersey (Olsen, 1980c).

In the map area the Lockatong is exposed in two narrow outcrop belts, one above the Palisades sill from near Jersey City to Alpine, New Jersey, and another discontinuously exposed belt below the sill from the Hoboken area to the vicinity of Lambiers Dock, New Jersey (fig. 1).

The Lockatong Formation in the northern Newark basin consists mostly of gray to black fine-grained sandstone, siltstone, and shale, interpreted as eyclic lake deposits. The cycles, mostly 1 to $2 \mathrm{~m}$ thick in the northern basin, can be subdivided into three parts, interpreted as reflecting features of transgression, maximum lake development, and regression. Typical lake cycles consist of the following sequence from the base upward (Olsen, 1980c): 1. gray or gray-green siltstone to very fine sandstone, generally ripple cross-laminated, cross-bedded, or convolutely laminated; desiccation cracks common in upper part;

2. black, platy, calcareous shale or thinly interlaminated carbonaceous siltstone and dolomite;

3. gray mudstone with ripple bedding or desiccation cracks overlain by gray, massive, silty mudstone with dolomite-rich clay matrix.

Olsen $(1984$, p. 368$)$ states that the Lockatong cycles in the northern Newark basin belong only to the 
detrital type cycle of Van Houten (1962) and suggests that during deposition of chemical cycles in the central part of the basin either no deposition took place in the northern part or arkosic sandstone was deposited locally. The absence of chemical cycles in the study area and the abundance of arkosic sandstone-bearing sequences interbedded with the Lockatong Formation in the northern part of the basin favor Olsen's idea that they may correspond to chemical cycles of the central basin. The upper Lockatong sequence above the Palisades sill, described by Olsen (Granton quarry section) (1980b, p. $378,1984)$, contains a vertebrate fossil assemblage that does not correlate with the lowermost Lockatong members of Olsen (Olsen, personal commun., 1986). The stratigraphic positions of the arkosic.sandstone beds that intertongue with the upper Lockatong sequence north of Jersey City provide indirect evidence to suggest that they may correlate to the thick cluster of chemical cycles shown by Van Houten (1962) near the middle of the Lockatong Formation along the Delaware River.

\section{Passaic Formation}

The Passaic Formation (Olsen, 1980a; herein adopted for use in New Jersey and New York by the U.S. Geological Survey) in the central Newark basin overlies the Lockatong Formation in gradational contact. It consists mostly of red and gray mudstone and siltstone deposited in cyclic sequences. Cycles in the Passaic Formation range from lacustrine sequences identical to those of the Lockatong Formation to entirely red mudflat cycles that culminate in rippled cross-laminated siltstone, as described by Smoot and Olsen (1985).

In the northern Newark basin, the Passaic Formation changes character and has been divided into four lithofacies units that are mappable in the study area (fig. 1). Massive gray lacustrine beds in the Passaic Formation delineated in the central portion of the basin (Olsen, 1984) appear to be less abundant in the northern part of the basin. Several localities of gray beds in Units 1 and 2 (fig. 1) have been noted: (1) along Route 280 near East Orange, New Jersey (Olsen, personal commun., 1986), (2) at Schuyler Mine near North Arlington, New Jersey, at mines near Lyndhurst, New Jersey, and at exposures near Secaucus, New Jersey (Olsen, 1980b), and (3) from a core log near Little Falls, New Jersey. Correlation of these gray beds with gray beds of the central basin is not certain, although Olsen (1980b, p. 375) suggests that the gray beds near Secaucus could be laterally equivalent to McLaughlin's (1948) Graters Member.

Red-bed cycles become increasingly prevalent toward the top of the Passaic Formation in the central basin. In the northern Newark basin, cycles are apparently obscured by channel and floodplain deposits, reflecting higher discharges in stream systems. The coarseness of fluvial facies within the Passaic Formation (Units 3 and 4, figs. 1 and 3) in the northern basin may reflect the availability of coarse material in the source area, higher velocities in stream systems, or high-gradient stream systems influenced by alluvial fans that prograded toward the east, southeast, and southwest from the northwest margin. Preliminary results from paleocurrent indicator measurements indicate a strongly southsouthwest oriented axial flow in the northern Newark basin (fig. 4). Coarsening of the sediments and an increase in large-scale trough cross-stratification toward the northwest, and the occurrence and dispersal pattern of clasts of Cambrian-Ordovician limestone and Devonian sandstone (Savage, 1967) in Units 3 and 4 (fig. 1), indicate a possible source of sediment and paleoflow from the northwest basin margin and suggest flow of tributary streams toward the axial drainage system.

Progressive coarsening of facies in the Passaic Formation toward the northwest margin permits the delineation of the four lithofacies units shown on the map (fig. 1). Measured sections of typical facies associations are shown graphically in figure 3 . The general progression of most of the Passaic is coarsening upward toward the northwest margin of the basin, although the lowermost facies fines upward from the coarse- to mediumgrained sandstone of the underlying Stockton beds. The lithofacies used in mapping for this study are given below.

The lower, fine-grained lithofacies of the Passaic Formation (Unit 1) forms a belt that widens toward the southwest and grades laterally into the main body of the formation in the central basin. The overlying Unit 2 tongues into Unit 1 , and the overlying coarse-grained units progressively tongue out to the south and form a concentric pattern around the alluvial fan complex along the northwest fault margin. The unit boundaries shown here for the lithofacies of the Passaic Formation (fig. 1) differ somewhat from those of Savage (1968) as used in a modified form on the State geologic map of New York (Fisher and others, 1970). Most of these differences can be attributed to our higher placement of the upper Stockton contact on the basis of different criteria and to lateral changes in the coarseness of the conglomeratic sandstone facies in the northern end of the basin.

Unit 1.-Siltstone, mudstone, and sandstone facies. This unit is characterized by thick fining-upward sequences of intercalated massive siltstone and mudstone. The massive mudstone commonly overlies indistinctly laminated siltstone and is characterized by intense burrowing, lack of bedding or sedimentary structures, polygonal mud cracks, and scattered lenses of carbonate nodules. Associated with some of the massive mudstone units are sandstone beds that are cross-laminated or have steep, tabular cross-beds. Channel-fill beds contain mostly trough cross-laminated fine-grained sandstone, com- 


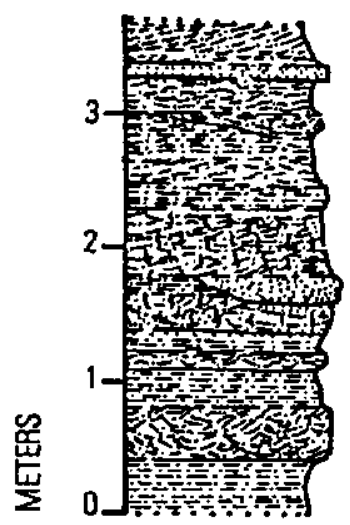

Sandstone, very fine, micaceous; no lamination apparent

Siltstone, muddy, micaceous; indistinct lamination

Siltstone, coarse; ripple or trough cross-laminated

Siltstone, muddy, micaceous; indistinct lamination

Siltstone, coarse, fissile, thin bedded

Siltstone, muddy, micaceous; irregular horizontal lamination; appears to have ripple and trough-fill bedding; small burrows on bedding planes

Sandstone, very fine, micaceous, coarsens upward; wavy and trough-fill bedded; parting surfaces heavily burrow marked

Mudstone, silty, micaceous; thin $(0.5 \mathrm{~cm})$ bedded; coarsens upward

Siltstone, wavy-bedded, fissile; calcareous cement; alternating laminae are silt-rich and mud-rich

Siltstone, muddy, micaceous

Siltstone, coarse; and sandstone, very fine, dark red-brown, micaceous; prominent trough cross-lamination; calcite cement

Mudstone, silty, bright red-brown, micaceous, indistinctly laminated

Unit JTRp 1-Siltstone, mudstone, and sandstone facies

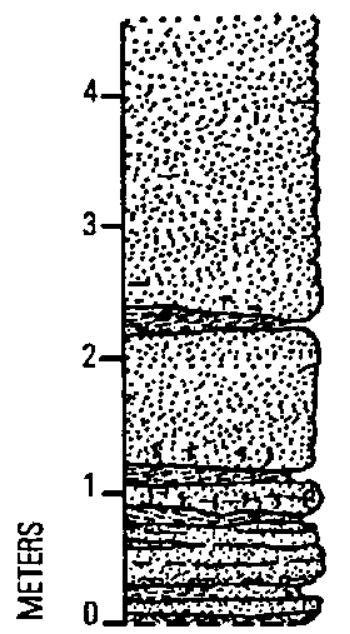

Sandstone, medium, red-brown, feldspathic; bedding mostly 5-10 cm thick; indistinct trough cross-lamination

Rare shale chips and subround to round pebbles at base

Mudstone, soft, slightly micaceous; irregular laminae $3-6 \mathrm{~mm}$ thick; lensoidal beds

Sandstone, medium, red-brown, feldspathic; vertical burrows near base

Mudstone, silty, micaceous, irregularly bedded, fissile; lensoidal beds

Sandstone, fine to medium, feldspathic to very feldspathic, micaceous in part; indistinct low-angle crosslamination; horizontal burrows

Unit JTRp 2-Sandstone and mudstone facies

Figure 3. Measured sections from Passaic Formation, northern Newark basin, showing typical facies associations of map units JTRp 1-4.

monly with "Scoyenia" burrows (Olsen, 1980b). In general, the unit fines upwards, but is sandier in the middle and towards the base. The lower part of Unit 1 is mostly fine-grained sandstone deposited in small channels, except for local sandstone beds 1 to $3 \mathrm{~m}$ thick. Unit 1 grades laterally into cyclic sequences of red and gray mudstone and siltstone of the Passaic Formation in the central Newark basin.

Unit 2.-Sandstone and mudstone facies. This unit consists of a major increase in coarser grained intervals over those of Unit 1. Progressing upward and marginward in the basin-fill sequence, massive mudstone typical of Unit 1 becomes less common in Unit 2, particularly in the upper part where fine- to medium-grained, planar to trough cross-bedded sandstone dominates. Sandstone is usually feldspathic and micaceous. Fining-upward sequences from 1.5 to $5 \mathrm{~m}$ thick are typical. This facies represents an increase in fluvial channel predominance compared to the lower Passaic Formation floodplain.

Unit 3.-Pebbly sandstone facies. Thick-bedded, coarse-grained, pebbly sandstone, including mainly feldspathic sandstone and limestone and quartz pebble lags, characterizes this facies; mudstone is a minor component. Sandstone beds consist of flat-laminated to trough cross-bedded units, and some trough sets are several meters thick. Pebbly beds having scoured bases (possibly channel fills) increase toward the top of this unit. This facies represents higher velocity streams than those in Unit 2.

Unit 4.-Conglomeratic sandstone facies. Channel-fill beds in this unit are conglomeratic and locally consist of quartz, quartzite, limestone, Devonian(?) sandstone, and 


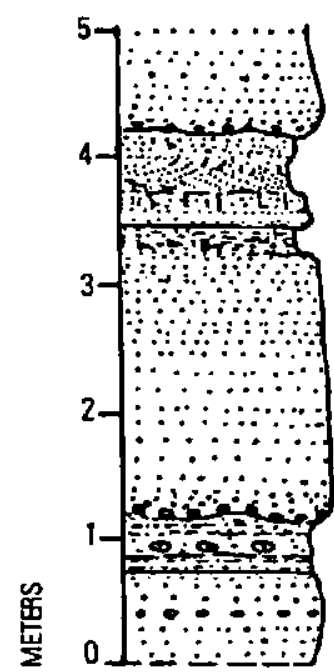

Fining-upward sequence; fine sandstone to siltstone; low-angle trough to horizontal lamination; burrows common in upper part of coarse sandstone bed

Fining-upward sequence; coarse to medium sandstone, brownish-red; 30 percent feldspar; horizontal planar lamination; scoured base with pebble lags

Mudstone, silty, dark red-brown, micaceous; lower part burrowed with faint trough lamination; middle part indistinctly bedded with calcite nodules and root casts

Sandstone, medium, red-brown, feldspathic, with scattered pebble layers; indistinctly laminated; horizontal planar bedding

Unlt JTRp 3-Pebbly sandstone facies

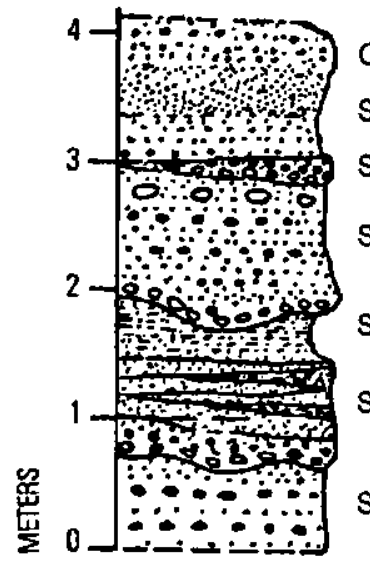

Coarsening-upward sequence (no break with underlying coarse sandstone): quartz pebbles, subangular to subrounded, mostly $2 \mathrm{~cm}$ in diameter

Sandstone, coarse, dark red-brown; 20 percent pink feldspar grains; indistinctly bedded; breaks off on trough-shaped surfaces

Sandstone, coarse to medium; fining upward

Sandstone, medium to coarse, red-brown; 20 percent feldspar; scattered pebble layers; cobble layer near top; indistinct lamination; deeply scoured base with pebble lag; scattered small trough cross-beds

Sandstone, thin-bedded; fines upward to muddy siltstone

Sandstone, medium, red-brown, arkosic, trough cross-bedded; pebble lenses; fines upward slightly; scour-fill base

Sandstone, medium, feldspathic; indistinct bedding; scattered pebble layers

Unlt JTRp 4-Conglomeratic sandstone facies

Figure 3. Continued.

mudstone pebbles and cobbles. Channels range in width from 3 to more than $15 \mathrm{~m}$ and consist of fining-upward and coarsening-upward pebbly coarse-grained sandstone sequences 1 to $5 \mathrm{~m}$ thick. The graded channel fills apparently record the passing of floods. The abundance and dispersal pattern of Paleozoic(?) clasts in this unit suggest a source to the northwest. Scour and fill, irregular cross-bedding, and lens- or wedge-shaped beds suggest a braided-stream origin, possibly associated with alluvial fan development along the northwestern basin margin for much of this unit. Gravel-filled channel beds and matrix-supported debris-flow beds are not mapped separately because of poor exposure; they appear to be limited to small areas within 2 to $3 \mathrm{~km}$ of the northwestern basin margin.

\section{SUMMARY}

Recent mapping in the northern Newark basin has delineated the nature and extent of intertonguing between the Stockton and Lockatong Formations and has resulted in a fourfold mappable subdivision of the overlying Passaic Formation (herein adopted). The composition and areal distribution of these stratigraphic units provide a basis for eventual determination of the sedimentological and tectonic evolution of the basin.

\section{ACKNOWLEDGMENTS}

We thank Nicholas M. Ratcliffe and William C. Burton for access to their field data on the structure of 


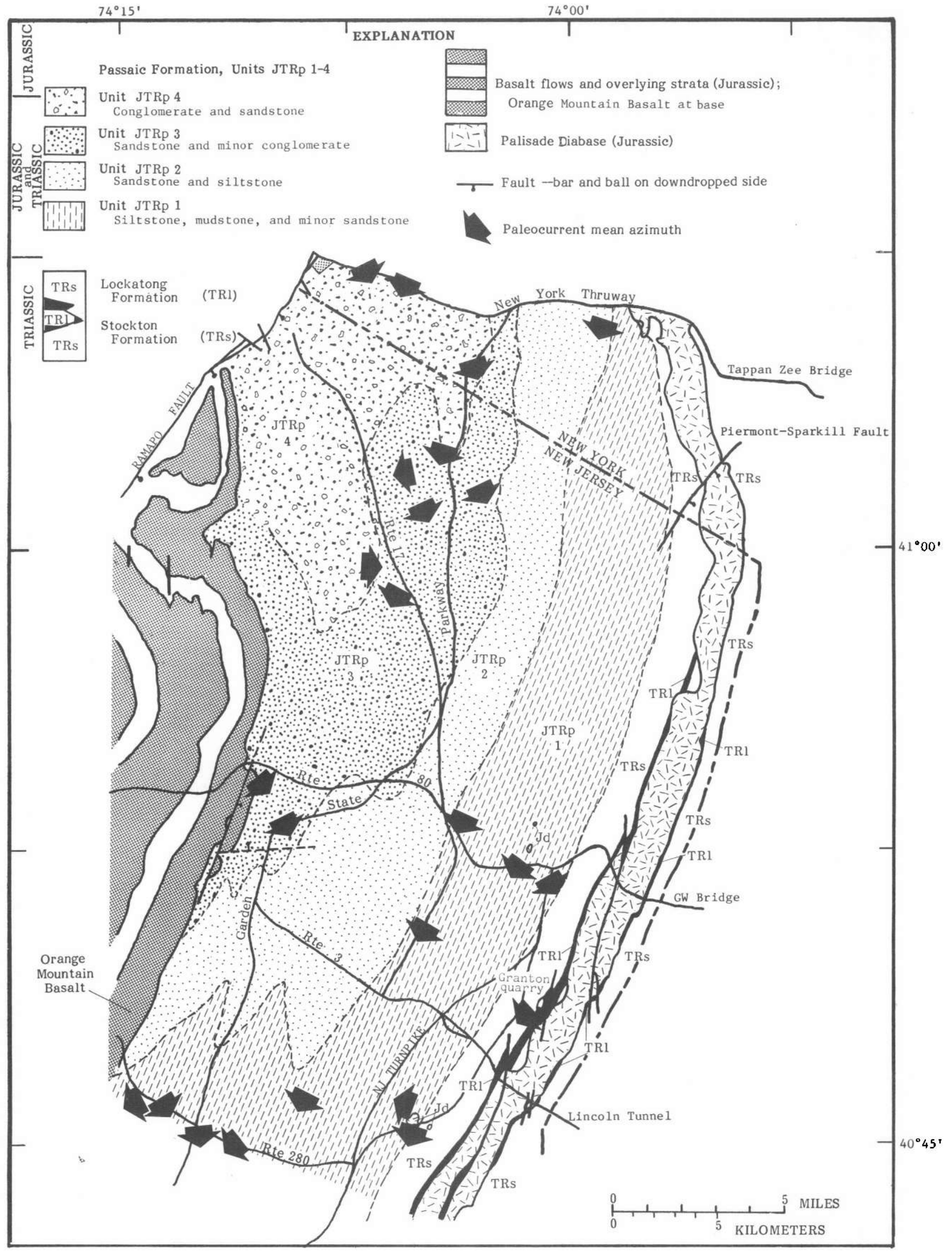

Figure 4. Map showing the relation of paleocurrent indicators to the distribution of Passaic Formation lithofacies. Nearly all readings are maximum-dip azimuths of troughs in cross-bedded sandstone of the Passaic Formation. Each arrow represents the mean of several azimuth measurements made at each station. A total of 113 measurements at 24 stations was recorded. 
the northern Newark basin. We are indebted to Paul E. Olsen for his field map compilation and his conversations with Houghton on the stratigraphy of the Lockatong Formation. We appreciate the guidance of Franklin Van Houten on the stratigraphy of the Stockton Formation. Support for the COGEOMAP program in New Jersey is provided in part by the 1981 Water Supply Bond Fund, administered by the Division of Water Resources, New Jersey Department of Environmental Protection.

\section{REFERENCES CITED}

Darton, N.H., 1890, The relations of the trap of the Newark System in the New Jersey region: U.S. Geological Survey Bulletin 67, 82 p.

Fisher, D.W., Isachsen, Y.W., and Richard, L.V., 1970, Geologic map of New York (Lower Hudson Sheet): New York State Museum and Science Service, Geologic Survey Map and Chart Series No. 15.

Kummel, H.B., 1897, The Newark System, report of progress: New Jersey Geological Survey Annual Report of the State Geology, 1896, p. 25-88.

McLaughlin, D.B., 1948, Continuity of strata in the Newark Series: Michigan Academic Scientific Papers, 32, p. 295-303.

-1959, Mesozoic Rocks, in Willard, B., Freedman, J., and others, eds., Geology and mineral resources of Bucks County, Pennsylvania: Pennsylvania Geological Survey Bulletin, 4th ser., C-9, p. 55-114.

Olsen, P.E., 1980a, The latest Triassic and Early Jurassic formations of the Newark basin (eastern North America Newark Supergroup): Stratigraphy, structure and correlation: New Jersey Academy Science Bulletin, v. 25, no. 2, p. 25-51.

1980b, Fossil great lakes of the Newark Supergroup in New Jersey, in Manspeizer, W., ed., Field studies of New Jersey geology and guide to field trips, 52d Annual Meeting, New York State Geological Association: Rutgers University, Newark, New Jersey, p. 352-398. 1980c, Triassic and Jurassic Formations of the Newark basin, in Manspeizer, W., ed., Field studies of New Jersey geology and guide to field trips, 52d Annual Meeting, New York State Geological Association: Rutgers University, Newark, New Jersey, p. 2-39.

1984, Comparative paleolimnology of the Newark Supergroup: A study of ecosystem evolution: unpublished Ph.D. dissertation, New Haven, Yale University, 726 p.

Sanders, J.E., 1974, Guidebook to field trip in Rockland County, New York: Petroleum Exploration Society, New York, $87 \mathrm{p}$.

Savage, E.L., 1967, The Triassic sediments of Rockland County, New York: unpublished Ph.D. dissertation, Rutgers University, $199 \mathrm{p}$.

1968, The Triassic rocks of the northern Newark Basin, in Finks, R.M., ed., Guidebook to field excursion: New York State Geological Association, 40th Annual Meeting: Flushing, New York, p. 49-100.

Smoot, J.P., and Olsen, P.E., 1985, Massive mudstones in basin analysis and paleoclimatic interpretation of the Newark Supergroup, in Robinson, G.R., Jr., and Froelich, A.J., eds., Proceedings of the second U.S. Geological Survey workshop on the early Mesozoic basins of the Eastern United States: U.S. Geological Survey Circular 946, p. 29-33.

Stose, G.W., 1925, Mineral resources of Adams County, Pennsylvania: Pennsylvania Geological Survey, 4th ser., Bulletin $\mathrm{C}-1,64 \mathrm{p}$.

U.S. Geological Survey, 1967, Engineering geology of the northeast corridor, Washington, D.C., to Boston, Massachusetts, bedrock geology: U.S. Geological Survey Miscellaneous Geologic Investigations Map I-514-A, scale $1: 1,500,000$.

Van Houten, F.B., 1962, Cyclic sedimentation and the origin of analcime-rich upper Triassic Lockatong Formation, westcentral New Jersey and adjacent Pennsylvania: American Journal of Science, v. 260, p. 561-576.

1969, Late Triassic Newark Group, north central New Jersey and adjacent Pennsylvania and New York, in Subitzky, S., ed., Geology of selected areas in New Jersey and eastern Pennsylvania: Rutgers University Press, New Brunswick, New Jersey, p. 314-347. 


\title{
PRELIMINARY ANALYSIS OF UNUSUAL PALYNOMORPHS FROM THE TAYLORSVILLE AND DEEP RUN BASINS IN THE EASTERN PIEDMONT OF VIRGINIA
}

\author{
Eleanora I. Robbins and Robert E. Weems
}

\begin{abstract}
Carbonaceous shale and impure coal from the Taylorsville and Deep Run basins, Virginia, contain unusual palynomorphs that may be older than others in the surrounding basins. In the Taylorsville basin, darker colored (Thermal Alteration index (TAl) 3) Apiculatisporites cornutus, cf. Gardenasporites, and cf. Pustilatisporites, all taxa that suggest a Permian age, are mixed with lighter colored (TAl 2 to 3-) forms typical of the middle Carnian. This implies that preCarnian materials are reworked into the strata of the Taylorsville basin. In the Deep Run basin, degraded pollen and spores from coal-mine-dump samples are tentatively identified as cf. Camptotriletes, cf. Densipollenites, two species of Densoisporites, cf. Gardenasporites, and cf. Gigantosporites. Although the exact age of this assemblage is uncertain, the age lies between Permian and Middle Triassic. The lack of Permian age-diagnostic species of striate bisaccate poilen suggests that an Early to Middle Triassic age is most likely. This unusual suite of palynomorphs indicates that the Deep Run basin represents older strata than presently exposed in the other Newark rift basins in the vicinity. Taylorsvilie and Richmond basin palynomorphs are lighter in color (TAI 2 to $3+)$ than palynomorphs and woody tissues from the Deep Run basin (TAl 4- to 4). This consistent difference in TAl values suggests that the Deep Run basin was subjected to a thermal event not recorded by organic matter in the other basins nearby.
\end{abstract}

\section{INTRODUCTION}

Most of the palynomorphs from the Taylorsville basin (fig. 1) are middle Carnian in age (Cornet, 1977; Robbins and others, in press). However, a few darker palynomorphs were found that are suggestive of a Permian age. These forms evidently were reworked from older beds and redeposited in the Taylorsville basin. Besides the putative Ladinian-age palynomorphs in the Richmond basin (Ediger, 1986), which are included by Robbins and others (in press) within the middle Carnian, the only other post-Pennsylvanian and pre-Carnian fossiliferous sedimentary rocks in the Eastern United States are of earliest Permian age (Barlow, 1975; Englund and others, 1986). They comprise the upper portion of the Dunkard Group, which is found principally in West Virginia and in contiguous portions of Ohio and Pennsylvania (fig. 1). Because this source of reworked palynomorphs is almost $200 \mathrm{mi}$ away, and because palynomorphs from this source also would be accompanied by other, earlier Paleozoic palynomorphs derived from intervening fossiliferous terranes (fig. 1), the Dunkard Group is an unlikely source for the unusual palynomorphs in the Taylorsville basin. Some other source, either undiscovered or now totally eroded, is much more likely.

The paleocurrent transport direction in the southern end of the Taylorsville basin was from the southwest (Ressitar and Taylor, in press, and written commun., 1986). Therefore, to determine if the nearest exposed sedimentary basin south of the Taylorsville basin also contained reworked palynomorphs, we sampled the Deep Run basin (fig. 1). Unexpectedly, none of the palynomorphs from that basin are characteristic of the Carnian. Instead, they suggest an older age for the strata in that basin.

The purpose of this paper is to report on the reworked palynomorphs in the Taylorsville basin and the unusual palynomorphs in the Deep Run basin. An unequivocal age assignment is not possible because of the sparse number of reworked taxa in the Taylorsville basin and because of the poor preservation within the suite of samples collected to date for the Deep Run basin. However, these tentative results are so unusual that they are reported here to make others aware of these developments.

\section{GEOLOGIC SETTING}

The largest sedimentary basins in the eastern Virginia Piedmont province are the Richmond and Taylorsville basins (fig. 1), both of which contain fossils of Late Triassic (middle Carnian) age (Cornet, 1977; Robbins, 1985). The Richmond basin was not specifically sampled for this study, but a recent compilation of information on this basin can be found in Goodwin and others (1985). The Taylorsville basin is located $6 \mathrm{mi}$ northeast of the Richmond basin (fig. 1). The exposed part of the Taylorsville basin is about $130 \mathrm{~km}^{2}$ in areal extent (fig. 2). A major portion of the basin, buried to the northeast beneath the Coastal Plain, is as yet poorly defined but could make the Taylorsville basin even larger than the Richmond basin (Weems, 1980a). The sedimentary rocks in the basin comprise the Doswell Formation, which is divided into three members. In ascending order, these are the Stagg Creek, Falling Creek, and Newfound Members. The Stagg Creek and Newfound Members are dominantly coarse-grained sandstones, pebbly arkoses, 


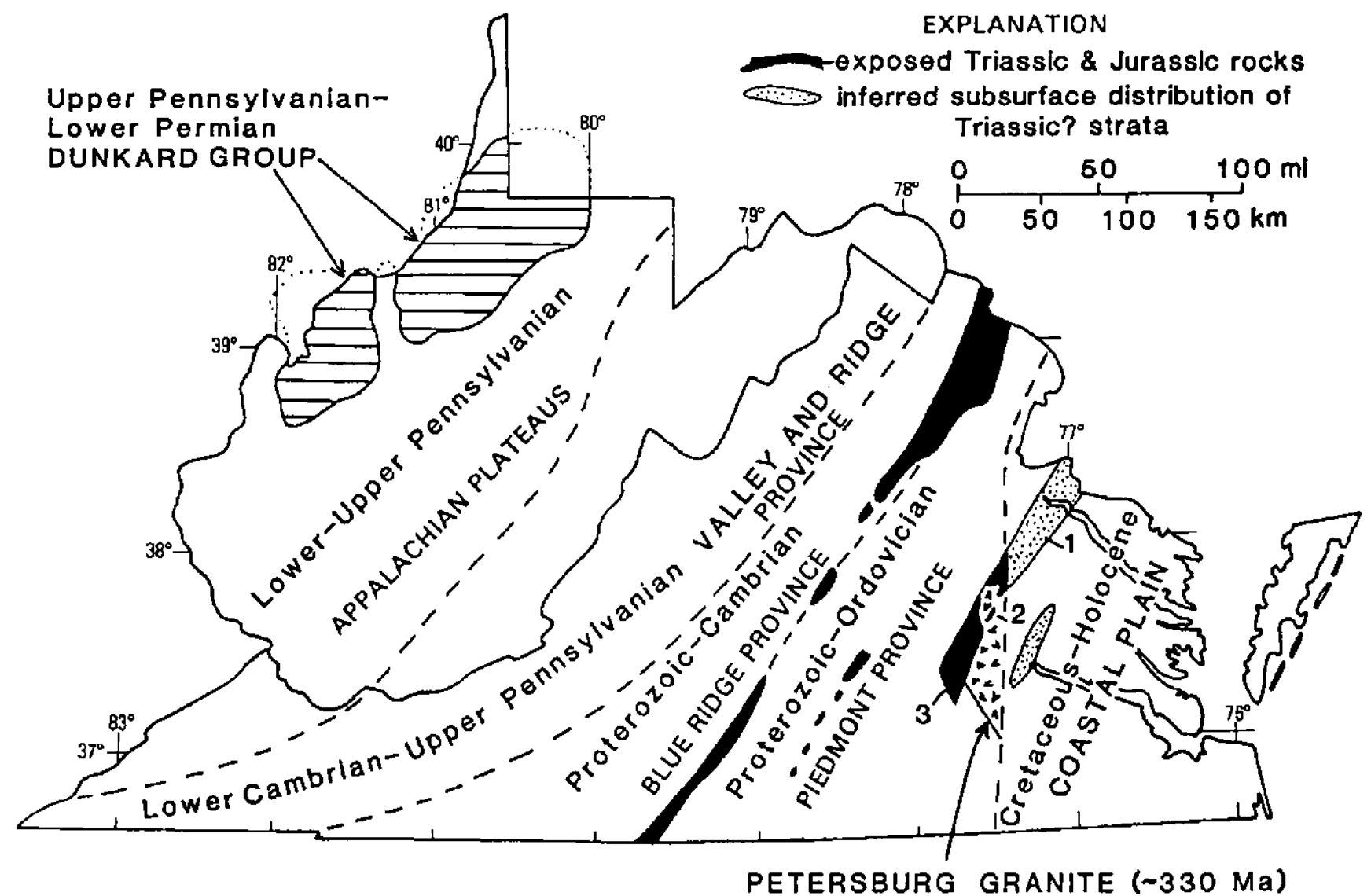

Figure 1. Map showing structural setting and age of rocks in Virginia and West Virginia surrounding Triassic and Jurassic basinal strata. 1, Taylorsville basin; 2, Deep Run basin; 3, Richmond basin.

conglomerates, and massive red mudstones; consequently, they have yielded only sparse assemblages of spores and pollen. The Falling Creek Member, in contrast, contains numerous fine-grained and dark-colored sedimentary rocks deposited in paludal to lacustrine environments. These have yielded a diverse assemblage of fossils (Cornet, 1977; Weems, 1980b; Robbins, 1985; Robbins and others, in press).

South of the Taylorsville basin and east of the Richmond basin are five small coal-bearing basins (fig. 3 ) usually considered to be erosional outliers of the Richmond basin (Shaler and Woodworth, 1899). These are the Deep Run (Springfield), Flat Branch (Tuckahoe), Blackheath, Union, and Stonehenge basins. All but the Flat Branch basin contained economic deposits of coal, most of which were mined before the Civil War.

The largest of these outlying basins is the Deep Run basin, located $6.6 \mathrm{~km}$ east of the Richmond basin and $9.6 \mathrm{~km}$ south of the Taylorsville basin in western Henrico County, Virginia. It is $4.5 \mathrm{~km}$ long by $0.6 \mathrm{~km}$ wide and has very few natural outcrops. Exploratory coal shafts penetrated a maximum of $120 \mathrm{~m}$ of section
(Clifford, 1888). A section more recently exposed along the western faulted border of the basin, compiled by B.K. Goodwin and G.H. Johnson, includes about $45 \mathrm{~m}$ of shale, siltstone, arkosic sandstone, and coal (Lucas, 1981). The lack of either border conglomerates or fanglomerates suggests that the present fault along the western margin was not tectonically active during deposition. The eastern margin of the Deep Run basin appears to be an unconformity underlain by Petersburg Granite; an arkose containing quartz pebbles overlies the unconformity (Goodwin and Johnson, 1967). Overlying the arkose are finer grained, dark-colored sedimentary rocks including coal, shale, and siltstone.

\section{MATERIALS AND METHODS}

Samples.-Coal, carbonaceous shale, and darkgray siltstone were sampled for this study. The Taylorsville basin samples were collected from outcrops. The Deep Run basin samples were collected primarily from mine dumps, although a few outcrop samples also were 


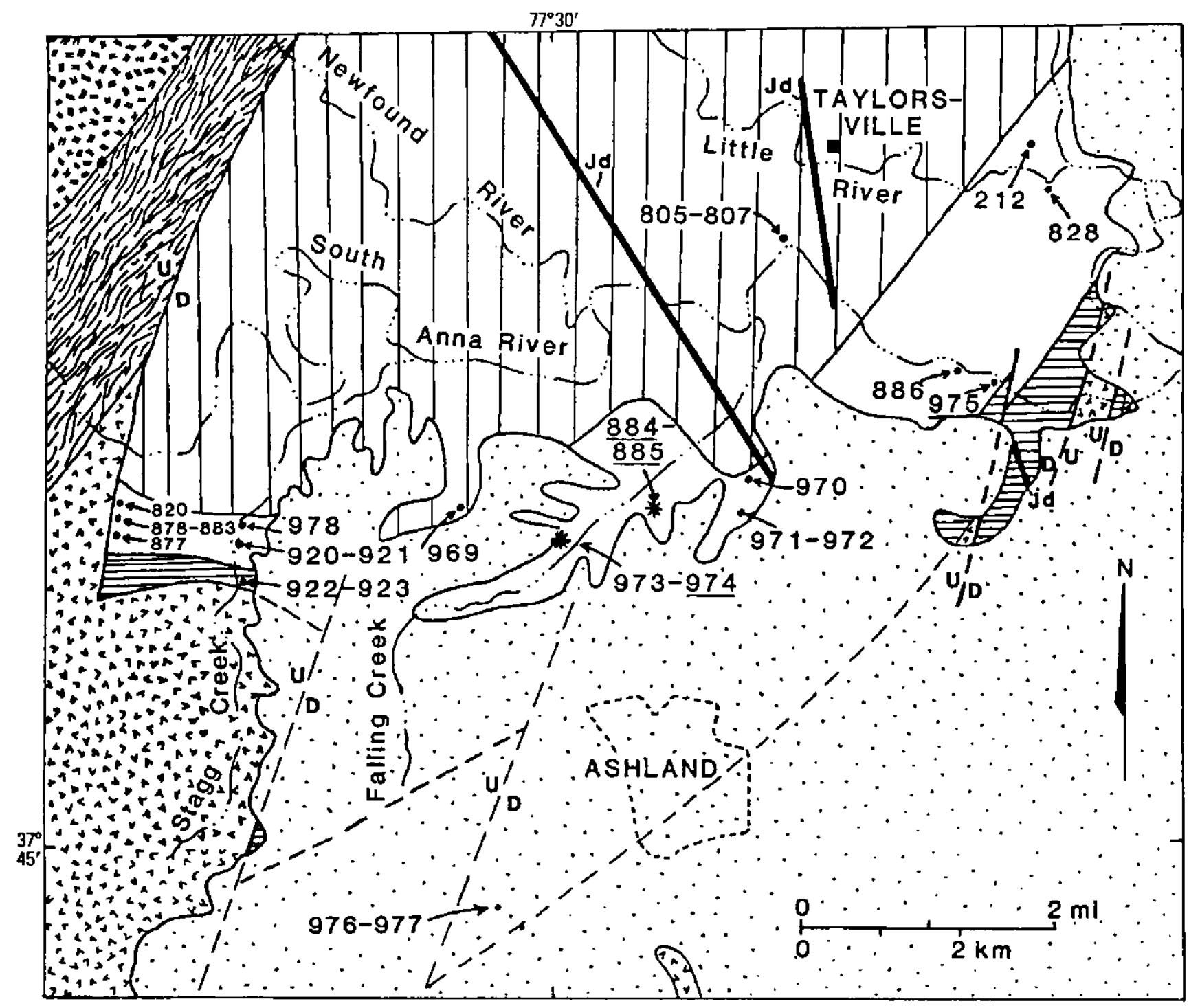

Figure 2. Map of the southern part of the Taylorsville basin. The Doswell Formation is divided into three members, the basal Stagg Creek Member (horizontal pattern), the overlying Falling Creek Member (no pattern), and the upper Newfound Member (vertical pattern). Rocks in the basin dip generally northwest toward the Hylas cataclastic zone (wavy pattern). The metamorphosed Goochland terrane (dashed pattern) and Petersburg Granite ("v" pattern) are exposed outside the basin. Diabase dikes of probable Early Jurassic age are indicated by the symbol "Jd," and faults are indicated by a heavy dashed line with "U/D" symbols (upthrown/downthrown). A solid black line indicates a contact. Cretaceous to Quaternary sediments of the Coastal Plain (fine dot pattern) overlap older rocks and structures (dashed lines where buried). Numbered dots indicate sample localities. Asterisks show localities with reworked palynomorphs; samples containing reworked palynomorphs are underlined. examined. A set of cuttings was made available by the Virginia Division of Mineral Resources from a water well (W-2340) that was bored in an area that has been mapped as the southernmost buried portion of the Taylorsville basin. Sample locations in the Taylorsville basin are shown in figure 2, and sample locations from the Deep Run basin are shown in figure 4. See table 5 (page 50) for a list of sample lithologies and other information.

Sample processing.-Standard kerogen processing that utilizes 10 percent $\mathrm{HCl}$ and 48 percent $\mathrm{HF}$ (Robbins and Traverse, 1980) was applied to the samples for biostratigraphic and Thermal Alteration Index (TAI) analyses. The TAI scale of Phillips Petroleum (Pearson, 1981) was used to quantify the color differences between palynomorphs (see table 4 for explanation of this scale). Coal samples usually required additional processing in Schulze's solution and 10 percent KOH (Doher, 1980) for detailed biostratigraphic analysis. The residues from acid and base treatments were mounted on glass slides with glycerin jelly. 


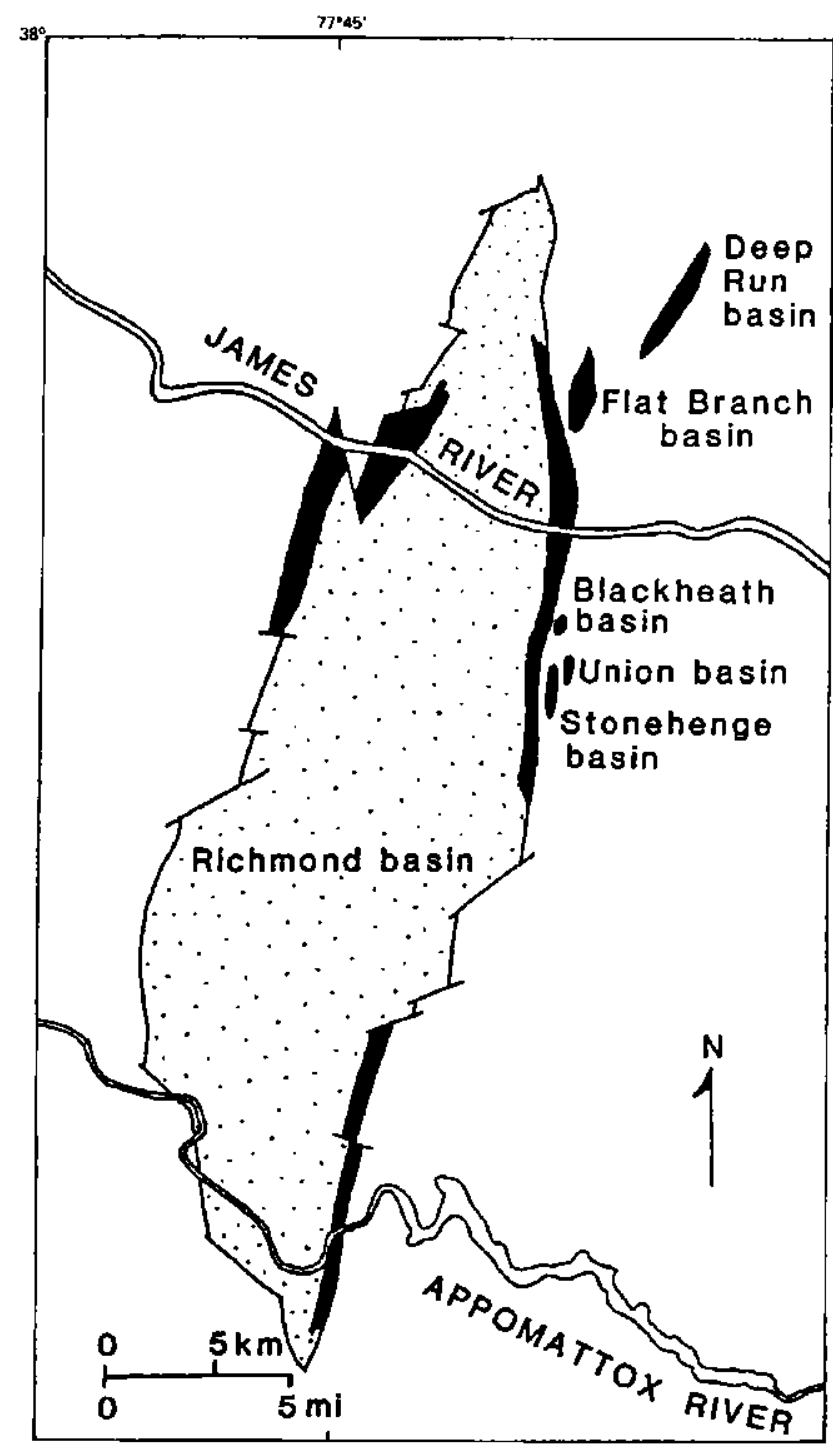

Figure 3. Map showing the Richmond basin and its nearby outliers (adapted from Goodwin and others, 1985). Coalbearing intervals are shown in black.

\section{PALYNOMORPHS FROM THE TAYLORSVILLE BASIN}

Most samples from the Taylorsville basin (fig. 2) contain palynomorphs diagnostic of Late Triassic age. Trilete and monolete spores, as well as bisaccate and nonbisaccate pollen, occur in the samples from the Taylorsville basin (table 1). The assemblage of Calamospora nathorstii, Deltoidospora magna, Dictyophyllidites mortonii, Osmundacidites senectus, "Placopollis raymondii" of Koob (1961), "Placopollis sp. Tetrad 39" of Cornet (1977), Sulcatisporites kraeuselii, Tigrisporites dubius, and Triadispora sp. A of Robbins (1982) indicates that the Falling Creek Member is of middle Carnian
(Julian) age (Cornet, 1977). Plate 1 illustrates some of these age-diagnostic taxa that have TAI 2 to 3 -colors.

Included with palynomorphs of undisputed Late Triassic age are some darker brown ones (TAI 3) that may be reworked and possibly Permian in age (plate 2 and table 2). Apiculatisporites cornutus ranges in age from Late Carboniferous to Middle Permian (Hart, 1970; Archangelsky and others, 1980; Balme, 1970; Foster, 1979). The two taxa that could be identified only to genus, cf. Gardenasporites sp. and cf. Pustilatisporites? sp. have been identified in Permian sequences elsewhere (Kaiser, 1976; Klaus, 1963). It is noteworthy that none of these taxa are known from the Pennsylvanian/Permian Dunkard Group (Clendening, 1970).

These reworked palynomorphs can be differentiated from in-situ ones on the basis of color; the older taxa are darker than the Carnian palynomorphs. Table 3 shows the total range of TAI values of palynomorphs in the Taylorsville basin, and an asterisk emphasizes samples that contain reworked taxa. The samples that contain reworked forms not only show a wide variety of TAI values in the different classes of palynomorphs (monolete and trilete spores; alete, bisaccate, and cycadlike pollen grains) but also appear to include grains with different densities. Darker colored palynomorphs appear to have floated higher and lighter colored palynomorphs appear to have sunk deeper in the mounting medium. The underlined samples on table 3 identify those that contain palynomorphs of different densities. This type of plot showing variable colors and variable densities may be useful in identifying samples that contain resistant, geologically recycled organic tissues (Eshet, 1987). For example, the length of the bars in the table suggests that samples $879,881,883,886$, and 921 also may contain reworked palynomorphs.

\section{PALYNOMORPHS FROM THE DEEP RUN BASIN}

All mine-dump samples from the Deep Run basin (fig. 4) contained palynomorphs, most of which are structurally degraded and darkened. The dark color of the grains obscures important wall characteristics that are needed to differentiate between species; even generic assignments are difficult because of the degradation. Samples include palynomorphs that most closely resemble cf. Camptotriletes, cf. Densipollenites, two species of Densoisporites, two species of cf. Gardenasporites, and cf. Gigantosporites (table 4 and plate 3 ). If these pollen and spores are assigned to the correct genera, then the following age restrictions would apply: Gardenasporites and Gigantosporites are restricted to the Permian, Camptotriletes ranges from the Carboniferous through the Permian, and Densipollenites ranges from the Permian 
Table 1. Carnian palynomorphs identified in Taylorsville basin

[?, presence uncertain]

\begin{tabular}{ll}
\hline Species & Sample number \\
\hline Trllete and monolete spores
\end{tabular}

Acanthotriletes varius Nilsson 1958..... 921

Calamospora nathorstii (Halle) Klaus

1960 ...........................

Camerosporites pseudovemucatus

Scheuring 1970

Camerosporites secatus Leschik 1955.

Convolutisporites affluens (Bolchovitina)

Schultz and Hope, 1973.............

Deltoidospora hallii Miner 1935 ........

D. magna (de Jersey) Norris 1965 ......

Deltoidospora sp. .................

Dictyophyllidites hamisii Couper $1958 \ldots$

D. mortonii (de Jersey) Playford and

Dettman 1965

$880,883,885$

878,881

974,975

885

883

878

885

$877,879,920$,

$921,975,978$ ?

Granulatisporites infirmus (Balme)

Cornet and Traverse 1975 ......... 975

Leschikisporis aduncus (Leschik)

Potonie $1958 \ldots \ldots \ldots \ldots \ldots \ldots \ldots$

Osmundacidites senectus Balme 1963 ...

Polycingulatisporites sp..............

Punctatisporites major Couper 1958....

P. sp.............................

Raistrickia grovensis Schopf 1944 ......

Stereisporites perforatus Leschik 1955....

Tigrisporites dubius Maedler 1964.......

Todisporites major Couper 1958 .......

Triletes klausii Bharadwaj and Singh

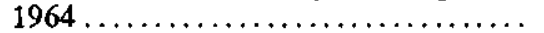

Vemucosisporites cheneyi Cornet and

Traverse $1975 \ldots \ldots \ldots \ldots \ldots \ldots \ldots$

\section{Bisaccate polien}

Alisporites grandis (Cookson) Dettmann 1963

A. ovatus (Balme and Hennelly)

Jansonius 1962

$820,880,883,885$

828B, 877,880 , $883,884,885$,

974,975

A. parnus de Jersey 1962

A. thomasii (Couper) Nilsson 1958 ....

A. toralis (Leschik) Clarke $1965 \ldots \ldots \ldots$

A. sp............................

Colpectopollis ellipsoideus Visscher

$1966 \ldots \ldots \ldots \ldots \ldots \ldots \ldots \ldots \ldots$ 877, 974, 975

Haplosporites varius Schaarschmidt

$1963 \ldots \ldots \ldots \ldots \ldots \ldots \ldots \ldots \ldots, 921,974$

$212,877 ?, 878$

$880,881,883$,

$885,886,975$

828B, 879,881 ,

$883,885 ?, 978$

880,884

$820,828 \mathrm{~B}, 877$,

$878,879,880$,

$881,883,884$,

$885,921,975,978$

\begin{tabular}{ll}
\hline Species & Sample number \\
\hline Blsaccate pollen - Continued \\
\hline
\end{tabular}

Microcachryidites doubingeri Klaus 1964. 212

Pityosporites devolvens Leschik $1955 \ldots$... 828B, 877, 884

P. inclusus Leschik 1955 ........... 807?, 920

$P$. scaurus (Nilsson) Schulz 1967...... 820, 828, 878

P. sp..................... 820, 880, 882, 884,975

Platysaccus queenslandi de Jersey 1962.885

Platysaccus sp................. 884

Podosporites cf. amicus Scheuring 1970 . 880

Sulcatisporites australis (de Jersey)

Dunay $1972 \ldots \ldots \ldots \ldots \ldots \ldots \ldots \ldots$ 878?

Sulcatisporites kraeuselii Maedler 1964 .. 881, 885

Triadispora stabilis Scheuring $1970 \ldots \ldots .978$

Triadispora sp. A Robbins 1982 ...... 807

\begin{tabular}{|c|c|}
\hline \multicolumn{2}{|l|}{ Nonbisaccate pollen } \\
\hline $\begin{array}{l}\text { Araucariacites fissus Reiser and } \\
\text { Williams } 1969 \ldots \ldots \ldots \ldots \ldots \ldots \ldots\end{array}$ & 820,878 \\
\hline $\begin{array}{l}\text { Corollina meyeriana (Klaus) Venkata- } \\
\text { chala and Goczan } 1964 \ldots \ldots \ldots \ldots \ldots\end{array}$ & $877,878,880$ \\
\hline $\begin{array}{l}\text { Cycadopites deterius (Balme) Pocock } \\
1970 \ldots \ldots \ldots \ldots \ldots \ldots \ldots \ldots \ldots \ldots\end{array}$ & 820,883 \\
\hline C. nitidus (Balme) Pocock $1970 \ldots \ldots$. . & 878 \\
\hline C. sp. ............. & $\begin{array}{l}828 \mathrm{~B}, 877,880 \\
881,882,885 \\
886,920,921 \\
974,975\end{array}$ \\
\hline Enzonalasporites vigens Leschik $1955 \ldots$ & 820 \\
\hline Monocolpopollenites sp. ............. & 878 \\
\hline Oralipollis ovalis Krutzsch $1955 \ldots \ldots \ldots$ & $\begin{array}{l}878,880,881 \\
884,920\end{array}$ \\
\hline Paracirculina scumilis Scheuring $1970 \ldots$ & $807,877,881,884$ \\
\hline Patinasporites densus Leschik 1955 & $807,828 \mathrm{~B}$ \\
\hline "Placopollis raymondii" Koob $1961 \ldots .$. & $\begin{array}{l}212,807,828 \mathrm{~B} \\
877,878,880 \\
881,883,885\end{array}$ \\
\hline "P. sp. Tetrad 39" Cornet $1977 \ldots \ldots \ldots$ & $820,883,974,975$ \\
\hline $\begin{array}{l}\text { Pseudoenzonalasporites summus } \\
\text { Scheuring } 1970 \ldots \ldots \ldots \ldots \ldots\end{array}$ & 885 \\
\hline Retisulcites sp. 126 Cornet $1977 \ldots \ldots$. . & 212 \\
\hline Zonizonasulculate sp. . & 877,879 \\
\hline
\end{tabular}

into the early Middle Triassic (Jansonius and Hills, 1976; Klaus, 1963; Potonie and Kremp, 1954). Densoisporites cf. playfordi, if correctly identified, is known only from beds that are Late Permian in age (Balme, 1970). The ranges of these poorly identifiable genera overlap in the Permian, but Permian age-diagnostic striate bisaccate pollen are not present. An Early or Middle Triassic age seems more likely, but a definitive age assignment must await discovery of better preserved and more diverse assemblages. 


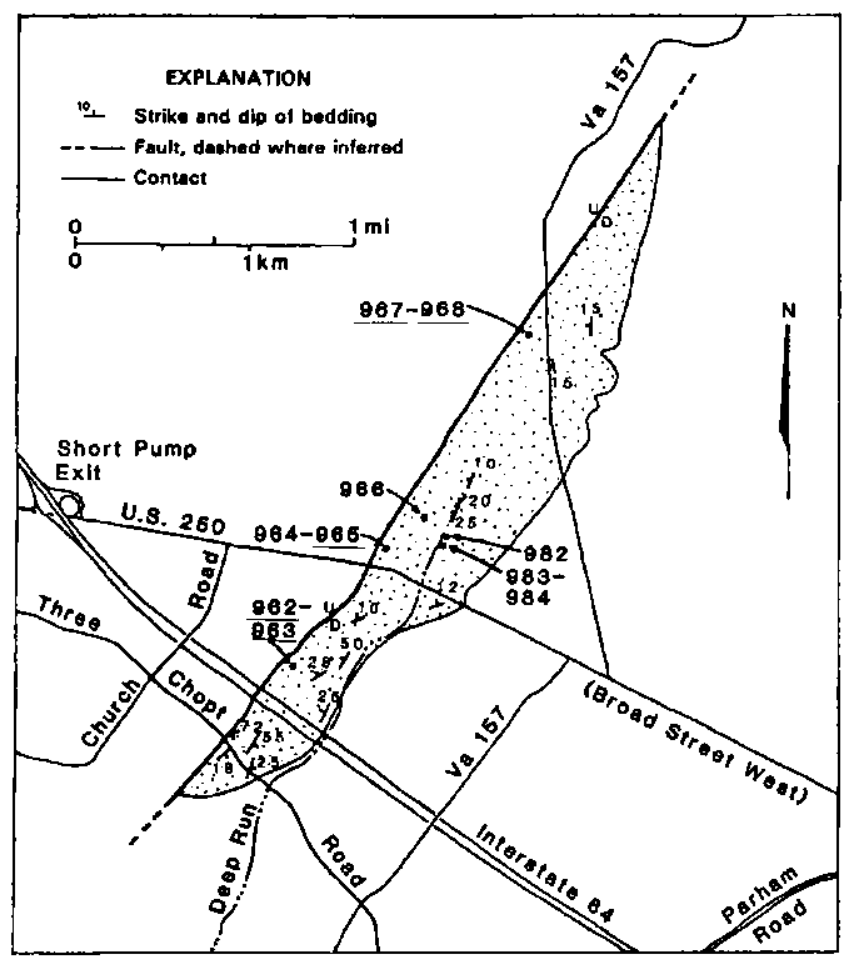

Figure 4. Map of the Deep Run basin (after Goodwin, 1981), Henrico County, Virginia, showing numbered locations sampled for palynomorphs. Samples containing Permian? palynomorphs are underlined. Triassic rocks shown in stippled pattern. U, upthrown, and D, downthrown side of fault.

Table 2. Unusual palynomorphs in the Taylorsville basin

\begin{tabular}{|c|c|}
\hline Taxon & Sample number \\
\hline $\begin{array}{l}\text { Apiculatisporites comutus Balme and } \\
\text { Hennelly } 1956 \ldots \ldots \ldots \ldots \ldots \ldots \ldots\end{array}$ & 885 \\
\hline cf. Gardensporites sp..... & 974 \\
\hline Nuskoisporites? sp... & 974 \\
\hline cf. Pustilatisporites sp. . & 975 \\
\hline
\end{tabular}

The use of mine-dump samples presents inherent problems. Differential preservation of thicker walled and more carbonized palynomorphs is a distinct possibility with such samples. Yet this flora, although sparse, contains taxa that commonly occur together elsewhere in situ. Although the few outcrop samples have been barren of palynomorphs, they contain woody tissues that are degraded and darkened to a degree comparable to that of the mine-dump samples. Therefore, a process of selective preservation of reworked, thick-walled palynomorphs of diverse ages is not likely to have occurred in the eight productive samples from the Deep Run basin.
The color of these palynomorphs and associated woody tissues is a distinctive dark brown to very darkbrown (TAI 4 - to 4 ) (table 3 and plate 3 ). The uniformly very dark color of these palynomorphs contrasts strongly with the lighter colors (TAI 2 to $3-$ ) of middle Carnian palynomorphs in the Taylorsville basin only $8.8 \mathrm{~km}$ to the north (table 3 ). Middle Carnian palynomorphs both from outcrops and from coal mine dumps in the Richmond basin (TAI 3- to 3+) have colors similar to middle Carnian palynomorphs in the Taylorsville basin (Robbins and others, in press). The darker colors of the palynomorphs from the Deep Run basin indicate that this basin probably was subjected to a thermal event that did not affect the other nearby basins; deep regional burial may be ruled out because the Richmond basin, only $6.4 \mathrm{~km}$ away, was not similarly affected. The darker colors suggest, independent of taxonomy, that the Deep Run sedimentary rocks may be older than rocks presently exposed in the Richmond and Taylorsville basins.

\section{AREA BETWEEN THE TAYLORSVILLE AND DEEP RUN BASINS}

Water well W-2340 penetrated a section considered by Weems (1980a) to be a southern extension of the Taylorsville basin. Cuttings from this well contained no identifiable palynomorphs. But cuttings from depths of 120 to $325 \mathrm{ft}$ (sample 977, located on fig. 2) contained unidentifiable fragmentary palynomorphs, a few of which are light brown in color (TAI 3-), and most of which are dark and very dark brown in color (TAI 4- to 4) (table 3). The dark-brown grains resemble those in the Deep Run basin, $8.8 \mathrm{~km}$ to the southwest.

Although no identifiable palynomorphs occur in these samples, two interpretations are possible from the state of preservation of the grains and their range of colors. The broken, dark-brown palynomorphs suggest possible reworking; they may have been transported to their present position along the southern border of the Taylorsville basin in Late Triassic time. Alternatively, the presence of both dark- and light-colored palynomorphs could mean that lighter colored Triassic palynomorphs from an unconformably overlying unit might have caved during drilling into an underlying older unit. Either interpretation is possible; thus a core from this locality is needed to determine if older palynomorphs are reworked into the Taylorsville basin or if a previously unrecognized older section is buried beneath the southern margin of the Taylorsville basin. 
Table 3. Color alteration of palynomorphs in and between the Taylorsville and Deep Run basins

L_, palynomorphs in samples have variable densities; *, sample contains unusual palynomorphs; ?, palynomorphs degraded beyond recognition; bn, brown; yw, yellow; dk, dark; lt, light; med, medium; vdk, very dark]

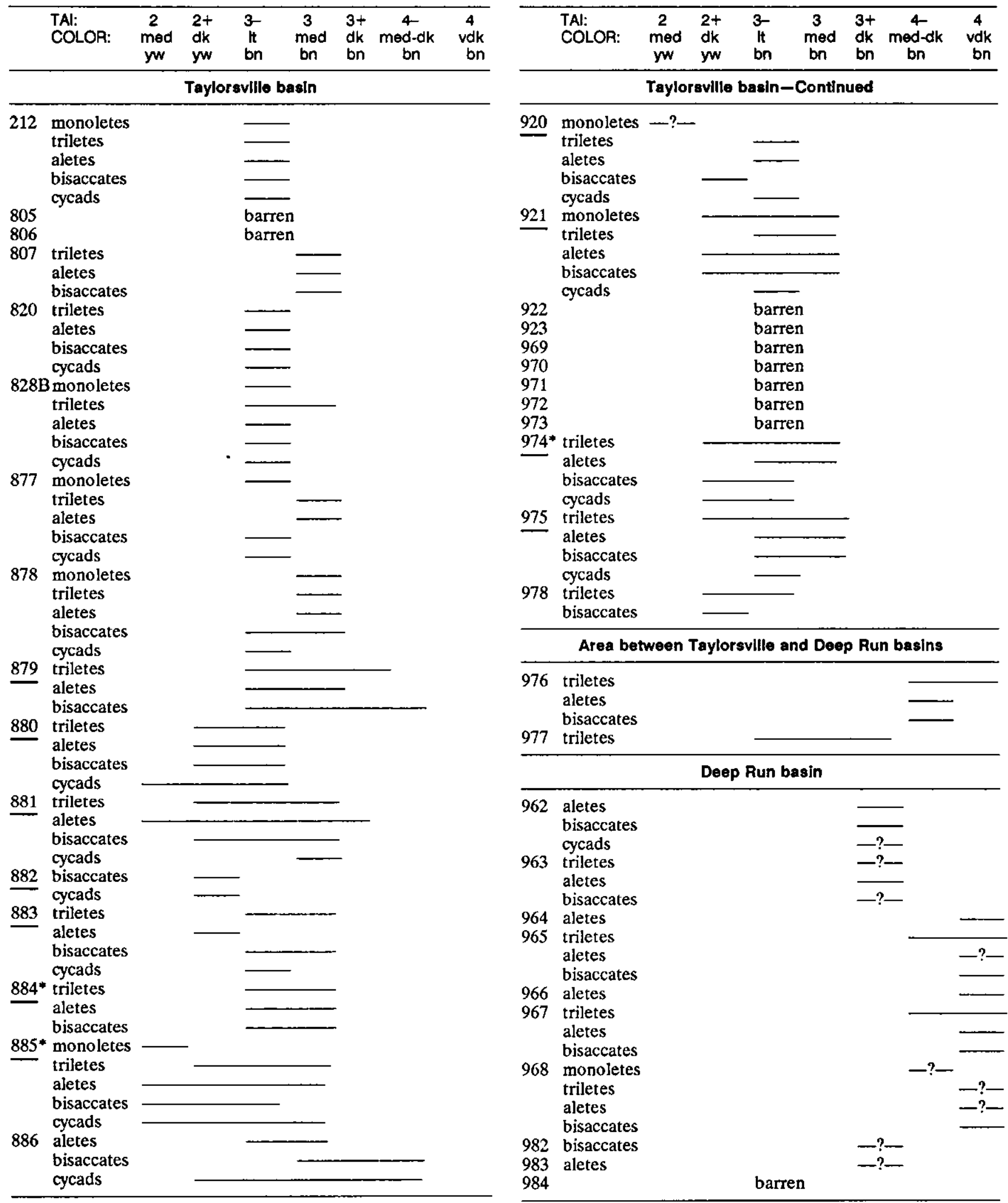


Table 4. Unusual palynomorphs in the Deep Run basin

\begin{tabular}{|c|c|}
\hline Taxon & Sample number \\
\hline cf. Camptotriletes sp. ............... & 962,963 \\
\hline Densipollenites cf. playfordi ............ & 965 \\
\hline cf. Densoisporites sp. ............... & 965 \\
\hline cf. Gardenasporites sp. ............. & 965,967 \\
\hline cf. Gigantosporites sp................ & 968 \\
\hline
\end{tabular}

\section{CONCLUSIONS}

1. The Upper Triassic Doswell Formation in the Taylorsville basin contains both in-situ middle Carnian palynomorphs of TAI 2 to 3 - and older, darker (TAI 3) palynomorphs that suggest a reworked origin. The source beds of these darker palynomorphs, possibly as old as Permian in age, probably are not the strata of the Deep Run basin because the reworked palynomorphs in the Taylorsville basin are not as dark as those in the Deep Run basin and because Apiculatisporites in the Taylorsville basin samples so far is unrepresented in the Deep Run samples.

2. The Deep Run basin, previously considered to be an erosional outlier of the Richmond basin, contains a palynoflora that may be older than the oldest palynoflora so far found in either the Taylorsville or Richmond basin. An unequivocal age assignment is not yet possible because of the lack of definite age-diagnostic taxa and the poor preservation of the palynomorphs. The assemblage can be used to support an age between Permian and Middle Triassic. The lack of characteristic Permian striate bisaccate pollen suggests that an Early to Middle Triassic age is most likely. The very dark colors of the palynomorphs (TAI 4 to 4 ) suggest that the strata have undergone a more pervasive thermal or degradational history than the exposed parts of either the Richmond or Taylorsville basin.

\section{ACKNOWLEDGMENTS}

We would like to thank D.G. Benson, A.J. Froelich, B.K. Goodwin, and G.P. Wilkes for providing samples for our study. E.J. Kidson and R.A. Morgan provided us with age-distribution data, and Bruce Cornet provided helpful information.

\section{REFERENCES CITED}

Archangelsky, S., Azcuy, C.L., and others, 1980, The Carboniferous and Early Permian of the South American Gond. wana area: Actas $2^{\circ}$ Congreso Argentino de Paleontologia y Bioestratigrafia y $1^{\circ}$ Congreso Latinoamericano de Paleontologia, Buenos Aires, v. 4, p. 257-269.

Balme, B.E., 1970, Palynology of Permian and Triassic strata in the Salt Range and Surghar Range, West Pakistan, in Kummel, B., and Teichert, G., eds., Stratigraphic boundary problems: Permian and Triassic of West Pakistan: Lawrence, Kansas, University of Kansas Press, Special Publication 4 , p. $305-453$.

Barlow, J.A., ed., 1975, Proceedings of the First I.C. White Memorial Symposium, The age of the Dunkard: West Virginia Geological and Economic Survey, $352 \mathrm{p}$.

Clendening, J.A., 1970, Sporological evidence on the geological age of the Dunkard strata in the Appalachian basin: unpublished $\mathrm{Ph}$.D. dissertation, Morgantown, University of West Virginia, $453 \mathrm{p}$.

Clifford, W., 1888, Richmond Coal-field Virginia: Transactions of the Manchester Geological Society, v. 19, p. 326-358, $430-432$.

Cornet, B., 1977, The palynostratigraphy and age of the Newark Supergroup: unpublished Ph.D. dissertation, University Park, Pennsylvania State University, 506 p.

Doher, L.I., 1980, Palynomorph preparation procedures currently used in the Paleontology and Stratigraphy Laboratories, U.S. Geological Survey: U.S. Geological Survey Circular 839, 29 p.

Ediger, V.S., 1986, Paleopalynological biostratigraphy, organic matter deposition, and basin analysis of the Triassic(?)Jurassic Richmond rift basin, Virginia, U.S.A.: unpublished Ph.D. dissertation, University Park, Pennsylvania State University, $548 \mathrm{p}$.

Englund, K.J., Arndt, H.H., Schweinfurth, S.P., and Gillespie, W.H., 1986, Pennsylvanian System stratotype sections, West Virginia, in Neathery, T.L., ed., Centennial field guide v. 6: Geological Society of America, Southeastern Section, p. 59-68.

Eshet, Y., 1987, Palynostratigraphy and paleoenvironmental interpretations of the Permo-Triassic in the subsurface of Israel: unpublished Ph.D. dissertation, New York, City University of New York, 203 p.

Foster, C.B., 1979, Permian plant microfossils of the Blair Athol Coal Measures, Baralaba Coal Measures, and Basal Rewan Formation of Queensland: Geological Survey of Queensland Publication 372, p. 1-244.

Goodwin, B.K., 1981, Geology of the Glen Allen quadrangle, Virginia $(1: 24,000)$ : Virginia Division of Mineral Resources Publication 31 (GM 127A).

Goodwin, B.K., and Johnson, G.H., 1967, Geologic structure and stratigraphy of a portion of the Triassic basin at Deep Run, Henrico County, Virginia: Virginia Journal of Science, v. 22, p. 185.

Goodwin, B.K., Weems, R.E., Wilkes, G.P., Froelich, A.J., and Smoot, J.P., 1985, The geology of the Richmond and Taylorsville basins, east-central Virginia: American Association of Petroleum Geologists Field Trip Guidebook 4, Williamsburg, Virginia, $60 \mathrm{p}$.

Hart, G.F., 1970, Micropaleontology of the Karroo deposits in south and central Africa (abs.), in Gondwana stratigraphy: International Union of Geological Sciences Symposium, 1967, Unesco, Paris, p. 23-35. 
Jansonius, J., and Hills, L.V., 1976, Genera file of fossil spores: Special Publication, Department of Geology, University of Calgary, Canada.

Kaiser, H., 1976, Der Permische mikroflora der Cathaysiaschichten von Nordwest-Schansi, China: Palaeontographica, Band 159, Abteilung B, p. 83-157.

Klaus, W., 1963, Sporen aus dem sud Alpinen Perm: Jahrbuch der Austria Geologischen Bundesanstalt, Vienna, Austria, v. 106, p. 299-361.

Koob, J.D., 1961, Triassic pollen and spore flora of the Cumnock Formation (Newark Series) of North Carolina: M.A. thesis, University of Massachusetts, Amherst, 47 p.

Lucas, J.R., 1981, The methane potential from coal seams in the Richmond basin of Virginia: Report to TRW Energy Systems Group, p. 1-93, 12 appendices.

Pearson, D.L., 1981, Pollen/spore color standard: Phillips Petroleum Co., 2 p.

Potonie, R., and Kremp, G.O.W., 1954, Die Gattungaen der palaeozoischen Sporae dispersae und ihre Stratigraphie: Geologisches Jahrbuch, Band 69, p. 142.

Ressitar, R., and Taylor, G.K., in press, Late Triassic depositional history of the Richmond and Taylorsville basins, eastern Virginia, in Manspeizer, W., ed., Triassic-Jurassic rifting of North America and Africa: Elsevier.

Robbins, E.I., 1982, "Fossil Lake Danville": The paleoecology of a Late Triassic ecosystem on the North Carolina-Vir- ginia border: unpublished $\mathrm{Ph} . \mathrm{D}$. dissertation, State College, Pennsylvania, Pennsylvania State University, $400 \mathrm{p}$.

1985, Palynostratigraphy of coal-bearing sequences in early Mesozoic basins of the Eastern United States, in Robinson, G.R., Jr., and Froelich, A.J., eds., Proceedings of the second U.S. Geological Survey workshop on the early Mesozoic basins of the Eastern United States: U.S. Geological Survey Circular 946, p. 27-29.

Robbins, E.I., and Traverse, A., 1980, Degraded palynomorphs from the Dan River (North Carolina)-Danville (Virginia) basin: Carolina Geological Society Field Trip Guidebook, p. BX1-11.

Robbins, E.I., Wilkes, G.P., and Textoris, D.A., in press, Coals of the Newark rift system, in Manspeizer, W., ed., TriassicJurassic rifting of North America and Africa: Elsevier.

Shaler, N.S., and Woodworth, J.B., 1899, Geology of the Richmond basin, Virginia: U.S. Geological Survey Annual Report 19, 1897-1898, part 2, p. 385-515.

Weems, R.E., 1980a, Geology of the Taylorsville basin, Hanover County, Virginia, in Contributions to Virginia Geology-IV: Virginia Division of Mineral Resources Publication 27, p. 23-38.

1980b, An unusual newly discovered archosaur from the Upper Triassic of Virginia, U.S.A.: Transactions of the American Philosophical Society, v. 70, part 7, p. 1-53. 
TABLE 5 
Table 5. Lithology and locality information for samples from and between the Taylorsville and Deep Run basins

[bitum, bituminous; bn, brown; calc, calcareous; carb, carbonaceous; cg, coarse grained; dk, dark; gy, gray; lam, laminated; mass, massive; sh, shale; sltst, siltstone]

\begin{tabular}{|c|c|c|c|c|c|}
\hline $\begin{array}{l}\text { Sample } \\
\text { number }\end{array}$ & Lithology & Field number & $\begin{array}{l}\text { Member or } \\
\text { formation }\end{array}$ & Quadrangle & Additional information \\
\hline \multicolumn{6}{|c|}{ Taylorsville basin } \\
\hline $\begin{array}{l}212 \ldots \ldots \\
805 \ldots \ldots\end{array}$ & $\begin{array}{l}\text { black lam sh } \\
\text { cg micaceous calc sandy } \\
\text { sitst }\end{array}$ & $\begin{array}{l}\text { Doswellia site } \\
\text { ASH-1 540-560' }\end{array}$ & $\begin{array}{l}\text { Falling Creek } \\
\text { do. }\end{array}$ & $\begin{array}{l}\text { Ashland } \\
\text { do. }\end{array}$ & $\begin{array}{l}\text { Weems, } 1980 \mathrm{~b} . \\
\text { test core. }\end{array}$ \\
\hline $806 \ldots \ldots$ & $\begin{array}{l}\text { mass gy-bn sandy sltst/ } \\
\text { bitum sh }\end{array}$ & ASH-1 $479^{\prime}$ & do. & do. & Do. \\
\hline $807 \ldots \ldots$ & $\begin{array}{l}\text { gy cross-bedded } \\
\text { sandstone }\end{array}$ & ASH-1 58-60' & do. & do. & Do. \\
\hline $820 \ldots \ldots$ & $\begin{array}{l}\text { impure coal } \\
\text { do. }\end{array}$ & $\begin{array}{l}\text { 8211ER1 } \\
\text { LR-3 }\end{array}$ & do. & $\begin{array}{l}\text { Hanover Academy } \\
\text { Ashland }\end{array}$ & \\
\hline $877 \ldots \ldots$ & carb sh & 8211ER2 & do. & Hanover Academy & $\begin{array}{l}\text { see also Robbins and } \\
\text { others, in press. }\end{array}$ \\
\hline $878 \ldots \ldots$ & black lam calc sh & 8211ER3 & do. & do. & \\
\hline $879 \ldots \ldots$ & black silty sandstone & 8211ER4 & do. & do. & \\
\hline $880 \ldots \ldots$ & black lam calc carb sh & 8211ER5 & do. & do. & \\
\hline $\begin{array}{l}881 \ldots \ldots \\
882 \ldots \ldots\end{array}$ & $\begin{array}{l}\text { black lam calc sltst } \\
\text { gy sandstone }\end{array}$ & $\begin{array}{l}\text { 8211ER6 } \\
8211 E R 7\end{array}$ & do. & do. & \\
\hline $883 \ldots \ldots$ & slightly calc impure coal & 8211ER8 & do. & do. & $\begin{array}{l}\text { see also Robbins and } \\
\text { others, in press. }\end{array}$ \\
\hline $\begin{array}{l}884 \ldots \ldots \\
885 \ldots \ldots \\
886 \ldots \ldots\end{array}$ & $\begin{array}{l}\text { black lam calc sh } \\
\text { black lam sh } \\
\text { impure coal }\end{array}$ & $\begin{array}{l}\text { 8211ER9 } \\
8211 \text { ER10 } \\
\text { SA-8 }\end{array}$ & $\begin{array}{l}\text { do. } \\
\text { do. } \\
\text { do }\end{array}$ & $\begin{array}{l}\text { Ashland } \\
\text { do. } \\
\text { do. }\end{array}$ & \\
\hline $920 \ldots \ldots$ & black lam carb sh & Outcrop A Bed 18 & do. & Hanover Academy & $\begin{array}{l}\text { see also Goodwin and } \\
\text { others, } 1985 \text {. }\end{array}$ \\
\hline $\begin{array}{l}921 \ldots \ldots \\
922 \ldots \ldots\end{array}$ & $\begin{array}{l}\text { dark-gy mass silty sh } \\
\text { schist clasts }\end{array}$ & $\begin{array}{l}\text { Outcrop A Bed } 6 \\
\text { "clasts" }\end{array}$ & $\begin{array}{c}\text { do. } \\
\text { Stagg Creek }\end{array}$ & $\begin{array}{l}\text { do. } \\
\text { do. }\end{array}$ & \\
\hline $923 \ldots \ldots$ & sandstone or schist & "sandstone" & do. & do. & \\
\hline $969 \ldots \ldots$ & $\begin{array}{l}\text { five gy and white } \\
\text { pebbles }\end{array}$ & 8603 ER5 & Falling Creek & do. & \\
\hline $970 \ldots \ldots$ & $\begin{array}{l}\text { green, } \mathrm{Cu} \text {-bearing } \\
\text { sandstone }\end{array}$ & 8603ER6 & do. & Ashland & \\
\hline $971 \ldots \ldots$ & green clay & 8603ER7 & do. & do. & \\
\hline $972 \ldots \ldots$ & gy-green mass clay & 8603ER8 & do. & do. & \\
\hline $\begin{array}{l}973 \ldots \ldots \\
974 \ldots \ldots\end{array}$ & $\begin{array}{l}\text { gy lam clayey sandstone } \\
\text { medium-gy lam clay }\end{array}$ & $\begin{array}{l}\text { 8603ER9 } \\
8603 \text { ER } 10\end{array}$ & $\begin{array}{l}\text { do. } \\
\text { do. }\end{array}$ & $\begin{array}{l}\text { do. } \\
\text { do. }\end{array}$ & \\
\hline $975 \ldots \ldots$ & black lam carb sh & $\begin{array}{l}\text { 8603ER11 Section } \\
3-11\end{array}$ & do. & do. & Weems, 1980a. \\
\hline 978. & impure coal & 8511ER10 Outcrop B & do. & Hanover Academy & $\begin{array}{l}\text { see also Goodwin and } \\
\text { others, } 1985 .\end{array}$ \\
\hline \multicolumn{6}{|c|}{ Area between the two basins } \\
\hline & cuttings of gy sh & $\mathrm{W}-2340130-150^{\prime}$ & $\begin{array}{l}\text { unnamed or } \\
\text { Stagg Creek }\end{array}$ & Glen Allen & Oak Hill Water Co. \\
\hline $977 \ldots \ldots$ & cuttings of black sh & $W-2340300-325^{\prime}$ & do. & do. & well. \\
\hline \multicolumn{6}{|c|}{ Deep Run basin } \\
\hline 962. & black lam carb sh & $8603 E R 1$ & unnamed & do. & from mine dump. \\
\hline $963 \ldots \ldots$ & black mass carb sh & do. & do. & do. & Do. \\
\hline $964 \ldots \ldots \ldots$ & slightly calc impure coal & $8603 E R 2$ & do. & do. & Do. \\
\hline $965 \ldots \ldots$ & $\begin{array}{l}\text { dk-gy-bn mass slightly } \\
\text { calc sh }\end{array}$ & do. & do. & do. & Do. \\
\hline $966 \ldots \ldots$ & impure coal & 8603ER3 & do. & do. & Do. \\
\hline $967 \ldots \ldots$ & impure coal & 8603ER4 & do. & do. & Do. \\
\hline 968 . & $\begin{array}{l}\text { black lam carb } \\
\text { micaceous sh }\end{array}$ & do. & do. & do. & Do. \\
\hline $982 \ldots \ldots$ & gy clay & $\begin{array}{l}150 \text { yards north of } \\
\# 983\end{array}$ & do. & do. & along Deep Run. \\
\hline $983 \ldots \ldots$ & $\begin{array}{l}\text { black medium-bedded } \\
\text { carb sh }\end{array}$ & shale above coal & do. & do. & Do. \\
\hline $984 \ldots \ldots$ & coal & coal & do. & do. & Do. \\
\hline
\end{tabular}




\section{PLATES 1-3}

Contact photographs of the plates in this report are available, at cost, from the U.S. Geological Survey Library, Federal Center, Denver, CO 80225. 


\section{PLATE 1}

Figure 1. Calamospora nathorstii. Sample 879.

2. Convolutisporites affluens. Sample 975.

3. Osmundacidites senectus. Sample 975 .

4. "Placopollis raymondir" of Koob 1961. Sample 878.

5. Haplosporites varius. Sample 921.

6. Triadispora "sp. A" of Robbins 1982. Sample 807.

7. Alisporites toralis. Sample 884.

8. Sulcatisporites krauselii. Sample 881.

9. Alisporites thomasi. Sample 881. 

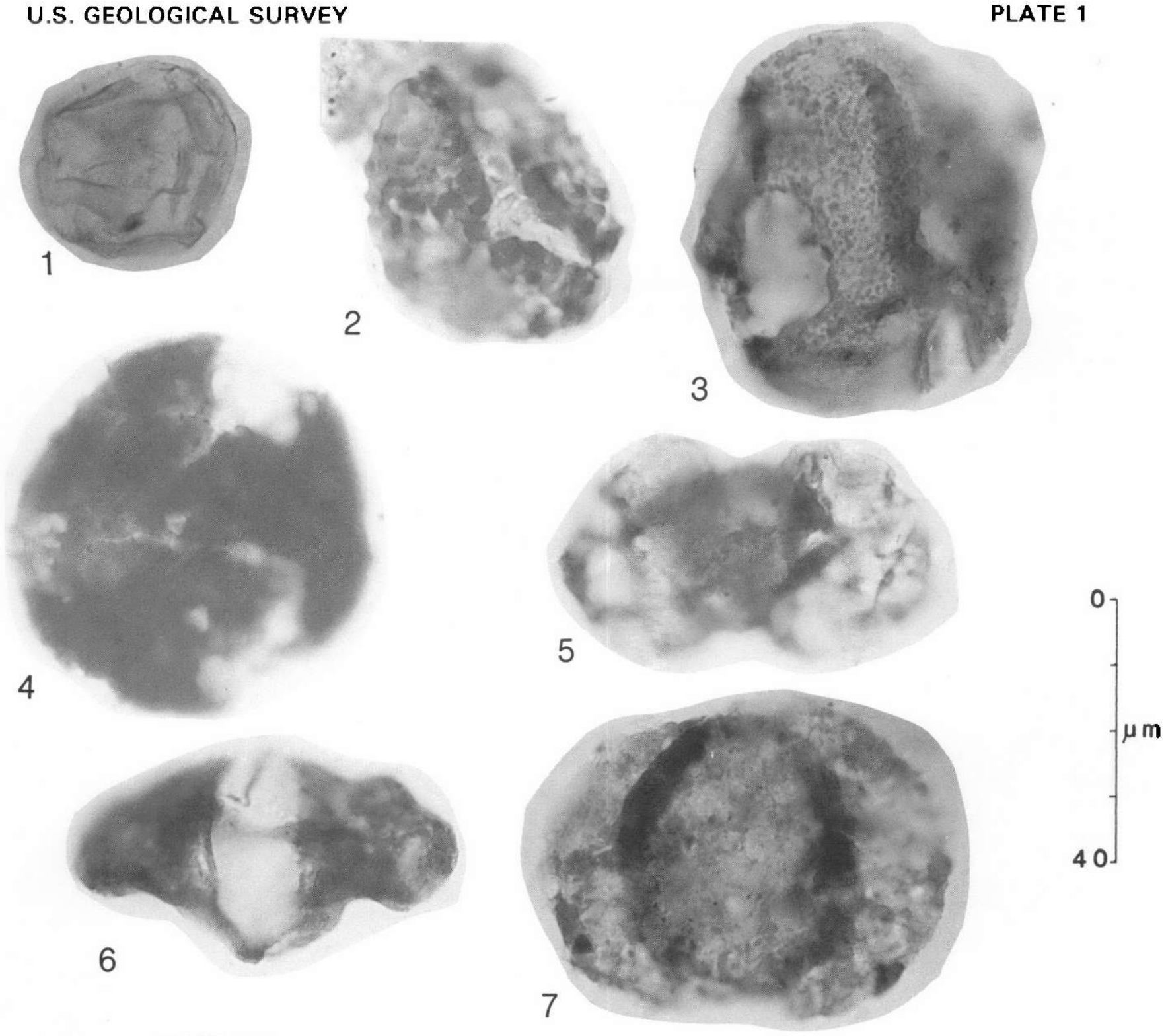

6
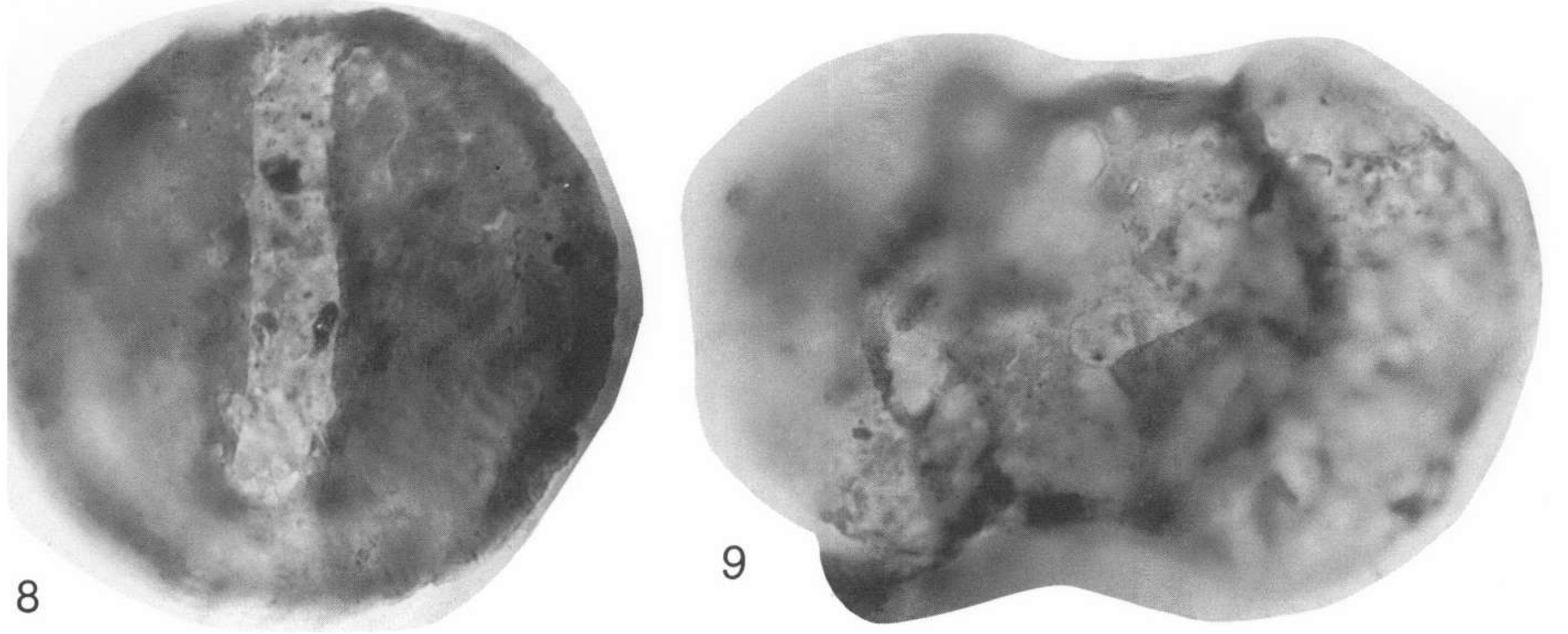


\section{PLATE 2}

[scale as given unless otherwise noted]

Figure 1-3. Apiculatisporites cornutus. Sample 885. Three different foci of same grain to show spines.

4. Cf. Pustilatisporites sp. Sample 975. Note triads of coni.

5. Nuskoisporites? sp. Sample 974. No trilete mark present.

6. Cf. Gardenasporites sp. Sample 974. Note thickened taenia.

7. Cf. Gardenasporites sp. on left and Carnian-age Sulcatisporites krauselii on right. Sample 885. Note darker color of Gardenasporites. $\times 1 / 2$. 

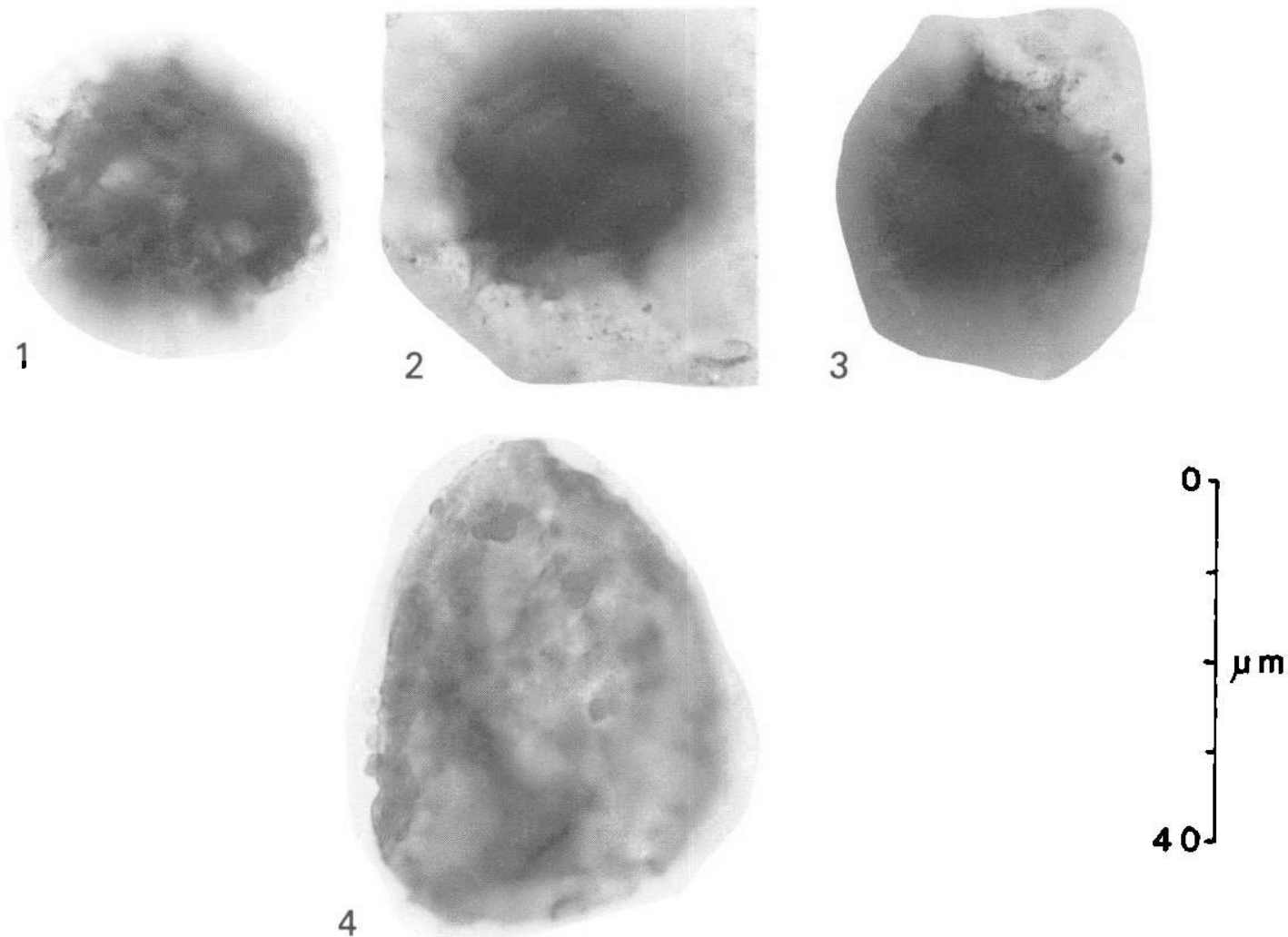

4
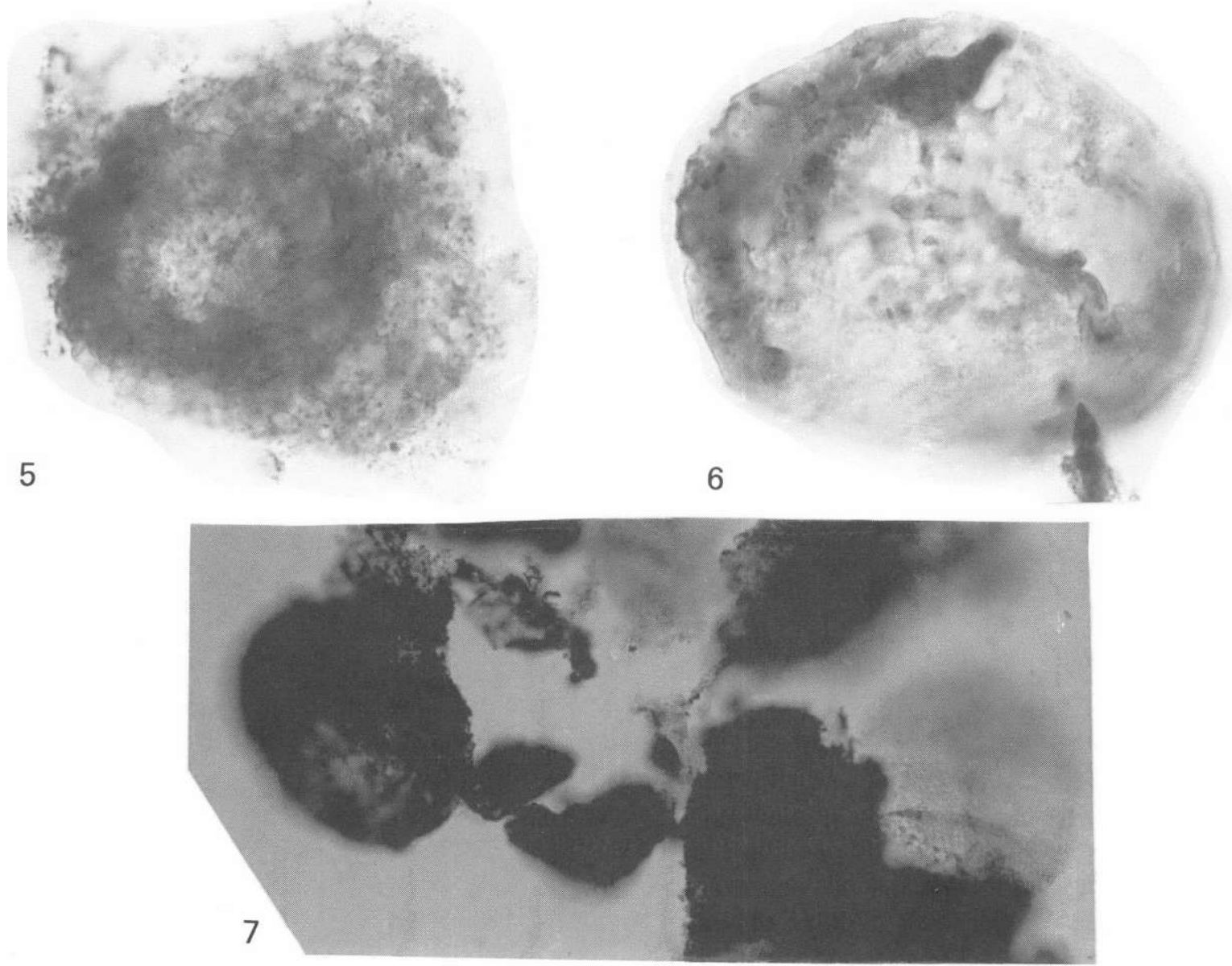

PALYNOMORPHS WITH PERMIAN AFFINITIES APPARENTLY REWORKED INTO THE TAYLORSVILLE BASIN 


\section{PLATE 3}

Figure 1. Cf. Camptotriletes. Sample 962. Note cristate processes.

2. Cf. Densipollenites. Sample 965. Note faintly rugulose surface.

3. Densoisporites sp. Sample 965. Note laesurae extend to equator.

4-5. Densoisporites cf. playfordi. Sample 965.

4. Focus on cingulum.

5. Focus on trilete mark.

6-8. Cf. Gardenasporites. Sample 965.

6. Note dark color of pollen grain.

7. Note thickened taenia.

8. Note sacci are differentiated from corpus. 

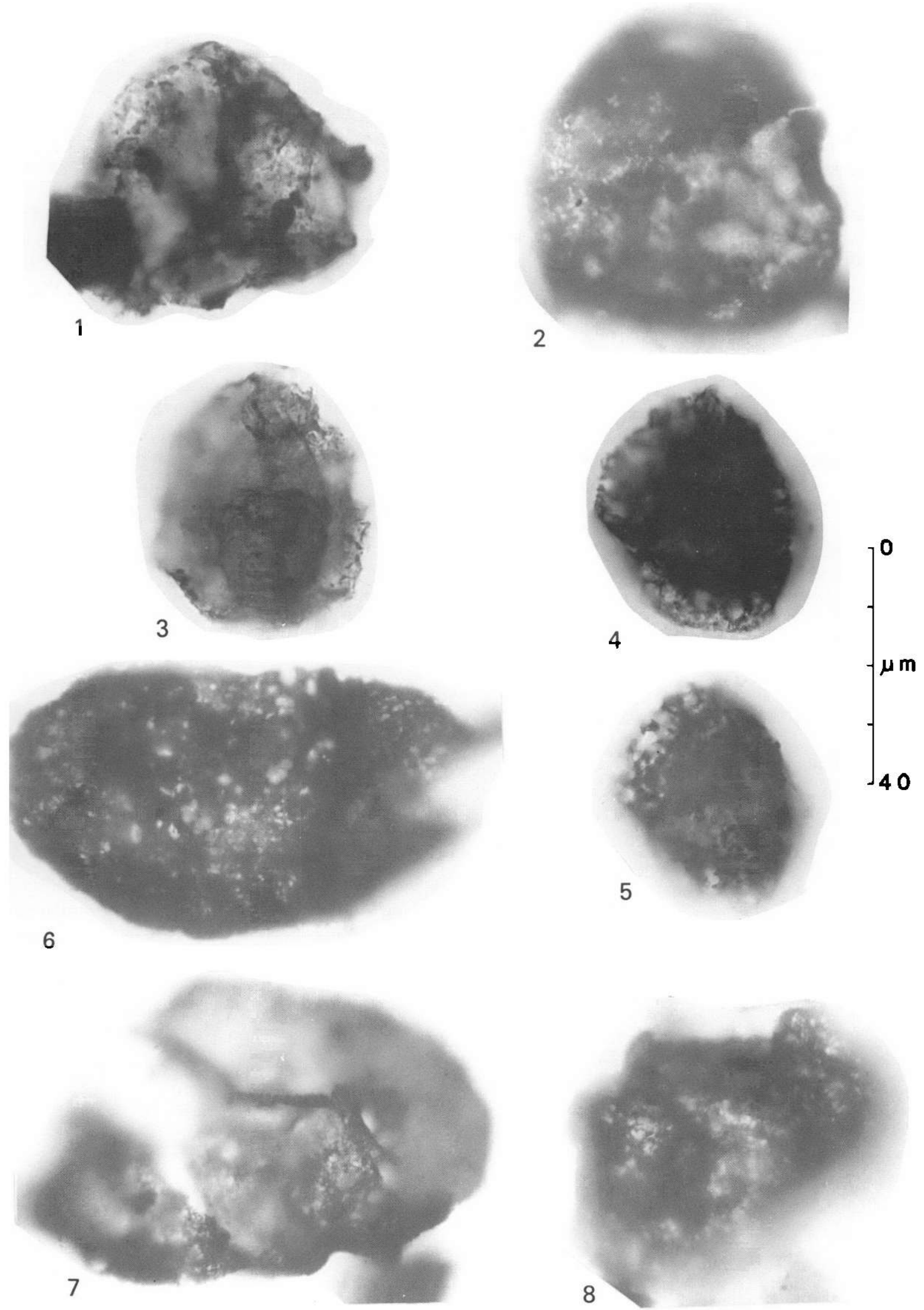


\title{
THERMAL HISTORIES OF THE HARTFORD AND NEWARK BASINS INFERRED FROM MATURATION INDICES OF ORGANIC MATTER
}

\author{
Lisa M. Pratt, C.A. Shaw, and Robert C. Burruss
}

\begin{abstract}
Regional patterns of thermal maturation in the Hartford and Newark basins were evaluated by using organic geochemical data on dark-gray to black shales inferred to be deep-water lacustrine deposits. In the Hartford basin, high thermal anomalies are present (1) in the central basin, where numerous northeast-trending faults are present and (2) in the northern quarter of the basin, where igneous intrusions and volcanic plugs are present. The southern portion of the Newark basin contains only Triassic strata and is uniformly overmature with respect to petroleum generation. The northern portion of the Newark basin contains overmature Triassic strata passing upward into mature and immature strata of Jurassic age. In both the Hartford and Newark basins, less than $1 \mathrm{~km}$ of stratigraphic section separates shales that are immature with respect to petroleum generation from shales that are at peak conditions for petroleum generation and migration. Such markedly contrasting levels of maturation in a narrow stratigraphic interval can be accounted for by a pulse of high heat flow late in the sedimentary history of these basins. It is proposed that regionally elevated heat flow and migration of hydrothermal fluids were associated with the major episode of basaltic intrusion and volcanism during the Early Jurassic in the Hartford and Newark basins.
\end{abstract}

\section{INTRODUCTION}

The regional and stratigraphic distribution of organic matter in the thick Triassic and Jurassic sedimentary succession in early Mesozoic rift basins of the Eastern United States strongly influences the potential for hydrocarbon generation. In addition, the interaction of connate waters with organic matter may have played an important role in sediment diagenesis and mineral precipitation. To study these processes, we have used organic geochemical analyses to characterize organic matter through the stratigraphic section and along strike in the Hartford basin (Connecticut and Massachusetts) and in the Newark basin (New Jersey, New York, and Pennsylvania). These two basins were selected for study because of their well established stratigraphic and sedimentologic framework (Krynine, 1950; Van Houten, 1965, 1977; Glaeser, 1966; Cornet and others, 1973; Hubert and others, 1976, 1978; Olsen, 1980, 1984). Unfortunately, interpretation of temperature and burial histories by use of organic geochemical data is limited by the poorly resolved tectonic history of the eastern Mesozoic basins, as evidenced by differing interpretations given by Manspeizer (1980) and Ratcliffe and Burton (1985).
Repeated intervals of deep-water lacustrine units composed of gray silty mudstone to black laminated shale are a distinctive feature of the Hartford and Newark basins. Hundreds of meters of dark shale and mudstone accumulated during Late Triassic time in the Lockatong Formation of the Newark basin. Numerous thin beds (1-2 $\mathrm{m}$ in thickness) of dark shale and mudstone also accumulated during Early Jurassic time in the Hartford and Newark basins. The organic-carbon content of these fine-grained rocks averages about 2 percent by weight. This is sufficiently high to warrant consideration of these rocks as possible sources of economic quantities of petroleum and natural gas. Furthermore, the presence of solid bitumen and hydrocarbon-bearing fluid inclusions in quartz- and calcite-bearing veins indicates that aqueous and petroleum fluids migrated simultaneously through fracture systems, possibly during deformation of these basins.

\section{MATERIALS AND METHODS}

During the 1984 through 1986 field seasons, about 100 samples from the Hartford basin and about 80 samples from the Newark basin were collected from outcrops and subsequently analyzed. An additional 14 samples from 3 core holes drilled in the Newark basin have been analyzed. These cores were drilled by the U.S. Geological Survey to study the orientation and timing of movement along major border faults of the eastern Mesozoic basins (Ratcliffe and Burton, 1985). Detailed descriptions of the sampling localities and rock types are given in Pratt and others (1986b) for samples collected during 1984 and the spring of 1985 . A similar report on subsequently collected samples is in preparation.

Procedures used for Rock-Eval pyrolysis, organic carbon determination, chloroform extraction, and gas chromatography (GC) are given in Pratt and others $(1986 a, b)$. Each sample was analyzed for organic and carbonate carbon content and for pyrolysis response. Thirty samples were Soxhlet extracted with chloroform and characterized by alumina-silica gel chromatography of the bitumen extract and GC of the saturated hydrocarbon fraction.

\section{REGIONAL PATTERNS OF THERMAL MATURATION}

The temperature of maximum pyrolytic yield during programmed pyrolysis $\left(\mathrm{T}_{\max }\right)$ can be used as an index 


\section{HARTFORD BASIN}

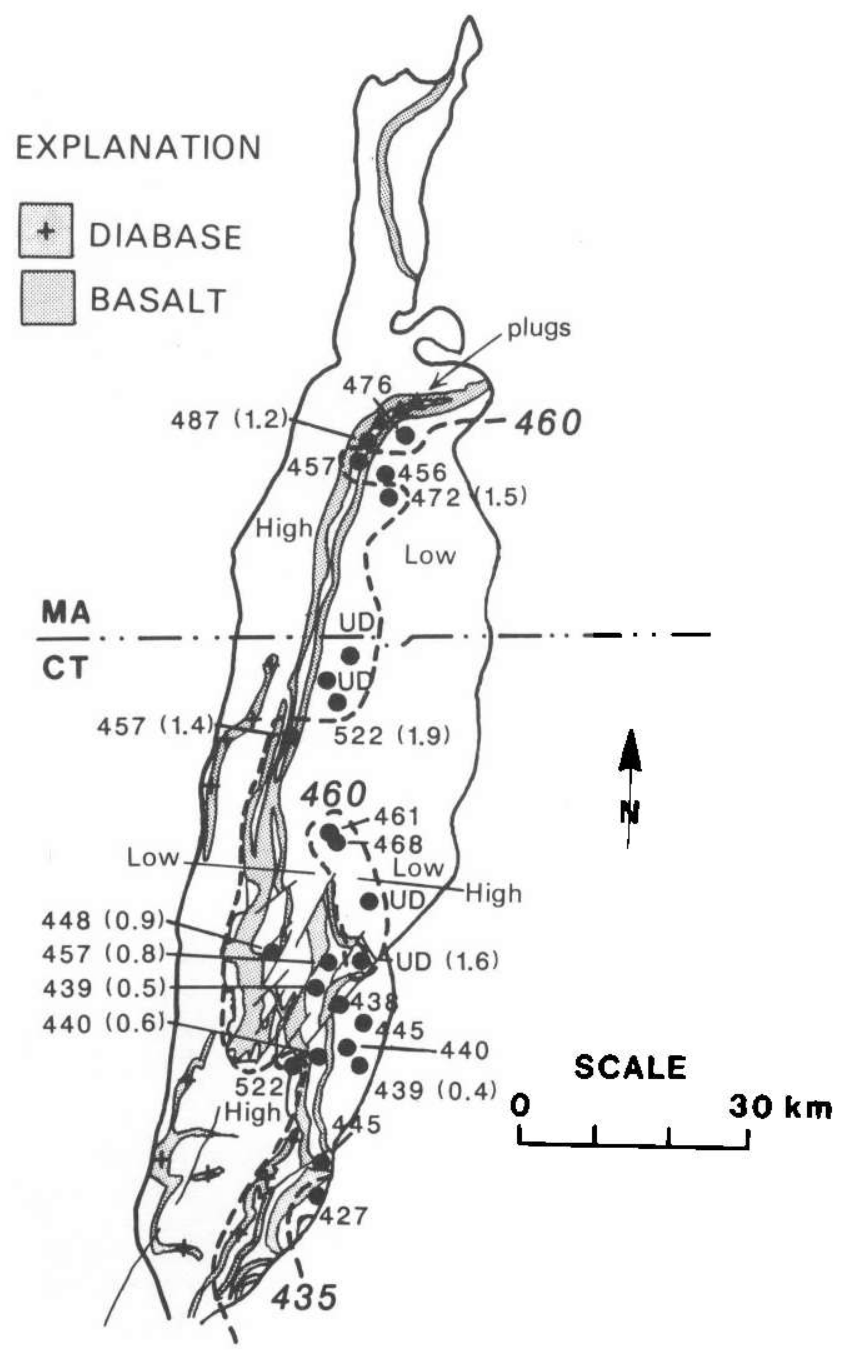

Figure 1. Map showing the distribution of medium-gray to black shale samples in the Hartford basin. Temperatures of maximum pyrolytic yield $\left(T_{\max }\right)$ are indicated by numbers adjacent to sample points. Mean vitrinite reflectance values (percent $\mathbf{R}_{0}$ ) are indicated by numbers in parentheses. Base map is taken from Philpotts (1985). UD indicates unable to determine $T_{\max }$ due to low yield of pyrolytic hydrocarbons.

of thermal maturation in fine-grained rocks containing greater than about 0.4 percent organic carbon (Espitalie and others, 1977; Tissot and Welte, 1984). $\mathrm{T}_{\max }$ values are measured in the laboratory and cannot be directly converted to burial temperatures because of the strong time dependence of most organic geochemical transformations. $T_{\max }$ values less than about $435^{\circ} \mathrm{C}$ are indicative of rocks that are thermally immature with respect to oil generation; values in the range of $435^{\circ} \mathrm{C}$ to $460{ }^{\circ} \mathrm{C}$ are indicative of rocks at ideal conditions (fully mature) for generation and preservation of oil; and values greater than about $465^{\circ} \mathrm{C}$ are indicative of rocks that are beyond the stage of effective petroleum generation (overmature) but may still be capable of hydrocarbon gas generation. Rocks that are thermally altered beyond the stage of hydrocarbon gas generation generally yield very low quantities of pyrolytic hydrocarbons and unreliable $\mathrm{T}_{\max }$ values. Isotherms of $T_{\max }$ values at $435^{\circ} \mathrm{C}$ and $460^{\circ} \mathrm{C}$ are contoured for the Hartford basin on figure 1 and the Newark basin in figure 2. Although the pyrolysis data are limited to those portions of the stratigraphic section that contain medium-gray to black, fine-grained rocks, they are sufficiently widespread so that regional patterns can be identified.

In the Hartford basin, high thermal anomalies are present (1) in the central basin where numerous northeast-trending faults separate outcrop blocks and offset regional strike orientations and (2) in the northern quarter of the basin where Jurassic diabase plugs related to the Hampden Basalt have been identified (Philpotts, 1985). The patterns of thermal maturation in the Newark basin show less evidence of local variation than in the Hartford basin. The southern portion of the Newark basin contains only Triassic strata intruded by Jurassic diabase and is uniformly overmature. The northern portion of the basin contains Triassic and Jurassic strata in a large synclinorium. In the northern Newark basin, the Triassic-Jurassic Passaic Formation is thermally overmature, the Jurassic Feltville Formation is fully mature, and younger Jurassic units are marginally mature to immature. In both the Hartford and Newark basins, a regional pattern of thermal maturation increases down the stratigraphic section and, therefore, increases with inferred depth of burial.

Regional patterns of thermal maturation suggested by $\mathrm{T}_{\max }$ values are confirmed by mean vitrinite reflectance values $\left(\mathrm{R}_{0} \%\right)$ and by the distribution of normal alkanes versus branched and cyclic compounds in the saturated fraction of the chloroform extracts (Pratt and Burruss, this volume). Figure 3 shows a plot of $R_{o}$ versus $T_{\max }$ with good correspondence in the range of $T_{\max }$ values from $430^{\circ} \mathrm{C}$ to $450^{\circ} \mathrm{C}$. At higher values of $T_{\max }$, pyrolytic yields are too low for accurate determination of $\mathrm{T}_{\max }$. For shales with a relatively uniform amount and type of original organic matter, hydrogen index is also a sensitive indicator of thermal maturity. Decreasing hydrogen indices are strongly correlated with increasing $\mathrm{T}_{\max }$ values in a set of samples collected along the north-south strike belt of lacustrine black shales in the Jurassic East Berlin and Portland Formations, Hartford basin (fig. 4). The wide range of hydrogen indices and $\mathrm{T}_{\max }$ values found in these shales reflects the influence of anomalously high heat flow in the central and northern Hartford basin. Extrapolating the trend defined by hydrogen index versus $T_{\max }$ to low thermal maturities 


\section{NEWARK BASIN}

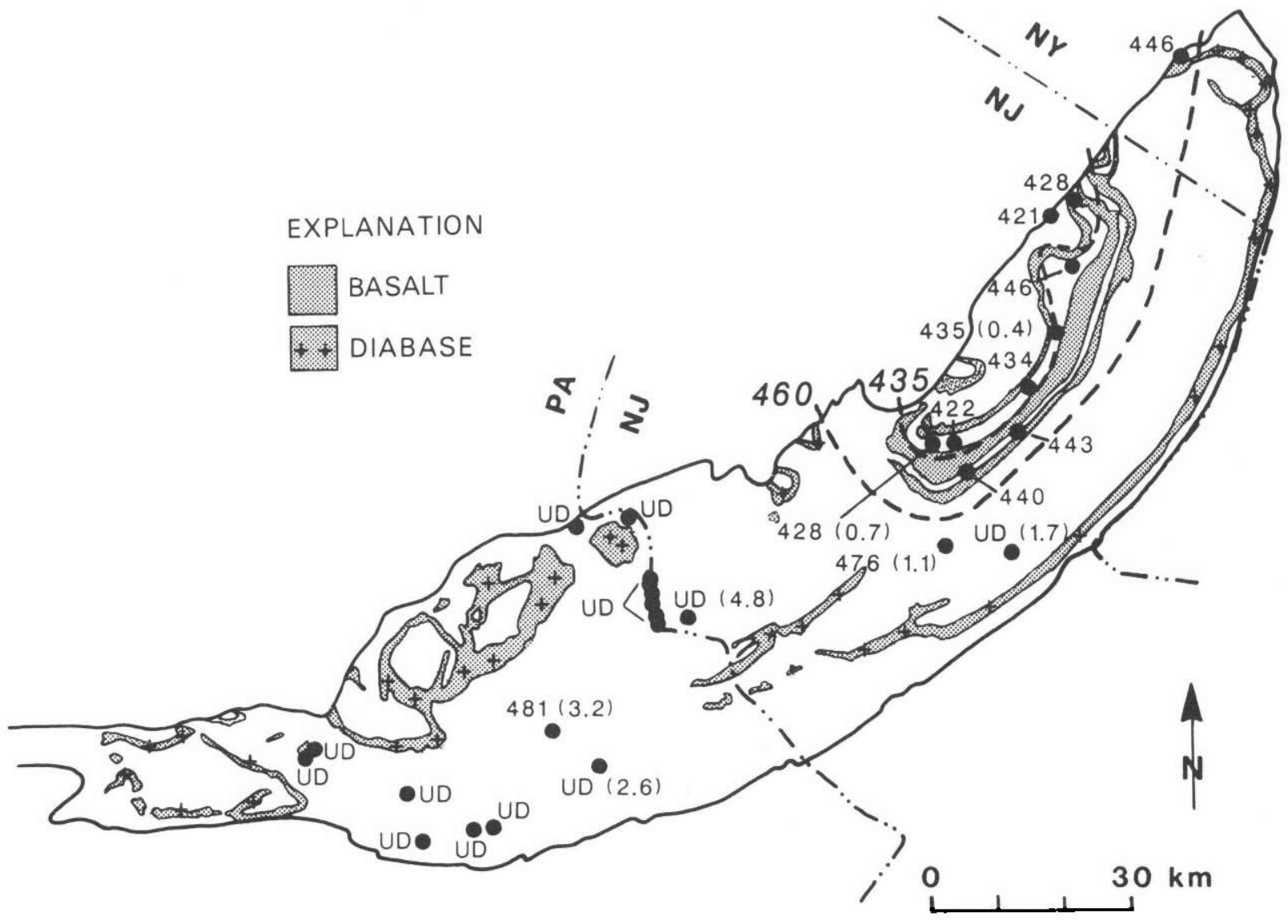

Figure 2. Map showing the distribution of medium-gray to black shale samples in the Newark basin. Temperatures of maximum pyrolytic yield $\left(T_{\max }\right)$ are indicated by numbers adjacent to sample points. Mean vitrinite reflectance values (percent $R_{o}$ ) are indicated by numbers in parentheses. Base map taken from Glaeser (1966) and Olsen (1984). UD indicates unable to determine $T_{\max }$ due to low yield of pyrolytic hydrocarbons.

suggests original hydrogen indices of 450 to $500 \mathrm{mg} / \mathrm{g}$. Hydrogen indices greater than $400 \mathrm{mg} / \mathrm{g}$ in rocks having organic carbon values greater than 0.5 percent are indicative of petroleum source rocks with good to excellent potential for oil generation.

With the exception of samples from areas of anomalously high thermal maturity, the dark-colored lacustrine shales in the Jurassic portion of the Hartford and Newark basins have pyrolysis and extraction properties typical of good to excellent petroleum source rocks. The extremely high thermal maturity of the Triassic Lockatong and Triassic-Jurassic Passaic Formations in the Newark basin precludes direct determination of their original potential for petroleum generation. The similarity in sedimentary structures and organic-carbon content between the Triassic and Jurassic lacustrine shales suggests that these units originally had similar organic geochemical characteristics.

\section{IMPLICATIONS OF ORGANIC MATURATION INDICES}

The most widely used models of organic geochemical transformations during thermal maturation assume exponential dependency of maturity on temperature and linear dependency of maturity on time (Lopatin and Bostick, 1973; Waples, 1980). Maturities calculated for time in millions of years at specified temperature intervals are summed to give total maturity. It is possible to infer a generalized temperature history for rocks in the Hartford and Newark basins from the reconstructed burial history of Olsen (1984) and from Waples' (1980) time-temperature model (TTI) of thermal maturation and correlation between TTI values and mean vitrinite reflectance values.

Samples from the Jurassic Portland Formation (Hartford basin) and the Jurassic Towaco Formation 


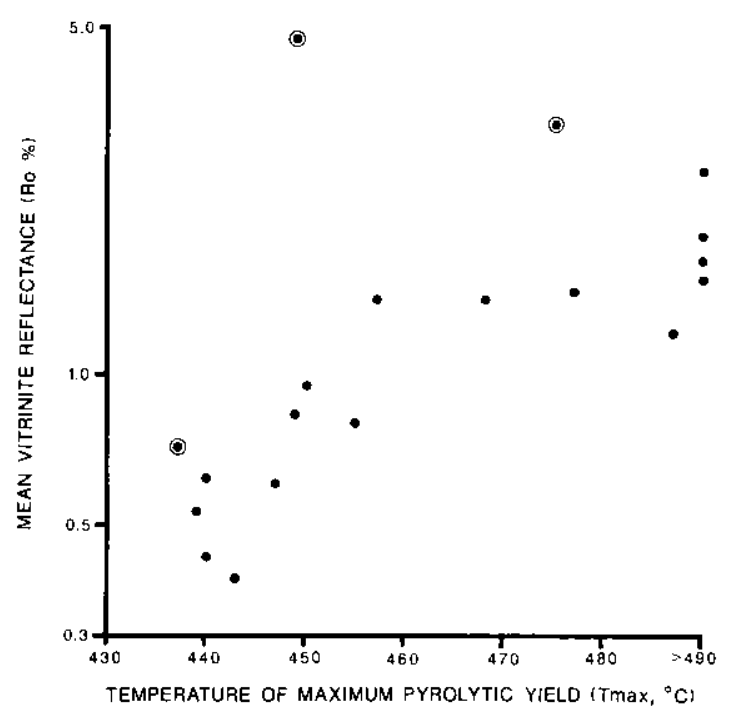

Figure 3. Plot of mean vitrinite reflectance (percent $R_{0}$ ) versus temperature of maximum pyrolytic yield $\left(T_{\max }\right)$ for samples from the Hartford and Newark basins. Circled data points indicate samples that have visual evidence of bitumen staining.

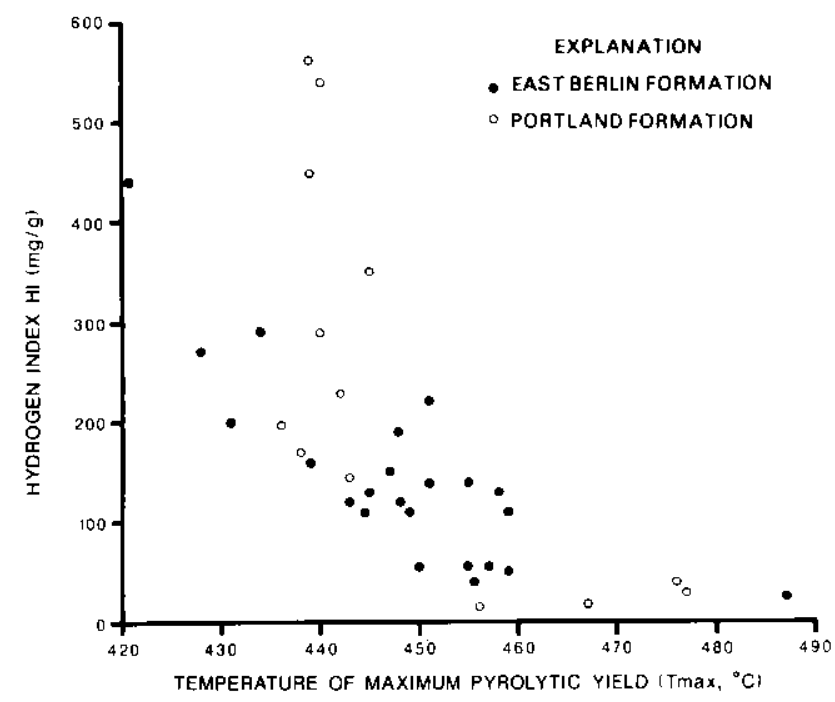

Figure 4. Plot of hydrogen index (HI) versus temperature of maximum pyrolytic yield $\left(T_{\max }\right)$ for samples containing 0.5 percent or higher organic-carbon content in the East Berlin and Portland Formations, Hartford basin. There is good correspondence between these two properties, and extrapolation of the trend of values to lower maturities indicates original hydrogen indices of 450 to $500 \mathrm{mg} / \mathrm{g}$.

(Newark basin) are the least thermally mature samples we collected $\left(T_{\max } \leq 430^{\circ} \mathrm{C}\right.$ and $R_{o} \leq 0.4$ percent $)$. The saturated hydrocarbons extracted from these samples are dominated by branched and cyclic compounds rather than by $n$-alkanes (Pratt and Burruss, this volume). This combination of properties indicates a level of thermal maturation below that required for effective petroleum generation and implies that these rocks did not reach burial temperatures above $90^{\circ} \mathrm{C}$. The low thermal maturity of these samples at inferred depths of 1 to $1.5 \mathrm{~km}$ below the top of the preserved stratigraphic section suggests erosion did not remove more than about 1,500 $\mathrm{m}$ from the upper part of the section. Less than $1 \mathrm{~km}$ stratigraphically below the immature strata, the shales are at peak conditions for petroleum generation in the Hartford (Shuttle Meadow and East Berlin Formations) and Newark (Feltville Formation) basins. These thermally mature strata have $T_{\max }$ values of 440 to $460{ }^{\circ} \mathrm{C}$ and $R_{o}$ values of 0.5 to 0.9 percent. The saturated hydrocarbons extracted from these samples are dominated by n-alkanes and contain relatively low abundances of branched and cyclic compounds. The organic geochemical properties imply that these rocks reached burial temperatures of 90 to $110^{\circ} \mathrm{C}$ for 30 to 40 million years or reached temperatures of $110-130^{\circ} \mathrm{C}$ for about 10 million years. We were unable to collect shale samples suitable for organic geochemical characterization from the Triassic portion of the Hartford basin. In the Newark basin, all samples collected from Triassic strata are thermally overmature with respect to petroleum generation.

It is difficult to account for these markedly contrasting thermal maturities in a narrow stratigraphic interval unless there was a pulse of high heat flow late in the sedimentary history of these basins. Extremely rapid sedimentation rates $(150-200 \mathrm{~m} / \mathrm{m} . \mathrm{y}$.) suggest moderately high crustal extension ( $b=2$ to 3 ) and associated heat flow during basin development (Mckenzie, 1981; Dewey, 1982). Exponential cooling following a single initial phase of high heat flow associated with formation of a rift basin (Mckenzie, 1981; Royden and Keen, 1980) is not consistent with our maturity data for the Hartford and Newark basins. In Mckenzie's (1981) model of a cooling rift basin $(b=2)$ the zone of petroleum generation stabilizes within an approximately $1.5-\mathrm{km}$-thick interval at $5 \mathrm{~km}$ depth about 100 m.y. after initiation of sedimentation. Assuming uplift and erosion of the Newark and Hartford basins sometime later than 100 m.y. after onset of sedimentation, the narrow and relatively shallow zone of effective oil generation may indicate an episode of high heat flow late in the sedimentary history of these basins.

\section{CONCLUSIONS}

The Hartford and Newark basins contain entirely nonmarine sedimentary rocks and are probably located on continental crust of normal thickness, but the high rates of sediment deposition indicate moderately high crustal extension and associated heat flow during initial basin development. Emplacement of numerous extrusive 
basalts and intrusive diabase late in the sedimentary history of these basins implies deep crustal fracturing with extensive magmatic activity at this time. Regardless of the process, a pulse of high heat flow probably was associated with movement of basaltic magma and hydrothermal fluids through the sedimentary fill. The highly thermally altered character of the Triassic Lockatong and Triassic-Jurassic Passaic Formations throughout the Newark basin suggests regional rather than localized high heat flow while the non-uniform pattern of thermal maturation in the Jurassic portion of the Hartford basin suggests significant local perturbations of heat flow in the basin at that time.

\section{ACKNOWLEDGMENTS}

Assistance from P.E. Olsen, P.M. LeTourneau, and N.G. McDonald in locating suitable outcrops for organic geochemical studies is gratefully acknowledged. M.J. Pawlewicz provided the vitrinite reflectance data. T.A. Daws provided the Rock-Eval pyrolysis data.

\section{REFERENCES CITED}

Cornet, B., Traverse, A., and McDonald, N.G., 1973, Fossil spores, pollen, and fishes from Connecticut indicate Early Jurassic age for part of Newark Group: Science, v. 182, p. 1243-1247.

Dewey, J.F., 1982, Plate tectonics and the evolution of the British Isles: Journal Geological Society of London, v. 139, p. 371-412.

Espitalie, J., Laporte, J.L., Madec, M., Marquis, F., Leplat, P., Paulet, J., and Boutefeu, A., 1977, Methode rapide de caracterisation des roches meres, de leur potentiel petrolier et de leur degre d'evolution [Rapid method for characterization of source rocks, their petroleum potential, and their degree of evolution]: Revue de l'Institut francais du petrole, v. 32 , p. $23-42$.

Glaeser, J.D., 1966, Provenance, dispersal, and depositional environments of Triassic sediments in the Newark-Gettysburg basin: Pennsylvania Geological Survey Bulletin G43, 168 p.

Hubert, J.F., Reed, A.A., and Carey, P.J., 1976, Paleogeography of the East Berlin Formation, Newark Group, Connecticut Valley: American Journal of Science, v. 276, p. 1183-1207.

Hubert, J.F., Reed, A.A., Dowdall, W.L., and Gilchrist, J.M., 1978 , Guide to the Mesozoic redbeds of central Connecticut: State Geological and Natural History Survey of Connecticut, Guidebook No. 4, 129 p.

Krynine, P.D., 1950, Petrology, stratigraphy, and origin of the Triassic sedimentary rocks of Connecticut: State Geologi- cal and Natural History Survey of Connecticut, Hartford, $247 \mathrm{p}$.

Lopatin, N.J., and Bostick, N.H., 1973, Geologicheskiye faktory katageneza ugley [The geologic factors in coal catagenesis], in Symposium Volume, Priroda organicheskogo veshchestva sovremennykh $i$ iskopaemykh osadkov [Nature of organic matter in recent fossil sediments]: "Nauka" Press, Moscow: 1973, p. 79-90. English translation, Illinois State Geological Survey Reprint Series 1974Q, 15 p.

Manspeizer, W., 1980, Rift tectonics inferred for volcanic and clastic structures, in Manspeizer, W., ed., Field studies of New Jersey geology and guide to field trips, 52nd Annual Meeting of the New York State Geological Association: Newark, New Jersey, Rutgers University, p. 315-350.

McKenzie, D., 1981, The variation of temperature with time and hydrocarbon maturation in sedimentary basins formed by extension: Earth and Planetary Science Letters, v. 55, p. 87-98.

Olsen, P.E., 1980, The latest Triassic and Early Jurassic formations of the Newark basin (eastern North America, Newark Supergroup): Stratigraphy, structure, and correlation: New Jersey Academy of Science Bulletin, v. 25, p. 25-51. 1984, Comparative paleolimnology of the Newark Supergroup-A study of ecosystem evolution: New Haven, Connecticut, Yale University, unpublished Ph.D. dissertation, $726 \mathrm{p}$.

Philpotts, A.R, 1985, Recent petrologic studies of Mesozoic igneous rocks in Connecticut, in Robinson, G.R., Jr., and Froelich, A.J., eds., Proceedings of the second U.S. Geological Survey workshop on the early Mesozoic basins of the Eastern United States: U.S. Geological Survey Circular 946, p. 107-110.

Pratt, L.M., Claypool, G.E., and King, J.D., 1986a, Geochemical imprint of depositional conditions on organic matter in laminated-bioturbated interbeds from fine-grained marine sequences: Marine Geology, v. 70, p. 67-84.

Pratt, L.M., Vuletich, A.K., and Shaw, C.A., 1986b, Preliminary results of organic geochemical and stable isotope analyses of Newark Supergroup rocks in the Hartford and Newark basins, Eastern U.S.: U.S. Geological Survey Open-File Report 86-284, 29 p.

Ratcliffe, N.M., and Burton, W.C., 1985, Fault reactivation models for origin of the Newark basin and studies related to Eastern U.S. seismicity, in Robinson, G.R., Jr., and Froelich, A.J., eds., Proceedings of the second U.S. Geological Survey workshop on the early Mesozoic basins of the Eastern United States: U.S. Geological Survey Circular 946 , p. $36-45$.

Royden, L., and Keen, C.E., 1980, Rifting processes and thermal evolution of the continental margin of eastern Canada determined from subsidence curves: Earth and Planetary Science Letters, v. 51, p. 343-361.

Tissot, B.P., and Welte, D.H., 1984, Petroleum formation and occurrence: Springer-Verlag, Berlin, 699 p.

Van Houten, F.B., 1965, Composition of Triassic Lockatong and associated formations of Newark Group, central New Jersey and adjacent Pennsylvania: American Journal of Science, v. 263, p. 825-863. 
1977, Triassic-Liassic deposits of Morocco and Eastern North America-Comparison: American Association of Petroleum Geologists Bulletin, v. 61, no. 1, p. 79-99.
Waples, D.W., 1980, Time and temperature in petroleum formation-Application of Lopatin's method to petroleum exploration: American Association of Petroleum Geologists Bulletin, v. 64, p. 916-926.

\title{
SOURCE OF KEROGEN IN BLACK SHALES FROM THE HARTFORD AND NEWARK BASINS, EASTERN UNITED STATES
}

\author{
E.C. Spiker, R.K. Kotra, P.G. Hatcher, R.M. Gotttried, M.F. Horan, and Paul E. Olsen'
}

\begin{abstract}
To determine the source of kerogen in Mesozoic black shales, a comparison was made between the stable carbon isotopic compositions and the degree of aromaticity of kerogen and of associated coalified wood fragments (phytoclasts) from the Hartford and Newark basins. A correlation between the aromaticity and ${ }^{13} \mathrm{C} /{ }^{12} \mathrm{C}$ ratio in samples of relatively low maturity, equivalent to subbituminous to high volatile bituminous rank, indicates that the kerogens were derived from a mixture of autochthonous lacustrine algae and allocthonous woody plant detritus, including soil organic matter. Mass balance calculations indicate that the woody plant contribution can be quite high, ranging between approximately 30 and 70 percent of the total kerogen. The abundance of terrestrial-derived organic matter in the kerogen may have favored the generation of natural gas more than oil in these basins.
\end{abstract}

\section{INTRODUCTION}

Lacustrine units of the Hartford and Newark basins in the Eastern United States consist of mudstones and black laminated shales. The black shales examined contain about 0.5 to 3.5 weight percent organic matter, the bulk of which is insoluble kerogen. This kerogen may be derived from both autochthonous lacustrine algae (termed Type I kerogen) and allochthonous terrestrial plant detritus (termed Type III kerogen). Such a mixed source kerogen is termed Type II (Tissot and Welte, 1984).

Knowledge of the origin and chemical composition of organic matter is fundamental to an assessment of the hydrocarbon potential of basins (Tissot and Welte, 1984) and also aids our understanding of the possible role that organic matter may play in sedimentary ore deposition (Maynard, 1983; Kelly and Nishioka, 1985; Parnell, 1986). The type and character of the organic matter

\footnotetext{
${ }^{1}$ Lamont-Doherty Geological Observatory, Columbia University, Palisades, NY 10964.
}

control its ability to complex metal and metal-containing cations, possibly leading to solubilization, transport, and precipitation (Schnitzer and Kahn, 1972; Hatcher and others, 1986). The present study examines the chemical and isotopic composition of the kerogen in an effort to determine its source.

Although some components of kerogen can be identified by microscopic examination, the bulk of kerogen often lacks recognizable structures and is amorphous. Many of the same samples examined in the present study from the Hartford and Newark basins contain a large proportion of amorphous material in addition to vitrinite material in the kerogen (Braghetta, 1985).

The origin of this amorphous kerogen is generally difficult to determine chemically, as a result of the complex effects of diagenesis and thermal maturation, as well as the multiple sources from which kerogen is derived (for example, algae, bacteria, fungi, terrestrial and aquatic plant and animal debris) (Lewan, 1986; Tissot and Welte, 1984). Loss of hydrogen-rich labile components of the organic matter during thermal maturation can result in significant changes in the chemical character of kerogen. This altered kerogen can be used to estimate the degree of thermal heating the rock has experienced (Tissot and Welte, 1984). However, this technique requires an understanding of the original composition of the organic matter. For example, thermally altered Type I kerogen can have a chemical composition similar to that of less altered Type III kerogen. Thus Type III kerogen could be incorrectly identified as altered Type I kerogen, resulting in an overestimate of the thermal maturity.

A number of chemical techniques may be used to characterize kerogen, including pyrolysis gas chromatography-mass spectrometry, solid-state nuclear magnetic resonance (NMR) spectroscopy, and examination of the elemental and stable carbon isotopic $\left({ }^{13} \mathrm{C} /{ }^{12} \mathrm{C}\right)$ compositions (Tissot and Welte, 1984). NMR can determine the degree of aromaticity, that is, the percent of the total 
carbon in aromatic structures (Miknis and others, 1979). In immature rocks, this measure of aromaticity is indicative of the component of aromatic-rich woody kerogen (Breger and others, 1983; Barwise and others, 1984). At a rank higher than that of bituminous coal, however, aromaticity increases with increasing maturity (Saxby and others, 1986). In contrast, the carbon isotopic compositions appear to change little from maturation (Lewan, 1986; Buchardt and others, 1986; Arneth and Matzigkeit, 1986; Deines, 1980) and appear to be the best indicator of source.

Solid-state NMR was applied by Hatcher and Romankiw (1985) to study small pieces of coalified wood, termed phytoclasts, embedded in shale from several of the Eastern United States' early Mesozoic basins. In that study, NMR and elemental data revealed a wide range in the degree of coalification. Spiker (1985) examined the stable isotopic compositions of carbon, nitrogen, and hydrogen in these phytoclasts and found that coalification had little effect on the isotopic compositions.

In this study we examined phytoclasts and the associated kerogen from the shale matrix and compared the stable carbon isotopic compositions to the aromaticity as determined by solid-state NMR. Eight of the samples examined, all Lower Jurassic, are from the Hartford basin and two are from the Newark basin, one Lower Jurassic, one Upper Triassic. Some of the same samples were also studied by Spiker (1985), Hatcher and Romankiw (1985), Braghetta (1985), Pratt and others $(1986 a, b)$, and Kotra and others (this volume).

\section{METHODS}

Preparation of the kerogen and phytoclast samples is described by Kotra and others (this volume) and the stable carbon isotope methods are described by Spiker and Hatcher (1987). The carbon isotopic compositions are reported in standard $\delta^{13} \mathrm{C}$ notation (that is, per mil) relative to the PDB standard (Craig, 1957). Replicate sample precision for $\delta^{13} \mathrm{C}$ is approximately 0.1 per mil. Solid-state ${ }^{13} \mathrm{C}$ NMR spectra were obtained as described previously (Hatcher and others, 1982) by using cross polarization with magic-angle spinning (CPMAS).

\section{RESULTS AND DISCUSSION}

Sample descriptions are given in table 1 and the results of NMR and stable isotope analyses are presented in table 2. The vitrinite reflectance values for most of the samples are also shown in table 2. On the basis of vitrinite reflectance analysis of the phytoclasts, all but one of the samples discussed here appear to be of relatively low rank. Corresponding kerogens are of low maturity. Vitrinite reflectance values range from about 0.4 to 0.7
Table 1. Description of samples from the Hartford and Newark basins

\begin{tabular}{|c|c|c|c|}
\hline & mple number & Formation & Location \\
\hline \multicolumn{4}{|c|}{ Hartford basin-all Lower Jurassic } \\
\hline 1 & $\mathrm{PO}-7,8$ & Shuttle Meadow & $\begin{array}{l}\text { Durham or Bluff Head } \\
\text { fish bed, Bluff Head } \\
\text { Connecticut. }\end{array}$ \\
\hline 2 & PO-11, 12 & Shuttle Meadow & $\begin{array}{l}\text { Southington limestone } \\
\text { quarry, Southington } \\
\text { Connecticut. }\end{array}$ \\
\hline 3 & PO-20C & East Berlin & $\begin{array}{l}\text { Westfield fish bed, } \\
\text { Westfield, } \\
\text { Connecticut. }\end{array}$ \\
\hline 4 & PO-20I & East Berlin & $\begin{array}{l}\text { Westfield fish bed, } \\
\text { Westfield, } \\
\text { Connecticut. }\end{array}$ \\
\hline 5 & $\mathrm{PO}-22$ & East Berlin & $\begin{array}{l}\text { Westfield fish bed, } \\
\text { North Branford, } \\
\text { Connecticut. }\end{array}$ \\
\hline 6 & PO-25, 26 & East Berlin & $\begin{array}{l}\text { Westfield fish bed, } \\
\text { east side Lake } \\
\text { Saltonstall, East } \\
\text { Haven, Connecticut }\end{array}$ \\
\hline 7 & $\mathrm{PO}-28 \mathrm{M}, 28$ & East Berlin & $\begin{array}{l}\text { Stevens locality, } \\
\text { Parmele Brook, } \\
\text { Durham, } \\
\text { Connecticut. }\end{array}$ \\
\hline 8 & PO-33, 34 & Portland & $\begin{array}{l}\text { Middlefield fish bed, } \\
\text { Laurel Brook, } \\
\text { Middlefield, } \\
\text { Connecticut. }\end{array}$ \\
\hline \multicolumn{4}{|c|}{ Newark basin } \\
\hline 9 & NB584-14, 15 & $\begin{array}{l}\text { Lockatong } \\
\text { (Member at } \\
\text { Skunk Hollow) } \\
\text { (Upper Triassic) }\end{array}$ & $\begin{array}{l}\text { H and } \mathbf{K} \text { quarry } \\
\text { Chalfont, } \\
\text { Pennsylvania. }\end{array}$ \\
\hline 10 & NB584-24 & $\begin{array}{l}\text { Towaco (Lower } \\
\text { Jurassic) }\end{array}$ & $\begin{array}{l}\text { Pompton Lakes, } \\
\text { New Jersey. }\end{array}$ \\
\hline
\end{tabular}

percent (table 2), indicating approximately subbituminous to high-volatile bituminous rank. In contrast, the one sample of Late Triassic age from the Lockatong Formation (sample 9) has a high vitrinite reflectance value of 2.8 percent and very high aromaticity $(\mathrm{fa}=97$ percent), indicating anthracite rank (Hatcher and Romankiw, 1985). The Lockatong Formation appears to be highly mature throughout much of the Newark basin, possibly as a result of depth of burial and the thermal influence of widespread igneous intrusions.

Aromaticity of the low-rank kerogen samples ranges from 39 to 60 percent, or about 2 to 20 percent less than the aromaticity of the associated phytoclasts (table 2). The $\delta^{13} \mathrm{C}$ values in the kerogens range from -26.9 to -30.2 per mil, or 1.8 to 3.6 per mil less than values of the associated phytoclast (table 2). The $\delta^{13} \mathrm{C}$ values in the phytoclasts range from about -23.3 to -26.7 per mil, similar to values in modern and coalified woods (Spiker and Hatcher, 1987; Deines, 1980). 
Table 2. Stable carbon isotope compositions in kerogen and lipids $\left(\delta^{13} \mathrm{C}\right.$, in per mil), NMR aromaticity (fa, in percent), vitrinite reflectance $\left(R_{0}\right.$, in percent), and the fraction of algal kerogen in phytoclasts and black shale samples, Hartford and Newark basins, based on equations 1 and 2 discussed in text

[Sample numbers same as table $1 ;--$, not analyzed]

\begin{tabular}{|c|c|c|c|c|c|c|c|c|c|c|}
\hline \multirow[t]{2}{*}{$\begin{array}{l}\text { Sample } \\
\text { number }\end{array}$} & \multirow[t]{2}{*}{ Formation } & \multicolumn{3}{|c|}{ Phytoclast } & \multicolumn{3}{|c|}{ Kerogen } & \multirow{2}{*}{$\begin{array}{l}\text { Lipids } \\
\delta^{19} \mathrm{C}\end{array}$} & \multicolumn{2}{|c|}{ Algal kerogen } \\
\hline & & $\delta^{13} \mathrm{C}$ & $\mathrm{fa}$ & $R_{0}$ & $\delta^{\mathrm{xg}} \mathrm{C}$ & $\mathrm{fa}$ & $R_{0}$ & & Eq 1. & Eq. 2 \\
\hline \multicolumn{11}{|c|}{ Hartford basin } \\
\hline 1 & Shuttle Meadow & -23.3 & 0.52 & 0.34 & -26.9 & 0.46 & $0.64^{2}$ & -28.1 & 0.32 & 0.48 \\
\hline 2 & Shuttle Meadow & -25.2 & .65 & .71 & -27.2 & .60 & $.62^{2}$ & -28.4 & .37 & .20 \\
\hline 3 & East Berlin & -26.6 & .71 & -- & -29.0 & .55 & -- & -30.8 & .67 & .30 \\
\hline 4 & East Berlin & -26.0 & .55 & -- & -29.3 & .39 & $.50^{2}$ & -- & .72 & .62 \\
\hline 5 & East Berlin & -25.3 & .52 & .46 & -27.8 & .50 & $.66^{2}$ & -31.0 & .47 & .40 \\
\hline 6 & East Berlin & -26.7 & .52 & -- & -28.5 & .43 & $.73^{2}$ & -- & .58 & .54 \\
\hline 7 & East Berlin & -26.5 & .57 & .46 & -28.3 & .52 & $.48^{2}$ & -30.8 & .55 & .36 \\
\hline 8 & Portland & -26.0 & .64 & - & -28.9 & .45 & $*$ & -30.9 & .65 & .50 \\
\hline \multicolumn{11}{|c|}{ Newark basin } \\
\hline 9 & Lockatong & -24.3 & .97 & $2.8^{1}$ & -27.5 & .95 & -- & -- & .42 & -- \\
\hline 10 & Towaco & -25.5 & .61 & $.3^{1}$ & -30.2 & .41 & -- & -- & .87 & .58 \\
\hline
\end{tabular}

${ }^{1}$ Neely Bostic, personal commun.

${ }^{2}$ Braghetta (1985).

The lower aromaticity in the kerogens, compared to the phytoclasts, indicates the presence of an additional component of aliphatic-rich kerogen from an algal source. The lower $\delta^{13} \mathrm{C}$ values of the kerogen indicate that the kerogen is depleted in ${ }^{13} \mathrm{C}$ by several per mil relative to the phytoclasts. This algal kerogen is evidently the major source of lipids extracted from the shales. These lipids are depleted in ${ }^{13} \mathrm{C}$, with $\delta^{13} \mathrm{C}$ values ranging from -28.1 to -31 per mil (table 2).

Aromaticity is positively correlated with $\delta^{13} \mathrm{C}$ in the relatively low rank phytoclasts and kerogens $\left(R_{\circ}<0.8\right.$ percent) (fig. 1). This correlation can be attributed to the mixing of autochthonous algal and allocthonous terrestrial woody derived organic matter. Kerogen containing an admixture of these two types of organic matter, termed Type II kerogen, would be expected to plot along a line between the average compositions of algal and woody kerogen.

A simple two-end-member mixing model is shown as a solid line in figure 1 . In this model, woody kerogen is assumed to have about 70 percent aromaticity $(\mathrm{fa}=70$ ) and $\delta^{13} \mathrm{C}$ of about -25 per mil. The algal kerogen is assumed to have about 20 percent aromaticity and $i^{13} \mathrm{C}$ of about -31 per mil. These aromaticity values are selected on the basis of NMR studies of algal kerogen and coalified woods (Breger and others, 1983; Hatcher and others, 1982; Barwise and others, 1984; Saxby and others, 1986). It is assumed that maturation is equivalent to high-volatile bituminous coal rank, corresponding to a vitrinite reflectance value of less than 0.8 percent. The $\delta{ }^{13} \mathrm{C}$ assumed for the woody kerogen end-member is a typical value for coalified wood (Spiker and Hatcher, 1987; Deines, 1980). The $\delta{ }^{13} \mathrm{C}$ value of the algal kerogen end-member is assumed to be similar to that of the most negative lipid extract.

The percent of algal kerogen in these samples can be calculated using the $\hat{\delta}^{13} \mathrm{C}$ and aromaticity (fa) values of the model for woody kerogen $\left(\delta^{13} \mathrm{C}_{\mathrm{w}}\right.$ and $\left.\mathrm{fa}_{\mathrm{w}}\right)$ and algal kerogen $\left(\delta^{13} \mathrm{C}_{\mathrm{a}}\right.$ and $\left.\mathrm{fa}_{\mathrm{a}}\right)$ in the following mass balance equations:

$$
\begin{gathered}
\mathrm{C}_{\mathrm{a}} \hat{\delta}^{13} \mathrm{C}_{\mathrm{a}}+\left(1-\mathrm{C}_{\mathrm{a}}\right) \delta^{13} \mathrm{C}_{\mathrm{w}}=\delta^{13} \mathrm{C}_{\mathrm{k}} \\
\mathrm{C}_{\mathrm{a}} \mathrm{fa}_{\mathrm{a}}+\left(1-\mathrm{C}_{\mathrm{a}}\right) \mathrm{fa}_{\mathrm{w}}=\mathrm{fa}_{\mathrm{k}}
\end{gathered}
$$

where $\mathrm{C}_{\mathrm{a}}$ is the fraction of algal kerogen, and $\delta^{13} \mathrm{C}_{\mathrm{k}}$ and $\mathrm{fa}_{\mathrm{k}}$ are the measured carbon isotopic and aromaticity values of the total kerogen.

Values for the algal kerogen fraction $\left(\mathrm{C}_{\mathrm{a}}\right)$ given in table 2 have been calculated on the basis of both the $\delta^{13} \mathrm{C}$ values (eq. 1) and the aromaticity values (eq. 2). These calculations indicate that between about 30 and 70 percent of the kerogen is derived from algal sources or, conversely, from woody sources. The error in these calculations is probably as large as 20 percent, as a result of variation in the composition of the end-members and contributions from other sources of organic matter (for example, bacteria, fungi, and aquatic plant and animal debris).

Although this simple mixing model can account for most of the NMR and isotope values, differences in the calculated values of algal kerogen $\left(C_{\mathrm{a}}\right)$ using equations 1 and 2 range from 4 to 37 percent. Assuming the model and the end-member compositions are reasonable, these differences may provide some important clues regarding the composition of the phytoclasts and kerogens. It is noteworthy that the phytoclasts generally plot below the two end-member mixing line in figure 1 and that the kerogens generally plot above this mixing line. The 


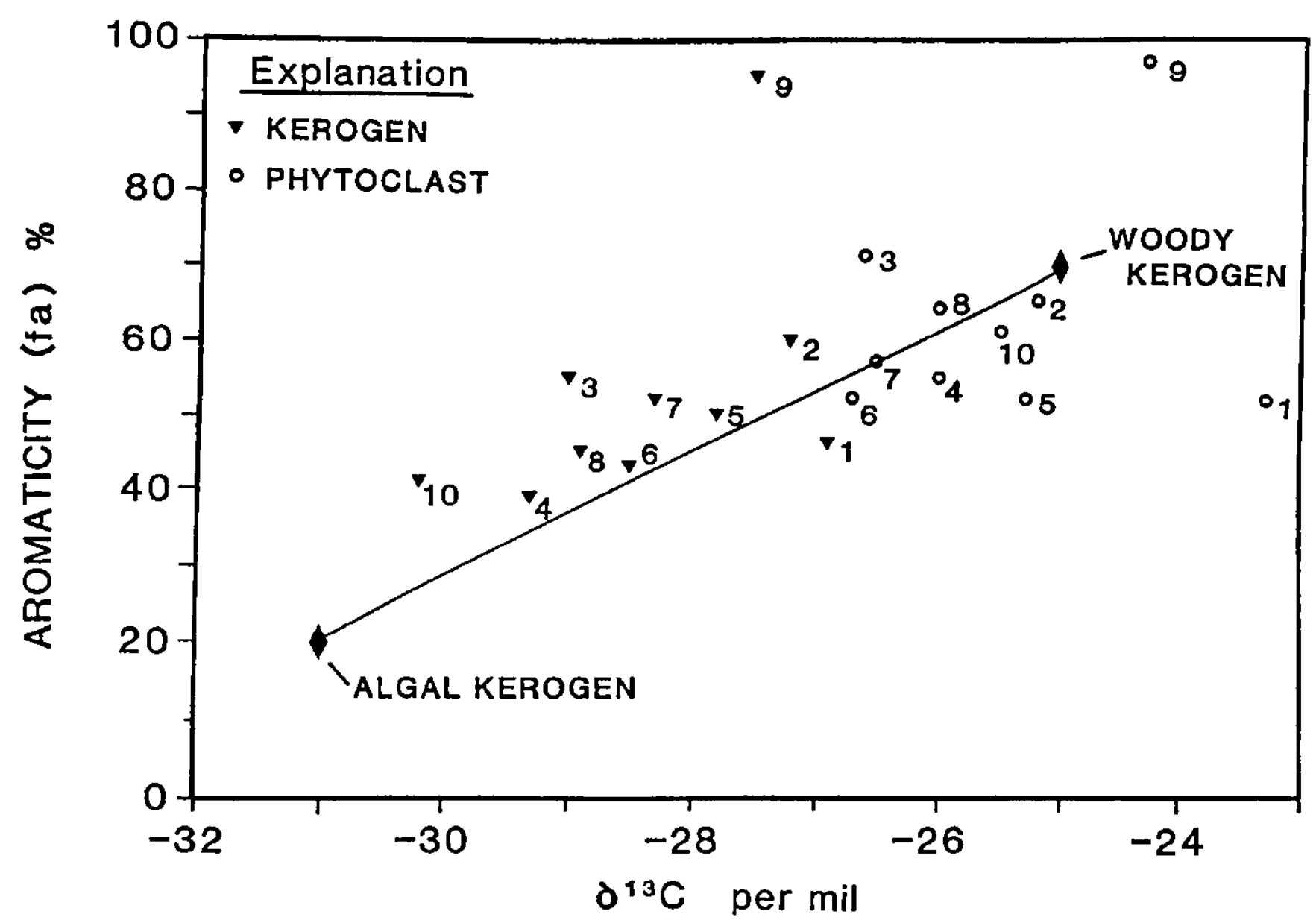

Figure 1. NMR aromaticity (fa, percent) and stable carbon isotope compositions $\left(\delta^{13} \mathrm{C}\right.$, per mil). Solid line represents a two end-member mixing model discussed in the text. $\delta{ }^{13} \mathrm{C}$ and fa compositions of the end-members are assumed to be -25 per mil and 70 percent, respectively, for woody kerogen, and -31 per mil and 20 percent, respectively, for algal kerogen.

phytoclasts are generally less aromatic and the kerogens generally more aromatic than the model predicts.

This apparently low aromaticity of some phytoclasts may be caused by more aliphatic-rich organic matter from the sediment matrix and pore water that may have infiltrated the phytoclasts. Such a matrix effect could also explain the relatively high nitrogen content of the phytoclasts, noted by Spiker (1985), and the abundance of $n$-alkanes in the pyrolysis products of the phytoclasts, noted by Kotra and others (this volume).

The relatively high aromaticity of some kerogens, which plot above the two-end-member mixing line in figure 1, may be caused by the presence of highly aromatic material, such as charcoal or oxidized soil organic matter, which could significantly increase the average aromaticity of a kerogen sample. For example, the difference in the calculated algal component $\left(\mathrm{C}_{\mathrm{a}}\right)$ using equation 1 versus equation 2 is largest for sample 3 . This is because the aromaticity of kerogen in sample 3 is relatively high compared to what the model would predict. We noted that the phytoclast in sample 3 had the visual appearance of charcoal. Although this does not necessarily indicate that the associated kerogen contains significant amounts of charcoal, relatively high aromaticity values may be attributed to charcoal in this kerogen sample.

The presence of varying and significant amounts of aromatic, wood-derived kerogen may at first appear to be inconsistent with results of pyrolysis studies (Kotra and others, this volume). These studies suggest that very little of the pyrolyzable portion of the kerogen was derived from a woody source, rather that most was from an algal source. Rock-Eval pyrolysis studies by Pratt and others (1986a) indicated a uniform source of organic matter. However, it is important to note that pyrolysis techniques analyze the pyrolyzable portion and are much more sensitive to volatile components generated preferentially by algal derived components (Tissot and Welte, 1984; Larter and Senftle, 1985; Peters, 1986).

The apparent deficiency of pyrolyzable aromatic material in kerogens that contain significant amounts of wood-derived organic matter, as shown by NMR and 
isotopic data, indicates that some of this woody material is probably very highly aromatic. This underscores the importance of using as many analytical techniques as possible, because of inherent differences and the somewhat different insights each technique may provide. In this case, these differences indicate that the kerogen may contain significant amounts of highly aromatic material, such as oxidized soil organic matter or charcoal.

The values of the kerogens reported here are typical of values for kerogens from the Newark and Hartford basins (Spiker, unpublished data from samples not discussed here; Pratt and others, 1986b). Therefore, it appears that the kerogen from these basins may typically contain significant amounts of allochthonous, terrestrial-derived material.

\section{CONCLUSIONS}

On the basis of NMR and stable carbon isotope results, it appears that kerogens from the Hartford and Newark basins are Type II and III, containing a mixture of wood- and algal-derived organic matter. Mass balance calculations suggest that between 30 and 70 percent of the kerogen examined here was derived from allochthonous woody sources, apparently including significant amounts of oxidized soil organic matter and possibly charcoal. Although such mixed-source kerogen is common in oil source rocks, the presence of large amounts of terrestrial woody debris is deemed a potential source of natural gas (Breger and others, 1983).

\section{ACKNOWLEDGMENTS}

We thank Nicholas G. McDonald and Joseph P. Smoot for providing samples and help in the field work. We thank Dianna Mills, Lisa Romankiw, and Vicki Comer for technical assistance. We also thank Tyler B. Coplen and Carol Kendall for the isotope ratio analyses.

\section{REFERENCES CITED}

Arneth, J.D., and Matzigkeit, U., 1986, Laboratory-simulated thermal maturation of different types of sediments from the Williston basin, North America-Effects on the production rates, the isotopic and organo-geochemical composition of various pyrolysis products: Chemical Geology, v. 58 , p. $339-360$.

Barwise, A.J.G., Mann, A.L., Eglinton, G., Gowar, A.P., Wardroper, A.M.K., and Gutteridge, C.S., 1984, Kerogen characterization by ${ }^{19} \mathrm{C}$ NMR spectroscopy and pyrolysismass spectrometry: Organic Geochemistry, v. 6, p. 343349.
Braghetta, A., 1985, A study of hydrocarbon maturity of the Hartford and Newark basins by vitrinite reflectance: Senior thesis, Princeton Unjversity, 96 p.

Breger, I.A., Hatcher, P.G., Romankiw, L.A., Miknis, F.P., and Maciel, G.E., 1983, Upper Devonian black shales of the Eastern United States-Organic geochemical studies, past and present, in Miknis, F.P., and McKay, J.F., eds., Geochemistry and chemistry of oil shales: American Chemical Society Symposium Series, no. 230, p. 181-198.

Buchardt, B., Clausen, J., and Thomsen, E., 1986, Carbon isotope composition of Lower Paleozoic kerogen: Effects of maturation: Organic Geochemistry, v. 10, p. 127-134.

Craig, H., 1957, Isotopic standards for carbon and oxygen and correction factors for mass spectrometric analysis of carbon dioxide: Geochimica et Cosmochimica Acta, v. 12, p. 133-149.

Deines, P., 1980, The isotopic composition of reduced organic carbon, in Fritz, P., and Fontes, J.C., eds., Handbook of Environmental Isotope Geochemistry: v. 1, Amsterdam, Elsevier, p. 329-406.

Hatcher, P.G., Breger, I.A., Szeverenyi, N.M., and Maciel, G.E., 1982, Nuclear magnetic resonance studies of ancient buried wood-II, Observations on the origin of coal from lignite to bituminous coal: Organic Geochemistry, v. 4, p. 9-18.

Hatcher, P.G., and Romankiw, L.A., 1985, Nuclear magnetic resonance of organic-matter-rich sedimentary rocks of some early Mesozoic basins of the Eastern United States, in Robinson, G.R., Jr., and Froelich, A.J., eds., Proceedings of the second U.S. Geological Survey workshop on the early Mesozoic basins of the Eastern United States: U.S. Geological Survey Circular 946, p. 65-70.

Hatcher, P.G., Spiker, E.C., and Orem, W.H., 1986, Oxidative origin of sedimentary humic acids, important carriers of metals, in Dean, W.E., ed., Proceedings of the Denver Regional Exploration Geologists Society symposium on organics and ore deposits, April 25-26, 1985: Denver Regional Exploration Geologists Society, Wheat Ridge, Colorado, p. 57-68.

Kelly, W.C., and Nishioka, G.K., 1985, Precambrian oil inclusions in late veins and the role of hydrocarbons in copper mineralization at White Pine, Michigan: Geology, v. 13, p. 334-337.

Larter, S.R., and Senftle, J.T., 1985, Improved kerogen typing for petroleum source rock analysis: Nature, v. 318, p. 277-280.

Lewan, M.D., 1986, Stable carbon isotopes of amorphous kerogens from Phanerozoic sedimentary rocks: Geochimica et Cosmochimica Acta, v. 50, p. 1583-1591.

Maynard, J.B., 1983, Geochemistry of sedimentary ore deposits: Springer-Verlag, 305 p.

Miknis, F.P., Maciel, G.E., and Bartuska, V., 1979, Cross polarization magic angle spinning ${ }^{19} \mathrm{C}$ NMR spectra of oil shales: Organic Geochemistry, v. 1, p. 169-176.

Parnell, J., 1986, Hydrocarbons and metalliferous mineraliza. tion in a lacustrine rift basin: The Hartford-Deerfield basin, Connecticut Valley: Neues Jahrbuch für Mineralogie Abhandlungen, v. 154, no. 1, p. 93-110. 
Peters, K.E., 1986, Guidelines for evaluating petroleum source rock using programmed pyrolysis: American Association of Petroleum Geologists Bulletin, v. 70, p. 318-329.

Pratt, L.M., Vuletich, A.K., and Burruss, R.C., 1986a, Petroleum generation and migration in Lower Jurassic lacustrine sequences, Hartford basin, Connecticut and Massachusetts, in Carter, L.M.H., ed., USGS research on energy resources-1986, program and abstracts: U.S. Geological Survey Circular 974, p. 57-58.

Pratt, L.M., Vuletich, A.K., and Shaw, C.A., 1986b, Preliminary results of organic geochemical and stable isotope analyses of Newark Supergroup rocks in the Hartford and Newark basins, Eastern U.S.: U.S. Geological Survey Open-File Report 86-284, 29 p.

Saxby, J.D., Bennett, A.J.R., Corcoran, J.F., Lambert, D.E., and Riley, K.W., 1986, Petroleum generation: Simulation over six years of hydrocarbon formation from torbanite and brown coal in a subsiding basin: Organic Geochemistry, v. 9 , p. $69-81$.

Schnitzer, M., and Khan, S.U., 1972, Humic substances in the environment: Marcel Dekker, New York, 327 p.

Spiker, E.C., 1985, Stable-isotope characterization of organic matter in the early Mesozoic basins of the Eastern United States, in Robinson, G.R., Jr., and Froelich, A.J., eds., Proceedings of the second U.S. Geological Survey workshop on the early Mesozoic basins of the Eastern United States: U.S. Geological Survey Circular 946, p. 70-73.

Spiker, E.C., and Hatcher, P.G., 1987, The effects of early diagenesis on the chemical and stable isotopic composition of wood: Geochimica et Cosmochimica Acta, v. 51, p. 1385-1391.

Tissot, B., and Welte, D.H., 1984, Petroleum formation and occurrence, 2d ed.: Springer-Verlag, 699 p.

\title{
CHEMICAL COMPOSITION AND THERMAL MATURITY OF KEROGEN AND PHYTOCLASTS OF THE NEWARK SUPERGROUP IN THE HARTFORD BASIN
}

\author{
R.K. Kotra, R.M. Gottfried, E.C. Spiker, L.A. Romankiw, and P.G. Hatcher
}

\begin{abstract}
Organic geochemical analyses of more than 50 samples from three Lower Jurassic units of the Hartford basin have been carried out by use of elemental ratios, pyrolysis, nuclear magnetic resonance spectroscopy, and stable isotope ratios. Results indicate that the organic matter is of the appropriate type and maturity to have generated fluid hydrocarbons. Kerogen appears to be of mixed origins, on the basis of bulk chemical parameters. Molecular-level analysis shows that it is derived mostly from an algal source. Kerogen thermal maturity derived from phytoclast rank is approximately equivalent to subbituminous to high-volatile bituminous coal rank, or 0.5 to 1.0 percent $R_{0}$. A general decrease in thermal maturity is observed from north to south.
\end{abstract}

\section{INTRODUCTION}

Many of the exposed lacustrine units of the early Mesozoic Newark Supergroup of the Eastern United States consist of sedimentary rocks that have significant amounts of organic matter. Under the proper geologic conditions, this organic matter (OM) may have played an important role in mineralization processes, and some of it may have been converted to liquid and gaseous hydrocarbons during burial diagenesis and catagenesis. The first step in understanding the roles and fate of OM in the early Mesozoic basins of the Eastern United States is the detailed characterization of the OM. Information on the type and maturity of the OM combined with information on the inorganic geochemistry and mineralogy will be used in developing models of the thermal history of the basins.

Most of the reduced carbon in a sedimentary rock is in the form of kerogen, an insoluble, disseminated, chemically and physically complex mixture of OM. Bulk chemical parameters such as elemental ratios and hydrogen and oxygen indices have been used to classify kerogen into the three principal broad categories, Types I, II, and III (Tissot and Weite, 1984). Type I is usually derived from algal material in lacustrine environments; Type II is primarily composed of autochthonous marine $\mathrm{OM}$; and Type III is derived from terrestrial plant debris. A plot of the atomic $\mathrm{H} / \mathrm{C}$ versus $\mathrm{O} / \mathrm{C}$ ratios, known as the van Krevelen diagram (Tissot and Welte, 1984), shows in a concise manner how kerogen composition evolves during maturation. Any given point on such a plot does not necessarily describe a unique chemical composition, nor can it be taken that all sedimentary $\mathrm{OM}$ evolves along the main pathways defined by the diagram. By mixing together two or more of the chemically distinct kerogen types, it is possible to produce almost any composition on a van Krevelen diagram. Thus, it is important to classify kerogen more definitively by also applying molecularlevel methods to predict the products of kerogen maturation accurately. Both kerogen and maturation products 
may play a role in sediment diagenesis and may be involved in mineralization processes.

Phytoclasts are macroscopic pieces of woody (or Type III) material that are occasionally found embedded in sedimentary rocks. Assuming that phytoclasts and kerogen from the same layer are syndepositional, the degree of coalification, or rank of the phytoclast, should reflect the level of thermal maturity of the kerogen. Therefore, the rank of phytoclasts can provide an additional means to define the thermal maturity of kerogen, assuming minimal alteration of the phytoclast prior to deposition. If the rank of the phytoclast is substantially higher than the maturity of the kerogen, then it is most likely that the woody material was thermally altered prior to deposition. Whenever possible, we have analyzed kerogen and phytoclasts coexisting in the same sample to attempt to separate source and thermal effects on the current state of the OM by using both bulk and molecular-level parameters. In addition, extractable OM is also being examined to determine the type and amount of hydrocarbons present. This paper discusses the results of kerogen and phytoclast analyses of samples from the Hartford basin.

\section{METHODS}

Phytoclasts were manually separated from the rock matrix, rinsed in distilled water, and dried. Some phytoclasts were treated with $\mathrm{HCl}$ and $\mathrm{HF}$ if excess mineral matter was attached to them. Kerogen from dark-gray to black shales, mudstones, and siltstones was prepared by dissolving the rock matrix with $1: 1 \mathrm{HCl} / \mathrm{HF}$ mixtures, after extraction with organic solvents in a Soxhlet apparatus and treatment with $3 \mathrm{M} \mathrm{HCl}$ to remove carbonates. If the ash content of kerogen was high, samples were treated with $\mathrm{AlCl}_{3}$ or $\mathrm{ZnBr}_{2}$ solutions to further concentrate the kerogen. The samples were then analyzed by elemental analysis $\left(\mathrm{C}, \mathrm{H}, \mathrm{N}\right.$, and $\mathrm{O}$ ), solid-state ${ }^{13} \mathrm{C}$ nuclear magnetic resonance spectroscopy (NMR), pyrolysis gas chromatography (PYGC), pyrolysis gas chromatography-mass spectrometry (PYGCMS), and stable isotope ratio mass spectrometry.

\section{RESULTS AND DISCUSSION}

More than 50 kerogen and phytoclast samples have been examined from the Early Jurassic Shuttle Meadow, East Berlin, and Portland Formations of the Hartford basin in Connecticut and Massachusetts. Detailed descriptions of the samples and sample locations can be found elsewhere (Pratt and others, 1986a; Kotra and others, unpub. data, 1987). The range of total organiccarbon content of these samples is from 0.4 percent to greater than 3.5 percent by weight.
The atomic $\mathrm{H} / \mathrm{C}$ ratio for phytoclasts ranged from 0.53 to 1.1 , and in the same samples, the atomic $\mathrm{O} / \mathrm{C}$ ratio ranged from 0.04 to 0.13 . Most phytoclasts have atomic $\mathrm{H} / \mathrm{C}$ ratios near 1.0 and atomic $\mathrm{O} / \mathrm{C}$ ratios near 0.08 , indicating a rank approximately equivalent to that of high-volatile bituminous coal. The few phytoclasts that have lower ratios have evolved to higher ranks, and the agents responsible for this must be determined individually. For example, a phytoclast from a coppermineralized sandstone in the Portland Formation is of a high rank (atomic $\mathrm{H} / \mathrm{C}=0.70$ ). This increase in rank may have been caused by the passage of hot fluids, which led to the mineralization.

The atomic $\mathrm{H} / \mathrm{C}$ ratio for kerogen samples ranged from 0.7 to 1.5 , and in the same samples the atomic $\mathrm{O} / \mathrm{C}$ ratio ranged from 0.03 to 0.16 . If the elemental data were plotted on a van Krevelen diagram, the Hartford basin kerogens we have analyzed would span the broad categories, Types I, II, and III. The maturity of the kerogen samples cannot be determined by using elemental ratios alone, as noted earlier.

NMR results for a set of 13 phytoclasts from four Mesozoic basins were reported in an earlier study (Hatcher and Romankiw, 1985). Two of those analyses were on samples from the Portland Formation in the Hartford basin. Elemental and NMR data indicated that the two phytoclasts were of low-volatile bituminous to semianthracite rank. However, it was suggested that the elevated atomic $\mathrm{O} / \mathrm{C}$ ratio and the presence of a phenolic peak in high-ranked phytoclasts indicated a carbonization process rather than a normal coalification path, implying higher than normal geothermal gradients. The larger set of samples we have examined here shows that most of the phytoclasts are of much lower rank. Aromaticity, or the fraction of all carbons in a given organic material that are aromatic, is a measure of rank (Miknis and others, 1981; Wilson and others, 1984). The range of aromaticity values is from 0.5 to greater than 0.8 . Most of the phytoclasts from the Shuttle Meadow and East Berlin Formations, which underlie the Portland Formation, have aromaticities between 0.5 and 0.65 with pronounced phenolic peaks. This is equivalent to subbituminous to high-volatile bituminous coal rank. For the Portland Formation phytoclasts, aromaticities are between 0.65 to greater than 0.8 . Some phytoclasts of higher rank show a phenolic peak and some do not. Thus the earlier suggestion of a carbonization process to account for the elevated $\mathrm{O} / \mathrm{C}$ ratio and the presence of a phenolic peak probably applies only to isolated locations that experienced unusually high thermal conditions.

The range of kerogen aromaticities is from 0.45 to greater than 0.8 , with most values being less than 0.6 . Aromaticities for kerogen from shales can be less than 0.2 or higher, depending on the sources of the kerogen and the degree of thermal maturity. Kerogen composed 
predominantly of a hydrogen-rich material like alginite, such as in torbanites, is an example of kerogen with very low aromaticity, usually 0.2 or less (Breger and others, 1983; Saxby and others, 1986). As the proportion of materials with lower hydrogen content, like that derived from terrestrial vascular plants, increases in the kerogen, the aromaticity also increases.

On the basis of NMR data, the two sources of kerogen in the Hartford basin appear to be terrestrial vascular plant debris and nonvascular plant material, such as algae, from the ancient lakes. Alternatively, if the Hartford basin kerogen were composed predominantly of nonvascular plant remains, thermal maturation has increased the aromaticity to present levels. It has been observed that aromaticity gradually increases with thermal maturity in long-term experiments that started with a pure Type I kerogen simulating the formation of hydrocarbons in a subsiding basin (Saxby and others, 1986). This increase in kerogen aromaticity probably does not occur until a rank equivalent to that of high-volatile $C$ bituminous coal is reached (Breger and others, 1983).

The composition of the bitumen extracted from these shales might reflect the composition of the kerogen, assuming that the bitumen has not migrated into the strata from elsewhere. A number of extracts have been examined by GCMS, and indications are that the extractable hydrocarbons are derived from algal and bacterial sources (Kotra, unpub. data, 1987). The n-alkane maxima are at $\mathrm{C}_{20}$ or less, and higher molecular weight $\mathrm{n}$-alkanes are of low abundance and have no odd-carbon preference. Detailed analysis of the extractables is currently under way.

PYGC and PYGCMS were applied to determine differences in the chemical structure of phytoclasts and kerogen samples at the molecular level. Figure 1 shows three $610^{\circ} \mathrm{C}$ PYGC traces (pyrograms) of phytoclasts from three formations of the Hartford basin. Many of the largest peaks are n-alkanes. Pyrolysis was carried out directly in the injector port of a gas chromatograph. Abundant n-alkanes are released both initially, when the sample is inserted into the port, which is at $280^{\circ} \mathrm{C}$, and after pyrolysis at $610^{\circ} \mathrm{C}$. In general, material released at the lower temperature is extractable and material released at higher temperature is not extractable. The low-temperature fraction may have been incorporated into the phytoclast after deposition. Thus, the phytoclasts may have adsorbed/absorbed hydrocarbons from the surrounding shale, and some hydrocarbons may be part of the structure of the phytoclast material. In addition, other compounds that are pyrolysis products of woody material, such as many different phenolic species, are also present. Detailed identification of the phenolic species is currently in progress. Extraction of the phytoclasts by organic solvents at room temperature did not signifi- cantly reduce the amount of n-alkanes released on pyrolysis both at low temperature and at high temperature.

Figure 2 shows pyrograms from three kerogen samples isolated from the shales from which the phytoclasts shown in figure 1 were collected. The clear difference between kerogen and phytoclasts is that the kerogen pyrolyzates are dominated by a homologous series of alkene-alkane doublets (labeled on fig. 2). The dominant alkene-alkane doublets are probably derived from highmolecular-weight aliphatic structures in the kerogen. This type of a pyrolysis pattern is typical of kerogen derived almost solely from algae (Larter, 1984). Most of the Hartford basin kerogen samples from areas not near an obviously high heat source yield pyrolysis patterns similar to those in figure 2 . In these pyrograms small amounts of aromatic compounds, possibly cleaved from a vascular plant component in the kerogen, are present.

Stable carbon isotope ratios (expressed in standard per mil notation relative to the Pee Dee Belemnite standard) were also determined for a select number of kerogen and phytoclast samples. The values for the phytoclasts span the range from -23.3 to -26.7 with most being around -26.0 . These values are typical of woody material. Kerogen values range from -24.0 to -30.4 , with most being -28.0 or lighter. Kerogen $\delta^{13} \mathrm{C}$ values are typical of Type I and II kerogen with possibly some Type III contribution. A more detailed discussion of the stable isotopic data is presented in another paper in this volume (Spiker and others).

It is worth noting some of the differences in the type of information obtained by use of bulk techniques like NMR and information obtained by use of molecularlevel techniques like PYGC. Samples having similar aromaticity values do not necessarily give rise to the same pyrolysis pattern. For example, the aromaticities of the East Berlin Formation phytoclast and kerogen in figures 1 and 2 are 0.52 and 0.50 , respectively. On the basis of aromaticity alone, the kerogen pyrolyzates might be expected to contain a high amount of aromatic compounds. But, as shown in figure 2, the East Berlin kerogen is dominated by a homologous series of alkenealkane pairs. The aromatic moieties in the kerogen apparently are not as easily pyrolyzed. This may be because most of the aromatic carbons are linked in a network just large enough not to be affected by the temperature of pyrolysis. The development of such an aromatic network (aromatization) can be the result of maturation. The presence of abundant hydrogen-poor components (dead carbon) in the kerogen can also give this type of NMR and PYGC results. Examples of such hydrogen-poor components are charcoal, oxidized sedimentary carbon, and carbonaceous material that was already metamorphosed to high rank prior to deposition. 


\section{PYGC PHYTOCLASTS}
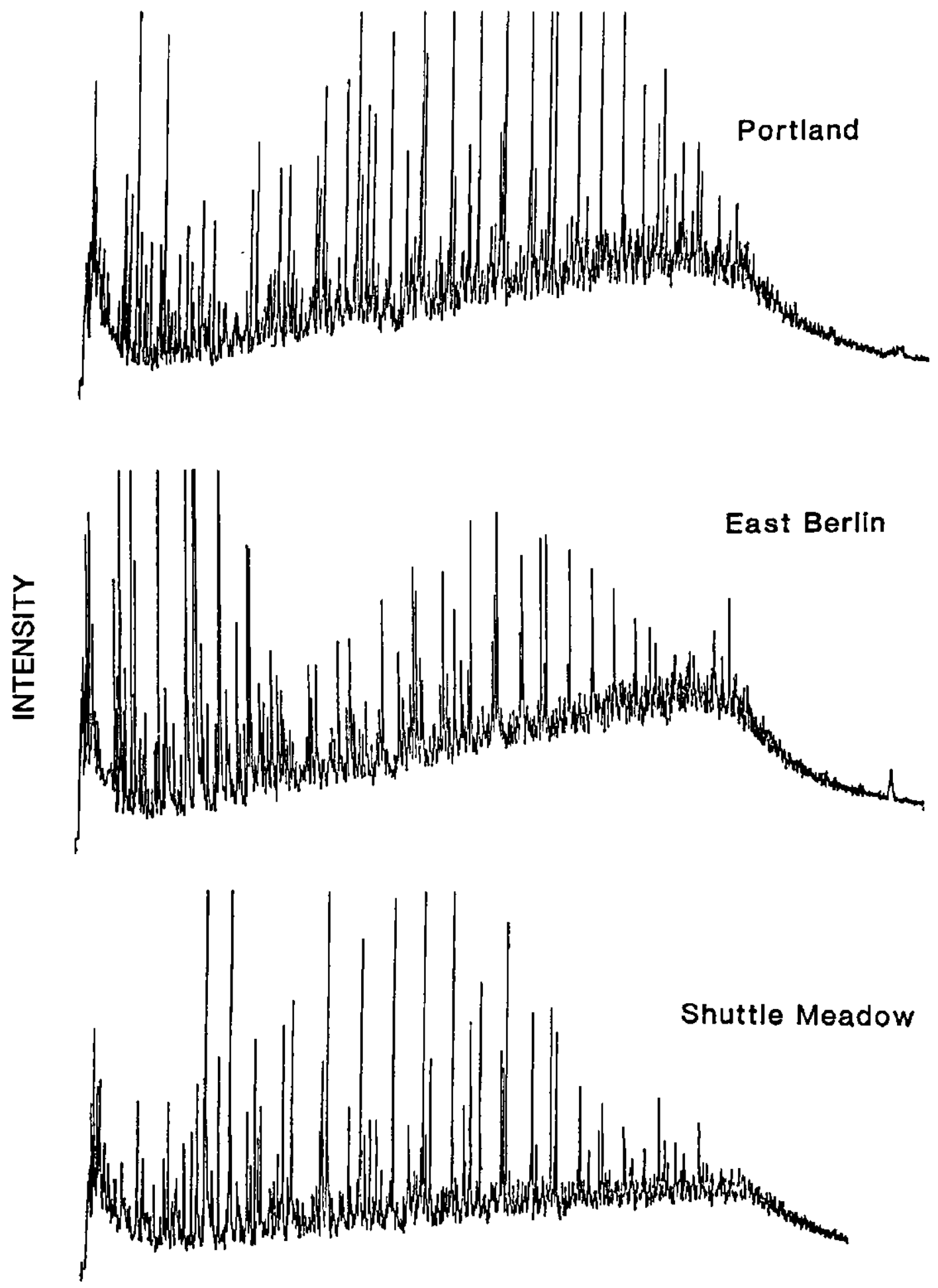

\section{RETENTION TIME}

Figure 1. Pyrograms of three Hartford basin phytoclasts. 


\section{PYGC KEROGEN}
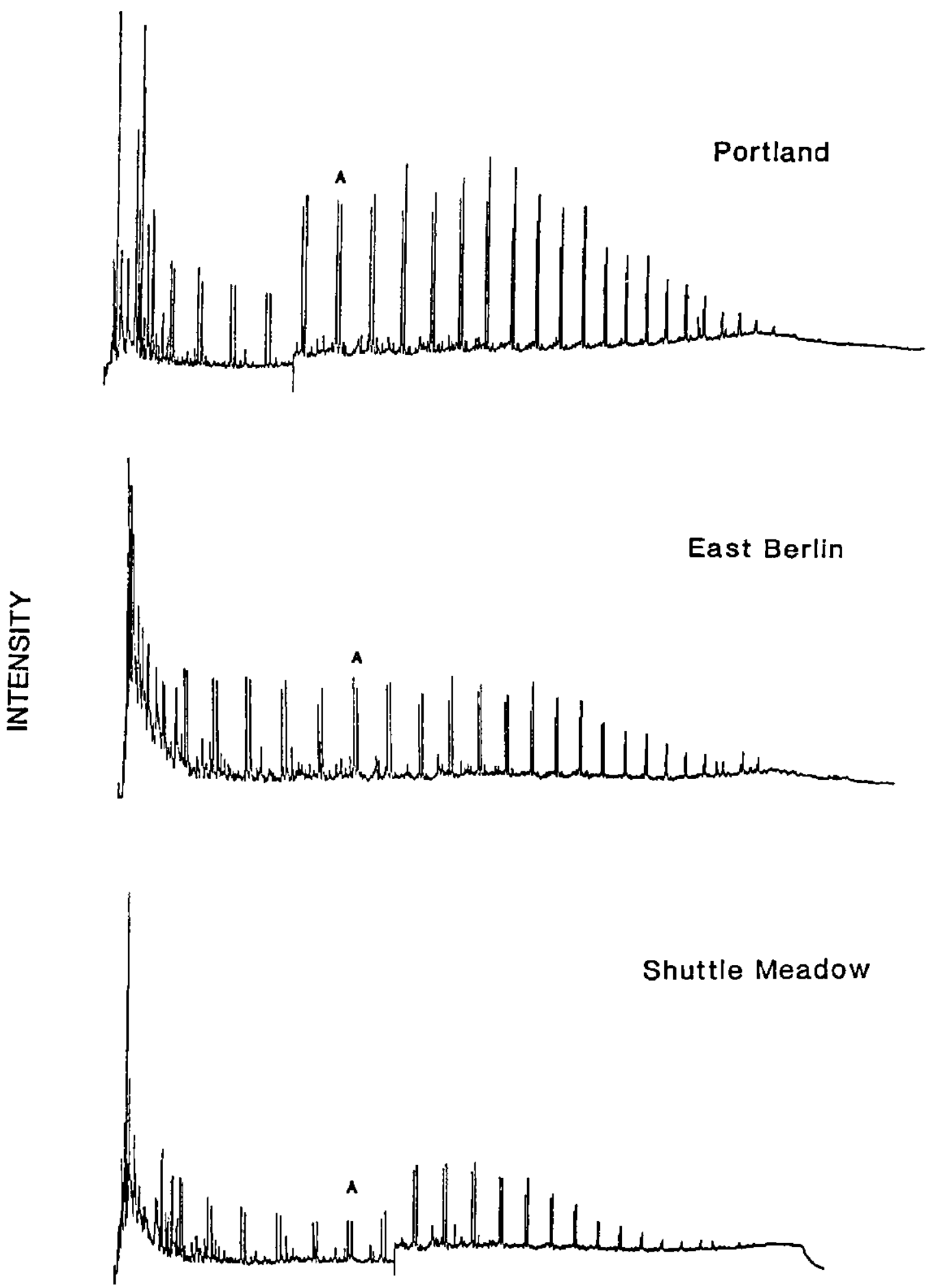

\section{RETENTION TIME}

Figure 2. Pyrograms of three kerogen samples isolated from the same samples as in figure 1. A, alkene-alkane pair. 
Microscopic examination also permits the identification of various materials that comprise kerogen. Vitrinite reflectance measurement of some of these materials can be used as a measure of the degree of coalification or organic metamorphism. Vitrinite reflectance values have been reported for kerogen samples from the same localities as our samples from the Hartford basin (Braghetta, 1985). The mean reflectance values ranged from 0.4 to 0.8 percent $R_{o}$. These values indicate that the $\mathrm{OM}$ is of low to moderate maturity. A few samples from highly faulted zones had values greater than 0.8 percent $R_{o}$. The vitrinite reflectance value for a sample equivalent to the East Berlin kerogen discussed above was about 0.6 percent $R_{\mathrm{o}}$. If large amounts of $a$ higher rank vitrinitic component were present in the kerogen, the reflectance value would be higher. Amorphous components of kerogen are not amenable to reflectance measurement. Therefore, vitrinite reflectance values do not adequately represent those components which are reported to be a major fraction of the Hartford basin kerogen samples (Braghetta, 1985).

To summarize, the kerogen samples from the Hartford basin, as indicated by the bulk chemical techniques, are composed of a mixture of Types I and III material. Pyrolysis indicates that most kerogen samples contain predominantly Type I material. It is possible that the bulk techniques are overestimating the amount of a Type III component and pyrolysis is underestimating the amount of a Type III component. Nevertheless, kerogen in the Hartford basin samples contains enough of a hydrogen-rich component to produce or to have produced a fluid hydrocarbon product during maturation.

We have observed, as have others (Pratt and others, 1986b), a general north-to-south decrease in thermal maturity of the OM in the Hartford basin. More examples of kerogen and phytoclasts of lower rank were found in the southern portion of the basin. This trend is more pronounced in the Portland Formation samples. A decrease in atomic $\mathrm{H} / \mathrm{C}$ ratios, an increase in aromaticity, and a decline in the yield of pyrolysis products are seen for these samples in a northerly direction. This type of a thermal trend also has been indicated by illite crystallinity data (Gottfried and Kotra, this volume) and by vitrinite reflectance data (Braghetta, 1985). Further analysis of the setting of these samples, such as proximity to intrusions and faults, is in progress.

It should be emphasized that all of the samples we have examined are from outcrops. Great effort was expended to collect unweathered material wherever possible. However, as the possibility of weathering cannot be completely ruled out, any values for the amount of mobile OM in these units are probably minimum values. Given the promising nature of the OM with respect to hydrocarbon potential in outcrops of sedimentary rocks, especially in the southern portion of the Hartford basin, it would be fruitful to study material that is currently not exposed. A discussion of the thicknesses of the OM-rich sedimentary rocks, possible fluid migration pathways, reservoir rocks, and potential traps is beyond the scope of this paper. Investigations are currently in progress on the inorganic geochemistry and clay mineralogy of the same samples examined in this study. An integrated picture of the low-temperature geochemistry of the Hartford basin will emerge when organic geochemical studies are combined with the results of those investigations.

\section{SUMMARY}

We have applied elemental analysis, NMR, PYGCMS, and stable isotope analysis to more than 50 kerogen and phytoclast samples from three Jurassic stratigraphic units of the Hartford basin. Sedimentary rocks rich in OM from the Shuttle Meadow, East Berlin, and Portland Formations contain kerogen with sufficient hydrogen-rich components to yield or to have yielded fluid hydrocarbons. Bulk techniques, like NMR and stable isotope ratios, indicate that the kerogen is made up of a mixture of material derived from terrestrial vascular plant as well as from lacustrine algal sources. However, the pyrolyzable portion of most of these kerogen samples resembles material derived from algae. Kerogen thermal maturity deduced from phytoclast rank is equivalent to subbituminous to high-volatile bituminous coal rank, or approximately 0.5 to 1.0 percent $R_{o}$. A general north-tosouth decrease in thermal maturity in the Hartford basin is indicated, which appears to be more pronounced in the Portland Formation than in the underlying units.

\section{ACKNOWLEDGMENTS}

We thank Paul Olsen, Lamont-Doherty Geological Observatory of the Columbia University, Palisades, New York, Nick McDonald, Westminster School, Simsbury, Connecticut, and Joe Smoot, U.S. Geological Survey, for providing many interesting phytoclast and rock samples and for their expert guidance in the field. We thank Tyler B. Coplen, Carol Kendall, and Mary F. Horan, all of the U.S. Geological Survey, for assistance in obtaining isotope ratio data. We would also like to thank Dianna Mills for her technical assistance.

\section{REFERENCES CITED}

Braghetta, A., 1985, A study of hydrocarbon maturity of the Hartford and Newark basins by vitrinite reflectance: Senior thesis, Princeton University, 96 p.

Breger, I.A., Hatcher, P.G., Romankiw, L.A., Miknis, F.P., and Maciel G.E., 1983, Upper Devonian black shales of the Eastern United States-Organic geochemical studies, past 
and present, in Miknis, F.P., and McKay, J.F., eds, American Chemical Society Symposium Series, No. 230, Geochemistry and chemistry of oil shales: Washington, D.C., American Chemical Society, p. 181-198.

Hatcher, P.G., and Romankiw, L.A., 1985, Nuclear magnetic resonance studies of organic-matter-rich sedimentary rocks of some early Mesozoic basins of the Eastern United States, in Robinson, G.R., Jr., and Froelich, A.J., eds., Proceedings of the second U.S. Geological Survey workshop on the early Mesozoic basins of the Eastern United States: U.S. Geological Survey Circular 946, p. 65-70.

Larter, S.R., 1984, Application of analytical pyrolysis techniques to kerogen characterization and fossil fuel exploration/exploitation, in Voorhees, K.J., ed., Analytical pyrolysis-techniques and applications: Butterworths, London, p. 212-275.

Miknis, F.P., Sullivan, M., Bartuska, V.J., and Maciel, G.E., 1981, Cross polarization magic-angle spinning ${ }^{13} \mathrm{C}$ NMR spectra of coals of varying rank: Organic Geochemistry, v. 3, p. 19-28.

Pratt, L.M., Vuletich, A.K., and Shaw, C.A., 1986a, Preliminary results of organic geochemical and stable isotope analyses of Newark Supergroup rocks in the Hartford and Newark basins, Eastern U.S.: U.S. Geological Survey Open-File Report 86-284, 29 p.

Pratt, L.M., Vuletich, A.K., and Burruss, R.C., 1986b, Petroleum generation and migration in Lower Jurassic lacustrine sequences, Hartford basin, Connecticut and Massachusetts, in Carter, L.M.H., ed., USGS research on energy resources, 1986, program and abstracts: U.S. Geological Survey Circular 974, p. 57-58.

Saxby, J.D., Bennett, A.J.R., Corcoran, J.F., Lambert, D.E., and Riley, K.W., 1986, Petroleum generation: Simulation over six years of hydrocarbon formation from torbanite and brown coal in a subsiding basin: Organic Geochemistry, v. 9, p. 69-81.

Tissot, B.P., and Welte, D.H., 1984, Petroleum formation and occurrence, second edition: Springer-Verlag, 699 p.

Wilson, M.A., Pugmire, R.J., Karas, J., Alemany, L.B., Woolfenden, W.R., Grant, D.M., and Given, P.H., 1984, Carbon distribution in coals and coal macerals by cross polarization magic angle spinning carbon-13 nuclear magnetic resonance spectrometry: Analytical Chemistry, v. 56, p. 933-943.

\title{
EVIDENCE FOR PETROLEUM GENERATION AND MIGRATION IN THE HARTFORD AND NEWARK BASINS
}

\author{
Lisa M. Pratt and Robert C. Burruss
}

\begin{abstract}
Medium-gray to black deep-water lacustrine shales and siltstones are present in cyclic deposits within the Jurassic strata of the Hartford and Newark basins. In each basin, the combined thickness of dark-colored Jurassic shales and siltstones is estimated at 30 to $40 \mathrm{~m}$, and in addition, several hundred meters of interbedded mudstone and deep-water shale are present in the Triassic portion of the Newark basin. The Triassic and Jurassic deep-water shales and siltstones have average organic-carbon contents of about 2 percent (range 0.5 to 6 percent). The basinwide continuity and the thickness of these organic-matter-rich units suggest an adequate volume of potential source rocks for economically significant petroleum generation.

Field evidence and fluid-inclusion studies indicate that petroleum and aqueous fluids repeatedly migrated through fracture networks during deformation of the Hartford and Newark basins. Zoned veins, formed by multiple phases of calcite and bitumen precipitation, as well as petroleum in fluid inclusions, provide a record of these migration events. Homogenization temperatures of petroleum inclusions indicate temperatures during migration near $100^{\circ} \mathrm{C}$ and are consistent with levels of thermal maturation inferred from
\end{abstract}

organic maturation indices. The distribution of saturated hydrocarbons is remarkably similar for extracts from shale, solid bitumen in veins and fractures, and viscous petroleum in concretions. We infer that the organic-matter-rich lacustrine shales and siltstones in these basins were effective petroleum source rocks.

\section{INTRODUCTION}

The Hartford and Newark basins are two of a series of elongate fault-bounded basins in eastern North America. Medium-gray to black deep-water lacustrine shales and siltstones are present in cycles within the Jurassic strata of both basins. In each basin, the combined thickness of dark-colored shales and siltstones is estimated at 30 to $40 \mathrm{~m}$, on the basis of the description of a composite Jurassic stratigraphic section by Olsen (1984). Several hundred meters of cyclic interbedded shallow-water mudstone and deep-water shale are present in the Triassic portion (Lockatong Formation) of the Newark basin. Both the Triassic and Jurassic deep- 
water shales and siltstones are medium gray to black in color and have average organic carbon contents of about 2 percent (range 0.5 to 6 percent). The basinwide continuity and thickness of these organic-matter-rich units suggest an adequate volume of potential source rocks for economically significant petroleum generation.

Until recently, few published organic geochemical data were available on the type, amount, and thermal maturity of organic matter in the eastern Mesozoic basins. This situation has changed with the publication of numerous abstracts in the last 3 years by industry, academic, and government research groups on the petroleum potential of the eastern Mesozoic basins. A preliminary report by Pratt and others (1986b) contains organic geochemical and carbon and oxygen isotopic data on most of the formations in the Hartford and Newark basins. Data in that initial report and our subsequent work indicate widespread generation and migration of petroleum in the Hartford and Newark basins. This paper presents the evidence for migrated liquid petroleum in both the Hartford and Newark basins.

\section{MATERIALS AND METHODS}

Samples were collected during four fieldtrips in the Hartford and Newark basins from 1984 to 1986. Outcrops were excavated as necessary to penetrate the zone of pervasively weathered rock (10 to $100 \mathrm{~cm}$ ). In the laboratory, shale samples were screened for the presence of finely disseminated pyrite by using a binocular microscope. The presence of unoxidized fine-grained pyrite in shale is a good indication that the sample is not deeply weathered and is suitable for organic geochemical analyses.

About 100 samples from the Hartford basin and about 80 samples from the Newark basin were analyzed for pyrolysis response (Rock-Eval instrument) and organic carbon content (LECO instrument). Results of these analyses are described in Pratt and others (this volume). Sixteen outcrop samples from the Hartford basin and 11 outcrop and 4 core samples from the Newark basin were extracted with chloroform $(24 \mathrm{hr}$ in a Soxhlet apparatus) and separated into four fractions (asphaltenes, saturated hydrocarbons, aromatic hydrocarbons, nitrogen-sulfur-oxygen compounds) by aluminasilica gel chromatography. The extracts were characterized by using gas chromatography (GC) and gas chromatography-mass spectrometry (GCMS) of the saturated hydrocarbons. More detailed descriptions of the analytical techniques are given in Pratt and others (1986a,b).

\section{FIELD OBSERVATIONS}

Common occurrences of migrated bitumen observed in Mesozoic rocks of the Hartford and Newark basins are, in order of decreasing abundance, (1) small tension fractures filled with solid bitumen, (2) mineralized veins from 1 to $3 \mathrm{~cm}$ in width filled with intergrown calcite and solid bitumen, and (3) bitumen-stained porous sandstones. Unusual occurrences of migrated bitumen in these basins include calcareous concretions containing small tension fractures rimmed with calcite and containing liquid bitumen (Feltville Formation, Newark basin), highly fractured chert with solid bitumen filling the fracture network (Towaco Formation, Newark basin), and a siliceous concretion containing viscous bitumen in its core (East Berlin Formation, Hartford basin). Virtually every outcrop of Jurassic deep-water shales and siltstones and many outcrops of Triassic shales and mudstones that we studied in the Hartford and Newark basins contain evidence of bitumen migration. The diversity and abundance of bitumen occurrences in these outcrops indicate that regional heatflow, rather than locally elevated heatflow, probably was responsible for the generation of petroleum.

Bitumen-stained porous sandstones are less common than the occurrence of bitumen in fractures or veins in the Hartford and Newark basins. This suggests that fracture networks were more effective migration pathways than sandstones. This is not surprising, considering the mineralogically immature character of coarse clastics in these rift basins. The immature mineralogy contributes to pervasive cementation by quartz, albite, ferroan dolomite, and calcite (Hubert and Reed, 1978), which occluded available intergranular porosity and permeability.

\section{FLUID-INCLUSION OBSERVATIONS}

The occurrence of two-phase petroleum liquid plus vapor inclusions in diagenetic minerals is direct evidence of the presence of liquid petroleum during diagenesis of sediments. By inference, it is also evidence of the generation of liquid petroleum from source rocks. The petrographic setting of the inclusions in diagenetic cements is an important indicator of the timing of oil generation and migration relative to cementation, fracturing, and tectonic deformation (Burruss, 1981; Burruss and others, 1985).

Thin sections of samples from 15 localities in the Hartford and Newark basins were examined by using UV-excited fluorescence microscopy to identify petroleum inclusions (Burruss, 1981). Samples from six localities in the Hartford basin and one locality in the Newark basin contain petroleum inclusions. The fact that several widely separated sites in the Hartford basin contain petroleum inclusions is additional evidence of petroleum generation on a regional scale.

An example of the occurrence of petroleum inclusions in a calcite-bitumen vein in the Hampden Basalt, 

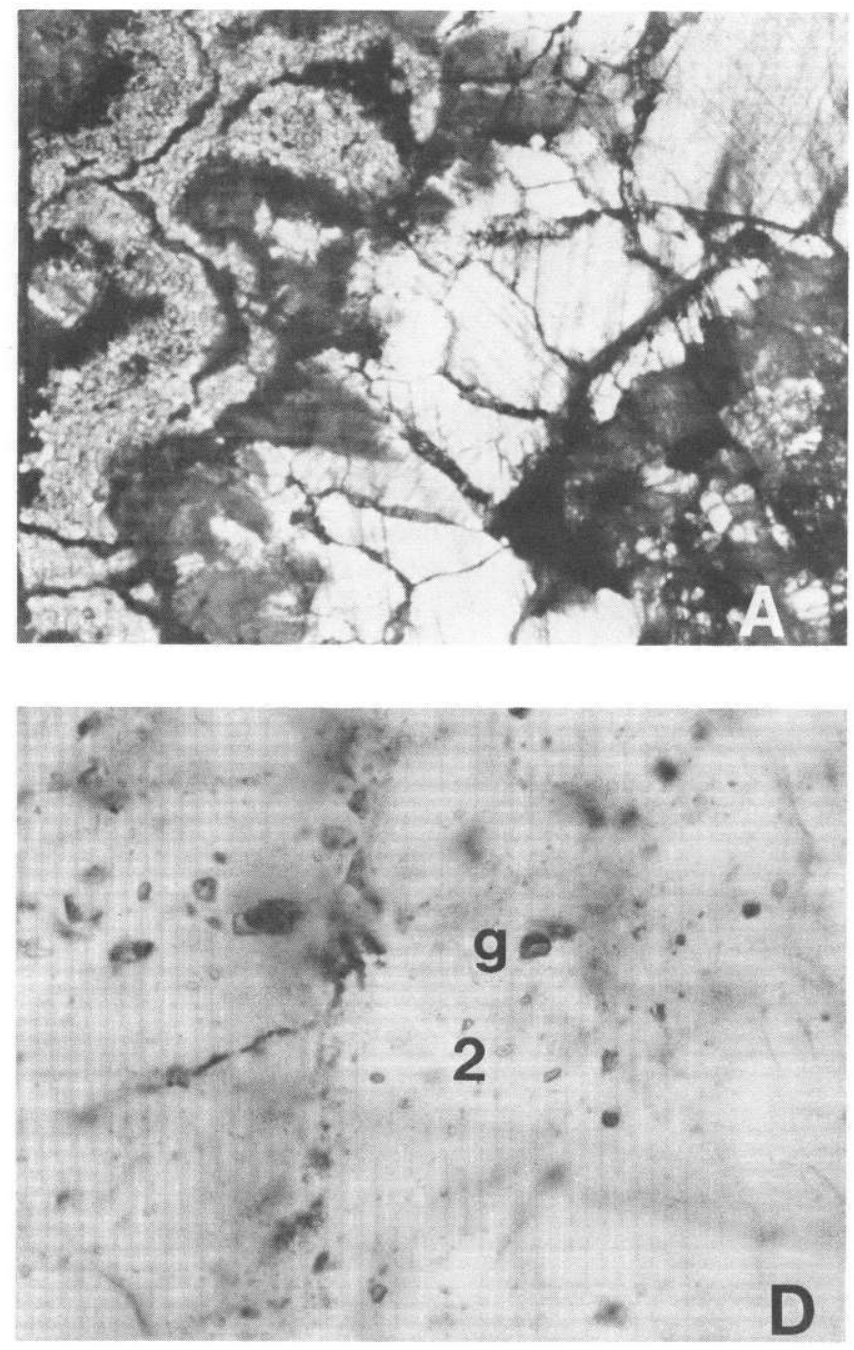

Figure 1. Photomicrographs of petroleum fluid inclusions in a calcite-bitumen vein in the Hampden Basalt, Hartford basin. $A$, Vein filling from margin (left side of photo) to center consists of fine-grained, botryoidal calcite followed by calcite spar intergrown with bitumen. Transmitted light, width of field is $8 \mathrm{~mm}$. $B$, Two generations of calcite cement with petroleum inclusions. Primary inclusions $(p)$ occur on growth zones parallel to euhedral crystal terminations coated with solid bitumen (b). Later calcite contains secondary petroleum inclusions (s) along healed microfractures. Transmitted light,

Hartford basin, is shown in figure 1. Typical margin to center vein filling is shown in figure $1 A$. The firstgeneration cement is fine-grained botryoidal calcite followed by coarse, sparry calcite that is intergrown with solid bitumen (left to right in fig. $1 A$ ). Petroleum inclusions are visible at higher magnification in figure $1 B$. Primary inclusions (labeled $\mathrm{p}$ ) occur along growth zones parallel to the euhedral crystal termination that is coated with bitumen (b). Secondary inclusions (s) occur along
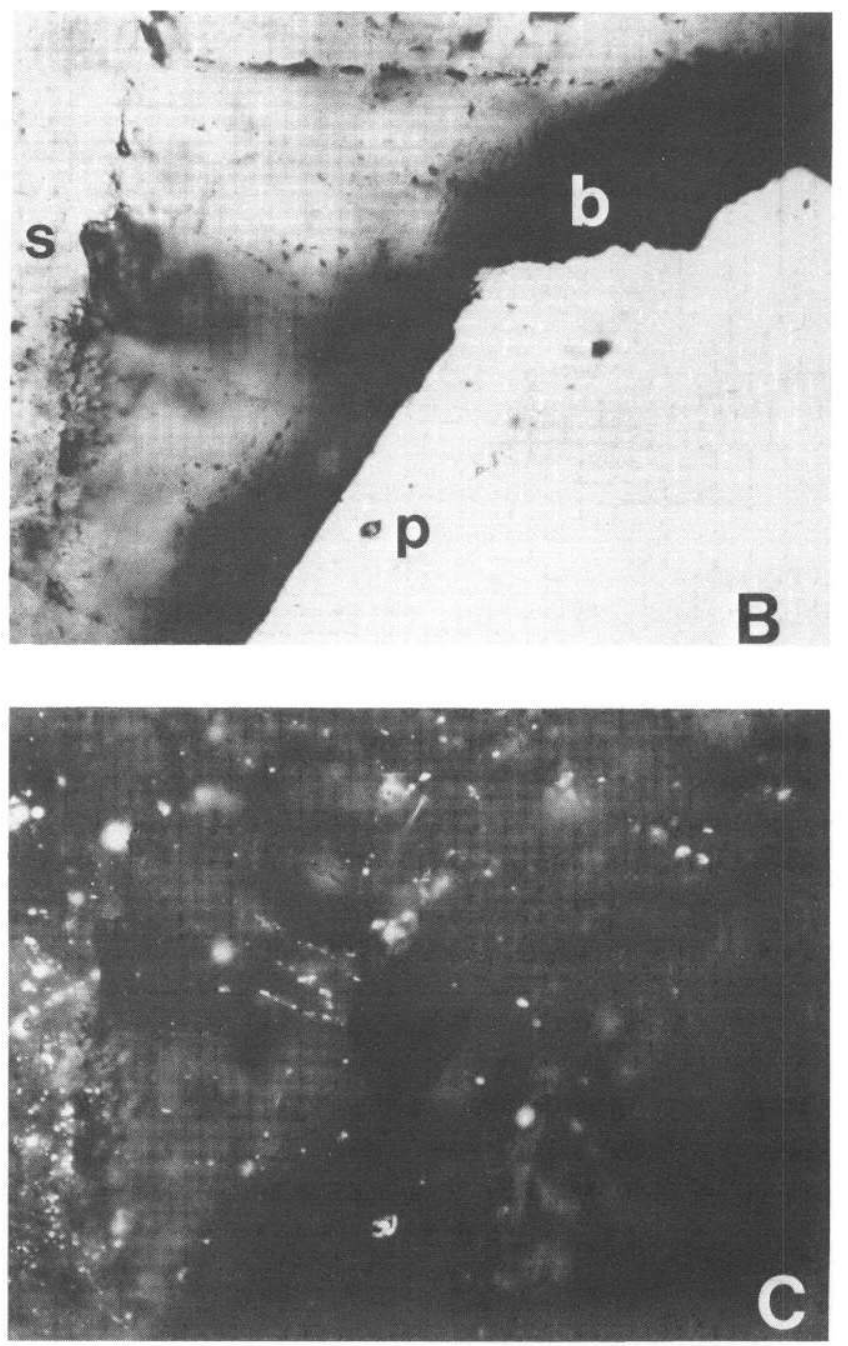

width of field is $0.6 \mathrm{~mm}$. $C$, Longwave, UV-excited fluorescence image of the same field of view as $B$. The petroleum inclusions occur as bright fluorescent spots on a dark background. Epifluorescence, width of field is $0.6 \mathrm{~mm}$. $D$, Occurrence of secondary inclusions with a wide range of liquid/ vapor ratios. Many dark, gas-rich inclusions (g) occur with typical two-phase, liquid-rich inclusions (2) that may be liquid water plus vapor, liquid petroleum plus vapor, or less commonly, three-phase, liquid water plus liquid petroleum plus vapor inclusions. Transmitted light, width of field is $0.3 \mathrm{~mm}$. healed microfractures. The same field of view shown in figure $1 B$ is also shown in figure $1 C$ in longwave, UVexcited fluorescence in which the petroleum inclusions occur as bright spots on a dark, nonfluorescent background. The petroleum inclusions occur as both primary and secondary inclusions. Both occurrences are important because the primary inclusions were trapped during mineral growth, whereas the secondary inclusions were trapped later, during fracturing events that occurred 
after calcite precipitation. This suggests that petroleum migrated through fractures over a considerable interval of geologic time.

Other occurrences of fluid inclusions may be directly related to oil generation and preservation. Several samples from the Hartford basin contain petroleum inclusions and these samples span the range of thermal maturity for oil generation and preservation as indicated by pyrolysis response and vitrinite reflectance. The least thermally mature sample in this set is an organic-matterrich siltstone containing thin microfractures filled with calcite. The organic matter in the siltstone is fluorescent under UV light, and fluorescent petroleum inclusions occur in fracture-filling calcite, silt-size diagenetic carbonate grains, and quartz overgrowths. The most thermally mature sample contains calcite-filled fractures in (1) fibrous calcite veins parallel to slaty cleavage and (2) euhedral calcite in fractures crosscutting cleavage. Petroleum inclusions are limited to euhedral type 2 calcite, suggesting that oil migrated after pervasive deformation at this locality.

The only occurrence of petroleum inclusions from the Newark basin that was examined is in concretionary carbonates in the Feltville Formation. Samples consist of alternating carbonate-rich and organic-matter-rich layers 1 to $3 \mathrm{~cm}$ in thickness. The carbonate-rich layers contain small tension fractures that terminate at the organicmatter-rich layers. The edges of these fractures are rimmed with calcite, but the centers are incompletely cemented, forming microvugs that bleed oil on freshly broken surfaces. The calcite contains fluorescent, one phase, liquid petroleum inclusions. Typical petroleum inclusions contain two phases at room temperature. These one-phase liquid inclusions may indicate relatively low temperatures of trapping of the fluid.

\section{HOMOGENIZATION TEMPERATURES OF FLUID INCLUSIONS}

Homogenization temperature measurements on about 12 inclusions from a mineralized vein in the Hampden Basalt are consistent with our observations of the regional levels of thermal maturity in the Hartfordbasin (Pratt and others, this volume). Primary petroleum inclusions homogenize to liquid at $65^{\circ}$ to $74^{\circ} \mathrm{C}$, whereas later, secondary petroleum inclusions homogenize at $85^{\circ}$ to $112^{\circ} \mathrm{C}$, with coexisting aqueous inclusions homogenizing in the range $113^{\circ}$ to $118^{\circ} \mathrm{C}$. These are minimum temperatures of formation and may require correction, due to overburden pressure, of $+10^{\circ}$ to $+25^{\circ} \mathrm{C}$ above the homogenization temperature (Narr and Burruss, 1984). Temperatures of the secondary inclusions may not require a significant correction because these inclusions occur with gas-rich and liquid-rich inclusions (figure $1 D$ ), suggesting that the inclusions were trapped from a heterogeneous, gas-saturated fluid.

\section{CHARACTERIZATION OF BITUMEN}

We studied 31 samples of sedimentary rocks and mineralized veins by using GC and GCMS of the saturated hydrocarbon fraction. Of these, 17 samples are dark-gray to black lacustrine shales that contain greater than 1 percent organic carbon. These lacustrine shales yield 400 to $5,700 \mathrm{ppm}$ extractable organic matter (bitumen). The shales inferred from pyrolysis response and vitrinite reflectance to be at optimal levels of thermal maturation for petroleum generation yield an average (10 samples) of $2,400 \mathrm{ppm}$ bitumen. The average organic-carbon content of these 10 shales is 3.3 percent, and the bitumen yield divided by the organic-carbon content gives an average value of 7.3 percent, which is typical of good to excellent petroleum source rocks (Hunt, 1979).

Representative GC profiles of the saturated hydrocarbons extracted from rock and vein samples of the Hartford and Newark basins are shown in figure 2. The pair of chromatograms on the left illustrate the differences between an immature shale (Towaco Formation) and a mature shale (Feltville Formation) from the Newark basin. Compared to the distribution of compounds in the mature shale, extracts from immature shales in the Hartford and Newark basins are characterized by high relative abundance of the acyclic regular isoprenoids (i-15, i-16, i-18, pristane, phytane, i-21) and highmolecular-weight branched and cyclic compounds such as b-carotane. The pair of chromatograms on the right illustrate the closely matching distribution of compounds in a mature shale (East Berlin Formation) and a bitumen-calcite vein filling (Hampden Basalt) from the Hartford basin. The distinctive chemical fingerprint of the acyclic isoprenoids is strong evidence of a productprecursor relationship between these samples.

\section{CONCLUSIONS}

Field evidence and fluid-inclusion studies indicate that petroleum and aqueous fluids repeatedly migrated through fracture networks during deformation of the Hartford and Newark basins. Zoned veins, formed by multiple phases of calcite and bitumen precipitation, as well as petroleum in fluid inclusions, provide a record of these migration events. Homogenization temperatures of petroleum inclusions indicate temperatures during migration near $100{ }^{\circ} \mathrm{C}$ and are consistent with levels of thermal maturation inferred from organic maturation indices. The distribution of saturated hydrocarbons is remarkably similar for extracts from lacustrine shale, 


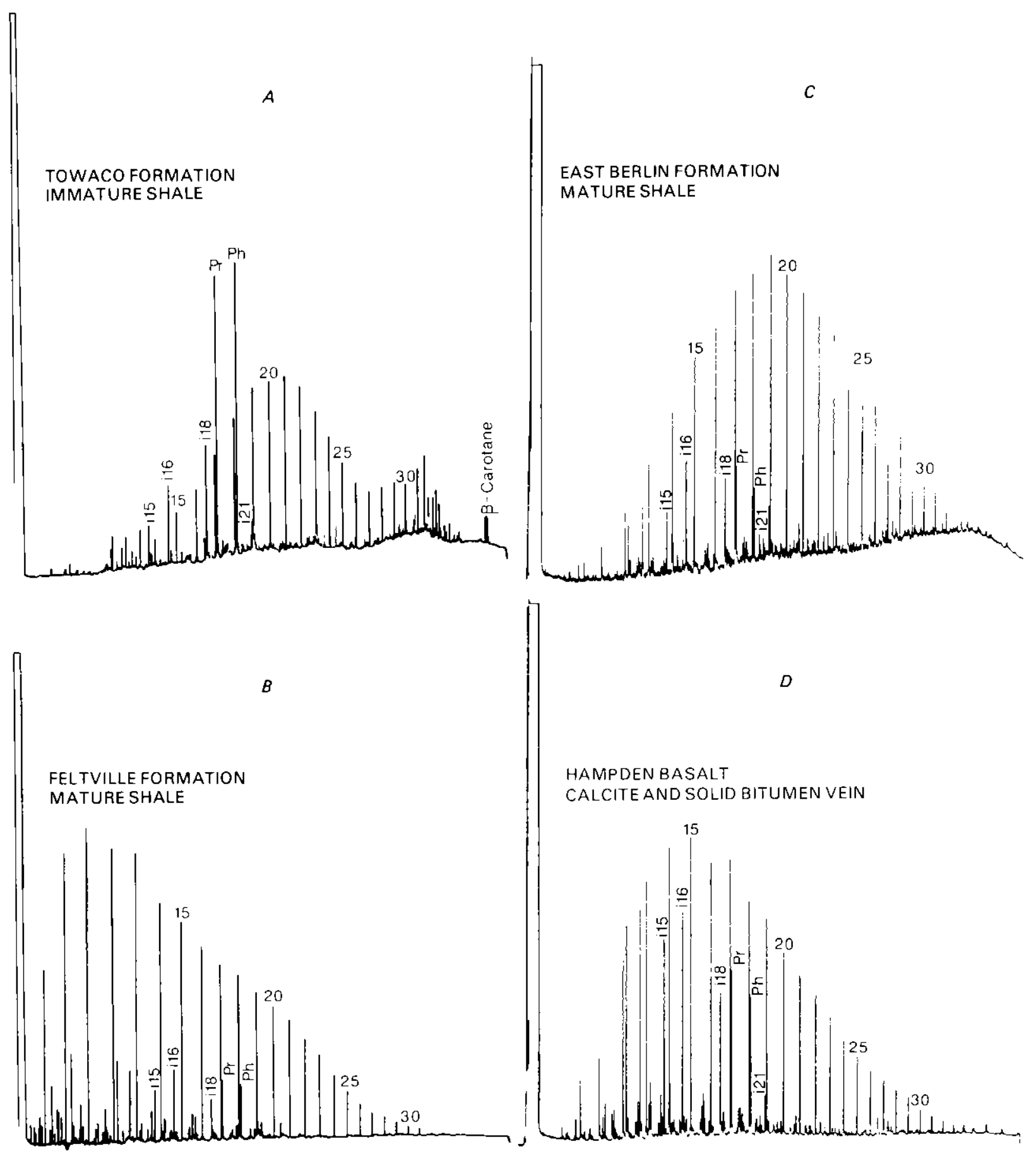

Figure 2. Four capillary column gas chromatograms of the saturated hydrocarbon fraction of rock extracts from the Newark ( $A$ and $B)$ and Hartford ( $C$ and $D$ ) basins (see text for discussion).

solid bitumen in veins and fractures, and viscous petroleum in concretions. We infer that the organic-matterrich lacustrine shales and siltstones in these basins were effective petroleum source rocks. However, the occurrence of economic quantities of petroleum may be strongly limited by erosion of potential reservoirs and lack of porous and permeable sandstones.

\section{REFERENCES CITED}

Burruss, R.C., 1981, Hydrocarbon fluid inclusions in studies of sedimentary diagenesis, Chapter 6, in Hollister, L.S., and Crawford, M.L., eds., Fluid inclusions: Applications to petrology: Mineralogical Association of Canada, Short Course Notes, v. 6, p. 138-156, Calgary. 
Burruss, R.C., Cercone, K.R., and Harris, P.M., 1985, Timing of hydrocarbon migration: Evidence from fluid inclusions in calcite cements, tectonics and burial history, in Harris, P.M., and Schneidermann, N.M., eds., Carbonate cements revisited: Society of Economic Paleontologists and Mineralogists, Special Publication Number 36, p. 277-289.

Hubert, J.F., and Reed, A.A., 1978, Red-bed diagenesis in the East Berlin Formation, Newark Group, Connecticut Valley: Journal of Sedimentary Petrology, v. 48, p. 175-184.

Hunt, J.M., 1979, Petroleum Geochemistry and Geology: W.H. Freeman and Company, San Francisco, $617 \mathrm{p}$.

Narr, W.M., and Burruss, R.C., 1984, Origin of reservoir fractures in Little Knife Field, North Dakota: American Association of Petroleum Geologists Bulletin, v. 68, p. 1087-1100.
Olsen, P.E., 1984, Comparative paleolimnology of the Newark Supergroup-A study of ecosystem evolution: New Haven, Connecticut, Yale University, unpublished Ph.D. dissertation, $726 \mathrm{p}$.

Pratt, L.M., Claypool, G.E., and King, J.D., 1986a, Geochemical imprint of depositional conditions on organic matter in laminated-bioturbated interbeds from fine-grained marine sequences: Marine Geology, v. 70, p. 67-84.

Pratt, L.M., Vuletich, A.K., and Shaw, C.A., 1986b, Preliminary results of organic geochemical and stable isotope analyses of Newark Supergroup rocks in the Hartford and Newark basins, Eastern U.S.: U.S. Geological Survey Open-Fjle Report 86-284, 29 p.

\title{
INORGANIC GEOCHEMISTRY OF FINE-GRAINED SEDIMENTARY ROCKS AND HORNFELS IN THE NEWARK SUPERGROUP
}

\author{
Walter E. Dean
}

\begin{abstract}
Fine-grained, organic-carbon-rich sedimentary rocks (black shales) are commonly enriched in certain trace metals, particularty if the organic matter in these rocks is hydrogen rich (sapropelic). Most samples of black and dark-gray shales and hornfels from the Newark Supergroup, however, are not enriched in metals. In general, the Newark rocks do not show correlations between contents or organic matter and any metals, but there are many significant correlations between trace-element concentrations and concentrations of iron and aluminum. This relation implies that the trace metals are associated with the inorganic clay fraction and not the organic fraction. The concentration of copper has the greatest variability of any trace metal in Newark rocks. Highest concentrations of copper (to 2,800 ppm) were measured in samples of dark-gray shale containing solid bitumen from the Passaic Formation in the Newark basin. Q-mode factor analyses of sample sets from the Newark and Hartford basins show distinctive detrital, carbonate, and organic associations of major and trace elements.
\end{abstract}

\section{INTRODUCTION}

Inorganic geochemical analyses (major, minor, and trace element) were obtained on five groups of samples of fine-grained sedimentary rocks (mostly black or darkgray shales) and thermally metamorphosed sedimentary rocks (hornfels) in order to characterize the baseline geochemistry of organic-carbon-rich rocks of the Newark Supergroup and to identify anomalous concentrations of any elements. The organic matter in two sample sets also was characterized in order to determine if there were any relations between organic matter and metal concentrations that might be used to predict locations of metal-rich deposits.

Sample set 1 consisted of nine samples of hornfels from the Culpeper basin (Virginia). Sample set 2 consisted of 11 samples of dark-gray shales from the Culpeper (Virginia), Newark (New Jersey), and Deep River (North Carolina) basins. Sample set 3 consisted of 35 samples of calcareous black shales from the Lockatong Formation (Upper Triassic) from the southern Newark basin in Pennsylvania. Sample set 4 consisted of 18 samples of black and dark-gray calcareous shales from the Lockatong Formation in the southern Newark basin in Pennsylvania and New Jersey, and 5 samples of siltstone and shale from the Towaco Formation (Lower Jurassic) from the northern Newark basin. Sample set 5 consisted of 11 samples of black shale and chert from the Passaic and Towaco Formations (Upper Triassic and Lower Jurassic) in the central and northern Newark basin of New Jersey, and 14 samples of black shale, chert, and coalified plant remains from the East Berlin and Portland Formations (both Lower Jurassic) in the Hartford basin of Connecticut and Massachusetts. 
The organic matter in the latter two sample sets from the Newark and Hartford basins was characterized by Rock-Eval pyrolysis and stable carbon-isotope composition. Results of these analyses and descriptions of the samples are given in Pratt and others (1986). Samples from the Lockatong Formation in the southern Newark basin were all thermally altered and had no or low hydrocarbon yields by pyrolysis. All samples from the Passaic, Towaco, East Berlin, and Portland Formations had significant hydrocarbon yield and could be characterized by hydrogen and oxygen contents and temperature of maximum hydrocarbon yield $\left(\mathrm{T}_{\max }\right)$ as determined by Rock-Eval pyrolysis. In fact, the samples in sample set 5 were selected from a larger sample set to cover the entire range of hydrogen richness and $T_{\max }$ values from Rock-Eval pyrolysis results (Pratt and others, 1986).

\section{METHODS}

Major elements in all sample sets except sample set 3 (Lockatong Formation, Pennsylvania) were determined by X-ray fluorescence. In sample set 1 , concentrations of $\mathrm{As}, \mathrm{B}, \mathrm{Ga}, \mathrm{Li}, \mathrm{Mo}, \mathrm{Pb}, \mathrm{Sr}$, and $\mathrm{V}$ were determined by optical emission spectroscopy; concentrations of $\mathrm{Ba}, \mathrm{Cr}$, and $\mathrm{La}$ were determined by neutron activation analysis; and concentrations of $\mathrm{Co}, \mathrm{Cu}$, and $\mathrm{Ni}$ were determined by atomic absorption spectrophotometry. In sample set 2 , concentrations of $\mathrm{Co}, \mathrm{Cu}$, and $\mathrm{Ni}$ were determined by optical emission spectroscopy; concentrations of $\mathrm{Ba}, \mathrm{Cr}, \mathrm{La}$, and $\mathrm{Zn}$ were determined by neutron activation analysis; and concentrations of $\mathrm{B}$ were determined by colorimetry. Concentrations of all trace elements in sample sets 4 and 5 were determined by inductively coupled argon-plasma emission spectrometry. Major and trace elements in samples from data set 3 (Lockatong Formation, Pennsylvania) were determined by semiquantitative optical emission spectroscopy. The major-element concentrations, however, were refined by normalizing element concentrations using the results of quantitative $\mathrm{X}$-ray diffraction mineralogy obtained from the same samples.

\section{RESULTS}

Minimum, maximum, and average concentrations of 10 major-element oxides and 15 trace elements in each of the sample sets are shown in figure 1 . The average concentrations of major-element oxides and trace elements are also given in table 1 along with average concentrations in basalt, crust, shale, Devonian black shale, and black shale. To facilitate comparison of concentrations of some of the trace transition elements commonly reported as being high in organic-carbon-rich
(OC-rich) sediments and rocks, the ranges and mean concentrations of $\mathrm{Cu}, \mathrm{Co}, \mathrm{Ni}, \mathrm{Cr}, \mathrm{V}$, and $\mathrm{Zn}$ are plotted as histograms in figure 2. For purposes of comparison, the most important averages in table 1 and figure 2 are those for average black shale and "metal-rich" black shale. Two average black shales are shown. First is the average black shale of Vine and Tourtelot $(1969,1970)$, in which concentrations are given as the median of medians of 20 sets of black shale samples. The second is average Upper Devonian black shale, in which concentrations are given as the arithmetic means of concentrations in up to 400 samples as reported by Leventhal and colleagues (Leventhal, 1980; Leventhal and others, 1981 and 1984; Leventhal and Hosterman, 1982). The concentration of each element considered by Vine and Tourtelot (1970) as the lower limit of metal-rich black shales also is shown in figure 2 . This value is the 90 th percentile of concentrations in black-shale samples from their 20 data sets.

\section{DISCUSSION}

\section{Metal Enrichment}

Concentrations of $\mathrm{Cu}$ as well as other trace transition elements, particularly $\mathrm{Ni}, \mathrm{V}$, and $\mathrm{Zn}$, commonly are high in rocks rich in organic carbon (OC) (see review by Eugster, 1985), and analyses of OC-rich shales often show a correlation between concentrations of some trace transition elements and both amount and hydrogen richness of organic matter. Holland (1984) stated that enrichment of trace elements in carbonaceous shales was roughly proportional to the OC content. Eugster (1985), on the other hand, pointed out that of the 20 data sets of black shale used by Vine and Tourtelot $(1969,1970)$, only 6 were "metal enriched"; a high OC content, therefore, does not necessarily imply a high concentration of trace elements. Lewan and Maynard (1982) found that trace metals, especially $\mathrm{Cu}, \mathrm{V}$, and $\mathrm{Ni}$, are enriched only in hydrogen-rich organic matter, from which they concluded that lipid-rich (sapropelic) organic matter was the source of these metals. Further evidence for this conclusion is that most trace transition elements are not particularly enriched in freshwater, nonalgal coals (Gluskoter, 1977; Hatch, 1983) but commonly are extremely enriched in marine black shales (Desborough and Poole, 1983).

Although the association of high concentrations of trace transition metals with organic matter, particularly marine organic matter, is well known, the actual cause of this relation is not known. There are at least three types of interactions between organic matter and trace metals, and all probably are important in the observed associations of high metal concentrations in black shales. First, 

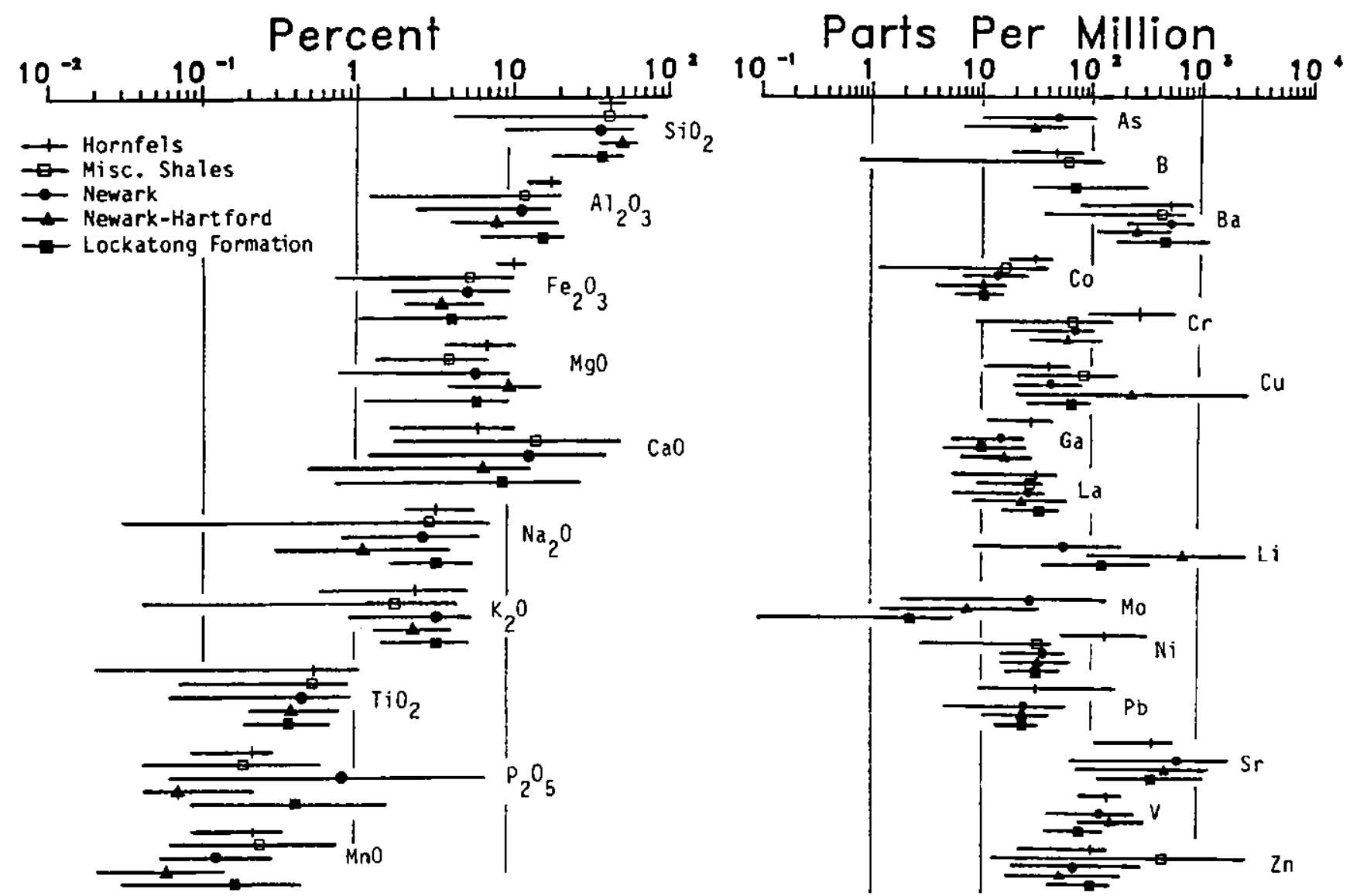

Figure 1. Comparison of concentrations of major-element oxides and trace elements in samples of hornfels from the Culpeper basin, Virginia (hornfels); black and dark-gray shales from the Culpeper, Newark, and Deep River basins (misc. shales); black and dark-gray shales from the Lockatong and Towaco Formations from the Newark basin (Newark); black shale from the Passaic and Towaco Forma-

marine plankton are known to concentrate trace elements, especially $\mathrm{Ba}, \mathrm{Pb}, \mathrm{Cu}, \mathrm{Ni}, \mathrm{V}, \mathrm{Zn}, \mathrm{Mn}$, and $\mathrm{Fe}$ (Goldberg, 1957; Boyle and Lynch, 1968; Knauer and Martin, 1973; Martin and Nauer, 1973; Bostrom and others, 1974; Chester and others, 1978; Moore and Bostrom, 1978; Leinen and Stakes, 1979; Collier and Edmond, 1984), and Dean and Greeson (1979) have shown that freshwater plankton also concentrate trace metals, especially $\mathrm{Mn}, \mathrm{Fe}, \mathrm{B}, \mathrm{Ba}, \mathrm{Cu}, \mathrm{Ni}$, and $\mathrm{Sr}$. Concentration by organisms is, therefore, a potentially important mechanism for incorporation of certain trace metals in OC-rich sediments. Studies of the factors controlling enrichment of $\mathrm{V}$ and $\mathrm{Ni}$ in OC-rich strata by Lewan and Maynard (1982) showed that high concentrations of these two elements only occur in bitumens associated with hydrogen-rich kerogen, and under conditions of rapid burial of the organic matter. Second, the great effectiveness of adsorption of trace elements by organic matter suggests that this process also may play an

tions of the Newark basin and East Berlin and Portland Formations of the Hartford basin (Newark-Hartford); and black calcareous shales from the Lockatong Formation from the southern Newark basin (Lockatong Formation). Bars indicate total range of concentration; symbols are plotted on the arithmetic mean concentration for each oxide or element.

important role in removal of trace elements from the water column (Tourtelot, 1964; Brongersma-Sanders, 1965; Brewer and Spencer, 1974; Volkov and Fomina, 1974; Holland, 1979; Balistrieri and others, 1981; Balistrieri and Murray, 1984; Jacobs and others, 1985). Holland (1984) suggested that scavenging from seawater alone can account for most enrichments of metals in Precambrian and Phanerozoic carbonaceous shales. The final accumulation of metals in the sediments is controlled by diagenetic release of adsorbed trace metals under anoxic conditions within the sediments and precipitation of these metals as sulfide minerals (see review by Eugster, 1985).

Table 1 and figure 2 show that most of the samples are not particularly "metal rich." The hornfels samples from the Culpeper basin are enriched in $\mathrm{Cr}$ and $\mathrm{Ni}$ relative to most other materials. The high average $\mathrm{Zn}$ concentration in the miscellaneous eastern Mesozoic basin (EMB) suite (sample set 2) is due to a few samples 
Table 1. Chemical compositions of average basaltic crust, average upper continental crust, average shale, average black shale, and averages of samples of sedimentary rocks and hornfels from the Newark Supergroup

[See footnotes for identification of sample groups; oxides in percent; elements in parts per million; - , no analyses available]

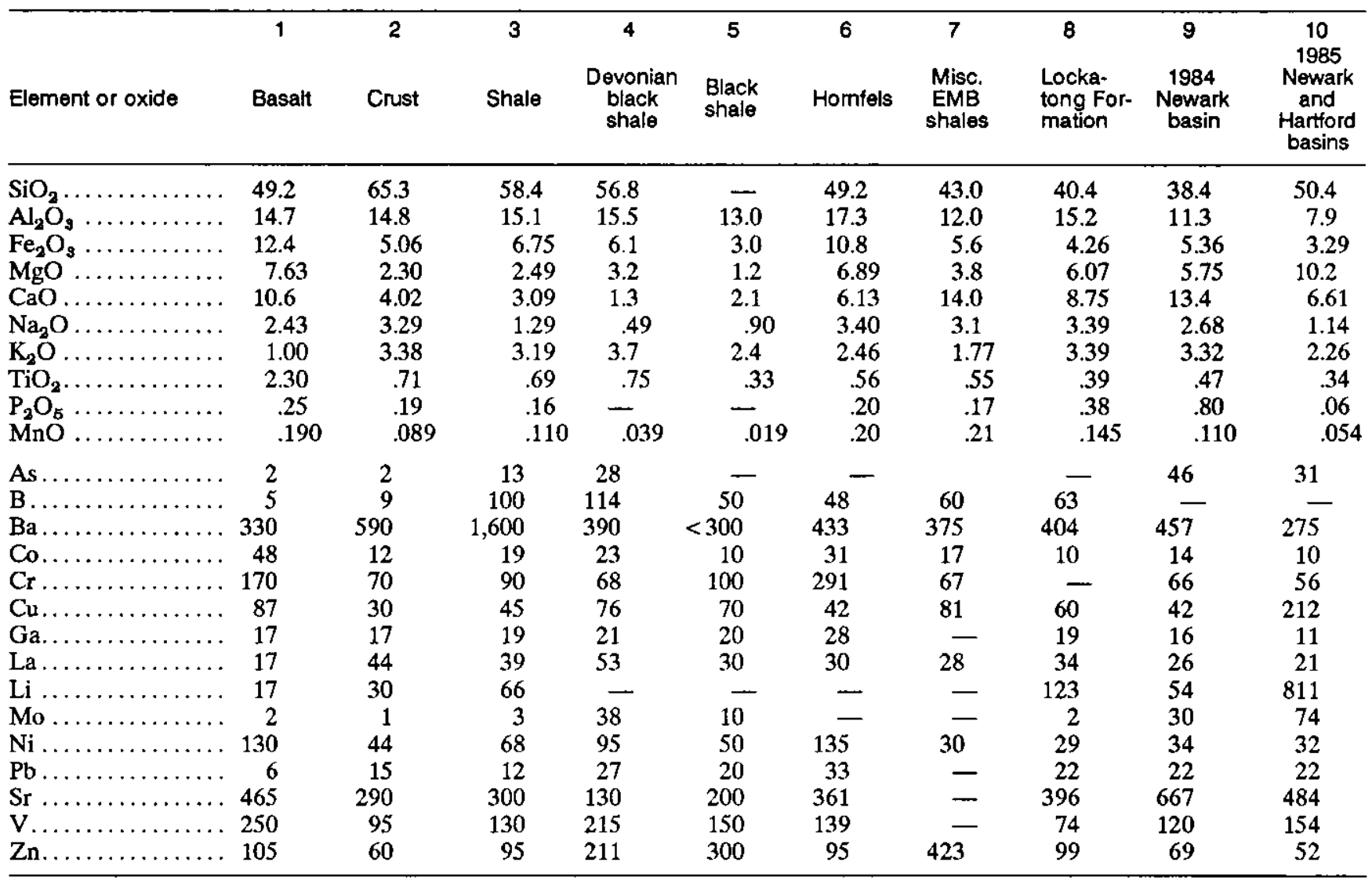

Sample identification by column number:

1. Average basaltic crust (Turekian, 1972).

2. Average upper continental crust (Wedepohl, 1971).

3. Average shale (Turekian, 1972).

4. Average Upper Devonian black shale, Appalachian Basin, Eastern United States (data of Leventhal, 1980; Leventhal and others, 1981; Leventhal and Hosterman, 1982; and Leventhal and others, 1984).

5. Average black shale (median of 20 data sets, Vine and Tourtelot, 1970).

6. Average of nine hornfels samples from the Culpeper basin (A.J. Froelich, unpublished data).

7. Average of 11 samples of black and dark-gray shales from the Culpeper, Gettysburg, Danville, Dan River, and Durham basins (A.J. Froelich, unpublished data).

8. Average of $\mathbf{3 5}$ samples of black calcareous shale in the Lockatong Formation from two localities in the southern Newark basin, southeastem Pennsylvania (G.R. Robinson, unpublished data).

9. Average of 23 samples of black and dark-gray fine-grained sedimentary rocks in the Lockatong and Towaco Formations from the Newark basin, Pennsylvania and New Jersey.

10. Average of 20 samples of black shale from the Passaic and Towaco Formations from the northern Newark basin, New Jersey.

of black shale from the Culpeper basin. Two samples of black shale from the "Midland fish beds" contained 428 and $373 \mathrm{ppm} \mathrm{Zn}$. One sample of black shale from the Culpeper Crushed Stone quarry, Stevensville, Virginia, contained $2,750 \mathrm{ppm} \mathrm{Zn}$. A sample of hornfels from the same quarry (not included in the statistics for data set 2) contained 5,250 ppm $\mathrm{Zn}$.

Copper appears to have the greatest variability, particularly in the Newark basin. This is not too surpris- ing because sediment-hosted stratabound copper sulfide mineralization is widespread in eastern Mesozoic basins (Robinson, 1985), although the source of the copper is not known. Two samples of dark-gray shale from the Passaic Formation in New Jersey contain 750 and 2,800 ppm copper. Both of these samples were taken from shale outcrops that have bitumen in fractures. A sample of coalified plant stems in a copper-mineralized sandstone in the East Berlin Formation in Connecticut con- 

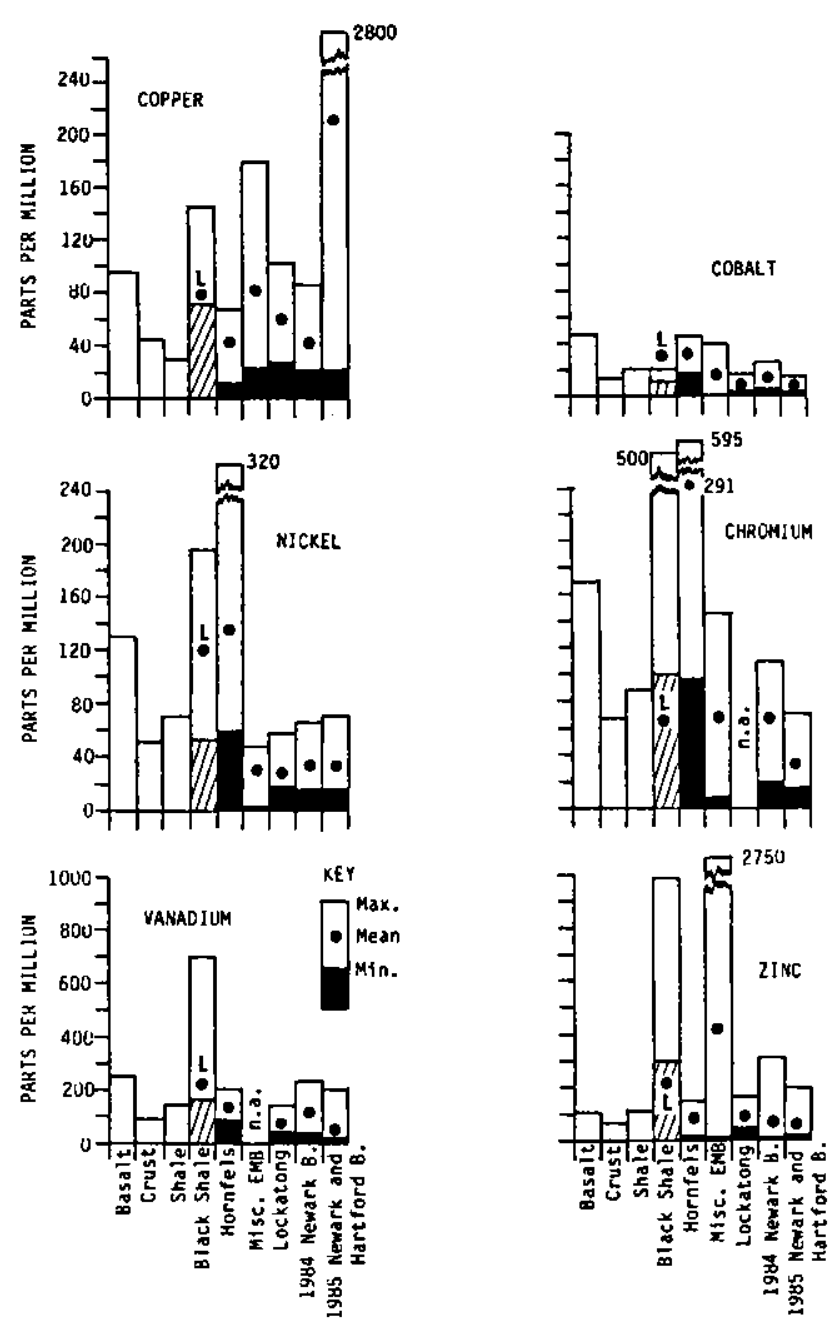

Figure 2. Histograms of average concentrations of copper, cobalt, nickel, chromium, vanadium, and zinc in selected groups of samples. Basalt: average basaltic crust (Turekian, 1972). Crust: average upper continental crust (Wedepohl, 1971). Shale: average shale (Turekian, 1972). Black shale: lower bar (diagonally ruled) is the median of medians of 20 data sets of black shale samples (Nine and Tourtelot, 1970); upper bar (white) is the 90th percentile of the Vine and Tourtelot (1969 and 1970) samples, a value they consider as the lower limit of metal-rich shales; point marked $L$ is the arithmetic mean of up to 400 samples of Upper Devonian black shales from the Appalachian Basin reported by Leventhal and colleagues (Leventhal, 1980; Leventhal and others, 1981, 1984; Leventhal and Hosterman, 1982). For the next five histograms, the lower bar (black) is the minimum, the upper bar (white) is the maximum, and the dot is the arithmetic mean concentration in each data set. Misc. EMB: miscellaneous black and dark-gray shales from the Culpeper, Newark, and Deep River basins. Lockatong: black and dark-gray calcareous shales from the Lockatong Formation, Newark basin, southeastern Pennsylvania. 1984 Newark B.: samples of black and dark-gray shale collected in 1984 from the Lockatong and Towaco Formations in the Newark basin. 1985 Newark and Hartford B.: samples of black shale collected in 1985 from the Passaic and Towaco Formations in the northern Newark basin and East Berlin and Portland Formations in the Hartford basin. tained a $\mathrm{Cu}$ concentration that was well above the upper limits of detection by inductively coupled plasma spectrometry and was semiquantitatively estimated to be about 56 percent $\mathrm{Cu}$. Lee and Froelich (1985) reported concentrations of $\mathrm{Cu}$ as high as 650 and $340 \mathrm{ppm}$ in fine-grained sedimentary rocks and hornfels, respectively, from the northern Culpeper basin, but the average $\mathrm{Cu}$ concentration in their samples is less than $100 \mathrm{ppm}$.

Because of the commonly observed association of trace transition metals with $O C$-rich shales, I anticipated that the OC-rich rocks of the Newark Supergroup might show correlations among concentrations of trace elements and amount of organic matter (percent $O C$ ) and hydrogen richness of that organic matter as indicated by the hydrogen index (HI) measured by Rock-Eval pyrolysis (Pratt and others, 1986). Within a relatively constant depositional system, black shales with hydrogenrich organic matter usually have a strong positive correlation between percent OC and HI (Dean and others, 1986). This implies that rocks with higher concentrations of organic matter tend to be more hydrogen rich, or, to put it another way, that increases in OC above about 1 percent are due to enhanced preservation of hydrogenrich (sapropelic) organic matter. Unfortunately, I only had usable pyrolysis results for the 1985 Newark and Hartford basin samples (sample set 5), but had data on percent $\mathrm{OC}$ for several of the data sets. Correlation coefficients between $\mathrm{Al}_{2} \mathrm{O}_{3}, \mathrm{Fe}_{2} \mathrm{O}_{3}$, total sulfur, $\mathrm{OC}, \mathrm{HI}$, and several trace transition elements for the 1985 Newark and Hartford basin samples, 1984 Newark basin samples, and Lockatong samples are given in table 2 . Table 2 shows that, in general, there are few significant correlations between trace-element concentrations and percent $\mathrm{OC}$, although many correlations are significant among trace elements and between trace elements and $\mathrm{Al}_{2} \mathrm{O}_{3}$ and $\mathrm{Fe}_{2} \mathrm{O}_{3}$. The implication of these relations is that the trace elements tend to be associated with the inorganic clay fraction and not with the organic fraction. Kulick and others (1984) also found little correlation between concentrations of organic carbon and trace transition elements, except for vanadium, in the Kupferschiefer. As pointed out by Eugster (1985), however, metal sulfide enrichment in the Kupferschiefer could not have occurred in the absence of organic matter.

\section{Metal Associations}

To examine relations among geochemical variables and attempt to isolate distinctive groups of samples based on their geochemistry, I ran Q-mode factor analyses on three sample sets by using the extended CABFAC program described by Klovan and Miesch (1976). The analyses revealed a "detrital" association of elements (usually $\mathrm{Si}, \mathrm{Al}, \mathrm{Fe}, \mathrm{Ti}, \mathrm{K}, \mathrm{Na}$, and many trace elements) 
Table 2. Matrices of correlation coefficients between concentrations of $\mathrm{Al}_{2} \mathrm{O}_{3}, \mathrm{Fe}_{2} \mathrm{O}_{3}$, organic carbon (OC), total sulfur (T-S), Rock-Eval hydrogen index $(\mathrm{HI})$, and selected trace elements of three sets of samples of the Newark Supergroup, Newark and Hartford basins

\begin{tabular}{|c|c|c|c|c|c|c|c|c|c|c|c|c|}
\hline \multicolumn{13}{|c|}{1985 Newark and Hartford basin samples } \\
\hline & $\mathrm{Al}_{2} \mathrm{O}_{3}$ & $\mathrm{Fe}_{2} \mathrm{O}_{3}$ & T-S & OC & $\mathrm{HI}$ & $\mathrm{Cr}$ & $\mathrm{Cu}$ & $\mathrm{Ni}$ & V & Y & $\mathrm{Zn}$ & Mo \\
\hline $\begin{array}{l}\mathrm{Al}_{2} \mathrm{O}_{3} \\
\mathrm{Fe}_{2} \mathrm{O}_{3} \\
\mathrm{~T}-\mathrm{S} \\
\mathrm{OC} \\
\mathrm{HI} \\
\mathrm{Cr} \\
\mathrm{Cu} \\
\mathrm{Ni} \\
\mathrm{V} \\
\mathrm{Y} \\
\mathrm{Zn} \\
\mathrm{Mo}\end{array}$ & $\begin{array}{r}1.00 \\
.93 \\
.04 \\
-.24 \\
-.09 \\
.97 \\
.81 \\
.97 \\
.73 \\
.87 \\
.95 \\
.02\end{array}$ & $\begin{array}{r}0.93 \\
1.00 \\
.20 \\
-.13 \\
-.07 \\
.87 \\
.69 \\
.89 \\
.50 \\
.79 \\
.83 \\
.07\end{array}$ & $\begin{array}{r}0.04 \\
.20 \\
1.00 \\
-.24 \\
-.10 \\
-.06 \\
-.25 \\
-.04 \\
-.03 \\
-.09 \\
-.10 \\
.62\end{array}$ & $\begin{array}{r}-0.24 \\
-.13 \\
-.24 \\
1.00 \\
.49 \\
-.22 \\
-.14 \\
-.16 \\
-.46 \\
-.18 \\
-.21 \\
-.01\end{array}$ & $\begin{array}{r}-0.09 \\
-.07 \\
-.10 \\
.49 \\
1.00 \\
-.10 \\
-.32 \\
-.06 \\
-.13 \\
-.13 \\
-.16 \\
.11\end{array}$ & $\begin{array}{r}0.97 \\
.87 \\
-.06 \\
-.22 \\
-.10 \\
1.00 \\
.81 \\
.98 \\
.77 \\
.85 \\
.94 \\
-.06\end{array}$ & $\begin{array}{r}0.81 \\
.69 \\
-.25 \\
-.14 \\
-.32 \\
.81 \\
1.00 \\
.81 \\
.64 \\
.89 \\
.91 \\
-.12\end{array}$ & $\begin{array}{r}0.97 \\
.89 \\
-.04 \\
-.16 \\
-.06 \\
.98 \\
.81 \\
1.00 \\
.75 \\
.86 \\
.93 \\
-.04\end{array}$ & $\begin{array}{r}0.73 \\
.50 \\
-.03 \\
-.46 \\
-.13 \\
.77 \\
.64 \\
.75 \\
1.00 \\
.70 \\
.74 \\
.12\end{array}$ & $\begin{array}{r}0.87 \\
.79 \\
-.09 \\
-.18 \\
-.13 \\
.85 \\
.89 \\
.86 \\
.70 \\
1.00 \\
.88 \\
.00\end{array}$ & $\begin{array}{r}0.95 \\
.83 \\
-.10 \\
-.21 \\
-.16 \\
.94 \\
.91 \\
.93 \\
.74 \\
.88 \\
1.00 \\
-.08\end{array}$ & $\begin{array}{r}0.02 \\
.07 \\
.62 \\
-.01 \\
.11 \\
-.06 \\
-.12 \\
-.04 \\
.12 \\
.00 \\
-.08 \\
1.00\end{array}$ \\
\hline \multicolumn{13}{|c|}{1984 Newark basin samples } \\
\hline & $\mathrm{Al}_{2} \mathrm{O}_{3}$ & $\mathrm{Fe}_{2} \mathrm{O}_{3}$ & OC & $\mathrm{Cr}$ & $\mathrm{Cu}$ & $\mathrm{Ni}$ & v & $\mathrm{Zn}$ & & & & \\
\hline $\begin{array}{l}\mathrm{Al}_{2} \mathrm{O}_{3} \\
\mathrm{Fe}_{2} \mathrm{O}_{3} \\
\mathrm{OC} \\
\mathrm{Cr} \\
\mathrm{Cu} \\
\mathrm{V}\end{array}$ & $\begin{array}{r}1.00 \\
.72 \\
-.44 \\
.92 \\
.51 \\
.22\end{array}$ & $\begin{array}{r}0.72 \\
1.00 \\
-.44 \\
.64 \\
.44 \\
.29\end{array}$ & $\begin{array}{r}-0.44 \\
-.44 \\
1.00 \\
-.28 \\
.26 \\
-.20\end{array}$ & $\begin{array}{r}0.92 \\
.64 \\
-.28 \\
1.00 \\
.58 \\
.24\end{array}$ & $\begin{array}{r}0.51 \\
.44 \\
.26 \\
.58 \\
1.00 \\
.49\end{array}$ & $\begin{array}{r}0.80 \\
.76 \\
-.17 \\
.83 \\
.48 \\
.09\end{array}$ & $\begin{array}{r}0.22 \\
.29 \\
-.20 \\
.24 \\
.49 \\
1.00\end{array}$ & $\begin{array}{r}0.41 \\
.31 \\
-.31 \\
.36 \\
.01 \\
.05\end{array}$ & & & & \\
\hline \multicolumn{13}{|c|}{ Lockatong Formation, Pennsylvania } \\
\hline & $\mathrm{Al}_{2} \mathrm{O}_{3}$ & $\mathrm{Fe}_{2} \mathrm{O}_{3}$ & OC & $\mathrm{Cu}$ & V & $\mathrm{Ni}$ & $\mathrm{Zn}$ & & & & & \\
\hline $\begin{array}{l}\mathrm{Al}_{2} \mathrm{O}_{3} \\
\mathrm{Fe}_{2} \mathrm{O}_{3} \\
\mathrm{OC} \\
\mathrm{Cu} \\
\mathrm{V} \\
\mathrm{Ni} \\
\mathrm{Zn}\end{array}$ & $\begin{array}{r}1.00 \\
.83 \\
-.38 \\
.35 \\
.18 \\
.54 \\
-.42\end{array}$ & $\begin{array}{r}0.83 \\
1.00 \\
-.54 \\
.22 \\
.01 \\
.42 \\
-.37\end{array}$ & $\begin{array}{r}-0.38 \\
-.54 \\
1.00 \\
.35 \\
.66 \\
.15 \\
.25\end{array}$ & $\begin{array}{r}0.35 \\
.22 \\
.35 \\
1.00 \\
.40 \\
.33 \\
-.10\end{array}$ & $\begin{array}{r}0.18 \\
.01 \\
.66 \\
.40 \\
1.00 \\
.49 \\
.07\end{array}$ & $\begin{array}{r}0.54 \\
.42 \\
.15 \\
.33 \\
.49 \\
1.00 \\
-.28\end{array}$ & $\begin{array}{r}-0.42 \\
-.37 \\
.25 \\
-.10 \\
.07 \\
-.28 \\
1.00\end{array}$ & & & & & \\
\hline
\end{tabular}

and a carbonate association ( $\mathrm{Ca}$ and $\mathrm{Sr}$ ). In the Newark basin samples (sample set 4 ), $P, O C$, and Th also are included in the carbonate association, and a second carbonate association reflects the correlation between $\mathrm{Ca}$ and $\mathrm{Mg}$ in dolomitic mudstones. These Newark samples have, by far, the highest $P$ concentrations (fig. 1; table 1) which, together with the association of $\mathrm{P}$ with $\mathrm{Ca}$, suggests that they are richer in apatite. In the NewarkHartford basin samples (sample set 5), $\mathrm{P}$ is associated with the "detrital" fraction, and in the Lockatong samples from Pennsylvania (sample set 3 ) a separate association includes $\mathrm{P}, \mathrm{Sr}, \mathrm{V}, \mathrm{Y}$, and $\mathrm{Fe}(\mathrm{II})$. About half the variance in the Newark-Hartford data set is explained by a Li-Mg association. The high concentrations of $\mathrm{Mg}$ and $\mathrm{Li}$ (fig. 1; table 1) in the Newark-Hartford data confirm the observations by Gottfried and Chang (1986) that $\mathrm{Li}$ is correlated with $\mathrm{Mg}$ in $\mathrm{Mg}$-rich trioctahedral illite-smectite that is particularly abundant in the shales of the Hartford basin.

\section{CONCLUSIONS}

1. Most samples of hornfels and carbonaceous shales from the Newark Supergroup in the eastern Mesozoic basins are not particularly metal rich. A few samples from the Culpeper basin are enriched in $\mathrm{Zn}$, and several samples from the Culpeper, Newark, and Hartford basins are enriched in $\mathrm{Cu}$.

2. Trace metals in rocks of the Newark Supergroup are mostly associated with the inorganic clastic fraction and not with organic matter. Concentrations of some metals, particularly copper, tend to be highest in rocks that contain the highest concentrations of organic matter, but, in general, correlations between metals and organic matter are very weak. 


\section{REFERENCES CITED}

Balistrieri, L.S., and Murray, J.W., 1984, Marine scavenging: Trace metal adsorption by interfacial sediment from MANOP site H: Geochimica et Cosmochimica Acta, v. 48 , p. 921-929.

Balistrieri, L.S., Brewer, P.G., and Murray, J.W., 1981, Scavenging residence times of trace metals and surface chemistry of sinking particles in the deep ocean: Deep Sea Research, v. 28A, p. 101-121.

Bostrom, K., Joensuu, O., and Brohm, I., 1974, Plankton: Its composition and its significance as a source of pelagic sediments: Chemical Geology, v. 14, p. 255-271.

Boyle, R.W., and Lynch, J.J., 1968, Speculation on the source of zinc, cadmium, lead, copper, and sulfur in Mississippi Valley and similar types of lead-zinc deposits: Economic Geology, v. 63, p. 421-422.

Brewer, P.G., and Spencer, D.W., 1974, Distribution of some trace elements in Black Sea and their flux between dissolved and particulate phases, in Ross, D.A., and Degens, E.T., eds., The Black Sea-Geology, chemistry, and biology: Tulsa, American Association of Petroleum Geologists Memoir 20, p. 137-142.

Brongersma-Sanders, M., 1965, Metals in the Kupferschiefer supplied by normal seawater: Geologisches Rundschau, v. 55, p. $365-375$.

Chester, R., Griffiths, A., and Stoner, J.H., 1978, Minor metal contents of surface seawater particulates and organic-rich shelf sediments: Nature, v. 275, p. 308-309.

Collier, R., and Edmond, J., 1984, The trace element geochemistry of marine biogenic particulate matter: Progress in Oceanography, v. 13, p. 113-199.

Dean, W.E., and Greeson, P.E., 1979, Influences of algae on the formation of freshwater ferromanganese nodules, Oneida Lake, New York: Archive fir Hydrobiologie, v. 86, p. 181-192.

Dean, W.E., Arthur, M.A., and Claypool, G.E., 1986, Depletion of ${ }^{19} \mathrm{C}$ in Cretaceous marine organic matter: Source, diagenetic, or environmental signal?: Marine Geology, v. 70 , p. 119-157.

Desborough, G.A., and Poole, F.G., 1983, Metal concentrations in some marine black shales of the United States, in Shanks, W.C., III, ed., Cameron volume on unconventional mineral deposits: New York, Society of Mining Engineers, p. 99-110.

Eugster, H.P., 1985, Oil shales, evaporites, and ore deposits: Geochimica et Cosmochimica Acta, v. 49, p. 619-635.

Gluskoter, H.J., 1977, Trace elements in coals: Occurrence and distribution: Illinois State Geological Survey Circular 499, $154 \mathrm{p}$.

Goldberg, E.D., 1957, Biogeochemistry of trace metals, in Hedgepeth, J.W., ed., Treatise on marine ecology and paleoecology, Volume 1, Ecology: Geological Society of America Memoir 67, p. 345-357.

Gottfried, R., and Chang, L.Y., 1986, Clay mineralogy of selected eastern Mesozoic basins: Geological Society of America Abstracts with Programs, v. 18, p. 20.

Hatch, J.R., 1983, Geochemical processes that control minor and trace element composition of United States coals, in
Shanks, W.C., III, ed., Cameron volume on unconventional mineral deposits: New York, Society of Mining Engineers, p. 89-98.

Holland, H.D., 1979, Metals in black shales-A reassessment: Economic Geology, v. 74, p. 1676-1680.

1984, The Chemical evolution of the atmosphere and oceans: Princeton University Press, 582 p.

Jacobs, L., Enerson, S., and Skei, J., 1985, Partitioning and transport of metals across the $\mathrm{O}_{2} / \mathrm{H}_{2} \mathrm{~S}$ interface in a permanently anoxic basin: Framcaren Fjord, Norway: Geochimica et Cosmochimica Acta, v. 49, p. 1433-1444.

Klovan, J.E., and Miesch, A.T., 1976, Extended CABFAC QMODEL computer programs for Q-mode factor analysis of compositional data: Computers and Geosciences, v. 1, p. 161-178.

Knauer, G.A., and Martin, J.H., 1973, Seasonal variations in cadmium, copper, manganese, lead, and zinc in water and plankton in Monterey Bay, California: Limnology and Oceanography, v. 18, p. 597-604.

Kulick, J., Leifeld, D., Meisl, S., Poschl, W., Stellmacher, R., Strecker, G., Theuerjahr, A., and Wolf, M., 1984, Petrofazielle und chemische Erkundung des Kupferschiefers der Hessischen Senke und des Harz-Westrandes: Geologisches Jahrbuch Reine, v. 68, 225 p.

Lee, K.Y., and Froelich, A.J., 1985, Geochemical data for Triassic sedimentary and thermally metamorphosed rocks of the northern Culpeper basin, Virginia: U.S. Geological Survey Open-File Report 85-217, 20 p.

Leinen, M., and Stakes, D., 1979, Metal accumulation rates in the central equatorial Pacific during Cenozoic time: Geological Society of America Bulletin, v. 90, p. 357-375.

Leventhal, J.S., 1980, Comparative geochemistry of Devonian shale cores from the Appalachian Basin, Mason, Monongalia, and Upshur Counties, West Virginia; Illinois basin, Tazewell County, Illinois and Clark County, Indiana; and Michigan basin, Sanilac County, Michigan: U.S. Geological Survey Open-File Report 80-938, 36 p.

Leventhal, J.S., Briggs, P.H., and Baker, J.W., 1984, Geochemistry of the Chattanooga Shale, DeKalb County, central Tennessee: Southeastern Geology, v. 24, p. 101-116.

Leventhal, J.S., Crock, J.R., and Malcolm, M.J., 1981, Geochemistry of trace elements and uranium in Devonian shales of the Appalachian Basin: U.S. Geological Survey OpenFile Report, 81-778, 80 p.

Leventhal, J.S., and Hosterman, J.W., 1982, Chemical and mineralogical analysis of Devonian black-shale samples from Martin County, Kentucky; Carroll and Washington Counties, Ohio; Wise County, Virginia; and Overton County, Tennessee, U.S.A.: Chemical Geology, v. 37, p. 239-264.

Lewan, M.D., and Maynard, J.B., 1982, Factors controlling enrichment of vanadium and nickel in the bitumen of organic sedimentary rocks: Geochimica et Cosmochimica Acta, v. 46, p. 2547-2560.

Martin, J.H., and Knauer, G.A., 1973, The elemental composition of plankton: Geochimica et Cosmochimica Acta, v. 37, p. 1639-1653.

Moore, C., and Bostrom, K., 1978, The elemental composition of lower marine organisms: Chemical Geology, v. 23, p. 1-9. 
Pratt, L.M., Vuletich, A.K., and Shaw, C.A., 1986, Preliminary results of organic geochemical and stable isotope analyses of Newark Supergroup rocks in the Hartford and Newark basins, eastern U.S.: U.S. Geological Survey Open File Report 86-284, 29 p.

Robinson, G.R., Jr., 1985, Ore deposit models and mineral resource studies in the early Mesozoic basins of the Eastern United States, in Robinson, G.R., Jr., and Froelich, A.J., eds., Proceedings of the second U.S. Geological Survey workshop on the early Mesozoic basins of the Eastern United States: U.S. Geological Survey Circular 946, p. $117-120$.

Tourtelot, H.A., 1964, Minor-element composition and organic carbon content of marine and nonmarine shales of Late Cretaceous age in the western interior of the United
States: Geochimica et Cosmochimica Acta, v. 28, p. 1579-1604.

Turekian, K.K., 1972, Chemistry of the Earth: New York, Holt, Rinehart, and Winston, $131 \mathrm{p}$.

Vine, J.D., and Tourtelot, E.B., 1969, Geochemical investigations of some black shales and associated rocks: U.S. Geological Survey Bulletin 1314-A, 43 p.

1970, Geochemistry of black shale deposits-A summary report: Economic Geology, v. 65, p. 253-272.

Volkov, I.I., and Fomina, L.S., 1974, Influences of organic materials and processes in deep-water sediments of the Black Sea, in Degens, E.T., and Ross, D.A., eds., The Black Sea-Geology, chemistry, and biology: American Association of Petroleum Geologists Memoir 20, p. $457-476$.

Wedepohl, K.H., 1971, Geochemistry: New York, Holt, Rinehart, and Winston, $231 \mathrm{p}$.

\title{
MINERAL-BOUND AMMONIUM IN BLACK SHALES OF THE TRIASSIC CUMNOCK FORMATION, DEEP RIVER BASIN, NORTH CAROLINA
}

\author{
M.D. Krohn, John Evans, and Gilpin R. Robinson, Jr.
}

\begin{abstract}
Significant ammonium $\left(\mathrm{NH}_{4}{ }^{+}\right)$concentrations are bound in minerals in the black shales of the Cumnock Formation of the Deep River basin (Sanford and Durham basins) in North Carolina. Near-infrared spectroscopy and ion chromatograph analyses for mineral-bound ammonium, supported by total rock analyses for nitrogen and semiquantitative X-ray mineral diffraction measurements, indicate a consistent pattern of distribution for inorganic ammonium. Illite is the most probable host mineral containing ammo. nium. High ammonia $\left(\mathrm{NH}_{3}\right)$ concentrations were known to be associated with organic-matter-rich intervals (informally known as blackband) above and below coal beds in the Cumnock Formation. Ion chromatograph measurements, however, show the highest concentrations of mineral-bound ammonium in illite-rich layers $60 \mathrm{~m}$ (200 ft) above the blackband horizon. Nitrogen enrichment in phytoclasts from a number of early Mesozoic basins of eastern North America and the presence of mineral-bound ammonium in sedimentary rocks in the Deep River basin suggest that periods of nitrogen transport occurred that resulted in local areas of nitrogen enrichment at mineralogically favorable sites.
\end{abstract}

\section{INTRODUCTION}

Rocks with elevated ammonia concentrations in the Mesozoic Deep River basin, North Carolina, were probably first noted by farmers because of their beneficial agricultural properties. Reinemund (1955) reported that North Carolina farmers would place a type of rock known locally as blackband directly on their fields as a fertilizer. This rock occurs in the Cumnock Formation of the Sanford and Durham subbasins in eastern North Carolina (fig. 1 $\mathrm{A}$ ) and is associated with the Deep River coal field. High phosphorus values (reported as $\mathrm{P}_{2} \mathrm{O}_{5}$ ) and ammonia values (reported as $\mathrm{NH}_{3}$ or $\left(\mathrm{NH}_{4}\right)_{2} \mathrm{SO}_{4}$ ) have been discussed for the samples from the blackband interval (Reinemund, 1955; Murphy and Vilbrandt, 1930). Although other coal-bearing formations are present in the exposed Mesozoic basins of eastern North America, only the Cumnock Formation (fig. $1 B$ ) is known to have high ammonia values. Three questions are discussed here. Is the nitrogen associated with organic matter or is it present in the inorganic phase as mineralbound ammonium? Why has this ammonium-rich lithology formed here? What is its geochemical significance in the Mesozoic paleoenvironment?

Ammonium is present as a trace component in a variety of aluminosilicate minerals (Erd and others, 1964; Higashi, 1982; Hori and others, 1986). Recent advances in analytical techniques have permitted a more detailed analysis of the occurrence and distribution of mineral-bound ammonium in the natural environment. The ammonium cation, $\mathrm{NH}_{4}^{+}$, has an ionic radius and charge similar to $\mathrm{K}^{+}$, so that $\mathrm{NH}_{4}^{+}$can substitute for $\mathrm{K}^{+}$ or other alkali cations of similar ionic radius and charge that are bound in the silicate structure. It is distinct from 


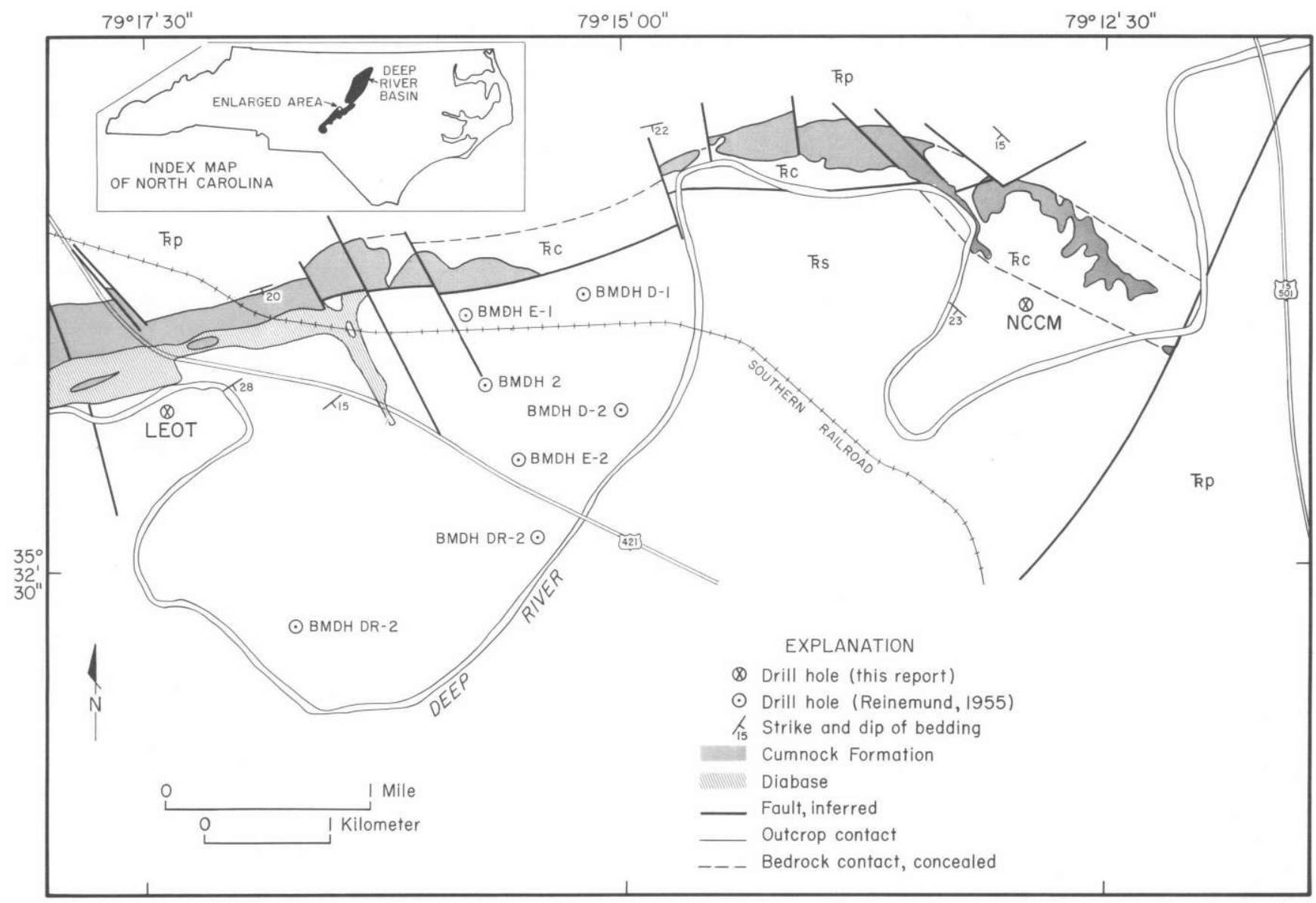

Figure 1A. Index map and bedrock geologic map of part of the Deep River basin showing parts of the Cumnock Formation and location of drill hole from this report and drill holes reported by Reinemund (1955). Fp, Pekin Formation; Rc, Cumnock Formation; Rs, Sanford Formation.

the ammonia molecule, $\mathrm{NH}_{3}$, that is associated with organic compounds in typical organic-matter-rich rocks. Trace quantities of bound ammonium have been detected in a variety of crystalline rocks on the basis of wet chemical analyses for nitrogen; concentrations range from 1 to $100 \mathrm{ppm}$ (Stevenson, 1962).

Recently, work based on other analytical techniques has shown ammonium enrichment in several distinctive geological environments. Direct detection of ammonium is feasible in certain settings by measurement of N-H vibrational modes using infrared spectroscopy and by chemical measurement of the $\mathrm{NH}_{4}{ }^{+}$ion using the ion chromatograph. Studies have shown ammonium enrichment in certain hydrothermal and organic-matterrich systems. Certain $\mathrm{Hg}-\mathrm{Au}$ hot-spring deposits and $\mathrm{Pb}-\mathrm{Zn}-\mathrm{Ag}$ sedimentary exhalative deposits have been found to have ammonium concentrations between 1,000 and $10,000 \mathrm{ppm}$. In these deposits, the ammonium occurs primarily in feldspars and in illites (Krohn, 1986; Krohn and Altaner, 1987; White and others, 1971; Sterne and others, 1982, 1984). High aqueous $\mathrm{NH}_{4}^{+}$values have been found in active hot-spring waters and undersea "black smoker" hydrothermal vents (Von Damm and others, 1985). Identification of ammonium-bearing minerals at the surface of these hydrothermally altered systems suggests that such minerals can persist in an oxidizing environment. In addition, mineral-bound ammonium occurs in several types of organic accumulations: in feldspars of oil-shale deposits in Idaho and Australia, in illites of Gulf Coast sediments, and in underclays of anthracite coal beds in northeastern Pennsylvania (Gulbrandsen, 1974; Cooper and Abedin, 1981; Paxton, 1983; Loughnan and others, 1983).

Relatively little is known about the distribution of ammonium in the geologic environment because ammonium is not routinely analyzed in rocks. $\mathrm{NH}_{4}{ }^{+}$has no known distinctive optical properties, so ammonium-rich samples cannot be identified readily in hand specimen or in thin section. In addition, nitrogen is too light an element to be measured reliably by the microprobe or in $\mathrm{X}$-ray fluorescence. However, $\mathrm{NH}_{4}{ }^{+}$can be detected by midinfrared techniques on the basis of fundamental N-H vibrational modes (Vedder, 1965; Mortland and others, 1963; Karyakhin and others, 1973). The primary N-H 


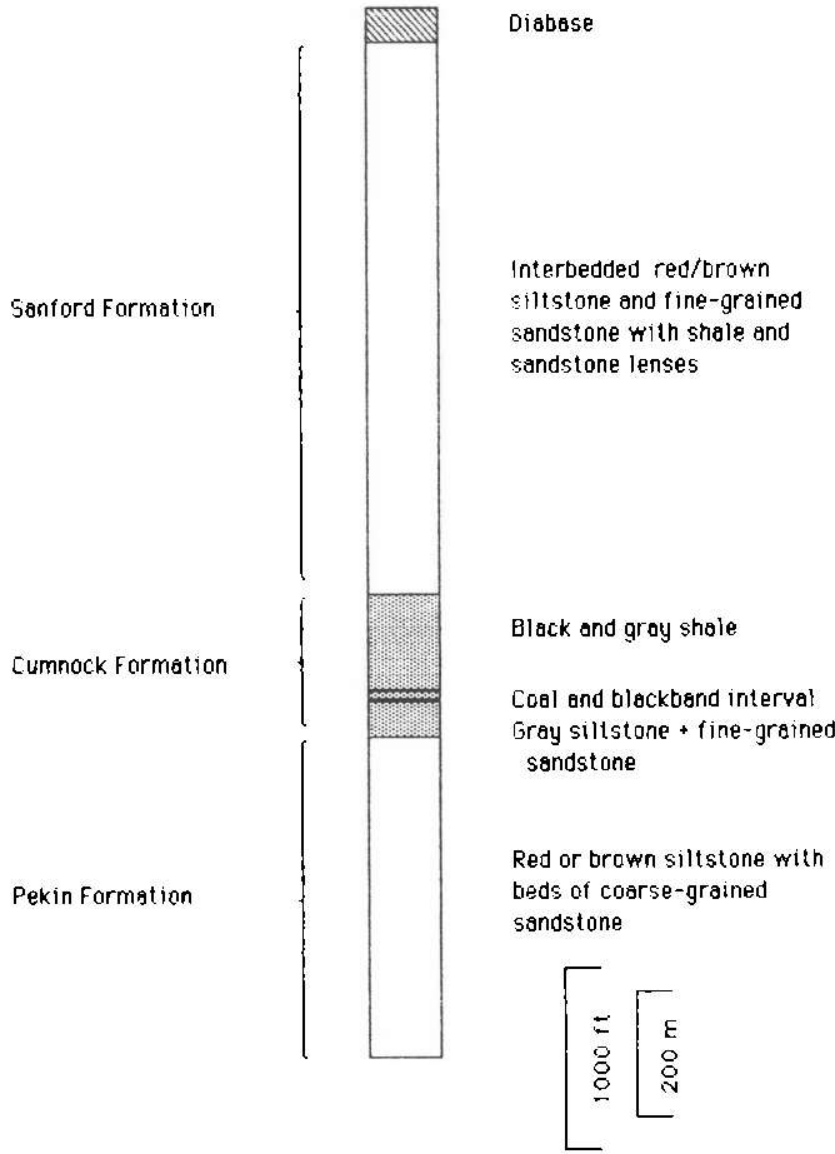

Figure 1B. Generalized stratigraphic column for bedrock geologic map of part of the Deep River basin showing location of the blackband interval of Cumnock Formation (after Reinemund, 1955).

bend absorption feature at $7 \mu \mathrm{m}$ occurs at the same wavelength as a carbonate absorption feature, so chemical pretreatment of the sample to remove carbonate is required. Some questions have arisen concerning the effect of carbonate removal on the $\mathrm{NH}_{4}{ }^{+}$content, so the midinfrared technique can be used only in a limited fashion as a quantitative technique (Kydd and Levinson, 1986). $\mathrm{NH}_{4}{ }^{+}$can also be detected directly by X-ray diffraction techniques on the basis of differences in ionic radius and in electron density from alkali cations in ammonium-bearing minerals (Sterne and others, 1982; Altaner and others, 1985). However, the X-ray technique has relatively low sensitivity to $\mathrm{NH}_{4}{ }^{+}$in minerals because the inherent peak shifts in the diffraction patterns are small and are difficult to measure for small percentages of $\mathrm{NH}_{4}^{+}$substitution.

The objective of this study is to determine the concentration, mineralogy, and stratigraphic location of mineral-bound ammonium within the black shale and blackband interval of the Cumnock Formation in the
Deep River basin of North Carolina. Because of the uncertainties of detecting mineral-bound ammonium in rocks, a substantial portion of the discussion is devoted to the analytical techniques themselves. From the mineralogy, we will attempt to infer the source and the thermochemical history of $\mathrm{NH}_{4}{ }^{+}$within the Cumnock Formation and address the question of the overall nitrogen distribution in the early Mesozoic basins of the Eastern United States.

\section{DESCRIPTION OF ANALYTICAL TECHNIQUES}

Several analytical techniques can detect the presence of ammonium in silicate rocks. Early investigators successfully used the Kjeldahl procedure to detect nitrogen in the ammonium feldspar, buddingtonite (table 1). The Kjeldahl procedure involves heating the sample with a strong $\mathrm{NaOH}$ solution to release ammonia as a gas. The gaseous ammonia is condensed, and the distillate is trapped in a vessel containing a weak sulfuric acid solution to neutralize the ammonia. The remaining acid is subsequently titrated with $\mathrm{NaOH}$ to determine the amount of acid neutralized by the ammonia. This method can allow some leakage of ammonia gas if great care is not maintained to prevent vapor loss (bumping) during heating. After initial investigation into the Kjeldahl procedure as well as other techniques, Klock and Lamothe (1986) developed a new analytical method to circumvent previous difficulties associated with ammonium detection. The procedure makes use of an ion chromatograph (IC) to detect ammonium and a microwave oven to facilitate the decomposition of the samples. The IC method provided results consistent with those obtained by the Kjeldahl technique and proved to be within acceptable standard deviation of known ammonium values for geologic standards and reagents.

Other analytical methods were also employed to determine the presence of inorganic ammonium in the rocks of the Cumnock Formation. The C-H-N elemental analyzer was used to determine total nitrogen content. Although this method does not differentiate between nitrogen as bound ammonium and other species of nitrogen, it proved to be a valuable analytical tool to corroborate the IC data as well as to evaluate thermal decomposition data and provide estimates of organic nitrogen in the samples.

Because nitrogen is not detected by $\mathrm{X}$-ray fluorescence (XRF) techniques, an alternate investigative approach was to identify ionic species that are easily substituted by ammonium in solid solution. Both potassium and rubidium have ionic radii and charge distributions similar to ammonium. Minerals that typically con- 
Table 1. Listing of instrumentation and sample preparation for chemical techniques discussed in the text

\begin{tabular}{|c|c|c|c|c|}
\hline Technique & $\begin{array}{l}\text { Type and method of } \\
\text { sample preparation }\end{array}$ & Species detected & $\begin{array}{c}\text { Type of } \\
\text { instrumentation }\end{array}$ & References \\
\hline $\begin{array}{l}\text { X-ray fluorescence.. } \\
\text { (XRF) (Major } \\
\text { elements) }\end{array}$ & 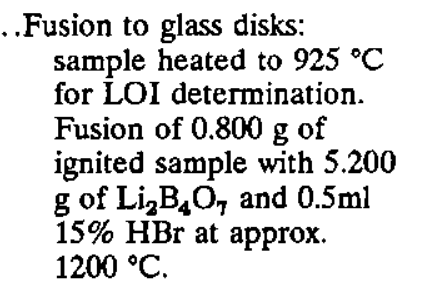 & $\begin{array}{l}\text { Oxides of } \mathrm{K}, \mathrm{Mg}, \mathrm{Na} \\
\mathrm{Si}, \mathrm{Al}, \mathrm{Ca}, \mathrm{Fe}, \mathrm{Mn} \\
\text { Ti, } \mathrm{P} .\end{array}$ & $\begin{array}{l}\text { Diano XRD-8300 } \\
\text { wavelength- } \\
\text { dispersive XRF } \\
\text { spectrometer. }\end{array}$ & $\begin{array}{l}\text { Norrish and Hutton, } \\
\text { 1969; Taggart and } \\
\text { others, in press; } \\
\text { Tertian and } \\
\text { Claisse, 1982. }\end{array}$ \\
\hline $\begin{array}{l}\text { X-ray fluorescence .. } \\
\text { (XRF) (Trace } \\
\text { elements) }\end{array}$ & $\begin{array}{l}\text { Loose powdered pellets: } \\
\text { approx. } 1.0 \mathrm{~g} \text { of powdered } \\
\text { sample }(100 \text { mesh) in } \\
0.00025 \text {-in. mylar window. }\end{array}$ & $\mathbf{R b} \ldots \ldots \ldots \ldots \ldots$ & $\begin{array}{l}\text { Kevex } 700 \text { XRF } \\
\text { spectrometer with } \\
\text { Model } 7000 \\
\text { analyzer. }\end{array}$ & $\begin{array}{l}\text { Johnson, 1984; } \\
\text { Taggart and } \\
\text { others, in press. }\end{array}$ \\
\hline $\begin{array}{l}\text { Ion chromatography. } \\
\text { (IC) }\end{array}$ & $\begin{array}{l}\text {.HF and } \mathrm{HCl} \text { digestion, } \\
\text { microwave dissolution: } \\
0.100-\mathrm{g} \text { sample }(200 \text { mesh) } \\
\text { with } 1 \mathrm{ml} 3 \mathrm{M} \mathrm{HCl} \text { and } 4 \\
\text { ml } 40 \% \mathrm{HF} \text { in } 250 \mathrm{ml} \\
\text { polycarbonate bottle. } \\
\text { Microwave (high setting) } \\
\text { total of } 2.5 \text { min. }\end{array}$ & $\mathrm{NH}_{4}^{+}, \mathrm{K}^{+}, \mathrm{Na}^{+}$. & $\begin{array}{l}\text { Dionex } 16 \text { ion } \\
\text { chromatograph. }\end{array}$ & $\begin{array}{l}\text { Klock and Lamothe, } \\
1986 .\end{array}$ \\
\hline \multicolumn{5}{|l|}{ Elemental C-H-N } \\
\hline analysis......... & $\begin{array}{l}.1-20 \mathrm{mg} \text { in platinum } \\
\text { "boats." }\end{array}$ & $\begin{array}{l}\text { Total carbon, } \\
\text { hydrogen, and } \\
\text { nitrogen detected } \\
\text { as } \mathrm{CO}_{2}, \mathrm{H}_{2} \mathrm{O} \text {, and } \\
\mathrm{N}_{2}\end{array}$ & $\begin{array}{l}\text { Perkin-Elmer Model } \\
240 \text { elemental } \\
\text { analyzer. }\end{array}$ & $\begin{array}{l}\text { Din and Jones, } \\
\text { 1978; Perkin- } \\
\text { Elmer, 1974; } \\
\text { Skinner and } \\
\text { others, 1981. }\end{array}$ \\
\hline Kjeldahl . & $\begin{array}{l}\text {.Heating with } \mathrm{NaOH} \text { in } \\
\text { Kjeldahl flask: } 0.500-\mathrm{g} \\
\text { sample in a } 500-\mathrm{m} \text { ] } \\
\text { Kjeldahl flask with } 300 \mathrm{ml} \\
\mathrm{H}_{2} \mathrm{O} \text { and } 50 \mathrm{~g} \mathrm{NaOH} .\end{array}$ & $\mathrm{NH}_{4}^{+}{ }^{+} \ldots \ldots \ldots \ldots \ldots$ & Kjeldahl flask... & $\begin{array}{l}\text { Erd and others, } \\
1964 .\end{array}$ \\
\hline
\end{tabular}

tain high concentrations of $\mathrm{K}^{+}$and $\mathrm{Rb}^{+}$in the crystal structure are possible candidates for ammonium substitution. XRF analysis for these mineral species may lead to the detection of host lithologies for the ammoniumbearing silicates. Near-infrared spectroscopy also can be used to qualitatively identify ammonium-bearing minerals (Krohn and Bethke, 1984).

\section{Sample Preparation}

Samples were taken from two drill cores housed at the North Carolina Geological Survey in Raleigh. The majority of the samples came from core LEOT-1-82 (table 2; fig. 1). This core was drilled by Beutel Corporation under contract to the Department of Energy to test the potential of the Deep River coal field. The hole was drilled down to the level of the coals, approximately $900 \mathrm{ft}(275 \mathrm{~m})$, and was situated close to the area of Reinemund's report (1955). General lithologic descriptions of the drill holes can be derived from previous published reports (for example, Reinemund, 1955). Several additional samples were taken from drill hole NCCM-1 (fig. $1 A$; table 2 ).

\section{Major-Element Analysis}

All major-element samples were prepared for XRF analysis by means of the fusion technique (Taggart and others, in press; Tertian and Claisse, 1982). Loss on ignition (LOI) values were first determined by heating the samples in a muffle furnace at $925^{\circ} \mathrm{C}$ for 1 hour to remove water, carbon dioxide, and any organic material. To $0.800 \mathrm{~g}$ of the heated sample were added $5.200 \mathrm{~g}$ of lithium tetraborate and approximately $0.5 \mathrm{~mL}$ of a 15 percent $\mathrm{HBr}$ solution. This mixture was transferred to a platinum/gold crucible and fused at approximately 1200 ${ }^{\circ} \mathrm{C}$ for 30 minutes. After cooling, a homogenous glass disk was produced.

The fused specimens were subsequently analyzed with a Diano XRD-8300 wavelength-dispersive X-ray fluorescence spectrometer. Calibration curves were prepared for 10 major oxides by using USGS standard rock powders (Taggart and others, in press). Results are reported as weight percent of the oxide (table 2). Matrix effects due to absorption and fluorescence were not a factor because of the almost tenfold dilution of sample to flux material. 
Table 2. Listing of chemical and X-ray diffraction analyses for drill cores LEOT-1-82 and NCCM-1

[Depth of samples reported in feet; chemical values reported as weight percent of oxides; mineralogical values reported as percent of sample; $R R$ is an internal identification number; midinfrared data reported as $\log$ of intensity at the continuum divided by the intensity of the absorption band; Rb reported as Ppm; LOI, loss on ignition; IC, ion chromatography; -, no measured value; $x$, insufficient sample for analysis; samples for total carbon, hydrogen, and nitrogen were measured twice in split fraction of the sample]

\begin{tabular}{|c|c|c|c|c|c|c|c|c|c|}
\hline & $\begin{array}{l}\text { LEOT } \\
688.6\end{array}$ & $\begin{array}{l}\text { LEOT } \\
701.6\end{array}$ & $\begin{array}{l}\text { LEOT } \\
712.6\end{array}$ & $\begin{array}{l}\text { LEOT } \\
713.11\end{array}$ & $\begin{array}{l}\text { LEOT } \\
716\end{array}$ & $\begin{array}{c}\text { LEOT } \\
720\end{array}$ & $\begin{array}{l}\text { LEOT } \\
728\end{array}$ & $\begin{array}{l}\text { LEOT } \\
737.6\end{array}$ & $\begin{array}{l}\text { LEOT } \\
743.6\end{array}$ \\
\hline 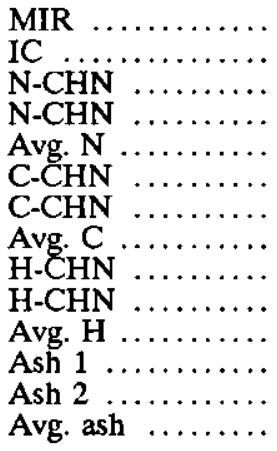 & $\begin{array}{l}-0.06 \\
.04 \\
.06 \\
.05 \\
3.1 \\
3.1 \\
3.1 \\
.41 \\
.43 \\
.42 \\
91.6 \\
91.8 \\
91.7\end{array}$ & $\begin{array}{c}0.06 \\
.08 \\
.01 \\
.045 \\
3.6 \\
3.6 \\
3.6 \\
.5 \\
.5 \\
.5 \\
85.8 \\
85.7 \\
85.75\end{array}$ & $\begin{array}{l}-0.06 \\
.05 \\
.05 \\
.05 \\
1.5 \\
1.5 \\
1.5 \\
.54 \\
.54 \\
.54 \\
90.8 \\
90.9 \\
90.85\end{array}$ & $\begin{array}{c}\overline{0} .06 \\
.06 \\
.06 \\
.06 \\
3.8 \\
3.8 \\
3.8 \\
.56 \\
.57 \\
.565 \\
87.3 \\
87.5 \\
87.4\end{array}$ & $\begin{array}{l}-\overline{0.08} \\
.2 \\
.21 \\
.205 \\
7.2 \\
7.3 \\
7.25 \\
.71 \\
.72 \\
.715 \\
85.3 \\
85.3 \\
85.3\end{array}$ & $\begin{array}{c}0.05 \\
.08 \\
.12 \\
.1 \\
7.3 \\
7.3 \\
7.3 \\
.62 \\
.62 \\
.62 \\
78.5 \\
78.1 \\
78.3\end{array}$ & $\begin{array}{l}\overline{0} \\
.03 \\
.03 \\
.03 \\
3.7 \\
3.7 \\
3.7 \\
.43 \\
.43 \\
.43 \\
83.6 \\
83.7 \\
83.65\end{array}$ & $\begin{array}{l}- \\
0.4 \\
.3 \\
.34 \\
.32 \\
1.6 \\
1.6 \\
1.6 \\
.63 \\
.65 \\
.64 \\
92.8 \\
92.9 \\
92.85\end{array}$ & $\begin{array}{l}0 \\
.02 \\
.01 \\
.015 \\
9.1 \\
9.1 \\
9.1 \\
.26 \\
.26 \\
.26 \\
65.3 \\
65.4 \\
65.35\end{array}$ \\
\hline 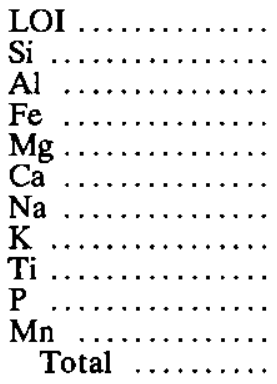 & $\begin{array}{c}7.94 \\
47.12 \\
19.96 \\
7.16 \\
5.77 \\
5.6 \\
2.97 \\
3.63 \\
.68 \\
.3 \\
.14 \\
101.27\end{array}$ & $\begin{array}{c}14.16 \\
41.21 \\
15.2 \\
6.03 \\
5.8 \\
13.06 \\
1.91 \\
2.17 \\
.57 \\
.62 \\
.17 \\
100.9\end{array}$ & $\begin{array}{r}8.95 \\
48.2 \\
17.23 \\
8.35 \\
5.58 \\
6.32 \\
2.04 \\
2.76 \\
.69 \\
.35 \\
.11 \\
100.58\end{array}$ & $\begin{array}{r}12.63 \\
43.07 \\
16.54 \\
7.21 \\
5.18 \\
8.78 \\
2.14 \\
2.61 \\
.67 \\
.37 \\
.15 \\
99.35\end{array}$ & $\begin{array}{c}14.6 \\
43.64 \\
18.24 \\
6.93 \\
4.64 \\
6.22 \\
2.16 \\
2.99 \\
.67 \\
.31 \\
.1 \\
100.5\end{array}$ & $\begin{array}{r}21.73 \\
31.17 \\
14.63 \\
6.07 \\
6.59 \\
16.73 \\
1.48 \\
1.77 \\
.43 \\
.31 \\
.27 \\
101.18\end{array}$ & $\begin{array}{r}16.33 \\
41.18 \\
12.37 \\
5.51 \\
5.44 \\
15.66 \\
1.38 \\
2.01 \\
.47 \\
.33 \\
.2 \\
100.88\end{array}$ & $\begin{array}{r}6.89 \\
50.08 \\
21.97 \\
7.91 \\
3.67 \\
1.26 \\
1.17 \\
3.66 \\
.8 \\
.34 \\
.09 \\
97.84\end{array}$ & $\begin{array}{c}34.21 \\
14.85 \\
6.38 \\
2.51 \\
6.09 \\
35.3 \\
1.54 \\
.48 \\
.13 \\
.34 \\
.26 \\
102.09\end{array}$ \\
\hline $\mathrm{Rb} \ldots \ldots \ldots \ldots \ldots$ & 129 & 96 & 120 & 124 & 137 & 76 & 78 & 163 & 20 \\
\hline $\begin{array}{l}\text { RR } \ldots \ldots \ldots \ldots \ldots \\
\text { Quartz } \ldots \ldots \ldots \ldots \\
\text { K-feldspar } \ldots \ldots \ldots \\
\text { Plagioclase } \ldots \ldots \ldots \\
\text { Calcite } \ldots \ldots \ldots \ldots \ldots \\
\text { Dolomite } \ldots \ldots \ldots \ldots \\
\text { Siderite } \ldots \ldots \ldots \ldots \\
\text { Pyrite } \ldots \ldots \ldots \ldots \ldots \\
\text { Illite } \ldots \ldots \ldots \ldots \ldots \\
\text { Chlorite } \ldots \ldots \ldots \ldots \\
\text { Kaolinite } \ldots \ldots \ldots \ldots \\
\text { Diffuse scattering }\end{array}$ & $\begin{array}{r}20 \\
0 \\
18 \\
11 \\
5 \\
0 \\
0 \\
0 \\
46 \\
20 \\
2 \\
13\end{array}$ & $\begin{array}{r}12 \\
29 \\
0 \\
6 \\
13 \\
0 \\
0 \\
0 \\
27 \\
15 \\
11 \\
0\end{array}$ & $\begin{array}{r}32 \\
19 \\
0 \\
4 \\
3 \\
0 \\
0 \\
0 \\
39 \\
30 \\
7 \\
1\end{array}$ & $\begin{array}{r}6 \\
18 \\
2 \\
4 \\
8 \\
0 \\
0 \\
0 \\
38 \\
23 \\
7 \\
0\end{array}$ & $\begin{array}{r}24 \\
9 \\
0 \\
5 \\
6 \\
0 \\
1 \\
0 \\
48 \\
22 \\
9 \\
8\end{array}$ & $\begin{array}{r}13 \\
18 \\
0 \\
3 \\
26 \\
0 \\
0 \\
0 \\
21 \\
23 \\
10 \\
4\end{array}$ & $\begin{array}{r}31 \\
22 \\
0 \\
2 \\
13 \\
0 \\
0 \\
0 \\
36 \\
23 \\
5 \\
0\end{array}$ & $\begin{array}{r}30 \\
16 \\
0 \\
1 \\
0 \\
0 \\
0 \\
0 \\
68 \\
8 \\
8 \\
1\end{array}$ & $\begin{array}{r}25 \\
9 \\
0 \\
0 \\
49 \\
6 \\
0 \\
12 \\
9 \\
12 \\
4 \\
0\end{array}$ \\
\hline
\end{tabular}

\section{Trace-Element Analysis}

The samples were prepared for analysis as loose powders (Johnson, 1984). Approximately $1.0 \mathrm{~g}$ of the powdered sample (100 mesh) was added to a sample holder constructed by stretching a piece of 0.00025 -in.thick mylar film over one end of an aluminum ring. The mylar was held in place by means of an outer teflon ring.

Analysis of trace elements was conducted on a Kevex 700 XRF spectrometer with a Model 7000 analyzer. Intensity measurements for $\mathrm{Rb}$ were obtained by excitation of the specimen by means of a $\mathrm{Ag}$ secondary target excited from a rhodium X-ray source. By use of the ratio of the $R b$ intensity to the Compton scattering peak, $\mathrm{Rb}$ data were calculated from a simple linear regression calibration curve. Calibration curves for all trace elements were determined from analysis of USGS standards.

\section{Ammonium Analysis}

IC technique.-The samples were readied for ion chromatograph (IC) analysis by digestion in sealed polycarbonate bottles with $\mathrm{HCl}$ and $\mathrm{HF}$ and subsequent heating by a microwave oven (Klock and Lamothe, 1986). After diluting with water, the solutions were injected into a Dionex 16 ion chromatograph with two cation-separator columns $(6 \times 250$ and $9 \times 250 \mathrm{~mm})$ and a $9 \times 250 \mathrm{~mm}$ suppressor column. Values for ammonium standards from geologic materials as well as commercial 
Table 2. Listing of chemical and X-ray diffraction analyses for drill cores LEOT-1-82 and NCCM-1-Continued

[Depth of samples reported in feet; chemical values reported as weight percent of oxides; mineralogical values reported as percent of sample; RR is an internal identification number; midinfrared data reported as log of intensity at the continuum divided by the intensity of the absorption band; $\mathrm{Rb}$ reported as ppm; LOI, loss on ignition; IC, ion chromatography; $\rightarrow$, no measured value; $x$, insufficient sample for analysis; samples for total carbon, hydrogen, and nitrogen were measured twice in split fraction of the sample]

\begin{tabular}{|c|c|c|c|c|c|c|c|c|c|}
\hline & $\begin{array}{l}\text { LEOT } \\
\mathbf{7 4 7 . 6}\end{array}$ & $\begin{array}{l}\text { LEOT } \\
755\end{array}$ & $\begin{array}{c}\text { LEOT } \\
759\end{array}$ & $\begin{array}{c}\text { LEOT } \\
767\end{array}$ & $\begin{array}{c}\text { LEOT } \\
808\end{array}$ & $\begin{array}{c}\text { LEOT } \\
829\end{array}$ & $\begin{array}{l}\text { LEOT } \\
840.4\end{array}$ & $\begin{array}{l}\text { LEOT } \\
865.9\end{array}$ & $\begin{array}{r}\text { LEOT } \\
888\end{array}$ \\
\hline 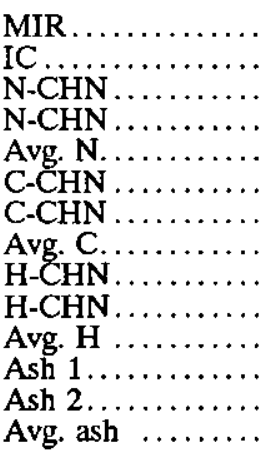 & $\begin{array}{l}0 \\
.01 \\
.03 \\
.02 \\
10 \\
10.1 \\
10.05 \\
.21 \\
.21 \\
.21 \\
64.2 \\
63.8 \\
64\end{array}$ & $\begin{array}{l}- \\
0.09 \\
.08 \\
.09 \\
.085 \\
3.3 \\
3.3 \\
3.3 \\
.49 \\
.49 \\
.49 \\
84.8 \\
84.7 \\
84.75\end{array}$ & $\begin{array}{c}-0.3 \\
.28 \\
.22 \\
.25 \\
4.2 \\
4.2 \\
4.2 \\
.82 \\
.82 \\
.82 \\
89.9 \\
85.5 \\
87.7\end{array}$ & $\begin{array}{c}-0.3 \\
.33 \\
.41 \\
.37 \\
9.6 \\
9.6 \\
9.6 \\
.97 \\
.97 \\
.97 \\
82 \\
82 \\
82\end{array}$ & $\begin{array}{l}-0.07 \\
.08 \\
.09 \\
.085 \\
9.3 \\
9.4 \\
9.35 \\
.3 \\
.29 \\
.295 \\
67.4 \\
67.1 \\
67.25\end{array}$ & $\begin{array}{c}-0.2 \\
.37 \\
.36 \\
.365 \\
16.2 \\
16.1 \\
16.15 \\
.9 \\
.86 \\
.88 \\
68 \\
68.1 \\
68.05\end{array}$ & $\begin{array}{l}- \\
\mathbf{x} \\
\mathbf{x} \\
\mathbf{x} \\
\mathbf{x} \\
\mathbf{x} \\
\mathbf{x} \\
\mathbf{x} \\
\mathbf{x} \\
\mathbf{x} \\
\mathbf{x} \\
\mathbf{x} \\
\mathbf{x} \\
\mathbf{x}\end{array}$ & $\begin{array}{l}-0.2 \\
.24 \\
.24 \\
.24 \\
1.9 \\
1.8 \\
1.85 \\
.68 \\
.68 \\
.68 \\
91 \\
91 \\
91\end{array}$ & $\begin{array}{l}-0.07 \\
.14 \\
.11 \\
.125 \\
1.2 \\
1.2 \\
1.2 \\
.37 \\
.37 \\
.37 \\
95.5 \\
95.3 \\
95.4\end{array}$ \\
\hline 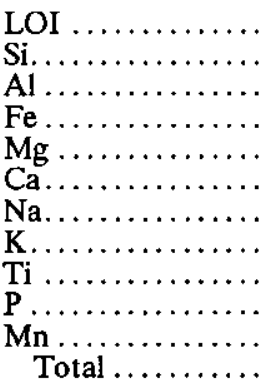 & $\begin{array}{c}36.11 \\
9.24 \\
4.82 \\
3.2 \\
7.94 \\
36.86 \\
1.62 \\
.15 \\
.08 \\
.3 \\
.38 \\
100.7\end{array}$ & $\begin{array}{c}12.72 \\
41.14 \\
14.14 \\
7.68 \\
5.34 \\
12.03 \\
1.2 \\
2.5 \\
.51 \\
.35 \\
.17 \\
97.78\end{array}$ & $\begin{array}{c}10.44 \\
45.18 \\
21.52 \\
10.8 \\
3.34 \\
2.52 \\
1.87 \\
3.21 \\
.75 \\
.98 \\
.34 \\
100.95\end{array}$ & $\begin{array}{r}16.95 \\
43.25 \\
19.93 \\
6.3 \\
11.42 \\
5.27 \\
5.46 \\
2.97 \\
.56 \\
.56 \\
.21 \\
112.88\end{array}$ & $\begin{array}{r}31.8 \\
18.81 \\
7.4 \\
7.74 \\
11.29 \\
20.75 \\
1.19 \\
.85 \\
.21 \\
.47 \\
.53 \\
101.04\end{array}$ & $\begin{array}{r}28.66 \\
26.45 \\
12.21 \\
4.21 \\
2.38 \\
19.55 \\
1.36 \\
1.46 \\
.3 \\
1.51 \\
.26 \\
98.35\end{array}$ & $\begin{array}{c}24.89 \\
18.17 \\
4.99 \\
42.2 \\
3.1 \\
3.36 \\
.23 \\
.18 \\
.2 \\
.66 \\
2.22 \\
100.2\end{array}$ & $\begin{array}{r}9.28 \\
46.42 \\
19.74 \\
9.43 \\
3.28 \\
3.57 \\
.92 \\
3.25 \\
.81 \\
.33 \\
.12 \\
97.15\end{array}$ & $\begin{array}{r}4.84 \\
69.48 \\
14.33 \\
4.24 \\
.57 \\
.37 \\
1.29 \\
1.48 \\
.85 \\
.14 \\
.1 \\
97.69\end{array}$ \\
\hline Rb............. & 18 & 90 & 137 & 134 & 51 & 71 & $\mathbf{x}$ & 134 & 65 \\
\hline 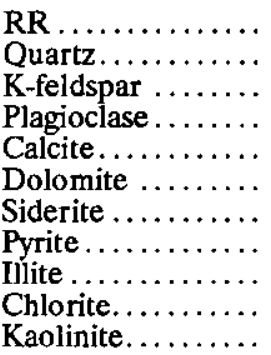 & $\begin{array}{r}1 \\
3 \\
0 \\
0 \\
61 \\
14 \\
0 \\
8 \\
0 \\
14 \\
0\end{array}$ & $\begin{array}{r}19 \\
23 \\
0 \\
2 \\
9 \\
0 \\
0 \\
0 \\
38 \\
19 \\
10\end{array}$ & $\begin{array}{r}5 \\
11 \\
0 \\
1 \\
0 \\
0 \\
1 \\
0 \\
55 \\
13 \\
19\end{array}$ & $\begin{array}{r}7 \\
0 \\
0 \\
0 \\
1 \\
0 \\
0 \\
0 \\
73 \\
17 \\
9\end{array}$ & $\begin{array}{r}9 \\
17 \\
0 \\
0 \\
1 \\
50 \\
0 \\
0 \\
15 \\
8 \\
10\end{array}$ & $\begin{array}{r}21 \\
8 \\
0 \\
4 \\
18 \\
0 \\
1 \\
0 \\
44 \\
17 \\
7\end{array}$ & $\begin{array}{r}3 \\
97 \\
0 \\
0 \\
3 \\
0 \\
0 \\
0 \\
0 \\
0 \\
0\end{array}$ & $\begin{array}{r}22 \\
9 \\
0 \\
2 \\
0 \\
1 \\
0 \\
0 \\
49 \\
21 \\
17\end{array}$ & $\begin{array}{r}16 \\
57 \\
0 \\
4 \\
0 \\
0 \\
0 \\
0 \\
23 \\
17 \\
0\end{array}$ \\
\hline
\end{tabular}

reagents were used to determine the accuracy of the technique.

C-H-N Technique.-A Perkin-Elmer Model 240

Elemental Analyzer was used to analyze the samples for carbon, hydrogen, and nitrogen (C-H-N) contents. Carbon, hydrogen, and nitrogen were determined by combustion of the sample and subsequent detection of the carbon dioxide, water, and nitrogen combustion products. Accurate weights of approximately 1 to $20 \mathrm{mg}$ of the sample were used and combusted at various temperatures in the combustion tube. Acetanilide was used as the standard, and a calibration curve was constructed from the acetanilide C-H-N content for each run. Blanks were also run to remove any instrumental background values affecting the data.

\section{X-Ray Analysis}

Semiquantitative estimates of sample mineralogy were obtained by $\mathrm{X}$-ray diffraction. A technique based on peak intensity is described by Hosterman and Whitlow (1981) and is accurate within 5 to 10 percent. Generally, diffractograms were aligned on the basis of the reflection of quartz at $20.85^{\circ} 2 \theta$ as an internal standard. Most samples had over 90 percent of the total peaks identified; samples below that threshold were rerun, with a quartz standard inserted if necessary. Mineral identification by optical methods was hampered by the abundance of opaque minerals present in these organic-rich samples and by the fine grain size. 
Table 2. Listing of chemical and X-ray diffraction analyses for drill cores LEOT-1-82 and NCCM-1-Continued [Depth of samples reported in feet; chemical values reported as weight percent of oxides; mineralogical values reported as percent of sample; RR is an internal identification number; midinfrared data reported as log of intensity at the continuum divided by the intensity of the absorption band; Rb reported as ppm; LOI, loss on ignition; IC, ion chromatography; - , no measured value; $x$, insufficient sample for analysis; samples for total carbon, hydrogen, and nitrogen were measured twice in split fraction of the sample]

\begin{tabular}{|c|c|c|c|c|c|c|c|c|}
\hline & $\begin{array}{l}\text { LEOT } \\
903.6\end{array}$ & $\begin{array}{l}\text { LEOT } \\
907.6\end{array}$ & $\begin{array}{l}\text { LEOT } \\
920.6\end{array}$ & $\begin{array}{c}\text { LEOT } \\
927\end{array}$ & $\begin{array}{l}\text { LEOT } \\
936.6\end{array}$ & $\begin{array}{c}\text { LEOT } \\
938\end{array}$ & $\begin{array}{c}\text { LEOT } \\
942\end{array}$ & $\begin{array}{c}\text { LEOT } \\
949\end{array}$ \\
\hline 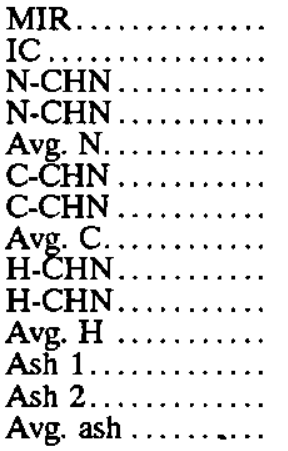 & $\begin{array}{l}0.76 \\
.1 \\
.55 \\
.57 \\
.56 \\
18.2 \\
18.3 \\
18.25 \\
.97 \\
1 \\
.985 \\
64.2 \\
64.5 \\
64.35\end{array}$ & $\begin{array}{l}0.90 \\
0 \\
.12 \\
.13 \\
.125 \\
10.9 \\
11 \\
10.95 \\
.32 \\
.33 \\
.325 \\
67.6 \\
67.5 \\
67.55\end{array}$ & $\begin{array}{l}0.19 \\
0 \\
1.3 \\
1.3 \\
1.3 \\
58.5 \\
58.2 \\
58.35 \\
3.5 \\
3.5 \\
3.5 \\
23.1 \\
23.4 \\
23.25\end{array}$ & $\begin{array}{l}0.56 \\
.06 \\
.05 \\
.04 \\
.045 \\
3.7 \\
3.7 \\
3.7 \\
.37 \\
.37 \\
.37 \\
85.7 \\
86 \\
85.85\end{array}$ & $\begin{array}{l}0.17 \\
.06 \\
.03 \\
.03 \\
.03 \\
1.2 \\
1.2 \\
1.2 \\
.46 \\
.46 \\
.46 \\
93 \\
92.7 \\
92.85\end{array}$ & $\begin{array}{l}0.77 \\
0 \\
.03 \\
.02 \\
.025 \\
7.5 \\
7.5 \\
7.5 \\
.26 \\
.25 \\
.255 \\
73.9 \\
74 \\
73.95\end{array}$ & $\begin{array}{l}0.27 \\
0 \\
.01 \\
.01 \\
.01 \\
1.8 \\
1.8 \\
1.8 \\
.24 \\
.24 \\
.24 \\
93.2 \\
93.3 \\
93.2\end{array}$ & $\begin{array}{c}0.68 \\
.08 \\
.26 \\
.26 \\
.26 \\
8.8 \\
8.8 \\
8.8 \\
.67 \\
.68 \\
.675 \\
77 \\
77.2 \\
77.1\end{array}$ \\
\hline 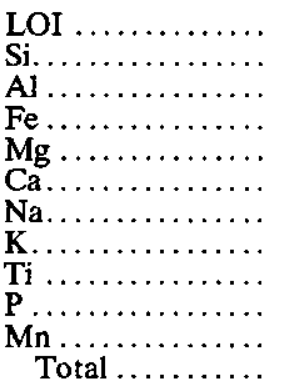 & $\begin{array}{c}34.82 \\
12.92 \\
3.3 \\
26.16 \\
1.56 \\
11.9 \\
.53 \\
.44 \\
.12 \\
6.3 \\
1.28 \\
99.33\end{array}$ & $\begin{array}{r}30.52 \\
10.75 \\
2.47 \\
42.97 \\
3.83 \\
5.31 \\
.32 \\
.2 \\
.1 \\
.69 \\
1.47 \\
98.63\end{array}$ & $\begin{array}{c}76.49 \\
10.39 \\
5.48 \\
6.67 \\
.16 \\
.29 \\
.04 \\
.49 \\
.18 \\
.07 \\
.009 \\
100.269\end{array}$ & $\begin{array}{c}13.98 \\
44.21 \\
12.74 \\
22.95 \\
1.6 \\
1.74 \\
.59 \\
1.84 \\
.52 \\
.63 \\
.22 \\
101.02\end{array}$ & $\begin{array}{r}7.27 \\
64.64 \\
15.95 \\
6.75 \\
1.98 \\
.45 \\
.91 \\
1.45 \\
.83 \\
.09 \\
.1 \\
100.42\end{array}$ & $\begin{array}{r}24.96 \\
17.87 \\
6.29 \\
36.08 \\
4.11 \\
5.91 \\
.27 \\
.8 \\
.29 \\
2.31 \\
.48 \\
99.37\end{array}$ & $\begin{array}{c}6.45 \\
68.82 \\
9.21 \\
10.5 \\
.87 \\
1.18 \\
1.56 \\
.64 \\
.57 \\
.33 \\
.2 \\
100.33\end{array}$ & $\begin{array}{c}24.76 \\
20.1 \\
9.78 \\
30.72 \\
2.73 \\
5.87 \\
.42 \\
1.41 \\
.35 \\
2.63 \\
.82 \\
99.59\end{array}$ \\
\hline Rb........... & 31 & 42 & 39 & 92 & 78 & 50 & 31 & 93 \\
\hline 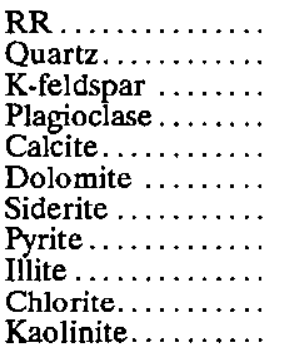 & $\begin{array}{r}28 \\
48 \\
0 \\
4 \\
0 \\
0 \\
0 \\
0 \\
48 \\
0 \\
0\end{array}$ & $\begin{array}{r}15 \\
30 \\
0 \\
0 \\
9 \\
0 \\
37 \\
0 \\
0 \\
12 \\
11\end{array}$ & $\begin{array}{r}23 \\
26 \\
0 \\
1 \\
0 \\
0 \\
0 \\
27 \\
20 \\
7 \\
9\end{array}$ & $\begin{array}{r}17 \\
31 \\
0 \\
2 \\
0 \\
0 \\
0 \\
0 \\
44 \\
8 \\
15\end{array}$ & $\begin{array}{r}18 \\
56 \\
0 \\
2 \\
0 \\
0 \\
1 \\
0 \\
22 \\
4 \\
16\end{array}$ & $\begin{array}{r}34 \\
30 \\
0 \\
2 \\
0 \\
0 \\
32 \\
0 \\
36 \\
0 \\
0\end{array}$ & $\begin{array}{r}26 \\
74 \\
0 \\
5 \\
0 \\
0 \\
2 \\
0 \\
8 \\
12 \\
0\end{array}$ & $\begin{array}{r}8 \\
4 \\
0 \\
1 \\
0 \\
0 \\
6 \\
0 \\
60 \\
17 \\
11\end{array}$ \\
\hline
\end{tabular}

\section{MINERALOGICAL ANALYSIS}

Samples of the drill core (primarily LEOT) were taken predominantly in the dark, fine-grained shales and siltstones in an effort to find bound ammonium. The distribution of minerals with depth as derived from the XRD data (fig. 2) shows a relatively low content of quartz and relatively high content of clay and layer silicate minerals. No systematic pattern is seen; rather, the interbedded nature of the section is reflected in the mineralogical distribution. Surprisingly, many of the samples in the blackband interval near a depth of 900 feet $(275 \mathrm{~m})$ contain between 25 to 30 percent of the mineral fraction as quartz (fig. 2), which is generally a higher percentage than in most of the other intervals sampled, although many of these samples have high loss on ignition (LOI) values as well (fig. 3 ).

Most of the high $\mathrm{SiO}_{2}$ values are associated with quartz, but sample 688.6 is made up of 29 percent feldspar with no detectable quartz (table 2). No other sample has such a high feldspar content. The second interesting aspect of the drill core is the relatively large amount of carbonate present in this section, particularly near the $700 \mathrm{ft}$ depth (table 2). Some samples contain over 50 percent carbonate (fig. 2), which is a combination of calcite, dolomite, and siderite. Such samples have relatively high $\mathrm{CaO}$ content, nearly 35 percent, and accordingly high LOI values due to the release of $\mathrm{CO}_{2}$. Siderite is present in at least trace amounts in many samples and in two samples is present at concentrations in excess of 30 percent (fig. 2). Such siderite-rich samples 
Table 2. Listing of chemical and X-ray diffraction analyses for drill cores LEOT-1-82 and NCCM-1Continued

[Depth of samples reported in feet; chemical values reported as weight percent of oxides; mineralogical values reported as percent of sample; $R R$ is an internal identification number; midinfrared data reported as log of intensity at the continuum divided by the intensity of the absorption band; Rb reported as ppm; LOI, loss on ignition; IC, ion chromatography; $\rightarrow$, no measured value; $x$, insufficient sample for analysis; samples for total carbon, hydrogen, and nitrogen were measured twice in split fraction of the sample]

\begin{tabular}{|c|c|c|c|c|c|c|c|}
\hline & $\underset{351}{\mathrm{NCCM}}$ & $\underset{364}{\mathrm{NCCM}}$ & $\begin{array}{c}\mathrm{NCCM} \\
373\end{array}$ & $\underset{647}{\operatorname{NCCM}}$ & $\begin{array}{c}\text { NCCM } \\
672\end{array}$ & $\underset{729}{\operatorname{NCCM}}$ & $\begin{array}{l}\mathrm{NCCM} \\
760.5\end{array}$ \\
\hline 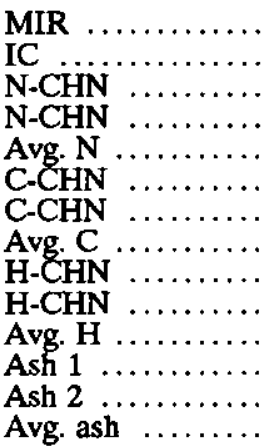 & $\begin{array}{c}0.09 \\
.1 \\
.07 \\
.085 \\
3.8 \\
3.8 \\
3.8 \\
.49 \\
.51 \\
.5 \\
81.1 \\
81.9 \\
81.5\end{array}$ & $\begin{array}{l}-\overline{0.1} \\
.12 \\
.11 \\
.115 \\
3.2 \\
3.2 \\
3.2 \\
.58 \\
.59 \\
.585 \\
83.4 \\
83.4 \\
83.4\end{array}$ & $\begin{array}{l}-\overline{0.1} \\
.11 \\
.1 \\
.105 \\
2.5 \\
2.5 \\
2.5 \\
.6 \\
.61 \\
.605 \\
86.1 \\
86.3 \\
86.2\end{array}$ & $\begin{array}{l}0.3 \\
.4 \\
.34 \\
.37 \\
5.8 \\
5.9 \\
5.85 \\
1 \\
1 \\
1 \\
84.5 \\
85 \\
84.75\end{array}$ & $\begin{array}{c}-0.1 \\
.15 \\
.15 \\
.15 \\
8.1 \\
8.1 \\
8.1 \\
.44 \\
.44 \\
.44 \\
73.6 \\
73.4 \\
73.5\end{array}$ & $\begin{array}{l}\overline{0} \\
.03 \\
.02 \\
.025 \\
6.1 \\
6.1 \\
6.1 \\
.29 \\
.29 \\
.29 \\
78.2 \\
72.1 \\
75.15\end{array}$ & $\begin{array}{c}\overline{0} .06 \\
.06 \\
.05 \\
.055 \\
1.9 \\
1.9 \\
1.9 \\
.29 \\
.29 \\
.29 \\
90.9 \\
91 \\
90.95\end{array}$ \\
\hline 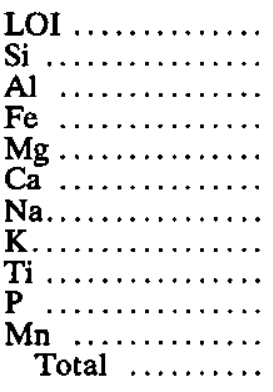 & $\begin{array}{r}17.24 \\
40.64 \\
14.17 \\
4.97 \\
4.81 \\
12.94 \\
1.42 \\
3.11 \\
.54 \\
.38 \\
.17 \\
100.39\end{array}$ & $\begin{array}{l}16.52 \\
33.73 \\
16.5 \\
5.58 \\
5.97 \\
9.73 \\
2.39 \\
3.41 \\
.58 \\
.28 \\
.18 \\
94.87\end{array}$ & $\begin{array}{c}13.93 \\
42.2 \\
17.59 \\
6.19 \\
4.85 \\
7.8 \\
2.08 \\
3.54 \\
.7 \\
.46 \\
.19 \\
99.53\end{array}$ & $\begin{array}{r}13.52 \\
41.74 \\
22.04 \\
7.35 \\
2.44 \\
5.36 \\
1.09 \\
3.44 \\
.59 \\
.8 \\
.16 \\
98.53\end{array}$ & $\begin{array}{r}25.33 \\
23.07 \\
8.32 \\
31.35 \\
4.74 \\
3.3 \\
.42 \\
1.23 \\
.32 \\
.31 \\
1.65 \\
100.04\end{array}$ & $\begin{array}{r}21.09 \\
29.8 \\
8.24 \\
33.65 \\
2.89 \\
1.97 \\
.16 \\
1.02 \\
.35 \\
.41 \\
.28 \\
99.86\end{array}$ & $\begin{array}{c}9.12 \\
59.91 \\
14.52 \\
4.6 \\
2.33 \\
5.7 \\
1.52 \\
2.14 \\
.6 \\
.21 \\
.22 \\
100.87\end{array}$ \\
\hline n.w. & 108 & 117 & 134 & 149 & 63 & 56 & 97 \\
\hline 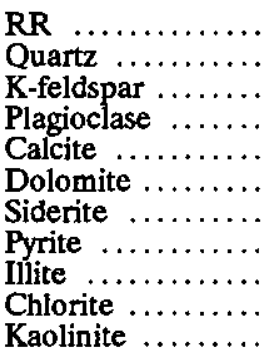 & $\begin{array}{r}27 \\
14 \\
0 \\
1 \\
12 \\
9 \\
0 \\
0 \\
44 \\
13 \\
5\end{array}$ & $\begin{array}{r}10 \\
4 \\
0 \\
2 \\
4 \\
18 \\
0 \\
0 \\
44 \\
15 \\
6\end{array}$ & $\begin{array}{r}14 \\
9 \\
0 \\
2 \\
4 \\
8 \\
0 \\
0 \\
49 \\
12 \\
10\end{array}$ & $\begin{array}{r}2 \\
0 \\
0 \\
1 \\
0 \\
0 \\
0 \\
0 \\
69 \\
20 \\
8\end{array}$ & $\begin{array}{r}29 \\
23 \\
0 \\
1 \\
1 \\
0 \\
27 \\
0 \\
40 \\
9 \\
0\end{array}$ & $\begin{array}{r}33 \\
30 \\
0 \\
2 \\
0 \\
0 \\
13 \\
0 \\
38 \\
0 \\
18\end{array}$ & $\begin{array}{r}11 \\
49 \\
0 \\
4 \\
1 \\
0 \\
0 \\
0 \\
30 \\
7 \\
9\end{array}$ \\
\hline
\end{tabular}

generally contain large percentages of total iron as $\mathrm{Fe}_{2} \mathrm{O}_{3}$ (table 2), although this is not the only mineralogical site for the iron.

Illite and other clay and layer-silicate minerals generally comprise between 30 to 60 percent of the samples. Illite is by far the most abundant clay mineral present (table 2); generally, illite is twice as abundant as chlorite. One exception occurs in a siderite-rich sample from the blackband interval, sample 907.6, which contains no detectable illite. Kaolinite is a common clay mineral constituent, but it is generally less abundant than chlorite and illite.

\section{AMMONIUM ANALYSIS}

Detection of mineral-bound ammonium in organicmatter-rich rocks is an inferential procedure because analytical techniques still need to be refined. Nitrogen analysis by chemical methods can provide estimates of the total nitrogen present; however, identification of the relative amounts of organic and inorganic nitrogen components is difficult. Detection of inorganic versus organic nitrogen compounds by differential heating in $\mathrm{C}-\mathrm{H}-\mathrm{N}$ analysis has been proposed (Kydd and Levinson, 1986), but this technique can be hampered by the presence of 

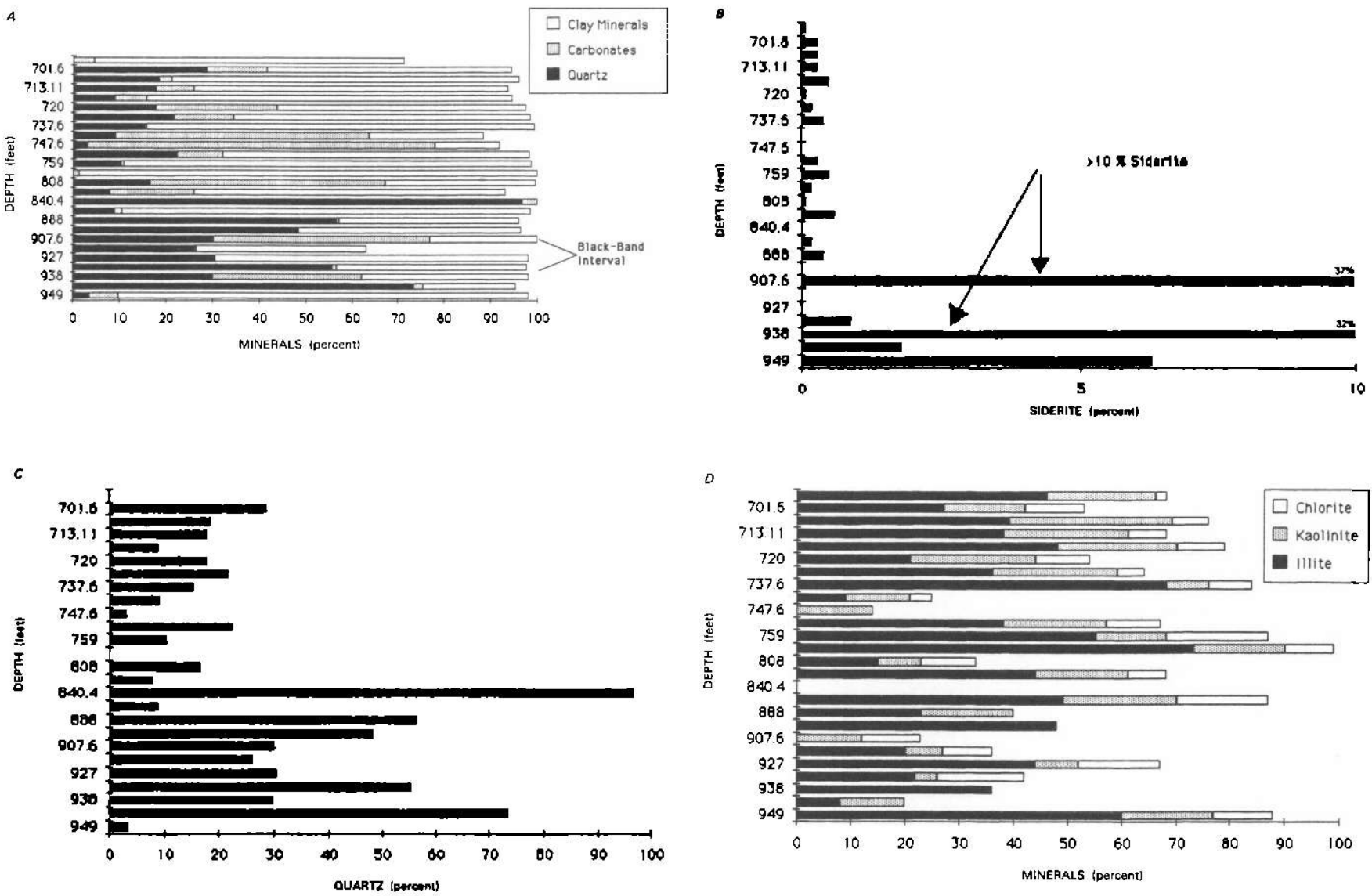

Figure 2. Mineralogical analysis for drill core LEOT-1-82 from X-ray diffraction data. $A$, Mineralogy versus depth. $B$, Siderite versus depth. $C$, Quartz content versus depth. $D$, Clay and layer silicate mineral content versus depth.

ammonia in the kerogen fraction. The ion chromatograph appears to be the best technique to date to distinguish mineral-bound ammonium, but it is still a relatively new technique and requires $\mathrm{HF}-\mathrm{HCl}$ digestion of the sample.

Infrared spectral analysis is a direct measure of $\mathrm{NH}_{4}{ }^{+}$bonds within minerals. However, sample pretreatment is required to remove carbonate because of the overlapping carbonate band. This procedure may in turn remove part of the $\mathrm{NH}_{4}{ }^{+}$. In the near-infrared range, $\mathrm{NH}_{4}{ }^{+}$bands do not overlap with carbonate bands, but they can be masked by the presence of organic matter or opaque minerals. XRD offers the most definitive evidence of mineral-bound ammonium by distinguishing changes in the crystal structure. However, XRD has low sensitivity to ammonium concentrations because the differences in atomic radii between ammonium and other substituting ions in illite are small. Also, the presence of other substituting cations with smaller ionic radii, such as sodium, can average out the effect of the ammonium cation. Since no single analytical technique can positively identify inorganic ammonium, an integration of several techniques is necessary to develop a consistent pattern.
Midinfrared (MIR) techniques have been used previously in organic-matter-rich areas, such as sedimentary exhalative deposits, to determine the presence of ammonium (Sterne and others, 1982). However, the high concentrations of siderite in the Cumnock Formation (fig. 2) have complicated analysis by MIR techniques. No correlation is seen between the concentration of ammonium as measured by the IC technique and the MIR technique (see fig. 4). Siderite is highly resistant to dissolution and does not appear to be removed by the standard sodium acetate treatment. MIR analysis showed the presence of a second carbonate band and XRD indicated siderite was still present. The diagnostic $7-\mu \mathrm{m}$ band was considerably broadened in these samples. Recently, a revised sodium acetate procedure has been proposed to remove siderite. However, such increased digestion makes it unlikely that the MIR technique can be used quantitatively; rather, MIR in these situations can be used qualitatively to confirm the presence of bound ammonium.

At present, the IC is the best analytical technique for estimating content of mineral-bound ammonium in the Cumnock samples. The IC values (fig. 3) seem to fall into three categories: the absence of detectable ammo- 

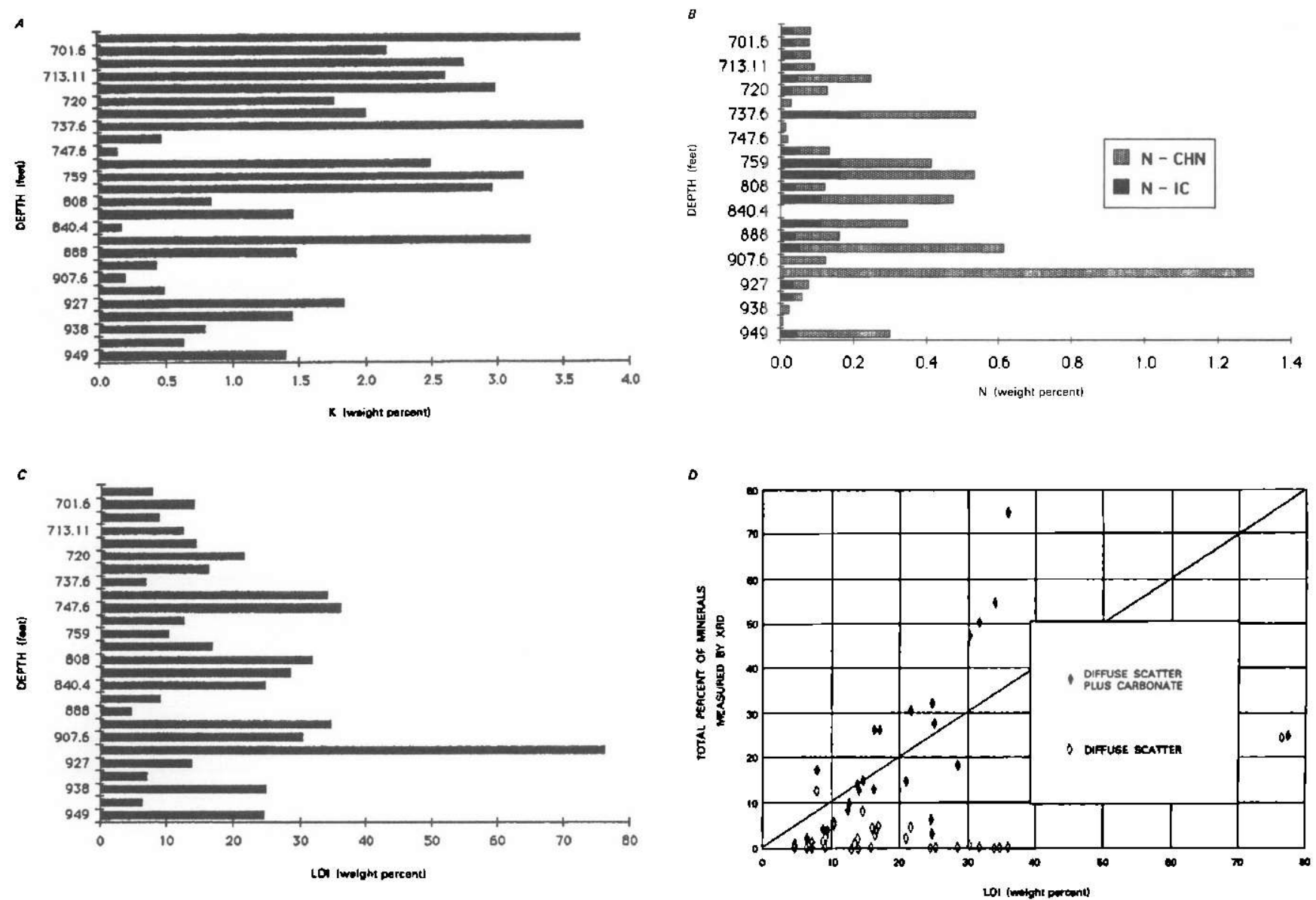

Figure 3. Geochemical analyses for drill core LEOT-1-82. $A$, Potassium content versus depth. $B$, Nitrogen content as measured by ion chromatograph and $\mathrm{C}-\mathrm{H}-\mathrm{N}$ techniques versus depth. $C$, Loss on ignition versus depth. $D$, Comparison of loss on ignition to diffuse scattering measured as percent of total mineral content recognized by XRD and diffuse scattering plus carbonate content measured as percent of total mineral content recognized by XRD.

nium values, the presence of trace amounts of ammonium, generally less than 0.06 weight percent $\mathrm{NH}_{4}{ }^{+}$, and measurable values of ammonium between 0.06 and 0.40 weight percent $\mathrm{NH}_{4}{ }^{+}$. Only the last category should be counted as definitive evidence for mineral-bound ammonium. By use of this criterion, 15 of the 34 samples appear to have evidence of bound ammonium. Also, the NCCM drill core (fig 1; table 2) appears to contain a much greater amount of bound ammonium than the LEOT drill core, although the LEOT core was sampled more intensively.

The question of whether the ammonium is organically or inorganically bound cannot be answered definitively for these samples, because no direct evidence of ammonium was observed in the XRD analysis. Recent work on underclays from anthracite in Pennsylvania has shown that the bound ammonium in the $<1-\mu \mathrm{m}$ size fraction (E. Daniels, 1987, personal commun.) is mainly detectable in XRD. However, several lines of reasoning suggest that mineral-bound ammonium is being detected by the IC. There is a surprising absence of ammonium in the blackband interval as reported by IC. In contrast, total nitrogen values measured by $\mathrm{C}-\mathrm{H}-\mathrm{N}$ and high ammonia $\left(\mathrm{NH}_{3}\right)$ values reported by Reinemund (1955) indicate a large fraction of organic nitrogen (table 2; fig. 3 ). The LOI values are also generally higher in the blackband interval than in the rest of the drill core, suggesting the presence of organic material. Sample LEOT 920.6 has over 75 percent loss on ignition (table 2). Another estimate of the organic matter content can be made by summing the diffuse scattering percentage of the X-ray diffraction. To be comparable to LOI, the diffuse scattering component from XRD was added to carbonate values, because $\mathrm{CO}_{2}$ is lost on ignition (fig. 3). A comparison of ammonium values by the IC and LOI shows a general inverse relationship, tempered by the observation that samples that have low IC values may also have low LOI values.

If the ammonium is bound in the mineral structure, then it should occur in a mineral that has a suitable site for cation substitution. The potassium site in illite is the most likely repository for ammonium. Illite, however, is 

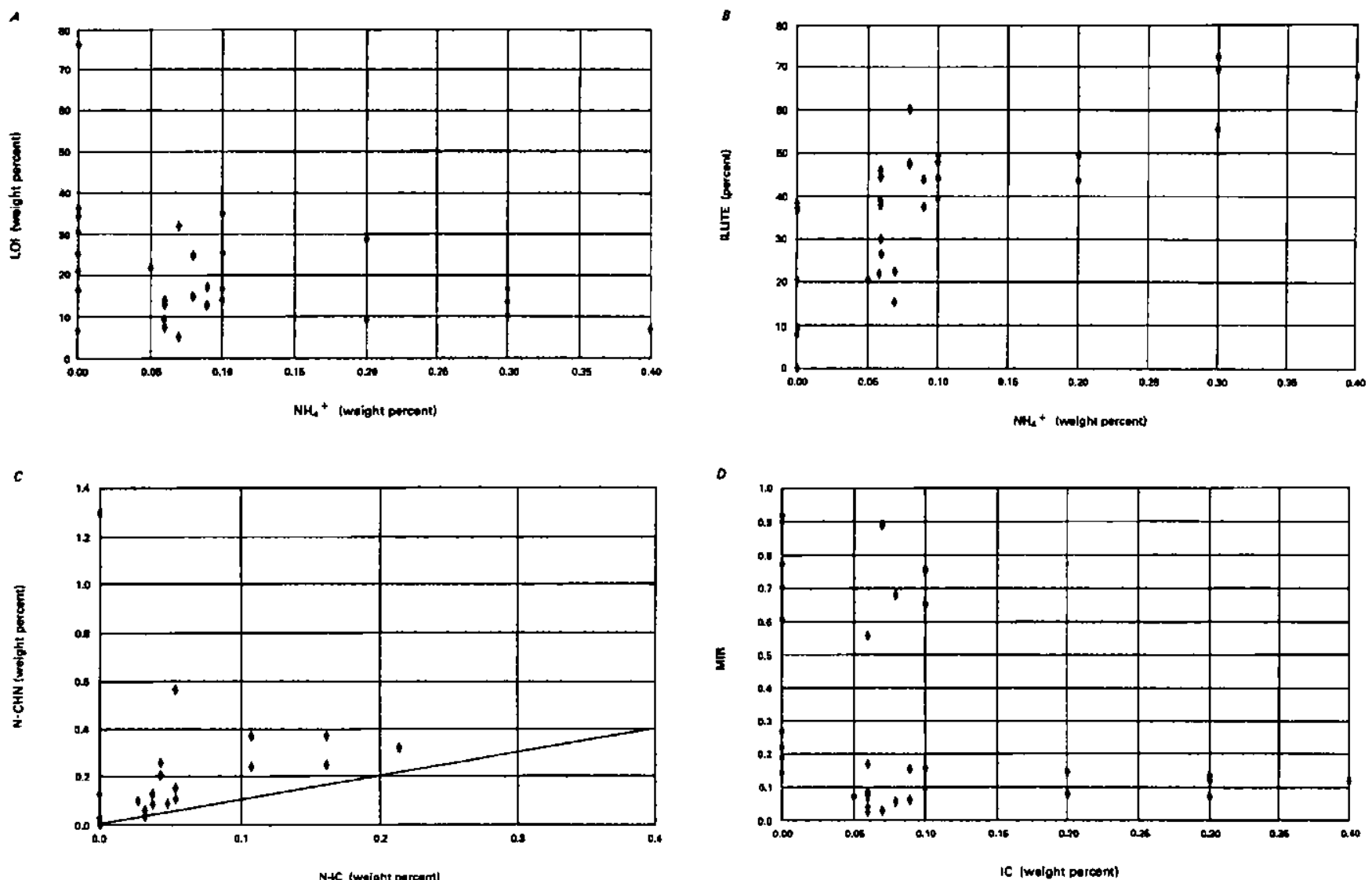

Figure 4. Comparisons of geochemical and mineralogical techniques. $A_{1} \mathrm{NH}_{4}{ }^{+}$content as measured by the ion chromatograph versus loss on ignition. $\mathrm{B}, \mathrm{NH}_{4}^{+}$content as measured by the ion chromatograph versus illite content. $C$, Comparison of nitrogen values for elemental $\mathrm{C}-\mathrm{H}-\mathrm{N}$ analysis versus nitrogen content derived from the ion chromatograph. $D$, Comparison of midinfrared to the ion chromatograph.

not especially concentrated in the blackband interval and has the same general distribution with depth as potassium (fig. 3). A comparison of illite composition and the IC ammonium values shows a general positive relation (fig. 4). Again, there is no reason to preclude high illite concentrations without ammonium.

A third piece of evidence comes from comparison of nitrogen values determined by the IC technique with nitrogen determined by the C-H-N technique (table 1 ). The general positive correlation of the techniques (fig. 4) indicates that they are in approximate agreement. However, all but one of the C-H-N nitrogen values are consistently higher than the IC nitrogen values (that is, occurring above the 1:1 line in fig. $4 C$ ). The largest $\mathrm{C}-\mathrm{H}-\mathrm{N}$ value is in the blackband interval and indicates the high proportion of organic nitrogen in these samples (table 2). Given the analytical precision of the $\mathrm{C}-\mathrm{H}-\mathrm{N}$ nitrogen measurement (table 1), this discrepancy is believed to be a geologic feature rather than an analytical error. The presence of organic ammonia presumably accounts for the consistently higher values determined from the C-H-N analysis compared to the IC analysis.
From this discrepancy between the two techniques, one can surmise that the majority of nitrogen in the interval away from the blackbands exists as mineral-bound ammonium, whereas in the blackband interval nitrogen is predominantly in the organic fraction.

\section{DISCUSSION}

Geochemical analysis of the drill core from the Cumnock Formation has revealed several interesting features about the distribution of mineral-bound ammonium in rocks of Mesozoic age. Our analysis generally agrees with the earlier results of Murphy and Vilbrandt (1930) and Reinemund (1955) in showing that the samples from this area are enriched in nitrogen and phosphorus. The highest phosphorus values occur close to the blackband interval and occur concurrently with high values for loss on ignition and high nitrogen values in $\mathrm{C}-\mathrm{H}-\mathrm{N}$ analysis. Such an interval would be likely to contain organic nitrogen in the form of ammonia, $\mathrm{NH}_{3}$.

Enrichment in the mineral-bound or inorganic ammonium appears to occur in different areas than does 
enrichment in organic nitrogen. Direct detection of the bound ammonium in these rocks is hampered because of competing influences of other mineral constituents. Infrared detection is made difficult by the presence of opaque organic components, and X-ray detection is hampered by low concentrations. However, the ion chromatograph is able to detect ammonium in these rocks and the results agree relatively well with $\mathrm{C}-\mathrm{H}-\mathrm{N}$ analysis.

On the basis of the ion chromatograph analyses, the ammonium may be bound inorganically throughout the stratigraphic interval of the Cumnock Formation, rather than being concentrated in the blackband interval. The average ammonium content in these intervals is rather low, generally less than 0.1 weight percent. However, the highest ammonium concentrations occur in an interval roughly 60 to $100 \mathrm{~m}$ (200 to $328 \mathrm{ft}$ ) above the blackband in both the LEOT and NCCM drill cores. The direct cause of this distribution is unknown at this time, but the presence of large amounts of illite would provide a mineralogical site favorable for substitution.

Previous work with ammonium in hot springs systems indicates that ammonium is transported by hydrothermal solutions from organic-matter-rich source rocks to near-surface rocks containing minerals with a suitable ammonium substitution site, generally feldspar (buddingtonite) (White and others, 1971). A similar transport and redeposition mechanism may have occurred in the Mesozoic rocks of the Deep River basin as well. In this case the organic-matter-rich rocks of the blackband may be the nitrogen source; sedimentary units that are potassium rich, because of a higher proportion of illite in the rock, appear to be preferred deposition sites for ammonium. The cause of ammonium transport may have been from hydrothermal circulation related to the nearby Jurassic diabase intrusives.

The presence of ammonium in the Deep River basin suggests that bound ammonium may be present in the other Mesozoic basins as well. Hatcher and Romankiw (1985) have noted that total nitrogen values are higher in phytoclasts from the early Mesozoic basins of the Eastern United States than in any other sample localities. Analysis for ammonium should become part of the routine analytical procedures for rocks from the basins. The presence of bound ammonium in the Mesozoic rocks may indicate the nitrogen-bearing transport of material through the basin. The elevated nitrogen values for these rocks from both the bound ammonium and phytoclast sources suggest that the nitrogen flux through these basins is greater than previously realized.

\section{SUMMARY}

High nitrogen concentrations observed previously in the Mesozoic rocks of the Cumnock Formation in the
Deep River basin of North Carolina have been confirmed by our analysis. However, inorganic ammonium, most likely bound to a layer silicate, appears to constitute a sizable fraction of the total ammonium content. No direct detection of the ammonium site within a mineral was achieved. The presence of siderite and opaque minerals in the interval hinders detection by infrared analysis; in $\mathrm{X}$-ray diffraction, the low concentration of ammonium and the variability of the illite host hinder detection. Analysis by the ion chromatograph for $\mathrm{NH}_{4}{ }^{+}$appears most reliable. The maximum content of ammonium observed in any sample was 0.4 weight percent in an interval $60 \mathrm{~m}(200 \mathrm{ft})$ above the organic-matter-rich blackband interval. Elemental C-H-N analyses for total nitrogen give consistently higher results than the ion chromatograph, suggesting that there is an organic fraction of ammonium in the blackband interval. Other studies have indicated that the nitrogen content of phytoclasts in the Mesozoic rocks is higher than in most other settings. The observed values of inorganic ammonium in the Cumnock Formation away from the organicmatter-rich zone suggest that layer silicates and other potassium-bearing minerals may have significant concentrations of ammonium and may shed light on the transport and enrichment of nitrogen-bearing materials throughout the early Mesozoic basins of eastern North America.

\section{SELECTED REFERENCES}

Altaner, S.P., Krohn, M.D., and Klock P.R., 1985, Analytical techniques for determining bound ammonium (abs.): Geological Society of America Abstracts with Programs, v. 17, p. 512.

Cooper, J.E., and Abedin, K.Z., 1981, The relationship between fixed ammonium-nitrogen and potassium in clays from a deep well on the Texas gulf coast: Texas Journal of Science, v. 33, p. 103-111.

Din, V.K., and Jones, G.C., 1978, The determination of total carbon and combined water in silicates using a $\mathrm{C}, \mathrm{H}, \mathrm{N}$ elemental analyzer: Chemical Geology, v. 23, no. 4, p. 347-352.

Erd, R.C., White, D.E., Fahey, J.J., and Lee, D.E., 1964, Buddingtonite, an ammonium feldspar with zeolitic water: American Mineralogist, v. 49, no. 7, p. 831-850.

Gulbrandsen, R.A., 1974, Buddingtonite, ammonium feldspar, in the Phosphoria Formation, southeastern Idaho: Journal of Research of the U.S. Geological Survey, v. 2, p. 693-697.

Hatcher, P.G., and Romankiw, L.W., 1985, Nuclear magnetic resonance studies of organic-matter-rich sedimentary rocks of some early Mesozoic basins of the Eastern United States, in Robinson, G.R., Jr., and Froelich, A.J., eds., Proceedings of the second U.S. Geological Survey workshop on the early Mesozoic basins of the Eastern United States, p. 61-64. 
Higashi, S., 1982, Tobelite, a new ammonium dioctahedral mica: Mineralogical Journal, v. 11, no. 3, p. 138-146.

Hori, H., Nagashima, K., Yamada, M., Miyawaki, R., and Marubashi, T., 1986, Ammonioleucite, a new mineral from Tatarazawa, Fujioka, Japan: American Mineralogist, v. 71, p. 1022-1027.

Hosterman, J.W., and Whitlow, S.I., 1981, Clay mineralogy of Devonian shales in the Appalachian Basin: U.S. Geological Survey Open File Report 81-585, 170 p.

Johnson, R. G., 1984, Trace element analysis of silicates by means of energy-dispersive X-ray spectrometry: X-ray Spectrometry, v. 13, no. 2, p. 64-68.

Karyakin, A.V., Volynets, V.F., and Kriventsova, O., 1973, Investigation of nitrogen compounds in micas by infrared spectroscopy: Geochemical International, v. 10, no. 2, p. 326-329.

Klock, P.R., and Lamothe, P.J., 1986, Determination of ammonium in a buddingtonite sample by jon-chromatography: Talanta, v. 33, no. 6 , p. $495-498$.

Krohn, M.D., 1986, Spectral properties (0.4 to 25 microns) of selected rocks associated with disseminated gold and silver deposits in Nevada and Idaho: Journal of Geophysical Research, v. 91, no. 1, B. 1, p. 767-783.

Krohn, M.D., and Altaner, S.P., 1987, Near-infrared detection of ammonium minerals: Geophysics, v. 52, no. 7, p. 924-930.

Krohn, M.D., and Bethke, P.M., 1984, Near-infrared spectral features of ammonium minerals: Applications for remote sensing of hot spring deposits (abs.): Geological Society of America Abstracts with Programs, v. 16, p. 566.

Kydd, R.A., and Levinson, A.A., 1986, Ammonium halos in lithogeochemical exploration for gold at the Horse Canyon carbonate-hosted deposit, Nevada, U.S.A.: Use and limitations: Applied Geochemistry, v. 1, p. 407-417.

Loughnan, F.C., Roberts, F.I., and Lindner, A.W., 1983, Buddingtonite $\left(\mathrm{NH}_{4}{ }^{-}\right.$-feldspar) in the Condor oilshale deposit, Queensland, Australia: Mineralogical Magazine and Journal of the Mineralogical Society, v. 47, p. 327-334.

Mortland, M.M., Fripiat, J.J., Chaussidon, J., and Uytterhoeven, J., 1963, Interaction between ammonia and the expanding lattices of montmorillonite and vermiculite: Journal of Physical Chemistry, v. 67, p. 248-258.

Murphy, A., and Vilbrandt, F.C., 1930, Fertilizer value of some North Carolina shales, in Bryson, H.J., The mining indus- try in North Carolina during 1927 and 1928: North Carolina Department of Conservation and Development, Economic Paper 63, p. 65-72.

Norrish, K., and Hutton, J.T., 1969, An accurate X-ray spectrographic method for the analysis of a wide range of geological samples: Geochimica et Cosmochimica Acta, v. 33 , no. $1-6$, p. $431-453$.

Paxton, S.T., 1983, Relationships between Pennsylvanian-age lithic sandstone and mudrock diagenesis and coal rank in the central Appalachians: Pennsylvania State University, unpublished Ph.D. thesis, 503 p.

Perkin-Elmer, 1974, Instruction manual, Model 240 elemental analyzer: Norwalk Connecticut, p. 2-1 to 3-9.

Reinemund, J.A., 1955, Geology of the Deep River Coal Field, North Carolina: U.S. Geological Survey Professional Paper 246, 159 p.

Skinner, N.G., Brown, F.W., and Flanagan, F.J., 1981, The $\mathrm{H}_{2} \mathrm{O}^{+}$contents of some geochemical standards predicted by a calibration line: Geostandards Newsletter, v. 5, no. 1, p. 3-11.

Sterne, E.J., Reynolds, R.C., and Zantop, H., 1982, Natural ammonium illites from black shales hosting a stratiform base metal deposit, DeLong Mountains, northern Alaska: Clays and Clay Minerals, v. 30, no. 3, p. 161-166.

Sterne, E.J., Zantop, H., and Reynolds, R.C., 1984, Clay mineralogy and carbon-nitrogen geochemistry of the Lik and Competition Creek zinc-lead-silver prospects, DeLong Mountains, Alaska: Economic Geology, v. 79, p. 1406-1411.

Stevenson, F.J., 1962, Chemical state of the nitrogen in rocks: Geochimica et Cosmochimica Acta, v. 26, p. 797-809.

Taggart, J.E., Jr., and others, in press, Analysis of geologic materials by wavelength dispersive $\mathrm{X}$-ray fluorescence spectrometry, in Methods of geochemical analysis: U.S. Geological Survey Bulletin.

Tertian, R., and Claisse, F., 1982, Principles of quantitative $\mathrm{X}$-ray fluorescence analysis: London, Heyden and Son Ltd., p. 323-333.

Vedder, W., 1965, Ammonium in muscovite: Geochimica et Cosmochimica Acta, v. 29, p. 221-228.

Von Damm, K.L., Edmond, J.M., Measures, C.I., and Grant, B., 1985, Chemistry of submarine hydrothermal solutions at Guaymas Basin, Gulf of California: Geochimica et Cosmochimica Acta, v. 49, p. 2221-2237.

White, D.E., Muffler, L.J.P., and Truesdell, A.H., 1971, Vapordominated hydrothermal systems compared with hot-water systems: Economic Geology, v. 66, p. 75-97. 


\title{
COMPARATIVE MINERALOGY OF CLAY-RICH STRATA IN SELECTED EARLY MESOZOIC BASINS OF THE EASTERN UNITED STATES
}

\author{
R.M. Gottfried and R.K. Kotra
}

\begin{abstract}
The focus of this study is on the discrimination of clay polytypes in gray and black lacustrine units of four early Mesozoic basins in the Eastern United States. X-ray diffraction analysis shows that illite is present in almost all samples and that chlorite is also widely distributed. Smectites occur in many samples from the Hartford basin but are absent or sparse in the Newark, Gettysburg, and Culpeper basin samples. Whereas kaolinite is present in many samples from the Culpeper basin, it is found only in a few samples outside this basin. One Hartford basin sample contains palygorskite. These mineralogical differences may be related to variations in climatic conditions and (or) paleohydrology. For example, the assemblage palygorskite-smectite and illite-smectite mixed-layer clay found in an East Berlin Formation sample from the Hartford basin suggests deposition under dry evaporitic conditions, contrasted with possibly more humid conditions for several Culpeper basin samples, as suggested by the presence of kaolinite.

The highest illite crystallinity values were obtained for samples from the Hartford basin, indicating a lower diagenetic stage, assuming only burial effects during diagenesis. For most samples, a polytype assessment reveals $1 \mathrm{M}_{\mathrm{d}}$ illite, with only minor occurrences of the $2 \mathrm{M}$ polytype in the $<2-\mu$ fraction. The $2 \mathrm{M}$ polytype is more prevalent in coarser size fractions; thus, the illite in the $<2-\mu$ fraction of the lacustrine units is interpreted to be authigenic. Samples where chlorite polytypes were also analyzed gave similar results.
\end{abstract}

\section{INTRODUCTION}

Recent interest in the early Mesozoic basins of eastern North America has led to increased knowledge of the stratigraphy, sedimentology, and tectonics of individual basins (for example, Olsen, 1984; Gore, 1983; Smoot and others, 1985). However, few studies have related the clay mineralogy and geochemistry to sedimentary and diagenetic processes (April, 1978, 1980; Schamel and Hubbard, 1985). The goal of our overall study is to understand the clay mineralogy and geochemistry of the sedimentary rocks in order to compare the burial and diagenetic histories of these basins. Fine-grained Mesozoic lithologies vary from fluvial, flood-plain and playalake red-bed sequences to gray, green, and black lacustrine sequences. The present research is focused on the discrimination of clays in gray and black lacustrine units of the Hartford, Newark, Gettysburg, and Culpeper basins. This includes the identification and distribution of specific clay minerals, illite crystallinity determination, and polytype analyses.

\section{METHODS}

Fifty samples were selected from Upper Triassic and Lower Jurassic strata in the four basins for initial analysis. Most samples represent the lacustrine facies, particularly the gray mudrocks and shales. The samples were referenced to Lower Jurassic basalt flows that are common to all four basins. Table 1 shows the relative position of the formations from the four basins and the formations sampled.

Following the procedures of Starkey and others (1984) for preparation of clay size fractions, both oriented and randomly oriented samples were prepared. Samples having high carbonate content were treated with $1 \mathrm{~N} \mathrm{HCl}$ for 5 minutes. A few black shale samples with high organic content (3 percent total organic carbon) were treated with 5 percent $\mathrm{H}_{2} \mathrm{O}_{2}$. Each clay size fraction was treated with ethylene glycol, heated to $350^{\circ} \mathrm{C}$ for 1 hour, reheated to $550{ }^{\circ} \mathrm{C}$ for 1 hour, and analyzed by $\mathrm{X}$-ray diffraction (XRD) after each treatment. Special care was taken to distinguish between chlorite and kaolinite. The disappearance of the 7.15-Angstrom (A) peak upon heating to $550{ }^{\circ} \mathrm{C}$ identifies kaolinite. The resolution of the 004 chlorite peak at $3.55 \mathrm{~A}$ from the 002 kaolinite peak at $3.58 \mathrm{~A}$ aided in the discrimination of these two minerals. When resolution of those peaks was impossible, boiling a $<2-\mu$ split with $1 N \mathrm{HCl}$ to remove chlorite was used, following the method of Brindley and Brown (1980).

The illite crystallinity index was determined by measuring the width of the illite 001 peak at half its height and expressing the result in terms of the Bragg angle, $2 \Theta$ (Kisch, 1983). Higher index values indicate a less ordered structure and thus a lower diagenetic stage, assuming that the minerals were affected only by burial. Because internal standards to correct for machinedependent effects were not used, the crystallinity values reported should be compared only qualitatively with values of other workers. Randomly oriented samples were used in the identification of illite and chlorite polytypes.

\section{RESULTS}

\section{Clay Mineralogy}

Table 2 shows the distribution of various clay minerals by basin and formation. Illite and chlorite are 
Table 1. Correlation of stratigraphic units in the Hartford, Newark, Gettysburg, and Culpeper basins [ $x$, units sampled for clay mineralogy in this study]

\begin{tabular}{|c|c|c|c|c|}
\hline & Hartford basin & Newark basin & Gettysburg basin & Culpeper basin \\
\hline 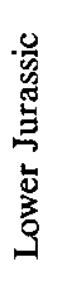 & $\begin{array}{l}\text { Portland Formation }(x) \\
\text { Hampden Basalt } \\
\text { East Berlin Formation (x) } \\
\text { Holyoke Basalt } \\
\text { Shuttle Meadow } \\
\quad \text { Formation (x) } \\
\text { Talcott Basalt }\end{array}$ & $\begin{array}{l}\text { Boonton Formation } \\
\text { Hook Mountain Basalt } \\
\text { Towaco Formation (x) } \\
\text { Preakness Basalt } \\
\text { Feltville Formation (x) } \\
\text { Orange Mountain } \\
\quad \text { Basalt }\end{array}$ & $\begin{array}{l}\text { Gettysburg Formation } \\
\text { Basalt at Aspers }\end{array}$ & $\begin{array}{l}\text { Waterfall Formation (x) } \\
\text { Sander Basalt } \\
\text { Turkey Run Formation } \\
\text { Hickory Grove Basalt } \\
\text { Midland Formation (x) } \\
\text { Mount Zion Church } \\
\text { Basalt }\end{array}$ \\
\hline 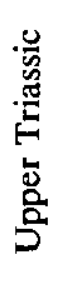 & New Haven Arkose & $\begin{array}{l}\text { Passaic Formation } \\
\text { Lockatong Formation (x) } \\
\text { Stockton Formation }\end{array}$ & $\begin{array}{c}\text { Heidlersburg } \\
\text { Sandstone } \\
\text { Member }(x) \\
\text { New Oxford Formation }\end{array}$ & $\begin{array}{l}\text { Catharpin Creek } \\
\text { Formation } \\
\text { Balls Bluff Siltstone (x) } \\
\text { Manassas Sandstone }\end{array}$ \\
\hline
\end{tabular}

Table 2. Distribution of clay minerals by formation or member

$[+$, most samples; $+r$, only one sample; - , not found)

\begin{tabular}{lllll}
\hline Basin and Formation or Member & illite Smectite & Chlorite & Kaolinite \\
\hline Culpeper & & & & \\
Waterfall Formation & + & - & + & + \\
Midland Formation & + & - & + & + \\
Balls Bluff Siltstone & + & $+r$ & + & + \\
Gettysburg & & & & \\
Heidlersburg Sandstone & + & - & + & - \\
$\quad \begin{array}{l}\text { Member of the Gettysburg } \\
\text { Formation }\end{array}$ & & & & \\
Newark & & & & \\
Towaco Formation & + & - & + & - \\
Feltville Formation & + & - & + & - \\
Lockatong Formation & + & - & + & - \\
Hartford & & & & \\
Portland Formation & + & + & + & $+r$ \\
East Berlin Formation & \\
Shuttle Meadow Formation & + & + & + & $+r$ \\
\hline
\end{tabular}

${ }^{1}$ Major mixed-layer clay component.

present in most samples. This is represented in the table by the occurrence of these minerals in all formations analyzed, although not necessarily in every sample in each formation. Palygorskite is tentatively identified in one East Berlin Formation sample on the basis of XRD and chemical analysis of the clay fraction.

Both smectites and mixed-layer clays (for example, illite-smectite, chlorite-smectite) are found in the Hartford basin samples and are the predominant clays in the East Berlin Formation. In contrast, they are not as abundant in the other basins. Kaolinite is found in the clay fraction of all Culpeper basin samples representing all three formations sampled. It was found in only two samples outside this basin (one Portland Formation sample and one East Berlin Formation sample), and in both cases it was a predominant phase in the silt rather than in the clay fraction, suggesting a detrital origin. The occurrence of kaolinite in the Culpeper basin samples may be provenance related or may indicate differences in climatic or paleohydrologic conditions.

\section{Illite Crystallinity}

The illite crystallinity was calculated for the $<2-\mu$ fractions, except for the Portland Formation samples, where the $<0.5-\mu$ fraction was utilized to determine the interstratification ratio for the samples (Srodon, 1980). Table 3 summarizes the results from 20 samples analyzed; all values are reported for the $<2-\mu$ fraction. The illite crystallinity values $\left(\Delta^{\circ} 2 \Theta\right)$ obtained are lowest in the Newark and Gettysburg basin samples. Samples from the East Berlin Formation of the Hartford basin in particular have the highest values. The values ranged from $0.24^{\circ} 2 \Theta$ for a well-crystallized illite from the Lockatong Formation to a value of $0.61^{\circ} 2 \Theta$ for a clayey siltstone from the East Berlin Formation.

\section{Polytype Analyses}

The results of the $<2-\mu$ fraction illite polytype analyses are summarized in table 4 . The 3.74/2.58-A intensity ratio was used to determine the relative amounts of these polytypes (Velde and Hower, 1963; Brindley and Brown, 1980). The 112 reflection at $3.63 \mathrm{~A}$ and 112 at $3.07 \mathrm{~A}$ were also used to indicate the presence 
Table 3. Illite crystallinity for the $<2-\mu$ fraction of selected samples

\begin{tabular}{|c|c|c|c|}
\hline $\begin{array}{l}\text { Sample } \\
\text { number }\end{array}$ & Formation & Lithology & $\begin{array}{l}\text { Crystallinity in } \\
\Delta^{\circ} 2 \Theta(<2 \mu)\end{array}$ \\
\hline \multicolumn{4}{|c|}{ Culpeper basin } \\
\hline $\mathrm{PO}-41$. & Waterfall & Gray mudstone & 0.33 \\
\hline $\mathrm{CB}-13$. & Midland & Gray silty shale & .32 \\
\hline $\mathrm{CB}-15$ & Midland & Black shale & .32 \\
\hline $\mathrm{CB}-2 \ldots$ & Balls Bluff & Black shale & .27 \\
\hline $\mathrm{CB}-4$ & Balls Bluff & Gray mudstone & .35 \\
\hline $\mathrm{CB}-\mathrm{S}$ & Balls Bluff & Gray shale & .50 \\
\hline
\end{tabular}

Gettysburg basin

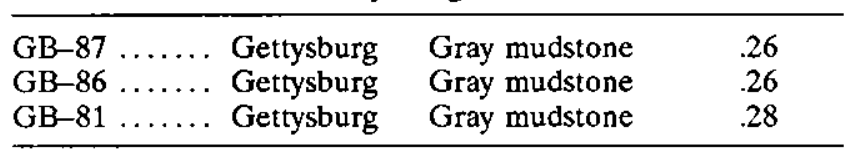

\begin{tabular}{llll}
\hline \multicolumn{3}{c}{ Newark basin } \\
\hline NB-24...... & Towaco & Gray silty shale & .28 \\
NB-25...... & Towaco & Black shale & .32 \\
NB-1084-2... & Feltville & Gray mudstone & .31 \\
NB-16....... & Lockatong & Gray mudstone & .24 \\
NB-26...... & Lockatong & Gray shale & .26 \\
\hline
\end{tabular}

\begin{tabular}{|c|c|c|c|}
\hline \multicolumn{4}{|c|}{ Hartford basin } \\
\hline PO-32. & Portland & Gray mudstone & .48 \\
\hline PO-34. & Portland & Gray mudstone & .55 \\
\hline PO-36. . & Portland & Gray mudstone & .41 \\
\hline $\mathrm{HB}-12 \ldots$ & East Berlin & $\begin{array}{l}\text { Gray clayey } \\
\text { siltstone }\end{array}$ & .61 \\
\hline $\mathrm{HB}-15$ & East Berlin & Gray mudstone & .55 \\
\hline PO-18. & $\begin{array}{l}\text { Shuttle } \\
\text { Meadow }\end{array}$ & Gray mudstone & .28 \\
\hline
\end{tabular}

of the $1 \mathbf{M}_{\mathbf{d}}$ illite polytype (Brindley and Brown, 1980). Analyses were run only on samples where peaks due to other phases were minimal. $1 \mathrm{M}_{\mathrm{d}}$ and $2 \mathrm{M}$ were the major illite polytypes identified. Most samples appear to be mixtures of the two types, with the $2 \mathrm{M}$ polytype predominant in the $<10-\mu$ fraction and $1 \mathrm{M}_{\mathrm{d}}$ dominant in the finer fractions. Analyses indicate that $1 \mathrm{M}_{d}$ illite predominates in the $<2-\mu$ fraction of the gray beds and that $1 \mathrm{M}_{\mathrm{d}}$ illite was almost the only illite polytype found in the $<0.5-\mu$ fraction of the Portland Formation samples.

Results of chlorite polytype analyses are given in table 5 . Chlorite polytypes were identified by $h 0 l$ reflections (Hayes, 1970; Brindley and Brown, 1980). Because relative intensities and d-values depend on compositions and are greatly affected by the presence of illite (and because the presence of illite makes identification of the IIb polytype difficult), samples were analyzed where illite peaks were absent or weak.
Table 4. Illite polytype analyses of selected samples

\begin{tabular}{|c|c|c|}
\hline Sample number & $\begin{array}{l}\text { Intensity ratio } \\
(3.74 \mathrm{~A} / 2.58 \mathrm{~A})\end{array}$ & $\frac{2 \mathrm{M}}{2 \mathrm{M}+1 \mathrm{M}_{\mathrm{d}}}$ (in percent) \\
\hline $\mathrm{CB}-2$. & 0.00 & 100 \\
\hline $\mathrm{CB}-4 \ldots \ldots \ldots \ldots \ldots$ & .09 & 15 \\
\hline $\mathrm{CB}-9 \ldots \ldots \ldots \ldots \ldots$ & .11 & 18 \\
\hline $\mathrm{CB}-13 \ldots \ldots \ldots \ldots$ & .27 & 70 \\
\hline $\mathrm{HB}-10 \ldots \ldots \ldots \ldots$ & .12 & 20 \\
\hline HB-15 $\ldots \ldots \ldots \ldots$ & .14 & 23 \\
\hline $\mathrm{HB}-17 \ldots \ldots \ldots \ldots$ & .15 & 25 \\
\hline $\mathrm{HB}-12 \ldots \ldots \ldots \ldots$ & .00 & 0 \\
\hline $\mathrm{NB}-16 \ldots \ldots \ldots \ldots$ & .29 & 95 \\
\hline NB-1084-2....... & .21 & 30 \\
\hline $\mathrm{NB}-24 \ldots \ldots \ldots \ldots$ & .14 & 23 \\
\hline
\end{tabular}

Table 5. Chlorite polytype analyses of selected samples

\begin{tabular}{lll}
\hline Sample number & \multicolumn{1}{l}{ d-spacing (in A) } & Polytype \\
\hline NB-6 $\ldots \ldots \ldots \ldots \ldots$ & $2.55,2.59,2.66$ & IIb \\
HB-10 $\ldots \ldots \ldots \ldots \ldots$ & $2.01,2.51,2.65$ & Ib \\
HB-12 $\ldots \ldots \ldots \ldots \ldots$ & $2.14,2.51,2.57,2.58$ & Ib and IIb \\
HB-15 $\ldots \ldots \ldots \ldots \ldots$ & $2.60,2.66$ & IIb \\
GB-87A $\ldots \ldots \ldots \ldots$ & $2.56,2.59,2.66$ & IIb \\
GB-81 $\ldots \ldots \ldots \ldots \ldots$ & $2.55,2.59,2.65$ & IIb \\
\hline
\end{tabular}

\section{DISCUSSION}

Clay mineral assemblages may provide insight into paleoenvironmental conditions. Smectite clays are present in many of the Hartford basin samples, particularly those from the East Berlin Formation, whereas mixed-layer illite-smectite plus discrete smectite are the predominant mineral assemblage in the few black shale samples. Currently, there is no evidence for the presence of smectite in the few black shale samples from the Culpeper basin. These differences, and the occurrence of kaolinite in the Culpeper samples, may be indicative of variations in climatic conditions or in paleohydrology (Velde, 1985). For example, the tentatively identified assemblage palygorskite-smectite and illite-smectite mixed-layer clay found in one East Berlin Formation sample suggests deposition under dry-evaporitic conditions, whereas the presence of kaolinite in several Culpeper basin samples suggests accumulation under more humid conditions. Alternatively, the different clay mineralogies may reflect differences in paleohydrology, such as ground-water saturation with alkaline brines in the East Berlin assemblage, in contrast to saturation by relatively fresh ground water in the Culpeper assemblage.

Kubler (1964) introduced the technique of measuring illite crystallinity as a diagenetic index, and subsequent workers (for example, Srodon and Eberl, 1984) have identified problems and refined the method. For example, illite may be detrital or authigenic, and the relative weathering contribution of detrital illite in each basin must be ascertained for a proper interpretation of 
Table 6. Illite/smectite diagenetic index for the $<0.5-\mu$ fraction of selected samples

\begin{tabular}{lrr}
\hline Sample number & $\begin{array}{c}\text { Crystallinity } \\
\text { index }\end{array}$ & ${ }^{\mathrm{I}_{r}}{ }^{1}$ \\
\hline PO-36 $\ldots \ldots \ldots \ldots \ldots$ & 0.44 & 1.0 \\
PO-32 $\ldots \ldots \ldots \ldots \ldots$ & .48 & 1.2 \\
Portland, Conn...... & .56 & 1.0 \\
PO-34 ............ & .60 & 2.0 \\
\hline
\end{tabular}

${ }^{1} I_{r}$ is the interstratification index, which equals $\frac{\mathrm{I}(001) / \mathrm{I}(003) \text { air dried }}{\mathrm{I}(001) / \mathrm{I}(003) \text { glycolated }}$

$I_{r}=1.0$, absence or low amount of expandable component;

$=1.5$, intermediate amount of expandable component:

$=2.0$, high amount of expandable component.

illite crystallinity values. Metastable polytypes such as the $1 \mathrm{M}_{\mathrm{d}}$ illite crystallize early and persist at low temperatures. Therefore, these polytypes are the ones most apt to form diagenetically in sediments by alteration and replacement by low-temperature solutions or by lowgrade metamorphism. The predominance of the $1 \mathrm{M}_{\mathrm{d}}$ polytype in the finer fractions (table 4) suggests that the $1 \mathrm{M}_{\mathrm{d}}$-illite is authigenic, and the predominance of the $2 \mathrm{M}$ polytype in the coarser fractions suggests that it represents detrital material (Velde and Hower, 1963).

Analysis of chlorite polytypes is hindered by the ubiquitous occurrence of illite. This is because of overlap of an illite peak and the chlorite IIb peak in the X-ray diffractograms. In the East Berlin Formation samples, where chlorite polytypes could be analyzed, both Ib and IIb polytypes are identified. The Ib polytype represents diagenetic chlorite and is consistent with the results obtained from the same rocks using illite polytypes. The IIb polytype implies a higher temperature origin (metamorphic, hydrothermal, etc.) for the chlorite and would be expected to be found in deeply buried sediments or as a detrital mineral. This is the polytype found in the samples from the Heidlersburg Sandstone Member of the Gettysburg Formation and the Lockatong Formation and is consistent with the above interpretation.

The crystallinity index, at temperatures less than $360^{\circ} \mathrm{C}$, has recently been recognized as being a function of the amount and composition of the expandable smectite layers interstratified with the illite (Weaver and Broekstra, 1984). Srodon (1980) previously had suggested that the identification of such components in the $<0.2-\mu$ fraction gives a diagenetic index independent of sample composition and grain size. A procedure to quantify the diagenetic index is summarized in Srodon and Eberl (1984). This technique was applied to four samples from the Portland Formation. Table 6 compares crystallinity values and $I_{r}$ (interstratification index) values of four Portland Formation samples. The samples are listed from the most northern site to the most southern.
These values suggest a thermal trend or differences in depth of burial. The samples from the northern portion of the basin appear to have been buried deeper or affected by higher temperatures. Organic geochemical studies also suggest a similar trend (for example, Kotra and others, this volume).

\section{CONCLUSIONS}

The results of this study show that the lacustrine shales and mudstones are primarily composed of illite and chlorite. Smectite is prevalent only in the Hartford basin. Kaolinite is present in samples from the Culpeper basin but absent from most other samples analyzed. These differences in the clay mineral assemblages are related to climate, provenance, hydrology, geochemical environment, and the influence of these upon diagenetic processes. Crystallinity analyses indicate that most samples represent a late diagenetic stage. Of the formations studied, the East Berlin Formation of the Hartford basin contains strata with a different clay mineralogy and crystallinity, compared to other formations within this or other basins. This suggests a difference in the processes operating in the East Berlin lakes and (or) during diagenesis.

\section{ACKNOWLEDGMENTS}

We thank Carol Popish, U.S. Geological Survey, for her assistance in the preparation of this paper. We thank Professor Sam Root, Wooster College, Wooster, Ohio, for providing the Gettysburg basin samples. We are indebted to A.J. Froelich, U.S. Geological Survey, Paul Olsen, Lamont-Doherty Geological Observatory of the Columbia University, Palisades, New York, and Nick McDonald, Westminster School, Simsbury, Connecticut, for their guidance in the field. We also thank Professor $\mathrm{L}$. Chang, University of Maryland, College Park, Maryland, for stimulating discussions on clay mineralogy.

\section{REFERENCES CITED}

April, R.H., 1978, Clay mineralogy and geochemistry of the Triassic?-Jurassic sedimentary rocks of the Connecticut Valley: Amherst, Mass., University of Massachusetts, unpublished Ph.D. thesis, 206 p.

- 1980, Regularly interstratified chlorite/vermiculite in contact metamorphosed redbeds, Newark Group, Connecticut Valley: Clays and Clay Minerals, v. 28, p. 1-11.

Brindley, G.W., and Brown, G., eds., 1980, Crystal structures of clay minerals and their X-ray identification: The Mineralogical Society, London, 495 p. 
Gore, P.J.W., 1983, Sedimentology and invertebrate paleontology of Triassic and Jurassic lacustrine deposits, Culpeper basin, Northern Virginia: Washington, D.C., The George Washington University, unpublished Ph.D. thesis, $356 \mathrm{p}$.

Hayes, J.B., 1970, Polytypism of chlorite in sedimentary rocks: Clays and Clay Minerals, v. 18, p. 285-306.

Kisch, H.J., 1983, Mineralogy and petrology of burial diagenesis (burial metamorphism) and incipient metamorphism in clastic rocks, in Larsen, G., and Chilingar, G.V., eds., Diagenesis in sediments and sedimentary rocks: Amsterdam, Elsevier, v. 2, p. 289-493.

Kubler, B., 1964, Les argiles, indicateurs de metamorphisme [Clays, indicators of metamorphism]: Revue de l'Institut Francais du Petrole, v. 19, p. 1093-1112.

Olsen, P.E., 1984, Comparative paleolimnology of the Newark Supergroup, a study of ecosystem evolution: New Haven, Connecticut, Yale University, unpublished Ph.D. thesis, $726 \mathrm{p}$.

Schamel, S., and Hubbard, I.G., 1985, Thermal maturity of Newark Supergroup basins from vitrinite reflectance and clay mineralogy (abs.): Bulletin of the American Association of Petroleum Geologists, v. 69, p. 1447.

Smoot, J.P., LeTourneau, P.M., Turner-Peterson, C., and
Olsen, P.E., 1985, Sandstone and conglomerate shoreline deposits in Triassic-Jurassic Newark and Hartford Basins of Newark Supergroup: Bulletin of the American Association of Petroleum Geologists, v. 69, p. 1449.

Srodon, J., 1980, Precise identification of the illite-smectite interstratifications by $\mathrm{X}$-ray powder diffraction: Clays and Clay Minerals, v. 28 , p. $401-411$.

Srodon, J., and Eberl, D.D., 1984, Illite, in Bailey, S.W., ed., Reviews in mineralogy: Washington, D.C., Mineralogical Society of America, v. 13, p. 495-539.

Starkey, H.C., Blackman, P.D., and Hauff, P.L., 1984, The routine mineralogical analysis of clay-bearing samples: U.S. Geological Survey Bulletin 1563, 32 p.

Velde, B., 1985, Clay minerals: A physico-chemical explanation of their occurrence: New York, Elsevier, Developments in Sedimentology, v. 40, p. 427.

Velde, B., and Hower, J., 1963, Petrological significance of illite polymorphism in Paleozoic sedimentary rocks: American Mineralogist, v. 48, p. 1239-1254.

Weaver, C.E., and Broekstra, B.R., 1984, Illite-mica, in Weaver, C.E., and others, eds., Shale-slate metamorphism in southern Appalachians: Amsterdam, Elsevier, p. 67-199. 



\title{
PETROGRAPHIC AND MAJOR-ELEMENT CHARACTERISTICS OF MESOZOIC BASALTS, CULPEPER BASIN, VIRGINIA
}

\author{
Richard P. Tollo ${ }^{1}$
}

\begin{abstract}
Basalts of the Culpeper basin encompass a range of petrochemical types defined by variations in petrographic characteristics and major-element composition. The Mount Zion Church and Hickory Grove Basalts, and the lowermost flow of the Sander Basalt, represent the earliest eruptions and are uniform in both composition and mineralogy throughout the basin. The overlying Sander Basalt flows are distinct in composition and divide the basin into two provinces characterized by different volcanic histories. The Culpeper basalt sequence is not related by tholeiitic differentiation and may have been derived, at least in part, from a series of spatially distinct magma bodies.
\end{abstract}

\section{INTRODUCTION}

Mesozoic volcanic rocks comprise three flow series exposed in the western half of the Culpeper basin in northern Virginia. Mapped by Lee $(1979,1980)$ and Lee and Froelich (in press) as (from oldest to youngest) thc Mount Zion Church, Hickory Grove, and Sander Basalts, these flow series are separated by Lower Jurassic sedimentary formations of variable thicknesses. A possible fourth and presumably much younger volcanic unit, the Midland basalt of Leavy and Puffer (1983), probably represents a shattered, fault-bounded sliver of the Sander (Froelich, personal commun., 1985). Previous studies (McCollum, 1971; Leavy and Puffer, 1983; Lee and others, 1984; Puffer, 1986) have served to delineate separate aspects of the field, petrologic, and geochemical characteristics of these basalts, which are considered part of the eastern North America (ENA) tholeiite suite of Weigand and Ragland (1970). The present study is based on a considerably more extensive sampling program and both greatly refines and expands the available data base. Major-element compositions, detailed petrographic characteristics, and limited trace-element data are used to define a series of basalt petrochemical types that,

\footnotetext{
1 Department of Geology, George Washington University, Washington, DC 20052.
}

combined with all available field data, provide the basis for basinwide comparison of basalt flow stratigraphy.

\section{FIELD RELATIONS}

The basalts of the Culpeper basin are generally poorly exposed and typically underlie a series of subtle topographic ridges throughout most of the west-central part of the basin. They strike approximately northnortheast, dip westerly, and are truncated against the border fault in three broad areas (fig. 1). Most basalt outcrops are characterized by distinctive columnar jointing locally overprinted by later, closely spaced brittle fractures. Clear contact relations between the basalt and underlying sediments, although rarely observed, are typically sharp, with metamorphic aureoles only several centimeters thick. Pillowed basalts have not been observed in the Culpeper basin.

On the basis of the position of intercalated Jurassic sedimentary rocks, Lee $(1979,1980)$ defined and mapped the three flow series as encompassing at least six different flows. More recent field work (this study) and consideration of the surface geology, topography, and available geophysical evidence (Froelich, personal commun., 1985) indicate that the 3 flow series probably represent at least 13 separate flows (Mount Zion Church: 2; Hickory Grove: 2; Sander: 9) separated by Jurassic sedimentary sequences of variable thickness or noneruptive periods of undetermined duration.

\section{PETROGRAPHY}

The petrographic characteristics of the Culpeper basalts are summarized in table 1. Differences between the basalts of the Hickory Grove and Sander series are subtle. However, the flows of the Mount Zion Church series are clearly distinct petrographically in that this basalt (1) is always porphyritic, (2) has an augite:plagioclase phenocryst ratio of 10:1, (3) contains no pigeonite, (4) contains substantial amounts of brown glass, and (5) contains only fine-grained, skeletal magnetite (Flagel, 1985; this study). 


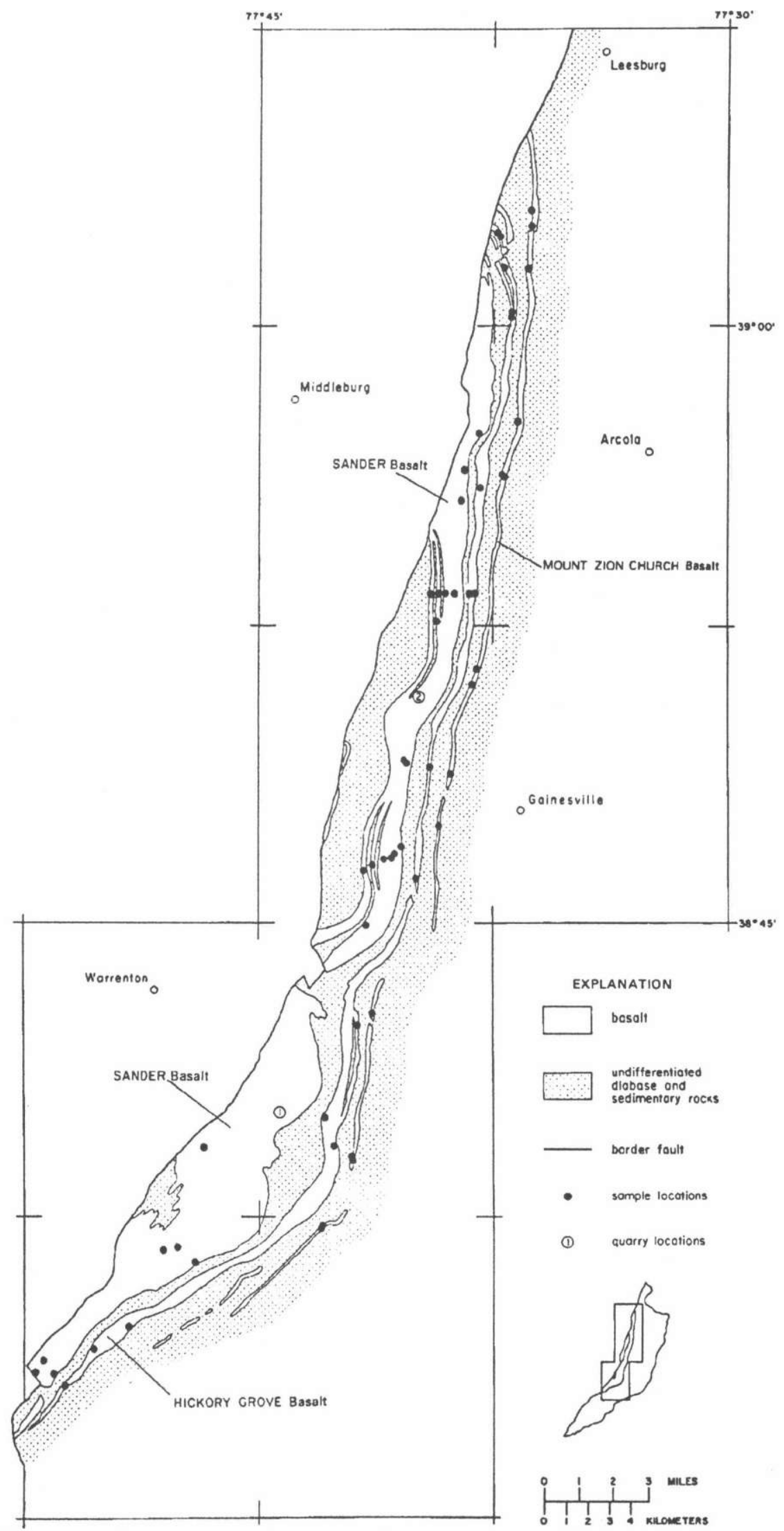

Figure 1. Geologic map of part of the Culpeper basin showing the location of the three basalt flow series and all geochemical sampling sites. Map modified after Leavy and others (1983). 
Table 1. Petrographic characteristics of the three major basalt flow series of the Culpeper basin

[Abbreviations: aug, augite; plag, plagioclase; mt, magnetite; pig, pigeonite; ilm, ilmenite; chl, chlorite; serp, serpentine; ser, sericite; saus, saussurite; cc, calcite; zeol, zeolite; ac, actinolitic amphibole; ap, apatite; tr, present in trace quantities]

\begin{tabular}{|c|c|c|c|}
\hline & Mount Zion Church Basalt & Hickory Grove Basalt & Sander Basalt \\
\hline Color. & Dark gray to black & Dark gray to gray & Dark gray to gray. \\
\hline Grain size.......... & V. fine-grained to aphanitic & Fine- to medium-grained & Fine- to medium-grained. \\
\hline Texture ............ & Microporphyritic & $\begin{array}{l}\text { Microporphyritic to nearly } \\
\text { equigranular }\end{array}$ & $\begin{array}{l}\text { Porphyritic to microporphyritic to } \\
\text { nearly equigranular (see remarks } 4 \text {, } \\
5 \text {, and } 6 \text { below). }\end{array}$ \\
\hline \multicolumn{4}{|l|}{ Phenocrysts } \\
\hline Modal amount ...... & $\leq 10 \%$ & $\leq 10 \%$ & $\leq 14 \%$ \\
\hline Assemblage......... & aug + plag & plag + aug \pm pig & plag + aug \pm pig \\
\hline Modal ratio ......... & $10: 1$ & $3: 1:$ (rare) & $4: 1:($ rare $)$ \\
\hline Grain shape ... & Eu-subhedral & $\begin{array}{l}\text { plag+ aug: eu-subhedral } \\
\text { pig: subhedral }\end{array}$ & $\begin{array}{l}\text { plag + aug: eu-subhedral } \\
\text { pig: subhedral }\end{array}$ \\
\hline Grain size . & $\begin{array}{l}\text { aug: } \leq 2 \mathrm{~mm} \\
\text { plag: } \leq 0.8 \mathrm{~mm}\end{array}$ & $\begin{array}{l}\text { plag+ aug: } \leq 2 \mathrm{~mm} \\
\text { pig: } \leq 1 \mathrm{~mm}\end{array}$ & $\begin{array}{l}\text { plag + aug: } \leq 2 \mathrm{~mm} \\
\text { pig: } \leq 1 \mathrm{~mm} \text { and intergrown with aug }\end{array}$ \\
\hline \multicolumn{4}{|l|}{ Groundmass } \\
\hline Assemblage ........ & plag + aug $+m t$ & plag + aug + pig $+m t+i l m(?)$ & plag + aug + pig $+m t+i l m$ \\
\hline Modal ratio ......... & $1: 1: \operatorname{tr}$ & $2: 1: 1: \operatorname{tr}$ & $2: 1: 1: \operatorname{tr}: t r$ \\
\hline Grain size $\ldots \ldots \ldots$ & plag+ aug: $\leq 0.5 \mathrm{~mm}$ & $\begin{array}{l}\text { plag+ aug }+ \text { pig: } \leq 0.5 \mathrm{~mm} \\
\mathrm{mt}: \leq 0.2 \mathrm{~mm}\end{array}$ & $\begin{array}{l}\text { plag+aug+ pig: } \leq 0.5 \mathrm{~mm} \\
\mathrm{mt}+\text { ilm: } \leq 0.2 \mathrm{~mm}\end{array}$ \\
\hline Oxides.. & $\begin{array}{l}\mathrm{mt}: \mathrm{v} \text {. fine-grained, trellis- } \\
\text { shaped, skeletal; occurs } \\
\text { only in mesostasis }\end{array}$ & $\begin{array}{l}\text { mt: fine-grained, blocky to } \\
\text { irregular; may be locally } \\
\text { phenocrystic }\end{array}$ & $\begin{array}{l}\mathrm{mt}>>\text { ilm: fine-grained; mt blocky to } \\
\text { irregular; may be locally pheno- } \\
\text { crystic. }\end{array}$ \\
\hline Mesostasis ......... & $\begin{array}{l}\leq 10 \% ; \text { intersertal, brown, } \\
\text { locally turbid }\end{array}$ & $\begin{array}{l}\leq 5 \% \text {; intersertal, colorless, } \\
\text { includes brown globules } \\
\text { (see remark } 3 \text { below); also } \\
\text { contains ap(?) and oxides }\end{array}$ & $\begin{array}{l}\leq 5 \% \text {; intersertal, colorless, includes } \\
\text { brown globules (see remark } 3 \\
\text { below); also contains ap(?) and } \\
\text { oxides. }\end{array}$ \\
\hline Secondary minerals.... & $\begin{array}{l}\text { chl+serp after aug } \\
\text { ser+saus after plag } \\
\text { cc+zeol as vug fillings }\end{array}$ & $\begin{array}{l}\text { chl+serp }+ \text { act after pyroxene } \\
\text { ser }+ \text { saus after plag } \\
\text { cc }+ \text { zeol as vug fillings }\end{array}$ & $\begin{array}{l}\text { chl+serp+act after pyroxene } \\
\text { ser+saus after plag } \\
\text { cc+zeol as vug fillings }\end{array}$ \\
\hline Remarks. . & $\begin{array}{l}\text { 1. Contains glomero- } \\
\text { porphyritic clusters of } \\
\text { aug with rare plag. }\end{array}$ & $\begin{array}{l}\text { 2. Usually less distinctly } \\
\text { porphyritic than Sander } \\
\text { type A basalt. }\end{array}$ & $\begin{array}{l}\text { 4. Sander type A locally bears } \\
\text { plag phenocrysts with peripheral } \\
\text { melt inclusions. }\end{array}$ \\
\hline & & $\begin{array}{l}\text { 3. Similar to those described } \\
\text { by Philpotts and Doyle } \\
\text { (1983). }\end{array}$ & $\begin{array}{l}\text { 5. Sander type A is the most distinctly } \\
\text { porphyritic. } \\
\text { 6. Lowermost flows contain glomero- } \\
\text { porphyritic clusters dominated by } \\
\text { plag. }\end{array}$ \\
\hline
\end{tabular}

\section{GEOCHEMISTRY}

Analyses of fresh specimens from all flows sampled within the Culpeper basin indicate that these basalts are quartz normative tholeiites. Plotted in terms of $\mathrm{TiO}_{2}$ content and 100 times the mafic index $\left(\mathrm{FeO}+\mathrm{Fe}_{2} \mathrm{O}_{3} / \mathrm{FeO}\right.$ $+\mathrm{Fe}_{2} \mathrm{O}_{3}+\mathrm{MgO}$ ) in figure 2 , most of the analyses fall within the field of the high-TiO ${ }_{2}$, quartz normative magma type defined for the ENA province by Ragland and Whittington (1983) in a revision of the classification previously proposed by Weigand and Ragland (1970). Two distinct groupings are apparent on this plot. The Mount Zion Church analyses form a tight clustering corresponding to the more restricted high- $\mathrm{TiO}_{2}$, quartz normative (HTQ) subgroup of the original ENA magma type classification, whereas the Hickory Grove and Sander data show considerable overlap within the highiron, quartz normative (HFQ) field of this earlier scheme at higher mafic index values and generally lower $\mathrm{TiO}_{2}$ contents. All of the data points falling outside of this field and defining the obvious positive trend are from the Sander flow series.

The parameters for figure 3 were chosen because magnesium and titanium are reliable indicators of magmatic evolution, have been analyzed to a high degree of precision (0.03 and 0.022 weight percent, respectively), and appear to be relatively unaffected by the various degrees of weathering that have affected some of the samples. The Mount Zion Church data again form a distinct grouping at relatively high $\mathrm{MgO}$ (7.4-8.0 weight percent) and $\mathrm{TiO}_{2}(1.13-1.18$ weight percent) contents. In this figure, however, the Hickory Grove analyses can be resolved from those of the Sander by lower $\mathrm{MgO}$ contents at comparable values of $\mathrm{TiO}_{2}$. In addition, distinct clusterings of Sander data points are apparent and enable the definition of basalt petrochemical types (table 2). Sander types A and B correspond to the HTQ designation of Weigand and Ragland (1970). Sander type 


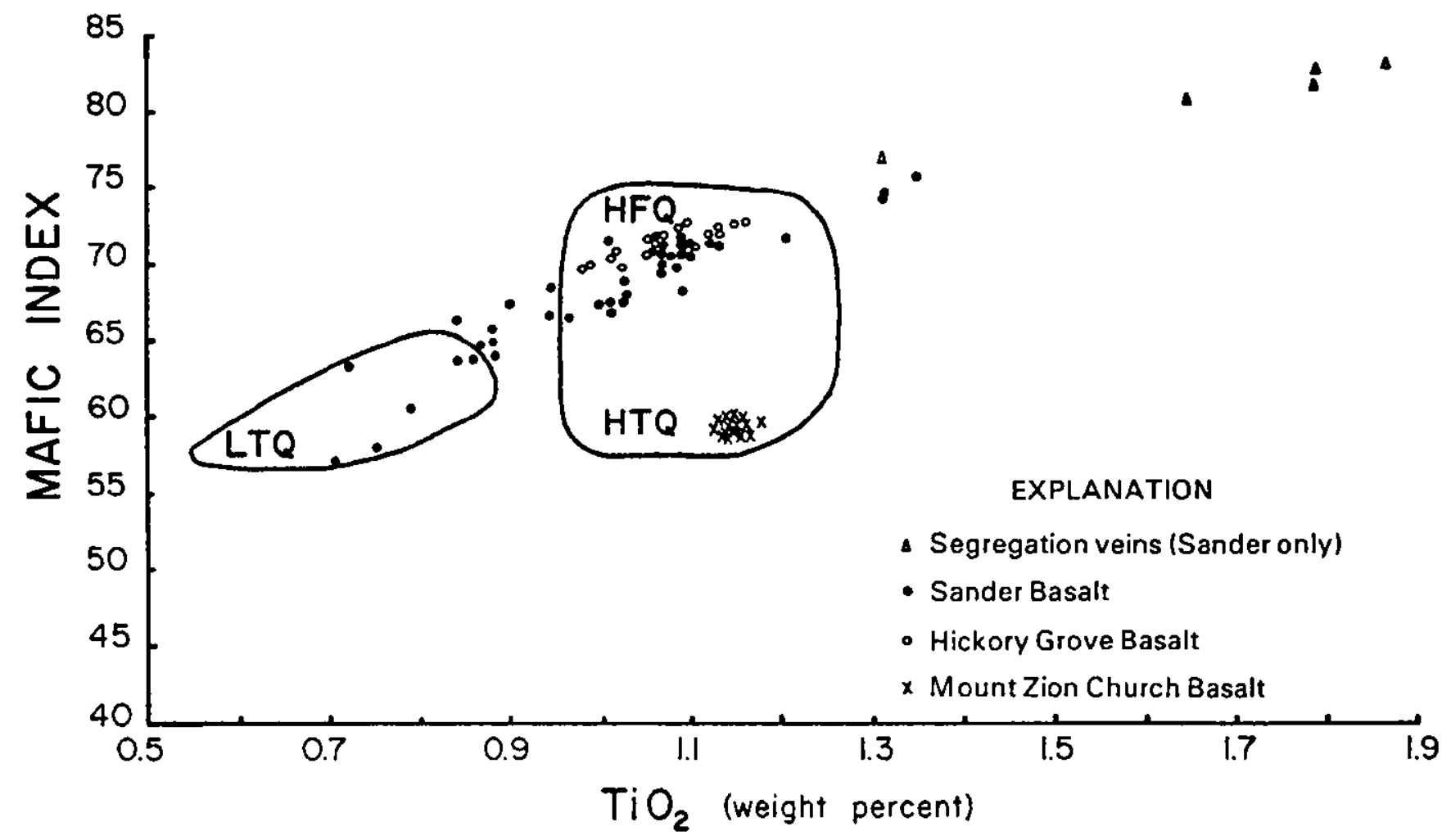

Figure 2. Plot of mafic index $\left(\left(\mathrm{FeO}+\mathrm{Fe}_{2} \mathrm{O}_{3} / \mathrm{FeO}+\mathrm{Fe}_{2} \mathrm{O}_{3}+\mathrm{MgO}\right) \times 100\right.$ ) versus $\mathrm{TiO}_{2}$ (in weight percent) for the Culpeper basalt sequence. Figure modified from Weigand and Ragland (1970). HTQ, high-titanium, quartz-normative magma type; LTQ, low-titanium, quartz-normative magma type; HFQ, high-iron, quartz-normative magma type.

C basalt, however, includes compositions that are mostly without analog in the Weigand and Ragland (1970) scheme. Sander type D basalt is characterized by the highest $\mathrm{MgO}$ values and lowest $\mathrm{TiO}_{2}$ contents of the flow series, appears to be relatively rare in the Culpeper basin, and corresponds to the low- $\mathrm{TiO}_{2}$, quartz normative (LTQ) magma type of Weigand and Ragland (1970). Sander type E basalt, characterized by low $\mathrm{MgO}$ values and high $\mathrm{TiO}_{2}$ contents, is known only from one thick horizon in Sander quarry (location 1 on fig. 1) near Casanova, Virginia, where it is associated with largescale, gabbroid segregation veins. The segregation veins, exposed at both Sander quarry and Silver Lake quarry (location 2 on fig. 1), form meter-scale bodies traceable over considerable distances at the former locality, occurring on a scale that is, to my knowledge, heretofore unreported in the literature.

The distinction between basalt types extends to other elements (table 2). The Mount Zion Churcl, for instance, is characterized by $\mathrm{SiO}_{2}$ and total iron concentrations lower than those of all overlying basalts except Sander type D. The latter, a volumetrically rare Sander type, while similar to the Mount Zion Church flows, is distinct compositionally by markedly lower $\mathrm{TiO}_{2}$ and $\mathrm{P}_{2} \mathrm{O}_{5}$ contents and petrographically by having less abundant, dominantly colorless mesostasis, an obvious lack of skeletal oxides, and a higher modal ratio of phenocrystic plagioclase:clinopyroxene. The distinction between the Hickory Grove and Sander type $A$ is also reflected in the relative contents of total iron, $\mathrm{SiO}_{2}$, and $\mathrm{P}_{2} \mathrm{O}_{5}$. Although there is slight overlap, the Hickory Grove Basalt is generally lower in total iron and higher in both $\mathrm{SiO}_{2}$ and $\mathrm{P}_{2} \mathrm{O}_{5}$.

The distinction between the Sander types A and B is fundamentally a difference in $\mathrm{MgO}$ and total iron. However, the distinction between them is further supported by limited trace-element data that indicate that the Sander type B is relatively enriched in $\mathrm{Y}, \mathrm{Ni}$, and $\mathrm{Cr}$ and depleted in $\mathrm{Zr}$ and $\mathrm{V}$.

Sander types B and C are differentiated primarily on the basis of the overall clustering of $\mathrm{TiO}_{2}$ (fig. 3), total iron, and $\mathrm{P}_{2} \mathrm{O}_{5}$ contents, all of which are lower in the latter. The Sander $\mathrm{D}$ type, characterized by relatively low contents of $\mathrm{TiO}_{2}$, total iron, and $\mathrm{P}_{2} \mathrm{O}_{5}$, is compositionally distinct from all other types. Trace-element data indicating a relative depletion in $\mathrm{Y}, \mathrm{Pb}, \mathrm{Zn}, \mathrm{V}$, and $\mathrm{Zr}$ and a relative enrichment in $\mathrm{Ni}$ and $\mathrm{Cr}$ in the Sander $\mathrm{D}$ type relative to the other Sander types further support this distinction.

The Sander type E basalt is known only from one section of Sander quarry where it forms part of a thick, massive flow otherwise composed of type $A$ basalt. The 
EXPLANATION

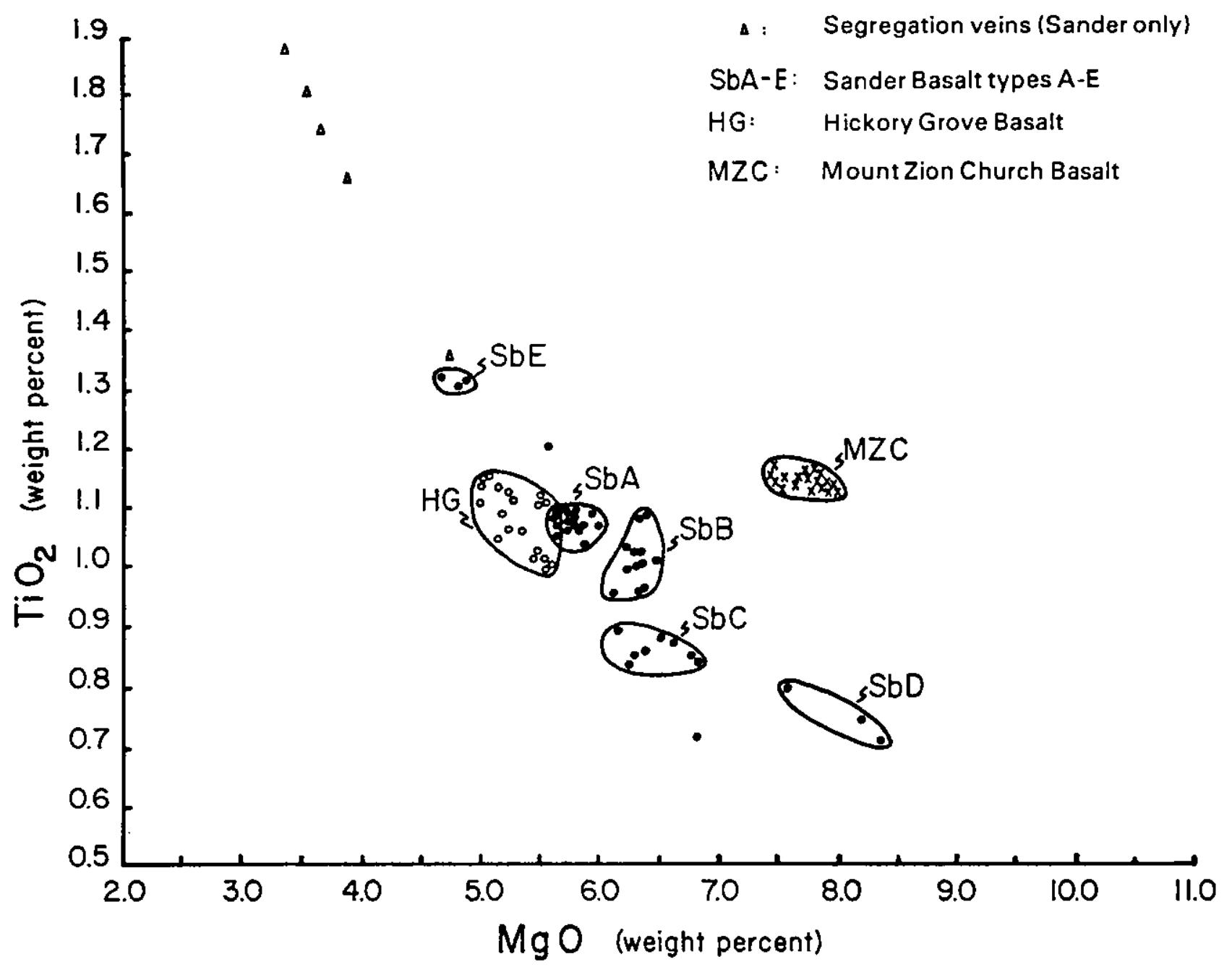

Figure 3. Plot of $\mathrm{TiO}_{2}$ (in weight percent) versus $\mathrm{MgO}$ (in weight percent) for the Culpeper basalt sequence.

relative enrichment in $\mathrm{TiO}_{2}$ and total iron and the low $\mathrm{MgO}$ values are the major identifying characteristics and suggest that it is the most chemically evolved basalt type yet identified in the Culpeper basin. The segregation veins found cutting this basalt type at Sander quarry and Sander type B basalt at Silver Lake quarry contain the same plagioclase+augite + pigeonite primary assemblage but are further enriched in total iron and $\mathrm{TiO}_{2}$.

\section{STRATIGRAPHIC SYSTEMATICS AND PETROGENESIS}

Lindstrom and Haskin (1981) demonstrated that random geochemical variation in a single, apparently homogeneous, Icelandic tholeiite flow exceeded the analytical error for all major elements and a selected suite of trace elements. Their data suggested that short-range elemental segregation may produce chemical inhomoge- neity as large as interflow compositional differences. These authors cautioned that fractionation models based solely on compositional differences of this magnitude could be inappropriate where unconfirmed by independent evidence. The data of McFall (1985) and Tollo and others (1986), representing a suite of 10 samples collected along a vertical traverse of $75 \mathrm{ft}(22.5 \mathrm{~m})$ through the lowermost Sander flow, indicate close agreement between the observed chemical variation and the analytical uncertainty. Random segregation, as proposed by Lindstrom and Haskin (1981), appears to be minimal and, in the case of titanium, undetectable. This intraflow homogeneity is further demonstrated by application of the homogeneity index calculation of Rhodes (1983), which is equal to the sum of the differences between the statistical standard deviation of each element and the analytical precision, divided by the number of elements. $A$ value close to unity indicates that the observed varia- 
Table 2. Average chemical compositions of the basalt petrochemical types defined for the Culpeper basalt sequence [All compositions are normalized to 100 percent; s.g., segregation (gabbroid) veins]

\begin{tabular}{|c|c|c|c|c|c|c|c|c|}
\hline & \multirow{2}{*}{$\begin{array}{c}\text { Mount Zion } \\
\text { Church Basalt }\end{array}$} & \multirow{2}{*}{$\begin{array}{c}\text { Hickory } \\
\text { Grove Basalt }\end{array}$} & \multicolumn{6}{|c|}{ Sander Basalt } \\
\hline & & & $\mathrm{A}$ & $\mathrm{B}$ & $\mathrm{C}$ & D & $E$ & s.g. \\
\hline $\mathrm{SiO}_{2} \ldots \ldots \ldots \ldots$ & 51.89 & 53.63 & 51.97 & 52.28 & 52.81 & 51.12 & 53.45 & 53.53 \\
\hline $\mathrm{TiO}_{2} \ldots \ldots \ldots \ldots$ & 1.15 & 1.08 & 1.08 & 1.02 & .87 & .75 & 1.31 & 1.66 \\
\hline $\mathrm{Al}_{2} \mathrm{O}_{9} \ldots \ldots \ldots$ & 14.42 & 13.97 & 14.03 & 14.15 & 14.41 & 15.39 & 13.33 & 12.28 \\
\hline $\mathrm{Fe}_{2} \mathrm{O}_{3}{ }^{1} \ldots \ldots \ldots$ & 11.14 & 13.14 & 13.62 & 12.99 & 12.10 & 11.19 & 14.31 & 16.00 \\
\hline $\mathrm{FeO} \ldots \ldots \ldots \ldots$ & - & - & - & - & - & - & - & - \\
\hline $\mathrm{MnO} \ldots \ldots \ldots \ldots$ & .18 & .23 & .22 & .21 & .20 & .19 & .22 & .25 \\
\hline $\mathrm{MgO} \ldots \ldots \ldots \ldots$ & 7.70 & 5.29 & 5.68 & 6.29 & 6.40 & 8.02 & 4.80 & 3.78 \\
\hline $\mathrm{CaO} \ldots \ldots \ldots \ldots$ & 10.34 & 8.41 & 9.27 & 8.98 & 9.48 & 10.07 & 9.14 & 8.79 \\
\hline $\mathrm{Na}_{2} \mathrm{O} \ldots \ldots \ldots$ & 2.78 & 3.10 & 3.39 & 3.37 & 3.08 & 2.61 & 2.56 & 2.61 \\
\hline $\mathrm{K}_{2} \mathrm{O} \ldots \ldots \ldots \ldots$ & .27 & .97 & .60 & .57 & .55 & .58 & .70 & .89 \\
\hline $\mathrm{P}_{2} \mathrm{O}_{5} \ldots \ldots \ldots$ & .13 & .18 & .14 & .14 & .10 & .08 & .18 & .21 \\
\hline Total .......... & 100.00 & 100.00 & 10000 & 100.00 & 100.00 & 100.00 & 100.00 & 100.00 \\
\hline Number of & & & & & & & & \\
\hline samples....... & 18 & 19 & 16 & 11 & 9 & 3 & 3 & 5 \\
\hline Type locality ..... & $\begin{array}{l}\text { Goose } \\
\text { Creek } \\
\text { stream- } \\
\text { cut, } \\
\text { Lees- } \\
\text { burg } \\
\text { quad }\end{array}$ & $\begin{array}{l}\text { Goose } \\
\text { Creek } \\
\text { stream- } \\
\text { cut, } \\
\text { Lees- } \\
\text { burg } \\
\text { quad }\end{array}$ & $\begin{array}{l}\text { Sander } \\
\text { quarry } \\
\text { so. pit, } \\
\text { Catlett } \\
\text { quad }\end{array}$ & $\begin{array}{l}\text { Silver } \\
\text { Lake } \\
\text { quarry, } \\
\text { Thor- } \\
\text { oughfare } \\
\text { Gap } \\
\text { quad }\end{array}$ & $\begin{array}{l}\text { Mountain } \\
\text { Road } \\
\text { quarry } \\
\text { no. pit, } \\
\text { Middle. } \\
\text { burg } \\
\text { quad }\end{array}$ & $\begin{array}{l}\text { Quarry } \\
\text { near } \\
\text { Rtes. } \\
631 \\
\& 50, \\
\text { Middle- } \\
\text { burg } \\
\text { quad }\end{array}$ & $\begin{array}{l}\text { Sander } \\
\text { quarry } \\
\text { no. pit, } \\
\text { Catlett } \\
\text { quad }\end{array}$ & $\begin{array}{c}\text { Sander } \\
\text { quarry } \\
\text { no. pit, } \\
\text { Catlett } \\
\text { quad }\end{array}$ \\
\hline
\end{tabular}

${ }^{1}$ Total iron expressed as $\mathrm{Fe}_{2} \mathrm{O}_{3}$.

tion in an eruptive event approximates the error of analysis. The value of 2 calculated for this traverse through the lowermost Sander flow indicates a close similarity between the variation characterizing this basalt and some of the remarkably homogeneous flows of Mauna Loa (Rhodes, 1983). Application of this statistical parameter indicates that at least five of the Culpeper basalt flows are sufficiently homogeneous to warrant petrochemical correlation along strike.

The two flows composing the Mount Zion Church series, characterized by very limited petrographic and compositional variation, represent such an example. Analyses from 18 locations yield a modified (without the alkalis and $\mathrm{CaO}$, which vary widely as a result of weathering) major-element homogeneity index of 2.6, comparable to both the Sander vertical traverse and several flows from Mauna Loa (Rhodes, 1983). The two flows composing the Hickory Grove series are also strikingly homogeneous (modified homogeneity index of 4.3) and can be geochemically correlated throughout the basin.

The first flow in the Sander series has been sampled at seven different localities covering a distance of 30 mi $(48 \mathrm{~km})$ along strike. This flow is made up of Sander type A basalt and is characterized by remarkable compositional uniformity, as indicated by a modified homogeneity index of 1.7. Inclusion of the alkalis and $\mathrm{CaO}$ in the calculation raises the value to only 3.8 , indicating the relatively fresh nature of the suite. Although many of the petrographic characteristics of this flow are not unique among the Sander series, samples from this flow are nearly always characterized by (1) phenocrystic or subphenocrystic pigeonite, (2) glomeroporphyritic clusters of plagioclase +augite, and (3) phenocrystic plagioclase with distinct peripheral zones of melt inclusions.

The basinwide correlation between chemical type and flow stratigraphy becomes more restricted above the first Sander flow. In the central and northern portions of the basin (fig. 4), the second flow of the Sander series is made up of type B basalt. This is, in turn, overlain by type $D$ basalt in the central region and probably also at northern locations. The second and third Sander flows in the southern portion of the basin are, however, both composed of type $\mathrm{A}$ basalt and are indistinguishable, both petrographically and geochemically, from the lowermost Sander flow in that area. In the ceniral and northern sections, the fourth and fifth Sander flows are composed of type $\mathrm{C}$ and $\mathrm{B}$ basalt, respectively. The record above the third Sander flow in the south is incomplete, but limited data indicate that the fourth and fifth Sander flows are composed of type B and C, respectively.

It is possible that the extrusion of type A basalt in the central and northern portions of the basin as the first Sander flow correlates with the extrusion of the three lowermost Sander flows in the south. However, the field and petrochemical data presently available are not adequate to justify such a correlation at this time. Neverthe- 


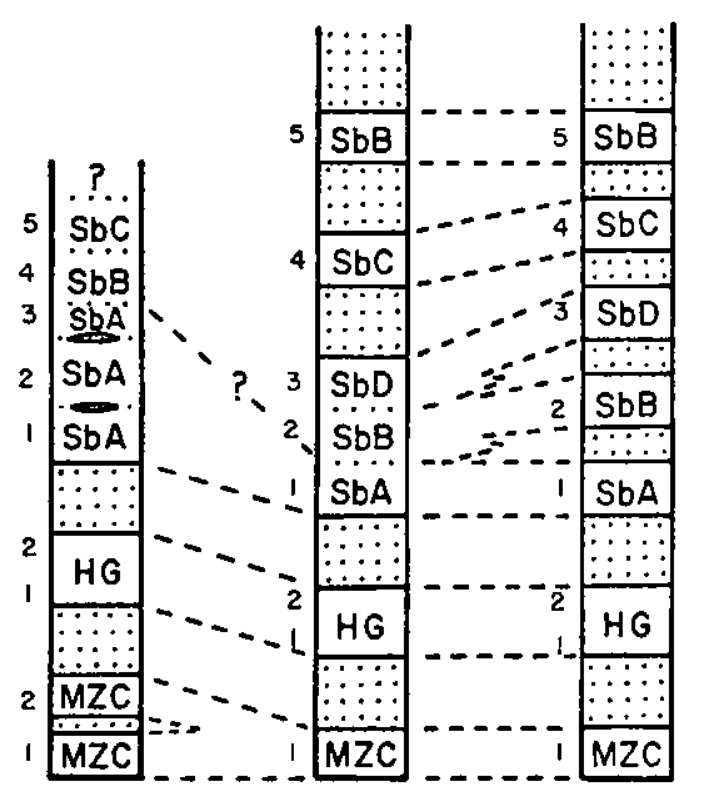
SbB SbC SbD Sander A-D

HG Hickory Grove

MZC Mount Zion Church

$\because: \vdots$

Sedimentary strata

Figure 4. Generalized chemical stratigraphy and tentative correlation of the Culpeper basalt sequence compiled along three transects. Numbers to the left of each column indicate flow stratigraphy. Dotted lines indicate both observed and inferred interflow contacts. Sander type $E$ basalt, limited in occurrence to one area of Sander quarry, is not shown for clarity.

less, the data do indicate that the volcanic record of the southern Culpeper basin differs from the other sections, at least in the relative volume of type A basalt and in the order of chemical types extruded after the eruption of the first Sander flow.

Evidence for this distinct history may be preserved in the basalt stratigraphy of Sander quarry where a nearly continuous section through the lower Sander series is exposed in a location approximately equidistant from the two transects used to compile the volcanic stratigraphy of the southern and central sections of the basin. The lowermost unit at this locality is typical type A basalt similar to that exposed at the base of the Sander series throughout the basin. McFall (1985) and Tollo and others (1986) used the uniformity in modal data and texture, homogeneity in chemical composition, lack of field evidence for multiple flows, and the consistency of the oxide subsolidus oxidation assemblages to infer that this section represents only part of a much thicker accumulation of basalt that may have originated by ponding. Such a model, involving the rapid extrusion of relatively large volumes of lava, followed by differentiation in a relatively static and thermally isolated pond, is consistent with the observed in-situ development of largescale segregation veins associated with highly evolved type $\mathbf{E}$ basalt at Sander quarry. The presence of quenched basalt entablature only at this locality contrasts with the nearly ubiquitous colonnade type of jointing elsewhere and is further suggestive of the development of thick, relatively voluminous flows (Long and Wood, 1986) solely in that part of the basin. Thus, the majority of available evidence suggests that the sequence of basalt stratigraphy, the relative volumes of at least some of the different chemical types, and possibly the mechanics of extrusion and accumulation were different in the southern Culpeper basin during the period of Sander volcanism.

Detailed modeling of the petrogenesis of the Culpeper basalt sequence must await further sampling and completion of the trace-element analyses. Nevertheless, the data presented in this study are sufficient to impose limited constraints on some possible relations. The Mount Zion Church flows represent the initial outpouring of lava in the basin and are characterized by a relatively restricted range in composition and the highest $\mathrm{MgO}$ contents of the Culpeper sequence. As a result, these lavas represent a possible parental composition from which the overlying basalts could have been derived by fractional crystallization. Such a relation, based on major-element compositions and experimental data, has in fact been proposed for the Hartford basin by Philpotts and Reichenbach (1985) as a plausible means by which to derive the HFQ type lava of the Holyoke Basalt from HTQ magma similar to the underlying Talcott Basalt. Trace-element data, however, suggest that such a model may not be applicable to the Culpeper basin because, as noted by Puffer (1986), any model involving simple tholeitic fractionation of Mount Zion Church (HTQ) 
type magma to produce the Hickory Grove and Sander type A (HFQ) basalts fails to explain the lack of relative enrichment of $\mathrm{P}_{2} \mathrm{O}_{5}$ and incompatible trace elements such as Zr. Furthermore, the stratigraphic rclations of these basalts demonstrate that any such fractionation could not have been unidirectional over time because the Hickory Grove Basalt is characterized by lower $\mathrm{MgO}$ contents than the overlying flows of the Sander series.

The stratigraphy of geochemical types within the Sander series (fig. 4), provides further evidence for the lack of a consistent fractionation mechanism. Throughout the basin, the lowermost Sander flow (type A) is overlain by chemically less evolved basalts that could not have been derived by simple tholeiitic fractionation from either a liquid of type A composition or a liquid inferred to be parental to it. The alternation of chemical types overlying the lowermost Sander flow is also difficult to reconcile in a single fractionation scheme. Such variable petrochemical st ratigraphy is not uncommon in continental flood basalt and rift environments (for example: Mangan and others, 1986; Basalt Volcanism Study Project, 1981), however, and appears to be indicative of the complex petrogenetic evolution of these provinces.

The compositional diversity, geographic distribution, and stratigraphic sequence of basalt chemical types in the Culpeper basin suggest that these volcanics may have been derived from multiple, spatially distinct magma bodies. Although possibly derivatives from a common source, such bodies appear to have fractionated at different rates and possibly along different liquid lines of descent, developing a suite of magmas of variable composition. The Mount Zion Church, Hickory Grove, and Sander type A basalts, characterized by uniform compositions throughout the basin, were either derived from widespread sources, marked by high extrusion rates, or both. All subsequent eruptive activity, however, appears to be the result of derivation from more local sources.

\section{SUMMARY AND CONCLUSIONS} lowing:

The data presented in this study indicate the fol-

1. The three major flow series in the Culpeper basin represent compositionally distinct types of basalt.

2. The Mount Zion Church, Hickory Grove, and Sander type A petrochemical types represent the first three eruptive phases. These were all widespread extrusions, and each is characterized by a relatively restricted range in geochemical composition. None of these basalt types, to the limits of present sampling, is represented in the overlying volcanics of the Culpeper basin.

3. The Sander series is characterized by significant petrographic and compositional variation and is composed of at least four distinct petrochemical types.

4. All flows overlying the first Sander flow are distinct in composition and cannot be geochemically correlated between the southern and central-northern sections of the basin.

5. Ponding of large volumes of Sander type A basalt may have occurred in the southern Culpeper basin and was possibly contemporaneous with the extrusion of multiple flows of varying composition to the north.

6. The Culpeper basalt sequence is not related by tholeiitic differentiation and may have been derived, at least in part, from a series of spatially distinct magma bodies.

\section{ACKNOWLEDGMENTS}

I would like to thank A.J. Froelich and David Gottfried of the USGS for their assistance with this project and for many insightful conversations. I would also like to acknowledge the George Washington University (GWU) for financial support that made this work possible. Practical assistance, for which I am grateful, was given by GWU students Sara Arav, N.J. Byrd, and D.P. Hawkins, and by my wife, Stacie. Joel Sparks of the University of Massachusetts helped with the geochemical analyses performed at the University of Massachusetts Analytical Geochemistry Facility. Robin Taylor of GWU assisted in the preparation of the manuscript. Finally, I would like to acknowledge former GWU students K.S. McFall and S.F. Flagel for their excellent senior projects that first served to involve me in this work.

\section{REFERENCES CITED}

Basalt Volcanism Study Project, 1981, Basalt volcanism on the terrestrial planets: Pergamon Press, Inc., New York, 1286 p.

Flagel, S.F., 1985, A petrographic and geochemical study of the basalts in the Culpeper basin, Virginia: senior thesis (unpublished), George Washington Unjversity, $60 \mathrm{p}$.

Leavy, B.D., and Puffer, J.H., 1983, Physical and chemical characteristics of four Jurassic basalts in the Culpeper basin, Virginia: Geological Society of America Abstracts with Programs, v. 15, p. 92.

Leavy, B.D., Froelich, A.J., and Abram, E.C., 1983, Bedrock map and geotechnical properties of rocks of the Culpeper basin and vicinity, Virginia and Maryland: U.S. Geological Survey Miscellaneous Investigations Series Map I-1313-C, scale 1:125,000.

Lee, K.Y., 1979, Triassic-Jurassic geology of the northern part of the Culpeper basin, Virginia and Maryland: U.S. Geological Survey Open-File Report 79-1557, 29 p., 16 pl., scale $1: 24,000$. 
1980, Triassic-Jurassic geology of the southern part of the Culpeper basin and the Barboursville basin, Virginia: U.S. Geological Survey Open-File Report 80-468, 19 p., 18 pls., scale 1:24,000.

Lee, K.Y., and Froelich, A.J., in press, Triassic-Jurassic stratigraphy of the Culpeper and Barboursville basins, Virginia: U.S. Geological Survey Professional Paper.

Lee, K.Y., Leavy, B.D., and Gottfried, D., 1984, Geochemical data for Jurassic diabase and basalt of the northern Culpeper basin, Virginia: U.S. Geological Survey OpenFile Report 84-771, 19 p.

Lindstrom, M.M, and Haskin, L.A., 1981, Compositional inhomogeneities in a single Icelandic tholeiite flow: Geochimica et Cosmochimica Acta, v. 45, p. 15-31.

Long, P.E., and Wood, B.J., 1986, Structures, textures and cooling histories of Columbia River basalt flows: Geologjcal Society of America Bulletin, v. 97, p. 1144-1155.

Mangan, M.T., Wright, T.L., Swanson, D.A., and Bycrly, G.R., 1986, Regional correlation of Grande Ronde Basalt flows, Columbia River Basalt Group, Washington, Oregon, and Idaho: Geological Society of America Bulletin, v. 97, p. 1300-1318.

McCollum, M.B., 1971, Basalt flows in the Triassic Culpeper basin, Virginia: Geological Society of America Bulletin, v. 82, p. 2331-2332.

McFall, K.S., 1985, Petrography and geochemistry of the constituent flows of the Sander basalt, Culpeper basin, Virginia: senior thesis (unpublished), George Washington University, $36 \mathrm{p}$.
Philpotts, A.R., and Doyle, C.D., 1983, Effect of magma oxidation state on the extent of silicate liquid immiscibility in a tholeiitic basalt: American Journal of Science, v. 283, p. 967-986.

Philpotts, A.R., and Reichenbach, I., 1985, Differentiation of the Mesozoic basalts of the Hartford basin, Connecticut: Geological Society of America Bulletin, v. 96, p. 1131-1139.

Puffer, J.H., 1986, Intravolcanic relationships within Culpeper basin, Virginia: Geological Society of America Abstracts with Programs, v. 18, no. 3, p. 261.

Ragland, P.C., and Whittington, D., 1983, Early Mesozoic diabase dikes of eastern North America: Magma types: Geological Society of America Abstracts with Programs, v. 15 , no. 6 , p. 666 .

Rhodes, J.M., 1983, Homogeneity of lava flows: Chemical data for historic Mauna Loan eruptions: Proceedings of the 13th Lunar and Planetary Science Conference, Part 2, Journal of Geophysical Research, v. 88, Supplement, p. A869-A879.

Tollo, R.P., McFall, K.S., and Flagel, S.F., 1986, Petrologic and geochemical evidence for ponded lava in the Culpeper basin, Virginia: Geological Society of America Abstracts with Programs, v. 18, no. 3, p. 269.

Weigand, P.W., and Ragland, P.C., 1970, Geochemistry of Mesozoic dolerite dikes from eastern North America: Contributions to Mineralogy and Petrology, v. 29, p. 195-214.

\title{
REINTERPRETATION OF THE RELATIONSHIP OF THE WESTERN EXTENSION OF THE PALISADES SILL TO THE LAVA FLOWS AT LADENTOWN, NEW YORK, BASED ON NEW CORE DATA
}

\author{
Nicholas M. Ratcliffe
}

\begin{abstract}
New core data and chemical analyses of basalt and fine-grained diabase from the area of the Ladentown fissureflow complex in Rockland County, New York, indicate clearly that these igneous rocks are chemically and physically linked to the Palisades sill. Drill core from the Mount Ivy area has established the connection of the thinned ( $80 \mathrm{~m}$ thick) Palisades sill with outcrops near Camp Hill that were previously incorrectly interpreted as lava flows. In addition, part of the Ladentown flow sequence itself consists of fine-grained diabase and vesicular basalt that is apparently intrusive into the documented basalt flows and the sedimentary rocks. The southern extension of the intrusive rock that truncates Triassic and Jurassic strata is best interpreted as the southwestern
\end{abstract}

extension of the Palisades sill that extends to the Ramapo fault.

The chemistry of the two cored basalt flows at the base of the basaltic flows at Ladentown is nearly identical with Orange Mountain Basalt and with basalt from the upper contact of the Palisades sill at Mount Ivy. The interior part of Palisades sill and the basalt that crosscuts the flows at Ladentown are similar to one another and to basaltic flow rocks at Union Hill near Suffern and to the Preakness Basalt.

The data do not rule out the possibility that the Palisades magma did surface to produce basalt flows and that a later phase of the Palisades magma produced an extension of the feeder to the south and formed basalts at Union Hill near Suffern. 
Conglomerates that underlie pillow basalt at Union Hill are truncated by the upper surface of the Palisades sill in the Mount lvy cores and contain clasts of fine-grained vesicular basalt, suggesting that both the Palisades sill (intrusive magma) and the basalt at Union Hill postdate some basaltic volcanism in the northern Newark basin. If these basalt clasts were derived from the Orange Mountain Basalt, as seems likely, the Palisades sill and the basalt flows at Ladentown probably both postdate the Orange Mountain Basalt and may be correlative with the Preakness Basalt.

\section{DEFINITION OF TERMS}

The terms basalt and diabase are used only in the petrographic sense to describe grain size and textural characteristics of the rocks and not to imply their habit, either extrusive (as is generally true for basalt) or intrusive (as is generally true for diabase). In the case of hypabyssal sills and fissure-flow complexes the use of the terms in a genetic sense interferes with the major interpretation regarding origin and is not recommended. In this paper basalt refers to a fine-grained rock of basaltic composition having plagioclase laths with an average grain size less than $2 \mathrm{~mm}$ (Manson, 1967, p. 217). The term diabase is used to describe basaltic rock having a grain size greater than $2 \mathrm{~mm}$ and a well-developed ophitic or subophitic texture. It is important to note that a chilled diabase refers to a basaltic rock that retains its ophitic or subophitic texture regardless of grain size. A fine-grained basaltic rock, either extrusive or intrusive and having intergranular or other non-ophitic texture, is described as basalt. In the northern part of the Palisades sill much of the rock is fine grained, vesicular, and contains a moderate percentage of altered glassy mesostasis. The amount of glass and of vesicles increases westward as the sill intrudes higher into the section. Petrographically, most of the western tip of the sill consists of very fine-grained and vesicular rock, petrographically better described as basalt than diabase. Columnar jointing that is well developed throughout the sill extends as far west as Mount Ivy. West of this point, well developed columnar joints are absent, although irregular, steeply dipping joint sets are present locally.

\section{INTRODUCTION AND PREVIOUS WORK}

As far north as the Haverstraw quarry at Long Cove, Walker (1969) could define the base of the second Palisades magma by the bronzite dolerite $34 \mathrm{~m}$ above the base of the sill. According to Walker (1969), the upper chill zone of the Palisades was quenched from the initial magma pulse as well. According to Walker, the upper and lower chill compositions of the sill should be identical and representative of the melt composition. Recent work by Shirley (1985) in the area of Walker's (1969)
Englewood Cliffs section has discovered evidence for a third pulse of magma $60 \mathrm{~m}$ above the base. The remaining 80 percent of the sill then crystallized as a closed system having variable percentages of trapped residuum locally affected by compaction and filter pressing. According to Shirley (1985), the upper chill contact and the internal contact $60 \mathrm{~m}$ above the base may represent this last magma pulse, which is different from the magma quenched at the lower contact.

Two-dimensional (cross-sectional) models of magmatic differentiation are very important and serve to define important sequences of events. Undoubtedly, equally important variations can be expected in alonglength traverses, particularly in dike-sill complexes that are thought to be open, that is, flowing, systems. Alonglength variations in modal mineralogy, principally in bronzite concentration, have been noted for thick sheets in Virginia, as well as laterally fractionated zones of granophyre and iron-rich gabbro (Gottfried and others, 1985). According to their data, significant thickness of $\mathrm{MgO}$-enriched cumulate in any one vertical section should be balanced by comparable lateral variations towards zones enriched in incompatible elements. In the most simple, closed-system crystallization, vertical and lateral summations should balance. In systems where sheets interconnect, jump levels, or penetrate to the surface, such mass balance may be very difficult to determine. If the Palisades sill is connected to fissure eruptions, as proposed here, then mass balance and longitudinal chemical variations in the sill may well be explainable by open-system behavior.

Puffer and others (1982) present chemical analyses of samples from the northern Palisades, the Ladentown area (fig. 1, loc. E, F, Z), and basalts at Union Hill. They conclude that the northern part of the Palisades sampled by them consists of slightly differentiated magma characteristic of the bulk of the second pulse of Palisades magma, having a relatively low and restricted range of MgO (5-6 percent). The normal chill composition of the first pulse of the Palisades magma as recognized by Walker (1969) is $\mathrm{MgO}$ rich (7.5 percent) and similar to that of the Orange Mountain Basalt. Puffer and others (1982) propose that the initial Palisades magma extruded to form the Orange Mountain Basalt and that the second Palisades magma (the one that differentiated to form the diabase of northern Palisades) erupted to form the basalts at Ladentown. Ratcliffe $(1980,1982)$ proposed that the basalts at Ladentown formed from a fissure-flow eruption of Palisades sill magma but chose not to assign a time for that extrusive event. Crosscutting of TriassicJurassic(?) strata on the southwestern limb of the Ladentown syncline (fig. 1, loc. 2) was attributed to prebasalt stream incision and subsequent infilling by basalt and ponding near the border fault (fig. 1, loc. 1). Data 
presented in this report call this interpretation, as well as the interpretations of Puffer and others (1982), into question.

Detailed gravity and magnetic surveys in the covered area between the exposed diabasic rocks at Camp Hill (fig. 1, loc. 5) and the western termination of the Palisades sill were conducted by Ken Kodama. His results (Kodama, 1983) indicate that a south-dipping sheet of magnetic rock is near the surface in the critical area at Mount Ivy that is buried by surficial deposits, thus establishing the subsurface connection of the sill and the area of vesicular basalt at Camp Hill.

Figure 1 shows the generalized geology of the northern end of the Newark basin in Rockland County, New York (after Ratcliffe 1980, 1982). Patterns used on the map illustrate distinctive lithofacies, some of which appear in several formations. Attention is called to the distribution of the three conglomeratic facies consisting largely either of dolostone, Lower Cambrian quartzite, or probable Silurian and Devonian quartzite clasts. Several general levels of coarse conglomerate are present: in the Stockton Formation (fig. 1, loc. 8) and at the base of, in the middle of, and near the top (fig. 1, loc. 7, 6, and 5) of the Passaic Formation and in the Feltville Formation(?). In the central part of the map, discontinuous and thin zones of conglomerate appear to feather out towards the south in the middle of the Passaic Formation. Clasts of unique Late Ordovician quartz-feldspar dikes from the Cortlandt-Beemerville dike swarm have been found in conglomerates at all levels within the Passaic Formation and within the Stockton Formation at localities numbered 6 and 8 . These dikes are exposed in the Proterozoic basement gneiss in a narrow, $10-\mathrm{km}$-long, east-west zone situated 2 to $5 \mathrm{~km}$ north and northwest of the terminus of the basin, in an area east of the Green Pond syncline (see fig. 1 of Ratcliffe, 1981). This area of gneiss was exposed to erosion during deposition of the Passaic Formation and served as a source area for detritus making up the Passaic Formation conglomerates.

Lava flows and fissure-flow feeders are mapped at Union Hill and Ladentown. Verifiable basalt flows, the Orange Mountain and Preakness Basalts, are exposed in the southwest portion of the map. As discussed later in this report, a conjectural contact is shown between the Passaic Formation and Feltville Formation in the area of the basalts at Union Hill, at Ladentown, and in the vicinity of Mount Ivy. Rocks assigned to the Feltville Formation are largely coarse-grained, dolostone conglomerate, locally dark shale, and dark-gray sandstones rich in organic matter. Assignment of the basalts at Ladentown and at Union Hill to the Preakness Basalt, rather than to the Orange Mountain Basalt, as suggested here may mean that the Passaic and Feltville Formations are in contact in those areas where the Orange Mountain Basalt is absent.
Recent maps (Fisher and others, 1971; Puffer and others, 1982) show a northwest-trending dike near New City that connects with the main part of the Palisades sill at Nyack. Mapping in this zone does not support the presence of a continuous feature at the surface. Instead, a series of northeast-trending dikes is present in much the same sense as those described by Kummel (1898).

This report presents results of coring in and near the Ladentown exposures and provides chemical and petrographic data relating the igneous rocks of the Palisades sill with exposures at Ladentown and possibly with those at Union Hill.

\section{RESULTS OF CORING}

\section{Corehole at Haverstraw Road}

A 154-ft-deep, 2-in.-diameter core was taken at the elevation of Route 202 (Haverstraw Rd.) near the base of a marked zone of highly vesiculated basalt along the western border of the Ladentown outlier (fig. 1, loc. 4). Two separate lava flows were penetrated (fig. 2). The basalt near the top of the hole (0-31 ft) contained pipe vesicles and zones of glassy appearing, pillowed basalt and palagonitic basalt. Two samples of chilled pillow basalt at 23 and $31 \mathrm{ft}$ were analyzed (table 1). The lower contact with baked arkosic sandstone and fine-grained dolostone conglomerate was preserved. From a depth of $31 \mathrm{ft}$ down to $35 \mathrm{ft}$, dark-gray palagonite and cristobaliterich volcanic breccia underlie the flow rock. Partial fusion of quartzofeldspathic clasts in the palagonite layer is apparent in thin section. Monomineralic quartz and feldspar are the most refractory materials. In peperite at the base of the basalt, cristobalite replaces the refractory, pure quartz grains to form subhedral crystals. This zone of altered sediment and mixed basalt several feet thick is known from outcrop data to lie beneath the floor of the basalt flows along the northern part of the eastern lobes of the Ladentown flows along the western contact of the flow rocks just south of the drill site, and along the southern border of the flows. Evidently the basalt flowed over water-saturated sediments and filled swampy depressions, giving rise to hyaloclasites and intermixed quartzose sediment and basalt. The upper basalt is underlain by about $25 \mathrm{ft}$ of reddish-gray to dark-gray laminated sandstone that contains abundant wood fragments. This rock grades downward into a fine, reddishbrown laminated siltstone and black organic-matter-rich siltstone that nonconformably overlies the chilled lower basalt at $73 \mathrm{ft}$. A sketch of the contact of the laminated rock with the basalt is shown in the inset in figure 2 . Sedimentary compaction faults that terminate downward affected the lower few tenths of a foot of the overlying sediments. The basalt is glassy at its contact and contains 


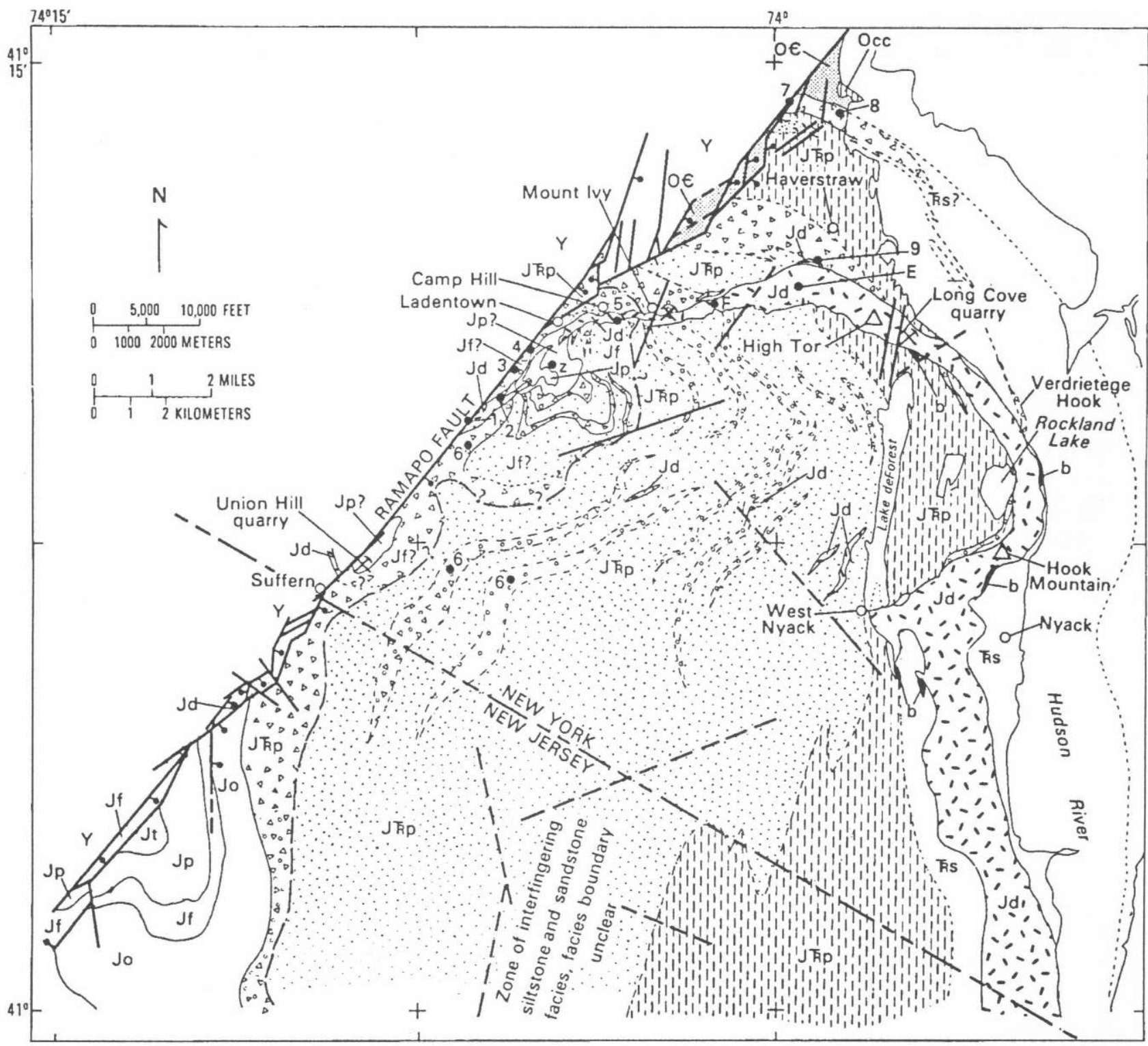

Figure 1. Schematic geologic map of southern Rockland County, New York, and northern Bergen County, New Jersey, showing the location of drill sites, the relationship of igneous rocks to strata of Triassic and Early Jurassic age, and the disposition of basalt flows and intrusives (based on mapping by Ratcliffe in 1979-81). Localities 1-9 discussed in text.

micropressure ridges and fine pinhole vesicles. Glassy to very fine-grained vesicular basalt continues downward to a pillowed zone at the base, at about $93 \mathrm{ft}$. The lower contact of the basalt on the dark mudstone is irregular but contains cracks in the chilled rind, into which apophyses of dark mudstone are injected (see lower inset, fig. 2). The lower flow is $23 \mathrm{ft}$ thick. The dark mudstone and sandstone are more typical of lithologies in the Feltville Formation than the Passaic Formation. Chemical analyses from the upper, glassy top and from vesicular basalt at 74 and $78 \mathrm{ft}$ are given in table 1. Beneath a fault zone in black mudstone, about $4 \mathrm{ft}$ of normal red siltstone and fine-grained cross-bedded sand- stone and green phyllite chip conglomerate and coarse dolostone fanglomerate are present. Outcrop and other nearby cores indicate that $300 \mathrm{ft}$ of coarse dolostone fanglomerate underlie the entire sequence.

Despite the great amount of hydration and carbonation, the samples from the upper lava flow (taken $8 \mathrm{ft}$ apart) are very similar in all aspects. These two lava flows have mafic index versus $\mathrm{TiO}_{2}$ plots (fig. 3 ) that are close to the average chill Palisades magma from the upper and lower contacts and intermediate between average Orange Mountain and Preakness Basalts. In the $\mathrm{MgO}$ versus total $\mathrm{FeO}$ diagram (fig. 4), three of the four samples are similar to the upper Palisades chill compo- 

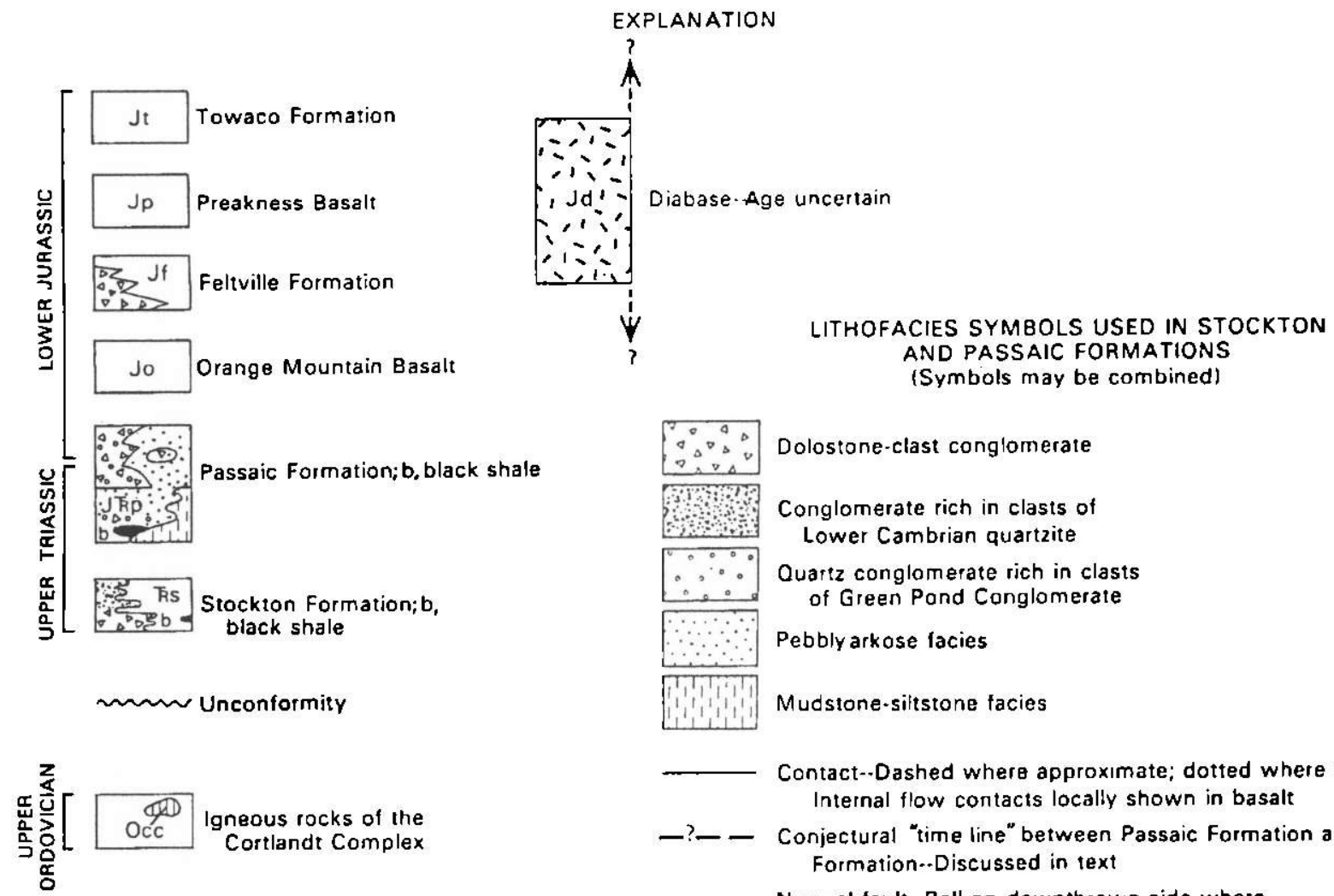

Dolostone-clast conglomerate

Conglomerate rich in clasts of Lower Cambrian quartzite

Quartz conglomerate rich in clasts of Green Pand Conglomerate

Pebbly arkose facies

Mudstone-siltstone facies
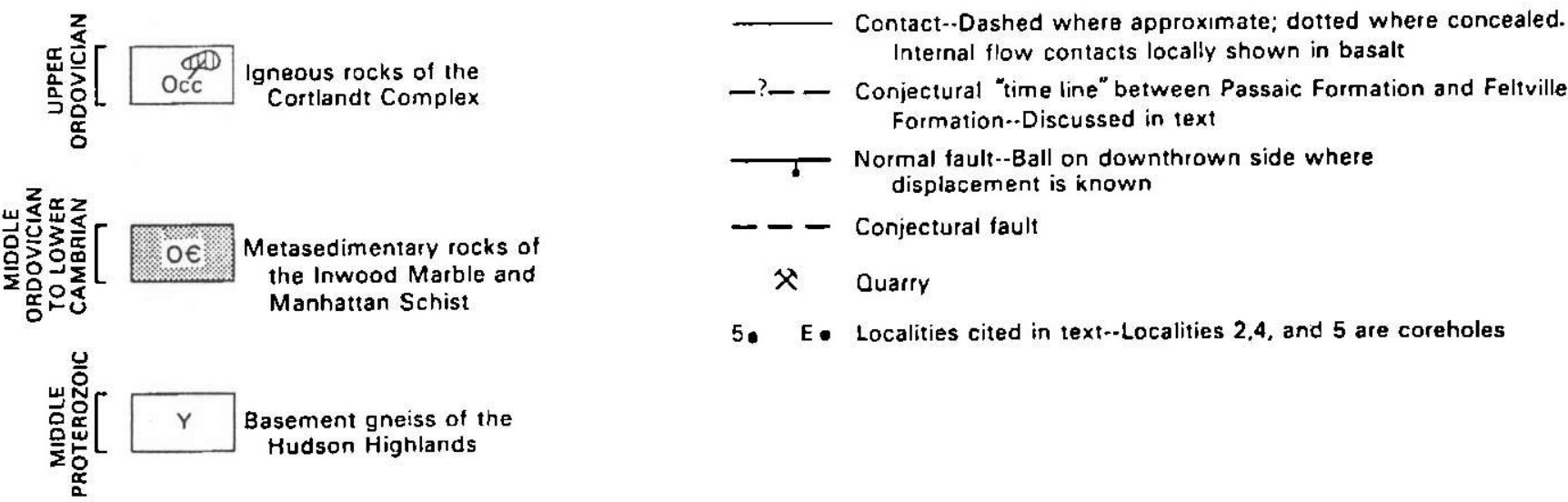

the Inwood Marble and Manhattan Schist

Figure 1. Continued.

sition and to sample PAL-A from the Palisades sill collected at the Palisades Parkway. Despite the very high $\mathrm{H}_{2} \mathrm{O}$ content and obvious alteration, these rocks contain high $\mathrm{MgO}$ and $\mathrm{TiO}_{2}$ contents characteristic of the Orange Mountain Basalt but are not clearly distinguishable from the Preakness Basalt.

\section{Coreholes at Mount Ivy}

Four coreholes were attempted in the area between the Palisades sill exposures at the Mount Ivy quarry (fig. 5) and the exposures of basalt near Ladentown, north and south of Route 202 (fig. 1, loc. 5). A fifth drillhole (F, in fig. 5) that bottomed in diabase was cited in Frimpter (1967). The two eastern holes were not successful in reaching basalt and were abandoned. MI-3 reached a depth of $116 \mathrm{ft}$ and recovered possible rubble of hornfels from that depth. In MI -4 , no bedrock was reached and was terminated at $138 \mathrm{ft}$. In hole MI-1 merocrystalline basalt, locally vesiculated, was recovered from $28 \mathrm{ft}$ to $56 \mathrm{ft}$, where coring was terminated. In hole MI-2 the metamorphosed sandstone and fanglomerate were cored to $100 \mathrm{ft} 11 \mathrm{in}$. where the contact with basalt was recovered. Vesicular basalt was cored down to $113 \mathrm{ft}$. Near the end of MI-2, from 109 to $113 \mathrm{ft}$, the rock is coarser grained and closely resembles the merocrystalline basalt cored in MI-1. Clear evidence of contact metamorphism in the overlying sediments and the chill contact indicates that the upper contact of the sill was cored. Two samples of basaltic rocks from each corehole were analyzed (see table 2) and are comparable to samples PAL-A, $-\mathrm{B}$, and $-\mathrm{C}$, taken from the closest exposure of the Palisades sill. 


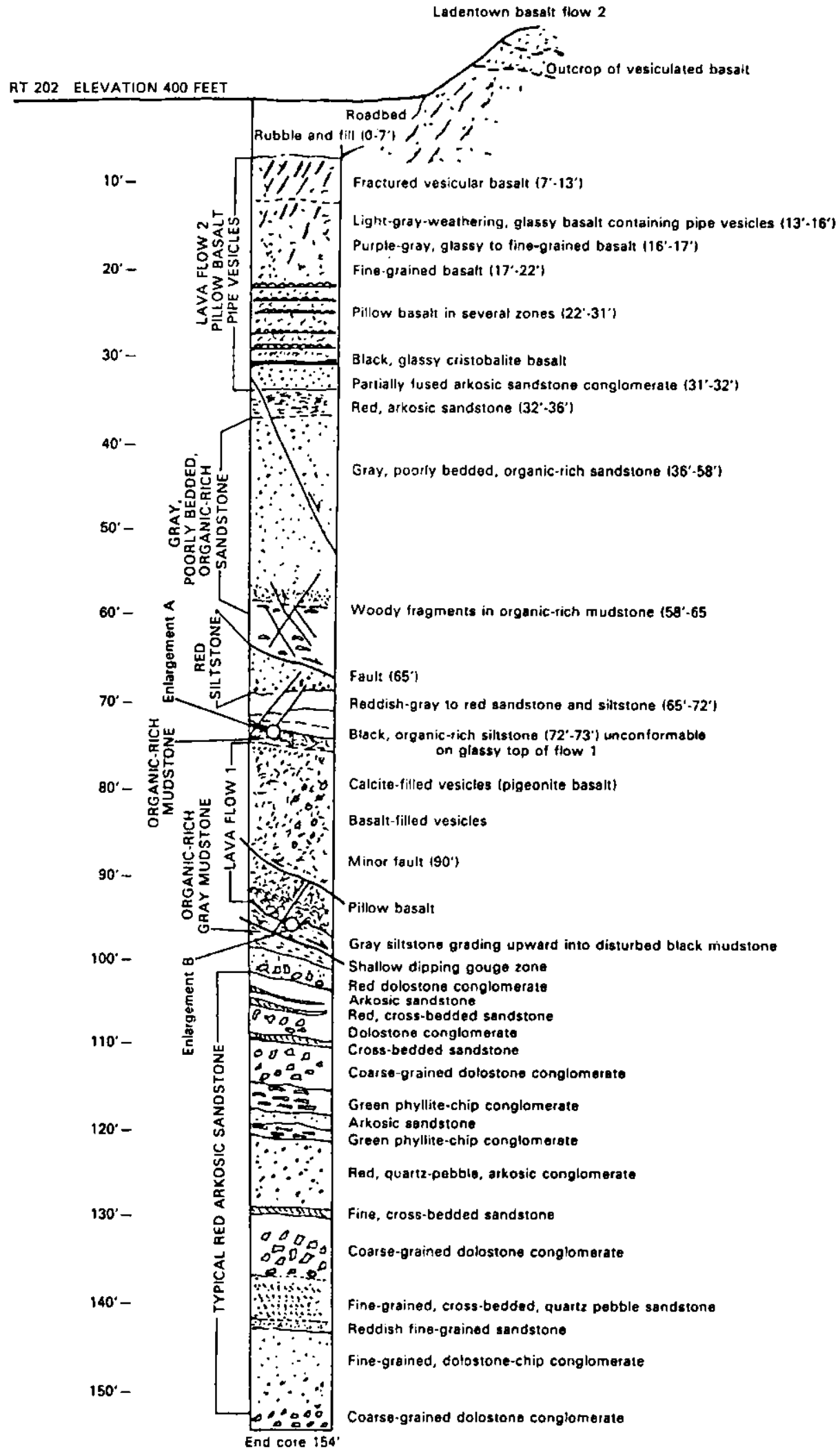

Figure 2. Detailed graphic log of the core that penetrated two lava flows of the Ladentown basalt flow complex, locality 4 on figure 1. 


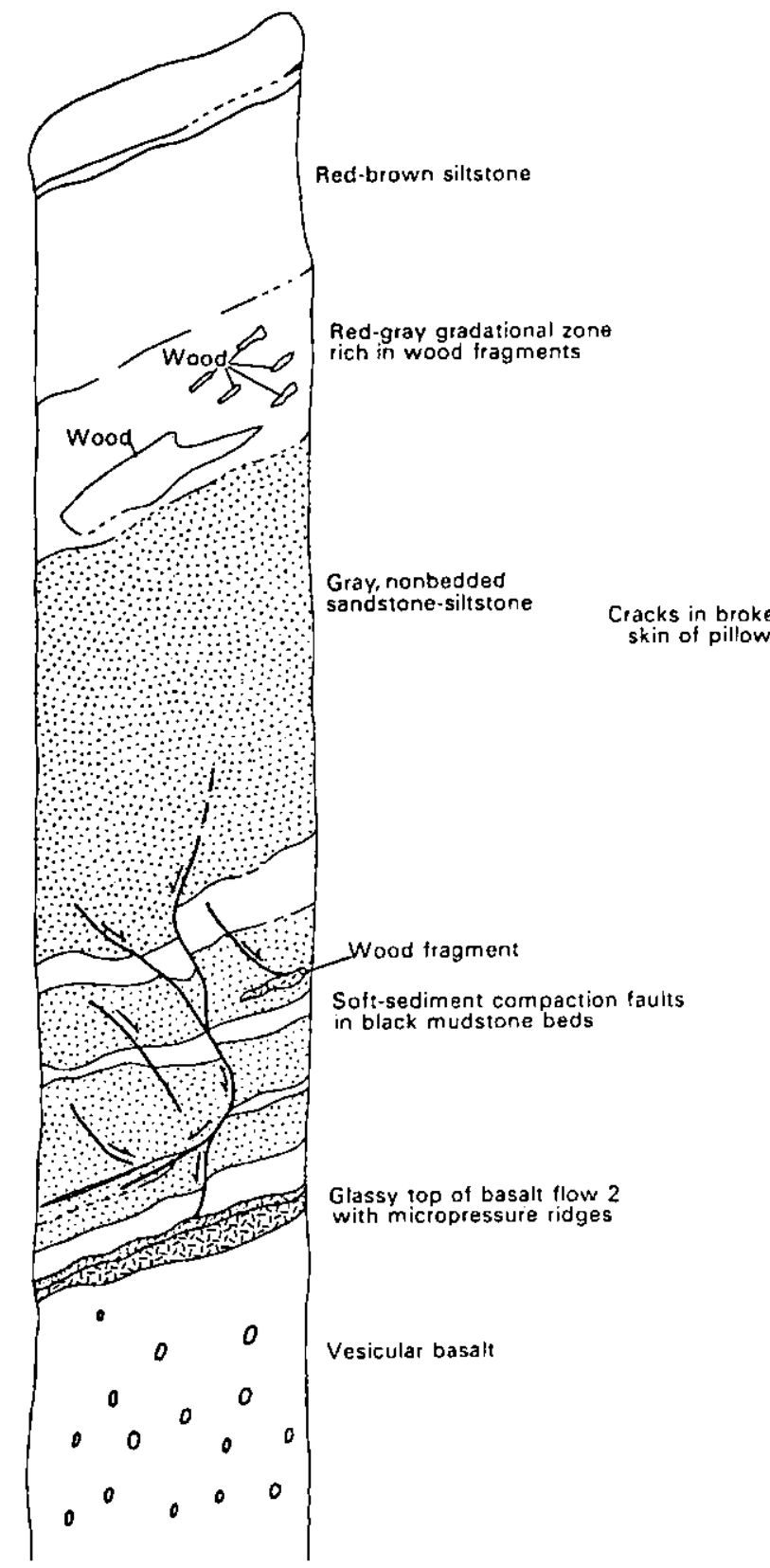

ENLARGEMENT A

Detailed drawing of sedimentary contact of organic-rich mudstone on upper surface of lava llow i between 74 and $96 \mathrm{ft}$.

Figure 2. Continued.

The chill contact rock (MI-2-101 and MI-2-110) is very comparable in the mafic index (MI) versus $\mathrm{TiO}_{2}$ and $\mathrm{MgO}$ versus total $\mathrm{FeO}$ diagrams (figs. 3,4) to the upper and lower chill zones of the Palisades and to the lava flow samples in the Haverstraw Road cores.

The samples from MI-1, however, are distinctly richer in iron for the same $\mathrm{TiO}_{2}$ value and contain markedly lower $\mathrm{MgO}$. These rocks compare more closely with samples PAL-B and PAL-C of the Palisades (table 2) and with analyses of diabase of the Palisades sill at 355

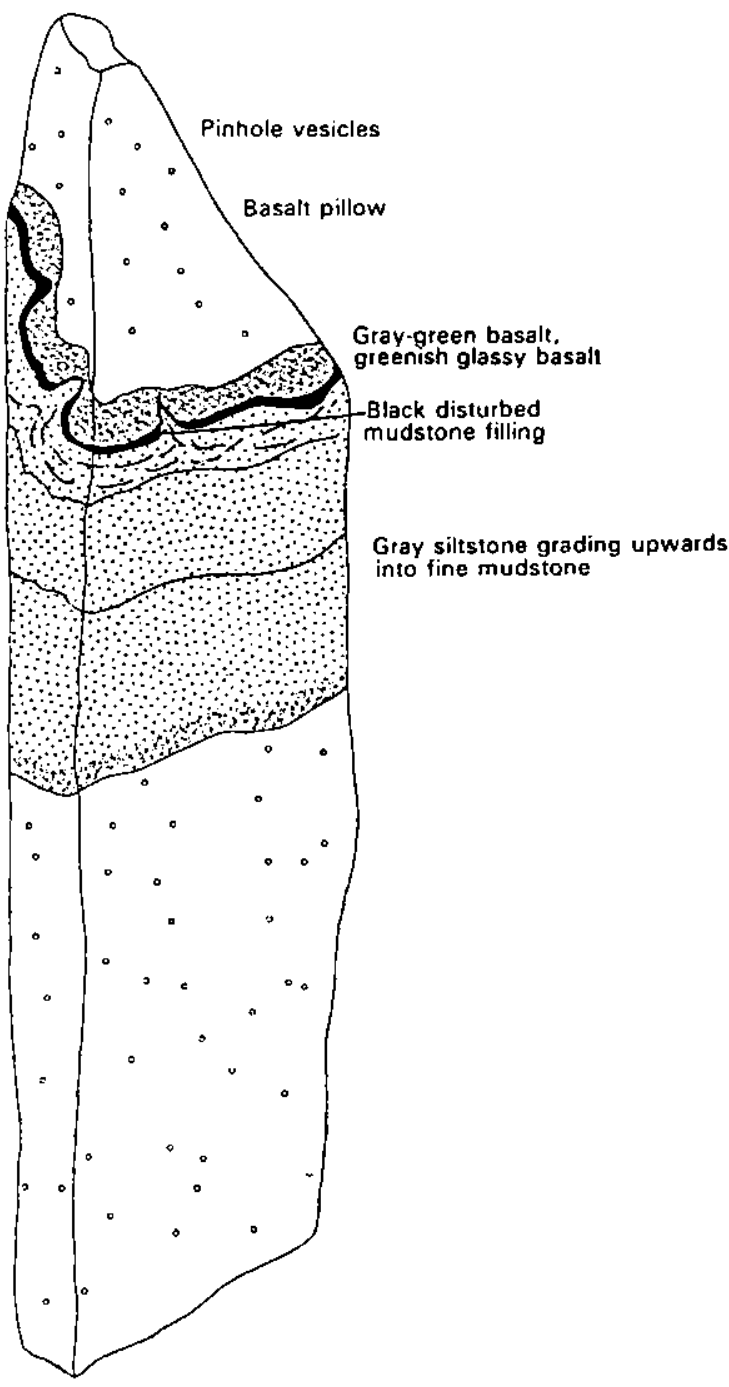

ENLARGEMENT B

Detailed drawing of lower contact of lava flow at $96 \mathrm{it}$ showing sedimentary injection into broken basalt pillow. Core diameter 2 in.

to $500 \mathrm{ft}$ above the base in the Englewood Cliffs section of Walker (1969).

A possible explanation for the variation in chemistry and position of the samples is shown in figure 6 . The drill sites MI-1 and MI-2 are shown transecting the roof of the Palisades sill. The $12 \mathrm{ft}$ of chill rock in MI-2 represents upper Palisades chill zone and lower Palisades chill comparable to diabase sample PAL-A, having approximately 7 percent $\mathrm{MgO}$ and low mafic indices (figs. 3, 4). PAL-A contains anomalously high $\mathrm{Na}_{2} \mathrm{O}$, 
Table 1. Major-element chemical analyses and normative constituents of basalt flows from the Ladentown area obtained from core at the Haverstraw Road site (see fig. 2)

[†, water- and $\mathrm{CO}_{2}$-free totals; $\mathrm{HR} 23,31,74$, and 78 refer to depth in feet of sample]

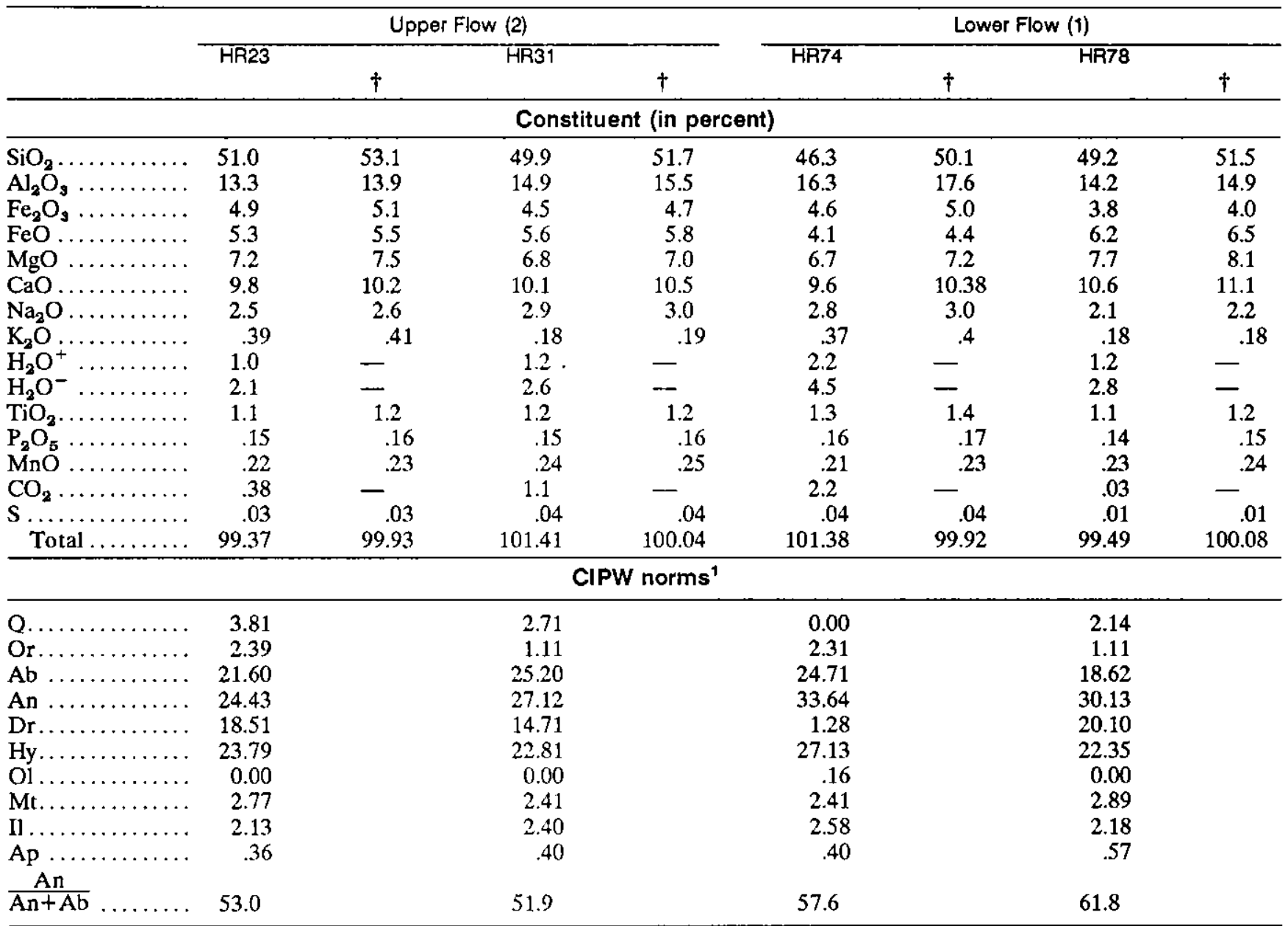

$$
{ }^{1} \frac{\mathrm{Fe}_{2} \mathrm{O}_{3}}{\mathrm{Fe}_{2} \mathrm{O}_{3}+\mathrm{FeO}}=0.235
$$

causing the presence of olivine in the norm. The cause of the elevated $\mathrm{Na}_{2} \mathrm{O}$ is unknown. Samples PAL-B and $-\mathrm{C}$ match closely the samples from MI-1 and are construed to have come from a zone 35 to $65 \mathrm{ft}$ below the chill diabase samples. These samples have higher mafic indices and lower $\mathrm{MgO}$ values comparable to samples of the interior of the Palisades sill (figs. 3, 4). Parts of each core are vesicular basalt, as are samples from the Palisades Parkway roadcut (sample PAL-C).

The interpretation of the structural data requires either a right-lateral strike-slip fault, a west-dipping normal fault, or a left-oblique normal fault to downdrop the roof of the Palisades sill in the area west of the Palisades Parkway (see fig. 5). The position of the proposed fault that offsets the roof of the sill is not well constrained. It is shown passing near or through MI-4, because this apparently is the deepest part of the low in the bedrock surface.
On the basis of the outcrop width of the Palisades sill and the probable dip at Mount Ivy, the calculated thickness of the sill is $240 \mathrm{ft}$. The positions of samples PAL $-A,-B$, and $-C$ from the roadcut and the position of the cored rock from MI-1 and MI-2 are shown projected into the cross section in figure 6 . The vesicular diabase in MI-1 resembles closely similar vesicular and complexly veined diabase seen in the sample locality for PAL-C.

Conglomerate $5 \mathrm{ft}$ above the sill in MI-2 contains clasts of vesicular basalt. Because no volcanism in the Newark basin is known to be older than Early Jurassic (Cornet, 1977), the conglomerate beds intruded by the sill in MI-2 are considered Early Jurassic rather than Late Triassic in age as commonly assumed. A similar bed of conglomerate that contains basaltic clasts is present immediately beneath pillow basalt at Union Hill (Ratcliffe, 1980) (fig. 1), also suggesting an Early Jurassic age for the conglomerates there. In addition, these data 


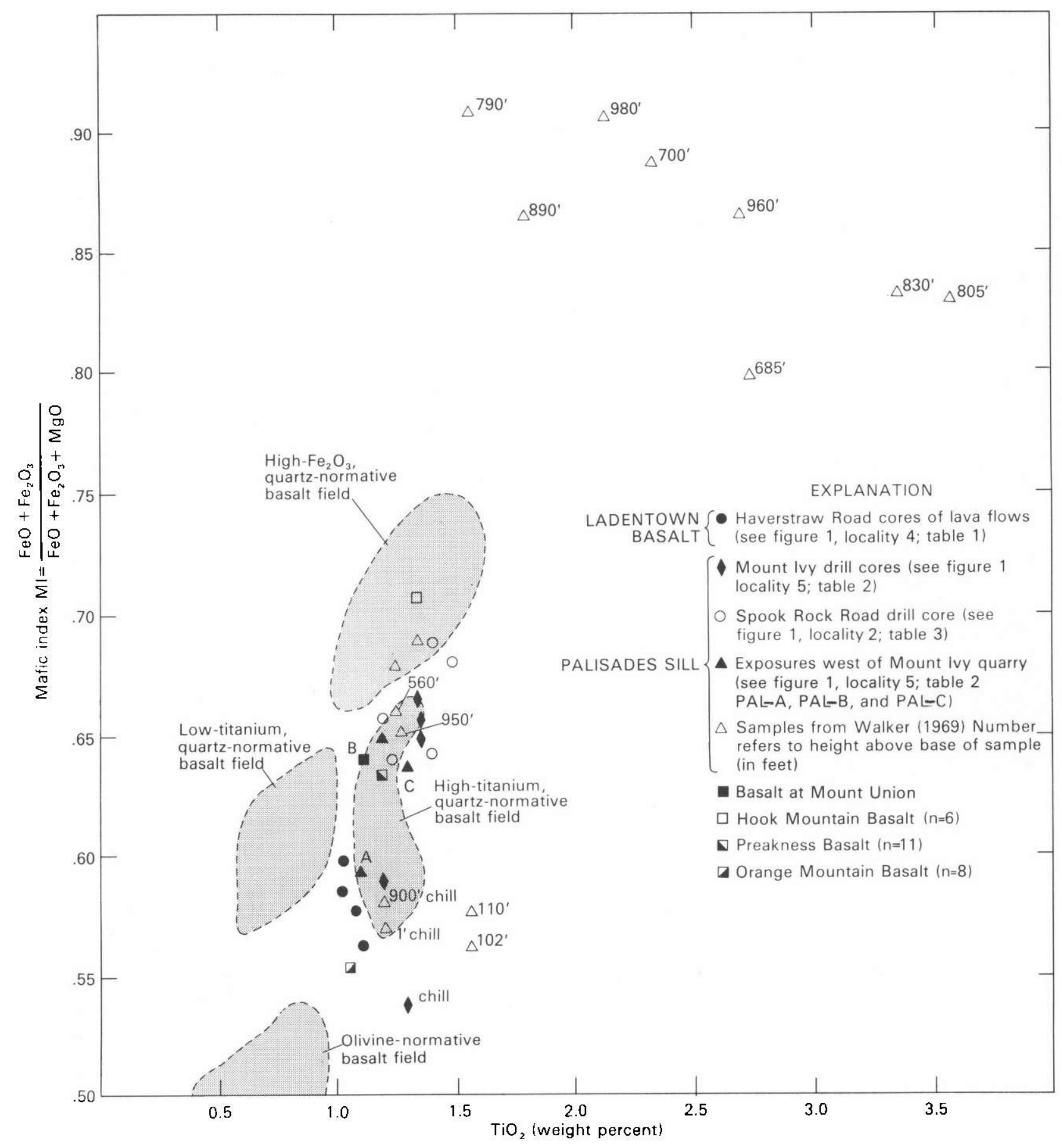

Figure 3. Mafic index (MI) versus $\mathrm{TiO}_{2}$ diagram for the chemically undifferentiated rocks from the Palisades sill and Ladentown flows (this study) in comparison to Palisades sill (Walker, 1969), the average Orange Mountain, Preakness, and Hook Mountain Basalts, and the basalts at Union Hill (data from this paper, Walker (1969), and Puffer and others (1982)).

suggest that the Palisades sill, the Ladentown flow rocks, and the rocks at Union Hill are all somewhat younger than the Orange Mountain Basalt, on the basis of their interpreted structural position above these conglomerates. If this interpretation is correct, then the sedimentary rocks contained in the core of the Ladentown syncline postdate the Orange Mountain Basalt and are correlative with the Feltville Formation.

\section{Corehole at Spook Rock Road}

A 184-ft corehole (called the Spook Rock Road core) was completed near the eastern margin of the 


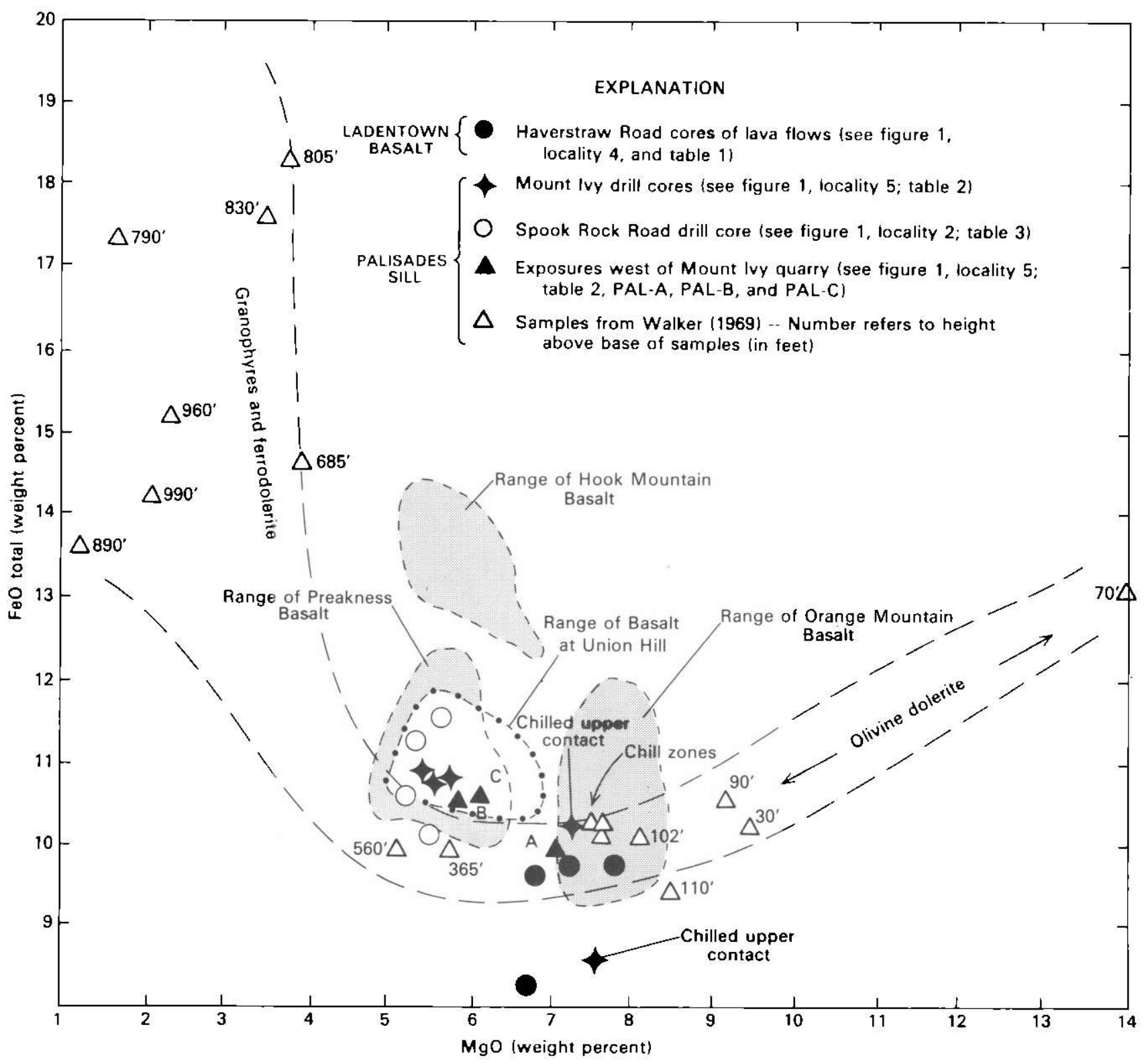

Figure 4. Total FeO versus $\mathrm{MgO}$ diagram for basalts and diabases from the northern Palisades sill, from the Ladentown area, and from Union Hill.

Ladentown flows south of Mount Ivy Road (fig. 1, loc. 2). The site was selected to intersect the floor of the basalt in an area suspected to be the flow channel to the ponded basalts cored to the southwest (fig. 1, loc. 1) at Sky Meadow Road (Ratcliffe, 1982). The site plan shows the location of the drill site and the local geology (fig. 7). On this map, areas of amygdaloidal basalt and flow breccia and flow-layered glassy basalt are shown overlying sedimentary beds. From a point north of Limekiln Road an apparently crosscutting wedge-shaped belt of igneous rock extends southwestward. This tongue of variably vesicular basalt was previously believed to be basalt flows deposited in an erosional channel cut into previously tilted strata. The absence of hornfels and the local presence of pillows in this area, and gradation of finegrained diabase into basalt flows, suggested this interpretation. The core sampled $183 \mathrm{ft}$ of variably vesicular, merocrystalline basalt marked by an abundance of basalt-filled vesicles. Abundant dark circular patches as much as $3 \mathrm{~mm}$ in diameter, resembling vesicles, are filled with fine-grained and glassy basalt. These features are trapped between irregular zones of fine-grained diabase with typical subophitic texture. The basalt is finer grained and more vesicular near the top of the core and coarser 


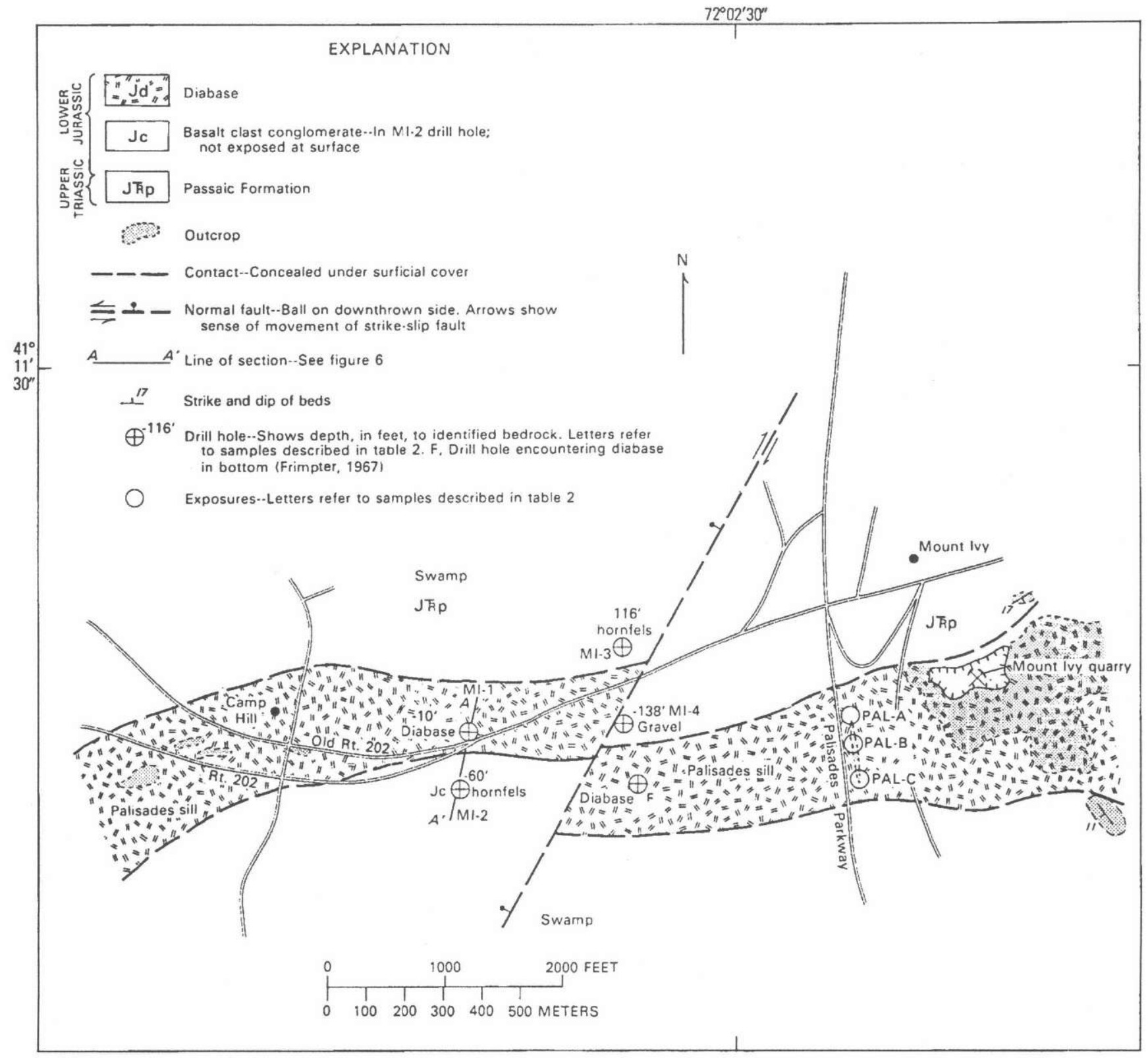

Figure 5. Geologic sketch map showing relationship of coreholes at Mount lvy, New York, to surface samples of Palisades diabase (PAL-A, $-B$, and $-\mathrm{C})$.

grained and locally diabasic near the base. Four Spook Rock Road samples were analyzed (table 3 ) and are comparable to samples from MI-1 and Palisades samples PAL-B and $-C$ and markedly dissimilar from the lava flows in the Haverstraw Road core and the chill zone rocks in MI-2.

The fine-grained diabase and basalt sampled in the Spook Rock Road core are all remarkably similar (table 3 ). They contain low amounts of $\mathrm{CO}_{2}$ and only moderate amounts of $\mathrm{H}_{2} \mathrm{O}$. The $\mathrm{FeO} / \mathrm{Fe}_{2} \mathrm{O}_{3}$ ratios are fairly consistent (2 to 1.4) and the rocks appear fresh. $\mathrm{TiO}_{2}$ and $\mathrm{P}_{2} \mathrm{O}_{5}$ increase regularly up the section as does $\mathrm{K}_{2} \mathrm{O}$, although $\mathrm{Na}_{2} \mathrm{O}$ is not stable. $\mathrm{MgO}$ varies only slightly and not systematically.

These basaltic rocks resemble closely the rocks from the interior of the Palisade sill (PAL-B and -C) and the samples from Mount Ivy 1, in figures 3 and 4, but have textures transitional from fine-grained diabase into merocrystalline basalt. Careful examination of the core and thin sections for flow structures and for flattened vesicles did not reveal any indications of subhorizontal flow. Locally a weakly defined subvertical flow orientation of plagioclase was detected, but overall textures suggest static crystallization. 
Table 2. Major-element chemical analyses and normative constituents of basaltic rocks from the Mount Ivy drillholes and from nearby exposures of the Palisades sill

[H. Smith, analyst; see figs. 3 and 4 ]

\begin{tabular}{|c|c|c|c|c|c|c|c|c|}
\hline & $\begin{array}{l}\text { Chill contact } \\
\text { MI-2-101 }\end{array}$ & $\begin{array}{c}\text { Fine-grained } \\
\text { diabase } \\
\mathrm{Ml}-2-112\end{array}$ & $\begin{array}{l}\text { Fine-grained } \\
\text { merocrystalline } \\
\text { diabase } \\
\mathrm{MI}-1\left(45-46^{\prime}\right)\end{array}$ & $\begin{array}{c}\text { Fine-grained } \\
\text { to glassy } \\
\text { basalt } \\
M-1\left(52-53^{\prime}\right)\end{array}$ & $\begin{array}{l}\text { Merocrystalline } \\
\text { basalt } M \mid-1-34^{\prime}\end{array}$ & $\begin{array}{c}\text { Diabase } \\
\text { PAL-A }\end{array}$ & $\begin{array}{l}\text { Diabase } \\
\text { PAL-B }\end{array}$ & $\begin{array}{c}\text { Vesicular } \\
\text { diabase } \\
\text { PAL-C }\end{array}$ \\
\hline \multicolumn{9}{|c|}{ Constituent (in percent) } \\
\hline $\mathrm{SiO}_{2} \ldots \ldots \ldots$ & 49.5 & 51.8 & 52.2 & 51.9 & 52.0 & 52.1 & 51.7 & 51.3 \\
\hline $\mathrm{Al}_{2} \mathrm{O}_{3} \ldots \ldots \ldots$ & 15.3 & 14.0 & 14.2 & 14.5 & 14.5 & 14.5 & 14.5 & 14.1 \\
\hline $\mathrm{Fe}_{2} \mathrm{O}_{3} \ldots \ldots \ldots$ & 4.4 & 3.2 & 3.0 & 3.7 & 3.7 & 3.1 & 3.8 & 3.6 \\
\hline $\mathrm{FeO} \ldots \ldots \ldots \ldots$ & 4.5 & 7.4 & 8.2 & 7.4 & 7.4 & 7.2 & 7.2 & 7.4 \\
\hline $\mathrm{MgO} \ldots \ldots \ldots$ & 7.5 & 7.2 & 5.4 & 5.9 & 5.6 & 7.1 & 5.9 & 6.1 \\
\hline $\mathrm{CaO} \ldots \ldots \ldots$ & 8.5 & 9.5 & 9.7 & 10.4 & 10.1 & 8.7 & 9.9 & 9.9 \\
\hline $\mathrm{Na}_{2} \mathrm{O} \ldots \ldots \ldots$ & 1.9 & 2.0 & 2.2 & 2.1 & 2.3 & 4.0 & 2.6 & 2.5 \\
\hline $\mathrm{K}_{2} \stackrel{\mathrm{O}}{\mathrm{O}} \ldots \ldots \ldots$ & .64 & .69 & .90 & .86 & .71 & 1.0 & .79 & .86 \\
\hline $\mathrm{H}_{2} \mathrm{O}^{+} \ldots \ldots \ldots$ & 2.0 & .60 & 1.4 & .50 & .67 & .42 & .68 & .68 \\
\hline $\mathrm{H}_{2} \mathrm{O}^{-} \ldots \ldots \ldots$ & 3.2 & 1.2 & .71 & 1.2 & .83 & .78 & .82 & .92 \\
\hline $\mathrm{TiO}_{2} \ldots \ldots \ldots$ & 1.3 & 1.2 & 1.3 & 1.3 & 1.3 & 1.1 & 1.2 & 1.3 \\
\hline $\mathrm{P}_{2} \mathrm{O}_{5} \ldots \ldots \ldots$ & .17 & .16 & .18 & .17 & .19 & .16 & .18 & .18 \\
\hline $\mathrm{MnO} \ldots \ldots \ldots$ & .07 & .14 & .16 & .19 & .16 & .27 & .22 & .20 \\
\hline $\mathrm{CO}_{2} \ldots \ldots \ldots$ & .14 & .08 & .02 & .02 & .11 & .07 & .21 & .03 \\
\hline Total. ....... & 99.12 & 99.17 & 99.57 & 100.14 & 99.57 & 100.5 & 99.7 & 99.07 \\
\hline \multicolumn{9}{|c|}{ CIPW norms ${ }^{1}$} \\
\hline$\ldots \ldots \ldots$ & 5.19 & 5.41 & 8.33 & 4.69 & 4.28 & 0.00 & 3.82 & 2.67 \\
\hline Or $\ldots \ldots \ldots \ldots$ & 4.00 & 4.17 & 5.61 & 5.18 & 4.29 & 5.95 & 4.73 & 5.23 \\
\hline $\mathrm{Ab} \ldots \ldots \ldots$ & 17.09 & 17.36 & 19.60 & 18.04 & 19.82 & 34.08 & 22.39 & 21.71 \\
\hline An $\ldots \ldots \ldots$ & 33.38 & 27.93 & 27.60 & 28.04 & 27.68 & 18.77 & 26.04 & 25.34 \\
\hline 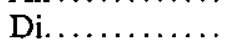 & 7.60 & 16.28 & 4.67 & 19.87 & 18.71 & 19.72 & 17.63 & 20.43 \\
\hline Hy $\ldots \ldots \ldots \ldots$ & 26.78 & 23.39 & 27.8 & 18.34 & 20.29 & 0.00 & 19.56 & 18.70 \\
\hline Ol. .......... & .00 & 0.00 & 0.00 & 0.00 & 0.00 & 12.06 & 0.00 & 0.00 \\
\hline Mt $\ldots \ldots \ldots \ldots$ & 2.61 & 3.00 & 3.27 & 3.10 & 3.12 & 2.87 & 3.07 & 3.10 \\
\hline I] $\ldots \ldots \ldots \ldots$ & 2.62 & 2.34 & 2.61 & 2.50 & 2.02 & 2.11 & 2.32 & 2.53 \\
\hline $\operatorname{Ap}_{\text {An }} \ldots \ldots \ldots$ & .43 & .40 & .44 & .40 & .47 & 1.37 & .43 & .43 \\
\hline$\overline{\mathrm{An}+\mathrm{Ab}} \ldots \ldots$ & 66.1 & 61.7 & 58.5 & 60.8 & 58.0 & & & \\
\hline
\end{tabular}

${ }^{1} \frac{\mathrm{Fe}_{2} \mathrm{O}_{3}}{\mathrm{Fe}_{2} \mathrm{O}_{3}+\mathrm{FeO}}=0.235$

\section{RARE-EARTH ELEMENT AND TRACE-ELEMENT DATA}

Trace-element data determined by instrumental neutron activation analysis (INAA) for known or suspected intrusive components of the Ladentown-Palisades suite are given in table 4.

Samples PAL-A, MI-2-112 ft, and MI-2-101 ft are among the most primitive samples, consistent with their being chilled margin rocks, as indicated by their $\mathrm{MgO}$ contents, which are $7.1,7.2$, and 7.5 percent, respectively. Samples with lower $\mathrm{MgO}$ values from the Spook Rock Road core and from MI-1 and PAL-B and $-C$ and the samples from Spook Rock Road show elevated rare-earth element (REE) patterns and a slight negative Eu anomaly. The REE data are consistent with the diabase at Spook Rock Road representing the interior, slightly more differentiated portion of the Palisades sill cored in MI-1. Chondrite-normalized REE patterns for samples from the Palisades sill outcrop, from the Mount Ivy core, and from Spook Rock Road drill core are shown in figure 8.

Chilled basalt (samples MI-2-101 and -112) have $\mathrm{La}=37$ and $39 \times$ chondrite and $\mathrm{Yb}=12$ and $13 \times$ chondrite. Samples from the interior of the sill corresponding to distances approximately $220 \mathrm{ft}$ beneath the roof have chondrite-normalized $\mathrm{La}$ values that range from 37 to 44 , and $\mathrm{Yb}$ values of approximately 12 . Elevated chondrite-normalized REE patterns characterize the Spook Rock Road cores as compared to the Mount Ivy samples ( $\mathrm{La}=42$ to $59, \mathrm{Yb}=13$ to 19$)$. The chondrite-normalized $\mathrm{La} / \mathrm{Yb}$ ratios of all rocks, however, are comparable. The $\mathrm{La} / \mathrm{Yb}$ ratios, (not chondrite normalized) range from 5.0 in chilled samples to 5.8 in PAL $-B$ and $-C$, somewhat higher than the 4.5 value for the Orange Mountain Basalt (Kay and others, 1970). Chilled samples have markedly greater Ba (260 ppm) and greater $\mathrm{Yb}(2.54 \mathrm{ppm})$ than the chilled Palisades 


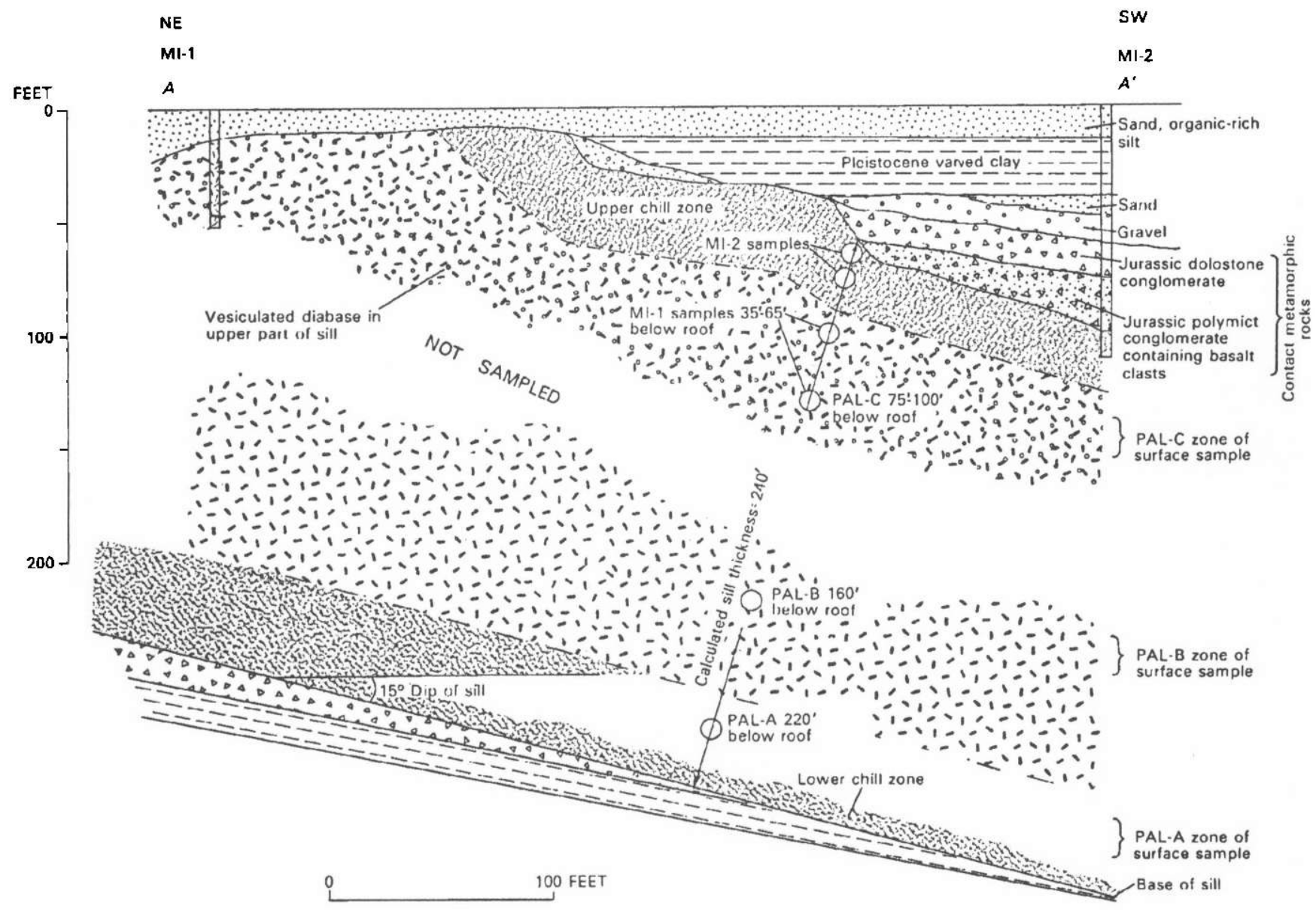

Figure 6. Cross section through Mount Ivy coreholes 1 and 2 (MI-1 and MI-2) showing projected position of core and surface exposure samples discussed in text. Line of section shown in figure 5.

magma at Englewood Cliffs, although other rare-earth data (Philpotts and Schnetzler, 1968, table 1) and the chondrite-normalized patterns are nearly identical. The upper range of REE enrichment in these samples is comparable to, although not as extreme as, the enrichment found in the most differentiated Palisades sill rocks, which ranges up to about $75 \times$ chondrite for La (Philpotts and Schnetzler, 1968, figure 1). The REE values of both suites are very comparable to the values determined for the Orange Mountain Basalt as determined by Kay and others (1970). REE data are not available for the Preakness Basalt.

The Palisades samples are enriched in Th with respect to some other continental quartz tholeiites, such as the late Carboniferous dikes of Scotland (Macdonald and others, 1981), and Snake River basalts (see Wood, 1980). On a Hf/3-Th-Ta tectonomagmatic discrimination diagram (Wood, 1980) (fig. 9), the Palisades sill plots in the same general field as other Mesozoic-rift basalt-diabase-granophyre associations. They are particularly similar to the basait from the Club House crossroads drillhole at Charleston, South Carolina (Gottfried and others, 1983). These data illustrate well the noneffectiveness of the Wood (1980) discrimination diagram in determining the tectonic setting of some continental tholeiites, as pointed out by Gottfried and others (1983). The chilled diabase samples (solid circles) from the Palisades sill show a tight clustering with $\mathrm{Th} / \mathrm{Ta}$ values of approximately 0.4 .

$\mathrm{MnO}-\mathrm{TiO}_{2}$ and $\mathrm{P}_{2} \mathrm{O}_{5}$ relationships can be used to evaluate qualitatively the effects of olivine fractionation, as early separation of olivine leaves the residual melt enriched in $\mathrm{TiO}_{2}$. In figure $10 \mathrm{~B}$ Walker's (1969) samples of fractionated and unfractionated chilled samples are plotted on Mullen's (1983) $\mathrm{MnO}-\mathrm{TiO}_{2}-\mathrm{P}_{2} \mathrm{O}_{5}$ diagram. Olivine and hypersthene cumulates from the hyalosiderite zone are enriched in $\mathrm{MnO}$ and late-stage ferrodiorites are enriched in $\mathrm{TiO}_{2}$. By comparison, samples from the Palisades sill and Ladentown area of this report (fig. $10 A$ ) show nearly constant $\mathrm{TiO}_{2}-\mathrm{P}_{2} \mathrm{O}_{5}$ ratios but a wide range of $\mathrm{MnO}-\mathrm{TiO}_{2}$ ratios. Four samples of lava flows from the Haverstraw Road site are similar in $\mathrm{MnO} / \mathrm{TiO}_{2}$ values to Palisades sill samples PAL-A, $-B$, and $-C$. From these data, it is clear that samples of the Palisades 


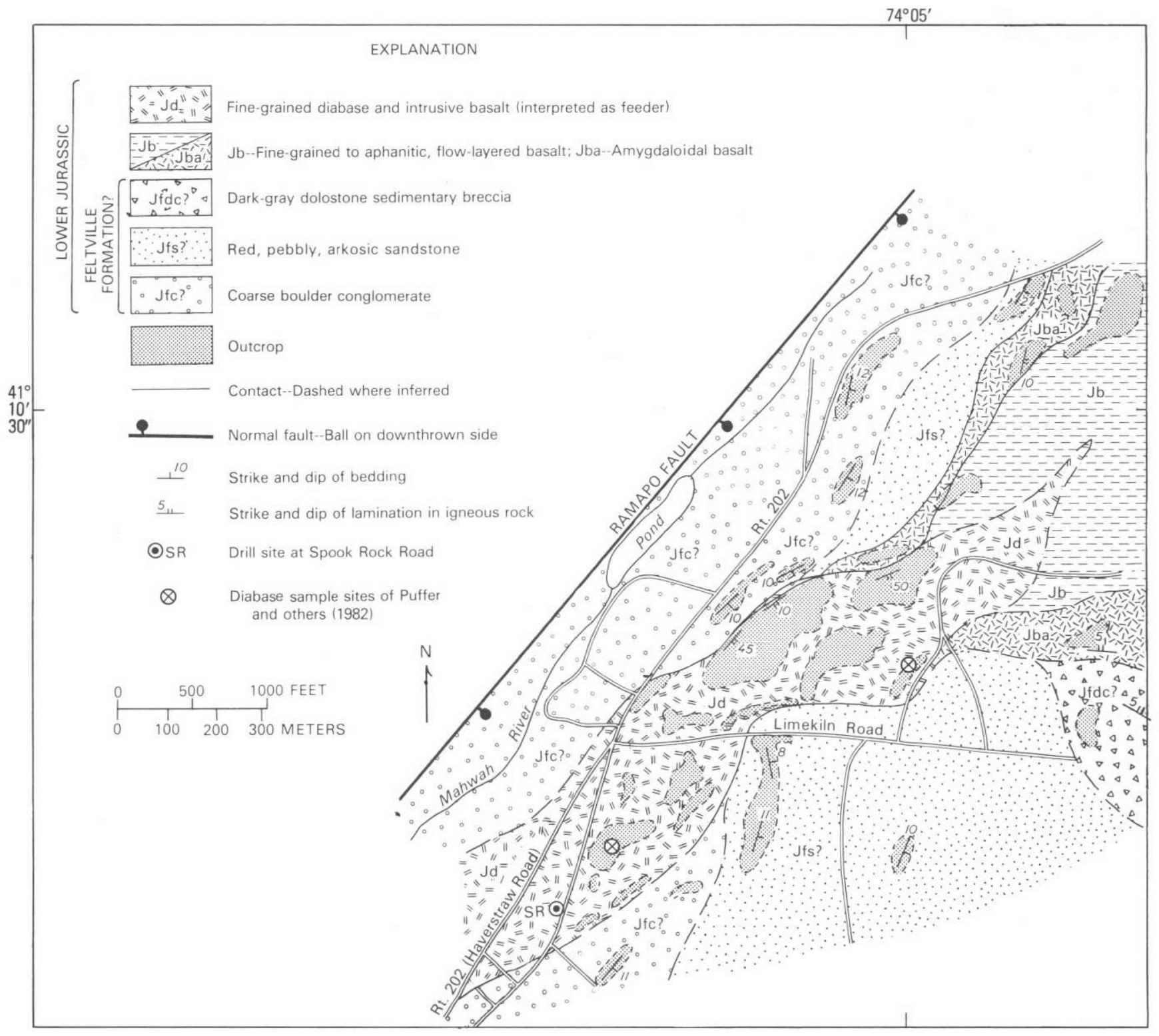

Figure 7. Geologic sketch map of corehole locality at Spook Rock Road (locality 2, fig. 1) showing interpreted intrusive rocks and feeder(?) and basaltic flows. The diabase forms a prominent line of ridges that rise approximately 100 $\mathrm{ft}$ above Jurassic(?) strata to the west. Flow structures within

sill and Ladentown fissure-flow complex do not show evidence of olivine fractionation or hypersthene accumulation within the range of the samples. This does not preclude earlier olivine fractionation, before injection and solidification.

The fields for oceanic basalt types are shown for illustration only and to point out the problem of using the discrimination diagram to characterize continental basalts, a point stressed by Mullen (1983). As in the case of the Hf-Th-Ta diagram, continental basalts are not well discriminated as to magma type by these diagrams. chill diabase on the hills and northwest of Limekiln Road are interpreted as minor-scale protrusion structures similar to the textures described in the text that refer to figure 6. Sedimentary rocks of uncertain age and correlation beneath basalts are tentatively assigned to the Feltville Formation.

\section{DISCUSSION OF FIELD RELATIONSHIPS}

Locally the basaltic rocks at Ladentown are amygdaloidal, pillowed, and flow layered. Minor pahoehoe snouts or buds, tilted and flattened pipe vesicles, and pillow zones suggest surface flows. On the basis of surface mapping of the amygdaloidal basalts, there appear to be three lava flows in the Ladentown flow complex (Ratcliffe, 1980). The lower one, seen in drill core, measures only $20 \mathrm{ft}$ thick and is separated at this 
Table 3. Major-element chemical analyses and normative constituents of diabasic rocks from the Spook Rock Road core.

[H. Smith, analyst]

\begin{tabular}{|c|c|c|c|c|}
\hline & SA-68.1' & $S R-82^{\prime}-83^{\prime}$ & SR-109' & SR-133' \\
\hline \multicolumn{5}{|c|}{ Constituent (in percent) } \\
\hline 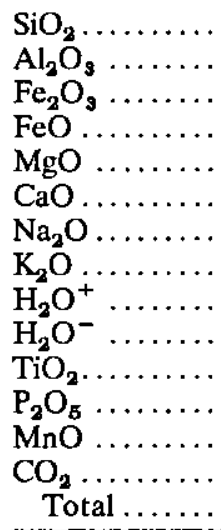 & $\begin{array}{c}52.3 \\
. \quad 13.7 \\
. \quad 4.0 \\
. \quad 8.0 \\
. \quad 5.6 \\
. \quad 9.6 \\
. \quad 2.4 \\
. \quad .95 \\
. \quad .30 \\
. \quad 1.0 \\
. \quad 1.5 \\
. \quad .20 \\
. \quad .19 \\
. \quad .07 \\
. \quad 99.81\end{array}$ & $\begin{array}{c}52.2 \\
14.0 \\
4.2 \\
7.5 \\
5.3 \\
9.3 \\
2.3 \\
.85 \\
.20 \\
1.0 \\
1.4 \\
.20 \\
.20 \\
.28 \\
98.93\end{array}$ & $\begin{array}{c}51.7 \\
14.2 \\
4.5 \\
6.5 \\
5.2 \\
10.0 \\
2.3 \\
.87 \\
.60 \\
1.2 \\
1.4 \\
.19 \\
.19 \\
.60 \\
99.45\end{array}$ & $\begin{array}{c}51.6 \\
14.7 \\
3.7 \\
6.8 \\
5.5 \\
10.1 \\
2.3 \\
.71 \\
.50 \\
1.1 \\
1.2 \\
.18 \\
.14 \\
.22 \\
98.75\end{array}$ \\
\hline \multicolumn{5}{|c|}{ CIPW norms ${ }^{1}$} \\
\hline 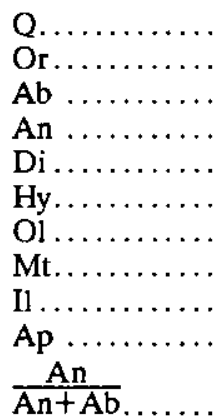 & $\begin{array}{r}5.02 \\
.67 \\
. \quad 20.60 \\
24.17 \\
. \quad 19.48 \\
18.16 \\
. \quad 0.00 \\
. \quad 4.23 \\
2.89 \\
. \quad 47 \\
\\
\end{array}$ & $\begin{array}{r}6.63 \\
5.12 \\
19.92 \\
25.96 \\
15.99 \\
19.45 \\
0.00 \\
3.40 \\
2.71 \\
.47 \\
\\
56.6\end{array}$ & $\begin{array}{r}6.27 \\
5.34 \\
20.16 \\
26.80 \\
16.85 \\
18.15 \\
0.00 \\
3.14 \\
2.81 \\
.48 \\
\\
57.1\end{array}$ & $\begin{array}{r}5.40 \\
4.34 \\
10.03 \\
28.48 \\
17.77 \\
17.91 \\
0.00 \\
2.98 \\
2.35 \\
.43 \\
\\
58.7\end{array}$ \\
\hline
\end{tabular}

locality by $40 \mathrm{ft}$ of sedimentary rock from the next higher flow. The second flow contains an amygdaloidal zone, flow breccia, and peperite along its base. A third zone of amygdaloidal and coarser grained copper-stained basait forms a topographic bench $60 \mathrm{ft}$ above the base of the second flow unit. The total thickness of the exposed flow and interlayered sedimentary rocks is only about $220 \mathrm{ft}$. On figure 1 the boundary between flows 2 and 3 is shown. The upper contact of the basalt is not seen, so the total original thickness is unknown. However, the uppermost layers in the core of the syncline are flow-layered, glassy basalt and possibly represent the top of the basalt. Areas where flow structures, pillows, or strongly vesiculated basalt are recognized are used to define the limits of the flow rocks as shown on figure 1 .

Within what now appears to be intrusive rocks, internal chill contacts are numerous, as are zones of lamellar flow. Lobate forms resembling pahoehoe snouts are present within these rocks, but these may be intrusive features rather than extrusive. Reexamination of some of the flow-layered rocks on the hills northwest of Limekiln
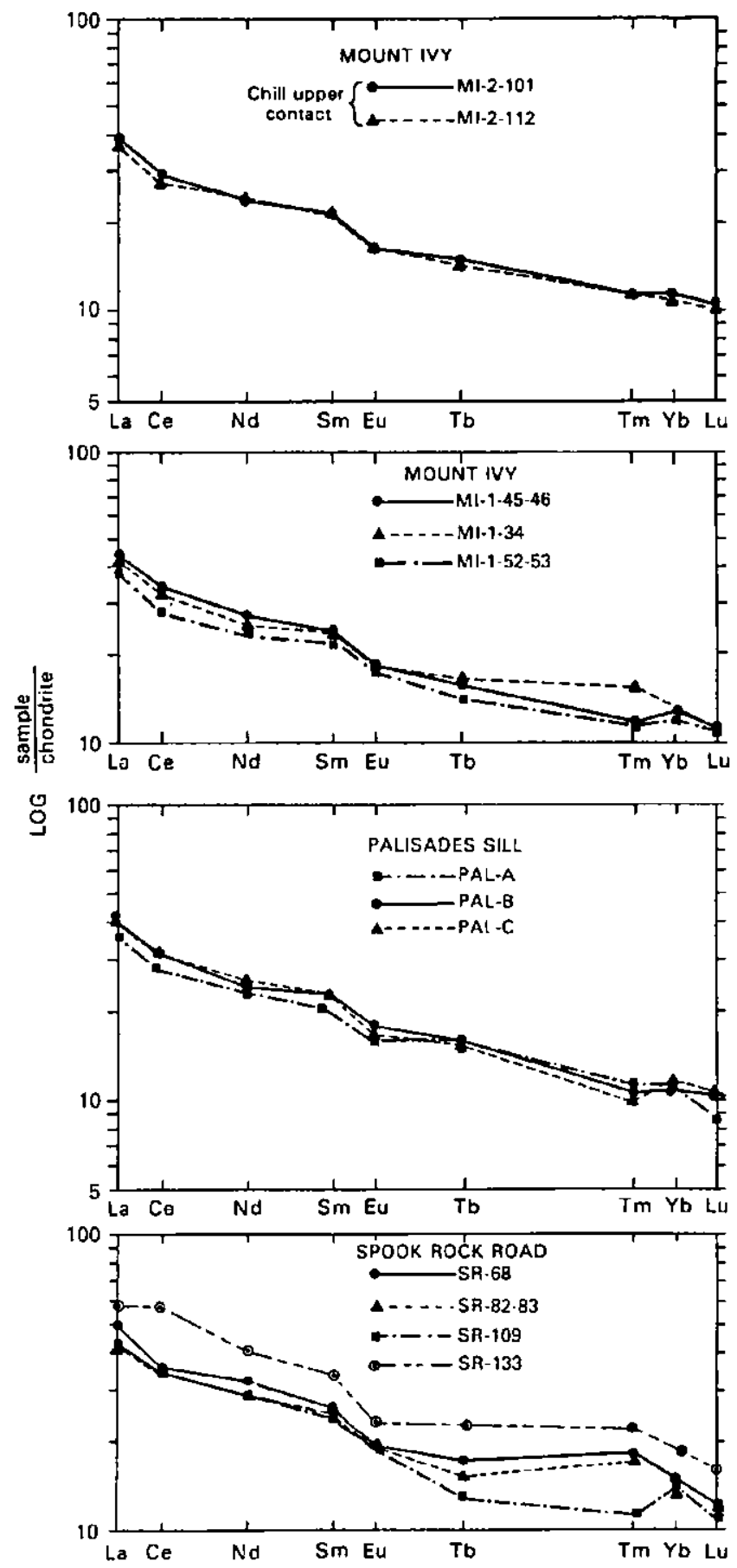

Figure 8. Chondrite-normalized rare-earth element (REE) patterns for diabase samples from the chill zone of the Palisades sill, the interior of the sill, and from the margin of the dike at Spook Rock Road. Normalized to chondrite values of Haskin and others (1968).

Road (fig. 7) (fig. 1, loc. 3) suggests that these features that dip as much as $50^{\circ}$ to the southeast may be intrusive flow structures formed by uneven protrusion into already injected diabase, rather than indications of surface flows.

An exposure of such protrusion forms from an exposed intrusive sill and low-angle cross-cutting dike 
Table 4. Rare-earth element and trace-element data from the Palisades sill and diabase at Ladentown

[Analyses by instrumental neutron activation techniques at Reston, Va.; LJ. Schwartz, analyst; all analyses are ppm except for Fe, which is in percent]

\begin{tabular}{|c|c|c|c|c|c|c|c|c|c|c|c|c|}
\hline \multirow[b]{3}{*}{ Sample } & \multirow{2}{*}{\multicolumn{3}{|c|}{$\begin{array}{c}\text { Outcrop samples } \\
\text { Palisades sill at Mount Ivy }\end{array}$}} & \multicolumn{9}{|c|}{ Subsurface samples } \\
\hline & & & & \multicolumn{4}{|c|}{ Spook Rock Rd. fissure feeder(?) } & \multicolumn{2}{|c|}{ Mount Ivy chill diabase } & \multicolumn{3}{|c|}{ Mount Ivy interior of sill } \\
\hline & PAL-A & PAL-B & PAL-C & SR-68' & SR-82'-83' & SR-109' & SR-133' & $\mathrm{MI}-2-101^{\prime}$ & MI-2-112' & $M \mid-1-\left(45-46^{\prime}\right)$ & $M I-1-\left(52-53^{\prime}\right)$ & $\mathrm{MI}-1-34$ \\
\hline$\ldots \ldots$ & 7.99 & 8.54 & 8.43 & 9.32 & 8.91 & 8.49 & 8.21 & 6.61 & 8.08 & 8.78 & 8.37 & 8.46 \\
\hline Cs.......... & .25 & .87 & .43 & .57 & .23 & .67 & 1.3 & .54 & .74 & .37 & $<.600$ & $<.600$ \\
\hline $\mathrm{Ba} \ldots \ldots \ldots \ldots$ & 140 & 200 & 200 & 220 & 180 & 240 & $<200$ & 250 & 210 & 260 & 180 & 190 \\
\hline $\mathrm{Co} \ldots \ldots \ldots \ldots$ & 45.0 & 44.4 & 43.6 & 45.2 & 44.8 & 42.5 & 41.6 & 38.4 & 44.0 & 43.6 & 43.7 & 42.6 \\
\hline $\mathrm{Cr} \ldots \ldots \ldots \ldots$ & 177 & 63.9 & 91.3 & 35.4 & 44 & 49.7 & 40.0 & 267 & 238 & 41.5 & 72.1 & 63.1 \\
\hline Hf $\ldots \ldots \ldots \ldots$ & 2.70 & 3.07 & 3.07 & 3.54 & 3.20 & 3.33 & 4.76 & 3.08 & 2.89 & 3.19 & 2.85 & 2.98 \\
\hline $\mathrm{Ta} \ldots \ldots \ldots \ldots$ & .56 & .75 & .60 & .70 & .71 & .76 & .56 & .65 & .57 & .69 & .62 & .72 \\
\hline $\mathbf{R b} \ldots \ldots \ldots$ & 29 & 29 & 34 & 33 & 24 & 33 & $<30.0$ & 21 & 22 & 24 & 27 & 20 \\
\hline Sb........... & $<.900$ & .40 & $<.900$ & $<1.00$ & $<2.00$ & $<1.00$ & 1.5 & .46 & $<.900$ & $<.900$ & $<.900$ & $<.900$ \\
\hline $\mathrm{Th} \ldots \ldots \ldots \ldots$ & 2.35 & 2.74 & 2.89 & 3.43 & 2.81 & 2.95 & 3.2 & 2.54 & 2.21 & 2.97 & 2.45 & 2.68 \\
\hline $\mathrm{U} \ldots \ldots \ldots \ldots$ & .54 & .60 & .65 & .73 & .73 & .69 & .79 & .57 & .56 & .48 & .49 & .58 \\
\hline $\mathrm{Z}_{n} \ldots \ldots \ldots \ldots$ & 95.2 & 93.5 & 102 & 122 & 95.8 & 94.9 & 197 & 103 & 102 & 96.4 & 98.8 & 96.3 \\
\hline Zr. $\ldots \ldots \ldots \ldots$ & 160 & 160 & $<300$ & 120 & 100 & $<300$ & 160 & $<300$ & 110 & $<300$ & 140 & 150 \\
\hline $\mathrm{Gd} \ldots \ldots \ldots$ & 3.5 & 4.4 & 3.9 & 5.6 & 4.6 & 4.5 & 7.0 & 3.0 & 4.9 & 4.3 & 4.7 & 4.9 \\
\hline Sc $\ldots \ldots \ldots \ldots$ & 36.0 & 35.1 & 35.7 & 36.2 & 35.7 & 34.8 & 23.5 & 39.0 & 36.8 & 35.1 & 34.8 & 34.6 \\
\hline$\ldots \ldots \ldots$ & 12.2 & 13.6 & 13.5 & 16.5 & 14.0 & 14.2 & 19.4 & 13.0 & 12.4 & 14.7 & 12.3 & 13.9 \\
\hline $\mathrm{Ce}$ & 24.5 & 27.9 & 28.1 & 32.3 & 29.7 & 29.6 & 51.8 & 26.0 & 23.8 & 30.3 & 24.5 & 28.4 \\
\hline$\ldots \ldots$ & 14 & 15 & 15 & 20 & 17 & 17 & 24.6 & 14 & 15 & 16.6 & 14 & 15.4 \\
\hline Sm .... & 3.69 & 4.17 & 4.18 & 4.80 & 4.58 & 4.49 & 6.24 & 3.95 & 3.84 & 4.44 & 4.04 & 4.26 \\
\hline $\mathrm{Eu} \ldots \ldots \ldots \ldots$ & 1.12 & 1.27 & 1.17 & 1.37 & 1.33 & 1.31 & 1.64 & 1.14 & 1.15 & 1.28 & 1.20 & 1.21 \\
\hline $\mathrm{Tb}$ & .69 & .764 & .73 & .814 & .71 & .61 & 1.08 & .71 & .68 & .748 & .67 & .77 \\
\hline $\operatorname{Tm} .$. & .35 & .33 & .30 & .56 & .52 & .34 & .68 & .50 & .38 & .51 & .35 & .46 \\
\hline $\mathrm{Yb}$. & 2.38 & 2.44 & 2.41 & 3.02 & 2.7 & 2.82 & 3.83 & 2.54 & 2.43 & 2.63 & 2.43 & 2.60 \\
\hline Lu. & .309 & .369 & .377 & .42 & .400 & .385 & .566 & .367 & .359 & .388 & .376 & .390 \\
\hline Ho ........... & .58 & .79 & $<1.00$ & .74 & .53 & .4 & $<7.00$ & $<2.00$ & .3 & .80 & .3 & .73 \\
\hline
\end{tabular}




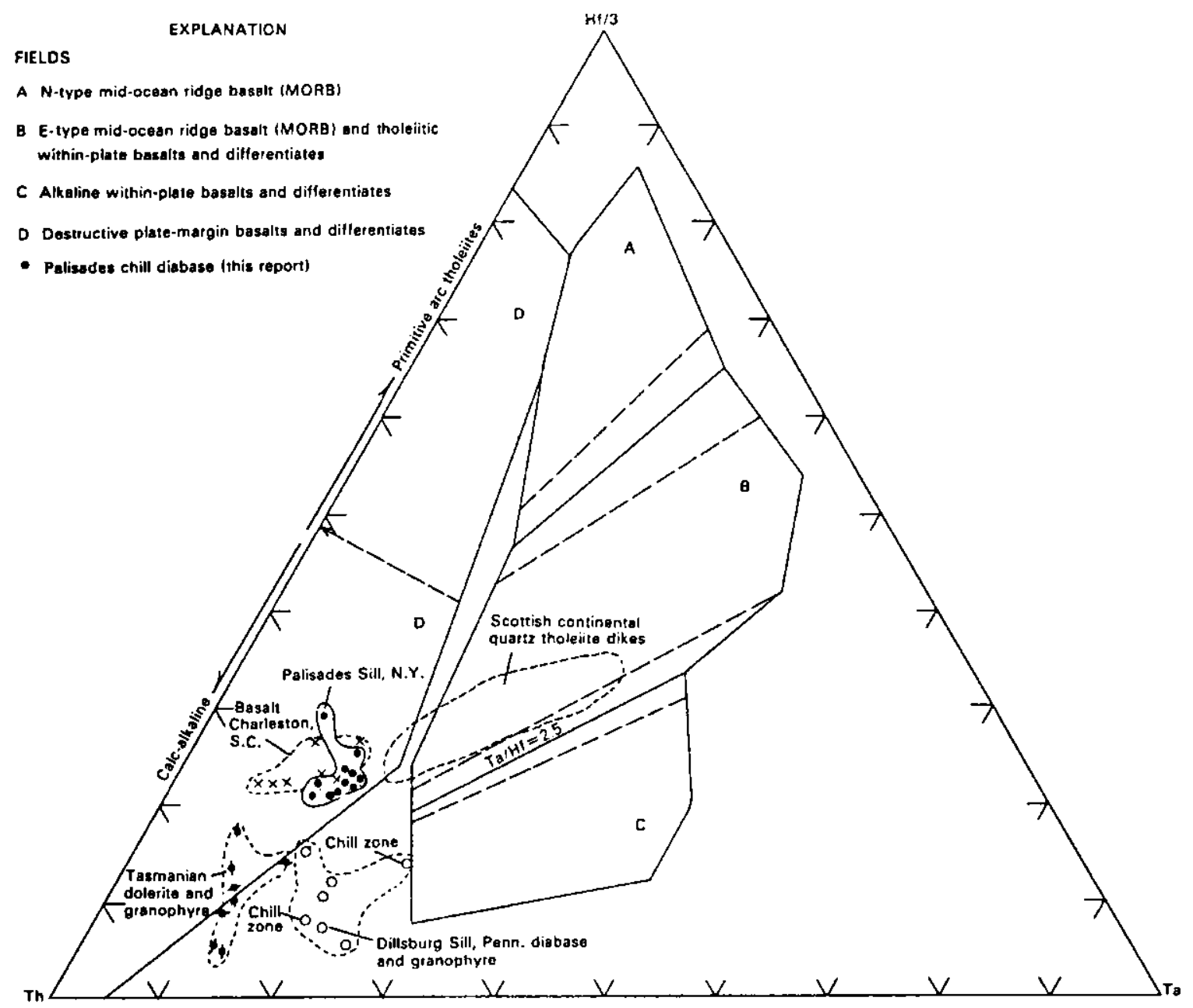

Figure 9. Samples of Palisades sill, Rockland County, New York, plotted in HF/3-Th-Ta discrimination diagram of Wood (1980) showing other continental quartz tholeiites of late Carboniferous and Mesozoic age. Dashed lines represent areas of overlap and hence uncertainties in

complex (fig. 1, loc. 9) from just beneath the main Palisades sill is shown in figure 11 . At this locality two narrow 4- to 5-ft-thick dikes crosscut gently inclined strata that strike $\mathrm{N} .35^{\circ} \mathrm{W}$. and dip $12^{\circ} \mathrm{SW}$. Although the dikes appear folded, the enclosing strata are not. An irregularly developed zone of "pillow basalt" forms a margin around aphanitic basalt. The actual chilled, aphyric margin of the dikes is highly irregular. Irregular pseudofolds are formed at the termination of dikes, where smooth, curved, hingelines define the bulging shapes of the protruding snouts of basalt that resemble sheath folds (fig. 11D). The hingelines plunge in many directions.

The obvious ductile character of the protrusion forms suggests that these features are the result of irregularities in viscous flow along the margins of the N. $70^{\circ} \mathrm{W} .20^{\circ} \mathrm{SW}$.-dipping walls of the dikes. The general field boundaries. Data for Charleston basalt from Gottfried and others (1983); Tasmanian dolerite and Dillsburg sill, Pennsylvania, Gottfried and others (1968); Midland, Scotland, quartz tholeiite dikes, Macdonald and others (1981).

shape of the walls of the dikes constrains or contains the flow direction of intrusion within this plane, where minor variations in flow can be used to approximate the flow direction for the magma, by analogy to pressure ridges in ropey lava described by Scott and Hansen (1969). In their analysis, the rotation sense of the plunging, curvilinear hingelines of pressure ridges will "box out," or define a separation angle between clockwise and counterclockwise rotation that approximates the flow direction.

In figure $11 B$, the plunge of hingelines and rotation sense from protrusion forms at this locality are plotted. They define a flow plane of $\mathrm{N} .65^{\circ} \mathrm{W}, 1^{\circ} \mathrm{SW}$. with an absence of points in the range $\mathrm{S} .30^{\circ} \mathrm{E}$. to $\mathrm{S} .10^{\circ} \mathrm{E}$. In figure $11 C$ the attitudes of walls of the dikes are plotted as planes and their mutual intersections noted. These planes (walls) and their intersections (edges) define 


\section{EXPLANATION}

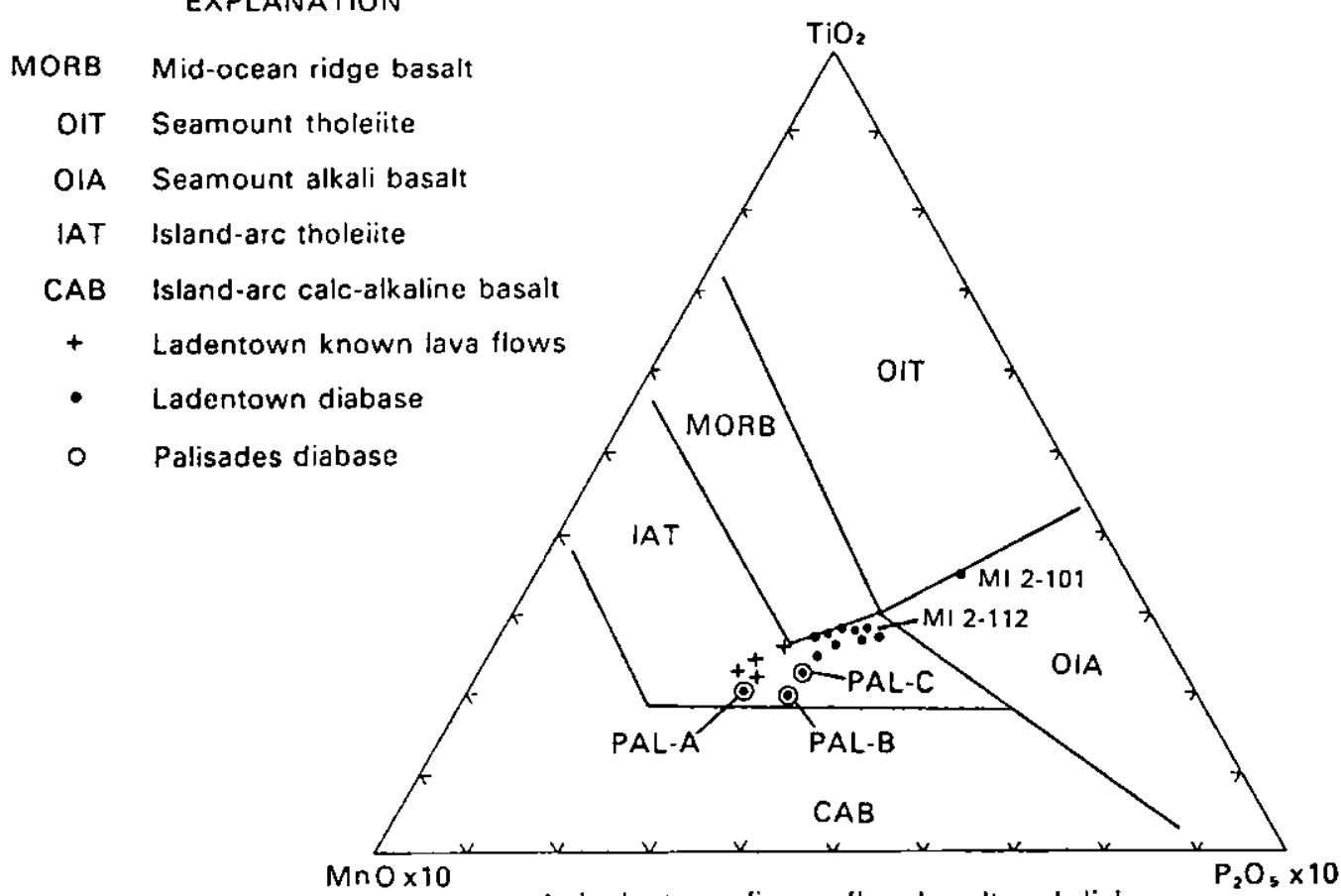

A. Ladentown fissure-flow basalt and diabase

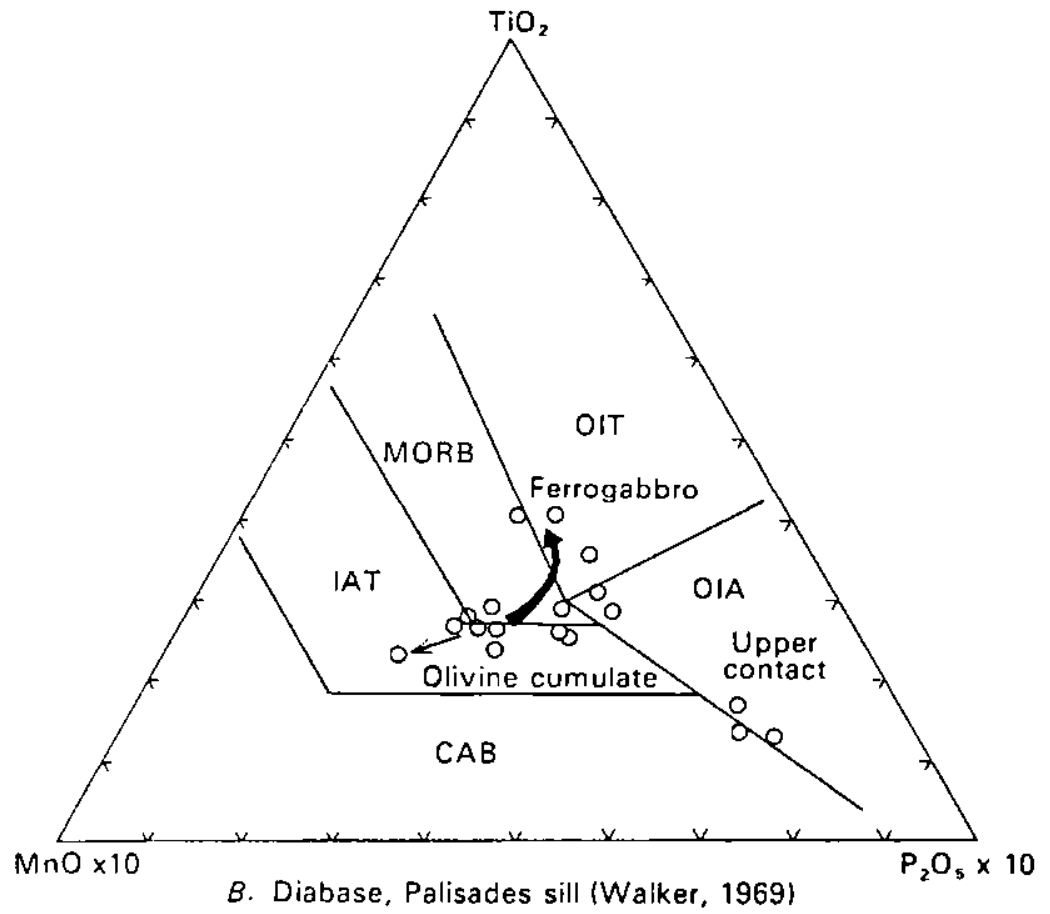

Figure 10. Samples of Palisades sill and Ladentown lava flows plotted in $\mathrm{MnO} \times 10, \mathrm{TiO}_{2}, \mathrm{P}_{2} \mathrm{O}_{5} \times 10$ diagram of Mullen (1983), showing discrimination fields for oceanic basaltic rocks $\left(\mathrm{SiO}_{2} 45-54\right.$ percent). $A$, Palisades sill and Ladentown basalts (this paper). $B$, Palisades sill samples from Walker (1969) showing olivine cumulate rocks and ferrodioritic differentiates. Arrows show composition on diagram resulting from crystal accumulation of olivine and resulting liquid fractionation trend toward ferrogabbro. 
EXPLANATION
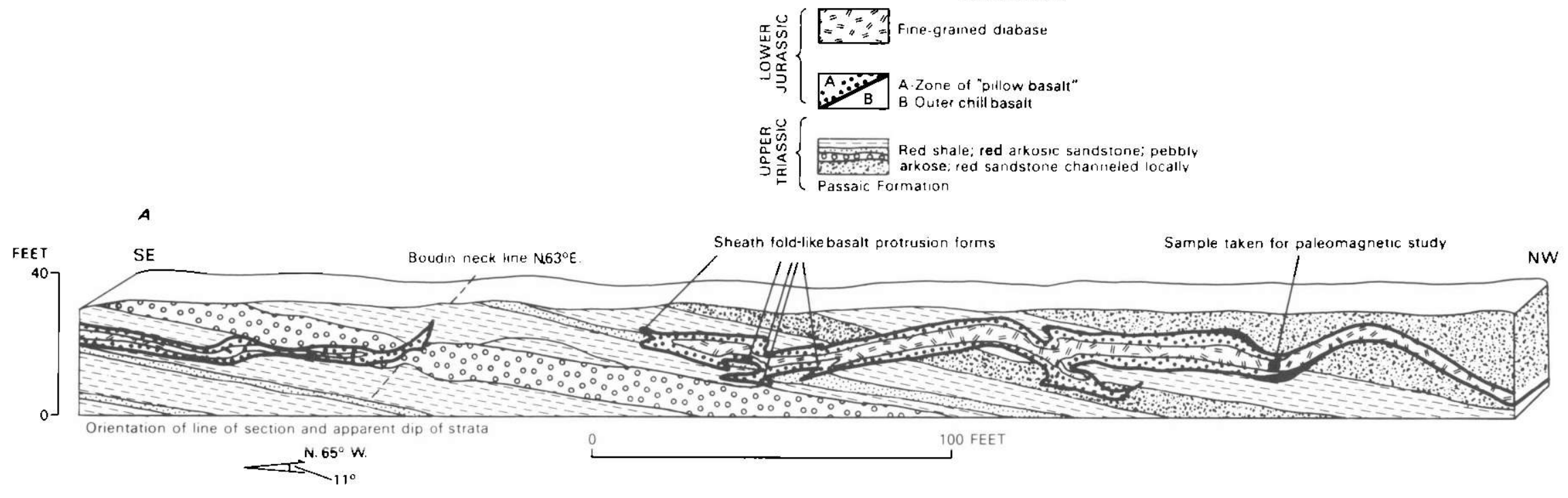

$B$

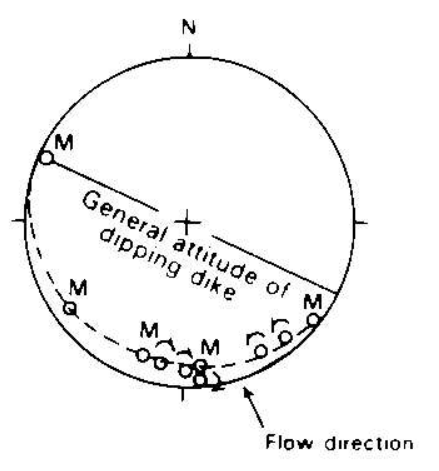

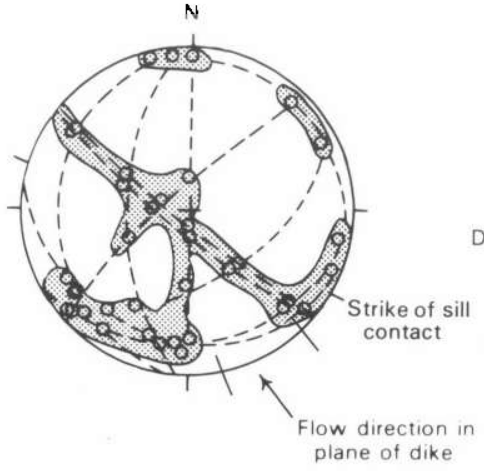

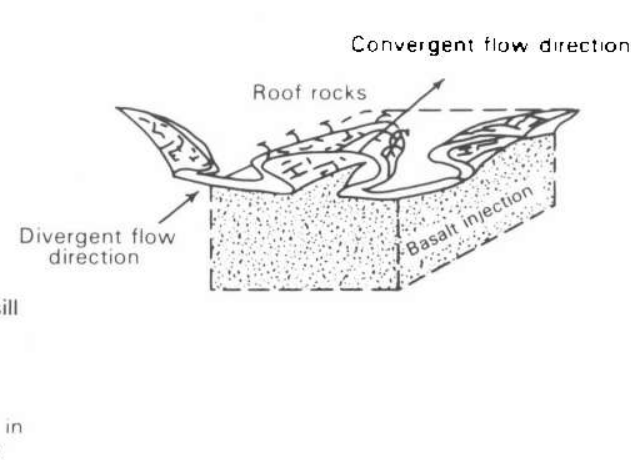

Figure 11. Sketch of diabase sill-dike complex (A) (location 9, fig. 1) showing lower hemisphere stereonet projection of important structural elements used to infer flow direction of intrusion. In $B$, plunge of hingelines of minor folds, showing asymmetry or rotation sense (shown by arcs), and " $M$ " folds without asymmetry are used to define a separation arc and flow direction as shown diagrammatically in $D$. In $C$, intersections of straight-walled segments of dike border are plotted as planes and their mutual intersections noted. 
the topology of the forms confining the magma. Two

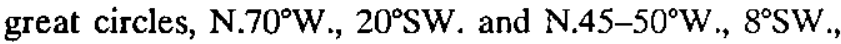
are apparent. The former great circle coincides with general strike and dip of the dikes. The absence of intersections (that is, edges) within a part of this great circle in the southeast quadrant defines a potential flow direction (that is, openings) in the same area as in figure $11 C$, namely $\mathrm{S} .5^{\circ} \mathrm{E}$. to $\cdot \mathrm{S} .40^{\circ} \mathrm{E}$. The median azimuth in both data sets agrees approximately at $\mathrm{S} .15^{\circ} \mathrm{E}$. and $\mathrm{S} .25^{\circ} \mathrm{E}$. The protrusion folds suggest that at this locality the magma was intruding upwards toward $\mathrm{N} .15^{\circ} \mathrm{W}$. to $\mathrm{N} .25^{\circ} \mathrm{W}$. within the general $\mathrm{N} .70^{\circ} \mathrm{W} .15^{\circ}$ to $20^{\circ} \mathrm{SW}$.dipping dike as it chilled.

Internal flow structures seen in the igneous rocks at some localities in the Ladentown area mentioned above may represent protrusion forms similar to those described here rather than pahoehoe tongues indicative of surface flows as described by Ratcliffe (1980).

Many outcrops of massive, fine-grained diabase and vesicular basalt in the central area of the Ladentown flows do not contain obvious flow layers but contain basalt-filled glassy vesicles and matrixes of merocrystalline basalt and stellate plagioclase crystals. The Spook Rock Road core penetrated $184 \mathrm{ft}$ of this material. Rock of this general texture was seen in the Mount Ivy cores of the Palisades sill, in road cuts at PAL-C sample site, and in the Camp Hill area. It is likely that all of these areas are intrusive rock, and part of the feeder system.

Subsurface data from water wells southwest of locality 5 (fig. 1) and modeling of gravity and magnetic data (Kodama, 1983) suggest that the sheetlike intrusive form of the Palisades sill extends from Camp Hill southwestward into the area of the flow rocks. The Spook Rock Road core suggests that this feature is still present at that point. The Spook Rock Road core may have penetrated the upper portion of a southeast- or eastdipping sheet of diabase, as the deepest sample (SR-183) shows LREE enrichment comparable to that of the ferrodiorites found in the upper part of the Palisades sill. Ratcliffe's (1982) interpretation of the $500 \mathrm{ft}$ of igneous rock cored in the Sky Meadow drill site as flow basalt probably is incorrect in the light of these findings and the rock cored there is probably also intrusive.

At the Union Hill quarry (figs. 1 and $12 A$ ), pillow basalts overlie coarse dolostone fanglomerate and an upward-fining, red siltstone and green phyllite chip conglomerate sequence similar to that seen beneath the lower flow in the Haverstraw Road core. The basalt at Union Hill has been quarried to a depth at least $100 \mathrm{ft}$ lower than the exposed contact, and the lower contact is not exposed in the deepest part of the quarry. The geometry of the igneous body here suggests the possibility of a fissure feeder similar to that proposed at Ladentown. However, horizontal to gently west-dipping amygdaloidal basalt and flow breccia are exposed at the deepest level in the Union Hill quarry, thus suggesting that the base of the flow complex may be nearly exposed. Two interpretations of the Mount Union basalts are (1) a basalt flow complex flowing in a topographic depression west of the conglomerate or (2) a westward-dipping or vertical fissure feeder surfacing in flow rocks. These two interpretations are presented in figure 12. In $12 \mathrm{~A}$, a 3-dimensional block diagram of the Mount Union quarry shows the pillow basalts and breccia overlying fanglomerate that contains clasts of basalt. From the exposed contact this amygdaloidal, pillowed zone can be traced northward at the same elevation as the exposed contact against sediment along the east wall of the quarry where it separates basalt flow units. The four levels of the quarry expose only basalt, which has uniformly eastdipping columnar joint sets. At the lowest point in the quarry, along the east wall, closest to the fanglomerate exposures, a well-developed zone of pillow basalt and flow breccia is exposed (labeled in fig. 12A). An explanation for the thickening of the basalt flows may result from flowage of basalts in a Jurassic valley, perhaps developed along a pre-basalt antithetic normal fault as shown in figure $12 B$. This explanation, that is, the interpretation from (1) above, is the preferred interpretation for the Mount Union occurrence. The Ladentown fissure-flow complex, however, is interpreted as in figure $12 C$.

The major-element chemistry of fine-grained samples from the Union Hill quarry is similar to samples of the feeder at Spook Rock Road and to the Preakness Basalt as pointed out by Puffer and others (1982) (see fig. 3, this paper). Very fine-grained to aphanitic greenish-white basalt has been recovered from water wells as much as $1.8 \mathrm{mi}$ northeast of Union Hill. Examination of these chips shows this rock to be identical to fine-grained and flow-layered basalt exposed as the highest basalt layers in the Ladentown syncline. Reversal of plunge from south to north in the area north of the last subsurface exposures of the basalt from Union Hill and the Ladentown area also suggests correlation (Ratcliffe, 1980). A small, previously unrecognized outcrop of coarse-grained diabase lies along the Ramapo fault $2.4 \mathrm{mi}$ soutbwest of Suffern. This diabase may be a faulted remnant of the Palisades-Preakness feeder system.

\section{SUMMARY AND CONCLUSIONS}

Re-analyses of chemical data and core information from the Palisades sill and demonstrable basalt flows at Ladentown suggest that the area previously mapped (Ratcliffe, 1980, 1982) as surface flows at Ladentown consists in part of intrusive basalt and fine-grained diabase that may be part of the feeder system. Previous samples collected for chemical analyses (Puffer and others, 1982) of basalt flows attributed to Orange Moun- 
Union Hill Quarry, Suffern, N.Y.

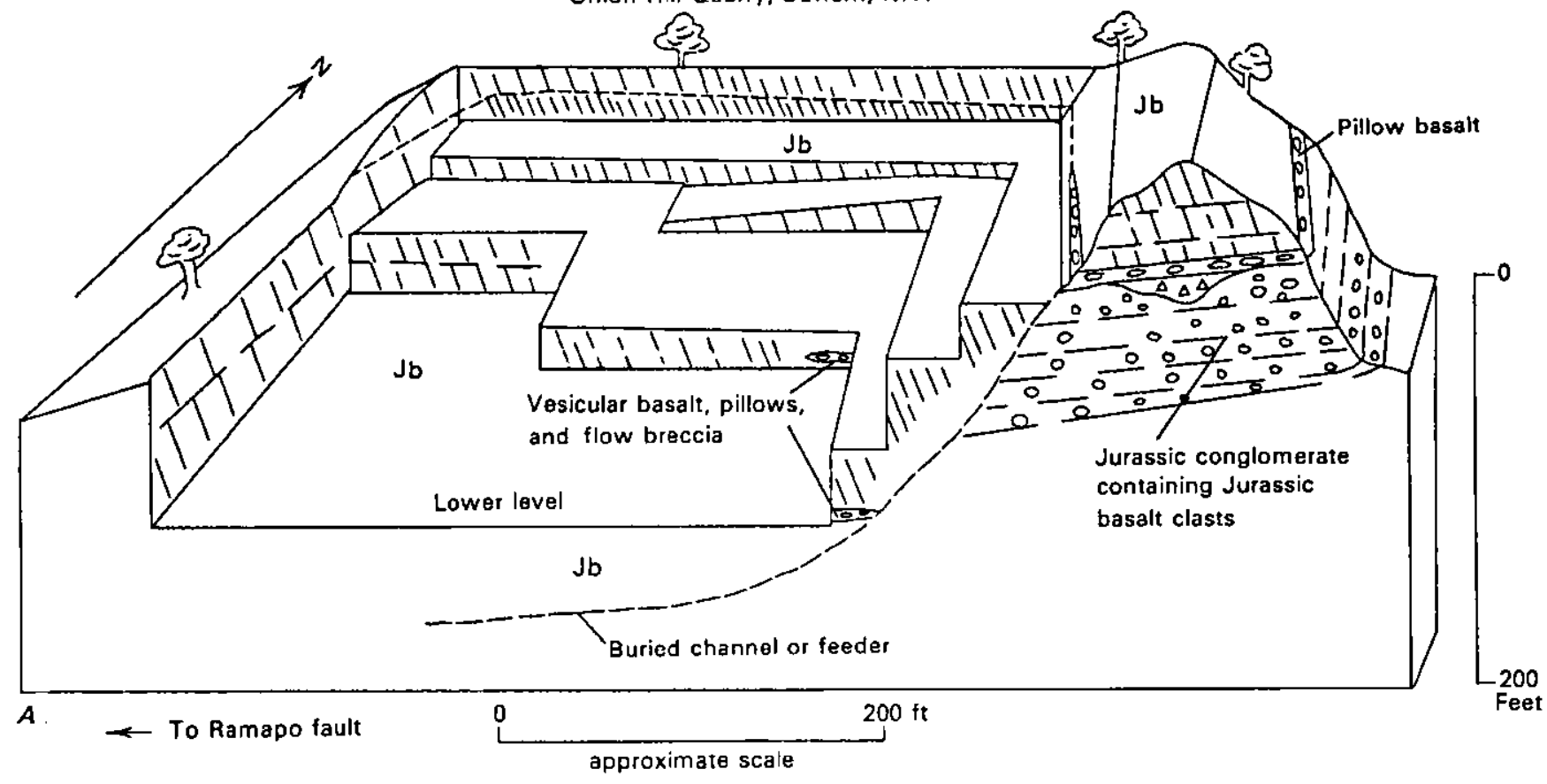

E

w
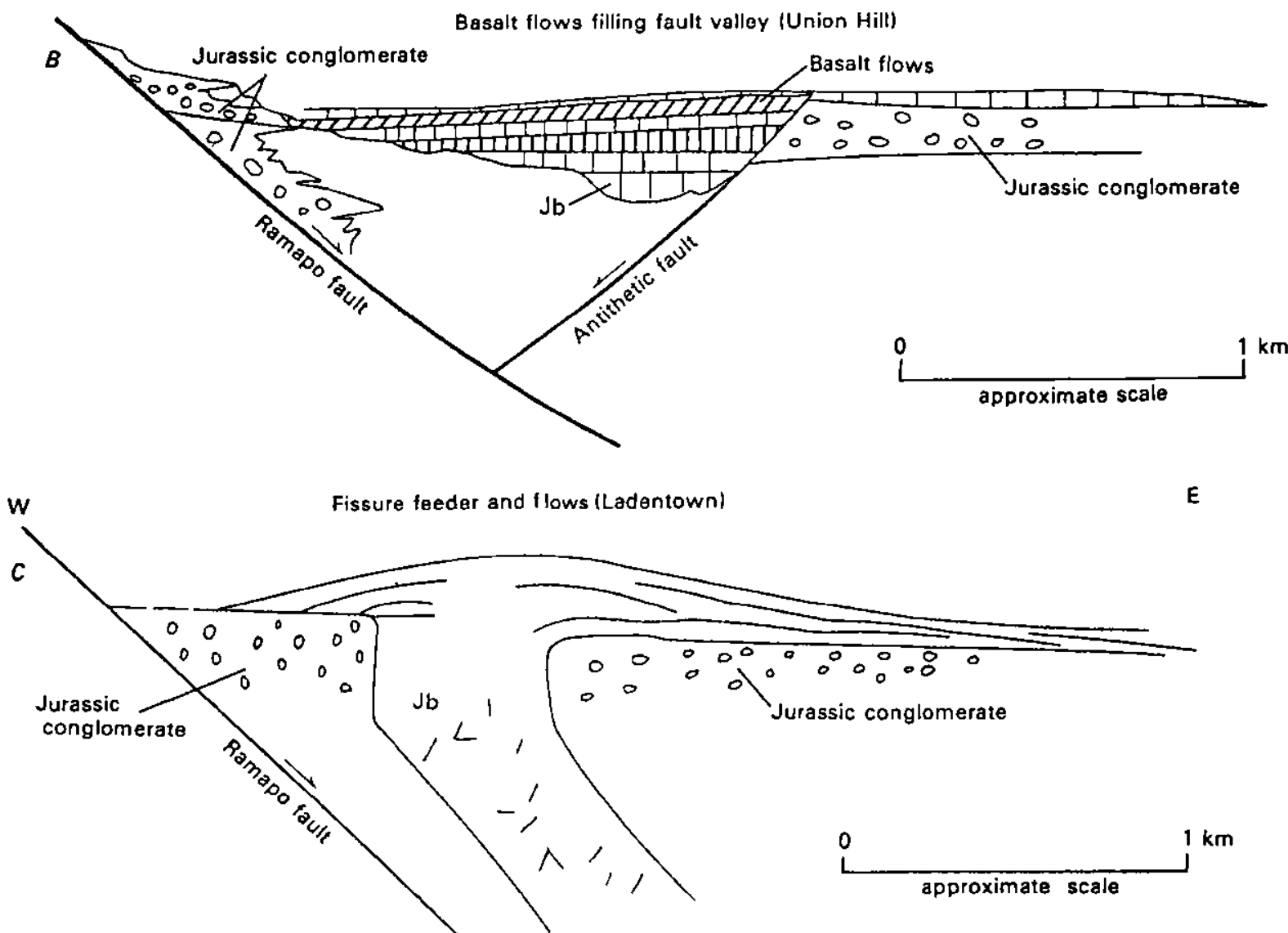

Figure 12. A, Block diagram of Union Hill quarry, Suffern, New York (see fig. 1 for location) showing exposed contact of lava flows with fanglomerate and amygdaloidal basalt flow and breccia in quarry floor. $B$, Ponding model. Interpretation of relationships at Union Hill quarry as channelized basalt flows filling fault valley. $C$, Fissure-flow model. Interpretations of relationships in the Ladentown, New York, area as fissure feeder and flows. Jb, Jurassic basalt; conglomerate with Jurassic basalt clasts, Jurassic Feltville(?) Formation that is discussed in text. 
tain or Preakness Basalts came from areas now believed to be within the feeder system and compare closely with the interior and partially differentiated center of the Palisades sill. Four samples of proven but altered basaltic flow rock (table 1) have chemistry markedly different from the bulk of the other samples. However, these basalts do agree closely in chemistry with chill rock of the Palisades sill at Mount Ivy at the upper contact of the sill, and with either the Orange Mountain Basalt or the Preakness Basalt. The chemical data therefore leave open to question whether the basalt eruptions at Ladentown could have developed from the second Palisades magma and be comparable to the Orange Mountain Basalt, or are younger.

The fact that the upper chill zone of the Palisades sill intrudes conglomerates that contain clasts of basalt at Mount Ivy argues for the chilled second Palisades magma being the time equivalent of the Preakness Basalt rather than the Orange Mountain Basalt. The similarity of the basalt flows at Ladentown to Palisades chill rock suggests that they may also correlate with the Preakness Basalt. Acceptance of this interpretation requires that the Orange Mountain Basalt be absent from the northern part of the Newark basin. For this reason the sedimentary rocks beneath the basalt at Union Hill and in the core of the Ladentown Syncline are shown on figure 1 as Feltville Formation(?). Local relief developed on fans of coarse conglomerate in the upper Passaic may have restricted the Orange Mountain Basalt flows.

The data presented in this paper generally support the fissure-flow model proposed previously (Kummel, 1898; Ratcliffe, 1980). The basalt and diabase now filling the fissure is more differentiated than the original eruptions at Ladentown and the upper chill zone of the Palisades sill, but the chemistry agrees closely with the interior of the Palisades sill and with both the basalt at Union Hill and Preakness Basalt. These data therefore suggest that a late phase of Palisades magma formed the sickle-shaped extension of the Palisades sill as a semiformed cone sheet and that this material erupted to the surface at Ladentown and Union Hill from fissure feeders at about the same time as the Preakness Basalt flows.

$\mathrm{A}{ }^{39} \mathrm{Ar} /{ }^{40} \mathrm{Ar}$ biotite plateau age of $202.2 \pm 1.3 \mathrm{Ma}$ from a xenolith of Stockton Formation arkose from the base of the Palisades sill at Edgewater, New Jersey, is the most accurate date for diabase intrusion in the early Mesozoic basins (Sutter, this volume). The field relationships described here indicate that the sedimentary rocks underlying the lava flows at Ladentown, the basalt-clastbearing conglomerate above the upper contact of the Palisades sill in MI-2, and the strata under the basalts at Union Hill are 202 Ma or older.

Recent paleomagnetic measurement of rocks from Ladentown flow rocks, from the Palisades sill in Rockland County (K.P. Kodama, unpub. data), suggests that the Palisades sill was affected by considerable postintrusion tilting and possibly by folding. These data, in conjunction with the new field data and chemistry of the basalt and diabase, suggest that Ratcliffe's (1980) suggestion that pre-Early Jurassic deformation affected the Passaic and older rocks of the Newark basin may not be correct. The paleomagnetic and geologic data are consistent with the idea that the bulk of the deformation of the Triassic and Jurassic strata postdates the intrusion of the Palisades sill and related fissure-flow complexes at about 202 Ma.

\section{REFERENCES CITED}

Cornet, B., 1977, The palynostratigraphy and age of the Newark Supergroup: University Park, The Pennsylvania State University, unpublished $\mathrm{Ph} . \mathrm{D}$. thesis, $506 \mathrm{p}$.

Fisher, D.W., Isachen, Y.W., and Rickard, L.V., 1971, Geologic map of the State of New York: New York State Museum and Science Service Map and Chart Series, no. 15, 5 sheets, $1: 250,000$.

Frimpter, M.H., 1967, Geology of the Thiells Quadrangle, New York with emphasis on igneous and metamorphic rocks: Boston, Boston University Graduate School, unpublished Ph.D. thesis, $142 \mathrm{p}$.

Gottfried, D., Annell, C.S., and Byerly, G.R., 1983, Geochemistry and tectonic significance of subsurface basalts near Charleston, South Carolina: Clubhouse Crossroads test holes \#2 and \#3, in Gohn, G.S., ed., Studies related to the Charleston, South Carolina, earthquake of 1886-tectonics and seismicity: U.S. Geological Survey Professional Paper 1313, p. A1-A19.

Gottfried, D., Greenland, P.C., and Campbell, E.Y., 1968, Variation of $\mathrm{Nb}-\mathrm{Ta}, \mathrm{Zr}-\mathrm{Hf}$ and $\mathrm{K}-\mathrm{Cs}$ in two diabasegranophyre suites: Geochimica et Cosmochimica Acta, v. 32, p. 925-947.

Gottfried, D., Ragland, P.C., Froelich, A.J., 1985, Styles of differentiation of some Mesozoic diabase sheets in the eastern United States: Geological Society of America Abstracts with Programs, v. 17, no. 7, p. 595.

Haskin, L.A., Haskin, M.A., Frey, F.A., and Wildeman, T.R., 1968, Relative and absolute terrestrial abundances of the rare earths, in Ahrens, L.H., ed., Origin and distribution of elements, 1: Oxford, Pergamon Press, p. 889-911.

Kay, R.W., Hubbard, N.J., and Gast, P.W., 1970, Chemical characteristics and origin of ocean ridge volcanic rocks: Journal of Geophysical Research, v. 75, p. 1585-1613.

Kodama, K.P., 1983, Magnetic and gravity evidence for a subsurface connection between the Palisades sill and the Ladentown basalts: Geological Society of America Bulletin, v. 94 , p. $151-158$.

Kummel, H.B., 1898, The Newark or Red Sandstone rocks of Rockland County, New York: 18th Annual Report of the State Geologist of New York, p. 9-50.

Macdonald, R., Gottfried, D., Farrington, M.J., Brown, F.W., and Skinner, N.G., 1981, Geochemistry of a continental 
tholeiite suite: Late Paleozoic quartz dolerites of Scotland: Transactions of the Royal Society of Edinburgh, Earth Sciences, 72, p. 57-74.

Manson, V., 1967, Geochemistry of basaltic rocks: Major elements: Basalts: The Poldervaart Treatise on rocks of basaltic composition, in Hess, H.H., and Poldervaart, A., eds., v. 1: Interscience Publishers, John Wiley and Sons, New York, p. 215-219.

Mullen, E.D., 1983, $\mathrm{MnO} / \mathrm{TiO}_{2} / \mathrm{P}_{2} \mathrm{O}_{5}$ : A minor element discriminant for basaltic rocks of oceanic environments and its implications for petrogenesis: Earth and Planetary Science Letters, v. 63, no. 1, p. 53-62.

Philpotts, J.A., and Schnetzler, C.C., 1968, Genesis of continental diabases and oceanic tholeites considered in light of rare-earth and barium abundances and partition coefficients, in Ahrens, L.H., ed., Origin and distribution of elements: Oxford, Pergamon Press, p. 939-947.

Puffer, J.H., Geiger, F.J., and Camanno, E.J., 1982, Mesozoic igneous rocks of Rockland County, New York: Northeastern Geology, v. 4, p. 121-130.

Ratcliffe, N.M., 1980, Brittle faults (Ramapo fault) and phyllonitic ductile shear zones in the basement rocks of the Ramapo seismic zone, New York and New Jersey, and their relationship to current seismicity, in Manspeizer, W., ed., Field studies of New Jersey geology and guide to field trips, 52d Annual meeting of the New York State Geological Association: Newark, New Jersey, Rutgers University, p. 278-813.

-1981, Cortlandt-Beemerville magmatic belt: A probable late Taconian alkalic cross trend in the Central Appalachians: Geology, v. 9, p. 329-335.

1982, Results of core drilling of the Ramapo fault at Sky Meadow Road, Rockland County, New York, and assessment of evidence for reactivation to produce current seismicity: U.S. Geological Survey Miscellaneous Investigations Series Map I-1401.

Scott, W.H., and Hansen, E., 1968, Movement directions and the axial-plane fabrics of flexural folds: Annual report of the Director Geophysical Laboratory, Camegie Institution Yearbook for 1968-69, p. 254-258.

Shirley, D.N., 1985, Differentiation of the Palisades sill: Geological Society of America Abstracts with Programs, v. 17, no. 7, p. 716 .

Walker, K.R., 1969, The Palisades sill, New Jersey, a reinvestjgation: Geological Society of America Special Paper 111, $178 \mathrm{p}$.

Wood, D.A., 1980, The application of a Th-Hf-Ta diagram to problems of tectonomagmatic classification and to establishing the nature of crustal contamination of basaltic lavas of the British Tertiary Volcanic Province: Earth and Planetary Science Letters, v. 50, p. 11-30.

\title{
EFFECTS OF POSTCUMULUS FRACTIONATION IN THE PALISADES SHEET: FURTHER EVIDENCE FROM WEEHAWKEN, NEW JERSEY
}

\author{
David N. Shirley ${ }^{1}$
}

\begin{abstract}
Twenty whole-rock samples were analyzed by instrumental neutron activation analysis across a section of the Palisades diabase sheet at Weehawken, New Jersey. This section is compared to another section $9.5 \mathrm{~km}$ to the northnortheast where it was found that postcumulus transport of interstitial magma significantly modified primary elemental profiles. Qualitatively, the sections are quite similar, indicating that differentiation of the sheet by fractional crystallization was modified by postcumulus transport at both locations. At the time the floor and the roof converged and solidified together, substantial amounts of residual interstitial magma remained trapped in a region extending 80 to $150 \mathrm{~m}$ below the freshly formed "sandwich horizon." Due to its low density, the residual interstitial magma migrated upward and was concentrated 25 to $45 \mathrm{~m}$ below the sandwich horizon and formed a granophyric zone. The net result of this differen-
\end{abstract}

\footnotetext{
${ }^{1}$ Department of Geology and Geophysics, University of California, Berkeley, CA 94720.
}

tiation process is that granophyre-rich zones are observed both at the sandwich horizon and at the level where the residual interstitial liquid was concentrated. Quantitatively, the amount of postcumulus transport observed at Weehawken is less than that observed in the other section. The cause of the difference between the two sections is apparently that cooling through the roof was less enhanced at Weehawken due to less effective hydrothermal circulation in the overlying strata there. This caused the layer of crystals plus interstitial liquid that remained when the sandwich horizon formed to be thinner at Weehawken.

\section{INTRODUCTION}

It is widely recognized that the primary mechanism of differentiation in mafic intrusions is crystal-liquid fractionation. This is thought to occur primarily through crystallization of mineral phases and accumulation of these phases along the margins. In addition to this primary process, postcumulus fractionation can also 
occur if a significant amount of intercumulus magma is included in the interstices between the mineral phases. If a thick layer of crystals plus intercumulus liquid accumulates on the floor of an intrusion, the liquid phase will migrate upward, provided the solids are denser. Accompanying this movement, the crystalline matrix of the cumulate zone must compact (McKenzie, 1984; Richter and McKenzie, 1984). This process has been studied both theoretically (Sparks and others, 1985; Shirley 1986a) and geochemically (Irvine, 1980; Raedeke and McCallum, 1983; Shirley, in press) and can be shown to frequently have a substantial effect on the final elemental profiles observed in mafic intrusions, particularly for incompatible elements.

A major effect of postcumulus transport is that elements that partition into the liquid are carried upsection, whereas those residing in the solids move downward, carried by the mineral phases. In addition to this transport, chemical reaction between the liquid and solid is continuous because they are generally not in equilibrium. In layered cumulates, this has been shown to lead to complex phenomena such as reaction fronts that originate at layer boundaries and propagate through the cumulates (Irvine, 1980; Raedeke and McCallum, 1983). In unlayered cumulates the effects are less abrupt and thus more subtle.

This paper is a progress report on an extensive ongoing investigation of the differentiation of the Palisades sheet. Most of the observations presented here are similar to those made on another section, which was the subject of more detailed work (Shirley, in press). The main purpose of this part of the study is to determine if the processes that operated in the other section also operated here. Thus, the degree to which the other section is representative is being tested. Because of the nature of this report some points are not fully documented here. Readers interested in a more complete accounting are referred to Shirley (in press).

\section{PREVIOUS AND ONGOING WORK}

Previous work on the Palisades sheet (Lewis, 1908; Walker, 1940; Hess, 1956; Walker, 1969; Shirley, in press) indicates that it is a differentiated diabase sill whose bulk composition is a 4 to 5 percent quartz normative tholeiite. In the extensive study by Walker (1969) the sheet was subdivided into a sequence of petrographic units that were inferred to have been produced by fractional crystallization. The units of interest for this study are the two that are most differentiated, because postcumulus transport apparently played an important role in modifying the lower one (Shirley, in press). The zone that contained the last of the magma sandwiched between the converging floor and roof of the

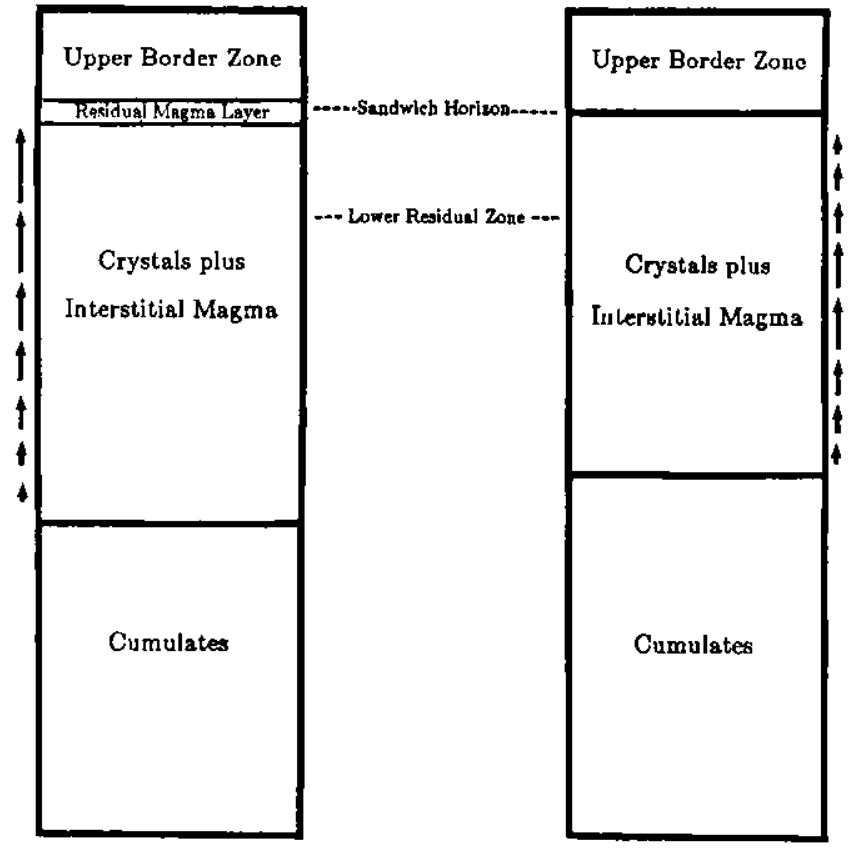

Figure 1. Sketch showing the effect of postcumulus transport. The left side shows the sheet shortly before the floor and roof converged. In the zone containing crystals and trapped liquid, compaction was occurring and causing interstitial liquid to be transported up, where some returned to the magma layer. The arrows on the left schematically show the flux of liquid moving upward. On the right the sheet is shown after the roof and floor have attached. Interstitial liquid cannot escape out the top of the zone containing crystals and trapped liquid now, so the upward flux of liquid is zero there. This change in the upper boundary causes the liquid flux to change, as shown by the arrows to the right. This new flow pattern causes residual liquid to be concentrated in the upper half of the zone. The levels of the center of the two residual zones are shown in the middle.

sheet was Walker's unit 8: ferrodolerite. This will be referred to here as the "sandwich horizon." Located below this is unit 7 , which appears in two varieties, either as (1) fayalite granophyre or (2) granophyric dolerite, depending on location. In either case, this zone is alkali and iron enriched and was formed under hydrous conditions (Walker, 1969). A major finding of the investigation of a centrally located section of the sheet along Interstate 95 (I-95) (Shirley, in press) is that a distinct granophyreand incompatible-element-rich zone exists within Walker's (1969) unit 7. This second granophyre-rich zone lies significantly below the sandwich horizon and will be referred to here as the "lower residual zone." The previous study indicated that intercumulus magma migrated to and concentrated in this lower residual zone during and after the time the sandwich horizon crystallized. A diagram showing the levels of the two granophyre-rich zones and the mechanism leading to their formation is shown in figure 1. A major goal of this 
study is to determine whether the same phenomenon occurred in the Weehawken section.

The sampling in the accompanying study (Shirley, in press) was sufficiently dense that two residual zones were well defined. It was also determined that the concentration of incompatible elements peaked within each of these zones. Four samples were located between the samples that marked the peak incompatible-element concentrations in each zone. The analyses of these samples documented the separation of the residual zones geochemically. In addition, the samples located between the residual zones contained as little as 10 percent granophyre as compared to peak concentrations of 30 percent in the lower zone and 60 percent in the upper zone (Shirley, in press).

\section{PRESENT RESULTS}

The section investigated here is located about 9.5

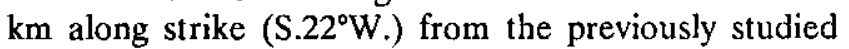
section, which is located at the center of the $70 \mathrm{~km}$ of exposure. Twenty samples from the Conrail Westshore Tunnel in Union City and Weehawken, New Jersey, were analyzed by Instrumental Neutron Activation Analysis (INAA) for 27 elements. The experimental procedure is the same as that described elsewhere (Shirley, 1986b). The results of the analyses and the stratigraphic heights of the samples are listed in table 1.

Profiles of incompatible elements are extremely similar to each other and are like those observed in the I-95 section. A plot of Th is shown in figure 2 as an example. The data points represent this section, whereas the line is the same data for the I-95 section, scaled to the same thickness. The effect of concentration of residual material in a zone below the main residual zone is less in this section than in the previously studied one (see shoulder to the left of the main peak). The abundance of granophyre in the final residuum of this section is 40 percent, and is 13 percent in the underlying two samples. The profile shown in figure 2 shows some other differences. There is no observable minimum in the abundance of granophyre or incompatible elements as observed in the I-95 section. Also, the shoulder is closer to the main peak here, and the position of the sandwich horizon is at a lower relative position in the section. These differences are consistent with a lower water concentration at this location and less hydrothermal circulation above.

\section{EFFECTS OF POSTCUMULUS TRANSPORT IN THE PALISADES SHEET}

Detailed geochemical and petrographic work on the I-95 section indicates that a thick layer of cumulate crystals plus interstitial liquid developed on the floor of

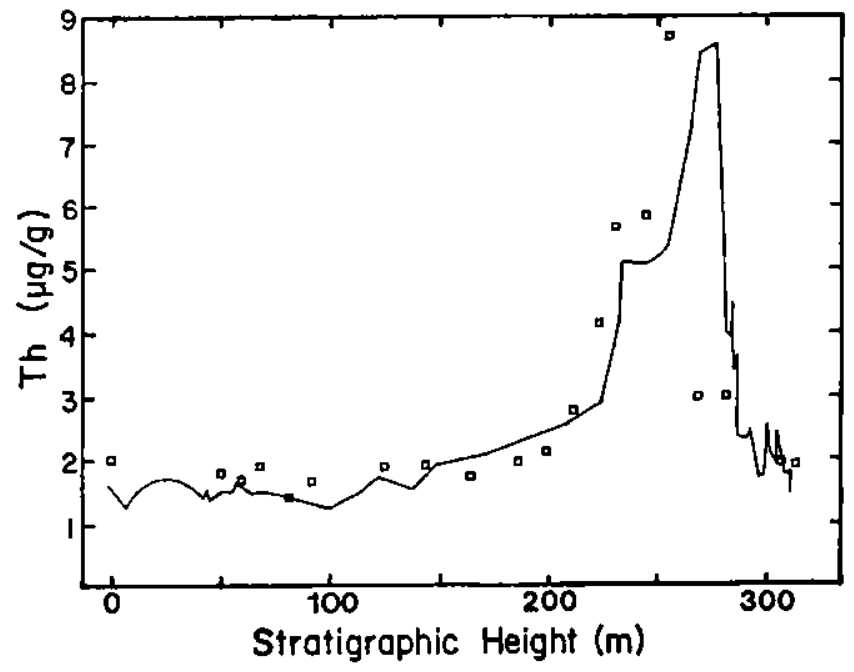

Figure 2. Profile of whole-rock thorium across the Palisades sheet. The squares represent present results. The line is the profile from the I-95 section. The thickness of the I-95 section is scaled by a factor of 0.91 because the sheet is thicker there. The profiles are extremely similar, implying that the postcumulus transport mechanism operating at $1-95$ also operated here. The lower position of the main peak and the closer shoulder in the present results reflect less efficient hydrothermal circulation above the sheet in this section. Note that the concentration variation shown here is primarily caused by variations in the composition and amount of trapped liquid, as evidenced by extreme similarity in profiles of Th, U, Hf, Ta, and rare-earth elements except Eu (Shirley, in press).

the sheet during its differentiation (Shirley, in press). The floor and roof of the sheet converged at the $300-\mathrm{m}$ level, producing a horizon that contains over 50 percent granophyre and extensive local aqueous alteration. When this sandwich horizon formed, the still partially molten zone material below was approximately $150 \mathrm{~m}$ thick. Postcumulus transport then led to an upward movement of incompatible elements and water to the upper half of this zone. This postcumulus transport produced a second, lower, residual zone whose peak concentration is located at $255 \mathrm{~m}$ at $\mathrm{I}-95$.

Two distinct residual zones formed rather than a single thicker one, because when the top of the region containing crystals plus interstitial liquid became attached to the roof, the flow pattern in that zone changed abruptly. Before then intercumulus magma could freely pass upward through the cumulate-magma interface and return to the magma layer. After the upper boundary became attached to the roof, the upward movement was halted there because the subsidence of the crystalline matrix that must accompany such movement was halted. Deeper in the zone, intercumulus magma continued to move upward, with maximum flux near the midpoint of the melt-containing zone (see fig. 1). Numerical simulations show that the level of maximum enrichment in intercumulus liquid occurred about 
Table 1. Whole-rock Instrumental Neutron Activation Analysis of 20 samples

[Values in ppm unless otherwise noted]

\begin{tabular}{|c|c|c|c|c|c|c|c|c|c|c|c|c|c|c|c|}
\hline Sample & $\begin{array}{c}\text { Strat' }^{1} \\
\text { Height }(\mathrm{m})\end{array}$ & $\begin{array}{l}\mathrm{Na} \\
(\%)\end{array}$ & $\begin{array}{c}K \\
(\%)\end{array}$ & $\begin{array}{l}\mathrm{Ca} \\
(\%)\end{array}$ & Sc & $\mathrm{Cr}$ & $\begin{array}{l}\mathrm{Mn} \\
(\%)\end{array}$ & $\begin{array}{l}F_{\theta} \\
(\%)\end{array}$ & Co & $\mathrm{Ni}$ & $\mathrm{Zn}$ & $\mathrm{Ga}$ & $\mathrm{Rb}$ & $\mathrm{Sr}$ & $\underset{(\mathrm{ppb})}{\mathrm{Sb}}$ \\
\hline ev. . & & 3 & 6 & 5 & 7 & 5 & 3 & 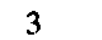 & 4 & 2 & $J$ & 2 & 15 & 20 & 20 \\
\hline$\ldots$ & 314 & 1.34 & $0.46^{4}$ & 7.6 & 36.4 & 277 & 0.121 & 7.7 & 47 & & 93 & & & & $151^{5}$ \\
\hline & 30 & 1.49 & .80 & 7 & 37.9 & 272 & .127 & 7.8 & & 89 & 94 & & & $190^{5}$ & 209 \\
\hline$\ldots$ & 284 & 1.78 & 1.20 & 6.3 & 33.5 & 47 & .119 & 7.7 & 42 & $<89$ & 92 & 1 & 66 & 220 & 313 \\
\hline W-4 & 271 & 1.69 & .73 & 6.6 & 35.1 & $11.3^{3}$ & .126 & 8.7 & 46 & 56 & 105 & 20 & 34 & 220 & 255 \\
\hline W.5 & 258 & 1.82 & 2.06 & 3.8 & 25.2 & $4.0^{4}$ & .164 & 10.7 & 33 & $<63$ & 207 & 2 & 111 & 220 & 563 \\
\hline W-6 & 247 & 2.51 & .93 & 6.3 & 28.6 & $2.6^{4}$ & .132 & 10.0 & 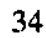 & $<44$ & 118 & 19 & 45 & 230 & 248 \\
\hline 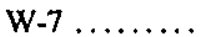 & 234 & 2.22 & 1.23 & 5.7 & 29.8 & $3.7^{4}$ & .147 & 13.4 & 5 & $<62$ & 68 & & 61 & 160 & 306 \\
\hline . & 225 & 2.09 & 1.37 & 5.4 & 32.2 & $5.5^{9}$ & .133 & 9.6 & 4 & $<77$ & 111 & & 69 & 290 & 319 \\
\hline W-9 & 213 & 1.70 & .83 & 7. & 33.2 & 43.6 & .123 & 8.1 & 44 & $<88$ & 104 & 15 & 47 & 280 & 304 \\
\hline$\ldots$ & 20 & 1.36 & .47 & 7.4 & 37.9 & 191 & .124 & 8.1 & 48 & 85 & 104 & 16 & 30 & 240 & 153 \\
\hline$\ldots$ & 18 & 1.35 & $.48^{3}$ & 8.1 & 38.6 & 380 & .119 & 7.5 & 48 & 94 & 88 & 17 & 27 & 180 & 156 \\
\hline$\cdots$ & 16 & 1.24 & $.38^{s}$ & 7. & 38.1 & 578 & .122 & 7.3 & 51 & 114 & 89 & 12 & 18 & $140^{5}$ & $123^{6}$ \\
\hline$\cdots$ & 1. & 1. & .52 & 7. & 37.9 & 601 & .118 & 7.2 & 48 & 108 & 90 & 16 & 30 & 180 & $117^{5}$ \\
\hline & & & .51 & 7 & 37.7 & 298 & .123 & 7.9 & 49 & 67 & 91 & & 26 & $200^{8}$ & $161^{5}$ \\
\hline & 9 & & .64 & 7 & 38.9 & 4 & .119 & 7.1 & 48 & 88 & 93 & & 20 & $180^{6}$ & \\
\hline & 8 & 1. & $.32^{3}$ & 8 & 38.8 & 587 & .112 & 6.7 & 47 & 112 & 78 & & $15^{4}$ & 170 & \\
\hline & 6 & 1.29 & .41 & 7. & 40.5 & 620 & .131 & 7.5 & 52 & 12 & 89 & 1 & & $220^{5}$ & \\
\hline . & 59 & 1.29 & $.41^{3}$ & 7. & 38.6 & 537 & .120 & 7.2 & 50 & 135 & 84 & 12 & 19 & $180^{5}$ & \\
\hline & 50 & 1.24 & $.38^{3}$ & 7. & 37.7 & 62 & .123 & 7.4 & 52 & 143 & 83 & 12 & 24 & $200^{5}$ & $<406$ \\
\hline$\cdots$ & 0 & 1.37 & $.33^{3}$ & 7.6 & 38.2 & 321 & .129 & 8.1 & 50 & 84 & 101 & 1 & 21 & 230 & 198 \\
\hline $\mathrm{BF}$ & - & 1.5 & $.42^{3}$ & 8.8 & 32.1 & 299 & .122 & 8.7 & 47 & 111 & 113 & 1 & 0 & 400 & $209^{5}$ \\
\hline & Cs & & 19 & $\mathrm{Ce}$ & $\mathrm{Nd}$ & $\mathrm{Sm}$ & $\mathrm{Eu}$ & $T$ & & h & Lu & $\mathrm{Hf}$ & $\overline{\mathrm{Ta}}$ & Th & $\bar{U}$ \\
\hline ev... & 7 & 17 & 0 & 4 & 8 & 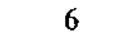 & 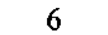 & - & & 6 & 7 & & 8 & & 15 \\
\hline & $1.05^{3}$ & $138^{4}$ & 11.1 & $22.7^{2}$ & $14.3^{4}$ & 3 & 1.17 & 0.69 & & 2.12 & 0.47 & 2.51 & $0.39^{\mathrm{s}}$ & 92 & $0.36^{5}$ \\
\hline W & 1.52 & 152 & $10.7^{4}$ & $24.4^{2}$ & $14.4^{3}$ & $2.98^{3}$ & 1.24 & $.70^{\circ}$ & & 2.26 & .48 & 2.47 & .44 & 1.98 & $.48^{4}$ \\
\hline W. & 1.52 & & $14.7^{4}$ & 31.2 & $18.8^{4}$ & $3.45^{3}$ & 1.44 & .82 & & 2.36 & .54 & 3.10 & .53 & 3.02 & $.70^{4}$ \\
\hline W. & 1.26 & & .0 & & 18.6 & & 1.4 & .79 & & 2.70 & .58 & 3.27 & .58 & 9 & $.79^{5}$ \\
\hline $\mathrm{u}$ & 5 & & & & $47.1^{\mathrm{s}}$ & & 2.8 & 1.94 & & & 1.27 & 8.92 & & & 2.21 \\
\hline . &. & & & & $46.7^{3}$ & & 2. & 1 & & & & 638 & & & 1.82 \\
\hline . & 1. & & & & & & & & & & & & 5 & & 1.30 \\
\hline . & $\begin{array}{l}1 . \\
.\end{array}$ & & & & & & 1. & & & & .76 & & .76 & & 1.22 \\
\hline • & - 1 & & & & $3^{4}$ & & 1. & .82 & & & .54 & 7 & $.55^{3}$ & 0 & $.68^{4}$ \\
\hline & . 1.0 & & & & & & & .73 & & & .50 & 2 & $.49^{9}$ & & $.51^{4}$ \\
\hline & . 1.2 & 1 & 4 & & & 9 & 1.12 & .67 & & & .45 & 2.21 & .40 & 95 & $.55^{5}$ \\
\hline & 1. & & $3^{4}$ & & $3^{4}$ & 4 & 1.12 & .58 & & $2^{s}$ & .39 & 2.00 & & & .44 \\
\hline $\mathrm{w}$ & 1.06 & & $9.6^{4}$ & & & & 1.06 & .61 & & & .42 & 2.08 & .38 & & $.44^{5}$ \\
\hline W & .9 & 176 & $11.4^{4}$ & & & 3 & 1.17 & $.66^{\circ}$ & & & .46 & $\begin{array}{l}2.00 \\
2.44\end{array}$ & $.40^{4}$ & 1 & .544 \\
\hline W & 9 & 14 & 9.37 & & $10.7^{5}$ & & .96 & .53 & & $1.67^{4}$ & .39 & 1.92 & $.30^{5}$ & 1.64 & $.63^{4}$ \\
\hline$w$ & $.54^{3}$ & $108^{4}$ & $8.1^{4}$ & 1 & $9.2^{4}$ & $6^{4}$ & .89 & .55 & & & .35 & $1.71^{\mathrm{s}}$ & .30 & 2 & .96 \\
\hline W & $.99^{3}$ & 13 & $\begin{array}{l}0.1 \\
9.1^{4}\end{array}$ & & $12.5^{9}$ & $2.48^{4}$ & 1.00 & .60 & & & .41 & 2.06 &. & 1 & .77 \\
\hline $\mathrm{W}$ - & $.73^{4}$ & 146 & $8.8^{4}$ & & $11.8^{4}$ & $2.30^{3}$ & .97 & .53 & & & .39 & 1.88 & $.37^{3}$ & 8 & $.77^{5}$ \\
\hline W-20 & $.86^{4}$ & $110^{4}$ & $9.4^{4}$ & 20. & 11 & 2. & .9 & .5 & & $1.70^{3}$ & .41 & 1.99 & $.39^{3}$ & 1.80 & $.97^{6}$ \\
\hline W. & $.99^{s}$ & 184 & $11.0^{5}$ & $22.8^{2}$ & $16.1^{4}$ & 3.0 & 1.18 & .69 & & 1.92 & .45 & 2.37 & $.35^{4}$ & 2 & $<1.60$ \\
\hline BHVO-1..... & $<.39$ & 125 & $16.6^{4}$ & 39.0 & 28.7 & $4.83^{9}$ & 2.23 & 1.01 & & 2.02 & .42 & 4.08 & 1.05 & $1.20^{2}$ & $1.51^{5}$ \\
\hline
\end{tabular}

${ }^{1}$ Stratigraphic height based on a strike of $\mathrm{N} .22^{\circ} \mathrm{E}$. and $13^{\circ}$ dip to the west. The lower contact was not located in this section. Sample W-21 was assigned a stratigraphic height of 0 because this sample was judged to be within a few meters of the contact based on its appearance. ${ }^{2-6}$ Error is $5,10,20,35$, or $50 \%$, respectively, rather than stated error for that element.

70 percent of the way towards the upper boundary of the partially molten zone, producing the lower residual zone (Shirley, in press). It is because of the abruptness of the change in the flow pattern that two distinct zones were produced.

The formation of a second residual zone by postcumulus transport observed in the Palisades sheet was apparently produced by a specific external factor. It is clear that such a zone will develop only if a thick layer of partially molten material accumulates on the floor. The numerical simulations indicate that a thick zone will form only if the sheet is preferentially cooled through the roof. In the Palisades this condition was apparently achieved by hydrothermal circulation in the strata over- 
lying the sheet. It seems probable that this is the only mechanism that can produce sufficiently asymmetric cooling, so similar behavior in other sheets should be expected when similar conditions prevail.

There is strong geologic evidence that the Palisades sheet was in a setting in which hydrothermal circulation was likely to occur. The sheet is believed to be an intrusive equivalent of the second Watchung Basalt (Puffer and Lechler, 1980), which is located 3 to $4 \mathrm{~km}$ stratigraphically above (Faust, 1975), and somewhat less in the northern part of the sheet (Kodama, 1983). The basalt flow is subaqueous, and the arkose, shale, and sandstone underlying the basalt and overlying the sheet presumably contained interstitial water that could participate in the circulation. Also, the observation of chlorinerich amphiboles in the sheet provides direct evidence of interaction with a saline fluid (Shirley, in press). Given these circumstances, it seems highly likely that hydrothermal circulation occurred above the sheet during its crystallization.

When heat transport is enhanced through the roof, deposition of partially molten material on the floor is rapid because the crystallization rate is rapid. This causes a thick pile of crystals plus interstitial liquid to accumulate on the floor, because the deposition rate exceeds the crystallization rate there. A quantitative prediction of the relative rates of growth of the floor and roof awaits a full description of heat and mass transfer in a convecting crystal-rich sheet and of crystal deposition mechanisms. Qualitatively, however, rapid cooling through the roof should lead to accumulation of less material there (Brandeis and Jaupart, 1986).

\section{RELATION OF PRESENT AND PREVIOUS RESULTS}

The profiles of Th in the two sections are quite similar, although quantitative differences are significant. Qualitatively, both profiles show a basically flat trend in the lower two-thirds, an abrupt increase to a plateau, followed by a main peak. Quantitatively, the present profile of Th shows a main peak at $258 \mathrm{~m}$ and a shoulder at $234 \mathrm{~m}$ that correspond to the peak and shoulder observed at 300 and $255 \mathrm{~m}$ in the I-95 section (these appear at 275 and $234 \mathrm{~m}$ here). These features are located at a lower relative position and closer together than in the I-95 section, as illustrated in figure 2. Also, there is no valley between these points, although the limited sampling leaves this possibility open. The abundance of granophyre at the main peak is about 40 percent, whereas it is about 13 percent for the two underlying samples so there is apparently only a shoulder in the granophyre abundance at this location also. These observations support the hypothesis that the transport mechanism that operated at I-95 was less important here but clearly still present. Achievement of a net reversal in the upward trends of incompatible elements and granophyre abundance in a system that is fractionating as rapidly as the last $50 \mathrm{~m}$ of thickness of the Palisades sheet requires an exceptionally large effect.

The reason for the lesser effect at this location is hypothesized to be that enhanced cooling through the roof caused by hydrothermal circulation was less effective here. The most direct effect of this is that the thickness of crystals plus intercumulus liquid that accumulates on the floor is less. This in turn leads to less postcumulus transport, both because there is less trapped liquid available and because the efficiency of such transport decreases sharply with the thickness (Shirley, 1986b). Another reason that there is less postcumulus transport in this section is that there was less water in the magma, as evidenced by the lower abundance of granophyre. Water in the magma would enhance transport by lowering the melt and matrix viscosities and increasing permeability (Shaw, 1972; Shirley, in press; Fujii and Osamura, 1986).

The reduction in enhanced upward heat transport is possibly due to a greater depth of intrusion as suggested by previously cited geological evidence. A greater depth would lead to reduced porosity in the overlying strata, which would inhibit convection there. Despite this factor it seems more likely that the cause of the relatively efficient cooling above the I-95 section is due to a local phenomenon rather than a regional one because it seems unlikely that the thickness of overburden was sufficiently different to produce the observed difference. The strata above the I-95 section may, for example, have been more fractured during intrusion of the sheet. Whatever the reason, both an increased water content in the sediments and increased permeability would be expected to enhance cooling and contamination of the magma by water. Thus, one could speculate that these phenomena will be correlated in other sections.

Having discussed the possible explanations for the differences in the two sections, it must also be noted that it is uncertain how significant the quantitative differences really are because the scale of lateral heterogeneities is unknown. It is probable that the observed units have nonplanar or inclined boundaries so that the thicknesses cannot be measured reliably in a single section, especially since the sampling was inclined only about $10^{\circ}$ relative to the contacts. It does seem safe to say that the sections are approximately representative because of their extreme similarity. The same petrographic units appear in each and the bulk compositions are close to one another. This contrasts with sheets farther south where lateral 
transport has resulted in complementary fractions of cumulate zones that are located miles from each other (Gottfried and Froelich, 1985). Given the great similarity between the two sections, it seems safe to assume at least that the qualitative features discussed are genuine, although exact thicknesses should not be considered reliable until questions pertaining to lateral heterogeneities are answered definitively.

\section{CONCLUSIONS}

This study supports the results of a more detailed study of another section of the Palisades shect. The two sections, which are located $9.5 \mathrm{~km}$ apart, are similar in that they show evidence of postcumulus transport caused by enhanced cooling through the roof. The main result of interest is the unique role that postcumulus transport played in producing two granophyre- and incompatibleelement-rich residual zones. The northern section shows a stronger effect, apparently because of higher permeability in the overlying strata there. The two zones do not appear to be distinct in the southern section although the presence of the lower residual zone is clear in the geochemical profiles.

The major factor leading to two granophyrc-rich layers is enhanced cooling from above during solidification of the sheet. This led to exceptionally rapid deposition of crystals on the floor. The rapid deposition caused a thick layer of cumulate crystals plus interstitial liquid to accumulate there. Due to the greater density of the solid phases, compaction occurred, expelling the interstitial magma upward. While the main body of magma was present the expelled intercumulus magma was simply returned to the chamber. After the floor and roof became attached, subsequent upward movement of magma in the remaining crystals plus interstitial liquid was modified because magma could no longer escape through the top. This led to maximum enrichment of residual material below the sandwich horizon, producing a second residual zone.

\section{ACKNOWLEDGMENTS}

I thank P. Warren for accompanying me in collecting the samples, J. Wasson for helpful discussions, and J. Kelley and Conrail for providing access to the railroad tunnel in which the samples were collected. The manuscript was substantially improved from reviews by $\mathrm{A}$. Froelich, M. Foose, and D. Gottfried of the USGS. I also thank L. Mikami and A. Tsang for technical assistance. This work was mainly supported by National Science Foundation grant EAR 84-08167 and partially supported by National Aeronautics and Space Administration grant NAG 9-96.

\section{REFERENCES CITED}

Brandeis, G., and Jaupart, C., 1986, On the interaction between convection and crystallization in cooling magma chambers: Earth and Planetary Science Letters, v. 77, p. 345-361.

Faust, G.T., 1975, A review and interpretation of the geologic setting of the Watchung basalt flows, New Jersey: U.S. Geological Survey Professional Paper 864-A, 40 p.

Fujii, N, and Osamura, K., 1986, Effect of water saturation on the distribution of partial melt in the olivine-pyroxeneplagioclase system: Journal of Geophysical Research, v. 91, p. 9253-9259.

Gottfried, D., and Froelich, A.J., 1985, Geochemical and petrologic features of some Mesozoic diabase sheets in the northern Culpeper basin, in Robinson, G.R., Jr., and Froelich, A.J., eds., Proceedings of the second U.S. Geological Survey workshop on the early Mesozoic basins of the Eastern United States: U.S. Geological Survey Circular 946, p. 86-91.

Hess, H.H., 1956, The magnetic properties and differentiation of dolerite sills - A critical discussion: American Journal of Science, v. 254, p. 446-451.

Irvine, T.N., 1980, Magmatic infiltration metasomatism, double-diffusive fractional crystallization, and adcumulus growth in the Muskox intrusion and other layered intrusions, in Hargraves, R.B., ed., Physics of magmatic processes: Princeton University Press, Princeton, New Jersey, p. 325-383.

Kodama, K.P., 1983, Magnetic and gravity evidence for a subsurface connection between the Palisades sill and the Ladentown basalts: Geological Society of America Bulletin, v. 94, p. 151-158.

Lewis, J.V., 1908, The Palisades diabase of New Jersey: American Journal of Science, v. 176, p. 155-162.

McKenzie, D., 1984, The generation and compaction of partially molten rock: Journal of Petrology, v. 25, p. 713-765.

Puffer, J.H., and Lechler, P., 1980, Geochemical cross section through the Watchung basalts of New Jersey: Bulletin of the Geological Society of America, v. 91, p. II156-II191.

Raedeke, L.D., and McCallum, I.S., 1983, Investigations in the Stillwater complex: Part II, Petrology and petrogenesis of the ultramafic series: Joumal of Petrology, v. 25, p. 395-420.

Richter, F.M., and McKenzie, D., 1984, Dynamical models for melt segregation from a deformable matrix: Journal of Geology, v. 92, p. 729-740.

Shaw, H.R., 1972, Viscosities of magmatic silicate liquids: An empirical method of prediction: American Journal of Science, v. 272 , p. $870-893$.

Shirley, D.N., 1986a, Compaction of igneous cumulates: Journal of Geology, v. 94, p. 795-809.

1986b, Magmatic differentiation in partially molten systems: Applications to the moon and the Palisades sill: unpublished Ph.D. thesis, U.C.L.A., Los Angeles, 189 p.

-in press, Differentiation and compaction in the Palisades Sill, New Jersey: Journal of Petrology.

Sparks, R.S.J., Huppert, H.E., Kerr, R.C., McKenzie, D.P., and Tait, S.R., 1985, Postcumulus processes in layered intrusions: Geological Magazine, v. 122, p. 555-568. 
Walker, F.R., 1940, Differentiation of the Palisade Diabase, New Jersey: Geological Society of America Bulletin, v. 51, p. 1059-1106.
Walker, K.R., 1969, The Palisades sill, New Jersey: A reinvestigation: Geological Society of America Special Paper 111, $178 \mathrm{p}$.

\title{
SIGNIFICANCE OF MAJOR- AND TRACE-ELEMENT VARIATION TRENDS IN MESOZOIC DIABASE, WEST-CENTRAL NEW JERSEY AND EASTERN PENNSYLVANIA
}

\author{
Jonathan M. Husch ${ }^{1}$
}

\begin{abstract}
Petrographic and major- and trace-element analyses of diabase samples from seven sheetlike intrusions and one associated dike exposed in the west-central New Jersey and eastern Pennsylvania region of the Mesozoic Newark basin indicate a common parentage. When plotted on Harker-type variation diagrams, $\mathrm{SiO}_{2}, \mathrm{TiO}_{2}, \mathrm{P}_{2} \mathrm{O}_{5}, \mathrm{Al}_{2} \mathrm{O}_{3}, \mathrm{CaO}$, $\mathrm{Na}_{2} \mathrm{O}+\mathrm{K}_{2} \mathrm{O}, \mathrm{Ni}$, and $\mathrm{Cr}$ whole-rock variation trends are compatible with the compositional variability resulting largely from in-situ crystal fractionation acting upon quartz normative, high-titanium tholeiite (HTQ) magmas of essentially identical composition; accumulations of orthopyroxene and (or) clinopyroxene in the HTQ magmas produce high-magnesium compositions. Localized contamination by enclosing Triassic sedimentary rocks also appears to have contributed to some of the observed compositional variability, although generally to a lesser degree.
\end{abstract}

\section{INTRODUCTION}

Mesozoic diabase of west-central New Jersey and eastern Pennsylvania occurs in the central portion of the Newark basin (fig. 1) and includes at least seven exposures of sheetlike intrusive bodies. These intrusions, originally studied by Husch and others (1984), are, from west to east (fig. 1), the Point Pleasant (Byram) diabase, Stockton diabase, Lambertville sill (Solebury Mountain diabase), Belle Mountain (Bowman Hill) diabase, Baldpate Mountain diabase, Pennington Mountain diabase, and Rocky Hill diabase. With obvious exceptions at the western end of the Rocky Hill diabase and the central portion of the Lambertville sill (fig. 1), all seven intrusions are roughly conformable with enclosing Upper Triassic sedimentary rocks of the Lockatong and Passaic Formations. Numerous smaller, fine-grained dikes also are present, such as the Solebury dike and the Quarry 08648 . dike (fig. 1), the latter studied by Husch and Schwimmer (1985). Although none of the diabase sheets or dikes from the west-central New Jersey and eastern Pennsylvania diabase region have been age-dated, it is assumed they were intruded at essentially the same time as the Early Jurassic Palisades sill (approximately $195 \mathrm{Ma}$ ) (Dallmeyer, 1975; Sutter and Smith, 1979; Seidemann and others, 1984) and the flows of the Orange Mountain and Preakness Basalts, located approximately 20 miles northeast of this province.

\section{PETROGRAPHY}

Petrographic observations show that most diabase samples are composed predominantly of plagioclase $\left(A n_{50-70}\right)$, clinopyroxene (augite and pigeonite), orthopyroxene $\left(E_{n_{75-80}}\right)$, and opaque oxides. Accessory minerals include biotite, apatite, quartz, alkali feldspar, and sphene. In highly fractionated granophyric samples (for example, MS1), orthopyroxene is absent, clinopyroxene commonly is replaced by deuteric hornblende and biotite, plagioclase compositions may be much more sodic $\left(\mathrm{An}_{20-50}\right)$ than normal, particularly near grain boundaries, and quartz and alkali feldspar usually occur in graphic micropegmatitic intergrowths. Olivine is rarely found in diabase from the region; there are no known olivine accumulation zones as in the Palisades sill (Walker, 1969). In those few samples from diabase chill margins (for example, PP2) and the Quarry dike where olivine is seen, it is present in only small amounts (less than 2 modal percent) and commonly is embayed and anhedral in form, suggesting extensive peritectic reaction with the liquid.

On the other hand, accumulations of large (to 4 $\mathrm{mm}$ ), euhedral clinopyroxene and (or) orthopyroxene are found in porphyritic and (or) seriate samples from the Baldpate Mountain diabase (T4), Lambertville sill (for example, ELS11), and Point Pleasant diabase (PP5). In addition, glomeroporphyritic masses of clinopyroxene 


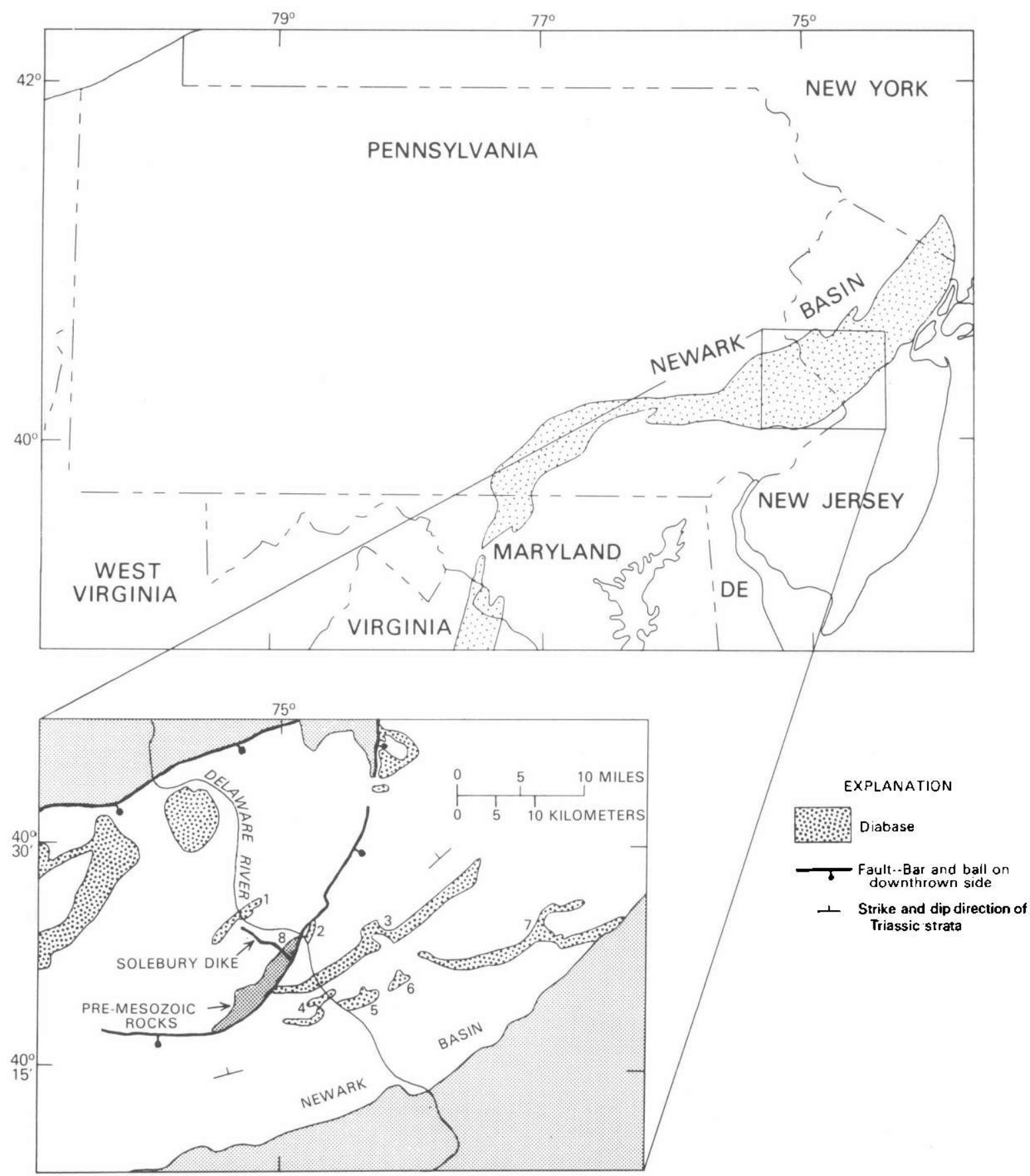

Figure 1. Location of Newark basin and geologic sketch map of Mesozoic diabase in west-central New Jersey and eastern Pennsylvania. Individually numbered intrusions shown are (1) Point Pleasant (Byram) diabase; (2) Stockton diabase; (3) Lambertville sill; (4) Belle Mountain diabase; (5) Baldpate Mountain diabase; (6) Pennington Mountain dia-

are common in just about every chill margin sampled. Microphenocrysts (less than $0.7 \mathrm{~mm}$ in length) of plagioclase are seen only in the chill margin for the Point Pleasant diabase and within the Quarry dike. For all chills, phenocrysts are set in a fine-grained (averages 0.1 $\mathrm{mm}$ ) intergranular or subophitic groundmass of augite base; (7) Rocky Hill diabase; and (8) Quarry dike locality. Regional strike of Newark basin strata also shown. PreTriassic and post-Jurassic rocks outside of the basin are shaded gray. Triassic sedimentary rocks inside the basin are unpatterned.

and plagioclase. With few exceptions, groundmass glass is found in only trace amounts. Textures for coarser grained diabase are typically holocrystalline and subophitic with grain size averaging from 1 to $6 \mathrm{~mm}$.

Almost every sample collected exhibits at least some trace of alteration as evidenced by the saussuriti- 
zation of plagioclase and the uralitization, epidotization, and (or) chloritization of pyroxene. However, with few exceptions (for example, WH3), samples were not analyzed geochemically if observed alteration effects were extensive (major replacement of original minerals). More importantly, no meaningful correlation between whole-rock chemistry and extent of alteration was found for the samples analyzed (see also Husch and Schwimmer, 1985).

\section{WHOLE-ROCK COMPOSITIONS}

Major- and trace-element whole-rock compositions determined by direct current plasma atomic emission spectroscopy (Feigenson and Carr, 1985) and calculated CIPW norms for all analyzed diabase samples collected from the seven sheetlike intrusions of the region are presented in table 1 . Analyzed compositions are quite variable and include high magnesium ( $>9$ percent $\mathrm{MgO}$ ) diabase, diabase extremely similar in bulk chemistry to the quartz normative, high-titanium tholeiite (HTQ) of Weigand and Ragland (1970) and York Haven tholeiite of Smith and others (1975), the high-iron type basalt or diabase derivatives, and more highly evolved granophyre. Table 1 represents a recent compilation of data acquired by Husch and others (1984), Trione (1985), and Eliason (1986). Previously unreported $\mathrm{Cu}, \mathrm{Cr}$, and $\mathrm{Ni}$ values, replacing those given in Husch and others (1984), also are included. All majorelement values have been normalized to 100 percent anhydrous with the $\mathrm{Fe}_{2} \mathrm{O}_{3} / \mathrm{FeO}$ ratio set at 0.235 . This value represents the average for Mesozoic igneous rocks of similar composition and occurrence from Pennsylvania and New Jersey (Smith and others, 1975; Puffer and Lechler, 1979; Puffer and others, 1981). Original majorelement (all $\mathrm{Fe}$ as $\mathrm{FeO}$ ) plus loss-on-ignition (LOI) totals range between 97.2 and 102.6 weight percent with LOI values between 0.82 and 2.17 weight percent. No correlation between LOI values and alkali content was found.

Table 2 presents the major- (normalized) and trace-element whole-rock compositions for samples collected from fine-grained chill zones in the region, including the chill zone of the Quarry dike. Also included in Table 2 are average compositions for various HTQ basalts and diabases from the Mesozoic eastern North America (ENA) province. The analyzed fine-grained chill zone samples are thought to give the best available approximation of magma compositions parental to the Mesozoic intrusions of the west-central New Jersey and eastern Pennsylvania region. This assumption is supported by their remarkable compositional and petrographic uniformity throughout the region and their extreme similarity to numerous other ENA HTQ basalts and diabases (table 2).

\section{VARIATION TRENDS}

Selected major-element oxide and trace-element versus $\mathrm{MgO}$ diagrams are presented in figure 2 to illustrate important variation trends for the seven sheetlike diabases of the study area. In general, the geochemical variations are similar to those seen for vertical sections through the Palisades sill (Walker, 1969). Variation trends not shown as part of figure 2 are omitted because of similarities with those presented. Quarry dike samples are not plotted in figure 2, as their MgO contents remain almost constant at about 8 weight percent and, therefore, would form vertical trends. As shown by Husch and Schwimmer (1985), this is because crystal fractionation was not a significant cause of compositional variations within the Quarry dike. Besides the Quarry dike samples, whole-rock samples with $\mathrm{MgO}$ contents greater than 9 weight percent also are not plotted. These samples (PP5, ELS11, LS2, and LSGRAB) are believed to be mafic enriched because of the observed accumulation of both orthopyroxene and clinopyroxene (Husch and others, 1984) and are discussed separately.

As seen in figure $2, \mathrm{SiO}_{2}, \mathrm{TiO}_{2}$, and $\mathrm{P}_{2} \mathrm{O}_{5}$ contents initially remain nearly constant or rise only slightly until $\mathrm{MgO}$ values fall to approximately 3 to 4 weight percent. At lower $\mathrm{MgO}$ values, concentrations increase dramatically for all three oxides, and then fall at the lowest $\mathrm{MgO}$ values ( $<2$ weight percent) for $\mathrm{TiO}_{2}$ and $\mathrm{P}_{2} \mathrm{O}_{3} ; \mathrm{FeO}^{*}$ (total iron calculated as $\mathrm{FeO}$ ) and $\mathrm{V}$ trends (not shown) exhibit similar behavior. $\mathrm{Al}_{2} \mathrm{O}_{3}$ (fig. 2) and $\mathrm{Sr}$ (not shown) concentrations, on the other hand, increase dramatically until $\mathrm{MgO}$ contents decrease to approximately 4 to 5 weight percent. At lower $\mathrm{MgO}$ contents there is a dramatic reversal in trend and $\mathrm{Al}_{2} \mathrm{O}_{3}$ and $\mathrm{Sr}$ contents decrease markedly. In addition, it is noted that one sample (T8) is quite low in $\mathrm{SiO}_{2}$ (and possibly $\mathrm{Al}_{2} \mathrm{O}_{3}$ ). This somewhat anomalous sample is also higher in $\mathrm{TiO}_{2}$, $\mathrm{FeO}^{*}$ (not shown), $\mathrm{V}$ (not shown), and Sc (not shown) contents than samples with similar $\mathrm{MgO}$ contents that plot along the main variation trend. Petrographic studies show this sample to be enriched in Fe-Ti oxides (approximately 8 modal percent), and the geochemical data are consistent with this observation.

$\mathrm{CaO}$ concentrations (fig. 2) exhibit a third pattern that shows a slight decrease until $\mathrm{MgO}$ contents fall to 4 or 5 weight percent. At this point the slope shows a distinct increase and $\mathrm{CaO}$ is depleted markedly. Sc concentrations (not shown) produce a similar pattern with the difference that the abrupt depletion occurs at $\mathrm{MgO}$ values of approximately 2 weight percent or less. Significantly, at least four samples (WH3, T9, ELS6, and ELS24) and perhaps as many as six samples (if WH1 and ELS21 are included) are notably depleted in $\mathrm{CaO}$ and plot well below the main variation trend. 
Table 1. Major, trace, and CIPW normative compositions of diabase samples from west-central New Jersey and eastern Pennsylvania (See appendix for sample locations)

[Major elements normalized to 100 percent anhydrous; $\mathrm{Fe}_{2} \mathrm{O}_{3} / \mathrm{FeO}$ ratio set at $0.235 ; \mathrm{Q}$, quartz; OR, orthoclase; $\mathrm{AB}$, albite; $\mathrm{AN}$, anorthite; $\mathrm{NE}$, nepheline; DI, diopside; HY, hypersthene; OL, olivine; MT, magnetite; IL, ilmenite; AP, apatite]

\begin{tabular}{|c|c|c|c|c|c|c|c|c|c|c|c|c|c|}
\hline & & & & & & $n$ & & & & & & & \\
\hline & LS11 & ELS6 & ELS24 & ELS5 & ELS25 & & LS10 & ELS13 & ELS14 & ELS15 & ELS18 & ELS19 & ELS21 \\
\hline $\begin{array}{l}\ldots \\
\cdots \\
\cdots \\
\cdots \\
\cdots \\
\cdots \\
\cdots \\
\cdots\end{array}$ & $\begin{array}{r}52.37 \\
.94 \\
11.47 \\
1.92 \\
8.14 \\
.18 \\
10.66 \\
11.87 \\
1.80 \\
.53 \\
.12\end{array}$ & $\begin{array}{r}52.62 \\
1.04 \\
15.20 \\
1.92 \\
8.14 \\
.17 \\
6.68 \\
9.03 \\
2.69 \\
2.33 \\
.18\end{array}$ & $\begin{array}{r}1.19 \\
15.85 \\
1.96 \\
8.34 \\
.17 \\
5.03 \\
7.98 \\
4.16 \\
2.53 \\
.17\end{array}$ & $\begin{array}{r}52.60 \\
1.16 \\
14.11 \\
1.97 \\
8.36 \\
.17 \\
7.81 \\
10.65 \\
2.13 \\
.86 \\
.18\end{array}$ & $\begin{array}{r}52.36 \\
1.13 \\
14.15 \\
1.97 \\
8.36 \\
.17 \\
7.81 \\
10.63 \\
2.44 \\
.81 \\
.17\end{array}$ & $\begin{array}{r}53.39 \\
1.41 \\
15.27 \\
2.05 \\
8.71 \\
.17 \\
5.14 \\
9.90 \\
2.86 \\
.89 \\
.21\end{array}$ & $\begin{array}{r}52.68 \\
1.04 \\
12.25 \\
2.23 \\
9.51 \\
.20 \\
8.27 \\
11.21 \\
1.83 \\
.64 \\
.14\end{array}$ & $\begin{array}{r}.95 \\
15.23 \\
1.83 \\
7.79 \\
.16 \\
7.19 \\
11.30 \\
2.23 \\
.53 \\
.13\end{array}$ & $\begin{array}{r}52.88 \\
1.03 \\
14.09 \\
2.04 \\
8.64 \\
.18 \\
7.35 \\
11.04 \\
2.03 \\
.58 \\
.14\end{array}$ & $\begin{array}{r}52.23 \\
1.13 \\
13.37 \\
2.01 \\
8.52 \\
.18 \\
8.42 \\
1.33 \\
1.95 \\
.73 \\
.13\end{array}$ & $\begin{array}{r}1.01 \\
15.07 \\
1.93 \\
8.19 \\
.17 \\
6.14 \\
10.77 \\
2.87 \\
.63 \\
.16\end{array}$ & $\begin{array}{r}52.92 \\
1.03 \\
15.54 \\
1.99 \\
8.46 \\
.17 \\
5.70 \\
10.56 \\
2.53 \\
.61 \\
.17\end{array}$ & $\begin{array}{r}1.43 \\
15.11 \\
2.27 \\
9.64 \\
.21 \\
4.72 \\
8.86 \\
3.60 \\
1.31 \\
.17\end{array}$ \\
\hline & $\begin{array}{r}88 \\
590 \\
70 \\
102 \\
15 \\
29 \\
109 \\
167 \\
34\end{array}$ & $\begin{array}{r}172 \\
173 \\
111 \\
72 \\
93 \\
36 \\
162 \\
281 \\
95\end{array}$ & $\begin{array}{r}259 \\
22 \\
128 \\
56 \\
95 \\
29 \\
300 \\
278 \\
102\end{array}$ & $\begin{array}{r}148 \\
278 \\
115 \\
96 \\
33 \\
37 \\
235 \\
257 \\
107\end{array}$ & $\begin{array}{r}149 \\
280 \\
110 \\
96 \\
32 \\
39 \\
222 \\
252 \\
97\end{array}$ & $\begin{array}{r}178 \\
49 \\
131 \\
56 \\
34 \\
33 \\
227 \\
290 \\
113\end{array}$ & $\begin{array}{r}142 \\
322 \\
147 \\
95 \\
22 \\
42 \\
140 \\
314 \\
98\end{array}$ & $\begin{array}{r}142 \\
186 \\
96 \\
86 \\
19 \\
35 \\
191 \\
249 \\
78\end{array}$ & $\begin{array}{r}146 \\
104 \\
118 \\
87 \\
22 \\
39 \\
177 \\
297 \\
99\end{array}$ & $\begin{array}{r}128 \\
359 \\
107 \\
98 \\
29 \\
38 \\
165 \\
267 \\
85\end{array}$ & $\begin{array}{r}132 \\
31 \\
103 \\
63 \\
21 \\
36 \\
246 \\
241 \\
102\end{array}$ & $\begin{array}{r}147 \\
22 \\
109 \\
60 \\
19 \\
35 \\
201 \\
268 \\
88\end{array}$ & $\begin{array}{r}175 \\
9 \\
51 \\
44 \\
48 \\
34 \\
250 \\
331 \\
82\end{array}$ \\
\hline $\begin{array}{l}\mathrm{Q} \\
\mathrm{OR} \\
\mathrm{AB} \\
\mathrm{AN}\end{array}$ & $\begin{array}{r}1.23 \\
3.13 \\
15.23 \\
21.65 \\
.00 \\
29.44 \\
24.47 \\
.00 \\
2.78 \\
1.79 \\
.28\end{array}$ & $\begin{array}{r}.00 \\
13.77 \\
22.76 \\
22.52 \\
.00 \\
17.27 \\
14.07 \\
4.43 \\
2.78 \\
1.98 \\
.42\end{array}$ & $\begin{array}{r}.00 \\
14.95 \\
30.69 \\
17.10 \\
2.44 \\
17.66 \\
.00 \\
11.65 \\
2.84 \\
2.26 \\
.39\end{array}$ & $\begin{array}{r}2.90 \\
5.08 \\
18.02 \\
26.40 \\
.00 \\
20.58 \\
21.54 \\
.00 \\
2.86 \\
2.20 \\
.42\end{array}$ & $\begin{array}{r}1.28 \\
4.79 \\
20.65 \\
25.27 \\
.00 \\
21.48 \\
21.15 \\
.00 \\
2.86 \\
2.15 \\
.39\end{array}$ & $\begin{array}{r}4.93 \\
5.26 \\
24.20 \\
26.20 \\
.00 \\
16.18 \\
17.08 \\
.00 \\
2.97 \\
2.68 \\
.49\end{array}$ & $\begin{array}{r}3.91 \\
3.78 \\
15.49 \\
23.32 \\
.00 \\
25.65 \\
22.32 \\
.00 \\
3.23 \\
1.98 \\
.32\end{array}$ & $\begin{array}{r}3.30 \\
3.13 \\
18.87 \\
29.98 \\
20.00 \\
19.38 \\
1.00 \\
2.65 \\
1.80 \\
.30\end{array}$ & $\begin{array}{r}4.46 \\
3.43 \\
17.18 \\
27.62 \\
.00 \\
21.45 \\
20.62 \\
.00 \\
2.96 \\
1.96 \\
.32\end{array}$ & $\begin{array}{r}2.39 \\
4.31 \\
16.50 \\
25.57 \\
.00 \\
24.24 \\
21.62 \\
.00 \\
2.91 \\
2.15 \\
.30\end{array}$ & $\begin{array}{r}2.28 \\
3.72 \\
24.29 \\
26.38 \\
.00 \\
21.35 \\
16.89 \\
.00 \\
2.80 \\
1.92 \\
.37\end{array}$ & $\begin{array}{r}5.03 \\
3.60 \\
21.41 \\
29.25 \\
.00 \\
17.29 \\
18.17 \\
.00 \\
2.89 \\
1.96 \\
.40\end{array}$ & $\begin{array}{r}.00 \\
7.74 \\
30.46 \\
21.20 \\
.00 \\
18.01 \\
14.90 \\
.00 \\
3.29 \\
2.72 \\
.39\end{array}$ \\
\hline & & & Lam & tville sill & & & & & Point $P$ & asant & & Stoc & xton \\
\hline & LS2 & LS3 & LS8 & LS9 & $\overline{L S 11}$ & $\overline{\mathrm{LSG}}$ & $\bar{B}$ & $\overline{\text { PP1 }}$ & $\overline{\mathrm{PP} 2}$ & $\overline{\mathrm{PP5}}$ & PP6 & LQ1 & $\overline{\mathrm{LQ4}}$ \\
\hline $\begin{array}{l}\mathrm{SiO}_{2} \\
\mathrm{TiO}_{2} . . \\
\mathrm{Al}_{2} \mathrm{O}_{3} \\
\mathrm{Fe}_{2} \mathrm{O}_{3} \\
\mathrm{FeO}_{2} \\
\mathrm{MnO} . \\
\mathrm{MgO} . \\
\mathrm{CaO}_{\ldots} . . \\
\mathrm{Na}_{2} \mathrm{O} . \\
\mathrm{K}_{2} \mathrm{O}_{\ldots} \\
\mathrm{P}_{2} \mathrm{O}_{3}\end{array}$ & $\begin{array}{r}52.19 \\
.90 \\
11.50 \\
1.93 \\
8.23 \\
.17 \\
11.97 \\
10.94 \\
1.67 \\
.47 \\
.03\end{array}$ & $\begin{array}{r}52.63 \\
1.11 \\
14.23 \\
1.94 \\
8.26 \\
.16 \\
8.04 \\
10.93 \\
1.99 \\
.59 \\
.12\end{array}$ & $\begin{array}{r}53.08 \\
1.03 \\
18.09 \\
1.69 \\
7.20 \\
.15 \\
4.65 \\
10.55 \\
2.84 \\
.58 \\
.14\end{array}$ & $\begin{array}{r}52.78 \\
.97 \\
15.47 \\
1.88 \\
7.99 \\
.17 \\
6.92 \\
10.83 \\
2.35 \\
.55 \\
.09\end{array}$ & $\begin{array}{r}52.76 \\
.90 \\
14.99 \\
1.81 \\
7.70 \\
.16 \\
71.75 \\
11.22 \\
2.25 \\
.35 \\
.11\end{array}$ & & & $\begin{array}{r}52.58 \\
1.13 \\
14.63 \\
1.94 \\
8.26 \\
.16 \\
7.52 \\
10.69 \\
2.34 \\
.61 \\
.14\end{array}$ & $\begin{array}{r}52.42 \\
1.11 \\
14.19 \\
1.93 \\
8.22 \\
.16 \\
8.14 \\
11.00 \\
2.08 \\
.61 \\
.14\end{array}$ & $\begin{array}{r}52.51 \\
10.76 \\
1.87 \\
7.95 \\
.18 \\
15.39 \\
9.03 \\
1.56 \\
.35 \\
.11\end{array}$ & $\begin{array}{r}52.58 \\
1.10 \\
14.26 \\
1.95 \\
8.30 \\
.16 \\
8.03 \\
10.95 \\
1.98 \\
.55 \\
.14\end{array}$ & $\begin{array}{r}52.82 \\
1.00 \\
14.50 \\
2.06 \\
8.77 \\
.19 \\
6.98 \\
10.64 \\
2.35 \\
.58 \\
.11\end{array}$ & $\begin{array}{r}52.81 \\
1.00 \\
14.27 \\
2.11 \\
8.98 \\
.20 \\
7.15 \\
10.52 \\
2.23 \\
.60 \\
.13\end{array}$ \\
\hline & $\begin{array}{r}125 \\
470 \\
106 \\
110 \\
13 \\
40 \\
121 \\
241 \\
71\end{array}$ & $\begin{array}{r}163 \\
274 \\
104 \\
90 \\
19 \\
36 \\
162 \\
260 \\
93\end{array}$ & $\begin{array}{r}152 \\
35 \\
94 \\
55 \\
17 \\
30 \\
218 \\
232 \\
96\end{array}$ & $\begin{array}{r}141 \\
91 \\
91 \\
.76 \\
19 \\
35 \\
173 \\
261 \\
84\end{array}$ & $\begin{array}{r}121 \\
174 \\
98 \\
86 \\
13 \\
36 \\
142 \\
245 \\
80\end{array}$ & $\begin{array}{r}15 \\
41 \\
9 \\
9 \\
1 \\
3 \\
14 \\
23\end{array}$ & & $\begin{array}{r}98 \\
82 \\
21 \\
35\end{array}$ & $\begin{array}{l}99 \\
6\end{array}$ & $\begin{array}{r}90 \\
482 \\
101 \\
122 \\
10 \\
37 \\
109 \\
109\end{array}$ & $\begin{array}{r}100 \\
89 \\
18 \\
36 \\
161 \\
258 \\
96\end{array}$ & $\begin{array}{r}139 \\
105 \\
109 \\
69 \\
18 \\
40 \\
183 \\
283 \\
82\end{array}$ & $\begin{array}{r}146 \\
106 \\
90 \\
70 \\
15 \\
40 \\
171 \\
300 \\
82\end{array}$ \\
\hline $\begin{array}{l}\mathrm{Q} \ldots . \\
\text { OR... } \\
\text { AB } \\
\text { AN. }\end{array}$ & $\begin{array}{r}.68 \\
2.78 \\
14.13 \\
22.50 \\
.00 \\
25.44 \\
29.90 \\
.00 \\
2.80 \\
1.71 \\
.07\end{array}$ & $\begin{array}{r}3.71 \\
3.49 \\
16.84 \\
28.15 \\
.00 \\
20.58 \\
22.03 \\
.00 \\
2.81 \\
2.11 \\
.28\end{array}$ & $\begin{array}{r}4.03 \\
3.43 \\
24.03 \\
34.90 \\
.00 \\
13.62 \\
15.26 \\
.00 \\
2.45 \\
1.96 \\
.32\end{array}$ & $\begin{array}{r}3.34 \\
3.25 \\
19.89 \\
30.04 \\
.00 \\
18.88 \\
19.83 \\
.00 \\
2.73 \\
1.84 \\
.21\end{array}$ & $\begin{array}{r}3.27 \\
2.07 \\
19.04 \\
29.77 \\
.00 \\
20.49 \\
20.78 \\
.00 \\
2.62 \\
1.71 \\
.25\end{array}$ & & & $\begin{array}{r}2.74 \\
3.60 \\
19.80 \\
27.62 \\
.00 \\
19.99 \\
20.97 \\
.00 \\
2.81 \\
2.15 \\
.32\end{array}$ & $\begin{array}{r}2.86 \\
3.60 \\
17.60 \\
27.58 \\
.00 \\
21.21 \\
21.91 \\
.00 \\
2.80 \\
2.11 \\
.32\end{array}$ & $\begin{array}{r}.00 \\
2.07 \\
13.20 \\
20.04 \\
.00 \\
19.24 \\
40.49 \\
.55 \\
2.71 \\
1.44 \\
.25\end{array}$ & $\begin{array}{r}3.81 \\
3.25 \\
16.75 \\
28.40 \\
.00 \\
20.36 \\
22.19 \\
.00 \\
2.83 \\
2.09 \\
.32\end{array}$ & $\begin{array}{r}3.42 \\
3.43 \\
19.89 \\
27.30 \\
.00 \\
20.30 \\
20.53 \\
.00 \\
2.99 \\
1.90 \\
.25\end{array}$ & $\begin{array}{r}3.80 \\
3.55 \\
18.87 \\
27.16 \\
.00 \\
19.83 \\
21.54 \\
.00 \\
3.06 \\
1.90 \\
.30\end{array}$ \\
\hline
\end{tabular}


Table 1. Major, trace, and CIPW normative compositions of diabase samples from west-central New Jersey and eastern Pennsylvania (see appendix for sample locations) - Continued

[Major elements normalized to 100 percent anhydrous; $\mathrm{Fe}_{2} \mathrm{O}_{9} / \mathrm{FeO}$ ratio set at 0.235 ; Q, quartz; OR, orthoclase; $\mathrm{AB}$, albite; $\mathrm{AN}$, anorthite; $\mathrm{NE}$, nepheline; DI, diopside; HY, hypersthene; OL, olivine; MT, magnetite; IL, ilmenite; AP, apatite]

\begin{tabular}{|c|c|c|c|c|c|c|c|c|c|c|c|c|}
\hline & \multicolumn{12}{|c|}{ Baldpate Mountain } \\
\hline & MS1 & MS2 & MS3 & TMS1 & T1 & T2 & T3 & T4 & T5 & T6 & T7 & T8 \\
\hline 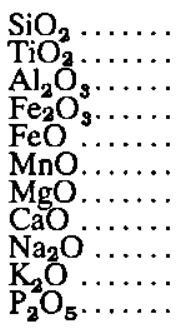 & $\begin{array}{r}61.29 \\
1.63 \\
12.05 \\
2.46 \\
10.46 \\
.18 \\
1.09 \\
4.53 \\
3.57 \\
2.29 \\
.45\end{array}$ & $\begin{array}{r}61.64 \\
1.59 \\
11.85 \\
2.41 \\
10.24 \\
.22 \\
.96 \\
4.80 \\
3.38 \\
2.41 \\
.50\end{array}$ & $\begin{array}{r}61.59 \\
1.51 \\
12.11 \\
2.44 \\
10.38 \\
.22 \\
1.00 \\
4.50 \\
3.34 \\
2.42 \\
.49\end{array}$ & $\begin{array}{r}60.79 \\
1.70 \\
11.75 \\
2.44 \\
10.38 \\
.19 \\
1.23 \\
5.13 \\
3.76 \\
2.14 \\
.49\end{array}$ & $\begin{array}{r}57.61 \\
2.59 \\
11.72 \\
2.81 \\
11.97 \\
.19 \\
1.75 \\
5.51 \\
3.21 \\
2.11 \\
.53\end{array}$ & $\begin{array}{r}52.94 \\
1.33 \\
15.60 \\
2.04 \\
8.66 \\
.19 \\
5.32 \\
10.46 \\
2.48 \\
.80 \\
.18\end{array}$ & $\begin{array}{r}52.93 \\
1.00 \\
15.33 \\
1.93 \\
8.19 \\
.17 \\
6.51 \\
10.93 \\
2.26 \\
.62 \\
.13\end{array}$ & $\begin{array}{r}52.77 \\
1.10 \\
13.67 \\
2.00 \\
8.49 \\
.18 \\
8.20 \\
10.46 \\
2.28 \\
.71 \\
.14\end{array}$ & $\begin{array}{r}53.38 \\
1.15 \\
13.73 \\
1.94 \\
8.25 \\
.19 \\
7.75 \\
10.46 \\
2.33 \\
.69 \\
.13\end{array}$ & $\begin{array}{r}53.27 \\
1.03 \\
15.09 \\
1.73 \\
7.37 \\
.16 \\
7.13 \\
11.20 \\
2.33 \\
.55 \\
.14\end{array}$ & $\begin{array}{r}52.52 \\
.83 \\
17.13 \\
1.61 \\
6.87 \\
.15 \\
6.08 \\
11.18 \\
2.87 \\
.65 \\
.11\end{array}$ & $\begin{array}{r}51.73 \\
3.06 \\
12.57 \\
3.25 \\
13.81 \\
.24 \\
3.51 \\
6.70 \\
3.19 \\
1.72 \\
.22\end{array}$ \\
\hline $\begin{array}{l}\mathrm{Ba} . . \\
\mathrm{Cr} \ldots \\
\mathrm{Cu} . . \\
\mathrm{Ni} . . \\
\mathrm{Rb} . . \\
\mathrm{Sc} . \ldots \\
\mathrm{Sr} \ldots \\
\mathrm{V} \ldots \\
\mathrm{Zr} . .\end{array}$ & $\begin{array}{r}451 \\
9 \\
325 \\
18 \\
66 \\
21 \\
142 \\
23 \\
306\end{array}$ & $\begin{array}{r}478 \\
9 \\
350 \\
18 \\
69 \\
19 \\
142 \\
22 \\
279\end{array}$ & $\begin{array}{r}508 \\
12 \\
258 \\
17 \\
73 \\
20 \\
150 \\
25 \\
296\end{array}$ & $\begin{array}{r}454 \\
9 \\
325 \\
10 \\
70 \\
25 \\
160 \\
38 \\
312\end{array}$ & $\begin{array}{r}450 \\
12 \\
271 \\
14 \\
80 \\
32 \\
165 \\
139 \\
301\end{array}$ & $\begin{array}{r}231 \\
59 \\
163 \\
59 \\
28 \\
36 \\
219 \\
293 \\
124\end{array}$ & $\begin{array}{r}180 \\
74 \\
130 \\
80 \\
25 \\
36 \\
194 \\
283 \\
124\end{array}$ & $\begin{array}{r}192 \\
306 \\
103 \\
101 \\
32 \\
36 \\
171 \\
273 \\
95\end{array}$ & $\begin{array}{r}140 \\
317 \\
142 \\
96 \\
32 \\
36 \\
168 \\
298 \\
110\end{array}$ & $\begin{array}{r}163 \\
276 \\
111 \\
86 \\
24 \\
33 \\
171 \\
261 \\
105\end{array}$ & $\begin{array}{r}160 \\
76 \\
91 \\
66 \\
17 \\
24 \\
224 \\
200 \\
82\end{array}$ & $\begin{array}{r}353 \\
4 \\
221 \\
28 \\
55 \\
38 \\
227 \\
570 \\
203\end{array}$ \\
\hline \multirow[t]{3}{*}{ 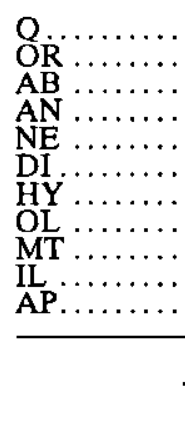 } & $\begin{array}{r}16.99 \\
13.53 \\
30.21 \\
10.09 \\
.00 \\
8.21 \\
13.26 \\
.00 \\
3.57 \\
3.10 \\
1.04\end{array}$ & $\begin{array}{r}18.07 \\
14.24 \\
28.60 \\
10.05 \\
.00 \\
9.15 \\
12.22 \\
.00 \\
3.49 \\
3.02 \\
1.16\end{array}$ & $\begin{array}{r}18.11 \\
14.30 \\
28.26 \\
10.90 \\
.00 \\
7.16 \\
13.72 \\
.00 \\
3.54 \\
2.87 \\
1.14\end{array}$ & $\begin{array}{r}15.53 \\
12.65 \\
31.82 \\
8.86 \\
.00 \\
11.61 \\
11.63 \\
.00 \\
3.54 \\
3.23 \\
1.14\end{array}$ & $\begin{array}{r}13.20 \\
12.47 \\
27.16 \\
11.34 \\
.00 \\
11.47 \\
14.18 \\
.00 \\
4.07 \\
4.92 \\
1.19\end{array}$ & $\begin{array}{r}4.65 \\
4.73 \\
20.99 \\
29.07 \\
.00 \\
17.87 \\
16.79 \\
.00 \\
2.96 \\
2.53 \\
.42\end{array}$ & $\begin{array}{r}4.22 \\
3.66 \\
19.12 \\
29.86 \\
.00 \\
19.28 \\
18.87 \\
.00 \\
2.80 \\
1.90 \\
.30\end{array}$ & $\begin{array}{r}2.49 \\
4.20 \\
19.29 \\
24.97 \\
.00 \\
21.18 \\
22.56 \\
.00 \\
2.90 \\
2.09 \\
.32\end{array}$ & $\begin{array}{r}3.75 \\
4.08 \\
19.72 \\
24.97 \\
.00 \\
21.25 \\
20.94 \\
.00 \\
2.81 \\
2.18 \\
.30\end{array}$ & $\begin{array}{r}4.03 \\
3.25 \\
19.72 \\
29.09 \\
.00 \\
20.81 \\
18.32 \\
.00 \\
2.51 \\
1.96 \\
.32\end{array}$ & $\begin{array}{r}.91 \\
3.84 \\
24.29 \\
31.94 \\
.00 \\
18.63 \\
16.23 \\
.00 \\
2.33 \\
1.58 \\
.25\end{array}$ & $\begin{array}{r}3.04 \\
10.16 \\
26.99 \\
14.90 \\
.00 \\
14.33 \\
19.54 \\
.00 \\
4.71 \\
5.81 \\
.51\end{array}$ \\
\hline & \multicolumn{2}{|c|}{ Baldpate Mountain } & \multicolumn{3}{|c|}{ Rocky Hill } & \multicolumn{4}{|c|}{ Pennington Mountain } & \multicolumn{3}{|c|}{ Belle Mountain } \\
\hline & T9 & T10 & KO6 & $\mathrm{KQ7}$ & KQ8 & PQ2 & PQ3 & PQ4 & PQ6 & WH1 & WH2 & WH3 \\
\hline $\begin{array}{l}\mathrm{SiO}_{2} \ldots \ldots \\
\mathrm{TiO}_{3} \ldots \ldots \ldots \\
\mathrm{Al}_{2} \mathrm{O}_{9} \ldots \ldots \\
\mathrm{Fe}_{2} \mathrm{O}_{3} \ldots \ldots \\
\mathrm{FeO} \\
\mathrm{MnO} \ldots \ldots \\
\mathrm{MgO} \ldots \ldots \\
\mathrm{CaO} \ldots \ldots \\
\mathrm{Na}_{2} \mathrm{O} \ldots \ldots \\
\mathrm{K}_{2} \mathrm{O} \ldots \ldots \\
\mathrm{P}_{2} \mathrm{O}_{5} \ldots \ldots \\
\ldots\end{array}$ & $\begin{array}{r}52.77 \\
1.10 \\
16.09 \\
1.84 \\
7.84 \\
.16 \\
5.72 \\
9.25 \\
2.83 \\
2.25 \\
.15\end{array}$ & $\begin{array}{r}52.95 \\
1.12 \\
16.21 \\
1.92 \\
8.16 \\
.18 \\
5.40 \\
10.32 \\
2.89 \\
.71 \\
.14\end{array}$ & $\begin{array}{r}53.08 \\
1.06 \\
17.01 \\
1.85 \\
7.86 \\
.16 \\
5.12 \\
10.37 \\
2.65 \\
.72 \\
.12\end{array}$ & $\begin{array}{r}52.90 \\
.97 \\
15.82 \\
1.88 \\
8.01 \\
.17 \\
6.54 \\
10.43 \\
2.33 \\
.83 \\
.12\end{array}$ & $\begin{array}{r}53.43 \\
1.09 \\
16.70 \\
1.82 \\
7.75 \\
.15 \\
5.29 \\
10.37 \\
2.58 \\
.70 \\
.12\end{array}$ & $\begin{array}{r}53.89 \\
1.84 \\
14.55 \\
2.50 \\
10.64 \\
.18 \\
3.56 \\
8.51 \\
2.84 \\
1.28 \\
.21\end{array}$ & $\begin{array}{r}53.76 \\
1.65 \\
15.73 \\
2.25 \\
9.59 \\
.18 \\
3.67 \\
9.13 \\
2.88 \\
.96 \\
.20\end{array}$ & $\begin{array}{r}61.13 \\
1.52 \\
12.11 \\
2.47 \\
10.53 \\
.26 \\
1.05 \\
4.74 \\
3.23 \\
2.49 \\
.47\end{array}$ & $\begin{array}{r}54.86 \\
2.40 \\
12.10 \\
3.13 \\
13.33 \\
.27 \\
2.04 \\
5.68 \\
3.77 \\
1.87 \\
.55\end{array}$ & $\begin{array}{r}52.99 \\
1.37 \\
16.40 \\
2.13 \\
9.08 \\
.17 \\
4.07 \\
8.37 \\
3.57 \\
1.74 \\
.11\end{array}$ & $\begin{array}{r}53.64 \\
1.12 \\
16.85 \\
1.82 \\
7.73 \\
.16 \\
5.19 \\
9.92 \\
2.86 \\
.60 \\
.11\end{array}$ & $\begin{array}{r}52.90 \\
1.30 \\
16.32 \\
1.98 \\
8.43 \\
.19 \\
5.63 \\
7.33 \\
4.46 \\
1.33 \\
.13\end{array}$ \\
\hline 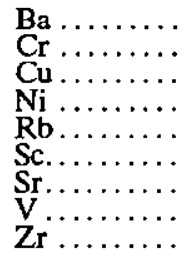 & $\begin{array}{r}248 \\
44 \\
134 \\
64 \\
99 \\
32 \\
316 \\
269 \\
108\end{array}$ & $\begin{array}{r}142 \\
26 \\
123 \\
61 \\
30 \\
33 \\
205 \\
314 \\
107\end{array}$ & $\begin{array}{r}169 \\
43 \\
103 \\
57 \\
20 \\
31 \\
192 \\
233 \\
89\end{array}$ & $\begin{array}{r}164 \\
87 \\
91 \\
71 \\
27 \\
34 \\
187 \\
224 \\
83\end{array}$ & $\begin{array}{r}175 \\
48 \\
99 \\
57 \\
20 \\
31 \\
191 \\
231 \\
104\end{array}$ & $\begin{array}{r}280 \\
22 \\
200 \\
39 \\
41 \\
34 \\
195 \\
331 \\
161\end{array}$ & $\begin{array}{r}236 \\
22 \\
195 \\
43 \\
25 \\
33 \\
198 \\
295 \\
141\end{array}$ & $\begin{array}{r}520 \\
24 \\
178 \\
19 \\
79 \\
21 \\
147 \\
29 \\
323\end{array}$ & $\begin{array}{r}440 \\
20 \\
210 \\
21 \\
54 \\
30 \\
173 \\
68 \\
208\end{array}$ & $\begin{array}{r}281 \\
27 \\
168 \\
45 \\
53 \\
31 \\
225 \\
271 \\
109\end{array}$ & $\begin{array}{r}174 \\
62 \\
117 \\
64 \\
18 \\
35 \\
221 \\
257 \\
115\end{array}$ & $\begin{array}{r}303 \\
94 \\
119 \\
66 \\
36 \\
34 \\
204 \\
266 \\
108\end{array}$ \\
\hline $\begin{array}{l}\text { Q... } \\
\text { OR: } \\
\text { AB } \\
\text { AN: } \\
\text { NE: } \\
\text { DI. } \\
\text { HY. } \\
\text { OL : } \\
\text { MT: } \\
\text { IL. } \\
\text { AP.. }\end{array}$ & $\begin{array}{r}.00 \\
13.30 \\
23.95 \\
24.56 \\
.00 \\
16.72 \\
13.63 \\
2.75 \\
2.67 \\
2.09 \\
.35\end{array}$ & $\begin{array}{r}2.80 \\
4.20 \\
24.45 \\
29.16 \\
.00 \\
17.40 \\
16.75 \\
.00 \\
2.78 \\
2.13 \\
.32\end{array}$ & $\begin{array}{r}4.12 \\
4.26 \\
22.42 \\
32.39 \\
.00 \\
15.06 \\
16.77 \\
.00 \\
2.68 \\
2.01 \\
.28\end{array}$ & $\begin{array}{r}3.48 \\
4.91 \\
19.72 \\
30.26 \\
.00 \\
16.95 \\
19.85 \\
.00 \\
2.73 \\
1.84 \\
.28\end{array}$ & $\begin{array}{r}4.92 \\
4.14 \\
21.83 \\
31.92 \\
.00 \\
15.42 \\
16.78 \\
.00 \\
2.64 \\
2.07 \\
.28\end{array}$ & $\begin{array}{r}6.61 \\
7.56 \\
24.03 \\
23.17 \\
.00 \\
14.88 \\
16.14 \\
.00 \\
3.62 \\
3.49 \\
.49\end{array}$ & $\begin{array}{r}6.41 \\
5.67 \\
24.37 \\
27.16 \\
.00 \\
14.10 \\
15.42 \\
.00 \\
3.26 \\
3.13 \\
.46\end{array}$ & $\begin{array}{r}17.46 \\
14.72 \\
27.33 \\
11.19 \\
.00 \\
8.06 \\
13.69 \\
.00 \\
3.58 \\
2.89 \\
1.09\end{array}$ & $\begin{array}{r}6.75 \\
11.05 \\
31.90 \\
10.57 \\
.00 \\
12.08 \\
17.29 \\
.00 \\
4.54 \\
4.56 \\
1.27\end{array}$ & $\begin{array}{r}.00 \\
10.28 \\
30.21 \\
23.59 \\
.00 \\
14.37 \\
14.71 \\
.90 \\
3.09 \\
2.60 \\
.25\end{array}$ & $\begin{array}{r}4.65 \\
3.55 \\
24.20 \\
31.37 \\
.00 \\
14.10 \\
17.11 \\
.00 \\
2.64 \\
2.13 \\
.25\end{array}$ & $\begin{array}{r}.00 \\
7.86 \\
37.74 \\
20.58 \\
.00 \\
12.29 \\
4.50 \\
11.38 \\
2.87 \\
2.47 \\
.30\end{array}$ \\
\hline
\end{tabular}



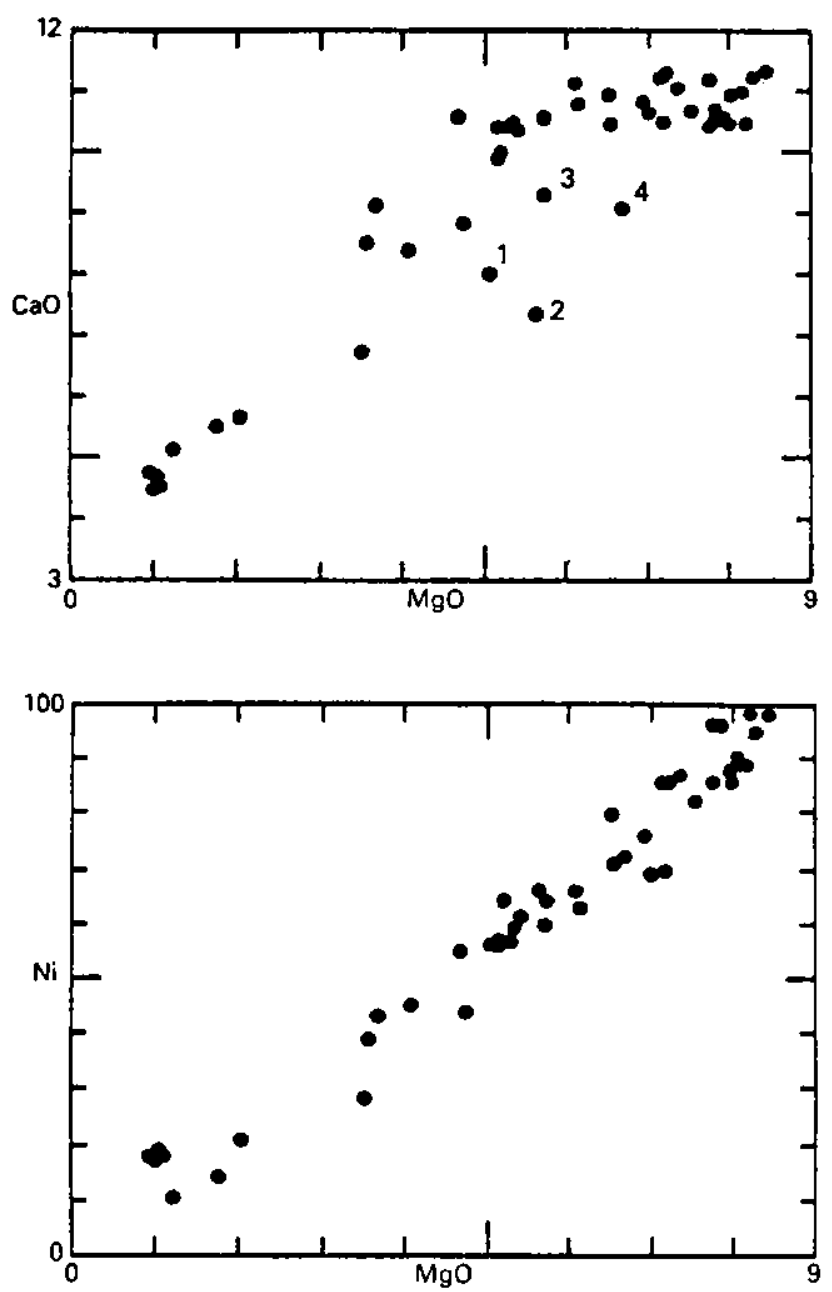

Figure 2. Variation trends of selected oxides and traceelements versus $\mathrm{MgO}$ variation trends for Mesozoic diabases of west-central New Jersey and eastern Pennsylvania. Oxide concentrations are shown in weight percent (wt \%) and trace elements in parts per million (ppm). Samples having $\mathrm{MgO}$

In contrast to the behavior for $\mathrm{CaO}$, all alkali elements and $\mathrm{Zr}$ act incompatibly throughout the entire range of $\mathrm{MgO}$ values shown. This behavior is exemplified by the variation trend for total alkali $\left(\mathrm{Na}_{2} \mathrm{O}+\mathrm{K}_{2} \mathrm{O}\right.$; Alk in fig. 2). Not coincidentally, all of the samples exhibiting a relative depletion in $\mathrm{CaO}$ are correspondingly enriched in alkalis (although not $\mathrm{Zr}$ ). These relations have been shown by Husch and Schwimmer (1985) and Benimoff and Sclar (1984) to result from the contamination of some samples by local country rocks with compositions best represented by the Triassic Lockatong Formation (fig. 3). As detailed by Benimoff and Sclar (1984), contamination was apparently controlled by the selective diffusion of alkalis from the contaminant into the magma and of $\mathrm{Ca}$ from the magma into an anatectic melt derived from the contaminating material. Thus, the presence of contamination is manifested most obviously by samples that either exhibit anomalously high values for the alkalis
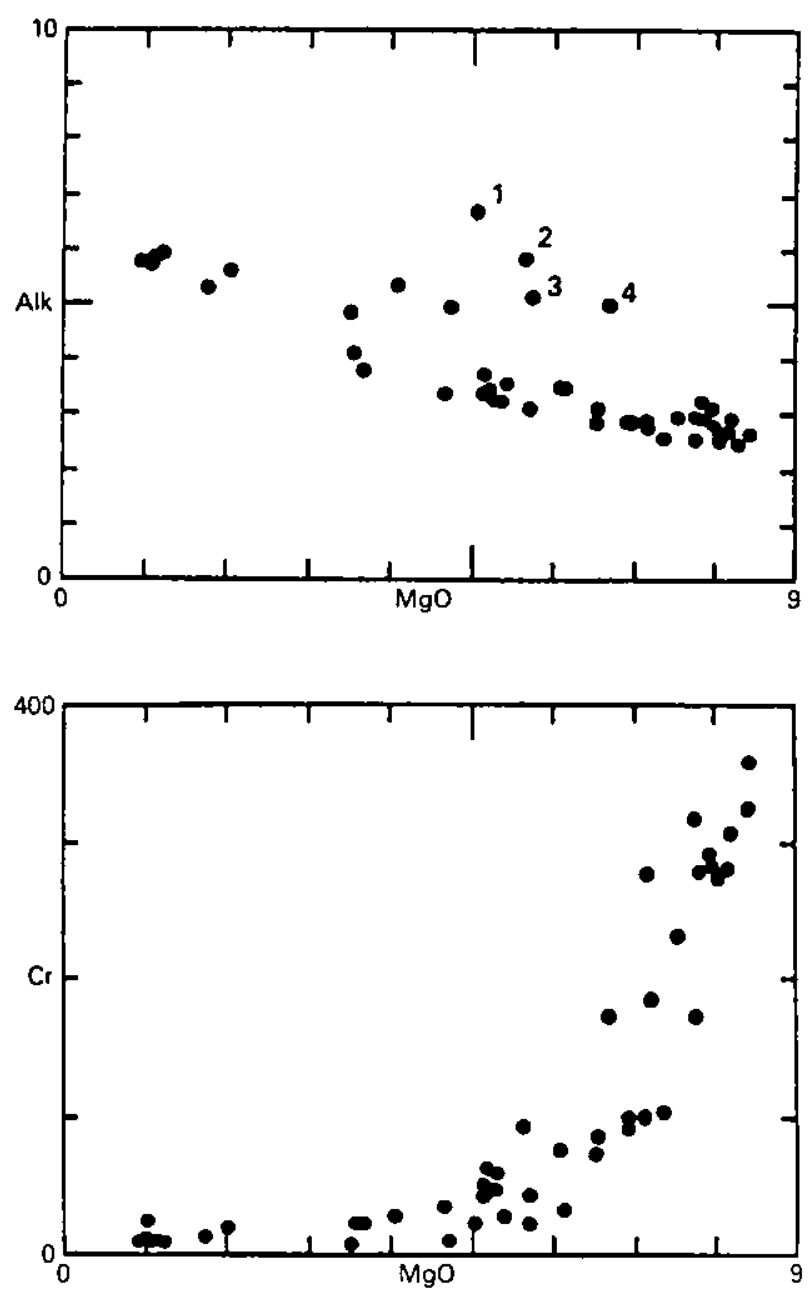

contents greater than 9 weight percent and all samples from the Quarry dike are omitted. Alk is total alkali $\left(\mathrm{Na}_{2} \mathrm{O}+\mathrm{K}_{2} \mathrm{O}\right)$. Contaminated diabase samples labeled in trend of $\mathrm{CaO}$ versus $\mathrm{MgO}$ and Alk versus MgO are (1) ELS24, (2) WH3, (3) T9, and (4) ELS6.

and anomalously low values for $\mathrm{CaO}$, at a given value for $\mathrm{MgO}$ (fig. 2), or that plot to the right of the main diabase variation trend on a mafic index versus felsic index diagram (fig. 3). The Quarry dike trend in figure 3 apparently is largely controlled by this contamination mechanism (Husch and Schwimmer, 1985). None of the diabase samples thought to be contaminated on the basis of their geochemistry are located at a contact with Triassic sedimentary rocks. This is comparable to the situation for the Quarry dike where contamination levels increase inward from the margin (Husch and Schwimmer, 1985). Thus the source of contamination is either at depth, as is apparently the case for the Quarry dike (Husch and Schwimmer, 1985), or within the individual intrusions themselves, as documented by Benimoff and Sclar (1984) in the Palisades sill.

Variation trends for $\mathrm{Ni}$ and $\mathrm{Cr}$ document their compatible behavior (fig. 2). However, $\mathrm{Cr}$ concentrations 

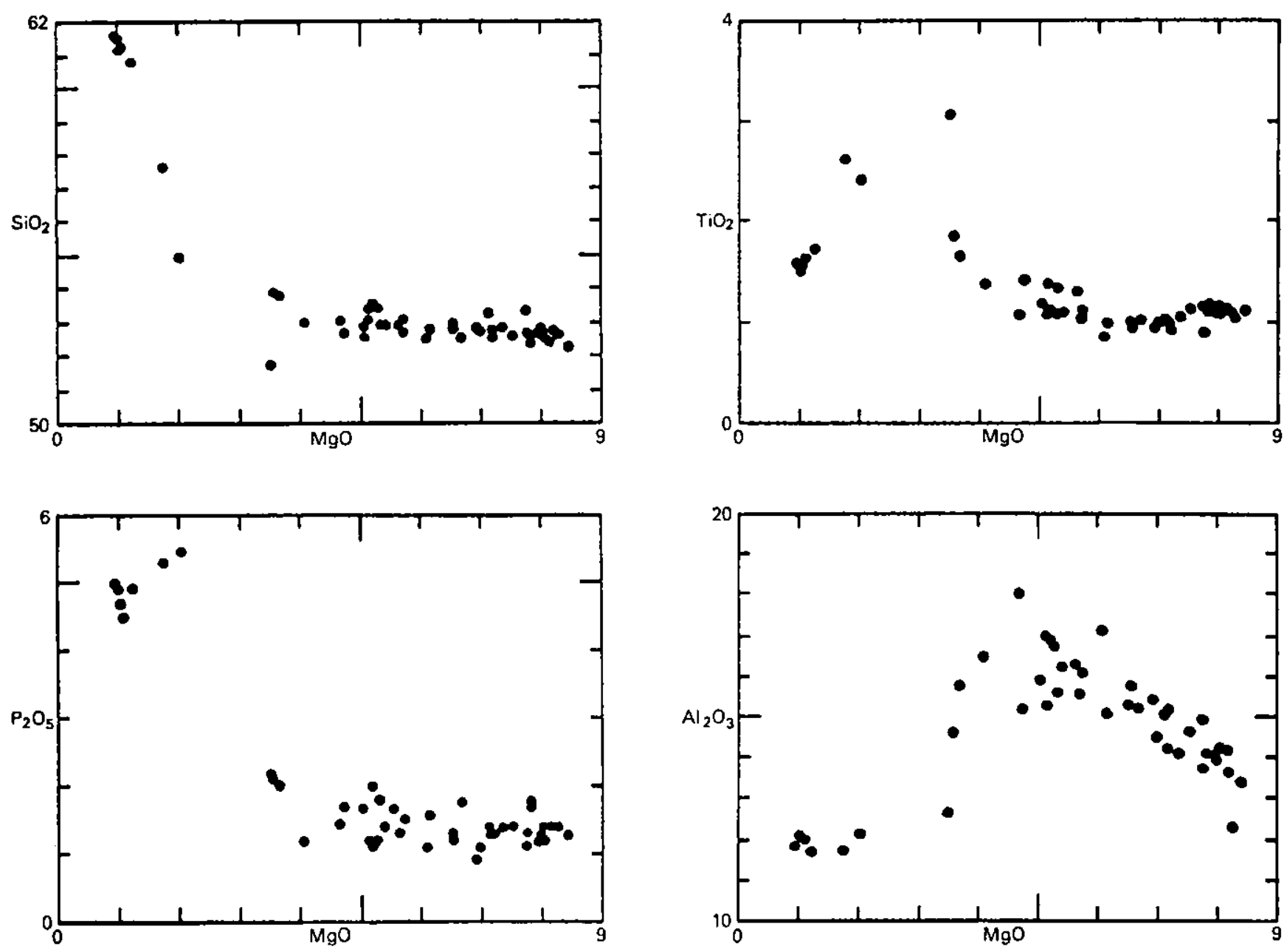

Figure 2. Continued.

fall much more abruptly than $\mathrm{Ni}$ with decreasing $\mathrm{MgO}$ content. In fact, the variation trend for $\mathrm{Ni}$ is quite linear. This led Philpotts and Burkett (1985) to suggest that the entire range of rock compositions in the region was controlled almost entirely by orthopyroxene (of constant composition), either through its addition or removal. However, the obvious nonlinearity of the $\mathrm{Cr}$ variation trend over the entire $\mathrm{MgO}$ range is not compatible with this idea.

\section{DISCUSSION}

Extensive olivine fractionation is not indicated by the variation trends presented in figure 2, particularly those for $\mathrm{SiO}_{2}$ and $\mathrm{Ni}$. If olivine fractionated early in the crystallization sequence, residual liquid concentrations for $\mathrm{SiO}_{2}$ would have increased while those for $\mathrm{Ni}$ would have decreased much more dramatically than observed.
The near absence of modal olivine in diabase (even that with high magnesium) from the region is consistent with this conclusion.

Fractionation of high- and low-calcium pyroxenes is consistent with the observed petrography of the analyzed samples and with the more highly compatible behavior of $\mathrm{Cr}$ as compared to $\mathrm{Ni}$; $\mathrm{Cr}$ pyroxene/basalt distribution coefficients are two to four times higher than those for Ni (Henderson, 1982). Furthermore, the slight early depletion of $\mathrm{CaO}$ and $\mathrm{Sc}$ and the lack of early $\mathrm{SiO}_{2}$ enrichment agree with the early crystallization of both pyroxene phases. A $\mathrm{CaO}-\mathrm{MgO}$ two-oxide mixing diagram (fig. 4) indicates that the early variation trend could be produced by removing three times as much clinopyroxene as orthopyroxene from chill margin compositions, representing initial HTQ basalt compositions of eastern North America.

Figure 4 also shows that high magnesium ( $>9$ percent $\mathrm{MgO}$ ) samples can be produced by the addition 
Table 2. Mesozoic diabase chill and basalt compositions

[ - , not determined; major elements normalized to 100 percent anhydrous]

\begin{tabular}{|c|c|c|c|c|c|c|c|c|c|c|}
\hline & 1 & 2 & 3 & 4 & 5 & 6 & 7 & 8 & 9 & 10 \\
\hline 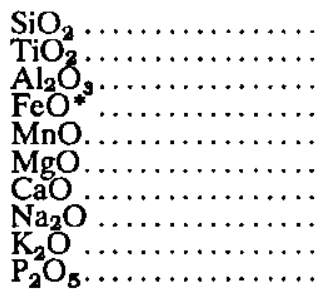 & $\begin{array}{r}52.88 \\
1.13 \\
14.26 \\
10.13 \\
.16 \\
7.91 \\
10.26 \\
2.01 \\
1.12 \\
.13\end{array}$ & $\begin{array}{r}52.52 \\
1.11 \\
14.22 \\
9.98 \\
.16 \\
8.16 \\
11.02 \\
2.08 \\
.61 \\
.14\end{array}$ & $\begin{array}{r}52.73 \\
1.11 \\
14.26 \\
10.01 \\
.16 \\
8.06 \\
10.95 \\
1.99 \\
.59 \\
.12\end{array}$ & $\begin{array}{r}52.57 \\
1.15 \\
14.16 \\
10.15 \\
.17 \\
7.82 \\
10.66 \\
2.29 \\
.84 \\
.18\end{array}$ & $\begin{array}{r}53.18 \\
1.13 \\
13.73 \\
10.16 \\
.19 \\
7.99 \\
10.48 \\
2.30 \\
.70 \\
.14\end{array}$ & $\begin{array}{r}52.55 \\
1.22 \\
14.64 \\
10.40 \\
.16 \\
7.67 \\
10.44 \\
2.06 \\
.89 \\
.14\end{array}$ & $\begin{array}{r}51.61 \\
1.09 \\
14.34 \\
10.20 \\
.15 \\
8.32 \\
11.41 \\
2.15 \\
.59 \\
.13\end{array}$ & $\begin{array}{r}51.86 \\
1.07 \\
14.27 \\
10.86 \\
.16 \\
7.98 \\
11.24 \\
2.06 \\
.50 \\
.12\end{array}$ & $\begin{array}{r}52.69 \\
1.11 \\
14.57 \\
9.97 \\
.20 \\
7.83 \\
10.90 \\
1.99 \\
.61 \\
.12\end{array}$ & $\begin{array}{r}52.65 \\
1.13 \\
14.37 \\
10.58 \\
.19 \\
7.49 \\
10.78 \\
2.15 \\
.67 \\
-\end{array}$ \\
\hline 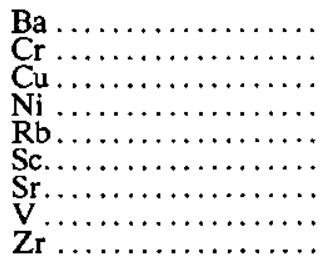 & $\begin{array}{r}156 \\
298 \\
99 \\
92 \\
37 \\
36 \\
189 \\
265 \\
101\end{array}$ & $\begin{array}{r}147 \\
281 \\
105 \\
89 \\
16 \\
36 \\
169 \\
264 \\
94\end{array}$ & $\begin{array}{r}163 \\
274 \\
104 \\
90 \\
19 \\
36 \\
162 \\
260 \\
93\end{array}$ & $\begin{array}{r}149 \\
279 \\
113 \\
96 \\
33 \\
38 \\
225 \\
255 \\
102\end{array}$ & $\begin{array}{r}166 \\
311 \\
122 \\
98 \\
32 \\
36 \\
170 \\
285 \\
102\end{array}$ & $\begin{array}{r}195 \\
315 \\
110 \\
95 \\
37 \\
175 \\
235 \\
120\end{array}$ & $\begin{array}{r}182 \\
260 \\
127 \\
61 \\
37 \\
183 \\
272 \\
116\end{array}$ & $\begin{array}{r}174 \\
322 \\
123 \\
72 \\
22 \\
186 \\
270 \\
87\end{array}$ & $\begin{array}{r}160 \\
302 \\
121 \\
89 \\
25 \\
187 \\
310 \\
115\end{array}$ & $\begin{array}{r}2 \overline{77} \\
111 \\
81 \\
21 \\
\frac{186}{92}\end{array}$ \\
\hline
\end{tabular}

1 Quarry dike chill (average of samples 2, 3, and 14 of Husch and Schwimmer (1985)).

2 Point Pleasant (Byram) diabase chill (sample PP2 of Husch and others (1984)); reanalyzed for $\mathrm{Cr}, \mathrm{Cu}$, and $\mathrm{Ni}$.

3 Lambertville sill chill-New Jersey side (sample LS3 of Husch and others (1984)); reanalyzed for $\mathrm{Cr}, \mathrm{Cu}$, and Ni.

4 Lambertville sill chill-Pennsylvania side (average of samples ELS5 and ELS25 of Eliason (1986)).

5 Baldpate Mountain chill (average for samples 4 and 5 of Trione (1985)).

6 Palisades sill chill (sample W-889LC-60 of Walker (1969)).

7 Average Orange Mountain Basalt (Puffer and Lechler, 1980).

8 Average Talcott Basalt (Puffer and others, 1981).

9 Average York Haven basalt (Smith and others, 1975).

10 Average HTQ diabase chill and basalt (Weigand and Ragland, 1970).

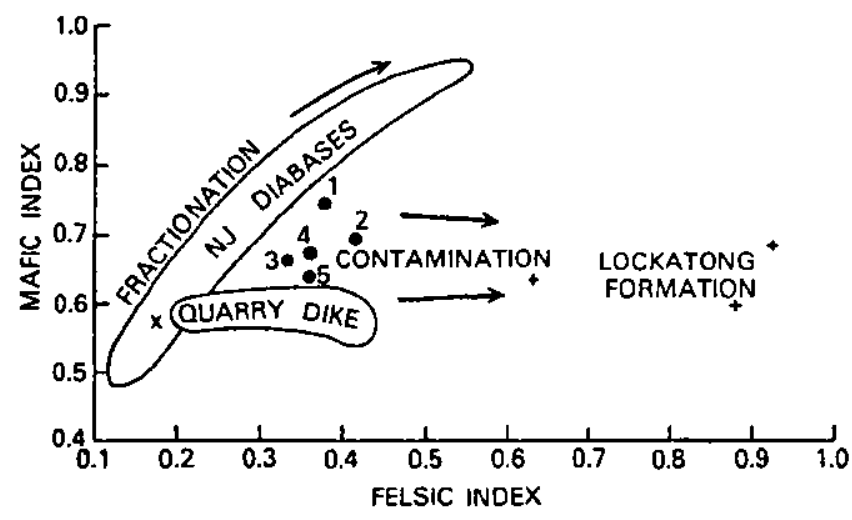

Figure 3. Mafic index $\left(\mathrm{Fe}_{2} \mathrm{O}_{3}{ }^{\star} / \mathrm{Fe}_{2} \mathrm{O}_{3}{ }^{*}+\mathrm{MgO}\right)$ versus felsic index $\left(\mathrm{Na}_{2} \mathrm{O}+\mathrm{K}_{2} \mathrm{O} / \mathrm{Na}_{2} \mathrm{O}+\mathrm{K}_{2} \mathrm{O}+\mathrm{CaO}\right)$ variation trends. Quarry dike and New Jersey diabase fields from Husch and Schwimmer (1985). Lockatong Formation compositions from Sturgis (1983) and Benimoff and Sclar (1984; sample XB). Contaminated diabase samples shown by closed circles are (1) WH1, (2) WH3, (3) sample D1 of Benimoff and Sclar (1984), (4) ELS24, and (5) T9. Average composition of diabase chill margins shown by $X$.

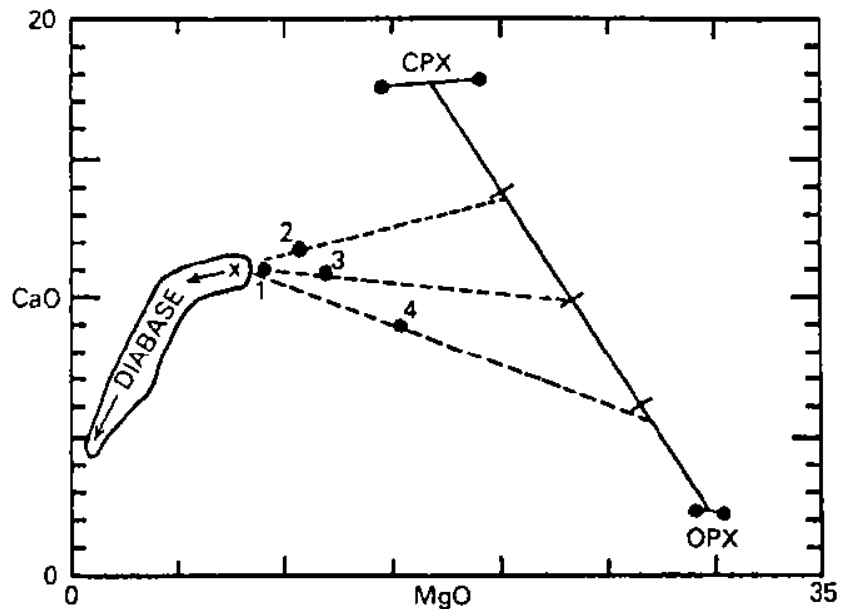

Figure 4. $\mathrm{CaO}$ versus $\mathrm{MgO}$ (wt \%) mixing diagram. Diabase field taken from $\mathrm{CaO}$ versus $\mathrm{MgO}$ trend in figure 2. Samples (labeled) with greater than 9 weight percent $\mathrm{MgO}$ are shown by filled circles. Three addition/removal lines with one end-member being the average chill margin composition $(x)$ from the region and the other end-member being a variable mixture of clinopyroxene (CPX) (compositions from Walker (1969) and Philpotts and Reichenbach (1985)) and orthopyroxene (OPX) (compositions from Smith (1973) and Philpotts and Reichenbach (1985)) are shown by the dashed lines. Four high-magnesium samples discussed in text are (1) LSGRAB, (2) ELS11, (3) LS2, and (4) PP5. Arrows in diabase field show direction of variation due to crystal fractionation. 
of variable amounts of clinopyroxene and orthopyroxene to chill margin composition. For example, mixing lines suggest that in one instance (sample PP5) accumulation is dominated by orthopyroxene. while in another (sample ELS11) it is dominated by clinopyroxene; other samples (LSGRAB and LS2) can be produced by accumulating roughly equal proportions of the two pyroxenes. Modal determinations are in agreement with these results. Whether these accumulations took place in situ, at depth, or in a combination of the two circumstances has not been determined. However, the accumulation of highpressure orthopyroxenes has been described for the Talcott Basalt by Philpotts and Reichenbach (1985), and sample PP5 is texturally very similar; large phenocrysts of euhedral orthopyroxene rimmed by clinopyroxene in a fine-grained groundmass are seen in both occurrences. On the other hand, in-situ accumulation for ELS11 is more likely, considering that its composition in figure 4 plots directly along a mafic extension of the early variation trend. In addition, it is texturally distinct from PP5 and lacks large concentrations of phenocrystic orthopyroxene.

The change in $\mathrm{Al}_{2} \mathrm{O}_{3}$ and $\mathrm{CaO}$ trends seen in figure 2 at an $\mathrm{MgO}$ concentration of approximately 5 weight percent is compatible with the onset of extensive plagioclase crystallization and fractionation, along with continuing pyroxene fractionation. This would explain the rapid depletions of $\mathrm{Al}_{2} \mathrm{O}_{3}, \mathrm{CaO}$, and $\mathrm{Sr}$ in rocks with lower $\mathrm{MgO}$ contents. Preliminary mass balance calculations, based on mineral compositions from Walker (1969), Smith (1973), and Philpotts and Reichenbach (1985), suggest that plagioclase fractionation began after approximately 20 percent pyroxene crystallization. Pyroxene and plagioclase fractionation would be followed at still lower $\mathrm{MgO}$ values by the addition of extensive $\mathrm{Fe}-\mathrm{Ti}$ oxide and finally apatite fractionation. The former accounts for the depletion of $\mathrm{FeO}^{*}, \mathrm{TiO}_{2}, \mathrm{Sc}$, and $\mathrm{V}$ in the late-stage granophyres, while the latter accounts for decreasing $\mathrm{P}_{2} \mathrm{O}_{5}$ values in the same rocks.

Finally, the extremely restricted compositional variability of analyzed chill margin samples (table 2) suggests it is unlikely that more than one parental magma type was generated in the region. Also, no evidence from the chill margin compositions presently available supports the suggestion of Philpotts and Burkett (1985) that two distinct, though similar, HTQ magmas were intruded. Similarly, the conclusion of Husch and others (1984) that extensive deep crustal fractionation of ponded high-titanium type basalt produced a variety of derived high-iron type parental magmas also is not supported. Future detailed sampling and analysis (including isotopic) of chill zones may resolve thesc issues.

\section{ACKNOWLEDGMENTS}

I would like to thank A.J. Froelich, R.P. Koeppen, and Klaus Schulz for their critical reviews of the original manuscript. I also wish to thank Geraldine Hutner for her editorial advice. M.J. Carr was most helpful during the whole-rock analysis of samples. His patience and expertise are most gratefully appreciated. All financial and computer support was provided by Rider College.

\section{REFERENCES CITED}

Benimoff, A.I., and Sclar, C.B., 1984, Coexisting silicic and mafic melts resulting from marginal fusion of a xenolith of Lockatong Argillite in the Palisades sill, Graniteville, Staten Island, New York: American Mineralogist, v. 69, p. 1005-1014.

Dallmeyer, R.D., 1975, The Palisades Sill: A Jurassic intrusion? Evidence from 40Ar/39Ar incremental release ages: Geology, v. 3, p. 243-245.

Eliason, W.M., 1986, Geochemical variations through the Lambertville Sill: unpublished B.S. thesis, Rider College, Lawrenceville, New Jersey, 36 p.

Feigenson, M.D., and Carr, M.J., 1985, Determination of major, trace, and rare-earth elements in rocks by DCPAES: Chemical Geology, v. 51, p. 19-27.

Henderson, P., 1982, Inorganic Geochemistry: Pergamon Press, Oxford, $353 \mathrm{p}$.

Husch, J.M., and Schwimmer, R., 1985, Major and trace element concentrations across a Mesozoic basaltic dike, New Hope, Pennsylvania: Northeastern Geology, v. 7, p. 144-160.

Husch, J.M., Sturgis, D.S., and Bambrick, T.C., 1984, Mesozoic diabases from west-central New Jersey: Major and trace element geochemistry of whole-rock samples: Northeastern Geology, v. 6, p. 51-63.

Philpotts, A.R., and Burkett, D.H., 1985, Mesozoic diabases from west-central New Jersey: A discussion: Northeastern Geology, v. 7, p. 47-49.

Philpotts, A.R., and Reichenbach, I., 1985, Differentiation of Mesozoic basalts of the Hartford Basin, Connecticut: Geological Society of America Bulletin, v. 96, p. 1131-1139.

Puffer, J.H., and Lechler, P., 1979, The geochemistry of Cushetunk Mountain, New Jersey: Bulletin of the New Jersey Academy of Science, v. 24, p. 1-5.

Puffer, J.H., Hurtubise, D.O., Geiger, F.J., and Lechler, P., 1981, Chemical composition and stratigraphic correlation of Mesozoic basalt units of the Newark Basin, New Jersey, and the Hartford Basin, Connecticut: Geological Society of America Bulletin, v. 92, p. 515-553.

Seidemann, D.E., Masterson, W.D., Dowling, M.P., and Turekian, K.K., 1984, K-Ar dates and 40Ar/39Ar age spectra for Mesozoic basalt flows of the Hartford Basin, Connecticut, and the Newark Basin, New Jersey: Geological Society of America Bulletin, v. 95, p. 594-598.

Smith, R.C., II, 1973, Geochemistry of Triassic diabase from southeastern Pennsylvania: unpublished Ph.D. thesis, 
Pennsylvania State University, University Park, Pennsylvania, 262 p.

Smith, R.C., II, Rose, A.N., and Lanning, R.M., 1975, Geology and geochemistry of Triassic diabase in Pennsylvania: Geological Society of America Bulletin, v. 86, p. 943-945.

Sturgis, D.S., 1983, The geochemistry of four Mesozoic diabase bodies in west-central New Jersey: Southern bodies: unpublished B.S. thesis, Rider College, Lawrenceville, New Jersey, $50 \mathrm{p}$.

Sutter, J.F., and Smith, T.E., 1979, 40Ar/39Ar ages of diabase intrusions from Newark trend basins in Connecticut and Maryland: Initiation of central Atlantic rifting: American Journal of Science, v. 279, p. 808-831.

Trione, C.W., 1985, The geochemistry of the Mesozoic Baldpate Mountain diabase, Lambertville, New Jersey: unpublished B.S. thesis, Rider College, Lawrenceville, New Jersey, 42 p.

Walker, K.R., 1969, The Palisades Sill, New Jersey: A reinvestigation: Geological Society of America Special Paper 111, $178 \mathrm{p}$.

Weigand, P.W., and Ragland, P.C., 1970, Geochemistry of Mesozoic dolerite dikes from eastern North America: Contributions to Mineralogy and Petrology, v. 29, p. 194-214.

\section{APPENDIX: SAMPLE LOCATIONS}

All Point Pleasant diabase samples are from a roadcut located along the east side of New Jersey Route 29 approximately 4 miles northwest of Stockton, New Jersey. Samples PP1 and PP2 are fine-grained chills collected within 5 feet of a (faulted?) contact with Triassic Lockatong Formation. Sample PP5 was taken from the top of the roadcut, 70 feet above road level and is porphyritic in texture. Sample PP6 is slightly coarser grained and was collected at the southern end of the roadcut, 6 feet above road level. It is located stratigraphically below PP5 but above PP1 and PP2.

Both Stockton diabase samples (LQ1 and LQ4) are from the same level along the south face of the Lambertville quarry located east of Route 29, 1 mile south of Stockton. All Pennington Mountain diabase samples are from the Pennington quarry located just west of Route 31,2 miles north of Pennington, New Jersey. Samples PQ2 and PQ3 were collected from the south (stratigraphically lower) wall of the west pit and samples PQ4 and PQ6 from the north (stratigraphically higher) wall. All Rocky Hill diabase samples are from the Kingston quarry located along Crusher Road 1 mile north of Kingston, New Jersey. The diabase samples KQ6, KQ7, and KQ8 were collected from the north and eastem walls of the east pit at approximately the same stratigraphic position (126-foot bench level). Two thermally metamorphosed Lockatong Formation samples (KQ2 and KQ10) also were collected from the quarry. Belle Mountain diabase samples were collected from the small abandoned Mercer County Work House quarry located east of Route 29, 2 miles south of Lambertville, New Jersey. Samples WH1, WH2, WH3 are from the north, northeast, and south walls of the quarry, respectively. Samples from the Stockton,
Pennington Mountain, Rocky Hill, and Belle Mountain sheets are coarse grained and from interior portions of their respective diabase intrusions.

Four Belle Mountain diabase samples (TMS1, MS1, MS2, and MS3) are from the southeast wall of the Moore's Station quarry located east of Route 29 approximately 3 miles south of Lambertville. The stratigraphic position for these four granophyric samples is approximately 100 feet beneath the upper contact of the intrusion. Ten other samples were collected from various natural exposures. Samples T4 and T5 were collected from the lower (southern) chill zone of the intrusion within 15 feet of the contact with the Triassic Passaic Formation. Samples T6, T3, and T7 are from the lower portions of the intrusion, located approximately 150,200 , and 300 feet, respectively, above its base. Samples T2, T9, and T10 are all from approximately 400 feet above the base. Samples T8 and T1 are from approximately 450 and 500 feet, respectively, above the base. All samples except T4 and T5 are coarse grained. Sample $\mathrm{T} 1$ is granophyric and from a slightly lower stratigraphic level than Moore's Station quarry samples.

Samples from the Lambertville sill were collected along two parallel traverses located on opposite sides of the Delaware River. However, only the western (Pennsylvania) traverse has reasonable stratigraphic control with sample positions measured relative to the (exposed) upper contact along Pennsylvania Route 32 south of New Hope, Pennsylvania. Sample ELS25 is from a small sill-like intrusion separated from the main Lambertville diabase by a layer of Triassic sedimentary rock (upper Lockatong Formation or lower Passaic Formation) approximately 20 feet thick. Sample ELS5 is from the chill zone of the Lambertville sill, proper. Samples ELS24, ELS6, and ELS23 are coarser grained and were collected from 50,75, and 100 feet beneath the upper contact, respectively. Samples ELS21, ELS19, ELS18, ELS15, ELS14, and ELS13 are all coarse-grained diabase and were collected from approximately $225,425,500,575,800$, and 875 feet beneath the upper contact, respectively. It is estimated that ELS13 is located approximately 75 to 100 feet above the base of the intrusion. Two additional samples, ELS10 and ELS11, were collected from float at the southern end of the traverse. However, their stratigraphic positions are uncertain. Texturally, ELS10 is medium grained and may be gradational into the lower chill zone. E1S11 exhibits a porphyritic/seriate texture with phenocrysts of orthopyroxene and augite. Samples LS2, LS3, LS8, LS9, and LSGRAB were collected along a traverse run east of New Jersey Route 29,3/4 to 1/2 mile south of Lambertville. Sample LS11 was collected from a roadcut on the east side of Route 29 at the Lambertville town line. Sample LS2 has a relatively fine-grained, seriate texture and appears to be from within 50 feet of the lower contact. Samples LS3 and LSGRAB were collected from low outcrops approximately 150 to 200 feet up section. Both are similar in texture to ELS11; LS2 also contains orthopyroxenes similar to PP5. Samples LS8 and LS9 are coarse grained and were collected from a small abandoned quarry approximately 400 to 500 feet above the base of intrusion. Finally, sample LS11 is medium grained and was collected from a position approximately 100 feet beneath the upper contact. 


\title{
AN OVERVIEW OF EARLY MESOZOIC INTRUSIVE ROCKS IN THE CULPEPER BASIN, VIRGINIA AND MARYLAND
}

\author{
Albert J. Froelich and David Gottfried
}

Abstract

Jurassic diabase sheets and dikes have extensively intruded Triassic sedimentary rocks in the Culpeper basin of northern Virginia and southern Maryland. The diabase is part of the eastern North America tholeiitic suite of Weigand and Ragland (1970). Intrusive igneous rocks comprise about one-fifth of the preserved basin fill, with an estimated volume probably in excess of $40 \mathrm{mi}^{3}\left(170 \mathrm{~km}^{3}\right)$.

$\mathrm{MgO}$ versus $\mathrm{TiO}_{2}$ covariation of chill-margin samples, perspectives based on field relations, and petrographic data have enabled subdivision of all the sheets and most of the dikes into two principal types of quartz-normative diabase: high $\mathrm{TiO}_{2}$ (HTO) and low $\mathrm{TiO}_{2}$ (LTQ). A few plugs and dikes are olivine tholeiites. Chill margins of individual sheets and dikes have characteristic major- and trace-element abundances and rare-earth element (REE) patterns that support the distinction between the two quartz-normative magma types.

The thickest and most extensive sheets are HTQ (1.0-1.2 percent $\mathrm{TiO}_{2}$ ); at the north and south margins of the basin these are characterized by thick zones containing cumulus orthopyroxene (Boyds, Maryland; Rapidan, Virginia). Adjacent sheets containing abundant syenitic granophyre, pegmatite, ferrogabbro, and aplite (Belmont and Germanna Bridge, Virginia) that are enclosed by diabase with minor cumulate zones may represent complementary fractions to the aforementioned sheets having thick cumulate zones. The chill margins of thick HTQ sheets are consistent in composition; however, geochemical traverses across these sheets in different areas show differing patterns of major- and trace-element enrichment and depletion. None of the HTQ diabase sheets exhibit mass balance in any given section across exposed tilted sheets or through those penetrated by core holes. These geochemical and petrologic variations of the widely distributed HTQ sheets are best explained by wholesale lateral flow differentiation, modified locally by gravitational settling and by late-stage filter pressing of granophyric differentiates.

The central part of the Culpeper basin is characterized by LTQ sheets $\left(0.65-0.85\right.$ percent $\left.\mathrm{TiO}_{2}\right)$. These sheets show little geochemical, petrographic, or field evidence of differentiation and display neither well-developed cumulate zones nor late-stage differentiates. LTQ sheets and dikes show less enrichment in light REE and lower incompatible traceelement abundances than found in any HTQ sheets.

The geochemical data for the quartz-normative tholeiites of the Culpeper basin indicate that the HTQ and LTQ magmas are not related by any simple crystallizationdifferentiation process. They are derived either from separate source areas or by complex melting processes.

\section{INTRODUCTION}

A complex network of Early Jurassic tholeiitic diabase sheels and dikes has extensively intruded and thermally metamorphosed Upper Triassic sedimentary rocks in the Culpeper basin of northern Virginia and southern Maryland (Leavy and others, 1983). The diabase intrusions form part of the eastern North America (ENA) tholeiitic suite of Weigand and Ragland (1970) and comprise about one-fifth of the basin fill with a preserved volume probably in excess of $40 \mathrm{mi}^{3}\left(170 \mathrm{~km}^{3}\right)$.

The best exposures of unweathered diabase are in aclive quarries, nine of which were operative in 1986 in seven sheets in the Culpeper basin (Froelich and Leavy, 1982; fig. 1). Another excellent source of fresh samples, that in some areas provides a continuous sequence, is core holes into and through some of the igneous bodies. Five diabase sheets have been extensively cored, some to depths of $500 \mathrm{ft}(150 \mathrm{~m})$ (fig. 1). Unweathered samples from abandoned quarries, fresh roadcuts, and stream valley outcrops provide the balance of geographic coverage of the diabase collected throughout the basin. More than 350 samples were collected and geochemically analyzed. Regional distribution, attitudes and thickness of the sheets, and the enclosing sedimentary and thermally metamorphosed rocks are mainly from Lee $(1979,1980)$ and Lee and others (1984), in places modified by the authors.

This regional gcochemical compilation for diabase in the Culpeper basin was made possible by integrating mapping, sampling, and analytical work of more than a dozen scientists during the past decade. Data on the geochemistry of the diabase of the northern Culpeper basin in Virginia are presented in Lee and others (1984), and on the Boyds, Nokesville, and Gainesville East sheets by Gottfricd and Froelich (1985). Unpublished chemical data on the Belmont sheet are summarized in an abstract by Mihm and Nielson (1985), and on the other sheets by Kcahcy (1976), Mihm (1986), and Gottfried, Leavy, Froelich, Ragland, and Arthur (unpub. data, 1982-86). Also, Gottfried and others (1986) documented Th/Hf ratios, and Sutter and Arth (1983) reported on Sr isotope ratios in Culpeper diabase sheets and dikes. Paleomagnetic data have been summarized by Raymond and others (1982).

All of the sheels and most of the principal dikes are quartz normative, (51-53 percent $\left.\mathrm{SiO}_{2}\right)$, but a few plugs and dikes are olivine tholeiites $\left(46-49\right.$ percent $\mathrm{SiO}_{2}$; 9.5-11 percent $\mathrm{MgO}$ ). The thickest and most extensive sheels are characterized by chill margins with high $\mathrm{TiO}_{2}$ 


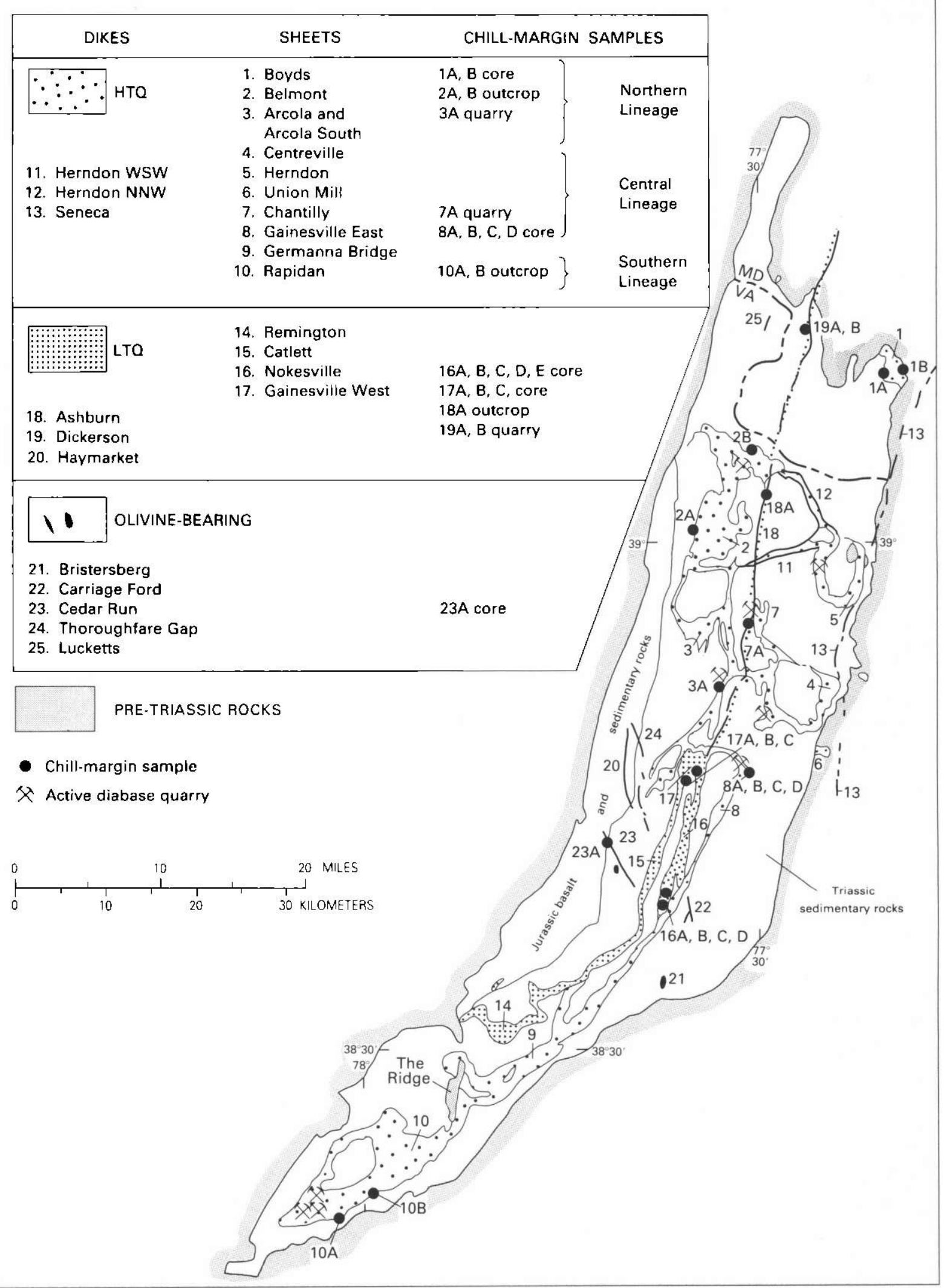

Figure 1. Mesozoic diabase and location of chill margin samples of principal sheets in the Culpeper basin, Virginia and Maryland. $\mathrm{HTQ}$, high- $\mathrm{TiO}_{2}$ quartz-normative diabase; $\mathrm{LTQ}$, low- $\mathrm{TiO}_{2}$ quartz-normative diabase. 
contents (1.0-1.2 percent) (HTQ of Weigand and Ragland, 1970) similar to the York Haven-type of the Gettysburg basin, Pennsylvania, described by Smith and others (1975). Sheets at the north and south margins of the basin are characterized by thick zones enriched in cumulus orthopyroxene (opx) (Boyds, Maryland; Rapidan, Virginia). Adjacent sheets having minor zones of opx that contain abundant late-stage differentiates including granophyric syenite, pegmatite, ferrogabbro, and minor aplite (Belmont and Germanna Bridge, Virginia) may represent complementary fractions to the aforementioned sheets containing thick opx cumulate zones.

In contrast, diabase sheets in the central part of the basin are characterized by chill margins having low $\mathrm{TiO}_{2}$ contents (0.65-0.85 percent) (LTQ of Weigand and Ragland, 1970) similar to the Rossville-type of the Gettysburg basin (Smith and others, 1975). The LTQ sheets in the Culpeper basin show little evidence of differentiation; they rarely display either (1) cumulate zones with sparse olivine and (or) opx or (2) late-stage differentiates, which locally occur as thin pegmatitic veinlets or pod-shaped segregations.

The principal dike systems in and near the Culpeper basin trend north-northeast and northwest and include all of the magmatic variants of the ENA tholeiitic province of Weigand and Ragland (1970). The easternmost throughgoing dikes that trend north-northeast are HTQ varieties; the central, subparallel north-northeasttrending dike system related to the throughgoing Frederick dike system located about $5 \mathrm{mi}(8 \mathrm{~km})$ to the west is LTQ. A few poorly exposed plugs and relatively short, northwest- and north-northwest-trending dikes are olivine tholeiites, and in places, picritic; other northwesttrending dikes that cut Lower Jurassic basalt flows are both olivine bearing and LTQ. The very thick northwestand west-trending dikes that connect the HTQ Herndon sheet to the Belmont and Arcola HTQ sheets are also HTQ, as would be expected.

Whole-rock samples from several representative HTQ diabase sheets and LTQ dikes throughout the Culpeper basin have total gas ${ }^{40} \mathrm{Ar} /{ }^{39} \mathrm{Ar}$ age spectra with a mean age of $198.4 \pm 2.1$ Ma (2 sigma), which was interpreted as the best estimate for the age of intrusion and crystallization by Sutter (1985, p. 111). Although there apparently is no reliable geochronologic evidence for significant temporal separation of these two quartznormative magma types, local field relations indicate that the LTQ intrusives cut and are chilled against the HTQ sheets. Olivine- and quartz-normative diabase dikes cut the Mesozoic strata that lie beneath and are intercalated with a series of lower Jurassic basalt flows, but no intrusives appear to cut the sedimentary rocks overlying the flows, suggesting that the dikes are of the same general age as the flows. These dike-flow-sedimentary rock relations are similar to those in the Newark basin (Olsen, 1984) and Hartford basin (Philpotts, 1985), where thick sections of Jurassic sedimentary rocks, apparently not intruded by diabase, also overlie basalt flows.

Plots of $\mathrm{MgO}-\mathrm{TiO}_{2}$ contents of chill-margin samples in conjunction with field relations and petrography are used in this study to classify the compositional type of the diabase. This geochemical characterization is refined by using the major- and trace-element abundances and REE patterns of chill-margin samples of representative sheets and dikes. By plotting $\mathrm{MgO}$ content against petrologic zones, we used internal variations within the thickest and most widely distributed HTQ sheets to define a characteristic style of differentiation. REE patterns reinforce this definition and show depletion in cumulate zones and enrichment in late-stage granophyric differentiates. The vertical distribution and map patterns can best be explained by a process of wholesale lateral flow differentiation, locally modified by gravitational settling and late-stage filter pressing of ferrogabbroic, granophyric, or pegmatitic differentiates (Gottfried and others, 1985). On the basis of our studies, the Boyds, Rapidan, Belmont, and Nokesville sheets appear to represent the principal products and styles of igneous differentiation observed in sheets within the Culpeper basin.

\section{CHILL MARGINS OF DIABASE}

\section{Field Relations and Major-Element Geochemistry}

The chill margin refers to the aphanitic or finely crystalline envelope enclosing an intrusive body formed when the invading magma crystallized rapidly against the cooler host rocks. In studying the geochemical composition of the parent magma and attempting to avoid the complications of in-situ differentiation, Smith and others (1975, p. 943) considered the most appropriate material for analysis to be the chilled margin of sheets and dikes. Geochemical data on chill margins of most diabase sheets and dikes in the Culpeper basin are relatively sparse and widely scattered; however, the sample distribution is adequate to define the compositional affinities of all of the major sheets and most of the dikes and minor intrusives (fig. 1). Outcrops of fresh aphanitic diabase at chill borders are rare, and most reliable samples are from drill cores and quarry exposures. Table 1 summarizes the major-element chemistry for representative samples of chill margins from the diabase in the Culpeper basin. Median chill-margin compositions of diabase in the Gettysburg basin, based on multiple analyses presented by Smith and others (1975), are included here to facilitate regional comparisons. 
Table 1. Summary of major-element geochemistry (in weight percent) of chill margins of selected quartz-normative diabase, Culpeper basin, Virginia and Maryland, and comparison with median York Haven- and Rossville-type chill margins, Gettysburg basin, Pennsylvania

[Based on samples of Lee and others (1984); Froelich and Gottfried (1985, and unpublished data); Ragland and Arthur (unpublished data); Mihm, 1986; Smith and others, 1975; analysts: Katherine Mihm, R.C. Smith II, P.C. Ragland, J.D. Arthur, USGS analysts: Hezekiah Smith, Norma Rait, Philip Aruscavage, Leo Mei, Zoe Ann Brown, 1983-86; minor variations in total abundances may be due to analytical differences in different laboratories; - , not analyzed; $\mathrm{Fe}^{*}$, total iron; $\mathrm{R}$, recalculated to 100 percent; $\mathrm{n}$, number of analyses averaged; (L, $U$ ), lower ( $(\mathrm{L}$ ) and upper (U) chill margins of sheet; $(E, W)$, east (E) and west $(W)$ chill margins of dike]

\begin{tabular}{|c|c|c|c|c|c|c|c|c|c|c|c|c|c|c|}
\hline & \multicolumn{8}{|c|}{$\mathrm{High} \mathrm{TiO}_{2}$} & \multicolumn{6}{|c|}{ Low $\mathrm{TiO}_{2}$} \\
\hline & $\begin{array}{l}\text { Boyds } \\
\text { sheet- } \\
\text { USGS } \\
(n=2, L)\end{array}$ & $\begin{array}{l}\text { Belmont } \\
\text { sheet- } \\
\text { Mihm } \\
(n=2, U)\end{array}$ & $\begin{array}{l}\text { Belmont } \\
\text { sheet- } \\
\text { Mihm } \\
(n=1, L)\end{array}$ & $\begin{array}{c}\text { Gainesville } \\
\text { East } \\
\text { sheet-- } \\
\text { USGS } \\
(n=3, U)\end{array}$ & $\begin{array}{l}\text { Gainesville } \\
\text { East } \\
\text { sheet- } \\
\text { USGS } \\
(n=3, U)\end{array}$ & $\begin{array}{l}\text { Chantilly } \\
\text { sheet- } \\
\text { USGS } \\
(n=1, U)\end{array}$ & $\begin{array}{l}\text { Rapidan } \\
\text { sheet- } \\
\text { USGS } \\
(n=2, L)\end{array}$ & $\begin{array}{l}\text { Median } \\
\text { York } \\
\text { Haven, } \\
\text { Pa.-. } \\
\text { Smith } \\
\text { (n=30, } \\
\text { U\&L) }\end{array}$ & $\begin{array}{l}\text { Gainesville } \\
\text { West } \\
\text { sheet- } \\
\text { Ragland } \\
(n=3, L)\end{array}$ & $\begin{array}{l}\text { Nokesville } \\
\text { sheet- } \\
\text { USGS } \\
\text { (n=2,U) }\end{array}$ & $\begin{array}{l}\text { Nokesville } \\
\text { sheet- } \\
\text { Ragland } \\
(n=2, U)\end{array}$ & $\begin{array}{l}\text { Nokesville } \\
\text { sheet- } \\
\text { Ragland } \\
(n=1, L)\end{array}$ & $\begin{array}{l}\text { Dickerson } \\
\text { dike- } \\
\text { USGS } \\
(n=2, \\
\text { E\&W) }\end{array}$ & $\begin{array}{l}\text { Median } \\
\text { Rossville, } \\
\text { Pa.-ith } \\
\text { Smith } \\
\text { (n=20, } \\
\text { U\&L }\end{array}$ \\
\hline $\mathrm{SiO}_{2}$. & 52.1 & 51.02 & 51.77 & 50.6 & 50.3 & 51.5 & 51.8 & 51.84 & 51.0 & 50.1 & 51.1 & 50.26 & 50.2 & 50.56 \\
\hline $\mathrm{TiO}_{2}$. & 1.1 & 1.12 & 1.12 & 1.13 & 1.1 & 1.2 & 1.05 & 1.09 & .74 & .71 & .75 & .79 & .735 & .74 \\
\hline $\mathrm{Al}_{2} \mathrm{O}_{3}$ & 13.95 & 14.28 & 14.29 & 14.5 & 14.3 & 14.5 & 13.65 & 14.34 & 15.52 & 15.3 & 16.37 & 16.52 & 15.2 & 16.56 \\
\hline $\mathrm{FeO}$. & 7.95 & - & - & - & 8.3 & 7.3 & 8.2 & 8.75 & 8.9 & 7.9 & 8.67 & 8.91 & 7.8 & 9.02 \\
\hline $\mathrm{Fe}_{2} \mathrm{O}_{3}$ & 2.5 & - & - & - & 2.1 & 2.6 & 1.9 & 1.18 & 1.73 & 2.6 & 1.70 & 1.74 & 2.6 & 1.07 \\
\hline $\mathrm{Fe}^{*} \ldots$ & - & 11.12 & 11.31 & 11.1 & - & - & - & - & - & - & - & - & - & - \\
\hline $\mathrm{MnO} .$. & .25 & .155 & .17 & .20 & .19 & .21 & .18 & .20 & .21 & .21 & .18 & .18 & .18 & .18 \\
\hline $\mathrm{MgO}$. & 7.55 & 7.04 & 6.85 & 7.0 & 7.0 & 6.6 & 8.25 & 7.72 & 8.19 & 8.0 & 7.25 & 8.05 & 7.9 & 6.79 \\
\hline $\mathrm{CaO}$. & 10.45 & 10.86 & 10.21 & 10.1 & 10.2 & 9.8 & 10.6 & 10.73 & 11.15 & 11.2 & 11.69 & 11.45 & 11.05 & 10.81 \\
\hline $\mathrm{Na}_{2} \mathrm{O}$. & 1.95 & 2.35 & 1.92 & 2.2 & 2.2 & 2.0 & 1.9 & 1.96 & 1.89 & 2.0 & 1.88 & 1.71 & 2.1 & 1.95 \\
\hline $\mathrm{K}_{2} \mathrm{O}$. & .65 & .43 & .68 & .78 & .76 & .75 & .62 & .60 & .67 & .32 & .41 & .39 & .43 & .39 \\
\hline $\mathrm{P}_{2} \mathrm{O}_{5}$. & .15 & - & - & .17 & .17 & .15 & .14 & .12 & - & .11 & - & - & .10 & .09 \\
\hline $\mathrm{H}_{2} \mathrm{O}^{+}$. & .85 & - & - & - & 1.5 & 1.4 & .86 & .23 & - & 1.1 & - & - & .58 & .46 \\
\hline $\mathrm{H}_{2} \mathrm{O}^{-}$. & .34 & - & - & - & .7 & - & .29 & - & - & .32 & - & - & .21 & - \\
\hline $\mathrm{CO}_{2} \ldots \ldots \ldots$ & .04 & - & - & - & .03 & .02 & .03 & .08 & - & .08 & - & - & .05 & 12 \\
\hline Total.... & 99.83 & 98.375 & 98.32 & 97.78 & 98.85 & 98.03 & 99.47 & 98.84 & $100 . \mathrm{R}$ & 99.95 & $100 . \mathrm{R}$ & $100 . R$ & 99.135 & 98.74 \\
\hline
\end{tabular}



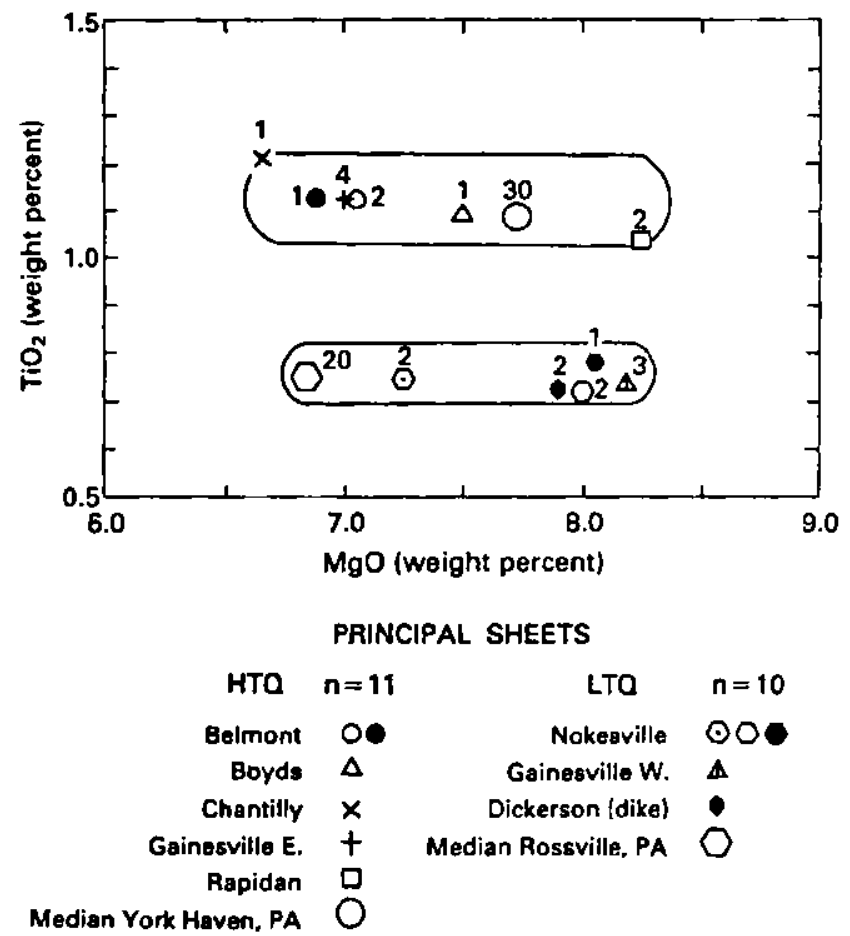

Figure 2. $\mathrm{TiO}_{2}$ versus $\mathrm{MgO}$ plot for selected chill margins, early Mesozoic quartz-normative diabase, Culpeper basin, Virginia and Maryland. The number above each symbol is keyed to table 1 and represents number of chill margins sampled and averaged.

Figure 2, a plot of $\mathrm{TiO}_{2}$ against $\mathrm{MgO}$ content for selected chill margins, shows two distinct populations in the quartz-normative tholeiites of the Culpeper basin: (1) a high-TiO $\mathrm{TH}_{2}$ (HT) or York Haven-type magma and (2) a low- $\mathrm{TiO}_{2}$ (LTQ) or Rossville-type magma (Weigand and Ragland, 1970; Smith and others, 1975). Whereas the median York Haven magma type plots within the field of Culpeper basin HTQ samples, the median Rossville type shows a lower $\mathrm{MgO}$ content for similar $\mathrm{TiO}_{2}$ content. It is not known at this time whether this difference in $\mathrm{MgO}$ content is geologically meaningful or due to analytical biases in different laboratories. The HTQ chill-margin samples from the Culpeper basin diabases are consistently higher than LTQ samples in $\mathrm{TiO}_{2}, \mathrm{~K}_{2} \mathrm{O}$, and $\mathrm{P}_{2} \mathrm{O}_{5}$, consistently lower in $\mathrm{Al}_{2} \mathrm{O}_{3}$ and $\mathrm{CaO}$, but otherwise similar in all other major and minor oxides (table 1).

An effective field criterion for identifying the LTQ diabase is the presence of coarse $(1 \mathrm{~cm})$, euhedral, calcic plagioclase phenocrysts distributed sparsely throughout the aphanitic or finely crystalline matrix at or near chill margins of both sheets and dikes. This characteristic was also reported by Smith and others (1975) in the margins of the Rossville-type sheets in the Gettysburg basin. The chill margins of the HTQ diabase are generally aphyric, although sparse phenocrysts of augite and fine plagioclase may be present locally.

\section{Trace-Element Geochemistry of Chill Margins}

Trace-element data for 11 samples of chill margins from six sheets and one dike of the HTQ and LTQ magma types in the Culpeper basin are presented in table 2 as well as the data for average York Haven (HTQ) and Rossville (LTQ) magmas of Pennsylvania. The elements are grouped mainly on the basis of ionic radii and charge, and similar geochemical behavior.

Large cations. - The elements of large ionic radii $(\mathrm{Cs}, \mathrm{Rb}, \mathrm{Ba}$, and $\mathrm{K}$ ) are highly susceptible to leaching and remobilization by postmagmatic processes (Hart, 1969, 1971; Gottfried and others, 1977, 1983). This is especially true for $\mathrm{Cs}$ and $\mathrm{Rb}$, which show twofold to threefold variations in the chilled margins. It is important to note, however, that some of the samples containing higher contents of these elements (for example, $30 \mathrm{ppm} \mathrm{Rb}$ and $2 \mathrm{ppm} \mathrm{Cs}$ ) may reflect selective contamination of the parent magmas by interaction with wall rocks during intrusion. In the absence of isotopic data, it is impossible to assess the role of contamination for these samples.

High-valence cations. - With few exceptions, the contents of $\mathrm{Th}, \mathrm{U}, \mathrm{Nb}, \mathrm{Ta}, \mathrm{Zr}$, and $\mathrm{Hf}$ are uniform within analytical uncertainty, in each of the two suites of samples. Previous studies of subsurface HTQ basalts indicated that the contents of these incompatible elements were extremely constant and remained quite stable during weathering, hydrothermal alteration, and burial metamorphism (Gottfried and others, 1977, 1983). The striking uniformity of the abundances of these elements in the chill margins of Culpeper diabases is in sharp contrast to the variations in $\mathrm{Rb}$ and Cs contents. Except for the twofold variations in $\mathrm{Nb}$, which may be due to relatively poor precision of niobium analysis in the LTQ samples, the contents of Th, U, Zr, Hf, and Ta are about twice as great in the HTQ samples as in the LTQ samples.

Ferromagnesian elements. - The Ni contents in the HTQ samples are quite uniform, but although more variable, Ni contents in the LTQ samples are consistently less. Co and Sc abundances are nearly the same in the two suites, although Sc tends to be slightly less abundant in the HTQ samples. The Ni/Co ratios differ in the two suites, with the lowest ratios occurring in the LTQ Dickersen dike, which also contains the lowest Ni content. The two magma types show overlapping $\mathrm{Cr}$ contents.

A significant difference between the two magma types is the twofold difference in $\mathrm{Cu}$ content between the HTQ and the LTQ samples. This feature was previously noted for Pennsylvania diabases by Smith (1973) and for diabases regionally in the Eastern United States by Weigand (1970).

Rare-earth elements. - The rare-earth elements (REE) within each magma type are remarkably uniform 
Table 2. Distribution of trace elements (ppm) and ratios in chill margins of selected quartz-normative diabase, Culpeper basin, Virginia and Maryland, and comparison with median York Haven- and Rossville-type chill margins, Gettysburg basin, Pennsylvania

[Based on samples of Smith and others (1975) from the Gettysburg basin, Pennsylvania; Mihm, 1986 (Belmont sheet); and Froelich and Gottfried, USGS, unpublished data; R.C. Smith II, 1975, analyst; USGS analysts: G.A. Wandless, J.N. Grossman, C.A. Palmer, L.J. Schwartz, CJ. Skeen, B. Spiliane, W.B. Crandell, Z.A. Brown, and A.F. Dorrzapf, Jr., 1983-86; minor variations in total abundances may be due to analytical differences in different laboratories; -, not analyzed; $x$, chondrite-normalized values; $(L, U)$, lower (L) and upper (U) chill margins of sheet; (E,W), east (E) and west $(W)$ chill margins of dike]

\begin{tabular}{|c|c|c|c|c|c|c|c|c|c|c|c|c|}
\hline \multirow[b]{3}{*}{ Trace element } & \multicolumn{7}{|c|}{ High- $\mathrm{TiO}_{2}$} & \multicolumn{5}{|c|}{ Low- $\mathrm{TiO}_{2}$} \\
\hline & \multirow{2}{*}{$\begin{array}{c}\text { Boyds } \\
\text { sheet } \\
\text { B9-123 } \\
\text { (L) }\end{array}$} & \multicolumn{2}{|c|}{$\begin{array}{l}\text { Belmont sheet } \\
\text { (Mihm, 1985) }\end{array}$} & \multirow{2}{*}{$\begin{array}{l}\text { East } \\
\text { Gainesville } \\
\text { sheet } \\
\text { RD16-140 } \\
\text { (U) }\end{array}$} & \multicolumn{2}{|c|}{ Rapidan sheet } & \multirow{2}{*}{$\begin{array}{c}\text { Median', } \\
\text { York Haven, } \\
\text { Pa. } \\
\text { (Smith, } \\
1975) \\
\text { (U \& L) }\end{array}$} & \multicolumn{2}{|c|}{ Nokesville sheet } & \multicolumn{2}{|c|}{ Dickerson dike } & \multirow{2}{*}{$\begin{array}{c}\text { Median } 2, \\
\text { Rossville, } \\
\text { Pa. } \\
\text { (Smith, } \\
1975) \\
\text { (U \& L) }\end{array}$} \\
\hline & & $\underset{(U)}{L-82}$ & $\begin{array}{c}L-93 \\
(U)\end{array}$ & & $\begin{array}{c}\mathrm{K}-7 \\
(\mathrm{~L})\end{array}$ & $\begin{array}{l}8 A \\
(L)\end{array}$ & & $\begin{array}{c}57-346 \\
(L)\end{array}$ & $\begin{array}{c}39 \mathrm{~V}- \\
283 \\
(L)\end{array}$ & $\begin{array}{c}\text { MD-84 } \\
-1 \\
\mathrm{~W})\end{array}$ & $\begin{array}{c}\text { MD_84- } \\
17 \\
(E)\end{array}$ & \\
\hline \multicolumn{13}{|c|}{ Large cations } \\
\hline$\ldots \ldots$ & 0.92 & 0.95 & 0.74 & 1.59 & 1.7 & 1.4 & 1.3 & 2.06 & 1.07 & .56 & .76 & 1.0 \\
\hline $\mathrm{Rb}$. & 17 & 8 & 21 & 30 & 27 & 26 & $25 ?$ & 12 & 10 & 11.7 & 11.3 & $21 ?$ \\
\hline & 169 & - & 200 & 147 & 180 & 159 & 160 & 95 & 72 & 112 & 108 & 115 \\
\hline $\mathbf{K}$. & 4,480 & 2,320 & 4,900 & 6,300 & 5,310 & 5,150 & 4,980 & 2,320 & 3,400 & 4,230 & 2,900 & 3,237 \\
\hline $\mathrm{Sr}$ & 234 & 154 & 187 & 191 & 179 & 183 & 187 & 135 & 131 & 131 & 131 & 137 \\
\hline K/Rb $\ldots \ldots$ & 263 & 290 & 233 & 210 & 197 & 198 & $200 ?$ & 193 & 340 & 352 & 257 & $154 ?$ \\
\hline \multicolumn{13}{|c|}{ High-valence cations } \\
\hline & 2.2 & 2.21 & 2.18 & 2.23 & 2.16 & 1.95 & 2.2 & 1.1 & 1.0 & 1.2 & - & 1.7 \\
\hline $\mathrm{U}$. & - & .41 & .49 & .54 & .48 & - & .57 & - & .32 & - & - & .45 \\
\hline $\mathrm{Zr} \ldots \ldots \ldots$ & 115 & 108 & 98 & 91 & 104 & 106 & 115 & 64 & 60 & 66 & 64 & 66 \\
\hline $\mathrm{Hf} \ldots \ldots \ldots$ & 2.5 & 2.6 & 2.8 & 2.38 & 2.46 & 2.48 & 2.1 & 1.29 & 1.24 & 1.29 & 1.48 & 1.2 \\
\hline $\mathrm{Nb} \ldots \ldots \ldots$ & 7.4 & 6.2 & 7.4 & 7.4 & 6.8 & 6.3 & 9.6 & 4.2 & 4.3 & 2.7 & 2.8 & 6.6 \\
\hline $\mathrm{Ta} \ldots \ldots \ldots$ & .55 & .55 & .50 & .53 & .496 & .53 & .48 & .2 & .2 & .21 & .25 & .18 \\
\hline $\mathrm{Th} / \mathrm{U} \ldots \ldots$ & - & 5.3 & 4.4 & 4.1 & 4.5 & - & 3.9 & - & 3.1 & - & - & 3.7 \\
\hline $\mathrm{Zr} / \mathrm{Hf} \ldots \ldots$ & 46 & 42 & 35 & 53 & 42 & 43 & 55 & 49 & 48 & 51 & 43 & 55 \\
\hline $\mathrm{Nb} / \mathrm{Ta} . . . .$. & 13.5 & 11.3 & 14.8 & 14 & 13.9 & 12 & 20 & 21 & 21 & 13 & 11.2 & 36.7 \\
\hline $\mathrm{Jb} / \mathrm{Ti}$ & .11 & .10 & .11 & .11 & .10 & .11 & .15 & .10 & .10 & .06 & .07 & .15 \\
\hline \multicolumn{13}{|c|}{ Ferromagneslan elements } \\
\hline & 99 & - & 107 & 83 & 91 & 100 & $89^{*}$ & 70 & 63 & 54 & 51 & $63^{*}$ \\
\hline Co. & 45 & 48.5 & 45.8 & 46.3 & 49.7 & 46.4 & $47^{*}$ & 47.5 & 46.9 & 48.1 & 48.0 & $46^{*}$ \\
\hline$\ldots \ldots$ & 120 & 111 & 117 & 110 & 110 & 110 & $121^{*}$ & 70 & 69 & 64 & 66 & $66^{*}$ \\
\hline $\mathrm{Zn}$. & 89 & 75 & 87 & 120 & 88 & 89 & $77^{*}$ & 91 & 88 & 88 & 93 & $79^{*}$ \\
\hline $\mathrm{Cr}$. & 289 & 313 & 264 & 275 & 412 & 421 & $302 *$ & 262 & 260 & 249 & 253 & $205^{*}$ \\
\hline Sc......... & 36.5 & 38.9 & 39.4 & 36.3 & 37.1 & 36.9 & 41 & 42.1 & 42.0 & 43.0 & 43.9 & 51 \\
\hline $\mathrm{Ni} / \mathrm{Co} \ldots . .$. & 2.2 & 2.2 & 2.3 & 1.8 & 1.8 & 2.2 & 1.9 & 1.9 & 2.1 & 1.1 & 1.1 & 1.4 \\
\hline \multicolumn{13}{|c|}{ Rare-earth elements } \\
\hline & 11.3 & 11.2 & 11.8 & 11.3 & 10.9 & 10.1 & 8.5 & 5.4 & 5.2 & 5.84 & 5.43 & 4.5 \\
\hline & 23.8 & 24.7 & 24.7 & 21.8 & 22.4 & 23.5 & 33 & 10.6 & 10.5 & 11.6 & 11.7 & 16 \\
\hline Nd....... & 16 & 10.8 & 12.1 & 13.0 & 14.1 & 23 & 32 & - & 7 & - & - & 24 \\
\hline Sm.... & 3.4 & 3.62 & 3.76 & 3.68 & 3.47 & 3.27 & 3.2 & 1.96 & 2.05 & 2.17 & 2.19 & 1.9 \\
\hline Eu $\ldots \ldots \ldots$ & 1.0 & 1.10 & 1.16 & .96 & 1.00 & 1.06 & 1.22 & .7 & .73 & .708 & .74 & .92 \\
\hline $\mathbf{T b} \ldots \ldots \ldots$ & .6 & .66 & .73 & .59 & .62 & .56 & .78 & .43 & .47 & .49 & .52 & .50 \\
\hline Yb ......... & 2.06 & 2.33 & 2.43 & 2.20 & 2.24 & 2.02 & 2.1 & 2.0 & 1.88 & 2.20 & 2.22 & 2.2 \\
\hline Lu $\ldots \ldots \ldots$ & .32 & .32 & .36 & .37 & .32 & .36 & .50 & .31 & .32 & .33 & .35 & .49 \\
\hline & 28 & 26 & 26 & 22 & 30 & 27 & 20 & 25 & 23 & 27 & 24 & 20 \\
\hline$(\mathrm{La} / \mathrm{Yb}) \mathbf{x} \ldots$ & 3.3 & 3.2 & 3.3 & 3.5 & 3.3 & 3.4 & 4.0 & 1.8 & 1.8 & 1.7 & 1.6 & 2.0 \\
\hline
\end{tabular}

${ }^{1}$ Average of six analyses, except as noted by asterisk.

${ }^{2}$ Average of four analyses, except as noted by asterisk, in which case $30+$ analyses were performed. 

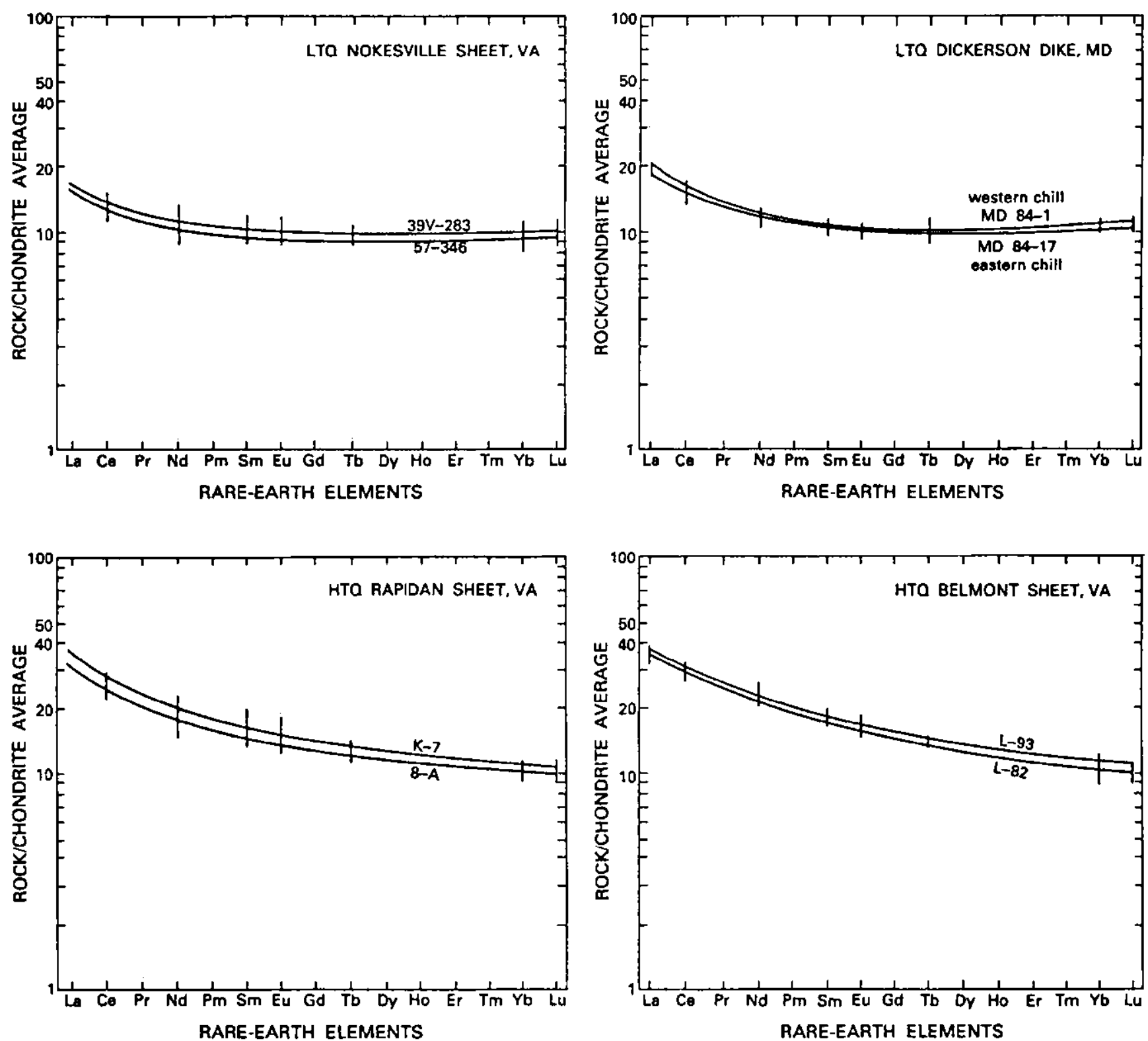

Figure 3. Chondrite-normalized REE patterns of chill-margin samples of selected diabase sheets and dikes, Culpeper basin, Virginia and Maryland. $\mathrm{HTQ}$, high-TiO $\mathrm{O}_{2}$ quartz-normative diabase; LTQ, low- $\mathrm{TiO}_{2}$ quartz-normative diabase. The short vertical bars indicate the range of variation for each measured rare-earth element.

in abundance. Of particular significance is the twofold difference in $\mathrm{La}$ and $\mathrm{Ce}$ contents between the two suites, whereas the $\mathrm{Yb}$ content in the two suites is essentially the same. Chondrite-normalized (Anders and Ebihara, 1982) REE patterns of some chill-margin samples are shown in figure 3. The patterns show that the HTQ magma type is characterized by greater light REE contents and steeper REE slopes $(\mathrm{La} / \mathrm{Yb}$ about 3.3) than the LTQ magma type (La/Yb about 1.7). The patterns are quite similar to those of Ragland and others (1971) for HTQ and LTQ dikes in the eastern North American province. The HTQ basalts from the subsurface near Charleston, South Carolina, have virtually the same REE patterns and abundances (Gottfried and others, 1977, 1983) as the chilled margin samples from the HTQ diabase sheets in the Culpeper basin.

\section{THICKNESS AND VOLUME OF DIABASE}

Estimates of the thickness and volume of individual diabase sheets are summarized in table 3. These estimates are based on geologic mapping (Lee, 1979, 1980), geophysical surveys (Wise and Johnson, 1980; Johnson and Froelich, 1982), and sparse drill hole and core hole data. The thickness of some sheets can be calculated or 
Table 3. Estimated thickness and volume of diabase in the principal quartz-normative sheets, Culpeper basin, Virginia and Maryland

[See figure 1 for locations of sheets listed in "Map number" column; HTQ, high-TiO 2 quartz-normative diabase; $\mathrm{LTQ}$, low- $\mathrm{TiO}_{2}$ quartz-normative diabase; $\mathrm{Db}$, "typical" diabase; C, orthopyroxene cumulates; $\mathrm{G}$, granophyric differentiates]

\begin{tabular}{|c|c|c|c|c|c|}
\hline Name & Map number & Type & $\begin{array}{l}\text { Area } \\
\left(\mathrm{mi}^{2}\right)\end{array}$ & $\begin{array}{l}\text { Thickness (in ft) } \\
\text { (range; average) }\end{array}$ & $\begin{array}{r}\text { Volume }{ }^{1} \\
\left(\mathrm{mi}^{3}\right)\end{array}$ \\
\hline \multicolumn{6}{|c|}{ High- $\mathrm{TiO}_{2}$ quartz-normative diabase ${ }^{2}$} \\
\hline Boyds & 1 & $\mathrm{C}$ & 3 & $0-500 ; 400 \pm$ & 0.28 \\
\hline Belmont ............ & 2 & $\begin{array}{l}\text { Db } \\
\text { G } \\
\text { C }\end{array}$ & $231 / 2$ & $\begin{array}{l}500-2,000+; 1,200 \\
0-600 ; 450 \\
0-100 ; 50\end{array}$ & $\begin{array}{r}5.34 \\
.51 \\
.05\end{array}$ \\
\hline Arcola (+ Arcola S.) ... & 3 & $\mathrm{Db}$ & $201 / 4$ & $\begin{array}{l}100-800 ; 500 \\
300-800 ; 400\end{array}$ & 1.73 \\
\hline Centreville............ & 4 & $\mathrm{Db}$ & $201 / 2$ & $330-660 ; 500$ & 1.94 \\
\hline Herndon. . . . . . . . $\ldots \ldots$ & 5 & $\mathrm{Db}$ & $131 / 4$ & $500-725 ; 650$ & 1.63 \\
\hline Chantilly............. & 7 & $\begin{array}{l}\mathrm{G} \\
\mathrm{Db}\end{array}$ & $21 / 2$ & $\begin{array}{l}50-600 ; 450 \\
0-200 ; 100\end{array}$ & $\begin{array}{l}.15 \\
.05\end{array}$ \\
\hline Gainesville East........ & 8 & $\mathrm{G}$ & 7 & $300-1,000 ; 750$ & 1.0 \\
\hline Germanna Bridge....... & 9 & $\begin{array}{l}\mathrm{G} \\
\mathrm{C} \\
\mathrm{Db}\end{array}$ & $33 \%$ & $300-1,500 ; 1,000$ & $\begin{array}{l}1.58 \\
1.58 \\
3.16\end{array}$ \\
\hline Rapidan ............ & 10 & $\mathrm{C}$ & 37 & $1,000-1,800 ? ; 1,200$ & 8.41 \\
\hline \multicolumn{6}{|c|}{ Low $\mathrm{TiO}_{2}$ quartz-normative dlabase ${ }^{2}$} \\
\hline Remington............ & 14 & $\mathrm{Db}$ & 10 & $200-1,000 ; 800$ & 1.52 \\
\hline Catlett................ & 15 & $\mathrm{Db}$ & 9 & $200-800 ; 600$ & 1.02 \\
\hline Nokesville ............ & 16 & $\mathrm{Db}$ & $11 \frac{1}{2}$ & $300-1,400 ; 700$ & 1.52 \\
\hline Gainesville West ........ & 17 & $\mathrm{Db}$ & 8 & $200-800 ; 600$ & .91 \\
\hline
\end{tabular}

measured with precision, whereas others can only be approximated by projecting dips of local contacts or enclosing hornfels. The subsurface extent of some sheets, such as Boyds, Herndon, Centreville, and Rapidan, can be calculated with some confidence; however, volumes of sheets, such as Gainesville West, Belmont, Nokesville, and Catlett, were computed on the basis of assuming down-dip buried extents of $0.6 \mathrm{mi}(1 \mathrm{~km})$ and represent only minimum values. Furthermore, the volume of diabase removed by erosion is incalculable.

Although the estimates given in table 3 are only a crude approximation of the amount of intrusive rock preserved in the Culpeper basin, a few generalizations are possible: (1) the thickness of individual sheets is highly variable, ranging from about $100 \mathrm{ft}(30 \mathrm{~m})$ to more than $2,000 \mathrm{ft}(600 \mathrm{~m})$; (2) the preserved volume of diabase within the Culpeper basin is probably in excess of $40 \mathrm{mi}^{3}\left(170 \mathrm{~km}^{3}\right)$; (3) approximately 80 percent of the volume is in HTQ sheets and dikes, 20 percent in LTQ sheets and dikes, and only a negligible volume in olivinebearing plugs and dikes; (4) of the HTQ bodies, about 11 $\mathrm{mi}^{3}\left(46 \mathrm{~km}^{3}\right)$, or 40 percent, is enriched in cumulus orthopyroxene, $3 \mathrm{mi}^{3}\left(12 \mathrm{~km}^{3}\right)$, or 12 percent, is late- stage differentiates, mainly granophyre, ferrogabbro, and ferrodiorite, and the balance is "typical" diabase.

\section{Variation Within Individual Sheets: Quartz-Normative Tholeiite, High-TiO ${ }_{2}$ (York Haven) Magma Type}

Rapidan.-The Rapidan sheet, a large, canoeshaped diabase body about $37 \mathrm{mi}^{2}$ in area, occupies much of the southern extremity of the Culpeper basin in Culpeper and Madison Counties, Virginia. It intruded and thermally metamorphosed Triassic sedimentary rocks. The central part of the sheet is roofed by hornfels, and most of the margins are exposed and upturned, forming a basinlike structure. However, the northeast part of the sheet, east of the pre-Mesozoic basement inlier at The Ridge (see fig. 1), has an offshoot that extends northeasterly, providing continuity to the granophyre-bearing diabase sheets at Germanna Bridge, Berry Hill, and their extensions. If the attitude of the diabase is parallel to the dip of the hornfels, the sheet is about $1,200 \mathrm{ft}(360 \mathrm{~m})$ thick on the southeast flank but is 


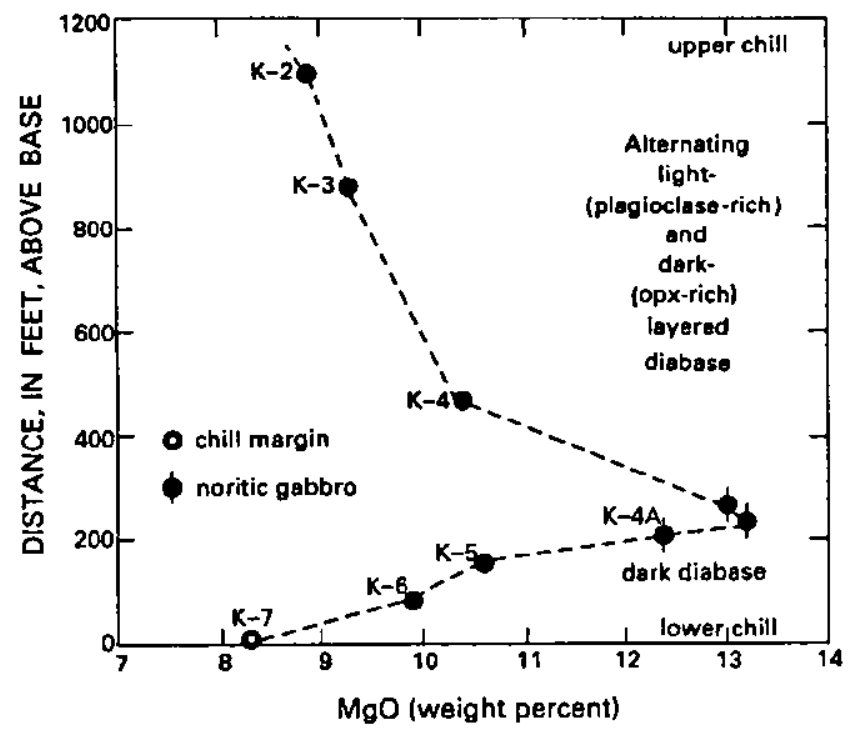

Figure 4A. Plot of the distance above the lower contact of the Rapidan, Virginia, sheet against $\mathrm{MgO}$ and petrologic zones. Opx, orthopyroxene.

possibly much thicker to the northeast. The west flank is cut by longitudinal faults parallel to the margin, and thickness cannot be estimated reliably.

Samples for geochemical analysis were collected at about $200-\mathrm{ft}(60-\mathrm{m})$ intervals across the southeast flank, including the upper and lower chill margins, from three quarries, and from scattered fresh outcrops. Analyses of the aphyric lower chill margin (table 1) indicate that the parent magma is HTQ, containing 51.8 percent $\mathrm{SiO}_{2}$, 8.25 percent $\mathrm{MgO}$, and 1.05 percent $\mathrm{TiO}_{2}$.

The lower part of the sheet along the southeast margin is largely melanocratic, fine- to mediumcrystalline, opx-bearing diabase. It is overlain by medium- to coarse-crystalline, noritic gabbro with conspicuous phenocrysts of honey brown opx. The noritic zone is overlain by alternating light and dark layers of medium crystalline, opx-bearing diabase, with opx progressively less abundant towards the upper contact. This layered unit shows many indications of magmatic current action with "cut and fill" and "cross-bedded" features commonplace in the light and dark layers. A few widely scattered pegmatite layers, seams, veins, and pods are present, most visible on quarry walls at the Mitchells and Virginia Black Granite quarries. In addition to coarse plagioclase and pyroxene crystals, tourmaline and sulfides are prominent locally.

As shown in figure $4 A$, the $\mathrm{MgO}$ content in the Rapidan sheet increases from 8.3 percent at the base to more than 13 percent near the top of the noritic gabbro. The upper $750 \mathrm{ft}(235 \mathrm{~m})$ of alternating dark- and light-layered diabase shows an upward decrease in $\mathrm{MgO}$ content from about 11 percent to less than 9 percent near the upper contact. The chondrite-normalized REE pat-

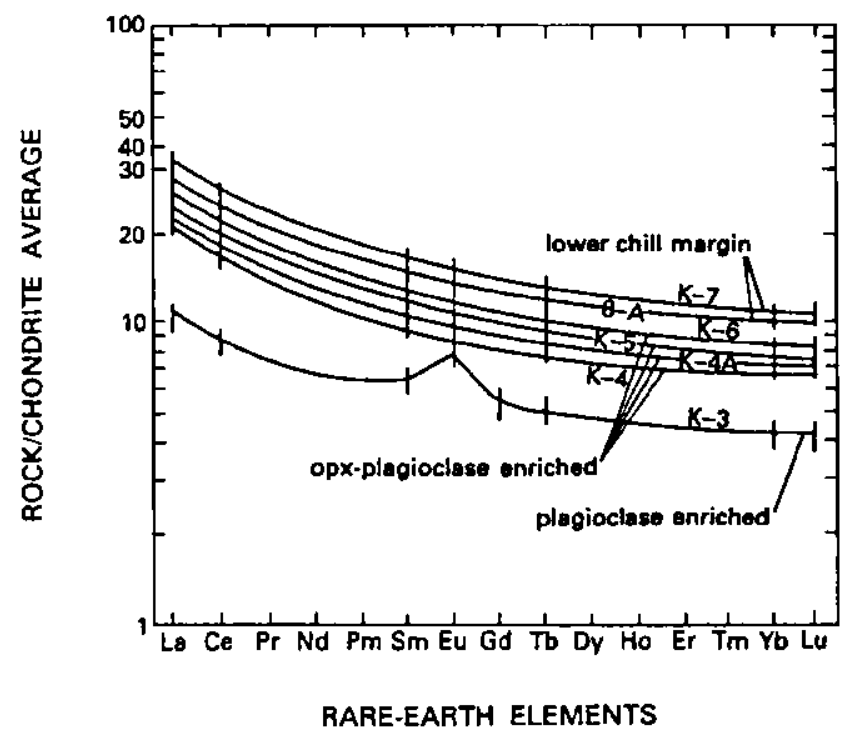

Figure 4B. Chondrite-normalized REE patterns of the Rapidan, Virginia, sheet. Opx, orthopyroxene.

terns of seven samples of the Rapidan sheet are shown in figure $4 B$. The two chill-margin samples show REE abundances and patterns typical for HTQ tholeiites elsewhere in eastern North America, with light REE (La through $\mathrm{Sm}$ ) markedly enriched relative to the heavy REE (Tb through Lu). The norite and the other opx-rich zones show lower REE abundances, but patterns parallel to the chill-margin samples. A leucocratic sample with sparse opx shows the lowest abundances and a positive Eu anomaly, probably reflecting cumulus plagioclase. Conversely, samples that have increasing REE abundances generally have increasing negative Eu anomalies, showing the effects of plagioclase fractionation. Other trace-element data (unpublished) are consistent with REE variations.

The large difference between the average $\mathrm{MgO}$ content of the bulk of the sheet and that of the chill margins indicates an apparent lack of mass balance in the vertical section. The extremely thick and widespread zones enriched in cumulus opx reflected by the high $\mathrm{MgO}$ content, the lack of any significant complementary fraction between upper and lower contacts, and the prominent layered sequence showing evidence of flowage and magmatic currents suggest that the Rapidan sheet probably formed by flow differentiation resulting from lateral migration of the residual magma, possibly accompanied by local in-situ fractionation. The complementary fraction is probably represented in the contiguous Germanna Bridge sheet some 10 to $20 \mathrm{mi}$ (16 to $32 \mathrm{~km}$ ) to the north-northeast that has a core of granophyre and ferrogabbroic differentiates.

Boyds. - The Boyds sheet, an isolated, saucershaped diabase body about $3 \mathrm{mi}^{2}$ in area, is situated in the extreme northeast corner of the Culpeper basin in 


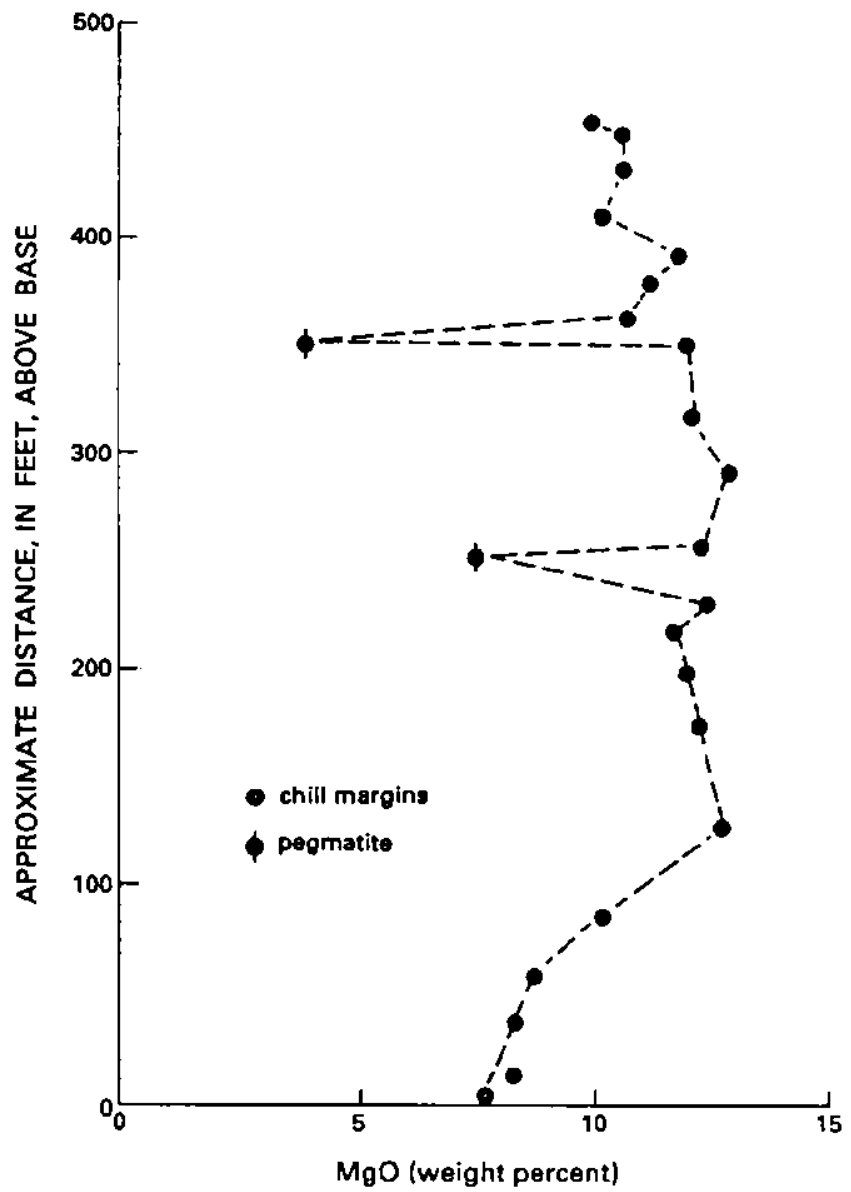

Figure 5A. Plot of the distance above the lower contact of the Boyds, Maryland, sheet against MgO. (From Gottfried and Froelich, 1985.)

Montgomery County, Maryland (fig. 1). It intrudes and overlies pre-Mesozoic schist and gneiss and has thermally metamorphosed basal Triassic sandstone on the south and west. Although the sheet is unroofed and the upper $100 \mathrm{ft}(30 \mathrm{~m})$ or more removed by erosion, about $500 \mathrm{ft}$ $(150 \mathrm{~m})$ remain. Three core holes $(9-75,2 \mathrm{~A}-75,11-75)$ of some 15 available were sampled for petrographic and geochemical analysis at about $20-\mathrm{ft}(6 \mathrm{~m})$ intervals, or where conspicuous lithologic changes occurred. Analyses of the aphyric chill margins (table 1) indicate that the parent magma is HTQ, containing 52.1 percent $\mathrm{SiO}_{2}$, 7.55 percent $\mathrm{MgO}$, and 1.1 percent $\mathrm{TiO}_{2}$.

According to Ragland and Arthur (1985, p. 91), rocks in the lower $75 \mathrm{ft}(23 \mathrm{~m})$ of the Boyds sheet grade upward in texture from aphyric intergranular to subophitic, porphyritic, noritic diabase, locally injected by mafic pegmatite veins.

As shown in figure $5 A$ (from Gottfried and Froelich, 1985 , p. 89 , fig. $16-5$ ), the MgO content increases uniformly across the aphyric zone from 7.5 percent at the lower chill to more than 13 percent near the base of the noritic diabase. Except for the two thin pegmatitic zones with 4 and 7 percent $\mathrm{MgO}$, the $\mathrm{MgO}$ content of the

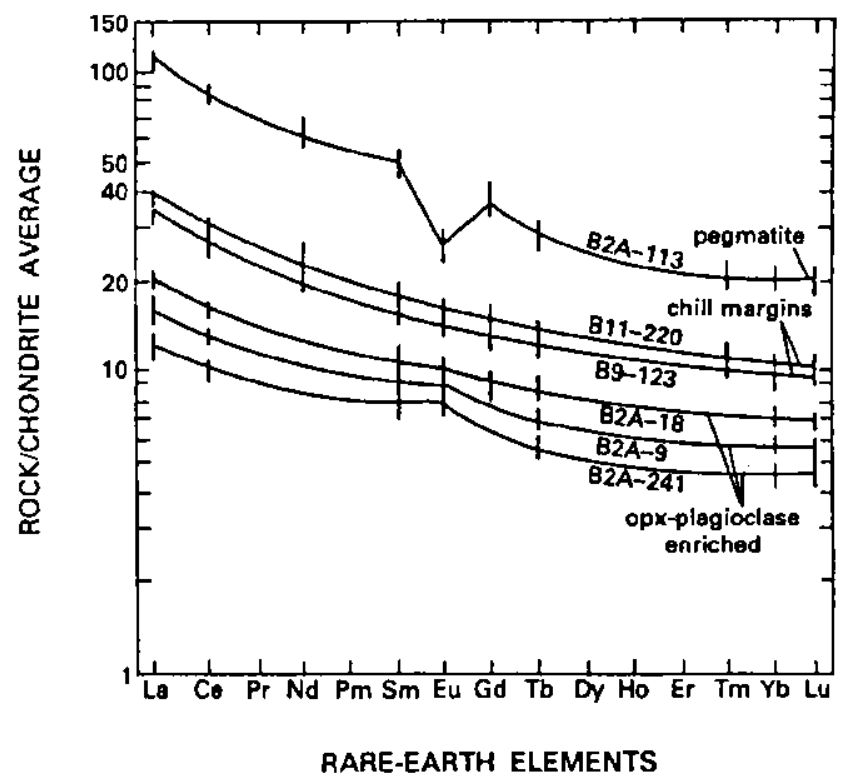

Figure 5B. Chondrite-normalized REE patterns of the Boyds, Maryland, sheet. Opx, orthopyroxene. (From Gottfried and Froelich, 1985,

overlying noritic diabase fluctuates between 12 and 13 percent, whereas the upper $65 \mathrm{ft}(20 \mathrm{~m})$ varies narrowly between 9 and 10 percent. Plots of $\mathrm{Cr}$ and $\mathrm{Ni}$ against distance above the lower contact mimic the $\mathrm{MgO}$ variation (Gottfried and Froelich, 1985). The chondritenormalized REE patterns of seven representative samples through the Boyds sheet are shown in figure $5 B$. Plots of other incompatible trace elements (Gottfried and Froelich, 1985) and unpublished data mimic the variations shown by the REE. The two chill-margin samples show REE abundances and patterns strikingly similar to the chill margin of the Rapidan sheet, and the opx-rich zones show similar patterns of depletion; however, the pegmatoid shows striking enrichment in all REE abundances and a prominent negative Eu anomaly.

Belmont. - The Belmont sheet is an irregularly shaped, northerly aligned diabase body about $231 / 2 \mathrm{mi}^{2}$ in area in the northwestern Culpeper basin extending south from Leesburg, Virginia. It intruded Triassic strata and is now nearly surrounded by Triassic hornfels, with meta-arkose and metaconglomerate on the west flank. Four closely spaced core holes penetrate a granophyric differentiate at least $500 \mathrm{ft}(150 \mathrm{~m})$ thick, and fresh samples of granophyre and ferrodiorite were collected and analyzed from several quarries at Goose Creek near the north end of the sheet, as documented by Lee and others (1984) and Mihm (1986). Mihm (1986), in her study of the geochemistry, petrography, and petrogenesis of the Belmont and Arcola sheets, collected numerous samples from fresh outcrops and road cut exposures to obtain regional coverage. Analyses of the chill margins (table 1) indicate that the parent magma is HTQ, the 


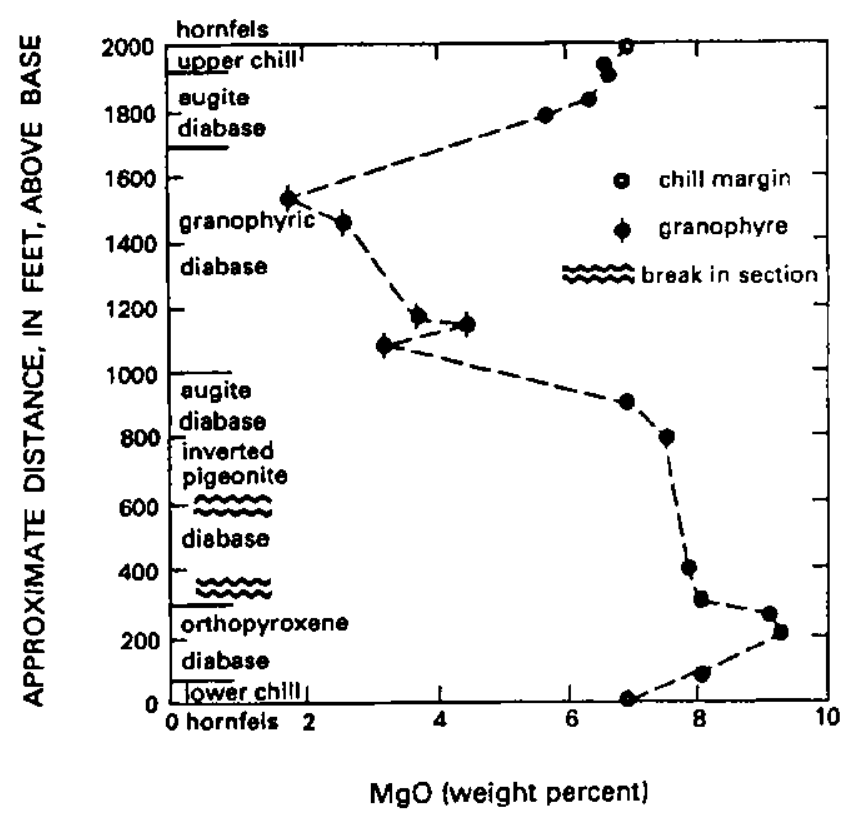

Figure 6. Plot of the approximate distance above the lower contact of the Belmont, Virginia, sheet against $\mathrm{MgO}$ and petrologic zones.

lower chill having 51.77 percent $\mathrm{SiO}_{2}, 6.85$ percent $\mathrm{MgO}$, and 1.12 percent $\mathrm{TiO}_{2}$, and the upper chill having 51.02 percent $\mathrm{SiO}_{2}, 7.04$ percent $\mathrm{MgO}$, and 1.12 percent $\mathrm{TiO}_{2}$.

Mihm (1986, p. 18) subdivided the Belmont sheet into four main petrographic types based on texture and pyroxene population: (1) chill zone; (2) orthopyroxene diabase; (3) inverted pigeonite diabase; (4) augite diabase. The augite diabase encloses abundant ferrodiorite and granophyric and granitic differentiates.

Figure 6 is a plot of the MgO content against the estimated distance in feet above various lower contacts to create a composite section of the complex Belmont sheet. It shows that the $\mathrm{MgO}$ content increases from 6.85 percent at the base to more than 9 percent in the orthopyroxene diabase. The $\mathrm{MgO}$ content of the inverted pigeonite and overlying augite diabase decreases gradually from about 8 to 7 percent, then ranges from less than 2 to 6 percent across the ferrodiorite and pegmatitic and granophyric differentiates that are overlain by augite diabase having an $\mathrm{MgO}$ content of 6.5 to 7.04 percent at the upper chill margin.

The chondrite-normalized REE patterns of six representative samples of the Belmont sheet are shown in figure 7. The two chill-margin samples show abundances and patterns similar to the chill samples of Rapidan and Boyds sheets (figs. $4 B, 5 B$ ) and the opx cumulate sample is also similarly depleted in REE. The late-stage ferrodiorite and granophyric differentiates show an enrichment pattern of REE relative to the chill-margin samples, especially in the light REE (La through $\mathrm{Sm}$ ), and a moderate negative Eu anomaly,

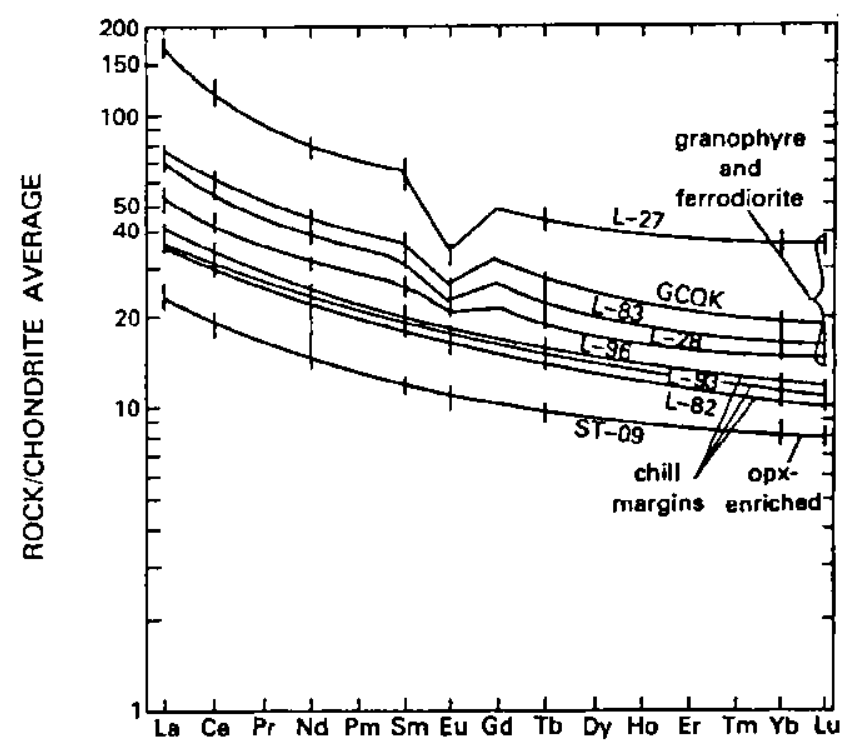

\section{RARE-EARTH ELEMENTS}

Figure 7. Chondrite-normalized REE patterns of the Belmont, Virginia, sheet.

probably reflecting plagioclase fractionation effects. The REE abundances and patterns are similar but more subdued than the pegmatoid at Boyds (fig. $5 A$ ). Unpublished trace-element data are consistent with patterns of enrichment and depletion that are based on REE.

The areally restricted, comparatively thin basal zone enrichment in cumulus orthopyroxene at the north part of the Belmont sheet, reflected by the moderate $\mathrm{MgO}$ content (8.5-9.5 percent) relative to the extensive and thick zone of low $\mathrm{MgO}$ differentiates in the core, indicates an apparent lack of mass balance. The complementary mafic fraction enriched in $\mathrm{MgO}$ is possibly represented in the Boyds shect to the northeast.

\section{Quartz-Normative Tholeiite, Low-TiO (Rossville) Magma Type}

Nokesville.-The Nokesville sheet, a tabular, northeast-trending, gently west-dipping, medium-grained diabase sill, extends for $19 \mathrm{mi}(30 \mathrm{~km})$ in a belt $0.6 \mathrm{mi}(1.0$ $\mathrm{km}$ ) wide. In places it is a single sheet, in other areas it is divided into two or three bodies by intercalated lenticular rafts of Triassic hornfels several kilometers long and as much as $250 \mathrm{ft}(75 \mathrm{~m})$ thick, similar in most respects to the overlying and underlying hornfels. At its south end, the Nokesville sheet is intruded and chilled against the HTQ Gainesville East sheet; to the north it overlies, is parallel to, and separated from the Gainesville East sheet by a northward-thickening prism of Triassic hornfels and unmetamorphosed red siltstone. Thickness of the sheet 


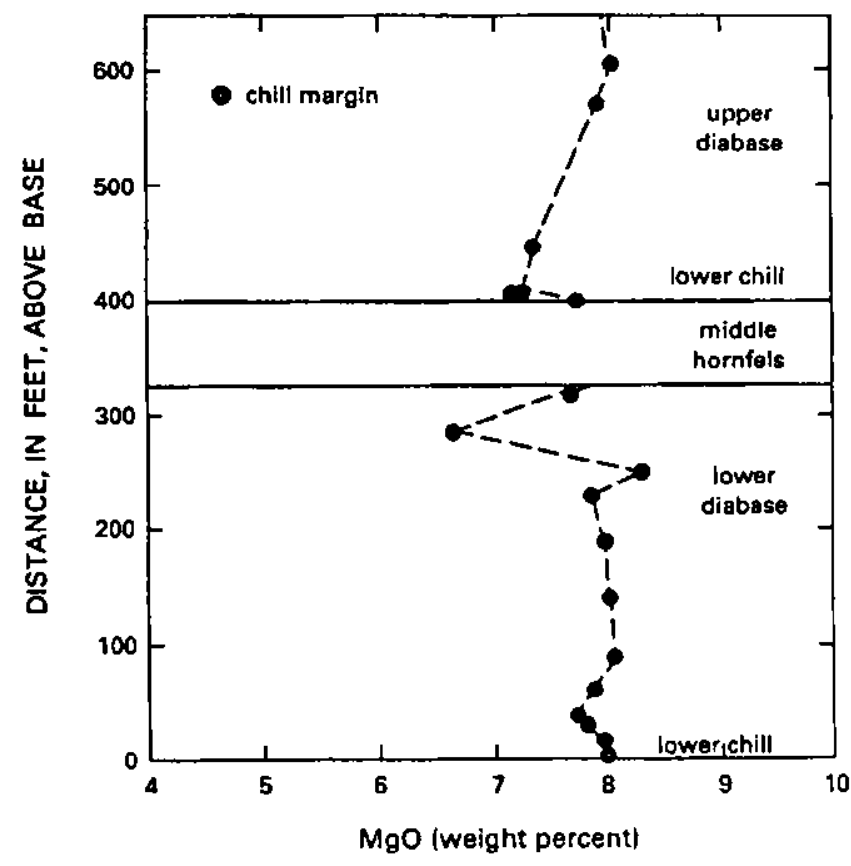

Figure 8. Plot of the distance above the base of the lower Nokesville, Virginia, sheet against MgO.

ranges from about $330 \mathrm{ft}(100 \mathrm{~m})$ to more than $1,300 \mathrm{ft}$ $(400 \mathrm{~m})$ and averages $700 \mathrm{ft}(210 \mathrm{~m})$. The south part of the Nokesville sheet has been extensively cored by 21 holes, of which parts of 11 have been analyzed. Analyses of the chill-margin samples (table 1) indicate that the parent magma is an LTQ, containing an average (5 samples) of 50.5 percent $\mathrm{SiO}_{2}, 7.8$ percent $\mathrm{MgO}$, and 0.75 percent $\mathrm{TiO}_{2}$. Small variations in major-element chemistry of the chill margins may reflect differences due to sampling the margins of upper and lower sheets where separated by hornfels.

The mineralogy and major-element chemistry are very consistent and show no discernible trends of differentiation across the lower $400 \mathrm{ft}(120 \mathrm{~m})$; a local variation or differentiation possibly due to an unusual concentration of plagioclase phenocrysts by flotation is apparent near the upper contact of the lower sheet with hornfels, but such changes are relatively minor (fig. 8 ).

The chondrite-normalized REE abundances and patterns in the Nokesville LTQ sheet (fig. 9) show less enrichment in the light REE than found in any of the HTQ sheets, a characteristic noted from chill-margin patterns (fig. 3). The REE patterns and abundances are similar throughout the several hundred feet of diabase sampled at Nokesville. Unpublished incompatibleelement data are consistent with the REE patterns. Plots of $\mathrm{Cu}$ and $\mathrm{Pd}+\mathrm{Pt}$ against $\mathrm{MgO}$ content (shown in figs. 16.2 and 16.3 of Gottfried and Froelich, 1985) show that

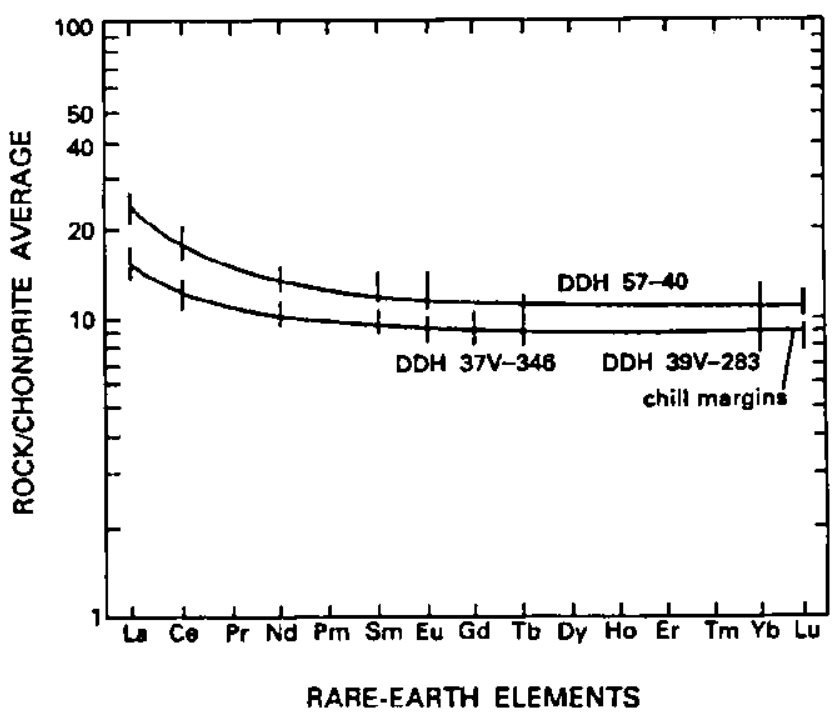

Figure 9. Chondrite-normalized REE patterns of the Nokesville, Virginia, sheet.

the LTQ has consistently lower $\mathrm{Cu}$ and Pd+Pt contents than the HTQ magma type (see also Gottfried and Froelich, this volume).

\section{DIABASE LINEAGES}

The principal diabase sheets of the Culpeper basin are quartz-normative tholeiites of Early Jurassic age. The thickest, most voluminous (table 3 ), and chemically most varied are HTQ, whereas the LTQ are relatively thin, areally restricted (table 3 and fig. 1), and appear to be uniform chemically. Dikes include both quartznormative and olivine-normative types, but the latter have been insufficiently studied to allow generalizations.

Mass balance in a closed igneous system refers to the expected proportional distribution of an element or compound between rocks in the same igneous body that are either depleted or enriched in that element relative to the chill margin. None of the HTQ diabase sheets in the Culpeper basin exhibit mass balance in any given section across the exposed tilted sheets or penetrated vertically by core holes, and mass balance in what is typically considered a single sheet is thus far unknown. Taken as a whole, the HTQ magma type exhibits major-element geochemical manifestations of fractional crystallization along the classic iron-enrichment trend characteristic of fractionating tholeiitic magmas (McBirney, 1984). Chill margin geochemistry of the HTQ magma type in the Culpeper basin, whether enclosing opx cumulates, evolved diabase, or late-stage differentiates, is remarkably uniform and homogeneous.

Field geologic relations, especially the mapped distribution of zones enriched in cumulus opx compare 


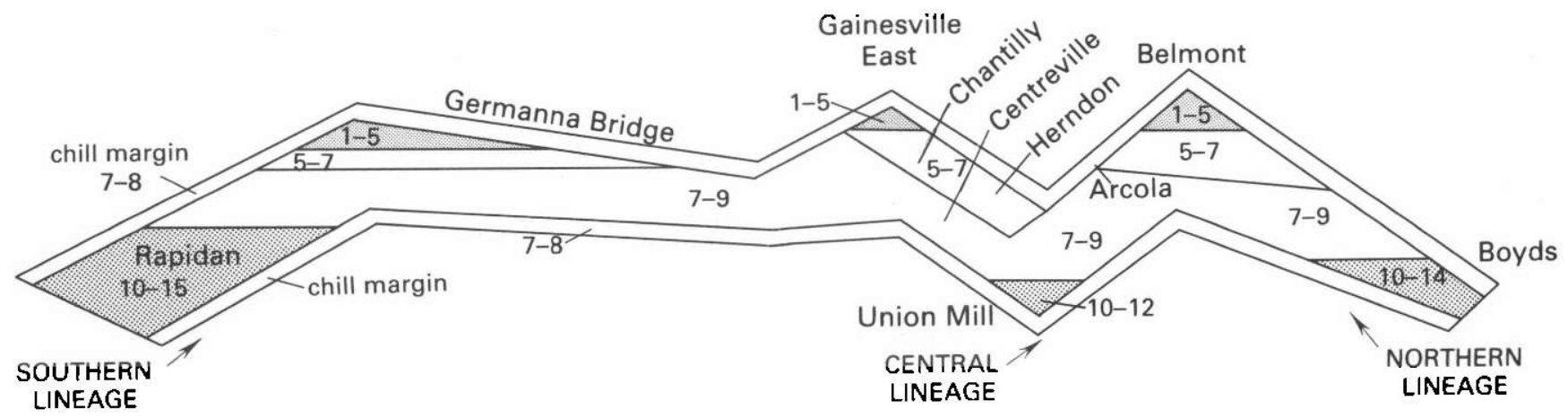

EXPLANATION

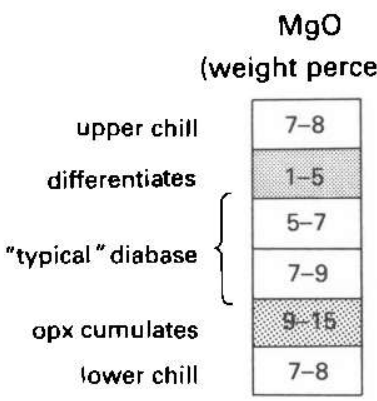

Figure 10. Schematic north-south section through high- $\mathrm{TiO}_{2}$ quartz-normative (HTQ) sheets of the Culpeper basin, Virginia and Maryland, showing inferred geochemical relations and lineages.

to the distribution of granophyric zones in the same or in contiguous sheets (supplemented by petrography and the available geochemical data), indicate that at least two and possibly three separate lineages of HTQ magma are represented in the diabase sheets of the Culpeper basin (fig. 10 and fig. 1). As used in this report, a diabase lineage is a group of comagmatic sheets and dikes whose geographic, geologic, and petrologic configuration imply a close genetic relationship. Taken collectively, the group of HTQ sheets may approximate mass balance. These are: a northern lineage that includes the Boyds opx cumulate, and the Belmont, Arcola, and Arcola South sheets that enclose differentiates; a southern lineage that includes the Rapidan opx cumulate and the Germanna Bridge sheet that encloses aplite, granophyre, and ferrogabbro; and an east-central lineage that includes the Union Mill opx-bearing plug, the Herndon sheets and dikes, the Centreville, Chantilly, and Gainesville East evolved sheets, and probably the Seneca dike system.

Thus far, only a single LTQ lineage has been delineated in the west-central Culpeper basin. This includes the Remington sheet, the Catlett, Nokesville, and Gainesville West sheets, the Haymarket dike, and the Ashburn-Dickerson dike system.

The geochemical data for the quartz-normative tholeiites of the Culpeper basin indicate that the HTQ and LTQ magmas are not related by any simple crystallization-differentiation process. They are derived either from separate source areas or by complex melting processes.

On the basis of preliminary unpublished data, all of the olivine-tholeiitic plugs and dikes may belong to a single lineage, but the spectrum of petrographic types is so broad that future work may necessitate further subdivision. The HTQ, LTQ, and olivine tholeiites of the Culpeper basin may represent the products of separate magmatic systems. It is equally possible that some of the olivine-normative magma is parental to the LTQ and HTQ magmas, but additional work that includes $R b$ and $\mathrm{Sr}$ isotopic studies is needed before interrelationships betwcin the magma types in the Culpeper basin are established.

\section{REFERENCES CITED}

Anders, E., and Ebihara, M., 1982, Solar-system abundances of the elements: Geochimica and Cosmochimica Acta, v. 46, p. 2363-2380.

Froclich, A.J., and Gottfried, D., 1985, Early Jurassic diabase sheets of the eastern United States-A preliminary overview, in Robinson, G.R., Jr., and Froelich, A.J., eds., Proceedings of the second U.S. Geological Survey workshop on the early Mesozoic basins of the Eastern United States: U.S. Geological Survey Circular 946, p. 79-86.

Froelich, A.J., and Leavy, B.D., 1982, Map showing mineral resources of the Culpeper basin, Virginia and Maryland: 
Availability and planning for future needs: U.S. Geological Survey Miscellaneous Investigations Series Map I-1313-B, scale 1:125,000.

Gottfried, D., and Froelich, A.J., 1985, Geochemical and petrologic features of some Mesozoic diabase sheets in the northern Culpeper basin, in Robinson, G.R., Jr., and Froelich, A.J., eds., Proceedings of the second U.S. Geological Survey workshop on the early Mesozoic basins of the Eastern United States: U.S. Geological Survey Circular 946, p. 86-91.

Gottfried, D., Annell, C.S., and Schwartz, L.J., 1977, Geochemistry of subsurface basalt from the deep corehole (Clubhouse Crossroads Corehole 1) near Charleston, South Carolina-Magma type and tectonic implications, in Rankin, D.W., ed., Studies related to the Charleston, South Carolina, earthquake of $1886-$ A preliminary report: U.S. Geological Survey Professional Paper 1028, p. 91-113.

Gottfried, D., Annell, C.S., and Byerly, G.R., 1983, Geochemistry and tectonic significance of subsurface basalts from Charleston, South Carolina: Clubhouse Crossroads Test Holes \#2 and \#3, in Gohn, G.S., ed., Studies related to the Charleston, South Carolina, earthquake of 1886-Tectonics and seismicity: U.S. Geological Survey Professional Paper 1313, p. A1-A19.

Gottfried, D., Ragland, P.C., and Froelich, A.J., 1985, Styles of differentiation of some Mesozoic diabase sheets in the eastern United States: Geological Society of America Abstracts with Programs, v. 17, no. 7, p. 595.

Gottfried, D., Arth, J.G., and Ragland, P.C., 1986, Lowpartition coefficient trace elements and initial ${ }^{87} \mathrm{Sr} /{ }^{86} \mathrm{Sr}$ ratios in Mesozoic tholeiitic rocks from the southeastern United States: Geological Society of America Abstracts with Programs, v. 18, no. 3, p. 223.

Hart, S.R., 1969, K, Rb, Cs contents and K/Rb, K/Cs ratios of fresh and altered submarine basalts: Earth and Planetary Science Letters, v. 6, no. 4, p. 295-303.

$-1971, \mathrm{~K}, \mathrm{Rb}, \mathrm{Cs}, \mathrm{Sr}$ and $\mathrm{Ba}$ contents and $\mathrm{Sr}$ isotope ratios of ocean floor basalts: Philosophical Transactions of the Royal Society of London, Series A, v. 268, p. 573-587.

Johnson, S.S., and Froelich, A.J., 1982, Aeromagnetic contour map of the Culpeper basin and vicinity, Virginia: Virginia Division of Mineral Resources Publication 41, scale $1: 125,000$.

Keahey, J.M., 1976, Triassic diabases of the Potomac basin, Virginia: unpublished M.S. thesis, University of Connecticut, Storrs, 72 p.

McBirney, A.R., 1984, Igneous petrology: Freeman, Cooper and Co., San Francisco, 504 p.

Leavy, B.D., and Puffer, J.H., 1983, Physical and chemical characteristics of four Jurassic basalts in the Culpeper basin, Virginia: Geological Society of America Abstracts with Programs, v. 15, p. 92.

Leavy, B.D., Froelich, A.J., and Abram, E.C., 1983, Bedrock map and geotechnical properties of rocks of the Culpeper basin and vicinity, Virginia and Maryland: U.S. Geological Survey Miscellaneous Investigations Series Map I-1313-C, scale 1:125,000.
Lee, K.Y., 1979, Triassic-Jurassic geology of the northern part of the Culpeper basin, Virginia and Maryland: U.S. Geological Survey Open-File Report 79-1557, 29 p., 16 pl., scale $1: 24,000$.

1980, Triassic-Jurassic geology of the southern part of the Culpeper basin and the Barboursville basin, Virginia: U.S. Geological Survey Open-File Report 80-468, 19 p., $18 \mathrm{pl}$, scale $1: 24,000$.

Lee, K.Y., Leavy, B.D., and Gottfried, D., 1984, Geochemical data for Jurassic diabase and basalt of the northern Culpeper basin, Virginia: U.S. Geological Survey OpenFile Report 84-771, 19 p.

Mihm, K.A., 1986, Geochemistry, petrography, and petrogenesis of the Belmont diabase sheet, northern Culpeper basin, Virginia: unpublished M.S. thesis, University of Maryland, 202 p.

Mihm, K.A., and Nielson, R.I., 1985, Geochemistry and petrogenesis of the Belmont diabase sheet, northern Culpeper basin, Virginia: Geological Society of America Abstracts with Programs, v. 17, p. 663.

Olsen, P.E., 1984, Comparative paleolimnology of the Newark Supergroup-A study in ecosystem evolution: unpublished Ph.D. thesis, Yale University, New Haven, Connecticut, $726 \mathrm{p}$.

Philpotts, A.R., 1985, Recent petrologic studies of Mesozoic igneous rocks in Connecticut, in Robinson, G.R., Jr., and Froelich, A.J., eds., Proceedings of the second U.S. Geological Survey workshop on the early Mesozoic basins of the Eastern United States: U.S. Geological Survey Circular 946, p. $107-110$.

Ragland, P.C., and Arthur, J.D., 1985, Petrology of the Boyds diabase sheet, northern Culpeper basin, Maryland, in Robinson, G.R., Jr., and Froelich, A.J., eds., Proceedings of the second U.S. Geological Survey workshop on the early Mesozoic basins of the Eastern United States: U.S. Geological Survey Circular 946, p. 91-99.

Ragland, P.C., Brunfelt, A.D., and Weigand, P.W., 1971, Rare earth abundances in Mesozoic dolerite dikes from eastern United States, in Brunfelt, A.O., and Steinnes, Eiliv, eds., Activation analysis in geochemistry and cosmochemistry: Oslo University, Sfortaget, p. 227-235.

Raymond, C.A., Ellwood, B.B., Chaves, L., and Leavy, B.D., 1982, Paleomagnetic analyses of lower Mesozoic diabase and basalt from the central and southern Appalachians: Geological Society of America Abstracts with Programs, v. 14 , p. 76.

Smith, R.C., II, 1973, Geochemistry of Triassic diabase from southeastern Pennsylvania: unpublished Ph.D. thesis, University Park, Pennsylvania State University, 262 p.

Smith, R.C., II, Rose, A.W., and Lanning, R.M., 1975, Geology and geochemistry of Triassic diabase in Pennsylvania: Geological Society of America Bulletin, v. 86, p. 943-955.

Sutter, J.F., 1985, Progress on geochronology of Mesozoic diabase and basalts, in Robinson, G.R., Jr., and Froelich, A.J., eds., Proceedings of the second U.S. Geological Survey workshop on the early Mesozoic basins of the Eastem United States: U.S. Geological Survey Circular 946 , p. $110-114$. 
Sutter, J.F., Arth, J.G., Leavy, B.D., 1983, ${ }^{40} \mathrm{Ar} /{ }^{99} \mathrm{Ar}$ age spectrum dating and strontium isotope geochemistry of diabase sills from the Culpeper basin, Virginia: Geological Society of America Abstracts with Programs, v. 15, p. 92. Weigand, P.W., 1970, Major- and trace-element geochemistry of Mesozoic dolerite dikes from eastern North America: unpublished Ph.D. thesis, University of North Carolina, $162 \mathrm{p}$.
Weigand, P.W., and Ragland, P.C., 1970, Geochemistry of Mesozoic dolerite dikes from eastem North America: Contributions to Mineralogy and Petrology, v. 29, no. 3, p. 195-214.

Wise, M.A., and Johnson, S.S., 1980, Simple Bouguer gravity anomaly map of the Culpeper basin and vicinity, Virginia: Virginia Division of Mineral Resources Publication 24, scale $1: 125,000$.

\title{
ELEMENT MOBILITY DURING ALTERATION OF EARLY MESOZOIC DIABASE SHEETS, CULPEPER BASIN, VIRGINIA
}

\author{
Paul C. Ragland ${ }^{1}$ and Jonathan D. Arthur ${ }^{1}$
}

\begin{abstract}
Twenty-six samples from nine cores in the Nokesville and Gainesville West early Mesozoic diabase sheets, Culpeper basin, Virginia, have been analyzed chemically and petrographically. All samples apparently represent the lowtitanium, quartz-normative (LTQ, or Rossville) magma type, although several unaltered samples are minimally olivine normative. The samples can be divided into four groups based upon their degree of secondary alteration as determined by petrographic analysis and X-ray diffraction. The alteration assemblages primarily consist of chlorite, amphibole, and muscovite (sericite).

Diabases having loss on ignition (LOI) values greater than 2 percent and significant alteration of plagioclase as well as augite are more variable in composition than those whose LOI values are less than 2 percent and in which plagioclase is not apparently altered. This increased compositional variability affects a large number of elements, including some that are generally considered to be immobile (for example, $\mathrm{Al}_{2} \mathrm{O}_{3}$ and $\mathrm{TiO}_{2}$ ), and is commonly sufficient to obscure primary igneous trends on standard variation diagrams. Alkalis and strontium are, on average, significantly enriched in the altered samples relative to the unaltered samples. Average compositions of a few other elements may be affected as well.

It is recommended that less than 2 percent LOI and unaltered plagioclase be used as criteria to screen diabase samples that are used for petrogenetic interpretations of magmatic characteristics of early Mesozoic diabases from eastern North America. However, this screen is not infallible for the alkalis, because $\mathrm{K}_{2} \mathrm{O}$ and rubidium are apparently mobilized in a few samples having LOI values less than 2 percent.
\end{abstract} FL 32306.

\section{INTRODUCTION}

This paper is a preliminary report related to an ongoing study of early Mesozoic diabase (or "dolerite") sheets and surrounding wall rocks in the Culpeper basin, Virginia. The term "sheet" is used to describe any concordant or semiconcordant igneous intrusion, such as a sill, laccolith, or lopolith.

A comparison of chemical compositions and the degree of secondary alteration for some diabases suggests a correlation. Moreover, a surprisingly large number of samples, approximately one-half, are at least moderately altered in thin section. Observation of chemical effects due to secondary alteration in diabases is not unique to this study (for example, Dennen, 1951; Drez, 1977; Fratta and Shaw, 1973; Gottfried and others, 1977). These studies, however, are primarily concerned with chemical changes and either ignore or only briefly deal with the relationship between mineralogical and chemical variability.

Hence the main purpose of this preliminary report is to identify mineralogical changes during secondary alteration of these diabases and to examine the effect of these changes on their chemical compositions. Of particular interest is whether or not secondary alteration has affected chemical trends on variation diagrams typically interpreted as being the result of primary igneous processes. An additional purpose of this report is to develop petrographic and chemical criteria that can be used to screen out samples too highly altered to be used for determining primary igneous characteristics. Such problems as physicochemical conditions under which the alteration took place or origin of the presumed altering fluids must await additional work, such as electron microprobe analyses of minerals, as well as stable trace element and isotope studies. 


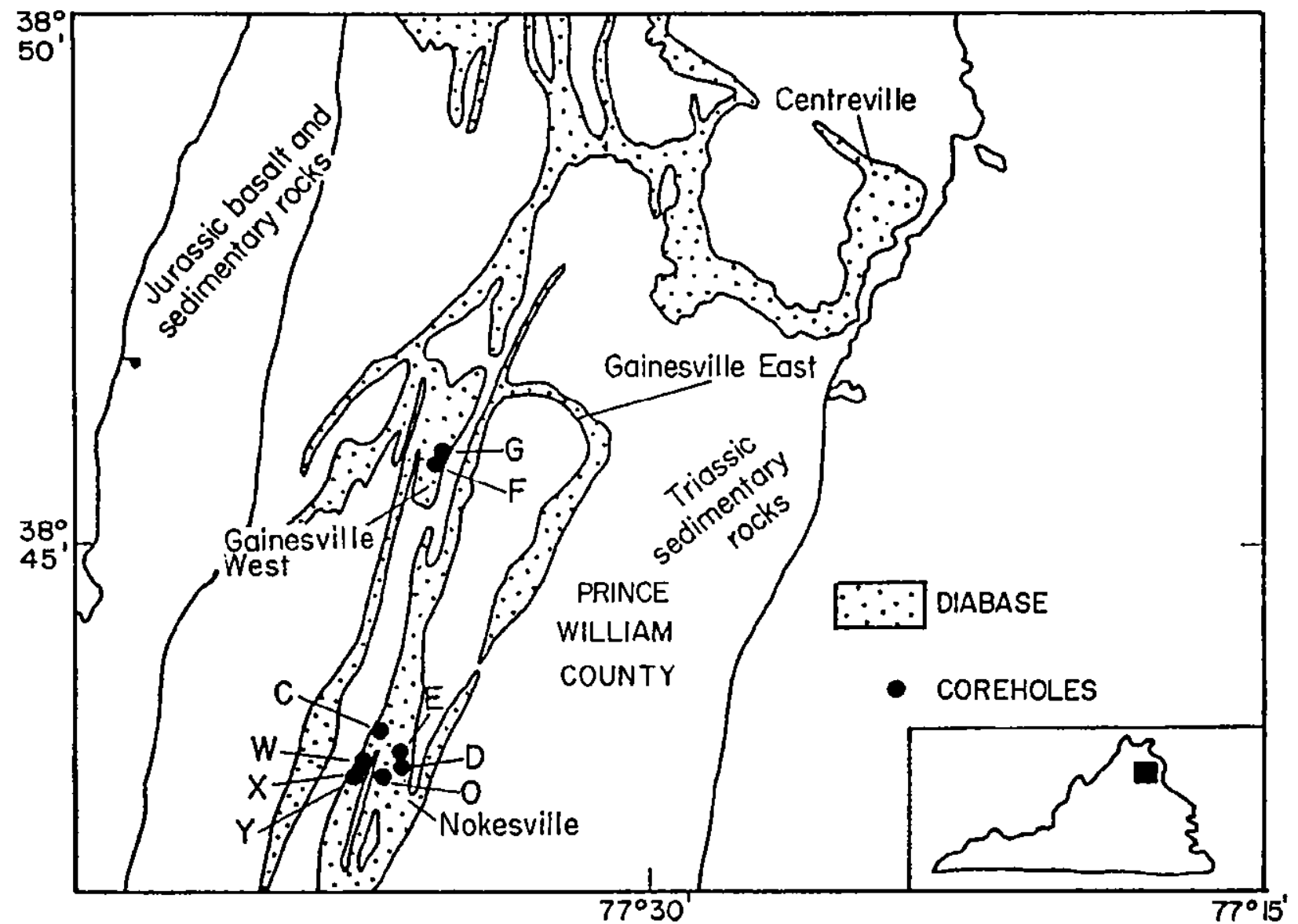

Figure 1. Locality map for nine cores in the Gainesville West and Nokesville sheets, central Culpeper basin, Virginia. Map modified from Gottfried and Froelich (1985). See table 1, footnote 1, for explanation of letter codes.

This study reports on 26 samples from the Gainesville West and Nokesville sheets in the Culpeper basin of Virginia (fig. 1). These two sheets were chosen in order to minimize original compositional differences in the diabase. Rocks from both sheets are of the low-titanium, quartz-normative (LTQ) magma type (Gottfried and Froelich, 1985; Froelich and Gottfried, this volume; Weigand and Ragland, 1970), also referred to as the Rossville magma type (Smith and others, 1975). In addition, these samples were chosen from a restricted geologic and geographic area to minimize variations in wall-rock lithology of the enclosing Triassic Balls Bluff Siltstone and to restrict the range in depth of intrusion.

Samples were taken from seven cores in the Nokesville sheet and two in the Gainesville West sheet (fig. 1). The 26 samples have been analyzed for 10 major and 10 trace elements, as well as loss on ignition (LOI). LOI is determined gravimetrically by placing a $1-\mathrm{g}$ sample in a muffle furnace at $800^{\circ} \mathrm{C}$ for 45 minutes and determining the weight loss. It can be considered as the difference between the total volatiles and the oxygen taken on when all or part of the $\mathrm{Fe}^{2+}$ is oxidized to $\mathrm{Fe}^{3+}$. All elements but $\mathrm{MgO}$ and $\mathrm{Na}_{2} \mathrm{O}$ were analyzed by wavelength- dispersive X-ray fluorescence spectroscopy. These latter two elements were determined by atomic-absorption spectrometry. Calibration curves were prepared from basaltic rock standards. Mass-absorption corrections were made on all trace-element analyses. Precision was within 3 percent for all major elements and within 6 percent for LOI and all trace elements except $Y, C r$, and $\mathrm{Rb}$ ( $<12$ percent). The chemical similarity of four petrographically similar samples (G370.5, G372, G372.5, and G373.5, table 1) taken within $3 \mathrm{ft}$ of one another supports the contention that the chemical analyses are of acceptable precision (table 2 ).

\section{PETROGGAPHY AND ALTERATION}

Fresh or moderately altered samples reveal textures and phenocryst assemblages similar to the eastern North America diabase province as a whole (Chalcraft, 1972). Table 1 summarizes the petrographic and X-ray diffraction data for each of the 26 samples. Grain sizes of groundmass phases indicate that the rocks vary texturally from relatively coarse-grained basalts to fine-grained gabbros. No chill-margin samples were included in this 
Table 1. Petrographic and sample locality data [See footnote 1 and figure 1 for location of cores]

\begin{tabular}{|c|c|c|c|c|c|c|}
\hline Sample' & Feet to base ${ }^{2}$ & Group $^{3}$ & Alteration mineralogy 4 & Texture ${ }^{5}$ & Phenocrysts $^{\theta}$ & Grain size ${ }^{7}$ \\
\hline$\ldots \ldots \ldots$ & 8.5 & 1 & A & $\mathrm{p}, \mathbf{I}$ & $\mathrm{r}, \mathrm{P}, \mathrm{O}$ & $\mathrm{F}-\mathrm{M}$ \\
\hline F313 $\ldots \ldots \ldots \ldots$ & 23.5 & 1 & $\mathrm{~B}$ & $\mathrm{e}, \mathrm{I}$ & $\mathrm{n}$ & $\mathrm{F}-\mathrm{M}$ \\
\hline $\mathrm{G} 341 \ldots \ldots \ldots \ldots$ & 34 & 1 & $\mathrm{Ch}, \mathrm{F}$ & $\mathrm{p}, I$ & $\mathrm{r}, \mathrm{A}, \mathrm{P}$ & $\mathbf{M}$ \\
\hline $\mathrm{X} 101 \ldots \ldots \ldots \ldots$ & $3-8^{8}$ & 1 & $\mathrm{~B}$ & $\mathrm{e}, \mathrm{I}$ & n & $\mathbf{M}$ \\
\hline F274 $\ldots \ldots \ldots \ldots$ & 62.5 & 1 & $\mathrm{~B}, \mathrm{Ch}$ & p,Is-I & $\mathrm{r}, \mathrm{P}$ & $\mathbf{M}$ \\
\hline $\mathrm{G} 350 \ldots \ldots \ldots \ldots$ & $25^{8}$ & 1 & $\mathrm{~B}, \mathrm{Ch}, \mathrm{F}$ & e,Is & $\mathrm{n}$ & $\mathrm{F}-\mathrm{M}$ \\
\hline $\mathrm{D} 91 \ldots \ldots \ldots \ldots \ldots$ & $149^{8}$ & 1 & $\mathrm{~B}, \mathrm{Ch}, \mathrm{F}$ & $\mathrm{p}, \mathrm{Is}-\mathrm{I}$ & $\mathrm{r}, \mathbf{P}$ & $\mathrm{M}-\mathrm{C}$ \\
\hline $\mathrm{D} 150 \ldots \ldots \ldots$ & 90 & 2 & $\mathrm{~B}, \mathrm{Ch}, \mathrm{F}$ & $\mathrm{p}, \mathrm{I}$ & $A, P$ & $\mathbf{M}$ \\
\hline F333 $\ldots \ldots \ldots \ldots$ & 3.5 & 2 & $\mathrm{~A}, \mathrm{~B}, \mathrm{Ch}, \mathrm{M}$ & $\mathrm{p}, \mathrm{S}$ & $\mathrm{r}, \mathrm{A}, \mathrm{P}, \mathrm{O}$ & $\mathbf{M}$ \\
\hline D140............ & 100 & 2 & $\mathrm{~A}, \mathrm{~B}, \mathrm{Ch}$ & $\mathrm{e}, \mathrm{I}$ & n & $\mathrm{M}-\mathrm{C}$ \\
\hline $\mathrm{D} 200 \ldots \ldots \ldots \ldots$ & 40 & 2 & A & $\mathrm{p}, \mathrm{S}$ & A,P & $\mathbf{M}$ \\
\hline $\mathrm{O} 240 \ldots \ldots \ldots \ldots$ & 4 & 2 & $\mathrm{~A}, \mathrm{Ch}, \mathrm{F}, \mathrm{M}$ & $\mathrm{p}, \mathrm{I}$ & $\mathrm{r}, \mathrm{P}$ & $\mathrm{F}-\mathrm{M}$ \\
\hline $\mathrm{O} 241 \ldots \ldots \ldots \ldots$ & 3 & 2 & $\mathrm{~A}, \mathrm{Ch}, \mathrm{M}, \mathrm{Z}$ & $\mathrm{e}, \mathrm{I}$ & $\mathrm{n}$ & F-M \\
\hline G369.......... & 6 & 2 & $\mathrm{~A}, \mathrm{C}, \mathrm{Ch}, \mathrm{M}, \mathrm{F}$ & $\mathrm{e}, \mathrm{S}$ & $\mathrm{n}$ & $\mathrm{M}-\mathrm{C}$ \\
\hline $\mathrm{O} 230 \ldots \ldots \ldots \ldots$ & 14 & 2 & $\mathrm{Ch}, \mathrm{F}, \mathrm{M}$ & $\mathrm{p}, \mathrm{I}$ & $\mathrm{r}, \mathrm{P}$ & F-M \\
\hline $\mathrm{w} 62.5 \ldots \ldots \ldots \ldots$ & $8-15$ & 4 & $\mathrm{~A}, \mathrm{Ch}, \mathrm{F}, \mathrm{M}$ & e,I & $\mathrm{n}$ & $\mathrm{M}-\mathrm{C}$ \\
\hline $\mathrm{Y} 87 \ldots \ldots \ldots \ldots \ldots$ & 6 & 3 & $\mathrm{~A}, \mathrm{~B}, \mathrm{Ch}, \mathrm{F}, \mathrm{M}, \mathrm{Z}$ & $e, I$ & $\mathrm{n}$ & $\mathrm{M}$ \\
\hline $\mathrm{D} 136 \ldots \ldots \ldots \ldots \ldots$ & 104 & 3 & $\mathrm{~B}, \mathrm{Ch}, \mathrm{F}, \mathrm{M}$ & $\mathrm{e}, \mathrm{I}$ & $n$ & $M-C$ \\
\hline $\mathrm{E} 95 \ldots \ldots \ldots \ldots \ldots$ & . $\quad 90^{8}$ & 3 & $\mathrm{~A}, \mathrm{Ch}, \mathrm{M}, \mathrm{Z}$ & $\mathrm{p}, \mathrm{I}$ & $\mathrm{P}, \mathrm{A}$ & $\mathrm{M}-\mathrm{C}$ \\
\hline $\mathrm{G} 372.5 \ldots \ldots \ldots$ & 2.5 & 3 & $\mathrm{~A}, \mathrm{Ch}, \mathrm{F}, \mathrm{Z}$ & $\mathrm{e}, \mathrm{I}$ & n & $\mathbf{M}$ \\
\hline G372............ & 3.0 & 3 & $\mathrm{~A}, \mathrm{Ch}, \mathrm{F}, \mathrm{M}$ & e,I & $\mathrm{n}$ & M \\
\hline G373.5 $\ldots \ldots \ldots$ & 1.5 & 4 & $\mathrm{~A}, \mathrm{Ch}, \mathrm{F}$ & $\mathrm{e}, \mathrm{I}$ & $\mathrm{n}$ & $\mathrm{F}-\mathrm{M}$ \\
\hline $\mathrm{G} 370.5 \ldots \ldots \ldots$ & 4.5 & 4 & $\mathrm{~A}, \mathrm{Ch}, \mathrm{M}, \mathrm{Z}$ & $\mathrm{e}, \mathrm{I}$ & n & $\mathbf{M}$ \\
\hline $\mathrm{E} 151 \ldots \ldots \ldots \ldots$ & $34^{8}$ & 4 & $\mathrm{~A}, \mathrm{Ch}, \mathrm{F}, \mathrm{M}$ & e,Is & $\mathrm{n}$ & $\mathrm{M}-\mathrm{C}$ \\
\hline E161 $\ldots \ldots \ldots \ldots$ & $24^{8}$ & 3 & $\mathrm{~A}, \mathrm{~B}, \mathrm{Ch}, \mathrm{M}$ & $\mathrm{e}, \mathrm{I}$ & $\mathrm{n}$ & $\mathrm{M}-\mathrm{C}$ \\
\hline $\mathrm{C} 140 \ldots \ldots \ldots \ldots$ & . $1-9$ & 4 & $\mathrm{~A}, \mathrm{C}, \mathrm{Ch}, \mathrm{F}, \mathrm{M}$ & e,Is & $\mathrm{n}$ & $\mathrm{F}-\mathrm{M}$ \\
\hline
\end{tabular}

\footnotetext{
${ }^{1}$ Numbers refer to depth below ground level in feet. Letter prefixes refer to the following core designations and sheets: C, Lehigh-4, Nokesville; D, Lehigh-10, Nokesville; E, Lehigh-12, Nokesville; F, 5GV-85, Gainesville West; G, 3GV-85, Gainesville West; O, 51V, Nokesville; W, 36V, Nokesville; X, 37V, Nokesville; Y, 38V, Nokesville.

${ }^{2}$ Approximate distance from basal contact in feet. Accuracy constrained by sampling intervals near contact.

Alteration group based on petrography and geochemistry as explained in text.

${ }^{4}$ Alteration mineralogy as observed by $\mathrm{X}$-ray diffraction and in thin section: A, amphibole; B, biotite; C, calcite; Ch, chlorite; $F, F e$ oxides; $M$, muscovite; $Z$, zeolites.

${ }^{B}$ Texture: e, equigranular; $\mathrm{p}$, porphyritic; I, intergranular; Is, isogranular; $\mathrm{S}$, subophitic.

Phenocryst assemblage: $P$, plagioclase; $A$, augite; $O$, olivine; $r$, rare; $n$, not present.

${ }^{7}$ Average grain size of groundmass (long dimension): $\mathrm{F}$, fine $(<0.1 \mathrm{~mm})$; $\mathrm{M}$, medium $(0.1-1.0 \mathrm{~mm})$; $\mathrm{C}$, coarse $(>1.0 \mathrm{~mm})$

${ }^{8}$ Indicates that sample was within approximately $5 \mathrm{ft}$ of a joint or fracture.
}

study. However, geochemistry of chill margins of LTQ diabases in the Culpeper basin is discussed by Froelich and Gottfried elsewhere in this volume. Most of the samples would be classified as diabase, using the term to denote a certain grain size $(0.1-1.0 \mathrm{~mm}$ in diameter or long dimension). Groundmass textures include isogranular, intergranular, and subophitic. Some rocks are equigranular, but most contain at least a few phenocrysts. Where present, the phenocryst (or microphenocryst) assemblage is plagioclase + augite +olivine. Sparse olivine phenocrysts were only observed in two samples (F333 and F328), both of which contained less than 2 volume percent. The unaltered groundmass assemblage invariably consists of plagioclase, augite, and $\mathrm{Fe}-\mathrm{Ti}$ oxides.

The most common alteration products, as identified by both $\mathrm{X}$-ray diffraction and petrography, are: chlorite - penninite and clinochlore, amphibole - uralite, actinolite, and oxyhornblende(?), and muscovite (sericite).

Any of these minerals, in addition to calcite, can fill veins, small vuglike cavities, and amygdules (fig. 2 ). In addition, any of them can be disseminated throughout the groundmass and form rims around and fracture fillings in phenocrysts. Initial development of alteration in the groundmass begins with alteration products along fractures, partings, and cleavage planes in augite. Very small amounts of secondary(?) biotite are disseminated in the groundmass of most of the relatively unaltered samples. Secondary iron oxides are also products of the alteration of all primary ferromagnesian phases. Very weak zeolite $\mathrm{X}$-ray peaks were detected for some samples, but it was 


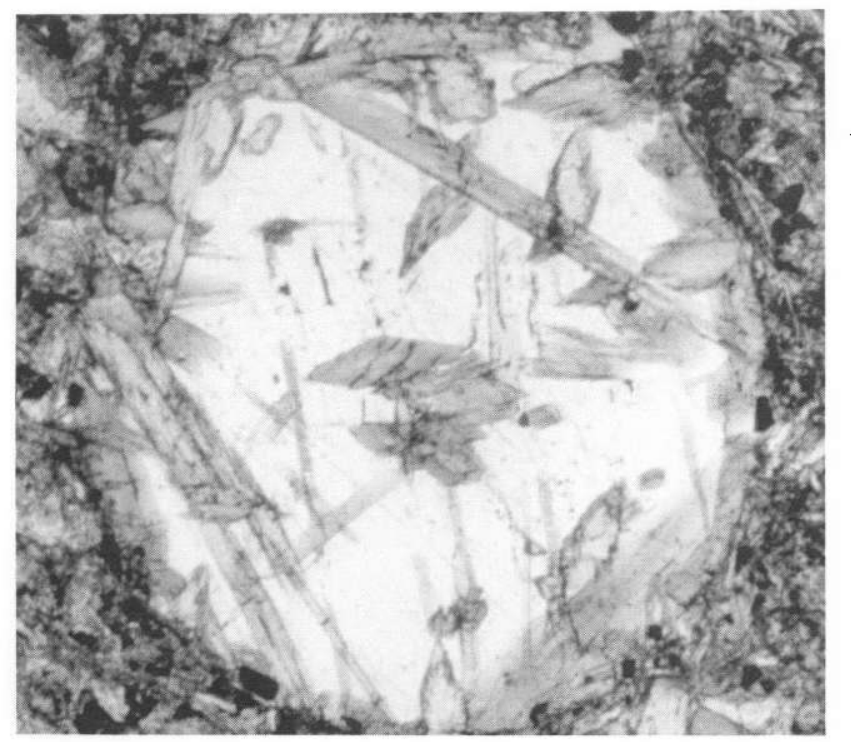

Figure 2. Photomicrograph of calcite- and actinolite-filled amygdule. Gray, bladelike crystals are actinolite. Plane light; $\times 72$.

impossible to determine which zeolite was present. In the most altered samples, no primary phases remain, and phenocrysts have been pseudomorphously replaced by secondary minerals. After alteration has progressed to a considerable degree, pyroxene pseudomorphs are most commonly chlorite, but some are actinolite. The only recognizable mineral in plagioclase pseudomorphs is muscovite (sericite). Uralite is the most common alteration product of olivine. A careful check, both optically and by X-ray diffraction, was made to determine if epidote-clinozoisite was an alteration product of plagioclase, but none was detected. An unidentified, very fine-grained material of extremely low birefringence is common in plagioclase pseudomorphs, but electron probe analysis will be required to identify it. Samples tend to be more altered toward the base of each sheet or near joints and fractures, with numerous exceptions (table 1).

Petrographic examination revealed that the rocks could be divided into four groups on the basis of degree of alteration. An important observation, on which these four groupings are based, is that the pyroxenes break down before plagioclase. Hence the four groups are delineated as follows:

Group $1-$ fresh and unaltered; alteration products constitute $<10$ percent of both groundmass plagioclase and augite.

Group 2 - slightly altered; groundmass plagioclase $<10$ percent altered; groundmass augite 10 to 50 percent altered.
Group 3 - altered; groundmass plagioclase 10 to 90 percent altered; groundmass augite 50 to 90 percent altered.

Group 4 - highly altered; both groundmass plagioclase and augite $>90$ percent altered.

Examples of each of these four groups are illustrated in figure 3 . The four groups above were based on observations of the groundmass assemblage, not phenocrysts. Many samples contain no phenocrysts (table 1), and where present, their degree of alteration appears to be nonsystematic.

\section{CHEMICAL TRENDS}

Major- and trace-element analyses for the 26 samples are given in table 2 . Note that all samples in groups 3 and 4 have LOI values $>2$ percent. It should be re-emphasized, however, that samples were classified into four groups on the basis of petrography, not LOI. Inasmuch as most samples from groups 3 and 4 are also apparently chemically altered for many elements (see discussion below), an LOI value of 2 percent is considered a maximum as a screen for fresh samples. Other than LOI and perhaps the content of $\mathrm{K}_{2} \mathrm{O}$ and $\mathrm{Rb}$, no obvious chemical differences were noted between petrographic groups 1 and 2 or between groups 3 and 4 . LOI values are clearly lower in group 1 than group 2 , whereas $\mathrm{K}_{2} \mathrm{O}$ and $\mathrm{Rb}$ contents appear to be somewhat more variable in group 2 (for example, note $\mathrm{K}_{2} \mathrm{O}$ and $\mathrm{Rb}$ contents in samples G369 and D150, table 2). This apparent chemical similarity between groups 1 and 2 and between groups 3 and 4 for all remaining elements may reflect an insufficient number of samples in this study or a true lack of chemical differences. Because of the similarity in chill margin analyses in both the Nokesville and Gainesville West sheets (Froelich and Gottfried, this volume), the latter is more likely. In any case, for purposes of the subsequent discussion, petrographic groups 1 and 2 are combined into one chemical group representing relatively unaltered samples (group $U$ ), and groups 3 and 4 are combined into a group of relatively altered samples (group A).

In addition to an LOI value of 2 percent as an upper limit for adequately fresh samples, these grcupings suggest that the alteration of plagioclase can be used as an additional, qualitative screen. Since alteration of plagioclase ( $>10$ percent) and augite ( $>50$ percent) are the main criteria by which petrographic groups 2 and 3 are distinguished from one another, it follows that the same criteria will apply to distinguish groups $U$ and $A$.

Evidence in this section suggests that the averagc composition for group A prior to alteration was quite similar to that for group U. The first line of evidence to support this claim is that classification of a sample into a 


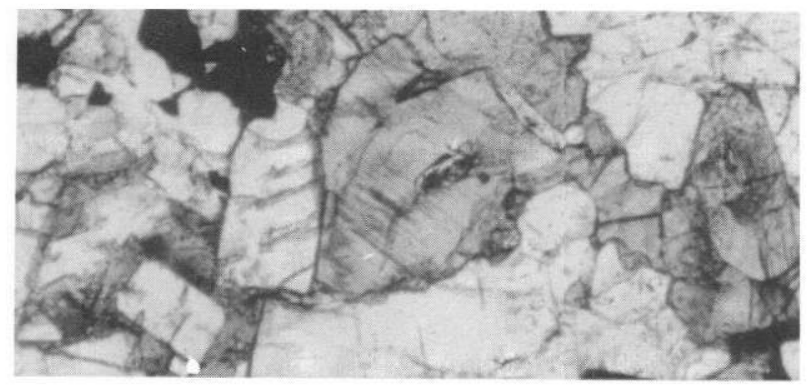

GROUP 1

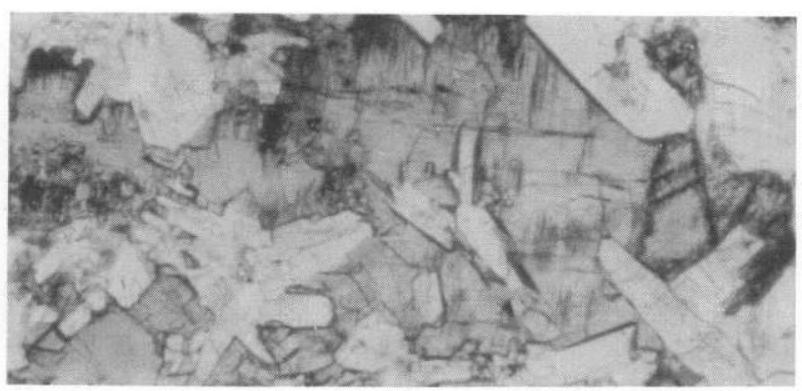

GROUP 2

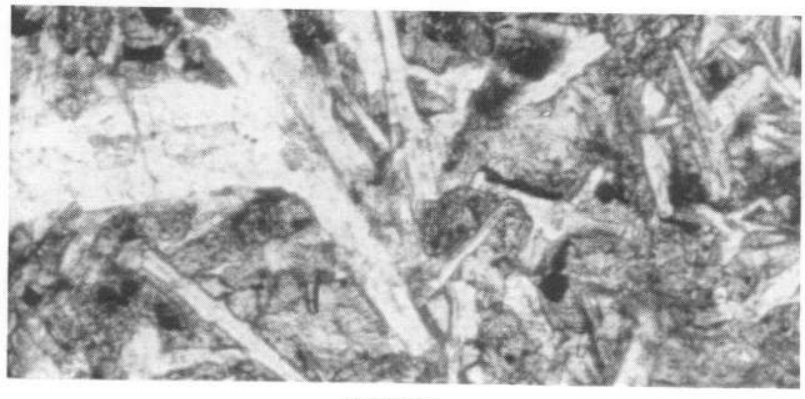

GROUP 3

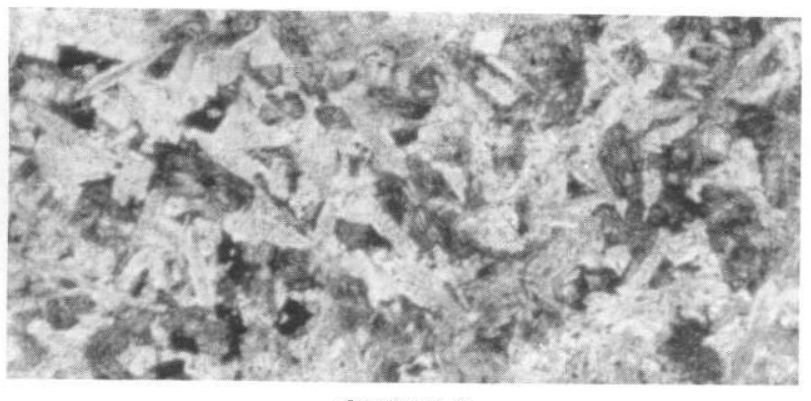

GROUP 4

Figure 3. Photomicrographs depicting four groups based on degree of alteration. See text for explanation. Either fresh or altered augite can be distinguished from fresh or altered plagioclase in that the augite is darker and plagioclase laths are apparent. Plane light; $\times 72$.

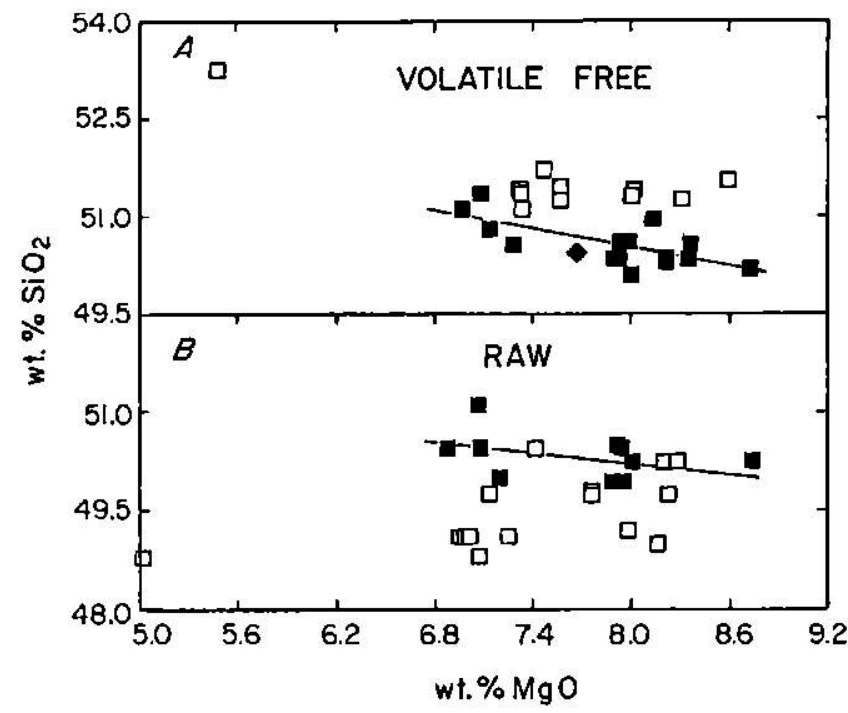

Figure 4. Weight percent $\mathrm{MgO}$ versus weight percent $\mathrm{SiO}_{2}$. $A$, Data recalculated to 100 percent on a volatile-free basis. $B$, Raw data. On this and subsequent figures, open squares represent relatively altered (group A) samples; closed squares represent relatively fresh (group U) samples. For figures 4 through 6: (1) solid line is least-squares regression best-fit line for samples in group $U$ and (2) Nokesville average chill margin $(n=5)$ denoted by closed diamond. Chill-margin data for Nokesville sheet from Froelich and Gottfried (this volume).

group is not related to either the core or sheet from which the sample was collected (table 1).

Figure 4 is indicative of a problem that was encountered at the outset of this study. The introduction of $\mathrm{H}_{2} \mathrm{O}$ (and possibly $\mathrm{CO}_{2}$ ) accompanying alteration, with a concomitant increase in LOI (table 2), results in a dilution effect on all other constituents. Even if the rocks were isochemically altered with regard to every constituent except the volatiles, compositions of other oxides are lowered in proportion to the amount of volatiles introduced. The simplest solution to avoid the dilution effect is to recalculate the raw data excluding volatiles to 100 percent, in this case as measured by LOI. Figure 4 graphically illustrates the effect of recalculation of the data to 100 percent on a volatile-free basis. The negative correlation between $\mathrm{MgO}$ and $\mathrm{SiO}_{2}$ on figure 4 for group $\mathrm{U}$ is typical of primary igneous processes, such as crystal fractionation. Note, however, that when the raw data are used, $\mathrm{SiO}_{2}$ (fig. $4 B$ ) is systematically lower in group $\mathrm{A}$ than group $\mathrm{U}$, whereas the opposite exists after recalculation as volatile-free analyses (fig. $4 A$ ). As a result, subsequent discussions are based on data recalculated on a volatile-free basis (table 3 ).

It is significant to note that the most MgO-depleted and $\mathrm{SiO}_{2}$-enriched sample on figure $4 B$ (sample $\mathrm{C140}$, table 2 ) is probably the most altered. Although chemically it superficially resembles andesite, sample C140 is in petrographic group 4 and has the highest LOI value, 
Table 2. Major- and trace-element analyses for the 26 samples

[Major elements are in weight percent and trace elements are in ppm; samples are arranged in order of increasing loss on ignition (LOI); total

\begin{tabular}{|c|c|c|c|c|c|c|c|c|c|c|c|c|}
\hline Sample & F313 & G341 & $\times 101$ & F274 & G350 & D91 & D150 & F333 & D140 & $\mathrm{D} 200$ & O240 & 0241 \\
\hline 1 & 1 & 1 & 1 & 1 & 1 & 1 & 2 & 2 & 2 & 2 & 2 & 2 \\
\hline $\begin{array}{lc}\mathrm{SiO}_{2} \ldots \ldots \ldots \ldots & 49.9 \\
\mathrm{TiO}_{2} \ldots \ldots \ldots \ldots & .74 \\
\mathrm{Al}_{2} \mathrm{O}_{3} \ldots \ldots \ldots \ldots & 15.4 \\
\mathrm{Fe}_{2} \mathrm{O}_{3} \ldots \ldots \ldots \ldots & 11.4 \\
\mathrm{MnO} \ldots \ldots \ldots \ldots & .19 \\
\mathrm{MgO} \ldots \ldots \ldots \ldots & 7.97 \\
\mathrm{CaO} \ldots \ldots \ldots \ldots & 11.6 \\
\mathrm{Na} \mathrm{Na}_{2} \mathrm{O} \ldots \ldots \ldots \ldots & 2.04 \\
\mathrm{~K}_{2} \mathrm{O} \ldots \ldots \ldots \ldots & .35 \\
\mathrm{P}_{2} \mathrm{O}_{5} \ldots \ldots \ldots \ldots & .07 \\
\mathrm{LOI} \ldots \ldots \ldots \ldots & .13\end{array}$ & $\begin{array}{c}50.2 \\
.80 \\
15.0 \\
11.6 \\
.19 \\
8.22 \\
11.3 \\
2.07 \\
.39 \\
.09 \\
.24\end{array}$ & $\begin{array}{c}50.5 \\
.80 \\
15.5 \\
11.7 \\
.19 \\
7.93 \\
11.2 \\
1.95 \\
.50 \\
.10 \\
.30\end{array}$ & $\begin{array}{c}50.4 \\
.78 \\
15.6 \\
11.5 \\
.18 \\
7.09 \\
11.5 \\
1.73 \\
.38 \\
.11 \\
.37\end{array}$ & $\begin{array}{c}50.4 \\
.80 \\
15.3 \\
12.1 \\
.20 \\
7.96 \\
11.0 \\
1.94 \\
.41 \\
.07 \\
.38\end{array}$ & $\begin{array}{c}50.2 \\
.80 \\
15.1 \\
11.5 \\
.20 \\
8.21 \\
11.1 \\
2.07 \\
.51 \\
.08 \\
.45\end{array}$ & $\begin{array}{r}50.2 \\
.77 \\
14.7 \\
11.9 \\
.20 \\
8.76 \\
11.1 \\
1.96 \\
.40 \\
.10 \\
.55\end{array}$ & $\begin{array}{c}50.5 \\
.78 \\
15.2 \\
11.6 \\
.20 \\
7.92 \\
10.9 \\
2.09 \\
.61 \\
.08 \\
.60\end{array}$ & $\begin{array}{c}49.7 \\
.71 \\
14.7 \\
11.5 \\
.20 \\
8.25 \\
11.2 \\
1.98 \\
.41 \\
.07 \\
.80\end{array}$ & $\begin{array}{c}50.0 \\
.79 \\
15.2 \\
11.8 \\
.20 \\
7.21 \\
10.9 \\
2.19 \\
.57 \\
.10 \\
.99\end{array}$ & $\begin{array}{c}51.1 \\
.88 \\
15.0 \\
11.8 \\
.21 \\
7.07 \\
10.7 \\
2.12 \\
.56 \\
.10 \\
1.02\end{array}$ & $\begin{array}{c}50.2 \\
.74 \\
14.7 \\
11.5 \\
.18 \\
8.31 \\
11.3 \\
1.93 \\
.34 \\
.11 \\
1.16\end{array}$ & $\begin{array}{c}49.9 \\
.72 \\
14.8 \\
11.4 \\
.19 \\
7.89 \\
11.4 \\
1.97 \\
.30 \\
.08 \\
1.18\end{array}$ \\
\hline . 99.79 & 100.10 & 100.67 & 99.64 & 100.56 & 100.22 & 100.64 & 100.48 & 99.52 & 99.95 & 100.56 & 100.47 & 99.83 \\
\hline 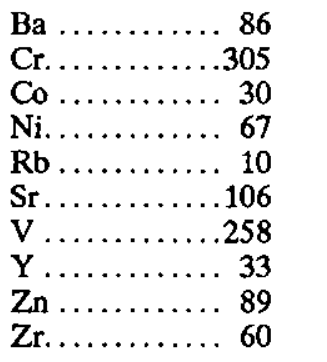 & $\begin{array}{r}113 \\
274 \\
34 \\
68 \\
14 \\
127 \\
271 \\
40 \\
96 \\
66\end{array}$ & $\begin{array}{r}268 \\
32 \\
70 \\
17 \\
123 \\
275 \\
40 \\
72 \\
70\end{array}$ & $\begin{array}{r}116 \\
267 \\
38 \\
69 \\
11 \\
106 \\
279 \\
31 \\
72 \\
63\end{array}$ & $\begin{array}{r}35 \\
67 \\
15 \\
107 \\
283 \\
31 \\
81 \\
69\end{array}$ & $\begin{array}{r}112 \\
268 \\
29 \\
65 \\
17 \\
113 \\
290 \\
37 \\
80 \\
66\end{array}$ & $\begin{array}{r}35 \\
77 \\
11 \\
108 \\
250 \\
34 \\
82 \\
64\end{array}$ & $\begin{array}{r}37 \\
67 \\
23 \\
132 \\
259 \\
42 \\
82 \\
74\end{array}$ & $\begin{array}{r}285 \\
34 \\
75 \\
12 \\
95 \\
258 \\
35 \\
90 \\
55\end{array}$ & $\begin{array}{r}253 \\
35 \\
71 \\
19 \\
158 \\
239 \\
42 \\
88 \\
71\end{array}$ & $\begin{array}{r}214 \\
36 \\
58 \\
21 \\
125 \\
287 \\
44 \\
82 \\
80\end{array}$ & $\begin{array}{r}86 \\
230 \\
33 \\
71 \\
13 \\
101 \\
229 \\
31 \\
94 \\
59\end{array}$ & $\begin{array}{r}71 \\
257 \\
32 \\
73 \\
12 \\
138 \\
260 \\
32 \\
77 \\
56\end{array}$ \\
\hline
\end{tabular}

Table 3. Major-element analyses and CIPW norms recalculated to 100 percent on a volatile-free basis

[Major elements and norms are in weight percent; values are rounded after recalculation to 100 percent. Samples are arranged in order of MT, magnetite; IL, ilmenite; $\mathrm{AP}$, apatite; - indicates these minerals do not occur in the normative calculation; total iron ( $\mathrm{Fe}_{2} \mathrm{O}_{3}+\mathrm{FeO}_{\text {) reported }}$

\begin{tabular}{|c|c|c|c|c|c|c|c|c|c|c|c|c|c|}
\hline Sample & $F 328$ & $F 313$ & G341 & $\times 101$ & $F 274$ & G350 & D91 & D150 & F333 & D140 & D200 & $\mathrm{O} 240$ & O241 \\
\hline Group & 1 & 1 & 1 & 1 & 1 & 1 & 1 & 2 & 2 & 2 & 2 & 2 & 2 \\
\hline 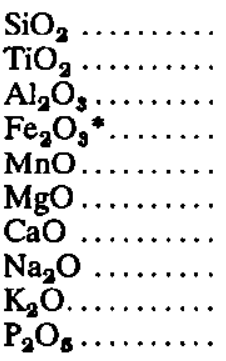 & $\begin{array}{c}50.1 \\
.74 \\
15.4 \\
11.4 \\
.19 \\
8.00 \\
11.6 \\
2.05 \\
.35 \\
.07\end{array}$ & $\begin{array}{c}50.2 \\
.80 \\
15.0 \\
11.6 \\
.19 \\
8.23 \\
11.3 \\
2.07 \\
.39 \\
.09\end{array}$ & $\begin{array}{c}50.3 \\
.80 \\
15.4 \\
11.7 \\
.19 \\
7.90 \\
11.6 \\
1.94 \\
.50 \\
.10\end{array}$ & $\begin{array}{c}50.8 \\
.79 \\
15.7 \\
11.6 \\
.18 \\
7.14 \\
11.6 \\
1.74 \\
.38 \\
.11\end{array}$ & $\begin{array}{c}50.3 \\
.80 \\
15.3 \\
12.1 \\
.20 \\
7.95 \\
11.0 \\
1.94 \\
.41 \\
.07\end{array}$ & $\begin{array}{c}50.3 \\
.80 \\
15.1 \\
11.5 \\
.20 \\
8.23 \\
11.1 \\
2.07 \\
.51 \\
.08\end{array}$ & $\begin{array}{c}50.2 \\
.77 \\
14.7 \\
11.9 \\
.20 \\
8.75 \\
11.1 \\
1.96 \\
.40 \\
.10\end{array}$ & $\begin{array}{c}50.6 \\
.78 \\
15.2 \\
11.6 \\
.20 \\
7.93 \\
10.9 \\
2.09 \\
.61 \\
.08\end{array}$ & $\begin{array}{c}50.3 \\
.72 \\
14.9 \\
11.7 \\
.20 \\
8.63 \\
11.4 \\
2.01 \\
.42 \\
.07\end{array}$ & $\begin{array}{c}50.5 \\
.80 \\
15.4 \\
11.9 \\
.20 \\
7.29 \\
11.0 \\
2.21 \\
.58 \\
.10\end{array}$ & $\begin{array}{c}51.3 \\
.88 \\
15.1 \\
11.9 \\
.21 \\
7.10 \\
10.8 \\
2.13 \\
.56 \\
.10\end{array}$ & $\begin{array}{c}50.6 \\
.75 \\
14.8 \\
11.6 \\
.18 \\
8.37 \\
11.4 \\
1.94 \\
.34 \\
.11\end{array}$ & $\begin{array}{l}50.6 \\
73 \\
15.0 \\
11.6 \\
.19 \\
8.00 \\
11.6 \\
2.00 \\
.30 \\
.08\end{array}$ \\
\hline 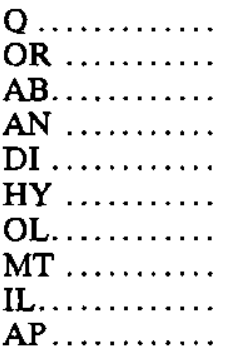 & $\begin{array}{l}- \\
2.10 \\
17.4 \\
32.1 \\
20.7 \\
21.6 \\
1.89 \\
2.51 \\
1.41 \\
.15\end{array}$ & $\begin{array}{l}\overline{2.33} \\
17.7 \\
30.7 \\
20.5 \\
23.2 \\
1.42 \\
2.52 \\
1.52 \\
.20\end{array}$ & $\begin{array}{l}.23 \\
2.97 \\
16.6 \\
32.1 \\
18.6 \\
25.5 \\
-\quad \\
2.57 \\
1.51 \\
.22\end{array}$ & $\begin{array}{l}2.61 \\
2.28 \\
14.9 \\
34.1 \\
18.8 \\
23.1 \\
- \\
2.54 \\
1.49 \\
.24\end{array}$ & $\begin{array}{l}.46 \\
2.44 \\
16.5 \\
32.0 \\
18.2 \\
26.1 \\
-\quad \\
2.65 \\
1.52 \\
.15\end{array}$ & $\begin{array}{l} \\
3.05 \\
17.7 \\
30.6 \\
19.8 \\
22.7 \\
1.93 \\
2.53 \\
1.52 \\
.18\end{array}$ & $\begin{array}{c}- \\
2.39 \\
16.7 \\
30.3 \\
19.8 \\
24.8 \\
1.72 \\
2.62 \\
1.46 \\
.22\end{array}$ & $\begin{array}{c} \\
3.64 \\
17.9 \\
30.5 \\
19.0 \\
24.0 \\
.78 \\
2.55 \\
1.48 \\
.18\end{array}$ & $\begin{array}{l}- \\
2.48 \\
17.1 \\
30.6 \\
20.8 \\
23.8 \\
1.27 \\
2.55 \\
1.36 \\
.16\end{array}$ & $\begin{array}{c}-3.44 \\
18.9 \\
30.4 \\
19.5 \\
22.9 \\
.45 \\
2.62 \\
1.51 \\
.22\end{array}$ & $\begin{array}{c}1.94 \\
3.36 \\
18.2 \\
30.1 \\
18.7 \\
23.2 \\
- \\
2.61 \\
1.68 \\
.22\end{array}$ & $\begin{array}{c}.42 \\
2.04 \\
16.6 \\
30.8 \\
20.5 \\
25.5 \\
- \\
2.54 \\
1.41 \\
.24\end{array}$ & $\begin{array}{r}.52 \\
1.81 \\
17.1 \\
31.2 \\
21.1 \\
24.2 \\
-\quad \\
2.54 \\
1.38 \\
.18\end{array}$ \\
\hline
\end{tabular}


iron $\left(\mathrm{Fe}_{3} \mathrm{O}_{3}+\mathrm{FeO}\right)$ reported as $\left.\mathrm{Fe}_{2} \mathrm{O}_{3}^{*}\right]$

\begin{tabular}{cccccccccccccc}
\hline G369 & O230 & W62.5 & Y87 & D136 & E95 & G372.5 & G372 & G373.5 & G370.5 & E151 & E161 & C140 \\
\hline 2 & 2 & 4 & 3 & 3 & 3 & 3 & 3 & 4 & 4 & 4 & 3 & 4 \\
50.2 & 50.4 & 49.8 & 49.7 & 50.4 & 49.1 & 49.7 & 49.2 & 49.1 & 49.0 & 48.8 & 49.1 & 48.8 \\
.71 & .79 & .73 & .65 & .78 & .81 & .77 & .84 & .76 & .80 & .81 & .85 & .65 \\
14.6 & 15.3 & 13.9 & 14.8 & 14.4 & 14.9 & 14.2 & 13.5 & 13.3 & 13.7 & 14.3 & 13.3 & 11.2 \\
11.6 & 11.4 & 11.3 & 11.6 & 10.9 & 10.7 & 10.8 & 12.0 & 11.9 & 11.5 & 10.8 & 10.4 & 10.4 \\
.23 & .18 & .17 & .18 & .19 & .21 & .18 & .19 & .19 & .20 & .17 & .16 & .13 \\
8.03 & 6.89 & 7.77 & 7.14 & 7.42 & 7.03 & 7.77 & 7.99 & 7.26 & 8.17 & 7.07 & 6.99 & 5.03 \\
10.5 & 11.4 & 10.1 & 9.72 & 10.4 & 9.34 & 11.0 & 9.69 & 10.9 & 9.32 & 9.70 & 12.00 & 13.00 \\
1.75 & 1.81 & 2.16 & 2.57 & 2.78 & 2.72 & 1.84 & 2.14 & 2.00 & 1.85 & 2.02 & 2.07 & 1.51 \\
.89 & .39 & 1.12 & .91 & .69 & .77 & .43 & .45 & .44 & .47 & .71 & .57 & .54 \\
.08 & .12 & .07 & .06 & .05 & .07 & .06 & .07 & .05 & .04 & .09 & .10 & .09 \\
1.59 & 1.84 & 2.24 & 2.55 & 2.69 & 3.39 & 3.52 & 4.10 & 4.10 & 4.29 & 4.50 & 4.94 & 9.41 \\
100.18 & 100.52 & 99.36 & 99.88 & 100.70 & 99.04 & 100.27 & 100.17 & 100.00 & 99.34 & 98.97 & 100.48 & 101.76 \\
138 & 103 & 168 & 158 & 132 & 149 & 85 & 127 & 86 & 89 & 109 & 118 & 98 \\
256 & 235 & 224 & 260 & 250 & 192 & 172 & 251 & 279 & 247 & 176 & 206 & 244 \\
30 & 25 & 35 & 34 & 29 & 32 & 30 & 35 & 28 & 32 & 30 & 34 & 28 \\
83 & 64 & 81 & 65 & 67 & 70 & 73 & 73 & 80 & 83 & 70 & 70 & 63 \\
39 & 12 & 58 & 44 & 26 & 36 & 19 & 17 & 19 & 19 & 28 & 22 & 23 \\
113 & 105 & 295 & 228 & 194 & 237 & 124 & 124 & 126 & 127 & 123 & 128 & 121 \\
265 & 279 & 271 & 238 & 251 & 227 & 284 & 297 & 271 & 283 & 280 & 293 & 273 \\
41 & 37 & 25 & 21 & 40 & 39 & 38 & 36 & 34 & 21 & 42 & 44 & 36 \\
89 & 91 & 71 & 77 & 90 & 80 & 92 & 96 & 88 & 98 & 86 & 90 & 86 \\
58 & 61 & 57 & 55 & 77 & 79 & 63 & 66 & 64 & 68 & 80 & 83 & 66 \\
\hline & & & & & & & & & & &
\end{tabular}

increasing LOI from table 2; $\mathrm{Q}$, quartz; OR, orthoclase; $\mathrm{AB}$, albite; $\mathrm{AN}$, anorthite; $\mathrm{DI}$, diopside; HY, hypersthene; OL, olivine; as $\mathrm{Fe}_{2} \mathrm{O}_{3}{ }^{*}$ ]

\begin{tabular}{|c|c|c|c|c|c|c|c|c|c|c|c|c|}
\hline G369 & 0230 & W62.5 & Y87 & D136 & E95 & G372.5 & G372 & G373.5 & G370.5 & E151 & E161 & $\mathrm{C}_{140}$ \\
\hline 2 & 2 & 4 & 3 & 3 & 3 & 3 & 3 & 4 & 4 & 4 & 3 & 4 \\
\hline $\begin{array}{r}50.9 \\
.72\end{array}$ & $\begin{array}{r}51.1 \\
.80\end{array}$ & $\begin{array}{r}51.3 \\
.75\end{array}$ & $\begin{array}{r}51.1 \\
.67\end{array}$ & $\begin{array}{r}51.4 \\
.80\end{array}$ & $\begin{array}{r}51.3 \\
.85\end{array}$ & $\begin{array}{r}51.4 \\
.80\end{array}$ & $\begin{array}{r}51.2 \\
.87\end{array}$ & $\begin{array}{r}51.2 \\
.79\end{array}$ & $\begin{array}{r}51.6 \\
.84\end{array}$ & $\begin{array}{r}51.7 \\
.86\end{array}$ & $\begin{array}{r}51.4 \\
.89\end{array}$ & $\begin{array}{r}53.3 \\
.71\end{array}$ \\
\hline 14.8 & 15.5 & 14.3 & 15.2 & 14.7 & 15.6 & 14.7 & 14.1 & 13.9 & 14.4 & 15.1 & 13.9 & 12.2 \\
\hline 11.8 & 11.6 & 11.6 & 11.9 & 11.1 & 11.2 & 11.2 & 12.5 & 12.4 & 12.1 & 11.4 & 10.9 & 11.4 \\
\hline .23 & .18 & .18 & .18 & .19 & .22 & .19 & .20 & .20 & .21 & .18 & .17 & .14 \\
\hline 8.14 & 6.98 & 8.00 & 7.34 & 7.57 & 7.35 & 8.03 & 8.32 & 7.57 & 8.60 & 7.48 & 7.32 & 5.49 \\
\hline 10.7 & 11.6 & 10.4 & 9.99 & 10.6 & 9.76 & 11.4 & 10.1 & 11.4 & 9.81 & 10.3 & 12.6 & 14.5 \\
\hline 1.78 & 1.83 & 2.22 & 2.64 & 2.84 & 2.84 & 1.90 & 2.23 & 2.09 & 1.95 & 2.14 & 2.17 & 1.65 \\
\hline .90 & .40 & 1.15 & .93 & .70 & .81 & .44 & .47 & .46 & .49 & .75 & .60 & .59 \\
\hline .08 & .12 & .07 & .06 & .05 & .07 & .06 & .07 & .05 & .04 & .10 & .10 & .10 \\
\hline .73 & 2.88 & - & - & - & - & 1.93 & .72 & 1.25 & 2.17 & 1.77 & .71 & 6.41 \\
\hline 5.39 & 2.36 & 6.88 & 5.58 & 4.20 & 4.80 & 2.65 & 2.80 & 2.74 & 2.95 & 4.48 & 3.56 & 3.52 \\
\hline 15.2 & 15.7 & 19.0 & 22.6 & 24.2 & 24.3 & 16.2 & 19.0 & 17.8 & 16.6 & 18.3 & 18.5 & 14.1 \\
\hline 29.9 & 33.1 & 25.8 & 27.0 & 25.4 & 27.5 & 30.3 & 27.1 & 27.3 & 29.3 & 29.6 & 26.6 & 24.3 \\
\hline 18.4 & 19.5 & 20.7 & 18.3 & 22.1 & 16.8 & 21.1 & 18.4 & 23.8 & 15.6 & 17.0 & 28.9 & 39.5 \\
\hline 26.3 & 22.3 & 20.9 & 17.4 & 14.8 & 17.9 & 23.7 & 27.4 & 22.8 & 29.1 & 24.5 & 17.4 & 8.17 \\
\hline- & - & 2.63 & 5.20 & 5.25 & 4.50 & - & - & - & - & - & - & - \\
\hline 2.59 & 2.54 & 2.57 & 2.62 & 2.45 & 2.45 & 2.45 & 2.75 & 2.74 & 2.65 & 2.51 & 2.39 & 2.49 \\
\hline 1.37 & 1.52 & 1.43 & 1.67 & 1.51 & 1.61 & 1.51 & 1.66 & 1.50 & 1.60 & 1.63 & 1.69 & 1.34 \\
\hline .18 & .27 & .16 & .14 & .11 & .16 & .14 & .16 & .12 & .09 & .21 & .23 & .22 \\
\hline
\end{tabular}


Table 4. Means, percent deviations, and results of $F$ - and t-tests for recalculated (volatile-free) analyses of groups $U$ and $\mathrm{A}$

[nr, not reported; total iron $\left(\mathrm{Fe}_{2} \mathrm{O}_{3}+\mathrm{FeO}\right)$ reported as $\mathrm{Fe}_{2} \mathrm{O}_{9}{ }^{*}$ ]

\begin{tabular}{|c|c|c|c|c|c|c|}
\hline \multirow[b]{2}{*}{ Element } & \multirow{2}{*}{$\begin{array}{c}\text { Low-Ti, } \\
\text { quartz: } \\
\text { normative }\end{array}$} & \multicolumn{2}{|c|}{ Average } & \multicolumn{2}{|c|}{ Percent deviation ${ }^{2}$} & \multirow{2}{*}{$\begin{array}{l}\text { F. and } \\
\text { t-tests }\end{array}$} \\
\hline & & Group U & Group A & Group U & Group A & \\
\hline . & 51.7 & 50.5 & 51.5 & 0.7 & 1.2 & $\mathrm{~F}, \mathrm{~T}$ \\
\hline & .76 & .78 & .80 & 5 & & $\mathbf{F}$ \\
\hline & 15.0 & 15.2 & 14.4 & 2.0 & 6.3 & $\mathrm{~F}, \mathrm{~T}$ \\
\hline & 11.8 & 11.7 & 11.6 & 1.5 & 4.7 & $\mathbf{F}$ \\
\hline$\ldots$ & .20 & .20 & .19 & 6.6 & 12 & $F$ \\
\hline$\ldots$ & 7.44 & 7.89 & 7.55 & 6. & 11 & $\mathrm{~F}$ \\
\hline . & 10.8 & 11.2 & 11.0 & 2. & 13 & $F$ \\
\hline $\mathrm{a}_{2} \mathrm{O} \ldots$ & 2.23 & 1.98 & 2.24 & 6.5 & 17 & $\mathrm{~F}, \mathrm{~T}$ \\
\hline & .48 & .47 & .67 & 32 & 34 & $\mathrm{~T}$ \\
\hline $\mathrm{P}_{2} \mathrm{O}_{5}$ & $\mathrm{nr}$ & .09 & .07 & 18 & 31 & $\mathrm{~T}$ \\
\hline 7 & nr & .77 & 4.16 & 66 & 47 & $\mathrm{~F}, \mathrm{~T}$ \\
\hline & $\mathrm{nr}$ & 113 & 131 & 22 & 25 & ns \\
\hline C & 53 & 33 & 33 & 10 & 7.9 & ns \\
\hline $\mathrm{Cr}$. & 218 & 263 & 237 & 9.0 & 16 & $\mathrm{~T}$ \\
\hline $\mathrm{Ni}$ & 48 & 70 & 75 & 8.6 & 8.6 & $\mathrm{~T}$ \\
\hline $\mathrm{Rb}$. & 15 & 16 & 29 & 46 & 44 & $\mathrm{~F}, \mathrm{~T}$ \\
\hline Sr. & 127 & 118 & 173 & 14 & 36 & $\mathrm{~F}, \mathrm{~T}$ \\
\hline V. & $\mathrm{nr}$ & 267 & 282 & 6.7 & 9.1 & ns \\
\hline $\mathbf{Y}$ & $\mathrm{nr}$ & 37 & 36 & 13 & 24 & $\mathrm{~F}$ \\
\hline & 86 & 85 & 90 & 9.1 & 9.8 & ns \\
\hline $\mathrm{Zr}$. & 60 & 65 & 72 & 11 & 14 & ns \\
\hline
\end{tabular}

${ }^{1}$ The average low-titanium, quartz-normative (LTQ) analysis is from Weigand and Ragland (1970).

${ }^{2}$ The percent deviations listed in columns 3 and 4 are also referred to as coefficients of variation $(V)$, where $V=100 \mathrm{~s} / X$. The standard deviation is designated as $s$, and $X$ is the arithmetic mean. The average low-titanium, quartz-normative (LTQ) analysis is from Weigand and Ragland (1970).

${ }^{3}$ An $F$ in the last column indicates that the variances are significantly different at the 95 -percent confidence level as determined by an $F$-test. $A T$ in the last column indicates that the arithmetic means are significantly different at the 95-percent confidence level as determined by a two-sided t-test. An ns in the last column indicates that neither variances nor means are significantly different at the 95 percent confidence level.

9.41 percent. No evidence exists in thin section to suggest that this sample was originally andesitic in composition. Furthermore, concentrations of many other chemical constituents in this sample are not very different from typical unaltered diabase samples (table 2). All samples in group A, including C140, appear to be similar in composition to group $\mathrm{U}$ before alteration, as shown by similar concentrations of immobile elements such as $\mathrm{Zr}$, $\mathrm{P}_{2} \mathrm{O}_{5}$, and $\mathrm{TiO}_{2}$ after recalculation of analyses to 100 percent on a volatile-free basis.

Additional representative examples of "stacked" Mg) variation diagrams, for two major and two trace elements, are given in figure 5 . In each case the lines fit by linear regression are for group $U$ only. All group $U$ samples are actually quite similar chemically (table 2 ), and the most evolved (lowest $\mathrm{MgO}$ ) group $\mathrm{U}$ sample is not greatly fractionated relative to the least evolved

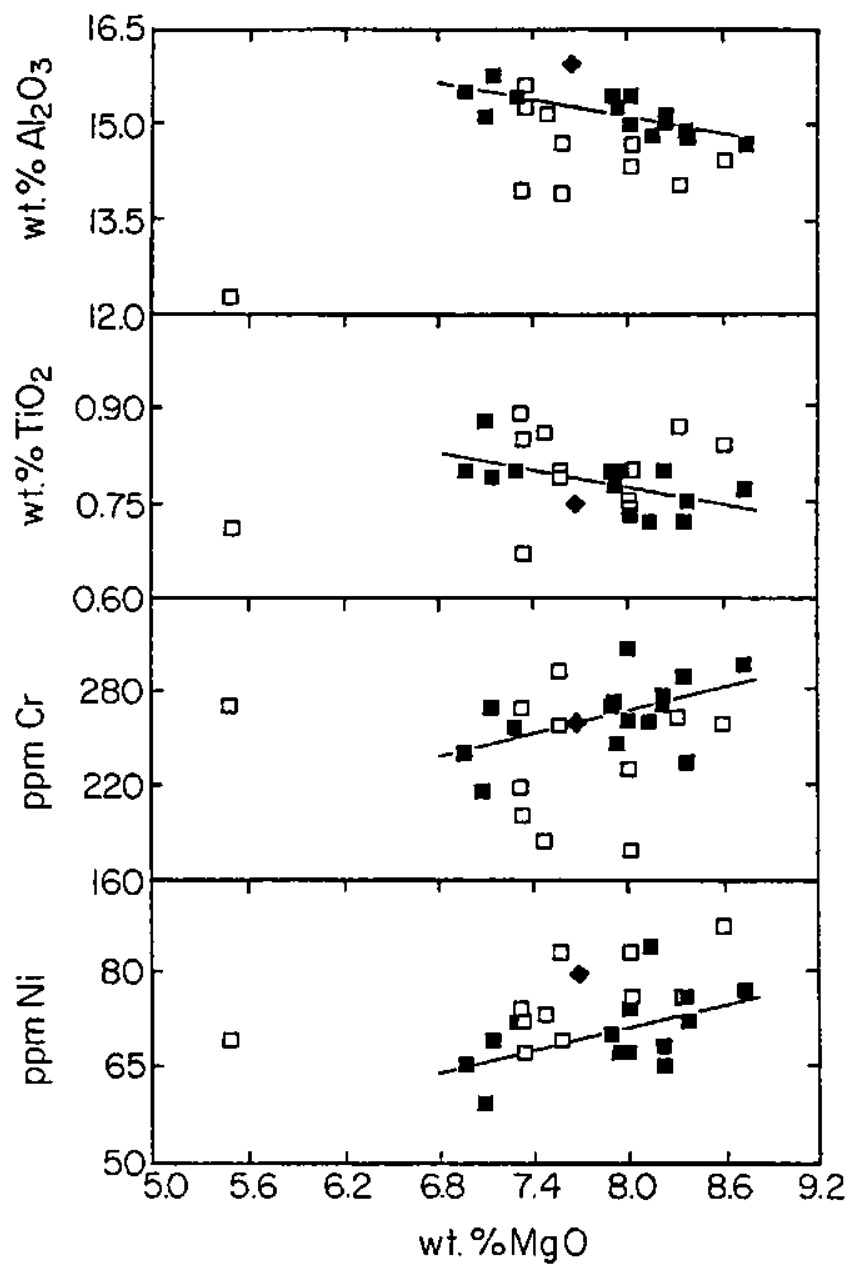

Figure 5. Weight percent $\mathrm{MgO}$ versus weight percent $\mathrm{Al}_{2} \mathrm{O}_{3}$ and $\mathrm{TiO}_{2}$; weight percent $\mathrm{MgO}$ versus $\mathrm{ppm} \mathrm{Cr}$ and $\mathrm{Ni}$. For $\mathrm{MgO}-\mathrm{Cr}$ in average Nokesville chill margin, $\mathrm{n}=2$; for remaining Nokesville plots, $n=5$. Symbols are explained in caption of figure 4 .

(highest $\mathrm{MgO}$ ) sample. Linear mixing calculations suggest that the chemical trends for group $U$ can be explained by low-pressure fractionation of plagioclase, augite, and olivine, as suggested by the phenocryst assemblage (Ragland, unpublished data). Chemical trends for group $\mathrm{U}$ samples on other plots can be similarly explained. On figure $5, \mathrm{Al}_{2} \mathrm{O}_{3}$ and $\mathrm{Cr}$ may be systematically lower in group $\mathrm{A}$ than in group $\mathrm{U}$; $\mathrm{Ni}$ may be higher in group $\mathrm{A}$; and $\mathrm{TiO}_{2}$ and $\mathrm{MgO}$ exhibit little difference. For all elements on figure 5, group A compositions are more variable than those from group $U$.

Two elements commonly considered to be immobile during alteration are $\mathrm{TiO}_{2}$ and $\mathrm{Zr}$ (for example, Pearce and Cann, 1973). Gottfried and others (1977), in a study of subsurface lower Mesozoic basalts from a core near Charleston, South Carolina, concluded that $\mathrm{TiO}_{2}$ and $\mathrm{Zr}$ were among the most immobile elements during alteration. These are plotted on figure 6 and exhibit the positive correlation typically found in basaltic rocks. Both 


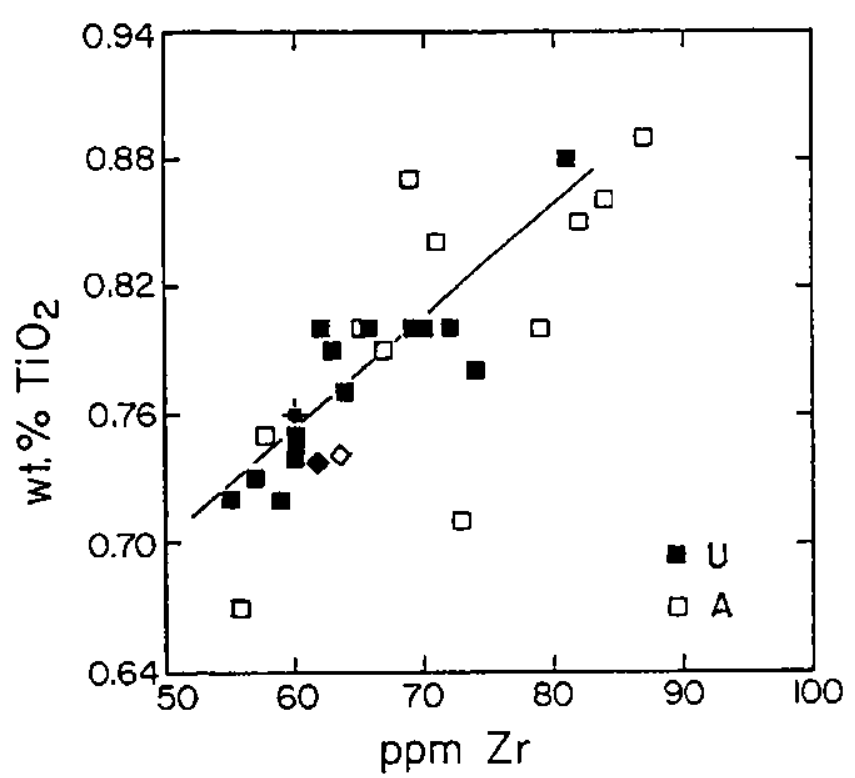

Figure 6. Weight percent $\mathrm{TiO}_{2}$ versus ppm Zr. Average LTQ diabase $(n=37)$ from Weigand and Ragland (1970) plotted as crossed square. Open diamond represents average Rossville ( $n=20$; equivalent to LTQ) from Smith and others (1975). Symbols explained in more detail in caption of figure 4.

elements commonly behave incompatibly during primary igneous processes involving basaltic magmas. As in figure 5 , the data are considerably more scattered for group A than for group U, although their averages apparently do not greatly differ. This is taken as evidence that samples from group A were similar in chemical composition to those of group $U$ prior to alteration. The crossed square represents the average LTQ composition from Weigand and Ragland (1970), and the open diamond denotes the average Rossville composition (equivalent to LTQ) from Smith and others (1975). Thus, group U samples are similar in $\mathrm{TiO}_{2}$ and $\mathrm{Zr}$ composition to typical LTQ analyses. Moreover, the average chill-margin composition from the Nokesville sheet is generally similar to that of group $U$ (figs. 4-6: chill-margin data from Froelich and Gottfried, this volume).

Two additional elements that commonly behave incompatibly during primary igneous processes involving basaltic magmas are $\mathrm{K}_{2} \mathrm{O}$ (plotted as $\mathrm{K}$ ) and $\mathrm{Rb}$ (fig. 7). The excellent covariance so commonly observed between these elements is maintained, but for group $\mathrm{A}$ the trend is at least partially caused by alteration. The group $A$ samples are clearly the most enriched in both $\mathrm{K}$ and $\mathrm{Rb}$. Because muscovite (sericite) has pseudomorphously replaced plagioclase in the highly altered rocks, this is not surprising. The $K / R b$ ratio is generally lower in the group A rocks, from a rather typical ratio of about 250 for group $U$ to a ratio of about 200 for group $A$. The only deviation among the $U$ samples is $G 369$, near the boundary between the two groups; it has a marginal LOI of 1.59 percent and anomalously high $\mathrm{K}_{2} \mathrm{O}$ and $\mathrm{Rb}$ contents.

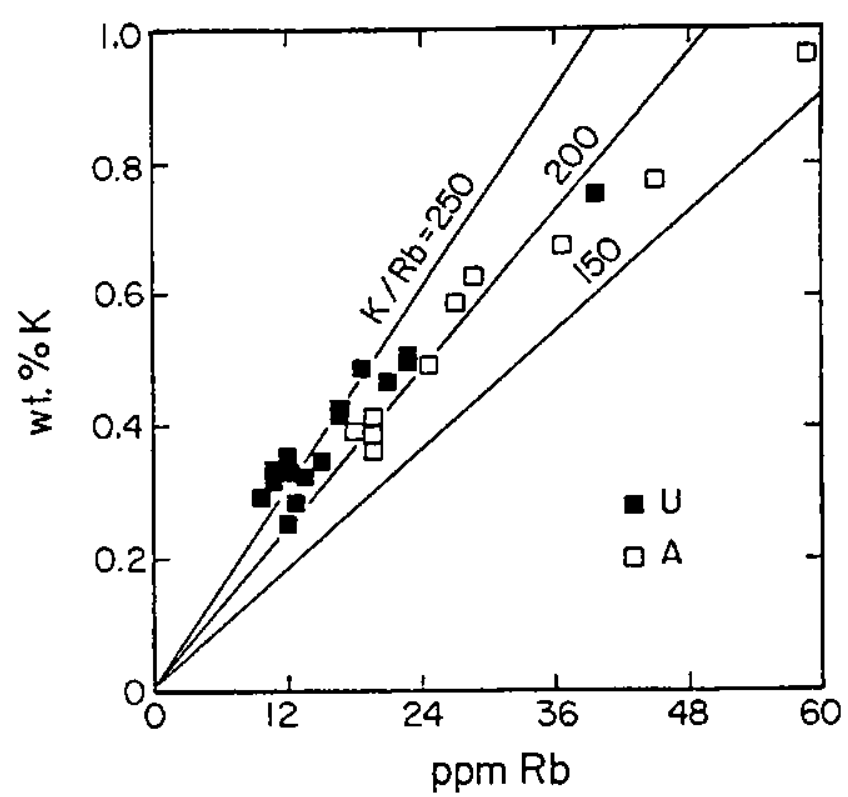

Figure 7. Weight percent $\mathrm{K}$ versus ppm $\mathrm{Rb}$ with constant ratio lines of 250,200 , and 150 . Symbols explained in more detail in caption of figure 4.

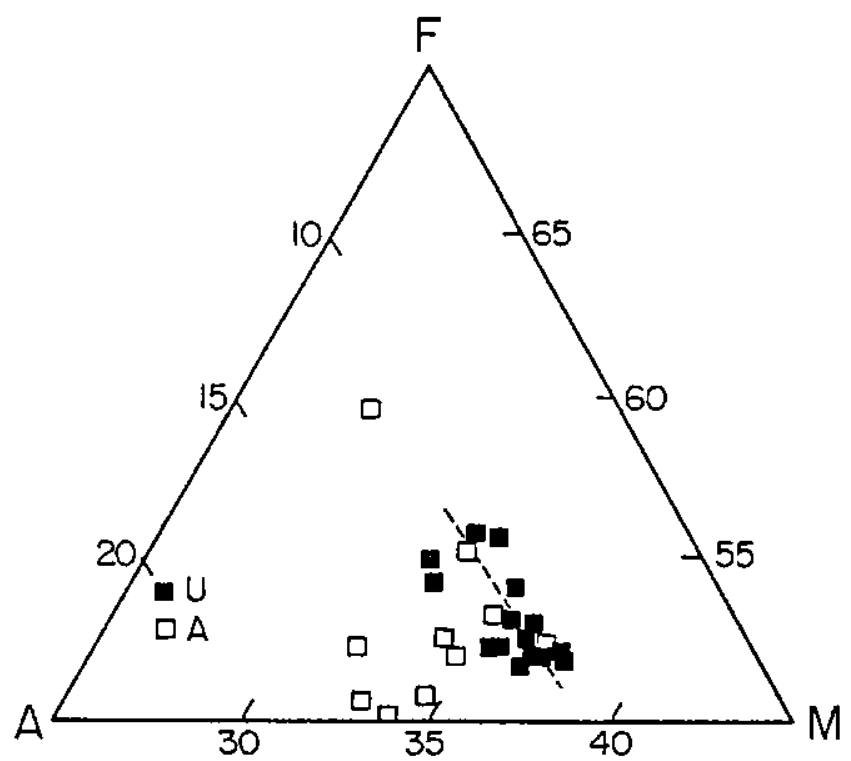

Figure 8. Portion of an AFM diagram. $\mathrm{A}_{1}\left(\mathrm{Na}_{2} \mathrm{O}+\mathrm{K}_{2} \mathrm{O}\right) ; \mathrm{F}$, $\left(\mathrm{Fe}_{2} \mathrm{O}_{3}{ }^{\star}\right) ; \mathrm{M}, \mathrm{MgO}$. Dashed line is best fit through unaltered (U) samples. Symbols explained in more detail in caption of figure 4.

Figure 7 implies that both $\mathrm{K}$ and $\mathrm{Rb}$ were introduced into the diabase sheets during alteration. Gottfried and others (1977), in their study of basalts from a core hole near Charleston, South Carolina, arrived at a similar conclusion. The effect of introduction of alkalis on a classical AFM diagram can be seen on figure 8 . These rocks are so similar in composition that figure 8 is a blow-up of a small part of an entire AFM diagram. Group U samples exhibit an iron-enrichment trend typical of tholeiitic basaltic rocks, but group A samples show 


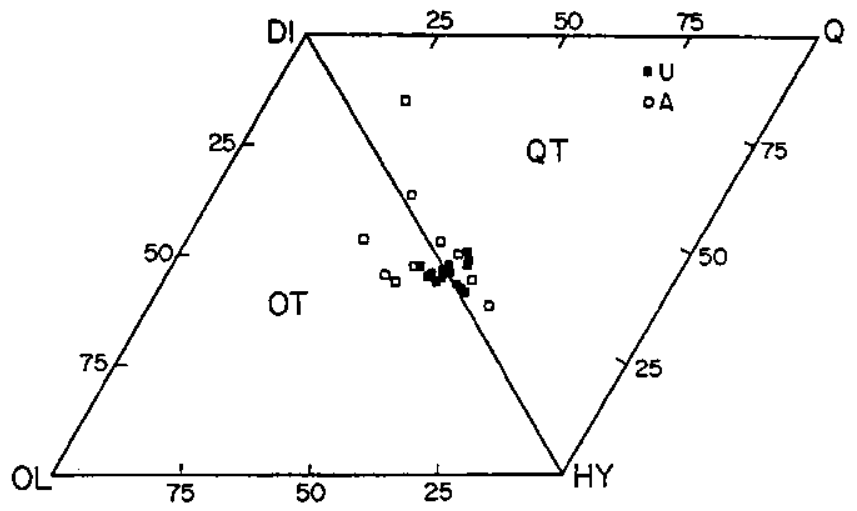

Figure 9. Normative projections from plagioclase onto the DI-OL-HY (olivine-tholeitie, or OT field) and DI-HY-Q (quartztholeiite, or QT field) triangles in the "basalt tetrahedron" (Yoder and Tilley, 1962). Symbols explained in more detail in caption of figure 4 .

no apparent trend, and most are relatively enriched in alkalis. A few group A samples fall within the field of the group $U$ iron-enrichment trend, suggesting that their alkali contents were relatively undisturbed by the alteration. Again, this suggests that group A rocks were similar in composition to group $U$ rocks before alteration.

Another classic variation diagram for basaltic rocks is the combination of equilateral triangular projections from the plagioclase apex of Yoder and Tilley's (1962) normative basalt tetrahedron (fig. 9). The near"horizontal" trend for group U is typical of low-pressure fractionation toward quartz-tholeiite compositions. Note, however, that not all these "low-titanium, quartznormative" samples plot as "truly" quartz normative. Most samples plot on or near the QT/OT boundary (fig. 9). $\mathrm{A} \mathrm{FeO} /\left(\mathrm{Fe}_{2} \mathrm{O}_{3}+\mathrm{FeO}\right)$ oxidation ratio of 0.85 was assumed to calculate the norms. An increase in this ratio to 0.90 will shift these points even farther into the olivine-normative field, increasing normative olivine by about 2 to 3 percent. The original oxidation ratio during crystallization of these magmas was probably between 0.85 and 0.90 , but it is impossible to be more accurate. Thus the designation of these group $U$ rocks as quartz-or olivine-normative is uncertain. Cummins (1987) concluded that all LTQ magmas from diabase dikes in Virginia were derivatives of olivine tholeiites through low-pressure fractionation, which is supported by figure 9. As observed on previous figures, group A samples are considerably scattered relative to group $U$ samples and exhibit no obvious trend.

\section{DISCUSSION AND CONCLUSIONS}

Various methods have been proposed to assess the mobility of components during secondary alteration of igneous rocks. Although relative mobilities can be readily evaluated by such simple methods as comparisons of ratios, determination of absolute mobilities is more difficult. Two common techniques are the compositionvolume method of Gresens (1967) and recalculation of the data to number of cations per fixed number of anions (similar to conversion of weight-percent oxides to mineral formulas). A classical concept utilizing this second method is Barth's (1948) "standard cell" - number of cations per $160 \mathrm{O}_{2}^{-}$ions. An even simpler method is to compare weight-percent oxides recalculated on a volatile-free basis (table 3). All three of these techniques were applied to the data in table 2 , and all three gave generally similar results. Consequently, the following discussion is based on the simplest of the three methods, volatile-free oxide data (table 3). A fourth method involves calculation of ratios in which the denominator is the concentration of an element presumed to be immobile. This method was not pursued because we chose not to make a priori assumptions about relative element mobility.

Arithmetic means, percent deviations (coefficients of variation), and results of F- and t-tests for recalculated (volatile-free) groups $U$ and $A$ are listed in table 4 . Results for LOI and the average LTQ composition from Weigand and Ragland (1970) are included as well. Interestingly, some elements in the average LTQ diabase (for example, $\mathrm{SiO}_{2}$ and $\mathrm{Na}_{2} \mathrm{O}$ ) are more similar in composition to the average group $A$, whereas others (for example, $\mathrm{Al}_{2} \mathrm{O}_{3}$ and $\mathrm{K}_{2} \mathrm{O}$ ) more closely compare to the average group $U$. Perhaps some of the samples used to calculate the average LTQ would not have passed the two-part screen outlined above. The group $U$ diabases, however, are sufficiently close in composition to the average LTQ to warrant their classification as LTQ (Rossville). Only $\mathrm{Ni}$ and $\mathrm{Co}$ are appreciably different between LTQ and group U or group A, and these comparisons may reflect analytical differences between laboratories.

The F-test is used to evaluate differences in variances (standard deviations squared) between two groups of samples, while the t-test evaluates differences in arithmetic means (Davis, 1973). Both tests were conducted at the 95-percent confidence level (alpha equals 0.05 ). A two-sided test was used for $t$, and normal distributions were assumed. Our data base was not adequate to assess normality within the two groups. Both tests, however, are reasonably robust to departures from normality. An F or T entered in the last column of table 4 indicates that the nulk hypothesis is rejected and the variances (F-test) or means (t-test), respectively, are significantly different at the 95 -percent level.

The results in table 4 can be considered on the basis of both differences in averages and differences in percent deviations. Differences in percent deviations are just as important as differences in averages because increased variability accompanying alteration can 
obscure primary igneous trends, as observed on some of the variation diagrams presented above. Excluding LOI, 20 chemical constituents are listed on table 4 . Of these, 11 are significantly more variable in group $A$ samples than in group $U$ samples; none are more variable in group U samples. Several more major elements than trace elements are significantly more variable in group A samples. Perhaps this is a reflection of the fact that variability for trace elements in group $U$ is on average considerably more than that of major elements. $\mathrm{CaO}$ shows the greatest increase in variability in group $\mathrm{A}$ relative to group $\mathrm{U}$. Unexpectedly, $\mathrm{TiO}_{2}$ and $\mathrm{Y}$, two elements normally considered to be immobile, are significantly more variable in group A samples.

As implied above, determination of absolute gains and losses during alteration is not easily quantified. The following elements have significantly higher averages in group $\mathrm{A}: \mathrm{SiO}_{2}, \mathrm{Na}_{2} \mathrm{O}, \mathrm{K}_{2} \mathrm{O}, \mathrm{Rb}$, and $\mathrm{Sr}$. These are likely candidates for being introduced during alteration. A larger data base might indicate that the average barium content is significantly higher in group $\mathrm{A}$ as well. $\mathrm{Al}_{2} \mathrm{O}_{3}$ may have been depleted during alteration (see also fig. 5). $\mathrm{P}_{2} \mathrm{O}_{5}, \mathrm{Cr}$, and $\mathrm{Ni}$ also passed the t-test, which is surprising. $\mathrm{MgO}-\mathrm{Ni}$ and $\mathrm{MgO}-\mathrm{Cr}$ plots (fig. 5) support these differences. A larger data set is required to determine if these latter elements are indeed mobile during secondary alteration of these diabases.

In conclusion, this paper demonstrates that LTQ diabases having LOI values greater than 2 percent and significant alteration of plagioclase as well as augite (group A) are more variable in composition than those that meet these two screening criteria (group U). Moreover, alkali contents may be disturbed in samples with LOI values between 1 and 2 percent. This increased variability for many elements is sufficient to obscure primary igneous trends on standard variation diagrams. Alkalis and $\mathrm{Sr}$ are, on average, significantly enriched in the altered samples relative to the unaltered samples. Average compositions of other elements may be affected as well.

We recommend the use of these criteria to screen diabase samples used for petrogenetic interpretations of lower Mesozoic diabases from eastern North America. Inasmuch as LOI analyses and thin-section observations require a rather minimal expenditure of time and money, we further recommend that both be done before additional analytical work is attempted on any diabase samples collected.

\section{REFERENCES CITED}

Barth, T.F.W., 1948, Oxygen in rocks: A basis for petrographic calculations: Journal of Geology, v. 56, p. 50-60.

Chalcraft, R.G., 1972, A petrographic study of Mesozoic dolerites from eastem North America: Chapel Hill, University of North Carolina, unpublished Ph.D. thesis, 175 p.

Cummins, L.E., 1987, Geochemistry, mineralogy and origin of Mesozoic diabase dikes of Virginia: Tallahassee, Florida State University, unpublished Ph.D. thesis, $476 \mathrm{p}$.

Davis, J.C., 1973, Statistics and data analysis in geology: New York, John Wiley, $550 \mathrm{p}$.

Dennen, W.H., 1951, Variations in chemical composition across igneous contacts: Geological Society of America Bulletin, v. 62 , p. $547-557$.

Drez, P., 1977, Hydrothermal alteration of low-K tholeiitic dikes and intruded clastic sediments: Chapel Hill, University of North Carolina, unpublished $\mathrm{Ph} . \mathrm{D}$. thesis, $290 \mathrm{p}$.

Fratta, M., and Shaw, D.M., 1973, 'Residence' contamination of $\mathrm{K}, \mathrm{Rb}, \mathrm{Li}$ and $\mathrm{T}]$ in diabase dikes: Canadian Journal of Earth Sciences, v. 11, p. 422-429.

Gottfried, D., and Froelich, A.J., 1985, Geochemical and petrologic features of some Mesozoic diabase sheets in the northern Culpeper basin, in Robinson, G.R., Jr., and Froelich, A.J., eds., Proceedings of the second U.S. Geological Survey workshop on the early Mesozoic basins of the Eastern United States: U.S. Geological Survey Circular 946, p. $86-90$.

Gottfried, D., Annell, C.S., and Schwarz, L.J., 1977, Geochemistry of subsurface basalt from the deep corehole (Clubhouse Crossroads corehole 1) near Charleston, South Carolina-Magma type and tectonic implications, in Rankin, D.W., ed., Studies related to the Charleston, South Carolina, earthquake of 1886-A preliminary report: U.S. Geological Professional Paper 1028-G, p. 91-113.

Gresens, R.L., 1967, Composition-volume relationships of metasomatism: Chemical Geology, v. 2, p. 47-65.

Pearce, J.A., and Cann, J.R., 1973, Tectonic setting of basic volcanic rocks determined using trace element analyses: Earth and Planetary Science Letters, v. 19, p. 290-300.

Smith, R.C., II, Rose, A.W., and Lanning, R.M., 1975, Geology and geochemistry of Triassic diabase in Pennsylvania: Geological Society of America Bulletin, v. 86, p. 943-955.

Weigand, P.W., and Ragland, P.C., 1970, Geochemistry of Mesozoic dolerite dikes from eastern North America: Contributions to Mineralogy and Petrology, v. 29, p. 195-214.

Yoder, H.S., Jr., and Tilley, C.E., 1962, Origin of basalt magmas: An experimental study of natural and synthetic rock systems: Journal of Petrology, v. 3, p. 342-532. 


\title{
STRUCTURAL ANALYSIS OF THE FURLONG FAULT AND THE RELATION OF MINERALIZATION TO FAULTING AND DIABASE INTRUSION, NEWARK BASIN, PENNSYLVANIA
}

\author{
Nicholas M. Ratcliffe and William C. Burton
}

\begin{abstract}
Dips of $47^{\circ}$ to $50^{\circ}$ have been determined for the Furlong fault in Pennsylvania on the basis of two continuous core holes. Cataclastic mudstones of the Brunswick Group, a horse of granophyric diabase, and Paleozoic carbonate rocks constitute the fault zone rocks. Faulting, brecciation, and abundant pyrite, albite, calcite, dolomite, and hematite mineralization have affected all rocks, almost totally replacing the granophyre. This alteration was accomplished at low temperatures of approximately 200 to $300^{\circ} \mathrm{C}$.

The lack of high-temperature contact metamorphism around the walls of the granophyre and analysis of the major-element chemistry suggest that the granophyre is a downfaulted sliver of differentiated high-Ti quartz-normative diabase of the Solebury sheet. Na mineralization accompanied normal faulting and northwest-southeast extension, indicating that albitizing fluids probably were interchanging with connate brines in the underlying Brunswick Group and Lockatong Formation.
\end{abstract}

\section{INTRODUCTION}

Cataclasis and subsequent alteration of footwall and hanging wall rocks is widespread in Mesozoic border faults of the Newark basin and in Mesozoic faults outside the basin. The effects of migration of water and carbonate-rich solutions, of precipitation of pyrite, hematite, zeolites, riebeckite, and albite, and of the wholesale replacement of fault zone rocks are characteristic of all sites cored along the Newark basin margin. For example, previous studies of the Ramapo and Flemington faults (Ratcliffe 1980; Burton and Ratcliffe, 1985b) and this study of the Furlong fault indicate that the replacement of Mesozoic basaltic rocks, shales, sandstones, and limestone conglomerates of the hanging wall is especially extensive and commonly results in multiple episodes of cementation of the fault breccias. The presence of intense alteration in Mesozoic fault zones at or near the basin margin raises the question of the extent and nature of syn- and post-fault migration of mineralizing fluids.

At many localities granophyric diabase or diabase is spatially associated with the faults, and intrusion of diabase into hanging wall and footwall blocks is suggested by field data. At locations where carbonate rocks of Paleozoic age form the hanging wall, as near Cornwall, and near Boyertown, Pennsylvania, economically important deposits of magnetite replace both diabase and cataclastic carbonate rocks of the footwall block, indicat- ing that diabase intruded the fault zones. Examination of fault zone rocks far from basin margins indicates that hematite, magnetite, copper, and zeolite mineralization is widespread, suggesting that mineralization along Mesozoic faults extended well beyond presently exposed Mesozoic basins, even in localities where evidence for igneous activity is lacking. For example, $\mathrm{Pb}$ and $\mathrm{Ag}$ and $\mathrm{Cu}$ mineralization along Mesozoic faults has been traced in the lower Hudson River valley as far north as Stissing Mountain and Ancram, New York, a distance of $32 \mathrm{mi}$ north of the northern end of the Newark basin (Ratcliffe, unpub. data).

The Furlong fault (fig. 1), located in the widest portion of the Newark basin in eastern Pennsylvania, is a major intrabasinal Mesozoic fault that truncates the Mesozoic section from the Stockton Formation to the lower part of the Brunswick Group and downdrops these rocks against Cambrian metasedimentary rocks of the Buckingham anticline. Stratigraphic separation on the Furlong has been estimated to be $990 \mathrm{ft}$ in Bucks County, Pennsylvania (McLaughlin 1959, p. 131), but may be as great as $1.2 \mathrm{mi}$. To the north the Furlong fault connects, through a complex zone of unnamed faults, with the Flemington fault in New Jersey (figs. 1, 2.) In figure 2, form lines, constructed from our strike and dip data on bedding, outline the general shape of folds and identify potential zones of faulting, which are shown by dashed lines. Tick marks on the form lines indicate direction of dip. Well-located faults, supported by fracture-intensity data or by exposures of fault zone rocks (breccia, gouge, cataclasite), are shown by heavy solid lines. To the north and northeast the Flemington fault interconnects with splays from the Newark basin margin fault near Oldwick, New Jersey (fig. 2), and to the northeast at Pottersville (Burton and Ratcliffe 1985a,b). Coarse-grained granophyric diabase is spatially associated with both the Flemington and Furlong faults. At one locality north of Flemington, New Jersey, and west of Cushetunk Mountain (fig. 2), a dike of coarse granophyre appears to have intruded along the Flemington fault, and brecciated rocks of the hanging wall (Passaic Formation of the Brunswick Group) and Stockton Formation of the footwall develop the texture of hornfels adjacent to the granophyric diabase. In the same area copper mineralization and specular hematite occur in Paleozoic carbonate rocks of the footwall block and 
barite veins are present in the Stockton near the same granophyre (Frank Markewicz, personal commun., 1980).

Along the trace of the Furlong-Flemington fault system to the south, in the Sand Brook syncline, we have mapped a very coarse-grained diabase stock and hornfels in the Stockton of the footwall (fig. 2). Previous workers have identified this poorly exposed igneous rock as Preakness Basalt, but we do not concur with that interpretation. Coarse diabase also intrudes the Stockton and Lockatong Formations in the footwall block for a length of $4 \mathrm{~km}$ just north of the Delaware River (fig. 1).

The data for the Flemington, as for the Cornwall and Boyertown, Pennsylvania, areas suggest that intrusion of diabase was controlled by normal faults. It seems clear that igneous activity and faulting overlapped in space and time, making certain Mesozoic fault zones conduits for transport of base metals from the basin rock into bordering rocks of the footwall, and very likely zones for extensive interchange with pore fluids of the sedimentary rock.

In this report we document the occurrence of such a granophyric diabase body and extensive chemical alteration of rocks of the Furlong fault near New Hope, Pennsylvania. Our data come principally from two continuously cored drill holes across the Furlong fault. This drill site was established in order to (1) determine the dip of the fault, (2) assess movement history of the fault, (3) document periods of mineralization in relation to faulting, and (4) assess the extent of barite and copper mineralization known to be present in the immediate area of the drill site.

\section{Location of the Drill Site and Regional Geology}

Two continuously cored, vertical drill holes, 716 and $355 \mathrm{ft}$ deep were completed in July 1985 across the Furlong fault near Lake Aquetong, New Hope, Pennsylvania, in the Lambertville (Pennsylvania-New Jersey) $71 / 2$ minute quadrangle (figs. 1 and 3 ). The cores were taken at two sites flanking Lower Mountain Road $0.5 \mathrm{mi}$ south of the intersection with Route 202. Deer Park No. 1 (DP-1) is just east of the road and Deer Park No. 2 (DP-2) is $344 \mathrm{ft}$ northwest of No. 1. The core sites are located about $1,000 \mathrm{ft}$ northeast of two test water wells installed for the Bucks County Planning Commission by Roy Weston Environmental Scientists and Engineers in 1968 (Bucks County test well Nos. 3 and 5).

The geology portrayed on figure 1 is from the work of McLaughlin (1959), except where modified by our mapping, chiefly in the Buckingham Mountain area and along the trace of the Furlong fault-Chalfont fault systems. The Buckingham Mountain and the area immedi- ately to the west are underlain by Middle Proterozoic gneiss, Lower Cambrian Hardyston Quartzite, and Cambrian and Ordovician carbonate rocks. A small area of green, gray, and purple phyllite of probable Cambrian age constitutes a remnant of a much larger Taconic allochthon, which is comparable to an area of rocks in the Jutland klippe $30 \mathrm{mi}$ to the north at the western margin of the Newark basin. Collectively these Lower Paleozoic rocks form a faulted anticline of Mesozoic age that is framed on the west and north by unconformable cover of the Stockton Formation. At the north end, closure of this anticline is shown by bedding in the carbonate rocks that trends northwest and dips to the northeast down the plunge of the fold, and by a small area of outcrop of red Triassic siltstone that unconformably overlies carbonate rocks on the east flank of the anticline just west of the Furlong fault. Breaching of the Buckingham anticline has exposed the floor of the Newark basin. East of the anticline the Furlong fault has downdropped Triassic strata, and locally there is evidence for a narrow faultdrag syncline. To the southwest the Furlong is intersected by the Chalfont fault, a more easterly trending fault that may have a significant component of left-lateral motion. To the east the Chalfont appears to connect with the Buckmanville fault and the Pidcock Creek fault. The dips of the Furlong, Chalfont, and other faults are not well known, as the faults are rarely exposed. Two surface exposures of the Furlong fault are known. One exposure is located at the drill site in a trench cut (figs. 3 and 7). The second is a natural exposure $0.8 \mathrm{mi}$ north of the drill site near the structural symbol that indicates a $22^{\circ}$ dip for Triassic strata east of the Furlong fault (fig. 1). At both localities cataclastic structures, gouge zones, and the fault surface itself dip southeast at $45^{\circ}$.

The drill site is located on the west flank of a narrow fault-drag syncline in red siltstones of the lower part of the Brunswick Group north of the sicklelike termination of the Lambertville diabase sill, exposed on Solebury Mountain (fig. 1). On the basis of distribution of float, we have extended the diabase to the Furlong fault, although McLaughlin (1959) shows the diabase terminating east of the fault. Between the Delaware River and the Furlong fault the Lambertville sill cuts approximately $0.3 \mathrm{mi}$ upsection. The dip of the sill in natural exposures on both sides of the Delaware is to the northwest, approximately concordant with the enclosing strata. The attitude of the western sickle-shaped mass of the sill as it approaches the fault is unknown, but it probably dips north at a moderately steep angle. The trend of the diabase where it intersects the fault is approximately parallel to the northwest-trending Solebury dike that abuts the Furlong fault from the west. Minor near-vertical diabase dikes north of the Solebury dike trend N. $20^{\circ}$ to N. $25^{\circ}$ E., subparallel to the Furlong fault. One of these dikes, to be discussed later, is the 

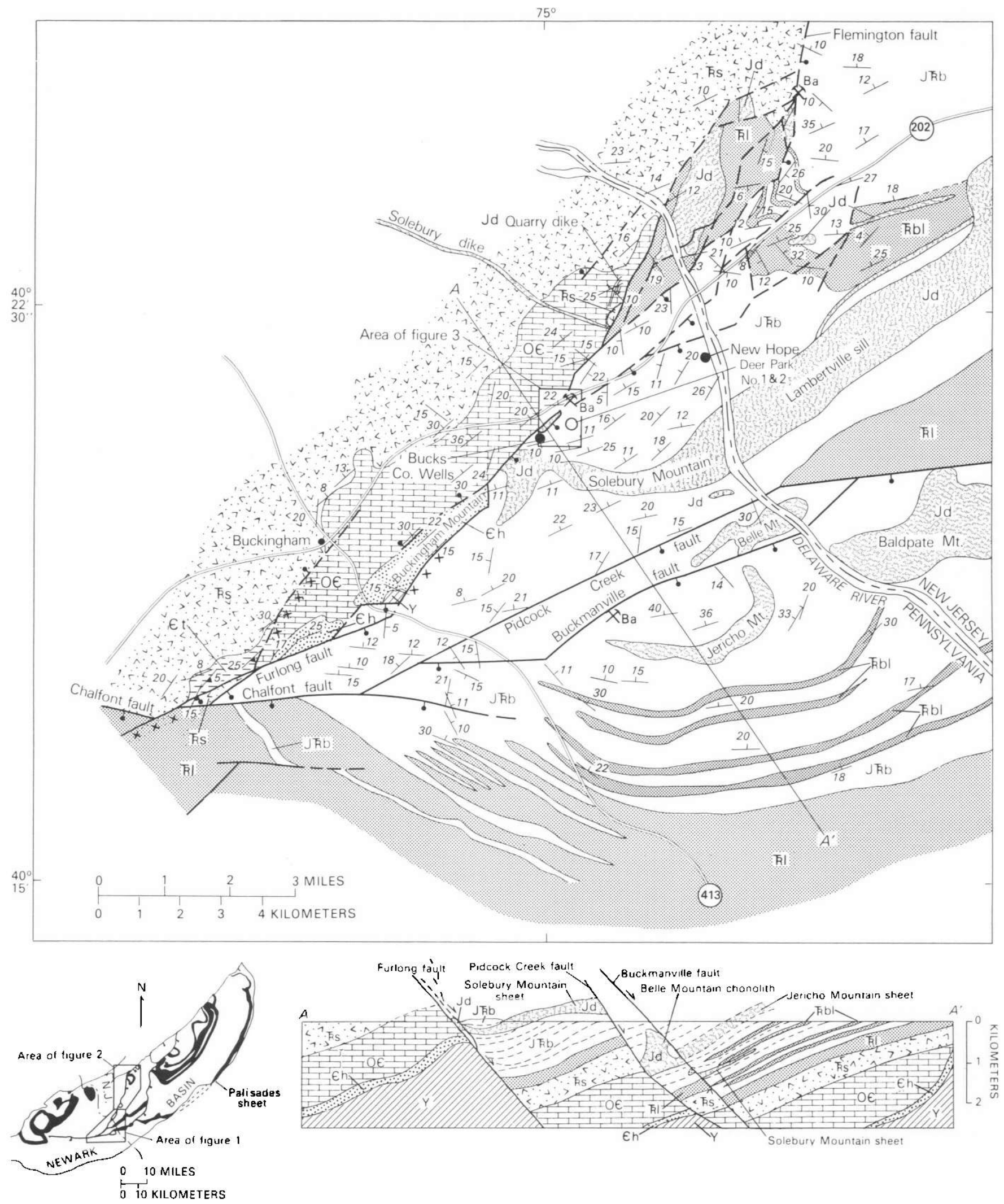
EXPLANATION

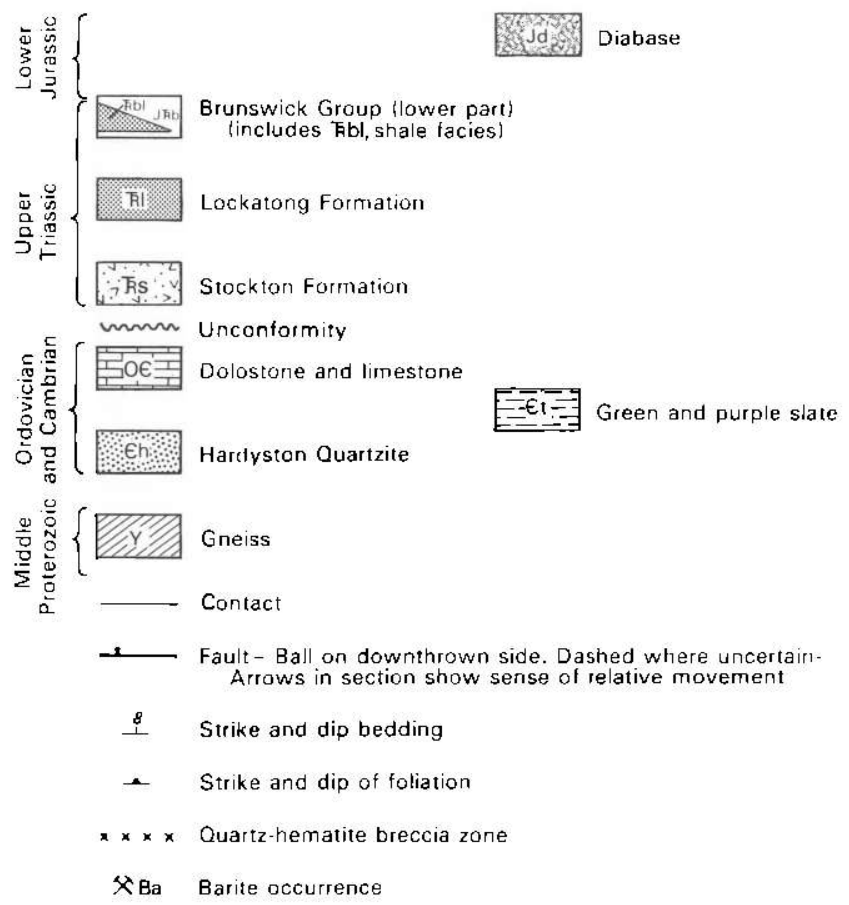

Figure 1. Geologic map and cross section of the Furlong fault in eastern Pennsylvania and New Jersey showing the location of drill site at Deer Park, major diabase bodies, and known barite prospects.

Quarry dike (of Husch and Schwimmer, 1985) that is exposed in a large dolostone quarry (fig. 1). Northeast of the Delaware River, coarse-grained, highly faulted diabase is found at three localities intruded into black shales of the Lockatong Formation and mudstone and sandstones of the Stockton Formation.

In the area of figure 1, coarse-grained diabase crops out on Jericho, Belle, and Baldpate Mountains. The relationship of these diabase bodies to the Lambertville sill is uncertain. However, the Jericho Mountain mass is at a much higher stratigraphic level (than the Lambertville sill) as measured from the Lockatong Formation.

Our interpretation of the geology (section $A-A^{\prime}$, fig. 1), modified from McLaughlin (1959), shows the Furlong fault dipping $45^{\circ} \mathrm{SE}$. and displacing the basement approximately $1.2 \mathrm{mi}$ vertically. The Lambertville sill (Solebury Mountain sheet in section $A-A^{\prime}$ ) is downdropped on the Pidcock Creek fault. We show a stocklike feeder at Belle Mountain cutting upsection from the stratigraphic level of the Lambertville sill to feed the sill-like mass at Jericho Mountain. We therefore suggest that the Jericho Mountain sheet and Belle Mountain chonolith represent the southwestward and upsection termination of the Palisades sill. By this analysis the Lambertville sheet is the lower of two separate but interconnected sheets of diabase. From VIBROSEIS data in the Oldwick area, Ratcliffe and Costain (1985) have interpreted a westwardly rising high-velocity zone near the base of the Triassic section to be the updip extension of the Lambertville sill. The stocklike granophyre near Oldwick, New Jersey (Burton and Ratcliffe, 1985b, fig. 1), and the one near Cushetunk Mountain (fig. 2) may be irregular stocklike plugs (chonoliths) like the Belle Mountain mass.

Near the drill site a small area of coarse-grained diabase is exposed along the Furlong fault from Aquetong Road north to Deer Park No. 2 (fig. 3). Local copper and barite prospects are present along the fault northeast of Deer Park No. 2 and in fields north of Aquetong Road. Copper staining is common on slickensided fault surfaces in the lower Brunswick Group along the trace of the Furlong fault immediately northeast of Lake Aquetong. Barite was discovered in dark hornfels near a branch of the Furlong-Flemington fault system north of the Delaware River (fig. 1). An additional barite prospect in the Brunswick Group is in the hanging-wall block of the Buckmanville fault (fig. 1). A small vein of barite was recovered from the mineralized mudstone in an excavation near Deer Park No. 2 (see fig. 8).

\section{RESULTS OF CORING}

Two major faults (fig. 4) were encountered. The lower fault is clearly expressed by a marked gouge zone and forms the contact between granophyre and cataclastic but weakly mineralized dolostone. The upper fault marks the contact between different materials in the two holes. In Deer Park No. 2, the upper fault, at $94 \mathrm{ft}$ depth, downdrops cataclastic red mudstone of the Brunswick Group against a zone of massive, sulfide-rich and highly albitized breccia derived from protoliths of mudstone, fine-grained diabase, and possibly dolostone. In Deer Park No. 1, the upper fault, (490-ft depth) is the contact between a relatively unmineralized breccia of Brunswick Group mudstone that also may contain fragments of dolostone and coarse-grained granophyre. Assignment of either of these faults to the Furlong fault depends upon knowing the age of the intrusion of the diabasegranophyre relative to that of the major $(\simeq 1.2 \mathrm{mi})$ downdropping on the fault. The structural setting, involving. carbonate rocks, diabase, and fault breccia, is remarkably similar to the previously discussed magnetite deposits at Cornwall and Boyertown.

Deer Park No. 1 penetrated $458 \mathrm{ft}$ of red and deep-reddish-brown mudstone of the Brunswick Group. Bedding dips as much as $20^{\circ}$ to the southeast (as determined from oriented core to be discussed), consistent with surface dips (fig. 3). Below $458 \mathrm{ft}$ down to $490 \mathrm{ft}$ is a weakly mineralized fault breccia having well-developed cataclastic textures. The breccia contains clasts of albite- 


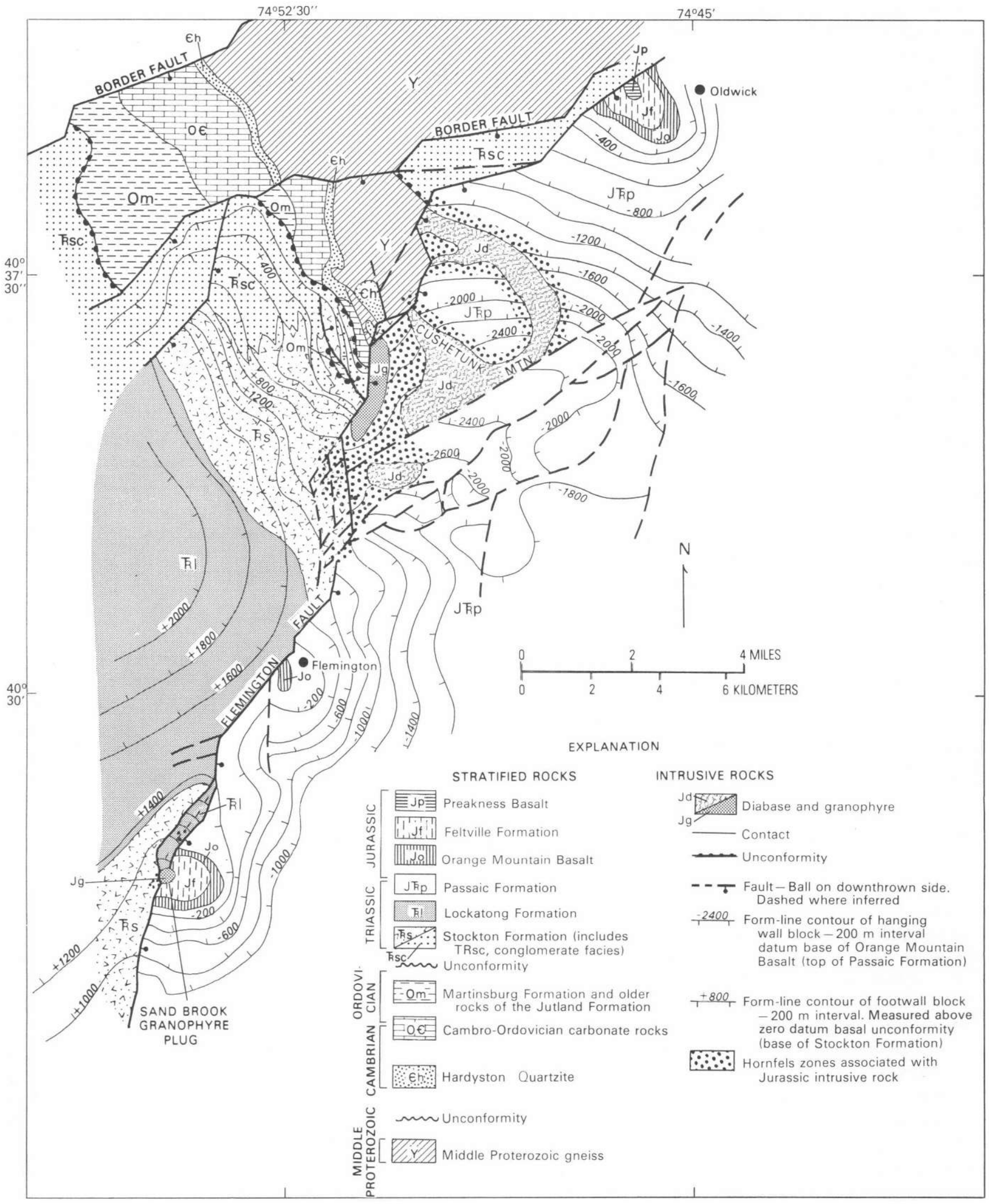

Figure 2. Regional geologic map of the Flemington fault system showing the location of coarse granophyre and hornfels. Mapping by Burton and Ratcliffe (1984 and 1985). 
calcite-dolomite-altered mudstone, possible hornfe]s, and possible quartzitic dolostone. The contact between mudstone and breccia at $458 \mathrm{ft}$ is interpreted to be a fault, healed by later mineralization. The latest faults are expressed by chlorite- and (or) hematite-coated fractures and pull-apart veins of calcite and (or) albite. Growth of euhedral crystals of pyrite and dolomite in the breccia matrix also appears to postdate all fault movement.

A sharp, faulted contact at $490 \mathrm{ft}$, between fault breccia and underlying, altered coarse-grained diabase, was recovered. The actual fault consists of a 5-mm-wide zone of green clay gouge, bordered by $1-$ to $2-\mathrm{cm}$-wide zones of hematization and cataclasis above and below (see fig. 7). The diabase of the footwall shows no evidence of chilling. Fragments in the mineralized breccia consist of albitized hornfels(?), altered mudstone, and white albite rock.

From $490 \mathrm{ft}$ to $712 \mathrm{ft}$ altered coarse-grained diabase and quartz-rich granophyre were recovered. Veins of calcite, dolomite, low-temperature albite, hematite, and pyrite crosscut the granophyre, which is locally cataclastic. Veins are brecciated by minor faults younger than the mineralization. Little primary mineralogy is preserved in the diabase, although igneous textures are readily apparent. Near the base of the granophyre, at 700 to $712 \mathrm{ft}$, thick veins(?) of light-gray, albite-rich granophyre cut the more predominant granophyric diabase.

At $712 \mathrm{ft}$ a sharp fault contact between diabase and dolostone is preserved that dips $50^{\circ}$ to the southeast. The fault zone consists of several centimeters of clayey and hematitic breccia. Four feet of gray dolostone and white quartzite were recovered beneath the fault. Mineralization appears to stop abruptly at the fault.

In Deer Park No. 2, red and dark-brown mudstone and cataclastic mudstone were recovered to a depth of 94 $\mathrm{ft}$. A narrow zone of no recovery at $94 \mathrm{ft}$ probably marks the position of the upper fault (fig. 4). From $94 \mathrm{ft}$ to about $138 \mathrm{ft}$ a mixture of white dolomite-albite rock and pyrite-rich mineralized material was recovered. The white rock is highly mineralized fault breccia, apparently derived from highly albitized mudstone, brecciated hornfels, and possibly dolostone. A zone of dark-green, finegrained diabase, probably representing a partially preserved chill zone, is present beneath dolostone(?) at 138 ft. The contact of this fine-grained diabase with overlying rocks is obscure because it is abundantly veined by albite, dolomite, and quartz. If it originally was a fault contact, it was subsequently altered so as to destroy most fault fabrics. From 164 to $171 \mathrm{ft}$ a fault-bounded sliver of the white albite-rich rock occurs (not shown on fig. 4), underlain by altered green chilled diabase. Below $176 \mathrm{ft}$ to a depth of $311 \mathrm{ft}$, coarse-grained but highly altered diabase is present. The upper contact of the coarsegrained diabase with chilled diabase at $176 \mathrm{ft}$ also appears to be faulted, with subsequent mineralization.
Near $190 \mathrm{ft}$ down to $230 \mathrm{ft}$ the diabase is locally a very quartz-rich granophyre having up to 20 percent felsic residuum. Locally veins or segregations of albite-quartz granophyre, resembling the crosscutting granophyric material at 700 to $712 \mathrm{ft}$ in Deer Park No. 1, are present. The diabase and granophyre are largely replaced by calcite, dolomite, albite, and quartz, and veins of these minerals obscure the original texture. The contact at 311 $\mathrm{ft}$ with underlying dolostone was recovered and is a sharp fault contact identical in nature to the lower fault in Deer Park No. 1 at $712 \mathrm{ft}$. Cataclastic structures are strongly developed and dip $45^{\circ}$ to $55^{\circ}$ to the southeast. Dolostone under the fault is less mineralized than rocks above the fault, and a late, post-main-mineralization age for the fault seems likely, as seen in the lower fault of Deer Park No. 1.

Study of X-ray diffraction patterns from the diabase, altered fault breccia(?), and the red mudstone of both cores reveals the ubiquitous presence of low-temperature albite and the absence of clay minerals except in some of the younger well-defined gouge zones. Veins within all rocks consist of various proportions of dolomite, calcite, low-temperature albite, chlorite, pyrite, hematite, and quartz. Abundant specular hematite and pyrite are disseminated throughout the breccia zones.

\section{Summary}

The data indicate that the Furlong fault is a complex zone of subparallel faults and breccia zones that dip $47^{\circ}$ and $50^{\circ}$ to the southeast. The presence of hornfels and highly altered hornfels of Brunswick Group mudstone within the upper fault zone and the presence of the chilled diabase in Deer Park No. 2 suggest that the upper fault may be intersecting the roof of the diabase intrusion at a low angle. However, the association of the highly mineralized and replaced fault breccia and massive albite rock in Deer Park No. 2 with the chilled diabase suggest that the diabase intruded and chilled against alreadyfaulted rocks. The exotic blocks of apparent dolostone in the two drill holes in the upper fault zone suggest that the upper fault also passes through dolostone of the footwall at some point, either up-dip or to the northeast along strike of the fault.

Coarse granophyre increases in grain size downwards in both cores, also suggesting that the roof was up, towards the present trace of the fault. The lack of intense mineralization within the dolostone of the footwall rocks indicates that these rocks were not the immediate country rocks at the time of intrusion. Chemical data (cited later) support the conclusion that the diabase in the two core holes does not overlap in $\mathrm{TiO}_{2}$ and $\mathrm{P}_{2} \mathrm{O}_{5}$ values, suggesting that the faults transect cryptic layering in the diabase, as shown schematically in figure 4 , as zones A and $\mathrm{B}$. 


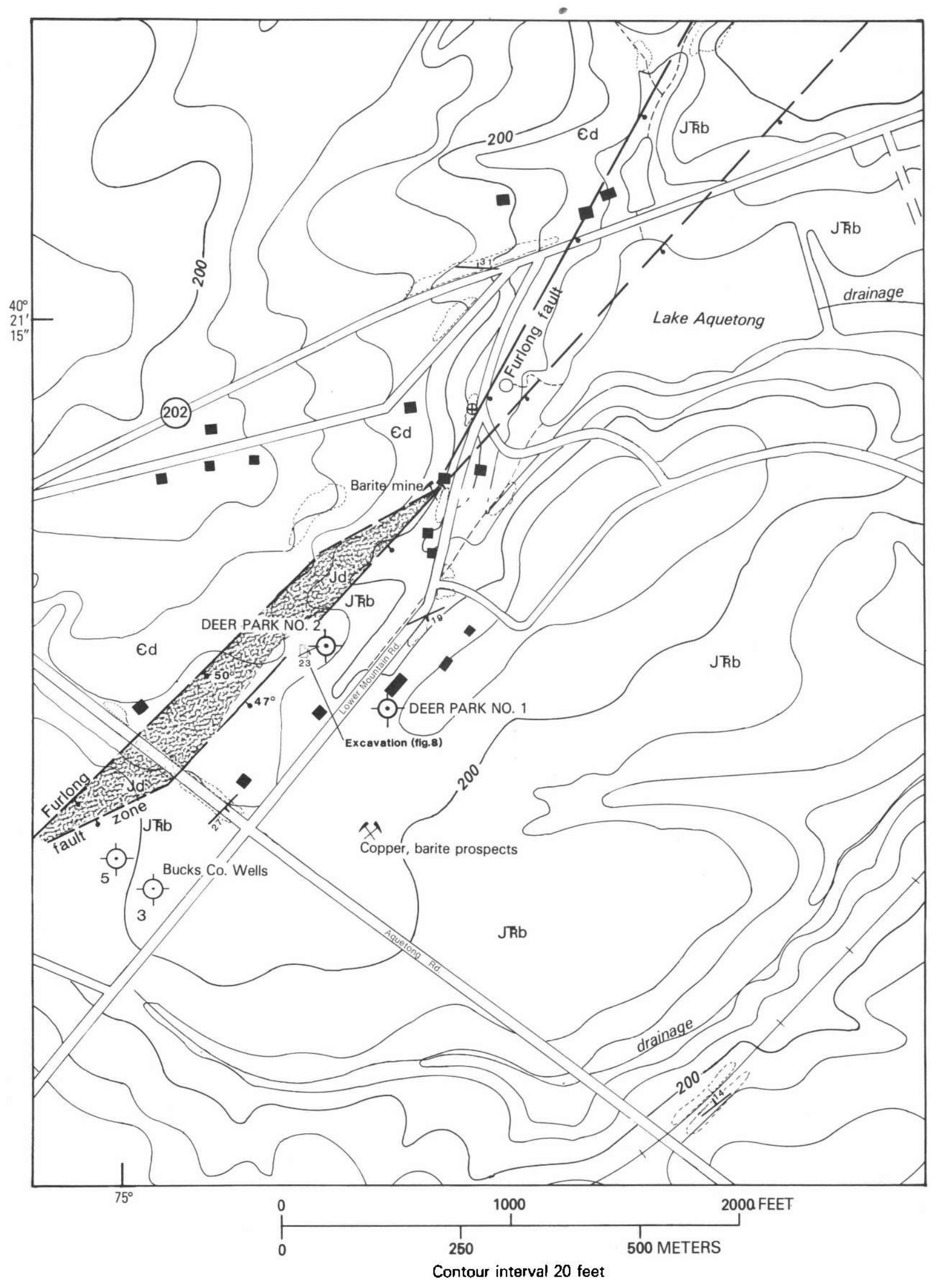




\section{EXPLANATION}

Jdirian Dase (Jurassic)

J kb Brunswick Group (Jurassic and Triassic)

$€ d$ Dolostone (Cambrian)

I Normal fault - Ball on downthrown side. Dashed where inferred. Dip shown where known

$\stackrel{23}{1}$ Strike and dip of bedding

B...... Bedrock outcrop

Figure 3. Detailed map showing location of the Deer Park core holes 1 and 2 and the trace of the Furlong fault.

\section{CHEMISTRY OF THE FAULT-ZONE ROCKS}

Preliminary data on the whole-rock composition of some of the rocks from the fault zone are presented in tables 1 and 2. Diabase from both cores is highly altered and contains high amounts of $\mathrm{CO}_{2}$ and $\mathrm{H}_{2} \mathrm{O}$ as well as high and quite variable amounts of $\mathrm{Na}_{2} \mathrm{O}$. Because of the known alteration and replacement by carbonate minerals and chlorite, the analyses of diabase are recalculated as volatile- and water-free totals. Complete replacement of pyroxene and partial replacement of the original andesine is observable in all thin sections. In addition, veins of albite, dolomite, and quartz in various proportions crisscross most samples. Undoubtedly, the $\mathrm{MgO}, \mathrm{CaO}, \mathrm{FeO}$, $\mathrm{Fe}_{2} \mathrm{O}_{3}, \mathrm{Na}_{2} \mathrm{O}$, and $\mathrm{K}_{2} \mathrm{O}$ values do not reflect the chemistry of the original igneous rocks. All samples of diabase, except for the chilled diabase at $149 \mathrm{ft}$ in DP-2, contain abundant granophyric quartz, albite micropegmatite, and

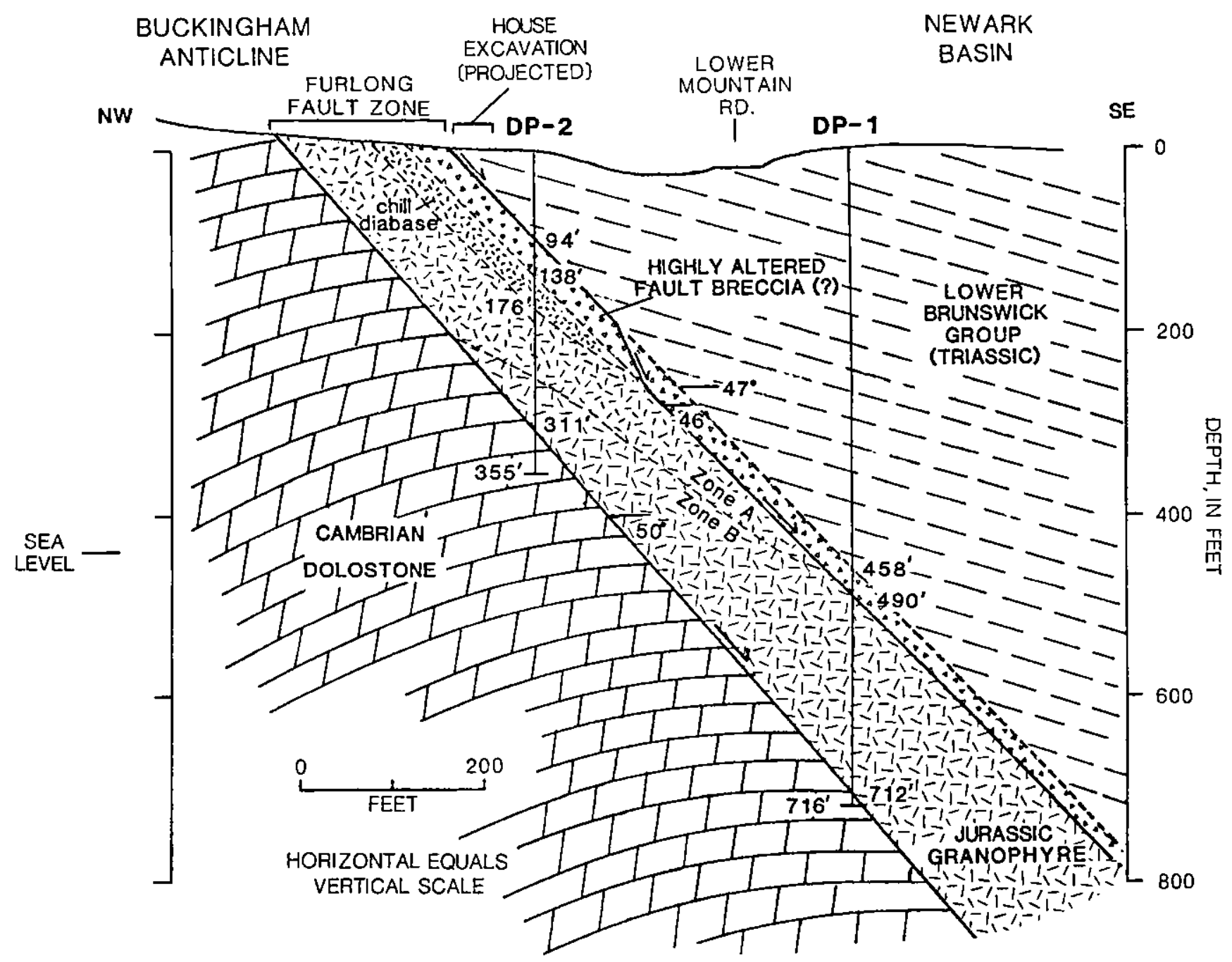

Figure 4. Interpretive cross section showing results of coring of the Furlong fault. DP-1, Deer Park core hole 1; DP-2, Deer Park core hole 2. 
Table 1. Major- and trace-element analyses of altered diabase, granophyre, and veined diabase in Deer Park Nos. 1 and 2

[Identification numbers refer to depth in core measured in feet below surface; major-element analyses by "rapid rock" technique described in Shapiro (1975); M. Kavulak, analyst; A, analysis; $B$, recalculated water and volative free; major elements in weight percent; trace elements in parts per million]

\begin{tabular}{|c|c|c|c|c|c|c|c|c|c|c|c|c|c|c|c|c|c|c|}
\hline \multirow{3}{*}{ Constituent } & \multicolumn{6}{|c|}{ Altered granophyric diabase } & \multirow{2}{*}{\multicolumn{2}{|c|}{$\begin{array}{l}\text { Albite-rich vein } \\
\text { in diabase } \\
\text { DP-1-618 }\end{array}$}} & \multirow{2}{*}{\multicolumn{2}{|c|}{$\begin{array}{c}\text { Chilled } \\
\text { diabase } \\
\text { DP-2-149.2 }\end{array}$}} & \multirow{2}{*}{\multicolumn{2}{|c|}{$\begin{array}{c}\text { Diabase } \\
\text { DP-2-179.3 }\end{array}$}} & \multirow{2}{*}{\multicolumn{2}{|c|}{$\begin{array}{l}\text { Granophyre } \\
\text { DP-2-222.5 }\end{array}$}} & \multirow{2}{*}{\multicolumn{2}{|c|}{$\begin{array}{c}\text { Diabase } \\
\text { DP-2 -272.8 }\end{array}$}} & \multirow{2}{*}{\multicolumn{2}{|c|}{$\begin{array}{c}\text { Net veined } \\
\text { diabase } \\
D P-2-202.4\end{array}$}} \\
\hline & \multicolumn{2}{|c|}{ DP-1-528 } & \multicolumn{2}{|c|}{ DP-1-590 } & \multicolumn{2}{|c|}{ DP-1-679 } & & & & & & & & & & & & \\
\hline & A & B & A & B & A & B & A & $\mathbf{B}$ & A & B & A & B & A & B & A & $\mathrm{B}$ & A & B \\
\hline$\ldots \ldots \ldots \ldots$ & 52.4 & 55.7 & 51.9 & 55.07 & 47.9 & 51.6 & 63.4 & 66.7 & 50.1 & 54.5 & 55.6 & 59.7 & 54.3 & 57.9 & 49.9 & 55.4 & 53.6 & 63.7 \\
\hline $\mathrm{Al}_{2} \mathrm{O}_{3} \ldots \ldots \ldots \ldots \ldots$ & 13.2 & 14.0 & 13.6 & 14.4 & 12.7 & 13.7 & 13.4 & 14.1 & 14.4 & 15.7 & 14.4 & 15.4 & 13.8 & 14.7 & 13.0 & 14.4 & 4.9 & 5.8 \\
\hline $\mathrm{Fe}_{2} \mathrm{O}_{3} \ldots \ldots \ldots$ & 6.1 & 6.5 & 6.6 & 7.0 & 11.4 & 12.3 & 2.9 & 3.0 & 3.0 & 3.3 & 4.8 & 5.1 & 4.8 & 5.1 & 4.9 & 5.4 & 3.2 & 3.8 \\
\hline $\mathrm{FeO} \ldots \ldots \ldots \ldots$ & 6.5 & 6.9 & 5.5 & 5.8 & 5.4 & 5.8 & 1.1 & 1.1 & 6.9 & 7.5 & 4.9 & 5.2 & 2.8 & 3.0 & 4.3 & 4.7 & 3.6 & 4.2 \\
\hline $\mathrm{MgO} \ldots \ldots \ldots \ldots$ & 4.3 & 4.6 & 3.5 & 3.7 & 3.0 & 3.2 & 1.1 & 1.2 & 6.1 & 6.6 & 3.7 & 3.9 & 2.6 & 2.8 & 3.5 & 3.9 & 4.4 & 5.2 \\
\hline $\mathrm{CaO} \ldots \ldots \ldots \ldots$ & 3.2 & 3.4 & 3.3 & 3.5 & 3.7 & 4.0 & 2.8 & 3.0 & 4.0 & 4.3 & 2.8 & 3.0 & 4.5 & 4.8 & 6.3 & 7.0 & 10.9 & 11.5 \\
\hline $\mathrm{Na}_{2} \mathrm{O} \ldots \ldots \ldots \ldots$ & 4.7 & 5.0 & 5.8 & 6.1 & 4.5 & 4.9 & 7.2 & 7.5 & 4.1 & 4.5 & 4.6 & 4.9 & 5.6 & 6.0 & 4.3 & 4.8 & 2.5 & 2.9 \\
\hline $\mathrm{K}_{2} \mathrm{O} \ldots \ldots \ldots \ldots$ & .64 & .68 & .83 & .88 & .85 & .92 & .21 & .22 & 1.7 & 1.9 & $<.01$ & .01 & 3.3 & 3.5 & 1.6 & 1.7 & .1 & .11 \\
\hline $\mathrm{H}_{2} \mathrm{O}^{+} \ldots \ldots \ldots \ldots$ & 2.6 & - & 1.2 & - & 1.8 & - & .55 & - & 3.4 & - & 2.3 & - & 1.3 & - & 1.8 & - & .33 & - \\
\hline $\mathrm{H}_{2} \mathrm{O}^{-} \ldots \ldots \ldots \ldots$ & .26 & - & .45 & - & .54 & - & .44 & - & .22 & - & .31 & - & .35 & - & .79 & - & $<.1$ & - \\
\hline $\mathrm{TiO}_{2} \ldots \ldots \ldots \ldots$ & 2.5 & 2.6 & 2.8 & 2.9 & 2.9 & 3.1 & 2.5 & 2.6 & 1.2 & 1.3 & 2.0 & 2.1 & 1.7 & 1.8 & 1.8 & 2.0 & .45 & .53 \\
\hline $\mathrm{P}_{2} \mathrm{O}_{5} \ldots \ldots \ldots \ldots$ & .29 & .3 & .28 & .29 & .27 & .29 & .29 & .3 & .18 & .19 & .26 & .27 & .26 & .27 & .23 & .25 & .09 & .1 \\
\hline $\mathrm{MnO} \ldots \ldots \ldots \ldots$ & .13 & .13 & .13 & .13 & .15 & .16 & .09 & .09 & .16 & .17 & .12 & .13 & .15 & .16 & .25 & .27 & .42 & .49 \\
\hline $\mathrm{CO}_{2} \ldots \ldots \ldots \ldots$ & 3.7 & - & 4.0 & - & 4.5 & - & 3.4 & - & 5.5 & - & 3.3 & - & 5.3 & - & 7.3 & - & 13.0 & - \\
\hline Total ........... & 100.52 & 99.81 & 99.89 & 99.77 & 99.61 & 99.97 & 99.38 & 99.81 & 100.96 & $99.96<$ & $<99.1$ & $<99.71$ & 100.76 & 100.03 & 99.97 & $99.82<$ & $<97.59$ & 98.33 \\
\hline $\mathrm{Nb}^{*}$ & & 16 & & 16 & & 14 & & 18 & & $<10$ & & 13 & & 16 & & 12 & & $<10$ \\
\hline$\ldots \ldots \ldots \ldots$ & & 14 & & 4 & & 32 & & 2 & & 50 & & 59 & & 47 & & 62 & & $<2$ \\
\hline$\ldots \ldots \ldots \ldots$ & & 74 & & 64 & & 71 & & 87 & & 42 & & 43 & & 50 & & $6 \overline{5}$ & & 70 \\
\hline$\ldots \ldots \ldots \ldots$ & & 194 & & 192 & & 175 & & 208 & & 109 & & 169 & & 173 & & 156 & & 43 \\
\hline$\ldots \ldots \ldots \ldots$ & & 36 & & 35 & & 40 & & 48 & & 18 & & 31 & & 32 & & 31 & & 22 \\
\hline $\mathrm{Ba}^{*} \ldots \ldots \ldots \ldots$ & & 43 & & 199 & & 95 & & 235 & & 29 & & 57 & & 60 & & 51 & & 110 \\
\hline $\mathrm{Ce}^{*} \ldots \ldots \ldots \ldots \ldots$ & & 22 & & 33 & & 33 & & 52 & & 16 & & 32 & & 15 & & 28 & & 26 \\
\hline $\mathrm{La}^{*} \ldots \ldots \ldots \ldots \ldots$ & & 20 & & 10 & & 24 & & 21 & & 12 & & 20 & & 25 & & 27 & & 11 \\
\hline $\mathrm{Cu} * \ldots \ldots \ldots \ldots$ & & 63 & & 13 & & 19 & & $<2$ & & 189 & & 66 & & 10 & & 17 & & $<2$ \\
\hline $\mathrm{Ni}^{*} \ldots \ldots \ldots \ldots \ldots$ & & 45 & & 43 & & 54 & & 13 & & 99 & & 43 & & 44 & & 43 & & 19 \\
\hline $\mathrm{Zn}^{*} \ldots \ldots \ldots \ldots \ldots$ & & 84 & & 59 & & 76 & & 25 & & 102 & & 78 & & 47 & & 67 & & 35 \\
\hline $\mathrm{Cr}^{*} \ldots \ldots \ldots \ldots \ldots$ & & 53 & & 65 & & 63 & & 20 & & 325 & & 36 & & 29 & & 38 & & $<20$ \\
\hline $\mathrm{B}^{* *} \ldots \ldots \ldots \ldots \ldots$ & & 14 & & 11 & & 81 & & 7 & & 91 & & 36 & & 28 & & 38 & & 8 \\
\hline $\mathrm{Co}^{* *} \ldots \ldots \ldots \ldots$ & & 13 & & 19 & & 22 & & 60 & & 26 & & 17 & & 76 & & 15 & & 130 \\
\hline $\mathrm{Pb}^{* *} \ldots \ldots \ldots \ldots \ldots$ & & 17 & & 18 & & 26 & & 21 & & 10 & & 17 & & 17 & & $<6.8$ & & 11 \\
\hline$V^{* *} \ldots \ldots \ldots \ldots \ldots$ & & 390 & & 530 & & 520 & & 250 & & 220 & & 270 & & 250 & & 340 & & 33 \\
\hline
\end{tabular}

* Determined by X-ray spectroscopy. R. Johnson and S. Fleming, analysts.

** Determined by emission spectrography. C. Skeen, analyst. The relative standard deviation for each reported concentration is plus 50 percent and minus 33 percent. 
Table 2. Major- and trace-element analyses of altered mudstone and albite rock

[Major-element analyses by "rapid rock" technique described in Shapiro (1975); M. Kavulak, analyst; major elements in weight percent; trace elements in parts per million]

\begin{tabular}{|c|c|c|c|c|c|c|c|c|c|c|c|c|}
\hline \multirow[b]{2}{*}{ Constituent } & \multicolumn{2}{|c|}{ Red mudstone } & \multicolumn{5}{|c|}{ Partially albitized mudstone } & \multirow{2}{*}{\multicolumn{2}{|c|}{$\begin{array}{l}\text { Gray albite } \\
\text { rock } \\
\text { DP-2-96.5 }\end{array}$}} & \multirow{2}{*}{\multicolumn{2}{|c|}{$\begin{array}{l}\text { Light-gray to white } \\
\text { albite hematite rock } \\
\text { DP-2-106 }\end{array}$}} & \multirow{2}{*}{$\begin{array}{c}\text { White albite } \\
\text { rock } \\
\text { DP-2-123.9 }\end{array}$} \\
\hline & DP-1-68 & $D P-1-228$ & $\mathrm{DP}-2-56.3$ & $\mathrm{DP}-2$ & 61.7 & $\mathrm{DP}-2$ & 84.5 & & & & & \\
\hline $\mathrm{SiO}_{2}$. & . 51.5 & 52.8 & 55.1 & 46.7 & $50.3^{*}$ & 49.9 & $51.6^{*}$ & 49.3 & $51.0^{*}$ & 39.7 & $41.6^{*}$ & 56.4 \\
\hline $\mathrm{Al}_{2} \mathrm{O}_{3} \ldots \ldots$ & . 20.7 & 17.1 & 17.0 & 17.4 & 18.7 & 13.4 & 13.8 & 15.6 & 16.1 & 12.4 & 12.9 & 17.1 \\
\hline $\mathrm{Fe}_{2} \mathrm{O}_{3}$ & . 8.0 & 5.9 & .83 & 12.9 & 14.0 & 6.4 & 6.6 & 9.4 & 9.7 & 9.4 & 9.8 & .78 \\
\hline $\mathrm{FeO}$. & 1.4 & 1.3 & .96 & - & - & - & - & - & - & - & - & 1.6 \\
\hline $\mathrm{MgO}$ & 3.6 & 3.7 & 2.4 & 2.7 & 2.9 & 3.3 & 3.4 & 2.9 & 3.0 & 1.2 & 1.3 & 2.1 \\
\hline $\mathrm{CaO}$. & .76 & 3.7 & 5.1 & 2.2 & 2.4 & 7.0 & 7.3 & 4.9 & 5.1 & 13.6 & 14.2 & 5.0 \\
\hline $\mathrm{Na}_{2} \mathrm{O} \ldots \ldots$ & 2.3 & 4.1 & 8.2 & 4.9 & 5.3 & 5.5 & 5.7 & 7.7 & 8.0 & 6.2 & 6.5 & 8.9 \\
\hline $\mathrm{K}_{2} \mathrm{O} \ldots \ldots$ & 5.3 & 3.3 & 1.0 & 2.8 & 3.0 & 1.3 & 1.3 & .10 & .11 & .34 & .35 & .59 \\
\hline $\mathrm{H}_{2} \mathrm{O}^{+} \ldots \ldots$ & 3.7 & 1.4 & .82 & - & - & - & - & - & - & - & - & .55 \\
\hline $\mathrm{H}_{2} \mathrm{O}^{-} \ldots \ldots$ & 1.4 & .82 & .72 & .57 & .61 & .91 & .94 & 39 & .40 & .16 & .16 & .16 \\
\hline $\mathrm{TiO}_{2} \ldots \ldots$ & .82 & .73 & .45 & .70 & .75 & .58 & .6 & .67 & .70 & .57 & .59 & .81 \\
\hline $\mathrm{P}_{2} \mathrm{O}_{5} \ldots \ldots$ & .23 & .20 & .15 & .19 & .20 & .16 & .16 & .18 & .18 & .14 & .14 & .17 \\
\hline $\mathrm{MnO}$ & .06 & .16 & .21 & .06 & .06 & .20 & .21 & .17 & .17 & .23 & .24 & .17 \\
\hline $\mathrm{CO}_{2}$ & .30 & 4.3 & 6.5 & 1.7 & 1.83 & 7.9 & 8.2 & 5.3 & 5.5 & 11.5 & 12.0 & 6.4 \\
\hline Total S... & . - & - & - & $>3$ & - & 2.96 & - & 4.36 & - & - & - & - \\
\hline Total $\% \ldots$ & 100.07 & 99.51 & 99.44 & $>95.82$ & 100.05 & 99.51 & 99.81 & 100.97 & 99.96 & 95.44 & 99.78 & 100.73 \\
\hline $\mathrm{Nb}^{* *}$ & . 21 & 19 & 13 & 17 & & 16 & & 14 & & 15 & & 20 \\
\hline $\mathrm{Rb}^{* *} \ldots \ldots$ & .259 & 157 & 44 & 134 & & 55 & & $<2$ & & 13 & & 22 \\
\hline $\mathrm{Sr}^{* *} \ldots \ldots \ldots$ & .171 & 204 & 90 & 59 & & 102 & & 90 & & 218 & & 129 \\
\hline $\mathrm{Zr}^{* *} \ldots \ldots \ldots$ & .157 & 184 & 111 & 143 & & 148 & & 104 & & 93 & & 148 \\
\hline $\mathrm{Y}^{* *} \ldots \ldots \ldots$ & . 39 & 36 & 21 & 29 & & 31 & & 19 & & 25 & & 27 \\
\hline $\mathrm{Ba}^{* *} \ldots \ldots \ldots$ & .403 & 278 & 110 & 585 & & 113 & & 31 & & 105 & & 141 \\
\hline $\mathrm{Ce}^{* *} \ldots \ldots \ldots$ & . 89 & 87 & 53 & 71 & & 63 & & 55 & & 49 & & 61 \\
\hline $\mathrm{La}^{* *} \ldots \ldots \ldots$ & . 38 & 38 & 17 & 50 & & 36 & & 39 & & 44 & & 53 \\
\hline $\mathrm{Cu}^{* *} \ldots \ldots \ldots$ & 4 & $<2$ & 3 & 86 & & 5 & & 47 & & 14 & & 5 \\
\hline $\mathrm{Ni}^{* *} \ldots \ldots \ldots$ & . 70 & 46 & 23 & 89 & & 29 & & 53 & & 21 & & 12 \\
\hline $\mathrm{Zn}^{* *} \ldots \ldots \ldots$ & . 101 & 75 & 42 & 71 & & 55 & & 51 & & 40 & & 35 \\
\hline $\mathrm{Cr}^{* *} \ldots \ldots \ldots$ & . 118 & 91 & 56 & 111 & & 69 & & 105 & & 71 & & 77 \\
\hline $\mathrm{B}^{* * *} \ldots \ldots$ & .450 & 260 & 11 & 240 & & 120 & & 140 & & 10 & & 26 \\
\hline $\mathrm{Co}^{* * *} \ldots \ldots$ & . 24 & 35 & 13 & 120 & & 25 & & $<32$ & & 8 & & 36 \\
\hline $\mathrm{Pb}^{* * *} \ldots \ldots$ & . 40 & 35 & 15 & 28 & & 17 & & 11 & & 14 & & 15 \\
\hline$V^{* * *} \ldots \ldots \ldots$ & .130 & 99 & 72 & 100 & & 83 & & 150 & & 57 & & 110 \\
\hline
\end{tabular}

* Recalculated to 100 percent sulfur free.

** Determined by X-ray spectroscopy. R. Johnson and S. Fleming, analysts.

*** Determined by emission spectography. C. Skeen, analyst. The relative standard deviation for each reported concentration is plus 50 percent and minus 33 percent.

myrmekite. Felsic residuum, present as fine-grained intergranular material and as coarse-grained segregations, amounts to 30 percent by volume of some samples, most notably DP-2-225.5. The original pyroxene content is variable, from approximately 30 percent in DP-2-149.2 to less than 2 percent in DP-2-225.5. The textures and the content of felsic minerals in the diabase indicate that this diabase is unusually fractionated granophyric diabase comparable in texture and amount of residuum to the most felsic portions of the Palisades sill at 790 to $800 \mathrm{ft}$ described by Walker (1969). Abundant skeletal magnetite-ilmenite is present in granophyres in DP-1.

Plots of mafic index versus $\mathrm{TiO}_{2}$ and of $\mathrm{TiO}_{2}$ versus $\mathrm{P}_{2} \mathrm{O}_{5}$ for diabase from holes DP-1 and DP-2 (figs. $5 A$, $B$ ) show the consistently high $\mathrm{TiO}_{2}$ values and coherent trends for the diabases despite the intense alteration. Less differentiated samples of the Lawrenceville sill (Husch and others, 1984) and of the Quarry dike (Husch and Schwimmer, 1985) are comparable to the least differentiated sample (DP-2-149). Importantly, the variation diagrams for both $\mathrm{TiO}_{2}$ versus $\mathrm{P}_{2} \mathrm{O}_{5}$ and for mafic index versus $\mathrm{TiO}_{2}$ show that the igneous rocks in DP-1 and DP-2 do not correlate on a 1:1 basis. These data suggest that the diabase in DP-1 was more differentiated than any diabase in DP-2.

The Lambertville sill and Quarry dikes (Husch and others, 1984, table 1; and Husch and Schwimmer, 1985) are weakly to moderately differentiated diabase in comparison to the samples from holes DP-1 and DP-2. The well-defined trend lines in both diagrams support fractional crystallization as the origin of the granophyre in 

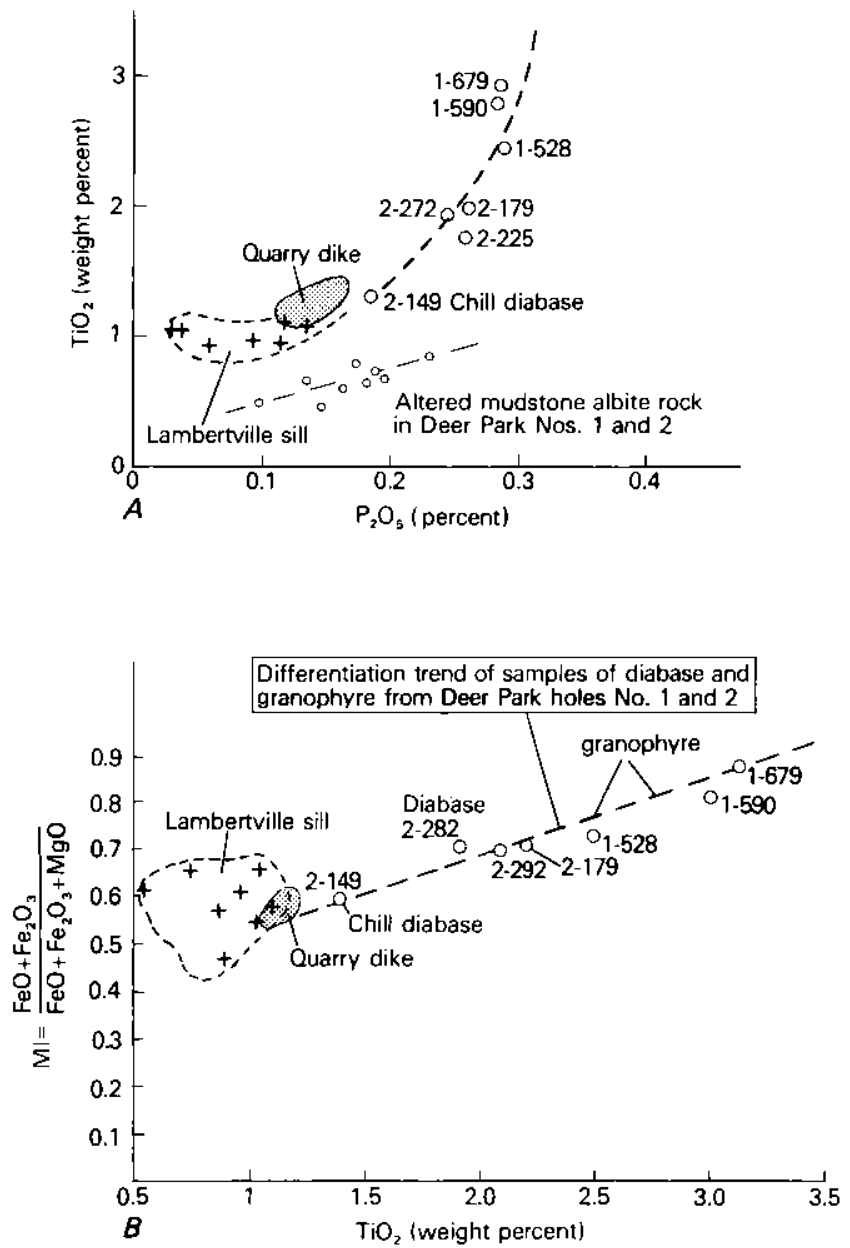

Figure 5. $\mathrm{TiO}_{2}$ versus $\mathrm{P}_{2} \mathrm{O}_{5}(A)$ and mafic index (MI) versus $\mathrm{TiO}_{2}(B)$ diagrams of diabase, chill diabase granophyre, mudstone, and albitized rocks from Deer Park core holes 1 and 2 in comparison to Palisades chill diabase and granophyre, to Lambertville sill, and to the Quarry dike. Core depths are in feet.

the two holes. The chill sample 2-149 agrees fairly closely with undifferentiated samples of the Quarry dike and with samples of the Lambertville sill. All appear to belong to the high-TiO ${ }_{2}$ quartz tholeiites of Weigand and Ragland (1970).

The highly variable chemistry and clear evidence for replacement is borne out by a plot of mafic index versus felsic index for diabase samples from both cores. The normal differentiation trend for the Palisades sill is shown for comparison, as are samples of altered mudstone and albite rock. All igneous rocks, including the chilled diabase, are, however, enriched in alkali over any normal diabase, and especially in $\mathrm{Na}_{2} \mathrm{O}$ (fig. 6). Comparison of the $\mathrm{Na}_{2} \mathrm{O}$ to $\mathrm{K}_{2} \mathrm{O}$ values across the diabase shows that this alteration was largely an addition of $\mathrm{Na}$, apparently in the form of albite-rich veinlets.

Major- and trace-element chemistry for samples of least altered Brunswick Group mudstone from DP-1 and
EXPLANATION

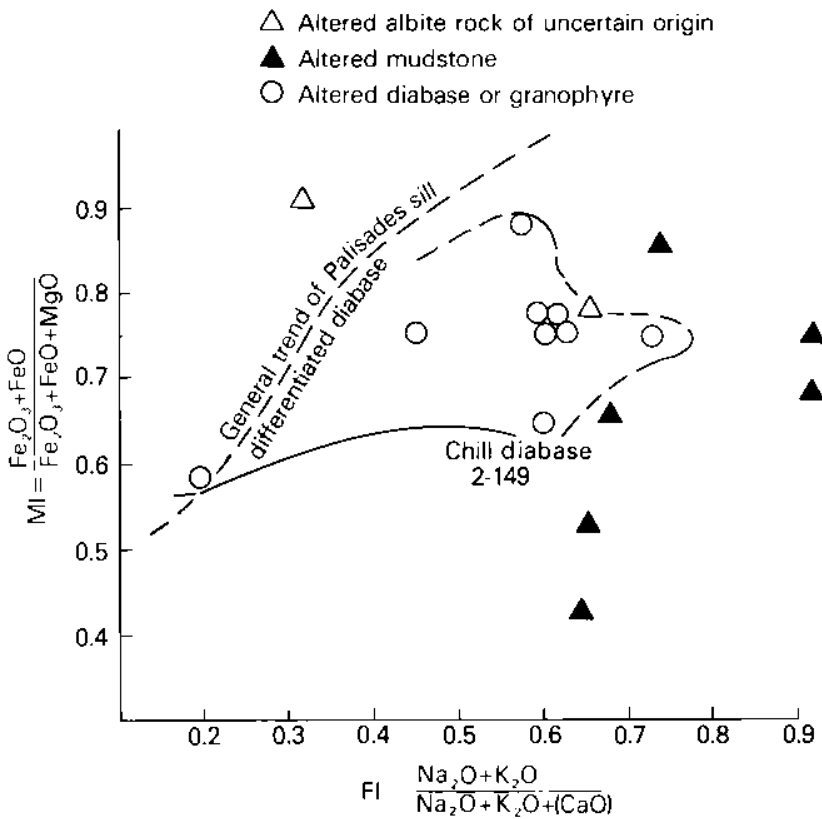

Figure 6. Plot of mafic index (MI) versus felsic index (FI) for altered diabase, granophyre, altered mudstone, and albite rock of uncertain origin from Deer Park coreholes 1 and 2 in comparison to the generalized uncontaminated trend of the Palisades diabase.

for variably altered mudstone in DP-2 is presented in table 2. Analyses of white to gray albite-calcite-dolomite rock of uncertain origin from DP-2 are given. Three of the samples in table 2 contain in excess of 3 percent total sulfur owing to abundant pyrite mineralization, and the analyses are incomplete for $\mathrm{FeO}$ and $\mathrm{H}_{2} \mathrm{O}^{+}$.

$\mathrm{X}$-ray diffraction patterns show that the rocks in tables 1 and 2 contain quartz, dolomite, calcite, chlorite, hematite, pyrite, and albite as the principal minerals. Proportions of these minerals vary, but even the least altered siltstone contains abundant albite and dolomite. Veins crosscutting the rocks consist of (1) dolomitecalcite, (2) albite, (3) calcite, and (4) albite-quartz-pyrite. Quartz crystals in albite veins are elongate 1:5 (width to length) and commonly show pyramidal terminations. Diffraction patterns suggest low-temperature albite. The quartz habit suggests crystallization of primary lowtemperature quartz. Clays are absent from the mudstone, although sericite is present in some samples. The assemblage dolomite plus quartz is stable in all rocks.

The mudstone, feldspathized mudstone, and albiterich rocks define a distinct $\mathrm{TiO}_{2}$ versus $\mathrm{P}_{2} \mathrm{O}_{5}$ trend that appears to separate these rocks from trends of the diabase and chilled diabase.

The albitized mudstone consists of variably replaced red mudstone in which albitization and sericitization follow cracks and faults. Textures in the upper part of DP-2 (near the fault beneath the mudstone) indicate 
Table 3. Comparison of major elements and selected trace elements in diabase from DP-1 and DP-2 with other Newark basin diabase samples

[Major elements in weight percent, trace elements in parts per million; tr, trace; -, not detectable or not analyzed for]

\begin{tabular}{|c|c|c|c|c|c|c|c|}
\hline \multirow[b]{3}{*}{ Constituent } & \multicolumn{2}{|c|}{ Palisades sill at Englewood Cliffs } & \multirow{3}{*}{$\begin{array}{c}\text { Quarry dike } \\
\text { (Husch and } \\
\text { Schwimmer, } \\
\text { 1985) }\end{array}$} & & & \multirow{3}{*}{\multicolumn{2}{|c|}{$\begin{array}{c}\text { Diabase } \\
\mathrm{DP}-1 \text { and } \mathrm{DP}-2 \\
\text { range of values } \\
\text { (anhydrous) }\end{array}$}} \\
\hline & \multirow{2}{*}{$\begin{array}{c}\text { Walker, 1969) } \\
\text { chill } \\
\text { average }\end{array}$} & \multirow{2}{*}{$\begin{array}{l}\text { Granophyre } \\
790 \text {-ft height }\end{array}$} & & \multicolumn{2}{|c|}{$\begin{array}{l}\text { Lambertville sill } \\
\text { (Husch and others, 1984) }\end{array}$} & & \\
\hline & & & & LS3 & LSB & & \\
\hline $\mathrm{SiO}_{2}$ & 52.0 & 58.59 & 52.88 & 52.63 & 53.07 & 51.6 & -59.7 \\
\hline $\mathrm{Al}_{2} \mathrm{O}_{3} \ldots \ldots \ldots$ & 14.2 & 11.26 & 14.26 & 14.23 & 18.09 & 15.7 & -13.7 \\
\hline $\mathrm{Fe}_{2} \mathrm{O}_{3} \ldots \ldots \ldots$ & 1.35 & 3.00 & - & 1.94 & 1.69 & 12.3 & -3.1 \\
\hline $\mathrm{FeO} \ldots \ldots \ldots$ & 8.9 & 10.80 & $10.13^{*}$ & 8.26 & 7.20 & 7.5 & -4.7 \\
\hline $\mathrm{MgO} \ldots \ldots \ldots$ & 7.6 & 1.35 & 7.91 & 8.04 & 4.65 & 6.6 & -3.2 \\
\hline $\mathrm{CaO} \ldots \ldots \ldots$ & 10.3 & 3.66 & 10.96 & 10.93 & 10.55 & 7.0 & -3.0 \\
\hline $\mathrm{Na}_{2} \mathrm{O} \ldots \ldots \ldots$ & 2.0 & 3.68 & 2.01 & 1.99 & 2.84 & 6.0 & -4.5 \\
\hline $\mathrm{K}_{2} \mathrm{O} \ldots \ldots \ldots$ & .85 & 2.52 & 1.12 & .59 & .58 & 3.5 & $-\quad .68$ \\
\hline $\mathrm{H}_{2} \mathrm{O} \ldots \ldots \ldots$ & 1.05 & 1.95 & - & - & - & - & -- \\
\hline $\mathrm{TiO}_{2} \ldots \ldots \ldots$ & 1.2 & 1.56 & 1.13 & 1.11 & 1.03 & 3.1 & -1.3 \\
\hline $\mathrm{P}_{2} \mathrm{O}_{5} \ldots \ldots \ldots$ & .15 & .85 & .13 & .12 & .14 & 3 & $-\quad .19$ \\
\hline $\mathrm{MnO} \ldots \ldots \ldots$ & .15 & .19 & .16 & & .15 & .13 & .17 \\
\hline Total \%..... & 99.75 & 99.41 & 100.69 & 99.84 & 99.99 & & \\
\hline$\ldots \ldots$ & $\mathrm{tr}$ & 140 & - & - & - & 91 & -11 \\
\hline $\mathbf{B a} \ldots \ldots \ldots$ & 195 & 560 & 156 & 163 & 153 & 199 & -29 \\
\hline Cr. ......... & 315 & 7 & 298 & 274 & 42 & 325 & -29 \\
\hline $\mathrm{Ni} \ldots \ldots \ldots \ldots$ & 95 & 7 & 92 & 90 & 186 & 99 & -43 \\
\hline Rb $\ldots \ldots \ldots$ & - & - & 37 & 19 & 17 & 62 & -4 \\
\hline Sc......... & 37 & 23 & 36 & 36 & 30 & - & -- \\
\hline Sr $\ldots \ldots \ldots \ldots$ & 175 & 185 & 189 & 162 & 218 & 65 & -42 \\
\hline$V \ldots \ldots \ldots$ & 235 & 13 & 256 & 260 & 232 & 530 & -220 \\
\hline $\mathrm{Zr} . \ldots \ldots \ldots \ldots$ & 120 & 330 & 101 & 93 & 96 & 120 & -27 \\
\hline
\end{tabular}

- Total Fe as FeO.

that albitization postdated formation of cataclastic fabrics in the mudstone. Textures indicating replacement of cataclastic structures in siltstone are present in samples DP-2-36.3 through DP-2-106. The albite rock down to a depth of $106 \mathrm{ft}$ is medium to dark gray and very much veined by calcite and white albite veins. Below $106 \mathrm{ft}$ the albite rock is much whiter, richer in albite, and poorer in total iron. This rock, represented by sample DP-2-123.9, extends to $138 \mathrm{ft}$, where chilled diabase begins. Throughout a considerable zone, brecciated chilled diabase and white albite rock are intermixed and a large portion of the whiter albite rock appears to be vein material. Locally the texture of the white rock develops into a mediumgrained (1-2 $\mathrm{mm})$ albite-quartz granophyric rock without the clear evidence of replacement textures seen in the mudstone above. The white massive albite rock is interpreted as a vein filling of the breccia zone. Textures seen in thin section indicate many episodes of brecciation and recementation of the albitized breccia. Near the bottom of the diabase in DP-2, from about $300 \mathrm{ft}$ down to the fault, a coarse-grained granophyric rock consisting of well-twinned albite $\left(\mathrm{An}_{0-5}\right)$ in crystals up to $5 \mathrm{~mm}$ long is developed. The coarse-grained albite rock contains quartz, possible $\mathrm{K}$-feldspar, and no indications of original pyroxene or skeletal magnetite characteristic of the granophyric diabase above. Despite the fact that this rock is thoroughly brecciated and veined by dolomite and calcite, it appears to have crystallized as a coarse-grained albite-quartz rock. A similar zone having diabasic texture about $10 \mathrm{ft}$ thick within the diabase at $199 \mathrm{ft}$ also contains abundant coarse albite and no pyroxene. The normal plagioclase in diabase elsewhere in DP-1 and DP-2 is approximately $\mathrm{An}_{40}$. These zones of coarse diabasic textured albite rock in the granophyric diabase appear to be $\mathrm{Na}_{2} \mathrm{O}$-rich segregations in the granophyric diabase.

\section{Discussion of Trace-Element Abundances}

Trace-element composition (table 3 ) of the chilled diabase (DP-2-149.2) is comparable to chill diabase of the Palisades, the Quarry dike, and the chill border of the Lambertville sill in having low $\mathrm{Ba}, \mathrm{Zr}, \mathrm{V}$, and $\mathrm{TiO}_{2}$ relative to granophyre of the Palisades and to granophyric diabase in DP-1 and DP-2 (table 3). Comparison of the range of values of trace elements in the altered diabase in DP-1 and DP-2 with the range in the Palisades sill between chill diabase and granophyre at $790 \mathrm{ft}$ in the Englewood Cliff section (Walker, 1969) reveals important differences.

Although the granophyric diabase in the cores is strongly enriched in $\mathrm{TiO}_{2}$ and $\mathrm{P}_{2} \mathrm{O}_{3}$ (figure $5 B$ ), well 
above any Palisades or Lambertville sill samples, the enrichment in $\mathrm{Ba}, \mathrm{B}, \mathrm{Sr}$, and $\mathrm{Zr}$ is not comparable. In fact the diabase samples are markedly depleted in $\mathrm{Sr}$ and $\mathrm{Ba}$ and unusually enriched in $\mathrm{V}$ and $\mathrm{TiO}_{2}$. Levels of these latter elements are comparable or exceed values in the most differentiated ferrodoleritic Palisades samples (790$800 \mathrm{ft}$ ) in the Englewood Cliffs section near the upper contact.

By comparison, the albitic veins, represented by the purest sample, DP-2-123.9, are very low in B, relatively depleted in $\mathrm{Ba}$ and $\mathrm{Sr}$, and low in $\mathrm{TiO}_{2}$ and $\mathrm{V}$, in agreement with the low total iron values. The major oxide in the albite rock appears to be specular hematite.

The variation in $\mathrm{TiO}_{2}, \mathrm{P}_{2} \mathrm{O}_{5}, \mathrm{~V}, \mathrm{Zr}$, and $\mathrm{Ba}$ in each core hole suggests that the diabases sampled in each hole tend to increase in late-stage residual elements downwards but that the two sections of diabase do not overlap completely. The data suggest that the diabase sequence from DP-2-147.2 down to DP-2-272.8 (Zone A in fig. 4 ) is a less differentiated sequence than that preserved in DP-1 between 528 and $679 \mathrm{ft}$ (Zone B in fig. 4). The boundary shown in figure 4 is hypothetical.

Alteration of all rocks by addition of $\mathrm{CO}_{2}, \mathrm{Na}$, and possibly $\mathrm{V}$ has been extreme. When allowances are made for the $\mathrm{CaO}$ and $\mathrm{MgO}$ tied up in dolomite and calcite veins, the $\mathrm{CaO}$ and $\mathrm{MgO}$ values for the igneous rocks themselves are low and net loss of $\mathrm{CaO}$ and $\mathrm{MgO}$ from the igneous rocks is likely.

Trace-element composition of the red mudstone, partially albitized mudstone, and gray and white albite rock show extreme variability that is not easily accounted for. $B$ and $B$ a contents are irregular but tend to be higher in the albitized and red mudstone than in the white or gray albite rock. $\mathrm{Rb}$ tends to decrease with increasing albitization and loss of $\mathrm{K}_{2} \mathrm{O}$, whereas $\mathrm{La}$ is highest in strongly albitized rock. $\mathrm{Cu}, \mathrm{Ni}, \mathrm{Cr}$, and $\mathrm{Zn}$ in red mudstone tend to be as high or higher than values within normal diabase, although values overlap considerably. In part the higher level of these elements coincides with samples having the greatest pyritization. In thin section, zones of albitization in otherwise pyrite-rich mudstone contain little or no pyrite but contain specular hematite instead.

The major- and trace-element data indicate clearly wholesale mobility of elements within the fault zone and within the overlying sedimentary rock. Even the apparently least altered mudstones have anomalous chemistry. As the contact with diabase is approached in both cores, albitization, either by replacement veins or by injection of albite-quartz veins, is increased. This albitization and alteration postdates some faulting in the mudstone and in the diabase but does not seem to affect rocks in the footwall, at the lower fault contact.

The data are consistent with $\mathrm{Na}, \mathrm{Ba}, \mathrm{B}, \mathrm{Mg}, \mathrm{Ca}, \mathrm{Si}$, and $S$ all being mobile during faulting. The mobility of $B$ and $\mathrm{Na}$ throughout the fault zone and overlying mudstone, in conjunction with the high degree of igneous fractionation in the diabase and albite granophyre, suggest strongly that the diabase was a source for some of the constituents of the mineralization. However, the low levels of $\mathrm{Cu}, \mathrm{K}_{2} \mathrm{O}, \mathrm{Sr}$, and $\mathrm{Ba}$ in the diabase itself suggest that wholesale alteration of the diabase also occurred. The very strong enrichment in $\mathrm{Na}_{2} \mathrm{O}$ and carbonate in both the diabase and the albitized mudstone suggests that the ultimate source of these alkaline solutions may have been connate brines present in the Lockatong Formation and overlying sediments at the time of intrusion.

\section{STRUCTURE OF THE FAULT ZONES}

Complete recovery of three fault gouge zones was achieved in the drill holes: at $490.7 \mathrm{ft}$ and $712 \mathrm{ft}$ in Deer Park No. 1, corresponding to the upper and lower border faults, respectively, and at $311 \mathrm{ft}$ in DP-2, from the lower border fault (fig. 7) and to the faults in the trench (fig. 8). Each of these zones contains a thin (1 to several $\mathrm{cm}$ thick) layer of soft clayey green or black gouge that is bordered, particularly on the hanging wall side, by a harder, more indurated fault breccia or cataclasite several centimeters thick that may or may not contain fluxion structure. The soft gouge is considered to be the locus of the main faulting and may mark the zone of latest movement along the fault. There are generally sharp planar contacts between the gouge and harder cataclasite and between both of these and the relatively undeformed rock. The contacts and fault fabrics all dip approximately parallel to the inferred trend of the main faults in each hole. In addition, thin auxiliary shear zones in the hanging and footwall rocks also are subparallel to the main fault.

Certain shear surfaces within the soft gouge, harder cataclasite, and auxiliary shear zones contain striae that are considered to reflect the direction of fault slip. Assuming that the strike of the main fault fabrics in each continuous core section is parallel to the main surface trace of the faults (N.45 E.), azimuth and rake of fault striae in each section were determined and plotted on a stereogram (fig. 7).

The results indicate two distinct patterns: the upper fault, recovered only in Deer Park No. 1, shows a very narrow azimuthal range of striae, mostly plunging in the southwest quadrant, whereas the lower fault zone in both holes (called the Furlong fault in fig. 8) has a wide range of slickenline directions with no predominant trend. The striae directions on the upper fault are consistent with a right-lateral-normal movement sense, while the lower fault data reflect a variety of fault movements. Striae from the lower fault gouge alone (heavy lines) in DP-1, 

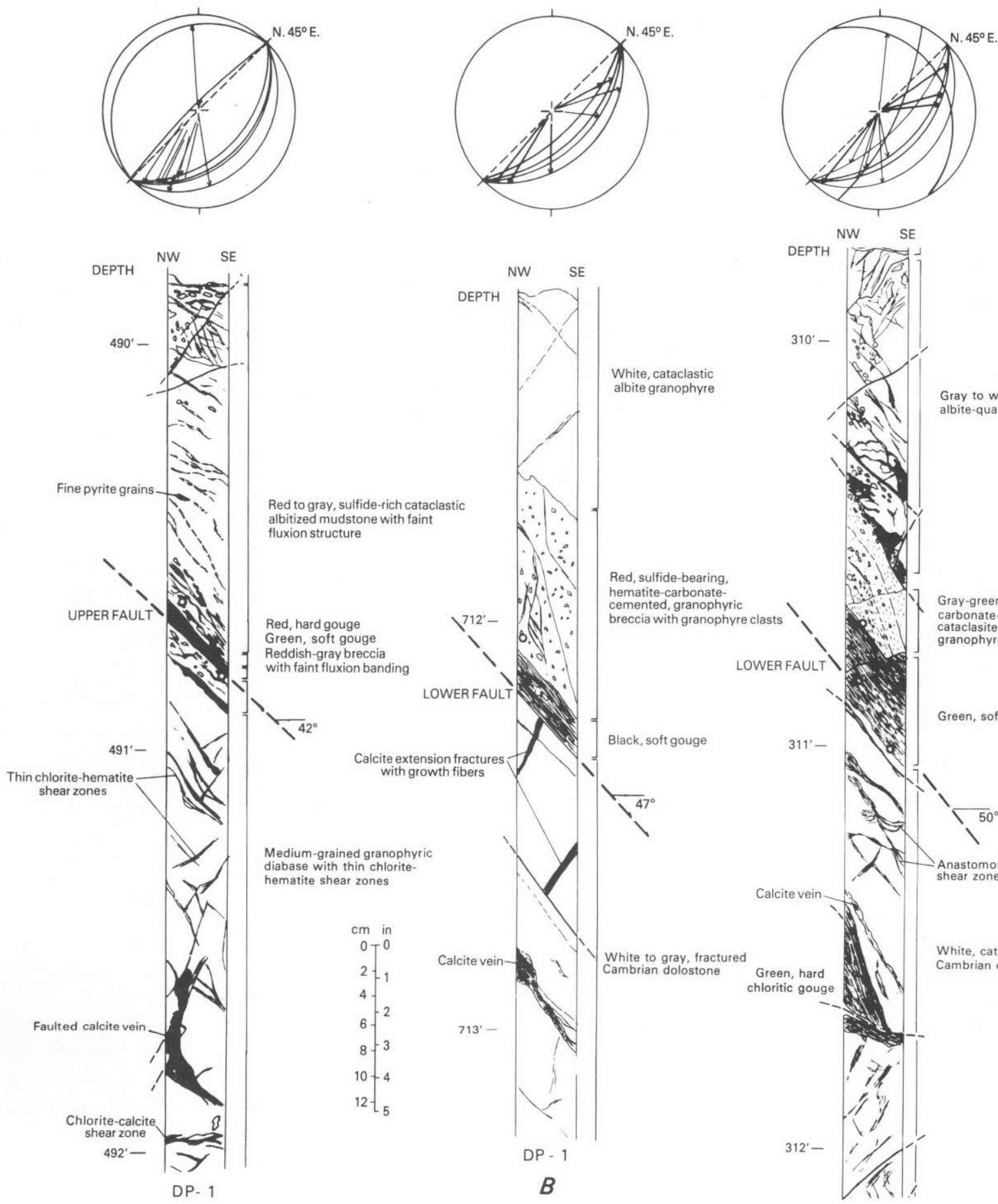

$\boldsymbol{A}$

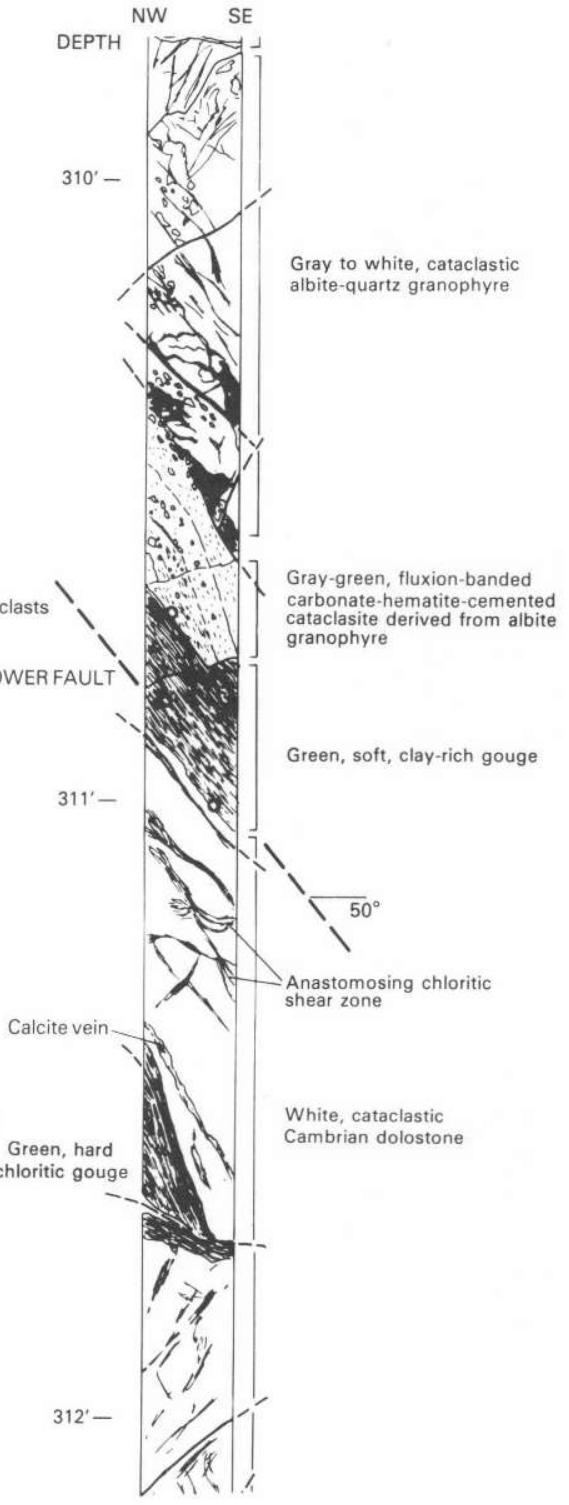

DP- 2

C

Figure 7. Detailed sketches of fault zones in Deer Park Nos. 1 and 2. A, Upper fault zone in DP-1 at 490-491 $\mathrm{ft}$ between dark gray pyritized cataclasite and diabase. $B$, Lower fault in DP-1 at $712 \mathrm{ft}$. $C$, The lower fault in DP-2 at $311 \mathrm{ft}$ between albitized granophyre and dolostone. Stereograms are lower hemisphere equal-area plots of fault zones and slickenlines measured from oriented core. Heavier arrows represent slickenlines measured in the central fault gouges. Azimuths determined from down-hole televiewer logs and from geometric constructions agree with $\pm 5^{\circ}$ of strike. 


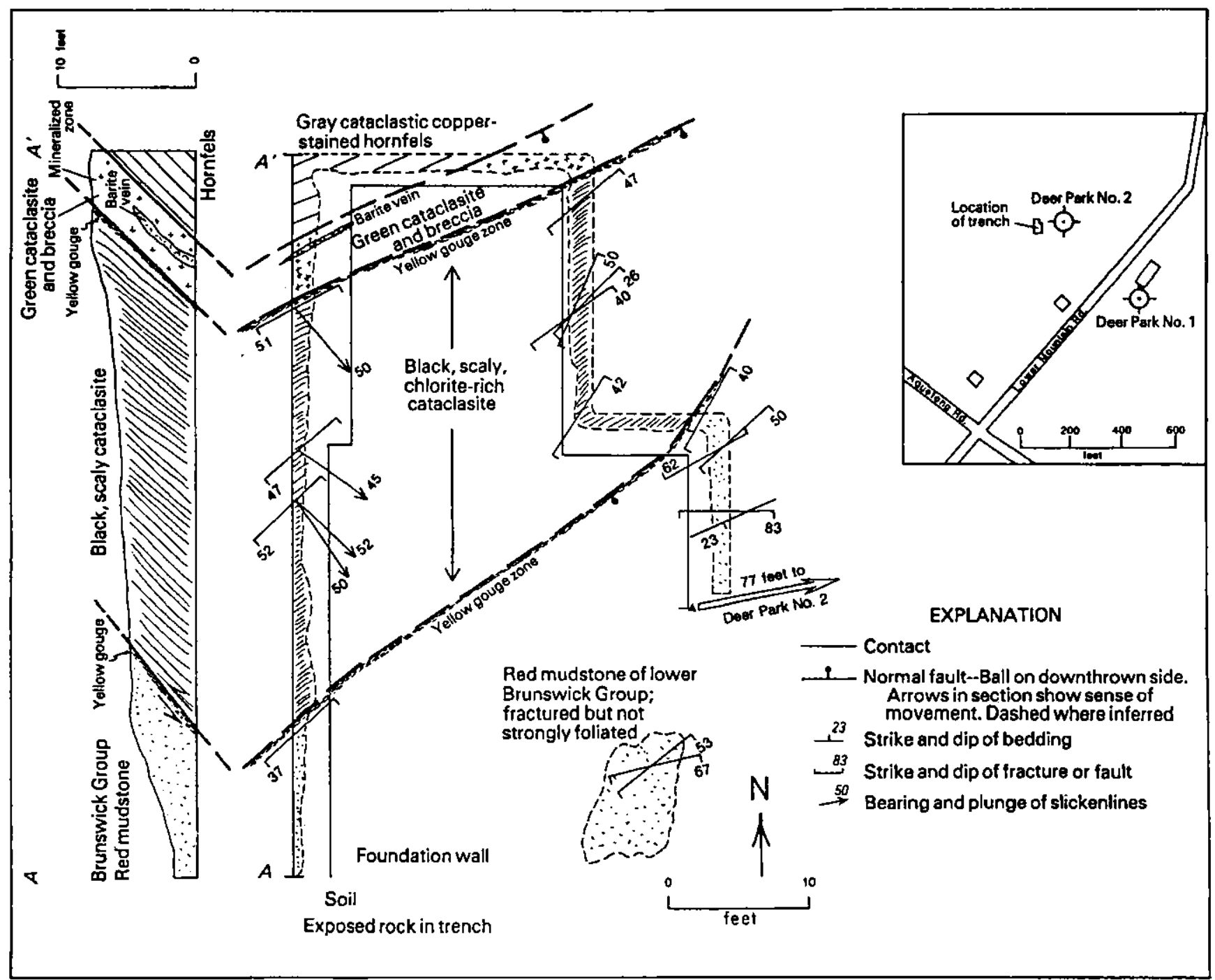

Figure 8. Detailed sketch map and section of trenched exposure of Furlong fault updip from DP-2 drill hole.

however, also suggest right-lateral-normal movements. It is possible that the slickenline pattern of the upper fault indicates a simpler, more recent history for that fault zone in contrast to a prolonged and more complicated movement history for the lower fault-an observation supported by the greater throw required on the lower fault and by the clear evidence for faulting after miner. alization.

\section{Orientation of Borehole Fractures via Televiewer Log}

Geophysical logs of Deer Park No. 1 hole were run by Dan Moos and Roger Anderson of the Borehole Research Group of Lamont-Doherty Geophysical Laboratories. A televiewer (BHTV) log was used to determine orientation of planar features such as fractures and faults on the borehole surface. These records were used to orient the core and permitted determination of strike of recovered features. The upper fault zone of DP1 shows up clearly on the log and has a measured strike and dip orientation in close agreement with borehole and

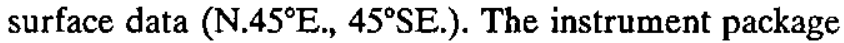
could not penetrate deeply enough to record the lower fault zone. Abundant auxiliary fractures and small faults in the mudstones of the hanging wall block could be detected in the BHTV log and were identified in the corresponding drill core as belonging to two types: (1) closely spaced, thin parallel fractures with intermediate dips, usually filled with calcite, and (2) thicker calcitefilled veins, sometimes with pull-apart geometry and moderate to near-vertical dips. The former appear to be calcite-filled faults and the latter to be near-vertical extension fractures and thick dilational fracture fillings.

A stereogram plot of poles to both these features (fig. 9) shows the vast majority falling in the northwest 


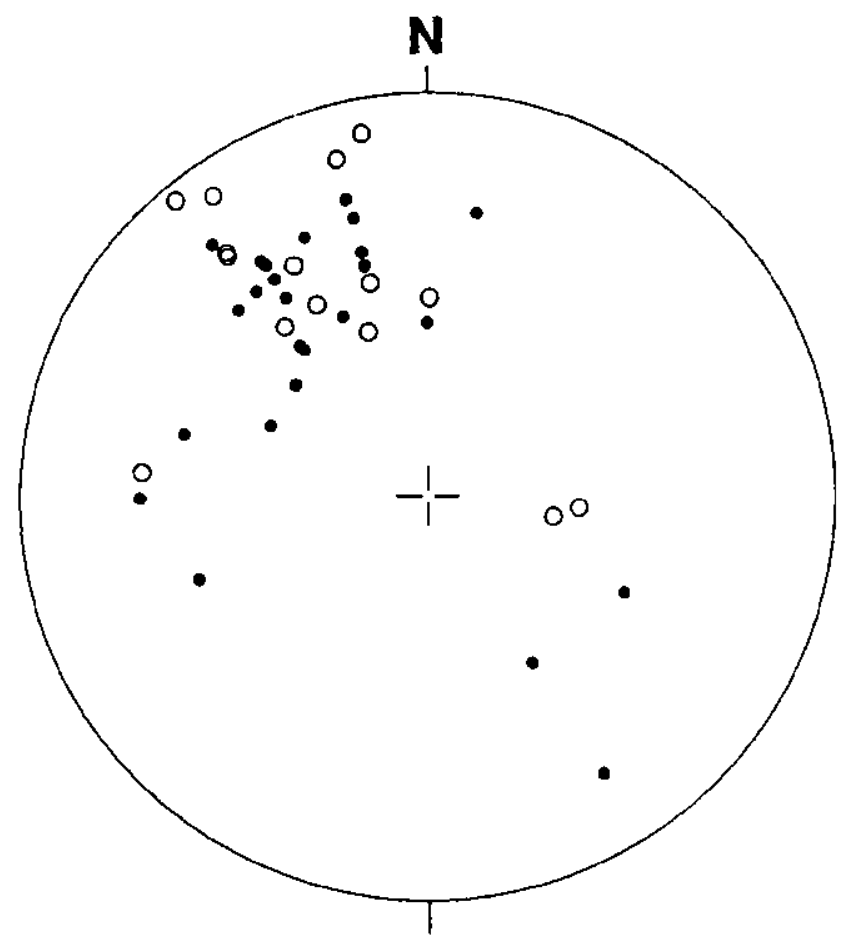

Figure 9. Lower hemisphere equal-area plot of poles to prominent calcite-filled joints (black dots) and extension fractures (open circles) in red mudstone and mineralized mudstone from 60 to $460 \mathrm{ft}$ in Deer Park core hole 1. Azimuths and dip determined by measurements from down. hole televiewer logs and corresponding core.

and southeast quadrants. The poles of the near-vertical extension fractures have azimuths mostly in the N. $10^{\circ} \mathrm{W}$. to $\mathrm{N} .40^{\circ} \mathrm{W}$. range and indicate the probable mean extension direction for the fault system.

An excavation for a house foundation exposed cataclasite rocks of the fault zone, including fractured mudstone, black scaly cataclasite, a yellow gouge zone, green cataclasite and breccia, and gray cataclastic hornfels. A stereogram plot of poles to the exposed fault fabrics (fig. 10) has points in the northwest and southeast quadrants, as in the BHTV-oriented fractures, implying a northeast-southwest trend for the fault zone.

\section{Mineralogy of the Fault Gouges}

Samples of soft gouge and more indurated cataclasite were taken for XRD analysis from the fault zones recovered in the cores, including the upper and lower fault in DP-1 (490.7 and $712 \mathrm{ft}$, respectively) and the lower fault in DP-2 (311 ft) as well as a minor shear zone below the fault in DP-2 (311.5 ft) (fig. 7). Powders from these zones were run on an X-ray diffractometer to determine nonclay minerals. The clay-size $(<2 \mu)$ fraction of each sample was also isolated and run to identify

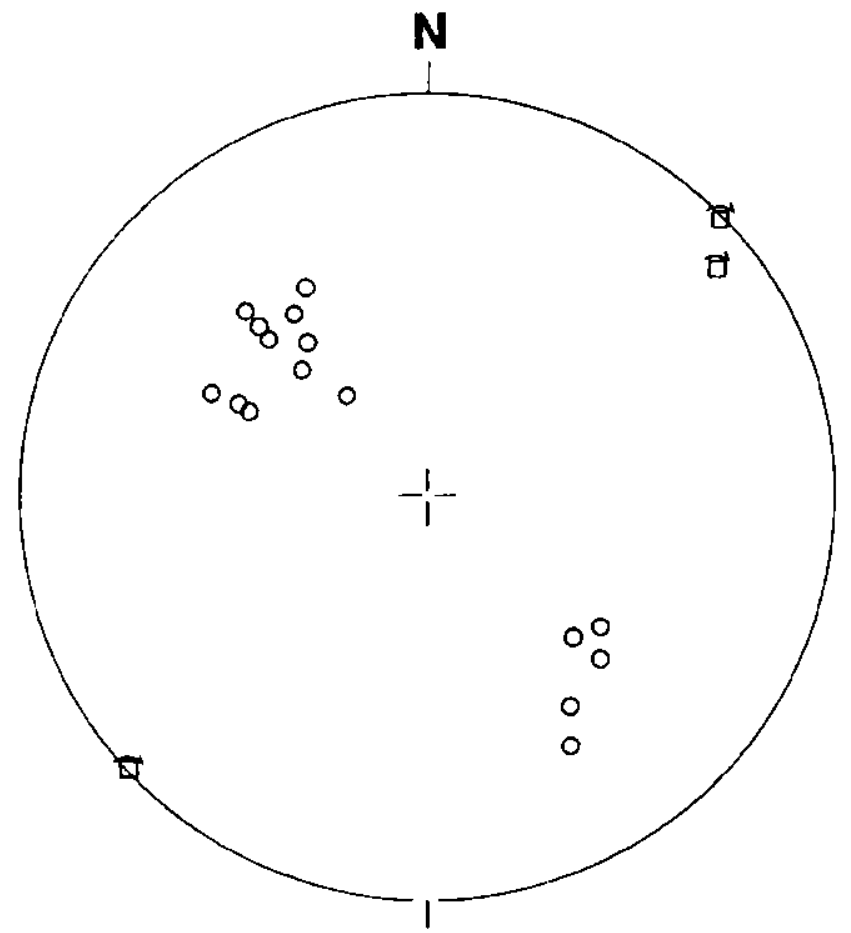

Figure 10. Lower hemisphere equal-area plot of poles (shown by circles) to cataclastic fluxion fabric, gouge zones, and antithetic fractures or joints measured in surface exposure of upper fault zone near Deer Park core hole 2 shown in figure 8 . Rotation axes (shown by squares) of slickenlines (normal to slickenlines within fault surface) show predominant downdip or normal fault motion as shown in figure 8.

chlorite and clay minerals. Clay identification included tests for swelling or mixed-layer clays by glycolation and heating, as described in Carroll (1970).

The coarse fraction powders of each sample commonly included quartz and albite, plus hematite, dolomite, and calcite. The source for these minerals could be either the footwall and hanging wall protoliths, introduced minerals, or both. Euhedral crystals of pyrite are distributed throughout the soft gouge and cataclasite in many fault zones, clearly indicating post-faulting sulfide mineralization.

The clay-size fractions of the fault gouges feature a mixture of clays and the notable absence of chlorite, with the exception of sample DP-2-311.5. The dominant clay species are pure smectite, interlayered smectite and illite, and kaolinite. There are no discernible differences in clay mineral composition between the soft gouge, thought to mark the main fault, and the bordering cataclastic material within a fault zone. However, the relative abundance of clay minerals is variable among the different fault zones. Samples from $490.7 \mathrm{ft}$ in DP-1 (upper fault) indicate the presence of interlayered smectite/illite, and kaolinite. The gouges from $712 \mathrm{ft}, \mathrm{DP}-1$ (lower fault), contain more pure smectite (less interlayered illite) and little or no kaolinite. The samples from $310.7 \mathrm{ft}, \mathrm{DP}-2$ 
(lower fault) contain relatively pure smectite and minor kaolinite. The fault at $311.5 \mathrm{ft}$ in DP-2 contains chlorite with minor interlayered smectite, plus a mica or illite.

The presence of clays and the absence of chlorite in the main fault zones contrasts with previous (unpublished) studies of gouges from the Ramapo fault that have consistently revealed a chlorite component in the gouge, commonly interlayered with smectite. The smectite component in the Ramapo gouge is thought to have resulted from late alteration of the chlorite, probably by surface waters at very low temperatures.

In this case the more extensive development of clay minerals, in conjunction with deposition of sulfides in the fault zones, suggests a low-temperature, hydrothermal origin. The occurrence of both clays and sulfides is common, for instance, in the alteration haloes around magma bodies associated with copper porphyry deposits (Grim, 1968; Rose, 1970; Rose and Burt, 1979). In these zones there is a crude spectrum of increasing alteration from chlorite through smectite and (or) illite, to kaolinite, and finally to sericite. Plagioclase and potassium feldspar are altered only in the innermost, most intense zones of alteration. By comparison, feldspar in thin sections taken close to the fault zones in the Deer Park cores looks relatively fresh.

The presence of dolomite and quartz and the absence of talc throughout the cores suggest that alteration temperatures never exceeded about $400{ }^{\circ} \mathrm{C}$ (Winkler, 1976, p. 114). However, the widespread presence of albite plus quartz and the absence of analcite in diabase suggest that the diabase was affected by alteration temperatures in excess of $200{ }^{\circ} \mathrm{C}$. The assemblage kaolinite and quartz in the fault gouge suggest that maximum temperatures in the gouge never exceeded approximately $300{ }^{\circ} \mathrm{C}$ (Winkler, 1976, p. 204). These temperature estimates of 200 to $300^{\circ} \mathrm{C}$ are consistent with the lowest temperature zones of hydrothermal alteration described above. The presence of smectite suggests a mildly alkaline environment with available magnesium and other cations, probably derived from the footwall dolostone or mafic minerals in the diabase. The kaolinite, confined mostly to the upper fault, may suggest an earlier or later hydrothermal episode with more acidic conditions and leaching of cations, or it may reflect a late, minor alteration by low-temperature surface waters. The presence of chlorite in the shear zone immediately below the lower fault in $\mathrm{DP}-2$ indicates that the regime of hydrothermal clay formation was very narrow and confined to the fault zones. The extensive alteration by albite, dolomite, and silica in rocks away from the fault zones undoubtedly has the same general hydrothermal origin. It is thus not necessary to involve late-stage meteoric alteration or recent fault movement to explain the presence of clay minerals in the fault gouges.

\section{SUMMARY AND CONCLUSIONS}

The Furlong fault zone near New Hope, Pennsylvania, has been determined through surface observation and coring to consist of two closely parallel faults that dip $47^{\circ}$ to $50^{\circ}$ to the southeast. The hanging wall block consists of mudstone of the Brunswick Group. An intervening horse of Jurassic diabase rests on the footwall block of Cambrian dolostone. The two faults consist of narrow zones of weakly mineralized cataclasite and gouge that mark the locus of latest movement along the fault zone. In contrast, the mudstone and diabase of the hanging wall and intermediate blocks reveal an extensive history of faulting and hydrothermal mineralization by albite, quartz, dolomite, calcite, hematite, and chlorite that annealed the older zones of faulting and cataclasis, probably at temperature less than $400{ }^{\circ} \mathrm{C}$ but greater than $200{ }^{\circ} \mathrm{C}$. The period of mineralization extended into the latest episode of fault movement, during which minor albitization and hydrothermal formation of clays and sulfides occurred in the fault gouges.

Chemical data from the igneous rocks, the presence of a chilled diabase near the top of DP-2, and the abundant albitization (replacement) of cataclastic mudstone in DP-2 suggest that the intermediate sliver of diabase is a downfaulted portion of the uppermost contact of a highly differentiated high-Ti quartz-normative diabase. Comparison of this diabase with samples of the Lambertville sill and the Quarry dike (Husch and others, 1984; Husch and Schwimmer, 1985) suggest that the diabase and granophyre preserved in the fault zone is more differentiated than any known samples of the Lambertville sill on the basis of $\mathrm{TiO}_{2}$ versus $\mathrm{P}_{2} \mathrm{O}_{5}$ and $\mathrm{MI}$ versus $\mathrm{TiO}_{2}$ plots of the diabase. However, the diabase in the cores may well have differentiated from the Lambertville sill, as it is very comparable to a narrow zone of highly differentiated high- $\mathrm{TiO}_{2}$ tholeiite present at or just beneath the upper chill zone of the Palisades sill (Walker, 1969).

The structural and geochemical data therefore suggest that the sliver of coarse granophyre present along the trace of the Furlong fault may be a partially downdropped fragment of the upper part of the Lambertville sill. Absence of diabase in the nearby Bucks County wells suggests that the diabase forms a horse block that only locally is preserved along the fault and that the throw on the upper fault must be considerable. Alternately, the granophyre may have intruded the fault before movement ceased, as suggested by the greater degree of alteration in the breccia zone now above the chilled diabase in DP-2.

Structural analyses of slickenlines, fault planes, and of major gouge zones in the cores and in outcrop indicate that the Furlong fault is a normal fault with some component of right-slip. Analyses of oriented calcite- 
filled subvertical extension fractures as determined from borehole televiewer logs suggest that bulk extension during faulting and mineralization was to the southeast and northwest. These results are consistent with results from the Ramapo fault and the Flemington fault, and from the Newark basin border fault at Riegelsville, Pennsylvania. At all of these localities northwestsoutheast extension has been documented. (Ratcliffe and others, 1986; Ratcliffe, 1980; Ratcliffe and Burton, 1984). Faulting and late-stage igneous activity may have overlapped in the Furlong fault, but the bulk of the data appears to favor considerable faulting after intrusion of the diabase.

Circulation of $\mathrm{H}_{2} \mathrm{O}$ - and $\mathrm{CO}_{2}$-rich, probably alkaline, solutions, at temperatures of approximately $200^{\circ}$ to $300{ }^{\circ} \mathrm{C}$, produced wholesale alteration of both the diabase and the overlying Brunswick Group. This alteration overlapped motion on the faults, and it is reasonable to assume that the ultimate source of the $\mathrm{Na}$ was connate pore fluids in the adjacent Brunswick Group and Lockatong Formation.

\section{REFERENCES CITED}

Burton, W.C., and Ratcliffe, N.M., 1985a, Compressional structures associated with right-oblique normal faulting of Triassic-Jurassic strata of the Newark basin near Flemington, New Jersey: Geological Society of America Abstracts with Programs, v. 17, no. 1, p. 9.

-1985b, Attitude, movement history and structure of cataclastic rocks of the Flemington fault-Results of core drilling near Oldwick, New Jersey: U.S. Geological Survey Miscellaneous Field Studies Map MF-1781.

Carroll, D., 1970, X-Ray identification of clay minerals: Geological Society of America Special Paper 126, 80 p.

Grim, R.E., 1968, Clay mineralogy, 2d edition: McGraw-Hill, New York, $596 \mathrm{p}$.

Husch, J.M., and Schwimmer, R.A., 1985, Major and trace element concentrations across a Mesozoic basaltic dike, New Hope, Pennsylvania: Northeastern Geology, v. 7, no. $3 / 4$, p. $144-160$.

Husch, J.M., Sturgis, D.S., and Bambrick, T.C., 1984, Mesozoic diabases from west-central New Jersey: Major and trace element geochemistry of whole-rock samples: Northeastern Geology, v. 6, p. 51-63.
McLaughlin, D.B., 1959, Mesozoic rocks, in Willard, B., and others, Geology and mineral resources of Bucks County Pennsylvania: Pennsylvania Geological Survey, 4th Series, Bulletin C-9, 243 p

Olsen, P.E., 1980, Triassic and Jurassic formations of the Newark basin, in Manspeizer, W., ed., Ficld studies of New Jersey geology and guide to field trips, 52d Annual Meeting of the New York State Geological Association: Newark, New Jersey, Rutgers University, p. 2-39.

Ratcliffe, N.M., 1980, Brittle faults (Ramapo fault) and phyllonitic ductile shear zones in basement rocks of the Ramapo seismic zone, New York and New Jersey, and their relationship to current seismicity, in Manspeizer, W., ed., Field studies of New Jersey geology and guide to field trips, 52d Annual Meeting of the New York State Geological Association: Newark, New Jersey, Rutgers University, p. 278-311.

Ratcliffe, N.M., and Burton, W.C., 1984, Brittle fault fabrics, mineralogy and geometry of border faults of the Newark basin, N.Y.-N.J., from drill-core information: Geological Society of America Abstracts with Programs, v. 16, no. 1, p. 57.

Ratcliffe, N.M., Burton, W.C., and Costain, J.K., 1986, Lowangle extensional faulting, reactivated thrust faults and seismic reflection geometry of the Newark basin in eastern Pennsylvania and New Jersey: Geological Society of America Abstracts with Programs, v. 18, no. 1, p. 61.

Ratcliffe, N.M., and Costain, J.K., 1985, Northeastern seismicity and tectonics, in Jacobson, M.L., and Rodriguez, T.R., compilers, National Earthquake Hazards Reduction Program; summaries of technical reports, vol. XX, prepared by participants in the National Earthquake Hazards Reduction Program, July 1985: U.S. Geological Survey Open-File Report 85-464, p. 54-58.

Rose, A., 1970, Zonal relations of wall rock alteration and sulfide distribution in porphyry copper deposits: Economic Geology, v. 65, p. 920-936.

Rose, A., and Burt, D.M., 1979, Hydrothermal alteration, in Barnes, H.L., ed., Geochemistry of hydrothermal ore deposits: John Wiley and Sons, New York, p. 173-235.

Shapiro, L., 1975, Rapid analysis of silicate, carbonate, and phosphate rocks (revised edition): U.S. Geological Survey Bulletin 1401, 76 p.

Walker, K.R., 1969, The Palisades sill, New Jersey: A reinvestigation: Geological Society of America Special Paper 111, $178 \mathrm{p}$.

Weigand, P.W., and Ragland, P.C., 1970, Geochemistry of Mesozoic dolerite dikes from eastern North America: Contributions to Mineralogy and Petrology, v. 29, p. 195-214.

Winkler, H.G., 1976, Petrogenesis of metamorphic rocks, 4th edition: Springer-Verlag, New York, 334 p. 


\title{
INNOVATIVE APPROACHES TO THE DATING OF IGNEOUS EVENTS IN THE EARLY MESOZOIC BASINS OF THE EASTERN UNITED STATES
}

\author{
John F. Sutter
}

Abstract

Numerical chronology of basalts and diabase sheets and dikes in the Mesozoic basins of the Eastern United States is difficult to establish because none of the mineral or whole-rock isotopic systems are, in general, reliable geochronometers. However, granophyric segregations, basal contact zones, and recrystallized sedimentary xenoliths associated with diabase sheets contain potentially reliable ${ }^{40} \mathrm{Ar} /{ }^{39} \mathrm{Ar}$ geochronometers such as the minerals hornblende, biotite, and K-feldspar. Hornblende from a granophyric segregation in the Germanna Bridge diabase sheet in the southern Culpeper basin yields a weight-average ${ }^{40} \mathrm{Ar} /{ }^{39} \mathrm{Ar}$ plateau age of $200.3 \pm 1.2 \mathrm{Ma}$; a whole-rock sample of unaltered diabase from the Gainesville East sheet, also in the Culpeper basin, has a weight-average plateau age of $201.2 \pm 1.3 \mathrm{Ma}$; and biotite from a recrystallized sedimentary xenolith of Stockton Formation(?) arkose in the Palisades sill in the Newark basin has a ${ }^{40} \mathrm{Ar} /{ }^{3 \theta} \mathrm{Ar}$ age of $202.2 \pm 1.3 \mathrm{Ma}$. All of these apparent ages are indistinguishable analytically at 95-percent confidence and could be reliable crystallization ages.

Potassium feldspars from granophyres and contact zones of diabase sheets in the Culpeper and Newark basins do not yield crystallization ages. However, they do record a low-temperature thermal event at about $175 \mathrm{Ma}$. Because of the rapid igneous cooling of the diabase sheets and because there is little evidence for deep burial of the Mesozoic basins, the thermal event recorded by the K-feldspars is thought to be of hydrothermal origin.

\section{INTRODUCTION}

Deciphering the chronology of igneous events in the Mesozoic basins of the Eastern United States has been hampered by the fact that Mesozoic diabases and basalts generally are not reliable geochronometers. Varjation in apparent ages of both whole-rock samples and of mineral concentrates (generally plagioclase plus glass and (or) the alteration products) are beyond the range of normal analytical error; thus, geologic events other than igneous crystallization have affected the apparent ages of these samples. In order to establish a reliable chronology of igneous events within and between Mesozoic basins of the Eastern United States, suitable materials that are capable of acting as closed isotopic systems must be found.
In an attempt to find datable minerals associated with igneous events in the Mesozoic basins of the Eastern United States, three geologic environments associated with diabase sheets were investigated: granophyric segregations, basal contact zones, and recrystallized sedimentary xenoliths. The hope was to find one or more of the following datable minerals that formed or was recrystallized as a result of the igneous intrusion: hornblende, feldspar, or biotite. Because hornblende has a very high closure temperature to argon diffusion $\left(>500^{\circ} \mathrm{C}\right)$ and because the diabase sheets initially cooled very rapidly, hornblende ${ }^{40} \mathrm{Ar} /{ }^{39} \mathrm{Ar}$ plateau ages should be close approximations of the time of igneous crystallization. It is believed that the diabase sheets and their contact zones would have cooled rapidly enough that ${ }^{40} \mathrm{Ar} /{ }^{39} \mathrm{Ar}$ ages of biotite (argon closure temperature $>300^{\circ} \mathrm{C}$ ) and feldspar (variable argon closure temperature depending on structural state and composition, but generally between 150 and $250{ }^{\circ} \mathrm{C}$ ) would approach times of igneous crystallization, help document the rapid cooling of the intrusions, and confirm their simple thermal history.

\section{DISCUSSION OF RESULTS}

The Germanna Bridge diabase sheet in the southern part of the Culpeper basin in Virginia (fig. 1) encloses a differentiate of syenitic granophyre that bears hornblende. The separated hornblende yields a nearly concordant ${ }^{40} \mathrm{Ar}{ }^{30} \mathrm{Ar}$ age spectrum (fig. 2) with a welldefined plateau age of $200.3 \pm 1.2 \mathrm{Ma}$ (table 1 , sample GUP-84-1). This age is interpreted to be a close approximation to the time of igneous intrusion, differentiation, and crystallization of the Germanna Bridge sheet. This is because the time elapsed between intrusion and cooling to the closure temperature for ${ }^{40} \mathrm{Ar}$ in hornblende $\left(>500{ }^{\circ} \mathrm{C}\right.$ ) is likely to be very short, probably between $10^{4}$ and $10^{6}$ years. In addition, a whole-rock sample of diabase from the Gainesville East sheet in the Culpeper basin (fig. 1) also yields a nearly concordant age spectrum (fig. 2) and a well-defined plateau age of $201.2 \pm 1.3$ Ma (Sutter, 1985, and table 1, sample MS-A1). This age is indistinguishable, at 95 -percent confidence, from the age of the Germanna Bridge syenite.

A recrystallized xenolith of Stockton Formation(?) arkose in the lower bronzite dolerite of the Palisades sill in the Newark basin at Edgewater, New Jersey, contains euhedral, coarse biotite. The biotite yields a ${ }^{40} \mathrm{Ar} /{ }^{39} \mathrm{Ar}$ 


\section{DIABASE SHEETS}

OURHAM
1 . CUMNOCK
C 2 . BRAGGTOWN
C 3 . NELLO TEER
C 4 . BUTNER
C 5 . OAK GAOVE
C 6 . WILTON
CULPEPER
C 7 RAPIDAN
G 8 . GERMANNA BR.
9 NOKESVILLE
G 10 GAINESVILLE EAST
11 HEANDON C VILLE
C 12 BOYDS

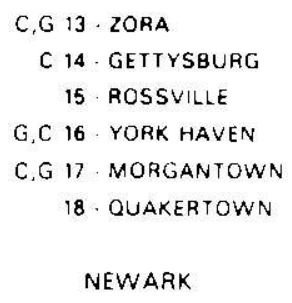

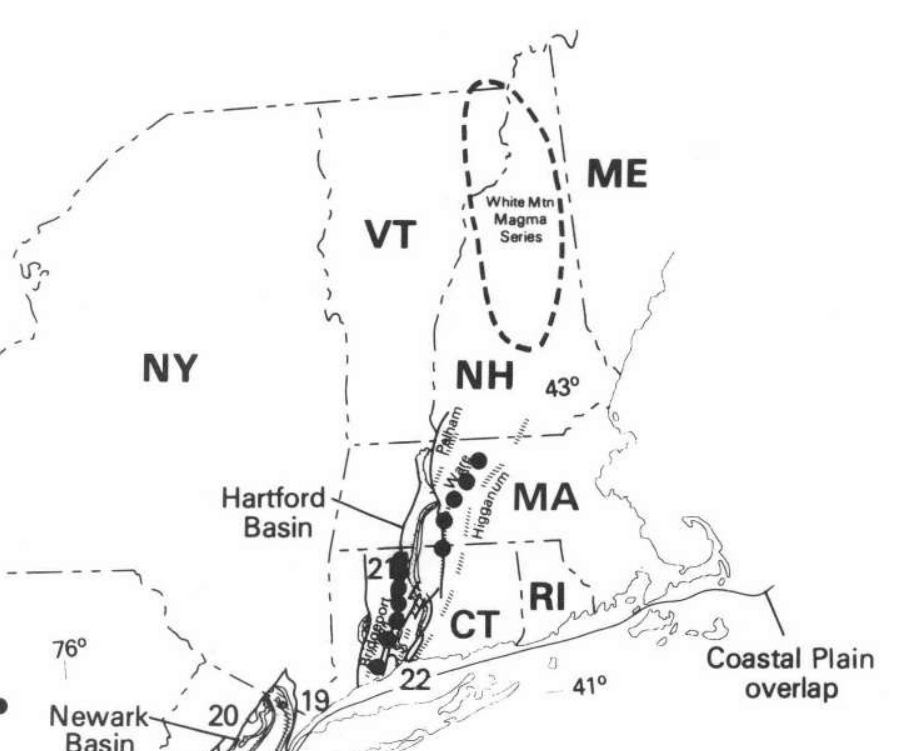

\section{BASALT}

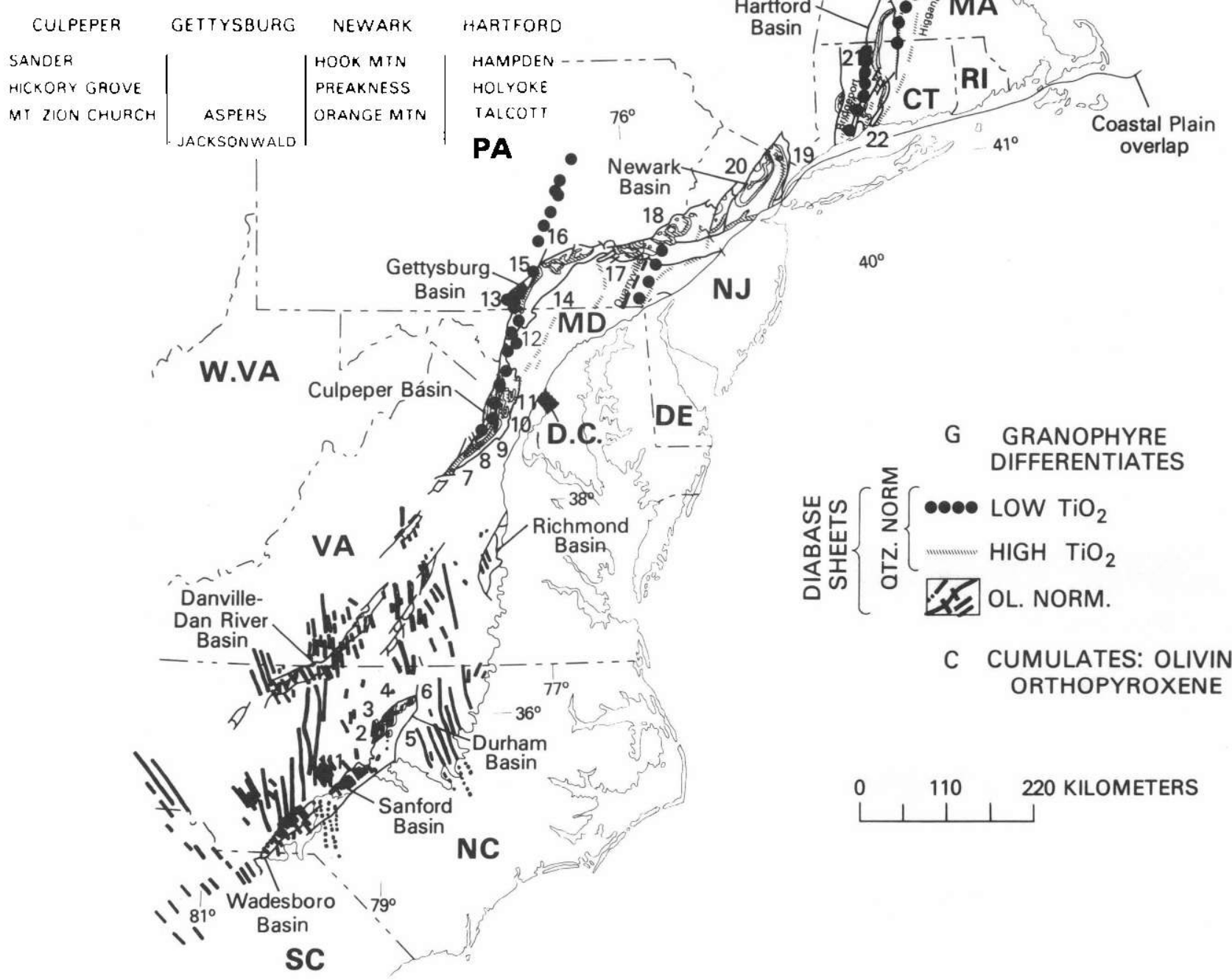

Figure 1. General location map for Mesozoic basins and their associated igneous rocks in the Eastern United States. 
Table 1. ${ }^{40} \mathrm{Ar} /{ }^{38} \mathrm{Ar}$ analytical data

[All isotope quantities are in moles; no blank corrections have been applied; the monitor mineral used in this study to calculate J-values was MMhb-1 with an accepted age of $519.4 \mathrm{Ma}$; see figure 2 for plots of samples from this table]

\begin{tabular}{|c|c|c|c|c|c|c|c|}
\hline Temp $\left({ }^{\circ} \mathrm{C}\right)$ & $\begin{array}{c}{ }^{39} \mathrm{Ar} \\
\text { (\% of total) }\end{array}$ & $\begin{array}{l}{ }^{40} \mathrm{Ar} \times 10^{-12} \\
\text { (initial and } \\
\text { radiogenic) }\end{array}$ & $\begin{array}{l}{ }^{39} \mathrm{Ar} \times 10^{-13} \\
\text { (K-derived) }\end{array}$ & $\begin{array}{l}{ }^{38} \mathrm{Ar} \times 10^{-14} \\
\text { (Cl-derived) }\end{array}$ & $\begin{array}{l}{ }^{37} \mathrm{Ar} \times 10^{-13} \\
(\mathrm{Ca}-\text { derived) }\end{array}$ & $\begin{array}{c}{ }^{30} \mathrm{Ar} \times 10^{-15} \\
\text { (initial) }\end{array}$ & $\mathrm{Age}^{1,2}(\mathrm{Ma})$ \\
\hline
\end{tabular}

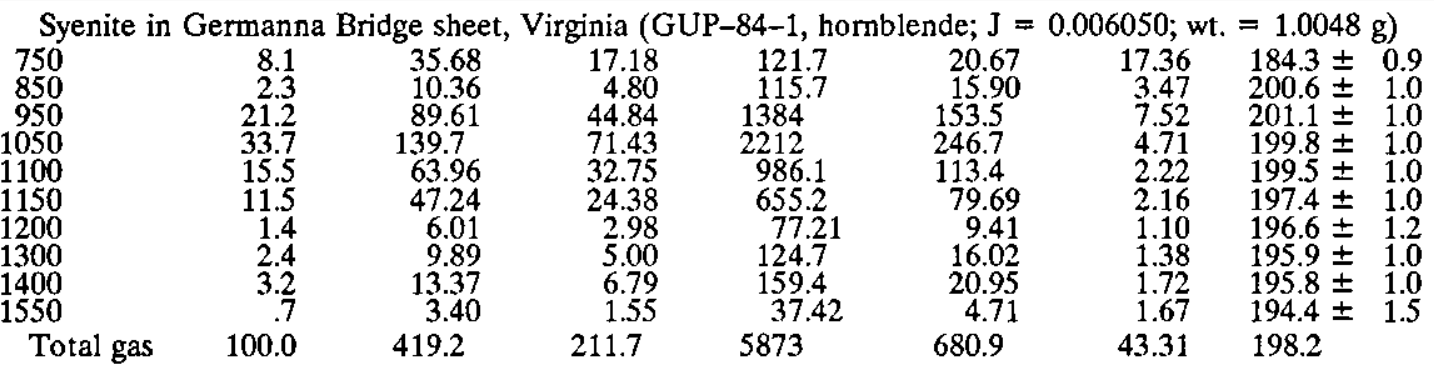

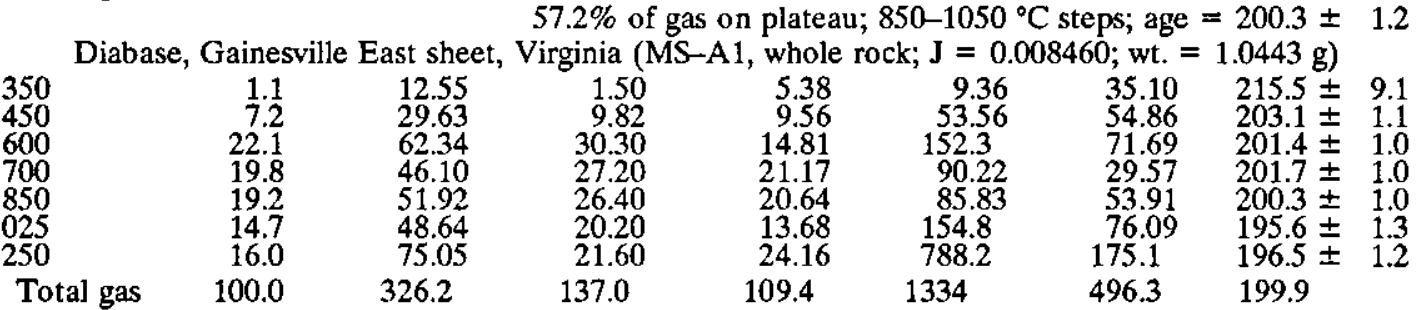

\begin{tabular}{|c|c|c|c|c|c|c|c|}
\hline & & & & . & & t. $=0$ & $3 \mathrm{~g})$ \\
\hline & 0.8 & 3.36 & 1.41 & 1.01 & 3 & 6.76 & $103.7 \pm$ \\
\hline 650 & 2.9 & 13.00 & 5.33 & 3.95 & 3 & 9.86 & $197.1 \pm$ \\
\hline $\begin{array}{r}850 \\
1050\end{array}$ & 7.7 & $\begin{array}{r}29.65 \\
157.7\end{array}$ & 14.02 & $\begin{array}{l}10.56 \\
50.12\end{array}$ & $s$ & 5.59 & $207.6 \pm$ \\
\hline 50 & $\begin{array}{l}42.0 \\
35.2\end{array}$ & 127.8 & 6434 & 4753 & 3 & 10.14 & 2020 \\
\hline 5 & 9.6 & 35.48 & 17.63 & 12. & 3 & 3 & 203.2 \\
\hline 1650 & 1.2 & 5.42 & 2. & 8 & 3 & 9 & 9 \\
\hline Total gas & 100.0 & 372.5 & 182.9 & 136.8 & 3 & 52.10 & 203.1 \\
\hline
\end{tabular}

$44.8 \%$ of gas in 1250 and $1450^{\circ} \mathrm{C}$ steps; age $=202.2 \pm 1.3$

Granophyric segregation in Palisades sill, New Jersey (PAL-4, K-feldspar; $\mathrm{J}=\mathbf{0 . 0 0 6 1 2 2}$; wt. $=0.1623 \mathrm{~g}$ )

$\begin{array}{rrrrrrrrr}650 & 13.0 & 11.19 & 5.85 & 1.00 & s & 8.42 & 157.2 \pm & 0.8 \\ 750 & 7.1 & 6.02 & 3.22 & .61 & s & 3.65 & 161.8 \pm & 1.2 \\ 850 & 2.3 & 1.90 & 1.04 & .27 & s & .63 & 173.8 \pm & 1.2 \\ 925 & 3.3 & 2.69 & 1.49 & .36 & s & .73 & 174.2 \pm & 2.6 \\ 1000 & 4.2 & 3.41 & 1.91 & .26 & s & 1.14 & 168.6 \pm & 2.0 \\ 1050 & 6.0 & 4.74 & 2.72 & .16 & s & .20 & 169.8 \pm & 1.7 \\ 1100 & 7.4 & 5.69 & 3.35 & .18 & s & 1.13 & 168.5 \pm & 1.1 \\ 1150 & 10.8 & 8.38 & 4.90 & .31 & s & 1.54 & 170.4 \pm & 1.2 \\ 1200 & 13.4 & 10.61 & 6.08 & .51 & s & 2.25 & 172.3 \pm \pm 0.9 \\ 1275 & 17.0 & 13.64 & 7.69 & .69 & s & 2.93 & 174.8 \pm & 0.9 \\ 1325 & 9.7 & 7.91 & 4.40 & .37 & 3 & 1.79 & 176.6 \pm & 1.50 \\ 1375 & 3.0 & 2.48 & 1.36 & .14 & s & .69 & 175.7 \pm & 4.3 \\ 1450 & 2.6 & 2.12 & 1.16 & .10 & 3 & .56 & 178.1 \pm 3.0 \\ \text { Total gas } & 100.0 & 80.79 & 45.17 & 4.96 & s & 26.66 & 170.0 & \end{array}$

${ }^{40} \mathrm{Ar}$ closure age about $176 \mathrm{Ma}$

Granophyric segregation in Boyds sheet, Maryland (B2A-8(113), K-feldspar; $\mathrm{J}=0.006122$; wt. $=0.1542 \mathrm{~g}$ )

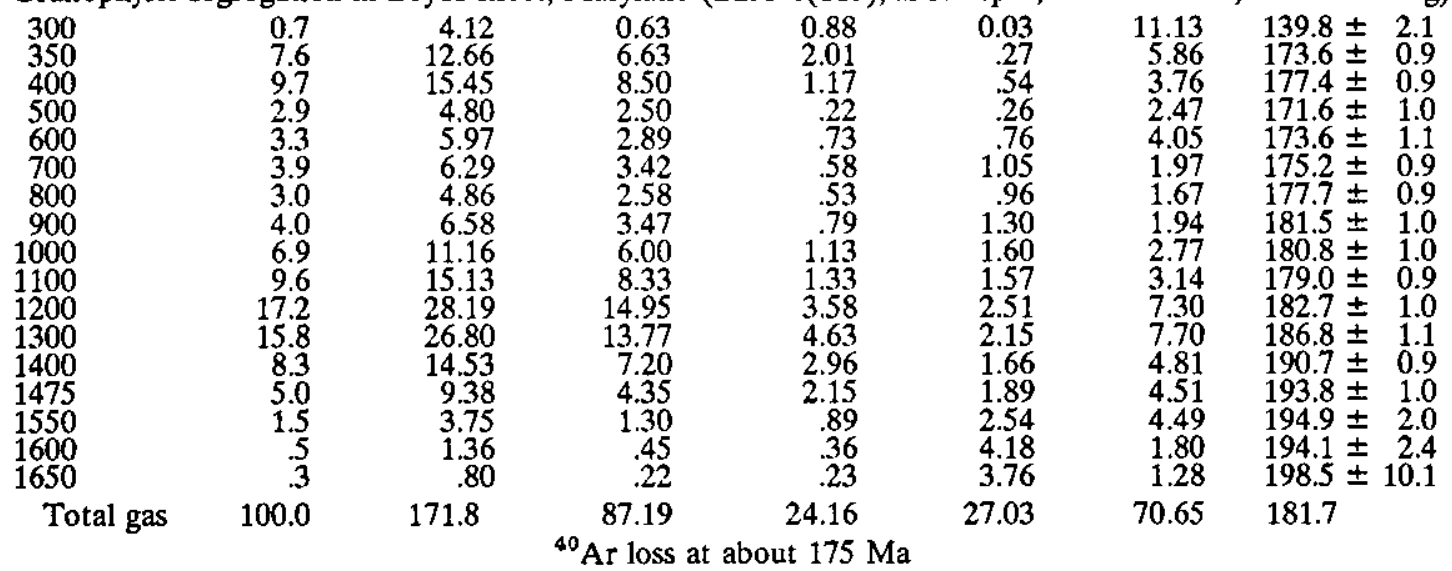


Table 1. ${ }^{40} \mathrm{Ar} /{ }^{\beta} \mathrm{Ar}$ analytical data-Continued

[All isotope quantities are in moles; no blank corrections have been applied; the monitor mineral used in this study to calculate J-values was MMhb-1 with an accepted age of $519.4 \mathrm{Ma}$; see figure 2 for plots of samples from this table]

\begin{tabular}{|c|c|c|c|c|c|c|c|c|}
\hline Temp $\left({ }^{\circ} \mathrm{C}\right)$ & $\begin{array}{c}{ }^{39} \mathrm{Ar} \\
(\% \text { of total) }\end{array}$ & $\begin{array}{l}{ }^{40} \mathrm{Ar} \times 10^{-12} \\
\text { (initial and } \\
\text { radiogenic) }\end{array}$ & $\begin{array}{l}{ }^{39} \mathrm{Ar} \times 10^{-13} \\
\text { (K-derived) }\end{array}$ & $\begin{array}{l}{ }^{38} \mathrm{Ar} \times 10^{-14} \\
\text { (Cl-derived) }\end{array}$ & $\begin{array}{l}{ }^{37} \mathrm{Ar} \times 10^{-13} \\
\text { (Ca-derived) }\end{array}$ & $\begin{array}{c}{ }^{36} \mathrm{Ar} \times 10^{-18} \\
\text { (initial) }\end{array}$ & \multicolumn{2}{|c|}{ Age $^{1,2}(\mathrm{Ma})$} \\
\hline \multicolumn{9}{|c|}{ Syenite in Germanna Bridge sheet, Virginia, (GUP-84-1, K-feldspar; J = 0.006100; wt. $=0.1139 \mathrm{~g}$ ) } \\
\hline 450 & 33.4 & 57.26 & 36.44 & 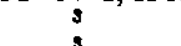 & 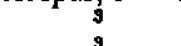 & 2.29 & $163.2 \pm$ & 0.8 \\
\hline 550 & 20.8 & 39.83 & 22.74 & & $\mathbf{g}$ & 2.88 & & 0.9 \\
\hline 650 & 6.3 & 13.47 & 6.84 & 0.34 & 3 & 5.01 & $183.4 \pm$ & 0.9 \\
\hline 800 & 3.3 & 7.16 & 3.59 & .50 & 3 & 2.60 & $185.9 \pm$ & 1.1 \\
\hline 900 & 2.3 & 4.95 & 2.54 & .91 & 3 & 1.81 & $182.3 \pm$ & 1.1 \\
\hline 1000 & 3.1 & 6.59 & 3.44 & 38 & 9 & 2.38 & $179.2 \pm$ & 1.1 \\
\hline 1150 & 3.4 & 6.93 & 3.76 & .17 & 9 & 1.73 & $178.4 \pm$ & 1.0 \\
\hline $\begin{array}{l}1150 \\
1250\end{array}$ & 3.6 & $\begin{array}{r}7.13 \\
17.75\end{array}$ & $\begin{array}{r}3.89 \\
1028\end{array}$ & .13 & s & 1.82 & $177.3 \pm$ & 1.0 \\
\hline 1350 & 10.3 & 19.43 & 11.26 & .13 & s & 1.33 & $177.2 \pm$ & 0.9 \\
\hline & & 03 & & .0 & 9 & & $177.7 \pm$ & 1.2 \\
\hline 0 & .7 & 1.50 & 1 & .0 & 9 & 1.13 & $171.9 \pm$ & 2.8 \\
\hline 1650 & .4 & 1.23 & .43 & .07 & $\mathrm{~s}$ & 1.57 & $187.6 \pm$ & 6.0 \\
\hline Total gas & 100.0 & 189.3 & 109.3 & 2.96 & $s$ & 26.98 & 173.9 & \\
\hline \multicolumn{9}{|c|}{ Heating event at about $177 \mathrm{Ma}$ ? } \\
\hline \multicolumn{9}{|c|}{ Granophyre in Rapidan sheet, Virginia, (RA-A2, feldspar; $\mathrm{J}=0.006122$; wt. $=0.1485 \mathrm{~g}$ ) } \\
\hline 650 & 7.0 & 10.83 & 1.72 & 4.03 & 3 & 25.75 & $164.2 \pm$ & 7.5 \\
\hline 750 & 5.2 & 5.01 & 1.27 & 1.30 & 3 & 8.20 & $6 \pm$ & 13.3 \\
\hline 850 & $5 . \overline{2}$ & 4.12 & 1.28 & .92 & 3 & 5.57 & & 12.8 \\
\hline 925 & 8.8 & 6.34 & 2.17 & 1.18 & 8 & 7.64 & 18 & 4.6 \\
\hline 1000 & 10.9 & 6.98 & 2.68 & .90 & 3 & 7. & & 2.5 \\
\hline 1050 & 11.5 & 7.32 & 2.82 & .92 & 3 & 7.48 & 18 & 3.4 \\
\hline 1100 & 9.7 & 6.27 & 2.39 & .94 & 3 & 6. & 17 & 1.7 \\
\hline 1150 & 8.0 & 5.1 & 1.96 & 1.10 & 3 & 5. & & 3.3 \\
\hline 1250 & 10.4 & 8.37 & 2.55 & 3.08 & 3 & 13. & 175 & 1.3 \\
\hline 1350 & 8.8 & 12. & 2.17 & 7.0 & 3 & 28 & \pm & 4.4 \\
\hline 1450 & 7.5 & & 1.85 & 8. & 3 & 41 & $181.0 \pm$ & 5.9 \\
\hline 1550 & 7.0 & & 1.73 & 7.52 & $\mathbf{s}$ & 46.65 & $177.3 \pm$ & 3.0 \\
\hline Total gas & 100.0 & 107.3 & 24.58 & 37.38 & $\mathbf{s}$ & 205.2 & 181.1 & \\
\hline \multirow{2}{*}{\multicolumn{9}{|c|}{$51.4 \%$ of gas on plateau; $1100-1550^{\circ} \mathrm{C}$ steps; age $=178.4 \pm 2.7$}} \\
\hline & & & & & & & & \\
\hline 300 & 0.8 & 3.41 & 0.32 & 0.51 & 0.54 & 10.29 & $7 \pm$ & 14.0 \\
\hline 350 & 1.2 & 2.16 & & .40 & .2 & & & 9.6 \\
\hline 400 & 2.4 & 3.25 & .96 & .61 & .6 & 5.24 & & 5.1 \\
\hline 500 & 2.8 & 3.06 & 1.12 & .28 & .9 & 3. & & 6.6 \\
\hline 600 & 3.1 & 3.5 & 1.28 & .26 & 1.20 & 3. & & 3.8 \\
\hline $\begin{array}{l}700 \\
800\end{array}$ & $\begin{array}{l}7.1 \\
4.1\end{array}$ & $\begin{array}{l}8.08 \\
6.66\end{array}$ & $\begin{array}{l}2.89 \\
1.65\end{array}$ & .55 & 2.11 & 8.24 & $203.5 \pm$ & $\begin{array}{l}2.1 \\
4.1\end{array}$ \\
\hline 900 & 5.0 & 5.23 & 2.01 & .2 & 3.88 & $\begin{array}{r}11.17 \\
4.01\end{array}$ & $7 \pm$ & 2.7 \\
\hline 975 & 10.4 & 10.37 & & 4 & 13.44 & 5.66 & $8 \pm$ & 1.6 \\
\hline 1025 & 4.6 & 5.17 & 1.87 & .29 & 5.90 & 4.54 & $8 \pm$ & 4.1 \\
\hline 1075 & 5.4 & 5. & & .3 & 5 . & 5. & & 2 \\
\hline 1150 & 9.0 & 9.90 & 3.66 & .95 & 8.09 & 7.96 & \pm & 2.5 \\
\hline 1250 & 11.2 & 12 & & 2.0 & 11. & 9. & & 1.9 \\
\hline 1350 & 11.2 & 12. & 4. & 2.8 & 9.63 & 9. & $9 \pm$ & 1.4 \\
\hline 14 & 11.5 & & & 3. & & 13 & \pm & 1. \\
\hline 1550 & & & & 2. & 61.97 & 14 & $3 \pm$ & 2.0 \\
\hline Total gas & 100.0 & 121.4 & 40.54 & 16.16 & 147.7 & 120.2 & 220.0 & \\
\hline \multicolumn{9}{|c|}{ Two ${ }^{40} \mathrm{Ar}$ loss events? } \\
\hline
\end{tabular}

\footnotetext{
${ }^{1}$ Ages are calculated by assuming initial ${ }^{10} \mathrm{Ar} /{ }^{36} \mathrm{Ar}=295.5 \pm 0$, except for sample RA-A2 feldspar where initial ${ }^{40} \mathrm{Ar} /{ }^{36} \mathrm{Ar}=316.2$.

1 -sigma precision estimates are for intrairradiation package reproducibility.

${ }^{3}$ Below the detection limit of mass spectrometer.
} 

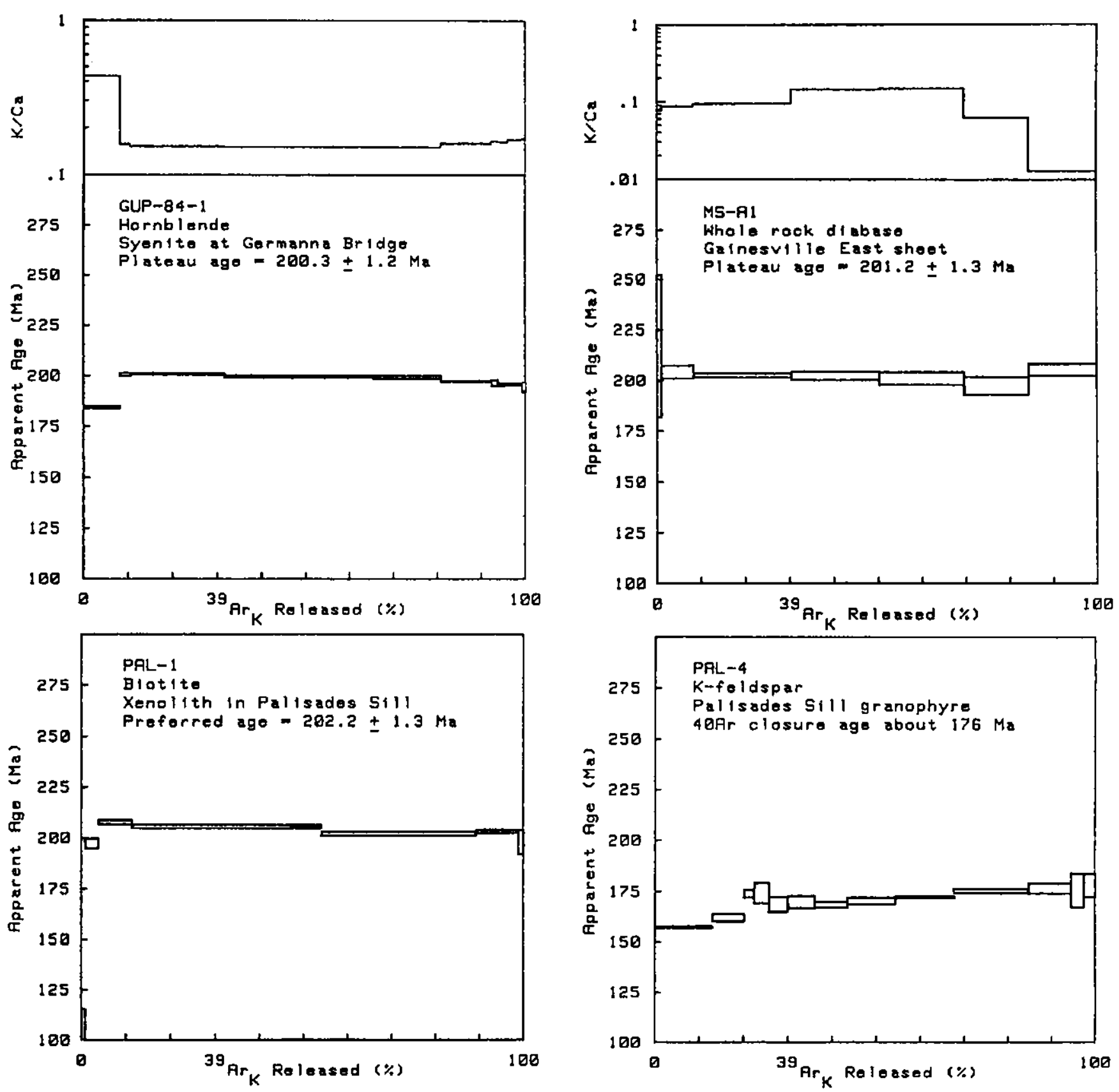

Figure 2. ${ }^{40} \mathrm{Ar} /{ }^{39} \mathrm{Ar}$ age spectra and, where appropriate, the associated $\mathrm{K} / \mathrm{Ca}$ plot. (See table 1.)

age of $202.2 \pm 1.3 \mathrm{Ma}$ (fig. 2 and table 1, sample PAL-1), interpreted to be a good estimate of the age of intrusion and crystallization of the Palisades diabase sheet.

Since Ratcliffe (this volume) has made a strong case for part of the Palisades sheet being a feeder to a basalt flow (possibly correlative with the Preakness Basalt) near Ladentown, New York, then the age of the Palisades sheet, 202.2 Ma, should be equivalent to the age of the basalt. This in turn puts a limit on the age of the Triassic-Jurassic boundary since the flow overlies palynologically dated Lower Jurassic strata (Cornet, 1977). Therefore, the age of the boundary must be greater than $202 \mathrm{Ma}$. It should also be pointed out that the 202.2 $\pm 1.3 \mathrm{Ma}$ age of the Palisades diabase sheet in the Newark basin is also analytically indistinguishable from the ages of the Germanna Bridge and Gainesville East sheets in the Culpeper basin. These sheets all belong to the high-titanium, quartz-normative (HTQ) magma type (Froelich and Gottfried, 1985), and so, at least to the temporal resolution possible by the ${ }^{40} \mathrm{Ar} /{ }^{39} \mathrm{Ar}$ 

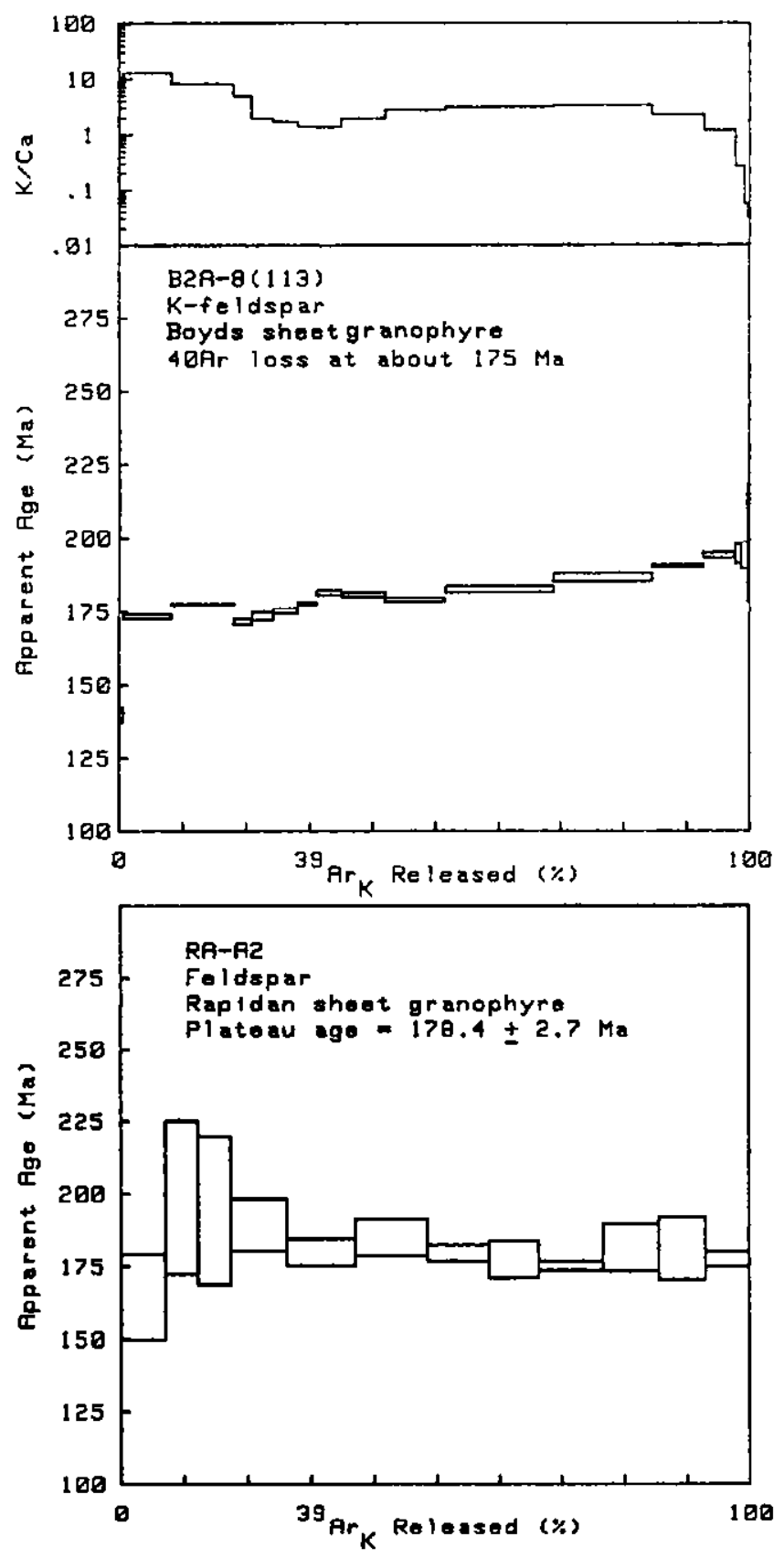

Figure 2. Continued.

technique ( $\sim 2 \mathrm{Ma}$ at 95-percent confidence), diabase sheets of this type from at least the Newark and Culpeper basins are coeval.

Feldspars from granophyres or pegmatoids in the Palisades, Boyds (northern Culpeper basin), Germanna Bridge, and Rapidan (southern Culpeper basin) diabase sheets (fig. 1) do not record igneous crystallization ages. Interestingly, however, all record similar argon closure ages of about 175 to $178 \mathrm{Ma}$ (fig. 2 and table 1). In addition, feldspar from country rock in the lower contact zone of the Boyds sheet shows evidence of two argon loss events (fig. 2 and table 1), one about 200-210 Ma
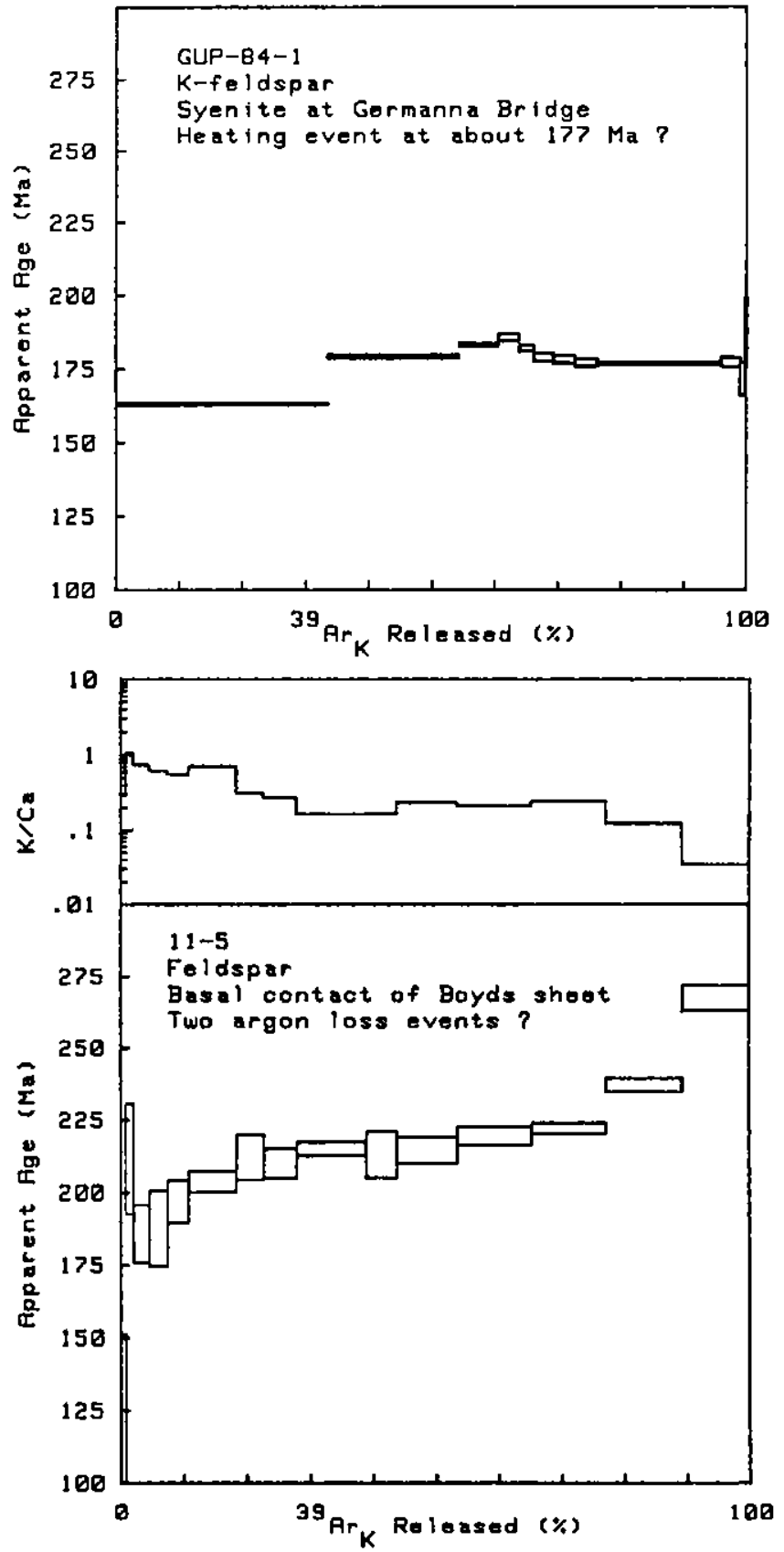

(presumably the age of igneous intrusion and crystallization), and a second about $175 \mathrm{Ma}$. It is difficult to interpret these $\sim 175$ - $\mathrm{Ma}$ argon closure ages as being the result of slow igneous cooling of the diabase sheets between 200 and $175 \mathrm{Ma}$. At reasonable geothermal gradients, all of the sheets in question would have to have been buried 5 to $8 \mathrm{~km}$ deep during this time interval, meaning that all strata at the stratigraphic level of the sheets and below would also have been heated as a result of deep burial, but there is no good evidence for this. A more tenable explanation of the $\sim 175$-Ma apparent ages of feldspars is a heating event $\left(\sim 200^{\circ} \mathrm{C}\right)$ that affected 
some portions of the Mesozoic basins and the diabase sheets and their contact zones. The most likely source of heat is hydrothermal fluids, possibly migrating in response to regional tilting and (or) uplift.

\section{REFERENCES CITED}

Cornet, B., 1977, The palynostratigraphy and age of the Newark Supergroup: University Park, Pennsylvania State University, unpublished Ph.D. thesis, 506 p.
Froelich, A.J., and Gottfried, D., 1985, Early Jurassic diabase sheets of the Eastern United States-A preliminary overview, in Robinson, G.R., Jr., and Froelich, A.J., eds., Proceedings of the second USGS workshop on the early Mesozoic basins of the Eastern United States: U.S. Geological Survey Circular 946, p. 79-86.

Sutter, J.F., 1985, Progress on geochronology of Mesozoic diabases and basalts, in Robinson, G.R., Jr., and Froelich, A.J., eds., Proceedings of the second USGS workshop on the early Mesozoic basins of the Eastern United States: U.S. Geological Survey Circular 946, p. 110-114.

\title{
MAGNETIC AND GRAVITY FIELDS OF EARLY MESOZOIC DIABASE SHEETS IN THE NORTHERN DURHAM BASIN, NORTH CAROLINA
}

\author{
David L. Daniels
}

\begin{abstract}
A new method for mapping diabase in early Mesozoic basins is demonstrated using continuous ground magnetic intensity profiles obtained from a vehicle-mounted fluxgate magnetometer. The data are collected rapidly along any roads that can be traversed by a 4-wheel drive vehicle. The nearly unique magnetic intensity signature of Mesozoic diabase in selected areas of the Durham basin was used to map the distribution of sheets and dikes in this geologic setting. The ground magnetic data and detailed gravity data were used to model the shape and subsurface configuration of one diabase sheet near Hester, North Carolina. The model shows that the gravity and magnetic profiles can be simulta. neously matched by a dishlike sheet and that the diabase thickness ranges from 120 to $250 \mathrm{~m}$. Strong reversed remanent magnetization in some diabase sheets of the Durham basin is indicated by both the modeling and aeromagnetic anomalies.
\end{abstract}

\section{INTRODUCTION}

Diabase sheets are present mainly in the largest of the exposed early Mesozoic basins of the Eastern United States-the Hartford, Newark, Gettysburg, Culpeper, Danville, and Deep River basins. Several subsurface basins covered by the Atlantic Coastal Plain-the South Georgia basin, the Florence basin, and unnamed basins in North Carolina and Maryland-also contain intrusions of diabase, some of which are inferred to be sheetlike (Phillips, this volume; Chowns and Williams, 1983; Daniels and others, 1983; Daniels and Zietz, 1978; Hansen and Wilson, 1984). Compared with most of the large exposed basins listed above, the area of diabase in the Deep River basin is small, and diabase is present mainly along the northern and western margin. The general outcrop pattern of these bodies and their occurrence along the eroded margin is similar to that of the Boyds, Herndon, and Centreville sheets of the Culpeper basin in Virginia (see Gottfried and Froelich, 1985, p. 87).

The Deep River basin is an elongate northnortheast-trending trough bounded on the east by the high-angle Jonesboro normal fault (Bain and Harvey, 1977). Triassic strata unconformably overlie rocks of the Carolina slate belt along the northwestern basin margin and dip and thicken markedly to the east-southeast. As used in this report, the Deep River basin includes, from north to south, the Durham, Sanford, and Wadesboro subbasins.

The precise extent of diabase in the Durham area is not well known, due to poor exposures and lack of large-scale geologic mapping. A compilation of available small-scale and reconnaissance geologic maps, including Wilson and Carpenter (1975) and Burt and others (1978), is used here to show the general location of diabase (A.J. Froelich, personal commun., 1986) (fig. 1).

\section{MAGNETIC DATA}

The study area (fig. 1) is covered by good quality aeromagnetic surveys (U.S. Geological Survey, 1973, 1974), flown at 120 and $305 \mathrm{~m}$ above ground along east-west flight lines spaced $800 \mathrm{~m}(0.5 \mathrm{mi})$ apart. To obtain higher resolution data, we used a USGS-built fluxgate magnetometer mounted on a 4-wheel drive vehicle to record continuous profiles of total magnetic intensity at a level about $3 \mathrm{~m}$ above ground. Profiles were 


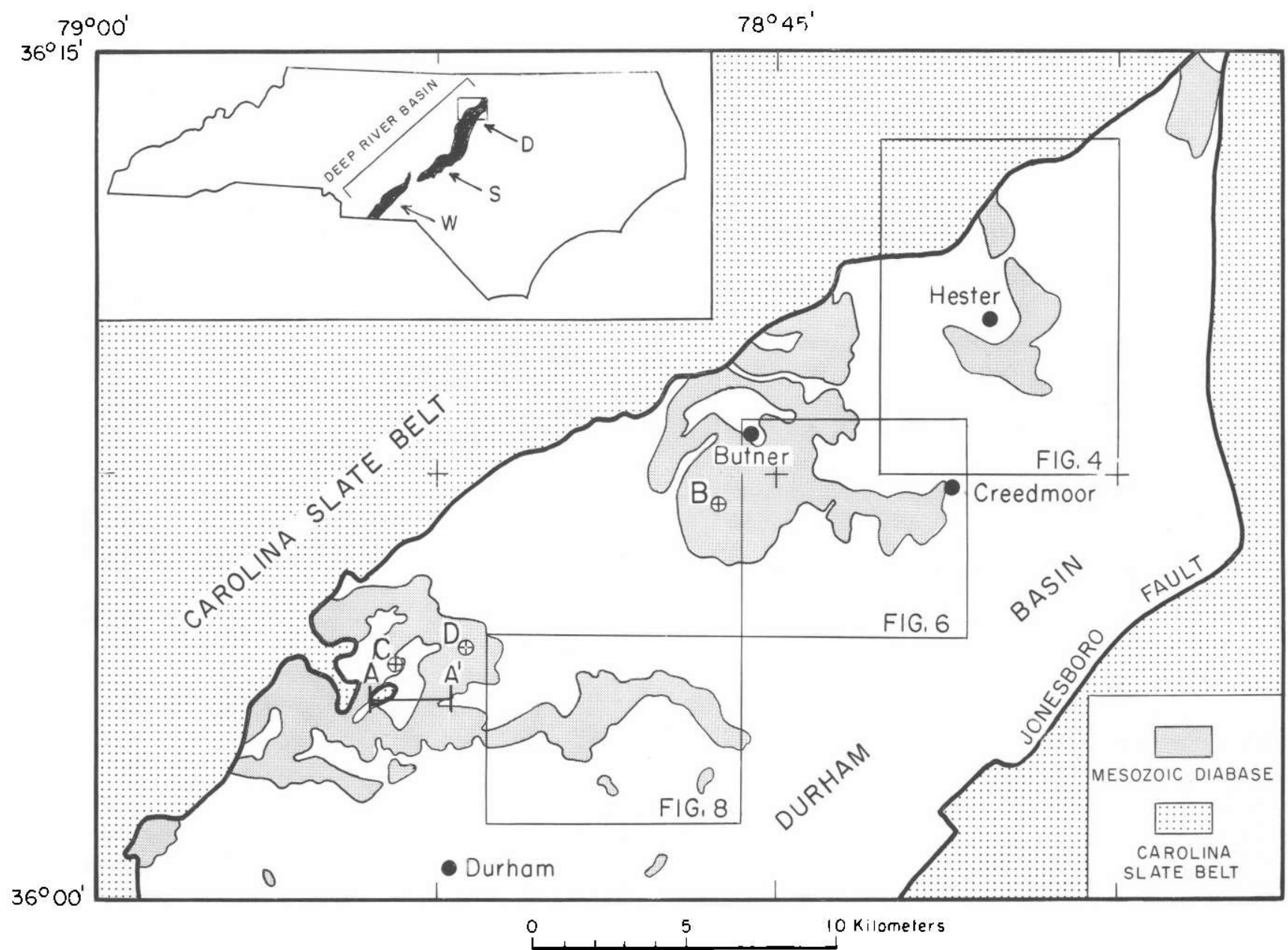

Figure 1. Map of the northern part of the Durham basin showing the approximate distribution of early Mesozoic diabase from a compilation of available reconnaissance geology and also showing location of profile A-A' (see fig. 2), drill holes B, C, and $D$, and areas of figures 4,6 , and 8 . Triassic sedimentary rocks are shown with no pattern. On the index map, D is Durham subbasin, $S$ is Sanford subbasin, and $W$ is Wadesboro subbasin.

recorded along many of the roads in the northern Durham basin that cross known or suspected diabase bodies. Data were collected with vehicle speeds of $20-30 \mathrm{mph}$ (32-48 kph); 6-9 minutes is required to traverse $5 \mathrm{~km}$ at these speeds. No correction for diurnal drift was made, nor was a reference field such as the International Geomagnetic Reference Field removed, because each profile was treated independently. In urban parts of the area, much of the magnetic data obtained is contaminated with noise generated by other vehicles, power lines, water pipes, bridges, and other deployments of ferrous metals. However, many noise-free segments, some across significant areas of diabase, were obtained in urban areas. In rural areas, more than 90 percent of the traverses are noise free.

\section{MAGNETIC ANALYSIS}

Although detailed aeromagnetic data are available for the study area, several factors favor the use of ground data for mapping diabase in the basin. First, the highfrequency content, and therefore the information content, of the ground data is greater than for the airborne data. Measurements made very close to a magnetic source greatly increase the amplitude of the anomalies from that source with respect to other more distant sources. Second, the positional accuracy of the ground data is higher. Third, features that lie parallel to the airborne flight lines are poorly defined in the areas between the flight lines. Disadvantages of the ground data include noise problems and the limitation of data collection to the road network. A comparison between airborne and ground magnetic profiles is shown in figure 2. The ground traverse (A-A', fig. 1 ) is along an eastwest road, NC-1656 north of Durham, and the flight line is parallel and $125 \mathrm{~m}$ north. Anomaly patterns produced by Mesozoic diabase, Triassic arkosic sandstone of the basin, and a probable schist inlier of the Carolina slate belt are clearly displayed in the ground profile in figure 2 


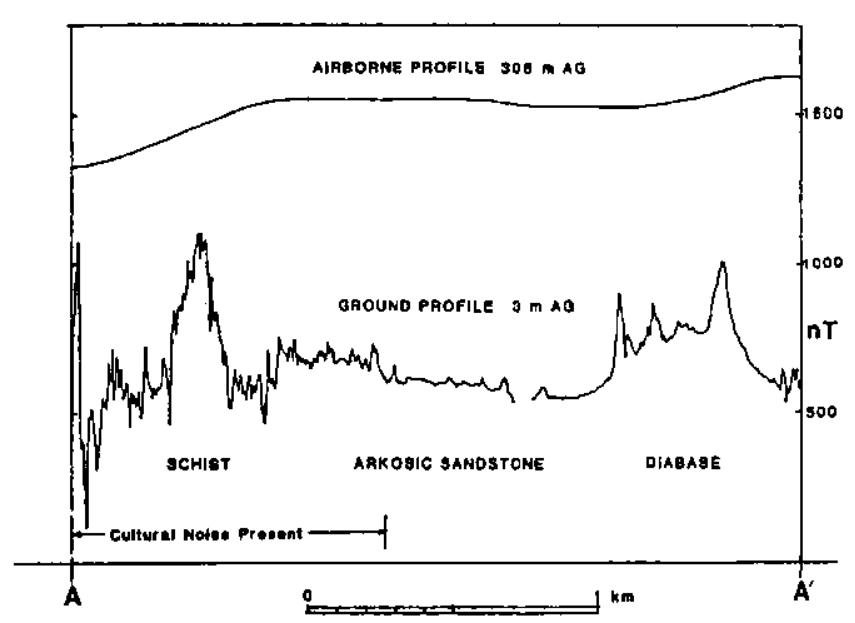

Figure 2. Comparison of draped airborne and ground total intensity magnetic profiles measured at two levels of ground clearance along profile $A-A^{\prime}$, shown in figure 1 . The ground profile (lower) was measured at $3 \mathrm{~m}$ above route NC-1656, and the airborne (upper) profile at $305 \mathrm{~m}$ above ground (AG), along a flight path that is parallel but displaced $125 \mathrm{~m}$ to the north. Amplitude in nanoteslas (nT); datum is arbitrary for both profiles.

and contrast with the absence of such patterns in the airborne profile. Note the higher level of cultural noise resulting from urbanization in the western part of the ground profile.

In most of the ground traverses within the basin, magnetic intensity rises abruptly where the magnetometer crosses a contact onto diabase. When the magnetometer was directly over diabase, a pattern of short wavelength anomalies, within an amplitude envelope of about 200-300 nanoteslas (nT), was typically recorded. The origin of this short-wavelength pattern is unknown but may arise from variations in the (1) magnetic susceptibility, (2) remanent magnetization, (3) depth to unweathered diabase, or may be due to (4) weathering and oxidation of magnetite along regularly spaced cooling fractures (M. Gettings, personal commun., 1987). All may contribute, but factors 3 and 4 may be the most significant. Mesozoic diabase typically has a moderate but relatively uniform magnetic susceptibility (Daniels, 1980). Little is known about the areal variations of the remanent magnetization.

The general correlation of mapped diabase with aeromagnetic anomalies in many early Mesozoic basins shows diabase to be consistently magnetic (for example, see Daniels, 1980; Phillips, 1985). Within the Durham subbasin diabase is essentially the only magnetic source rock, with the exception of magnetic hornfels and a few inliers of Carolina slate belt rocks. Diabase is, therefore, an ideal target for mapping from magnetic anomalies. In other basins, wide aureoles of thermally metamorphosed sedimentary rocks are found bordering the diabase (Leavy and others, 1983). A narrow part of these aure- oles adjacent to the diabase in the Culpeper and Gettysburg basins is enriched in magnetite (Daniels, 1980; Sumner, 1977) and can produce magnetic anomalies having amplitudes similar to those of the diabase. The general extent of a magnetite-rich zone within the thermal aureole is poorly known in any of the basins. As part of this study, the magnetic susceptibility of samples from a 146-m core hole that penetrated the Butner sheet $(B$, fig. 1) was measured. This included $124 \mathrm{~m}$ of diabase and $22 \mathrm{~m}$ of thermally metamorphosed Triassic arkose and arkosic wacke ( 90 percent) and shale (10 percent) that occur below the diabase. The magnetic susceptibility of the metashale (hornfels) is relatively high and nearly equivalent to that of the diabase, $1-2 \times 10^{-3}$ centimetergram-second (cgs), whereas the meta-arkose is only weakly magnetic $\left(3 \times 10^{-4} \mathrm{cgs}\right)$. From these data it can be inferred that wherever thermal aureoles are developed in shale adjacent to diabase, a magnetic hornfels could be present that would look like diabase on a magnetometer profile and thus introduce error if the mapping technique described here is used. Triassic strata in the northern Durham basin, however, are mapped as mainly arkose (North Carolina Geological Survey, 1985), which suggests that the amount of magnetic hornfels present may be small.

Anomalies of large amplitude are abundant in the aeromagnetic data over the adjacent Carolina slate belt. Similar rocks underlie the basin. It is evident from figure 2 that anomalies from these rocks or over inliers could be confused with diabase anomalies along the eroded northwest edge of the basin, especially where cultural noise is present.

\section{MAPPING DIABASE BY MAGNETIC ANOMALIES}

Profiles from two areas near Hester and Creedmoor (fig. 1) were selected for analysis because of relatively noise-free data. Magnetometer profiles in the Hester area are shown in figure 3 and the Creedmoor area in figure 5. Spikes of obvious cultural origin have been deleted from the profiles. The heavy lines beneath each profile in both figures depict the interpretation of exposed diabase based on higher intensities and the short-wavelength amplitude variations characteristic of diabase. Two borderline anomalies are interpreted as exposed diabase (1, fig. 5 ), and shallow subsurface diabase (2, fig. 3). Isolated anomalies may be due to diabase dikes (3, fig. 3 ). The locations of these profiles are shown in figures $4 A$ and $6 A$ with the traverses superimposed upon the aeromagnetic map of each area; the heavy lines show the interpreted location of the diabase. The dark pattern (fig. $4 A, B$; fig. $6 A, B$ ) depicts the surface extent of diabase as interpreted from ground and airborne magnetic data. 

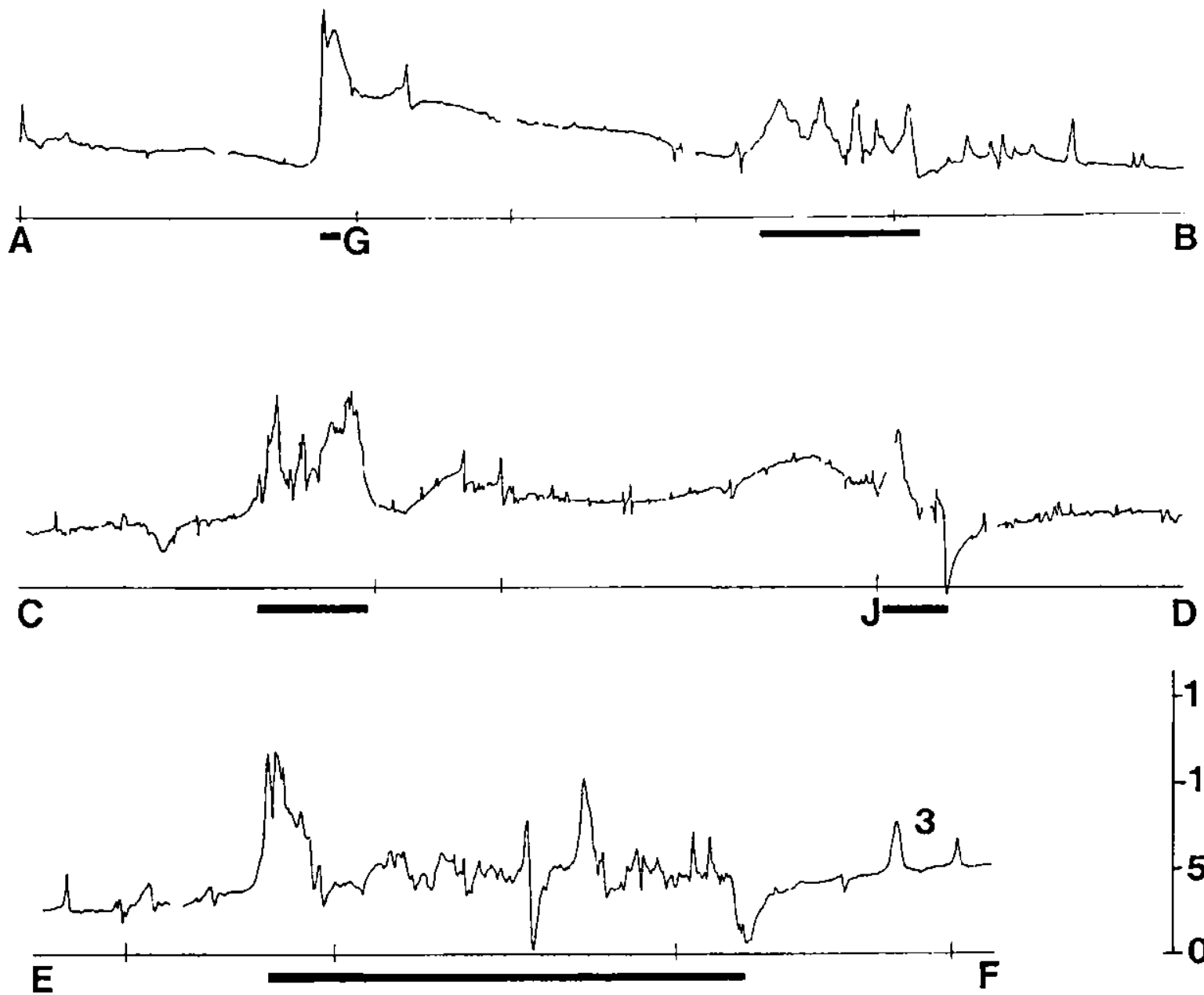

$-1500$

$-1000$

$-500$

nT

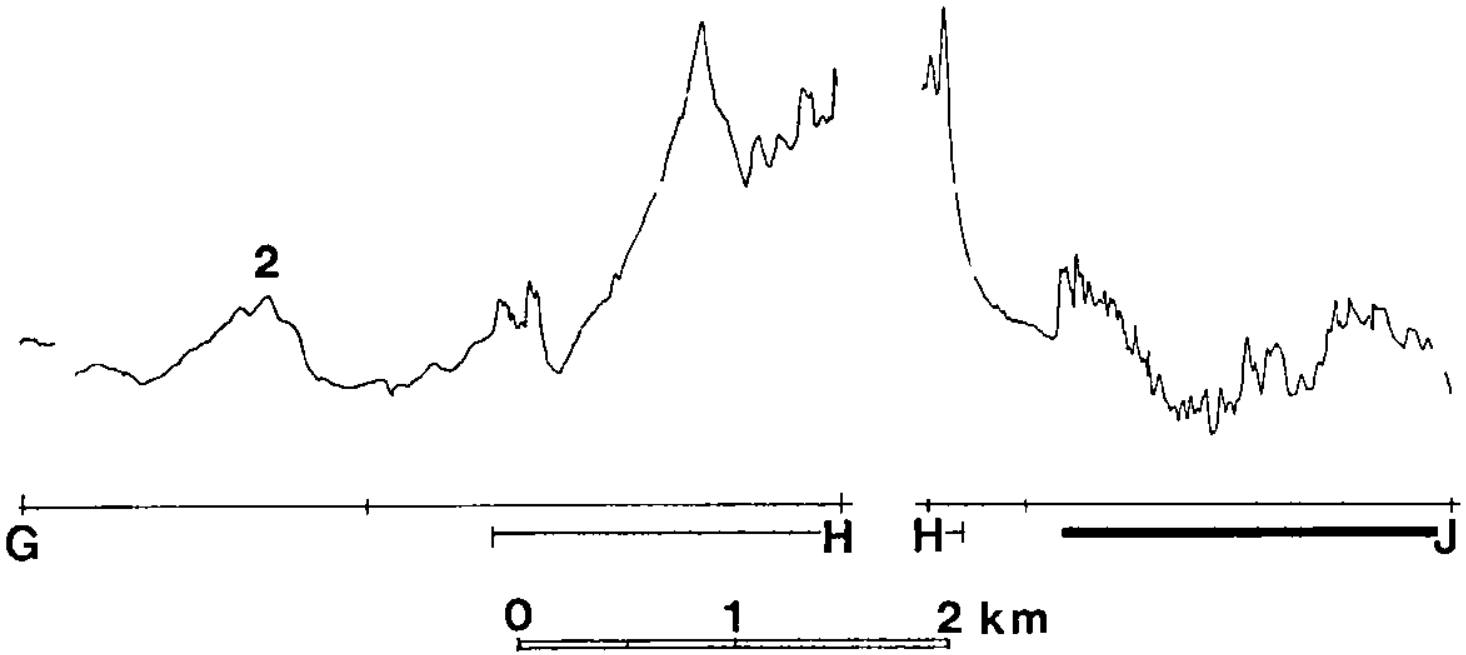

Figure 3. Profiles of total magnetic intensity, arbitrary datum, recorded along roads in Granville County, North Carolina, by use of a vehicle-mounted fluxgate magnetometer. Roads traversed: Profile A-B, NC-1129; Profile C-D, US-15; Profile E-F, NC-1636; Profile G-H, NC-1130; Profile $\mathrm{H}-\mathrm{J}, \mathrm{NC}-1132$. Interpreted surface extent of diabase is shown by a heavy line beneath each profile. Lightweight

lines beneath profiles $\mathrm{G}-\mathrm{H}$ and $\mathrm{H}-\mathrm{J}$ show the surface extent of rocks of the Carolina slate belt. Unmarked parts of the profiles are underlain by Triassic sedimentary rocks of the Durham basin. Amplitude in nanoteslas (nT). 3 on Profile $E-F$, isolated anomaly that may be due to a diabase dike; 2 on Profile $\mathrm{G}-\mathrm{H}$, borderline anomaly interpreted as shallow subsurface diabase. 


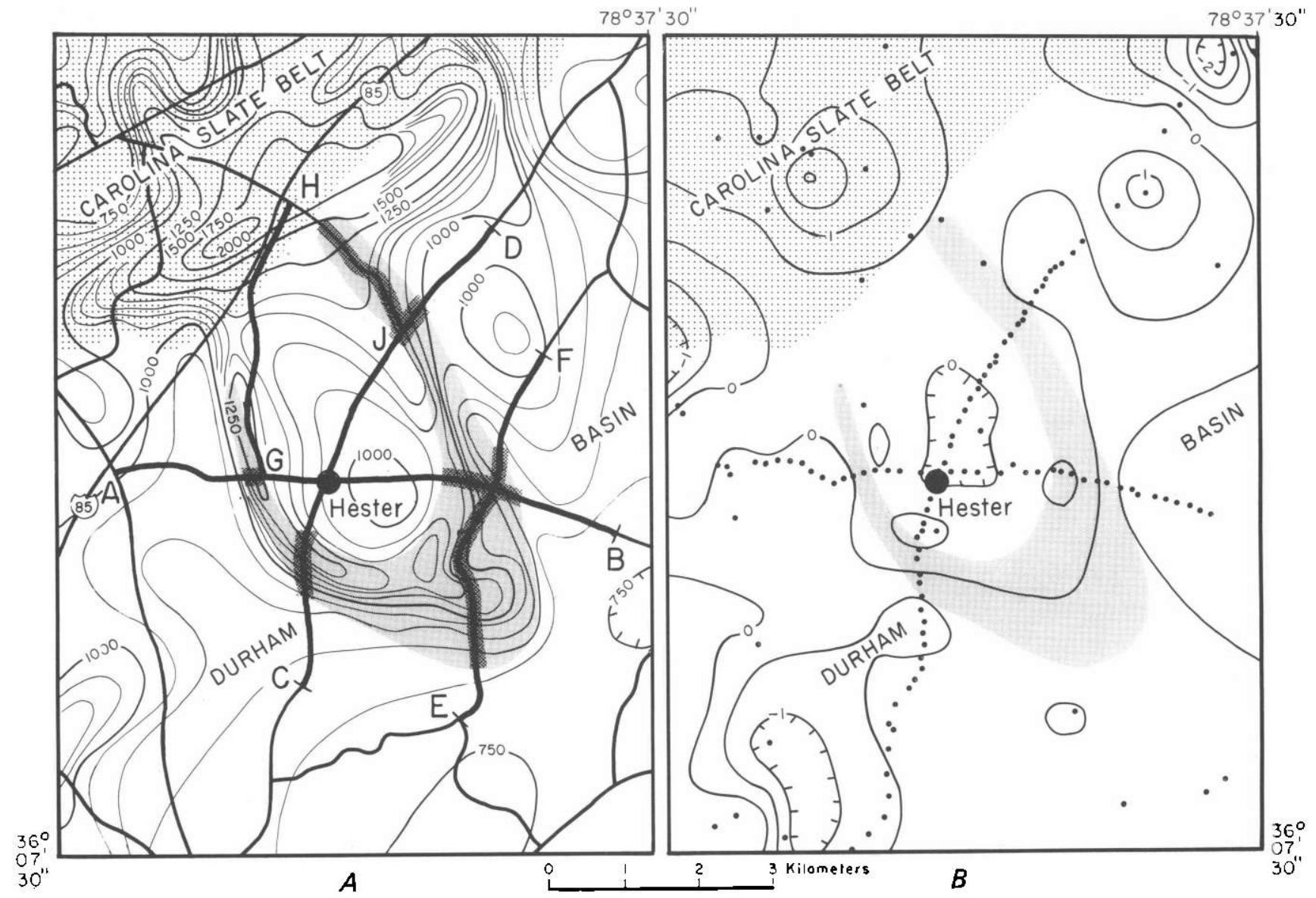

Figure 4. Potential field maps of the Hester area, Granville County, North Carolina. A, Aeromagnetic map (U.S. Geological Survey, 1973) showing the locations of profiles in figure 3. Dark pattern depicts diabase as mapped by the magnetic profiles. Light pattern depicts diabase as interpreted from ground and airborne magnetic data. $B$, Residual (high-pass filtered Bouguer) gravity anomaly map. Contour interval 0.5 milliGals. Gravity stations shown by dots.

In general, the diabase pattern derived by magnetic mapping differs from the regional geologic mapping mainly in the placement of the contacts. In the Hester area, Profile E-F (fig. $4 A$ ) shows a much larger surface extent of diabase than shown in figure 1. In the Creedmoor area (fig. 6), the magnetic method shows much less diabase. The Creedmoor body may not have the typical dishlike form described for diabase sheets in other basins (Hersey, 1944; Hotz, 1952; Daniels, 1980) but may be a south-dipping sheet that is connected in the subsurface to the Butner sheet on the west. Profile K-L (figs. 5, 6A) shows four separate regions of high intensity and indicates limited surface extent of the southeast edge of the Butner sheet.

\section{MODEL OF THE HESTER DIABASE SHEET}

Profile A-B (figs. 3, 4) along route NC-1129 was selected for modeling because it is oriented approxi- mately perpendicular to the apparent strike of the body and because a detailed gravity profile was also available. The modeling was carried out by using a semiautomatic magnetic/gravity Marquardt inversion program (M. Webring, unpublished computer program, U.S. Geological Survey, Denver, Colorado). Three findings resulted from the model of the Hester diabase (fig. 7): (1) the gravity and magnetic profiles can be simultaneously matched by a dishlike sheet; (2) diabase thickness ranges

Figure 5. Profiles of total magnetic intensity, arbitrary datum, recorded along roads in Granville County, North Carolina, by use of a vehicle-mounted fluxgate magnetometer. Roads traversed: Profile $\mathrm{K}-\mathrm{L}, \mathrm{NC}-1726$ and 1126; Profile M-N, NC-1104; Profile N-P, NC-1109; Profile Q-R, US-15; Profile S-T, NC-1110; Profile U-T, $\mathrm{NC}-1724$. Interpreted surface extent of diabase is shown as a heavy line beneath each profile; remaining lengths of profiles are underlain by Triassic sedimentary rocks. 1 on Profile K-L, anomaly interpreted as exposed diabase. 

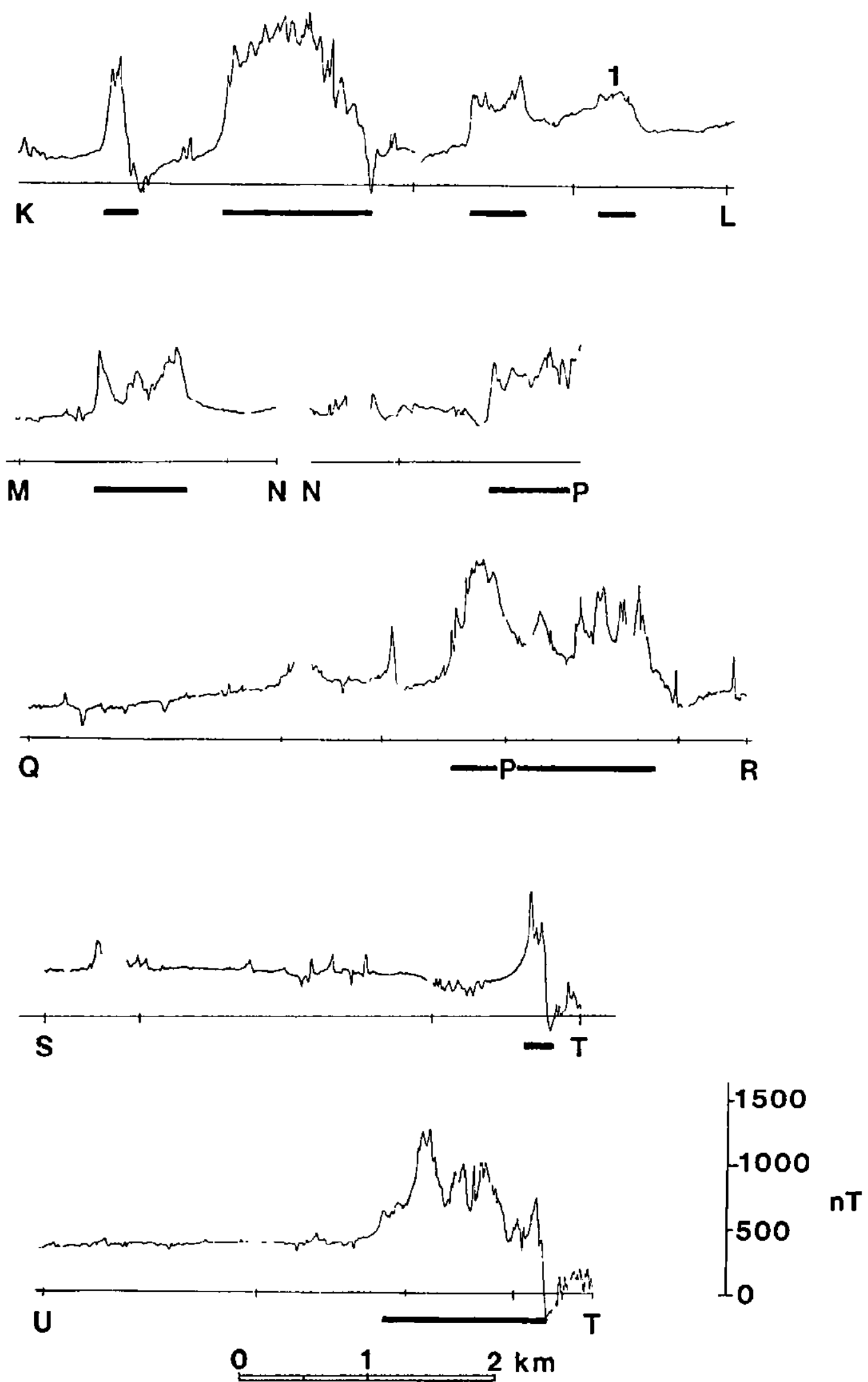

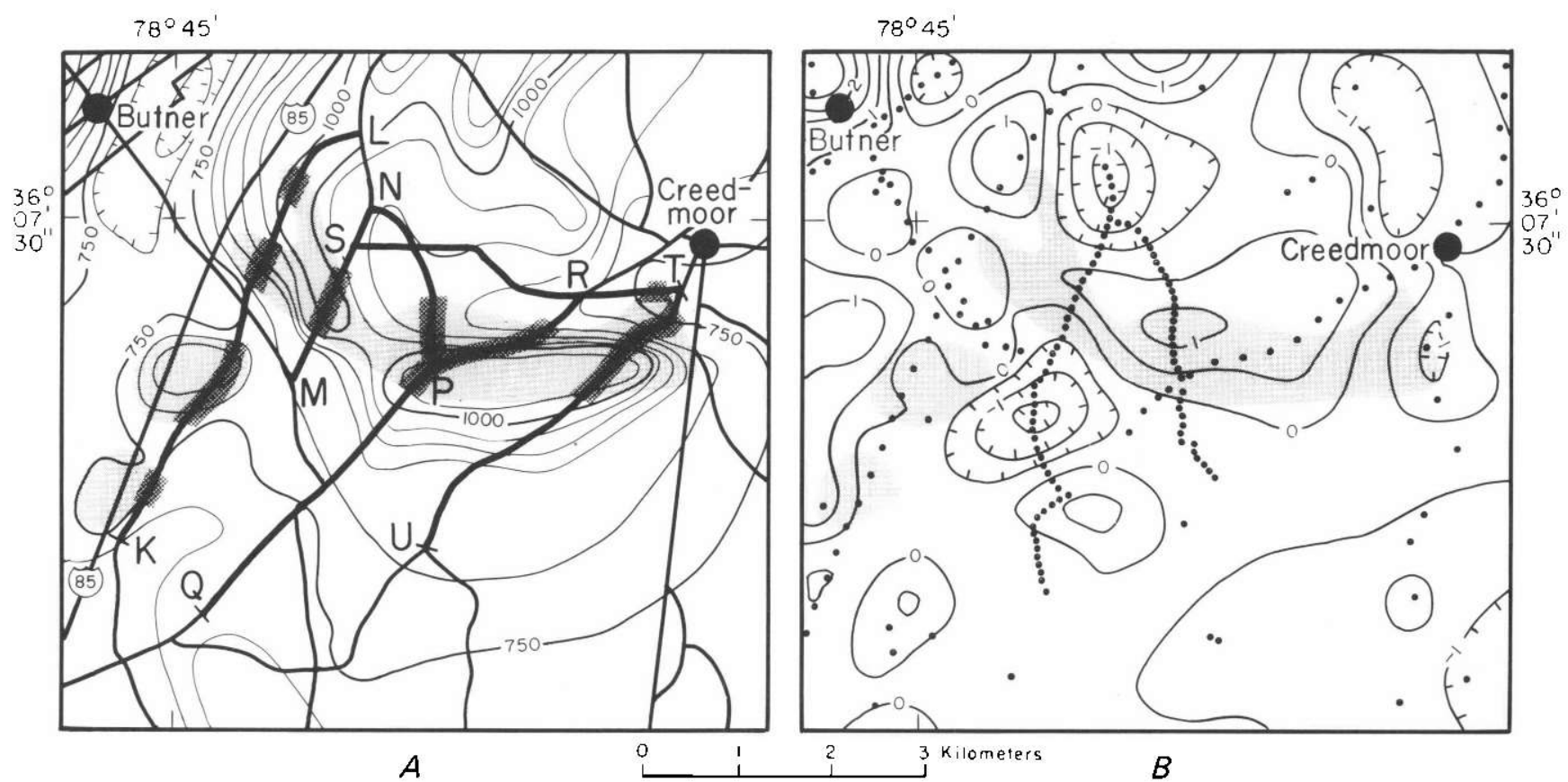

Figure 6. Potential field maps of the Creedmoor area, Granville County, North Carolina. A, Aeromagnetic map (U.S. Geological Survey, 1973, 1974) showing the locations of profiles in figure 5. Dark pattern depicts diabase as mapped by the magnetic profiles. Light pattern depicts diabase as interpreted from ground and airborne magnetic data. $B$, Residual (high-pass filtered Bouguer) gravity anomaly map. Contour interval 0.5 milliGals. Gravity stations shown by dots.

from 120 to $250 \mathrm{~m}$ (using a density contrast of 0.39 $\left.\mathrm{gm} / \mathrm{cm}^{3}\right)$; (3) the magnetic solution requires two bodies of differing magnetization-a western body having reversed remanent magnetization and relatively high magnetic susceptibility (body 1 , fig. 7), and an eastern body having moderate susceptibility and no remanent magnetization (body 2, fig. 7). Reversed remanent magnetization was required to match the anomaly at the western contact of the Hester sheet. No geometric modification alone could produce a match. Although no paleomagnetic studies of diabase sheets in the Durham basin are known to the writer, Phillips (1983) recorded six short intervals of reversed magnetization in cored Jurassic basalt from the South Georgia basin beneath the coastal plain in South Carolina. Additional evidence of strong remanent magnetization of diabase elsewhere in the Durham basin may be seen in the aeromagnetic map (fig. 8). Circular magnetic lows (B, fig. 8 ) both east and west of a circular magnetic high (A, fig. 8) coincide with diabase near Gorman. In this region a magnetic minimum is expected on the north side of a body that is magnetized principally by induction. The observed anomaly pattern indicates a strong magnetization vector that is not parallel to the vector of the Earth's present magnetic field.

Near the edge of the basin the short-wavelength pattern characteristic of diabase is superimposed upon anomalies of longer wavelength and much larger amplitude (Profile H-J, fig. 3). The large-amplitude anomaly at $\mathrm{H}$ (figs. 3 and 5) occurs mostly outside the basin and is therefore most likely produced by rocks of the Carolina slate belt.

\section{GRAVITY DATA AND ANALYSIS}

Three new gravity surveys were carried out in the northern Durham basin to supplement the magnetic data. Complete Bouguer anomalies due to diabase are present but are low in amplitude and not readily apparent against a background of longer wavelength anomalies caused by deeper sources. In order to enhance anomalies produced by shallow sources, long-wavelength anomalies were removed by filtering. The residual gravity anomaly map is shown in figure 9.

Correlation between diabase and positive residual gravity anomalies is variable, strongest for the Butner sheet, weak for the Durham sheet (fig. 9). Residual gravity maxima locally reach $+3.5 \mathrm{mGals}$ at Butner, but anomalies of $1.0-1.5 \mathrm{mGals}$ are more representative of diabase. The low amplitudes indicate that relatively small volumes of diabase are present. Assuming a sheet of infinite extent, the average thickness of the sheets can be estimated for a given anomaly from the formula $g=41.93$ $d t$, where $t$ is the sheet thickness in $\mathrm{km}, g$ is the amplitude of the gravity anomaly in mGals, and $d$ is the density contrast in $\mathrm{g} / \mathrm{cm}^{3}$ (Nettleton, 1976, p. 193). This type of thickness estimate should be acceptable for broad 


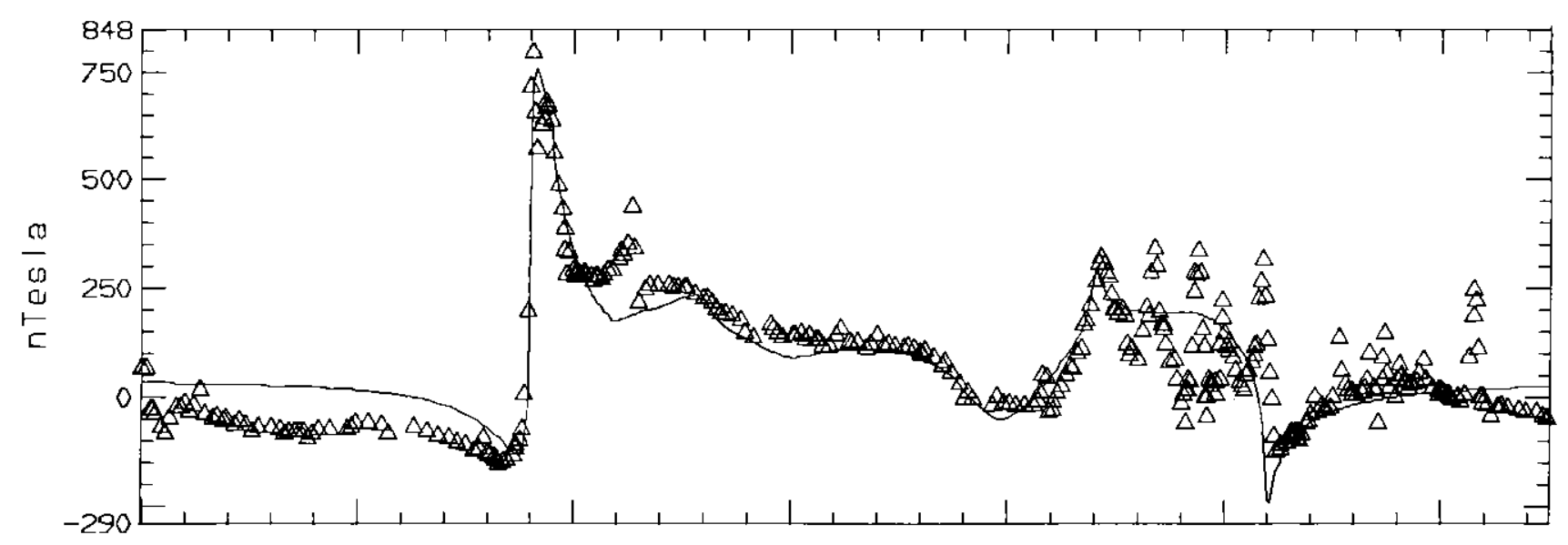

$B$

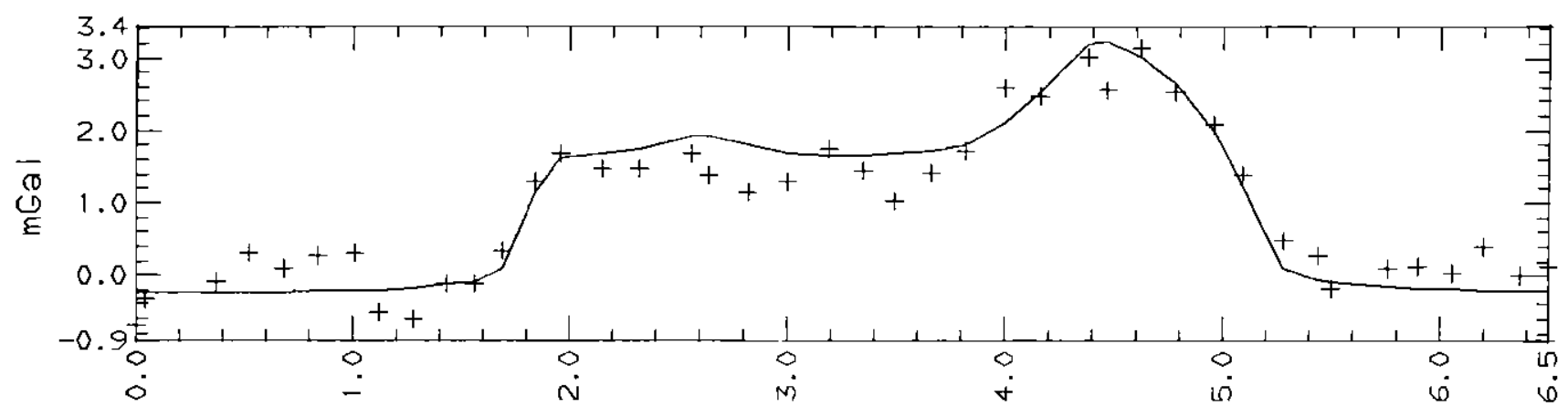

ki lometer

$\underline{E}$

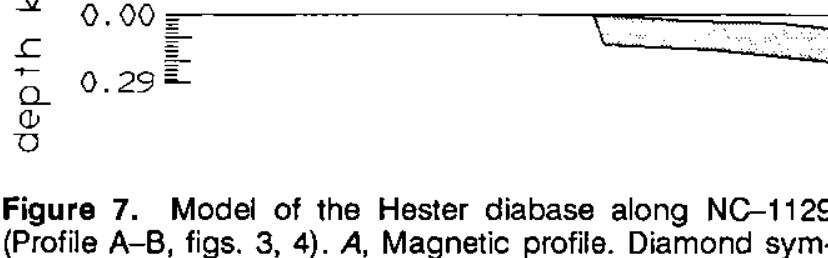
bols, observed data. $B$, Gravity profile. Plus symbols, observed data. Solid curves are calculated from the model. $C$, Model. Regional trends removed: magnetic profile -30

$\mathrm{nT} / \mathrm{km}$; gravity profile $-2.5 \mathrm{mGal} / \mathrm{km}$. Physical properties: density contrast $0.39 \mathrm{~g} / \mathrm{cm}^{3}$ (bodies 1 and 2); magnetic susceptibility $4.29 \times 10^{-3} \mathrm{cgs}$ (body 1), $2.23 \times 10^{-3} \mathrm{cgs}$ (body 2); remanent magnetization $3.5 \times 10^{-3}$ emu, azimuth $160^{\circ}$, inclination $-5^{\circ}$ (body 1$), 0^{\circ}$ (body 2 ).

exposures of diabase such as part of the Butner sheet (B, fig. 1) but probably underestimates the thickness at narrower exposures such as most parts of the sheet north of Durham (fig. 1). The thickness estimated for amplitudes of 1.0 to $1.5 \mathrm{mGals}$ is about 60 to $90 \mathrm{~m}$ for a density contrast of $0.39 \mathrm{~g} / \mathrm{cm}^{3}$. This contrast is based on a 2.98

$\mathrm{g} / \mathrm{cm}^{3}$ density of diabase and a $2.59 \mathrm{~g} / \mathrm{cm}^{3}$ density for the Triassic sedimentary rocks of the basin. These densities are averages of 25 samples of diabase from the core holes at Butner (B, fig. 1) and the Nello Teer Quarry (C, fig. 1) and of 64 measurements from the gamma-gamma density log of Triassic shale, sandstone, and conglomerate 


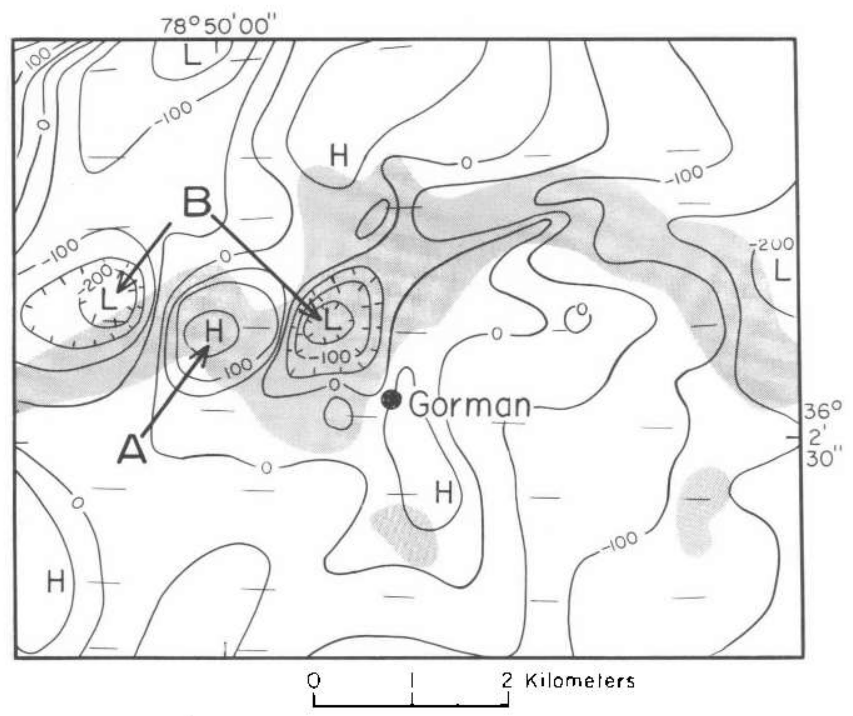

Figure 8. Aeromagnetic map of part of the north Durham area showing magnetic anomalies that are evidence of strong remanent magnetization of diabase sheets. Pattern shows distribution of diabase (from fig. 1). Circular magnetic lows (B) both east and west of a circular magnetic high $(A)$ coincide with diabase near Gorman.

\section{$78^{\circ} 45^{\prime}$}

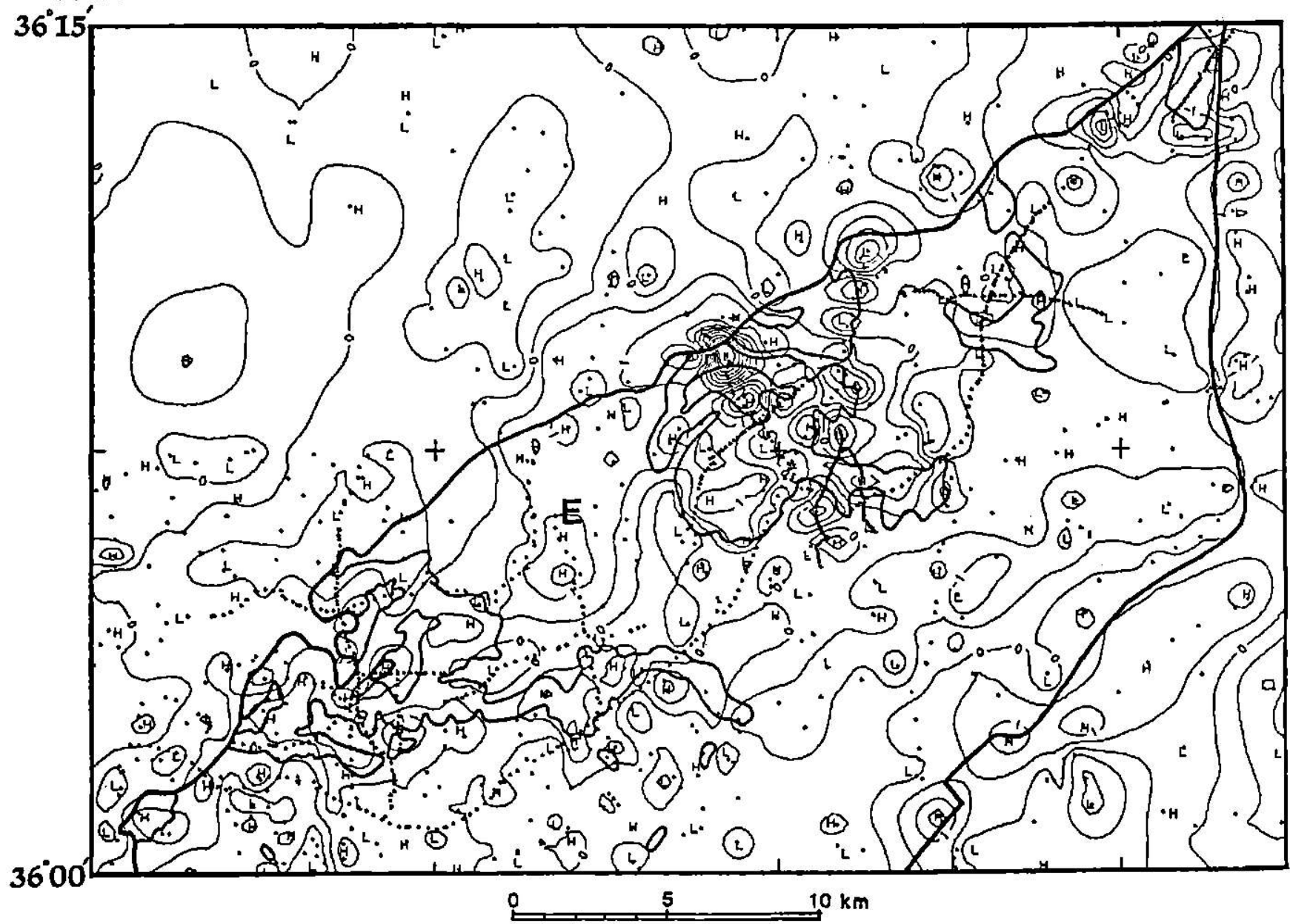

Figure 9. Residual gravity map from which long wavelengths have been removed by filtering. The filter was prepared from the radially averaged power spectrum of the complete Bouguer anomaly data (unpublished computer program MFILT, J.D. Phillips, U.S. Geological Survey, Reston, Virginia). Anomaly at $E$ may derive from either subsurface diabase or from mafic basement rocks. Gravity data are from three surveys conducted for the U.S. Geological
Survey by I.J. Won (North Carolina State University, Raleigh, North Carolina) in 1984, by L.S. Wiener (North Carolina Geological Survey, Raleigh, North Carolina) in 1985, and by S.L. Snyder (U.S. Geological Survey, Reston, Virginia) in 1986. Other data from D.M. Best (Northern Arizona University, Flagstaff, Arizona, written commun., 1987) and the Defense Mapping Agency; 1,415 stations total. 
(depths of 154 to $1,130 \mathrm{~m}$ ) in the Sears \#1 well near New Hill, North Carolina (Bain and Brown, 1980). Although this well is $35 \mathrm{~km}$ south of Durham, the density data are probably the best available for the sedimentary rocks of the basin. Density of the sedimentary rocks is less definite because of the wide range of lithologies and associated densities. The vertical thickness of diabase is known at three points from drill holes that have penetrated the sheets, points B, C, D, figure 1, where thicknesses of 124 , 90, and $125 \mathrm{~m}$, respectively, were encountered (A.J. Froelich, personal commun., 1986). The lesser thickness estimated from the residual gravity anomalies may result partly from the imperfect separation of regional and residual anomalies in the filtering process.

Other positive anomalies within the basin boundaries are not associated with presently known locations of diabase. These anomalies might be manifestations of either subsurface Mesozoic diabase or of mafic basement rocks that lie beneath the basin and that produce anomalies having wavelengths similar to those of the diabase sheets. The most conspicuous such anomaly (E, fig. 9), may derive from either diabase or Late Proterozoic basement rocks. One candidate lithology from the exposed Late Proterozoic rocks at the edge of the basin is metamorphosed intermediate to mafic volcanic rocks (unit X mapped by McConnell and Glover, 1982, p. 135).

\section{REFERENCES CITED}

Bain, G.L., and Brown, C.E., 1980, Evaluation of the Durham Triassic basin of North Carolina and techniques used to characterize its waste-storage potential: U.S. Geological Survey Open File Report 80-1295, 132 p.

Bain, G.L., and Harvey, B.W., 1977, Field guide to the geology of the Durbam Triassic basin: Carolina Geological Society, Fortieth Anniversary Meeting, October 7-9, 1977, 83 p.

Burt, E.R., Carpenter, P.A., III, McDaniel, R.D., and Wilson, W.F., 1978, Diabase dikes of the eastern Piedmont of North Carolina: North Carolina Geological Survey Section Information Circular 23, 12 p.

Chowns, T.M., and Williams, C.T., 1983, Pre-Cretaceous rocks beneath the Georgia Coastal Plain-Regional implications, in Gohn, G.S., ed., Studies related to the Charleston, South Carolina, earthquake of 1886; tectonics and seismicity: U.S. Geological Survey Professional Paper 1313, p. J1-J29.

Daniels, D.L., 1980, Geophysical-geological analysis of Fairfax County, Virginia: U.S. Geological Survey Open-File Report 80-1165, 64 p.

Daniels, D.L., and Zietz, I., 1978, Geologic interpretation of aeromagnetic maps of the Coastal Plain region of South Carolina and parts of North Carolina and Georgia: U.S. Geological Survey Open-File Report 78-261, 62 p., 4 maps.
Daniels, D.L., Zjetz, I., and Popenoe, P., 1983, Distribution of subsurface lower Mesozoic rocks in the Southeastern United States as interpreted from regional aeromagnetic and gravity maps, in Gohn, G.S., ed., Studies related to the Charleston, South Carolina, earthquake of 1886; tectonics and seismicity: U.S. Geological Survey Professional Paper 1313 , p. K1-K24.

Gottfried, D., and Froelich, A.J., 1985, Geochemical and petrologic features of some Mesozoic diabase sheets in the northern Culpeper basin, in Robinson, G.R., Jr., and Froelich, A.J., eds., Proceedings of the second U.S. Geological Survey workshop on the early Mesozoic basins of the Eastern United States: U.S. Geological Survey Circular 946 , p. $86-91$.

Hansen, H.J., and Wilson, J.M., 1984, Summary of hydrogeologic data from a deep $(2,678 \mathrm{ft})$ well at Lexington Park, St. Mary's County, Maryland: Maryland Geological Survey Open-File Report 84-02-1, 61 p.

Hersey, J.B., 1944, Gravity investigation of central-eastern Pennsylvania: Geological Society of America Bulletin, v. 55, p. $417-444$.

Hotz, P.E., 1952, Form of diabase sheets in southeastern Pennsylvania: American Journal of Science, v. 250, p. 375-388.

Leavy, B.D., Froelich, A.J., and Abram, E.C., 1983, Bedrock map and geotechnical properties of rocks of the Culpeper basin and vicinity, Virginia and Maryland: U.S. Geological Survey Miscellaneous Investigations Series Map I-1313-C, scale 1:125,000.

McConnell, K.I., and Glover, Lynn, III, 1982, Age and emplacement of the Flat River complex, an Eocambrian subvolcanic pluton near Durham, North Carolina: Geological Society of America Special Paper 191, p. 133-143.

Nettleton, L.L., 1976, Gravity and magnetics in oil prospecting: McGraw-Hill, Inc., 464 p.

North Carolina Geological Survey, 1985, Geologic map of North Carolina: North Carolina Geological Survey, scale 1:500,000.

Phillips, J.D., 1983, Paleomagnetic investigations of the Clubhouse Crossroads basalt, in Gohn, G.S., ed., Studies related to the Charleston, South Carolina, earthquake of 1886; tectonics and seismicity: U.S. Geological Survey Professional Paper 1313, p. C1-C18.

-1985, Aeromagnetic character and anomalies of the Gettysburg basin and vicinity, Pennsylvania-A preliminary appraisal, in Robinson, G.R., Jr., and Froelich, A.J., eds., Proceedings of the second U.S. Geological Survey workshop on the early Mesozoic basins of the Eastern United States: U.S. Geological Survey Circular 946, p. 133-135.

Sumner, J.R., 1977, Geophysical investigation of the structural framework of the Newark-Gettysburg Triassic basin, Pennsylvania: Geological Society of America Bulletin, v. 88, p. 935-942.

U.S. Geological Survey, 1973, Aeromagnetic map of the northern parts of the Durham North and the Creedmore [sic] quadrangles, north-central North Carolina: U.S. Geologi- 
cal Survey Geophysical Investigations Map GP-883, scale $1: 62,500$

1974, Aeromagnetic map of parts of the Greensboro and Raleigh $1^{\circ}$ by $2^{\circ}$ quadrangles, North Carolina: U.S. Geological Survey Open-File Report 74-29, scale $1: 250,000$.
Wilson, W.F., and Carpenter, P.A., III, 1975, Region J geology: A guide for North Carolina mineral resource development and land use planning: North Carolina Division of Resource Planning and Evaluation, Mineral Resources Section Regional Geology Series 1, 76 p. 


\title{
DEEP STRUCTURE OF RIFT BASINS FROM THE CONTINENTAL MARGIN AROUND NEW ENGLAND
}

\author{
D.R. Hutchinson and K.D. Klitgord
}

\begin{abstract}
Three types of structures appear to have controlled formation of rift basins buried on the continental margin around New England. These are paired border faults that extend deep into the crust (the Long Island rift basin-Block Island fault pair), a discontinuity in a buried detachment surface near the position of the Appalachian gravity gradient (the New York Bight-Newark rift basin pair), and a low-angle detachment beneath the continental margin (the Franklin rift basin and three subbasins along Georges Bank). These three types of structures probably represent reactivated Paleozoic structures. Many of the exposed basins of the Newark Supergroup formed along a discontinuity in a buried detachment surface. These structures imply that extension within the upper crust was by brittle faulting. Our understanding of crustal thinning responsible for this rifting is hampered by the absence of good velocity and depth information for the deep crust, although localized thinning probably occurs landward of the basement hinge zone, whereas more pervasive crustal thinning occurs seaward of it.
\end{abstract}

\section{INTRODUCTION}

Knowing the structure of the crust beneath rift basins is critically important to understanding the geometry and mechanisms of continental breakup. Because much of the rifted edge of the U.S. Atlantic continental margin (fig. 1) lies buried beneath large sedimentary basins (Folger and others, 1979), the details of synrift tectonics have largely come from analyses of rocks exposed in early Mesozoic rift basins along the East Coast (Van Houten, 1977; Manspeizer and others, 1978; Olsen and others, 1982) and from seismic reflection profiles and potential field data collected along both the coastal plain (Marine and Siple, 1974; Daniels and others, 1983; Peterson and others, 1984; Nelson and others, 1985 ) and the continental shelf (Klitgord and Behrendt, 1979; Behrendt and others, 1983; Benson, 1984; Hutchinson and others, 1986b). Deep-penetration seismic reflection profiles have demonstrated some of the complexity and heterogeneity of structures within rift basins and the underlying crust in the Northeastern United States (Hutchinson and others, 1986b) and elsewhere (Gibbs, 1984).
This paper describes three geometries observed or inferred beneath rift basins buried within the continental margin surrounding eastern and southern New England (fig. 2). Rift basin structure is interpreted from U.S. Geological Survey (USGS) multichannel seismicreflection profiles and potential field (magnetic and gravity anomaly) maps of the Long Island platform, the Gulf of Maine platform, and Georges Bank (fig. 2). Detailed descriptions of these data sets and representative record sections can be found in Grow and others (1979), Klitgord and Behrendt (1979), Klitgord and others (1982), Klitgord and Hutchinson (1985), and Hutchinson and others (1986b, in press).

\section{RIFT BASIN STRUCTURE}

Our analysis of the structure of rift basins beneath the continental shelf surrounding New England reveals the presence of three types of structures that controlled formation of the rift basins (fig. 3): (1) paired border faults that extend deep into the crust; (2) a discontinuity in a detachment surface near or just east of the position of the Appalachian gravity gradient; and (3) a low-angle detachment surface beneath the continental margin. Examples of these structures are shown in interpreted cross sections of figures 4 and 5 . Other structures may exist but have not been recognized, given the limited resolution of many of the multichannel seismic-reflection profiles.

Deep, paired border faults.-In this style of rifting, half-grabens form along planar or listric border faults that penetrate deep into the crust and dip at low angle towards each other (figs. $3 A$ and $B$ ). The crustal block may either downdrop, causing half-grabens to form on each paired fault (fig. $3 A$ ) or possibly rotate, causing asymmetric formation of a half-graben on only one side (fig. $3 B$ ). Crustal thinning may be localized in the region between the two faults. The deep, paired-fault geometry defines a large-scale crustal graben along low-angle faults, although at the surface, the mappable rift structures are half-grabens.

The best example of a paired border fault system is the Long Island rift basin-Block Island fault pair from 


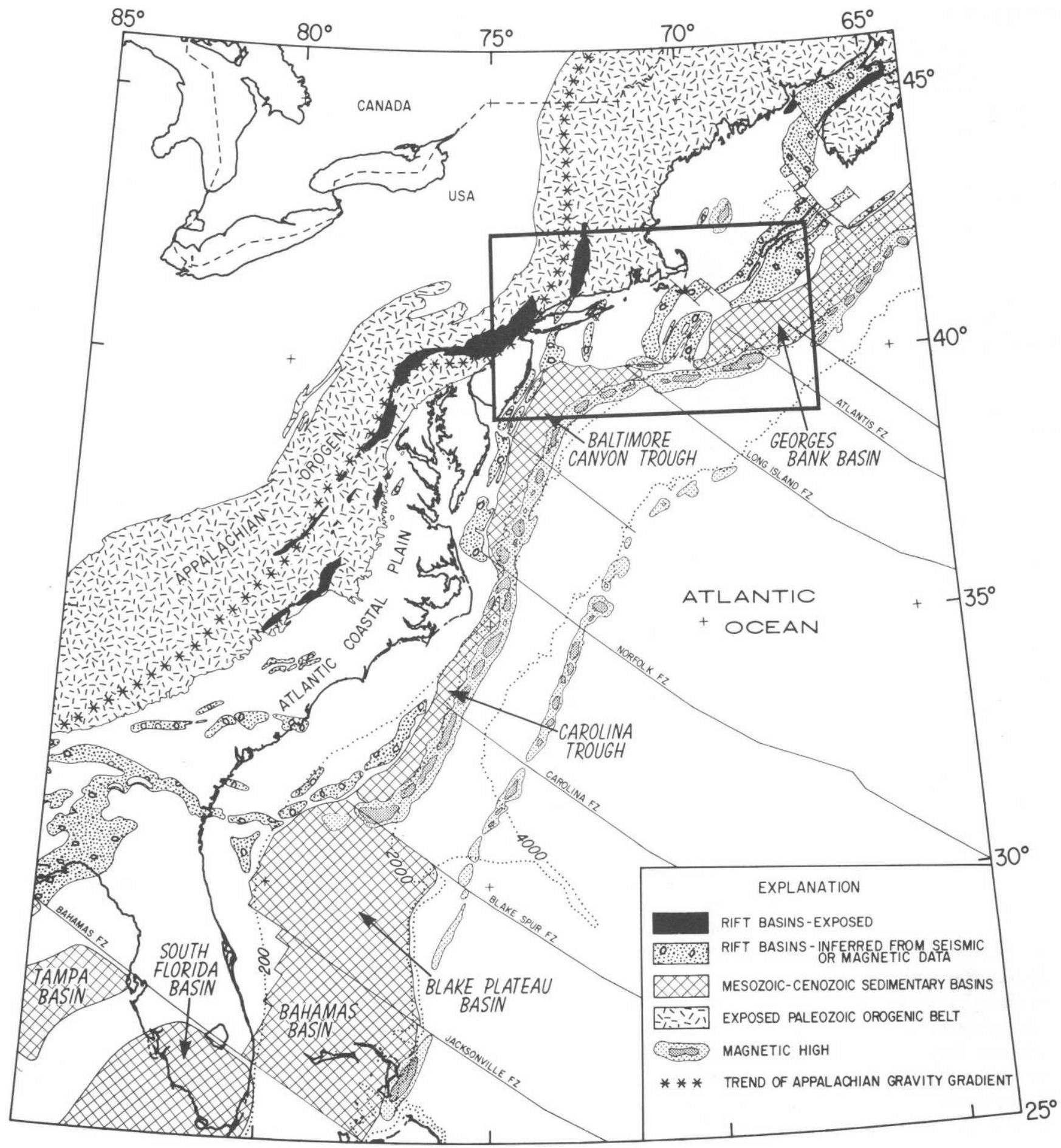

Figure 1. Regional map of the U.S. Atlantic continental margin. Selected features discussed in the text include exposed, buried, and inferred early Mesozoic rift basins, the Appalachian gravity gradient, the East Coast Magnetic Anomaly (marking the edge of Mesozoic oceanic crust), and

the Long Island platform (figs. 2, 4). The Long Island basin forms a half-graben that has a border fault that dips east at 15 to $25^{\circ}$. The border fault is not continuous into the lower crust but projects into a zone of subparallel, the large offshore Mesozoic-Cenozoic postrift basins. The basement hinge zone follows the landward edge of the offshore Mesozoic-Cenozoic postrift basins. Boxed-in area shows the location of figure 2. Depth contours in meters; FZ, fracture zone.

discontinuous, eastward-dipping reflections that extend to about 7 seconds (s) $(21 \mathrm{~km})$ and are interpreted to be extensional faults in the middle to lower crust (Hutchinson and others, 1986b). The facing fault, the Block 


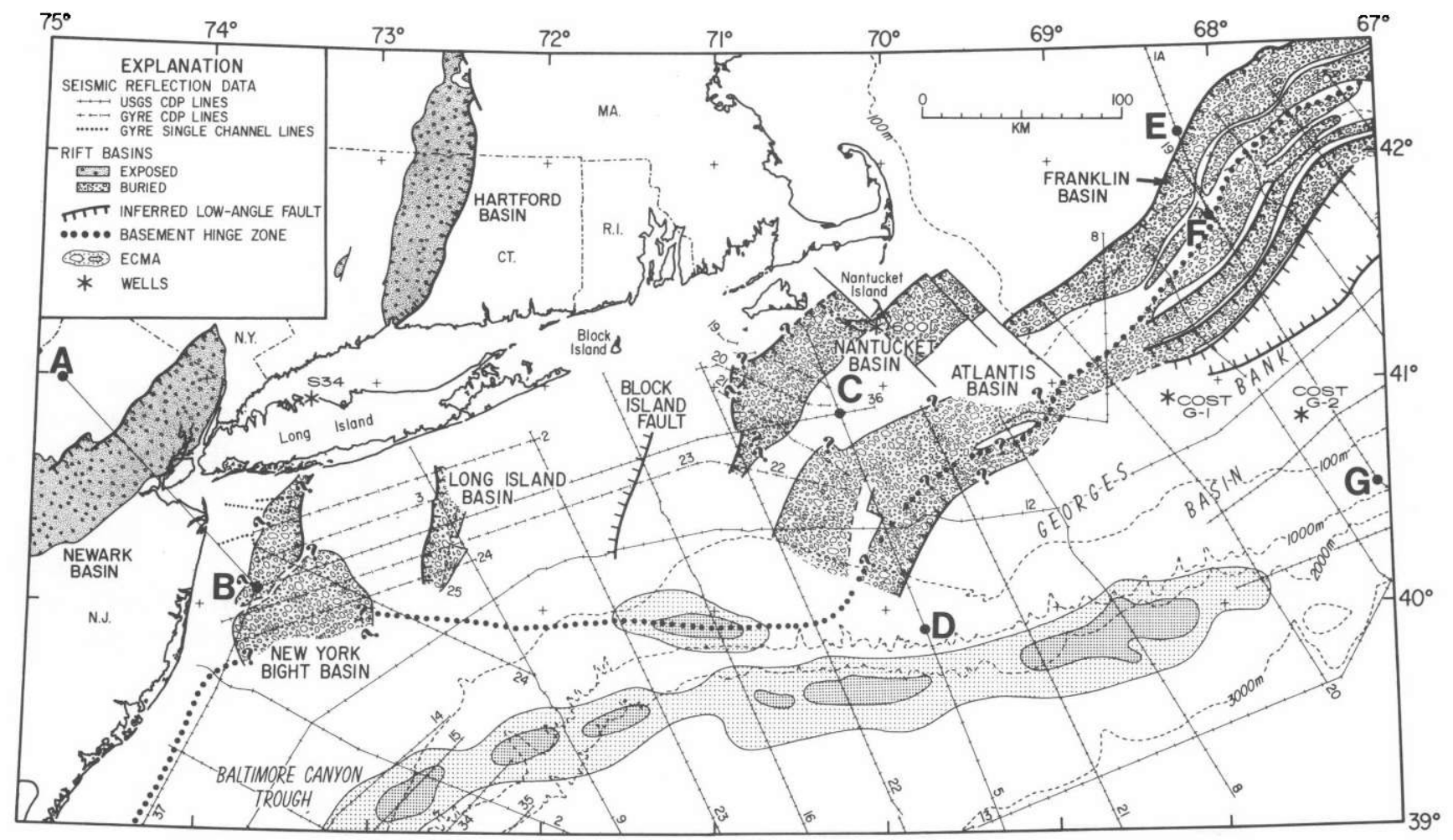

Figure 2. Location map of New England and its surrounding continental margin showing exposed and buried rift basins. Tracklines show the distribution of multichannel seismic profiles used in analyzing the buried basins. A-B-C-D locates the cross section of figure 4. E-F-G locates the cross section of figure 5 . Modified from Hutchinson and others (in press). ECMA, East Coast Magnetic Anomaly.

Island fault, consists of well-developed reflections that dip westward at 12 to $18^{\circ}$ to depths of about $24 \mathrm{~km}$, but no accompanying rift basin is present beneath the postrift sediments (Hutchinson and others, 1985). The border faults are horizontally separated by about $100 \mathrm{~km}$ at the basement subcrop. Reduced traveltimes to the Mohorovicic discontinuity (Moho) in the narrow region where the two faults merge in the lower crust suggest localized crustal thinning of about $3 \mathrm{~km}$ (Hutchinson and others, 1986a). The absence of a rift basin along the Block Island fault suggests that some rotation of the crustal block between the two border faults may have resulted in formation of only the easternmost half-graben, the Long Island basin. Alternatively, a half-graben could have formed along the Block Island fault that subsequently was removed by uplift and erosion.

A second example of a paired border-fault system is the Nantucket-Atlantis rift pair, also on the Long Island platform (figs. 2, 4). The border fault of the Nantucket basin dips southeastward toward the northwest-dipping border fault of the Atlantis basin. These basins are separated by approximately $140 \mathrm{~km}$ at the sea floor. Neither border fault can be traced into the middle or lower crust because of poor resolution in the multichannel seismic-reflection profiles. We infer that the faults continue at depth, similar to the Long Island border fault-Block Island fault pair.

Detachment discontinuity at the position of the Appalachian gravity gradient.-A set of low-angle detachment surfaces is observed in reflection profiles from the southern Appalachians (Cook and others, 1979, 1981), the central Appalachians (Harris and others, 1981), and the northern Appalachians (Ando and others, 1984; St.-Julien and others, 1983). These reflection profiles show that the Appalachian gravity gradient (fig. 1) marks the position of a first-order change in the detachment surface from strong subhorizontal or low-angle reflections in the west to steeper dips to the east. Reflection data and gravity models have not yet resolved whether this change in dip (that is, discontinuity) in the detachment is a ramp in which the detachment continues eastward at a deeper level (for example, Cook and others, 1981; Ando and others, 1984) or a steeply dipping root zone or suture into which the detachment terminates (Hatcher and Zietz, 1980; Cook and others, 1981; Iverson and Smithson, 1982).

The rift basins that formed along this discontinuity are half-grabens with paired border faults that generally dip towards each other (fig. $3 C$ ). These faults, which may be planar or listric, are structurally different from the 


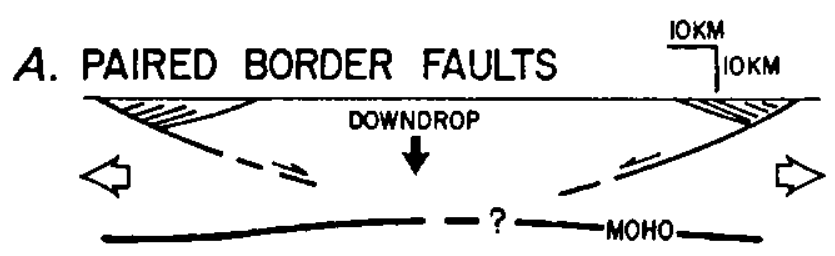

B. PAIRED BORDER FAULTS
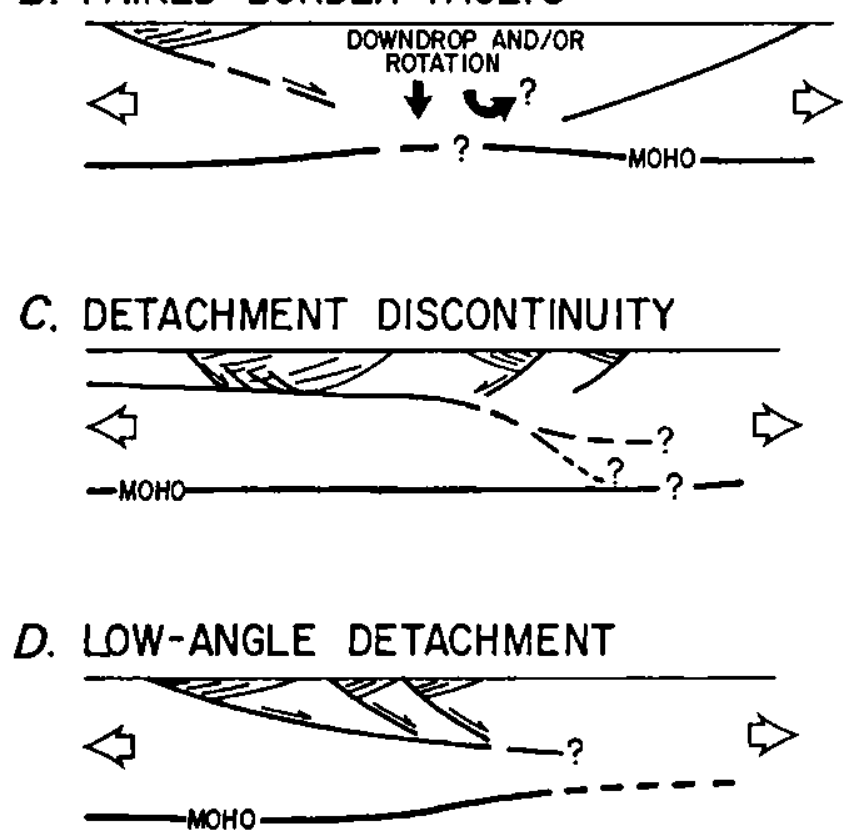

Figure 3. Simplified models of the structures controlling rift basin formation off New England. $A$, Symmetric graben formation by motion along paired border faults that dip toward each other and extend deep into the crust. $B$, Asymmetric graben formation by down dropping and (or) rotation of a crustal block along paired border faults similar to those shown in $A$. $C$, Formation of grabens with paired border faults along the change in dip of a detachment surface. This geometry coincides with the approximate location of the Appalachian gravity gradient. $D$, Formation of adjacent rift basins with subparallel border faults that merge into a low-angle detachment surface. The detachment may flatten at midcrustal depths or continue dipping into the lower crust.

deep, paired faults shown in figures $3 A$ and $B$ in that the faults probably only extend to the depth of the detachment. We surmise that the basins were formed by structures associated with the change in dip of the detachment surface. The east-dipping faults (those associated with the western half-graben in fig. $3 C$ ) are probably reactivated thrust faults off the detachment surface. The west-dipping border faults (those associated with the eastern rift basin) could be either reactivated backthrusts or extensional faults that cut through preexisting structures during the stretching. Crustal thinning could occur beneath or very close to the basins (and, therefore, close to the gravity gradient) if the detachment terminates in a root zone or suture (for example, Nelson and others, 1986). Alternatively, crustal thinning could be displaced many kilometers eastward if the detachment formed a ramp to deeper crustal levels, similar to geometries inferred beneath the U.S. Basin and Range (Wernicke and Burchfiel, 1982; Anderson and others, 1983).

The only example of this style of rifting from the New England continental margin is at the New York Bight basin (figs. 2, 4), where the structure represents the eastern half of the paired-basin geometry. We interpret a subbasement reflector on USGS line 37 just southwest of the New York Bight basin to represent part of the detachment surface as it dips from 6 to $9 \mathrm{~km}$ beneath the Baltimore Canyon trough (Hutchinson and others, 1986b). The Appalachian gravity gradient is located 50-60 km west of the New York Bight basin, near the position of the onshore Newark basin. In our interpretation, the New York Bight basin falls on the east side of the change in dip of the detachment, with one or more subbasins containing faults that dip westward towards the edge of the decollement. The Newark basin forms the western half-graben.

Low-angle detachment. - This style of rifting results in rift basins formed above or along a low-angle detachment surface that penetrates to the middle or lower crust. Multiple rift basins can form adjacent to each other (fig. $3 D$ ) and have parallel border faults that sole into the detachment surface. This differs from a discontinuity in the detachment surface in that no change in slope is required. Adjacent basins contain subparallel border faults that dip in the same direction rather than faults that dip towards each other to form pairs (compare figs. $3 C$ and $D$ ).

Our one example of rift basins formed above a low-angle detachment is from the Georges Bank area. The Franklin rift basin on the north side of Georges Bank (figs. 2, 5) formed along a south-southeast dipping fault that can be traced into the crust to depths of 12 to $13 \mathrm{~km}$ on reflection profiles (Hutchinson and others, in press). Other reflection profiles from Georges Bank reveal the existence of three more buried rift basins southeast of the Franklin basin, all having subparallel border faults dipping to the south-southeast (Klitgord and others, 1982). The reflection data from beneath these three basins are of poor quality and fail to image either a deeper detachment surface or the continuation of the border faults in the crust beneath each basin. However, the border fault of the Franklin basin projects beneath these basins, and we postulate that it acted as a low-angle detachment surface that helped control their formation. As shown in figure 5 , we are uncertain whether the detachment becomes subhorizontal in the middle crust or continues dipping into the lower crust. 


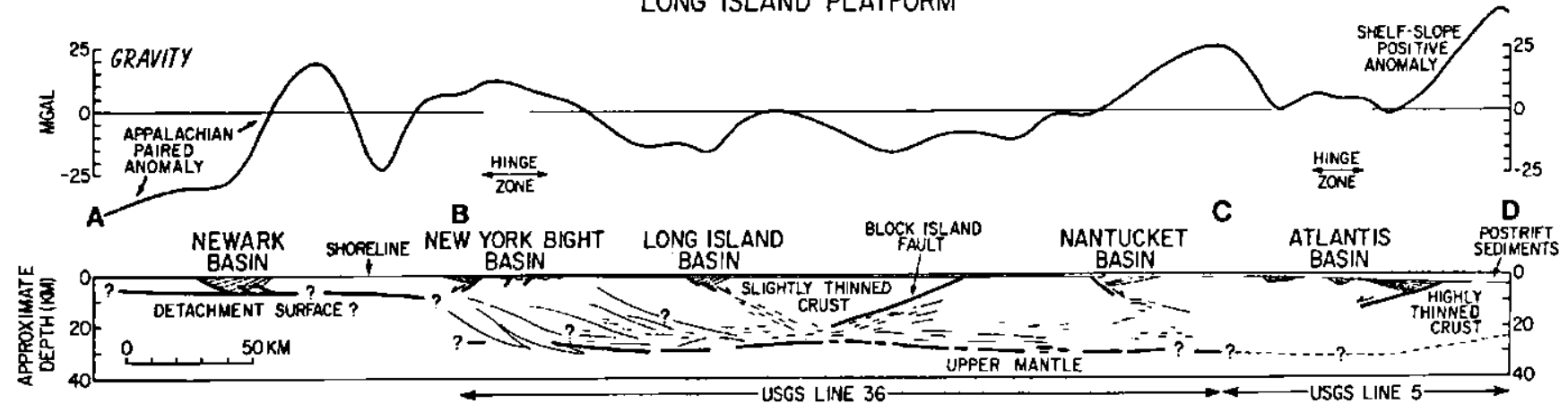

Figure 4. Schematic cross section from the Newark basin in New Jersey across the Long Island platform. A-B-C-D is located in figure 2. From Hutchinson and others (in press).

This northern part of Georges Bank is located along the basement hinge zone, which marks the western boundary of the zone of extensive crustal thinning associated with early Mesozoic continental breakup (Grow and others, 1979; Sawyer and others, 1983; Swift and others, in press). Consequently this detachment surface may be comparable to the S-reflection identified beneath the Bay of Biscay (Montadert and others, 1979), which they infer to represent the brittle-ductile transition within rifted crust.

This detachment surface beneath Georges Bank probably is not the same detachment observed farther north and west (Ando and others, 1984; Stewart and others, 1986) and in Quebec (St.-Julien and others, 1983). Deep-penetration multichannel reflection data across Maine and the Gulf of Maine to the north of Georges Bank show no evidence for a continuous horizontal or subhorizontal reflecting surface at mid-crustal depths that might be equivalent to the decollement beneath the Appalachian gravity gradient (Stewart and others, 1986; Hutchinson and others, in press).

\section{DISCUSSION}

Our analysis of rift basins in the offshore New England area has revealed rifting associated with three different types of structures: (1) paired border faults extending deep into the crust, (2) a discontinuity in a buried detachment near or slightly east of the position of the Appalachian gravity gradient, and (3) a low-angle detachment surface on the continental margin. Studies of exposed and buried rift basins show that the faults controlling basin formation are complex, with border faults of variable dip, antithetic faults of variable magnitude, and cross or transfer faults that fragment the basin into subbasins (Manspeizer, 1981). Clearly, our three models are oversimplified to emphasize the generalized framework within which the rift basin occurs.

Reactivation of preexisting structures.-A significant question about the deep structure associated with rift basins is the extent to which these structures followed or crossed preexisting structures. In a regional context, the rift basins off New England appear to have formed along Appalachian structures. The Block Island fault is inferred to be a reactivated Paleozoic fault (Hutchinson and others, 1985). The detachment discontinuity at the position of the Appalachian gravity gradient is a fundamental boundary associated with Appalachian tectonics (Cook and others, 1979, 1981; Cook, 1984), and our data indicate that the low-angle detachment off Georges Bank may be the reactivated late Paleozoic boundary between two crustal blocks (Hutchinson and others, in press).

Additional evidence for reactivation of older structures comes from the orientation of the rift basins on the Long Island platform. They are subparallel to the Appalachian tectonic grain and oblique to the basement hinge zone and axis of rifting (Hutchinson and others, 1986b). Other East Coast rift basins are inferred to follow Appalachian structures (for example, Ratcliffe, 1971; Petersen and others, 1984). Although the basins appear to be tectonically related to reactivation of Paleozoic structures, we cannot resolve whether the border faults follow mylonite zones, brittle faults, foliation, intrusive contacts, or some other preexisting zone of weakness.

Crustal thinning.-Models for the behavior of the crust during rifting postulate that the crust can be divided into a brittle upper layer and a ductile lower layer underlain by a relatively brittle upper mantle (for example, Smith and Bruhn, 1984). Rifting on the continental shelf around New England occurred primarily along low-angle faults within a brittle upper crust. These faults can be planar, such as paired faults extending deep in the crust, or listric, such as is possible for faults near the change in dip of the detachment near the Appalachian gravity gradient.

Understanding the nature of the lower crust beneath the continental shelf is more difficult. The fate of the detachment surface east of the Appalachian gravity gradient is ambiguous: It may step down to a deeper level in the middle crust (Cook and others, 1981; Secor and 


\section{GULF OF MAINE-GEORGES BANK}
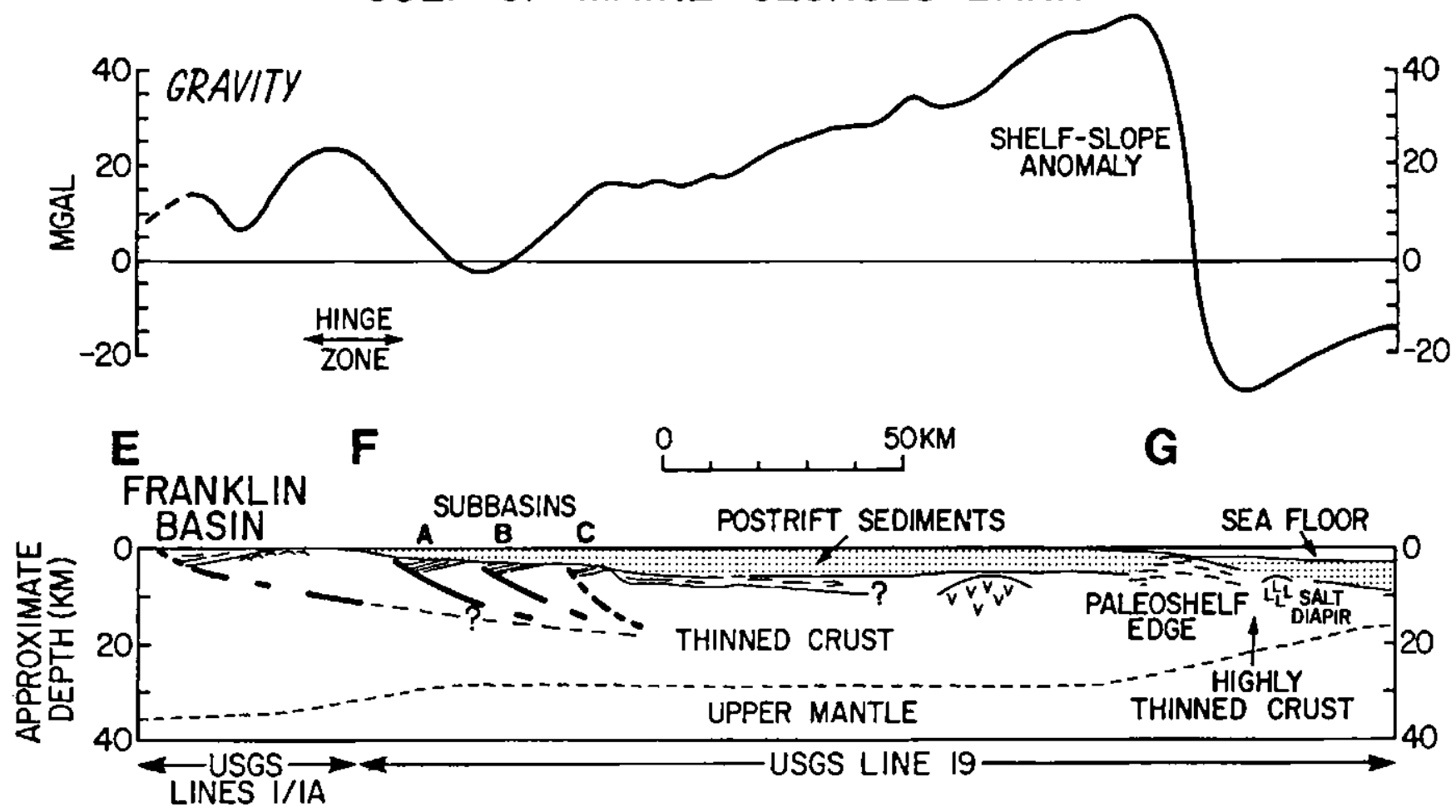

Figure 5. Schematic cross section from the Gulf of Maine across Georges Bank. E-F-G is shown in figure 2. Sources for the cross section are Klitgord and others (1982), Swift and others (in press), and Hutchinson and others (in press).

others, 1986) or become rooted in a steeply dipping suture zone (Iverson and Smithson, 1982). Either way, we cannot determine how brittle extension above the detachment was related to or affected by possible ductile extension deeper in the crust. Likewise, our data do not indicate whether the low-angle detachment inferred beneath Georges Bank flattens at midcrustal levels to mark the brittle-ductile transition (similar to the model of Montadert and others, 1979) or penetrates to near Moho depths (similar to the simple shear model of Wernicke, 1985).

The paired border faults, where identifiable within the crust, extend as discontinuous reflections to depths of 21 and $24 \mathrm{~km}$ (border fault of the Long Island basin and Block Island fault, respectively). Because these reflections merge into a thinned zone of subhorizontal reflections, the base of which is interpreted to be Moho (Hutchinson and others, 1986a,b), this may be the best example of brittle failure in the upper and middle crust accompanied by ductile thinning of the lower crust. Systematic and detailed studies of the deep velocity structure associated with these changes in reflection character are clearly needed. Our data are similar to deep reflection data from the continental margin around Great Britain and France (Matthews and Cheadle, 1985;
Pinet and others, in press) in which structures identified within the upper crust cannot be reliably traced through the lower crust into the upper mantle.

The nature and extent of crustal thinning responsible for rift basin formation is poorly understood. A first-order thinning occurs at or near the basement hinge zone (located in fig. 2), where gravity and subsidence models predict a change from continental crust of 35- to $40-\mathrm{m}$ thickness to stretched and rifted crust of 10 - to 25-m thickness (Grow and others, 1979; Watts, 1981; Sawyer and others, 1983). Crustal thinning landward of the hinge zone is much less than that seaward. Formation of rift basins at or near the hinge zone (such as the Franklin or New York Bight basins) is likely to be dominated by nearby pervasive crustal thinning, whereas formation of rift basins farther landward (such as the Long Island basin) may be controlled by localized crustal thinning, as interpreted by shorter traveltimes to the Moho in the zone between the paired border faults (Hutchinson and others, 1986a).

Recent deep reflection and refraction studies from Maine show that crustal thinning of several kilometers is associated with both a distinct gravity gradient and a zone of early Mesozoic diabase dikes (Unger and others, in press). This suggests that crustal thinning related to the 
early Mesozoic breakup of North America and Africa does not always require rift basin formation within the upper crust.

Studies in the Basin and Range extensional province suggest that crustal thinning can occur at great distance (up to hundreds of kilometers) from basin locations in regions of extensive low-angle detachments (Anderson and others, 1983; Wernicke, 1985). We have not observed this for the basins buried beneath the New England continental margin, although these basins are always relatively close to the region of greatest crustal thinning, because of their proximity to the basement hinge zone.

Distribution of rift basins.-Many of the exposed East Coast rift basins of the Newark Supergroup parallel the Appalachian gravity gradient (Longwell, 1943) with a western half-graben almost coincident with the gradient, and an eastern half-graben as much as $50 \mathrm{~km}$ east of the gradient. We postulate that these pairs of basins also are related to the change in dip of the detachment surface near the Appalachian gravity gradient. Examples are the facing border faults of the Newark and Hartford basins, and the Durham-Sanford-Wadesboro and Dan RiverDanville basins (Sanders, 1963; Manspeizer, 1981). Crustal thinning of 7 to $10 \mathrm{~km}$ is inferred to cause the gravity gradient and its flanking negative and positive gravity anomalies (Cook and Oliver, 1981; Hutchinson and others, 1983). The cause of the crustal thinning might be related either to late Precambrian continental structure (Cook, 1984), Paleozoic compressional tectonics (Hutchinson and others, 1983), or Mesozoic extension (Nelson and others, 1986). Because most of these basins are located more than $100 \mathrm{~km}$ landward of the basement hinge zone (that is, at great distance from the region of greatest Mesozoic crustal thinning), they would be excellent locations for further study of the deep structure as well as the location and causes of crustal thinning.

Elsewhere along the East Coast, numerous rift basins are buried beneath the coastal plain (Marine and Siple, 1974; Daniels and others, 1983) or beneath other parts of the U.S. Atlantic continental margin (for example, Behrendt and others, 1983). In general, the deep structure of these basins is poorly understood. Rift basins in the Charleston area may be related to a subhorizontal or low-angle detachment surface (Behrendt and others, 1983), but whether this surface is a more deeply buried continuation of the detachment found beneath the Appalachian gravity gradient or a separate detachment system is not clear. The South Georgia rift system may be an analog to rift basins that formed along paired faults extending deep in the crust, with the north-dipping border fault of the rift system and the south-dipping Alleghenian suture (Nelson and others, 1985) forming the paired faults, similar to the Long Island basin-Block
Island fault pair. The buried Riddleville basin formed along a border fault that is believed to merge at depth with an inferred low-angle Paleozoic fault, the Augusta fault (Petersen and others, 1984). Hence the deeper structure associated with some of the buried basins elsewhere on the East Coast bears some resemblance to those structures identified off New England, but additional studies are needed for better definition of the shallow and deep structures associated with these basins.

\section{CONCLUSIONS}

Our analysis of the deep structure of rift basins on the continental margin around New England suggests that three types of structures are responsible for the overall formation of the observed rifts: (1) paired border faults that extend deep into the crust, with rift basins forming along one or both faults; (2) a discontinuity in the buried detachment surface near the position of the Appalachian gravity gradient, with rift basins forming along border faults that dip toward each other but extend only to the approximate depth of the detachment; and (3) a low-angle detachment surface, beneath the continental margin, with adjacent rift basins forming along subparallel border faults.

These structures are mostly reactivated Paleozoic structures, although we cannot determine whether reactivation followed mylonite zones, brittle faults, or other preexisting zones of weakness. In general, the deep structure of rift basins along other parts of the East Coast resembles the structures identified off New England, but additional studies are needed to verify this.

The three types of structures imply brittle behavior of the upper crust. Current knowledge of crustal thinning along the East Coast is poor, although pervasive crustal thinning probably dominated rift basin formation seaward of the basement hinge zone, whereas more localized thinning probably controlled rift basin formation landward of the hinge zone. Determining the nature of crustal thinning responsible for formation of the basins that coincide with the detachment discontinuity at the position of the Appalachian gravity gradient (most of the exposed basins of the Newark Supergroup) requires additional information. Some crustal thinning, such as that interpreted in central Maine (Unger and others, in press) may not be accompanied by rift basin formation.

\section{ACKNOWLEDGMENTS}

We thank John Unger and Bill Dillon for reviewing the manuscript.

\section{REFERENCES CITED}

Anderson, R.E., Zoback, M.L., and Thompson, G.A., 1983, Implications of selected subsurface data on the structural 
form and evolution of some basins in the northern Basin and Range province, Nevada and Utah: Geological Society of America Bulletin, v. 94, p. 1055-1072.

Ando, C.J., and others, 1984, Crustal profile of mountain belt: COCORP deep seismic reflection profiling in New England Appalachians and implications for architecture of convergent mountain chains: American Association of Petroleum Geologists Bulletin, v. 68, p. 819-837.

Behrendt, J.C., Hamilton, R.M., Ackerman, H.D., Henry, V.J., and Bayer, K.C., 1983, Marine multichannel seismicreflection evidence for Cenozoic faulting and deep crustal structure near Charleston, South Carolina, in Gohn, G.S., ed., Studies related to the Charleston, South Carolina, earthquake of 1886; tectonics and seismicity: U.S. Geological Survey Professional Paper 1313, p. J1-J29.

Benson, R.N., 1984, Structure contour map of Pre-Mesozoic basement, landward margin of Baltimore Canyon trough: Delaware Geological Survey Miscellaneous Map Series No. 2, scale 1:500,000.

Cook, F.A., 1984, Geophysical anomalies along strike of the southern Appalachian Piedmont: Tectonics, v. 3, p. 45-61.

Cook, F.A., and Oliver, J.E., 1981, The Late Precambrian-Early Paleozoic continental edge in the Appalachian orogen: American Journal of Science, v. 281, p. 993-1008.

Cook, F.A., Albaugh, D.S., Brown, L.D., Kaufman, S., Oliver, J.E., and Hatcher, R.D., Jr., 1979, Thin-skinned tectonics in the crystalline southern Appalachians; COCORP seismic reflection profiling of the Blue Ridge and Piedmont: Geology, v. 7, p. 563-567.

Cook, F.A., Brown, L.D., Kaufman, S., Oliver, J.E., and Petersen, T.A., 1981, COCORP seismic profiling of the Appalachian orogen beneath the Coastal Plain of Georgia, Part I: Geological Society of America Bulletin, v. 92, p. 738-748.

Daniels, D.L., Zietz, I., and Popenoe, P., 1983, Distribution of subsurface lower Mesozoic rocks in the southeastern United States as interpreted from regional aeromagnetic and gravity maps, in Gohn, G.S., ed., Studies related to the Charleston, South Carolina, earthquake of 1886; tectonics and seismicity: U.S. Geological Survey Professional Paper 1313, p. K1-K24.

Folger, D.W., Dillon, W.P., Grow, J.A., Klitgord, K.D., and Schlee, J.S., 1979, Evolution of the Atlantic continental margin of the United States, in Talwani, M., Hay, W., and Ryan, W.B.F., eds., Deep drilling results in the Atlantic Ocean: Continental margins and paleo-environment: American Geophysical Union Maurice Ewing Series 3, p. 87-108.

Gibbs, A.D., 1984, Structural evolution of extensional basin margins: Journal of Geological Society of London, v. 141, p. $609-620$.

Grow, J.A., Bowin, C.O., and Hutchinson, D.R., 1979, The gravity field of the U.S. Atlantic continental margin: Tectonophysics, v. 59, p. 27-52.

Harris, L.D., Harris, A.G., de Witt, W., Jr., Bayer, K.C., 1981, Evaluation of southern Eastern Overthrust Belt beneath Blue-Ridge-Piedmont thrust: American Association of Petroleum Geologists Bulletin, v. 65, p. 2497-2505.

Hatcher, R., Jr., and Zietz, I., 1980, Tectonic implications of regional aeromagnetic and gravity data from the southern Appalachians, in Wones, D., ed., International Geological
Correlation program, Caledonide Orogen program symposium: Virginia Polytechnic Institute Memoir 2, p. 235-244.

Hutchinson, D.R., and Klitgord, K.D., in press, Evolution of rift basins on the continental margin off southern New England, in Manspeizer, Warren, ed., Triassic-Jurassic rifting: North America and Africa: American Association of Petroleum Geologists Memoir.

Hutchinson, D.R., Grow, J.A., and Klitgord, K.D., 1983, Crustal structure beneath the southern Appalachians: Non-uniqueness of gravity modeling: Geology, v. 11, p. 611-615.

Hutchinson, D.R., Klitgord, K.D., and Detrick, R.S., 1985, Block Island fault: A Paleozoic crustal boundary on the Long Island platform: Geology, v. 13, p. 875-879.

$1986 \mathrm{~b}$, Rift basins of the Long Island platform: Geological Society of America Bulletin, v. 97, p. 688-702.

Hutchinson, D.R., Grow, J.A., Klitgord, K.D., and Detrick, R.S., 1986a, Moho reflections from the Long Island platform, eastern United States, in Barazangi, M., and Brown, L., eds., International symposium on the deep structure of the continental crust: American Geophysical Union Geodynamics, v. 14, p. 173-187.

Iverson, W.P., and Smithson, S.B., 1982, Master decollement root zone beneath the southern Appalachians and crustal balance: Geology, v. 10 , p. 241-245.

Klitgord, K.D., and Behrendt, J.C., 1979, Basin structure of the U.S. Atlantic margin, in Watkins, J.S., Montadert, L., and Dickerson, P.W., eds., Geological and geophysical investigations of continental margins: American Association of Petroleum Geologists Memoir 29, p. 85-112.

Klitgord, K.D., and Hutchinson, D.R., 1985, Distribution and geophysical signatures of early Mesozoic rift basins beneath the U.S. Atlantic continental margin, in Robinson, G.R., Jr., and Froelich, A.J., eds., Proceedings of the second U.S. Geological Survey workshop on the early Mesozoic basins of the Eastern United States: U.S. Geological Survey Circular 946, p. 45-53.

Klitgord, K.D., Schlee, J.S., and Hinz, K., 1982, Basement structure, sedimentation, and tectonic history of the Georges Bank basin, in Scholle, P.A., and Wenkam, C.R., eds., Geological Studies of the COST nos. G-1 and G-2 wells, United States North Atlantic Outer Continental Shelf: U.S. Geological Survey Circular 861, p. 160-186.

LASE Study Group, 1986, Deep structure of the U.S. East Coast passive margin from large aperture seismic experiments (LASE): Marine and Petroleum Geology, v. 3, p. 234-242.

Longwell, C.R., 1943, Geologic interpretation of gravity anomalies in the southern New England-Hudson Valley region: Geological Society of America Bulletin, v. 54, p. 555-590.

Manspeizer, W., 1981, Early Mesozoic basins of the central Atlantic passive margins, in Bally, A.W., ed., Geology of passive continental margins: History, structure, and sedimentologic record (with special emphasis on the Atlantic margin): American Association of Petroleum Geologists Education Course Note Series No. 19, p. 4-1 to 4-60.

Manspeizer, W., Puffer, J.H., and Cousminer, H.L., 1978, Separation of Morocco and eastern North America: A Triassic-Liassic stratigraphic record: Geological Society of America Bulletin, v. 89, p. 901-920. 
Marine, I.W., and Siple, G.E., 1974, Buried Triassic basin in the central Savannah River area, South Carolina and Georgia: Geological Society of America Bulletin, v. 85, p. 311-320.

Matthews, D.H., and Cheadle, M.J., 1985, Deep reflections from the Caledonides and Variscides west of Britain and comparison with the Himalayas, in Barazangi, M., and Brown, L., eds., Reflection seismology: A global perspective: American Geophysical Union Geodynamics, v. 13, p. 5-19.

McKenzie, D., 1978, Some remarks on the development of sedimentary basins: Earth and Planetary Science Letters, v. 40 , p. $25-32$.

Montadert, L., Roberts, D.G., DeCharpal, O., and Guennoc, P., 1979, Rifting and subsidence of the northern continental margin of the Bay of Biscay, in Initial reports of the deep sea drilling project: v. 48, p. 1025-1060.

Nelson, K.D., Arnow, J.A., McBride, J.H., Willemin, J.H., Huang, J., Zheng, L., Oliver, J.E., Brown, L.D., and Kaufman, S., 1985, New COCORP profiling in the southeastern United States, Part I: Late Paleozoic suture and Mesozoic rift basin: Geology, v. 13, p. 714-718.

Nelson, K.D., McBride, J.H., and Arnow, J.A., 1986, Deep reflection character, gravity gradient, and crustal thickness variations in the Appalachian Orogen: Relation to Mesozoic extension and igneous activity: Geological Society of America Abstracts with Programs, v. 18, p. 704-705.

Olsen, P.E., McCune, A.R., and Thomson, K.S., 1982, Correlation of the early Mesozoic Newark Supergroup by vertebrates, principally fishes: American Journal of Science, $v$. 282 , p. 1-44.

Petersen, T.A., Brown, L.D., Cook, F.A., Kaufman, S., and Oliver, J.E., 1984, Structure of the Riddleville Basin from COCORP seismic data and implicatons for reactivation tectonics: Journal of Geology, v. 92, p. 261-271.

Pinet, B., Montadert, L., and the ECORS Scientific Party, in press, Deep seismic reflection and refraction profiling along the Aquitaine Shelf (Bay of Biscay): Geophysical Journal of the Royal Astronomical Society.

Ratcliffe, N.M., 1971, Ramapo fault system in New York and adjacent northern New Jersey: A case of tectonic heredity: Geological Society of America Bulletin, v. 82, p. 125-141.

Sanders, J.E., 1963, Late Triassic tectonic history of northeastem United States: American Journal of Science, v. 261, p. 501-524.

Sawyer, D.S., Toksoz, M.N., Sclater, J.G., and Swift, B.A., 1983, Thermal evolution of the Baltimore Canyon Trough and Georges Bank Basin, in Watkins, J.S., and Drake, C.L., eds., Studies in continental margin geology: American Association of Petroleum Geologists Memoir 34, p. 743-762

Secor, D.T., Jr., Snoke, A.W., and Dallmeyer, R.D., 1986, Character of the Alleghenian orogeny in the southern Appalachians, Part III, Regional tectonic relations: Geological Society of America Bulletin, v. 97, p. 1345-1353.

Sheridan, R.E., Grow, J.A., Behrendt, J.C., and Bayer, K.C., 1979 , Seismic refraction study of the continental edge off the eastern United States: Tectonophysics, v. 59, p. 1-26.

Smith, R.B., and Bruhn, R.L., 1984, Intraplate extensional tectonics of the eastern Basin-Range: Inferences on structural style from seismic reflection data, regional tectonics, and thermal-mechanical models of brittle-ductile deformation: Journal of Geophysical Research, v. 89, p. 5733-5762.

Stewart, D.B., and others, 1986, The Quebec-Western Maine seismic reflection profile: Setting and first year results, in Barazangi, M., and Brown, L., eds., Reflection seismology: The continental crust: American Geophysical Union Geodynamics Series, v. 14, p. 189-199.

St.-Julien, P., Slivitsky, A., and Feininger, T., 1983, A deep structural profile across the Appalachians of southern Quebec, in Hatcher, R.D., Jr., Williams, H., and Zietz, I., eds., Contributions to the tectonics and geophysics of mountain chains: Geological Society of America Memoir 158, p. $103-111$.

Swift, B.A., Sawyer, D.S., Grow, J.A., and Klitgord, K.D., in press, Subsidence, crustal structure, and thermal evolution of Georges Bank basin: American Association of Petroleum Geologists Bulletin.

Unger, J.D., Stewart, D.B., and Phillips, J.D., in press, Interpretation of migrated seismic reflection profiles across the northern Appalachians in Maine: Geophysical Journal of the Royal Astronomical Society.

Van Houten, F.B., 1977, Triassic-Liassic deposits of Morocco and eastern North America: A comparison: American Association of Petroleum Geologists Bulletin, v. 61 p. 79-99.

Watts, A.B., 1981, The U.S. Atlantic continental margin: Subsidence history, crustal structure and thermal evolution, in Bally, A.W., ed., Geology of passive margins: American Associaton of Petroleum Geologists Education Course Note Series No. 19, p. 2-1 to 2-75.

Wernicke, B., 1985, Uniform-sense normal simple shear of the continental lithosphere: Canadian Journal of Earth Sciences, v. 22, p. 108-125.

Wernicke, B., and Burchfiel, B.C., 1982, Modes of extensional terranes: Journal of Structural Geology, v. 4, p. 105-115. 


\section{USING BALANCED CROSS SECTIONS TO UNDERSTAND EARLY MESOZOIC EXTENSIONAL FAULTING}

Jean M. Crespi

\begin{abstract}
A model for extensional faulting in the upper crust underlying the landward portion of the Georges Bank basin is presented based on interpretation of seismic data and kinematic analysis of listric normal faulting. Extension values and fault structures at depth were determined by balancing cross sections of the rift basins. This modeling suggests that the upper crust extended and thinned by motion along faults that form an imbricate fan and sole into a detachment with a ramp-flat geometry. The Yarmouth sag, which lies directly seaward of the three rift basins analyzed, is interpreted to be a hanging-wall syncline that developed in response to motion along an extensional ramp. Geometric and kinematic arguments suggest that these early Mesozoic normal faults may be reactivated Alleghenian thrust faults. These results underscore the importance of incorporating the process of tectonic inversion into models attempting to explain the mechanism by which continental crust splits to form an ocean basin.
\end{abstract}

\section{INTRODUCTION}

Two fundamental questions concerning continental breakup are (1) how is extensional strain distributed throughout the crustal column during rifting? and (2) how does this extension lead to the accretion of oceanic crust? Essentially two end-member models for continental rifting have evolved from studies of regions of ancient and active extensional tectonics. In the first model, rifting is considered to result from regional-scale pure shear in which extension is distributed uniformly throughout the crust (McKenzie, 1978). Lower crustal extension may be accommodated by penetrative ductile necking (Eaton, 1979; Miller and others, 1983), by displacement along anastomosing shear zones (Hamilton, 1982; Kligfield and others, 1984), or by a combination of these two mechanisms. Alternatively, rifting and continental breakup may result from regional-scale simple shear in which extension is not distributed uniformly but is transferred laterally with depth along a low-dipping shear zone that transects the entire crust (Wernicke, 1981, 1985). This process of regional-scale simple shear may result in opposing continental margins with distinctive rifting and subsidence histories (Lister and others, 1986).

The Atlantic coast of the Eastern United States, which underwent rifting during Late Triassic to Early Jurassic time, is one of the most studied rifted continental margins anywhere. However, extensive erosion together with the lack of offset marker horizons has made quantification of the magnitude of upper crustal exten- sion difficult. Seismic studies, while effective in defining basin geometry, have generally been unable to resolve the deep structure of many of the border faults. As a result, little is known about which crustal-scale extension model is appropriate for the early Mesozoic rifting of the Eastern United States.

In this paper, I present a model for extensional faulting in the upper crust underlying the landward portion of the Georges Bank basin. Extension values and fault geometries at depth were determined by applying principles of listric normal faulting and cross-section balancing. This modeling allows for the development of a more detailed and complete understanding of the mechanism by which the crust extended and thinned during early Mesozoic rifting of the continents.

\section{BALANCED CROSS SECTIONS OF LISTRIC NORMAL FAULTS}

Both the magnitude of upper crustal extension and the geometry of listric normal faults at depth can be determined by applying principles of cross-section balancing. The construction of such a cross section rests upon the relationship that exists between the shape of the rift basin and that of the fault bounding the basin. As shown in figure 1 , the hanging wall of a listric normal fault must deform internally to prevent the formation of a gap between the hanging wall and the footwall. The hanging wall can be envisioned as subsiding into the void created by the moving apart of the footwall and hanging wall; it is clear then that the shape of the fault exerts a fundamental control on the geometry of the evolving basin. As a result, it is possible to use the shape of the basin floor or a bed within the basin to constrain the shape of the listric normal fault at depth.

The exact shape of the basin floor and fill depends not only on the shape of the fault bounding the rift basin but also on the deformation mechanism operating in the hanging wall. Strain within the hanging wall may be accommodated by either one of two general mechanisms: (1) simple shear along vertical (Verrall, 1981; Gibbs, 1983, 1984) or inclined planes (White and others, 1986) or (2) flexural slip folding (Suppe, 1983; Davison, 1986). The influence of the deformation mechanism can be best appreciated by examining the shapes of the basin floor that result from motion along faults that have the same shape and heave but have had their hanging walls deformed by different mechanisms. Figure 2 illustrates 

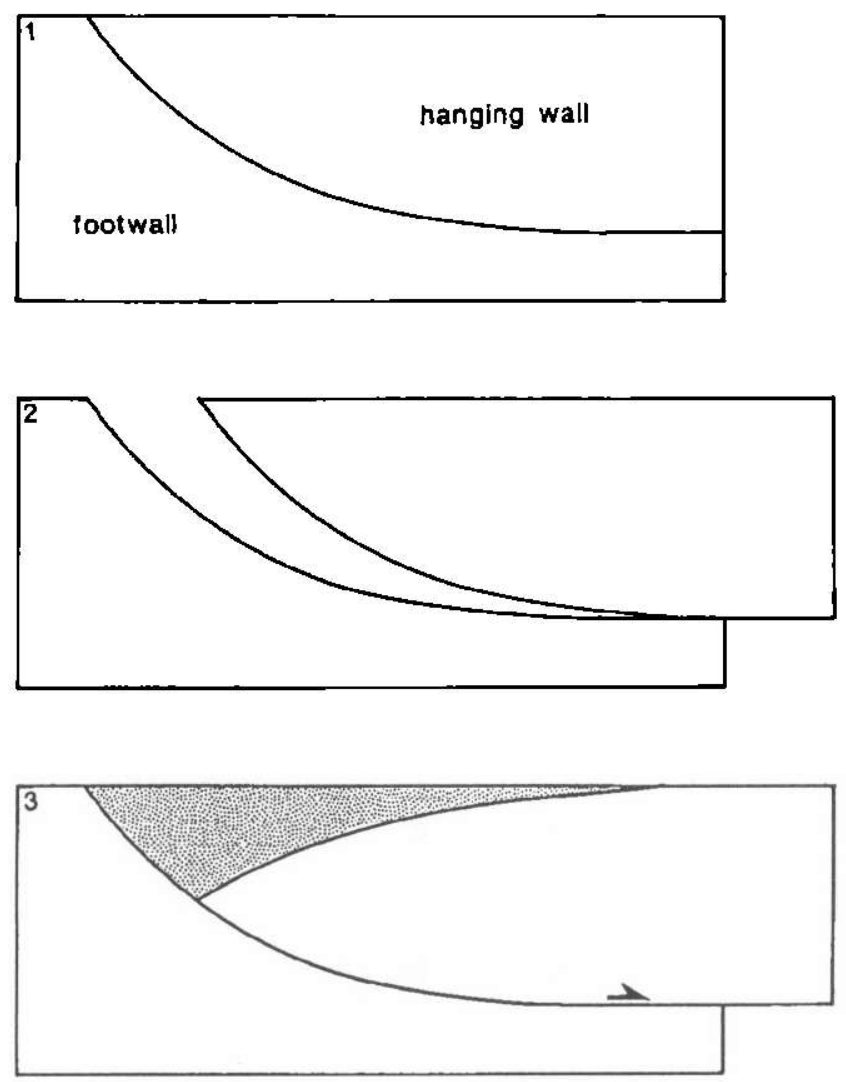

Figure 1 . Cross sections showing formation of a rift basin along a listric normal fault. The curved shape of the fault requires that the hanging wall deform internally.

the basin floor shapes that result from allowing the hanging wall to deform by (1) simple shear along vertical planes, (2) simple shear along planes that dip $45^{\circ}$ and are antithetic to the fault, and (3) flexural slip folding. Allowing the dip of the shear planes to vary has a marked effect on the shape of the rift basin: the basin produced by shear along $45^{\circ}$ dipping planes (fig. $2 B$ ) is both shallower and wider than the basin produced by shear along vertical planes (fig. $2 A$ ); moreover, the floor of the basin is planar rather than curved. Flexural slip folding (fig. $2 C$ ) produces a basin similar to that produced by shear along vertical planes in that both are characterized by relatively pronounced rollover geometries; however, flexural slip folding produces a slightly deeper basin.

In general, the shape of the basin floor and the fill is known from a seismic reflection profile, for example, and one would like to determine the heave and fault geometry at depth. As is clear from figure 2, this requires a knowledge of the operative deformation mechanism. Figure 3 emphasizes this by illustrating the predicted fault geometries at depth and heaves for a given rift basin geometry and different deformation mechanisms in the hanging wall. Flexural slip folding predicts the fault to sole into a detachment at a slightly greater depth than shear along vertical planes; shear along antithetic planes predicts the fault to sole into a detachment at a shallower depth than shear along vertical planes. The dependence of the heave on the deformation mechanism is also shown in figure 3. The heave associated with shear along antithetic planes is greater than those associated with shear along vertical planes; this is because an additional horizontal component of motion is introduced by allowing the hanging wall to deform by shear along antithetically dipping planes (A and B, fig. 3). Flexural slip folding predicts a smaller amount of heave; this is because hanging-wall deformation by shear along vertical or inclined planes requires the basin floor to extend, whereas bed length $\left(l_{0}\right)$ is preserved during flexural slip folding (C, fig. 3 ).

In order to balance a cross section and arrive at a unique solution, one must know the deformation mechanism in the hanging wall. If the fault can be traced for any distance beneath the horizon used to balance the section, it is possible to constrain the deformation mechanism by comparing predicted and observed fault shapes. The deformation mechanism that produces the best fit between predicted and observed fault shapes may be used to determine the heave and the portion of the fault not delineated on the section.

\section{STRUCTURAL ANALYSIS OF THE GEORGES BANK RIFT BASINS}

The postrift sediments that constitute the landward portion of the Georges Bank basin are underlain by three rift basins (A, B, and C in fig. 4) that are inferred to have formed during Late Triassic to Early Jurassic time (Klitgord and others, 1982). A model for extensional faulting in the upper crust of this portion of Georges Bank was determined by combining interpretations of seismic sections of the three rift basins with kinematic analyses based on listric normal faulting.

The data for the modeling were drawn from USGS multichannel seismic reflection line 19. This seismic line has been described by Klitgord and others (1982) and Klitgord and Hutchinson (1985), who present unmigrated portions of the record sections as well as geologic interpretations (see figs. 78 and 80 of Klitgord and others (1982) and figs. 9.6A and 9.6B of Klitgord and Hutchinson (1985)). The quality of the seismic imaging varies for the basins. Both the most landward basin (rift basin A) and the central basin (rift basin B) are well enough defined to be analyzed by the principles outlined in the previous section; extension values can only be estimated for the most seaward basin (rift basin C) because of the poor quality of the seismic imaging. In the following analysis, two-way traveltimes were converted to depth by using velocities appropriate to postrift strata (1.7-2.6 
$\boldsymbol{A}$

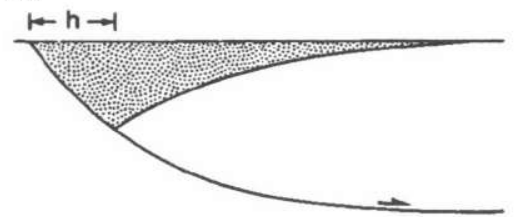

shear planes, vertical
B

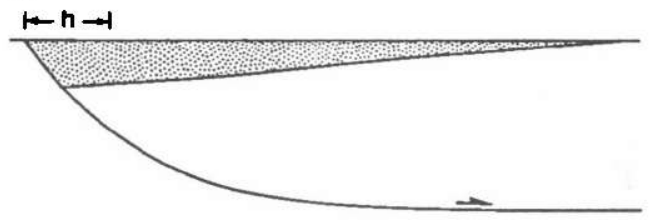

shear planes, antithetic $45^{\circ}$

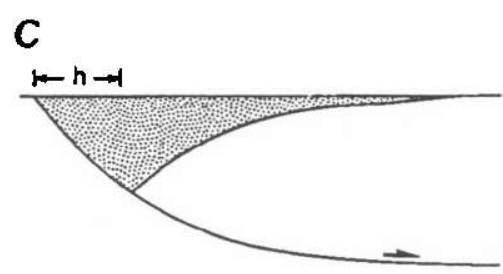

flexural slip

Figure 2. Cross sections of listric normal faults showing the relationship between basin floor shape and deformation mechanism in the hanging wall. Fault geometries and heaves (h) are the same in the three sections. Hanging-wall deformation is by $(A)$ simple shear along vertical planes, $(B)$ simple shear along planes that dip $45^{\circ}$ antithetically to the listric fault, and $(C)$ flexural slip folding. Boundary conditions are for pure shear.
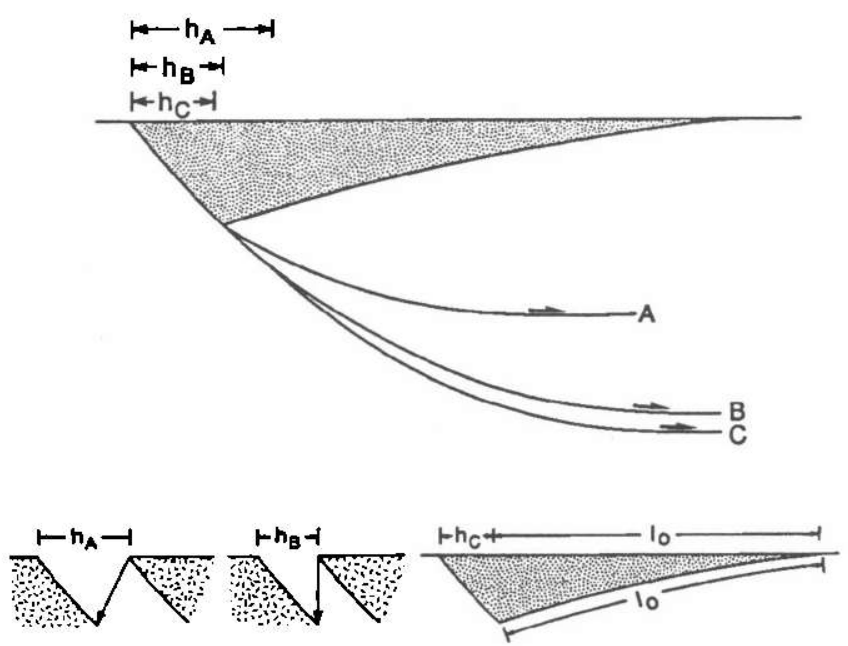

Figure 3. Heaves (h) and fault shapes at depth for different deformation mechanisms in the hanging wall. Line $\mathrm{A}$, simple shear along planes that dip $65^{\circ}$ antithetically to the fault. Line $B$, simple shear along vertical planes. Line $C$, flexural slip folding. Boundary conditions are for pure shear. The bottom row of diagrams shows the relationship between deformation mechanism and heave; original length of bed $\left(l_{0}\right)$ is preserved.

$\mathrm{km} / \mathrm{sec})$, synrift strata $(3.8-4.2 \mathrm{~km} / \mathrm{sec})$, and basement (5-6 km/sec). A migrated and depth-converted line drawing of rift basins $A$ and $B$ that uses intermediate values for the average velocities and a velocity gradient in each package of rocks that increases linearly with depth is shown in figure 5.

These seismic data suggest that each rift basin is bounded by a single, seaward-dipping fault that becomes more gently dipping with depth. In rift basin A, the fault contact between the sediments and crystalline basement in the uppermost part of the basin is interpreted to lie near the position labeled $\mathrm{A}$ in figure 5; the fault can be traced for a short distance beneath the basin where it is probably represented by the reflections labeled B. In rift basin $B$, the collapsed diffraction at point $C$ is interpreted to mark the position of the fault in the uppermost part of the basin, and the reflections labeled $D$ are considered to represent the fault near the bottom of the basin. In both cases, the border fault decreases in dip structurally downward from about $50^{\circ}$ to $25^{\circ}$ and is clearly listric.

The postrift unconformity (PRU) overlying the rift basins dips $1^{\circ}$ seaward and appears to be downdropped about $0.2 \mathrm{~km}$ at the landward edge of rift basin B along a planar normal fault, as suggested by the lack of rotation of the PRU with respect to the overlying beds. The uppermost preserved strata in both rift basins are essentially subparallel to the PRU, indicating that the basins have undergone minimal postrift erosion. Postrifting processes may have rotated the rift basins from their synrift orientations; however, the amount of this rotation is probably small. All depths are given by using the mean depth of the PRU over the rift basin being analyzed as the zero datum. Thus, depths are reported with respect to the land surface at the time of rifting.

In order to balance the rift basins, the degree of parallelism between the extension direction and the seismic line must be known. Although the extension direction cannot be determined directly for rift basin $\mathrm{A}-\mathrm{C}$, it is probably similar to that determined for the two closest onshore rift basins, the Newark and the HartfordDeerfield basins (see fig 2, p. 213, this volume). In both cases, the extension direction trends northwestsoutheast, with the extension direction determined for the Newark basin (Ratcliffe and Burton, 1985) being subparallel to the trend of USGS line 19 and the extension direction determined for the Hartford-Deerfield basin (Wise, 1978) being subperpendicular to the strike of the border faults of rift basins A-C or about $20^{\circ}$ oblique to the seismic line (fig. 4). The correction for the possible obliquity of the seismic line to the extension direction is therefore minimal, with dip angles being in error by at most $2^{\circ}$ and horizontal lengths being in error by at most 6 percent. Consequently, the constructions to determine extension values and fault structures at depth are based on the geometries seen in the seismic profile. 


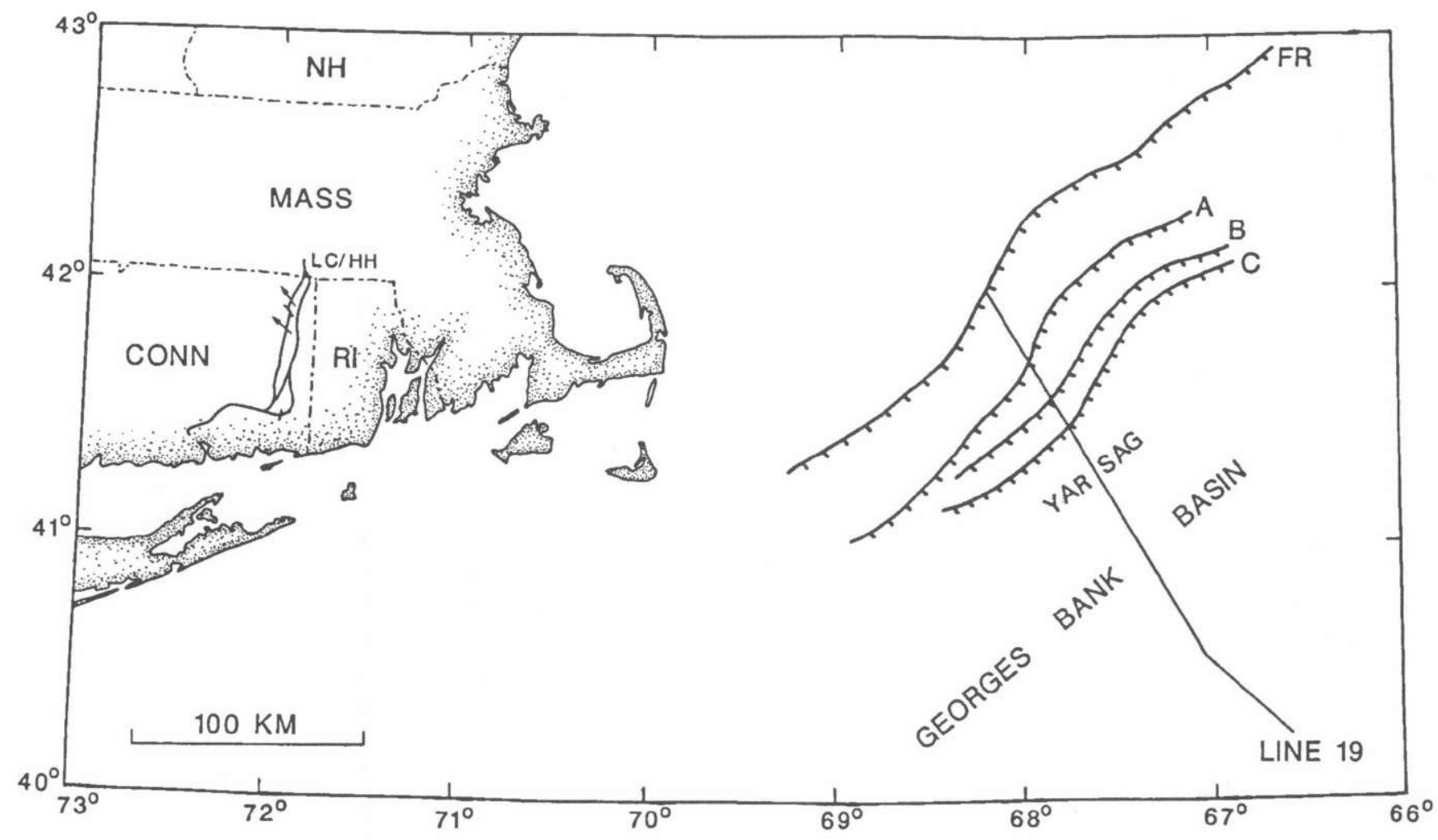

Figure 4. Location map showing Georges Bank basin, USGS line 19, surface projection of the border faults of rift basins A-C, the border fault of the Franklin rift basin (FR), the Yarmouth sag (Yar sag), and the Lake Char/Honey Hill fault system (LC/HH).

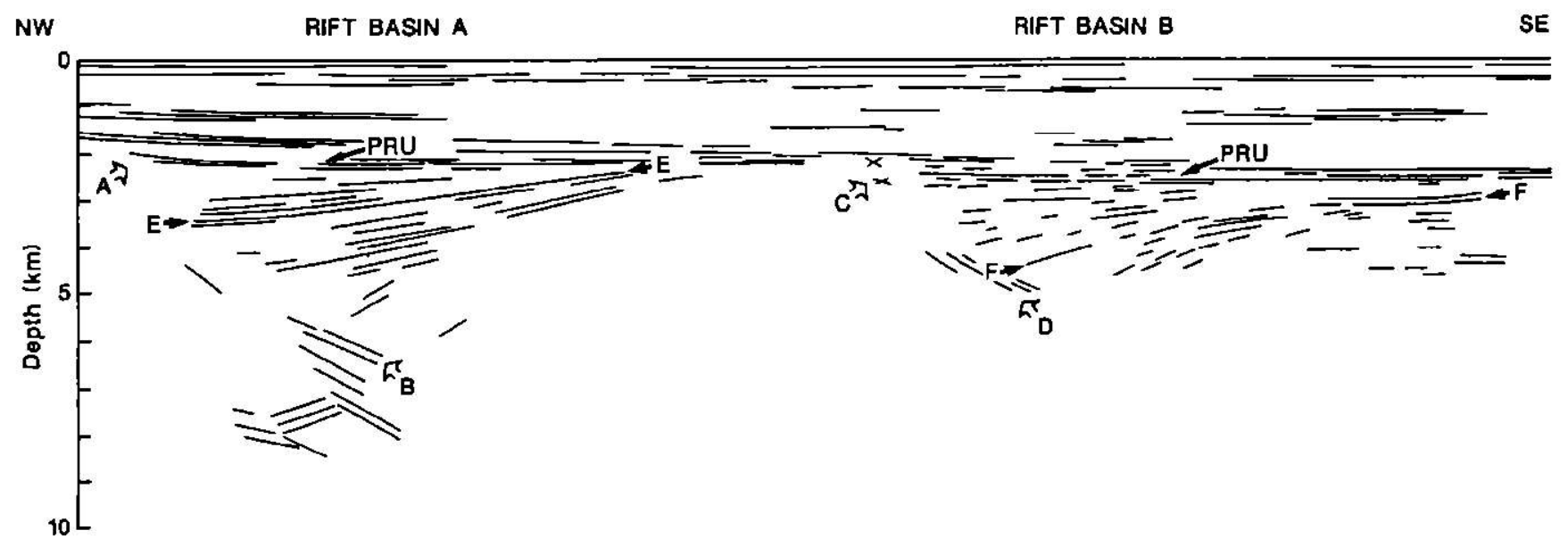

Figure 5. Line drawing of rift basins A and B based on migrated and depth-converted portions of USGS multichannel seismic reflection line 19. Horizontal and vertical scales are equal. See text for discussion and explanation of letters used in the figure.

\section{Rift Basin A}

Rift basin A can be most accurately balanced by using the reflection marked with the E's in figure 5 because this reflection represents the most continuous horizon within the rift basin. In addition, the border fault can be traced for several kilometers beneath this horizon, allowing for an accurate comparison of predicted and observed fault shapes to determine the mechanism of hanging-wall deformation. Compaction, however, has modified the shape of the strata within the rift basin as indicated by the bowed-down shape of horizon $E$ and the PRU (fig. 5). As a result, the effect of compaction on bed shape must be estimated and removed before rift basin A can be balanced. In the following paragraphs, I first present arguments for estimating the amount of compac- 


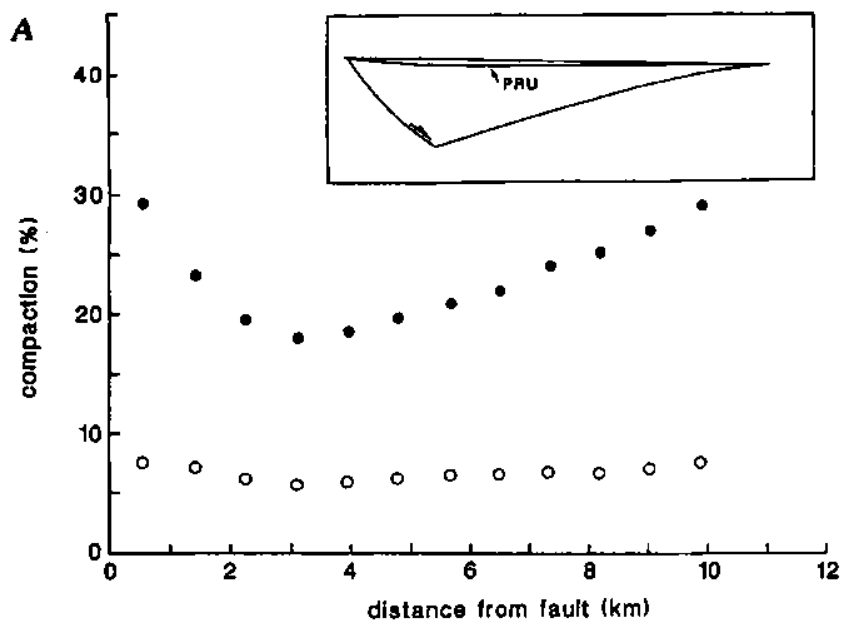

basin sediments, however, is complicated by the fact that vertical material lines may reorient during deformation. In order to make the mathematics tractable, simplifying assumptions about the nature of compaction must be made. For example, for the case of hanging-wall deformation along inclined shear planes, it must be assumed that the direction of compaction was parallel to the shear planes, resulting in a nonvertical direction of compaction (White and others, 1986). As a result, accurate determinations of compaction are possible only for the case of hanging-wall deformation along vertical shear planes because vertical material lines remain so throughout deformation. The portion of the following calculations that evaluates the syndeformational compaction within rift basin $\mathrm{A}$ assumes that the hanging wall deformed along vertical shear planes because this allows the direction of compaction to be vertical. Although balancing shows that the hanging wall actually deformed along inclined $\left(60-65^{\circ}\right)$ planes, the error that results from not incorporating the process of rotating vertical material lines is probably minimal because the shear planes are relatively steeply inclined. Moreover, most of the compaction that resulted in a modification of the shape of horizon $\mathrm{E}$ occurred during postrifting time when deformation within the rift basin had ceased.

Without a knowledge of the lithology of the basin fill, it is not possible to determine directly the amount of compaction undergone by the sediments beneath horizon E. However, it is possible to determine the amount of compaction undergone by the sediments beneath the PRU because this presently bowed-down surface can be assumed to have been originally planar (see inset of fig. $6 A$ ). As shown in figure $6 A$, the sediments beneath the PRU have compacted only 6 to 7 percent since PRU time. For the sake of comparison, the amount of compaction that these sediments would have undergone if they were uncemented sandy shales is also shown in figure $6 A$. The observed compaction is much less than the modeled compaction of 18 to 29 percent, suggesting that the sediments within the rift basin were cemented fairly early in their depositional history or that they are much more coarse grained than a sandy shale.

The amount of compaction undergone by the sediments beneath horizon $\mathrm{E}$ since deposition of this horizon can be estimated from the results based on the geometry of PRU. In order to compare the effects of compaction on the shapes of the PRU and horizon E, the sediments beneath horizon $\mathrm{E}$ are also modeled as sandy shale (fig. $6 B)$. Two results of this modeling are important: First, the model predicts the sediments beneath horizon $\mathrm{E}$ to have compacted slightly more (27-32 percent) than those beneath the PRU (18-29 percent), as expected from the slightly greater depth and age of horizon $\mathrm{E}$. Second, the percentage compaction of the sediments beneath horizon $\mathrm{E}$ is predicted to be fairly uniform, even though this 


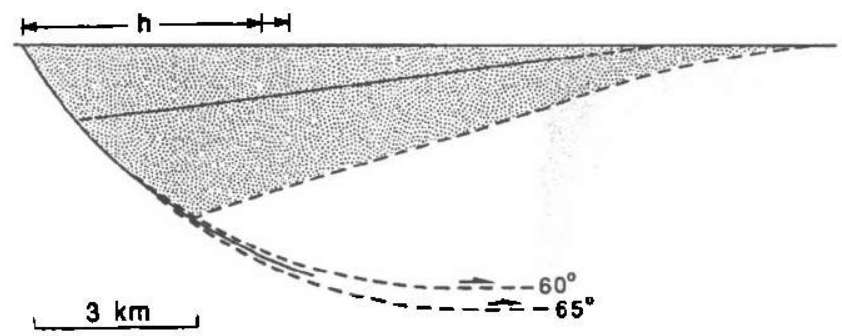

Figure 7. Results of structural analysis of rift basin A. Heavy, dashed lines represent the predicted fault shapes at depth using the decompacted shape of horizon $E$ and hanging-wall deformation by simple shear along planes that dip $60^{\circ}$ and $65^{\circ}$ antithetically to the border fault. Shear along $60^{\circ}$ dipping planes predicts a detachment at a depth of 4.6 $\mathrm{km}$ and a heave (h) of $4.9 \mathrm{~km}$; shear along $65^{\circ}$ dipping planes predicts a detachment at a depth of $5 \mathrm{~km}$ and a heave (h) of $4.4 \mathrm{~km}$. Heavy, solid line represents the trace of the border fault inferred from the seismic data. Horizontal and vertical scales are equal. See text for discussion.

horizon is a dipping surface and underlain by strata of variable thickness. These results suggest that the amount the sediments beneath horizon E compacted since deposition of this horizon is relatively uniform and slightly greater than the 6 to 7 percent determined for the PRU. The inset of figure $6 B$ shows the shape of horizon $E$ after decompacting the underlying sediment by 10 percent: the bowed-down shape is removed, and the horizon is restored to planarity. This planar geometry is considered to be a reasonable approximation of the decompacted shape of horizon $E$ and is used in the following analyses of rift basin A. It is important to note that the use of slightly different amounts of compaction as well as the use of slightly different velocity structures in the basin fill do not significantly alter the balancing results.

The results of balancing rift basin A by using the decompacted shape of horizon $\mathrm{E}$ are illustrated in figure 7. Hanging-wall deformation by simple shear along planes that dip 60 to $65^{\circ}$ antithetically to the border fault produces the best fit between predicted and observed fault geometries. The range in predicted fault shape results from the range in allowable velocities in the basement, with the fault shapes predicted by using $60^{\circ}$ and $65^{\circ}$ dipping planes corresponding to the fault shapes determined by using low and high velocities in the basement, respectively. As shown in figure 7 , these constructions predict that the border fault of rift basin A flattens into a subhorizontal detachment at a depth of about $4.6-5 \mathrm{~km}$.

The net heave accommodated by the border fault of rift basin $\mathrm{A}$ is determined by using the position of the basin floor, with hanging-wall deformation along $60^{\circ}$ and $65^{\circ}$ dipping planes corresponding to heaves of $4.9 \mathrm{~km}$ and $4.4 \mathrm{~km}$, respectively (fig. 7). As noted previously, these
RIFT BASIN B

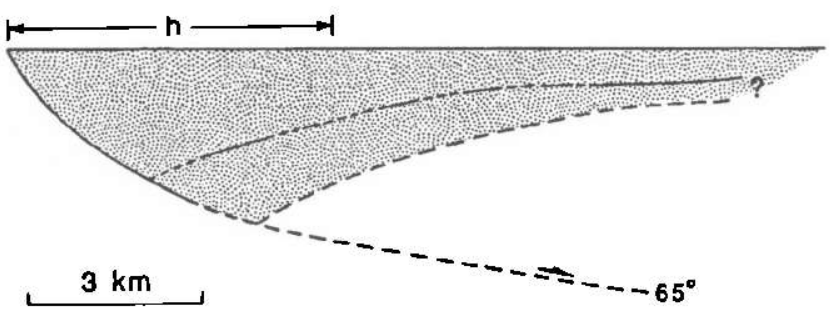

Figure 8. Results of structural analysis of rift basin B. Heavy, dashed line represents the predicted fault shape at depth using horizon $F$ and hanging-wall deformation by simple shear along planes that dip $65^{\circ}$ antithetically to the border fault. This construction allows the fault to be traced to a depth of $4.3 \mathrm{~km}$ and predicts that the heave $(\mathrm{h})$ is $5.6 \mathrm{~km}$. Heavy, solid line represents the trace of the border fault inferred from the seismic data. Horizontal and vertical scales are equal. See text for discussion.

values may overestimate the heave because the trend of the seismic line may be oblique to the extension direction by as much as $20^{\circ}$. A small amount of error also results from the leeway that exists in interpretation of the position of the basin floor. The heave associated with formation of rift basin $\mathrm{A}$ is therefore estimated to be about $4-5 \mathrm{~km}$.

\section{Rift Basin B}

The reflections marked with the F's in figure 5 are interpreted to represent the most continuous horizon within rift basin $B$ and as such have been used to balance the rift basin. Unlike rift basin A, the PRU over rift basin $B$ is relatively planar and shows little evidence of compaction (fig. 5). Consequently, it is inferred that compaction has not significantly modified the shape of horizon F.

Figure 8 shows the fault shape at depth predicted by using the shape of horizon $F$ and hanging-wall deformation by shear along planes that dip $65^{\circ}$ antithetically to the border fault. The fault trace inferred from the seismic data shown in this figure represents an intermediate position for the fault, given that the reflections marked with the $\mathrm{D}$ in figure 5 allow for some leeway in interpretation of the actual fault geometry. The predicted and observed fault shapes agree well, indicating that shear along $65^{\circ}$ dipping planes is a good approximation of the mechanism of hanging-wall deformation. As shown in figure 8 , this construction allows the border fault to be traced to a depth of $4.3 \mathrm{~km}$ and indicates that the heave is $5.6 \mathrm{~km}$.

Error in balancing rift basin B results largely from the range in inferred positions of the fault allowed by the seismic data. The dip of the shear planes can be constrained to within $5^{\circ}$; as a result, the fault depth and heave shown in figure 8 are accurate to about 10 percent. 


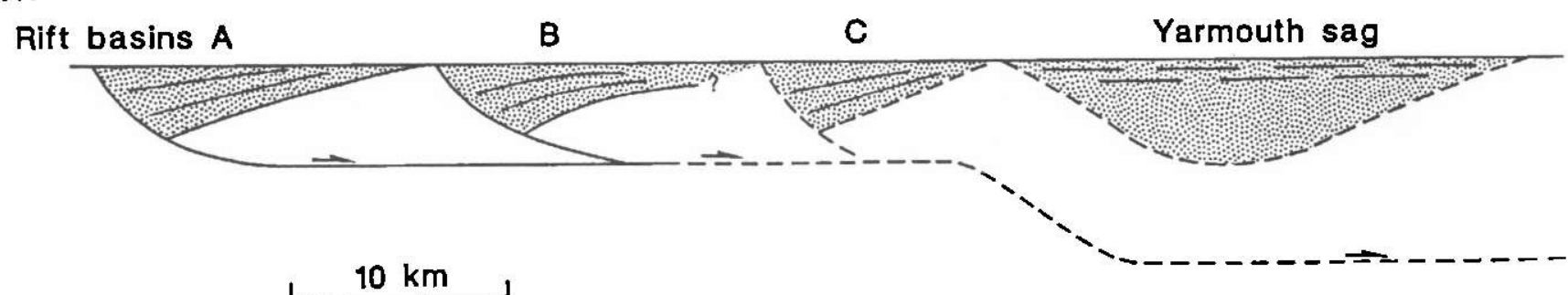

Figure 9. Speculative, balanced cross section showing what the structure of the upper crust underlying the Georges Bank basin may have looked like at the time rifting ceased. Horizontal and vertical scales are equal.

In the case of the heave, error also results from the possible obliquity of the section to the extension direction and the leeway that exists in interpretation of the position of the basin floor. The heave associated with formation of rift basin B is therefore estimated to be about $5-6 \mathrm{~km}$. The close correspondence between the depths to which the border faults of both rift basins A and B can be traced suggests that they sole into the same detachment surface.

These analyses show that similar deformation mechanisms are required to balance rift basins $\mathrm{A}$ and $\mathrm{B}$. The inference that the hanging walls of both border faults changed their shape by undergoing simple shear along 60 to $65^{\circ}$ dipping planes is consistent with the type of deformation expected in this geologic setting. The mechanism by which the rocks above a listric normal fault deform is controlled by a number of parameters, the most important being the mechanics of faulting and the nature of the preexisting anisotropy in the hanging wall. For example, flexural slip folding is likely to occur where the hanging wall is composed of well-bedded, subhorizontal strata. Extension in the Georges Bank region appears to have been accommodated by listric normal faulting in metamorphic basement rocks; basement lithologies penetrated by the COST G-1 well, which lies directly seaward of the rift basins analyzed, include phyllite and schist (Amato and Bebout, 1980). These basement rocks are correlated with the Meguma terrane in Nova Scotia (Hutchinson and others, in press), where subhorizontal attitudes are uncommon, and thus it is unlikely that flexural slip folding accommodated the deformation in the hanging wall. The Mohr-Coulomb failure criterion, however, predicts faults to form at dips of about $60^{\circ}$ in homogeneous materials undergoing subhorizontal extension. Simple shear along 60 to $65^{\circ} \mathrm{dip}-$ ping planes is, therefore, a geologically plausible mechanism of deformation in the hanging wall. It is also possible that the shear planes parallel the foliation in the basement rocks.

\section{Rift Basin C}

Seismic data suggest that rift basin $\mathrm{C}$ is also characterized by a seaward-dipping border fault and gently landward-dipping basin fill. However, little can be inferred about the details of the structure of this rift basin from the seismic section. The basin appears to be slightly narrower than rift basins $A$ and $B$, being about $10 \mathrm{~km}$ wide as opposed to 14 to $15 \mathrm{~km}$ wide. If the structure of this basin is similar to that of rift basins A and B and if the hanging wall deformed along $65^{\circ}$ dipping planes, then the heave is constrained to about 3.5 to $4.5 \mathrm{~km}$. The border fault of this rift basin probably soles into the detachment controlling formation of rift basins A and B.

The inferred geometry of the upper crust in the Georges Bank area at the time rifting ceased is summarized in figure 9. The border faults of rift basins $\mathrm{A}-\mathrm{C}$ are shown to sole into a single, subhorizontal detachment surface that lay at the relatively shallow depth of about 4.5 to $5 \mathrm{~km}$.

\section{Yarmouth Sag}

Extension may be transferred to deeper levels by ramps in the detachment surface. The Yarmouth sag (fig. 4), which lies directly seaward of rift basin C, is a 25 -km-wide depression in the pre-Mesozoic basement surface that is filled with subhorizontal synrift strata of unknown thickness (Klitgord and others, 1982). It is bounded by a basement high on both its landward and seaward edges. Both the width of the Yarmouth sag and the attitude of the synrift strata within it suggest that it may be a hanging-wall syncline that developed in response to motion along an extensional ramp. Such an interpretation is illustrated in figure 9. In this model, the detachment controlling rift basins $\mathrm{A}-\mathrm{C}$ is considered to ramp down seaward of rift basin $C$ to pass beneath the Yarmouth sag at a deeper structural level. Motion along faults with such a geometry will cause a hanging-wall syncline to develop seaward of the extensional ramp. Although the floor of the hanging wall is shown to be an unconformity in this simplified cross section, minor normal faulting may develop along the flanks of the basin. 
The width of the hanging-wall syncline $(w)$ can be determined from

$$
w=h+l_{1}+l_{2} \tan (90-\theta)
$$

where $h$ is the net heave of the three rift basins, $l_{1}$ is the horizontal length of the extensional ramp, $l_{2}$ is the structural relief of the ramp, and $\theta$ is the dip of the shear planes. If this ramp is similar to the dipping portions of the border faults of the rift basins and if the rocks above the fault deformed by simple shear along $65^{\circ}$ dipping planes, then the hanging-wall syncline is constrained to be about 22 to $27 \mathrm{~km}$ wide. This corresponds closely to the width of the Yarmouth sag.

An important consequence of this fault geometry is that it requires the hanging-wall syncline to deepen at a faster rate than that of rift basins $\mathrm{A}-\mathrm{C}$. Thus, the rate of extension may exceed the sedimentation rate, resulting in a sediment-starved basin. As illustrated in figure 9, the sediments that fill the basin late in the rifting process will be essentially flatlying.

\section{Summary}

The upper crust underlying the landward portion of the Georges Bank basin appears to have been extended and thinned by motion along faults that form an imbricate fan and sole into a single detachment surface with a ramp-flat geometry (fig. 9). Two types of extensional basins appear to have developed as a result of this fault geometry. The type exemplified by rift basins $\mathrm{A}-\mathrm{C}$ developed as a result of motion along a basin-bounding, listric normal fault; this type of basin is asymmetric and characterized by strata that are tilted toward the border fault. The other type, which is exemplified by the Yarmouth sag, developed as a result of motion along an underlying extensional ramp; this type of basin is symmetric, sediment starved, and characterized by relatively flatlying strata at high stratigraphic levels.

The amount of upper crustal extension and thinning that resulted from this extensional fault geometry is relatively small. The border faults of rift basins $\mathrm{A}-\mathrm{C}$ appear to have accommodated $14 \pm 1.5 \mathrm{~km}$ of extension; no additional extension is required to form the Yarmouth sag. Thus, the percentage extension from the landward edge of rift basin $A$ to the seaward edge of the Yarmouth sag, a distance of approximately $67 \mathrm{~km}$, is about 25 to 30 percent. This extension has allowed the crust underlying rift basins $\mathrm{A}-\mathrm{C}$ to reduce its thickness by about 1.5 to 2.0 $\mathrm{km}$ and the crust underlying the Yarmouth sag to have thinned by about 2.5 to $3.0 \mathrm{~km}$, if the geometry of the extensional ramp is correct.

\section{DISCUSSION}

The ramp-flat extensional fault geometry suggested by the balanced cross sections raises several important questions concerning the mechanisms by which continental crust thins. Namely: (1) how significant a role does reactivation of thrust faults play in the thinning process? and (2) if the upper crust extends along subhorizontal faults, how does the middle and lower crust thin and extend?

Many of the border faults of the onshore early Mesozoic rift basins of the Eastern United States have been shown to be reactivated Paleozoic faults (for example, Ratcliffe, 1971; Bobyarchick and Glover, 1979; Robinson, 1979; Glover and others, 1980; Ratcliffe and others, 1986). The geometry of the normal faults controlling the rift basins of Georges Bank is remarkably similar to that of thrust faults in compressional fold and thrust belts; both are characterized by ramp-flat and imbricate fan geometries. This suggests that the Georges Bank rift basins may have formed along a system of reactivated thrust faults.

Kinematic arguments also support the possibility that the faults are reactivated Alleghenian structures. Motion along the imbricate fan in a thrust fault frame of reference would be perpendicular to the ramp believed to be present landward of the Yarmouth sag and directed toward the northwest (fig. 4). This sense of overthrusting is consistent with Alleghenian deformation documented onshore in New England. For example, lineations and sense of shear indicators in mylonites of the Lake Char/Honey Hill fault system in eastern Connecticut (fig. 4) show that the upper plate moved toward the northwest (Goldstein, 1984). In addition, the high-grade metamorphic rocks in southern Rhode Island (O'Hara, 1986) may be the result of northwest-directed overthrusting.

The style of extension in continental crust may therefore be largely controlled by the nature of the preexisting anisotropy. For example, in the region of rift basins A-C, brittle faulting appears to have affected only the very uppermost portion of the crust simply because the detachment, or preexisting anisotropy, lay at a shallow level at the onset of rifting. Only a minimal amount of crustal thinning could be accommodated as a result of the detachment being both subhorizontal and shallow; extension along the fault system resulted in a crustal thinning of only $1.5-2 \mathrm{~km}$. In the region of the Yarmouth sag, brittle faulting appears to have been transferred to greater depth because of the presence of a preexisting ramp. The amount of crustal thinning in this area was controlled in large part by the geometry of this ramp, with thinning estimated to be only 2.5 to $3 \mathrm{~km}$.

Gravity modeling, however, shows that the crust underlying the Georges Bank basin has undergone a significant amount of thinning (Swift and others, 1987). 
Most of this crustal thinning must be the result of processes other than brittle normal faulting. Without seismic reflection data that better images the deep structure and base of the crust, it is difficult to determine whether this thinning of the lower crust is the result of (1) processes that approximate pure shear on a regional scale, (2) simple shear along a major, crustal-penetrating, and probably westerly dipping shear zone, (3) thermal erosion, or (4) some combination of these processes. The close correspondence between the extension value determined from the analysis of brittle faulting in the upper crust (25-30 percent) with that determined from subsidence analysis of the Georges Bank basin (25 percent; Swift and others, 1987), however, supports crustal thinning by regional-scale pure shear. It is probable that preexisting anisotropies also influenced the process by which the lower crust extended and thinned. By viewing the process of continental rifting as one of tectonic inversion, we may develop a better understanding of the mechanism of continental breakup.

\section{ACKNOWLEDGMENTS}

I thank John Unger for helping migrate the seismic sections; Roy Kligfield, Bill Burton, Al Froelich, and Nick Ratcliffe for insightful comments on various drafts of the manuscript; and Tim Byrne, Debbie Hutchinson, and $\mathrm{Kim}$ Klitgord for fruitful discussions on the processes by which continental crust extends. This research was done while the author held a National Research Council-U.S. Geological Survey Research Associateship.

\section{REFERENCES CITED}

Amato, R.V., and Bebout, J.W., eds., 1980, Geologic and operational summary, COST no. G-1 well, Georges Bank area, North Atlantic Outer Continental Shelf: U.S. Geological Survey Open-File Report 80-268, 112 p.

Bobyarchick, A.R., and Glover, Lynn, III, 1979, Deformation and metamorphism in the Hylas zone and adjacent parts of the eastern Piedmont in Virginia: Geological Society of America Bulletin, v. 90, p. 739-752.

Davison, I., 1986, Listric normal fault profiles: calculation using bed-length balance and fault displacement: Journal of Structural Geology, v. 8, p. 209-210.

Eaton, G.P., 1979, Regional geophysics, Cenozoic tectonics, and geologic resources of the Basin and Range province and adjoining areas, in Newman, G.W., and Goode, H.D., eds., Basin and Range symposium: Denver, Colorado, Rocky Mountain Association of Geologists, p. 11-39.

Gibbs, A.D., 1983, Balanced cross-section construction from seismic sections in areas of extensional tectonics: Journal of Structural Geology, v. 5, p. 153-160.

1984, Structural evolution of extensional basin margins: Journal of the Geological Society of London, v. 141, p. 609-620.
Glover, L. III, Poland, F.B., Tucker, R.K., and Bourland, W.C., 1980, Diachronous Paleozoic mylonites and structural heredity of Triassic-Jurassic basins in Virginia: Geological Society of America Abstracts with Programs, v. 12, p. 178.

Goldstein, A.G., 1984, Low-angle normal faults in the northern Appalachians and their relationship to the Late Paleozoic Alleghanian Orogeny: Geological Society of America Abstracts with Programs, v. 16, p. 521.

Hamilton, W.B., 1982, Structural evolution of the Big Maria Mountains, northeastern Riverside County, southeastern California, in Frost, E.G., and Martin, D.L., eds., Mesozoic-Cenozoic tectonic evolution of the Colorado River region, California, Arizona, and Nevada: San Diego, California, Cordilleran Publishers, p. 1-28.

Hutchinson, D.R., Klitgord, K.D., Lee, M.W., and Trehu, A.M., in press, USGS deep seismic reflection profile across the GuIf of Maine: Geological Society of America Bulletin.

Kligfield, R., Crespi, J.M., Naruk, S.J., and Davis, G.H., 1984, Displacement and strain patterns of extensional orogens: Tectonics, v. 3, p. 577-609.

Klitgord, K.D., Schlee, J.S., and Hinz, K., 1982, Basement structure, sedimentation, and tectonic history of the Georges Bank basin, in Scholle, P.A., and Wenkam, C.R., eds., Geological studies of the COST nos. G-1 and G-2 wells, United States North Atlantic Outer Continental Shelf: U.S. Geological Survey Circular 861, p. 160-186.

Klitgord, K.D., and Hutchinson, D.R., 1985, Distribution and geophysical signatures of early Mesozoic rift basins beneath the U.S. Atlantic continental margin, in Robinson, G.R., Jr., and Froelich, A.J., eds., Proceedings of the second U.S. Geological Survey workshop on the early Mesozoic basins of the Eastern United States: U.S. Geological Survey Circular 946, p. 45-61.

Lister, G.S., Etheridge, M.A., and Symonds, P.A., 1986, Detachment faulting and the evolution of passive continental margins: Geology, v. 14, p. 246-250.

McKenzie, D.P., 1978, Some remarks on the development of sedimentary basins: Earth and Planetary Science Letters, v. 40 , p. $25-32$.

Miller, E.L., Gans, P.B., and Garing, J., 1983, The Snake Range decollement: An exhumed mid-Tertiary ductile-brittle transition: Tectonics, v. 2, p. 239-263.

O'Hara, K., 1986, Tectonic implications of late Paleozoic metamorphism in southeastern New England: Geology, v. 14 , p. $430-432$.

Ratcliffe, N.M., 1971, The Ramapo fault system in New York and adjacent New Jersey: A case of tectonic heredity: Geological Society of America Bulletin, v. 82, p. 125-141.

Ratcliffe, N.M., and Burton, W.C., 1985, Fault reactivation models for origin of the Newark basin and studies related to eastern U.S. seismicity, in Robinson, G.R., Jr., and Froelich, A.J., eds., Proceedings of the second U.S. Geological Survey workshop on the early Mesozoic basins of the Eastern United States: U.S. Geological Survey Circular 946 , p. 36-45.

Ratcliffe, N.M., Burton, W.C., D'Angelo, R.M., and Costain, J.K., 1986, Low-angle extensional faulting, reactivated mylonites, and seismic reflection geometry of the Newark basin margin in eastern Pennsylvania: Geology, v. 14, p. $766-770$. 
Robinson, G.R., 1979, Pegmatite cutting mylonite-evidence supporting pre-Triassic faulting along the western border of the Danville Triassic basin, southern Virginia: Geological Society of America Abstracts with Programs, v. 11, p. 210.

Rubey, W.W., and Hubbert, M.K., 1959, Role of fluid pressure in mechanics of overthrust faulting, II, Overthrust belt in geosynclinal area of western Wyoming in light of fluid pressure hypothesis: Geological Society of America Bulletin, v. 70, p. 167-206.

Sclater, J.G., and Christie, P.A.F., 1980, Continental stretching: An explanation of the post-mid-Cretaceous subsidence of the central North Sea basin: Joumal of Geophysical Research, v. 85, p. 3711-3739.

Suppe, J., 1983, Geometry and kinematics of fault-bend folding: American Journal of Science, v. 283, p. 684-721.

Swift, B.A., Sawyer, D.S., Grow, J.A., and Klitgord, K.D., 1987, Subsidence, crustal structure, and thermal evolution of
Georges Bank basin: American Association of Petroleum Geologists Bulletin, v. 71, p. 702-718.

Verall, P., 1981, Structural interpretation with application to North Sea problems: Course Notes No. 3, Joint Association for Petroleum Exploration Courses (JAPEC), London.

Wernicke, B., 1981, Low-angle normal faults in the Basin and Range province: Nappe tectonics in an extending orogen: Nature, v. 291, p. 645-648.

1985, Uniform-sense normal simple shear of the continental lithosphere: Canadian Journal of Earth Science, $v$. 22 , p. 108-125.

White, N.J., Jackson, J.A., and McKenzie, D.P., 1986, The relationship between the geometry of normal faults and that of the sedimentary layers in their hanging walls: Journal of Structural Geology, v. 8, p. 897-909.

Wise, D.U., 1978, Fracture history of the Connecticut Valley: Abstract for field trip meetings of Red Beds of Connecticut: Society of Economic Paleontologists and Mineralogists, Hartford, Connecticut.

\title{
A SIMPLE TECHNIQUE FOR ANALYSIS AND MIGRATION OF SEISMIC REFLECTION PROFILES FROM THE MESOZOIC BASINS OF EASTERN NORTH AMERICA
}

\author{
John D. Unger
}

\begin{abstract}
The geometry of the internal and external structure of the Mesozoic basins of the Eastern United States makes unmigrated reflection profiles difficult to interpret and makes it essential to migrate reflection data to understand the details of their features. If only unmigrated data are available, line drawings of them can be migrated quickly and inexpensively with a microcomputer-based program, and the profiles can be more readily interpreted. More than $7,000 \mathrm{~km}$ of seismic reflection data collected over Mesozoic basins in eastern North America are summarized in a database format. These data show the extent to which the research community and the oil and gas industry have used this method to explore Mesozoic basins.
\end{abstract}

\section{INTRODUCTION}

The petroleum industry, in the past 8 years, has greatly increased the collection of seismic reflection data over exposed and buried Mesozoic basins in eastern North America. Heightened interest in these basins as potentially attractive sources for commercial oil and gas deposits has spurred this activity. Although much of the seismic reflection information is proprietary, the loca- tions of the profiles and some of the acquisition parameters are available in prospectus form for "nonexclusive" data and are known within the geological and geophysical communities. Reflection seismology has been emphasized as an exploration tool because it can provide an easily interpreted image of both the internal and external structures of the basins. If the data are recorded to sufficient depths, the method also yields information pertaining to the structure of the pre-Mesozoic basement rocks that enclose the basins. These "basement" features may play important roles in localizing faulting and subsidence in early Mesozoic basins. Other geophysical methods such as gravity and magnetics have also played an important role in placing constraints on the depth and shape of the basins (Daniels and others, 1983), but reflection seismology has supplied the most specific data about the form and internal layering of the basins.

Knowledge of subsurface geometries gained from seismic reflection data has changed our conception of rift basins. A few years ago it was common to see cross sections of Mesozoic basins drawn with border faults that dipped steeply through the upper crust; for example, see Lindholm (1978) or the cross sections of the Gettysburg basin shown in Berg and others (1980). Presently, most 


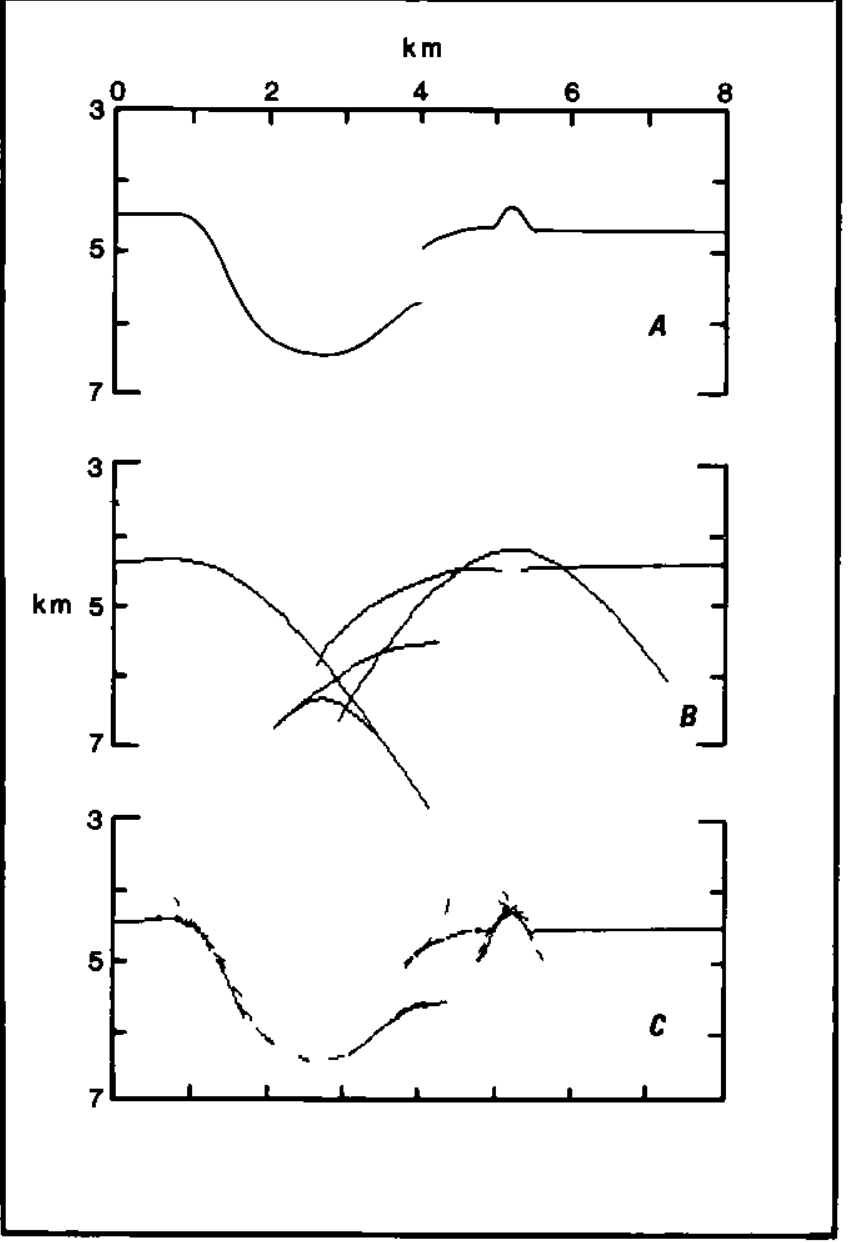

Figure 1. An example of how a relatively simple geologic structure $(A)$ is imaged by an unmigrated common depth point seismic reflection profile (B) (Schneider, 1978). The effects of the simple line migration program on the reflectors in $B$ and how the migration process can provide a vastly improved picture of subsurface structure are shown in $C$.

researchers depict these basins as having either listric or planar normal border faults that dip about $45^{\circ}$ (Ratcliffe and Burton, 1985; Froelich and Gottfried, 1985). The analysis of seismic reflection data and core drilling (Ratcliffe and Burton, 1985) has contributed greatly to our understanding of the shape and dip of the border faults of Mesozoic basins.

However, many problems exist with the interpretation of unmigrated reflection data from Mesozoic basins. The method gives a distorted picture of the subsurface if the reflectors dip more than a few degrees. Also, the presence of faults, intrusives, and basinlike features, if they have curvatures smaller than the wavefronts used to image them, can distort the ray paths and create artifacts in the seismic profiles. For example, figure 1 shows how a complex pattern of reflectors results from a relatively simple synthetic model of a syncline that has a vertical fault on one of its limbs. Furthermore, unmigrated profiles have two-way traveltime as their vertical axis rather than depth. Because the velocity of seismic waves generally increases with increasing depth in the crust, the vertical axis must be proportionately "stretched" to give an undistorted picture in that dimension when two-way traveltime is converted to depth.

Standard wave-equation migration techniques, which can correct artifacts and confusing features of unmigrated seismic profiles, have been successfully applied to data from Mesozoic basins. However, this method requires expensive, single-purpose seismic processing hardware and software as well as good velocity information throughout the profile. Even with the best control, the processing can introduce additional noise and artifacts into the data. In the modeling section below, a simple microcomputer-based program that can migrate line drawings of unmigrated seismic reflection profiles is described.

\section{DATA SETS}

Seismic reflection information, which has been collected over Mesozoic basins of the Eastern United States during the past 3 years, is presented in table 1 . Data are included from onshore basins, exposed or buried beneath the Atlantic Coastal Plain, and from the offshore basins discovered by marine geophysical surveys on the continental shelf and slope. The locations of the basins listed in table 1 are shown in figure 2 . The data originate from many sources and cover a wide spectrum both in the completeness of the information and its accuracy. For some of the lines, complete data sets have been obtained, including the field data tapes. For other profiles, commonly proprietary, the only information gathered consists of verbal descriptions that give a general idea of the location of the line(s) and the acquisition parameters.

This information has been collected into a data format that contains known details of the various parameters related to each of the reflection profiles. Table 1 summarizes this information and gives an indication of the extent that reflection seismology has been used to explore eastern Mesozoic basins. The information in table 1 is not complete and is continuously being updated. Corrections and additions to these data would be appreciated.

Table 1 is most notably incomplete for the Southeastern United States south of the Georgia-South Carolina border in the vicinity of the buried Riddlesburg basin, where industry has acquired data recently. Furthermore, the data set includes only the clearly identified, larger offshore basins and does not include smaller offshore Mesozoic structures that have been identified as possible basins related to the opening of the Atlantic Ocean. 


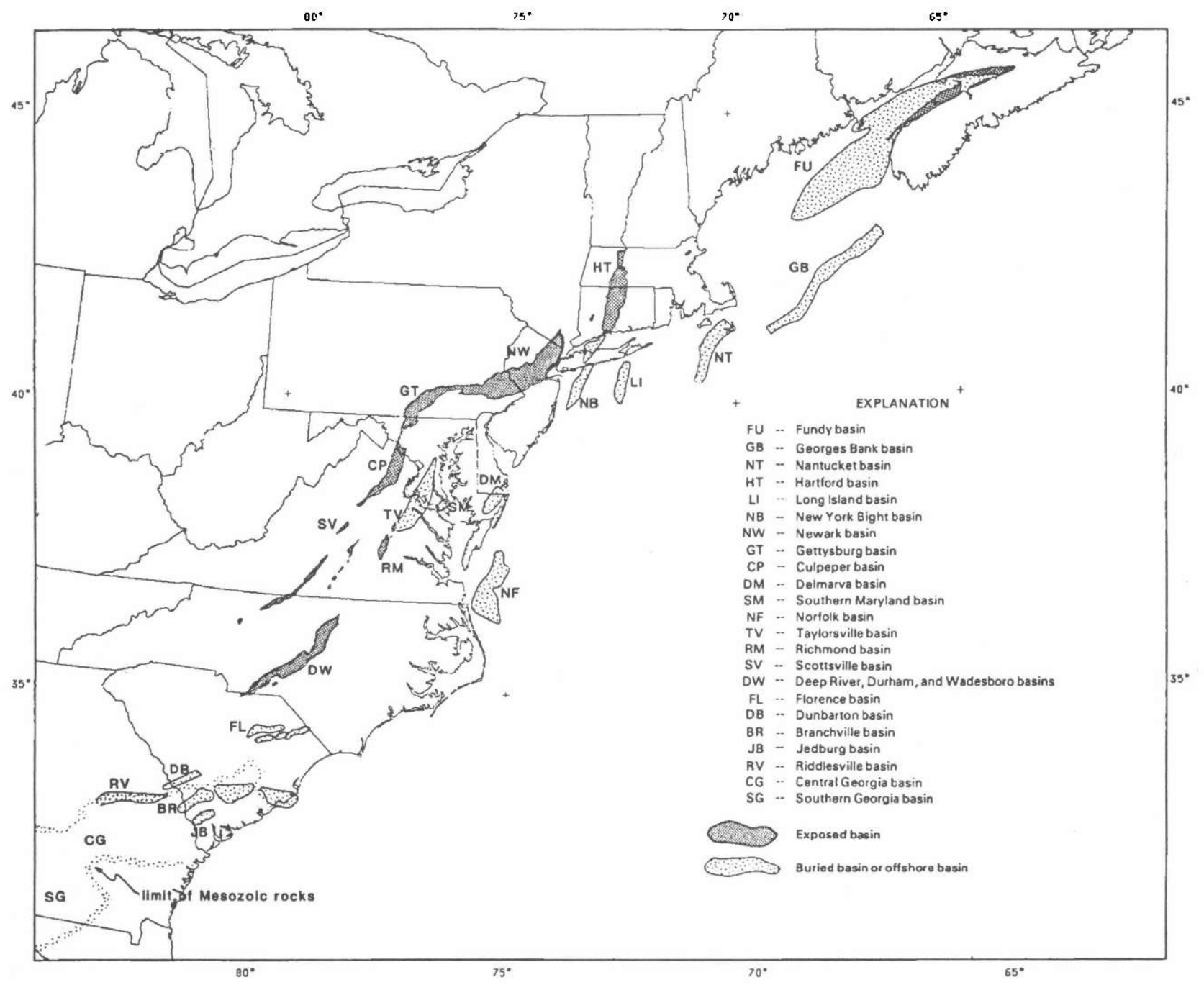

Figure 2. Location map for the Mesozoic basins listed in table 1. Map scale is approximately 1:15,000,000.

Having these data in a form that allows easy access and analysis enables one to examine relations that are not readily apparent. For example, it is easy to search the data set for all reflection profiles collected over exposed onshore basins and produce a table showing total miles of reflection profiles for each basin versus date of acquisition.

\section{MODELING STUDIES}

Interpretative line drawings have been made of the best reflection sections summarized in table 1 . Some reflection profiles are proprietary and cannot be published until released by their owners. Only data in the public domain are used to illustrate the points made in this paper.

The procedures followed to produce the data are straightforward and consist of the following steps. First, the prominent reflectors from the reflection profile were traced onto a clear mylar overlay. In this process all of the strong apparent reflections in the section were included, even those that were not readily interpretable in a conventional sense, for example, diffractions. Next, the line drawing was digitized, and the digital data made compatible for input into the line-migration program described by Unger (1986) (fig. 3).

The line migration program used to analyze these data takes a conventional line drawing of an unmigrated seismic reflection section and migrates it to a depth section by using a linear velocity model, a model in which the velocity has a fixed surface value that then increases at a constant rate with depth. This model can be expressed by:

$$
V=V o+k z
$$

where $V$ is the velocity to be determined at depth $z, V o$ is the velocity at the surface, and $k$ is the rate at which the velocity increases with depth. A linear increase of velocity 
Table 1. Summary of data available for seismic reflection profiles from Mesozoic basins of eastern North America [See figure 2 for basin locations; 19??, year of data acquisition uncertain; ?, length or fold of profile or collector unknown; VPI, Virginia Polytechnical Institute and State University; AOCS Atlantic Outer Continental Shelf]

\begin{tabular}{|c|c|c|c|c|c|c|c|c|c|}
\hline Basin name & $\begin{array}{c}\text { Year } \\
\text { collected }\end{array}$ & $\begin{array}{l}\text { Profile } \\
\text { length } \\
\text { (km) }\end{array}$ & Fold & Collector & Basin name & $\begin{array}{c}\text { Year } \\
\text { collected }\end{array}$ & $\begin{array}{l}\text { Profile } \\
\text { length } \\
(\mathrm{km})\end{array}$ & Fold & Collector \\
\hline \multirow{8}{*}{$\begin{array}{l}\text { Fundy, NS, Canada, } \\
\text { offshore }\end{array}$} & 1968 & 614 & 12 & Mobil & $\begin{array}{c}\text { Scottsville, VA } \\
\text { Total }\end{array}$ & 1981 & 8 & 24 & VPI \\
\hline & 1969 & 1,438 & 12 & Mobil & Deep River, NC & 1974 & $?$ & $?$ & SEPCO/ \\
\hline & $\begin{array}{l}1972 \\
1973 \\
1980\end{array}$ & $\begin{array}{r}492 \\
167 \\
62\end{array}$ & $\begin{array}{l}24 \\
48 \\
36\end{array}$ & GSI & (Sanford) & 1983 & 32 & $?$ & $\begin{array}{l}\text { Chevron } \\
\text { SEPCO/ }\end{array}$ \\
\hline & $\begin{array}{l}1980 \\
1980\end{array}$ & $\begin{array}{l}02 \\
44\end{array}$ & $\begin{array}{l}30 \\
36\end{array}$ & $\begin{array}{l}\text { Chevron } \\
\text { Chevron }\end{array}$ & Total & & 32 & & \\
\hline & 1980 & 807 & 36 & $\begin{array}{l}\text { Western } \\
\text { Geophy. }\end{array}$ & $\begin{array}{l}\text { Deep River, NC } \\
\text { (Durham) }\end{array}$ & 1973 & 16 & 1 & $\begin{array}{l}\text { USGS-Univ. } \\
\text { of NC }\end{array}$ \\
\hline & $\begin{array}{l}1981 \\
1981\end{array}$ & $\begin{array}{l}32 \\
28\end{array}$ & $\begin{array}{l}48 \\
48\end{array}$ & $\begin{array}{l}\text { Chevron } \\
\text { Chevron }\end{array}$ & & 1986 & $?$ & 12 & $\begin{array}{l}\text { Univ. of NC- } \\
\text { SEPCO }\end{array}$ \\
\hline & 1981 & 654 & 48 & $\begin{array}{l}\text { Western } \\
\text { Geophy. }\end{array}$ & $\begin{array}{l}\text { Total } \\
\text { Florence, sC }\end{array}$ & 1982 & $\begin{array}{l}16 \\
53\end{array}$ & 24 & Texaco \\
\hline & $\begin{array}{l}1982 \\
1982\end{array}$ & $\begin{array}{r}32 \\
474\end{array}$ & $\begin{array}{l}48 \\
48\end{array}$ & $\begin{array}{l}\text { Chevron } \\
\text { Sefel }\end{array}$ & & 1982 & $\begin{array}{r}85 \\
138\end{array}$ & 24 & Texaco \\
\hline \multirow{2}{*}{$\begin{array}{l}\text { Total } \\
\text { Georges Bank, AOCS } \\
\text { Total }\end{array}$} & & 4,844 & & & Dunbarton, SC, GA & $19 ? ?$ & $?$ & $?$ & Savannah \\
\hline & 1978 & $\begin{array}{l}60 \\
60\end{array}$ & 24 & USGS-GSI & & $19 ? ?$ & 25 & $?$ & $\begin{array}{l}\text { River Plant } \\
\text { ? }\end{array}$ \\
\hline \multirow{2}{*}{$\begin{array}{l}\text { Nantucket, AOCS } \\
\text { Total } \\
\text { Hartford, CT, MA }\end{array}$} & 1978 & 35 & 48 & GSI-USGS & Total & 17:! & 25 & $\cdot$ & \\
\hline & $\begin{array}{l}1985 \\
1985 \\
1985 \\
1985 \\
1985 \\
1985 \\
1985 \\
1986\end{array}$ & $\begin{array}{r}35 \\
45 \\
45 \\
70 \\
45 \\
65 \\
50 \\
? \\
25 \\
345\end{array}$ & $\begin{array}{r}? \\
? \\
? \\
? \\
? \\
\stackrel{?}{?} \\
\stackrel{?}{8}\end{array}$ & $\begin{array}{l}\text { Texaco } \\
\text { Texaco } \\
\text { Texaco } \\
\text { Texaco } \\
\text { Texaco } \\
\text { Texaco } \\
\text { Univ. CT } \\
\text { Teledyne }\end{array}$ & Branchville, SC & $\begin{array}{l}19 ? ? \\
19 ? ? \\
19 ? ? \\
19 ? ? \\
19 ? ? \\
19 ? ? \\
19 ? ? \\
19 ? ? \\
1981\end{array}$ & $\begin{array}{r}22 \\
30 \\
37 \\
35 \\
27 \\
34 \\
8 \\
30 \\
80\end{array}$ & $\begin{array}{l}24 \\
24 \\
24 \\
24 \\
24 \\
24 \\
24 \\
24 \\
24\end{array}$ & $\begin{array}{l}\text { SEPCO } \\
\text { SEPCO } \\
\text { SEPCO } \\
\text { SEPCO } \\
\text { SEPCO } \\
\text { SEPCO } \\
\text { SEPPCO } \\
\text { SEPCO } \\
\text { Seisdata }\end{array}$ \\
\hline Long Island, AOCS & $\begin{array}{l}1978 \\
1978\end{array}$ & $\begin{array}{r}343 \\
25 \\
25\end{array}$ & $\begin{array}{l}48 \\
48\end{array}$ & $\begin{array}{l}\text { GSI-USGS } \\
\text { GSI-USGS }\end{array}$ & $\begin{array}{l}\text { Total } \\
\text { Jedburg, SC }\end{array}$ & $\begin{array}{l}1974 \\
1974\end{array}$ & $\begin{array}{r}03 \\
2 \\
1\end{array}$ & $\begin{array}{l}4 \\
4\end{array}$ & $\begin{array}{l}\text { VPI-USGS } \\
\text { VPI-USGS }\end{array}$ \\
\hline \multirow{3}{*}{$\begin{array}{l}\text { New York Bight, NY } \\
\text { Total } \\
\text { Newark, PA, NJ }\end{array}$} & 1978 & $\begin{array}{l}50 \\
40 \\
40\end{array}$ & 48 & GSI-USGS & & $\begin{array}{l}1974 \\
1978 \\
1078\end{array}$ & $\begin{array}{r}4 \\
13 \\
26\end{array}$ & $\begin{array}{r}6 \\
24 \\
24\end{array}$ & $\begin{array}{l}\text { VPI-USGS } \\
\text { COCORP }\end{array}$ \\
\hline & $\begin{array}{l}1983 \\
1983 \\
1983\end{array}$ & $\begin{array}{r}40 \\
32 \\
120 \\
80\end{array}$ & $\begin{array}{l}12 \\
48 \\
48\end{array}$ & $\begin{array}{l}\text { VPI-USGS } \\
\text { NORPAC } \\
\text { North } \\
\quad \text { Central Oil }\end{array}$ & & $\begin{array}{l}1978 \\
1978 \\
1978 \\
1979 \\
1979\end{array}$ & $\begin{array}{l}26 \\
17 \\
12 \\
13 \\
22\end{array}$ & $\begin{array}{l}24 \\
24 \\
16 \\
12 \\
12\end{array}$ & $\begin{array}{l}\text { COCORP } \\
\text { COCORP } \\
\text { COCORP } \\
\text { USGS-GSI } \\
\text { USGS-GSI }\end{array}$ \\
\hline & $\begin{array}{l}1984 \\
1984\end{array}$ & $\begin{array}{r}30 \\
15 \\
277\end{array}$ & $\frac{12}{24}$ & $\begin{array}{l}\text { VPI-USGS } \\
\text { VPI-USGS }\end{array}$ & & $\begin{array}{l}1979 \\
1979 \\
1979\end{array}$ & $\begin{array}{r}8 \\
22 \\
16\end{array}$ & $\begin{array}{l}12 \\
12 \\
12\end{array}$ & $\begin{array}{l}\text { USGS-GSI } \\
\text { USGS-GSI } \\
\text { USGS-GSI }\end{array}$ \\
\hline \multirow[t]{3}{*}{$\begin{array}{l}\text { Total } \\
\text { Gettysburg, PA }\end{array}$} & $\begin{array}{l}1962 \\
1962 \\
1982\end{array}$ & $\begin{array}{r}18 \\
39 \\
8\end{array}$ & $\begin{array}{r}6 \\
6 \\
24\end{array}$ & $\begin{array}{l}\text { Gulf } \\
\text { Gulf } \\
\text { Berry Data } \\
\text { Services }\end{array}$ & & $\begin{array}{l}1979 \\
1979 \\
1979 \\
1979\end{array}$ & $\begin{array}{r}24 \\
9 \\
6 \\
9\end{array}$ & $\begin{array}{l}12 \\
12 \\
12 \\
12\end{array}$ & $\begin{array}{l}\text { USGS-GSI } \\
\text { USGS-GSI } \\
\text { USGS-GSI } \\
\text { USGS-GSI }\end{array}$ \\
\hline & 1982 & 19 & 24 & $\begin{array}{l}\text { Berry Data } \\
\text { Services }\end{array}$ & & $\begin{array}{l}1979 \\
1981\end{array}$ & 12 & 12 & $\begin{array}{l}\text { USGS-GSI } \\
\text { VPI }\end{array}$ \\
\hline & 1982 & 13 & 24 & $\begin{array}{l}\text { Berry Data } \\
\text { Services }\end{array}$ & & $\begin{array}{l}1981 \\
1981\end{array}$ & $\stackrel{?}{?}$ & $\begin{array}{l}24 \\
24 \\
24\end{array}$ & $\begin{array}{l}\text { VPI } \\
\text { VPI } \\
\text { VPI }\end{array}$ \\
\hline \multirow{2}{*}{$\begin{array}{l}\text { Total } \\
\text { Delmarva, MD } \\
\text { Total } \\
\text { Southern Maryland }\end{array}$} & 1986 & $\begin{array}{l}97 \\
82\end{array}$ & 60 & Teledyne & Total & 19 & $21 \stackrel{?}{?}$ & $\begin{array}{l}24 \\
24\end{array}$ & \\
\hline & $\begin{array}{l}1980 \\
1980 \\
1984 \\
1984\end{array}$ & $\begin{array}{r}82 \\
7 \\
4 \\
90 \\
67 \\
168\end{array}$ & $\begin{array}{l}24 \\
24 \\
48 \\
48\end{array}$ & $\begin{array}{l}\text { VPI } \\
\text { VPI } \\
\text { Texaco-GSI } \\
\text { Texaco-GSI }\end{array}$ & Riddlesville, GA & $\begin{array}{l}1978 \\
1978 \\
19 ? ? \\
19 ? ? \\
19 ? ?\end{array}$ & $\begin{array}{r}80 \\
10 \\
9 \\
7 \\
33\end{array}$ & $\begin{array}{l}24 \\
24 \\
24 \\
24 \\
24\end{array}$ & $\begin{array}{l}\text { COCORP } \\
\text { COCORP } \\
\text { SEPCO } \\
\text { SEPCO } \\
\text { SEPCO }\end{array}$ \\
\hline \multirow[t]{2}{*}{$\begin{array}{l}\text { Total } \\
\text { Culpeper, VA }\end{array}$} & 1980 & $\begin{array}{r}108 \\
11\end{array}$ & $2 \stackrel{?}{4}$ & $\stackrel{?}{\text { VPI-USGS }}$ & & $\begin{array}{l}19 ? ? \\
1981\end{array}$ & $\begin{array}{r}14 \\
80 \\
233\end{array}$ & $\begin{array}{l}24 \\
24\end{array}$ & $\begin{array}{l}\text { SEPCO } \\
\text { Seisdata }\end{array}$ \\
\hline & $\begin{array}{l}1982 \\
1983\end{array}$ & $?$ & $\begin{array}{r}24 \\
?\end{array}$ & $\begin{array}{l}\text { VPI-USGS } \\
\text { AMOCO }\end{array}$ & Central Georgia & $\begin{array}{l}19 ? ? \\
1981\end{array}$ & $\begin{array}{r}? 3 \\
60\end{array}$ & $?$ & Chevron \\
\hline \multirow{2}{*}{$\begin{array}{l}\text { Total } \\
\text { Norfolk, VA } \\
\text { Total } \\
\text { Taylorsville, VA }\end{array}$} & 1978 & $\begin{array}{l}18 \\
52 \\
52\end{array}$ & 48 & GSI-USGS & & $19 ? ?$ & 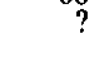 & $?$ & $\begin{array}{l}\text { Essex Oil } \\
\text { and Gas }\end{array}$ \\
\hline & $\begin{array}{l}1986 \\
19 ? ?\end{array}$ & 37 & 60 & $\begin{array}{l}\text { Teledyne } \\
\text { USGS }\end{array}$ & & $\begin{array}{l}1984 \\
1984 \\
1984\end{array}$ & $\begin{array}{l}70 \\
57 \\
35\end{array}$ & $\begin{array}{l}48 \\
48 \\
48\end{array}$ & $\begin{array}{l}\text { COCORP } \\
\text { COCORP } \\
\text { COCORP }\end{array}$ \\
\hline \multirow[t]{2}{*}{$\begin{array}{l}\text { Total } \\
\text { Richmond, VA }\end{array}$} & 1971 & 10 & 1 & $\begin{array}{l}\text { SEPCO/ } \\
\text { Chevron }\end{array}$ & & 1984 & $\begin{array}{l}63 \\
40\end{array}$ & $\begin{array}{l}48 \\
48\end{array}$ & $\begin{array}{l}\text { COCORP } \\
\text { COCORP }\end{array}$ \\
\hline & $\begin{array}{l}1981 \\
1984\end{array}$ & $\begin{array}{l}15 \\
15 \\
40\end{array}$ & $\begin{array}{l}12 \\
24\end{array}$ & $\begin{array}{l}\text { GSI-USGS } \\
\text { VPI-NRC }\end{array}$ & $\begin{array}{l}\text { Total } \\
\text { Total }\end{array}$ & & $\begin{array}{r}46 \\
371 \\
7,487\end{array}$ & 8 & $\mathbf{P}$ \\
\hline
\end{tabular}




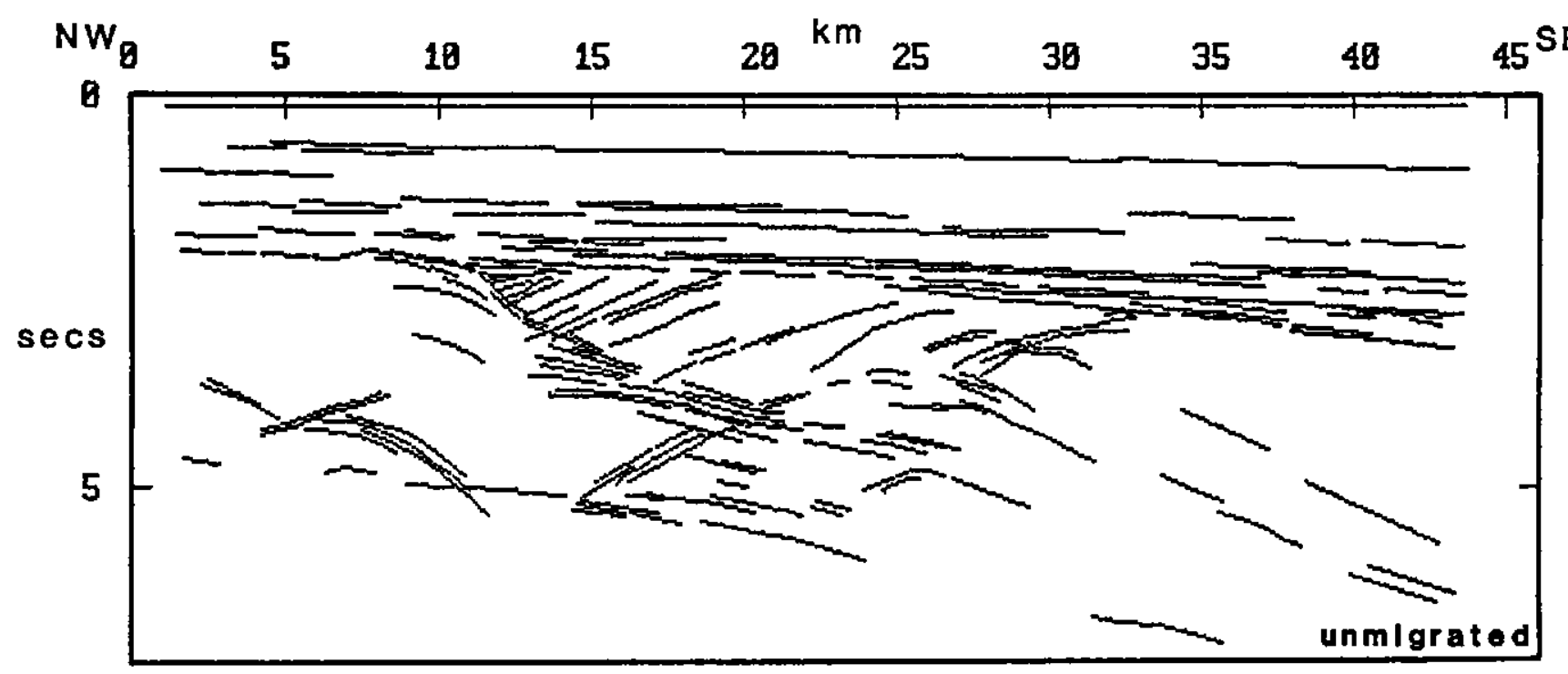

Figure 3. Line drawing of a portion of USGS offshore reflection profile Line 28, located near the mouth of Chesapeake Bay, across the Norfolk basin (Klitgord and Hutchinson, 1985). This shows the form of the digitized input data to Unger's (1986) migration program.

with depth is commonly used in areas such as the Gulf of Mexico and the Atlantic Coastal Plain, where it is an appropriate model of velocity in the compacted sediments and sedimentary rocks (Nettleton, 1949). In general, this type of velocity model has appeal because it is mathematically tractable, can describe many observed velocity-with-depth functions adequately, and is a better approximation to observed velocities in the crust than a simple constant velocity.

However, some crustal velocity distributions are not precisely portrayed by a linear velocity increase with depth. Insight into the effects of migration on seismic profiles in regions that have velocity reversals or sharp velocity contrasts can be gained by assuming a model that has a nearly constant velocity with depth (one where $k$ has some small value) and then using a range of these velocities to migrate the data in an iterative manner to determine where the various velocities best match specific parts of the profile.

The computer program (Unger, 1986) uses the linear velocity model to display the data in two ways. First, the data can be displayed unmigrated but with depth rather than two-way traveltime as the vertical axis (fig. 4). Second, a migrated depth section can be displayed (fig. 5). The program can also reproduce the line drawing with two-way traveltime as the vertical axis, independent of the velocity model chosen (fig. 3). The values of $V o$ and $k$ in the program can be varied rapidly and easily, and the effects of changes in the velocity model on the position of migrated and unmigrated reflectors in the profile are readily apparent. In this respect the program can be used as an iterative tool to determine the best migration velocity for a given seismic profile. In a more conventional approach, the velocity model is determined from additional data such as seismic refraction surveys or well logs.

\section{DISCUSSION}

The line drawing of the basin used as an example in figures 3, 4, and 5 was traced from the unmigrated reflection profile of USGS OCS Line 28 (Klitgord and Behrendt, 1979). This basin has been named the Norfolk basin by Klitgord and Hutchinson (1985). It is not the purpose of this paper to make a detailed stratigraphic interpretation of this basin on Line 28 , but certain features associated with the basin will be used to demonstrate the effects of migration on the unmigrated line drawing of the profile shown in figure 4.

If we examine the "reflectors" in the area labeled "A" on figure 4 and compare them to the same area on figure 5, we can see that these apparent reflectors consist mainly of diffractions that have "collapsed" to very short segments on the migrated section. One interpretation would be a fault, dipping to the southeast, that could be the border fault of a small subbasin east of the main basin.

Another area of the profile that has been changed dramatically by migration is the one marked "B." The rather ambiguous pattern of reflectors seen in figure 4 is resolved into a basinlike structure within the basement. However, the "limbs" of this structure in figure 5 may be caused by overmigration due to the use of too large a migration velocity in this part of the section. The problem needs further analysis. 


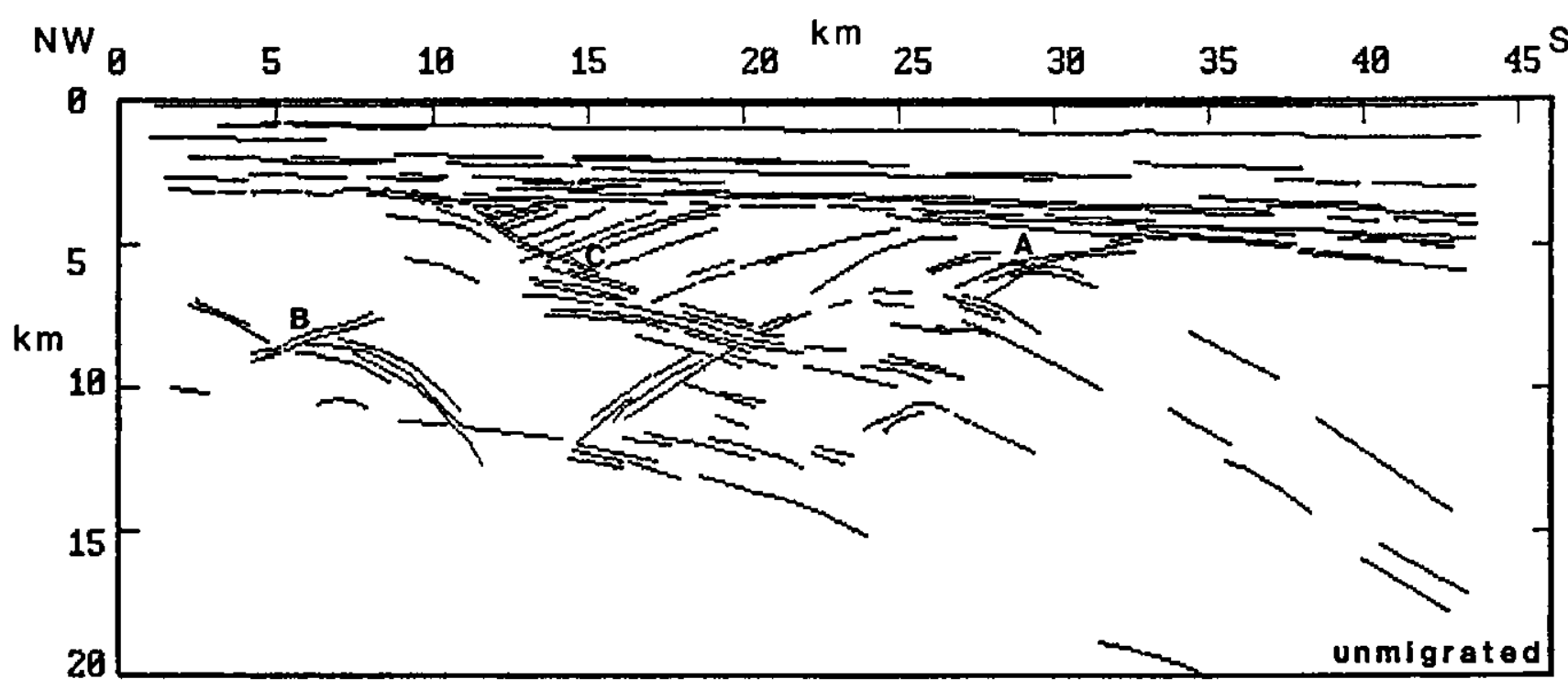

Figure 4. Depth portrayal of the line drawing in figure 3 using a linear velocity model. Refer to the "Discussion" for explanation of the letters in the figure.

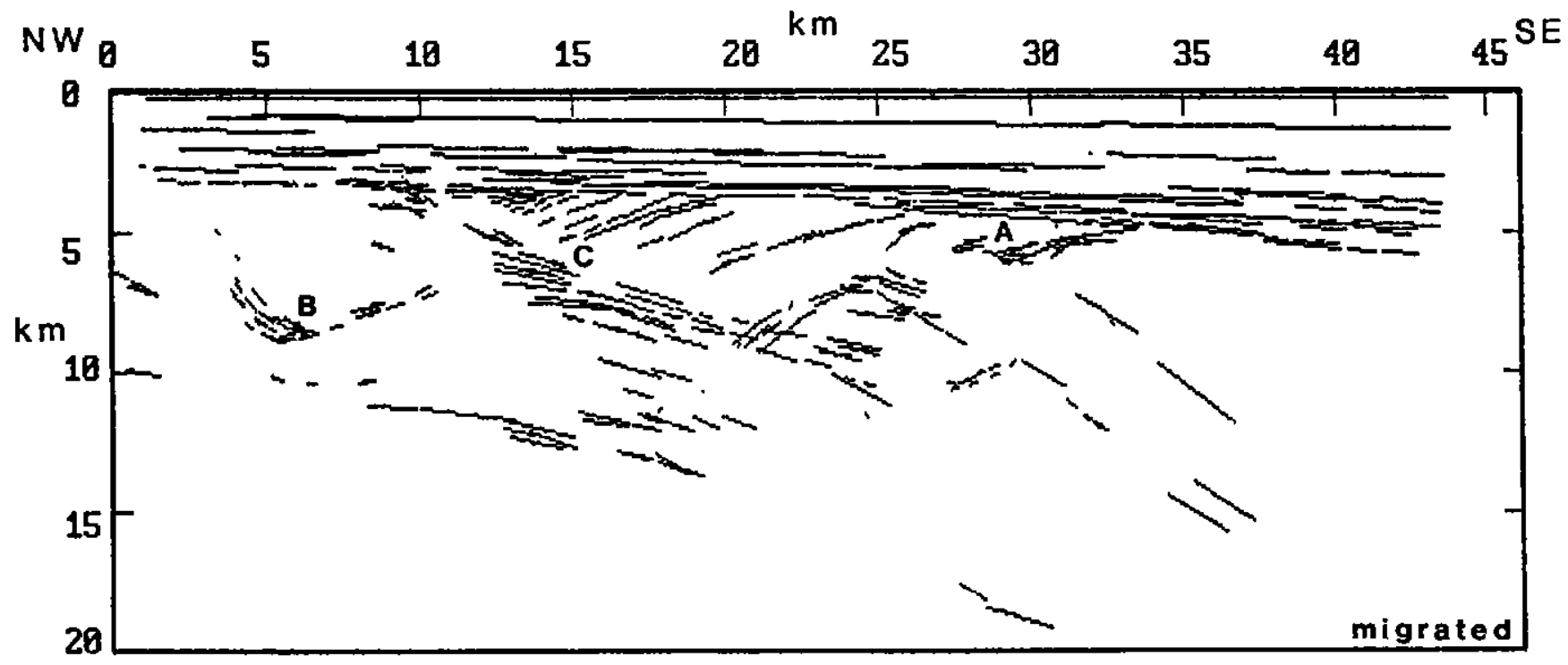

Figure 5. Migrated line drawing of the profile shown in figures 3 and 4 after migration with the program described in the text. Refer to the "Discussion" for explanation of the letters in the figure.

A final effect of migration can be seen on the northwest-dipping reflectors in the area labeled "C." In figure 4 these reflectors intersect the southeasterly dipping set of reflectors that represent the border fault. However, in figure 5 they have migrated away from the border fault and have left a nonreflective zone. This zone could be interpreted as conglomeratic rocks formed proximal to the basin margin during subsidence of the basin along an active fault.

\section{CONCLUSION}

Reflection seismology has proved to be an important tool in unraveling the structure and origins of eastern Mesozoic basins. The large number of reflection profiles already recorded over basins in the Eastern United States is testimony to this method's utility. Interpretation of unmigrated reflection sections must be done 
cautiously, and the usefulness of the data can be increased if they are migrated. Simple, inexpensive linemigration techniques provide an alternative to full waveequation migration processing, which requires a large investment in computer hardware and software. This microcomputer-based program can be applied to digitized line drawings of unmigrated reflection profiles and will enhance the utility and interpretation of the reflection data.

\section{REFERENCES CITED}

Berg, T.M., Edmunds, W.E., Geyer, A.R., Glover, A.D., Hoskins, D.M., MacLachlin, D.B., Root, S.I., Sevon, W.D., and Socolow, A.A., 1980, Geologic map of Pennsylvania: Harrisburg, Pennsylvania Department of Environmental Resources, Pennsylvania Geological Survey, 4th Series, scale $1: 250,000$.

Daniels, D.L., Zietz, I., and Popenoe, P., 1983, Distribution of subsurface lower Mesozoic rocks in the Southeastern United States as interpreted from regional aeromagnetic and gravity maps, in Gohn, G.S., ed., Studies related to the Charleston, South Carolina, earthquake of 1886; tectonics and seismicity: U.S. Geological Survey Professional Paper 1313, p. K1-K24.

Froelich, A.J., and Gottfried, D., 1985, Early Jurassic diabase sheets of the Eastern United States-A preliminary overview, in Robinson, G.R., Jr., and Froelich, A.J., eds., Proceedings of the second U.S. Geological Survey work- shop on the early Mesozoic basins of the Eastern United States: U.S. Geological Survey Circular 946, p. 79-86.

Klitgord, K.D., and Behrendt, J.D., 1979, Basin structure of the U.S. Atlantic margin, in Watkins, J.S., Montadert, L., and Dickerson, P.W., eds., Geological and geophysical investigations of the continental margins: American Association of Petroleum Geologists Memoir 29, p. 85-112.

Klitgord, K.D., and Hutchinson, D.R., 1985, Distribution and geophysical signatures of early Mesozoic rift basins beneath the U.S. Atlantic coastal margin, in Robinson, G.R., Jr., and Froelich, A.J., eds., Proceeding of the second U.S. Geological Survey workshop on the early Mesozoic basins of the Eastern United States: U.S. Geological Survey Circular 946, p. 45-61.

Lindholm, R.C., 1978, Triassic-Jurassic faulting in Eastern North America-A model based on pre-Triassic structures: Geology, v. 6, p. 365-368.

Nettleton, L.L., 1949, Geophysical prospecting for oil: New York, McGraw-Hill, 444 p.

Ratcliffe, N.M., and Burton, W.C., 1985, Fault reactivation models of the Newark basin and studies related to Eastem U.S. seismicity, in Robinson, G.R., Jr., and Froelich, A.J., eds., Proceeding of the second U.S. Geological Survey workshop on the early Mesozoic basins of the Eastern United States: U.S. Geological Survey Circular 946, p. 36-45.

Schneider, W.A., 1978, Integral formulation for migration in two and three dimensions: Geophysics, v. 43, p. 49-76.

Unger, J.D., 1986, A microcomputer program to migrate line drawings of seismic reflection sections: U.S. Geological Survey Open-File Report 86-296, 32 p.

\title{
A GEOPHYSICAL STUDY OF THE NORTHERN HARTFORD BASIN AND VICINITY, MASSACHUSETTS
}

\author{
Jeffrey D. Phillips
}

\begin{abstract}
Newly compiled digital aeromagnetic and gravity data for the early Mesozoic northern Hartford and Deerfield basins and vicinity, Massachusetts, are presented as gray-tone images and discussed in terms of known geology and inferred structure. Paired gravity and magnetic profiles extracted from the digital data have been used to construct geophysical models along two traverses across the northern Hartford basin. Aspects of the geophysical models that agree with published geologic cross sections include the dips of near-surface units, the presence of a continuous amphibolitic schist layer beneath the Connecticut Valley synclinorium, and the steep dip on the eastern border fault of the Hartford basin. Disagreement between the geophysical models and published geologic cross sections is largely restricted to the deeper structure of the Mesozoic basin; the models suggest
\end{abstract}

that a significant volume of crystalline rock, either Paleozoic metamorphic rocks or Jurassic diabase, lies directly beneath the Jurassic basalt flows in the central and eastern parts of the basin. No evidence is found for major faults within the basin paralleling the eastern border fault. The Appalachian gravity high is interpreted as being due to density variations within the upper $6 \mathrm{~km}$ of the crust, and it is shown that the gravity low over the Mesozoic basins is largely unrelated to the thickness of basin fill.

\section{INTRODUCTION}

New aeromagnetic and gravity maps have been compiled for the early Mesozoic northern Hartford basin and vicinity, Massachusetts. The data for these maps are 
in digital form, which permits them to be processed and displayed in a variety of formats, including traditional contour maps and color or gray-tone photographic images. Profiles can be rapidly extracted from the gridded data and interpreted by use of interactive gravity and magnetic anomaly modeling software. Two paired gravity and magnetic profiles across the northern Hartford basin have been interpreted in this way for comparison with published geologic cross sections. The resulting models suggest that many aspects of the published cross sections are consistent with the aeromagnetic and gravity data but that structures within the early Mesozoic basin may be more complex than the cross sections imply. The Appalachian gravity high is interpreted as being produced by Paleozoic rocks of moderately high density within the upper $6 \mathrm{~km}$ of the crust. The modeling also emphasizes those aspects of the geologic structure, in particular the dip on the eastern border fault, that cannot be adequately resolved by using gravity and magnetic data.

\section{AEROMAGNETIC DATA}

The aeromagnetic data were digitized from 36 published USGS 7.5-minute quadrangle aeromagnetic contour maps. The data for these maps were collected between 1959 and 1968 along east-west flight lines spaced approximately $0.5 \mathrm{mi}(0.8 \mathrm{~km})$ apart. All but two of the quadrangles were flown at a nominal elevation of $500 \mathrm{ft}(150 \mathrm{~m})$ above ground; the remaining two quadrangles (in the northeast corner of the area) were flown at $400 \mathrm{ft}(120 \mathrm{~m})$ above ground. Despite the decade-long data collection period and the flight elevation differences, all quadrangle maps were found to match at their joins, indicating that level adjustments were done by the original compilers. Therefore, no additional continuation or level adjustments were performed on the individual quadrangle data.

The residual aeromagnetic map (fig. 1) is presented as a continuous gray-tone image of the gridded aeromagnetic data following removal of a longwavelength field. A high-pass filter with a crossover wavelength of approximately $60 \mathrm{~km}$ was used to remove the long-wavelength field, which consisted of a high along the west side of the area and low to moderate levels elsewhere. This filtering operation was done to enhance the contrast of the image at short and intermediate wavelengths.

Although a few east-west-trending discontinuities are apparent, none of these occur at quadrangle boundaries. Truck-borne magnetometer profiles crossing the worst of these discontinuities, near latitude $42^{\circ} 15^{\prime} \mathrm{N}$., confirm that they represent errors in the initial data compilation rather than real anomalies. Such errors cannot be effectively corrected in the digitized data.
Regional features shown on the aeromagnetic map include intense linear anomalies over the CambrianOrdovician Rowe-Hawley zone (western margin of fig. 1) and over the late Proterozoic, Ordovician, and Silurian rocks of the Bronson Hill anticlinorium (eastern margin of fig. 1). Both these zones are made up primarily of schist, amphibolite, and gneiss. The major portion of the map consists of a broad, quiet zone over the Mesozoic Hartford and Deerfield basins (bounded by the white line on fig. 1), Silurian and Devonian rocks of the Connecticut Valley synclinorium west of the basins, and Proterozoic to Ordovician gneisses and quartz monzonites immediately east of the basins. Local positive magnetic anomalies are produced by Ordovician gneisses exposed in domes in the Connecticut Valley synclinorium, one of which extends under the western margin of the Hartford basin (see fig. 1 at latitude $42^{\circ} 10^{\prime} \mathrm{N}$.). The main Mesozoic border fault follows the eastern edge of the basins, except in the vicinity of the Deerfield-Hartford join where two Paleozoic inliers are found west of the border fault. The western edge of the Hartford basin is also faulted.

The exposed basalt flows in the Hartford and Deerficld basins produce arcuate paired high-low anomalies. There is evidence for additional shallow magnetic sources within the basins east of the basalt flows. The Mesozoic Pelham diabase dike (P on fig. 1) is evident as it trends northeastward from the eastern border fault between the two inliers. A nearly straight line can be drawn through three small, strong circular magnetic highs within the basins $(\mathrm{C} 1, \mathrm{C} 2, \mathrm{C} 3$ in fig. 1) and also marks the easternmost extent of thick basalt within the Deerfield basin. This line may represent a structure that controlled local intrusion and volcanism within the basins. The second of the three anomalies ( $\mathrm{C} 2$ on fig. 1 ) is associated with a mapped Jurassic basaltic breccia cone deposit, which predates the overlying flows (Bain, 1941). The sources of the other two anomalies are not known.

\section{Gravity Data}

Department of Defense gravity data were edited and supplemented by three new gravity data sets. Burger (1984) reported on 734 gravity measurements in seven 7.5-minute quadrangles covering the northern portion of the Hartford basin, the southern portion of the Deerfield basin, and portions of the Connecticut Valley synclinorium immediately west of the basins. Bond and Phillips (1986) reported on $\mathbf{3 1 4}$ gravity measurements at the southeastern and southwestern margins of the Hartford basin in Massachusetts, and in the adjacent gneiss belts. Two hundred seventy-four gravity measurements recovered from an unpublished senior thesis by an Amherst student (Ellen, 1964) were also used. These measurements covered the central and western Deerfield 


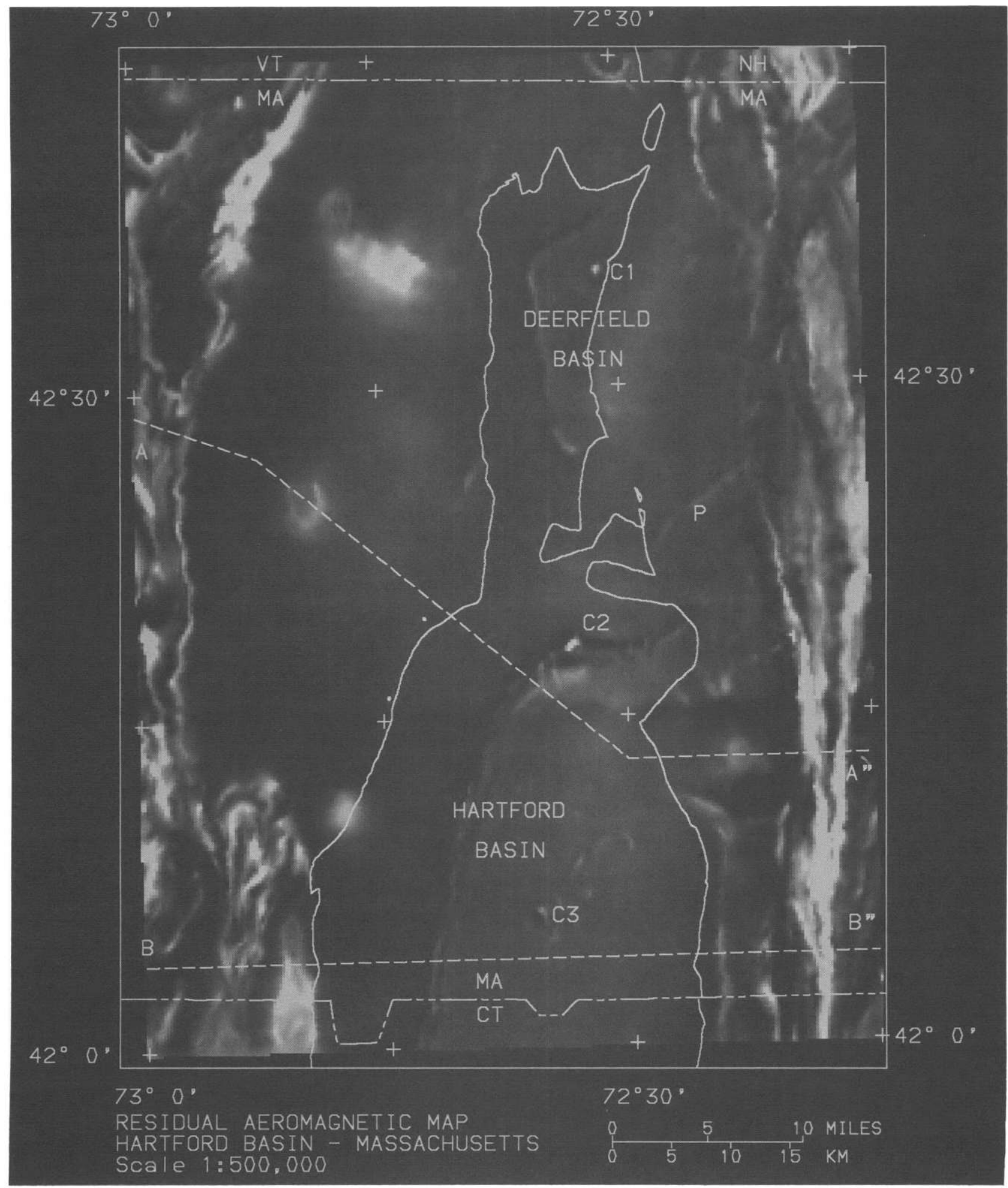

Figure 1. The residual aeromagnetic map of the Hartford and Deerfield basins shown as a continuous gray-tone image. Displayed intensities range from -177 nanoteslas (nT) (black) to $+357 \mathrm{nT}$ (white). The solid line encloses the two basins. The locations of profiles A-A" and B-B" (see figs. 4-7 and text) are indicated by dashed lines. C1, C2, and $\mathrm{C} 3$ are aligned circular highs. $P$ indicates the Mesozoic Pelham diabase dike. 
basin and the adjacent Connecticut Valley synclinorium. A reduction density of $2.67 \mathrm{~g} / \mathrm{cm}^{3}$ was used to compute complete Bouguer gravity anomalies for all gravity stations (fig. 2). Terrain corrections were computed to within $0.895 \mathrm{~km}$ of the stations by use of digital terrain data.

The gravity map (fig. 3 ) is contoured in 12 shades of gray. The contour interval is variable; levels were chosen to equalize the area for each shade. The map is dominated by (1) the Appalachian gravity high, which enters at the southwest corner of the area and trends north-northeast over the Connecticut Valley synclinorium, and (2) the high over the southern Bronson Hill anticlinorium on the eastern edge of the area. Lows occur over the northern Rowe-Hawley zone to the west of the Appalachian gravity high, over the Deerfield basin and the northern Bronson Hill anticlinorium, and over the northern and eastern portions of the Hartford basin. Local gravity lows are seen over some of the gneiss domes (G1, G2, and G3 in fig. 3) in the Connecticut Valley synclinorium, and local highs define the basement ridge between the Hartford and Deerfield basins.

The Appalachian gravity high forms the eastern edge of a west-sloping gravity gradient that extends the entire length of the Appalachians. The gravity high has been postulated to be a Mesozoic hinge zone (Griscom, 1962; Diment, 1968). As evidence for this, strata within exposed Mesozoic basins are tilted away from the gravity high, and the basins have their main border faults on the side farthest away from the gravity high. The sources of the Appalachian gravity high and its flanking low to the west are unknown. Diment (1968) used deep sources, including crustal thickness variations and an uplifted lower crustal layer, to model the gravity anomaly in New England. Hutchinson and others (1983) used crustal thickening to explain the low and preferred using a suture-zone model to explain the high in the southern Appalachians. Other models such as a shallow, dense body or a wedge of transitional crust have recently been put forward to explain the gravity high in the northern Appalachians (D. Daniels, personal commun., 1987).

The southwestern part of the Hartford basin in Massachusetts is coincident with a broad gravity high that suggests the basin is relatively shallow in this area and may overlie a flat or upwarped basement. A sharp change in gradient (L1-L2 in fig. 3) separates this gravity high from the Appalachian gravity high to the west. This change in gradient is a linear feature that is roughly on trend with the western margin of the Deerfield basin and thus may represent a fault. The basalt exposures in the Hartford basin produce a parallel local gravity high that helps emphasize this change in gradient. The gravity low along the eastern margin of the Hartford basin extends into Connecticut and might be expected to be due to increased thickness of Mesozoic basin fill along the main border fault. Model studies suggest that this is unlikely to be the sole cause. A low-density Paleozoic unit, probably either gneiss or schist, must underlie the border fault in order to fit the observed anomaly.

\section{Model Studies}

It is well known that geologic models based on gravity and magnetic fields are nonunique because many different models can be made to fit the observed data. However, a geologic model that fits the gravity and magnetic data is probably a better representation than one that does not. Also, ambiguities in the geologic interpretation identified through gravity and magnetic modeling can often be instructive.

In the northern Hartford basin, geologic models can be constrained by the mapped geology, the gravity and magnetic fields, and knowledge of characteristic densities and magnetic susceptibilities for various lithologies. Certain critical information is missing, and this contributes to the nonuniqueness of the resulting models. Included in this category are the actual densities and susceptibilities, the thickness of the basins, the basement lithology beneath the basins, and the density distribution within the deeper crust.

Gravity and magnetic models have been constructed along two traverses crossing the Hartford basin. Profile B-B' ${ }^{\prime \prime}$ crosses the basin in southern Massachusetts and was chosen to test geologic cross section $F \sim F^{\prime}$ on the geologic map of Massachusetts (Zen, 1983) and cross section $\mathrm{A}-\mathrm{A}^{\prime}$ on the geologic map of Connecticut (Rodgers, 1985). Profile A-A" crosses the northern end of the Hartford basin and has been designed to test geologic cross section $\mathrm{D}^{-\mathrm{D}^{\prime}}$ on the Massachusetts map. The locations of the gravity and magnetic profiles do not correspond exactly to the locations of the geologic cross sections but instead were chosen to intersect the gravity and magnetic contours at high angles, as required by the 21/2-D modeling software (Webring, 1985).

The Mesozoic basins in this area should have a significant effect on the gravity anomalies. In Massachusetts and northern Connecticut, Mesozoic arkose typically has a density range of 2.50 to $2.55 \mathrm{~g} / \mathrm{cm}^{3}$, Mesozoic basalt typically has a density of 2.90 to $2.93 \mathrm{~g} / \mathrm{cm}^{3}$, and undifferentiated Paleozoic rocks typically have a density of $2.75 \mathrm{~g} / \mathrm{cm}^{3}$ (Banks, 1982; Longwell, 1943). Two singlebody models having uniform density contrasts of -0.20 $\mathrm{g} / \mathrm{cm}^{3}$ were constructed to show the effects of the postulated basin cross sections taken from the Massachusetts and Connecticut geologic maps on the gravity anomaly along profile B-B" (fig. $4 A, B$ ). Gravity anomalies computed from the two models are similar in that both appear to overestimate the thickness of the central part of the basin, and both have minima located to the west of 


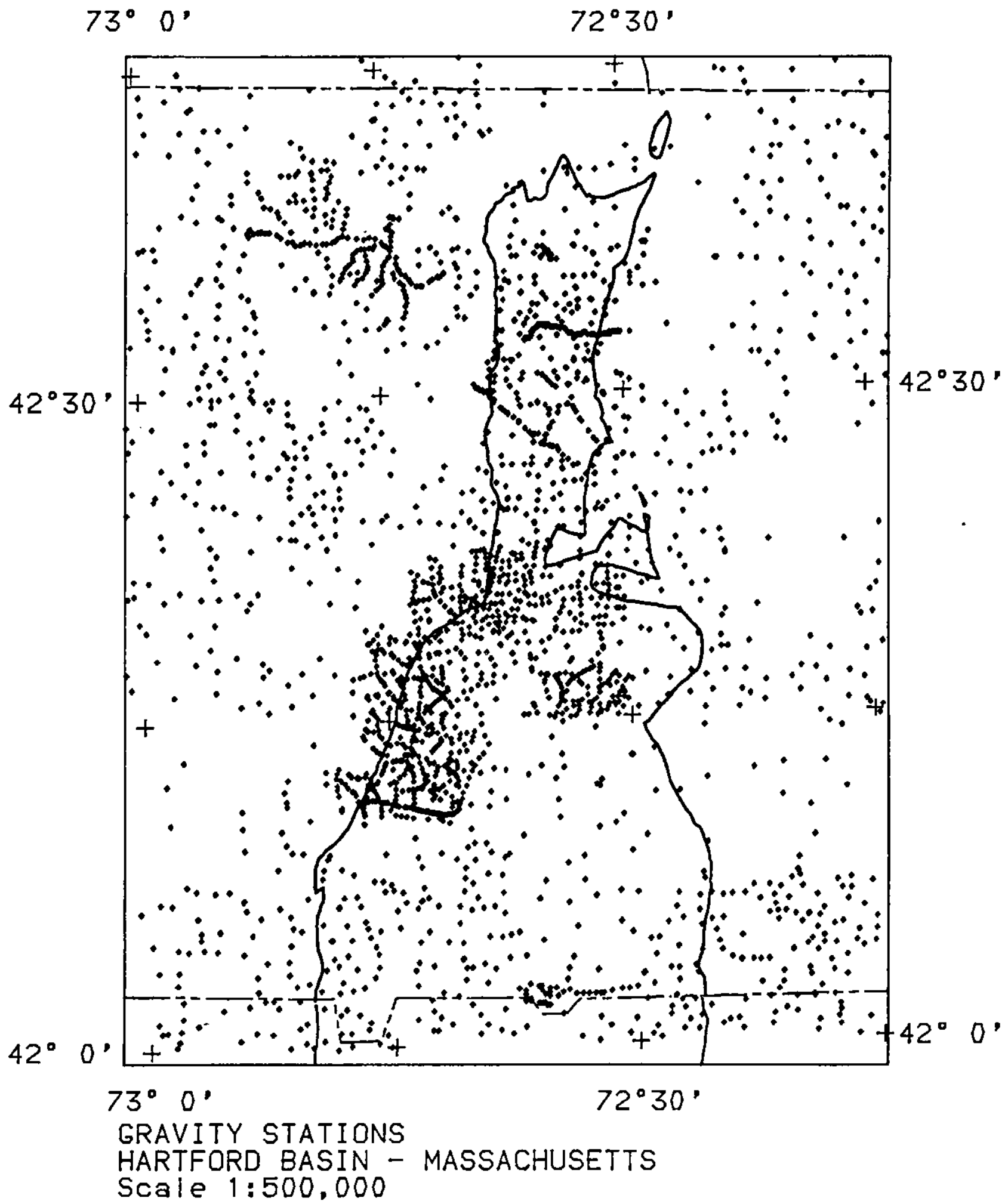

Figure 2. Gravity stations used in this study of the Hartford and Deerfield basins and vicinity, Massachusetts (scale $1: 500,000)$. 


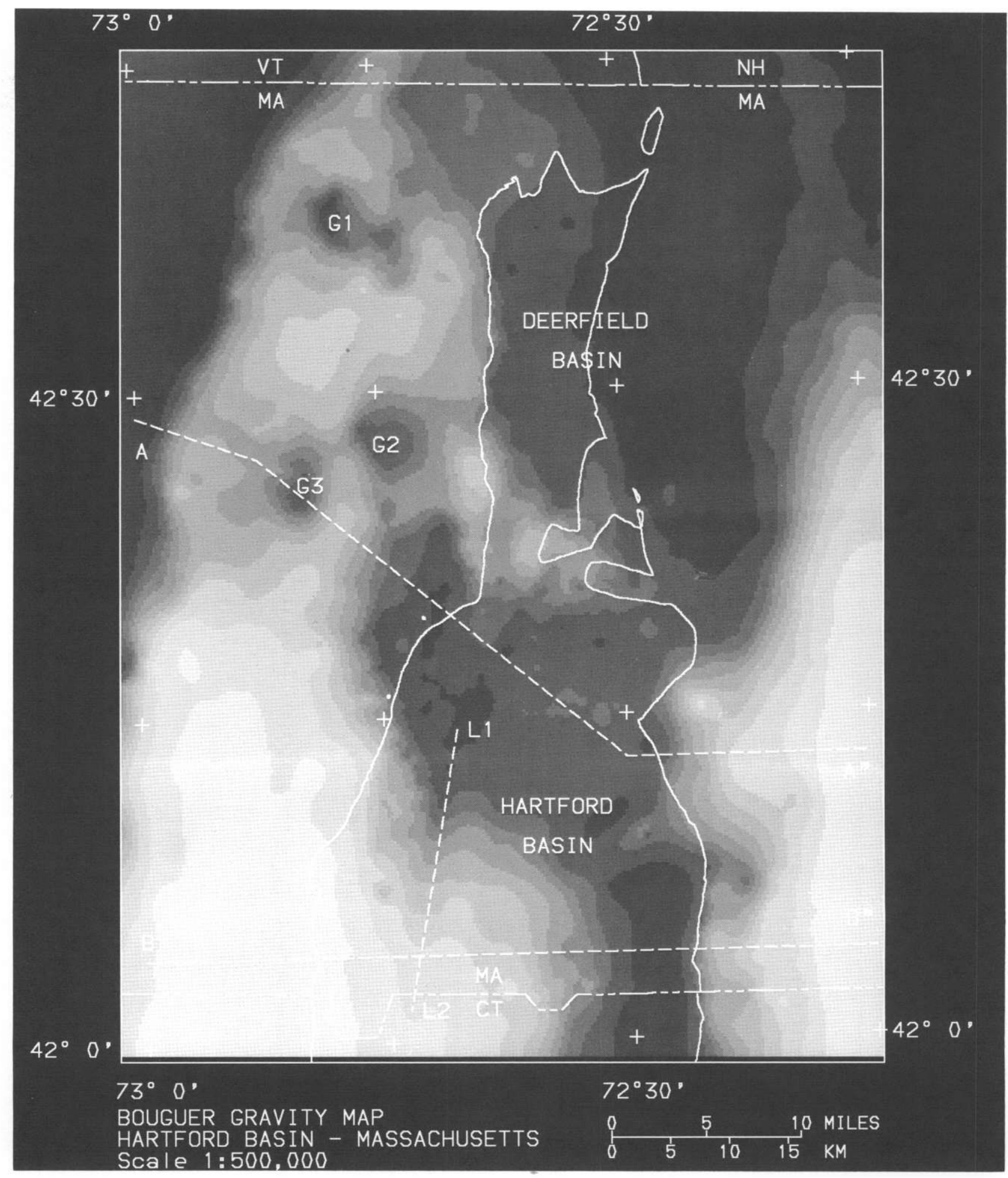

Figure 3. The Bouguer gravity map of the study area shown as a shaded contoured image. The contour interval is variable. Displayed intensities range from -33 milligals (mGals) (black) to +16 mGals (white). G1, G2, and G3 are low-density gneiss domes within the Connecticut Valley synclinorium. L1-L2 defines a break in the gravity gradient. The locations of profiles A-A' and B-B" (see figs. 4-7 and text) are indicated by dashed lines. 

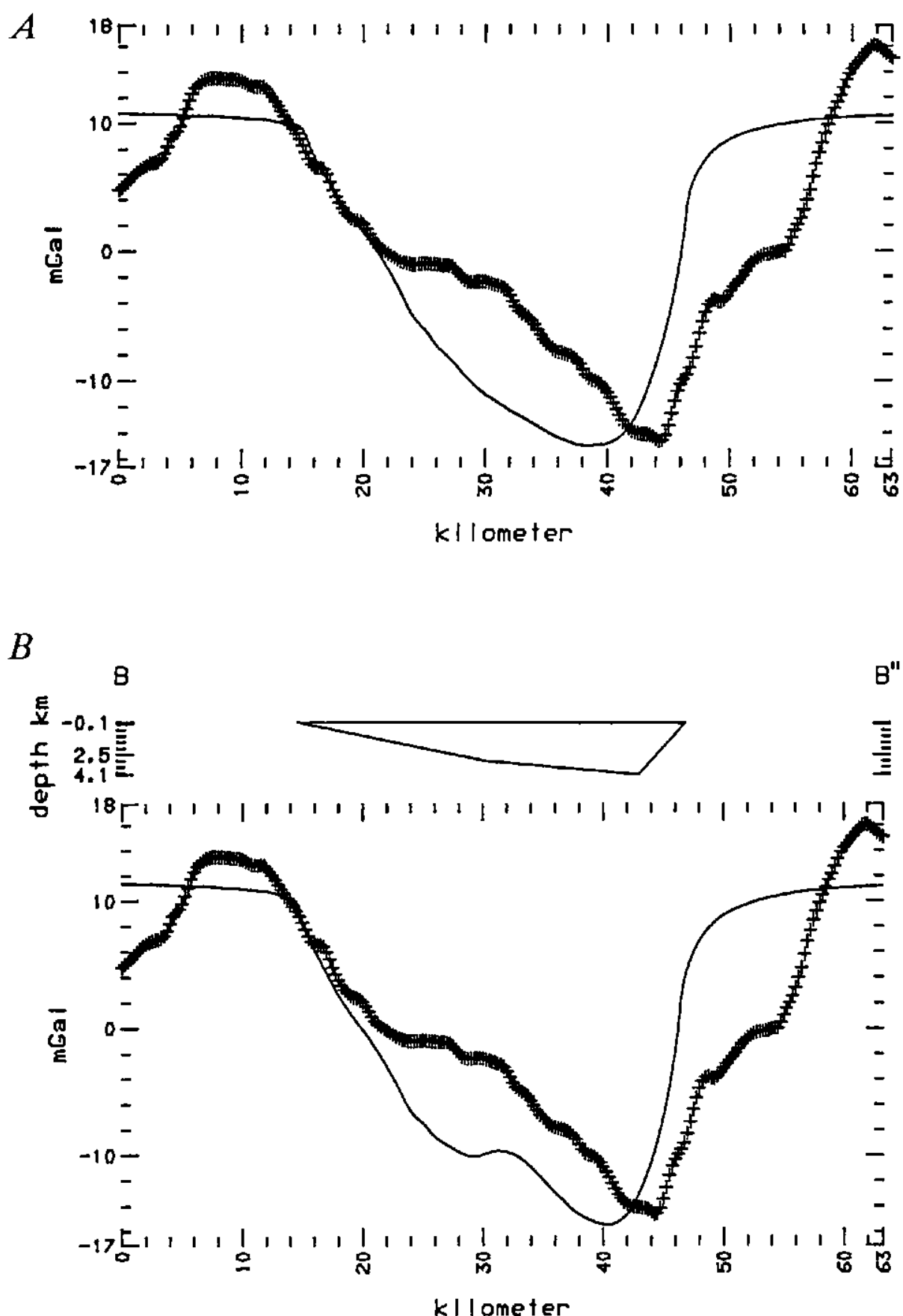

$B$

B"

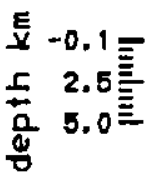

$\bar{E}$

Figure 4. Anticipated effect of the Hartford basin on the gravity anomaly along profile $B-B^{\prime \prime}$. A, Basin cross section generalized from the Massachusetts State geological map. $B$, Basin cross section generalized from the Connecticut State geological map. Computed anomalies are shown as solid curves; observed anomalies are shown as plus signs. A density contrast of $0.2 \mathrm{~g} / \mathrm{cm}^{3}$ was used. 

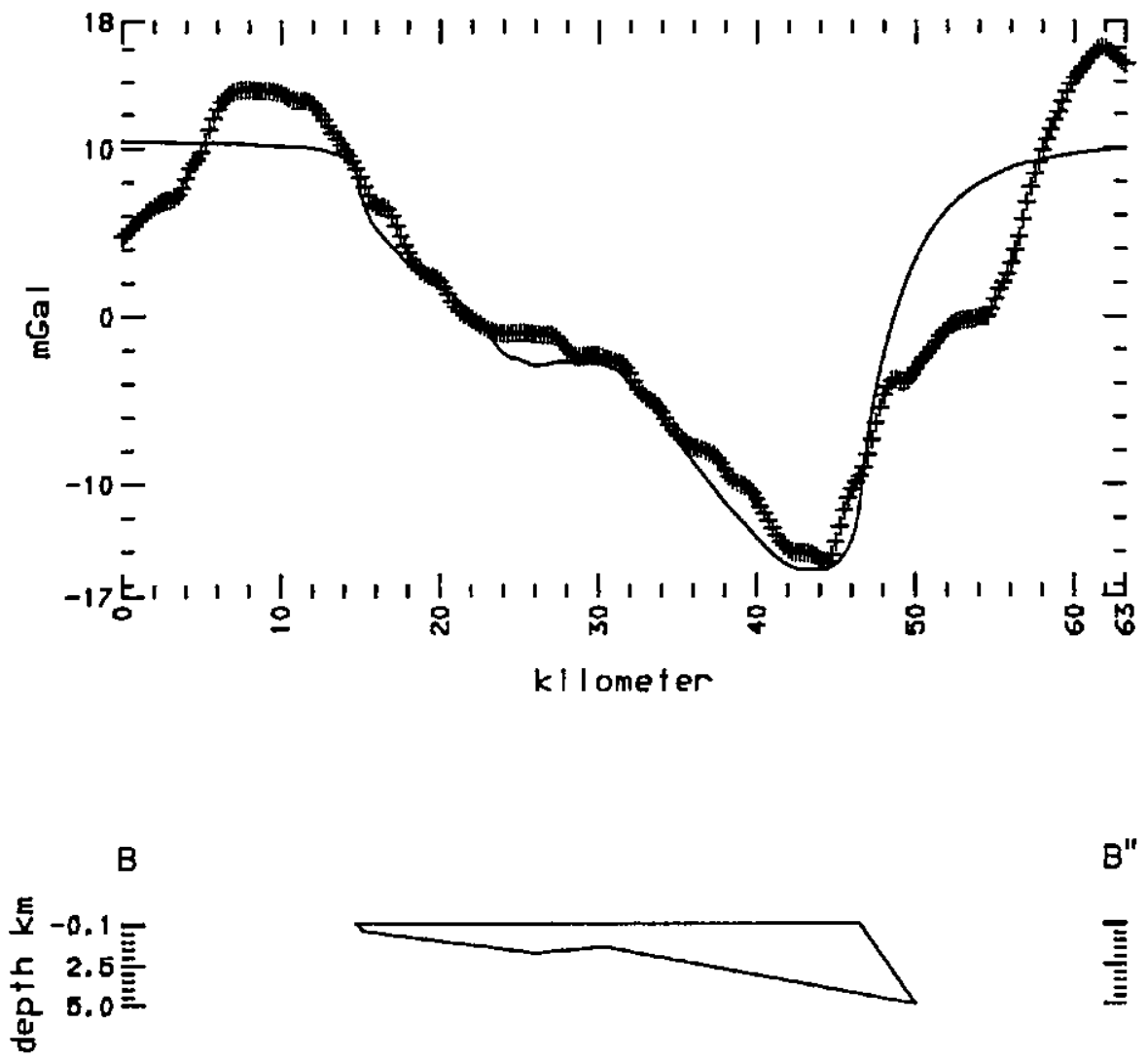

Figure 5. A hypothetical basinal cross section that provides a better fit to the gravity anomaly along profile B-B" than either State geologic map. A density contrast of 0.2 $\mathrm{g} / \mathrm{cm}^{3}$ was used.

the observed gravity low. To provide a better fit to the observed anomaly when using a single density contrast, it is necessary to thin the central part of the basin and reverse the dip on the eastern border fault (fig. 5). It seems unlikely that the eastern border fault dips to the east, because this is contrary to all known observations. A more likely explanation is that the position of the gravity low is controlled by a low-density Paleozoic gneiss or schist underlying the west-dipping border fault.

A more elaborate model, which attempts to fit both the gravity and aeromagnetic observations, has been constructed for profile B-B" (fig. 6, table 1). In this model the Appalachian gravity high is produced by moderately high-density Paleozoic schist and gneiss units (bodies 2 through 6) that extend to depths of about $6 \mathrm{~km}$. These units are contrasted with lower density Proterozoic gneiss and schist units on the west (body 1) and with Paleozoic rocks of average density on the east. The high-density gneiss units are also strongly magnetic (bodies 3, 4, and 6). The Mesozoic units used in the model include low-density nonmagnetic arkoses (bodies 7 and 9); moderately high-density magnetic basalts interbedded with arkose (body 8 ); a buried low-density mag- netic unit (body 10), which could be either a combination of basalt and arkose or part of the Paleozoic basement; a buried high-density magnetic unit (body 11 ), which could be either a diabase sill (if denser and thinner than modeled) or a unit within the Paleozoic basement; and a buried low-density nonmagnetic unit (body 12) that could either be Mesozoic arkose or a combination of arkose with Paleozoic schist or gneiss. Depending on the composition of body 12 , the basin reaches a maximum thickness of between 6 and $8 \mathrm{~km}$ beneath the gravity low. A low-density body that coincides with a Devonian schist at the surface (body 13) adjoins the eastern border fault and accounts for the eastward extent of the gravity low. Additional low-density units corresponding to mapped Paleozoic gneiss, schist, and amphibolite (bodies 14 through 17) extend to the east to a contact with gneiss of average density (Monson Gneiss, body 18 ) and moderately high-density schists (body 19) over the axis of the Bronson Hill anticlinorium at the eastern end of the profile. The amphibolite units (Ammonoosuc Volcanics) and the Monson Gneiss produce positive magnetic anomalies. Most Paleozoic units to the east of the Mesozoic basin are modeled as being truncated at a depth of about $5 \mathrm{~km}$. 

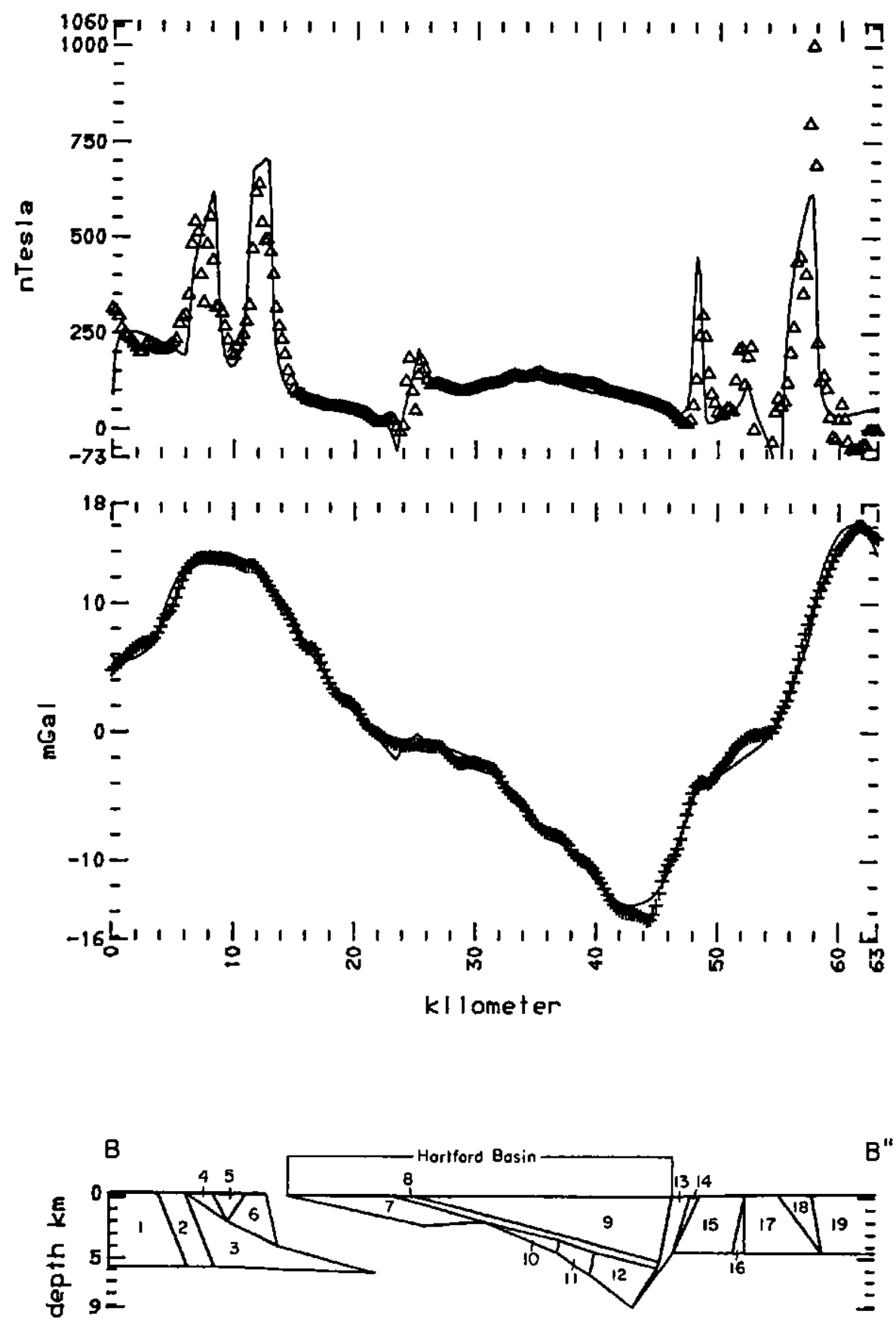

Figure 6. A more elaborate geophysical model for cross section B-B"'. Computed gravity (top) and magnetic (bottom) anomalies are shown as solid lines and are compared to the observed anomalies (plus signs and triangles). The modeled physical properties of bodies numbered B-1 through B-19 are given in table 1.

The model for cross section A-A" (fig. 7, table 2) includes the northern end of the Hartford basin and folded Paleozoic rocks of the Connecticut Valley synclinorium. At the western end of the section, a buried body having extremely low density and high magnetic susceptibility (body 1) is used to model the sharp gravity low/aeromagnetic high at the western edge of the Appalachian gravity high. The Appalachian gravity high is modeled by assigning high densities to exposed Devonian schists of the Connecticut Valley synclinorium (bodies 4 and 8 ). These units are underlain by an extensive, folded, magnetic, amphibolitic schist layer (Hawley, Cobble Mountain, and Partridge Formations, bodies 3, 5, and 7) and a magnetic low-density gneiss (body 6), both of Ordovician age. The gneiss is truncated in the model at a depth of $6 \mathrm{~km}$. At the eastern edge of the Connecticut 
Table 1. Parameters for model constructed for profile B-B" , Hartford and Deerfield basins

\begin{tabular}{|c|c|c|c|c|}
\hline Body number & $\begin{array}{l}\text { Density contrast } \\
\left(\mathrm{g} / \mathrm{cm}^{3}\right)\end{array}$ & $\begin{array}{l}\text { Susceptibility } \\
\text { contrast } \\
\text { (cgs units) }\end{array}$ & $\begin{array}{l}\text { Y-extent }{ }^{1} \\
(\mathrm{~km})\end{array}$ & Rock type (and age) \\
\hline$\ldots \ldots \ldots$ & -0.02 & 0.001 & \pm 8.0 & schist and gneiss (middle Proterozoic) \\
\hline$\ldots \ldots \ldots \ldots$ & .06 & .001 & \pm 8.0 & schist (Cambrian) \\
\hline$B-3 \ldots \ldots \ldots \ldots$ & .06 & .002 & \pm 8.0 & gneiss? (Ordovician) \\
\hline $\mathrm{B}-4 \ldots \ldots \ldots \ldots$ & .05 & .002 & \pm 8.0 & gneiss (Ordovician) \\
\hline$B-5 \ldots \ldots \ldots \ldots$ & .02 & .0 & \pm 8.0 & schist (Devonian) \\
\hline B-6 $\ldots \ldots \ldots \ldots \ldots$ & .04 & .002 & \pm 8.0 & gneiss (Ordovician) \\
\hline B-7. & -.13 & .0 & \pm 25.0 & arkose (Triassic) \\
\hline B-8. & .05 & .002 & \pm 25.0 & basalt/arkose (Jurassic) \\
\hline B-9. & -.13 & .0 & \pm 25.0 & arkose (Jurassic) \\
\hline $\mathrm{B}-10 \ldots \ldots \ldots \ldots$ & -.13 & .002 & \pm 25.0 & arkose? (Triassic) \\
\hline $\mathrm{B}-11 \ldots \ldots \ldots \ldots$ & .20 & .002 & \pm 25.0 & diabase? (Jurassic) \\
\hline $\mathrm{B}-12 \ldots \ldots \ldots \ldots$ & -.13 & .0 & \pm 25.0 & arkose? (Triassic) \\
\hline $\mathrm{B}-13 \ldots \ldots \ldots \ldots$ & -.075 & .0 & \pm 25.0 & schist (Devonian) \\
\hline $\mathrm{B}-14 \ldots \ldots \ldots \ldots$ & -.01 & .002 & \pm 25.0 & amphibolite (Ordovician) \\
\hline $\mathrm{B}-15 \ldots \ldots \ldots \ldots$ & -.05 & .0 & \pm 25.0 & gneiss (Ordovician) \\
\hline $\mathrm{B}-16 \ldots \ldots \ldots \ldots$ & -.03 & .002 & \pm 25.0 & amphibolite (Ordovician) \\
\hline B-17. & -.05 & .0 & \pm 25.0 & schist/quartzite (Devonian-Silurian) \\
\hline $\mathrm{B}-18 \ldots \ldots \ldots \ldots$ & .0 & .0023 & \pm 25.0 & gneiss (Ordovician) \\
\hline $\mathrm{B}-19 \ldots \ldots \ldots \ldots$ & .10 & .0 & \pm 25.0 & schist (Ordovician-Devonian) \\
\hline
\end{tabular}

${ }^{1}$ Y-extent is the distance the body extends out of the plane of the section.

Valley synclinorium, the amphibolite layer (body 7) is folded back on itself, forming a tight anticline. The position of the eastern limb of the anticline is not known but is assumed to lie directly below the western limb and thus does not appear as a separate body in the model. Low-density Devonian schist (body 10) is found east of this anticlinal crest. A buried high-density Devonian gneiss (body 11) lies under the western edge of the Hartford basin. This body corresponds to the Belchertown Complex, which is exposed north of the line of section and also on the eastern margin of the basin (body 19). The Mesozoic arkose units (12 and 14) and interbedded basalts and arkoses (body 13) define the Hartford basin. The eastern part of the basin may be intruded at depth by two diabase units, a magnetic diabase on the west (body 15) and a nonmagnetic diabase on the east (body 16). The modeled density of these bodies is low for diabase; therefore, their thicknesses may be exaggerated. Alternatively, these bodies may represent sources within the Paleozoic basement. Although no diabase is exposed in the northern Hartford or Deerfield basins, diabase is known to underlie basalts in the southern Hartford basin and in other early Mesozoic basins. The computed gravity anomaly over the western part of the basin does not match the short-wavelength features of the observed gravity; this implies that there are significant unmodeled density variations within the Paleozoic basement. At the eastern edge of the basin, a buried low-density Paleozoic unit (17) is required to match the position of the observed gravity low. The modeled maximum thickness of the sedimentary units within the basin along this cross section is about $3 \mathrm{~km}$. Unknown density and magnetic susceptibility variations within the Paleozoic rocks underlying the basin, which have largely been ignored in the model, could affect the configuration of the deeper parts of the basin. East of the basin, a buried gneiss unit (body 18) has been interpreted from the aeromagnetic map, and increasing densities in the Paleozoic gneisses and schists (bodies 20 through 24) are used to fit the gravity high over the Bronson Hill anticlinorium. The magnetic anomalies in this region are explained as being due to magnetic Ordovician gneisses (bodies 18, 21, and 23) contrasting with belts of nonmagnetic Devonian gneiss (body 20) and Ordovician schist (bodies 22 and 24).

Although the gravity low has essentially the same minimum value along lines $\mathrm{B}-\mathrm{B}^{\prime \prime}$ and $\mathrm{A}-\mathrm{A}^{\prime \prime}$, the modeled maximum thickness of the basin is quite different along the two lines. At first this appears to be a contradiction; as the gravity low is the same, the basin should have the same thickness along both lines. However, careful examination of the portion of gravity profile A-A" directly over the exposed Mesozoic units shows that there is almost no net effect of the basin on the gravity anomaly. This is accommodated in the model by using buried diabase to offset the gravity effect of the low-density arkose. Similar examination of gravity profile B-B" shows that the position of the basin correlates with a local negative gravity anomaly along this line, although its amplitude is small relative to the overall gravity low. Three conclusions may be drawn: (1) despite similar gravity minima along the two profiles, the basin is probably thicker under profile B-B"; (2) there must be a regional gravity gradient plunging to the north between 

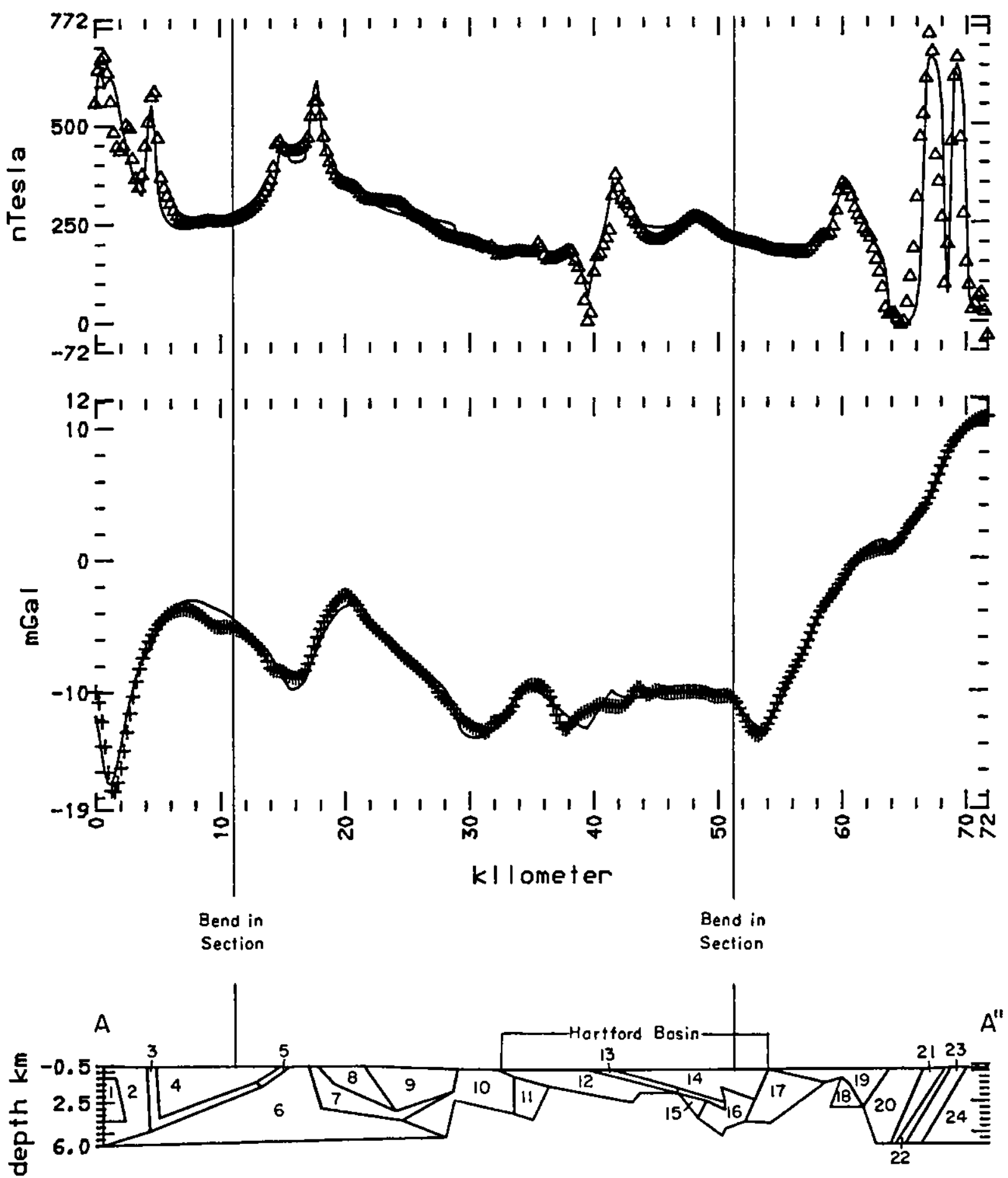

Figure 7. A geophysical model for cross section A-A". Computed gravity (top) and magnetic (bottom) anomalies are shown as solid lines and are compared to the observed anomalies (plus signs and triangles). The modeled physical properties of bodies A-1 through A-24 are given in table 2 .

the two lines; and (3) the deep-basin unit of model B-B" (body 12) could probably be reduced in thickness if it were partially replaced by low-density Paleozoic rocks (for example, body 13).

The model studies have borne out many aspects of recently published geologic cross sections across the
Hartford basin and adjacent terranes. In particular, geophysical model section $\mathrm{A}-\mathrm{A}^{\prime \prime}$ supports the idea that a continuous amphibolitic schist layer (fig. 7 and table 2, bodies 3,5 , and 7) may underlie the Devonian rocks of the Connecticut Valley synclinorium. This layer is exposed along the western margin of the synclinorium, 
Table 2. Parameters for model constructed for profile $A-A^{\prime \prime}$, Hartford and Deerfield basins

\begin{tabular}{|c|c|c|c|c|}
\hline Body number & $\begin{array}{l}\text { Density contrast } \\
\left(\mathrm{g} / \mathrm{cm}^{3}\right)\end{array}$ & $\begin{array}{c}\text { Susceptibility } \\
\text { contrast } \\
\text { (cgs units) }\end{array}$ & $\begin{array}{l}\text { Y-extent } \\
(\mathrm{km})\end{array}$ & Rock type (and age) \\
\hline$\ldots \ldots \ldots$ & -0.75 & 0.0047 & \pm 25.0 & unknown \\
\hline$\ldots \ldots$ & .05 & .00056 & \pm 25.0 & schist (Ordovician) \\
\hline$\ldots \ldots \ldots$ & .0 & .0015 & \pm 25.0 & schist/amphibolite (Ordovician) \\
\hline$\ldots \ldots \ldots$ & .04 & .0003 & \pm 25.0 & schist (Devonian) \\
\hline$\ldots \ldots \ldots$ & .0 & .0012 & \pm 2.5 & schist/amphibolite (Ordovician) \\
\hline A-6. & -.06 & .001 & \pm 2.5 & gneiss (Ordovician) \\
\hline A-7. & .0 & .0015 & \pm 2.5 & schist/amphibolite (Ordovician) \\
\hline A-8. & .05 & .00029 & \pm 10.0 & schist (Devonian) \\
\hline A-9. & -.01 & .00023 & \pm 10.0 & schist (Devonian) \\
\hline A-10. & -.10 & .0 & \pm 20.0 & schist (Devonian) \\
\hline $\mathrm{A}-11 \ldots \ldots \ldots \ldots$ & .05 & .0 & \pm 25.0 & gneiss (Devonian) \\
\hline $\mathrm{A}-12 \ldots \ldots \ldots \ldots$ & -.13 & .0 & \pm 25.0 & arkose (Triassic) \\
\hline A-13. & .05 & .002 & \pm 7.0 & basalt/arkose (Jurassic) \\
\hline$A-14 \ldots$ & -.13 & .0 & \pm 7.0 & arkose (Jurassic) \\
\hline $\mathrm{A}-15 \ldots \ldots \ldots \ldots$ & .10 & .0014 & \pm 5.0 & diabase? (Jurassic) \\
\hline$A-16 \ldots$ & .1115 & .0 & \pm 7.0 & diabase? (Jurassic) \\
\hline$A-17 \ldots$ & -.11 & .0 & \pm 7.0 & gneiss? (Devonian) \\
\hline$A-18 \ldots \ldots \ldots \ldots$ & -.05 & .002 & \pm 2.0 & gneiss? (Ordovician) \\
\hline A-19. & .05 & .0 & \pm 5.0 & monzodiorite (Devonian) \\
\hline A-20. & .013 & -.0007 & \pm 10.0 & gneiss (Devonian) \\
\hline A-21. & .02 & .002 & \pm 10.0 & gneiss (Ordovician) \\
\hline A-22. & .04 & -.0015 & \pm 10.0 & schist (Ordovician) \\
\hline A-23... & .07 & .002 & \pm 10.0 & $\begin{array}{l}\text { gneiss (Ordovician-Cambrian- } \\
\text { late Proterozoic) }\end{array}$ \\
\hline A-24. & .09 & -.0006 & \pm 10.0 & schist (Ordovician-Devonian) \\
\hline
\end{tabular}

${ }^{1} \mathrm{Y}$-extent is the distance the body extends out of the plane of the section.

around Ordovician cored gneiss domes that breach the Devonian rocks, and within a tight fold near the western border of the Hartford basin. Model section A-A" also supports the idea that Devonian gneiss (body 11) of the Belchertown Complex extends south beneath the northwestern edge of the Hartford basin. On the western end of model section B-B", the Ordovician gneisses plunge to the east, in agreement with Massachusetts geologic cross section F-F'. These two sections also agree on the maximum basin thickness of about $7 \mathrm{~km}$. The presence of a steep eastern border fault, as shown on both geophysical model sections, is in agreement with Connecticut geologic cross section $\mathrm{A}-\mathrm{A}^{\prime}$. To the east of the Hartford basin, geophysical model section $\mathrm{A}-\mathrm{A}^{\prime \prime}$ and Massachusetts geologic cross section D-D' agree on the general direction of dip of the contacts and on the flattening of the contacts or truncation of the units at depth. On Connecticut geologic cross section $\mathrm{A}-\mathrm{A}^{\prime}$, this truncation takes the form of an extensive decollement, which is in agreement with both geophysical model sections.

As shown by comparison of figure 4 with figure 5 , the deep structure of the Mesozoic basin is the major area of disagreement between the geological cross sections and the geophysical models. Both the Massachusetts and Connecticut geologic cross sections show a uniformly thick Triassic arkose unit (the New Haven Arkose) extending to the eastern border fault beneath the basalt flows. The geophysical models suggest that the central and easternmost parts of this unit should be replaced by crystalline rocks: Paleozoic basement rocks under the axis of the basin, and either Paleozoic rocks or thin Jurassic diabase bodies farther to the east. In the models, a steeply dipping border fault was used to minimize the volume of the adjacent low-density Paleozoic unit needed to fit the gravity low. A shallow-dipping or listric border fault, such as that indicated on the Massachusetts geologic cross sections, would tend to require a much larger, and therefore less believable, low-density body underlying the fault. The dip and nature of the border fault, however, are not well constrained by the geophysical data. There is little evidence in the geophysical data or the models for major faults within the basin paralleling the eastern border fault, such as the one indicated on the Connecticut geologic cross section (see fig. $4 B$ ). Such faults would produce clear anomalies on the aeromagnetic and gravity maps.

Another area of disagreement between the geophysical and geological sections concerns the nature of the base of the exposed units to the west of the basins. The Massachusetts geologic cross section shows these units 
plunging to depths in excess of $10 \mathrm{~km}$ consistent with their near-vertical contacts. The geophysical models, on the other hand, suggest that these units are truncated at depth along a decollement analogous to the one assumed to truncate the units east of the basins.

The geophysical model studies have shown that the Appalachian gravity high in Massachusetts can be explained by assigning appropriate density contrasts and thicknesses to exposed Paleozoic rocks. "Holes" seen in the gravity high, which correspond with Ordovician gneisses domed up through the Devonian rocks of the Connecticut Valley synclinorium, provide particularly convincing evidence that this explanation is viable. The geophysical maps and model studies have also suggested that at different places along the trend of the gravity high, vastly different, but similarly dense, rock units are associated with the high. As a corollary, a rock unit associated with the gravity high in one place may have no such association in another place farther along the strike of the same rock unit. Thus, in southern Massachusetts the high is associated with the gneisses and schists of the RoweHawley zone, whereas in northern Massachusetts these same units are correlative with a gravity low on the western side of the gravity high. In central Massachusetts the gravity high appears to be produced by Devonian rocks of the Connecticut Valley synclinorium, but in Vermont the same rocks are associated with a gravity low on the eastern side of the high.

In order to test the idea that the Appalachian gravity high is associated with along-strike density variations of exposed and upper-crustal Paleozoic rocks, and in order to test other aspects of the geophysical models developed here, it would be necessary to collect a great many density and rock magnetic measurements in Massachusetts. Also pertinent would be more geophysical work with seismic reflection, seismic refraction, and electrical methods to help understand the possible configurations and compositions of the Mesozoic rocks.

\section{REFERENCES CITED}

Bain, G.W., 1941, The Holyoke Range and Connecticut Valley structure: American Journal of Science, v. 239, no. 4, p. 261-275.

Banks, W., 1982, Detailed gravity profile and structural interpretation of the Mesozoic basin of northern Connecticut: M.S. thesis, University of Connecticut.

Bond, K.R., and Phillips, J.D., 1986, Principal facts for gravity stations in Hampden and Hampshire Counties, southwest Massachusetts: U.S. Geological Survey Open-File Report 86-218, 12 p.

Burger, R.H., 1984, Principal facts for gravity stations in part of west-central Massachusetts: U.S. Geological Survey OpenFile Report 84-636, 19 p.

Diment, W.H., 1968, Gravity anomalies in northwestern New England, in Zen, E-an, White, W.S., Hadley, J.B., and Thompson, J.B., Jr., eds., Studies of Appalachian geology: Northern and maritime: Interscience Publishers, New York, p. 399-413.

Ellen, S.D., 1964, A gravity survey of the northern Connecticut Valley Triassic basin: Senior thesis, Amherst College, $68 \mathrm{p}$.

Griscom, A., 1962, Tectonic significance of the Bouguer gravity field of the Appalachian system (abs.): Geological Society of America Special Paper 73, p. 163-164.

Hutchinson, D.R., Grow, J.A., and Klitgord, K.D., 1983, Crustal structure beneath the southern Appalachians: Nonuniqueness of gravity modeling: Geology, v. 11, p. 611-615.

Longwell, C.R., 1943, Geologic interpretation of gravity anomalies in the southern New England-Hudson Valley region: Geological Society of America Bulletin, v. 54, p. 555-590.

Rodgers, J., 1985, Bedrock geological map of Connecticut: Connecticut Geological and Natural History Survey, scale 1:125,000, 2 sheets.

Webring, M.W., 1985, SAKI: A Fortran program for generalized linear inversion of gravity and magnetic profiles: U.S. Geological Survey Open-File Report 85-122, 104 p.

Zen, E-an, 1983, Bedrock geologic map of Massachusetts: U.S. Geological Survey, scale 1:250,000, 3 sheets. 


\title{
BURIED STRUCTURES AT THE NORTHERN END OF THE EARLY MESOZOIC SOUTH GEORGIA BASIN, SOUTH CAROLINA, AS INTERPRETED FROM AEROMAGNETIC DATA
}

\author{
Jeffrey D. Phillips
}

\begin{abstract}
Illuminated and edge-enhanced gray-scale aeromagnetic images are used to map buried structures beneath the South Carolina Coastal Plain and to explore their relationship to seismicity. Border faults and diabase intrusions associated with the early Mesozoic South Georgia basin are evident in the images, as are an apparent fault that follows the coastline and a circular feature $31 \mathrm{mi}(50 \mathrm{~km})$ in diameter, which may be a Paleozoic impact crater or caldera structure. Present-day seismicity near Summerville, South Carolina, which is not reflected by surface faulting, is localized at the intersection of this circular feature and one of the Mesozoic border faults.
\end{abstract}

\section{INTRODUCTION}

Faults and early Mesozoic diabase intrusions buried beneath the South Carolina Coastal Plain have been mapped by using gridded aeromagnetic data displayed in two ways. An aeromagnetic map synthetically illuminated from the northwest (fig. 1) emphasizes structures that have northeast trends, such as border faults associated with the early Mesozoic South Georgia basin. An edgeenhanced gray-scale aeromagnetic map (fig. 2) emphasizes shallow geologic features having strong magnetic contrasts, such as buried early Mesozoic diabase dikes and sheets. Information gleaned from both displays is combined in an interpretation map (fig. 3).

The aeromagnetic data, digitally compiled from five surveys, represent the total field anomaly $1,000 \mathrm{ft}$ $(305 \mathrm{~m})$ above the surface of the Earth. The original surveys were flown north-south in the central part of the area, east-west in the southwest and northern part of the area, and northwest-southeast in the northwest part of the area and offshore. Flightline spacing was $1 \mathrm{mi}(1.6$ $\mathrm{km})$ onshore and $2 \mathrm{mi}(3.2 \mathrm{~km})$ offshore. The data have been reduced to the pole in order to center the anomalies and gradients over their sources. Because all the magnetic sources of geologic interest within the map area are buried beneath nonmagnetic Cretaceous and younger coastal plain sedimentary rocks, which vary in thickness from approximately $330 \mathrm{ft}(100 \mathrm{~m})$ in the northwest corner of the area to $3,300 \mathrm{ft}(1,000 \mathrm{~m})$ at the coast and $6,600 \mathrm{ft}(2,000 \mathrm{~m})$ in the southeast corner of the area, the observed magnetic anomalies tend to be of fairly long wavelength with subdued gradients. Short-wavelength anomalies associated with shallow early Mesozoic sources located just below the base of the coastal plain units tend to be suppressed in the observed data.

\section{THE ILLUMINATED MAP}

Synthetic illumination of aeromagnetic data (Dods and others, 1985) has become a standard technique for enhancing short-wavelength features having specific trends. Northwest illumination of the aeromagnetic data (fig. 1) reveals a 31 -mi-wide $(50 \mathrm{~km})$ northeast-trending region of subdued magnetic anomalies onshore that corresponds to a portion of the buried early Mesozoic South Georgia basin (Daniels and others, 1983). The sharp northwestern boundary of this region (fig. 3), which passes a few kilometers southeast of Bowman, is interpreted to be the faulted contact between the basin and northeast-trending folded metamorphic rocks of the subsurface Piedmont. Near Orangeburg, linear disruptions in the magnetic anomalies suggest that the Piedmont rocks are cut by a shear zone having a northnortheast trend. West of Orangeburg, a region of low magnetic gradients has been interpreted from gravity data and drill core samples to be a Devonian granitic pluton within the Piedmont (Speer, 1982). A larger area of similar magnetic character and low gravity around Georgetown has been interpreted as a pre-Mesozoic granitic pluton within the Piedmont (Daniels and Leo, 1985), a granitic pluton capped by a Mesozoic diabase sill or basalt flow (Popenoe and Zietz, 1977), or a deep Mesozoic basin capped by a diabase sill or basalt flow (Talwani and others, 1975).

The location of the southeastern edge of the South Georgia basin is not well known within the study area, but geophysical evidence shows that it extends well offshore. An interpretation of seismic refraction data (Ackermann, 1983) suggests that the early Mesozoic units are $3,300 \mathrm{ft}(1,000 \mathrm{~m})$ thick at the coast. An Early Jurassic basalt unit that caps the basin onshore is seen in seismic reflection data to extend $94 \mathrm{mi}(150 \mathrm{~km})$ offshore, and weak reflectors underlying this unit have been interpreted to be early Mesozoic strata (Dillon and others, 1983). The seismic refraction data also show that a deep subbasin lies northwest of Summerville. The southeastern edge of the subbasin, as interpreted fromthe aeromagnetic data, is indicated by a northeasttrending linear magnetic crest that bends sharply to the 


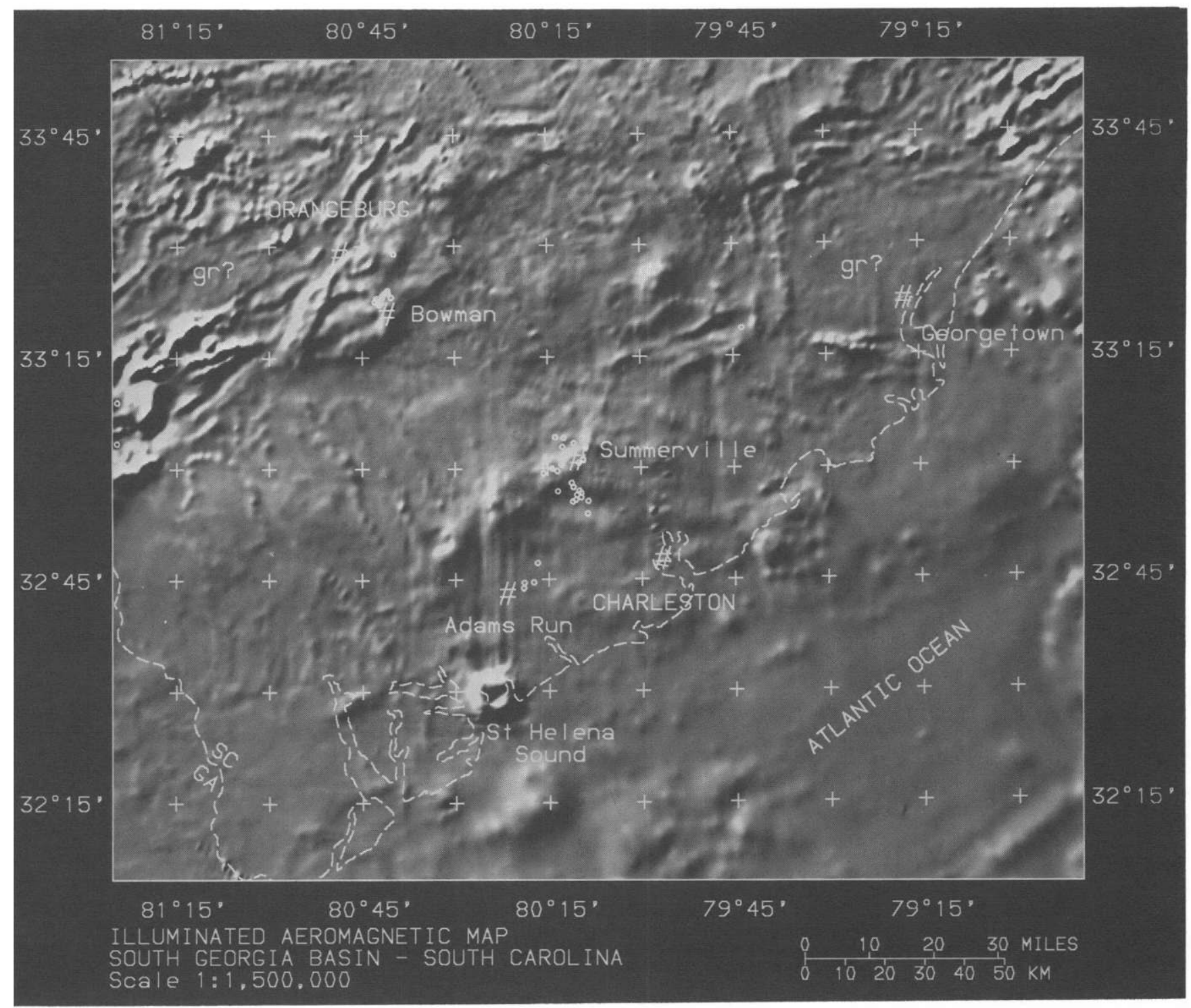

Figure 1. The aeromagnetic map of the southern South Carolina Coastal Plain and adjacent continental shelf synthetically illuminated from the northwest. Bright areas on the image indicate aeromagnetic gradients dipping to the northwest. Dark areas indicate gradients dipping to the

north-northeast within a large cluster of earthquake epicenters near Summerville (fig. 1). This bent linear crest is coincident with the subbasin border fault as mapped in the vicinity of Summerville by using seismic refraction (Amick, 1979; Ackermann, 1983). Note that this feature bisects a series of magnetic plutons of unknown age (bright areas, fig. 1). The illuminated aeromagnetic data cannot be used to trace the feature southwest of $80^{\circ} 30^{\prime}$ west longitude. It is possible that the structure turns south or southeast at this longitude, perhaps passing through the intense circular anomaly produced by a magnetic pluton in Saint Helena Sound (figs. 1,2). It is also possible that the structure merely terminates at this longitude. southeast. Small circles on the image represent earthquake epicenters from Rhea (1981). Cities are indicated by the symbol \#. Quiet magnetic regions that have been interpreted to be buried granitic plutons are indicated by gr?

Two previously unrecognized structures mapped from subtle features on the illuminated aeromagnetic map (fig. 1) may be related to the relatively high seismicity of the Charleston region, which experienced a major earthquake in 1886 (Dutton, 1889). The first of these is a fault or shear zone just onshore along nearly the entire length of the South Carolina coast. This feature, called here the Shoreline fault, is suggested by very subtle linear disruptions in the magnetic anomalies (fig. 1) and passes within a few kilometers of all the major shoreline cities (fig. 3). A subparallel fault, the Helena Banks fault, has been detected in seismic reflection profiles offshore (Behrendt and others, 1983). Subtle east-northeasttrending magnetic features offshore are aligned with the 


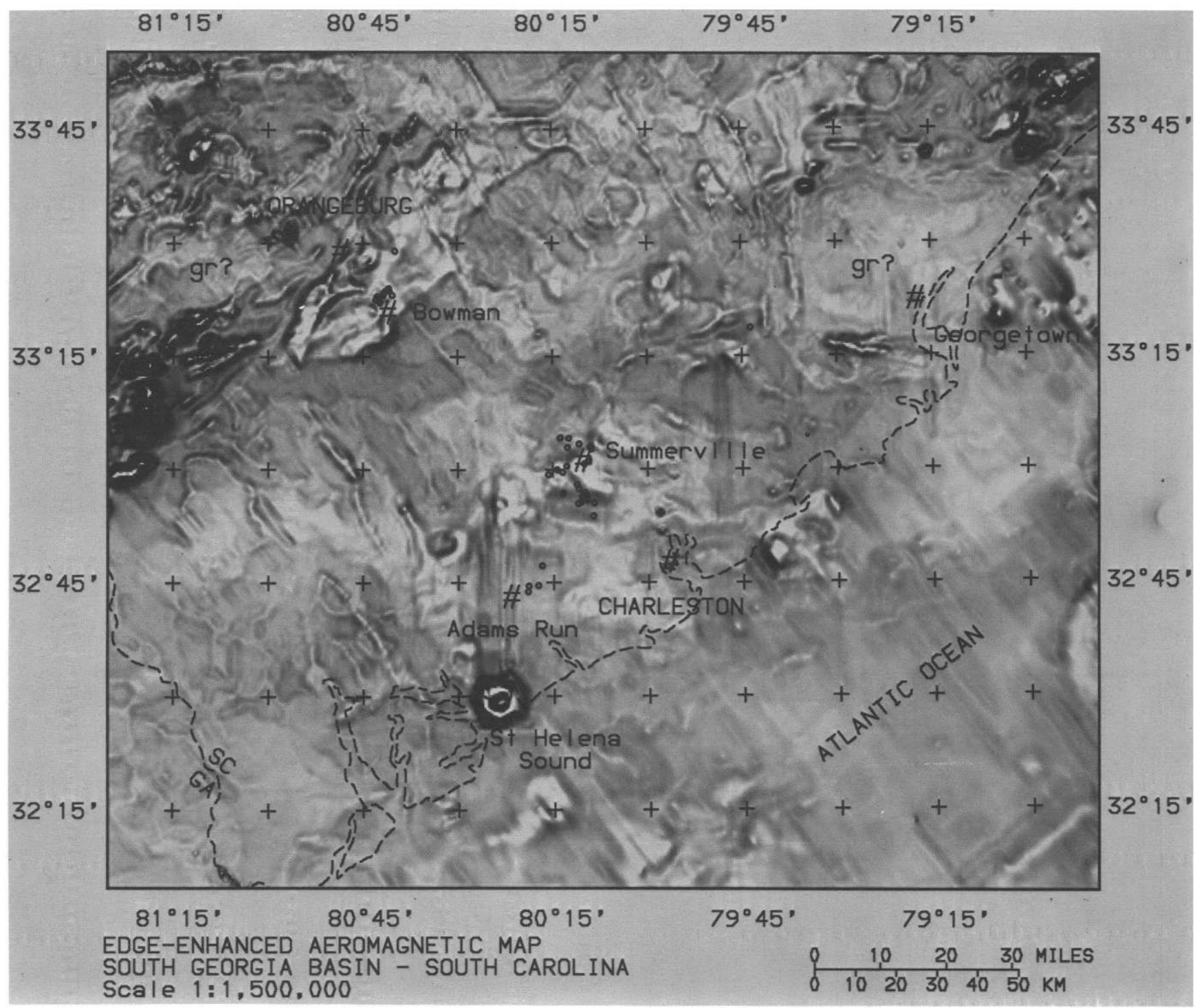

Figure 2. A residual aeromagnetic map edge-enhanced by darkening in the horizontal gradients. The highest intensities are shown in white. Symbols are as in figure 1.

mapped portion of the Helena Banks fault and extend to the eastern margin of the map.

The second previously unrecognized structure is a circular feature $31 \mathrm{mi}(50 \mathrm{~km})$ in diameter, which may be a Paleozoic impact crater or a Paleozoic caldera structure. The large cluster of seismicity near Summerville occurs at the intersection of this circular feature with the subbasin border fault (fig. 3). Structural analogies may be drawn between this circular feature and the Charlevoix impact structure of Quebec (Rondot, 1968; Leblanc, 1983), which has a $33.5-\mathrm{mi}(54-\mathrm{km})$ diameter and is also associated with seismic activity along reactivated rift faults (Roy and DuBerger, 1983; Anglin, 1984).

Hypothetical faults parallel to the northwestern border fault may control the location of a small cluster of earthquake epicenters near Bowman and other epicen- ters between latitudes $33^{\circ}$ and $33^{\circ} 15^{\prime}$ along the western margin of the map. A third cluster of four epicenters near Adams Run lies along what would be the southwestern extension of the north-northeast-trending segment of the subbasin border fault; however, there is no compelling evidence in the aeromagnetic data for a throughgoing structure with this trend.

\section{THE EDGE-ENHANCED MAP}

Studies of exposed early Mesozoic basins indicate that diabase dikes cut across both Mesozoic and preMesozoic lithologies, whereas diabase sheets are restricted to the basins (Froelich and Gottfried, 1985). Thus, mapping of the diabase sheets within a buried early Mesozoic basin provides a means of determining the 


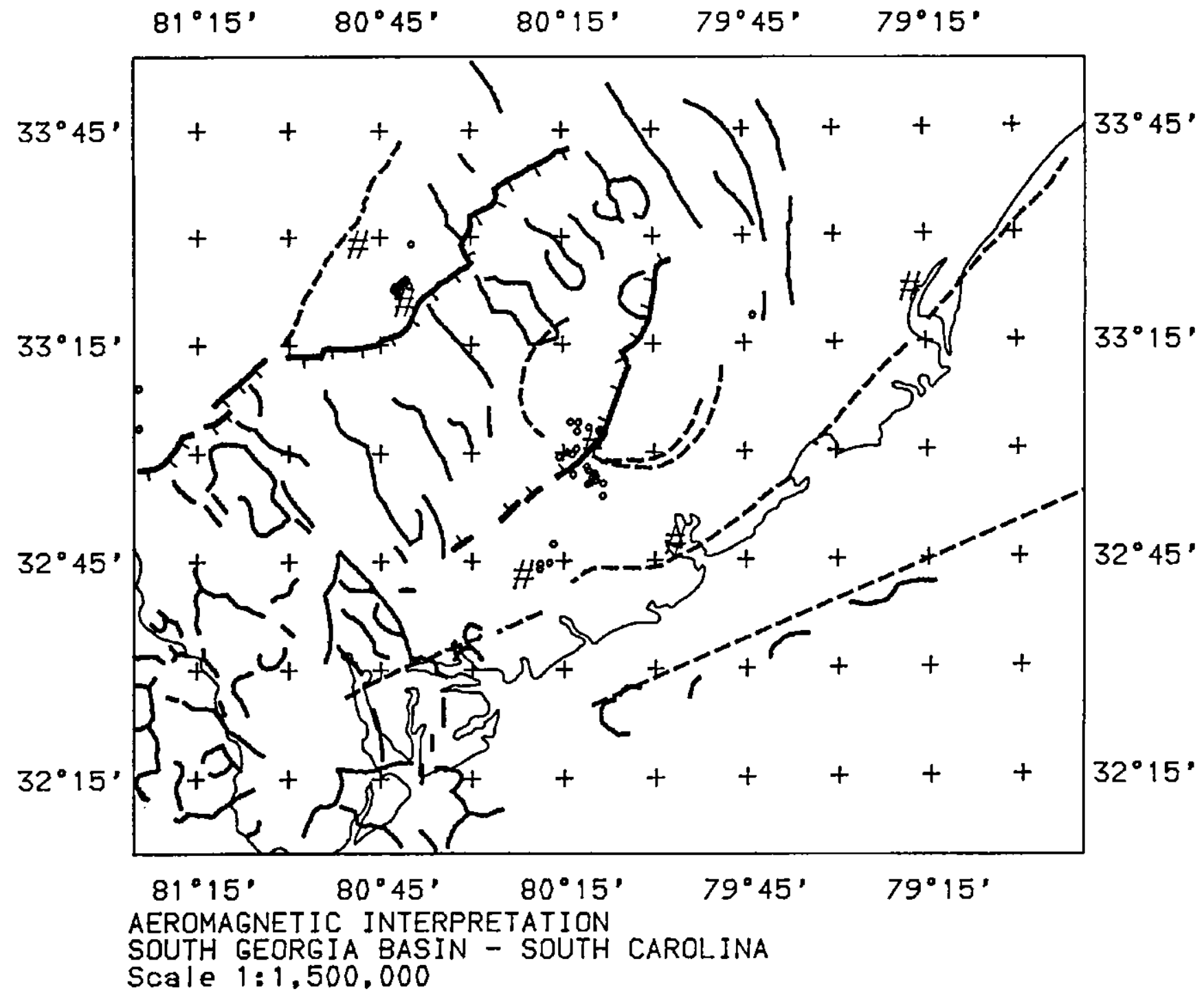

Figure 3. Buried structures interpreted from the aeromagnetic data. Heavy lines indicate Mesozoic border faults associated with the South Georgia basin. Medium lines indicate early Mesozoic diabase dikes (north and northwest linear trends) and diabase sheets (lobate shapes). Dashed lines indicate other interpreted structures, including a shear

extent of the basin in areas where the border faults lack magnetic contrast. The edge-enhanced gray-scale aeromagnetic map (fig. 2) is designed to emphasize narrow magnetic sources at shallow depths, such as diabase dikes and sheets. To construct the edge-enhanced map, a residual aeromagnetic grid was first produced by removing the long wavelengths from the reduced-to-the-pole aeromagnetic grid, then the following formula was used to produce the final result:

$$
E(x, y)=\left[R(x, y)-R_{\text {min }}\right]\left[1-G(x, y) / G_{\text {fact }}\right]+R_{\text {m in }}
$$

where $E$ is the edge-enhanced value, $R$ is the residual value, $G$ is the magnitude of the horizontal gradient of $R$,

zone within the subsurface Piedmont near Orangeburg, a circular feature passing through the cluster of earthquake epicenters at Summerville, the Shoreline fault along the coast, and the Helena Banks fault offshore (from Behrendt and others, 1983).

$R_{\min }$ is the minimum intensity value in the residual grid, and $G_{\text {fact }}$ is the mean plus three standard deviations of the horizontal gradient grid.

The edge-enhanced map clearly shows the narrow north and northwest-trending linear anomalies that are interpreted as diabase dikes and the narrow lobate anomalies that are interpreted as the edges of diabase sheets. Areas within the basin that appear in darker shades of gray may be relatively free of diabase or basalt. The map also provides good definition of the magnetic plutons and the northwestern Mesozoic border fault, but it does not emphasize northeast-trending linear structures as well as the illuminated map does. The inter- 
preted shear fault within the subsurface Piedmont near Orangeburg separates two lithologies of very different magnetic character. The anomalies over the unit to the west of the fault and south of latitude $33^{\circ} 20^{\prime} \mathrm{N}$. are similar in character to the anomalies in the northeast corner of the map. The offshore portions of the map are somewhat obscured by northwest-trending flightline anomalies, but there appears to be a pervasive northeast magnetic grain, and some diabase sheets may be present in the vicinity of the Helena Banks fault.

\section{ACKNOWLEDGMENT}

This research was supported in part by the U.S. Nuclear Regulatory Commission.

\section{REFERENCES CITED}

Ackermann, H.D., 1983, Seismic-refraction study in the area of the Charleston, South Carolina, 1886 earthquake, in Gohn, G.S., ed., Studies related to the Charleston, South Carolina, earthquake of 1886; tectonics and seismicity: U.S. Geological Survey Professional Paper 1313, p. F1-F20.

Amick, D., 1979, Crustal structure studies in the South Carolina Coastal Plain: M.S. thesis, University of South Carolina, $81 \mathrm{p}$.

Anglin, F.M., 1984, Seismicity and faulting in the Charlevoix zone of the St. Lawrence valley: Bulletin of the Seismological Society of America, v. 74, no. 2, p. 595-603.

Behrendt, J.C., Hamilton, R.M., Ackermann, H.D., Henry, V.J., and Bayer, K.C., 1983, Marine multichannel seismic reflection evidence for Cenozoic faulting and deep crustal structure near Charleston, South Carolina, in Gohn, G.S., ed., Studies related to the Charleston, South Carolina, earthquake of 1886; tectonics and seismicity: U.S. Geological Survey Professional Paper 1313, p. J1-J29.

Daniels, D.L., and Leo, G.W., 1985, Geologic interpretation of basement rocks of the Atlantic Coastal Plain: U.S. Geological Survey Open-File Report 85-655, 45 p.

Daniels, D.L., Zietz, I., and Popenoe, P., 1983, Distribution of subsurface lower Mesozoic rocks in the Southeastern United States, as interpreted from regional aeromagnetic and gravity maps, in Gohn, G.S., ed., Studies related to the Charleston, South Carolina, earthquake of 1886; tectonics and seismicity: U.S. Geological Survey Professional Paper 1313 , p. K1-K24.
Dillon, W.P., Klitgord, K.D., and Paull, C.K., 1983, Mesozoic development and structure of the continental margin off South Carolina, in Gohn, G.S., ed., Studies related to the Charleston, South Carolina, earthquake of 1886; tectonics and seismicity: U.S. Geological Survey Professional Paper 1313, p. N1-N16.

Dods, S.D., Teskey, D.J., and Hood, P.J., 1985, The new series of 1:1,000,000-scale magnetic anomaly maps of the Geological Survey of Canada: Compilation techniques and interpretation, in Hinze, W.J., ed., The utility of regional gravity and magnetic anomaly maps: Society of Exploration Geophysicists, p. 69-87.

Dutton, C.E., 1889, The Charleston earthquake of August 31, 1886: U.S. Geological Survey, Ninth Annual Report $1887-88$, p. $203-528$.

Froelich, A.J., and Gottfried, D., 1985, Early Jurassic diabase sheets of the Eastern United States-A preliminary overview, in Robinson, G.R., Jr., and Froelich, A.J., eds., Proceedings of the second U.S. Geological Survey workshop on the early Mesozoic basins of the Eastern United States: U.S. Geological Survey Circular 946, p. 79-86.

Leblanc, G., 1983, A basis for comparing La Malbaie, Quebec, to Charleston, South Carolina, in Hays, W.W., and Gori, P.L., eds., Proceedings of Conference XX, A workshop on "The 1886 Charleston, South Carolina, earthquake and its implications for today": U.S. Geological Survey Open-File Report 83-843, p. 435-455.

Popenoe, P., and Zietz, I., 1977, The nature of the geophysical basement beneath the Coastal Plain of South Carolina and northeastern Georgia, in Rankin, D.W., ed., Studies related to the Charleston, South Carolina, earthquake of 1886; a preliminary report: U.S. Geological Survey Professional Paper 1028, p. 119-137.

Rhea, S., 1981, South Carolina Seismic Program seismological data report, selected events March 1973-December 1977 and network events January 1978-July 1980: U.S. Geological Survey Open-File Report 81-362, 79 p.

Rondot, J., 1968, Nouvel impact meteoritique fossile? La structure semicirculaire de Charlevoix: Canadian Journal of Earth Sciences, v. 5, p. 1305-1317.

Roy, D.W., and DuBerger, R., 1983, Relations possibles entre la microseismicite recente et l'astorobleme de Charlevoix: Canadian Journal of Earth Sciences, v. 20, p. 1613-1618.

Speer, J.A., 1982, Description of the granitoid rocks associated with two gravity minima in Aiken and Barnwell Counties, South Carolina: South Carolina Geology, v. 26, p. 15-24.

Talwani, P., Ressetar, R., McAleer, J., Holmes, T., Grothaus, T., Findlay, M., Cable, M., and Amick, D., 1975, Gravity and magnetic profile across the Georgetown gravity low: South Carolina State Development Board, Division of Geology, Geologic Notes, v. 19, no. 2, p. 24-32. 


\title{
AEROMAGNETIC IMAGERY WITH GEOLOGIC CORRELATIONS FOR SOME EARLY MESOZOIC BASINS OF THE EASTERN UNITED STATES
}

\author{
Kevin R. Bond and Jeffrey D. Phillips
}

\begin{abstract}
Aeromagnetic maps for five areas of the Eastern United States that have exposed early Mesozoic basins are discussed in terms of known geology. The maps have been compiled from analog and digital sources and are presented as gray-tone images. In the eastern Newark basin, the Palisade Diabase and Orange Mountain, Preakness, and Hook Mountain Basalts are well defined, and the Ramapo border fault and the Green Pond syncline north of the basin are apparent. On the Culpeper basin image, the Catoctin Formation metabasalts on the basin margin and the Centreville and Herndon diabase sheets within the basin are evident. The buried extension of the Taylorsville basin can be seen beneath the coastal plain. On the northern Deep River basin image, the Mesozoic basin is clearly delineated, and the Farrington pluton is apparent west of the basin. On the southern Deep River basin image, however, the basin has no magnetic expression, although the nearby Pageland and Lilesville plutons are clearly seen. On the Davie County basin image, the small basin has no magnetic expression, whereas the Charlotte belt, the Churchland, Mooresville, and Landis plutons, and the Gold Hill fault zone are evident. On the latter three images, the north-trending and north-northwesttrending Mesozoic diabase dike systems of North and South Carolina are clearly delineated.
\end{abstract}

\section{INTRODUCTION}

Gray-tone, total field, residual aeromagnetic anomaly maps and brief geologic interpretations are presented for five Eastern United States areas that include exposed early Mesozoic basins (the eastern Newark basin of New Jersey and New York, the Culpeper basin of Virginia and Maryland, the Davie County basin of North Carolina, and the northern and southern Deep River basin of North Carolina). Aeromagnetic maps and interpretations for additional early Mesozoic basins are presented by Phillips (1985; this volume: "A geophysical study of the northern Hartford basin, Massachusetts," and "Buried structures at the northern end of the early Mesozoic South Georgia basin, South Carolina, as interpreted from aeromagnetic data").

\section{DATA PROCESSING}

For each of the five areas, the aeromagnetic data used in the compilation consists of a combination of digitally recorded data and data digitized from published and unpublished contour maps. Data for each individual survey were projected and gridded by using either a 0.16or $0.31-\mathrm{mi}(0.25$ - or a $0.5-\mathrm{km})$ grid interval. Surveys using flight-line spacings of $2 \mathrm{mi}(3.2 \mathrm{~km})$ or more were initially gridded at a coarser interval, then regridded. Data sets digitized from contour maps were converted to total field values to remove the effects of inconsistent or inappropriate geomagnetic reference fields subtracted during the original compilation. An appropriate geomagnetic reference field model (usually the International Geomagnetic Reference Field) was then used to remove the core field contribution as computed at the time and altitude of the original survey. Where necessary, the gridded data were continued to the final compilation surface $500 \mathrm{ft}(150 \mathrm{~m})$ above ground. Constant values were added to bring intensity levels for adjacent surveys into agreement. In the final compilation step the surveys were merged by use of smoothly weighted averages in the areas of overlap. Prior to display, a long-wavelength field was removed from some of the merged data sets to improve the contrast in the gray-tone image.

\section{EASTERN NEWARK BASIN}

The aeromagnetic map for the eastern Newark basin and vicinity, New Jersey and New York (fig. 1), was compiled from data collected from 14 separate surveys flown between 1950 and 1979. The data were collected digitally for three of the surveys. The majority of the surveys were conducted along east-west or north-south flight lines at a ground clearance of $500 \mathrm{ft}(150 \mathrm{~m})$. Two of the surveys used northwest-southeast flight lines. Flight-line spacings, usually $0.25 \mathrm{mi}(0.4 \mathrm{~km})$, varied from 0.25 to $3 \mathrm{mi}(0.4$ to $4.8 \mathrm{~km}$ )(table 1$)$. A $0.25-\mathrm{km}$ $(0.16 \mathrm{mi})$ grid interval was used during the compilation. The geologic interpretation is based on the State Geologic Maps of New Jersey (Lewis and Kummel, 1912) and New York (The State University of New York, 1961).

The Newark basin is the largest exposed early Mesozoic basin in the Eastern United States. It is bounded on the east by the Hudson River and on the west by the Ramapo fault. Within the map area, the southern edge of the basin is buried by sediments of the Atlantic Coastal Plain. The Palisade Diabase sill, which is nearly coincident with the eastern margin of the basin south of latitude $41^{\circ} \mathrm{N}$., can be easily traced as a linear magnetic high. North of latitude $41^{\circ} \mathrm{N}$., the eastern margin is not defined by the aeromagnetic data. Within the basin proper, flows of the Orange Mountain, 


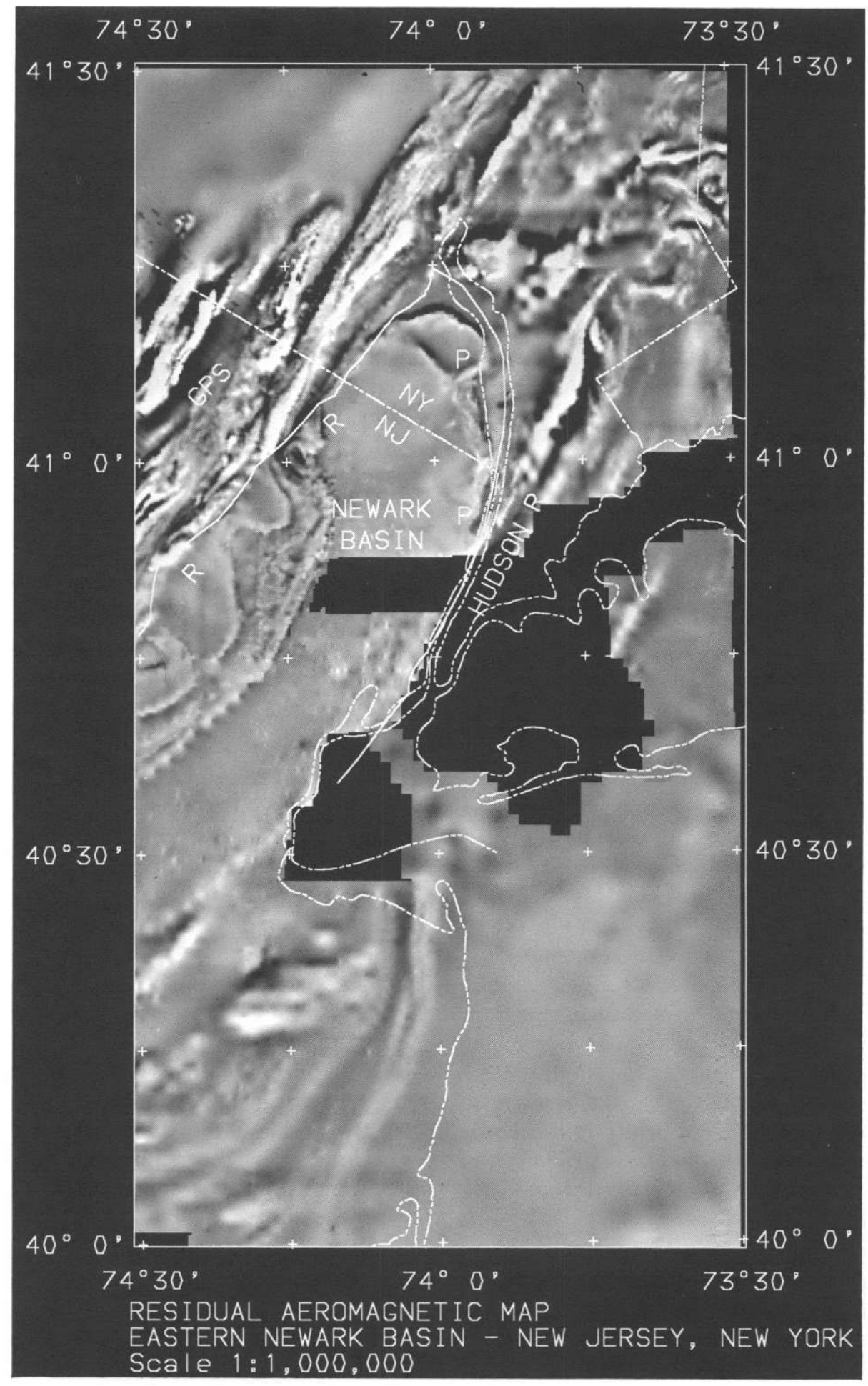

Figure 1A. Residual aeromagnetic map of the eastern Newark basin and vicinity, New Jersey and New York, presented as a gray-tone image. High intensities are shown in white. P, Palisade Diabase sill; R, Ramapo fault; GPS, Green Pond syncline. The basin boundary is defined by a solid line. A long-wavelength field with a crossover wavelength of $10 \mathrm{mi}(16 \mathrm{~km})$ was removed from the gridded data in order to enhance contrast in the image. 
Table 1. Specifications of flight lines for the eastern Newark basin and vicinity

[References are listed in appendix 1; a, analog source; d, digital source; ag, above ground; asl, above sea level; bar, barometric]

\begin{tabular}{|c|c|c|c|c|c|}
\hline $\begin{array}{l}\text { Area of } \\
\text { coverage on } \\
\text { index map }\end{array}$ & Source & Direction & Altitude & $\begin{array}{l}\text { Spacing } \\
\text { (in miles) }\end{array}$ & References \\
\hline A & d & E.-W. & $500 \mathrm{ft} \mathrm{ag}$ & 1 & USGS, 1979a \\
\hline $\mathrm{B}$ & d & NW.-SE. & $1,500 \mathrm{ft}$ asl & $2-3$ & Klitgord and Behrendt, 1977 \\
\hline $\mathrm{C}$ & a & NW.-SE. & $400 \mathrm{ft} \mathrm{ag}$ & .25 & LKB Resources, 1980 \\
\hline D & a & E.-W. & $3,000 \mathrm{ft}$ bar & 2 & USGS, $1979 \mathrm{~b}$ \\
\hline $\mathrm{E}$ & a & N.-S. & $500 \mathrm{ft} \mathrm{ag}$ & .25 & Henderson and others, 1966 \\
\hline $\bar{F}$ & a & E.-W. & $500 \mathrm{ft} \mathrm{ag}$ & .5 & Henderson and others, 1966 \\
\hline G & a & E.-W. & $400-500 \mathrm{ft} \mathrm{ag}$ & $.5-1$ & USGS, 1971a \\
\hline $\mathrm{H}$ & a & E.-W. & $400 \mathrm{ft} \mathrm{ag}$ & $.5-1$ & USGS, 1971c \\
\hline I & a & E.-W. & $400 \mathrm{ft} \mathrm{ag}$ & $.5-1$ & USGS, $1971 \mathrm{~b}$ \\
\hline $\mathbf{J}$ & a & E.-W. & $400-500 \mathrm{ft} \mathrm{ag}$ & $.5-\mathrm{]}$ & USGS, 1971d \\
\hline $\mathrm{K}$ & a & E.-W. & $500 \mathrm{ft} \mathrm{ag}$ & .5 & Popenoe and others, 1962 a \\
\hline $\mathrm{L}$ & a & E.-W. & $500 \mathrm{ft} \mathrm{ag}$ & .5 & Popenoe and others, $1962 \mathrm{~b}$ \\
\hline $\bar{M}$ & a & E.-W. & $500 \mathrm{ft} \mathrm{ag}$ & 1 & Zietz and others, 1972 \\
\hline
\end{tabular}

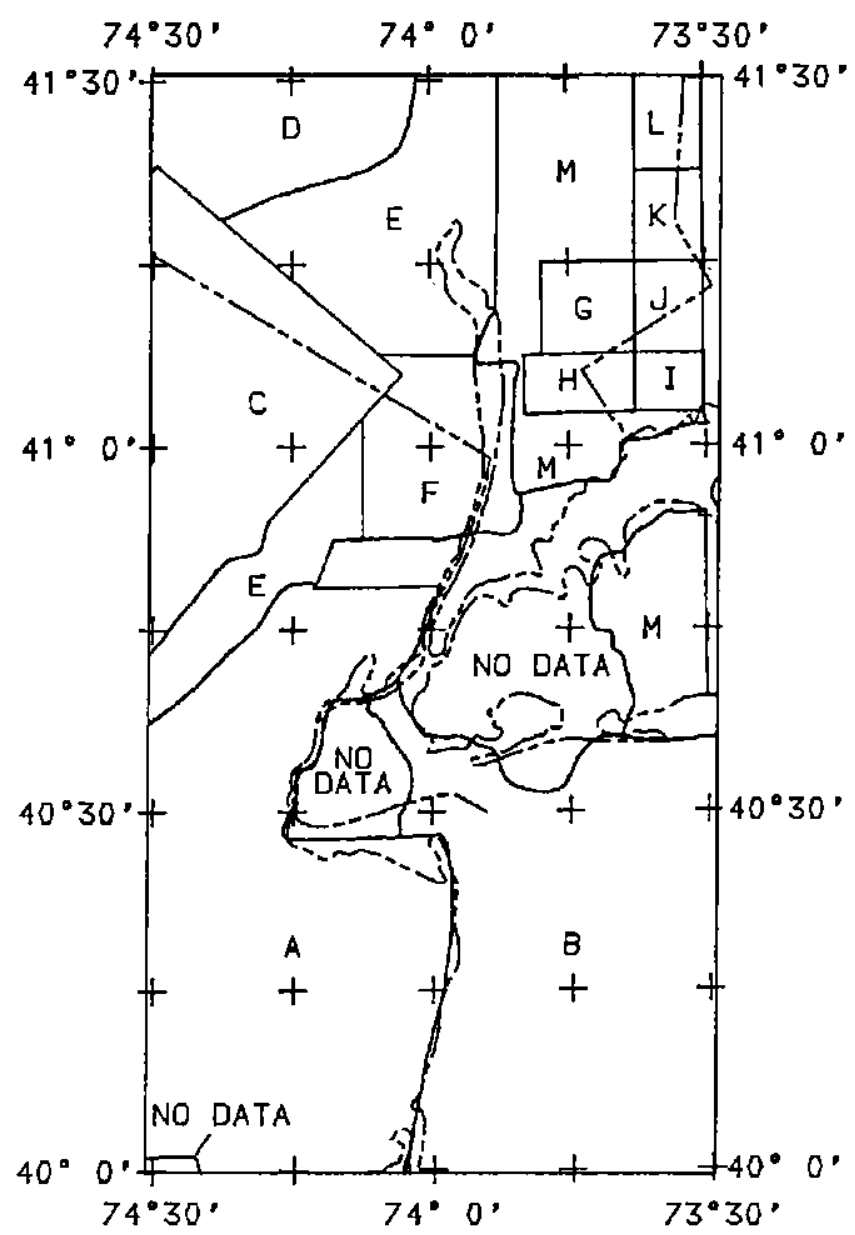

Figure 1B. Index map of the eastern Newark basin and vicinity showing sources of data. Letters are keyed to table 1.
Preakness, and Hook Mountain Basalts produce a broad, northeast-trending band of anomalies near the western margin. Some of the small circular anomalies present in the eastern part of the basin at latitude $40^{\circ} 45^{\prime} \mathrm{N}$. may be related to buried diabase associated with the Palisades and Snake Hills sills (Darton, 1890), but most are probably produced by steel in industrial complexes.

The western margin of the basin, as defined by the Ramapo fault, is delineated by a sharp change in magnetic character from low-amplitude, sinuous anomalies within the basin to high-amplitude, northeast-trending anomalies outside the basin. The northeast-trending broad belt of anomalies is associated with gneisses of Middle Proterozoic age. Within this belt, south of the New York-New Jersey State line and north of latitude $41^{\circ} \mathrm{N}$., a linear area of very low gradients corresponds to the Green Pond syncline, which is formed in sedimentary rocks of Silurian-Devonian age.

The very broad, low-gradient anomalies in the northwest part of the map correspond to Ordovician shales of the Trenton Group. The irregularly shaped anomalies present in the northeast part of the map are predominantly associated with gneiss and amphibolite of the Manhattan Schist. The circular magnetic high at latitude $41^{\circ} 15^{\prime} \mathrm{N}$., longitude $73^{\circ} 55^{\prime} \mathrm{W}$. reflects the highly magnetic mafic and ultramafic rocks of the Cortlandt Complex (The State University of New York, 1961).

\section{CULPEPER BASIN}

The aeromagnetic map for the Culpeper basin and vicinity, Virginia and Maryland (fig. 2), includes data from 18 different surveys flown between 1950 and 1981. For two of the surveys the data were collected digitally. Most of the surveys were conducted along east-west flight lines draped $500 \mathrm{ft}(150 \mathrm{~m})$ above ground (table 1). 


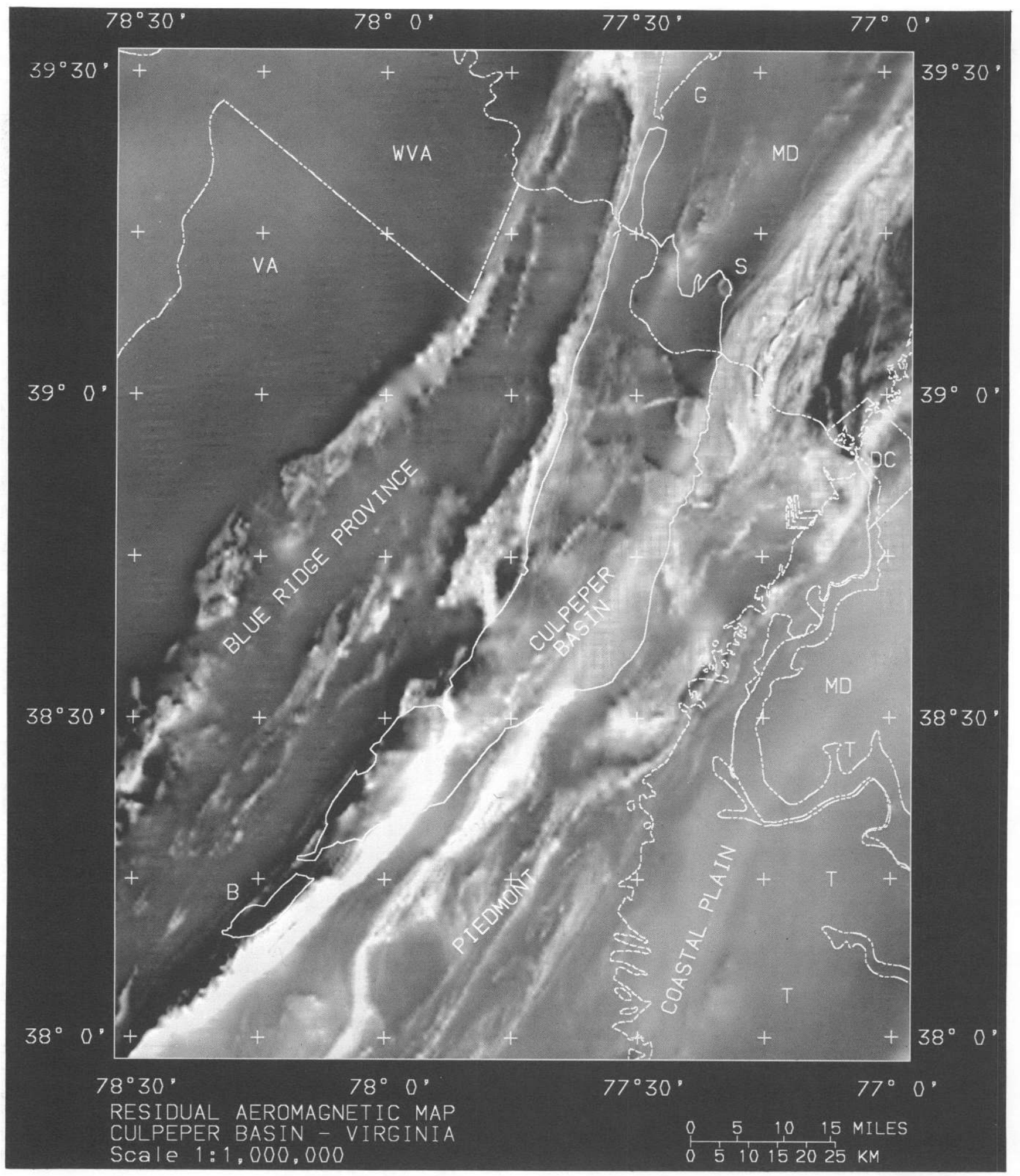

Figure 2A. Residual aeromagnetic map of the Culpeper basin and vicinity, Virginia and Maryland, presented as a gray-tone image. High intensities are shown in white. G, Gettysburg basin; B, Barboursville basin. T's, approximate location of the buried Taylorsville basin; $\mathrm{S}$, vicinity of the Boyds sill. The basin boundary is defined by a solid line. 
Table 2. Specifications of flight lines for the Culpeper basin and vicinity

[References are listed in appendix 2; all flight lines are east-west except $T$, which is northwest-southeast; a, analog source; d, digital source; ag, above ground; asl, above sea level; bar, barometric]

\begin{tabular}{|c|c|c|c|c|}
\hline $\begin{array}{l}\text { Area of coverage } \\
\text { on index map }\end{array}$ & Source & Altitude & $\begin{array}{l}\text { Spacing } \\
\text { (in miles) }\end{array}$ & References \\
\hline $\mathbf{A}$ & a & $3,500 \mathrm{ft}$ bar & ] & USGS, unpublished data \\
\hline B & a & $500 \mathrm{ft} \mathrm{ag}$ & 5 & USGS, 1973 \\
\hline C1 & a & $500 \mathrm{ft} \mathrm{ag}$ & 5 & USGS, $1974 \mathrm{a}$ \\
\hline $\mathrm{C} 2$ & a & $500 \mathrm{ft}$ ag & .25 & USGS, $1974 \mathrm{a}$ \\
\hline D1 & a & $500 \mathrm{ft} \mathrm{ag}$ & 1 & USGS, 1974b \\
\hline $\mathrm{D} 2$ & a & $500 \mathrm{ft}$ ag & .25 & USGS, $1974 \mathrm{~b}$ \\
\hline E1 & a & $500 \mathrm{ft}$ ag & .5 & USGS, $1974 c$ \\
\hline E2 & a & $500 \mathrm{ft} \mathrm{ag}$ & .25 & USGS, $1974 \mathrm{c}$ \\
\hline$\vec{F} 1$ & a & $500 \mathrm{ft} \mathrm{ag}$ & 1 & USGS, 1974d \\
\hline $\mathrm{F} 2$ & a & $500 \mathrm{ft} \mathrm{ag}$ & .25 & USGS, $1974 d$ \\
\hline $\mathrm{F} 3$ & a & $500 \mathrm{ft} \mathrm{ag}$ & .5 & USGS, 1974d \\
\hline G1 & $\mathrm{a}$ & $500 \mathrm{ft} \mathrm{ag}$ & .25 & Blanchett and others, $1963 a$ \\
\hline $\mathrm{G} 2$ & a & $500 \mathrm{ft} \mathrm{ag}$ & .25 & Blanchett and others, $1963 \mathrm{~b}$ \\
\hline G3 & $\mathrm{a}$ & $500 \mathrm{ft}$ ag & .25 & Blanchett and others, $1963 \mathrm{c}$ \\
\hline G4 & a & $500 \mathrm{ft}$ ag & .25 & Blanchett and others, $1963 \mathrm{~d}$ \\
\hline H1 & a & $500 \mathrm{ft} \mathrm{ag}$ & .5 & Bromery and others, $1963 \mathrm{~b}$ \\
\hline $\mathrm{H} 2$ & a & $500 \mathrm{ft} \mathrm{ag}$ & .5 & Bromery and others, $1963 \mathrm{c}$ \\
\hline I & a & $500 \mathrm{ft} \mathrm{ag}$ & 1 & USGS, unpublished data \\
\hline $\mathbf{J}$ & a & $500 \mathrm{ft}$ ag & .25 & USGS, unpublished data \\
\hline $\mathrm{K} 1$ & a & $5,000 \mathrm{ft}$ asl & 3 & Virginia Division of Mineral Resources, 1972 \\
\hline $\mathbf{K} 2$ & a & & 3 & Virginia Division of Mineral Resources, 1972 \\
\hline $\mathrm{K} 3$ & a & $500 \mathrm{ft}$ asl & 3 & Virginia Division of Mineral Resources, 1972 \\
\hline $\mathrm{L}$ & a & $500 \mathrm{ft} \mathrm{ag}$ & .5 & Virginia Division of Mineral Resources, 1972 \\
\hline $\mathbf{M}$ & a & $500 \mathrm{ft} \mathrm{ag}$ & .5 & Virginia Division of Mineral Resources, 1971 \\
\hline $\mathrm{N}$ & d & $500 \mathrm{ft} \mathrm{ag}$ & .75 & Johnson and Froelich, 1982 \\
\hline $\mathrm{O}$ & a & $500 \mathrm{ft} \mathrm{ag}$ & .25 & Balsley, 1952 \\
\hline $\mathrm{P}$ & d & $500 \mathrm{ft} \mathrm{ag}$ & .5 & USGS, 1980 \\
\hline Q & a & $500 \mathrm{ft} \mathrm{ag}$ & .5 & Bromery and others, 1963d \\
\hline $\mathbf{R}$ & a & $500 \mathrm{ft} \mathrm{ag}$ & .5 & USGS, unpublished data \\
\hline $\mathbf{S}$ & a & $500 \mathrm{ft} \mathrm{ag}$ & .5 & Neuschel, 1970 \\
\hline $\mathrm{T}$ & d & $1,000 \mathrm{ft} \mathrm{ag}$ & 2 & USGS, 1976 \\
\hline
\end{tabular}

${ }^{1}$ Elevation is tilted from $5,000 \mathrm{ft}$ asl in the west to $500 \mathrm{ft}$ ag in the east.

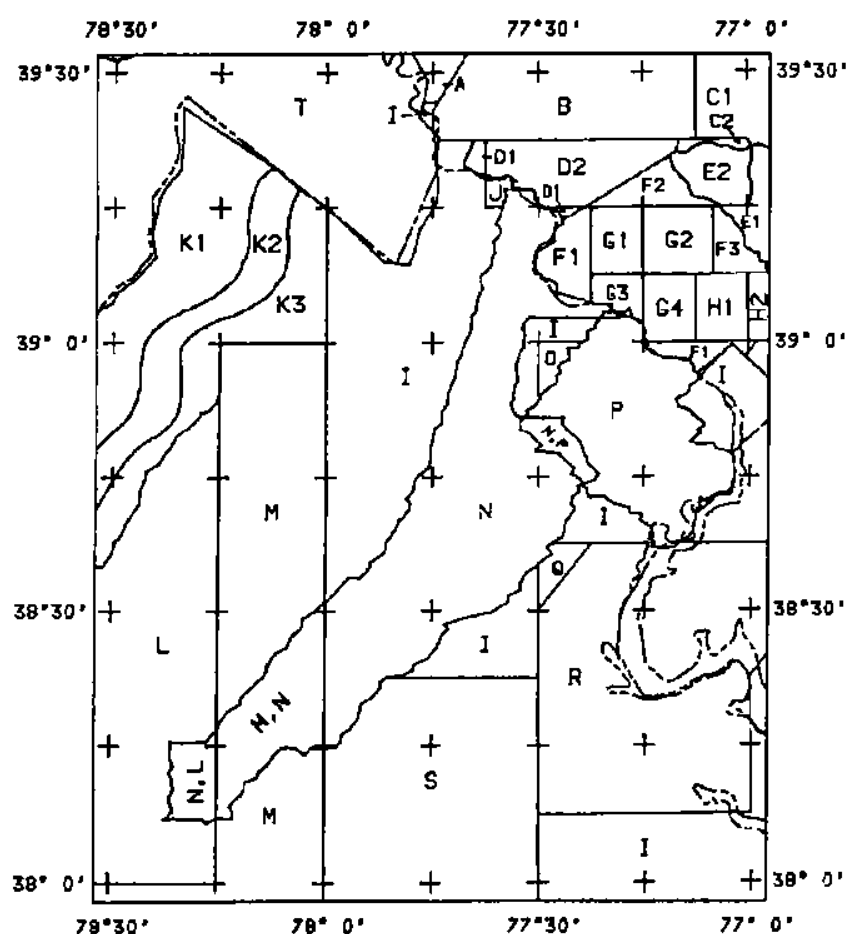

Figure 2B. Index map of the Culpeper basin and vicinity showing sources of data. Letters are keyed to table 2.
Flight-line spacings varied from $0.25 \mathrm{mi}(0.4 \mathrm{~km})$ for a few small areas to 2.0 and $3.0 \mathrm{mi}(3.2$ and $4.8 \mathrm{~km})$ over the magnetically quiet Valley and Ridge province. For the area excluding the Valley and Ridge, the average spacing was approximately $0.65 \mathrm{mi}(1 \mathrm{~km})$. Over the Mesozoic basins, flight-line spacings of 0.5 and $0.75 \mathrm{mi}$ $(0.8-1.25 \mathrm{~km})$ were common. During compilation, a grid interval of $0.25 \mathrm{~km}(0.16)$ was used. The geologic interpretation is based on the State Geologic Maps of Virginia (Milici and others, 1963) and Maryland (Cleaves and others, 1968) and the bedrock map of the Culpeper basin (Leavy and others, 1983).

The western part of the aeromagnetic map (fig. 2) is dominated by the intense positive anomaly associated with the metabasalts of the late Proterozoic Catoctin Formation (Espenshade, 1970). This unit forms an anticlinal structure having a steeply dipping western limb located near the western edge of the Blue Ridge province (Espenshade, 1970). The eastern limb of the anticline follows the faulted western margin of the Gettysburg and Culpeper basins in the north, then crosses beneath the southern part of the Culpeper basin and follows the eastern margin of the relatively small Barboursville basin to the south of the Culpeper basin. Short-wavelength 


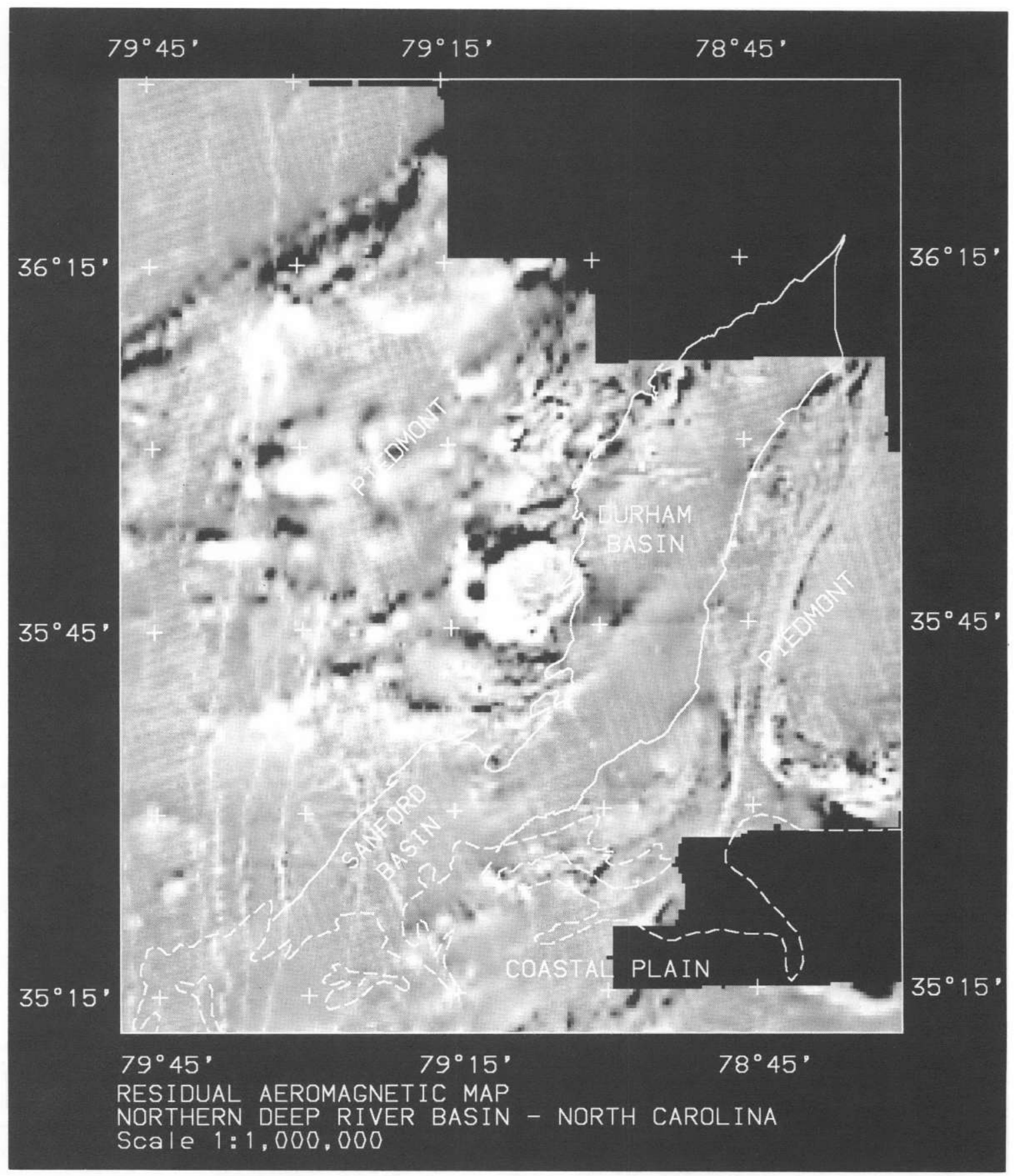

Figure 3A. Residual aeromagnetic map of the northern Deep River basin (consisting of the Durham and Sanford subbasins) and vicinity, North Carolina, presented as a gray-tone image. High intensities are shown in white. The basin boundary is defined by a solid line. The coastal plain contact is shown as a dashed line. A long-wavelength field with a crossover wavelength of $18 \mathrm{mi}(29 \mathrm{~km})$ was removed from the gridded data in order to enhance contrast in the image. 
Table 3. Specifications of flight lines for the northern and southern Deep River and Davie County basins

[References are listed in appendix 3; all flight line directions are east-west, measured above ground; a, analog source; d, digital source]

\begin{tabular}{ccccl}
\hline $\begin{array}{c}\text { Area of coverage } \\
\text { on index map }\end{array}$ & Source & Altitude (in feet) & Spacing (in miles) & \multicolumn{1}{c}{ Reference } \\
\hline A & d & 500 & 1 & USGS, 1977a \\
B & a & 1,000 & .5 & USGS, 1974 \\
C & d & 500 & 1 & USGS, 1977c \\
D & a & 500 & .5 & Bates and Bell, 1965 \\
E & a & 500 & 1 & USGS, unpublished data \\
F & d & 500 & 1 & USGS, 1977b \\
G & d & 500 & 1 & USGS, 1978b \\
H & d & 500 & 1 & USGS, 1976 \\
I & a & 500 & 1 & USGS, 1978a \\
J & d & 500 & .5 & USGS, 1970 \\
\hline
\end{tabular}

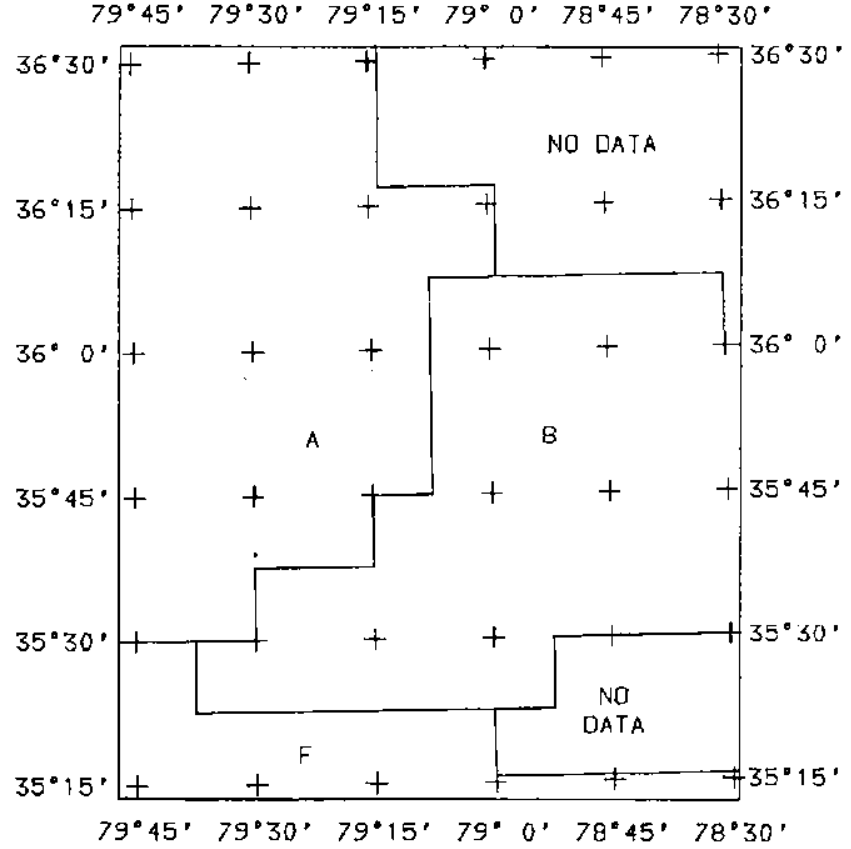

Figure 3B. Index map of the northern Deep River basin and vicinity showing sources of data. Letters are keyed to table 3.

magnetic anomalies within the Culpeper basin are primarily due to Mesozoic diabase sheets. In the northeast corner of the basin, a small arcuate anomaly is produced by the Boyds sill. Moving south along the eastern margin of the basin, a narrow, $U$-shaped anomaly is produced by the Herndon diabase sheet, and a W-shaped anomaly is produced by the Centreville diabase sheet. Additional diabase dikes and sills produce magnetic anomalies in the more western parts of the basin. Faint anomalies produced by the eastern edges of westward-dipping Mesozoic basalt flows are seen near the western margin of the basin between latitudes $38^{\circ} 45^{\prime}$ and $39^{\circ} \mathrm{N}$. In the Piedmont east of the basins, convoluted anomalies are produced by highly deformed metamorphosed sedimentary and ultramafic rocks. By using the magnetic anomaly map, we can trace some of these units beneath the thin eastern edge of the Culpeper basin. The amplitudes of the Piedmont anomalies diminish as the units plunge beneath the Atlantic Coastal Plain in the southeast corner of the area. The buried Taylorsville Mesozoic basin is known to underlie part of the coastal plain within the southeasternmost part of the map area (Weems, 1980). Its western border is approximately defined by the eastern edge of the arcuate positive anomaly extending into southern Maryland from the southern margin of the map at longitude $77^{\circ} 25^{\prime} \mathrm{W}$.

\section{NORTH CAROLINA BASINS}

The aeromagnetic maps for areas in North Carolina (figs. 3-5) were compiled by using data from 10 separate surveys flown between 1958 and 1978. The data were collected digitally for six of the surveys. All but one of the surveys were conducted along east-west flight lines draped at $500 \mathrm{ft}(150 \mathrm{~m})$ and spaced either 0.5 or $1 \mathrm{mi}$ $(0.8$ or $1.6 \mathrm{~km})$ apart (table 3$)$. For each of the surveys, the data were compiled on a $0.5-\mathrm{km}(0.31-\mathrm{mi})$ grid. The geologic interpretation is based on examination of the State Geologic Map of North Carolina (State of North Carolina, 1985).

The northern Deep River basin (fig. 3), consisting of the Durham and Sanford subbasins, is bounded on the west, north, and east by moderately magnetic, low-grade metamorphic rocks of the Carolina Slate Belt. Short segments of medium-grade metamorphic and igneous rocks of the Raleigh Belt also bound the basin on the east. The southernmost portion of the basin is overlain by sediments of the Atlantic Coastal Plain. The faulted eastern margin of the basin is clearly delineated by a sharp change in magnetic character, which can readily be traced beneath the sediments of the coastal plain. An extensive arcuate anomaly within the Raleigh Belt is 


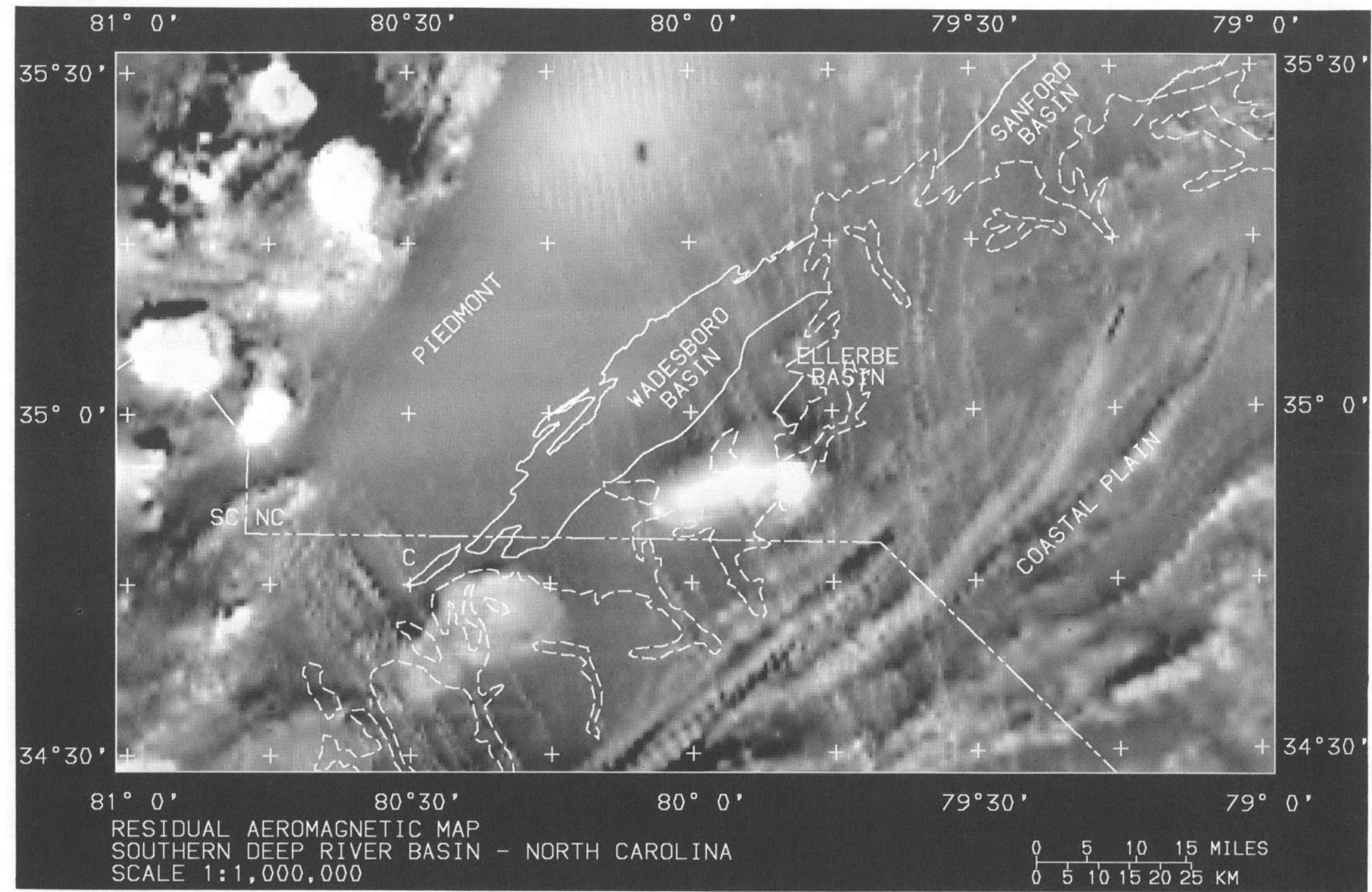

Figure 4A. Residual aeromagnetic map of the southern Deep River basin and vicinity, North Carolina, presented as a gray-tone image. High intensities are shown in white. C, Crowburg basin. The basin boundaries are defined by solid lines. The coastal plain contact is shown as a dashed line. 


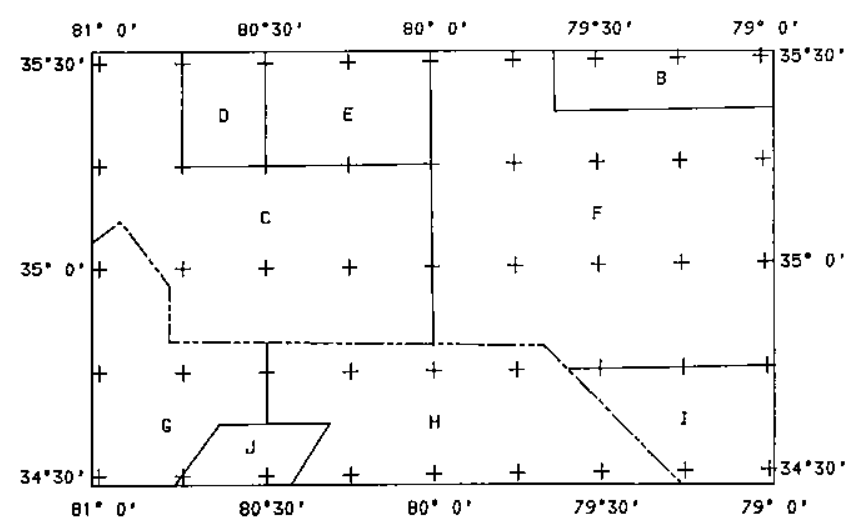

Figure 4B. Index map of the southern Deep River basin and vicinity showing sources of data. Letters are keyed to table 3.

associated with a belt of gneiss and minor amounts of schist. Because the western margin of the basin is unfaulted, it is not well defined on the magnetic map. In the south, the basement rocks are nonmagnetic, and Mesozoic diabase dikes continue across the basin margin. In the north, diabase sheets and sources within the shallow crystalline floor of the basin produce anomalies similar to those outside the basin to the west.

The dominant anomaly on the map lies outside the basin, immediately adjacent to its western boundary (latitude $35^{\circ} 50^{\prime} \mathrm{N}$.), and is associated with late Proterozoic to Late Cambrian metamorphosed granitic rocks of the Farrington pluton. The linear, northeast-trending anomaly lying within the center of the basin correlates with mapped normal faults. However, similar faults in the southern half of the basin appear to have no magnetic expression. The diffuse north-trending and northnorthwest-trending anomalies in the western Carolina Slate Belt and the southern half of the basin are produced by early Mesozoic diabase dikes, (Burt and others, 1978). These dikes are visible on all three maps of the North Carolina basins.

The southern Deep River basin (Wadesboro subbasin) (fig. 4) is also bounded by the Carolina Slate Belt and is connected with the Sanford basin to the north beneath coastal plain deposits. The southern terminus is near the Pageland pluton, a late Paleozoic postmetamorphic granite pluton, marked by an oval magnetic anomaly.

The margins of the Wadesboro basin are not well defined by the aeromagnetic data because of the nonmagnetic character of this part of the Carolina Slate Belt. The eastern margin is indirectly defined by the very large, high-amplitude anomaly visible in the center of the map associated with the late Paleozoic Lilesville Granite of Wascom and Butler (1971).

The Davie County basin (fig. 5) is bounded on the west by the Inner Piedmont Belt and on the east by the Charlotte Belt. The basin has no magnetic expression. Most of the intense positive anomalies are associated with gabbro of the Concord Plutonic Suite and other metamorphosed plutonic-volcanic complexes in the Charlotte Belt. Within the belt are three oval areas of extremely low gradient that correspond to the Pennsylvanian to Permian granites of the Churchland, Mooresville, and Landis plutons. The southeastern edge of the Charlotte Belt is clearly marked by a reduction in magnetic intensity across the Gold Hill fault zone that separates the Charlotte Belt from the Carolina Slate Belt to the east. In the northeastern part of the map, a pattern of low-intensity anomalies delineates a region of metamorphosed granitic rocks and distinguishes these rocks from the nonmagnetic metamorphosed mudstones and argillites to the south.

\section{SUMMARY}

Gray-tone residual aeromagnetic anomaly images are an important tool for regional studies of exposed Mesozoic basins in the Eastern United States. The faulted margins of basins located within magnetic terranes are generally visible on the images. Basins that are located in nonmagnetic terranes have little or no magnetic expression. Much of the magnetic character in the images is produced by plutons and other units outside the basins. Basalt flows and diabase sheets within the basins can be seen easily, as can the Mesozoic diabase dike systems of North and South Carolina. 


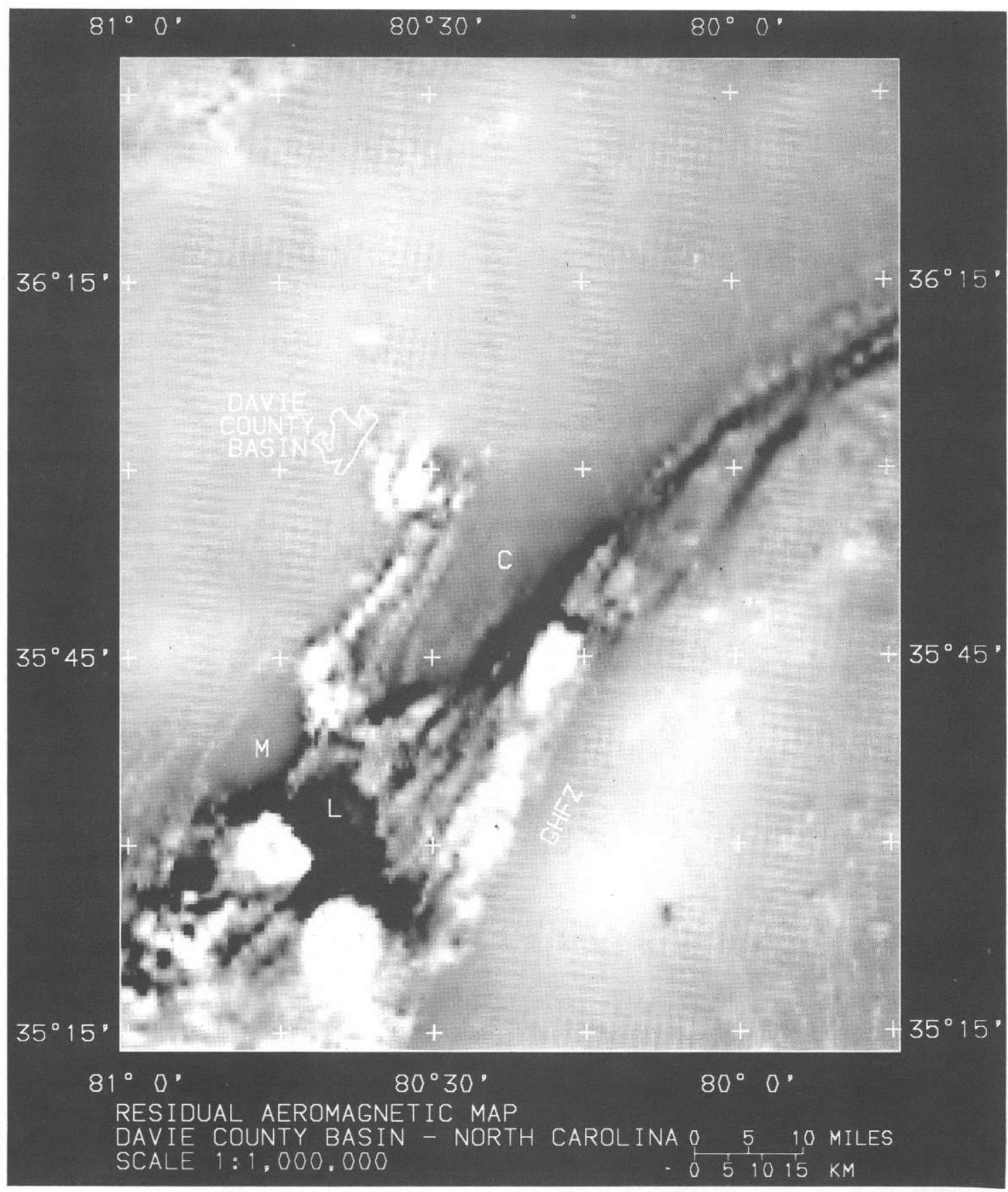

Figure 5A. Residual aeromagnetic map of the Davie County basin and vicinity, North Carolina, presented as a gray-tone image. High intensities are shown in white. C, Churchland pluton; M, Mooresville pluton; L, Landis pluton; GHFZ, Gold Hill fault zone. The basin boundary is defined by a solid line. 


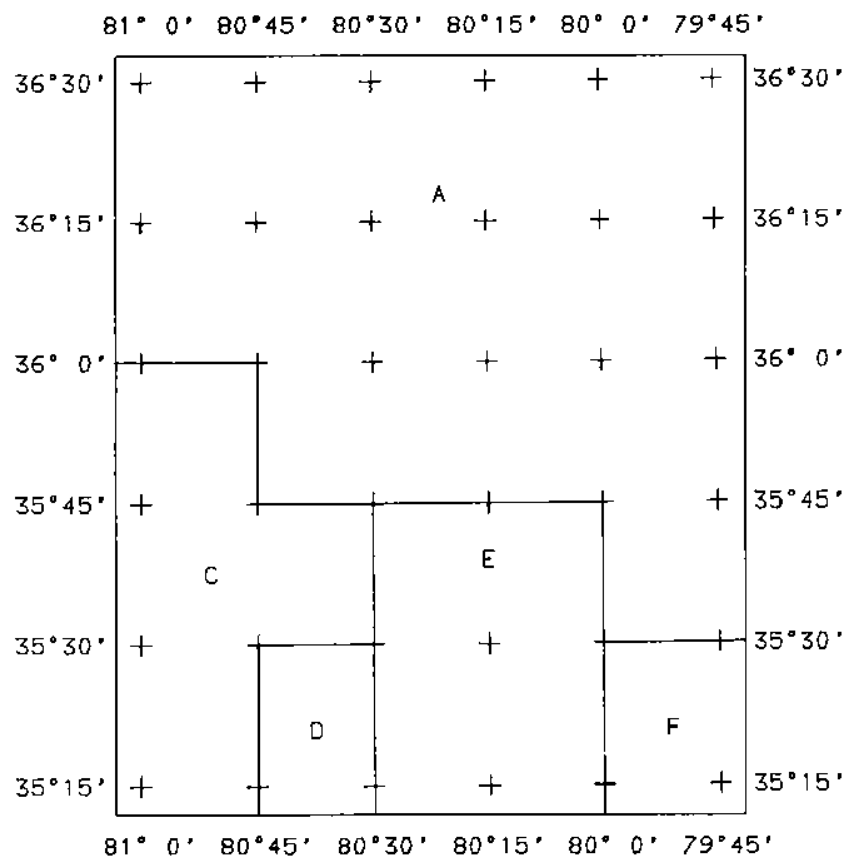

Figure 5B. Index map of the Davie County basin and vicinity showing sources of data. Letters are keyed to table 3.

\section{REFERENCES CITED}

Burt, E.R., Carpenter, P.A., III, McDaniel, R.D., and Wilson, F.W., 1978, Diabase dikes of the eastern Piedmont of North Carolina: North Carolina Geological Survey, scale $1: 250,000$.

Cleaves, E.T., Edwards J., Jr., and Glaser, J.D., compilers, 1968, Geologic map of Maryland: Maryland Geological Survey, scale 1:250,000.

Darton, N.H., 1890, The relations of the traps of the Newark System in the New Jersey region: U.S. Geological Survey Bulletin 67, 82 p.

Espenshade, G.H., 1970, Geology of the northern part of the Blue Ridge anticlinorium, in Fisher, G.W., Pettijohn, F.J., Reed, J.C., Jr., and Weaver, K.N., eds., Studies of Appalachian geology: Central and southern New York: John Wiley, p. 199-211.

Leavy, B.D., Froelich, A.J., and Abram, E.C., 1983, Bedrock map and geotechnical properties of rocks of the Culpeper basin and vicinity, Virginia and Maryland: U.S. Geological Survey Miscellaneous Investigations Series Map I-1313-C, scale 1:125,000.

Lewis, J.V., and Kummel, H.B., 1912, Geologic map of New Jersey (Johnson, M.E., revision of 1950): State of New Jersey, Department of Conservation and Economic Development, Atlas Sheet No. 40, scale 1:250,000.

Milici, R.C., Spiker, C.T., and Wilson, J.M., compilers, 1963, Geologic map of Virginia: Charlottesville, Virginia Division of Mineral Resources, scale 1:500,000.

Phillips, J.D., 1985, Aeromagnetic character and anomalies of the Gettysburg basin and vicinity, Pennsylvania-A preliminary appraisal, in Robinson, G.R., Jr., and Froelich, A.J., eds., Proceedings of the second U.S. Geological Survey workshop on the Early Mesozoic basins of the
Eastern United States: U.S. Geological Survey Circular 946, p. 133-135.

State of North Carolina, 1985, Geologic map of North Carolina: Department of Natural Resources and Community Development, Division of Land Resources, scale $1: 250,000$.

The State University of New York, 1961, Geologic map of New York, lower Hudson sheet: New York State Museum and Science Service, scale 1:250,000.

Wascom, J.D., and Butler, J.R., 1971, Geology and gravity of the Lilesville Granite batholith, North Carolina: Geological Society of America Bulletin, v. 82, no. 10, p. 2827-2844.

Weems, R.E., 1980, Geology of the Taylorsville basin, Hanover County, Virginia: Contributions to Virginia Geology-IV, Virginia Division of Mineral Resources Publication 27, p. 23-38.

\section{Appendix 1: Sources of Data for the Newark Basin Map (fig. 1)}

Henderson, J.R., Andreasen, G.E., and Petty, A.J., 1966, Aeromagnetic map of northern New Jersey and adjacent parts of New York and Pennsylvania: U.S. Geological Survey Geophysical Investigations Map GP-562, scale $1: 125,000$.

Klitgord, K.D., and Behrendt, J.C., 1977, Aeromagnetic map of the United States Atlantic Continental Margin: U.S. Geological Survey Miscellaneous Field Studies Map MF-913, 2 sheets, scale 1:1,000,000.

LKB Resources, Inc., 1980, National Uranium Resource Evaluation aerial gamma ray and magnetic detail survey, Reading Prong area-Final Report: U.S. Department of Energy Grand Junction Office, Report GJBX 90-80, v. 1, not paginated.

Popenoe, P., Andreasen, G.E., and Kirby, J.R., 1962a, Aeromagnetic map of the Peach Lake quadrangle, Fairfield County, Connecticut, and Putnam and Westchester Counties, New York: U.S. Geological Survey Geophysical Investigations Map GP-367, scale 1:24,000.

U.S. Geological Survey, 1971a, Aeromagnetic map of part of the Ossining quadrangle and the Mount Kisco quadrangle, Westchester County, New York, and Fairfield County, Connecticut: U.S. Geological Survey Geophysical Investigations Map GP-820, scale 1:24,000.

1971b, Acromagnetic map of part of the Stamford quadrangle, Fairfield County, Connecticut: U.S. Geological Survey Geophysical Investigations Map GP-826, scale 1:24,000.

-1971c, Aeromagnetic map of parts of the White Plains and Glenville quadrangles, Westchester County, New York, and Fairfield County, Connecticut: U.S. Geological Survey Geophysical Investigations Map GP-825, scale 1:24,000.

1971d, Aeromagnetic map of parts of the Pound Ridge quadrangle, Westchester County, New York, and Fairfield County, Connecticut: U.S. Geological Survey Geophysical Investigations Map GP-821, scale 1:24,000.

-1979a, Aeromagnetic map of parts of Delaware and New Jersey: U.S. Geological Survey Open-File Report 79-1683, 2 sheets, scale 1:250,000. 
1979b, Aeromagnetic map of southeastern New York: U.S. Geological Survey Open-File Report 79-654, scale $1: 250,000$.

Zietz, I., Gilbert, F.P., and Kirby, J.R., 1972, Northeastern United States regional aeromagnetic maps: U.S. Geological Survey Open File-Report 72-459, 13 sheets, scale $1: 250,000$.

\section{Appendix 2: Sources of Data for the Culpeper Basin Map (fig. 2)}

Balsley, J.R., 1952, Aeromagnetic map of Fairfax quadrangle, Virginia: Aeromagnetic surveying, in Advances in Geophysics: New York, Academic Press, v. 1, p. 333, scale 1:62,500.

Blanchett, J., Tyson, N.S., and McGowan, E.F., 1963a, Aeromagnetic map of the Germantown and part of the Poolesville quadrangles, Montgomery and Frederick Counties, Maryland: U.S. Geological Survey Geophysical Investigations Map GP-394, scale 1:24,000.

1963b, Aeromagnetic map of the Gaithersburg and part of the Sandy Spring quadrangles, Montgomery County, Maryland: U.S. Geological Survey Geophysical Investigations Map GP-395, scale 1:24,000.

1963c, Aeromagnetic map of the Seneca and part of the Sterling quadrangles, Montgomery County, Maryland, and Loudoun and Fairfax Counties, Virginia: U.S. Geological Survey Geophysical Investigations Map GP-396, scale 1:24,000.

1963d, Aeromagnetic map of the Rockville quadrangle, Montgomery County, Maryland, and Fairfax County, Virginia: U.S. Geological Survey Geophysical Investigations Map GP-397, scale 1:24,000.

Bromery, R.W., Galat, G.A., and Chandler, E.J., 1963a, Aeromagnetic map of the Joplin quadrangle, Prince William and Stafford Counties, Virginia: U.S. Geological Survey Geophysical Investigations Map GP-390, scale 1:24,000.

Bromery, R.W., Gilbert, F.P., and others, 1963b, Aeromagnetic map of the Kensington quadrangle, Montgomery County, Maryland: U.S. Geological Survey Geophysical Investigations Map GP-398, scale 1:24,000.

-1963c, Aeromagnetic map of the Beltsville quadrangle, Montgomery and Prince Georges Counties, Maryland: U.S. Geological Survey Geophysical Investigations Map GP-399, scale 1:24,000.

Johnson, S.S., and Froelich, A.J., 1982, Aeromagnetic contour map of the Culpeper basin and vicinity, Virginia: Virginia Division of Mineral Resources Publication 41, scale $1: 125,000$.

Neuschel, S.K., 1970, Correlation of aeromagnetic and aeroradjoactivity with lithology in the Spotsylvania area, Virginia: Geological Society of America Bulletin, v. 81, no. 12, p. 3575-3582, scale 1:62,500.

U.S. Geological Survey, 1973, Aeromagnetic map of northem Frederick County, Maryland, and parts of adjacent counties in Maryland and Pennsylvania: U.S. Geological Survey Open-File-Report 73-291, scale 1:62,500. 1974a, Aeromagnetic map of Carroll County, Maryland: U.S. Geological Survey Open-File Report 74-205, scale $1: 62,500$.

1974b, Aeromagnetic map of Frederick County, Maryland: U.S. Geological Survey Open-File Report 74-206, scale $1: 62,500$.

1974c, Aeromagnetic map of Howard County, Maryland: U.S. Geological Survey Open-File Report 74-207, scale $1: 62,500$.

1974d, Aeromagnetic map of Montgomery County, Maryland: U.S. Geological Survey Open-File Report 74-208, scale $1: 62,500$

1976, Aeromagnetic map of the northern part of West Virginia: Geological Survey Open-File Report 76-780, scale $1: 250,000$.

1980, Aeromagnetic map of Fairfax County, Virginia: U.S. Geological Survey Open-File Report 80-813, scale 1:48,000.

Virginia Division of Mineral Resources, 1971, Aeromagnetic maps of Virginia area B: Virginia Division of Mineral Resources aeromagnetic quadrangle maps (15-minute), six sheets, scale 1:62,500.

1972, Aeromagnetic maps of Virginia area C: Virginia Division of Mineral Resources aeromagnetic quadrangle maps (15-minute), 13 sheets, scale 1:62,500.

\section{Appendix 3: Sources of Data for the Northern and Southern Deep River and Davie County Basins (figs. 3-5)}

Bates, R.G., and Bell, H., III, 1965, Geophysical investigations in the Concord quadrangle, Cabarrus and Mecklenburg Counties, North Carolina: U.S. Geological Survey Geophysical Investigations Map GP-522, scale 1:250,000.

U.S. Geological Survey, 1970, Aeromagnetic map of the Camden-Kershaw area, north-central South Carolina, U.S. Geological Survey Open-File Report 70-334, 4 sheets, scale 1:250,000.

1974, Aeromagnetic map of parts of the Greensboro and Raleigh 1 degree by 2 degree quadrangles, North Carolina: U.S. Geological Survey Open-File Report 74-29, scale 1:250,000.

1976, Aeromagnetic maps of parts of Georgia, South Carolina, and North Carolina: U.S. Geological Survey Open-File Report 76-181, 13 sheets, scale 1:250,000.

1977a, Aeromagnetic map of north-central North Carolina: U.S. Geological Survey Open-File Report 77-192, scale 1:250,000.

1977b, Aeromagnetic map of south-central North Carolina: U.S. Geological Survey Open-File Report 77-205, scale 1:250,000.

1977c, Aeromagnetic map of Charlotte and vicinity, North Carolina: U.S. Geological Survey Open-File Report 78-723, scale $1: 250,000$.

1978a, Aeromagnetic map of Elizabethtown and vicinity, North Carolina: U.S. Geological Survey Open-File Report 78-758, scale 1:250,000.

1978b, Aeromagnetic map of northwestern South Carolina: U.S. Geological Survey Open-File Report 78-847, 2 sheets, scale $1: 250,000$. 


\title{
INVENTORY OF METAL MINES AND OCCURRENCES ASSOCIATED WITH THE EARLY MESOZOIC BASINS OF THE EASTERN UNITED STATES- SUMMARY TABLES
}

\author{
Gilpin R. Robinson, Jr., and C.M. Sears
}

\section{Abstract}

This report is a compilation of information on 276 metal mines, prospects, and occurrences associated with the early Mesozoic basins of the Eastern United States. Summary information on location, deposit type and size, host-rock lithology and age, and metal associations is tabulated for all known Mesozoic occurrences of $\mathrm{Cu}, \mathrm{Au}, \mathrm{Fe}, \mathrm{Pb}, \mathrm{Ag}, \mathrm{Zn}$, barite, and fluorite.

In general, the deposit types are grouped in three categories related to igneous activity, non-igneous-related brine circulation, and initial sedimentation. The first category, metal occurrences associated with igneous intrusions or the thermal aureoles bordering igneous intrusions, includes:

1. Skarn and skarn/replacement deposits in marble bordering tholeiitic diabase sheets. Such deposits contain abundant magnetite and accessory sulfide minerals enriched in $\mathrm{Cu}, \mathrm{Co}, \mathrm{Au}$, and $\mathrm{Ag}$.

2. Hornfels deposits in metamorphosed calcareous siltstone units bordering diabase and late-stage diabase differentiates, mainly bodies of ferrogabbro and granophyre. In such deposits, the hornfels is enriched in $\mathrm{Cu}$ or $\mathrm{Cu}$ and $\mathrm{Fe}$ and locally with $\mathrm{Au}, \mathrm{Mo}, \mathrm{Bi}$, and other trace metals.

3. Late-stage igneous segregations and veins within and bordering diabase sheets. The segregations and veins are enriched in copper and locally in precious and other trace metals.

The second category is sediment-hosted, stratabound, and vein-type mineralized occurrences associated with the migration of brines within the basins, apparently unrelated to igneous intrusion. Deposits in this category include:

1. Sediment-hosted and stratabound/replacement deposits of $\mathrm{Cu}$ and $\mathrm{Zn}$. Sandstone-hosted deposits are $\mathrm{Cu}$ rich, typically enriched in $\mathrm{Ag}$ and sometimes $\mathrm{U}$, and are associated with organic debris. Black-mudstone-hosted deposits are $\mathrm{Cu}$ and (or) $\mathrm{Zn}$ rich and occur, in general, as stratabound disseminated deposits or stratabound discordant veinlets and replacements.

2. Base-metal and barite vein and replacement bodies, locally enriched in $\mathrm{Pb}, \mathrm{Zn}, \mathrm{Cu}, \mathrm{Ag}$, barite, and fluorite.
Such deposits are in places associated with faults, fractures, or shear zones.

The third category is syngenetic metal occurrences formed during basin sedimentation, such as placer gold deposits in detritus derived by erosion of pre-Mesozoic igneous and metamorphic rocks bordering the basins.

Many of the localities listed in table 1 contain anomalous concentrations of $\mathrm{Au}$ and $\mathrm{Ag}$, some of which may constitute precious-metal resources. In particular, the resource potential of $\mathrm{Au}$ in sulfide-rich portions of magnetite skarn deposits and in Cu-rich hornfels deposits, and the resource potential of $\mathrm{Ag}$ in base-metal vein deposits, needs to be further evaluated. Also, the resource potential of $\mathrm{Cu}, \mathrm{Zn}$, and $\mathrm{Pb}$ in black-mudstone-hosted stratabound disseminated sulfide deposits may be substantial, judging from similar deposits elsewhere. Thus, the few known black-mudstonehosted stratabound base-metal occurrences listed in table 1 may have significance as indicators of more extensive mineralization.

\section{INTRODUCTION}

This report is a compilation of information from literature on metal mines, prospects, and occurrences associated with the early Mesozoic basins of the Eastern United States. The compilation includes information on all known occurrences of $\mathrm{Cu}, \mathrm{Au}, \mathrm{Fe}, \mathrm{Pb}, \mathrm{Ag}, \mathrm{Zn}$, barite, and fluorite and selected entries for $\mathrm{As}, \mathrm{Co}, \mathrm{Hg}$, and $\mathrm{Mo}$. Barite and fluorite are included here with the metal occurrences because of their common association with the metallic minerals. Uranium occurrences with no other associated metal have been omitted from the compilation; three included uranium entries are for base-metal occurrences that also have accessory uranium.

This compilation is intended as an aid to regional mineral-resource assessment, mineral exploration, and land-use planning. The data concerning mineral localities and the supplementary information on geologic and 
geochemical characteristics have been used to classify the occurrences into several categories of ore-deposit types, described below. The distribution and geologic features of the deposit types can be used in conjunction with regional geologic maps, tectonic models, and geophysical and geochemical surveys to predict favorable areas for mineral exploration.

The mineral occurrence information is summarized in four sections in table $1 A-D$. Information is given about:

1. Name and location (county, State, quadrangle, latitude, and longitude).

2. Deposit size (occurrence type: mine, prospect, or occurrence; production estimate).

3. Deposit type (classification of the deposit according to inferred genesis).

4. Host-rock information (lithology, age).

5. Metal associations (principal and accessory commodities).

6. Reference information.

Detailed descriptions of the information included under the table headings are given below.

\section{TABLE HEADINGS}

\section{Locality Number, Locality Name}

Each entry in table 1 has been assigned a site number. The site numbers are arranged, in general, in ascending order, from north to south and east to west.

The most prevalent name of a mine or prospect in reference descriptions or other written records is used. If there are multiple names for one mine or prospect site, generally the most recent name is used. Published sources of these names can be found in the "Deposit Bibliography" section of this report. For some prospects and mineral occurrences that have no record of a designated name, a name has been selected from a nearby geographic feature, such as a hill, stream, or town.

\section{County, State, Quadrangle, Latitude, Longitude}

Information about the county, State, quadrangle, latitude, and longitude was compiled by locating mineral localities on standard 71/2-minute U.S. Geological Survey topographic sheets (scale 1:24,000 or 1:25,000), wherever possible. The "Quadrangle" column in the table refers to the $71 / 2$-minute topographic sheets that give the site locations. For the few localities where $7 \frac{1}{2}$-minute topographic sheets are not available, standard USGS $71 \frac{1}{2} \times 15$-minute (scale $1: 25,000$ ) or 15 -minute (scale
1:62,500 or 62,300 ) topographic maps have been used. The series of the map used, if different from the standard $7 \frac{1}{2}$-minute series, follows the quadrangle name.

\section{Locality Type, Production}

The deposits in table 1 are classified as mines, prospects, or mineral occurrences $(\mathrm{m}, \mathrm{p}$, and $\mathrm{o}$, respectively, in table $1 D$ ). The designation "mine" is given to localities that have a written or recorded history of actual or attempted commercial development and ore production. The designation "prospect" is given to localities where some excavation or mineral exploration activity has occurred. The "mineral occurrence" designation is used for localities in which anomalously high metal values or interesting or unusual metal-bearing minerals occur but no mining or prospecting for metals has taken place. The volume of metal-enriched rock may be extremely small at some of the designated mineraloccurrence sites; nevertheless, such occurrences may have significance as indicators of important undiscovered mineral enrichment.

Available information concerning the amount of ore production was compiled for the mined deposits. The production history of the mined deposits has been categorized in table 1 as greater than 100,000 tons of ore (1, large), between 1,000 and 100,000 tons of ore (m, moderate), less than 1,000 tons of ore (n, negligible), and unknown production history (u). Most of the sites that have an unknown production history probably had negligible ore production.

\section{Deposit Types}

In general, the deposit types are grouped into three categories, although there is some overlap. The first category is metallic mineral concentrations associated with igneous intrusions and the thermal aureoles bordering igneous intrusions. Such deposits have been described in detail by Robinson (this volume); they include:

1. Skarn and skarn/replacement deposits in marble bordering tholeiitic diabase sheets. Skarn consists of coarse-grained $\mathrm{Ca}-\mathrm{Fe}-\mathrm{Mg}-\mathrm{Mn}$ silicates and formed by the replacement of carbonate-bearing rocks during contact metamorphism and metasomatism. The so-called skarn deposits are metal deposits that contain skarn as gangue and form during hydrothermal alteration of anhydrous skarns (Einaudi and others, 1981). The skarn deposits considered here contain abundant magnetite and accessory sulfide minerals enriched in $\mathrm{Cu}, \mathrm{Co}, \mathrm{Au}$, and $\mathrm{Ag}$. 
2. Hornfels deposits in metamorphosed calcareous siltstone units bordering diabase and late-stage diabase differentiates, mainly bodies of ferrogabbro and granophyre. Hornfels consists of fine-grained $\mathrm{Ca}-\mathrm{Fe}-\mathrm{Mg}$ Al silicates formed by the thermal alteration of impure carbonate-bearing pelitic rocks. Associated metal deposits formed by contact metamorphism and hydrothermal metasomatism of the host rocks, resulting in new oxide, sulfide, and silicate minerals. The hornfels deposits represent enrichments in $\mathrm{Cu}$, $\mathrm{Cu}$ and $\mathrm{Fe}$, and, locally, $\mathrm{Au}, \mathrm{Mo}, \mathrm{Bi}$, and other trace metals.

3. Late-stage igneous segregations and veins within and bordering diabase sheets. The segregations and veins formed by combined magmatic and postmagmatic processes that resulted in disseminated replacements of host rock by metallic minerals and epigenetic mineral fillings of tabular or sheetlike fractures in the host rock. The segregation and vein deposits contain enrichments of copper, and locally, of precious and other trace metals.

The second category is sediment-hosted, stratabound, and vein-type mineralization associated with the migration of brines within the basins, apparently unrelated to igneous intrusion. Such deposits include:

1. Sediment-hosted and stratabound/replacement deposits of $\mathrm{Cu}$ and $\mathrm{Zn}$. Sandstone-hosted deposits are $\mathrm{Cu}$ rich and typically are also enriched in $\mathrm{Ag}$ and, in places, $\mathrm{U}$; they are associated with areas of organic debris contained in the rocks. Blackmudstone-hosted deposits are $\mathrm{Cu}$ and (or) $\mathrm{Zn}$ rich and occur, in general, as stratabound disseminations or stratabound discordant veinlets and replacements. Additional information on these deposit types is contained in Smoot and Robinson ("Sedimentology of Stratabound Base-Metal Occurrences in the Newark Supergroup," this volume).

2. Base-metal and barite vein and replacement bodies, within which are local concentrations of minerals containing $\mathrm{Pb}, \mathrm{Zn}, \mathrm{Cu}$, and $\mathrm{Ag}$ plus barite and fluorite. These deposits in places are associated with faults, fractures, or shear zones and constitute epigenetic mineral fillings of fractures in the host rock. Additional information on these deposits is contained in Robinson and Woodruff (this volume).

The third category is syngenetic metal occurrences associated with basin sedimentation. The best example of such deposits is placer gold-fluvial sedimentary deposits formed by mechanical concentration-in detritus derived by the weathering and erosion of pre-Mesozoic igneous and metamorphic rocks bordering the basins.

\section{Metal Associations}

Table 1 includes information on all known occurrences of $\mathrm{Cu}, \mathrm{Au}, \mathrm{Fe}, \mathrm{Pb}, \mathrm{Ag}, \mathrm{Zn}$, barite, and fluorite associated with the early Mesozoic basins and contains selected entries for $\mathrm{As}, \mathrm{Co}, \mathrm{Hg}$, Mo, and U. Uranium occurrences with no other associated metal have been omitted from the compilation; three uranium entries included are for base-metal occurrences that have associated uranium enrichment.

Selected metals and the nonmetals, $\mathrm{Ba}$ and $\mathrm{F}$, are listed in the "metal associations" category of table 1 at each occurrence where present in anomalous concentrations. The elements listed in the "principal" subcategory are those base metals and selected nonmetals that are most abundant at each occurrence. In most cases, the elements noted as "principal" are major components of individual minerals in the occurrence, such as Fe in magnetite and $\mathrm{Cu}$ in chalcopyrite. The elements listed in the "accessory" subcategory are those base metals and selected nonmetals that occur in minor but anomalous amounts. Elements in this subcategory may occur both as major components of trace minerals and as minor components in relatively abundant minerals (such as silver in galena).

\section{Reference Information}

References used in compiling this information are identified in table $1 A-D$ by a series of numbers that are keyed to table $1 E$, which lists author name and year of publication. Complete citations are listed in the "Deposit Bibliography."

\section{DISCUSSION}

Numerous occurrences of minerals of $\mathrm{Cu}, \mathrm{Pb}, \mathrm{Zn}$, and $\mathrm{Fe}$ have been noted and prospected in the past in the early Mesozoic basins of the Eastern United States, particularly during the eighteenth and nineteenth centuries. Production of base metals from most of these occurrences was small, although some were important sources during the early history of the country. Only 15 of the 122 mines and prospects summarized in table 1 had production exceeding 100,000 tons of ore. Of the 15 mines having relatively large production, all but two are skarn deposits, where the principal ore mineral was magnetite. Four of these skarn deposits (or districts) produced or have existing ore reserves near or in excess of 1 million tons of ore (no. 160, French Creek mines; no. 171 , Grace mine; no. 179 , Cornwall mine; and nos. 202-219, Dillsburg district mines).

Approximately 43 percent of the 276 occurrences listed in table 1 are metal deposits associated with 
igneous intrusions or the thermal aureoles bordering igneous intrusions. Of the deposits in this igneousassociated category, approximately 25 percent of the 276 occurrences are skarn deposits, 15 percent are hornfels deposits, and 3 percent are diabase-hosted vein deposits. These percentages generally reflect the relative economic value of each of the deposit types. Approximately 54 percent of the 276 occurrences listed in table 1 are sediment-hosted stratabound or vein deposits associated with the migration of connate brines within the basins and adjacent basement rocks, and apparently are not associated with igneous intrusions. Of the deposits in this non-igneous-associated category, approximately 38 percent and 16 percent of the 276 occurrences are vein deposits and sediment-hosted stratabound deposits, respectively. Only 3 percent of the 276 occurrences are placer deposits, principally of gold.

Anomalous concentrations of $\mathrm{Au}$ and $\mathrm{Ag}$ are present in many of the occurrences listed in table $1 D$, and some of the deposits may have resource potential for precious metals. In particular, the resource potential of
$\mathrm{Au}$ in sulfide-rich portions of magnetite skarn deposits and $\mathrm{Cu}$-rich hornfels deposits, and the resource potential of $\mathrm{Ag}$ in base-metal vein deposits, needs to be further evaluated. Also, the resource potential of $\mathrm{Cu}, \mathrm{Zn}$, and $\mathrm{Pb}$ in stratabound black-mudstone-hosted disseminated sulfide deposits may be substantial, judging from similar deposits elsewhere. The base-metal deposits hosted by black mudstones resemble unmineralized black mudstones in outcrop and hand sample; therefore, extensive deposits containing this type of mineralization may go unrecognized if not carefully sampled. Thus, the few black-mudstone-hosted stratabound base-metal occurrences recognized to date and listed in table 1 may have significance as indicators of more extensive mineralization.

\section{REFERENCES CITED}

Einaudi, M.T., Meinart, L.D., and Newberry, R.J., 1981, Skarn Deposits: Economic Geology, Seventy-Fifth Anniversary Volume, p. 317-391. 
TABLE 1 
Table 1A. Inventory of metal mines and occurrences associated with the early Mesozoic basins of the Eastern United States [See text for in-depth descriptions of column headings; in the "Production" column, an l, $m, n$, or $u$ indicates ore production or reserves greater reference citation is listed in table $1 E$ ]

\begin{tabular}{|c|c|c|c|c|c|c|c|}
\hline $\begin{array}{l}\text { Locality } \\
\text { number }\end{array}$ & Name & County & State & Quadrangle & Latitude & Longitude & $\begin{array}{l}\text { Locality } \\
\text { typo }\end{array}$ \\
\hline \multicolumn{8}{|c|}{ New Hampshire, North of the Hartford basin-Area 0} \\
\hline $\begin{array}{r}1 \\
2 \\
3 \\
4 \\
5 \\
6 \\
7 \\
8 \\
9 \\
10\end{array}$ & $\begin{array}{l}\text { E. Surry Mtn. mine } \\
\text { Will Wise mine } \\
\text { Stoddard mine } 1 \\
\text { Stoddard mine } 2 \\
\text { Springer mine } \\
\text { fluorite prospect } \\
\text { Pierce mine } \\
\text { Streeter Hill } \\
\text { galena occurrence } \\
\text { Winchester mine }\end{array}$ & $\begin{array}{l}\text { Cheshire } \\
\text { Cheshire } \\
\text { Cheshire } \\
\text { Cheshire } \\
\text { Cheshire } \\
\text { Cheshire } \\
\text { Cheshire } \\
\text { Cheshire } \\
\text { Cheshire } \\
\text { Cheshire }\end{array}$ & $\begin{array}{l}\text { New Hampshire } \\
\text { New Hampshire } \\
\text { New Hampshire } \\
\text { New Hampshire } \\
\text { New Hampshire } \\
\text { New Hampshire } \\
\text { New Hampshire } \\
\text { New Hampshire } \\
\text { New Hampshire } \\
\text { New Hampshire }\end{array}$ & $\begin{array}{l}\text { Bellows Falls } 15^{\prime} \\
\text { Keene } 7.5 \times 15^{\prime} \\
\text { Keene } 7.5 \times 15^{\prime} \\
\text { Keene } 7.5 \times 15^{\prime} \\
\text { Keene } 7.5 \times 15^{\prime} \\
\text { Keene } 7.5 \times 15^{\prime} \\
\text { Keene } 7.5 \times 15^{\prime} \\
\text { Keene } 7.5 \times 15^{\prime} \\
\text { Winchester } \\
\text { Northfield }\end{array}$ & $\begin{array}{l}\mathrm{N} 43^{\circ} 02^{\prime} 01^{\prime \prime} \\
\mathrm{N} 42^{\circ} 56^{\prime} 55^{\prime \prime} \\
\mathrm{N} 42^{\circ} 56^{\prime} 01^{\prime \prime} \\
\mathrm{N} 42^{\circ} 56^{\prime} 00^{\prime \prime} \\
\mathrm{N} 42^{\circ} 55^{\prime} 50^{\prime \prime} \\
\mathrm{N} 42^{\circ} 55^{\prime} 45^{\prime \prime} \\
\mathrm{N} 42^{\circ} 55^{\prime} 44^{\prime \prime} \\
\mathrm{N} 42^{\circ} 55^{\prime} 21^{\prime \prime} \\
\mathrm{N} 42^{\circ} 49^{\prime} 17^{\prime \prime} \\
\mathrm{N} 42^{\circ} 43^{\prime} 42^{\prime \prime}\end{array}$ & $\begin{array}{l}\text { W72 } 12^{\circ} 26^{\prime \prime} \\
\text { W72 } 29^{\prime} 10^{\prime \prime} \\
\text { W72 } 27^{\circ} 56^{\prime \prime} \\
\text { W72 } 28^{\circ} 03^{\prime \prime} \\
\text { W72 } 28^{\prime} 32^{\prime \prime} \\
\text { W72 } 28^{\prime} 18^{\prime \prime} \\
\text { W72 } 27^{\circ} 55^{\prime \prime} \\
\text { W72 } 29^{\prime} 51^{\prime \prime} \\
\text { W72 } 23^{\prime} 24^{\prime \prime} \\
\text { W72 } 26^{\prime} 30^{\prime \prime}\end{array}$ & $\begin{array}{l}\text { mine } \\
\text { mine } \\
\text { mine } \\
\text { mine } \\
\text { mine } \\
\text { prospect } \\
\text { mine } \\
\text { occurrence } \\
\text { occurrence } \\
\text { mine }\end{array}$ \\
\hline
\end{tabular}

Hartford basin and vicinity, Massachusetts-Area 1

11 Bernardston

12 Turners Falls 1

13 Turners Falls 2

14 Deerfield

15 Unnamed $\mathrm{Pb}-\mathrm{Ba}$

16 Mt. Esther

17 Leverett

18 Unnamed $\mathrm{Pb}-\mathrm{Ba} 4$

19 Whately-Wm. 1

20 Whately-Wm. 2

21 Unnamed $\mathrm{Pb}-\mathrm{Ba} 1$

22 Unnamed $\mathrm{Pb}-\mathrm{Ba} 3$

23 Unnamed $\mathrm{Pb}-\mathrm{Ba} 2$

24 Whately-Wm. 3

25 Hatfield lead

26 Unnamed Pb-Ba 2

27 Unnamed $\mathrm{Pb}+\mathrm{Ba} 1$

28 Manhan Lead 1

29 Manhan Lead 2

30 Manhan Lead 3

31 Manhan Lead 4

32 Manhan Lead 5

33 Southampton

34 New mine vein

35 Woodland Dell
Franklin

Franklin

Franklin

Franklin

Franklin

Franklin

Franklin

Franklin

Franklin

Franklin

Franklin

Franklin

Franklin

Franklin

Hampshire

Hampshire

Hampshire

Hampshire

Hampshire

Hampshire

Hampshire

Hampshire

Hampshire

Hampshire

Hampden
Massachusetts

Massachusetts

Massachusetts

Massachusetts

Massachusetts

Massachusetts

Massachusetts

Massachusetts

Massachusetts

Massachusetts

Massachusetts

Massachusetts

Massachusetts

Massachusetts

Massachusetts

Massachusetts

Massachusetts

Massachusetts

Massachusetts

Massachusetts

Massachusetts

Massachusetts

Massachusetts

Massachusetts

Massachusetts
Bernardston

Greenfield

Greenfield

Williamsburg

Williamsburg

Williamsburg

Mt. Toby

Mt. Toby

Williamsburg

Williamsburg

Mt. Toby

Mt. Toby

Mt. Toby

Williamsburg

Williamsburg

Easthampton

Easthampton

Easthampton

Easthampton

Easthampton

Easthampton

Easthampton

Easthampton

Woronoco

Hampden
$\mathrm{N} 42^{\circ} 41^{\prime} 04^{\prime \prime}$ N42 $36^{\prime} 54^{\prime \prime}$ $\mathrm{N} 42^{\circ} 36^{\prime} 49^{\prime \prime}$

N42 $29^{\prime} 03^{\prime \prime}$

$\mathrm{N} 42^{\circ} 28^{\prime} 10^{\prime \prime}$

$\mathrm{N} 42^{\circ} 27^{\prime} 28^{\prime \prime}$

$\mathrm{N} 42^{\circ} 27^{\prime} 28^{\prime \prime}$

N42 $27^{\prime} 26^{\prime \prime}$

N42 $27^{\prime} 17^{\prime \prime}$

N42 $26^{\prime} 58^{\prime \prime}$

$\mathrm{N} 42^{\circ} 26^{\prime} 29^{\prime \prime}$

$\mathrm{N} 42^{\circ} 26^{\prime} 15^{\prime \prime}$

$\mathrm{N} 42^{\circ} 26^{\prime} 14^{\prime \prime}$

N42 $25^{\prime} 46^{\prime \prime}$

N42 $23^{\prime} 18^{\prime \prime}$

N42 $21^{\prime} 35^{\prime \prime}$

N42 $17^{\prime} 34^{\prime \prime}$

N42 $17^{\circ} 02^{\prime \prime}$

N $42^{\circ} 16^{\prime} 54^{\prime \prime}$

$\mathrm{N} 42^{\circ} 16^{\prime} 49^{\prime \prime}$

N42 $16^{\prime} 36^{\prime \prime}$

N42 $16^{\prime} 30^{\prime \prime}$

$\mathrm{N} 42^{\circ} 15^{\prime} 51^{\prime \prime}$

N42 $12^{\prime} 45^{\prime \prime}$

$\mathrm{N} 42^{\circ} 07^{\prime} 13^{\prime \prime}$
W72 $33^{\prime} 12^{\prime \prime}$ occurrence W72 $34^{\prime} 09^{\prime \prime}$ occurrence W72 $34^{\prime} 01^{\prime \prime}$ occurrence W72 $39^{\prime} 21^{\prime \prime}$ occurrence W7 $2^{\circ} 39^{\prime} 19^{\prime \prime}$ occurrence W72 $40^{\prime} 06^{\prime \prime}$ occurrence W72 $31^{\prime} 06^{\prime \prime}$ mine W72 $31^{\prime} 30^{\prime \prime}$ occurrence W72 $41^{\prime} 01^{\prime \prime}$ mine W72 $40^{\prime} 55^{\prime \prime}$ mine W72 $31^{\prime} 30^{\prime \prime}$ occurrence W72 $31^{\prime} 32^{\prime \prime}$ occurrence W72 $31^{\prime} 28^{\prime \prime}$ occurrence W7 $2^{\circ} 40^{\prime} 15^{\prime \prime}$ mine W72 $38^{\prime} 07^{\prime \prime}$ mine W7 $2^{\circ} 44^{\prime} 48^{\prime \prime}$ mine W72 $43^{\prime} 50^{\prime \prime}$ mine W72 $43^{\prime} 55^{\prime \prime}$ mine W72 $43^{\prime} 58^{\prime \prime}$ mine W72 $2^{\circ} 43^{\prime} 58^{\prime \prime}$ mine W7 $2^{\circ} 44^{\prime} 02^{\prime \prime}$ mine W72 $44^{\prime} 00^{\prime \prime}$ mine W7 $2^{\circ} 44^{\prime} 18^{\prime \prime}$ mine W72 $46^{\prime} 50^{\prime \prime}$ mine W7 $2^{\circ} 25^{\prime} 31^{\prime \prime}$ occurrence

Hartford basin and vicinity, Connecticut-Area 2

36 Somers sandpit

37 K \& F Suffield

38 Simsbury mine

39 New-gate Prison

40 Higley copper

41 Trinity College

42 Bristol copper

43 Farmington

44 basalt quarry

45 Plainfield quarry

46 Cook's Gap

47 Columbus Blvd.

48 Ellis Street

49 bitumen vein

50 Mattabesset River

51 Berlin Moores Mill

52 limestone quarry

53 barite vein

54 Middletown lead

55 copper prospect

56 barite vein

57 New Haven mine

58 Cheshire mine 3

59 Cheshire mine 2

60
Tolland

Hartford

Hartford

Hartford

Hartford

Hartford

Hartford

Hartford

Hartford

Hartford

Hartford

Hartford

Hartford

Hartford

Hartford

Hartford

Hartford

Middlesex

Middlesex

Middlesex

New Haven

New Haven

New Haven

New Haven

New Haven
Connecticut

Connecticut

Connecticut

Connecticut

Connecticut

Connecticut

Connecticut

Connecticut

Connecticut

Connecticut

Connecticut

Connecticut

Connecticut

Connecticut

Connecticut

Connecticut

Connecticut

Connecticut

Connecticut

Connecticut

Connecticut

Connecticut

Connecticut

Connecticut

Connecticut
Hampden

Broad Brook

Windsor Locks

Windsor Locks

Windsor Locks

Hartford North

Bristol

New Britain

New Britain

New Britain

New Britain

New Britain

New Britain

New Britain

Meriden

Meriden

Meriden

Middletown

Middle Haddam

Middle Haddam

Southington

Southington

Southington

Southington

Southington

$\mathrm{N} 42^{\circ} 01^{\prime} 43^{\prime \prime}$ N41 $58^{\prime} 33^{\prime \prime}$ N41 $58^{\circ} 13^{\prime \prime}$

N41 $57^{\circ} 41^{\prime \prime}$

N41 $56^{\prime} 16^{\prime \prime}$

$\mathrm{N} 41^{\circ} 45^{\prime} 04^{\prime \prime}$

N41 $41^{\circ} 16^{\prime \prime}$

$\mathrm{N} 41^{\circ} 42^{\prime} 26^{\prime \prime}$

$\mathrm{N} 41^{\circ} 40^{\prime} 27^{\prime \prime}$

$\mathrm{N}^{\circ} 1^{\circ} 40^{\prime} 17^{\prime \prime}$

N41 $41^{\circ} 02^{\prime \prime}$

N41 $39^{\prime} 51^{\prime \prime}$

N41 ${ }^{\circ} 39^{\prime} 28^{\prime \prime}$

N41 $37^{\prime} 33^{\prime \prime}$

N41 $37^{\circ} 16^{\prime \prime}$

N41 $37^{\circ} 09^{\prime \prime}$

N41 $37^{\prime} 09^{\prime \prime}$

N41 ${ }^{\circ} 36^{\prime} 53^{\prime \prime}$

N41 $33^{\prime} 33^{\prime \prime \prime}$

N41 $31^{\prime} 32^{\prime \prime}$

N4 $1^{\circ} 33^{\prime} 05^{\prime \prime}$

N41 $33^{\prime} 01^{\prime \prime}$ 
listed numerically according to geographic location

than 100,000 tons, between 1,000 and 100,000 tons, less than 1,000 tons, or unknown, respectively; in the "References" column, the number of the

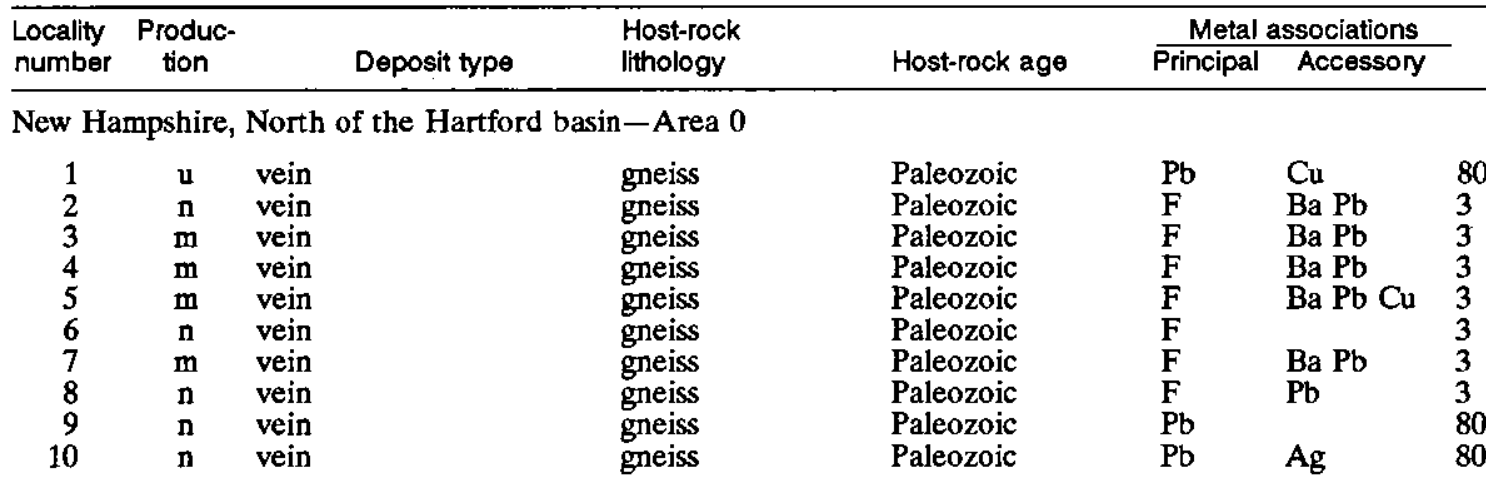

Hartford basin and vicinity, Massachusetts-Area 1

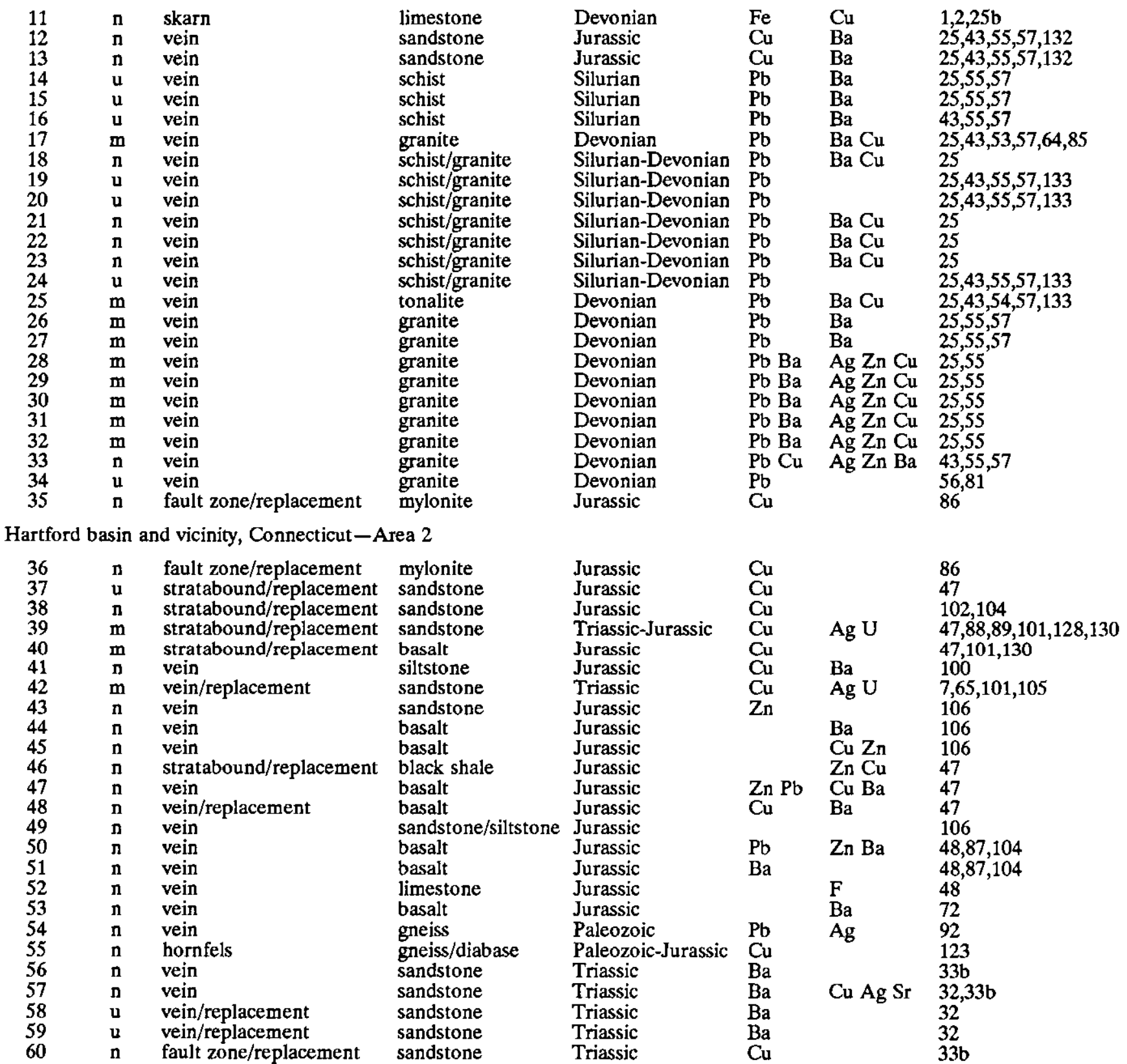


Table 1A. Inventory of metal mines and occurrences associated with the early Mesozoic basins of the Eastern United States [See text for in-depth descriptions of column headings; in the "Production" column, an l, $\mathrm{m}, \mathrm{n}$, or $\mathrm{u}$ indicates ore production or reserves greater reference citation is listed in table $\mathbf{1 E}$ ]

\begin{tabular}{lllllll}
\hline $\begin{array}{l}\text { Locality } \\
\text { number }\end{array}$ & Name & County & State & Quadrangle & Latitude & Longitude \\
\hline
\end{tabular}

Hartford basin and vicinity, Connecticut-Area 2-Continued

$\begin{array}{lllll}61 & \text { Booth \& Hinman } & \text { New Haven } & \text { Connecticut } & \text { Southington } \\ \text { 62 } & \text { Cheshire mine 1 } & \text { New Haven } & \text { Connecticut } & \text { Southington } \\ \text { 63 } & \text { copper mine } & \text { New Haven } & \text { Connecticut } & \text { Meriden } \\ \text { 64 } & \text { Jinny Hill } & \text { New Haven } & \text { Connecticut } & \text { Mount Carmel } \\ 65 & \text { Cross Rock } & \text { New Haven } & \text { Connecticut } & \text { Mount Carmel } \\ 66 & \text { Gaylord } & \text { New Haven } & \text { Connecticut } & \text { Mount Carmel } \\ 67 & \text { Tallman's mine } & \text { New Haven } & \text { Connecticut } & \text { Mount Carmel } \\ 68 & \text { copper prospect } & \text { New Haven } & \text { Connecticut } & \text { Mount Carmel } \\ 69 & \text { Copper Valley } & \text { New Haven } & \text { Connecticut } & \text { Mount Carmel } \\ 70 & \text { copper prospect } & \text { New Haven } & \text { Connecticut } & \text { Mount Carmel } \\ 71 & \text { silver prospect } & \text { New Haven } & \text { Connecticut } & \text { Branford }\end{array}$

Newark basin, New Jersey-Area 3

$\begin{array}{lll}72 & \text { Totowa mine } & \text { Passaic } \\ 73 & \text { Glen Ridge mine } & \text { Essex } \\ 74 & \text { Wigwam Brook } & \text { Essex } \\ 75 & \text { Dod mine } & \text { Essex } \\ 76 & \text { Schuyler mine } & \text { Bergen } \\ 77 & \text { Laurel Hill } & \text { Hudson } \\ 78 & \text { Hoffman } & \text { Somerset } \\ 79 & \text { Stony Brook } & \text { Somerset } \\ 80 & \text { Bridgewater } & \text { Somerset } \\ 81 & \text { Chimney Rock } & \text { Somerset } \\ 82 & \text { Menlo Park mine } & \text { Middlesex } \\ 83 & \text { New Brunswick } & \text { Middlesex } \\ 84 & \text { Flemington } & \text { Hunterdon } \\ 85 & \text { Monmouth Junction } & \text { Somerset } \\ 86 & \text { Griggstown } & \text { Somerset } \\ 87 & \text { Hopewell barite } & \text { Mercer } \\ 88 & \text { Woosamonsa pros. } & \text { Mercer }\end{array}$

Newark basin and vicinity, Pennsylvania-Area 4

$\begin{array}{ll}89 & \text { New Hope } \\ 90 & \text { Ingham Spring } \\ 91 & \text { Solebury } \\ 92 & \text { Buckmanville } \\ 93 & \text { Buckingham } \\ 94 & \text { W. Buckmanville } \\ 95 & \text { Bushington } \\ 96 & \text { Lodi } \\ 97 & \text { Tettemer's mine } \\ 98 & \text { Uhlerstown } \\ 99 & \text { Ferndale } \\ 100 & \text { Bursonville } \\ 101 & \text { Keller's Church } \\ 102 & \text { Hagersville } \\ 103 & \text { New Galena } \\ 104 & \text { Schuylkill Falls } \\ 105 & \text { Diehl's mine } \\ 106 & \text { Sellersville } \\ 107 & \text { Drakes Crossroad } \\ 108 & \text { Leithsville mine } \\ 109 & \text { Coopersburg } \\ 110 & \text { Pennsburg } \\ 111 & \text { Red Hill } \\ 112 & \text { Sumneytown } \\ 113 & \text { Kibblehouse quarry } \\ 114 & \text { Hendricks Station } \\ 115 & \text { Kober's mine } \\ 116 & \text { Karl's mine } \\ 117 & \text { Young's mine } \\ 118 & \text { Schwencksville } \\ 119 & \text { Lederachsville } \\ 120 & \text { Graters Ford } \\ & \end{array}$

$\begin{array}{lll}\text { Bucks } & \text { Pennsylvania } & \text { Stockton } \\ \text { Bucks } & \text { Pennsylvania } & \text { Lambertville } \\ \text { Bucks } & \text { Pennsylvania } & \text { Lambertville } \\ \text { Bucks } & \text { Pennsylvania } & \text { Lambertville } \\ \text { Bucks } & \text { Pennsylvania } & \text { Buckingham } \\ \text { Bucks } & \text { Pennsylvania } & \text { Buckingham } \\ \text { Bucks } & \text { Pennsylvania } & \text { Buckingham } \\ \text { Bucks } & \text { Pennsylvania } & \text { Frenchtown } \\ \text { Bucks } & \text { Pennsylvania } & \text { Frenchtown } \\ \text { Bucks } & \text { Pennsylvania } & \text { Frenchtown } \\ \text { Bucks } & \text { Pennsylvania } & \text { Riegelsville } \\ \text { Bucks } & \text { Pennsylvania } & \text { Riegelsville } \\ \text { Bucks } & \text { Pennsylvania } & \text { Bedminster } \\ \text { Bucks } & \text { Pennsylvania } & \text { Bedminster } \\ \text { Bucks } & \text { Pennsylvania } & \text { Doylestown } \\ \text { Philadelphia } & \text { Pennsylvania } & \text { Philadelphia } \\ \text { Bucks } & \text { Pennsylvania } & \text { Quakertown } \\ \text { Bucks } & \text { Pennsylvania } & \text { Telford/Quakertown } \\ \text { Montgomery } & \text { Pennsylvania } & \text { Telford } \\ \text { Northampton } & \text { Pennsylvania } & \text { Hellertown } \\ \text { Lehigh } & \text { Pennsylvania } & \text { Milford Square } \\ \text { Montgomery } & \text { Pennsylvania } & \text { Milford Square } \\ \text { Montgomery } & \text { Pennsylvania } & \text { Milford Square } \\ \text { Montgomery } & \text { Pennsylvania } & \text { Perkiomenville } \\ \text { Montgomery } & \text { Pennsylvania } & \text { Perkiomenville } \\ \text { Montgomery } & \text { Pennsylvania } & \text { Perkiomenville } \\ \text { Montgomery } & \text { Pennsylvania } & \text { Perkiomenville } \\ \text { Montgomery } & \text { Pennsylvania } & \text { Perkiomenville } \\ \text { Montgomery } & \text { Pennsylvania } & \text { Perkiomenville } \\ \text { Montgomery } & \text { Pennsylvania } & \text { Perkiomenville } \\ \text { Montgomery } & \text { Pennsylvania } & \text { Perkiomenville } \\ \text { Montgomery } & \text { Pennsylvania } & \text { Collegeville } \\ & & \\ & & \end{array}$

\begin{tabular}{|c|c|c|}
\hline $\begin{array}{l}\mathrm{N} 41^{\circ} 32^{\prime} 07^{\prime \prime} \\
\mathrm{N} 41^{\circ} 31^{\prime} 11^{\prime \prime} \\
\mathrm{N} 41^{\circ} 31^{\prime} 11^{\prime \prime} \\
\mathrm{N} 41^{\circ} 28^{\prime} 49^{\prime \prime} \\
\mathrm{N} 41^{\circ} 28^{\prime} 11^{\prime \prime} \\
\mathrm{N} 41^{\circ} 27^{\prime} 43^{\prime \prime} \\
\mathrm{N} 41^{\circ} 26^{\prime} 31^{\prime \prime} \\
\mathrm{N} 41^{\circ} 26^{\prime} 17^{\prime \prime} \\
\mathrm{N} 41^{\circ} 26^{\prime} 15^{\prime \prime} \\
\mathrm{N} 41^{\circ} 23^{\prime} 03^{\prime \prime} \\
\mathrm{N} 41^{\circ} 18^{\prime} 02^{\prime \prime}\end{array}$ & $\begin{array}{l}\text { W72 } 52^{\circ} 54^{\prime} 25^{\prime \prime} \\
\text { W72 } \\
\text { W7 } 54^{\prime} 47^{\prime \prime} \\
\text { W72 } 49^{\prime} 27^{\prime \prime} \\
\text { W72 } \\
\text { W72 } 53^{\circ} 49^{\prime} 52^{\prime} 39^{\prime \prime} \\
\text { W72 } \\
\text { W72 } 53^{\prime} 37^{\prime \prime} \\
\text { W72 } 54^{\circ} 02^{\prime \prime} \\
\text { W72 } \\
\text { W72 } 54^{\circ} 03^{\circ} 54^{\prime} 03^{\prime \prime} \\
\text { W72 } \\
\text { W72 } 51^{\circ} 50^{\prime} 55^{\prime \prime}\end{array}$ & $\begin{array}{l}\text { mine } \\
\text { mine } \\
\text { mine } \\
\text { mine } \\
\text { mine } \\
\text { prospect } \\
\text { mine } \\
\text { prospect } \\
\text { prospect } \\
\text { prospect } \\
\text { prospect }\end{array}$ \\
\hline
\end{tabular}

$\mathrm{N} 40^{\circ} 54^{\prime} 00^{\prime \prime} \mathrm{W} 74^{\circ} 13^{\prime} 12^{\prime \prime}$ mine $\mathrm{N} 40^{\circ} 47^{\prime} 58^{\prime \prime} \mathrm{W} 74^{\circ} 12^{\prime} 09^{\prime \prime}$ mine $\mathrm{N} 40^{\circ} 46^{\prime} 52^{\prime \prime} \mathrm{W} 74^{\circ} 13^{\prime} 49^{\prime \prime}$ mine $\mathrm{N} 40^{\circ} 46^{\prime} 51^{\prime \prime} \mathrm{W} 74^{\circ} 13^{\prime} 00^{\prime \prime}$ mine $\mathrm{N} 40^{\circ} 46^{\prime} 43^{\prime \prime} \mathrm{W} 74^{\circ} 07^{\prime} 45^{\prime \prime}$ mine N40 $45^{\prime} 32^{\prime \prime}$ W7 $4^{\circ} 05^{\prime} 11^{\prime \prime}$ occurrence $\mathrm{N} 40^{\circ} 38^{\prime} 31^{\prime \prime} \mathrm{W} 74^{\circ} 37^{\prime} 35^{\prime \prime}$ mine N40 $37^{\prime} 57^{\prime \prime}$ W74 $26^{\prime} 38^{\prime \prime}$ mine N40 $36^{\prime} 53^{\prime \prime}$ W74 $4^{\circ} 36^{\prime} 56^{\prime \prime}$ ' mine $\mathrm{N} 40^{\circ} 34^{\prime} 50^{\prime \prime} \mathrm{W} 74^{\circ} 33^{\prime} 30^{\prime \prime}$ mine $\mathrm{N} 40^{\circ} 33^{\prime} 52^{\prime \prime}$ W7 $74^{\circ} 20^{\prime} 01^{\prime \prime}$ mine N40 30'03" W7 $74^{\circ} 26^{\prime} 58^{\prime \prime}$ mine N40 $30^{\prime} 22^{\prime \prime}$ W74 $52^{\prime} 11^{\prime \prime}$ mine N40 $26^{\prime} 26^{\prime \prime}$ W74 $4^{\circ} 34^{\prime} 52^{\prime \prime}$ prospect N40 $25^{\prime} 34^{\prime \prime}$ W74 $36^{\prime} 45^{\prime \prime}$ mine N40 $22^{\prime} 19^{\prime \prime}$ W74 $44^{\circ} 13^{\prime \prime}$ mine $\mathrm{N} 40^{\circ} 20^{\prime} 17^{\prime \prime} \mathrm{W} 74^{\circ} 50^{\prime} 10^{\prime \prime}$ prospect
N40 $22^{\prime} 46^{\prime \prime} \quad \mathrm{W} 74^{\circ} 57^{\prime} 48^{\prime \prime}$ occurrence N40 $21^{\prime} 50^{\prime \prime}$ W7 $74^{\circ} 59^{\prime 3} 33^{\prime \prime}$ prospect $\mathrm{N} 40^{\circ} 20^{\prime} 11^{\prime \prime} \mathrm{W} 74^{\circ} 57^{\prime} 14^{\prime \prime}$ mine N40 $19^{\prime} 35^{\prime \prime} \mathrm{W} 74^{\circ} 58^{\prime} 52^{\prime \prime}$ mine N $40^{\circ} 20^{\prime} 09^{\prime \prime}$ W75 $03^{\prime} 21^{\prime \prime}$ occurrence N40 $19^{\prime} 47^{\prime \prime}$ W7 $75^{\circ} 00^{\prime} 57^{\prime \prime}$ prospect N40 $19^{\prime} 03^{\prime \prime}$ W75 $04^{\prime} 23^{\prime \prime}$ occurrence N40 $33^{\prime} 08^{\prime \prime}$ W7 $75^{\circ} 05^{\prime} 20^{\prime \prime}$ occurrence N40 32'00' W7 $5^{\circ} 05^{\prime} 24^{\prime \prime}$ mine N40 $31^{\prime} 36^{\prime \prime}$ W75 $05^{\prime} 26^{\prime \prime}$ occurrence N40 $32^{\prime} 45^{\prime \prime}$ W7 $75^{\circ} 10^{\prime} 20^{\prime \prime}$ occurrence $\mathrm{N} 40^{\circ} 32^{\prime} 25^{\prime \prime} \mathrm{W}^{\prime} 5^{\circ} 13^{\prime} 26^{\prime \prime}$ occurrence $\mathrm{N} 40^{\circ} 27^{\prime} 50^{\prime \prime} \mathrm{W} 75^{\circ} 13^{\prime} 24^{\prime \prime}$ prospect N40 $24^{\prime} 25^{\prime \prime}$ W75 $14^{\prime} 54^{\prime \prime}$ occurrence N40 $19^{\prime} 48^{\prime \prime}$ W75 $11^{\prime} 01^{\prime \prime}$ mine N39 $58^{\prime} 57^{\prime \prime}$ W7 $75^{\circ} 11^{\prime} 16^{\prime \prime}$ occurrence N40 $25^{\prime} 03^{\prime \prime}$ W75 $15^{\prime} 08^{\prime \prime}$ occurrence $\mathrm{N} 40^{\circ} 22^{\prime} 09^{\prime \prime}$ W7 $5^{\circ} 18^{\prime} 06^{\prime \prime}$ occurrence N40 $16^{\prime} 09^{\prime \prime}$ W $75^{\circ} 18^{\prime} 54^{\prime \prime}$ occurrence N40 $33^{\prime} 17^{\prime \prime}$ W7 $75^{\circ} 20^{\prime} 09^{\prime \prime}$ mine N40 $29^{\prime} 56^{\prime \prime}$ W7 $75^{\circ} 24^{\prime} 49^{\prime \prime}$ prospect N40 $24^{\prime} 19^{\prime \prime}$ W7 $75^{\circ} 28^{\prime} 57^{\prime \prime}$ occurrence N40 $23^{\prime} 06^{\prime \prime}$ W75 $28^{\prime} 23^{\prime \prime}$ occurrence N40 $19^{\prime} 54^{\prime \prime}$ W75 $25^{\prime} 37^{\prime \prime}$ occurrence N40 $19^{\prime} 27^{\prime \prime}$ W75 $28^{\prime} 21^{\prime \prime}$ occurrence $\mathrm{N} 40^{\circ} 19^{\prime} 09^{\prime \prime} \mathrm{W} 75^{\circ} 27^{\prime} 47^{\prime \prime}$ prospect N40 $19^{\prime} 02^{\prime \prime}$ W75 $26^{\prime} 11^{\prime \prime}$ mine N40 $19^{\prime} 01^{\prime \prime}$ W75 $29^{\prime} 38^{\prime \prime}$ mine N40 $18^{\prime} 33^{\prime \prime}$ W7 $75^{\circ} 28^{\prime} 02^{\prime \prime}$ mine N40 $16^{\prime} 20^{\prime \prime}$ W7 $75^{\circ} 27^{\prime} 25^{\prime \prime}$ prospect $\mathrm{N} 40^{\circ} 16^{\prime} 05^{\prime \prime} \mathrm{W} 75^{\circ} 23^{\prime} 19^{\prime \prime}$ occurrence N40 $13^{\prime} 46^{\prime \prime}$ W75 $27^{\prime} 28^{\prime \prime}$ occurrence 
listed numerically according to geographic location-Continued

than 100,000 tons, between 1,000 and 100,000 tons, less than 1,000 tons, or unknown, respectively; in the "References" column, the number of the

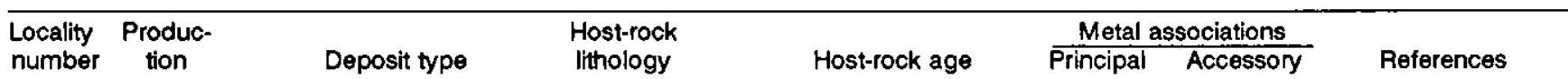

Hartford basin and vicinity, Connecticut-Area 2-Continued

$\begin{array}{lll}61 & \mathrm{n} & \text { vein } \\ 62 & \mathrm{u} & \text { vein/replacement } \\ 63 & \mathrm{u} & \text { fault zone/replacement } \\ 64 & \mathrm{l} & \text { vein } \\ 65 & \mathrm{n} & \text { vein/replacement } \\ 66 & \mathrm{n} & \text { vein/replacement } \\ 67 & \mathrm{~m} & \text { vein/replacement } \\ 68 & \mathrm{n} & \text { hornfels } \\ 69 & \mathrm{n} & \text { vein/replacement } \\ 70 & \mathrm{n} & \text { hornfels?/replacement } \\ 71 & \mathrm{n} & \text { sediment host }\end{array}$

$\begin{array}{ll}\text { sandstone } & \text { Triassic } \\ \text { sandstone } & \text { Triassic } \\ \text { sandstone } & \text { Jurassic } \\ \text { sandstone } & \text { Triassic } \\ \text { sandstone } & \text { Triassic } \\ \text { sandstone } & \text { Triassic } \\ \text { sandstone } & \text { Triassic } \\ \text { sandstone/diabase } & \text { Triassic-Jurassic } \\ \text { sandstone } & \text { Triassic } \\ \text { sandstone } & \text { Triassic } \\ \text { siltstone } & \text { Jurassic }\end{array}$

$\mathrm{Ba}$
$\mathrm{Ba}$
$\mathrm{Cu}$
$\mathrm{Ba}$
$\mathrm{Cu}$
$\mathrm{Cu}$
$\mathrm{Cu}$
$\mathrm{Cu}$
$\mathrm{Cu}$
$\mathrm{Cu}$
$\mathrm{Ag}$

$\begin{array}{ll} & 32 \\ & 32 \\ \mathrm{Cu} \mathrm{Ag} & \mathbf{4 8} \\ \mathrm{Ba} & 32,33 \\ \mathrm{Ba} \mathrm{Ag} & 32,33,104 \\ \mathrm{Ba} \mathrm{Ag} & 33,89,104 \\ \mathrm{Ba} \mathrm{Ag} & 33 \\ \mathrm{Ag} & 32,33 \\ & 32,33 \\ & 62\end{array}$

Newark basin, New Jersey-Area 3

$\begin{array}{lll}72 & \text { u } & \text { stratabound/vein } \\ 73 & \text { m } & \text { stratabound/replacement } \\ 74 & \text { u } & \text { stratabound/replacement } \\ 75 & \text { m } & \text { stratabound/replacement } \\ 76 & \text { m } & \text { stratabound/replacement } \\ 77 & \text { n } & \text { vein/replacement } \\ 78 & \text { n } & \text { stratabound/replacement } \\ 79 & \text { m } & \text { stratabound/replacement } \\ 80 & \text { u } & \text { stratabound/replacement } \\ 81 & \text { n } & \text { stratabound/replacement } \\ 82 & \text { n } & \text { vein/fault zone } \\ 83 & \text { n } & \text { stratabound/replacement } \\ 84 & \text { n } & \text { stratabound/replacement } \\ 85 & \text { n } & \text { hornfels/vein } \\ 86 & \text { n } & \text { stratabound/replacement } \\ 87 & \text { m } & \text { vein } \\ 88 & \text { n } & \text { hornfels/replacement }\end{array}$

$\begin{array}{lllll}\text { basalt } & \text { Jurassic } & \mathrm{Cu} & & 136 \\ \text { sandstone } & \text { Triassic } & \mathrm{Cu} & & 73,84,136 \\ \text { sandstone } & \text { Triassic } & \mathrm{Cu} & & 136 \\ \text { sandstone } & \text { Triassic } & \mathrm{Cu} & & 136 \\ \text { sandstone } & \text { Triassic } & \mathrm{Cu} & \mathrm{Ag} & 16,70,84,136 \\ \text { diabase } & \text { Jurassic } & \mathrm{Fe} & & 90 \\ \text { basalt } & \text { Jurassic } & \mathrm{Cu} & & 73,84,136 \\ \text { basalt } & \text { Jurassic } & \mathrm{Cu} & & 136 \\ \text { basalt } & \text { Jurassic } & \mathrm{Cu} & & 18,52,84,129,136 \\ \text { basalt } & \text { Jurassic } & \mathrm{Cu} & & 73,136 \\ \text { siltstone } & \text { Triassic } & \mathrm{Cu} & & 73,84,136 \\ \text { siltstone } & \text { Triassic } & \mathrm{Cu} & \mathrm{Ag} & 136 \\ \text { sandstone } & \text { Triassic } & \mathrm{Cu} & & 73,84,136 \\ \text { sandstone } & \text { Triassic } & \mathrm{Cu} & & 76 \\ \text { sandstone } & \text { Triassic } & \mathrm{Cu} & \mathrm{Ag} \mathrm{Au} & 73,136 \\ \text { diabase } & \text { Jurassic } & \mathrm{Ba} & & 15,21 \\ \text { siltstone/diabase } & \text { Triassic-Jurassic } & \mathrm{Cu} & & 66,73 \mathrm{~b}, 136\end{array}$

Newark basin and vicinity, Pennsylvania-Area 4

\begin{tabular}{|c|c|c|c|c|c|c|c|}
\hline 89 & $\mathbf{n}$ & hornfels & siltstone & Triassic & $\mathrm{Cu}$ & & 98,131 \\
\hline 90 & $\mathbf{n}$ & vein & siltstone & Triassic & $\mathrm{Cu} \mathrm{Ba}$ & & $98,131,134$ \\
\hline 91 & n & vein/hornfels & siltstone & Triassic & $\mathrm{Cu}$ & & $98,118,131,134$ \\
\hline 92 & $\mathbf{n}$ & fault zone/vein & sandstone & Triassic & $\mathbf{B a}$ & $\mathrm{Cu}$ & $98,118,131,134$ \\
\hline 93 & $\mathrm{n}$ & vein & sandstone & Triassic & $\mathrm{Ba}$ & & 44,98 \\
\hline 94 & $\mathbf{n}$ & vein & sandstone & Triassic & $\mathrm{Ba} \mathrm{Cu}$ & & 98,131 \\
\hline 95 & $\mathbf{n}$ & vein & sandstone & Triassic & $\mathrm{Ba}$ & & 44,98 \\
\hline 96 & $\mathbf{n}$ & hornfels & siltstone & Triassic & $\mathrm{Cu}$ & & 98,131 \\
\hline 97 & $\mathbf{n}$ & hornfels & shale & Triassic & $\mathrm{Cu}$ & & 98,131 \\
\hline 98 & $\mathbf{n}$ & hornfels & siltstone & Triassic & $\mathrm{Cu}$ & & 98,131 \\
\hline 99 & $\mathbf{n}$ & hornfels & siltstone & Triassic & $\mathrm{Cu}$ & & 98,131 \\
\hline 100 & $\mathbf{n}$ & hornfels & siltstone & Triassic & $\mathrm{Cu}$ & & 98,131 \\
\hline 101 & $\mathbf{n}$ & sediment host & shale & Triassic & $\mathrm{Cu}$ & & 98,131 \\
\hline 102 & $\mathbf{n}$ & sediment host & sandstone & Triassic & $\mathrm{Cu}$ & & 98,131 \\
\hline 103 & 1 & vein/fault zone & black shale & Triassic & $\mathrm{Pb} \mathrm{Zn}$ & $\mathrm{Ag} \mathrm{Au} \mathrm{Cu}$ & $22,28,98,110,111,134$ \\
\hline 104 & n & vein & & & $\mathrm{Pb}$ & $\mathrm{Zn}_{\mathbf{n}}$ & $44,78,98$ \\
\hline 105 & $\mathbf{n}$ & diabase host/vein & diabase & Jurassic & $\mathrm{Au}$ & $\mathrm{Cu}$ & $4,44,98,131$ \\
\hline 106 & $\mathbf{n}$ & sediment host & sandstone & Triassic & $\mathrm{Cu}$ & & $27,44,98$ \\
\hline 107 & $\mathbf{n}$ & sediment host & sandstone & Triassic & $\mathrm{Cu}$ & & $44,98,131$ \\
\hline 108 & $\mathbf{u}$ & sediment host? & conglomerate & Triassic & $\mathrm{Cu}$ & & 27,98 \\
\hline 109 & $\mathbf{n}$ & hornfels & siltstone & Triassic & $\mathrm{Cu}$ & & 98 \\
\hline 110 & $\mathbf{n}$ & sediment host & sandstone & Triassic & $\mathrm{Cu}$ & & $44,98,131$ \\
\hline 111 & $\mathbf{n}$ & sediment host & shale & Triassic & $\mathrm{Cu}$ & & 98,131 \\
\hline 112 & n & homfels & siltstone & Triassic & $\mathrm{Cu}$ & & 44,98 \\
\hline 113 & $\mathbf{n}$ & hornfels & siltstone & Triassic & $\mathrm{Cu}$ & Co & 112,116 \\
\hline 114 & $\mathbf{n}$ & hornfels & siltstone & Triassic & $\mathrm{Cu}$ & & $44,98,131$ \\
\hline 115 & $\mathbf{u}$ & hornfels/fault zone? & shale & Triassic & $\mathrm{Cu}$ & $\mathrm{Pb}$ & $4,44,84,98,131$ \\
\hline 116 & $\mathbf{u}$ & vein/hornfels? & shale & Triassic & $\mathrm{Cu}$ & & $4,44,84,98,131$ \\
\hline 117 & $\mathbf{n}$ & homfels & siltstone & Triassic & $\mathrm{Cu}$ & $\mathrm{Au}$ & $4,44,84,98,131$ \\
\hline 118 & n & hornfels? & siltstone & Triassic & $\mathrm{Cu}$ & & 98 \\
\hline 119 & $\mathbf{n}$ & sediment host & sandstone & Triassic & $\mathrm{Cu}$ & & $44,98,131$ \\
\hline 120 & $\mathbf{n}$ & sediment host & sandstone & Triassic & $\mathrm{Cu}$ & & $44,98,131$ \\
\hline
\end{tabular}


Table 1A. Inventory of metal mines and occurrences associated with the early Mesozoic basins of the Eastern United States [See text for in-depth descriptions of column headings; in the "Production" column, an l, $m, n$, or $u$ indicates ore production or reserves greater reference citation is listed in table $1 E$ ]

\begin{tabular}{|c|c|c|c|c|c|c|c|}
\hline $\begin{array}{l}\text { Locality } \\
\text { number }\end{array}$ & Name & County & State & Quadrangle & Latitude & Longitude & $\begin{array}{l}\text { Locality } \\
\text { type }\end{array}$ \\
\hline \multicolumn{8}{|c|}{ Newark basin and vicinity, Pennsylvania-Area $4-$ Continued } \\
\hline 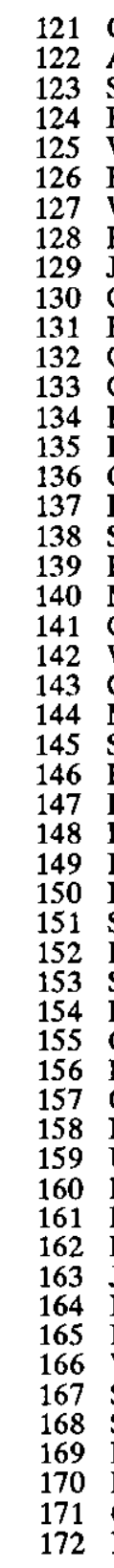 & $\begin{array}{l}\text { Collegeville } \\
\text { Arcola } \\
\text { Shannonville } \\
\text { Perkiomen mine } \\
\text { Whim mine } \\
\text { Ecton mine } \\
\text { Wetherill mine } \\
\text { Port Kennedy } \\
\text { Jug Hollow mine } \\
\text { Congo } 3 \\
\text { Fegley mine } \\
\text { Congo 2 } \\
\text { Congo 1 } \\
\text { Brendlinger mine } \\
\text { Layfield } \\
\text { Gilbertville } \\
\text { Pennsylvania mine } \\
\text { Saratoga } \\
\text { Phoenix. Tunnel } \\
\text { Morris copper } \\
\text { Charlestown mine } \\
\text { Wheatley mine } \\
\text { Chester Co. mine } \\
\text { Montgomery Co. } \\
\text { SW. Chester mine } \\
\text { Brookdale mine } \\
\text { Phoenix mine } \\
\text { Pethericks Penn } \\
\text { Pennypacker mine } \\
\text { Boyertown mine } \\
\text { Stonersville } \\
\text { Brower mine } \\
\text { Snydersville } \\
\text { Esterly mine } \\
\text { Gickerville } \\
\text { Dyer quarry } \\
\text { Glasgow } \\
\text { Bleims mine } \\
\text { Unnamed Fe mine } \\
\text { French Creek mines } \\
\text { Knauertown } \\
\text { Pine Swamp } \\
\text { Jones-Kinney mines } \\
\text { Hopewell mine } \\
\text { Leighton mine } \\
\text { Warwick mine } \\
\text { Steels mine } \\
\text { South of Reading } \\
\text { Raudenbush mine } \\
\text { Fritz Island mine } \\
\text { Grace mine } \\
\text { Bylers mine } \\
\text { The }\end{array}$ & $\begin{array}{l}\text { Montgomery } \\
\text { Montgomery } \\
\text { Montgomery } \\
\text { Montgomery } \\
\text { Montgomery } \\
\text { Montgomery } \\
\text { Montgomery } \\
\text { Montgomery } \\
\text { Chester } \\
\text { Montgomery } \\
\text { Berks } \\
\text { Montgomery } \\
\text { Montgomery } \\
\text { Montgomery } \\
\text { Montgomery } \\
\text { Montgomery } \\
\text { Montgomery } \\
\text { Montgomery } \\
\text { Chester } \\
\text { Chester } \\
\text { Chester } \\
\text { Chester } \\
\text { Chester } \\
\text { Chester } \\
\text { Chester } \\
\text { Chester } \\
\text { Chester } \\
\text { Chester } \\
\text { Chester } \\
\text { Berks } \\
\text { Berks } \\
\text { Berks } \\
\text { Berks } \\
\text { Berks } \\
\text { Berks } \\
\text { Berks } \\
\text { Montgomery } \\
\text { Montgomery } \\
\text { Chester } \\
\text { Chester } \\
\text { Chester } \\
\text { Chester } \\
\text { Berks } \\
\text { Chester } \\
\text { Chester } \\
\text { Chester } \\
\text { Chester } \\
\text { Berks } \\
\text { Berks } \\
\text { Berks } \\
\text { Berks } \\
\text { Berks }\end{array}$ & $\begin{array}{l}\text { Pennsylvania } \\
\text { Pennsylvania } \\
\text { Pennsylvania } \\
\text { Pennsylvania } \\
\text { Pennsylvania } \\
\text { Pennsylvania } \\
\text { Pennsylvania } \\
\text { Pennsylvania } \\
\text { Pennsylvania } \\
\text { Pennsylvania } \\
\text { Pennsylvania } \\
\text { Pennsylvania } \\
\text { Pennsylvania } \\
\text { Pennsylvania } \\
\text { Pennsylvania } \\
\text { Pennsylvania } \\
\text { Pennsylvania } \\
\text { Pennsylvania } \\
\text { Pennsylvania } \\
\text { Pennsylvania } \\
\text { Pennsylvania } \\
\text { Pennsylvania } \\
\text { Pennsylvania } \\
\text { Pennsylvania } \\
\text { Pennsylvania } \\
\text { Pennsylvania } \\
\text { Pennsylvania } \\
\text { Pennsylvania } \\
\text { Pennsylvania } \\
\text { Pennsylvania } \\
\text { Pennsylvania } \\
\text { Pennsylvania } \\
\text { Pennsylvania } \\
\text { Pennsylvania } \\
\text { Pennsylvania } \\
\text { Pennsylvania } \\
\text { Pennsylvania } \\
\text { Pennsylvania } \\
\text { Pennsylvania } \\
\text { Pennsylvania } \\
\text { Pennsylvania } \\
\text { Pennsylvania } \\
\text { Pennsylvania } \\
\text { Pennsylvania } \\
\text { Pennsylvania } \\
\text { Pennsylvania } \\
\text { Pennsylvania } \\
\text { Pennsylvania } \\
\text { Pennsylvania } \\
\text { Pennsylvania } \\
\text { Pennsylvania } \\
\text { Pennsylvania }\end{array}$ & $\begin{array}{l}\text { Collegeville } \\
\text { Collegeville } \\
\text { Collegeville } \\
\text { Collegeville } \\
\text { Collegeville } \\
\text { Collegeville } \\
\text { Valley Forge } \\
\text { Valley Forge } \\
\text { Valley Forge } \\
\text { Sassamansville } \\
\text { Sassamansville } \\
\text { Sassamansville } \\
\text { Sassamansville } \\
\text { Sassamansville } \\
\text { Sassamansville } \\
\text { Sassamansville } \\
\text { Sassamansville } \\
\text { Phoenixville } \\
\text { Phoenixville } \\
\text { Phoenixville } \\
\text { Malvern } \\
\text { Malvern } \\
\text { Malvern } \\
\text { Malvern } \\
\text { Malvern } \\
\text { Malvern } \\
\text { Malvern } \\
\text { Malvern } \\
\text { Malvern } \\
\text { Boyertown } \\
\text { Birdsboro } \\
\text { Boyertown } \\
\text { Birdsboro } \\
\text { Birdsboro } \\
\text { Birdsboro } \\
\text { Birdsboro } \\
\text { Boyertown } \\
\text { Boyertown } \\
\text { Elverson } \\
\text { Pottstown } \\
\text { Pottstown } \\
\text { Elverson } \\
\text { Elverson } \\
\text { Elverson } \\
\text { Elverson } \\
\text { Elverson } \\
\text { Elverson } \\
\text { Reading } \\
\text { Reading } \\
\text { Reading } \\
\text { Morgantown } \\
\text { Morgantown }\end{array}$ & 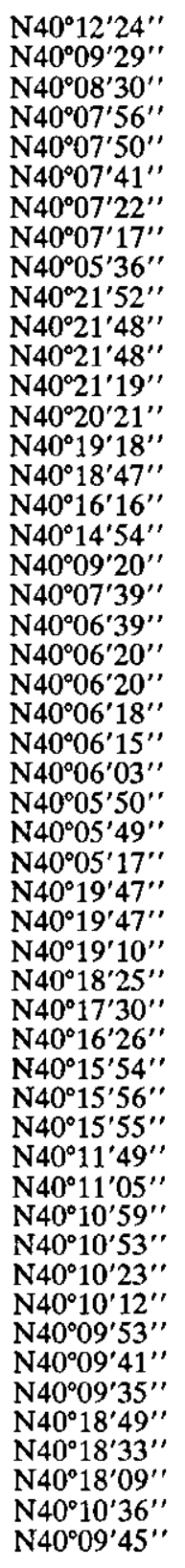 & 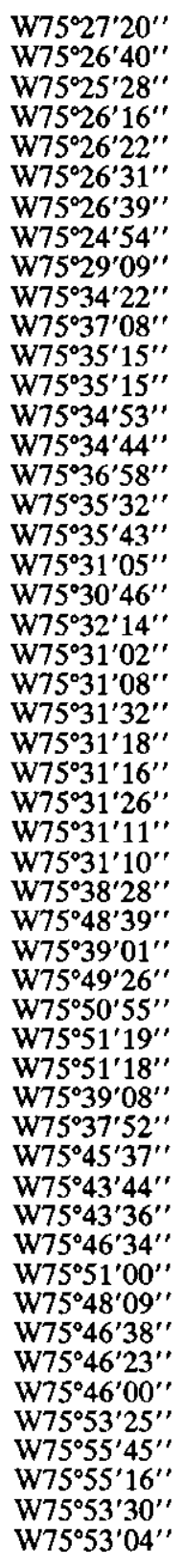 & $\begin{array}{l}\text { occurrence } \\
\text { occurrence } \\
\text { prospect } \\
\text { mine } \\
\text { mine } \\
\text { mine } \\
\text { mine } \\
\text { prospect } \\
\text { mine } \\
\text { prospect } \\
\text { mine } \\
\text { prospect } \\
\text { prospect } \\
\text { prospect } \\
\text { occurrence } \\
\text { occurrence } \\
\text { mine } \\
\text { prospect } \\
\text { occurrence } \\
\text { mine } \\
\text { mine } \\
\text { mine } \\
\text { mine } \\
\text { mine } \\
\text { mine } \\
\text { mine } \\
\text { mine } \\
\text { prospect } \\
\text { mine } \\
\text { mine } \\
\text { prospect } \\
\text { mine } \\
\text { occurrence } \\
\text { mine } \\
\text { occurrence } \\
\text { occurrence } \\
\text { occurrence } \\
\text { prospect } \\
\text { mine } \\
\text { mine } \\
\text { prospect } \\
\text { prospect } \\
\text { mine } \\
\text { mine } \\
\text { mine } \\
\text { mine } \\
\text { mine } \\
\text { occurrence } \\
\text { mine } \\
\text { mine } \\
\text { mine } \\
\text { mine }\end{array}$ \\
\hline \multicolumn{8}{|c|}{ Gettysburg basin and vicinity, Pennsylvania-Area 5} \\
\hline $\begin{array}{l}173 \\
174 \\
175 \\
176 \\
177 \\
178 \\
179 \\
180 \\
181 \\
182 \\
183 \\
184\end{array}$ & $\begin{array}{l}\text { Wheatfield mine } \\
\text { Ruth mine } \\
\text { Doner mine } \\
\text { Mt. Pleasant } \\
\text { Rexmont Reservoir } \\
\text { Carper mine } \\
\text { Cornwall mine } \\
\text { Hummelstown } \\
\text { Glenwood Station } \\
\text { Lecron's } \\
\text { Safe Harbor } \\
\text { Reesers Summit }\end{array}$ & $\begin{array}{l}\text { Berks } \\
\text { Berks } \\
\text { Lebanon } \\
\text { Lebanon } \\
\text { Lebanon } \\
\text { Lebanon } \\
\text { Lebanon } \\
\text { Dauphin } \\
\text { Lancaster } \\
\text { York } \\
\text { Lancaster } \\
\text { York }\end{array}$ & $\begin{array}{l}\text { Pennsylvania } \\
\text { Pennsylvania } \\
\text { Pennsylvania } \\
\text { Pennsylvania } \\
\text { Pennsylvania } \\
\text { Pennsylvania } \\
\text { Pennsylvania } \\
\text { Pennsylvania } \\
\text { Pennsylvania } \\
\text { Pennsylvania } \\
\text { Pennsylvania } \\
\text { Pennsylvania }\end{array}$ & $\begin{array}{l}\text { Sinking Spring } \\
\text { Sinking Spring } \\
\text { Lebanon } \\
\text { Palmyra } \\
\text { Lebanon } \\
\text { Palmyra } \\
\text { Lebanon } \\
\text { Hershey } \\
\text { Leola } \\
\text { Dover } \\
\text { Safe Harbor } \\
\text { Steelton }\end{array}$ & 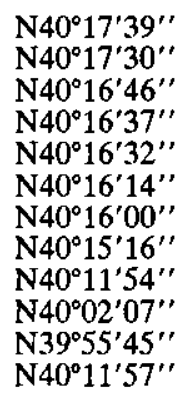 & $\begin{array}{l}\text { W76 } 01^{\prime} 59^{\prime \prime} \\
\text { W76 } 03^{\prime} 15^{\prime \prime} \\
\text { W76 } 23^{\prime} 03^{\prime \prime} \\
\text { W76 } 32^{\prime} 27^{\prime \prime} \\
\text { W76 } 22^{\prime} 12^{\prime \prime} \\
\text { W76 } 31^{\prime} 23^{\prime \prime} \\
\text { W76 } 24^{\prime} 43^{\prime} \\
\text { W76 } 40^{\prime} 49^{\prime \prime} \\
\text { W76 } 07^{\prime} 51^{\prime \prime} \\
\text { W76 } 45^{\prime} 36^{\prime \prime} \\
\text { W76 } 22^{\prime} 29^{\prime \prime} \\
\text { W76 } 51^{\prime} 41^{\prime \prime}\end{array}$ & $\begin{array}{l}\text { mine } \\
\text { mine } \\
\text { mine } \\
\text { prospect } \\
\text { prospect } \\
\text { mine } \\
\text { mine } \\
\text { mine } \\
\text { occurrence } \\
\text { mine } \\
\text { occurrence } \\
\text { occurrence }\end{array}$ \\
\hline
\end{tabular}


listed numerically according to geographic location-Continued

than 100,000 tons, between 1,000 and 100,000 tons, less than 1,000 tons, or unknown, respectively; in the "References" column, the number of the

\begin{tabular}{|c|c|c|c|c|c|c|c|}
\hline \multirow{2}{*}{$\begin{array}{l}\text { Locality } \\
\text { number }\end{array}$} & \multirow{2}{*}{$\begin{array}{l}\text { Produc- } \\
\text { tion }\end{array}$} & \multirow[b]{2}{*}{ Deposit type } & \multirow{2}{*}{$\begin{array}{l}\text { Host-rock } \\
\text { lithology }\end{array}$} & \multirow[b]{2}{*}{ Host-rock age } & \multicolumn{2}{|c|}{ Metal associations } & \multirow[b]{2}{*}{ References } \\
\hline & & & & & Principal & Accessory & \\
\hline \multicolumn{8}{|c|}{ Newark basin and vicinity, Pennsylvania-Area $4-$ Continued } \\
\hline 121 & $\mathbf{n}$ & sediment host & sandstone & Triassic & $\mathrm{Cu}$ & & $44,98,131$ \\
\hline 122 & $\mathbf{n}$ & vein & & Triassic & $\mathrm{Cu}$ & & 44,98 \\
\hline 123 & $\mathbf{n}$ & vein & & Triassic & $\mathrm{Cu}$ & & $44,78,98$ \\
\hline 124 & m & vein & sandstone & Triassic & $\mathrm{Pb} \mathrm{Cu}$ & & $22,98,111,135$ \\
\hline 125 & $\mathrm{~m}$ & vein/fault zone & sandstone & Triassic & $\mathrm{Pb} \mathrm{Cu}$ & $\mathrm{Zn} \mathrm{Ag}$ & $22,98,111,135$ \\
\hline 126 & $\overline{\mathbf{m}}$ & vein & sandstone & Triassic & $\mathrm{Pb}$ & $\mathrm{Zn} \mathrm{Ag}$ & $22,98,111,135$ \\
\hline 127 & $\bar{m}$ & vein & sandstone & Triassic & $\mathrm{Pb}$ & $\mathrm{Cu} \mathrm{Zn}$ & $22,98,111,135$ \\
\hline 128 & $\mathbf{n}$ & vein & & Triassic & & & $44,78,98$ \\
\hline 129 & m & vein & schist/gneiss & Precambrian & $\mathrm{Ba} \mathrm{Zn}$ & $\mathrm{Cu} \mathbf{P b}$ & $44,77,96,111$ \\
\hline 130 & $\bar{n}$ & diabase host/vein & diabase & Jurassic & $\mathrm{Cu}$ & & $98,117,131$ \\
\hline 131 & $\mathbf{n}$ & vein/replacement & diabase & Jurassic & $\mathrm{Fe}$ & & $44,51,98,117$ \\
\hline 132 & $\mathbf{n}$ & diabase host/vein & diabase & Jurassic & $\mathrm{Cu}$ & & $98,117,131$ \\
\hline 133 & $\mathbf{n}$ & diabase host/vein & diabase & Jurassic & $\mathrm{Cu}$ & & $98,117,131$ \\
\hline 134 & $\mathbf{n}$ & homfels? & siltstone & Triassic & $\mathrm{Cu}$ & & $84,98,131$ \\
\hline 135 & $\mathbf{n}$ & sediment host & sandstone & Triassic & $\mathrm{Cu}$ & & $44,98,131$ \\
\hline 136 & $\mathbf{n}$ & sediment host & sandstone & Triassic & $\mathrm{Cu}$ & & $44,98,131$ \\
\hline 137 & $\mathbf{n}$ & hornfels & siltstone & Triassic & $\mathrm{Cu}$ & & $98,118,131$ \\
\hline 138 & $\mathbf{n}$ & sediment host & sandstone & Triassic & $\mathrm{Cu}$ & & 5,98 \\
\hline 139 & $\mathbf{n}$ & vein & & Triassic & $\mathrm{Zn}$ & & 44,98 \\
\hline 140 & $\mathbf{n}$ & vein & & Triassic & $\mathrm{Cu}$ & & 78,98 \\
\hline 141 & $\mathbf{n}$ & vein & gneiss & Precambrian & $\mathrm{Pb} \mathrm{Ba}$ & $\mathrm{Zn} \mathrm{Cu} \mathrm{Ag}$ & $95,111,126$ \\
\hline 142 & $\mathbf{m}$ & vein & gneiss/siltstone & Precambrian-Triassic & $\mathrm{Pb} \mathrm{Zn}_{\mathrm{n}}$ & $\mathrm{Cu}$ Ag Mo & $12,50,59,95,108,111$ \\
\hline 143 & $\mathrm{~m}$ & vein & gneiss & Precambrian & $\mathrm{Pb} \mathrm{Zn}$ & $\mathrm{Cu} \mathrm{Ag}$ & $5,38,77,91,111,126$ \\
\hline 144 & $\mathbf{m}$ & vein & gneiss & Precambrian & $\mathrm{Zn} \mathrm{Pb}$ & $\mathrm{Cu} \mathrm{Ag}$ & $78,91,96,98,111,126$ \\
\hline 145 & $\mathbf{m}$ & vein & granodiorite & Precambrian & $\mathrm{Pb} \mathrm{Zn}$ & $\mathrm{Cu} \mathrm{Ag}$ & $5,38,77,91,111,126$ \\
\hline 146 & $\mathbf{m}$ & vein & gneiss & Precambrian & $\mathrm{Zn} \mathrm{Pb}$ & $\mathrm{Cu} \mathrm{Ag}$ & $12,50,59,96,108,111$ \\
\hline 147 & $\mathbf{m}$ & vein & gneiss & Precambrian & $\mathrm{Zn} \mathrm{Pb}$ & $\mathrm{Ag} \mathrm{Cu}$ & $12,50,59,96,108,111$ \\
\hline 148 & $\mathrm{n}$ & vein & & Triassic & $\mathrm{Pb}$ & & 78,98 \\
\hline 149 & $\mathbf{n}$ & vein & granodiorite & Precambrian & $\mathrm{Pb}$ & $\mathrm{Cu}$ & $5,96,111$ \\
\hline 150 & $\mathbf{n}$ & skarn & & Triassic & $\mathrm{Fe}$ & & $20,44,51,98,117$ \\
\hline 151 & $\mathrm{n}$ & skarn & & Triassic? & $\mathrm{Fe}$ & & 98,117 \\
\hline 152 & $\mathrm{~m}$ & skarn & shale & Triassic & $\mathrm{Fe}$ & & 98,117 \\
\hline 153 & $\mathbf{n}$ & hornfels & shale & Triassic & $\mathrm{Cu}$ & & $27,44,98$ \\
\hline 154 & $\mathbf{u}$ & skarn & siltstone & Triassic & $\mathrm{Fe}$ & & $20,98,117$ \\
\hline 155 & $\mathbf{n}$ & diabase host/vein & diabase & Jurassic & As Co & & 44,98 \\
\hline 156 & $\mathbf{n}$ & diabase host/vein & diabase & Jurassic & $\mathrm{Cu}$ & & 112,114 \\
\hline 157 & $\mathbf{n}$ & sediment host & sandstone & Triassic & $\mathrm{Cu}$ & & $44,98,131$ \\
\hline 158 & $\mathbf{n}$ & sediment host & sandstone & Triassic & $\mathrm{Cu}$ & & 44,98 \\
\hline 159 & $\mathbf{u}$ & skarn & shale/sandstone & Triassic & $\mathrm{Fe}$ & & 5,98 \\
\hline 160 & 1 & skarn & marble/gneiss & Precambrian & $\mathrm{Fe} \mathrm{Cu}$ & $\mathrm{Zn} \mathrm{Co}$ & $5,44,68,98,109$ \\
\hline 161 & $\mathbf{n}$ & skarn & & Triassic & $\mathrm{Fe}$ & & 5,98 \\
\hline 162 & $\mathbf{n}$ & skarn/replacement & marble/gneiss & Precambrian & $\mathrm{Fe}$ & & $37,98,110$ \\
\hline 163 & 1 & skarn & dolomite/shale & Cambrian & $\mathrm{F}$ & $\mathrm{Cu}$ & $44,63,96,98,117,121$ \\
\hline 164 & $\mathbf{u}$ & skarn & marble/gneiss & Precambrian & $\mathrm{Fe}$ & & $5,41,44,96,98,99,103$ \\
\hline 165 & $\mathbf{m}$ & skarn/replacement & gneiss/marble? & Precambrian & $\mathrm{Fe}$ & & $5,96,98$ \\
\hline 166 & 1 & skarn & Imst. conglomerate & Triassic & $\mathrm{Fe}$ & & $5,44,96,98,117$ \\
\hline 167 & $\mathbf{u}$ & skarn/replacement & gneiss/marble? & Precambrian & $\mathrm{Fe}$ & & $5,44,96,98$ \\
\hline 168 & $\mathbf{n}$ & hornfels & siltstone & Triassic & $\mathrm{Cl}$ & & 44,98 \\
\hline 169 & $\mathrm{~m}$ & skarn & dolomite & Cambrian & $\mathrm{Fe}$ & & $20,98,117$ \\
\hline 170 & 1 & skarn & dolomite & Cambrian & & $\mathrm{Cu}$ & $20,44,98,117$ \\
\hline 171 & 1 & skarn & limestone/dolomite & Cambrian & $\mathrm{Fe} \mathrm{Cu}$ & $\mathrm{Co} \mathrm{Ag} \mathrm{Au}$ & 6,107 \\
\hline 172 & 1 & skarn & limestone & Cambrian & $\mathrm{Fe}$ & & 5,98 \\
\hline
\end{tabular}

Gettysburg basin and vicinity, Pennsylvania-Area 5

\begin{tabular}{|c|c|c|c|c|c|c|c|}
\hline $\begin{array}{l}173 \\
174 \\
175 \\
176 \\
177 \\
178 \\
179 \\
180 \\
181 \\
182 \\
183 \\
184\end{array}$ & $\begin{array}{l}1 \\
\mathrm{~m} \\
\mathrm{~m} \\
\mathrm{n} \\
\mathrm{n} \\
\mathrm{m} \\
\mathrm{l} \\
\mathrm{m} \\
\mathrm{n} \\
\mathrm{n} \\
\mathrm{n} \\
\mathrm{n}\end{array}$ & $\begin{array}{l}\text { skarn } \\
\text { skarn } \\
\text { skarn } \\
\text { skarn } \\
\text { skarn } \\
\text { hornfels/replacement } \\
\text { skarn } \\
\text { skarn } \\
\text { sediment host } \\
\text { sediment host } \\
\text { vein } \\
\text { hornfels }\end{array}$ & $\begin{array}{l}\text { limestone/dolomite } \\
\text { limestone/dolomite } \\
\text { limestone } \\
\text { limestone/shale } \\
\text { slate/shale } \\
\text { limestone/dolomite } \\
\text { sandstone } \\
\text { shale } \\
\text { sandstone } \\
\text { dolomite }\end{array}$ & $\begin{array}{l}\text { Cambro-Ordovician } \\
\text { Cambro-Ordovician } \\
\text { Paleozoic } \\
\text { Triassic } \\
\text { Paleozoic } \\
\text { Ordovician } \\
\text { Cambrian } \\
\text { Triassic } \\
\text { Triassic } \\
\text { Triassic } \\
\text { Cambrian } \\
\text { Triassic }\end{array}$ & $\begin{array}{l}\mathrm{Fe} \\
\mathrm{Fe} \\
\mathrm{Fe} \\
\mathrm{Fe} \\
\mathrm{Fe} \\
\mathrm{Fe} \\
\mathrm{Fe} \mathrm{Cu} \\
\mathrm{Fe} \\
\mathrm{Cu} \\
\mathrm{Cu} \\
\mathrm{Zn} \mathrm{Ba} \\
\mathrm{Cu}\end{array}$ & $\mathrm{Au} \mathrm{Ag} \mathrm{Co}$ & $\begin{array}{l}20,44,98,117 \\
20,44,98,117 \\
69,98,117 \\
98,117 \\
98,117 \\
40,98,117 \\
39,46,67,69,98,117 \\
98,117 \\
9,44,98 \\
31,98,122 \\
8,98 \\
98,111\end{array}$ \\
\hline
\end{tabular}


Table 1A. Inventory of metal mines and occurrences associated with the early Mesozoic basins of the Eastern United States [See text for in-depth descriptions of column headings; in the "Production" column, an l, $\mathrm{m}, \mathrm{n}$, or $\mathrm{u}$ indicates ore production or reserves greater reference citation is listed in table $1 E$ ]

\begin{tabular}{lllllll}
\hline $\begin{array}{l}\text { Locality } \\
\text { number }\end{array}$ & Name & County & State & Quadrangle & Latitude & Longitude \\
\hline
\end{tabular}

Gettysburg basin and vicinity, Pennsylvania-Area 5-Continued

\begin{tabular}{|c|c|c|c|c|}
\hline 185 & Mt. Pleasant 2 & York & Pennsylvania & Wellsville \\
\hline 186 & Mt. Pleasant 1 & York & Pennsylvania & Wellsville \\
\hline 187 & Wellsville 2 & York & Pennsylvania & Wellsville \\
\hline 188 & Wellsville 1 & York & Pennsylvania & Wellsville \\
\hline 189 & Rossville roadcut & York & Pennsylvania & Wellsville \\
\hline 190 & Harman mine & York & Pennsylvania & Wellsville \\
\hline 191 & Brenneman mine & York & Pennsylvania & Wellsville \\
\hline 192 & Altland mine & York & Pennsylvania & Wellsville \\
\hline 193 & Comfort mine & York & Pennsylvania & Wellsville \\
\hline 194 & Cadwalader mine & York & Pennsylvania & Wellsville \\
\hline 195 & Marshall mine & York & Pennsylvania & Wellsville \\
\hline 196 & Sluthower mine & York & Pennsylvania & Wellsville \\
\hline 197 & Minebank School 1 & York & Pennsylvania & Wellsville \\
\hline 198 & Minebank School 2 & York & Pennsylvania & Wellsville \\
\hline 199 & Roler & York & Pennsylvania & Wellsville \\
\hline 200 & Smith prospect & York & Pennsylvania & Wellsville \\
\hline 201 & Grantham mines & York & Pennsylvania & Mechanicsburg \\
\hline 202 & Dillsburg North & York & Pennsylvania & Dillsburg \\
\hline 203 & McCormick mine & York & Pennsylvania & Dillsburg \\
\hline 204 & Longnecker mine & York & Pennsylvania & Dillsburg \\
\hline 205 & King mine & York & Pennsylvania & Dillsburg \\
\hline 206 & Underwood mine & York & Pennsylvania & Dillsburg \\
\hline 207 & Jauss mine & York & Pennsylvania & Dillsburg \\
\hline 208 & Altland mine & York & Pennsylvania & Dillsburg \\
\hline 209 & Smyser mine & York & Pennsylvania & Dillsburg \\
\hline 210 & Bell mine & York & Pennsylvania & Dillsburg \\
\hline 211 & Logan mine & York & Pennsylvania & Dillsburg \\
\hline 212 & Cox mine & York & Pennsylvania & Dillsburg \\
\hline 213 & Grove mine & York & Pennsylvania & Dillsburg \\
\hline 01 & Bender mine & York & Pennsylvania & Dillsburg \\
\hline 215 & Franklintown 1 & York & Pennsylvania & Dillsburg \\
\hline 216 & Franklintown 2 & York & Pennsylvania & Dillsburg \\
\hline 217 & Franklintown 3 & York & Pennsylvania & Dillsburg \\
\hline 8 & Franklintown 4 & York & Pennsylvania & Dillsburg \\
\hline & Lichte mine & York & Pennsylvania & Dillsburg \\
\hline & Clapper farm & Adams & Pennsylvania & Hampton \\
\hline 221 & Center Mills 1 & Adams & Pennsylvania & Biglerville \\
\hline רט & Center Mills 2 & Adams & Pennsylvania & Biglerville \\
\hline & Idaville & Adams & Pennsylvania & Biglerville \\
\hline & Heidlersburg & Adams & Pennsylvania & Biglerville \\
\hline & Stone Jug mine & Adams & Pennsylvania & Biglerville \\
\hline & Hunterstown & Adams & Pennsylvania & Biglerville \\
\hline & Gettysburg & Adams & Pennsylvania & Gettysburg \\
\hline & Bonneauville & Adams & Pennsylvania & Gettysburg \\
\hline & Teeter's quarry & Adams & Pennsylvania & Gettysburg \\
\hline 3 & Cashtown 2 & Adams & Pennsylvania & Arendtsville \\
\hline & Cashtown 1 & Adams & Pennsylvania & Arendtsville \\
\hline & Orrtana & Adams & Pennsylvania & Fairfield \\
\hline & Carr & dams & Pennsylvania & Fairfield \\
\hline & Fairtield & dams & ennsylvania & Fairtield \\
\hline & McI & & Pennsylvania & Fairf \\
\hline
\end{tabular}

Culpeper basin, Maryland-Area 6

$\begin{array}{lll}236 & \text { Boyds barite } & \text { Montgomery } \\ \text { 237 } & \text { Dawsonville 1 } & \text { Montgomery } \\ \text { 238 } & \text { Dawsonville 2 } & \text { Montgomery } \\ 239 & \text { Seneca Creek } & \text { Montgomery } \\ 240 & \text { Sugarland } & \text { Montgomery }\end{array}$

Culpeper basin, Virginia-Area 6

$\begin{array}{llll}241 & \text { Waterford gold } & \text { Loudoun } & \text { Virginia } \\ 242 & \text { Goose Creek } & \text { Loudoun } & \text { Virginia } \\ 243 & \text { Sugarland Run } & \text { Loudoun } & \text { Virginia } \\ 244 & \text { Sterling } & \text { Loudoun } & \text { Virginia }\end{array}$

$\begin{array}{ll}\text { Maryland } & \text { Germantown } \\ \text { Maryland } & \text { Germantown } \\ \text { Maryland } & \text { Germantown } \\ \text { Maryland } & \text { Seneca } \\ \text { Maryland } & \text { Sterling }\end{array}$

Waterford

Leesburg

Seneca

Sterling

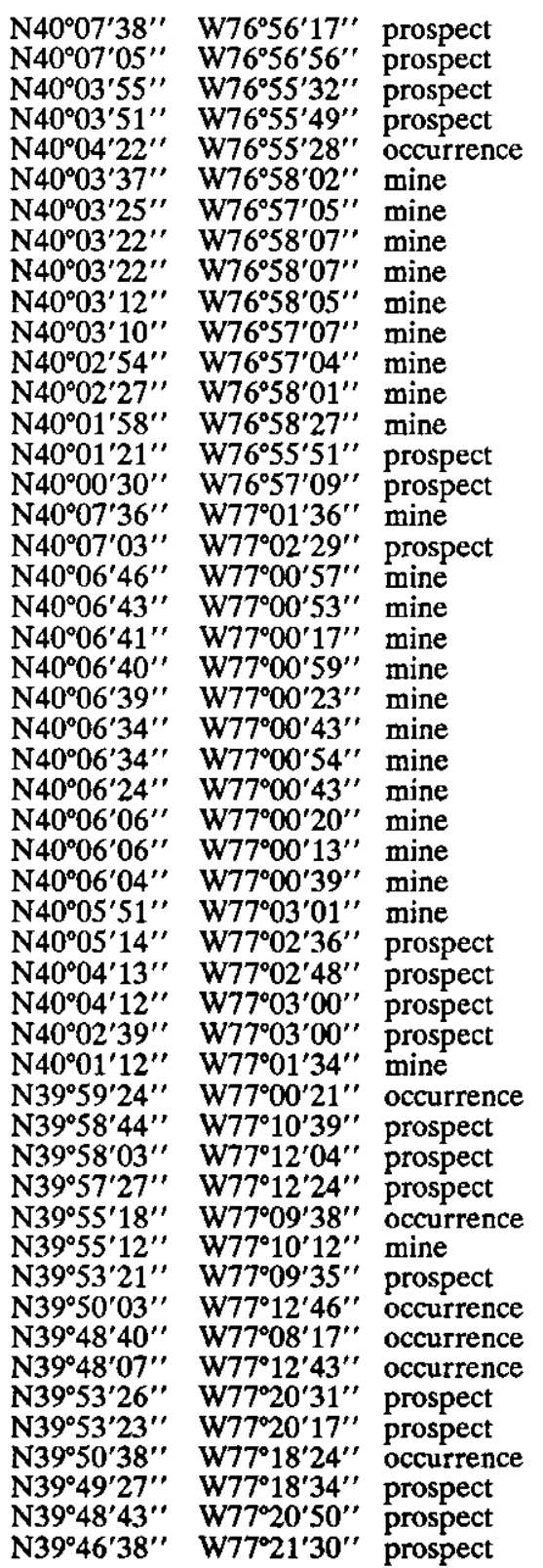

N39 $10^{\prime} 59^{\prime \prime}$ W7 $77^{\circ} 19^{\prime} 37^{\prime \prime}$ occurrence N39 $07^{\prime} 54^{\prime \prime}$ W7 $77^{\circ} 20^{\prime} 06^{\prime \prime}$ occurrence N39 $07^{\prime} 42^{\prime \prime}$ W77 $20^{\prime} 07^{\prime \prime}$ occurrence N39 $06^{\prime} 11^{\prime \prime}$ W7 $77^{\circ} 20^{\prime} 38^{\prime \prime}$ occurrence $\mathrm{N} 39^{\circ} 05^{\prime} 58^{\prime \prime}$ W77 $23^{\prime} 52^{\prime \prime}$ mine

N39 $07^{\prime} 57^{\prime \prime}$ W77 $7^{\circ} 33^{\prime} 05^{\prime \prime}$ occurrence N39 $05^{\prime} 53^{\prime \prime}$ W77 $30^{\circ} 01^{\prime \prime}$ prospect N39 $02^{\prime} 22^{\prime \prime}$ W $77^{\circ} 21^{\prime} 46^{\prime \prime}$ prospect N39 $00^{\prime} 20^{\prime \prime}$ W77 $26^{\prime} 05^{\prime \prime}$ occurrence 
listed numerically according to geographic location-Continued

than 100,000 tons, between 1,000 and 100,000 tons, less than 1,000 tons, or unknown, respectively; in the "References" column, the number of the

\begin{tabular}{|c|c|c|c|c|c|c|}
\hline \multirow{2}{*}{$\begin{array}{l}\text { Locality } \\
\text { number }\end{array}$} & \multirow{2}{*}{$\begin{array}{l}\text { Produc- } \\
\text { tion }\end{array}$} & \multirow{2}{*}{\multicolumn{2}{|c|}{$\begin{array}{l}\text { Host-rock } \\
\text { lithology }\end{array}$}} & & \multirow{2}{*}{$\frac{\text { Metal associations }}{\text { Principal Accessory }}$} & \multirow[b]{2}{*}{ References } \\
\hline & & & & Host-rock age & & \\
\hline
\end{tabular}

Gettysburg basin and vicinity, Pennsylvania-Area 5-Continued

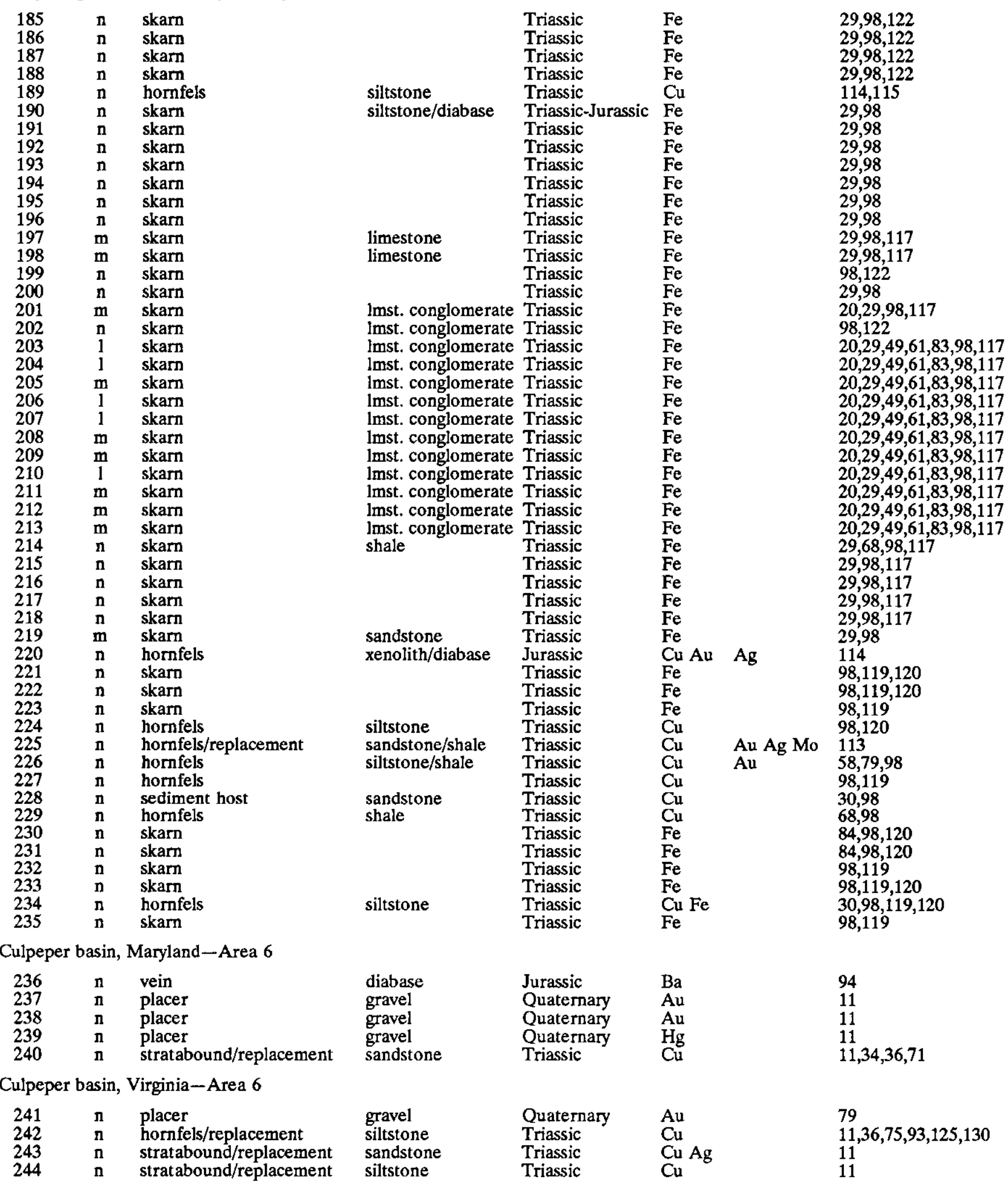


Table 1A. Inventory of metal mines and occurrences associated with the early Mesozoic basins of the Eastern United States [See text for in-depth descriptions of column headings; in the "Production" column, an l, $m, n$, or $u$ indicates ore production or reserves greater reference citation is listed in table $1 E$ ]

\begin{tabular}{|c|c|c|c|c|c|c|c|}
\hline $\begin{array}{l}\text { Locality } \\
\text { number }\end{array}$ & Name & County & State & Quadrangle & Latitude & Longitude & $\begin{array}{l}\text { Locality } \\
\text { type }\end{array}$ \\
\hline \multicolumn{8}{|c|}{ Culpeper basin, Virginia-Area 6-Continued } \\
\hline $\begin{array}{l}245 \\
246 \\
247 \\
248 \\
249 \\
250 \\
251 \\
252 \\
253 \\
254 \\
255 \\
256 \\
257 \\
258 \\
259 \\
260 \\
261 \\
262 \\
263 \\
264 \\
265 \\
266\end{array}$ & $\begin{array}{l}\text { Theodora } \\
\text { Spencer farm } \\
\text { Chantilly prospect } \\
\text { Cub Run copper } \\
\text { Chantilly } \\
\text { Fairfax quarry } \\
\text { Bull Run } \\
\text { Manassas } \\
\text { Brentsville } \\
\text { St. Stephens } \\
\text { Calverton } \\
\text { Cedar Run } \\
\text { Botts barite } \\
\text { Elk Run mine } \\
\text { Bealeton mine } \\
\text { Gear barite } \\
\text { Kemper } \\
\text { Mountain Run } \\
\text { Stevensburg } \\
\text { Culpeper prospect } \\
\text { Batna } \\
\text { Somerset mine }\end{array}$ & $\begin{array}{l}\text { Fairfax } \\
\text { Fairfax } \\
\text { Fairfax } \\
\text { Fairfax } \\
\text { Fairfax } \\
\text { Fairfax } \\
\text { Fairfax } \\
\text { Prince William } \\
\text { Prince William } \\
\text { Fauquier } \\
\text { Fauquier } \\
\text { Prince William } \\
\text { Fauquier } \\
\text { Fauquier } \\
\text { Fauquier } \\
\text { Fauquier } \\
\text { Fauquier } \\
\text { Culpeper } \\
\text { Culpeper } \\
\text { Culpeper } \\
\text { Culpeper } \\
\text { Orange }\end{array}$ & $\begin{array}{l}\text { Virginia } \\
\text { Virginia } \\
\text { Virginia } \\
\text { Virginia } \\
\text { Virginia } \\
\text { Virginia } \\
\text { Virginia } \\
\text { Virginia } \\
\text { Virginia } \\
\text { Virginia } \\
\text { Virginia } \\
\text { Virginia } \\
\text { Virginia } \\
\text { Virginia } \\
\text { Virginia } \\
\text { Virginia } \\
\text { Virginia } \\
\text { Virginia } \\
\text { Virginia } \\
\text { Virginia } \\
\text { Virginia } \\
\text { Virginia }\end{array}$ & $\begin{array}{l}\text { Herndon } \\
\text { Herndon } \\
\text { Herndon } \\
\text { Herndon } \\
\text { Herndon } \\
\text { Manassas } \\
\text { Manassas } \\
\text { Independent Hill } \\
\text { Independent Hill } \\
\text { Catlett } \\
\text { Catlett } \\
\text { Nokesville } \\
\text { Midland } \\
\text { Midland } \\
\text { Midland } \\
\text { Midland } \\
\text { Midland } \\
\text { Culpeper East } \\
\text { Culpeper East } \\
\text { Culpeper East } \\
\text { Culpeper East } \\
\text { Gordonsville }\end{array}$ & $\begin{array}{l}\text { N38 } 56^{\prime} 59^{\prime \prime} \\
\text { N38 } 54^{\circ} 17^{\prime \prime} \\
\text { N38 } 53^{\prime} 20^{\prime \prime} \\
\text { N38 } 52^{\prime} 54^{\prime \prime} \\
\text { N38 } 52^{\prime} 50^{\prime \prime} \\
\text { N38 } 38^{\circ} 33^{\prime \prime} \\
\text { N38 } 48^{\prime} 27^{\prime \prime} \\
\text { N38 } 43^{\prime} 43^{\prime \prime} \\
\text { N38 } 41^{\prime} 21^{\prime \prime} \\
\text { N38 } 40^{\prime} 49^{\prime \prime} \\
\text { N38 } 39^{\prime} 10^{\prime \prime} \\
\text { N38 } 37^{\prime} 32^{\prime \prime} \\
\text { N38 } 34^{\prime} 01^{\prime \prime} \\
\text { N38 } 33^{\prime} 21^{\prime \prime} \\
\text { N38 } 33^{\prime} 15^{\prime \prime} \\
\text { N38 } 32^{\circ} 45^{\prime \prime} \\
\text { N38 } 32^{\prime} 29^{\prime \prime} \\
\text { N38 } 27^{\prime} 09^{\prime \prime} \\
\text { N38 } 26^{\prime} 20^{\prime \prime} \\
\text { N38 } 36^{\circ} 08^{\prime \prime} \\
\text { N38 } 23^{\prime} 50^{\prime \prime} \\
\text { N38 } 12^{\prime} 56^{\prime \prime}\end{array}$ & 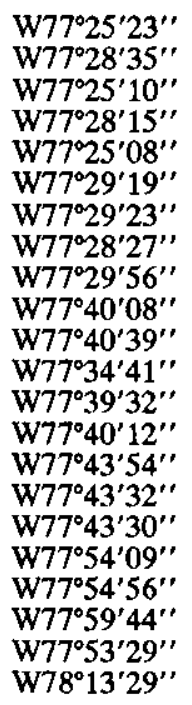 & $\begin{array}{l}\text { mine } \\
\text { prospect } \\
\text { prospect } \\
\text { occurrence } \\
\text { occurrence } \\
\text { occurrence } \\
\text { occurrence } \\
\text { occurrence } \\
\text { prospect } \\
\text { mine } \\
\text { occurrence } \\
\text { mine } \\
\text { occurrence } \\
\text { prospect } \\
\text { mine } \\
\text { prospect } \\
\text { prospect } \\
\text { occurrence } \\
\text { occurrence } \\
\text { occurrence } \\
\text { prospect } \\
\text { mine }\end{array}$ \\
\hline \multicolumn{8}{|c|}{ Miscellaneous areas, Virginia-Area 7} \\
\hline $\begin{array}{l}267 \\
268 \\
269\end{array}$ & $\begin{array}{l}\text { Albemarle mine } \\
\text { Scottsville barite } \\
\text { Dolan property }\end{array}$ & $\begin{array}{l}\text { Albemarle } \\
\text { Albemarle } \\
\text { Nelson }\end{array}$ & $\begin{array}{l}\text { Virginia } \\
\text { Virginia } \\
\text { Virginia }\end{array}$ & $\begin{array}{l}\text { Schuyler } \\
\text { Esmont } \\
\text { Howardsville }\end{array}$ & $\begin{array}{l}\text { N37 } 37^{\circ} 50^{\prime} 11^{\prime \prime} \\
\text { N37 } 47^{\circ} 32^{\prime \prime} \\
\text { N37 } 37^{\circ} 12^{\prime \prime}\end{array}$ & $\begin{array}{l}\text { W7 } 78^{\circ} 42^{\prime} 25^{\prime \prime} \\
\text { W7 } \\
\text { W7 } 34^{\circ} 35^{\prime} 45^{\prime} 33^{\prime \prime}\end{array}$ & $\begin{array}{l}\text { mine } \\
\text { occurrence } \\
\text { occurrence }\end{array}$ \\
\hline \multicolumn{8}{|c|}{ Davie County basin, North Carolina-Area 8} \\
\hline 270 & Bell Branch gold & Dave & North Carolina & Lone Hickory & $\mathrm{N} 36^{\circ} 02^{\prime} 38^{\prime \prime}$ & $\mathrm{W} 80^{\circ} 39^{\prime} 10^{\prime \prime}$ & occ \\
\hline \multicolumn{8}{|c|}{ Deep River basin and vicinity, North Carolina-Area 9} \\
\hline $\begin{array}{l}271 \\
272 \\
273 \\
274 \\
275 \\
276\end{array}$ & $\begin{array}{l}\text { Whomble prospect } \\
\text { Clegg copper mine } \\
\text { Tennessee copper } \\
\text { Harrisville barite } \\
\text { Mangum gold } 2 \\
\text { Mangum gold } 1\end{array}$ & $\begin{array}{l}\text { Orange } \\
\text { Lee } \\
\text { Moore } \\
\text { Montgomery } \\
\text { Richmond } \\
\text { Richmond }\end{array}$ & $\begin{array}{l}\text { North Carolina } \\
\text { North Carolina } \\
\text { North Carolina } \\
\text { North Carolina } \\
\text { North Carolina } \\
\text { North Carolina }\end{array}$ & $\begin{array}{l}\text { Merry Oaks } \\
\text { Colon } \\
\text { Bear Creek } \\
\text { Harrisville } \\
\text { Mangum } \\
\text { Mangum }\end{array}$ & $\begin{array}{l}\text { N35 } 35^{\circ} 18^{\prime \prime} \\
\text { N35 } 35^{\prime} 20^{\prime \prime} \\
\text { N35 } 30^{\prime} 08^{\prime \prime} \\
\text { N35 } 15^{\circ} 42^{\prime \prime} \\
\text { N35 } \\
\text { N35 } 35^{\circ} 07^{\prime} 25^{\prime \prime}\end{array}$ & $\begin{array}{l}\text { W79 } 07^{\prime} 17^{\prime \prime} \\
\text { W79 } 08^{\prime} 17^{\prime \prime} \\
\text { W79 } 25^{\prime} 06^{\prime \prime} \\
\text { W79 } 48^{\prime} 57^{\prime \prime} \\
\text { W79 } 58^{\prime} 30^{\prime \prime} \\
\text { W79 } 59^{\prime} 50^{\prime \prime}\end{array}$ & $\begin{array}{l}\text { prospect } \\
\text { mine } \\
\text { prospect } \\
\text { occurrence } \\
\text { occurrence } \\
\text { occurrence }\end{array}$ \\
\hline
\end{tabular}


listed numerically according to geographic location-Continued

than 100,000 tons, between 1,000 and 100,000 tons, less than 1,000 tons, or unknown, respectively; in the "References" column, the number of the

\begin{tabular}{|c|c|c|c|c|c|c|c|}
\hline & Produc- & & Host-rock & & Met & associations & \\
\hline number & & Deposit type & lithology & Host-rock age & Principal & Accessory & References \\
\hline Culpeper & r basin, & Virginia-Area $6-$ Continu & & & & & \\
\hline $\begin{array}{l}245 \\
246 \\
247 \\
248 \\
249 \\
250 \\
251 \\
252 \\
253 \\
254 \\
255 \\
256 \\
257 \\
258 \\
259 \\
260 \\
261 \\
262 \\
263 \\
264 \\
265 \\
266\end{array}$ & $\begin{array}{l}\mathrm{n} \\
\mathrm{n} \\
\mathrm{n} \\
\mathrm{n} \\
\mathrm{n} \\
\mathrm{n} \\
\mathrm{n} \\
\mathrm{n} \\
\mathrm{n} \\
\mathrm{m} \\
\mathrm{n} \\
\mathrm{m} \\
\mathrm{n} \\
\mathrm{n} \\
\mathrm{n} \\
\mathrm{n} \\
\mathrm{n} \\
\mathrm{n} \\
\mathrm{n} \\
\mathrm{n} \\
\mathrm{n} \\
\mathrm{n}\end{array}$ & $\begin{array}{l}\text { hornfels } \\
\text { hornfels/replacement } \\
\text { hornfels/replacement } \\
\text { hornfels/replacement } \\
\text { stratabound/replacement } \\
\text { diabase host/vein } \\
\text { placer } \\
\text { vein } \\
\text { sediment host } \\
\text { vein } \\
\text { stratabound/replacement } \\
\text { vein/fault zone } \\
\text { vein } \\
\text { fault zone/vein } \\
\text { hornfels/replacement } \\
\text { vein } \\
\text { vein } \\
\text { hornfels/replacement } \\
\text { stratabound/replacement } \\
\text { hornfels } \\
\text { hornfels } \\
\text { stratabound/replacement }\end{array}$ & $\begin{array}{l}\text { siltstone/sandstone } \\
\text { sandstone } \\
\text { siltstone } \\
\text { sandstone/siltstone } \\
\text { sandstone/shale } \\
\text { diabase } \\
\text { gravel } \\
\text { siltstone/shale } \\
\text { shale } \\
\text { siltstone/diabase } \\
\text { black shale } \\
\text { siltstone } \\
\text { shale } \\
\text { siltstone/shale } \\
\text { siltstone/shale } \\
\text { siltstone/sandstone } \\
\text { siltstone } \\
\text { sandstone } \\
\text { black shale } \\
\text { conglomerate } \\
\text { siltstone } \\
\text { sandstone/shale }\end{array}$ & $\begin{array}{l}\text { Triassic } \\
\text { Triassic } \\
\text { Triassic } \\
\text { Triassic } \\
\text { Triassic } \\
\text { Jurassic } \\
\text { Quaternary } \\
\text { Triassic } \\
\text { Triassic } \\
\text { Triassic-Jurassic } \\
\text { Triassic } \\
\text { Triassic } \\
\text { Triassic } \\
\text { Triassic } \\
\text { Triassic } \\
\text { Triassic } \\
\text { Triassic } \\
\text { Triassic } \\
\text { Triassic } \\
\text { Triassic } \\
\text { Triassic } \\
\text { Triassic }\end{array}$ & $\begin{array}{l}\mathrm{Cu} \\
\mathrm{Cu} \\
\mathrm{Cu} \\
\mathrm{Cu} \\
\mathrm{Cu} \\
\mathrm{Cu} \\
\mathrm{Au} \\
\mathrm{Ba} \\
\mathrm{Cu} \\
\mathrm{Ba} \\
\mathrm{Zn} \\
\mathrm{Ba} \\
\mathrm{Ba} \\
\mathrm{Cu} \\
\mathrm{Cu} \\
\mathrm{Ba} \\
\mathrm{Ba} \\
\mathrm{Cu} \\
\mathrm{Zn} \mathrm{Cu} \\
\mathrm{Cu} \\
\mathrm{Cu} \\
\mathrm{Cu}\end{array}$ & $\begin{array}{l}\mathrm{Fe} \mathrm{U} \\
\mathrm{Fe}\end{array}$ & $\begin{array}{l}11,36,60,75 \\
11,75 \\
11,75 \\
24 \\
11,17 \\
19,75 \\
11 \\
75,93 \\
11,93 \\
11,23,36,71,75,93 \\
45 \\
11,23,36,71,75 \\
23,75 \\
74,75 \\
75,93 \\
23,36,75 \\
23,36,71,75 \\
35 \\
11 \\
75,93 \\
36,75,93,130 \\
75,93,97,130\end{array}$ \\
\hline Miscella & neous ar & eas, Virginia-Area 7 & & & & & \\
\hline $\begin{array}{l}267 \\
268 \\
269\end{array}$ & $\begin{array}{l}\mathrm{u} \\
\mathrm{n} \\
\mathrm{n}\end{array}$ & $\begin{array}{l}\text { vein } \\
\text { vein } \\
\text { vein/fault zone }\end{array}$ & $\begin{array}{l}\text { gneiss } \\
\text { sandstone } \\
\text { shale }\end{array}$ & $\begin{array}{l}\text { Cambrian } \\
\text { Triassic } \\
\text { Triassic }\end{array}$ & $\begin{array}{l}\mathrm{Zn} \mathrm{Pb} \\
\mathrm{Ba} \\
\mathrm{Cu}\end{array}$ & $\mathrm{Ag}$ & $\begin{array}{l}42,82,127 \\
124 \\
26,75\end{array}$ \\
\hline Davie & nty ba & sin, North Carolina-Area & & & & & \\
\hline 270 & $\mathrm{n}$ & placer & gravel & Quaternary & $\mathrm{Au}$ & & 79 \\
\hline Deep F & bas & d vicinity, North Caro & Area 9 & & & & \\
\hline $\begin{array}{l}271 \\
272 \\
273 \\
274 \\
275 \\
276\end{array}$ & $\begin{array}{l}\mathrm{n} \\
\mathrm{n} \\
\mathrm{n} \\
\mathrm{n} \\
\mathrm{n} \\
\mathrm{n}\end{array}$ & $\begin{array}{l}\text { placer } \\
\text { vein } \\
\text { vein/replacement } \\
\text { vein } \\
\text { placer } \\
\text { placer }\end{array}$ & $\begin{array}{l}\text { gravel } \\
\text { metavolcanic } \\
\text { metavolcanic } \\
\text { diabase } \\
\text { sandstone } \\
\text { sandstone }\end{array}$ & $\begin{array}{l}\text { Quaternary } \\
\text { Paleozoic } \\
\text { Paleozoic } \\
\text { Jurassic } \\
\text { Triassic } \\
\text { Triassic }\end{array}$ & $\begin{array}{l}\mathrm{Au} \\
\mathrm{Cu} \\
\mathrm{Cu} \\
\mathrm{Ba} \\
\mathrm{Au} \\
\mathrm{Au}\end{array}$ & & $\begin{array}{l}10 \\
14 \\
14 \\
13 \\
79 \\
79\end{array}$ \\
\hline
\end{tabular}


Table 1B. Inventory of metal mines and occurrences associated with the early Mesozoic basins of the Eastern United States listed according to deposit type

[In column "Area number," locality is indicated by number: 0 , areas in New Hampshire north of the Hartford basin; 1, the Hartford basin and vicinity, Massachusetts; 2, the Hartford basin and vicinity, Connecticut; 3, the Newark basin, New Jersey; 4, the Newark basin and vicinity, Pennsylvania; 5, the Gettysburg basin and vicinity, Pennsylvania; 6, the Culpeper basin, Maryland and Virginia; 7, other areas in Virginia; 8, the Davie County basin area, North Carolina; 9 , the Deep River basin area, North Carolina. In the "Production" column, an l, $m, n$, or $u$ indicates ore production or reserves greater than 100,000 tons, between 1,000 and 100,000 tons, less than 1,000 tons, or unknown, respectively. In the "References" column, the number of the reference citation is listed in table $1 E$ ]

\begin{tabular}{llllllll}
\hline $\begin{array}{l}\text { Locality } \\
\text { number }\end{array}$ & Name & State & Area & Locality Produc- & Deposit & Metal associations \\
No. & type & tion & type & Principal Accessory & References \\
\hline
\end{tabular}

I. Metal occurrences associated with igneous intrusions

A. Skarn deposits

11 Bernardston

150 Boyertown mine

151 Stonersville

152 Brower mine

154 Esterly mine

159 Unnamed $\mathrm{Fe}$ mine

160 French Creek mines

161 Knauertown

162 Pine Swamp

163 Jones-Kinney mines

164 Hopewell mine

165 Leighton mine

166 Warwick mine

167 Steels mine

169 Raudenbush mine

170 Fritz Island mine

171 Grace mine

172 Bylers mine

173 Wheatfield mine

174 Ruth mine

175 Doner mine

176 Mt. Pleasant

177 Rexmont Reservoir

179 Cornwall mine

180 Hummelstown

185 Mt. Pleasant 2

186 Mt. Pleasant 1

187 Wellsville 2

188 Wellsville 1

190 Harman mine

191 Brenneman mine

192 Altland mine

193 Comfort mine

194 Cadwalader mine

195 Marshall mine

196 Sluthower mine

197 Minebank School 1

198 Minebank School 2

199 Roler

200 Smith prospect

201 Grantham mines

202 Dillsburg North

203 McCormick mine

204 Longnecker mine

205 King mine

206 Underwood mine

207 Jauss mine

208 Altland mine

209 Smyser mine

210 Bell mine

211 Logan mine

212 Cox mine

213 Grove mine

214 Bender mine

215 Franklintown 1

216 Franklintown 2

217 Franklintown 3

218 Franklintown 4
Massachusetts

Pennsylvania

Pennsylvania

Pennsylvania

Pennsylvania

Pennsylvania

ennsylvania

Pennsylvania

Pennsylvania

Pennsylvania

Pennsylvania

Pennsylvania

Pennsylvania

Pennsylvania

Pennsylvania

Pennsylvania

Pennsylvania

Pennsylvania

Pennsylvania

Pennsylvania

Pennsylvania

Pennsylvania

Pennsylvania

Pennsylvania

Pennsylvania

Pennsylvania

Pennsylvania

Pennsylvania

Pennsylvania

Pennsylvania

Pennsylvania

Pennsylvania

Pennsylvania

Pennsylvania

Pennsylvania

Pennsylvania

Pennsylvania

Pennsylvania

Pennsylvanja

Pennsylvania

Pennsylvania

Pennsylvania

Pennsylvania

Pennsylvania

Pennsylvania

Pennsylvania

Pennsylvania

Pennsylvania

Pennsylvania

Pennsylvania

Pennsylvania

Pennsylvania

Pennsylvania

Pennsylvania

Pennsylvania

Pennsylvania

Pennsylvania
1 occurrence

4 mine

4 prospect

4 mine

4 mine

4 mine

4 mine

4 prospect

4 prospect

4 mine

4 mine

4 mine

4 mine

4 mine

4 mine

4 mine

4 mine

4 mine

5 mine

5 mine

5 mine

5 prospect

5 prospect

5 mine

5 mine

5 prospect

5 prospect

5 prospect

5 prospect

5 mine

5 mine

5 mine

5 mine

5 mine

5 mine

5 mine

5 mine

5 mine

5 prospect

5 prospect

5 mine

5 prospect

5 mine

5 mine

5 mine

5 mine

5 mine

5 mine

5 mine

5 mine

5 mine

5 mine

5 mine

5 mine

5 prospect

5 prospect

5 prospect

5 prospect n skam $F$

n skarn $\quad F$

n skarn

m skarn

u skarn

u skarn

1 skarn

n skarm

n skarn

/replacement $\mathrm{Fe}$

u skarn

m skarn/replacement $F$

1 skarn $\mathrm{Fe}$

u skarn/replacement Fe

m skarn $\mathrm{Fe}$

1 skarn

1 skarn

l skarn

1 skarn

m skarn

m skarn

n skarn

n skarn

1 skarn

m skarn

n skarn

n skam

n skarn

n skarn

n skarn

n skarn

n skarn

n skarn

n skarn

n skarn

n skarn

m skarn

m skarn

n skarn

n skarn

m skarm

n skarn

] skarn

1 skarn

m skarn

1 skarn

1 skarn

m skarn

m skarn

1 skarm

m skarn

m skarn

m skarn

n skarn

n skarn

n skarn

n skarn

n skarn

$\mathrm{Fe}$

$\mathrm{Fe}$

$\mathrm{Fe}$

$\mathrm{Fe}$

$\mathrm{Fe}$

$\mathrm{Fe}$

$\mathrm{Fe}$

$\quad 1,2,25 \mathrm{~b}$

$20,44,51,98,117$

98,117

$\mathrm{Fe} \quad 98,117$

$20,98,117$

5,98

$\mathrm{Fe} \mathrm{Cu} \quad \mathrm{ZnCo} \quad 5,44,68,98,109$

5,98

$37,98,110$

$44,63,96,98,117,121$

$5,41,44,96,98,99,103$

$5,96,98$

$5,44,96,98,117$

$5,44,96,98$

$20,98,117$

$20,44,98,117$

$\begin{array}{lll}\mathrm{Fe} & \mathrm{Cu} & 20,44\end{array}$

$\mathrm{Fe}$ Co Ag Au 5,98

$\mathrm{Fe} \quad 20,44,98,117$

$\mathrm{Fe} \quad 20,44,98,117$

$\mathrm{Fe} \quad 69,98,117$

$\mathrm{Fe} \quad 98,117$

$\mathrm{Fe} \quad 98,117$

$\mathrm{Fe} \mathrm{Cu}$ Au Ag Co $39,46,67,69,98,117$

$\mathrm{Fe} \quad 98,117$

$\mathrm{Fe} \quad 29,98,122$

$\mathrm{Fe} \quad 29,98,122$

$\mathrm{Fe} \quad 29,98,122$

$\mathrm{Fe} \quad 29,98,122$

$\mathrm{Fe} \quad 29,98$

$\mathrm{Fe} \quad 29,98$

$\mathrm{Fe} \quad 29,98$

$\mathrm{Fe} \quad 29,98$

Fe 29,98

Fe 29,98

$\mathrm{Fe}$

Fe 29,98,117

$\mathrm{Fe} \quad 29,98,117$

$\mathrm{Fe} \quad 98,122$

29,98 
Table 1B. Inventory of metal mines and occurrences associated with the early Mesozoic basins of the Eastern United States listed according to deposit type-Continued

[In column "Area number," locality is indicated by number: 0 , areas in New Hampshire north of the Hartford basin; 1, the Hartford basin and vicinity, Massachusetts; 2, the Hartford basin and vicinity, Connecticut; 3, the Newark basin, New Jersey; 4, the Newark basin and vicinity, Pennsylvania; 5, the Gettysburg basin and vicinity, Pennsylvania; 6, the Culpeper basin, Maryland and Virginia; 7, other areas in Virginia; 8, the Davie County basin area, North Carolina; 9 , the Deep River basin area, North Carolina. In the "Production" column, an l, $m, n$, or $u$ indicates ore production or reserves greater than 100,000 tons, between 1,000 and 100,000 tons, less than 1,000 tons, or unknown, respectively. In the "References" column, the number of the reference citation is listed in table $1 E]$

Locality

Locality Locality Produc-

I. Metal occurrences associated with igneous intrusions-Continued

A. Skarn deposits-Continued

219 Lichte mine

221 Center Mills 1

222 Center Mills 2

223 Idaville

230 Cashtown 2

231 Cashtown 1

232 Orrtana

233 Carr Hill

235 McNair farm

B. Hornfels deposits

55 copper prospect

68 copper prospect

70 copper prospect

85 Monmouth Junction

88 Woosamonsa prospect

89 New Hope

91 Solebury

96 Lodi

97 Tettemer's mine

98 Uhlerstown

99 Ferndale

100 Bursonville

109 Coopersburg

112 Sumneytown

113 Kibblehouse quarry

114 Hendricks Station

115 Kober's mine

116 Karl's mine

117 Young's mine

118 Schwencksville

134 Brendlinger mine

137 Pennsylvania mine

153 Snydersville

168 South of Reading

178 Carper mine

184 Reeser's Summit

189 Rossville roadcut

220 Clapper farm

224 Heidlersburg

225 Stone Jug mine

226 Hunterstown

227 Gettysburg

229 Teeter's quarry

234 Fairfield

242 Goose Creek

245 Theodora

246 Spencer farm

247 Chantilly prospect

248 Cub Run copper

259 Bealeton mine

262 Mountain Run

264 Culpeper prospect

265 Batna

$\begin{array}{lll}\text { Pennsylvania } & 5 & \text { mine } \\ \text { Pennsylvania } & 5 & \text { prospect } \\ \text { Pennsylvania } & 5 & \text { prospect } \\ \text { Pennsylvania } & 5 & \text { prospect } \\ \text { Pennsylvania } & 5 & \text { prospect } \\ \text { Pennsylvania } & 5 & \text { prospect } \\ \text { Pennsylvania } & 5 & \text { occurrence } \\ \text { Pennsylvania } & 5 & \text { prospect } \\ \text { Pennsylvania } & 5 & \text { prospect }\end{array}$

Pennsylvania

Connecticut Connecticut

Connecticut

New Jersey

New Jersey

Pennsylvania

Pennsylvania

Pennsylvania

Pennsylvania

Pennsylvania

Pennsylvania

Pennsylvania

Pennsylvania

Pennsylvania

Pennsylvania

Pennsylvania

Pennsylvania

Pennsylvania

Pennsylvania

Pennsylvania

Pennsylvania

Pennsylvania

Pennsylvania

Pennsylvania

Pennsylvania

Pennsylvania

Pennsylvania

Pennsylvania

Pennsylvania

Pennsylvania

Pennsylvania

Pennsylvania

Pennsylvania

Pennsylvania

Virginia

Virginia

Virginia

Virginia

Virginia

Virginia

Virginia

Virginia

Virginia
2 prospect

2 prospect

2 prospect

3 prospect

3 prospect

4 mine

4 occurrence

4 mine

4 occurrence

4 occurrence

4 occurrence

4 prospect

4 occurrence

4 occurrence

4 prospect

4 mine

4 mine

4 mine

4 prospect

4 prospect

4 mine

4 occurrence

4 occurrence

5 mine

5 occurrence

5 occurrence

5 occurrence

5 occurrence

5 mine

5 prospect

5 occurrence

5 occurrence

5 prospect

6 prospect

6 mine

6 prospect

6 prospect

6 occurrence

6 mine

6 occurrence

6 occurrence

6 prospect
4 occurrence

$\begin{array}{ll}\text { m } & \text { skarn } \\ \text { n } & \text { skarn } \\ \text { n } & \text { skarn } \\ \text { n } & \text { skarn } \\ \text { n } & \text { skarn } \\ \text { n } & \text { skarn } \\ \text { n } & \text { skarn } \\ \text { n } & \text { skarn } \\ \text { n } & \text { skarn }\end{array}$

skarn

skarn

skarn

skarn

skarn

Deposit

Deposit
type

$\frac{\text { Metal associations }}{\text { Principal Accessory }}$

References
29,98

$98,119,120$

$98,119,120$

98,119

$84,98,120$

$84,98,120$

98,119

$98,119,120$

98,119

$\begin{array}{ll}\mathrm{Fe} & 98,119,120 \\ \mathrm{Fe} & 98,119,120 \\ \mathrm{Fe} & 98,119 \\ \mathrm{Fe} & 84,98,120 \\ \mathrm{Fe} & 84,98,120 \\ \mathrm{Fe} & 98,119 \\ \mathrm{Fe} & 98,119,120 \\ \mathrm{Fe} & 98,119\end{array}$

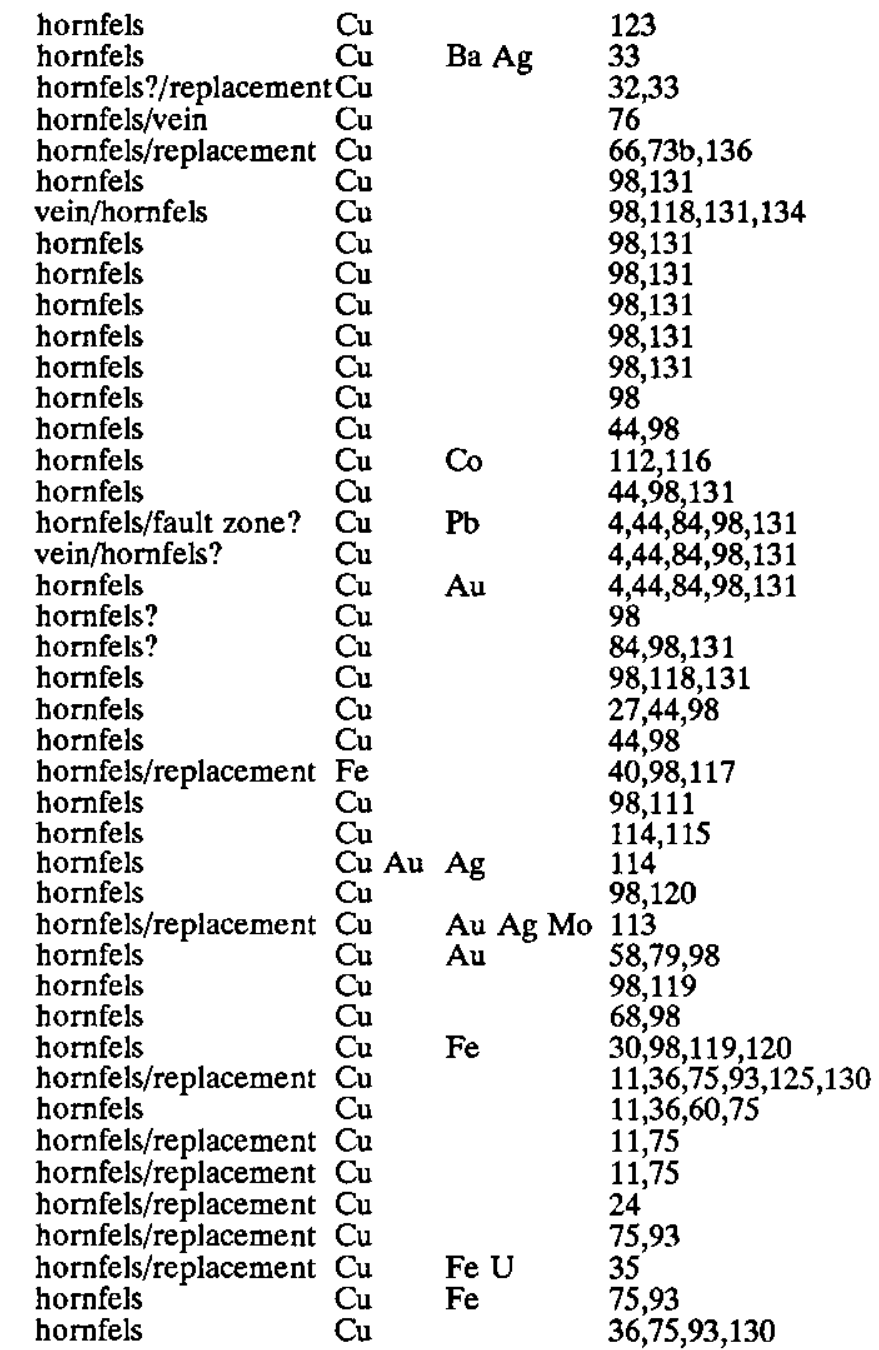

98,131

98,131

98,131

98,131

4,98

$84,98,131$

44,98

114,115

114

$30,98,119,120$

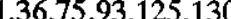

11,75

11,75

35

$36,75,93,130$ 
Table 1B. Inventory of metal mines and occurrences associated with the early Mesozoic basins of the Eastern United States listed according to deposit type-Continued

[In column "Area number," locality is indicated by number: 0 , areas in New Hampshire north of the Hartford basin; 1, the Hartford basin and vicinity, Massachusetts; 2, the Hartford basin and vicinity, Connecticut; 3, the Newark basin, New Jersey; 4, the Newark basin and vicinity, Pennsylvania; 5, the Gettysburg basin and vicinity, Pennsylvania; 6, the Culpeper basin, Maryland and Virginia; 7, other areas in Virginia; 8, the Davie County basin area, North Carolina; 9, the Deep River basin area, North Carolina. In the "Production" column, an l, $m, n$, or $u$ indicates ore production or reserves greater than 100,000 tons, between 1,000 and 100,000 tons, less than 1,000 tons, or unknown, respectively. In the "References" column, the number of the reference citation is listed in table 1E]

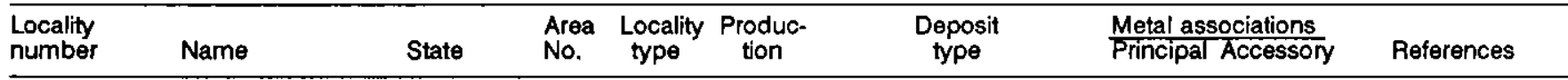

I. Metal occurrences associated with igneous intrusions-Continued

C. Diabase-hosted vein and segregation deposits

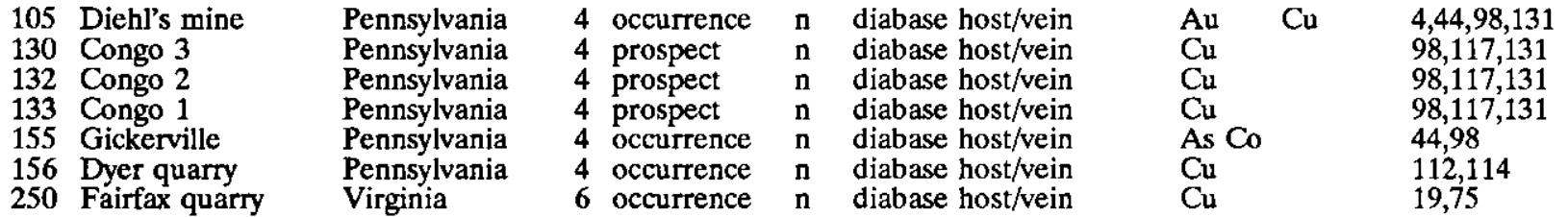

II. Metal occurrences associated with the migration of basin brines

A. Sediment-hosted and stratabound/replacement and disseminated deposits

$\begin{array}{rll}37 & \text { K \& F Suffield } & \text { Connecticut } \\ 38 & \text { Simsbury mine } & \text { Connecticut } \\ 39 & \text { New-gate Prison } & \text { Connecticut } \\ 40 & \text { Higley copper } & \text { Connecticut } \\ 46 & \text { Cook's Gap } & \text { Connecticut } \\ 71 & \text { silver prospect } & \text { Connecticut } \\ 72 & \text { Totowa mine } & \text { New Jersey } \\ 73 & \text { Glen Ridge mine } & \text { New Jersey } \\ 74 & \text { Wigwam Brook } & \text { New Jersey } \\ 75 & \text { Dod mine } & \text { New Jersey } \\ 76 & \text { Schuyler mine } & \text { New Jersey } \\ 78 & \text { Hoffman } & \text { New Jersey } \\ 79 & \text { Stony Brook } & \text { New Jersey } \\ 80 & \text { Bridgewater } & \text { New Jersey } \\ 81 & \text { Chimney Rock } & \text { New Jersey } \\ 83 & \text { New Brunswick } & \text { New Jersey } \\ 84 & \text { Flemington } & \text { New Jersey } \\ 86 & \text { Griggstown } & \text { New Jersey } \\ 101 & \text { Keller's Church } & \text { Pennsylvania } \\ 102 & \text { Hagersville } & \text { Pennsylvania } \\ 106 & \text { Sellersville } & \text { Pennsylvania } \\ 107 & \text { Drakes Crossroad } & \text { Pennsylvania } \\ 108 & \text { Leithsville mine } & \text { Pennsylvania } \\ 110 & \text { Pennsburg } & \text { Pennsylvania } \\ 111 & \text { Red Hill } & \text { Pennsylvania } \\ 119 & \text { Lederachsville } & \text { Pennsylvania } \\ 120 & \text { Graters Ford } & \text { Pennsylvania } \\ 121 & \text { Collegeville } & \text { Pennsylvania } \\ 135 & \text { Layfield } & \text { Pennsylvania } \\ 136 & \text { Gilbertville } & \text { Pennsylvania } \\ 138 & \text { Saratoga } & \text { Pennsylvania } \\ 157 & \text { Glasgow } & \text { Pennsylvania } \\ 158 & \text { Bleims mine } & \text { Pennsylvania } \\ 181 & \text { Glenwood Station } & \text { Pennsylvania } \\ 182 & \text { Lecron's } & \text { Pennsylvania } \\ 228 & \text { Bonneauville } & \text { Pennsylvania } \\ 240 & \text { Sugarland } & \text { Maryland } \\ 243 & \text { Sugarland Run } & \text { Virginia } \\ 244 & \text { Sterling } & \text { Virginia } \\ 249 & \text { Chantilly } & \text { Virginia } \\ 253 & \text { Brentsville } & \text { Virginia } \\ 255 & \text { Calverton } & \text { Virginia } \\ 263 & \text { Stevensburg } & \text { Virginia } \\ 266 & \text { Somerset mine } & \text { Virginia } \\ & \text { Dend } & \end{array}$

2 occurrence u stratabound/replacement $\mathrm{Cu}$

2 mine in stratabound/replacement $\mathrm{Cu}$

2 mine $\mathrm{m}$ stratabound/replacement $\mathrm{Cu}$

2 mine

2 occurrence

2 prospect

2 mine

3 mine

3 mine

3 mine

3 mine

3 mine

3 mine

3 mine

3 mine

3 mine

3 mine

3 mine

4 prospect

4 occurrence

4 occurrence

4 occurrence

4 mine

4 occurrence

4 occurrence

4 occurrence

4 occurrence

4 occurrence

4 occurrence

4 occurrence

4 prospect

4 occurrence

4 prospect

5 occurrence

5 mine

5 occurrence

6 mine

6 prospect

6 occurrence

6 occurrence

6 prospect

6 occurrence

6 occurrence

6 mine stratabound/replacement $\mathrm{Cu}$

stratabound/replacement $\mathrm{Zn} \mathrm{Cu}$

sediment host

stratabound/vein

$\mathrm{Ag}$

stratabound/replacement $\mathrm{Cu}$

stratabound/replacement $\mathrm{Cu}$

stratabound/replacement $\mathrm{Cu}$

stratabound/replacement $\mathrm{Cu}$

stratabound/replacement $\mathrm{Cu}$

stratabound/replacement $\mathrm{Cu}$

stratabound/replacement $\mathrm{Cu}$

stratabound/replacement $\mathrm{Cu}$

stratabound/replacement $\mathrm{Cu}$

stratabound/replacement $\mathrm{Cu}$

stratabound/replacement $\mathrm{Cu}$

sediment host

sediment host

sediment host

sediment host

sediment host?

sediment host

sediment host

sediment host

sediment host

sediment host

sediment host

sediment host

sediment host

sediment host

sediment host

sediment host

sediment host

sediment host

stratabound/replacement $\mathrm{Cu}$

stratabound/replacement $\mathrm{Cu} \mathrm{Ag}$

stratabound/replacement $\mathrm{Cu}$

stratabound/replacement $\mathrm{Cu}$

sediment host

stratabound/replacement $\mathrm{Zu}$

stratabound/replacement $\mathrm{Zn} \mathrm{C}$

stratabound/replacement $\mathrm{Cu}$
47

102,104

$\mathrm{Ag} U \quad 47,88,89,101,128,130$

$47,101,130$

47

62

136

$73,84,136$

136

136

Ag $16,70,84,136$

$73,84,136$

136

$18,52,84,129,136$

73,136

Ag $\quad 136$

$73,84,136$

$\mathrm{Ag} \mathrm{Au} \quad 73,136$

98,131

98,131

$27,44,98$

$44,98,131$

27,98

$44,98,131$

98,131

$44,98,131$

$44,98,131$

$44,98,131$

$44,98,131$

$44,98,131$

5,98

$44,98,131$

44,98

$9,44,98$

$31,98,122$

30,98

$11,34,36,71$

11

11

11,17

11,93

45

11

$75,93,97,130$

B. Vein deposits

1 E. Surry Mtn. mine New Hampshire 0 mine

2 Will Wise mine New Hampshire 0 mine

3 Stoddard mine 1 New Hampshire 0 mine

$\begin{array}{ll}\mathbf{u} & \text { vein } \\ \mathbf{n} & \text { vein } \\ \mathbf{m} & \text { vein }\end{array}$

$\begin{array}{ll}\mathbf{P b} & \mathrm{Cu} \\ \mathbf{F} & \mathrm{Ba} \mathrm{Pb} \\ \mathbf{F} & \mathrm{Ba} \mathrm{Pb}\end{array}$

80

3
$\mathbf{3}$ 
Table 1B. Inventory of metal mines and occurrences associated with the early Mesozoic basins of the Eastern United States listed according to deposit type-Continued

[In column "Area number," locality is indicated by number: 0 , areas in New Hampshire north of the Hartford basin; 1, the Hartford basin and vicinity, Massachusetts; 2, the Hartford basin and vicinity, Connecticut; 3, the Newark basin, New Jersey; 4, the Newark basin and vicinity, Pennsylvania; 5, the Gettysburg basin and vicinity, Pennsylvania; 6, the Culpeper basin, Maryland and Virginia; 7, other areas in Virginia; 8, the Davie County basin area, North Carolina; 9 , the Deep River basin area, North Carolina. In the "Production" column, an l, $\mathrm{m}$, $\mathrm{n}$, or $u$ indicates ore production or reserves greater than 100,000 tons, between 1,000 and 100,000 tons, less than 1,000 tons, or unknown, respectively. In the "References" column, the number of the reference citation is listed in table $1 E$ ]

\begin{tabular}{llllll}
\hline $\begin{array}{l}\text { Locality } \\
\text { number }\end{array}$ Name & State & No. & Nocality Produc- & Deposit & Metal associations \\
type & tion & Principal Accessory & References \\
\hline
\end{tabular}

II. Metal occurrences associated with the migration of basin brines-Continued

B. Vein deposits-Continued

4 Stoddard mine 2

5 Springer mine

6 fluorite prospect

7 Pierce mine

8 Streeter Hill

9 galena occurrence

10 Winchester mine

12 Turners Falls 1

13 Turners Falls 2

14 Deerfield

15 Unnamed $\mathrm{Pb}-\mathrm{Ba}$

16 Mt. Esther

17 Leverett

New Hampshire 0 mine

New Hampshire 0 mine

New Hampshire 0 prospect

New Hampshire 0 mine

New Hampshire 0 occurrence

New Hampshire 0 occurrence

New Hampshire 0 mine

Massachusetts 1 occurrence

Massachusetts

Massachusetts

Massachusetts

Massachusetts

Massachusetts

18 Unnamed $\mathrm{Pb}-\mathrm{Ba} 4$ Massachusetts

19 Whately-Wm. 1

20 Whately-Wm. 2

Massachusetts

Massachusetts

21 Unnamed $\mathrm{Pb}-\mathrm{Ba} 1$ Massachusetts

22 Unnamed $\mathrm{Pb}-\mathrm{Ba} 3$

23 Unnamed $\mathrm{Pb}-\mathrm{Ba} 2$

24 Whately-Wm. 3

25 Hatfield lead

Massachusetts

Massachusetts

Massachusetts

Massachusetts

26 Unnamed $\mathrm{Pb}-\mathrm{Ba} 2$ Massachusetts

27 Unnamed $\mathrm{Pb}-\mathrm{Ba} 1$ Massachusetts

28 Manhan Lead 1

29 Manhan Lead 2

30 Manhan Lead 3

31 Manhan Lead 4

32 Manhan Lead 5

33 Southampton

34 New mine vein

35 Woodland Dell

36 Somers sandpit

41 Trinity College

42 Bristol copper

43 Farmington

44 basalt quarry

45 Plainfield quarry

47 Columbus Blvd.

48 Ellis Street

49 bitumen vein

50 Mattabesset River

51 Berlin Moores Mill

52 limestone quarry

53 barite vein

54 Middletown lead

56 barite vein

57 New Haven mine

58 Cheshire mine 3

59 Cheshire mine 2

60 copper prospect

61 Booth \& Hinman

62 Cheshire mine 1

63 copper mine

64 Jinny Hill

65 Cross Rock

66 Gaylord

67 Tallman's mine

69 Copper Valley

77 Laurel Hill
Massachusetts

Massachusetts

Massachusetts

Massachusetts

Massachusetts

Massachusetts

Massachusetts

Connecticut

Connecticut

Connecticut

Connecticut

Connecticut

Connecticut

Connecticut

Connecticut

Connecticut

Connecticut

Connecticut

Connecticut

Connecticut

Connecticut

Connecticut

Connecticut

Connecticut

Connecticut

Connecticut

Connecticut

Connecticut

Connecticut

Connecticut

Connecticut

Connecticut

Connecticut

Connecticut

New Jersey
Massachusetts
1 occurrence

1 occurrence

1 occurrence

1 occurrence

1 mine

1 occurrence

1 mine

1 mine

1 occurrence

1 occurrence

1 occurrence

1 mine

1 mine

1 mine

1 mine

1 mine

1 mine

1 mine

1 mine

1 mine

1 mine

1 mine

1 occurrence

2 occurrence

2 occurrence

2 mine

2 occurrence

2 occurrence

2 occurrence

2 occurrence

2 occurrence

2 occurrence

2 mine

2 mine

2 occurrence

2 occurrence

2 mine

2 occurrence

2 mine

2 mine

2 mine

2 prospect

2 mine

2 mine

2 mine

2 mine

2 mine

2 prospect

2 mine

2 prospect

3 occurrence

\begin{tabular}{|c|c|}
\hline m & vein \\
\hline $\mathrm{m}$ & vein \\
\hline $\mathbf{n}$ & vein \\
\hline $\mathbf{m}$ & vein \\
\hline $\mathbf{n}$ & vein \\
\hline $\mathrm{n}$ & vein \\
\hline $\mathrm{n}$ & vein \\
\hline $\mathrm{n}$ & vein \\
\hline $\mathbf{n}$ & vein \\
\hline $\mathbf{u}$ & vein \\
\hline $\mathbf{u}$ & vein \\
\hline $\mathbf{u}$ & vein \\
\hline m & vein \\
\hline $\mathbf{n}$ & vein \\
\hline $\mathbf{u}$ & vein \\
\hline $\mathrm{u}$ & vein \\
\hline $\mathbf{n}$ & vein \\
\hline $\mathbf{n}$ & vein \\
\hline n & vein \\
\hline $\mathbf{u}$ & vein \\
\hline $\mathrm{m}$ & vein \\
\hline $\mathrm{m}$ & vein \\
\hline $\mathrm{m}$ & vein \\
\hline $\mathbf{m}$ & vein \\
\hline $\mathrm{m}$ & vein \\
\hline $\mathrm{m}$ & vein \\
\hline $\mathrm{m}$ & vein \\
\hline $\mathbf{m}$ & vein \\
\hline $\mathrm{n}$ & vein \\
\hline $\mathfrak{u}$ & vein \\
\hline $\mathbf{n}$ & fault zone/replacement \\
\hline n & fault zone/replacement \\
\hline $\mathbf{n}$ & vein \\
\hline $\mathbf{m}$ & vein/replacement \\
\hline $\mathrm{n}$ & vein \\
\hline $\mathbf{n}$ & vein \\
\hline$\rightarrow$ & vein \\
\hline
\end{tabular}

$\begin{array}{lll}\mathrm{F} & \mathrm{Ba} \mathrm{Pb} & \mathbf{3} \\ \mathrm{F} & \mathrm{Ba} \mathrm{Pb} \mathrm{Cu} & \mathbf{3} \\ \mathrm{F} & & \mathbf{3} \\ \mathrm{F} & \mathrm{Ba} \mathrm{Pb} & \mathbf{3} \\ \mathrm{F} & \mathrm{Pb} & \mathbf{3} \\ \mathrm{Pb} & & 80 \\ \mathrm{~Pb} & \mathrm{Ag} & 80 \\ \mathrm{Cu} & \mathrm{Ba} & 25\end{array}$

$\mathrm{Cu} \quad \mathrm{Ba} \quad 25,43,55,57,132$

$\mathrm{Cu} \quad \mathrm{Ba}$

$\mathrm{Ba}$

$\mathrm{Ba}$

$\mathrm{Ba}$

$\mathrm{Ba} \mathrm{Cu}$

$$
25,43,55,57,132
$$

$$
25,55,57
$$$$
25,55,57
$$

$\mathrm{Pb}$

$\mathrm{Pb}$

$\mathrm{Ba} \mathrm{Cu}$

$43,55,57$

$25,43,53,57,64,85$

$\mathrm{Pb}$

$\mathrm{Pb}$

$\mathrm{Pb} \quad \mathrm{BaCl}$

25

$25,43,55,57,133$

$\mathrm{Pb} \quad \mathrm{BaCu}$

$25,43,55,57,133$

$\begin{array}{ll}\mathrm{Ba} \mathrm{Cu} & 25 \\ & \end{array}$

$\mathrm{Pb} \quad \mathrm{BaCl} 25$

$\mathrm{Pb} \quad \mathrm{Ba} \mathrm{Cu} 25,43,54,57,133$

$\mathrm{Pb} \quad \mathrm{Ba} \quad 25,55,57$

$\mathrm{Pb} \quad \mathrm{Ba} \quad 25,55,57$

$\mathrm{Pb} \mathrm{Ba} \mathrm{Ag} \mathrm{Zn} \mathrm{Cu} 25,55$

$\mathrm{Pb} \mathrm{Ba} \mathrm{Ag} \mathrm{Zn} \mathrm{Cu} 25,55$

$\mathrm{Pb} \mathrm{Ba} \mathrm{Ag} \mathrm{Zn} \mathrm{Cu} \mathrm{25,55}$

$\mathrm{Pb} \mathrm{Ba} \quad \mathrm{Ag} \mathrm{Zn} \mathrm{Cu} 25,55$

$\mathrm{Pb} \mathrm{Ba} \mathrm{Ag} \mathrm{Zn} \mathrm{Cu} \mathrm{25,55}$

$\mathrm{Pb} \mathrm{Cu} \mathrm{Ag} \mathrm{Zn}$ Ba $43,55,57$

vein

vein/replacement

vein

vein

vein

vein

vein

vein

vein

vein

vein/replacement

vein/replacement

fault zone/replacement

vein

vein/replacement

fault zone/replacement

vein

vein/replacement

vein/replacement

vein/replacement

vein/replacement

vein/replacement
$\mathrm{Pb}$

$\mathrm{Cu}$

$\mathrm{Cu}$ Ag U

$\mathrm{Zn}$

56,81

86

86

100

$7,65,101,105$

106

$\mathrm{Ba} \quad 106$

$\mathrm{Cu} \mathrm{Zn} 106$

$\mathrm{Zn} \mathrm{Pb} \mathrm{Cu} \mathrm{Ba} \quad 47$

$\mathrm{Cu} \quad \mathrm{Ba} \quad 47$

$\mathrm{Pb} \quad \mathrm{Zn} \mathrm{Ba} \quad 48,87,104$

$\mathrm{Ba} \quad 48,87,104$

$\begin{array}{lll} & \mathrm{F} & 48 \\ \mathrm{~Pb} & \mathrm{Ba} & 72 \\ \mathrm{Ba} & \mathrm{Ag} & 92\end{array}$

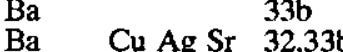

$\mathrm{Ba}$

$\mathrm{Ba}$

$\mathrm{Cu}$

$\mathrm{Ba}$

$\mathrm{Ba}$

$\mathrm{Cu}$

$\mathrm{Ba}$

$\mathrm{Cu}$

$\mathrm{Cu}$

$\mathrm{Cu}$

$\mathrm{Fe}$
32

32

$33 \mathrm{~b}$

32

32,33

$\mathrm{Ba} \mathrm{Ag}$

$32,33,104$

33,89,104

$\mathrm{Ag}$

32,33 
Table 1B. Inventory of metal mines and occurrences associated with the early Mesozoic basins of the Eastern United States listed according to deposit type-Continued

[In column "Area number," locality is indicated by number: 0 , areas in New Hampshire north of the Hartford basin; 1, the Hartford basin and vicinity, Massachusetts; 2, the Hartford basin and vicinity, Connecticut; 3, the Newark basin, New Jersey; 4, the Newark basin and vicinity, Pennsylvania; 5, the Gettysburg basin and vicinity, Pennsylvania; 6, the Culpeper basin, Maryland and Virginia; 7, other areas in Virginia; 8, the Davie County basin area, North Carolina; 9, the Deep River basin area, North Carolina. In the "Production" column, an l, m, n, or $u$ indicates ore production or reserves greater than 100,000 tons, between 1,000 and 100,000 tons, less than 1,000 tons, or unknown, respectivety. In the "References" column, the number of the reference citation is listed in table $1 E]$

\begin{tabular}{lllllll}
\hline $\begin{array}{l}\text { Locality } \\
\text { number }\end{array}$ & Name & State & No. & Locality Produc- & Deposit & Metal associations \\
type & tion & Principal Accessory & References \\
\hline
\end{tabular}

II. Metal occurrences associated with the migration of basin brines-Continued

B. Vein deposits-Continued

$\begin{array}{rll}82 & \text { Menlo Park mine } & \text { New Jersey } \\ 87 & \text { Hopewell barite } & \text { New Jersey } \\ 90 & \text { Ingham Spring } & \text { Pennsylvania } \\ 92 & \text { Buckmanville } & \text { Pennsylvania } \\ 93 & \text { Buckingham } & \text { Pennsylvania } \\ 94 & \text { W. Buckmanville } & \text { Pennsylvania } \\ 95 & \text { Bushington } & \text { Pennsylvania } \\ 103 & \text { New Galena } & \text { Pennsylvania } \\ 104 & \text { Schuylkill Falls } & \text { Pennsylvania } \\ 122 & \text { Arcola } & \text { Pennsylvania } \\ 123 & \text { Shannonville } & \text { Pennsylvania } \\ 124 & \text { Perkiomen mine } & \text { Pennsylvania } \\ 125 & \text { Whim mine } & \text { Pennsylvania } \\ 126 & \text { Ecton mine } & \text { Pennsylvania } \\ 127 & \text { Wetherill mine } & \text { Pennsylvania } \\ 128 & \text { Port Kennedy } & \text { Pennsylvania } \\ 129 & \text { Jug Hollow mine } & \text { Pennsylvania } \\ 131 & \text { Fegley mine } & \text { Pennsylvania } \\ 139 & \text { Phoenix. Tunnel } & \text { Pennsylvania } \\ 140 & \text { Morris copper } & \text { Pennsylvania } \\ 141 & \text { Charlestown mine } & \text { Pennsylvania } \\ 142 & \text { Wheatley mine } & \text { Pennsylvania } \\ 143 & \text { Chester Co. mine } & \text { Pennsylvania } \\ 144 & \text { Montgomery Co. } & \text { Pennsylvania } \\ 145 & \text { SW. Chester mine } & \text { Pennsylvania } \\ 146 & \text { Brookdale mine } & \text { Pennsylvania } \\ 147 & \text { Phoenix mine } & \text { Pennsylvania } \\ 148 & \text { Pethericks Penn } & \text { Pennsylvania } \\ 149 & \text { Pennypacker mine } & \text { Pennsylvania } \\ 183 & \text { Safe Harbor } & \text { Pennsylvania } \\ 236 & \text { Boyds barite } & \text { Maryland } \\ 252 & \text { Manassas } & \text { Virginia } \\ 254 & \text { St. Stephens } & \text { Virginia } \\ 256 & \text { Cedar Run } & \text { Virginia } \\ 257 & \text { Botts barite } & \text { Virginia } \\ 258 & \text { Elk Run mine } & \text { Virginia } \\ 260 & \text { Gear barite } & \text { Virginia } \\ 261 & \text { Kemper } & \text { Virginia } \\ 267 & \text { Albemarle mine } & \text { Virginia } \\ 268 & \text { Scottsville barite } & \text { Virginia } \\ 269 & \text { Dolan property } & \text { Virginia } \\ 272 & \text { Clegg copper mine } & \text { North Carolina } \\ 273 & \text { Tennessee copper } & \text { North Carolina } \\ 274 & \text { Harrisville barite } & \text { North Carolina } \\ & & \\ & \end{array}$

3 mine

3 mine

4 prospect

4 mine

4 occurrence

4 prospect

4 occurrence

4 mine

4 occurrence

4 occurrence

4 prospect

4 mine

4 mine

4 mine

4 mine

4 prospect

4 mine

4 mine

4 occurrence

4 mine

4 mine

4 mine

4 mine

4 mine

4 mine

4 mine

4 mine

4 prospect

4 mine

5 occurrence

6 occurrence

6 occurrence

6 mine

6 mine

6 occurrence

6 prospect

6 prospect

6 prospect

7 mine

7 occurrence

7 occurrence

9 mine

9 prospect

9 occurrence

$\begin{array}{ll}\text { n } & \text { vein/fault zone } \\ \text { m } & \text { vein } \\ \text { n } & \text { vein } \\ \text { n } & \text { fault zone/vein } \\ \text { n } & \text { vein } \\ \text { n } & \text { vein } \\ \text { n } & \text { vein } \\ \text { l } & \text { vein/fault zone } \\ \text { n } & \text { vein } \\ \text { n } & \text { vein } \\ \text { n } & \text { vein } \\ \text { m } & \text { vein } \\ \text { m } & \text { vein/fault zone } \\ \text { m } & \text { vein } \\ \text { m } & \text { vein } \\ \text { n } & \text { vein } \\ \text { m } & \text { vein } \\ \text { n } & \text { vein/replacement } \\ \text { n } & \text { vein } \\ \text { n } & \text { vein } \\ \text { n } & \text { vein } \\ \text { m } & \text { vein } \\ \text { m } & \text { vein } \\ \text { m } & \text { vein } \\ \text { m } & \text { vein } \\ \text { m } & \text { vein } \\ \text { m } & \text { vein } \\ \text { n } & \text { vein } \\ \text { n } & \text { vein } \\ \text { n } & \text { vein } \\ \text { n } & \text { vein } \\ \text { n } & \text { vein } \\ \text { m } & \text { vein } \\ \text { m } & \text { vein/fault zone } \\ \text { n } & \text { vein } \\ \text { n } & \text { fault zone/vein } \\ \text { n } & \text { vein } \\ \text { n } & \text { vein } \\ \text { u } & \text { vein } \\ \text { n } & \text { vein } \\ \text { n } & \text { vein/fault zone } \\ \text { n } & \text { vein } \\ \text { n } & \text { vein/replacement } \\ \text { n } & \text { vein } \\ & \end{array}$

$\begin{array}{lll}\mathrm{Cu} & & 73,84,136 \\ \mathrm{Ba} & & 15,21 \\ \mathrm{Cu} & \mathrm{Ba} & 98,131,134 \\ \mathrm{Ba} & \mathrm{Cu} & 98,118,131,134 \\ \mathrm{Ba} & & 44,98 \\ \mathrm{Ba} \mathrm{Cu} & & 98,131 \\ \mathrm{Ba} & & 44,98 \\ \mathrm{~Pb} \mathrm{Zn} & \mathrm{Ag} \mathrm{Au} \mathrm{Cu} & 22,28,98,110,111,134 \\ \mathrm{~Pb} & \mathrm{Zn} & 44,78,98 \\ \mathrm{Cu} & & 44,98 \\ \mathrm{Cu} & & 44,78,98 \\ \mathrm{~Pb} \mathrm{Cu} & \mathrm{Zn} & 22,98,111,135 \\ \mathrm{~Pb} \mathrm{Cu} & \mathrm{Zn} \mathrm{Ag} & 22,98,111,135 \\ \mathrm{~Pb} & \mathrm{Zn} \mathrm{Ag} & 22,98,111,135 \\ \mathrm{~Pb} & \mathrm{Cu} \mathrm{Zn} & 22,98,111,135 \\ \mathrm{Cu} & & 44,78,98 \\ \mathrm{Ba} \mathrm{Zn} & \mathrm{Cu} \mathrm{Pb} & 44,77,96,111 \\ \mathrm{Fe} & & 44,51,98,117 \\ \mathrm{Zn} & & 44,98 \\ \mathrm{Cu} & & 78,98\end{array}$

$\mathrm{Pb} \mathrm{Ba}$ Zn Cu Ag 95,111,126

$\mathrm{Pb} \mathrm{Zn}$ Cu Ag Mo $12,50,59,95,108,111$

$\mathrm{Pb} \mathrm{Zn} \mathrm{Cu} \mathrm{Ag} \quad 5,38,77,91,111,126$

$\mathrm{Zn} \mathrm{Pb} \mathrm{Cu} \mathrm{Ag} \quad 78,91,96,98,111,126$

$\mathrm{Pb} \mathrm{Zn} \mathrm{Cu} \mathrm{Ag} \mathrm{5,38,77,91,111,126}$

$\mathrm{Zn} \mathrm{Pb} \mathrm{Cu}$ Ag $12,50,59,96,108,111$

$\mathrm{Zn} \mathrm{Pb}$ Ag Cu $12,50,59,96,108,111$

$\mathrm{Pb}$

$\begin{array}{lll}\mathrm{Cu} & \mathbf{5}, 96,111\end{array}$

$\mathrm{Zn} \mathrm{Ba} \quad 8,98$

$\mathrm{Ba} \quad 75,93$

$\mathrm{Ba} \quad 11,23,36,71,75,93$

$\mathrm{Ba} \quad 11,23,36,71,75$

$\mathrm{Ba} \quad 23,75$

$\mathrm{Cu} \quad \mathbf{7 4 , 7 5}$

$\mathrm{Ba} \quad 23,36,75$

$\mathrm{Ba} \quad 23,36,71,75$

$\mathrm{Zn} \mathrm{Pb} \mathrm{Ag} \quad 42,82,127$

$\mathrm{Ba} \quad 124$

$\mathrm{Cu} \quad 26,75$

$\mathrm{Cu} \quad 14$

$\mathrm{Ba} \quad 13$

III. Metal occurrences associated with basin sedimentation A. Placer deposits

$\begin{array}{ll}237 & \text { Dawsonville 1 } \\ 238 & \text { Dawsonville 2 } \\ 239 & \text { Seneca Creek } \\ 241 & \text { Waterford gold } \\ 251 & \text { Bull Run } \\ 270 & \text { Bell Branch gold } \\ 271 & \text { Whomble prospect } \\ 275 & \text { Mangum gold 2 } \\ 276 & \text { Mangum gold 1 }\end{array}$

Maryland
Maryland
Maryland
Virginia
Virginia
North Carolina
North Carolina
North Carolina
North Carolina

6 occurrence

6 occurrence

6 occurrence

6 occurrence

6 occurrence

8 occurrence

9 prospect

9 occurrence

9 occurrence $\begin{array}{ll}\text { n } & \text { placer } \\ \text { n } & \text { placer } \\ \text { n } & \text { placer } \\ \text { n } & \text { placer } \\ \text { n } & \text { placer } \\ \text { n } & \text { placer } \\ \text { n } & \text { placer } \\ \text { n } & \text { placer } \\ \text { n } & \text { placer }\end{array}$

$\begin{array}{ll}\mathrm{Au} & 11 \\ \mathrm{Au} & 11 \\ \mathrm{Hg} & 11 \\ \mathrm{Au} & 79 \\ \mathrm{Au} & 11 \\ \mathrm{Au} & 79 \\ \mathrm{Au} & 10 \\ \mathrm{Au} & 79 \\ \mathrm{Au} & 79\end{array}$


Table 1C. Inventory of metal mines and occurrences associated with the early Mesozoic basins of the Eastern United States listed according to type of locality and size

[In column "Area number," locality is indicated by number: 0 , areas in New Hampshire north of the Hartford basin; 1 , the Hartford basin and vicinity, Massachusetts; 2, the Hartford basin and vicinity, Connecticut; 3, the Newark basin, New Jersey; 4, the Newark basin and vicinity, Pennsylvania; 5, the Gettysburg basin and vicinity, Pennsylvania; 6, the Culpeper basin, Maryland and Virginia; 7, other areas in Virginia; 8, the Davie County basin area, North Carolina; 9 , the Deep River basin area, North Carolina. In the "Production" column, an l, $m, n$, or $u$ indicates ore production or reserves greater than 100,000 tons, between 1,000 and 100,000 tons, less than 1,000 tons, or unknown, respectively. In the "References" column, the number of the reference citation is listed in table $1 E$ ]

\begin{tabular}{llllll}
\hline $\begin{array}{l}\text { Locality } \\
\text { number }\end{array}$ & Name & State & $\begin{array}{c}\text { Area Locality Produc- } \\
\text { No. type }\end{array}$ & $\begin{array}{c}\text { Deposit } \\
\text { type }\end{array}$ & $\frac{\text { Metal associations }}{\text { Principal Accessory }}$ References \\
\hline
\end{tabular}

I. Mine

A. Ore production greater than 100,000 tons

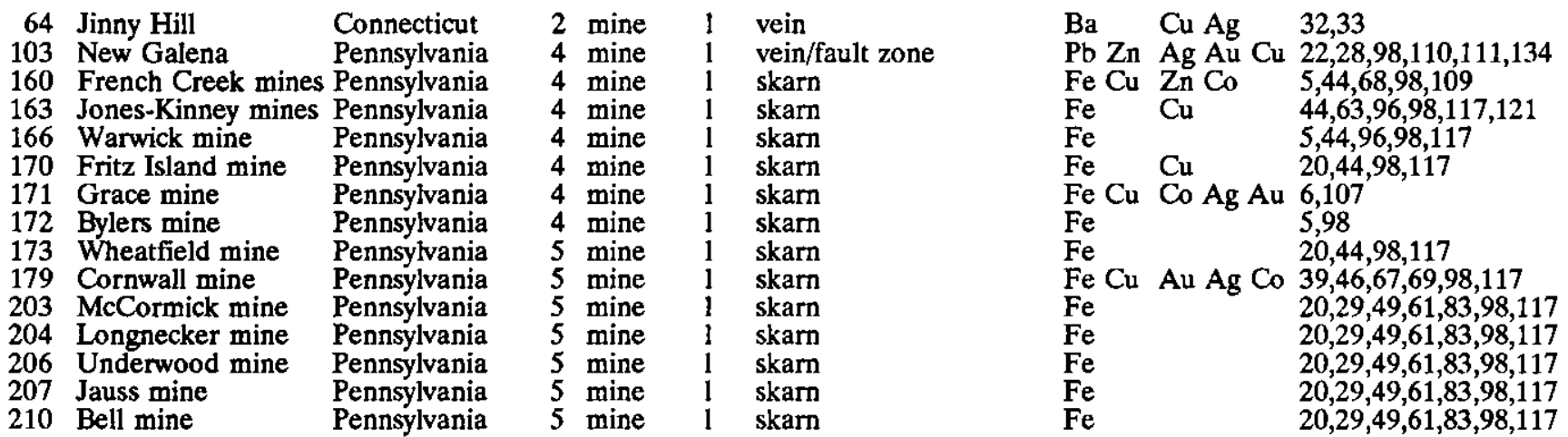

B. Ore production greater than 1,000 and less than 100,000 tons

3 Stoddard mine 1 New Hampshire 0 mine

4 Stoddard mine 2 New Hampshire 0 mine

5 Springer mine

7 Pierce mine

17 Leverett

25 Hatfield lead

New Hampshire 0 mine

New Hampshire 0 mine

Massachusetts 1 mine

Massachusetts 1 mine

6 Unnamed $\mathrm{Pb}-\mathrm{Ba} 2$ Massachusetts 1 mine

27 Unnamed $\mathrm{Pb}-\mathrm{Ba} 1$

28 Manhan Lead 1

29 Manhan Lead 2

30 Manhan Lead 3

31 Manhan Lead 4

32 Manhan Lead 5

39 New-gate Prison

40 Higley copper

42 Bristol copper

67 Tallman's mine

73 Glen Ridge mine

75 Dod mine

76 Schuyler mine

79 Stony Brook

87 Hopewell barite

124 Perkiomen mine

125 Whim mine

126 Ecton mine

127 Wetherill mine

129 Jug Hollow mine

142 Wheatley mine

143 Chester Co. mine

144 Montgomery Co.

$145 \mathrm{SW}$. Chester mine

146 Brookdale mine

147 Phoenix mine

152 Brower mine

165 Leighton mine

169 Raudenbush mine

174 Ruth mine

175 Doner mine

178 Carper mine

180 Hummelstown

Massachusetts

Massachusetts

Massachusetts

Massachusetts

Massachusetts

Massachusetts

Connecticut

Connecticut

Connecticut

Connecticut

New Jersey

New Jersey

New Jersey

New Jersey

New Jersey

Pennsylvania

Pennsylvania

Pennsylvania

Pennsylvania

Pennsylvania

Pennsylvania

Pennsylvania

Pennsylvania

Pennsylvania

Pennsylvania

Pennsylvania

Pennsylvania

Pennsylvania

Pennsylvania

Pennsylvania

Pennsylvania

Pennsylvania

Pennsylvania

197 Minebank School 1 Pennsylvania

198 Minebank School 2 Pennsylvania
1 mine

1 mine

1 mine

1 mine

1 mine

1 mine

2 mine

2 mine

2 mine

2 mine

3 mine

3 mine

3 mine

3 mine

3 mine

4 mine

4 mine

4 mine

4 mine

4 mine

4 mine

4 mine

4 mine

4 mine

4 mine

4 mine

4 mine

4 mine

4 mine

5 mine

5 mine

5 mine

5 mine

5 mine

5 mine

\begin{tabular}{|c|c|c|c|c|}
\hline $\mathbf{m}$ & vein & $\mathbf{F}$ & $\mathrm{Ba} \mathrm{Pb}$ & 3 \\
\hline In & $\begin{array}{l}\text { vein } \\
\text { yein }\end{array}$ & $\mathbf{F}$ & $\mathrm{Ba} \mathrm{Pb}$ & 3 \\
\hline $\mathrm{n}$ & vein & $\mathbf{F}$ & $\mathrm{Ba} \mathrm{Pb}$ & 3 \\
\hline & vein & $\mathrm{Pb}$ & $\mathrm{Ba} \mathrm{Cu}$ & $25,43,53,57,64,85$ \\
\hline & vein & $\mathrm{Pb}$ & $\mathrm{Ba} \mathrm{Cu}$ & $25,43,54,57,133$ \\
\hline & vein & $\mathrm{Pb}$ & $\mathrm{Ba}$ & $25,55,57$ \\
\hline & vein & $\mathrm{Pb}$ & $\mathrm{Ba}$ & $25,55,57$ \\
\hline & vein & $\mathrm{Pb} \mathrm{Ba}$ & $\mathrm{Ag} \mathrm{Zn} \mathrm{Cu}$ & 25,55 \\
\hline & vein & $\mathrm{Pb} \mathrm{Ba}$ & $\mathrm{Ag} \mathrm{ZnCu}$ & 25,55 \\
\hline & vein & $\mathrm{Pb} \mathrm{Ba}$ & $\mathrm{Ag} \mathrm{Zn} \mathrm{Cu}$ & 25,55 \\
\hline & vein & $\mathrm{Pb} \mathrm{Ba}$ & $\mathrm{Ag} \mathrm{ZnCu}$ & 25,55 \\
\hline & vein & $\mathrm{Pb} \mathrm{Ba}$ & $\mathrm{Ag} \mathrm{ZnCu}$ & 25,55 \\
\hline & stratabound/replacement & $\mathrm{Cu}$ & $\operatorname{Ag} \mathrm{U}$ & $47,88,89,101,128,130$ \\
\hline & $\begin{array}{l}\text { Stratabound/replace } \\
\text { vein/replacement }\end{array}$ & $\mathrm{Cu}$ & $A g U$ & $\begin{array}{l}47,101,130 \\
765101,105\end{array}$ \\
\hline & vein/replacement & $\mathrm{Cu}$ & $\mathrm{Ba} \mathrm{Ag}$ & $33,89,104$ \\
\hline & stratabound/replacement & $\mathrm{Cu}$ & & $73,84,136$ \\
\hline & stratabound/replacement & $\mathrm{Cu}$ & & 136 \\
\hline & stratabound/replacement & $\mathrm{Cu}$ & $\mathrm{Ag}$ & $16,70,84,136$ \\
\hline & stratabound/replacement & $\mathrm{Cu}$ & & 136 \\
\hline & vein & $\mathrm{Ba}$ & & 15,21 \\
\hline $\mathbf{n}$ & vein & $\mathrm{Pb} \mathrm{Cu}$ & $\mathrm{Zn}$ & $22,98,111,135$ \\
\hline & vein/fault zone & $\mathrm{Pb} \mathrm{Cu}$ & $\mathrm{Zn} \mathrm{Ag}$ & $22,98,111,135$ \\
\hline n & vein & $\mathrm{Pb}$ & $\mathrm{Zn} \mathrm{Ag}$ & $22,98,111,135$ \\
\hline & vein & $\mathrm{Pb}$ & $\mathrm{Cu} \mathrm{Zn}$ & $22,98,111,135$ \\
\hline & vein & $\mathrm{Ba} \mathrm{Zn}$ & $\mathrm{Cu} \mathrm{Pb}$ & $44,77,96,111$ \\
\hline & vein & $\mathrm{Pb} \mathrm{Zn}$ & $\mathrm{Cu} \mathrm{Ag} \mathrm{Mo}$ & $12,50,59,95,108,111$ \\
\hline & vein & $\mathrm{Pb} \mathrm{Zn}$ & $\mathrm{Cu} \mathrm{Ag}$ & $5,38,77,91,111,126$ \\
\hline & vein & $\mathrm{Zn} \mathrm{Pb}$ & $\mathrm{Cu} \mathrm{Ag}$ & $78,91,96,98,111,126$ \\
\hline & vein & $\mathrm{Pb} \mathrm{Zn}$ & $\mathrm{Cu} \mathrm{Ag}$ & $5,38,77,91,111,126$ \\
\hline & vein & $\mathrm{Zn} \mathrm{Pb}$ & $\mathrm{Cu} \mathrm{Ag}$ & $12,50,59,96,108,111$ \\
\hline & vein & $\mathrm{Zn} \mathrm{Pb}$ & $\mathrm{Ag} \mathrm{Cu}$ & $12,50,59,96,108,111$ \\
\hline & skarn & $\mathrm{Fe}$ & & 98,117 \\
\hline $\mathrm{n}$ & skarn/replacement & $\mathrm{Fe}$ & & $5,96,98$ \\
\hline & skam & $\mathrm{Fe}$ & & $20,98,117$ \\
\hline & skam & $\mathbf{F e}$ & & $20,44,98,117$ \\
\hline & sk & $\mathrm{Fe}$ & & $69,98,117$ \\
\hline & hornfels/replacement & $\mathrm{Fe}$ & & $40,98,117$ \\
\hline & skarn & Fe & & 98,117 \\
\hline & skarn & $\mathrm{Fe}$ & & $29,98,117$ \\
\hline & n & $\mathbf{F}$ & & 8,117 \\
\hline
\end{tabular}


Table 1C. Inventory of metal mines and occurrences associated with the early Mesozoic basins of the Eastern United States listed according to type of locality and size-Continued

[In column "Area number," locality is indicated by number: 0, areas in New Hampshire north of the Hartford basin; 1, the Hartford basin and vicinity, Massachusetts; 2, the Hartford basin and vicinity, Connecticut; 3, the Newark basin, New Jersey; 4, the Newark basin and vicinity, Pennsylvania; 5, the Gettysburg basin and vicinity, Pennsylvania; 6, the Culpeper basin, Maryland and Virginia; 7, other areas in Virginia; 8, the Davie County basin area, North Carolina; 9, the Deep River basin area, North Carolina. In the "Production" column, an l, $\mathrm{m}, \mathrm{n}$, or $u$ indicates ore production or reserves greater than 100,000 tons, between 1,000 and 100,000 tons, less than 1,000 tons, or unknown, respectively. In the "References" column, the number of the reference citation is listed in table $1 E]$

\begin{tabular}{llllll}
\hline $\begin{array}{l}\text { Locality } \\
\text { number }\end{array}$ & Name & State & $\begin{array}{c}\text { Area Locality Produc- } \\
\text { No. type }\end{array}$ & $\begin{array}{c}\text { Deposit } \\
\text { typen }\end{array}$ & $\frac{\text { Metal associations }}{\text { Principal Accessory }}$ References \\
\hline
\end{tabular}

I. Mine-Continued

B. Ore production greater than 1,000 and less than 100,000 tons-Continued

\begin{tabular}{|c|c|c|c|c|c|c|}
\hline $\begin{array}{ll}201 & \text { Grantham mines } \\
205 & \text { King mine } \\
208 & \text { Altland mine } \\
209 & \text { Smyser mine } \\
211 & \text { Logan mine } \\
212 & \text { Cox mine } \\
213 & \text { Grove mine } \\
219 & \text { Lichte mine } \\
254 & \text { St. Stephens } \\
256 & \text { Cedar Run }\end{array}$ & $\begin{array}{l}\text { Pennsylvania } \\
\text { Pennsylvania } \\
\text { Pennsylvania } \\
\text { Pennsylvania } \\
\text { Pennsylvania } \\
\text { Pennsylvania } \\
\text { Pennsylvania } \\
\text { Pennsylvania } \\
\text { Virginia } \\
\text { Virginia }\end{array}$ & $\begin{array}{ll}5 & \text { mine } \\
5 & \text { mine } \\
5 & \text { mine } \\
5 & \text { mine } \\
5 & \text { mine } \\
5 & \text { mine } \\
5 & \text { mine } \\
5 & \text { mine } \\
6 & \text { mine } \\
6 & \text { mine }\end{array}$ & $\begin{array}{l}\mathrm{m} \\
\mathrm{m} \\
\mathrm{m} \\
\mathrm{m} \\
\mathrm{m} \\
\mathrm{m} \\
\mathrm{m} \\
\mathrm{m} \\
\mathrm{m} \\
\mathrm{m}\end{array}$ & $\begin{array}{l}\text { skarn } \\
\text { skarn } \\
\text { skarn } \\
\text { skarn } \\
\text { skarn } \\
\text { skarn } \\
\text { skarn } \\
\text { skarn } \\
\text { vein } \\
\text { vein/fault zone }\end{array}$ & $\begin{array}{l}\mathrm{Fe} \\
\mathrm{Fe} \\
\mathrm{Fe} \\
\mathrm{Fe} \\
\mathrm{Fe} \\
\mathrm{Fe} \\
\mathrm{Fe} \\
\mathrm{Fe} \\
\mathrm{Ba} \\
\mathrm{Ba}\end{array}$ & $\begin{array}{l}20,29,98,117 \\
20,29,49,61,83,98,117 \\
20,29,49,61,83,98,117 \\
20,29,49,61,83,98,117 \\
20,29,49,61,83,98,117 \\
20,29,49,61,83,98,117 \\
20,29,49,61,83,98,117 \\
29,98 \\
11,23,36,71,75,93 \\
11,23,36,71,75\end{array}$ \\
\hline
\end{tabular}

C. Ore production known or assumed to be less than 1,000 tons

1 E. Surry Mtn. mine New Hampshire 0 mine

2 Will Wise mine New Hampshire 0 mine

10 Winchester mine

19 Whately-Wm. 1

20 Whately-Wm. 2

24 Whately-Wm. 3

33 Southampton

34 New mine vein

38 Simsbury mine

New Hampshire 0 mine

Massachusetts 1 mine

Massachusetts 1 mine

Massachusetts 1 mine

Massachusetts 1 mine

Massachusetts 1 mine

Connecticut 2 mine

50 Mattabesset River

51 Berlin Moores Mill

54 Middletown lead

57 New Haven mine

58 Cheshire mine 3

59 Cheshire mine 2

61 Booth \& Hinman

62 Cheshire mine 1

63 copper mine

65 Cross Rock

72 Totowa mine

74 Wigwam Brook

78 Hoffman

80 Bridgewater

81 Chimney Rock

82 Menlo Park mine

83 New Brunswick

84 Flemington

86 Griggstown

91 Solebury

92 Buckmanville

97 Tettemer's mine

108 Leithsville mine

115 Kober's mine

116 Karl's mine

117 Young's mine

131 Fegley mine

137 Pennsylvania mine

140 Morris copper

141 Charlestown mine

149 Pennypacker mine

150 Boyertown mine

154 Esterly mine

159 Unnamed Fe mine

164 Hopewell mine

167 Steels mine

182 Lecron's

190 Harman mine
Connecticut

Connecticut

Connecticut

Connecticut

Connecticut

Connecticut

Connecticut

Connecticut

Connecticut

Connecticut

New Jersey

New Jersey

New Jersey

New Jersey

New Jersey

New Jersey

New Jersey

New Jersey

New Jersey

Pennsylvania

Pennsylvania

Pennsylvania

Pennsylvania

Pennsylvania

Pennsylvania

Pennsylvania

Pennsylvania

Pennsylvania

Pennsylvania

Pennsylvania

Pennsylvania

Pennsylvania

Pennsylvania

Pennsylvania

Pennsylvania

Pennsylvania

Pennsylvania

Pennsylvania
2 mine

2 mine

2 mine

2 mine

2 mine

2 mine

2 mine

2 mine

2 mine

2 mine

2 mine

3 mine

3 mine

3 mine

3 mine

3 mine

3 mine

3 mine

3 mine

4 mine

4 mine

4 mine

4 mine

4 mine

4 mine

4 mine

4 mine

4 mine

4 mine

4 mine

4 mine

4 mine

4 mine

4 mine

4 mine

4 mine

5 mine

5 mine

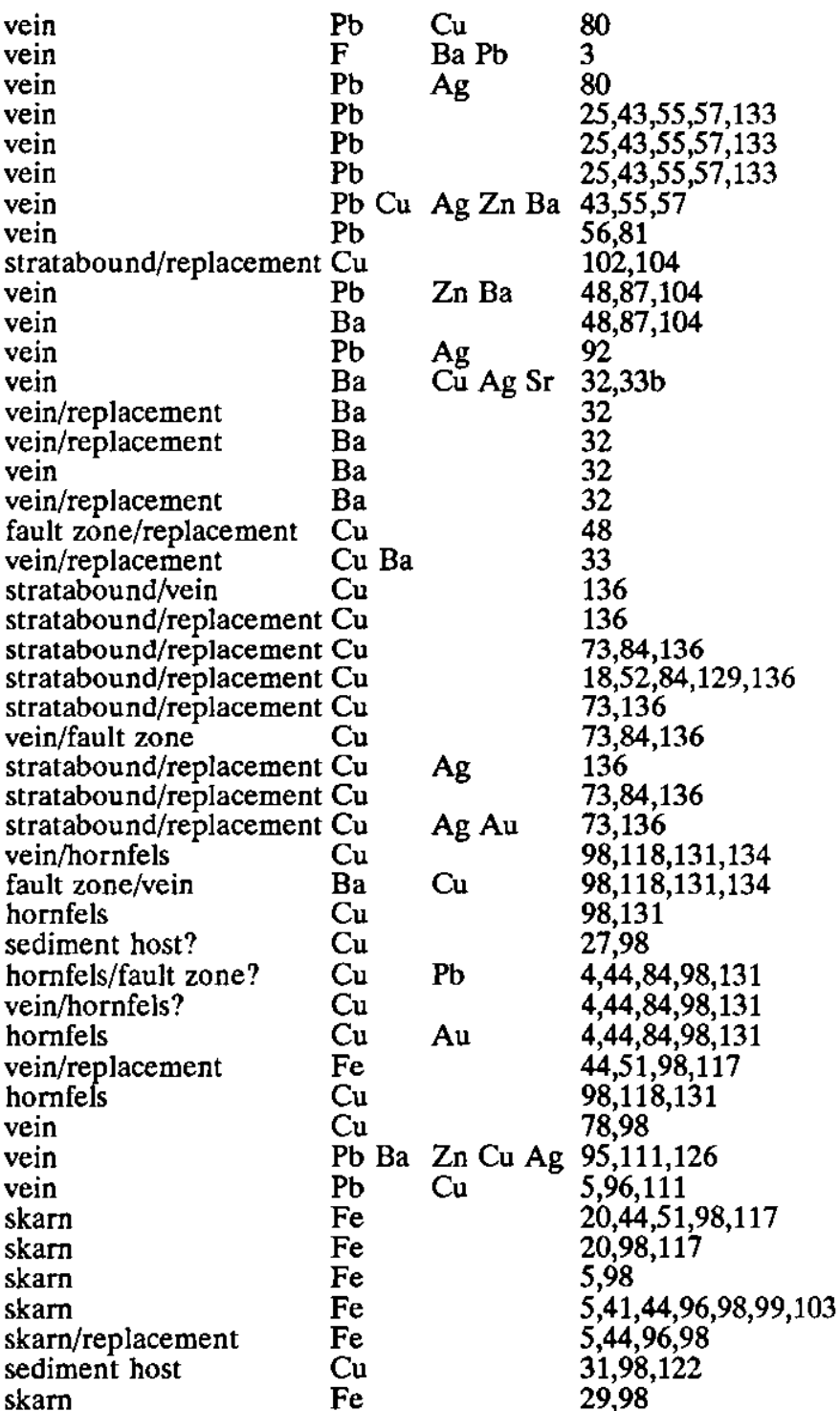


Table 1C. Inventory of metal mines and occurrences associated with the early Mesozoic basins of the Eastern United States listed according to type of locality and size-Continued

[In column "Area number," locality is indicated by number: 0 , areas in New Hampshire north of the Hartford basin; 1, the Hartford basin and vicinity, Massachusetts; 2, the Hartford basin and vicinity, Connecticut; 3, the Newark basin, New Jersey; 4, the Newark basin and vicinity, Pennsylvania; 5, the Gettysburg basin and vicinity, Pennsylvania; 6, the Culpeper basin, Maryland and Virginia; 7, other areas in Virginia; 8, the Davie County basin area, North Carolina; 9 , the Deep River basin area, North Carolina. In the "Production" column, an l, $m, n$, or $u$ indicates ore production or reserves greater than 100,000 tons, between 1,000 and 100,000 tons, less than 1,000 tons, or unknown, respectively. In the "References" column, the number of the reference citation is listed in table $1 E$ ]

\begin{tabular}{|c|c|c|c|c|}
\hline $\begin{array}{l}\text { Locality } \\
\text { number }\end{array}$ & Name & State & $\begin{array}{l}\text { Area Locality } \\
\text { No. type }\end{array}$ & $\begin{array}{l}\text { Produc- } \\
\text { tion }\end{array}$ \\
\hline
\end{tabular}

I. Mine-Continued

C. Ore production known or assumed to be less than 1,000 tons-Continued

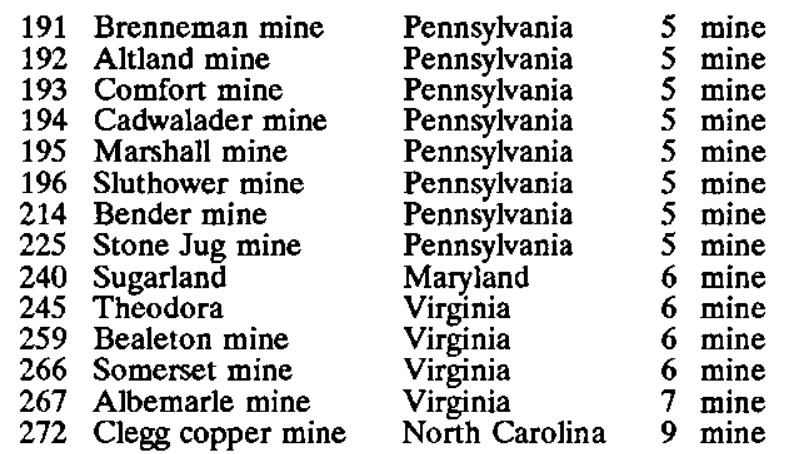

\section{Prospect}

6 fluorite prospect

55 copper prospect

60 copper prospect

66 Gaylord

68 copper prospect

69 Copper Valley

70 copper prospect

71 silver prospect

85 Monmouth Junction

88 Woosamonsa pro

94 W. Buckmanville

101 Keller's Church

109 Coopersburg

114 Hendricks Station

118 Schwencksville

123 Shannonville

128 Port Kennedy

130 Congo 3

132 Congo 2

133 Congo 1

134 Brendlinger mine

138 Saratoga

148 Pethericks Penn

151 Stonersville

158 Bleims mine

161 Knauertown

162 Pine Swamp

176 Mt. Pleasant

177 Rexmont Reservoir

185 Mt. Pleasant 2

186 Mt. Pleasant 1

187 Wellsville 2

188 Wellsville 1

199 Roler

200 Smith prospect

202 Dillsburg North

215 Franklintown 1

216 Franklintown 2

217 Franklintown 3

218 Franklintown 4

221 Center Mills 1

222 Center Mills 2
New Hampshire

Connecticut

Connecticut

Connecticut

Connecticut

Connecticut

Connecticut

Connecticut

New Jersey

Pennsylvania

Pennsylvania

Pennsylvania

Pennsylvania

Pennsylvania

Pennsylvania

Pennsylvania

Pennsylvania

Pennsylvania

Pennsylvania

Pennsylvania

Pennsylvania

Pennsylvania

Pennsylvania

Pennsylvania

Pennsylvania

Pennsylvania

Pennsylvania

Pennsylvania

Pennsylvania

Pennsylvania

Pennsylvania

Pennsylvania

Pennsylvania

Pennsylvania

Pennsylvania

Pennsylvania

Pennsylvania

Pennsylvania

Pennsylvania

Pennsylvania

Pennsylvania
0 prospect

2 prospect

2 prospect

2 prospect

2 prospect

2 prospect

2 prospect

2 prospect

3 prospect

3 prospect

4 prospect

4 prospect

4 prospect

4 prospect

4 prospect

4 prospect

4 prospect

4 prospect

4 prospect

4 prospect

4 prospect

4 prospect

4 prospect

4 prospect

4 prospect

4 prospect

4 prospect

4 prospect

5 prospect

5 prospect

5 prospect

5 prospect

5 prospect

5 prospect

5 prospect

5 prospect

5 prospect

5 prospect

5 prospect

5 prospect

5 prospect

5 prospect

5 prospect

skarn
skam
skarn
skarn
skarn
skarn
skarn
hornfels/replacement
stratabound/replacement
hornfels
hornfels/replacement
stratabound/replacement
vein
vein

$\mathrm{Fe}$

29,98

29,98

$\mathrm{Fe} \quad 29,98$

$\mathrm{Fe} \quad 29,98$

$\mathrm{Fe} \quad 29,98$

$\mathrm{Fe} \quad 29,98$

$\mathrm{Fe} \quad 29,68,98,117$

$\mathrm{Cu} \quad \mathrm{Au}$ Ag Mo 113

$11,34,36,71$

$11,36,60,75$

75,93

$75,93,97,130$

$42,82,127$

14 fault zone/replacement

vein/replacement

hornfels

vein/replacement

hornfels?/replacement

sediment host

hornfels/vein

hornfels/replacement

vein

vein

sediment host

hornfels

hornfels

hornfels?

vein

vein

diabase host/vein

diabase host/vein

diabase host/vein

hornfels?

sediment host

vein

skarn

sediment host

skarn

skarn/replacement

skarn

skarn

skarn

skarn

skarn

skarn

skarn

skarn

skarn

skarn

skarn

skarn

skarn

skarn

skarn
$\begin{array}{ll}\mathrm{F} & 3 \\ \mathrm{Cu} & 123 \\ \mathrm{Cu} & 33 \mathrm{~b}\end{array}$

$\begin{array}{ll}\mathrm{F} & 3 \\ \mathrm{Cu} & 123 \\ \mathrm{Cu} & 33 \mathrm{~b}\end{array}$

$\mathrm{Cu} \quad \mathrm{Ba} \mathrm{Ag} \quad 32,33,104$

$\mathrm{Cu} \quad \mathrm{Ba} \mathrm{Ag} \quad 33$

$\mathrm{Cu} \quad \mathrm{Ag} \quad 32,33$

$\mathrm{Cu} \quad 32,33$

Ag 62

$\mathrm{Cu} \quad 76$

$\mathrm{Cu}$

$\mathrm{Cu} \mathrm{Ba}$

$\mathrm{Ba} \mathrm{Cu}$

$\mathrm{Cu}$

$\mathrm{Cu}$

$\mathrm{Cu}$

$\mathrm{Cu}$

$\mathrm{Cu}$

Cu

$\mathrm{Cu}$

$\mathrm{Cu}$

$\mathrm{Cu}$

$\mathrm{Cu}$

$\mathrm{Cu}$

$\mathrm{Fe}$

$\mathrm{Fe}$

$\mathrm{Fe}$

$\mathrm{Fe}$

$\mathrm{Fe}$

$\mathrm{Fe}$

$\mathrm{Fe}$

$\mathrm{Fe}$

$\mathrm{Fe}$

$\mathrm{Fe}$

$\mathrm{Fe}$

$\mathrm{Fe}$

$\mathrm{Fe}$

$\mathrm{Fe}$

$\mathrm{Fe}$

$\mathrm{Fe}$

$\mathrm{Fe}$

$\mathrm{Fe}$

$\mathrm{Fe}$
$66,73 \mathrm{~b}, 136$

$98,131,134$

98,131

98,131

98

$44,98,131$

98

$44,78,98$

$44,78,98$

$98,117,131$

$98,117,131$

$98,117,131$

$84,98,131$

5,98

78,98

98,117

44,98

5,98

$37,98,110$

98,117

98,117

$29,98,122$

$29,98,122$

$29,98,122$

$29,98,122$

98,122

29,98

98,122

$29,98,117$

$29,98,117$

$29,98,117$

$29,98,117$

$98,119,120$

$98,119,120$ 
Table 1C. Inventory of metal mines and occurrences associated with the early Mesozoic basins of the Eastern United States listed according to type of locality and size-Continued

[In column "Area number," locality is indicated by number: 0 , areas in New Hampshire north of the Hartford basin; 1, the Hartford basin and vicinity, Massachusetts; 2, the Hartford basin and vicinity, Connecticut; 3, the Newark basin, New Jersey; 4, the Newark basin and vicinity, Pennsylvania; 5, the Gettysburg basin and vicinity, Pennsylvania; 6, the Culpeper basin, Maryland and Virginia; 7, other areas in Virginia; 8, the Davie County basin area, North Carolina; 9 , the Deep River basin area, North Carolina. In the "Production" column, an l, $m$, $n$, or $u$ indicates ore production or reserves greater than 100,000 tons, between 1,000 and 100,000 tons, less than 1,000 tons, or unknown, respectively. In the "References" column, the number of the reference citation is listed in table $1 E$ ]

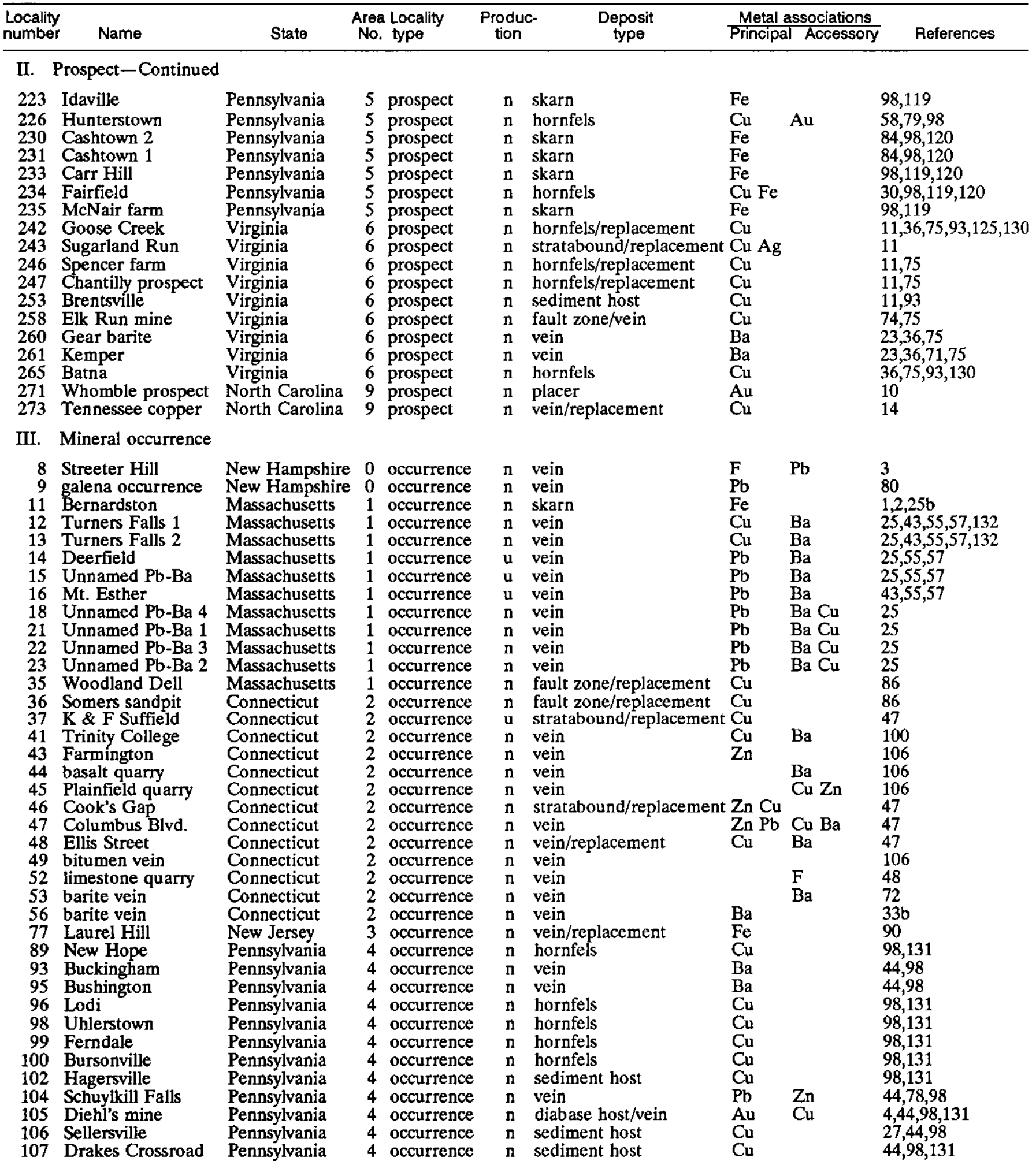


Table 1C. Inventory of metal mines and occurrences associated with the early Mesozoic basins of the Eastern United States listed according to type of locality and size-Continued

[In column "Area number," locality is indicated by number: 0, areas in New Hampshire north of the Hartford basin; 1, the Hartford basin and vicinity, Massachusetts; 2, the Hartford basin and vicinity, Connecticut; 3, the Newark basin, New Jersey; 4, the Newark basin and vicinity, Pennsylvania; 5, the Gettysburg basin and vicinity, Pennsylvania; 6, the Culpeper basin, Maryland and Virginia; 7, other areas in Virginia; 8, the Davie County basin area, North Carolina; 9, the Deep River basin area, North Carolina. In the "Production" column, an l, $m$, $n$, or $u$ indicates ore production or reserves greater than 100,000 tons, between 1,000 and 100,000 tons, less than 1,000 tons, or unknown, respectively. In the "References" column, the number of the reference citation is listed in table $1 E$ ]

\begin{tabular}{|c|c|c|c|c|c|c|c|}
\hline $\begin{array}{l}\text { Locality } \\
\text { number }\end{array}$ & Name & State & $\begin{array}{l}\text { Area } \\
\text { No. }\end{array}$ & $\begin{array}{l}\text { Locality } \\
\text { type }\end{array}$ & $\begin{array}{l}\text { Produc- } \\
\text { tion }\end{array}$ & $\begin{array}{l}\text { Deposit } \\
\text { type }\end{array}$ & $\frac{\text { Metal associations }}{\text { Principal Accessory References }}$ \\
\hline
\end{tabular}

III. Mineral occurrence-Continued

110 Pennsburg

112 Sumneytown

113 Kibblehouse quarry

119 Lederachsville

120 Graters Ford

121 Collegeville

122 Arcola

135 Layfield

136 Gilbertville

139 Phoenix. Tunnel

153 Snydersville

155 Gickerville

156 Dyer quarry

157 Glasgow

168 South of Reading

181 Glenwood Station

183 Safe Harbor

184 Reesers Summit

189 Rossville roadcut

220 Clapper farm

224 Heidlersburg

227 Gettysburg

228 Bonneauville

229 Teeter's quarry

232 Orrtana

236 Boyds barite

237 Dawsonville 1

238 Dawsonville 2

239 Seneca Creek

241 Waterford gold

244 Sterling

248 Cub Run copper

249 Chantilly

250 Fairfax quarry

251 Bull Run

252 Manassas

255 Calverton

257 Botts barite

262 Mountain Run

263 Stevensburg

264 Culpeper prospect

268 Scottsville barite

269 Dolan property

270 Bell Branch gold

274 Harrisville barite

275 Mangum gold 2

276 Mangum gold 1

\section{Pennsylvania}

Pennsylvania Pennsylvania

Pennsylvania

Pennsylvania

Pennsylvania

Pennsylvania

Pennsylvania

Pennsylvania

Pennsylvania

Pennsylvania

Pennsylvania

Pennsylvania

Pennsylvania

Pennsylvania

Pennsylvania

Pennsylvania

Pennsylvania

Pennsylvania

Pennsylvania

Pennsylvania

Pennsylvania

Pennsylvania

Pennsylvania

Pennsylvania

Pennsylvania

Maryland

Maryland

Maryland

Maryland

Virginia

Virginia

Virginia

Virginia

Virginia

Virginia

Virginia

Virginia

Virginia

Virginia

Virginia

Virginia

Virginia

Virginia

North Carolina

North Carolina

North Carolina

North Carolina

\begin{tabular}{ll}
4 & occurrence \\
4 & occurrence \\
4 & occurrence \\
4 & occurrence \\
4 & occurrence \\
4 & occurrence \\
4 & occurrence \\
4 & occurrence \\
4 & occurrence \\
4 & occurrence \\
4 & occurrence \\
4 & occurrence \\
4 & occurrence \\
4 & occurrence \\
4 & occurrence \\
4 & occurrence \\
5 & occurrence \\
5 & occurrence \\
5 & occurrence \\
5 & occurrence \\
5 & occurrence \\
5 & occurrence \\
5 & occurrence \\
5 & occurrence \\
5 & occurrence \\
5 & occurrence \\
6 & occurrence \\
9 & occurrence \\
6 & occurrence \\
6 & occurrence \\
6 & occurrence \\
6 & occurrence \\
6 & occurrence \\
6 & occurrence \\
6 & occurrence \\
6 & occurrence \\
6 & occurrence \\
6 & occurrence \\
6 & occurrence \\
6 & occurrence \\
6 & occurrence \\
6 & occurrence \\
\hline & occurence \\
\hline &
\end{tabular}

$\begin{array}{ll}\text { n } & \text { sediment host } \\ \text { n } & \text { sediment host } \\ \text { n } & \text { hornfels } \\ \text { n } & \text { hornfels } \\ \text { n } & \text { sediment host } \\ \text { n } & \text { sediment host } \\ \text { n } & \text { sediment host } \\ \text { n } & \text { vein } \\ \text { n } & \text { sediment host } \\ \text { n } & \text { sediment host } \\ \text { n } & \text { vein } \\ \text { n } & \text { hornfels } \\ \text { n } & \text { diabase host/vein } \\ \text { n } & \text { diabase host/vein } \\ \text { n } & \text { sediment host } \\ \text { n } & \text { hornfels } \\ \text { n } & \text { sediment host } \\ \text { n } & \text { vein } \\ \text { n } & \text { hormfels } \\ \text { n } & \text { hornfels } \\ \text { n } & \text { hornfels } \\ \text { n } & \text { hornfels } \\ \text { n } & \text { hornfels } \\ \text { n } & \text { sediment host } \\ \text { n } & \text { hornfels } \\ \text { n } & \text { skarn } \\ \text { n } & \text { vein } \\ \text { n } & \text { placer } \\ \text { n } & \text { placer } \\ \text { n } & \text { placer } \\ \text { n } & \text { placer }\end{array}$

n placer

n placer

n hornfels/replacement

n stratabound/replacement

n diabase host/vein

n placer

n vein

n stratabound/replacement $\mathrm{Zn}$

n vein

n hornfels/replacement

n stratabound/replacement

n hornfels

$n$ vein

n vein/fault zone

n placer

$n$ vein

n placer

n placer

\begin{tabular}{|c|c|c|}
\hline $\mathrm{Cu}$ & & $44,98,131$ \\
\hline $\mathrm{Cu}$ & & 98,131 \\
\hline $\mathrm{Cu}$ & & 44,98 \\
\hline $\mathrm{Cu}$ & Co & 112,116 \\
\hline $\mathrm{Cu}$ & & $44,98,131$ \\
\hline $\mathrm{Cu}$ & & $44,98,131$ \\
\hline $\mathrm{Cu}$ & & $44,98,131$ \\
\hline $\mathrm{Cu}$ & & 44,98 \\
\hline $\mathrm{Cu}$ & & $44,98,131$ \\
\hline $\mathrm{Cu}$ & & $44,98,131$ \\
\hline $\mathrm{Zn}$ & & 44,98 \\
\hline$\overline{\mathrm{Cu}}$ & & $27,44,98$ \\
\hline As Co & & 44,98 \\
\hline $\mathrm{Cu}$ & & $\begin{array}{l}112,114 \\
4498131\end{array}$ \\
\hline $\mathrm{Cu}$ & & 44,98 \\
\hline $\mathrm{Cu}$ & & $9,44,98$ \\
\hline $\mathrm{Zn} \mathrm{Ba}$ & & 8,98 \\
\hline $\mathrm{Cu}$ & & 98,111 \\
\hline $\mathrm{Cu}$ & & 114,115 \\
\hline $\mathrm{Cu} \mathrm{Au}$ & Ag & 114 \\
\hline $\mathrm{Cu}$ & & 98,120 \\
\hline $\mathrm{Cu}$ & & 98,119 \\
\hline $\mathrm{Cu}$ & & 30,98 \\
\hline $\mathrm{Cu}$ & & 68,98 \\
\hline $\mathrm{Fe}$ & & 98,119 \\
\hline $\mathrm{Ba}$ & & 94 \\
\hline $\mathrm{Au}$ & & 11 \\
\hline $\mathrm{Au}$ & & 11 \\
\hline Hg & & 11 \\
\hline $\mathrm{Au}$ & & 79 \\
\hline $\mathrm{Cu}$ & & 11 \\
\hline $\mathrm{Cu}$ & & 24 \\
\hline $\mathrm{Cu}$ & & 11,17 \\
\hline $\mathrm{Cu}$ & & 19,75 \\
\hline $\mathrm{Au}$ & & 11 \\
\hline $\mathrm{Ba}$ & & 75,93 \\
\hline $\mathrm{Zn}$ & & 45 \\
\hline $\mathrm{Ba}$ & & 23,75 \\
\hline $\mathrm{Cu}$ & $\mathrm{Fe} \mathrm{U}$ & 35 \\
\hline $\mathrm{ZnCu}$ & & 11 \\
\hline $\mathrm{Cu}$ & $\mathrm{Fe}$ & 75,93 \\
\hline $\mathrm{Ba}$ & & 124 \\
\hline $\mathrm{Cu}$ & & 26,75 \\
\hline $\mathrm{Au}$ & & 79 \\
\hline $\mathrm{Ba}$ & & 13 \\
\hline $\mathrm{Au}$ & & 79 \\
\hline $\mathrm{Au}$ & & 79 \\
\hline
\end{tabular}


Table 1D. Inventory of metal mines and occurrences associated with the early Mesozoic basins of the Eastern United States listed according to metal association

In column "Area number," locality is indicated by number: 0, areas in New Hampshire north of the Hartford basin; 1, the Hartford basin and vicinity, Massachusetts; 2, the Hartford basin and vicinity, Connecticut; 3, the Newark basin, New Jersey; 4, the Newark basin and vicinity, Pennsylvania; 5, the Gettysburg basin and vicinity, Pennsylvania; 6, the Culpeper basin, Maryland and Virginia; 7, other areas in Virginia; 8, the Davie County basin area, North Carolina; 9, the Deep River basin area, North Carolina. In the "Production" column, locality is indicated by a two-letter code: the first code letter, an $\mathrm{m}, \mathrm{p}$, or $\mathrm{o}$, indicates that the locality is a mine, prospect, or mineral occurrence, respectively; the second code letter, an l, m, n, or $\mathrm{u}$, indicates ore production or reserves greater than 100,000 tons, between 1,000 and 100,000 tons, less than 1,000 tons, or unknown, respectively. In the column "Deposit type," deposits are indicated by number: 1, a skam deposit; 2 , a hornfels deposit; 3 , a diabase-hosted vein or segregation deposit; 4, a sediment-hosted stratabound disseminated or replacement deposit; 5, a vein deposit; 6 , a placer deposit. In the "References" column, the number of the reference citation is listed in table $1 E$ ]

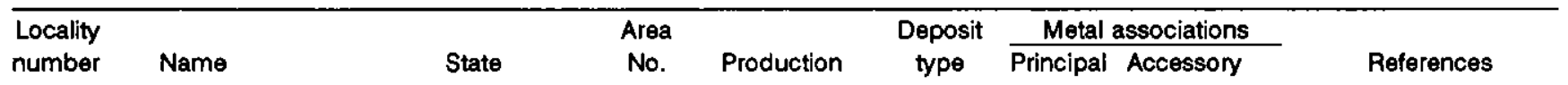

Ag-SILVER-principal metal

$\begin{array}{rll}71 & \text { silver prospect } & \text { Connecticut } \\ 243 & \text { Sugarland Run } & \text { Virginia }\end{array}$

Ag-SILVER - accessory metal

10 Winchester mine

28 Manhan Lead 1

29 Manhan Lead 2

30 Manhan Lead 3

31 Manhan Lead 4

32 Manhan Lead 5

33 Southampton

39 New-gate Prison

42 Bristol copper

54 Middletown lead

57 New Haven mine

64 Jinny Hill

66 Gaylord

67 Tallman's mine

68 copper prospect

69 Copper Valley

76 Schuyler mine

83 New Brunswick

86 Griggstown

103 New Galena

125 Whim mine

126 Ecton mine

141 Charlestown mine

142 Wheatley mine

143 Chester Co. mine

144 Montgomery Co.

145 SW. Chester mine

146 Brookdale mine

147 Phoenix mine

171 Grace mine

179 Cornwall mine

220 Clapper farm

225 Stone Jug mine

267 Albemarle mine

Connecticut

Connecticut

Connecticut

Connecticut

Connecticut

Connecticut

Connecticut

Connecticut

New Jersey

New Jersey

New Jersey

Pennsylvania

Pennsylvania

Pennsylvania

Pennsylvania

Pennsylvania

Pennsylvania

Pennsylvania

Pennsylvania

Pennsylvania

Pennsylvania

Pennsylvania

Pennsylvania

Pennsylvania

Pennsylvania

Virginia
New Hampshire

Massachusetts

Massachusetts

Massachusetts

Massachusetts

Massachusetts

Massachusetts

Connecticut

$\mathrm{Au}-\mathrm{GOLD}$ - principal metal

105 Diehl's mine

220 Clapper farm

237 Dawsonville 1

238 Dawsonville 2

241 Waterford gold

251 Bull Run

270 Bell Branch gold

271 Whomble prospect

275 Mangum gold 2

276 Mangum gold 1
Pennsylvania

Pennsylvania

Maryland

Maryland

Virginia

Virginia

North Carolina

North Carolina

North Carolina

North Carolina

$\begin{array}{ll}2 & \text { p n } \\ 6 & \text { p n }\end{array}$

$\mathrm{p} n$
$\mathrm{p} n$

$\mathrm{m} n$

$\mathrm{m} \mathrm{m}$

$\mathrm{m} \mathrm{m}$

$\mathrm{m} m$

$\mathrm{m}$ m

$\mathrm{m}$ m

$\mathrm{m} \mathrm{n}$

$\mathrm{m} \mathrm{m}$

$\mathrm{m} \mathrm{m}$

m n

$\mathrm{m} n$

m 1

$\mathrm{p} n$

m m

$\mathrm{p} n$

p n

$\mathrm{m} \mathrm{m}$

$\mathrm{m} n$

$\mathrm{m} n$

m 1

$\mathrm{m} \mathrm{m}$

$\mathrm{m} \mathrm{m}$

$\mathrm{m} \mathbf{n}$

$\mathrm{m} \mathrm{m}$

m m

m m

$\mathrm{m} \mathrm{m}$

$\mathrm{m}$

$\mathrm{m} \mathrm{m}$

$\mathrm{m} \mathrm{m}$

m 1

on

m n

$\mathrm{m} u$

$\mathrm{Au}$-GOLD_accessory metal

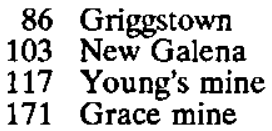

town

117 Young's mine

171 Grace mine
New Jersey

Pennsylvania

Pennsylvania

Pennsylvania on

o n

on

o $n$

on

on

on

p n

on

o $n$

$\mathrm{m} \mathrm{n}$

$\mathrm{m} 1$

m $n$

$\mathrm{m} \mathrm{m}$
Ag

$\mathrm{Cu} \mathrm{Ag}$

$\mathrm{Pb}$

$\mathrm{Pb} \mathrm{Ba}$

$\mathrm{Pb} \mathrm{Ba}$

$\mathrm{Pb} \mathrm{Ba}$

$\mathrm{Pb} \mathrm{Ba}$

$\mathrm{Pb} \mathrm{Ba}$

$\mathrm{Pb} \mathrm{Cu}$

$\mathrm{Cu}$

$\mathrm{Cu}$

$\mathrm{Pb}$

$\mathrm{Pb}$

$\mathrm{Ba}$

$\mathrm{Cu}$

$\mathrm{Cu}$

$\mathrm{Cu}$

$\mathrm{Cu}$

$\mathrm{Cu}$

$\mathrm{Cu}$

$\mathrm{Cu}$

$\mathrm{Pb} \mathrm{Zn}$

$\mathrm{Pb} \mathrm{Cu}$

$\mathrm{Pb}$

$\mathrm{Pb} \mathrm{Ba}$

$\mathrm{Pb} \mathrm{Zn}$

$\mathrm{Pb} \mathrm{Zn}$

$\mathrm{Zn} \mathrm{Pb}$

$\mathrm{Pb} \mathrm{Zn}$

$\mathrm{Zn} \mathrm{Pb}$

$\mathrm{Zn} \mathrm{Pb}$

$\mathrm{Fe} \mathrm{Cu}$

$\mathrm{Fe} \mathrm{Cu}$

$\mathrm{Cu} \mathrm{Au}$

$\mathrm{Cu}$

$\mathrm{Zn} \mathrm{Pb}$

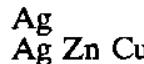

$\mathrm{Ag} \mathrm{Zn} \mathrm{Cu}$

Ag $\mathrm{Zn} \mathrm{Cu}$

Ag $\mathrm{Zn} \mathrm{Cu}$

$\mathrm{Ag} \mathrm{Zn} \mathrm{Cu}$

$\mathrm{Ag} \mathrm{Zn} \mathrm{Ba}$

$\mathrm{Ag} \mathrm{U}$

Ag U

$\mathrm{Ag}$

$\mathrm{Cu} \mathrm{Ag} \mathrm{Sr}$

$\mathrm{Cu} \mathrm{Ag}$

$\mathrm{Ba} \mathrm{Ag}$

$\mathrm{Ba} \mathrm{Ag}$

$\mathrm{Ba} \mathrm{Ag}$

$\mathrm{Ag}$

$\mathrm{Ag}$

$\mathrm{Ag}$

$\mathrm{Ag} \mathrm{Au}$

$\mathrm{Ag} \mathrm{Au} \mathrm{Cu}$

$\mathrm{Zn} \mathrm{Ag}$

$\mathrm{Zn} \mathrm{Ag}$

$\mathrm{Zn} \mathrm{Cu} \mathrm{Ag}$

$\mathrm{Cu} \mathrm{Ag} \mathrm{Mo}$

$\mathrm{Cu} \mathrm{Ag}$

$\mathrm{Cu}$ Ag

$\mathrm{Cu} \mathrm{Ag}$

$\mathrm{Cu} \mathrm{Ag}$

$\mathrm{Ag} \mathrm{Cu}$

$\mathrm{Co} \mathrm{Ag} \mathrm{Au}$

$\mathrm{Au} \mathrm{Ag} \mathrm{Co}$

$\mathrm{Ag}$

Au Ag Mo

$\mathrm{Ag}$

$\begin{array}{ll}\mathrm{Au} & \mathrm{Cu} \\ \mathrm{Cu} & \mathrm{Au}\end{array}$

$\mathrm{Au}$

$\mathrm{Au}$

$\mathrm{Au}$

Au

$\mathrm{Au}$

$\mathrm{Au}$

$\mathrm{Au}$

$\mathrm{Au}$

Ag 11

114

11

79

11

10

79

79

62
11

80

92

33

136

25,55

25,55

25,55

25,55

25,55

$43,55,57$

$47,88,89,101,128,130$

$7,65,101,105$

$32,33 b$

32,33

$32,33,104$

$33,89,104$

32,33

$16,70,84,136$

73,136

$22,28,98,110,111,134$

$22,98,111,135$

$22,98,111,135$

$95,111,126$

$12,50,59,95,108,111$

$5,38,77,91,111,126$

$78,91,96,98,111,126$

$5,38,77,91,111,126$

$12,50,59,96,108,111$

$12,50,59,96,108,111$

6,107 
Table 1D. Inventory of metal mines and occurrences associated with the early Mesozoic basins of the Eastern United States listed according to metal association-Continued

[In column "Area number," locality is indicated by number: 0, areas in New Hampshire north of the Hartford basin; 1, the Hartford basin and vicinity, Massachusetts; 2, the Hartford basin and vicinity, Connecticut; 3, the Newark basin, New Jersey; 4, the Newark basin and vicinity, Pennsylvania; 5, the Gettysburg basin and vicinity, Pennsylvania; 6, the Culpeper basin, Maryland and Virginia; 7, other areas in Virginia; 8, the Davie County basin area, North Carolina; 9 , the Deep River basin area, North Carolina. In the "Production" column, locality is indicated by a two-letter code: the first code letter, an $\mathrm{m}$, $\mathrm{p}$, or o, indicates that the locality is a mine, prospect, or mineral occurrence, respectively; the second code letter, an l, m, n, or $u$, indicates ore production or reserves greater than 100,000 tons, between 1,000 and 100,000 tons, less than 1,000 tons, or unknown, respectively. In the column "Deposit type," deposits are indicated by number: 1, a skarn deposit; 2, a hornfels deposit; 3, a diabase-hosted vein or segregation deposit; 4, a sediment-hosted stratabound disseminated or replacement deposit; 5, a vein deposit; 6, a placer deposit. In the "References" column, the number of the reference citation is listed in table $1 E$ ]

\begin{tabular}{|c|c|c|c|c|c|c|c|}
\hline \multirow{2}{*}{$\begin{array}{l}\text { Locality } \\
\text { number }\end{array}$} & \multirow[b]{2}{*}{ Name } & \multirow{2}{*}{\multicolumn{2}{|c|}{$\begin{array}{l}\text { Area } \\
\text { No. }\end{array}$}} & \multirow[b]{2}{*}{ Production } & \multirow{2}{*}{$\begin{array}{c}\text { Deposit } \\
\text { type }\end{array}$} & Metal associations & \multirow[b]{2}{*}{ References } \\
\hline & & & & & & Principal Accessory & \\
\hline
\end{tabular}

\begin{tabular}{|c|c|c|c|c|c|c|c|c|}
\hline \multicolumn{9}{|c|}{$\mathrm{Au}-\mathrm{GOLD}$-accessory metal-Continued } \\
\hline $\begin{array}{l}179 \\
225 \\
226\end{array}$ & $\begin{array}{l}\text { Cornwall mine } \\
\text { Stone Jug mine } \\
\text { Hunterstown }\end{array}$ & $\begin{array}{l}\text { Pennsylvania } \\
\text { Pennsylvania } \\
\text { Pennsylvania }\end{array}$ & $\begin{array}{l}5 \\
5 \\
5\end{array}$ & $\begin{array}{l}\mathrm{m} l \\
\mathrm{~m} n \\
\mathrm{p} n\end{array}$ & $\begin{array}{l}1 \\
2 \\
2\end{array}$ & $\begin{array}{l}\mathrm{Fe} \mathrm{Cu} \\
\mathrm{Cu} \\
\mathrm{Cu}\end{array}$ & $\begin{array}{l}\text { Au Ag Co } \\
\text { Au Ag Mo } \\
\text { Au }\end{array}$ & $\begin{array}{l}39,46,67,69,98,117 \\
113 \\
58,79,98\end{array}$ \\
\hline \multicolumn{9}{|c|}{ Ba-BARITE (BARIUM)-principal commodity } \\
\hline $\begin{array}{r}28 \\
29 \\
30 \\
31 \\
32 \\
51 \\
56 \\
57 \\
58 \\
59 \\
61 \\
62 \\
64 \\
65 \\
87 \\
90 \\
92 \\
93 \\
94 \\
95 \\
129 \\
141 \\
183 \\
236 \\
252 \\
254 \\
256 \\
257 \\
260 \\
261 \\
268 \\
274\end{array}$ & $\begin{array}{l}\text { Manhan Lead 1 } \\
\text { Manhan Lead 2 } \\
\text { Manhan Lead 3 } \\
\text { Manhan Lead 4 } \\
\text { Manhan Lead 5 } \\
\text { Berlin Moores Mill } \\
\text { barite vein } \\
\text { - New Haven mine } \\
\text { Cheshire mine 3 } \\
\text { Cheshire mine 2 } \\
\text { Booth \& Hinman } \\
\text { Cheshire mine 1 } \\
\text { Jinny Hill } \\
\text { Cross Rock } \\
\text { Hopewell barite } \\
\text { Ingham Spring } \\
\text { Buckmanville } \\
\text { Buckingham } \\
\text { W. Buckmanville } \\
\text { Bushington } \\
\text { Jug Hollow mine } \\
\text { Charlestown mine } \\
\text { Safe Harbor } \\
\text { Boyds barite } \\
\text { Manassas } \\
\text { St. Stephens } \\
\text { Cedar Run } \\
\text { Botts barite } \\
\text { Gear barite } \\
\text { Kemper } \\
\text { Scottsville barite } \\
\text { Harrisville barite }\end{array}$ & $\begin{array}{l}\text { Massachusetts } \\
\text { Massachusetts } \\
\text { Massachusetts } \\
\text { Massachusetts } \\
\text { Massachusetts } \\
\text { Connecticut } \\
\text { Connecticut } \\
\text { Connecticut } \\
\text { Connecticut } \\
\text { Connecticut } \\
\text { Connecticut } \\
\text { Connecticut } \\
\text { Connecticut } \\
\text { Connecticut } \\
\text { New Jersey } \\
\text { Pennsylvania } \\
\text { Pennsylvania } \\
\text { Pennsylvania } \\
\text { Pennsylvania } \\
\text { Pennsylvania } \\
\text { Pennsylvania } \\
\text { Pennsylvania } \\
\text { Pennsylvania } \\
\text { Maryland } \\
\text { Virginia } \\
\text { Virginia } \\
\text { Virginia } \\
\text { Virginia } \\
\text { Virginia } \\
\text { Virginia } \\
\text { Virginia } \\
\text { North Carolina }\end{array}$ & $\begin{array}{l}1 \\
1 \\
1 \\
1 \\
1 \\
2 \\
2 \\
2 \\
2 \\
2 \\
2 \\
2 \\
2 \\
2 \\
3 \\
4 \\
4 \\
4 \\
4 \\
4 \\
4 \\
4 \\
5 \\
6 \\
6 \\
6 \\
6 \\
6 \\
6 \\
6 \\
7 \\
9\end{array}$ & 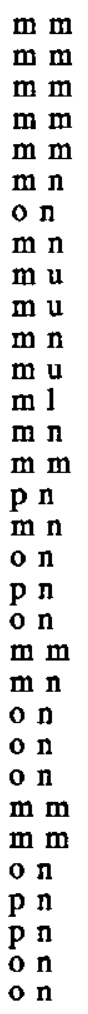 & $\begin{array}{l}5 \\
5 \\
5 \\
5 \\
5 \\
5 \\
5 \\
5 \\
5 \\
5 \\
5 \\
5 \\
5 \\
5 \\
5 \\
5 \\
5 \\
5 \\
5 \\
5 \\
5 \\
5 \\
5 \\
5 \\
5 \\
5 \\
5 \\
5 \\
5 \\
5 \\
5 \\
5\end{array}$ & $\begin{array}{l}\mathrm{Pb} \mathrm{Ba} \\
\mathrm{Pb} \mathrm{Ba} \\
\mathrm{Pb} \mathrm{Ba} \\
\mathrm{Pb} \mathrm{Ba} \\
\mathrm{Pb} \mathrm{Ba} \\
\mathrm{Ba} \\
\mathrm{Ba} \\
\mathrm{Ba} \\
\mathrm{Ba} \\
\mathrm{Ba} \\
\mathrm{Ba} \\
\mathrm{Ba} \\
\mathrm{Ba} \\
\mathrm{Cu} \mathrm{Ba} \\
\mathrm{Ba} \\
\mathrm{Cu} \mathrm{Ba} \\
\mathrm{Ba} \\
\mathrm{Ba} \\
\mathrm{Ba} \mathrm{Ca} \\
\mathrm{Ba} \\
\mathrm{Ba} \mathrm{Zn} \\
\mathrm{Pb} \mathrm{Ba} \\
\mathrm{Zn} \mathrm{Ba} \\
\mathrm{Ba} \\
\mathrm{Ba} \\
\mathrm{Ba} \\
\mathrm{Ba} \\
\mathrm{Ba} \\
\mathrm{Ba} \\
\mathrm{Ba} \\
\mathrm{Ba} \\
\mathrm{Ba}\end{array}$ & 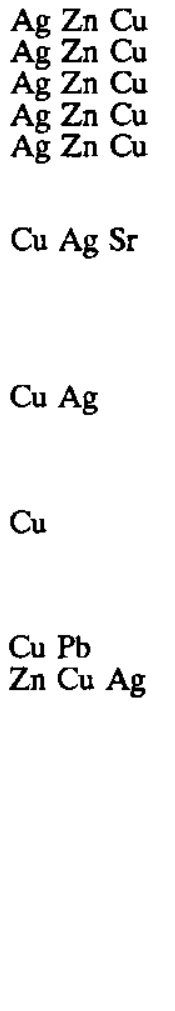 & $\begin{array}{l}25,55 \\
25,55 \\
25,55 \\
25,55 \\
25,55 \\
48,87,104 \\
33 b \\
32,33 b \\
32 \\
32 \\
32 \\
32 \\
32,33 \\
33 \\
15,21 \\
98,131,134 \\
98,118,131,134 \\
44,98 \\
98,131 \\
44,98 \\
44,77,96,111 \\
95,111,126 \\
8,98 \\
94 \\
75,93 \\
11,23,36,71,75,93 \\
11,23,36,71,75 \\
23,75 \\
23,36,75 \\
23,36,71,75 \\
124 \\
13\end{array}$ \\
\hline \multicolumn{9}{|c|}{ Ba-BARITE (BARIUM)-accessory commodity } \\
\hline $\begin{array}{r}2 \\
3 \\
4 \\
5 \\
7 \\
12 \\
13 \\
14 \\
15 \\
16 \\
17 \\
18 \\
21 \\
22 \\
23 \\
25 \\
26 \\
27\end{array}$ & $\begin{array}{l}\text { Will Wise mine } \\
\text { Stoddard mine } 1 \\
\text { Stoddard mine } 2 \\
\text { Springer mine } \\
\text { Pierce mine } \\
\text { Turners Falls } 1 \\
\text { Turners Falls } 2 \\
\text { Deerfield } \\
\text { Unnamed Pb-Ba } \\
\text { Mt. Esther } \\
\text { Leverett } \\
\text { Unnamed } \mathrm{Pb}-\mathrm{Ba} 4 \\
\text { Unnamed } \mathrm{Pb}-\mathrm{Ba} 1 \\
\text { Unnamed } \mathrm{Pb}-\mathrm{Ba} 3 \\
\text { Unnamed } \mathrm{Pb}-\mathrm{Ba} 2 \\
\text { Hatfield lead } \\
\text { Unnamed } \mathrm{Pb}-\mathrm{Ba} 2 \\
\text { Unnamed } \mathrm{Pb}-\mathrm{Ba} 1\end{array}$ & $\begin{array}{l}\text { New Hampshire } \\
\text { New Hampshire } \\
\text { New Hampshire } \\
\text { New Hampshire } \\
\text { New Hampshire } \\
\text { Massachusetts } \\
\text { Massachusetts } \\
\text { Massachusetts } \\
\text { Massachusetts } \\
\text { Massachusetts } \\
\text { Massachusetts } \\
\text { Massachusetts } \\
\text { Massachusetts } \\
\text { Massachusetts } \\
\text { Massachusetts } \\
\text { Massachusetts } \\
\text { Massachusetts } \\
\text { Massachusetts }\end{array}$ & $\begin{array}{l}0 \\
0 \\
0 \\
0 \\
0 \\
1 \\
1 \\
1 \\
1 \\
1 \\
1 \\
1 \\
1 \\
1 \\
1 \\
1 \\
1 \\
1\end{array}$ & 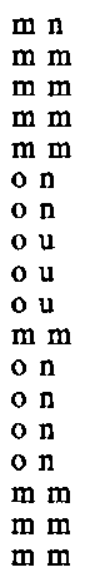 & $\begin{array}{l}5 \\
5 \\
5 \\
5 \\
5 \\
5 \\
5 \\
5 \\
5 \\
5 \\
5 \\
5 \\
5 \\
5 \\
5 \\
5 \\
5 \\
5\end{array}$ & $\begin{array}{l}\mathrm{F} \\
\mathrm{F} \\
\mathrm{F} \\
\mathrm{F} \\
\mathrm{F} \\
\mathrm{Cu} \\
\mathrm{Cu} \\
\mathrm{Pb} \\
\mathrm{Pb} \\
\mathrm{Pb} \\
\mathrm{Pb} \\
\mathrm{Pb} \\
\mathrm{Pb} \\
\mathrm{Pb} \\
\mathrm{Pb} \\
\mathrm{Pb} \\
\mathrm{Pb} \\
\mathrm{Pb}\end{array}$ & $\begin{array}{l}\mathrm{Ba} \mathrm{Pb} \\
\mathrm{Ba} \mathrm{Pb} \\
\mathrm{Ba} \mathrm{Pb} \\
\mathrm{Ba} \mathrm{Pb} \mathrm{Cu} \\
\mathrm{Ba} \mathrm{Pb} \\
\mathrm{Ba} \\
\mathrm{Ba} \\
\mathrm{Ba} \\
\mathrm{Ba} \\
\mathrm{Ba} \\
\mathrm{BaCu} \\
\mathrm{Ba} \mathrm{Cu} \\
\mathrm{Ba} \mathrm{Cu} \\
\mathrm{Ba} \mathrm{Cu} \\
\mathrm{Ba} \mathrm{Cu} \\
\mathrm{Ba} \mathrm{Cu} \\
\mathrm{Ba} \\
\mathrm{Ba}\end{array}$ & $\begin{array}{l}3 \\
3 \\
3 \\
3 \\
3 \\
25,43,55,57,132 \\
25,43,55,57,132 \\
25,55,57 \\
25,55,57 \\
43,55,57 \\
25,43,53,57,64,85 \\
25 \\
25 \\
25 \\
25 \\
25,43,54,57,133 \\
25,55,57 \\
25,55,57\end{array}$ \\
\hline
\end{tabular}


Table 1D. Inventory of metal mines and occurrences associated with the early Mesozoic basins of the Eastern United States listed according to metal association-Continued

[In column "Area number," locality is indicated by number: 0, areas in New Hampshire north of the Hartford basin; 1, the Hartford basin and vicinity, Massachusetts; 2, the Hartford basin and vicinity, Connecticut; 3, the Newark basin, New Jersey; 4, the Newark basin and vicinity, Pennsylvania; 5, the Gettysburg basin and vicinity, Pennsylvania; 6, the Culpeper basin, Maryland and Virginia; 7, other areas in Virginia; 8, the Davie County basin area, North Carolina; 9 , the Deep River basin area, North Carolina. In the "Production" column, locality is indicated by a two-letter code: the first code letter, an $\mathrm{m}, \mathrm{p}$, or $\mathrm{o}$, indicates that the locality is a mine, prospect, or mineral occurrence, respectively; the second code letter, an $\mathrm{l}, \mathrm{m}, \mathrm{n}$, or $\mathrm{u}$, indicates ore production or reserves greater than 100,000 tons, between 1,000 and 100,000 tons, less than 1,000 tons, or unknown, respectively. In the column "Deposit type," deposits are indicated by number: 1, a skarn deposit; 2 , a hornfels deposit; 3, a diabase-hosted vein or segregation deposit; 4 , a sediment-hosted stratabound disseminated or replacement deposit; 5 , a vein deposit; 6 , a placer deposit. In the "References" column, the number of the reference citation is listed in table $1 E$ ]

\begin{tabular}{lllllll}
\hline $\begin{array}{l}\text { Locality } \\
\text { number }\end{array}$ & Name & State & Area & Deposit & Metal associations & \\
No. & Production & type & Principal Accessory & References \\
\hline
\end{tabular}

Ba-BARITE (BARIUM)-accessory commodity-Continued

\begin{tabular}{|c|c|c|c|c|}
\hline 33 & Southampton & Massachusetts & 1 & $\mathrm{~m}$ \\
\hline 41 & Trinity College & Connecticut & 2 & on \\
\hline 44 & basalt quarry & Connecticut & 2 & On \\
\hline 47 & Columbus Blvd. & Connecticut & 2 & on \\
\hline 48 & Ellis Street & Connecticut & 2 & o 1 \\
\hline & Mattabesset River & Connecticut & 2 & $\mathrm{~m}$ \\
\hline & barite vein & Connecticut & & $n$ \\
\hline 66 & Gaylord & Connecticut & $L$ & $n$ \\
\hline 67 & Tallman's mine & Connecticut & 2 & $\mathrm{n} \mathrm{m}$ \\
\hline & copper prospect & Connecticut & 2 & \\
\hline
\end{tabular}

$n$

o

$\mathrm{p} n$

$\mathrm{m} \mathrm{m}$

Co-COBALT-accessory metal

155 Gickerville

113 Kibblehouse quarry

160 French Creek mines

171 Grace mine

179 Cornwall mine

Pennsylvania

Pennsylvania

Pennsylvania

Pennsylvania

Cu-COPPER-principal metal

$\begin{array}{lll}12 & \text { Turners Falls 1 } & \text { Massachusetts } \\ 13 & \text { Turners Falls } 2 & \text { Massachusetts } \\ \text { 33 } & \text { Southampton } & \text { Massachusetts } \\ \text { 35 } & \text { Woodland Dell } & \text { Massachusetts } \\ 36 & \text { Somers sandpit } & \text { Connecticut } \\ 37 & \text { K \& F Suffield } & \text { Connecticut } \\ 38 & \text { Simsbury mine } & \text { Connecticut } \\ 39 & \text { New-gate Prison } & \text { Connecticut } \\ 40 & \text { Higley copper } & \text { Connecticut } \\ 41 & \text { Trinity College } & \text { Connecticut } \\ 42 & \text { Bristol copper } & \text { Connecticut } \\ 48 & \text { Ellis Street } & \text { Connecticut } \\ 55 & \text { copper prospect } & \text { Connecticut } \\ 60 & \text { copper prospect } & \text { Connecticut } \\ 63 & \text { copper mine } & \text { Connecticut } \\ 65 & \text { Cross Rock } & \text { Connecticut } \\ 66 & \text { Gaylord } & \text { Connecticut } \\ 67 & \text { Tallman's mine } & \text { Connecticut } \\ 68 & \text { copper prospect } & \text { Connecticut } \\ \text { 69 } & \text { Copper Valley } & \text { Connecticut } \\ 70 & \text { copper prospect } & \text { Connecticut } \\ 72 & \text { Totowa mine } & \text { New Jersey } \\ 73 & \text { Glen Ridge mine } & \text { New Jersey } \\ 74 & \text { Wigwam Brook } & \text { New Jersey } \\ 75 & \text { Dod mine } & \text { New Jersey } \\ 76 & \text { Schuyler mine } & \text { New Jersey } \\ 78 & \text { Hoffman } & \text { New Jersey } \\ 79 & \text { Stony Brook } & \text { New Jersey } \\ 80 & \text { Bridgewater } & \text { New Jersey } \\ 81 & \text { Chimney Rock } & \text { New Jersey } \\ 82 & \text { Menlo Park mine } & \text { New Jersey } \\ 83 & \text { New Brunswick } & \text { New Jersey } \\ 84 & \text { Flemington } & \text { New Jersey } \\ 85 & \text { Monmouth Junction } & \text { New Jersey } \\ 86 & \text { Griggstown } & \text { New Jersey } \\ 88 & \text { Woosamonsa prospect } & \text { New Jersey } \\ 89 & \text { New Hope } & \text { Pennsylvania }\end{array}$

$\begin{array}{ll}4 & \text { o n } \\ 4 & \text { o n } \\ 4 & \text { m l } \\ 4 & \text { m m } \\ 5 & \text { m l }\end{array}$

n

m 1

$\mathrm{m} \mathrm{m}$

m 1

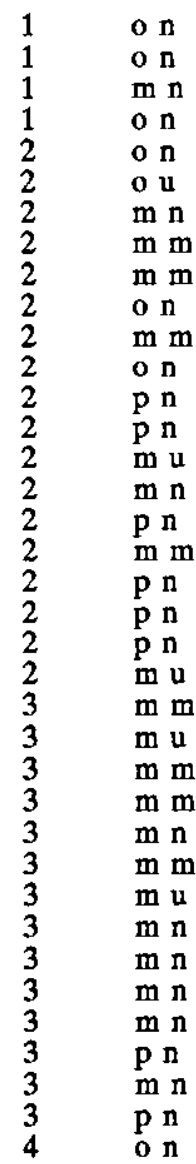

$\begin{array}{lll}\mathrm{Pb} \mathrm{Cu} & \mathrm{Ag} \mathrm{Zn} \mathrm{Ba} & 43,55,57 \\ \mathrm{Cu} & \mathrm{Ba} & 100 \\ & \mathrm{Ba} & 106 \\ \mathrm{Zn} \mathrm{Pb} & \mathrm{Cu} \mathrm{Ba} & 47 \\ \mathrm{Cu} & \mathrm{Ba} & 47 \\ \mathrm{~Pb} & \mathrm{Zn} \mathrm{Ba} & 48,87,104 \\ & \mathrm{Ba} & 72 \\ \mathrm{Cu} & \mathrm{Ba} \mathrm{Ag} & 32,33,104 \\ \mathrm{Cu} & \mathrm{Ba} \mathrm{Ag} & 33,89,104 \\ \mathrm{Cu} & \mathrm{Ba} \mathrm{Ag} & 33\end{array}$

As Co

$\mathrm{Cu}$

$\mathrm{Fe} \mathrm{Cu}$

$\mathrm{Fe} \mathrm{Cu}$

$\mathrm{Fe} \mathrm{Cu}$

Co

$\mathrm{Zn} \mathrm{Co}$

$\mathrm{Co} \mathrm{Ag} \mathrm{Au}$

112,116

$5,44,68,98,109$

Au Ag Co

$39,46,67,69,98,117$

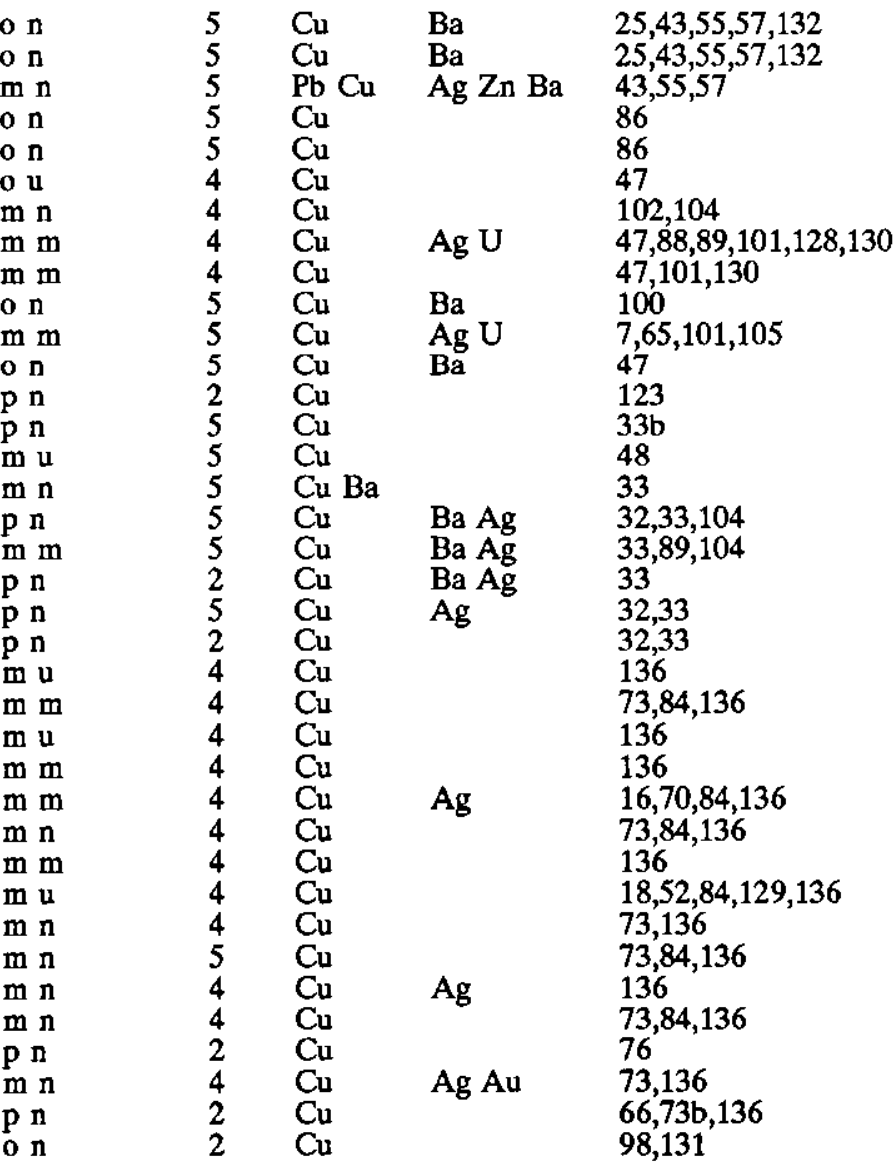


Table 1D. Inventory of metal mines and occurrences associated with the early Mesozoic basins of the Eastern United States listed according to metal association-Continued

[In column "Area number," locality is indicated by number: 0 , areas in New Hampshire north of the Hartford basin; 1, the Hartford basin and vicinity, Massachusetts; 2, the Hartford basin and vicinity, Connecticut; 3, the Newark basin, New Jersey; 4, the Newark basin and vicinity, Pennsylvania; 5, the Gettysburg basin and vicinity, Pennsylvania; 6, the Culpeper basin, Maryland and Virginia; 7, other areas in Virginia; 8, the Davie County basin area, North Carolina; 9, the Deep River basin area, North Carolina. In the "Production" column, locality is indicated by a two-letter code: the first code letter, an $\mathrm{m}, \mathrm{p}$, or $\mathrm{o}$, indicates that the locality is a mine, prospect, or mineral occurrence, respectively; the second code letter, an $\mathrm{l}, \mathrm{m}, \mathrm{n}$, or $\mathrm{u}$, indicates ore production or reserves greater than 100,000 tons, between 1,000 and 100,000 tons, less than 1,000 tons, or unknown, respectively. In the column "Deposit type," deposits are indicated by number: 1, a skarn deposit; 2, a hornfels deposit; 3, a diabase-hosted vein or segregation deposit; 4, a sediment-hosted stratabound disseminated or replacement deposit; 5 , a vein deposit; 6, a placer deposit. In the "References" column, the number of the reference citation is listed in table $1 E$ ]

\begin{tabular}{|c|c|c|c|c|c|c|c|c|}
\hline \multirow{2}{*}{$\begin{array}{l}\text { Locality } \\
\text { number }\end{array}$} & \multirow[b]{2}{*}{ Name } & \multirow[b]{2}{*}{ State } & \multirow{2}{*}{$\begin{array}{l}\text { Area } \\
\text { No. }\end{array}$} & \multirow[b]{2}{*}{ Production } & \multirow{2}{*}{$\begin{array}{c}\text { Deposit } \\
\text { type }\end{array}$} & \multicolumn{2}{|c|}{ Metal associations } & \multirow[b]{2}{*}{ References } \\
\hline & & & & & & Principal & Accessory & \\
\hline \multicolumn{9}{|c|}{$\mathrm{Cu}$-COPPER-principal metal-Continued } \\
\hline $\begin{array}{l}227 \\
228 \\
229 \\
234 \\
240 \\
242 \\
243 \\
244 \\
245 \\
246 \\
247 \\
248 \\
249 \\
250 \\
253 \\
258 \\
259 \\
262 \\
263 \\
264 \\
265 \\
266 \\
269 \\
272 \\
273\end{array}$ & $\begin{array}{l}\text { Gettysburg } \\
\text { Bonneauville } \\
\text { Teeter's quarry } \\
\text { Fairfield } \\
\text { Sugarland } \\
\text { Goose Creek } \\
\text { Sugarland Run } \\
\text { Sterling } \\
\text { Theodora } \\
\text { Spencer farm } \\
\text { Chantilly prospect } \\
\text { Cub Run copper } \\
\text { Chantilly } \\
\text { Fairfax quarry } \\
\text { Brentsville } \\
\text { Elk Run mine } \\
\text { Bealeton mine } \\
\text { Mountain Run } \\
\text { Stevensburg } \\
\text { Culpeper prospect } \\
\text { Batna } \\
\text { Somerset mine } \\
\text { Dolan property } \\
\text { Clegg copper mine } \\
\text { Tennessee copper }\end{array}$ & $\begin{array}{l}\text { Pennsylvania } \\
\text { Pennsylvania } \\
\text { Pennsylvania } \\
\text { Pennsylvania } \\
\text { Maryland } \\
\text { Virginia } \\
\text { Virginia } \\
\text { Virginia } \\
\text { Virginia } \\
\text { Virginia } \\
\text { Virginia } \\
\text { Virginia } \\
\text { Virginia } \\
\text { Virginia } \\
\text { Virginia } \\
\text { Virginia } \\
\text { Virginia } \\
\text { Virginia } \\
\text { Virginia } \\
\text { Virginia } \\
\text { Virginia } \\
\text { Virginia } \\
\text { Virginia } \\
\text { North Carolina } \\
\text { North Carolina }\end{array}$ & $\begin{array}{l}5 \\
5 \\
5 \\
5 \\
6 \\
6 \\
6 \\
6 \\
6 \\
6 \\
6 \\
6 \\
6 \\
6 \\
6 \\
6 \\
6 \\
6 \\
6 \\
6 \\
6 \\
6 \\
7 \\
9 \\
9\end{array}$ & $\begin{array}{l}o n \\
o n \\
o n \\
p n \\
m n \\
p n \\
p \text { n } \\
\text { on } \\
m n \\
p n \\
p n \\
o n \\
o n \\
o n \\
p n \\
p n \\
m n \\
o n \\
o n \\
o n \\
p n \\
m n \\
o n \\
m n \\
p n\end{array}$ & $\begin{array}{l}2 \\
4 \\
2 \\
2 \\
4 \\
2 \\
4 \\
4 \\
2 \\
2 \\
2 \\
2 \\
4 \\
3 \\
4 \\
5 \\
2 \\
2 \\
4 \\
2 \\
2 \\
4 \\
5 \\
5 \\
5\end{array}$ & $\begin{array}{l}\mathrm{Cu} \\
\mathrm{Cu} \\
\mathrm{Cu} \\
\mathrm{Cu} \mathrm{Fe} \\
\mathrm{Cu} \\
\mathrm{Cu} \\
\mathrm{Cu} \mathrm{Ag} \\
\mathrm{Cu} \\
\mathrm{Cu} \\
\mathrm{Cu} \\
\mathrm{Cu} \\
\mathrm{Cu} \\
\mathrm{Cu} \\
\mathrm{Cu} \\
\mathrm{Cu} \\
\mathrm{Cu} \\
\mathrm{Cu} \\
\mathrm{Cu} \\
\mathrm{Zn} \mathrm{Cu} \\
\mathrm{Cu} \\
\mathrm{Cu} \\
\mathrm{Cu} \\
\mathrm{Cu} \\
\mathrm{Cu} \\
\mathrm{Cu}\end{array}$ & $\begin{array}{l}\mathrm{Fe} \mathrm{U} \\
\mathrm{Fe}\end{array}$ & $\begin{array}{l}98,119 \\
30,98 \\
68,98 \\
30,98,119,120 \\
11,34,36,71 \\
11,36,75,93,125,130 \\
11 \\
11 \\
11,36,60,75 \\
11,75 \\
11,75 \\
24 \\
11,17 \\
19,75 \\
11,93 \\
74,75 \\
75,93 \\
35 \\
11 \\
75,93 \\
36,75,93,130 \\
75,93,97,130 \\
26,75 \\
14 \\
14\end{array}$ \\
\hline \multicolumn{9}{|c|}{$\mathrm{Cu}$-COPPER-accessory metal } \\
\hline $\begin{array}{r}1 \\
5 \\
11 \\
17 \\
18 \\
21 \\
22 \\
23 \\
25 \\
28 \\
29 \\
30 \\
31 \\
32 \\
45 \\
46 \\
47 \\
57 \\
64 \\
92 \\
103 \\
105 \\
127 \\
129 \\
141 \\
142 \\
143 \\
144 \\
145\end{array}$ & $\begin{array}{l}\text { E. Surry Mtn. mine } \\
\text { Springer mine } \\
\text { Bernardston } \\
\text { Leverett } \\
\text { Unnamed Pb-Ba } 4 \\
\text { Unnamed Pb-Ba } 1 \\
\text { Unnamed Pb-Ba } 3 \\
\text { Unnamed Pb-Ba } 2 \\
\text { Hatfield lead } \\
\text { Manhan Lead } 1 \\
\text { Manhan Lead } 2 \\
\text { Manhan Lead } 3 \\
\text { Manhan Lead 4 } \\
\text { Manhan Lead 5 } \\
\text { Plainfield quarry } \\
\text { Cook's Gap } \\
\text { Columbus Blvd. } \\
\text { New Haven mine } \\
\text { Jinny Hill } \\
\text { Buckmanville } \\
\text { New Galena } \\
\text { Diehl's mine } \\
\text { Wetherill mine } \\
\text { Jug Hollow mine } \\
\text { Charlestown mine } \\
\text { Wheatley mine } \\
\text { Chester Co. mine } \\
\text { Montgomery Co. } \\
\text { SW. Chester mine }\end{array}$ & $\begin{array}{l}\text { New Hampshire } \\
\text { New Hampshire } \\
\text { Massachusetts } \\
\text { Massachusetts } \\
\text { Massachusetts } \\
\text { Massachusetts } \\
\text { Massachusetts } \\
\text { Massachusetts } \\
\text { Massachusetts } \\
\text { Massachusetts } \\
\text { Massachusetts } \\
\text { Massachusetts } \\
\text { Massachusetts } \\
\text { Massachusetts } \\
\text { Connecticut } \\
\text { Connecticut } \\
\text { Connecticut } \\
\text { Connecticut } \\
\text { Connecticut } \\
\text { Pennsylvania } \\
\text { Pennsylvania } \\
\text { Pennsylvania } \\
\text { Pennsylvania } \\
\text { Pennsylvania } \\
\text { Pennsylvania } \\
\text { Pennsylvania } \\
\text { Pennsylvania } \\
\text { Pennsylvania } \\
\text { Pennsylvania }\end{array}$ & $\begin{array}{l}0 \\
0 \\
1 \\
1 \\
1 \\
1 \\
1 \\
1 \\
1 \\
1 \\
1 \\
1 \\
1 \\
1 \\
2 \\
2 \\
2 \\
2 \\
2 \\
4 \\
4 \\
4 \\
4 \\
4 \\
4 \\
4 \\
4 \\
4 \\
4\end{array}$ & 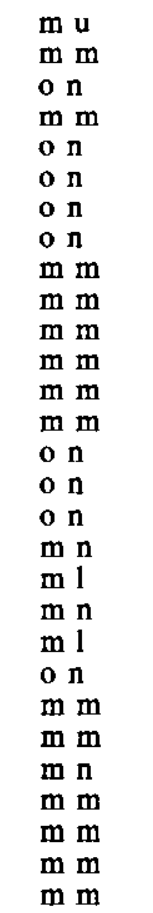 & $\begin{array}{l}5 \\
5 \\
1 \\
5 \\
5 \\
5 \\
5 \\
5 \\
5 \\
5 \\
5 \\
5 \\
5 \\
5 \\
5 \\
4 \\
5 \\
5 \\
5 \\
5 \\
5 \\
3 \\
5 \\
5 \\
5 \\
5 \\
5 \\
5 \\
5\end{array}$ & $\begin{array}{l}\mathrm{Pb} \\
\mathrm{F} \\
\mathrm{Fe} \\
\mathrm{Pb} \\
\mathrm{Pb} \\
\mathrm{Pb} \\
\mathrm{Pb} \\
\mathrm{Pb} \\
\mathrm{Pb} \\
\mathrm{Pb} \mathrm{Ba} \\
\mathrm{Pb} \mathrm{Ba} \\
\mathrm{Pb} \mathrm{Ba} \\
\mathrm{Pb} \mathrm{Ba} \\
\mathrm{Pb} \mathrm{Ba} \\
\\
\mathrm{Zn} \mathrm{Pb} \\
\mathrm{Ba} \\
\mathrm{Ba} \\
\mathrm{Ba} \\
\mathrm{Pb} \mathrm{Zn} \\
\mathrm{Au} \\
\mathrm{Pb} \\
\mathrm{Ba} \mathrm{Zn} \\
\mathrm{Pb} \mathrm{Ba} \\
\mathrm{Pb} \mathrm{Zn} \\
\mathrm{Pb} \mathrm{Zn} \\
\mathrm{Zn} \mathrm{Pb} \\
\mathrm{Pb} \mathrm{Zn}\end{array}$ & 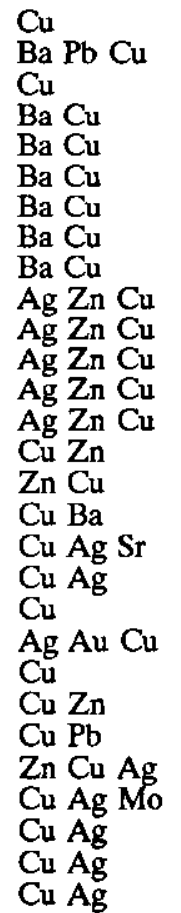 & $\begin{array}{l}80 \\
3 \\
1,2,25 \mathrm{~b} \\
25,43,53,57,64,85 \\
25 \\
25 \\
25 \\
25 \\
25,43,54,57,133 \\
25,55 \\
25,55 \\
25,55 \\
25,55 \\
25,55 \\
106 \\
47 \\
47 \\
32,33 \\
32,33 \\
98,118,131,134 \\
22,28,98,110,111,134 \\
4,44,98,131 \\
22,98,111,135 \\
44,77,96,111 \\
95,111,126 \\
12,50,59,95,108,111 \\
5,38,77,91,111,126 \\
78,91,96,98,111,126 \\
5,38,77,91,111,126\end{array}$ \\
\hline
\end{tabular}


Table 1D. Inventory of metal mines and occurrences associated with the early Mesozoic basins of the Eastern United States listed according to metal association-Continued

[In column "Area number," locality is indicated by number: 0 , areas in New Hampshire north of the Hartford basin; 1, the Hartford basin and vicinity, Massachusetts; 2, the Hartford basin and vicinity, Connecticut; 3, the Newark basin, New Jersey; 4, the Newark basin and vicinity, Pennsylvania; 5, the Gettysburg basin and vicinity, Pennsylvania; 6, the Culpeper basin, Maryland and Virginia; 7, other areas in Virginia; 8, the Davie County basin area, North Carolina; 9 , the Deep River basin area, North Carolina. In the "Production" column, locality is indicated by a two-letter code: the first code letter, an $\mathrm{m}, \mathrm{p}$, or $\mathrm{o}$, indicates that the locality is a mine, prospect, or mineral occurrence, respectively; the second code letter, an l, m, n, or $\mathrm{u}$, indicates ore production or reserves greater than 100,000 tons, between 1,000 and 100,000 tons, less than 1,000 tons, or unknown, respectively. In the column "Deposit type," deposits are indicated by number: 1, a skam deposit; 2, a hornfels deposit; 3, a diabase-hosted vein or segregation deposit; 4, a sediment-hosted stratabound disseminated or replacement deposit; 5 , a vein deposit; 6 , a placer deposit. In the "References" column, the number of the reference citation is listed in table $1 E$ ]

\begin{tabular}{llllllll}
\hline Locality & & & Area & & Deposit & Metal associations \\
number & Name & State & No. & Production & type & Principal Accessory & References \\
\hline
\end{tabular}

\section{$\mathrm{Cu}$-COPPER-accessory metal-Continued}

$\begin{array}{lll}146 & \text { Brookdale mine } & \text { Pennsylvania } \\ 147 & \text { Phoenix mine } & \text { Pennsylvania } \\ 149 & \text { Pennypacker mine } & \text { Pennsylvania } \\ 163 & \text { Jones-Kinney mines } & \text { Pennsylvania } \\ 170 & \text { Fritz Island mine } & \text { Pennsylvania }\end{array}$

F-FLUORITE (FLUORINE)-principal commodity

$\begin{array}{lll}2 & \text { Will Wise mine } & \text { New Hampshire } \\ 3 & \text { Stoddard mine 1 } & \text { New Hampshire } \\ 4 & \text { Stoddard mine 2 } & \text { New Hampshire } \\ 5 & \text { Springer mine } & \text { New Hampshire } \\ 6 & \text { fluorite prospect } & \text { New Hampshire } \\ 7 & \text { Pierce mine } & \text { New Hampshire } \\ 8 & \text { Streeter Hill } & \text { New Hampshire }\end{array}$

$\begin{array}{ll}4 & \mathrm{~m} \mathrm{~m} \\ 4 & \mathrm{~m} \mathrm{~m} \\ 4 & \mathrm{~m} \mathrm{n} \\ 4 & \mathrm{~m} 1\end{array}$

F-FLUORITE (FLUORINE)-accessory commodity
52 limestone quarry
Connecticut
2

Fe-IRON-principal metal

11 Bernardston

77 Laurel Hill

131 Fegley mine

150 Boyertown mine

151 Stonersville

152 Brower mine

154 Esterly mine

159 Unnamed Fe mine

160 French Creek mines

161 Knauertown

162 Pine Swamp

163 Jones-Kinney mines

164 Hopewell mine

165 Leighton mine

166 Warwick mine

167 Steels mine

169 Raudenbush mine

170 Fritz Island mine

171 Grace mine

172 Bylers mine

173 Wheatfield mine

174 Ruth mine

175 Doner mine

176 Mt. Pleasant

177 Rexmont Reservoir

178 Carper mine

179 Cornwall mine

180 Hummelstown

185 Mt. Pleasant 2

186 Mt. Pleasant 1

187 Wellsville 2

188 Wellsville 1

190 Harman mine

191 Brenneman mine

192 Altland mine

193 Comfort mine

194 Cadwalader mine

194 Cadwalader mine
Massachusetts

New Jersey

Pennsylvania

Pennsylvania

Pennsylvania

Pennsylvania

Pennsylvania

Pennsylvania

Pennsylvania

Pennsylvania

Pennsylvania

Pennsylvania

Pennsylvania

Pennsylvania

Pennsylvania

Pennsylvania

Pennsylvania

Pennsylvania

Pennsylvania

Pennsylvania

Pennsylvania

Pennsylvania

Pennsylvania

Pennsylvania

Pennsylvania

Pennsylvania

Pennsylvania

Pennsylvania

Pennsylvania

Pennsylvania

Pennsylvania

Pennsylvania

Pennsylvania

Pennsylvania

Pennsylvania

Pennsylvania

Pennsylvania m n

m m

$\mathrm{m} \mathrm{m}$

$\mathrm{m} \mathrm{m}$

p n

$\mathrm{m} m$

o $n$

on

o n

on

$\mathrm{m} n$

$\mathrm{m} n$

p n

$\mathrm{m}$ m

m u

$\mathrm{m} \mathrm{u}$

m 1

p n

p n

m l

m u

$\mathrm{m} \mathrm{m}$

$\mathrm{m} 1$

$\mathrm{m} \mathrm{u}$

$\mathrm{m} \mathrm{m}$

$\mathrm{m} \mathrm{I}$

m 1

$\mathrm{m} 1$

m 1

$\mathrm{m} \mathrm{m}$

$\mathrm{m} \mathrm{m}$

p n

p n

m m

$\mathrm{m} \mathrm{I}$

$\mathrm{m} \mathrm{m}$

p n

$\mathrm{p} n$

p n

p n

m n

$\mathrm{m} n$

$\mathrm{m} n$

m n

$\mathrm{m} n$

$\begin{array}{ll}\mathrm{Zn} \mathrm{Pb} & \mathrm{Cu} \mathrm{Ag} \\ \mathrm{Zn} \mathrm{Pb} & \mathrm{Ag} \mathrm{Cu} \\ \mathrm{Pb} & \mathrm{Cu} \\ \mathrm{Fe} & \mathrm{Cu} \\ \mathrm{Fe} & \mathrm{Cu}\end{array}$

$12,50,59,96,108,111$ $12,50,59,96,108,111$ $5,96,111$ $44,63,96,98,117,121$ $20,44,98,117$

m $n$

$\begin{array}{llll}5 & \mathrm{~F} & \mathrm{Ba} \mathrm{Pb} & 3 \\ 5 & \mathrm{~F} & \mathrm{Ba} \mathrm{Pb} & 3 \\ 5 & \mathrm{~F} & \mathrm{Ba} \mathrm{Pb} & 3 \\ 5 & \mathrm{~F} & \mathrm{Ba} \mathrm{Pb} \mathrm{Cu} & 3 \\ 5 & \mathrm{~F} & & 3 \\ 5 & \mathrm{~F} & \mathrm{Ba} \mathrm{Pb} & 3 \\ 5 & \mathrm{~F} & \mathrm{~Pb} & 3\end{array}$

3
3
3
3
3
3
3


Table 1D. Inventory of metal mines and occurrences associated with the early Mesozoic basins of the Eastern United States listed according to metal association-Continued

[In column "Area number," locality is indicated by number: 0, areas in New Hampshire north of the Hartford basin; 1, the Hartford basin and vicinity, Massachusetts; 2 , the Hartford basin and vicinity, Connecticut; 3 , the Newark basin, New Jersey; 4, the Newark basin and vicinity, Pennsylvania; 5, the Gettysburg basin and vicinity, Pennsylvania; 6, the Culpeper basin, Maryland and Virginia; 7, other areas in Virginia; 8, the Davie County basin area, North Carolina; 9, the Deep River basin area, North Carolina. In the "Production" column, locality is indicated by a two-letter code: the first code letter, an $\mathrm{m}, \mathrm{p}$, or o, indicates that the locality is a mine, prospect, or mineral occurrence, respectively; the second code letter, an l, m, n, or $\mathrm{u}$, indicates ore production or reserves greater than 100,000 tons, between 1,000 and 100,000 tons, less than 1,000 tons, or unknown, respectively. In the column "Deposit type," deposits are indicated by number: 1, a skarn deposit; 2, a hornfels deposit; 3, a diabase-hosted vein or segregation deposit; 4 , a sediment-hosted stratabound disseminated or replacement deposit; 5 , a vein deposit; 6 , a placer deposit. In the "References" column, the number of the reference citation is listed in table $1 E$ ]

\begin{tabular}{|c|c|c|c|c|c|c|c|}
\hline \multirow{2}{*}{$\begin{array}{l}\text { Locality } \\
\text { number }\end{array}$} & \multirow[b]{2}{*}{ Name } & \multicolumn{3}{|c|}{ Area } & \multirow{2}{*}{$\begin{array}{c}\text { Deposit } \\
\text { type }\end{array}$} & Metal associations & \multirow[b]{2}{*}{ References } \\
\hline & & State & No. & Production & & Principal Accessory & \\
\hline
\end{tabular}

Fe-IRON-principal metal-Continued

195 Marshall mine

196 Sluthower mine

197 Minebank School 1

198 Minebank School 2

199 Roler

200 Smith prospect

201 Grantham mines

202 Dillsburg North

203 McCormick mine

204 Longnecker mine

205 King mine

206 Underwood mine

207 Jauss mine

208 Altland mine

209 Smyser mine

210 Bell mine

211 Logan mine

212 Cox mine

213 Grove mine

215 Franklintown 1

216 Franklintown 2

217 Franklintown 3

218 Franklintown 4

219 Lichte mine

221 Center Mills 1

222 Center Mills 2

223 Idaville

230 Cashtown 2

231 Cashtown 1

232 Orrtana

233 Carr Hill

234 Fairfield

235 McNair farm
214 Bender mine

Pennsylvania

Pennsylvania

Pennsylvania

Pennsylvania

Pennsylvania

Pennsylvania

Pennsylvania

Pennsylvania

Pennsylvania

Pennsylvania

Pennsylvania

Pennsylvania

Pennsylvania

Pennsylvania

Pennsylvania

Pennsylvania

Pennsylvania

Pennsylvania

Pennsylvania

Pennsylvania

Pennsylvania

Pennsylvania

Pennsylvania

Pennsylvania

Pennsylvania

Pennsylvania

Pennsylvania

Pennsylvaria

Pennsylvania

Pennsylvania

Pennsylvania

Pennsylvania

Pennsylvania

Pennsylvania

Fe-IRON-accessory metal

262 Mountain Run Virginia

264 Culpeper prospect Virginia

$\mathrm{Pb}-\mathrm{LEAD}$ - principal metal

1 E. Surry Mtn. mine

9 galena occurrence

10 Winchester mine

14 Deerfield

15 Unnamed $\mathrm{Pb}-\mathrm{Ba}$

16 Mt. Esther

17 Leverett

18 Unnamed Pb-Ba 4

19 Whately-Wm. 1

20 Whately-Wm. 2

21 Unnamed $\mathrm{Pb}-\mathrm{Ba} 1$

22 Unnamed $\mathrm{Pb}-\mathrm{Ba} 3$

23 Unnamed $\mathrm{Pb}-\mathrm{Ba} 2$

24 Whately-Wm. 3

25 Hatfield lead
New Hampshire

New Hampshire

New Hampshire

Massachusetts

Massachusetts

Massachusetts

Massachusetts

Massachusetts

Massachusetts

Massachusetts

Massachusetts

Massachusetts

Massachusetts

Massachusetts

Massachusetts

$\begin{array}{ll}5 & \mathrm{~m} \mathrm{n} \\ 5 & \mathrm{~m} \mathrm{n} \\ 5 & \mathrm{~m} \mathrm{~m} \\ 5 & \mathrm{~m} \mathrm{~m} \\ 5 & \mathrm{p} \mathrm{n} \\ 5 & \mathrm{p} \mathrm{n} \\ 5 & \mathrm{~m} \mathrm{~m} \\ 5 & \mathrm{p} \mathrm{n} \\ 5 & \mathrm{~m} \mathrm{l} \\ 5 & \mathrm{~m} \mathrm{l} \\ 5 & \mathrm{~m} \mathrm{~m} \\ 5 & \mathrm{~m} \mathrm{l} \\ 5 & \mathrm{~m} \mathrm{l} \\ 5 & \mathrm{~m} \mathrm{~m} \\ 5 & \mathrm{~m} \mathrm{~m} \\ 5 & \mathrm{~m} \mathrm{l} \\ 5 & \mathrm{~m} \mathrm{~m} \\ 5 & \mathrm{~m} \mathrm{~m} \\ 5 & \mathrm{~m} \mathrm{~m} \\ 5 & \mathrm{~m} \mathrm{n} \\ 5 & \mathrm{p} \mathrm{n} \\ 5 & \mathrm{p} \mathrm{n} \\ 5 & \mathrm{p} \mathrm{n} \\ 5 & \mathrm{p} \mathrm{n} \\ 5 & \mathrm{~m} \mathrm{~m} \\ 5 & \mathrm{p} \mathrm{n} \\ 5 & \mathrm{p} \mathrm{n} \\ 5 & \mathrm{p} \mathrm{n} \\ 5 & \mathrm{p} \mathrm{n} \\ 5 & \mathrm{p} \mathrm{n} \\ 5 & \mathrm{o} \mathrm{n} \\ 5 & \mathrm{p} \mathrm{n} \\ 5 & \mathrm{p} \mathrm{n} \\ 5 & \mathrm{p} \mathrm{n}\end{array}$

$m n$

$\mathrm{n} \mathrm{m}$

p n

$\mathrm{p} n$

$\mathrm{m}$

m 1

$\mathrm{m}$

m $\mathrm{m}$

m 1

$\mathrm{m} \mathrm{m}$

$\mathrm{m} \mathrm{m}$

$\mathrm{m} n$

p I

p n

$\mathrm{m} \mathrm{m}$

p n

p n

PI

P 1

n

$\mathrm{p} n$
$\mathrm{p} n$

6 on

6 on

$2 \mathrm{Cu}$

$\mathrm{m} \mathrm{u}$

o n

m n

o u

o u

o u

$\mathrm{m} \mathrm{m}$

o $n$

m u

$\mathrm{m} \mathrm{u}$

o n

o $n$

$0 \mathrm{n}$

$\mathrm{m} u$

$\mathrm{m} \mathrm{m}$
$\mathrm{Fe}$

$\mathrm{Fe}$

$\mathrm{Fe}$

$\mathrm{Fe}$

$\mathrm{Fe}$

$\mathrm{Fe}$

$\mathrm{Fe}$

$\mathrm{Fe}$

$\mathrm{Fe}$

$\mathrm{Fe}$

$\mathrm{Fe}$

$\mathrm{Fe}$

$\mathrm{Fe}$

$\mathrm{Fe}$

$\mathrm{Fe}$

$\mathrm{Fe}$

$\mathrm{Fe}$

$\mathrm{Fe}$

$\mathrm{Fe}$

$\mathrm{Fe}$

$\mathrm{Fe}$

$\mathrm{Fe}$

$\mathrm{Fe}$

$\mathrm{Fe}$

$\mathrm{Fe}$

$\mathrm{Fe}$

$\mathrm{Fe}$

$\mathrm{Fe}$

$\mathrm{Fe}$

$\mathrm{Fe}$

$\mathrm{Cu} \mathrm{Fe}$

$\mathrm{Fe}$

$\stackrel{\mathrm{Cu}}{\mathrm{Cu}}$

Fe U

$\mathrm{Fe}$

35
75,93

$\mathrm{Pb}$
$\mathrm{Pb}$
$\mathrm{Pb}$
$\mathrm{Pb}$
$\mathrm{Pb}$
$\mathrm{Pb}$
$\mathrm{Pb}$
$\mathrm{Pb}$
$\mathrm{Pb}$
$\mathrm{Pb}$
$\mathrm{Pb}$
$\mathrm{Pb}$
$\mathrm{Pb}$
$\mathrm{Pb}$
$\mathrm{Pb}$

$\mathrm{Cu}$

Ag

$\mathrm{Ba}$

$\mathrm{Ba}$

$\mathrm{Ba}$

$\mathrm{Ba} \mathrm{Cu}$

$\mathrm{Ba} \mathrm{Cu}$

$\mathrm{Ba} \mathrm{C}$

$\mathrm{Ba} \mathrm{Cu}$

$\mathrm{Ba} \mathrm{Cu}$

$\mathrm{Ba} \mathrm{Cu}$
29,98

29,98

$29,98,117$

$29,98,117$

98,122

29,98

$20,29,98,117$

98,122

$20,29,49,61,83,98,117$

$20,29,49,61,83,98,117$

$20,29,49,61,83,98,117$

$20,29,49,61,83,98,117$

$20,29,49,61,83,98,117$

$20,29,49,61,83,98,117$

$20,29,49,61,83,98,117$

$20,29,49,61,83,98,117$

$20,29,49,61,83,98,117$

$20,29,49,61,83,98,117$

$20,29,49,61,83,98,117$

$29,68,98,117$

$29,98,117$

$29,98,117$

$29,98,117$

$29,98,117$

29,98

$98,119,120$

$98,119,120$

98,119

$84,98,120$

$84,98,120$

98,119

$\mathbf{9 8 , 1 1 9 , 1 2 0}$

$30,98,119,120$

98,119

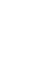


Table 1D. Inventory of metal mines and occurrences associated with the early Mesozoic basins of the Eastern United States listed according to metal association-Continued

[In column "Area number," locality is indicated by number: 0 , areas in New Hampshire north of the Hartford basin; 1, the Hartford basin and vicinity, Massachusetts; 2 , the Hartford basin and vicinity, Connecticut; 3, the Newark basin, New Jersey; 4, the Newark basin and vicinity, Pennsylvania; 5, the Gettysburg basin and vicinity, Pennsylvania; 6, the Culpeper basin, Maryland and Virginia; 7, other areas in Virginia; 8, the Davie County basin area, North Carolina; 9, the Deep River basin area, North Carolina. In the "Production" column, locality is indicated by a two-letter code: the first code letter, an $\mathrm{m}$, p, or o, indicates that the locality is a mine, prospect, or mineral occurrence, respectively; the second code letter, an l, m, n, or $u$, indicates ore production or reserves greater than 100,000 tons, between 1,000 and 100,000 tons, less than 1,000 tons, or unknown, respectively. In the column "Deposit type," deposits are indicated by number: 1, a skarn deposit; 2, a hornfels deposit; 3, a diabase-hosted vein or segregation deposit; 4, a sediment-hosted stratabound disseminated or replacement deposit; 5 , a vein deposit; 6, a placer deposit. In the "References" column, the number of the reference citation is listed in table $1 E$ ]

\begin{tabular}{|c|c|c|c|c|c|c|c|}
\hline \multirow{2}{*}{$\begin{array}{l}\text { Locality } \\
\text { number }\end{array}$} & \multirow[b]{2}{*}{ Name } & \multirow{2}{*}{\multicolumn{2}{|c|}{$\begin{array}{l}\text { Area } \\
\text { No. }\end{array}$}} & & \multirow{2}{*}{$\begin{array}{c}\text { Deposit } \\
\text { type }\end{array}$} & \multirow{2}{*}{ Metal associations } & \multirow[b]{2}{*}{ References } \\
\hline & & & & Production & & & \\
\hline
\end{tabular}

\begin{tabular}{rll}
\hline \multicolumn{3}{c}{ Pb-LEAD-principal metal-Continued } \\
26 & Unnamed Pb-Ba 2 & Massachusetts \\
27 & Unnamed Pb-Ba 1 & Massachusetts \\
28 & Manhan Lead 1 & Massachusetts \\
29 & Manhan Lead 2 & Massachusetts \\
30 & Manhan Lead 3 & Massachusetts \\
31 & Manhan Lead 4 & Massachusetts \\
32 & Manhan Lead 5 & Massachusetts \\
33 & Southampton & Massachusetts \\
34 & New mine vein & Massachusetts \\
47 & Columbus Blvd. & Connecticut \\
50 & Mattabesset River & Connecticut \\
54 & Middletown lead & Connecticut \\
103 & New Galena & Pennsylvania \\
104 & Schuylkill Falls & Pennsylvania \\
124 & Perkiomen mine & Pennsylvania \\
125 & Whim mine & Pennsylvania \\
126 & Ecton mine & Pennsylvania \\
127 & Wetherill mine & Pennsylvania \\
141 & Charlestown mine & Pennsylvania \\
142 & Wheatley mine & Pennsylvania \\
143 & Chester Co. mine & Pennsylvania \\
144 & Montgomery Co. & Pennsylvania \\
145 & SW. Chester mine & Pennsylvania \\
146 & Brookdale mine & Pennsylvania \\
147 & Phoenix mine & Pennsylvania \\
148 & Pethericks Penn & Pennsylvania \\
149 & Pennypacker mine & Pennsylvania \\
267 & Albemarle mine & Virginia \\
&
\end{tabular}

$\mathrm{Pb}$ - LEAD-accessory metal

$\begin{array}{rll}2 & \text { Will Wise mine } & \text { New Hampshire } \\ 3 & \text { Stoddard mine 1 } & \text { New Hampshire } \\ 4 & \text { Stoddard mine 2 } & \text { New Hampshire } \\ 5 & \text { Springer mine } & \text { New Hampshire } \\ 7 & \text { Pierce mine } & \text { New Hampshire } \\ 8 & \text { Streeter Hill } & \text { New Hampshire } \\ 115 & \text { Kober's mine } & \text { Pennsylvania } \\ 129 & \text { Jug Hollow mine } & \text { Pennsylvania }\end{array}$

$\begin{array}{ll}1 & \mathrm{~m} \mathrm{~m} \\ 1 & \mathrm{~m} \mathrm{~m} \\ 1 & \mathrm{~m} \mathrm{~m} \\ 1 & \mathrm{~m} \mathrm{~m} \\ 1 & \mathrm{~m} \mathrm{~m} \\ 1 & \mathrm{~m} \mathrm{~m} \\ 1 & \mathrm{~m} \mathrm{~m} \\ 1 & \mathrm{~m} \mathrm{n} \\ 1 & \mathrm{~m} \mathrm{u} \\ 2 & \mathrm{o} \mathrm{n} \\ 2 & \mathrm{~m} \mathrm{n} \\ 2 & \mathrm{~m} \mathrm{n} \\ 4 & \mathrm{~m} \\ 4 & \mathrm{o} \mathrm{n} \\ 4 & \mathrm{~m} \mathrm{~m} \\ 4 & \mathrm{~m} \mathrm{~m} \\ 4 & \mathrm{~m} \mathrm{~m} \\ 4 & \mathrm{~m} \mathrm{~m} \\ 4 & \mathrm{~m} \mathrm{n} \\ 4 & \mathrm{~m} \mathrm{~m} \\ 4 & \mathrm{~m} \mathrm{~m} \\ 4 & \mathrm{~m} \mathrm{~m} \\ 4 & \mathrm{~m} \mathrm{~m} \\ 4 & \mathrm{~m} \mathrm{~m} \\ 4 & \mathrm{~m} \mathrm{~m} \\ 4 & \mathrm{p} \mathrm{n} \\ 4 & \mathrm{~m} \mathrm{n} \\ 7 & \mathrm{~m} \mathrm{u}\end{array}$

$\begin{array}{lll}5 & \mathrm{~Pb} & \mathrm{Ba} \\ 5 & \mathrm{~Pb} & \mathrm{Ba} \\ 5 & \mathrm{~Pb} \mathrm{Ba} & \mathrm{Ag} \mathrm{Zn} \mathrm{Cu} \\ 5 & \mathrm{~Pb} \mathrm{Ba} & \mathrm{Ag} \mathrm{Zn} \mathrm{Cu} \\ 5 & \mathrm{~Pb} \mathrm{Ba} & \mathrm{Ag} \mathrm{Zn} \mathrm{Cu} \\ 5 & \mathrm{~Pb} \mathrm{Ba} & \mathrm{Ag} \mathrm{Zn} \mathrm{Cu} \\ 5 & \mathrm{~Pb} \mathrm{Ba} & \mathrm{Ag} \mathrm{Zn} \mathrm{Cu} \\ 5 & \mathrm{~Pb} \mathrm{Cu} & \mathrm{Ag} \mathrm{Zn} \mathrm{Ba} \\ 5 & \mathrm{~Pb} & \\ 5 & \mathrm{Zn} \mathrm{Pb} & \mathrm{Cu} \mathrm{Ba} \\ 5 & \mathrm{~Pb} & \mathrm{Zn} \mathrm{Ba} \\ 5 & \mathrm{~Pb} & \mathrm{Ag} \\ 5 & \mathrm{~Pb} \mathrm{Zn} & \mathrm{Ag} \mathrm{Au} \mathrm{Cu} \\ 5 & \mathrm{~Pb} & \mathrm{Zn} \\ 5 & \mathrm{~Pb} \mathrm{Cu} & \mathrm{Zn} \\ 5 & \mathrm{~Pb} \mathrm{Cu} & \mathrm{Zn} \mathrm{Ag} \\ 5 & \mathrm{~Pb} & \mathrm{Zn} \mathrm{Ag} \\ 5 & \mathrm{~Pb} & \mathrm{Cu} \mathrm{Zn} \\ 5 & \mathrm{~Pb} \mathrm{Ba} & \mathrm{Zn} \mathrm{Cu} \mathrm{Ag} \\ 5 & \mathrm{~Pb} \mathrm{Zn} & \mathrm{Cu} \mathrm{Ag} \mathrm{Mo} \\ 5 & \mathrm{~Pb} \mathrm{Zn} & \mathrm{Cu} \mathrm{Ag} \\ 5 & \mathrm{Zn} \mathrm{Pb} & \mathrm{Cu} \mathrm{Ag} \\ 5 & \mathrm{~Pb} \mathrm{Zn} & \mathrm{Cu} \mathrm{Ag} \\ 5 & \mathrm{Zn} \mathrm{Pb} & \mathrm{Cu} \mathrm{Ag} \\ 5 & \mathrm{Zn} \mathrm{Pb} & \mathrm{Ag} \mathrm{Cu} \\ 5 & \mathrm{~Pb} & \mathrm{Cu} \\ 5 & \mathrm{~Pb} & \mathrm{Ag} \\ 5 & \mathrm{Zn} \mathrm{Pb} & \mathrm{Ag}\end{array}$

$25,55,57$
$25,55,57$
25,55
25,55
25,55
25,55
25,55
$43,55,57$
56.81
47
$48,87,104$
92
$22,28,98,110,111,134$
$44,78,98$
$22,98,111,135$
$22,98,111,135$
$22,98,111,135$
$22,98,111,135$
$95,111,126$
$12,50,59,95,108,111$
$5,38,77,91,111,126$
$78,91,96,98,111,126$
$5,38,77,91,111,126$
$12,50,59,96,108,111$
$12,50,59,96,108,111$
78,98
$5,96,111$
$42,82,127$

$\begin{array}{ll}0 & \mathrm{~m} \mathrm{n} \\ 0 & \mathrm{~m} \mathrm{~m} \\ 0 & \mathrm{~m} \mathrm{~m} \\ 0 & \mathrm{~m} \mathrm{~m} \\ 0 & \mathrm{~m} \mathrm{~m} \\ 0 & \text { o n } \\ 4 & \mathrm{~m} \mathrm{u} \\ 4 & \mathrm{~m} \mathrm{~m}\end{array}$

Zn-ZINC-principal metal

$\begin{array}{rll}43 & \text { Farmington } & \text { Connecticut } \\ 47 & \text { Columbus Blvd. } & \text { Connecticut } \\ 103 & \text { New Galena } & \text { Pennsylvania } \\ 129 & \text { Jug Hollow mine } & \text { Pennsylvania } \\ 139 & \text { Phoenix. Tunnel } & \text { Pennsylvania } \\ 142 & \text { Wheatley mine } & \text { Pennsylvania } \\ 143 & \text { Chester Co. mine } & \text { Pennsylvania } \\ 144 & \text { Montgomery Co. } & \text { Pennsylvania } \\ 145 & \text { SW. Chester mine } & \text { Pennsylvania } \\ 146 & \text { Brookdale mine } & \text { Pennsylvania } \\ 147 & \text { Phoenix mine } & \text { Pennsylvania } \\ 183 & \text { Safe Harbor } & \text { Pennsylvania } \\ 255 & \text { Calverton } & \text { Virginia } \\ 263 & \text { Stevensburg } & \text { Virginia } \\ 267 & \text { Albemarle mine } & \text { Virginia }\end{array}$

$\begin{array}{ll}2 & \text { o n } \\ 2 & \text { o n } \\ 4 & \text { m l } \\ 4 & \text { m m } \\ 4 & \text { o n } \\ 4 & \text { m m } \\ 4 & \text { m m } \\ 4 & \text { m m } \\ 4 & \text { m m } \\ 4 & \text { m m } \\ 4 & \text { m m } \\ 5 & \text { o n } \\ 6 & \text { o n } \\ 6 & \text { o n } \\ 7 & \text { m u }\end{array}$

$\begin{array}{ll}\mathbf{F} & \mathrm{Ba} \mathrm{Pb} \\ \mathbf{F} & \mathrm{Ba} \mathrm{Pb} \\ \mathbf{F} & \mathrm{Ba} \mathrm{Pb} \\ \mathbf{F} & \mathrm{Ba} \mathrm{Pb} \mathrm{Cu} \\ \mathbf{F} & \mathrm{Ba} \mathrm{Pb} \\ \mathbf{F} & \mathrm{Pb} \\ \mathrm{Cu} & \mathrm{Pb} \\ \mathrm{Ba} \mathrm{Zn} & \mathrm{Cu} \mathrm{Pb}\end{array}$

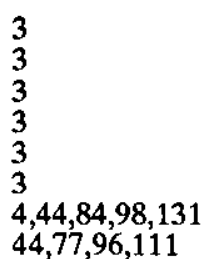

$\begin{array}{lllll}\text { o n } & 5 & \mathrm{Zu} & & 106 \\ \text { o n } & 5 & \mathrm{Zn} \mathrm{Pb} & \mathrm{Cu} \mathrm{Ba} & 47 \\ \text { m l } & 5 & \mathrm{~Pb} \mathrm{Zn} & \mathrm{Ag} \mathrm{Au} \mathrm{Cu} & 22,28,98,110,111,134 \\ \text { m m } & 5 & \mathrm{Ba} \mathrm{Zn} & \mathrm{Cu} \mathrm{Pb} & 44,77,96,111 \\ \text { o n } & 5 & \mathrm{Zn} & & 44,98 \\ \text { m m } & 5 & \mathrm{~Pb} \mathrm{Zn} & \mathrm{Cu} \mathrm{Ag} \mathrm{Mo} & 12,50,59,95,108,111 \\ \text { m m } & 5 & \mathrm{~Pb} \mathrm{Zn} & \mathrm{Cu} \mathrm{Ag} & 5,38,77,91,111,126 \\ \text { m m } & 5 & \mathrm{Zn} \mathrm{Pb} & \mathrm{Cu} \mathrm{Ag} & 78,91,96,98,111,126 \\ \text { m m } & 5 & \mathrm{~Pb} \mathrm{Zn} & \mathrm{Cu} \mathrm{Ag} & 5,38,77,91,111,126 \\ \text { m m } & 5 & \mathrm{Zn} \mathrm{Pb} & \mathrm{Cu} \mathrm{Ag} & 12,50,59,96,108,111 \\ \text { m m } & 5 & \mathrm{Zn} \mathrm{Pb} & \mathrm{Ag} \mathrm{Cu} & 12,50,59,96,108,111 \\ \text { o n } & 5 & \mathrm{Zn} \mathrm{Ba} & & 8,98 \\ \text { o n } & 4 & \mathrm{Zn} & & 45 \\ \text { o n } & 4 & \mathrm{Zn} \mathrm{Cu} & & 11 \\ \text { m u } & 5 & \mathrm{Zn} \mathrm{Pb} & \mathrm{Ag} & 42,82,127\end{array}$


Table 1D. Inventory of metal mines and occurrences associated with the early Mesozoic basins of the Eastern United States listed according to metal association-Continued

[In column "Area number," locality is indicated by number: 0 , areas in New Hampshire north of the Hartford basin; 1, the Hartford basin and vicinity, Massachusetts; 2, the Hartford basin and vicinity, Connecticut; 3, the Newark basin, New Jersey; 4, the Newark basin and vicinity, Pennsylvania; 5, the Gettysburg basin and vicinity, Pennsylvania; 6, the Culpeper basin, Maryland and Virginia; 7, other areas in Virginia; 8, the Davie County basin area, North Carolina; 9, the Deep River basin area, North Carolina. In the "Production" column, locality is indicated by a two-letter code: the first code letter, an $\mathrm{m}, \mathrm{p}$, or $\mathrm{o}$, indicates that the locality is a mine, prospect, or mineral occurrence, respectively; the second code letter, an $\mathrm{l}, \mathrm{m}, \mathrm{n}$, or $\mathrm{u}$, indicates ore production or reserves greater than 100,000 tons, between 1,000 and 100,000 tons, less than 1,000 tons, or unknown, respectively. In the column "Deposit type," deposits are indicated by number: 1 , a skam deposit; 2 , a hornfels deposit; 3 , a diabase-hosted vein or segregation deposit; 4, a sediment-hosted stratabound disseminated or replacement deposit; 5, a vein deposit; 6, a placer deposit. In the "References" column, the number of the reference citation is listed in table $1 E$ ]

\begin{tabular}{|c|c|c|c|c|c|c|c|c|}
\hline \multirow{2}{*}{$\begin{array}{l}\text { Locality } \\
\text { number }\end{array}$} & \multirow[b]{2}{*}{ Name } & \multirow[b]{2}{*}{ State } & \multirow{2}{*}{$\begin{array}{l}\text { Area } \\
\text { No. }\end{array}$} & \multirow[b]{2}{*}{ Production } & \multirow{2}{*}{$\begin{array}{c}\text { Deposit } \\
\text { type }\end{array}$} & \multicolumn{2}{|c|}{ Metal associations } & \multirow[b]{2}{*}{ References } \\
\hline & & & & & & Principal & Accessory & \\
\hline \multicolumn{9}{|c|}{$\mathrm{Zn}-\mathrm{ZINC}$-accessory metal } \\
\hline $\begin{array}{r}28 \\
29 \\
30 \\
31 \\
32 \\
33 \\
45 \\
46 \\
50 \\
104 \\
124 \\
125 \\
126 \\
127 \\
141 \\
160\end{array}$ & $\begin{array}{l}\text { Manhan Lead } 1 \\
\text { Manhan Lead } 2 \\
\text { Manhan Lead } 3 \\
\text { Manhan Lead } 4 \\
\text { Manhan Lead } 5 \\
\text { Southampton } \\
\text { Plainfield quarry } \\
\text { Cook's Gap } \\
\text { Mattabesset River } \\
\text { Schuylkill Falls } \\
\text { Perkomen mine } \\
\text { Whim mine } \\
\text { Ecton mine } \\
\text { Wetherill mine } \\
\text { Charlestown mine } \\
\text { French Creek mines }\end{array}$ & $\begin{array}{l}\text { Massachusetts } \\
\text { Massachusetts } \\
\text { Massachusetts } \\
\text { Massachusetts } \\
\text { Massachusetts } \\
\text { Massachusetts } \\
\text { Connecticut } \\
\text { Connecticut } \\
\text { Connecticut } \\
\text { Pennsylvania } \\
\text { Pennsylvania } \\
\text { Pennsylvania } \\
\text { Pennsylvania } \\
\text { Pennsylvania } \\
\text { Pennsylvania } \\
\text { Pennsylvania }\end{array}$ & $\begin{array}{l}1 \\
1 \\
1 \\
1 \\
1 \\
1 \\
2 \\
2 \\
2 \\
4 \\
4 \\
4 \\
4 \\
4 \\
4 \\
4\end{array}$ & $\begin{array}{l}\mathrm{m} \mathrm{m} \\
\mathrm{m} \mathrm{m} \\
\mathrm{m} \mathrm{m} \\
\mathrm{m} \mathrm{m} \\
\mathrm{m} \mathrm{m} \\
\mathrm{m} \mathrm{n} \\
\mathrm{on} \\
\mathrm{on} \\
\mathrm{m} \mathrm{n} \\
0 \mathrm{n} \\
\mathrm{m} \mathrm{m} \\
\mathrm{m} \mathrm{m} \\
\mathrm{m} \mathrm{m} \\
\mathrm{m} \mathrm{m} \\
\mathrm{m} \mathrm{n} \\
\mathrm{m} \mathrm{l}\end{array}$ & $\begin{array}{l}5 \\
5 \\
5 \\
5 \\
5 \\
5 \\
5 \\
4 \\
5 \\
5 \\
5 \\
5 \\
5 \\
5 \\
5 \\
1\end{array}$ & $\begin{array}{l}\mathrm{Pb} \mathrm{Ba} \\
\mathrm{Pb} \mathrm{Ba} \\
\mathrm{Pb} \mathrm{Ba} \\
\mathrm{Pb} \mathrm{Ba} \\
\mathrm{Pb} \mathrm{Ba} \\
\mathrm{Pb} \mathrm{Cu} \\
\mathrm{Pb} \\
\mathrm{Pb} \\
\mathrm{Pb} \mathrm{Cu} \\
\mathrm{Pb} \mathrm{Cu} \\
\mathrm{Pb} \\
\mathrm{Pb} \\
\mathrm{Pb} \mathrm{Ba} \\
\mathrm{Fe} \mathrm{Cu}\end{array}$ & $\begin{array}{l}\mathrm{Ag} \mathrm{Zn} \mathrm{Cu} \\
\mathrm{Ag} \mathrm{Zn} \mathrm{Cu} \\
\mathrm{Ag} \mathrm{Zn} \mathrm{Cu} \\
\mathrm{Ag} \mathrm{Zn} \mathrm{Cu} \\
\mathrm{Ag} \mathrm{Zn} \mathrm{Cu} \\
\mathrm{Ag} \mathrm{Zn} \mathrm{Ba} \\
\mathrm{Cu} \mathrm{Zn} \\
\mathrm{Zn} \mathrm{Cu} \\
\mathrm{Zn} \mathrm{Ba} \\
\mathrm{Zn} \\
\mathrm{Zn} \\
\mathrm{Zn} \mathrm{Ag} \\
\mathrm{Zn} \mathrm{Ag} \\
\mathrm{Cu} \mathrm{Zn} \\
\mathrm{Zn} \mathrm{Cu} \mathrm{Ag} \\
\mathrm{Zn} \mathrm{Co}\end{array}$ & $\begin{array}{l}25,55 \\
25,55 \\
25,55 \\
25,55 \\
25,55 \\
43,55,57 \\
106 \\
47 \\
48,87,104 \\
44,78,98 \\
22,98,111,135 \\
22,98,111,135 \\
22,98,111,135 \\
22,98,111,135 \\
95,111,126 \\
5,44,68,98,109\end{array}$ \\
\hline \multicolumn{9}{|c|}{ OTHER METALS } \\
\hline $\begin{array}{r}155 \\
239 \\
142 \\
225 \\
57 \\
39 \\
42 \\
262\end{array}$ & $\begin{array}{l}\text { Gickerville } \\
\text { Seneca Creek } \\
\text { Wheatley mine } \\
\text { Stone Jug mine } \\
\text { New Haven mine } \\
\text { New-gate Prison } \\
\text { Bristol copper } \\
\text { Mountain Run }\end{array}$ & $\begin{array}{l}\text { Pennsylvania } \\
\text { Maryland } \\
\text { Pennsylvania } \\
\text { Pennsylvania } \\
\text { Connecticut } \\
\text { Connecticut } \\
\text { Connecticut } \\
\text { Virginia }\end{array}$ & $\begin{array}{l}4 \\
6 \\
4 \\
5 \\
2 \\
2 \\
2 \\
6\end{array}$ & $\begin{array}{l}o n \\
o n \\
m m \\
m n \\
m n \\
m ~ m \\
m ~ m \\
o n\end{array}$ & $\begin{array}{l}3 \\
6 \\
5 \\
2 \\
5 \\
4 \\
5 \\
2\end{array}$ & $\begin{array}{l}\mathrm{As} \mathrm{Co} \\
\mathrm{Hg} \\
\mathrm{Pb} \mathrm{Zn} \\
\mathrm{Cu} \\
\mathrm{Ba} \\
\mathrm{Cu} \\
\mathrm{Cu} \\
\mathrm{Cu}\end{array}$ & $\begin{array}{l}\mathrm{Cu} \mathrm{Ag} \mathrm{Mo} \\
\mathrm{Au} \mathrm{Ag} \mathrm{Mo} \\
\mathrm{Cu} \mathrm{Ag} \mathrm{Sr} \\
\mathrm{Ag} \mathrm{U} \\
\mathrm{Ag} \mathrm{U} \\
\mathrm{Fe} \mathrm{U}\end{array}$ & $\begin{array}{l}44,98 \\
11 \\
12,50,59,95,108,111 \\
113 \\
32,33 b \\
47,88,89,101,128,130 \\
7,65,101,105 \\
35\end{array}$ \\
\hline
\end{tabular}


Table 1E. References cited in table 1A-D

[Refer to the following "Deposit Bibliography" for complete citations]

\begin{tabular}{|c|c|c|c|}
\hline Number & Reference & Number & Reference \\
\hline 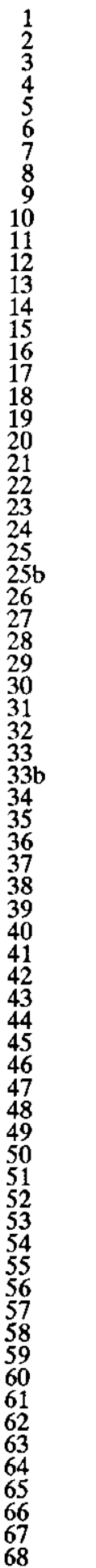 & 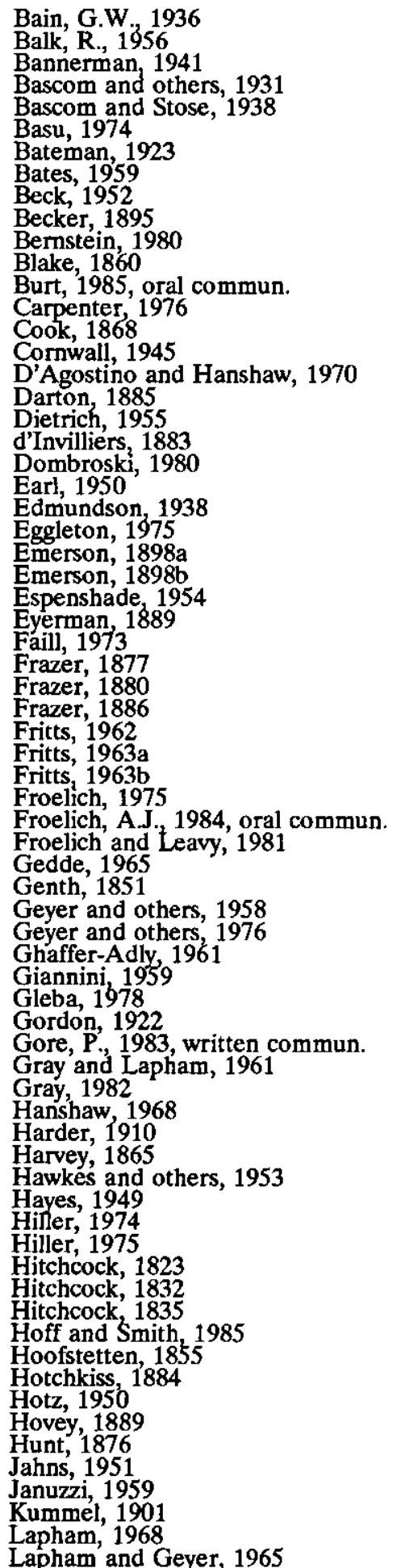 & $\begin{array}{c}69 \\
70 \\
71 \\
72 \\
73 \\
73 \mathrm{~b} \\
74 \\
75 \\
76 \\
77 \\
78 \\
79 \\
80 \\
81 \\
82 \\
83 \\
84 \\
85 \\
86 \\
87 \\
88 \\
89 \\
90 \\
91 \\
92 \\
93 \\
94 \\
95 \\
96 \\
97 \\
98 \\
99 \\
100 \\
101 \\
102 \\
103 \\
104 \\
105 \\
106 \\
107 \\
108 \\
109 \\
110 \\
111 \\
112 \\
113 \\
114 \\
115 \\
116 \\
117 \\
118 \\
119 \\
120 \\
121 \\
122 \\
123 \\
124 \\
125 \\
126 \\
127 \\
128 \\
129 \\
130 \\
131 \\
132 \\
133 \\
134 \\
135 \\
136\end{array}$ & 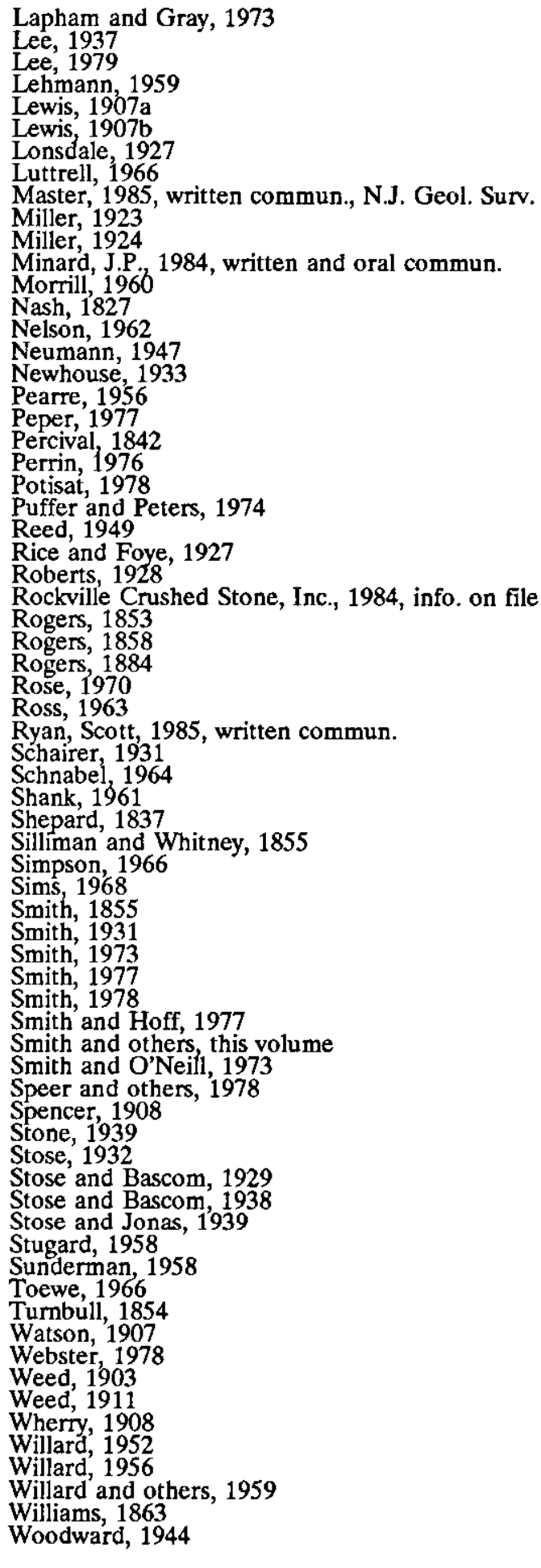 \\
\hline
\end{tabular}




\section{Deposit Bibliography}

[References are cited in table $1 A-D$ by reference number, which is listed in table $1 E$ with author name and date of publication]

Bain, G.W., 1936, Mechanics of metasomatism: Economic Geology, v. 31, no. 5, p. 505-526.

Balk, R., 1956, Bedrock geology of the Massachusetts portion of the Bernardston quadrangle, Massachusetts-Vermont: U.S. Geological Survey Geologic Quadrangle Map GQ-90.

Bannerman, H.M., 1941, The fluorite deposits of Cheshire County, N.H.: New Hampshire State Planning and Development Commission, New Hampshire Mineral Resource Survey, Part V, 11 p.

Bascom, F., and Stose, G.W., 1938, Geology and mineral resources of the Honeybrook and Phoenixville quadrangles, Pennsylvania: U.S. Geological Survey Bulletin 891, $145 \mathrm{p}$.

Bascom, F., Wherry, E.T., Stose, G.W., and Jonas, A.I., 1931, Geology and mineral resources of the QuakertownDoylestown District, Pennsylvania and New Jersey: U.S. Geological Survey Bulletin 828, 62 p.

Basu, D., 1974, Genesis of the Grace Mine magnetite deposit, Morgantown, Berks County, southeastern Pennsylvania: unpublished Ph.D. thesis, Lehigh University, 317 p.

Bateman, A.M., 1923, Primary chalcocite: Bristol Copper Mine, Connecticut: Economic Geology, v. 18, no. 2, p. 122-166.

Bates, R.O., 1959, An application of statistical analysis to exploration for uranium on the Colorado Plateau: Economic Geology, v. 54, p. 449-466.

Beck, H.H., 1952, The minerals of Lancaster County, 3d edition: Science Press, 13 p.

Becker, G.F., 1895, Reconnaissance of gold fields of the southern Appalachians: U.S. Geological Survey 16th Annual Report, Part 3, p. 251-331.

Bernstein, L.R., 1980, Minerals of the Washington, D.C. area: Maryland Geological Survey, Education Series No. 5, 148 p.

Blake, W.P., 1860, The Wheatley silver lead mines: Mining Magazine and Journal of Geology, 2d Series, v. 1, p. $411-418$

Carpenter, P.A. III, 1976, Metallic mineral deposits of the Carolina Slate Belt, North Carolina: North Carolina Department of Natural and Economic Resources, Bulletin $84,166 \mathrm{p}$.

Cook, G.H., 1868, Geology of New Jersey: New Jersey Geologjcal Survey, $900 \mathrm{p}$.

Cornwall, H.R., 1945, The Arlington Copper Mine, North Arlington, New Jersey: U.S. Geological Survey Strategic Minerals Investigations Report (unnumbered, 1943), 6 p.

D'Agostino, J.P., and Hanshaw, P.M., 1970, Malachite- and specularite-bearing Triassic sandstone localities near Chantilly, Virginia: U.S. Geological Survey Professional Paper 700-C, p. C103-C106.

Darton, N.H., 1885, On the occurrence of native silver in New Jersey: American Journal of Science, 3d series, v. 30, p. 80-81.

Dietrich, R.V., 1955, Additions to Virginia mineral localities: Virginia Polytechnical Institute Bulletin, Engineering Experiment Station, Series 105, 30 p.

d'Invilliers, E.V., 1883, The geology of the South Mountain belt of Berks County: Pennsylvania Geological Survey (2d), Report DDD, 441 p.
Dombroski, D.R., Jr., 1980, A geological and geophysical investigation of concealed contacts near an abandoned barite mine, Hopewell, New Jersey: unpublished M.S. thesis, Rutgers University, New Jersey, 33 p.

Earl, K.M., 1950, Investigation of Perkiomen Creek copper deposits, Montgomery County, Pennsylvania: U.S. Bureau of Mines, Report of Investigations 4666, 13 p.

Edmundson, R.S., 1938, Barite deposits of Virginia: Virginia Division of Mineral Resources, Bulletin 53, 85 p.

Eggleton, R.E., 1975, Preliminary geologic map of the Herndon quadrangle, Virginia: U.S. Geological Survey Open-File Report 75-386.

Emerson, B.K., 1898a, Holyoke Folio: U.S. Geological Survey Geologic Atlas No. 50, 13 p.

-1898b, Geology of old Hampshire County, Massachusetts, comprising Franklin, Hampshire, and Hampden Counties: U.S. Geological Survey Monograph 29, 790 p.

Espenshade, G.H., 1954, Geology and mineral deposits of the James River-Roanoke River manganese district, Virginia: U.S. Geological Survey Bulletin 1008, 155 p.

Eugster, H.P., and Chou, I-Ming, 1979, A model for the deposition of Cornwall-type magnetite deposits: Economic Geology, v. 74, no. 4, p. 763-774.

Eyerman, J., 1889, Mineralogy of Pennsylvania, Part I: Easton, Pennsylvania, n.p.

Faill, R.T., 1973, Tectonic development of the Triassic NewarkGettysburg basin in Pennsylvania: Geological Society of America Bulletin, v. 84, p. 725-740.

Frazer, P., Jr., 1877, Regarding some Mesozoic ores: American Philosophical Society, Proceedings, v. 16, p. 651-655.

1880, The geology of Lancaster County: Pennsylvania Geological Survey (2nd), Report of Progress in 1877, Report CCC, 350 p.

1886, Sketch on the geology of York County, Pennsylvania: American Philosophical Society Proceedings, v. 23, p. 391-410 (map).

Fritts, C.E., 1962, The barite mines of Cheshire: The Cheshire Historical Society, Cheshire, Connecticut.

1963a, Bedrock geology of the Mount Carmel quadrangle, Connecticut: U.S. Geological Survey Geologic Quadrangle Map GQ-199.

1963b, Geologic Map of the Southington quadrangle, Connecticut: U.S. Geological Survey Geologic Quadrangle Map GQ-200.

Froelich, A.J., 1975, Map showing mineral resources of Montgomery County, Maryland: U.S. Geological Survey Miscellaneous Investigations Map I-920-E.

Froelich, A.J., and Leavy, B.D., 1981, Map showing mineral resources of the Culpeper basin, Northern Virginia and Maryland; availability and planning for future needs: U.S. Geological Survey Miscellaneous Investigations Map I-1313-B.

Gedde, 'R.W., 1965, Geophysical investigation of a magnetite deposit, Chester County, Pennsylvania: unpublished M.S. thesis, Pennsylvania State University, 59 p.

Genth, F.A., 1851, Geological Report, in First report of the Board of Directors and the Superintendent of the Chester County Mining Company: Philadelphia, King and Baird, p. 19-28. 
Geyer, A.R., Gray, C., McLaughlin, D.B., and Moseley, J.R., 1958, Geology of the Lebanon quadrangle: Pennsylvania Geological Survey, 4th series, Geologic Atlas $167 \mathrm{C}$.

Geyer, A.R., Smith, R.C. II, and Barnes, J.H., 1976, Mineral collecting in Pennsylvania: Pennsylvania Geological Survey, General Geology Report 33, 260 p.

Ghaffer-Adly, R., 1961, A detailed gravity survey in the Triassic basin, north Chester County, Pennsylvania: M.S. thesis, The Pennsylvania State University.

Giannini, W.F., 1959, A study of the lead-zinc deposit near Faber, Virginia: unpublished M.S. thesis, University of Virginia.

Gleba, P., 1978, Massachusetts mineral and fossil localities: Cambridge, Massachusetts, Krueger Enterprises, Inc.

Gordon, S.G., 1922, The mineralogy of Pennsylvania: Special Publication No. 1, Academy of Natural Science, Philadelphia (reprinted 1973 by Friends of Mineralogy, Region III).

Gray, C., and Lapham, D.M., 1961, Guide to the geology of Cornwall, Pennsylvania: Pennsylvania Geological Survey, Bulletin G35, 18 p.

Gray, N.H., 1982, Copper occurrences in the Hartford basin of northern Connecticut, in Joesten, R., and Quarrier, S.S., eds., Guidebook for fjeldtrips in Connecticut and southcentral Massachusetts: New England Intercollegiate Geological Conference, 74th Annual Meeting, p. 195-211.

Hanshaw, P.M., 1968, Bedrock geology of the Meriden quadrangle, New Haven, Hartford, and Middlesex Counties, Connecticut: U.S. Geological Survey Geologic Quadrangle Map GQ-738.

Harder, E.C., 1910, Structure and origin of the magnetite deposits near Dillsburg, York County, Pennsylvania: Economic Geology, v. 5, p. 599-622.

Harvey, J., 1865, First annual report of the New York and Boston Silver Lead Mining Company: A.A. Moser, Stationer (New York).

Hawkes, H.E., Wedow, H., and Balsley, J.R., 1953, Geologic investigation of the Boyertown magnetite deposits in Pennsylvania: U.S. Geological Survey Bulletin 995-D, p. 135-149.

Hayes, W.H., 1949, The Bridgewater Copper Mine from the collector's standpoint: Rocks and Minerals, v. 24, p. 27-29.

Hiller, J., 1974, Connecticut mines and minerals: published by the author, Waterbury, Connecticut., $61 \mathrm{p}$.

1975, Massachusetts mines and minerals: published by the author, Stratford, Connecticut., $51 \mathrm{p}$.

Hitchcock, E., 1823, A sketch of the geology, mineralogy, and scenery of the regions contiguous to the River Connecticut; with a geological map and drawings of organic remains; and occasional botanical notices, Part II, Simple minerals: American Journal of Science, v. 6, p. 201-236.

-1832, Report on the geology of Massachusetts: American Journal of Science and Arts, v. 22, no. 1, p. 1-70.

-1835 , Report on the geology, mineralogy, botany and zoology of Massachusetts: Amherst, p. 68-74.

Hoff, D.T., and Smith, R.C., II, 1985, An Adams County copper-gold mine, doomed to failure: Pennsylvania Geology, v. 16, no. 6, p. 13-16.

Hoofstetten, C., 1855, in Wheatley, C.M., ed., Statement of the Pennsylvania Land Company: T.K. and P.G. Collins, Philadelphia.
Hotchkiss, J., 1884, The copper ores of Loudoun County, Virginia: The Virginias, v. 5, no. 12, p. 192.

Hotz, P.E., 1950, Diamond-drill exploration of the Dillsburg magnetite deposits, York County, Pennsylvania: U.S. Geological Survey Bulletin 969-A, 27 p.

Hovey, E.O., 1889, Observations on some of the trap ridges of the East Haven-Branford Region: American Journal of Science, 3d Series, v. 38, p. 361-383.

Hunt, T.S., 1876, A new ore of copper and its metallurgy: American Institute of Mining Engineers, Transactions, v. 4, p. 325-328.

Jahns, R.H., 1951, Surficial geology of the Mount Toby quadrangle, Massachusetts: U.S. Geological Survey Geologic Quadrangle Map GQ-9.

Januzzi, R.E., 1959, The minerals of western Connecticut and southeastern New York State: Danbury, Connecticut, The Mineralogical Press.

Kummel, H.B., 1901, Mining industry of New Jersey: New Jersey Geological Survey, Annual Report of the State Geologist for 1900, p. 197-213.

Lapham, D.M., 1968, Triassic magnetite and diabase at Cornwall, Pennsylvania, in Ridge, J.D., ed., Ore deposits of the United States 1933-1967: v. 1, American Institute of Mining and Metallurgical Engineers, p. 73-94.

Lapham, D.M., and Geyer, A.R., 1965, Mineral collecting in Pennsylvania, 2d ed.: Pennsylvania Geological Survey, 4th Series, Bulletin G-33, 148 p.

Lapham, D.M., and Gray, C., 1973, Geology and origin of the Triassic magnetite deposit and diabase at Cornwall, Pennsylvania: Pennsylvania Topographic and Geologic Survey, 4th Series, Bulletin M-56.

Lee, K.Y., 1979, Triassic stratigraphy in the northern part of the Culpeper basin, Virginia and Maryland: U.S. Geological Survey Bulletin 1422-C, C1-C17.

Lee, O.I., 1937, Ye ancient copper mine of Arent Schuyler: Rocks and Minerals, v. 12, p. 99-109.

Lehmann, E.P., 1959, Bedrock geology of the Middletown Quadrangle: Connecticut Geological Survey Quadrangle Report No. 8, 34 p.

Lewis, J.V., 1907a, Copper deposits of the New Jersey Triassic: Economic Geology, v. 2., p. 242-257.

1907b, The Newark (Triassic) copper ores of New Jersey: New Jersey Geological Survey, Annual Report of the State Geologist, 1906, p. 131-164.

Lonsdale, J.T., 1927, Geology of the gold-pyrite belt of the northeastern Piedmont, Virginia: Virginia Geological Survey Bulletin 30, $110 \mathrm{p}$.

Luttrell, G.W., 1966, Base- and precious-metal and related ore deposits of Virginia: Virginia Division of Mineral Resources, Mineral Resource Report 7, 167 p.

Miller, B.L., 1923, Lead and zinc ores near Phoenixville, Chester County, Pennsylvania: Pennsylvania Geological Survey, 4th Series, Progress Report 67.

1924, Lead and zinc ores of Pennsylvania: Pennsylvania Geological Survey, 4th Series, Bulletin M-5, 91 p.

Morrill, P., 1960, New Hampshire mines and mineral localities, 2d edition: Dartmouth College Museum, Hanover, New Hampshire, 46 p.

Nash, A., 1827, Notices of lead mines and veins of Hampshire County, Massachusetts and the geology and mineralogy 
of that region: American Journal of Science and Arts, v. XII, Article IX, p. 258.

Nelson, W.A., 1962, Geology and mineral resources of Albemarle County: Virginia Division of Mineral Resources, Bulletin 77, 92 p.

Neumann, G.L., 1947, Investigation of the Dillsburg magnetite deposits, York County, Pennsylvania: U.S. Bureau of Mines Report of Investigations 4145, 7 p.

Newhouse, W.H., 1933, Mineral zoning in the New JerseyPennsylvania-Virginia Triassic area: Economic Geology, v. 28 , p. $613-633$.

Pearre, N.C., 1956, Mineral deposits and occurrences in Massachusetts and Rhode Island, exclusive of clay, sand and gravel, and peat: U.S. Geological Survey Mineral Investigations Resource Map MR-4.

Peper, J.D., 1977, Bedrock geologic map of the Hampden quadrangle, Massachusetts and Connecticut: U.S. Geological Survey Geologic Quadrangle Map GQ-1368.

Percival, J.G., 1842, Report on the geology of the State of Connecticut: Osborn and Baldwin, New Haven, 495 p.

Perrin, J.D., 1976, Geology of the Newgate Prison Mine, East Granby, Connecticut: unpublished M.S. thesis, University of Connecticut.

Potisat, S., 1978, Copper and uranium deposits in red beds of the Connecticut Valley: unpublished M.S. thesis, Wesleyan University, 123 p.

Puffer, J.H., and Peters, J.J., 1974, Magnetite veins in diabase of Laurel Hill, New Jersey: Economic Geology, v. 69, p. 1294-1299.

Reed, D.F., 1949, Investigation of Pickering Creek lead-zinc deposits, Chester County, Pennsylvania: U.S. Bureau of Mines, Report of Investigations 4451, 11 p.

Rice, W.N., and Foye, W.G., 1927, Geology of Middletown, Connecticut and vicinity: Connecticut Geological and Natural History Survey, Bulletin 41, 137 p.

Roberts, J.K., 1928, The geology of the Virginia Triassic: Virginia Geological Survey Bulletin 29, 205 p.

Rogers, H.D., 1853, Report on the Wheatley and Brookdale Mines, Chester County, Pennsylvania: Mining Magazine, v. 1, p. 375-387.

1858, The geology of Pennsylvania: J.B. Lippincott and Company, Philadelphia, 815 p.

Rogers, W.B., 1884, A reprint of annual reports and other papers on the geology of the Virginias: D. Appleton and Company, New York, 832 p.

Rose, A.W., 1970, Atlas of Pennsylvania's mineral resources, Part 3: Metal mines and occurrences in Pennsylvania: Pennsylvania Geological Survey Bulletin M-50, 14 p.

Ross, H.P., 1963, Detailed electrical surveys in the Triassic basin, north Chester County, Pennsylvania: unpublished M.S. thesis, The Pennsylvania State University.

Schairer, J.F., 1931, The Minerals of Connecticut: Connecticut Geological and Natural History Survey Bulletin 51 .

Schnabel, R.W., 1964, Bedrock geologic map of the Windsor Locks quadrangle, Hartford County, Connecticut: U.S. Geological Survey Geologic Quadrangle Map GQ-388.

Shank, J.C., 1961, A detailed magnetic survey in the Triassic basin, North Chester County, Pennsylvania: unpublished M.S. thesis, The Pennsylvania State University.
Shepard, C.U., 1837, A report on the geological survey of Connecticut: Connecticut Geological Survey Report, New Haven, Connecticut, 188 p.

Silliman, B., Jr., and Whitney, J.D., 1855, Notice of the geological position and character of the copper mines at Bristol, Connecticut: American Journal of Science, v. 20, p. 361-368.

Simpson, H.E., 1966, Bedrock geology of the New Britain quadrangle, Connecticut: U.S. Geological Survey Geologic Quadrangle Map GQ-494.

Sims, S.J., 1968, The Grace mine magnetite deposit, Berks County, Pennsylvania, in Ridge, J.D., ed., Ore deposits of the United States 1933-1967, v. 1: American Institute of Mining and Metallurgical Engineers, p. 108-124.

Smith, J.L., 1855, Re-examination of American minerals, Part $\mathrm{V}$-The minerals of the Wheatley mine in Pennsylvania: American Journal of Science and Arts, v. 20, 2d Series, p. 242-253.

Smith, L.L., 1931, Magnetite deposits of French Creek, Pennsylvania: Pennsylvania Geological Survey, 4th Series, Bulletin $\mathrm{M}-14,52 \mathrm{p}$.

Smith, R.C., II, 1973, Geochemistry of Triassic diabase from southeastern Pennsylvania: Ph.D. thesis, The Pennsylvania State University, 262 p.

1977, Zinc and lead occurrences in Pennsylvania: Pennsylvania Geological Survey, Mineral Resource Report 72, 318 p.

1978, The mineralogy of Pennsylvania, 1966-1975: Friends of Mineralogy, Pennsylvania Chapter, Special Publication No. 1, 304 p.

Smith, R.C. II, and Hoff, D.T., 1977, Newly discovered minerals at Stone Jug copper prospect, Adams County: Pennsylvania Geology, v. 8, no. 5, p. 14-16.

Smith, R.C., II, and O'Neill, B.J., 1973, A new Triassic copper occurrence at Rossville, Pennsylvania: Pennsylvania Geology, v. 4 , no. 1, p. $6-7$.

Speer, J.A., Craig, J.R., and Hill, R.J., 1978, The "Cobaltite" crystals from the Kibblehouse quarry: Rocks and Minerals, v. 53 , no. 3 , p. $130-134$.

Spencer, A.C., 1908, Magnetite deposits of the Cornwall type in Pennsylvania: U.S. Geological Survey Bulletin 359, 102 p.

Stone, R.W., 1939, The minerals of PennsylvaniaNon-metallic minerals: Pennsylvania Geological Survey, 4th Series, Bulletin M-18-C, 49 p.

Stose, G.W., 1932, Geology and mineral resources of Adams County, Pennsylvania: Pennsylvania Geological Survey, 4th Series, Bulletin $\mathrm{C}-1,153 \mathrm{p}$.

Stose, G.W., and Bascom, F., 1929, Fairfield-Gettysburg, Pennsylvania, folio: U.S. Geological Survey Folio 225.

1938, Geology and mineral resources of the Honeybrook and Phoenixville quadrangles, Pennsylvania: U.S. Geological Survey Bulletin 891.

Stose, G.W., and Jonas, A.I., 1939, Geology and mineral resources of York County, Pennsylvania: Pennsylvania Geological Survey, 4th Serjes, Bulletin C-67, 199 p.

Stugard, F., Jr., 1958, Pegmatites of the Middletown area, Connecticut: U.S. Geological Survey Bulletin 1042-Q.

Sunderman, H.C., 1958, Geology and mineral resources of the Scottsville Triassic basin, Virginia: Virginia Division of Mineral Resources, Open-File Report, 58 p. 
Toewe, E.C., 1966, Geology of the Leesburg quadrangle, Virginia: Virginia Division of Mineral Resources, Report of Investigations 11, $52 \mathrm{p}$.

Turnbull, L., 1854, A visit to the lead and copper mines of Chester County, Pennsylvania: Journal of the Franklin Institute, 3d Series, v. 27, p. 52-54.

Watson, T.L., 1907, Mineral resources of Virginia: Virginia Jamestown Exposition Commission, Lynchburg, Virginia.

Webster, B., 1978, Mineral collector's field guide, Connecticut: E.R. Webster, Jr.

Weed, W.H., 1903, Copper deposits of New Jersey: New Jersey Geological Survey, Annual Report of the State Geologist, 1902 , p. $125-140$.

1911, Copper deposits of the Appalachian States: U.S. Geological Survey Bulletin 455, 166 p.

Wherry, E.T., 1908, The Newark copper deposits of southeastern Pennsylvania: Economic Geology, v. 3, p. 726-738.
Willard, B., and others, 1959, Geology and mineral resources of Bucks County, Pennsylvania: Pennsylvania Geological Survey, Bulletin C-9, 243 p.

Willard, M.E., 1952, Bedrock geology of the Greenfield quadrangle, Massachusetts: U.S. Geological Survey Geologic Quadrangle Map GQ-20.

1956, Bedrock geology of the Williamsburg quadrangle, Massachusetts: U.S. Geological Survey Geologic Quadrangle Map GQ-85.

Williams, C.P., 1863, A stock prospectus of the Perkiomen Mining Company, Philadelphia.

Woodward, H.P., 1944, Copper mines and mining in New Jersey: New Jersey Department of Conservation and Development, Geologic Series, Bulletin 57, 156 p.

\title{
BASE AND PRECIOUS METALS ASSOCIATED WITH DIABASE IN THE NEWARK, GETTYSBURG, AND CULPEPER BASINS OF THE EASTERN UNITED STATES-A REVIEW
}

\author{
Gilpin R. Robinson, Jr.
}

\section{Abstract}

Numerous hydrothermal base- and precious-metal occurrences are associated with Jurassic intrusions and adjacent thermally metamorphosed rocks in and near the early Mesozoic basins of the Eastern United States. Information on the geologic and geochemical characteristics of these occurrences has been used to classify them into three types of deposits:

1. Magnetite skarn/replacement deposits (Fe; accessory $\mathrm{Cu}, \mathrm{Co}, \mathrm{Au}$, and $\mathrm{Ag}$ ).

2. Hornfels copper deposits (Cu; accessory $\mathrm{Au}, \mathrm{Mo}$, and $\mathrm{Ag}$; minor $\mathrm{Bi}$ ).

3. Diabase-hosted vein and segregation deposits (minor $\mathrm{Cu}, \mathrm{Co}$, and $\mathrm{As}$; trace $\mathrm{Ag}, \mathrm{Au}$, and $\mathrm{Pd}$ ).

Anomalous concentrations of precious metals are present in some of the occurrences, and some of these may have resource potential for precious metals. In particular, the resource potential of gold in sulfide-rich portions of magnetite skarn deposits and hornfels copper deposits and platinum group elements in diabase-hosted vein and segregation deposits needs to be further evaluated.

Geologic factors considered favorable for controlling such deposits are voluminous diabase sheets with late-stage granophyric or ferrogabbro differentiates and extensive frac- tured and altered diabase-carbonate rock or diabasecalcareous hornfels contacts associated with positive magnetic anomalies.

\section{INTRODUCTION}

Many of the known base- and precious-metal occurrences in the early Mesozoic basins of the Eastern United States are associated with diabase intrusions within and bordering the basins. Although the occurrences described here are currently subeconomic, many are enriched in base and precious metals that may have resource potential in some cases. These deposits are of hydrothermal origin and are associated with alteration zones bordering intrusions of diabase and its differentiates. The implication is that the intrusions were not only important sources of heat but of metals and hydrothermal fluids in some cases. Information on the geologic and geochemical characteristics of the occurrences has been used to classify them into three types of deposits with both a spatial and temporal igneous association: (1) magnetite skarn/replacement deposits; (2) hornfels copper deposits; and (3) diabase-hosted vein deposits. Most of the occurrences are located in and near the Gettysburg 
and Newark basins in Pennsylvania; these locations are shown in figure 1. Summary information for each deposit is given in table 1 .

\section{MAGNETITE SKARN/REPLACEMENT DEPOSITS}

The magnetite skarn deposits are the most common, largest, economically significant, and intensively studied of the deposits associated with the early Mesozoic basins in the Eastern United States. Of the 68 deposits of this type in Pennsylvania listed in table $1 B, 12$ have a history of ore production exceeding 100,000 tons of ore. Three mines (Cornwall, Grace, and French Creek) and one district (Dillsburg) had ore production greatly in excess of 100,000 tons. At the Cornwall deposits, ore production exceeded 100 million tons. At the Grace mine, ore production was approximately 50 million tons (Smith and others, this volume), and the ore body itself is estimated to contain between 60 (Smith, 1977 , p. 271) and 100 (Rose, 1970) million tons of ore. Mining began at Cornwall in the mid-1700's and continued at the Cornwall and Grace mines into the 1970's. The deposits were mined chiefly for magnetite iron ore, but byproduct $\mathrm{Cu}, \mathrm{Ag}, \mathrm{Au}, \mathrm{Co}, \mathrm{S}$, and crushed limestone aggregate were recovered locally (Lapham, 1968). The deposits are also locally enriched in $\mathrm{Ni}$ and As (Lapham, 1968; Smith and others, this volume).

The magnetite skarn deposits are metasomatic replacements of carbonate rocks adjacent to sheets and dikes of Jurassic diabase. Each major diabase sheet in the Gettysburg and Newark basins of Pennsylvania is associated with at least one important magnetite skarn deposit (fig. $1 A, B)$. These deposits were classified by Spencer $(1908$, p. 10) as "Cornwall type" after the large deposit of this type at Cornwall, Pennsylvania, and were considered by Lindgren (1933, p. 696) to typify the pyrometasomatic class of ore deposits. A number of studies have been made of the Cornwall deposit (Hickok, 1933; Lapham, 1968; Lapham and Gray, 1973) and of the Grace mine (Morgantown) deposits (Sims, 1968; Basu, 1974). Genetic models of these deposits have been prepared by Eugster and Chou (1979) and Rose and others (1985).

\section{Commodities}

Iron produced from magnetite is the principal commodity of the magnetite skarn deposits, although byproduct $\mathrm{Cu}, \mathrm{Ag}, \mathrm{Au}$, and $\mathrm{Co}$ have also been recovered. At one time, the Cornwall deposit was the major domestic source of $\mathrm{Co}$, and considerable amounts of $\mathrm{Au}$ and Ag were recovered (Lapham and Gray, 1973). Typical ore consists of massive magnetite containing trace amounts of pyrite, chalcopyrite, sphalerite, and other silicate and sulfide minerals. The byproduct commodities listed above are all associated with sulfide mineral phases in the ore. Analyses for $\mathrm{Cu}, \mathrm{Ni}, \mathrm{Co}, \mathrm{Au}$, and $\mathrm{Ag}$ are given for some representative rocks, ores, and sulfide mill concentrate samples from selected deposits of the magnetite skarn type in table 2. Representative ore and rock samples from these deposits generally contain a few tenths of a percent $\mathrm{Cu}$, hundreds of $\mathrm{ppm} \mathrm{Ni}$ and $\mathrm{Co}$, 0.1 to $0.2 \mathrm{ppm} \mathrm{Au}$, and 1 to $5 \mathrm{ppm} \mathrm{Ag}$. Sulfide concentrates may be as much as $3 \mathrm{ppm} \mathrm{Au}$ and $18 \mathrm{ppm} \mathrm{Ag}$ (table 2). Sulfide minerals typically make up about 3 to 6 percent of the ore, but as the mining target was iron ore (magnetite), sulfide-rich areas may have been avoided during mine development. These magnetite ores are now considered uneconomic as iron ores, but $\mathrm{Au}, \mathrm{Ag}, \mathrm{Co}$, and $\mathrm{Cu}$ may be economically recovered where local sulfideenriched segregations occur. These deposits may warrant further investigation, particularly of sulfide-rich areas.

\section{Geologic Setting}

These magnetite skarn deposits are metasomatic replacements of carbonate rocks adjacent to intrusive diabase bodies. The large magnetite skarn deposits are preferentially associated with tholeiitic diabase sheets of the high-titanium, quartz-normative or York Haven composition type (Smith and Rose, 1972; Smith and others, 1975) that typically occurs in 60- to 600 -m-thick sheetlike intrusive bodies (Hotz, 1952; Smith and others, 1975; Froelich and Gottfried, 1985). Most of the deposits are localized along the margin of the Mesozoic basin near the bounding fault where the diabase sheets are in contact with pre-Mesozoic carbonate units; however, small deposits within the basin in the Dillsburg and Boyertown districts (Pennsylvania, fig. 1) replace Triassic limestone and limestone conglomerate (Hotz, 1950; Rose, 1970).

Lapham and Gray (1973) noted the following characteristic features of magnetite skarn deposits:

1. Ore is generally, but not everywhere, above diabase sheets.

2. Intrusions of granophyre and ferrogabbro are spatially associated with some ore bodies, as in the Dillsburg district, but do not occur near ore bodies or ore channels in most other deposits.

3. Diabase chill margins adjacent to ore are hydrothermally altered; at places magnetite- and sulfidebearing veins cut diabase.

4. Chlorite, actinolite, sulfides, and trace cations (Ag, $\mathrm{Au}, \mathrm{Ni}, \mathrm{Co}$ ) are closely associated.

The following discussion describes these features in more detail. 


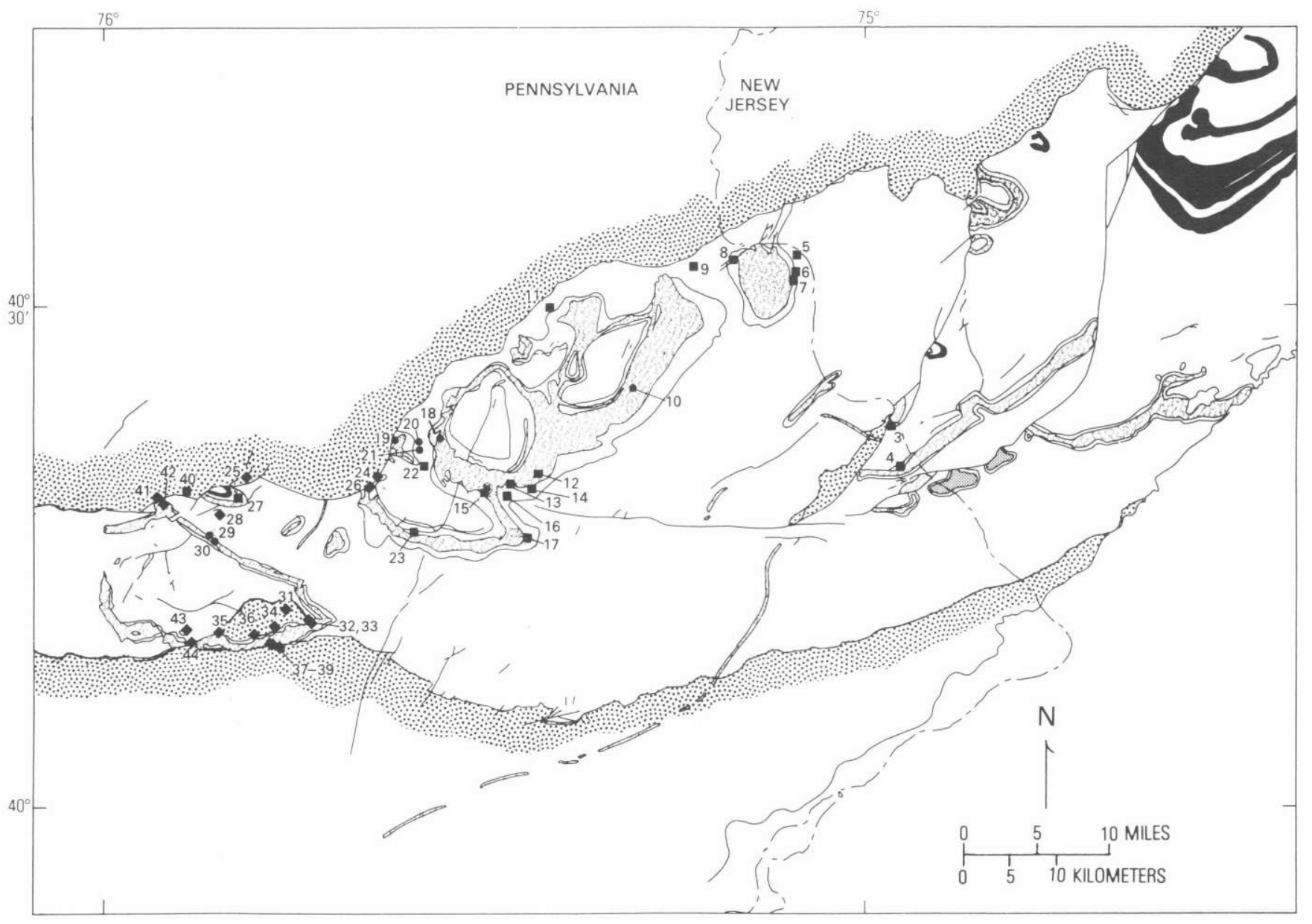

$A$

Figure 1. Maps showing the distribution of mines, prospects, and mineral occurrences associated with igneous and thermally altered rocks in the Newark, Gettysburg, and Culpeper early Mesozoic basins of New Jersey, Pennsylvania, Maryland, and Virginia. The distribution of basalt flows, diabase bodies of the York Haven type, diabase bodies of the Rossville type, and large ferrogabbro and granophyre bodies is shown by pattern. The definition of Rossville and York Haven diabase chemical types and the distribution of these chemical types and granophyre bodies are taken from Smith and others (1975) as modified by Froelich (1986, written commun.) for Pennsylvania and Froelich (1987, written commun.) for Virginia. The distribution of basalt flows is indicated by the solid black pattern. The distribution of diabase bodies of the York Haven type is indicated by the mottled pattern. The distribution of diabase bodies of the Rossville type is indicated by the horizontal ruled pattern. The distribution of large ferrogabbro and granophyre bodies is

The relationship of ore to the diabase is variable. The ore zones in the large deposits and many small deposits are located above the diabase body, as at the Cornwall and Grace mines, but is beneath the diabase at other small deposits. At most deposits, the ore zone is adjacent to diabase or is localized in a particular sedimentary unit that is laterally intersected by the diabase. indicated by the fine stippled pattern. The solid line surrounding the diabase bodies identifies the approximate outer limit of thermally altered rock surrounding the intrusive bodies. The outline of the early Mesozoic basins is indicated by solid line. The basin margins are predominantly controlled by fault contacts, although portions of the easternmost and southeasternmost borders of these basins are unconformities. Triassic and Jurassic sedimentary rocks within the basins are unpatterned; however, pre-Mesozoic rocks within the basins and surrounding the basin areas are indicated by the coarse stippled pattern. Symbols used are as follows: $\bullet$, magnetite skarn; घ, hornfels copper; and 0 , diabase-hosted vein deposits. Numbers adjacent to the deposit symbol indicate the deposit number given in table 1. $A$, Map of the Newark basin and vicinity, Pennsylvania and New Jersey. $B$, Map of the Gettysburg basin and vicinity, Pennsylvania, and Maryland. $C$, Map of the Culpeper basin and vicinity, Virginia and Maryland.

However, the ore-bearing horizon at some deposits is separated from diabase by meters of gneiss, shale, or sandstone (Spencer, 1908; Rose and others, 1985).

The carbonate host rock for the skarn mineralization is apparently not restricted to a specific stratigraphic unit or lithologic type. The host rock may be Cambrian shaly limestone with dolomitic interbeds as at the Corn- 


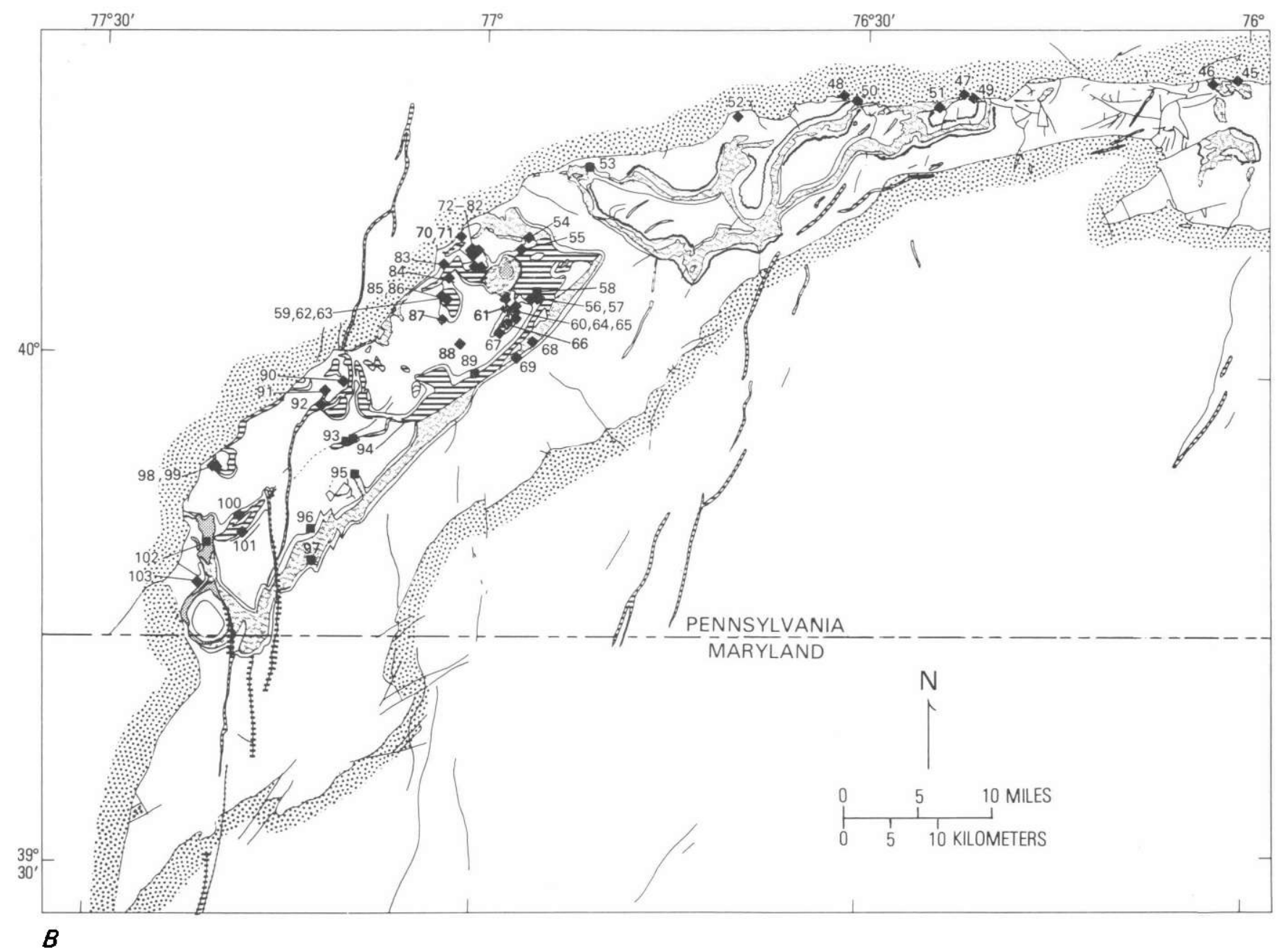

Figure 1. Continued.

wall (Lapham and Gray, 1972) and Grace mines (Sims, 1968); graphitic marble in Precambrian gneiss as at French Creek (Smith, 1931); Cambrian dolomite as at the Fritz Island mines (Spencer, 1908; Hotz, 1950); Triassic limestone conglomerate as at Dillsburg mines (Spencer, 1908; Hotz, 1950); and Triassic calcareous siltstones as at the Esterly mine (Spencer, 1908; Rose and others, 1985).

Magnetite sulfide mineralization postdates both crystallization of the adjacent diabase sheet and a hightemperature metasomatic mineral assemblage (Lapham and Gray, 1973). Chilled margins of the diabase sheets are locally altered in the vicinity of some ore zones (Lapham and Gray, 1973), but others are remarkably fresh and unaltered (Smith, 1973, p. 177). The early high-temperature metasomatic mineral assemblage consists of diopside, andradite-grossular garnet, phlogopite, and at places forsterite. Magnetite replaces calcite and the earlier ferromagnesian silicates. Pyrite and chalcopyrite were deposited both together with and later than magnetite; chalcopyrite commonly replaces magnetite
(Lapham and Gray, 1973). Veinlets containing chalcopyrite and sometimes sphalerite and galena develop late in the alteration history and cut across earlier skarn alteration (Lapham and Gray, 1973). At Cornwall, the ore zone is in banded carbonate host rock, and magnetite appears to have preferentially replaced calcite-rich limestone layers, whereas ferromagnesian silicates have replaced dolomite- and silica-rich layers (Lapham and Gray, 1973; Rose and others, 1985).

Postdiabase fractures and faults in some of the deposits are both pre-ore and post-ore (Cornwall: Lapham and Gray, 1973, p. 249) or syn-ore and post-ore (Grace mine: Sims, 1968). Fractures in diabase adjacent to the ore deposits commonly contain veins of magnetite, pyrite, chlorite, serpentine, and calcite (Cornwall: Lapham and Gray, 1973; Grace mine: Sims, 1968, Smith, 1973, p. 145). At Cornwall the ore body is located at a minor fault transecting the diabase body. Trace metal values and ore distribution at Cornwall are zoned above, around, and within this fault which cuts through the diabase (Lapham and Gray, 1973). This fault may have 


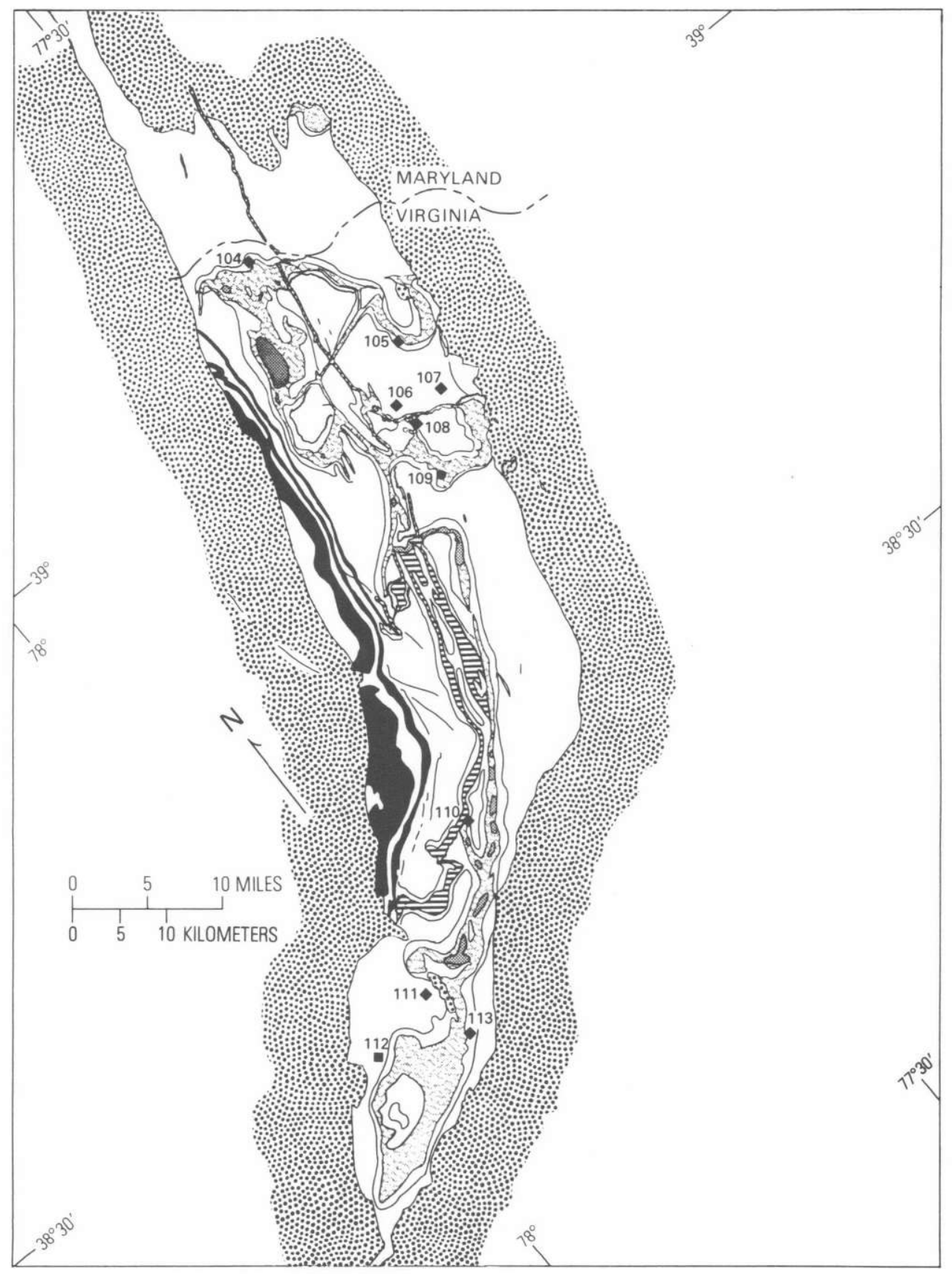

C

Figure 1. Continued.

controlled the flow of the hydrothermal fluids that deposited the ore at Cornwall (Lapham and Gray, 1973, p. 154).

Pyrite and chalcopyrite from the Cornwall, Dillsburg, and French Creek deposits have $\delta^{34} \mathrm{~S}$ isotopic values ranging from +5 to +17 per mil (Smitheringale and Jensen, 1963; Rose and others, 1985). These sulfides show enrichment in $\delta^{34} \mathrm{~S}$ with respect to the typical sulfur isotopic composition of tholeiitic basalts $\left(\delta^{34} S\right.$ near 0 per mil). The sulfur isotopic composition of the ore samples is similar to values for sulfides from nearby non-igneous rocks outside of the alteration halo of the ore deposits (Rose and others, 1985). Therefore, it appears that most of the sulfur in the ore zones had a non-igneous source.

Rose and others (1985) report $\hat{o}^{18} \mathrm{O}$ isotopic values for coexisting magnetite, calcite, and quartz from many of the magnetite skarn deposits (including Cornwall, Grace, and French Creek) that they interpret as 
Table 1A. Geographic listing of base- and precious-metal mines, prospects, and mineral occurrences associated with igneous and thermally altered rocks in the early Mesozoic basins of the Eastern United States

\begin{tabular}{|c|c|c|c|c|c|c|c|c|c|c|}
\hline Number ${ }^{1}$ & Name & \multirow{2}{*}{$\begin{array}{l}\text { County } \\
\text { New Haven }\end{array}$} & State & Quadrangle & \multicolumn{2}{|c|}{ Figure $^{2}$ Latitude } & Longitude & \multicolumn{2}{|c|}{$\begin{array}{l}\text { Deposit Principal } \\
\text { type }{ }^{3} \text { commodity }\end{array}$} & ty References 4 \\
\hline 1 & Unnamed copper & & Connecticut & Carn & 0 & $\mathrm{~N} 4$ & $51^{\prime} 55^{\prime \prime}$ & 2 p & $\mathrm{Cu}$ & 11,12 \\
\hline 2 & Laurel Hill & Hudson & New Jersey. & Weehawken & 0 & $\mathrm{~N} 40^{\circ} 45^{\prime} 32^{\prime \prime}$ & $W 74^{\circ} 05^{\prime} 11^{\prime \prime}$ & & & \\
\hline 4 & Solebury & Bucks & Pennsylvania & Lambertville & 1 & $\mathrm{~N} 40^{\circ} 20^{\prime} 11^{\prime \prime}$ & W74 $57^{\prime} 14^{\prime \prime}$ & $2 \mathrm{~m}$ & $\mathrm{Cu}$ & $37,50,57,58$ \\
\hline 5 & Lodi & Bucks & Pennsylvania & Frenchtown & 1 & N40 $33^{\prime} 08^{\prime \prime}$ & $\mathrm{W} 75^{\circ} 05^{\prime} 20^{\prime \prime}$ & 20 & $\mathrm{Cu}$ & 37,57 \\
\hline 6 & Tetemer's & Bucks & Pennsylvania & Frenchtown & 1 & $\mathrm{~N} 40^{\circ} 32^{\prime} 00^{\prime \prime}$ & W75 $05^{\prime} 24^{\prime \prime}$ & $2 \mathrm{~m}$ & $\mathrm{Cu}$ & 37,57 \\
\hline 7 & Uhlerstown & Bucks & Pennsylvania & Frenchtown & 1 & $\mathrm{~N} 40^{\circ} 31^{\prime} 36^{\prime \prime}$ & $\mathrm{W} 75^{\circ} 05^{\prime} 26^{\prime \prime}$ & 20 & $\mathrm{Cu}$ & 37,57 \\
\hline 10 & Diehl's mine & Bucks & Pennsylvania & Quakertown & 1 & $\mathrm{~N} 40^{\circ} 25^{\prime} 03^{\prime \prime}$ & $W 75^{\circ} 18^{\prime} 08^{\prime \prime}$ & 30 & $\mathrm{Au}$ & $1,19,37,57$ \\
\hline 11 & Coopersburg & Lehigh & Pennsylvania & Milford Square & re 1 & N $40^{\circ} 29^{\prime} 56^{\prime \prime}$ & $\mathrm{W} 75^{\circ} 24^{\prime} 49^{\prime \prime}$ & $2 \mathrm{p}$ & $\mathrm{Cu}$ & 37 \\
\hline 12 & Sumneytown & Montgomery & Pennsylvania & Perkiomenville & e 1 & $\mathrm{~N} 40^{\circ} 19^{\prime} 54^{\prime \prime}$ & W7 $5^{\circ} 25^{\prime} 37^{\prime \prime}$ & 20 & $\mathrm{Cu}$ & 19,37 \\
\hline 13 & Hendricks Station & Montgomery & Pennsylvania & Perkiomenville & e 1 & $\mathrm{~N} 40^{\circ} 19^{\prime} 09^{\prime \prime}$ & $W 75^{\circ} 27^{\prime} 47^{\prime \prime}$ & $2 \mathrm{p}$ & $\mathrm{Cu}$ & $19,37,57$ \\
\hline 14 & Kober's mine & Montgomery & Pennsylvania & Perkiomenville & e 1 & $\mathrm{~N} 40^{\circ} 19^{\prime} 02^{\prime \prime}$ & $W 75^{\circ} 26^{\prime} 11^{\prime \prime}$ & $2 \mathrm{~m}$ & $\mathrm{Cu}$ & $1,19,33,37,57$ \\
\hline 15 & Karl's mine & Montgomery & Pennsylvania & Perkiomenville & le 1 & N4 $40^{\circ} 19^{\prime} 01^{\prime \prime}$ & 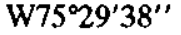 & $2 \mathrm{~m}$ & $\mathrm{Cu}$ & $1,19,33,37,57$ \\
\hline 16 & Young's mine & Montgomery & Pennsylvania & Perkiomenville & e 1 & $\mathrm{~N} 40^{\circ} 18^{\prime} 33^{\prime \prime}$ & W7 $75^{\circ} 28^{\prime} 02^{\prime \prime}$ & $2 \mathrm{~m}$ & $\mathrm{Cu}$ & 333757 \\
\hline 21 & Congo 1 & Montgomery & Pennsylvania & Sassamansville & e 1 & $N 40^{\circ} 21^{\prime} 19^{\prime \prime}$ & W75 $35^{\prime} 15^{\prime \prime}$ & 3 & $\mathrm{Cu}$ & $37,49,57$ \\
\hline 22 & Brendlinger mine & Montgomery & Pennsylvania & Sassamansville & e 1 & $\mathrm{~N} 40^{\circ} 20^{\prime} 21^{\prime \prime}$ & W75 $34^{\prime} 53^{\prime \prime}$ & $2 p$ & $\mathrm{Cu}$ & $33,37,57$ \\
\hline 23 & Pennsylvania & Montgomery & Pennsylvania & Sassamansville & e 1 & $16^{\prime} 16^{\prime \prime}$ & W75 $35^{\prime} 32^{\prime \prime}$ & $2 \mathrm{~m}$ & $\mathrm{Cu}$ & $37,50,57$ \\
\hline 24 & Boyertown mine & Berks & Pennsylvania & Boyertown & 1 & $19^{\prime} 47^{\prime \prime}$ & W75 $35^{\circ} 28^{\prime \prime}$ & , $1 \mathrm{~m}$ & $\mathbf{F e}$ & $6,19,22,37,49$ \\
\hline 25 & Stonersville & Berks & Pennsylvania & Birdsboro & 1 & $\mathrm{~N} 40^{\circ} 19^{\prime} 47^{\prime \prime}$ & W75 $48^{\prime} 39^{\prime \prime}$ & $1 \mathrm{p}$ & $\mathrm{Fe}$ & 37,49 \\
\hline 26 & Brower mine & Berks & Pennsylvania & Boyertown & 1 & $\mathrm{~N} 40^{\circ} 19^{\prime} 10^{\prime \prime}$ & W75 $39^{\prime} 01^{\prime \prime}$ & , $1 \mathrm{~m}$ & $\mathrm{Fe}$ & 37,49 \\
\hline 27 & Snydersville & Berks & Pennsylvania & Birdsboro & 1 & $18^{\prime} 25^{\prime \prime}$ & W7 $75^{\circ} 49^{\prime} 26^{\prime \prime}$ & 20 & $\mathrm{Cu}$ & $8,19,37$ \\
\hline 28 & Esterly mine & Berks & Pennsylvania & Birdsboro & 1 & ${ }^{\circ} 17^{\prime} 30^{\prime \prime}$ & W75 $50^{\prime} 55^{\prime \prime}$ & $1 \mathrm{~m}$ & $\mathbf{F e}$ & $6,37,49$ \\
\hline 29 & Gickerville & Berks & Pennsylvania & Birdsboro & 1 & $16^{\prime} 26^{\prime \prime}$ & W75 $51^{\prime} 19^{\prime \prime}$ & 30 & As Co 1 & 19,37 \\
\hline 30 & Dyer quarry & Berks & Pennsylvania & Birdsboro & 1 & $\mathrm{~N} 40^{\circ} 15^{\prime} 54^{\prime \prime}$ & W75 $51^{\prime} 18^{\prime \prime}$ & 30 & $\mathrm{Cu}$ & 43,48 \\
\hline 31 & Unnamed Fe mine & Chester & Pennsylvania & Elverson & 1 & $9^{\prime \prime}$ & W75 $45^{\prime} 37^{\prime \prime}$ & , $1 \mathrm{~m}$ & $\mathrm{Fe}$ & 2,37 \\
\hline 32 & French Creek mines & Chester & Pennsylvania & Pottstown & 1 & $11^{\prime} 05^{\prime \prime}$ & W75 $43^{\circ} 44^{\prime \prime}$ & , $1 \mathrm{~m}$ & $\mathrm{Fe} \mathrm{Cu} 2$ & $2,19,28,37,45$ \\
\hline 33 & Knauertown & Chester & Pennsylvania & Pottstown & 1 & $10^{\prime} 59^{\prime \prime}$ & $W 75^{\circ} 43^{\prime} 36^{\prime \prime}$ & $1 \mathrm{p}$ & $\mathrm{Fe}$ & 2,37 \\
\hline 34 & Pine Swamp & Chester & Pennsylvania & Elverson & 1 & $53^{\prime \prime}$ & $W 75^{\circ} 46^{\prime} 34^{\prime \prime}$ & $1 \mathrm{p}$ & $\mathrm{Fe}$ & $15,37,46$ \\
\hline 45 & Wheatfield mine & Berks & Pennsylvania & Sinking Sprin & 2 & $7^{\prime} 39^{\prime \prime}$ & W76 $01^{\prime} 59^{\prime \prime}$ & , $1 \mathrm{~m}$ & $\mathbf{F e}$ & $6,19,37,49$ \\
\hline 46 & Ruth mine & Berks & Pennsylvania & Sinking Spring & $\mathrm{g} 2$ & $\mathrm{~N} 40^{\circ} 17^{\prime} 30^{\prime \prime}$ & $\mathrm{W} 76^{\circ} 03^{\prime} 15^{\prime \prime}$ & $1 \mathrm{~m}$ & $\mathrm{Fe}$ & $6,19,37,49$ \\
\hline 47 & Doner mine & Lebanon & Pennsylvania & Lebanon & 2 & & '03'" & $1 \mathrm{~m}$ & $\mathrm{Fe}$ & $29,37,49$ \\
\hline 48 & Mt. Pleasant & Lebanon & Pennsylvania & Palmyra & 2 & No & $27^{\prime \prime}$ & 1 & $\mathrm{Fe}$ & 37 \\
\hline 49 & Rexmont reservoir & Lebanon & Pennsylvania & Lebanon & 2 & N40 & W76 $22^{\prime} 12^{\prime \prime}$ & $1 \mathrm{p}$ & $\mathrm{Fe}$ & 37,49 \\
\hline 50 & Carper mine & Lebanon & Pennsylvania & Palmyra & 2 & $\mathrm{~N} 40$ & $31^{\prime} 23^{\prime \prime}$ & $1 \mathrm{~m}$ & $\mathrm{Fe}$ & $17,37,49$ \\
\hline 51 & Cornwall mine & Lebanon & Pennsylvania & Lebanon & 2 & N40 & W7 & $1 \mathrm{~m}$ & $\mathrm{Fe} \mathrm{Cu} 1$ & $16,20,29,30,37,49$ \\
\hline 52 & Hummelstown & Dauphin & Pen & Hershey & 2 & N4 & '49" & 1 & $\mathrm{Fe}$ & 37,49 \\
\hline 53 & Reesers Summit & York & Pennsylvania & Steelton & 2 & $N 40^{\circ} 11^{\prime} 57^{\prime \prime}$ & W76 $51^{\prime} 41^{\prime \prime}$ & 20 & $\mathrm{Cu}$ & 37,47 \\
\hline 54 & Mt. Pleasant 2 & York & Pennsylvania & Wellsville & 2 & N40 & W76 $56^{\prime} 17^{\prime \prime}$ & $1 \mathrm{p}$ & $\mathrm{Fe}$ & $9,37,53$ \\
\hline 55 & Mt. Pleasant 1 & York & Pennsylvania & Wellsville & 2 & $\mathrm{~N} 4 \mathrm{C}$ & W76 $56^{\circ} 56^{\prime \prime}$ & $1 \mathrm{p}$ & $\mathrm{Fe}$ & $9,37,53$ \\
\hline 56 & Wellsville 2 & York & Pennsylvania & Wellsville & 2 & N40 & '32'" & 1 & $\mathrm{Fe}$ & $9,37,53$ \\
\hline 57 & Wellsville 1 & & Pennsylvania & Wellsville & 2 & N40 & $g^{\prime \prime} 49^{\prime \prime}$ & & $\mathrm{Fe}$ & $9,37,53$ \\
\hline 58 & Rossville & York & Pennsylvania & Wellsville & 2 & $\mathrm{~N} 40^{\circ} 04^{\prime} 22^{\prime \prime}$ & W76 $55^{\prime} 28^{\prime \prime}$ & 20 & $\mathrm{Cu}$ & 43,44 \\
\hline 59 & Harman mine & York & Pennsylvania & Wellsville & 2 & $\mathrm{~N} 40^{\circ} 03^{\prime} 37^{\prime \prime}$ & W76 $58^{\circ} 02^{\prime \prime}$ & $1 \mathrm{~m}$ & $\mathrm{Fe}$ & 9,37 \\
\hline 60 & Brenneman mine & York & Pennsylvania & Wellsville & 2 & $\mathrm{~N} 40^{\circ} 03^{\prime} 25^{\prime \prime}$ & W76 $57^{\circ} 05^{\prime \prime}$ & $1 \mathrm{~m}$ & $\mathrm{Fe}$ & 9,37 \\
\hline 61 & Altland mine & York & Pennsylvania & Wellsville & 2 & $\mathrm{~N} 40^{\circ} 03^{\prime} 22^{\prime \prime}$ & W76 $58^{\prime} 07^{\prime \prime}$ & $1 \mathrm{~m}$ & $\mathrm{Fe}$ & 9,37 \\
\hline & Comfort mine & York & Pennsylvania & Wellsville & 2 & $\mathrm{~N} 40^{\circ}$ & W76 $58^{\circ} 07^{\prime \prime}$ & , $1 \mathrm{n}$ & $\mathbf{F e}$ & 9,37 \\
\hline 63 & Cadwalade & York & Pennsylvania & Wellsville & 2 & $\mathrm{~N} 40^{\circ} 03^{\prime} 12^{\prime \prime}$ & W76 $58^{\circ} 05^{\prime \prime}$ & , $1 \mathrm{~m}$ & $\mathrm{Fe}$ & 9,37 \\
\hline 64 & Marshajl mine & & Pennsylvania & Wellsville & 2 & $\mathrm{~N} 40^{\circ} 03^{\prime} 10^{\prime \prime}$ & W76 $6^{\circ} 57^{\prime} 07^{\prime \prime}$ & $1 \mathrm{~m}$ & $\mathrm{Fe}$ & 9,37 \\
\hline 65 & Sluthower mine & York & Pennsylvania & Wellsville & 2 & $N 40^{\circ} 02^{\prime} 54^{\prime \prime}$ & W76 $57^{\circ} 04^{\prime \prime}$ & $1 \mathrm{~m}$ & $\mathbf{F e}$ & 9,37 \\
\hline 66 & Minebank School 1 & York & Pennsylvania & Wellsville & 2 & $\mathrm{~N} 40^{\circ} 02^{\prime} 27^{\prime \prime}$ & W76 $58^{\circ} 01^{\prime \prime}$ & $1 \mathrm{~m}$ & $\mathrm{Fe}$ & $9,37,49$ \\
\hline
\end{tabular}


Table 1A. Geographic listing of base- and precious-metal mines, prospects, and mineral occurrences associated with igneous and thermally altered rocks in the early Mesozoic basins of the Eastern United States-Continued

\begin{tabular}{|c|c|c|c|c|c|c|c|c|c|}
\hline Number ${ }^{1}$ Name & County & State & Quadrangle F & Figure & $\theta^{2}$ Latitude & Longitude & $\begin{array}{l}\text { Deposi } \\
\text { type }\end{array}$ & $\begin{array}{l}\text { Principal } \\
\text { ommodit }\end{array}$ & ity References 4 \\
\hline 67 Minebank School 2 & York & Pennsylvania & Wellsville & 21 & N40 $00^{\prime} 58^{\prime \prime}$ & W7 $6^{\circ} 58^{\prime} 27^{\prime \prime}$ & $\mathbf{m}$ & $\mathrm{Fe}$ & $9,37,49$ \\
\hline 68 Roler & York & Pennsylvania & Wellsville & 2 & $\mathrm{~N} 40^{\circ} 01^{\prime} 21^{\prime \prime}$ & $\mathrm{W} 76^{\circ} 55^{\prime} 51^{\prime \prime}$ & & $\mathrm{Fe}$ & 37,53 \\
\hline 69 Smith prospect & York & Pennsylvania & Wellsville & 2 & $\mathrm{~N} 40^{\circ} 00^{\prime} 30^{\prime \prime}$ & W76 $6^{\circ} 57^{\prime} 09^{\prime \prime}$ & & $\mathrm{Fe}$ & 9,37 \\
\hline 70 Grantham mines & York & Pennsylvania & Mechanicsburg & rg 2 & $\mathrm{~N} 40^{\circ} 07^{\prime} 36^{\prime \prime}$ & W77 $01^{\prime} 36^{\prime \prime}$ & $1 \mathrm{~m}$ & $\mathrm{Fe}$ & $6,9,37,49$ \\
\hline 71 Dillsburg North & York & Pennsylvania & Dillsburg & 2 & $\mathrm{~N} 40^{\circ} 07^{\prime} 03^{\prime \prime}$ & $\mathrm{W} 77^{\circ} 02^{\prime} 29^{\prime \prime}$ & & $\mathrm{Fe}$ & 37,53 \\
\hline 72 McCormick mine & York & Pennsylvania & Dillsburg & 2 & $\mathrm{~N} 40^{\circ} 06^{\prime} 46^{\prime \prime}$ & $\mathrm{W} 77^{\circ} 00^{\prime} 57^{\prime \prime}$ & $1 \mathrm{~m}$ & $\mathrm{Fe}$ & $6,9,21,26,32,37,49$ \\
\hline 73 Longnecker mine & & Pennsylvania & Dillsburg & 21 & $\mathrm{~N} 40^{\circ} 06^{\prime} 43^{\prime \prime}$ & $\mathrm{W} 77^{\circ} 00^{\prime} 53^{\prime \prime}$ & $1 \mathrm{~m}$ & $\mathrm{Fe}$ & $6,9,21,26,32,37,49$ \\
\hline 74 King mine & York & Pennsylvania & Dillsburg & 2 & $\mathrm{~N} 40^{\circ} 06^{\prime} 41^{\prime \prime}$ & $\mathrm{W} 77^{\circ} 00^{\prime} 17^{\prime \prime}$ & $1 \mathrm{~m}$ & $\mathrm{Fe}$ & $6,9,21,26,32,37,49$ \\
\hline 75 Underwood mine & York & Pennsylvania & Dillsburg & 2 & $N 40^{\circ} 06^{\prime} 40^{\prime \prime}$ & $\mathrm{W} 77^{\circ} 00^{\prime} 59^{\prime \prime}$ & $1 \mathrm{~m}$ & $\mathrm{Fe}$ & $6,9,21,26,32,37,49$ \\
\hline 76 Jauss mine & York & Pennsylvania & Dillsburg & 2 & $\mathrm{~N} 40^{\circ} 06^{\prime} 39^{\prime \prime}$ & W77 $07^{\prime} 23^{\prime \prime}$ & $1 \mathrm{~m}$ & $\mathbf{F e}$ & $6,9,21,26,32,37,49$ \\
\hline 77 Altland mine & York & Pennsylvania & Dillsburg & 2 & $\mathrm{~N} 40^{\circ} 06^{\prime} 34^{\prime \prime}$ & $\mathrm{W} 77^{\circ} 00^{\prime} 43^{\prime \prime}$ & $1 \mathrm{~m}$ & $\mathrm{Fe}$ & $6,9,21,26,32,37,49$ \\
\hline 78 Smyser mine & York & Pennsylvania & Dillsburg & 2 & $\mathrm{~N} 40^{\circ} 06^{\prime} 34^{\prime \prime}$ & $\mathrm{W} 77^{\circ} 00^{\prime} 54^{\prime \prime}$ & $1 \mathrm{~m}$ & $\mathrm{Fe}$ & $6,9,21,26,32,37,49$ \\
\hline 79 Bell mine & York & Pennsylvania & Dillsburg & 2 & $\mathrm{~N} 40^{\circ} 06^{\prime} 24^{\prime \prime}$ & $\mathrm{W} 77^{\circ} 00^{\prime} 43^{\prime \prime}$ & $1 \mathrm{~m}$ & $\mathrm{Fe}$ & $6,9,21,26,32,37,49$ \\
\hline 80 Logan mine & York & Pennsylvania & Dillsburg & 21 & $\mathrm{~N} 40^{\circ} 06^{\prime} 06^{\prime \prime}$ & $\mathrm{W} 77^{\circ} 00^{\prime} 20^{\prime \prime}$ & $1 \mathrm{~m}$ & 6 & $6,9,21,26,32,37,49$ \\
\hline 81 Cox mine & York & Pennsylvania & Dillsburg & 21 & 06 ' & $\mathrm{W} 77^{\circ} 00^{\prime} 13^{\prime \prime}$ & $1 \mathrm{~m}$ & $\mathrm{Fe}$ & $6,9,21,26,32,37,49$ \\
\hline 82 Grove mine & York & Pennsylvania & Dillsburg & 2 & $\mathrm{~N} 40^{\circ} 06^{\prime} 04^{\prime \prime}$ & $\mathrm{W} 77^{\circ} 00^{\prime} 39^{\prime \prime}$ & $1 \mathrm{~m}$ & $\mathrm{Fe}$ & $6,9,21,26,32,37,49$ \\
\hline 83 Bender mine & York & Pennsylvania & Dillsburg & 2 & $\mathrm{~N} 40^{\circ} 05^{\prime} 51^{\prime \prime}$ & $\mathrm{W} 77^{\circ} 03^{\prime} 01^{\prime \prime}$ & $1 \mathrm{~m}$ & $\mathrm{Fe}$ & $9,28,37,49$ \\
\hline 84 Franklintown 1 & York & Pennsylvanja & Dillsburg & 21 & $\mathrm{~N} 40^{\circ} 05^{\prime} 14^{\prime \prime}$ & W7 $77^{\circ} 02^{\prime} 36^{\prime \prime}$ & $1 \mathrm{p}$ & $\mathrm{Fe}$ & $9,37,49$ \\
\hline 85 Franklintown 2 & York & Pennsylvania & Dillsburg & 2 & $\mathrm{~N} 40^{\circ} 04^{\prime} 13^{\prime \prime}$ & W7 $77^{\circ} 02^{\prime} 48^{\prime \prime}$ & & $\mathbf{F}$ & $9,37,49$ \\
\hline 86 Franklintown 3 & York & Pennsylvania & Dillsburg & 21 & $\mathrm{~N} 40^{\circ} 04^{\prime} 12^{\prime \prime \prime}$ & W7 $77^{\circ} 03^{\prime} 00^{\prime \prime}$ & $1 \mathrm{p}$ & $\mathrm{Fe}$ & $9,37,49$ \\
\hline 87 Franklintown 4 & York & Pennsylvania & Dillsburg & 2 & $\mathrm{~N} 40^{\circ} 02^{\prime} 39^{\prime \prime}$ & $\mathrm{W} 77^{\circ} 03^{\prime} 00^{\prime \prime}$ & $1 \mathrm{p}$ & $\mathrm{Fe}$ & $9,37,49$ \\
\hline 88 Lichte mine & York & Pennsylvania & Dillsburg & 21 & $\mathrm{~N} 40^{\circ} 01^{\prime} 12^{\prime \prime}$ & W77 $70^{\circ} 34^{\prime \prime}$ & $1 \mathrm{~m}$ & $\mathrm{Fe}$ & 9,37 \\
\hline 89 Clapper farm & am & Pennsylvania & Hampton & 2 & $24 "$ & $\mathrm{~W} 77^{\circ} 00^{\prime} 21^{\prime \prime}$ & 20 & $\mathrm{Cu} \mathrm{Au} 4$ & 43 \\
\hline 90 Center Mills 1 & ns & Pennsylvania & Biglerville & 2 & $\mathrm{~N} 39^{\circ}$ & W7 $77^{\circ} 10^{\prime} 39^{\prime \prime}$ & $1 \mathrm{p}$ & 3 & $37,51,54$ \\
\hline 91 Center Mills 2 & Adams & Pennsylvania & Biglerville & 2 & $\mathrm{~N} 39^{\circ} 58^{\prime} 03^{\prime \prime}$ & W77 $17^{\circ} 04^{\prime \prime}$ & $1 \mathrm{p}$ & $\mathrm{Fe}$ & $37,51,54$ \\
\hline 92 Idaville & Adams & Pennsylvania & Biglerville & 2 & $27^{\prime \prime}$ & $\mathrm{W} 77^{\circ} 12^{\prime} 24^{\prime \prime}$ & $1 \mathrm{p}$ & $\mathrm{Fe}$ & 37,54 \\
\hline 93 Heidlersburg & Adams & Pennsylvania & Biglerville & 2 & $18^{\prime \prime}$ & W77 $07^{\prime} 38^{\prime \prime}$ & 20 & $\mathrm{Cu}$ & 37,51 \\
\hline 94 Stone Jug mine & Adams & Pennsylvania & Biglerville & 2 & $12^{\prime \prime}$ & W $77^{\circ} 10^{\prime} 12^{\prime \prime}$ & $2 \mathrm{~m}$ & $\mathrm{Cu}$ & 40,42 \\
\hline 95 Hunterstown & Adams & Pennsylvania & Biglerville & 2 & N39.53'21' & $\mathrm{W} 77^{\circ} 09^{\prime} 35^{\prime \prime}$ & $2 \mathrm{p}$ & $\mathrm{Cu}$ & 23,37 \\
\hline 96 Gettysburg & Adams & Pennsylvania & Gettysburg & 2 & $03^{\prime \prime}$ & $\mathrm{W} 77^{\circ} 12^{\prime} 46^{\prime \prime}$ & 20 & $\mathrm{Cu}$ & 37,54 \\
\hline 97 Teeter's quarry & Adams & Pennsylvania & Gettysburg & 2 & $77^{\prime \prime}$ & W77 $12^{\prime} 43^{\prime \prime}$ & 20 & C & 37 \\
\hline 98 Cashtown 2 & ns & Pennsylvania & Arendtsvil & 2 & $26^{\prime \prime}$ & W7 $77^{\circ} 20^{\prime} 31^{\prime \prime}$ & $1 \mathrm{p}$ & & $33,37,51$ \\
\hline 99 Cashtown 1 & Adams & Pennsylvania & Arendtsville & 21 & $3^{\prime} 23^{\prime \prime}$ & $\mathrm{W} 77^{\circ} 20^{\prime} 17^{\prime \prime}$ & $1 \mathrm{p}$ & & $33,37,51$ \\
\hline 100 Orrtana & Adams & Pennsylvania & Fairfield & 2 & $38^{\prime \prime}$ & W $77^{\circ} 18^{\prime} 24^{\prime \prime}$ & 10 & & 37,54 \\
\hline 101 Carr Hill & Adams & Pennsylvania & Fairfield & 2 & & W77 $17^{\prime} 34^{\prime \prime}$ & $1 \mathrm{p}$ & $\mathrm{F}$ & $37,51,54$ \\
\hline 102 Fairfield & Adams & Pennsylvania & Fairfield & 2 & $43^{\prime \prime}$ & $\mathrm{W} 77^{\circ} 20^{\prime} 50^{\prime \prime}$ & & $\mathrm{Fe} 1$ & $10,37,51,54$ \\
\hline 103 McNair farm & Adams & Pennsylvania & Fairfield & 2 & $N 39^{\circ} 46^{\prime} 38^{\prime \prime}$ & $\mathrm{W} 77^{\circ} 21^{\prime} 30^{\prime \prime}$ & $1 \mathrm{p}$ & & 37,54 \\
\hline 104 Goose Creek & Loudoun & Virginia & Leesburg & 3 & N39 $39^{\circ} 05^{\prime} 53^{\prime \prime}$ & W77 $30^{\prime} 01^{\prime \prime}$ & & & $4,13,31,35,55,56$ \\
\hline Theodora mine & Fairfax & Virginia & Herndon & 3 & $' 59$ ' & W7 $77^{\circ} 25^{\prime} 23^{\prime \prime}$ & $2 \mathrm{~m}$ & C & $4,13,25,31$ \\
\hline Spencer farm & Fairfax & Virginia & Herndon & 3 & N38 & W7 $77^{\circ} 28^{\prime} 35^{\prime \prime}$ & $2 \mathrm{p}$ & $\mathrm{Cu}$ & 4,31 \\
\hline Chantilly prospect & Fairfax & Virginia & Herndon & 3 & $20 \prime$ & W $77^{\circ} 25^{\prime} 10^{\prime \prime}$ & $2 \mathrm{p}$ & $\mathrm{Cu}$ & 4,31 \\
\hline 108 Cub Run copper & Fairfax & Virginja & Herndon & 3 & N38 $52^{\prime} 54^{\prime \prime}$ & W7 $77^{\circ} 28^{\prime} 15^{\prime \prime}$ & 20 & $\mathrm{Cu}$ & 7 \\
\hline 109 Fairfax quarry & Fairfax & Virginia & Manassas & 3 & N38 $48^{\circ} 33^{\prime \prime}$ & W77 $29^{\prime} 19^{\prime \prime}$ & 30 & $\mathrm{Cu}$ & 5,31 \\
\hline 110 Bealeton mine & Fauquier & Virginia & Midland & 3 & N38 $38^{\circ} 13^{\prime \prime}$ & W77 $43^{\prime} 54^{\prime \prime}$ & $2 \mathrm{~m}$ & $\mathrm{Cu}$ & 31,35 \\
\hline untain Run & Culpeper & Virginia & Culpeper East & 3 & $\mathrm{~N} 38^{\circ} 27^{\prime} 09^{\prime \prime}$ & W77 $54^{\circ} 09^{\prime \prime}$ & 20 & $\mathrm{Cu}$ & 14 \\
\hline 112 Culpeper prospect & Culpeper & Virginia & Culpeper East & 3 & $6^{\prime} 08^{\prime \prime}$ & W77 $59^{\prime} 44^{\prime \prime}$ & 10 & $\mathrm{Cu}$ & 31,35 \\
\hline 113 Batna & Culpeper & Virginia & Culpeper East & st 3 & $\mathrm{~N} 38^{\circ} 23^{\prime} 50^{\prime \prime}$ & W77 $53^{\prime} 29^{\prime \prime}$ & $2 \mathrm{p}$ & $\mathrm{Cu}$ & $13,31,35,56$ \\
\hline
\end{tabular}

${ }^{1}$ Number of deposit as shown at location of deposit in figure $1 A, B$, or $C$.

${ }^{2}$ Number identifies subfigure of figure 1 that shows the location of the deposit: 0 indicates the deposit is not shown in figure 1 ; 1,2 , or 3 indicates the deposit is shown in figure $1 A, B$, or $C$, respectively.

${ }^{3}$ Type of deposit. 1, 2, or 3 indicates either magnetite skarn, copper hornfels, or diabase-hosted vein type of deposit, respectively; m, o, or $p$ indicates mine, occurrence, or prospect, respectively.

"Number of reference citation that is listed in table $1 C$ and fully described in "References Cited."

equilibrium fractionation between these phases yielding temperatures from 350 to $450{ }^{\circ} \mathrm{C}$. The fluids that formed these minerals are calculated to have a $\delta^{18} \mathrm{O}_{\mathrm{H}_{2} \mathrm{O}}$ value of 13 to 16 per mil. The diabase, which has a normal igneous $\delta^{18} \mathrm{O}_{\mathrm{H}_{2} \mathrm{O}}$ of 7.4 to 7.8 per mil, would have furnished fluids with $\delta^{18} \mathrm{O}_{\mathrm{H}_{3} \mathrm{O}}$ of 7 to $10 \mathrm{per} \mathrm{mil}$ and therefore is not considered to be the principal source of the fluids that formed the skarn. The $\delta^{18} \mathrm{O}$ - and $\delta^{34} \mathrm{~S}$ - enriched ore fluid is interpreted as not being directly derived from the intrusive diabase body but as having formed by reaction of circulating heated meteoric or connate waters with non-igneous rocks near the diabase body, although a small contribution from magmatic waters cannot be ruled out (Rose and others, 1985).

The source of metals in these deposits has been a topic of conjecture in many studies (Spencer, 1908; Hotz, 
Table 1B. Listing by type of deposit for base- and precious-metal mines, prospects, and mineral occurrences associated with igneous and thermally altered rocks in the early Mesozoic basins of the Eastern United States

\begin{tabular}{|c|c|c|c|c|c|c|c|c|c|c|}
\hline \multicolumn{2}{|c|}{ Number' } & \multirow[t]{2}{*}{ County } & \multirow{2}{*}{\multicolumn{2}{|c|}{ State }} & \multirow[t]{2}{*}{$\begin{array}{l}\text { Type } \\
\text { size }\end{array}$} & \multirow[t]{2}{*}{$\begin{array}{l}\text { Host-rock } \\
\text { lithology }\end{array}$} & \multirow[t]{2}{*}{$\begin{array}{c}\text { Host-rock } \\
\text { age }\end{array}$} & \multicolumn{2}{|c|}{ Commodity } & \multirow[t]{2}{*}{$\bar{y}$ References $^{4}$} \\
\hline \multicolumn{4}{|c|}{ Magnetite skarn deposits } & & & & & & & \\
\hline 24 & Boyertown mine & Berks & Pennsylvania & 1 & $\mathrm{~m} \mathbf{n}$ & & Triassic & $\mathbf{F e}$ & & $6,19,22,37,49$ \\
\hline 25 & Stonersville & Berks & Pennsylvania & 1 & p & & Triassic? & $\mathrm{Fe}$ & & 37,49 \\
\hline 26 & Brower mine & Berks & Pennsylvania & 1 & m m & shale & Triassic & $\mathrm{Fe}$ & & 37,49 \\
\hline 28 & Esterly mine & Berks & Pennsylvania & 1 & $\mathrm{mu}$ & siltstone & Triassic & $\mathrm{Fe}$ & & $6,37,49$ \\
\hline 31 & Unnamed Fe mine & Chester & Pennsylvania & 1 & $\mathbf{m} \mathbf{u}$ & shale/sandstone & Triassic & $\mathrm{Fe}$ & & 2,37 \\
\hline 32 & French Creek mines & Chester & Pennsylvania & 1 & m 1 & marble/gneiss & Precambrian & $\mathrm{Fe} \mathrm{Cu}$ & $\mathrm{ZnCo}$ & $2,19,28,37,45$ \\
\hline 33 & Knauertown & Chester & Pennsylvania & 1 & $\mathbf{p}$ & & Triassic & $\mathrm{Fe}$ & & 2,37 \\
\hline 34 & Pine Swamp & Chester & Pennsylvania - & 1 & p & marble/gneiss & Precambrian & $\mathrm{Fe}$ & & $15,37,46$ \\
\hline 35 & Jones-Kinney mines & Berks & Pennsylvania & 1 & m l & dolomite/shale & Cambrian & $\mathrm{Fe}$ & $\mathrm{Cu}$ & $19,27,36,37,49,52$ \\
\hline 36 & Hopewell mine & Chester & Pennsylvania & 1 & $\mathrm{~m} \mathrm{u}$ & marble/gneiss & Precambrian & $\mathrm{Fe}$ & & $2,18,19,36,37,38,39$ \\
\hline 37 & Leighton mine & Chester & Pennsylvania & 1 & $\mathrm{~m}$ m & gneiss/marble? & Precambrian & $\mathrm{Fe}$ & & $2,36,37$ \\
\hline 38 & Wanwick mine & Chester & Pennsylvania & 1 & $\mathrm{~m} \mathrm{I}$ & limestone conglom. & Triassic & $\mathrm{Fe}$ & & $2,19,36,37,49$ \\
\hline 39 & Steels mine & Chester & Pennsylvania & 1 & $\mathrm{~m} \mathrm{u}$ & gneiss/marble? & Precambrian & $\mathrm{Fe}$ & & $2,19,36,37$ \\
\hline 41 & Raudenbush mine & Berks & Pennsylvania & 1 & $\mathrm{~m} \mathbf{m}$ & dolomite & Cambrian & $\mathbf{F e}$ & & $6,37,49$ \\
\hline 42 & Fritz Island mine & Berks & Pennsylvania & 1 & m 1 & dolomite & Cambrian & $\mathbf{F e}$ & $\mathrm{Cu}$ & $6,19,37,49$ \\
\hline 43 & Grace mine & Berks & Pennsylvania & 1 & $\mathrm{~m} \mathbf{m}$ & limestone/dolomite & Cambrian & $\mathrm{Fe} \mathrm{Cu}$ & Co Ag Au 3 & 3,41 \\
\hline 44 & Bylers mine & Berks & Pennsylvania & 1 & m l & limestone & Cambrian & $\mathbf{F e}$ & & 2,37 \\
\hline 45 & Wheatfield mine & Berks & Pennsylvania & 2 & m l & limestone/dolomite & Cambrian-Ordovician & $\mathrm{Fe}$ & & $6,19,37,49$ \\
\hline 46 & Ruth mine & Berks & Pennsylvania & 2 & $\mathbf{m} \mathbf{m}$ & limestone/dolomite & Cambrian-Ordovician & $\mathrm{Fe}$ & & $6,19,37,49$ \\
\hline 47 & Doner mine & Lebanon & Pennsylvania & 2 & $\mathbf{m} \mathbf{m}$ & limestone & Paleozoic & $\mathrm{Fe}$ & & $29,37,49$ \\
\hline 48 & Mt. Pleasant & Lebanon & Pennsylvania & 2 & $\mathrm{p}$ & & Triassic & $\mathrm{Fe}$ & & 37,49 \\
\hline 49 & Rexmont Reservoir & Lebanon & Pennsylvania & 2 & $\mathrm{p}$ & limestone/shale & Paleozoic & $\mathbf{F e}$ & & 37,49 \\
\hline 50 & Carper mine & Lebanon & Pennsylvania & 2 & $\mathbf{m} \mathbf{m}$ & slate/shale & Ordovician & $\mathrm{Fe}$ & & $17,37,49$ \\
\hline 51 & Cornwall mine & Lebanon & Pennsylvania & 2 & $\mathrm{ml}$ & limestone/dolomite & Cambrian & $\mathrm{Fe} \mathrm{Cu}$ & $\mathrm{Au} \mathrm{Ag} \mathrm{Co} 1$ & $16,20,29,30,37,49$ \\
\hline 52 & Hummelstown & Dauphin & Pennsylvania & 2 & $\mathbf{m} \mathbf{m}$ & sandstone & Triassic & $\mathbf{F e}$ & & 37,49 \\
\hline 54 & Mt. Pleasant 2 & York & Pennsylvania & 2 & p & & Triassic & $\mathrm{Fe}$ & & $9,37,53$ \\
\hline 55 & Mt. Pleasant 1 & York & Pennsylvania & 2 & $\mathrm{p}$ & & Triassic & $\mathrm{Fe}$ & & $9,37,53$ \\
\hline 56 & Wellsville 2 & York & Pennsylvania & 2 & p & & Triassic & $\mathrm{Fe}$ & & $9,37,53$ \\
\hline 57 & Wellsville 1 & York & Pennsylvania & 2 & $\mathrm{p}$ & & Triassic & $\mathrm{Fe}$ & & $9,37,53$ \\
\hline 59 & Harman mine & York & Pennsylvania & 2 & m n & siltstone/diabase & Triassic/Jurassic & $\mathrm{Fe}$ & & 9,37 \\
\hline 60 & Brenneman mine & York & Pennsylvania & 2 & $\mathbf{m} \mathbf{n}$ & & Triassic & $\mathrm{Fe}$ & & 9,37 \\
\hline 61 & Altland mine & York & Pennsylvania & 2 & $\mathbf{m} \mathbf{n}$ & & Triassic & $\mathbf{F e}$ & & 9,37 \\
\hline 62 & Comfort mine & York & Pennsylvania & 2 & $\mathbf{m} \mathbf{n}$ & & Triassic & $\mathbf{F e}$ & & 9,37 \\
\hline 63 & Cadwalader mine & York & Pennsylvania & 2 & $\mathrm{~m} n$ & & Triassic & $\mathrm{Fe}$ & & 9,37 \\
\hline 64 & Marshall mine & York & Pennsylvania & 2 & $\mathbf{m} \mathbf{n}$ & & Triassic & $\mathrm{Fe}$ & & 9,37 \\
\hline 65 & Sluthower mine & York & Pennsylvania & 2 & $\mathbf{m} \mathbf{n}$ & & Triassic & $\mathrm{Fe}$ & & 9,37 \\
\hline 66 & Minebank School 1 & York & Pennsylvania & 2 & $\mathbf{m} \mathbf{~ m}$ & limestone & Triassic & $\mathrm{Fe}$ & & $9,37,49$ \\
\hline 67 & Minebank School 2 & York & Pennsylvania & 2 & $\mathrm{~m} \mathbf{m}$ & limestone & Triassic & $\mathrm{Fe}$ & & $9,37,49$ \\
\hline 68 & Roler & York & Pennsylvania & 2 & $\bar{p}$ & & Triassic & $\mathrm{Fe}$ & & 37,53 \\
\hline 69 & Smith prospect & York & Pennsylvania & 2 & $\mathrm{p}$ & & Triassic & $\mathrm{Fe}$ & & 9,37 \\
\hline 70 & Grantham mines & York & Pennsylvania & 2 & m m & limestone conglom. & Triassic & $\mathrm{Fe}$ & & $6,9,37,49$ \\
\hline 71 & Dillsburg North & York & Pennsylvania & 2 & $\mathrm{p}$ & limestone conglom. & Triassic & $\mathrm{Fe}$ & & 37,53 \\
\hline 72 & McCormick mine & York & Pennsylvania & 2 & m I & limestone conglom. & Triassic & $\mathrm{Fe}$ & & $6,9,21,26,32,37,49$ \\
\hline 73 & Longnecker mine & York & Pennsylvania & 2 & $\mathrm{ml}$ & limestone conglom. & Triassic & $\mathrm{Fe}$ & & $6,9,21,26,32,37,49$ \\
\hline 74 & King mine & York & Pennsylvania & 2 & $\mathrm{~m} \mathbf{~ m}$ & limestone conglom. & Triassic & $\mathrm{Fe}$ & & $6,9,21,26,32,37,49$ \\
\hline 75 & Underwood mine & York & Pennsylvania & 2 & m l & limestone conglom. & Triassic & $\mathrm{Fe}$ & & $6,9,21,26,32,37,49$ \\
\hline 76 & Jauss mine & York & Pennsylvania & 2 & $\mathrm{~m} \mathrm{l}$ & limestone conglom. & Triassic & $\mathrm{Fe}$ & & $6,9,21,26,32,37,49$ \\
\hline 77 & Altland mine & York & Pennsylvania & 2 & $\mathrm{~m} \mathbf{m}$ & limestone conglom. & Triassic & $\mathbf{F e}$ & & $6,9,21,26,32,37,49$ \\
\hline 78 & Smyser mine & York & Pennsylvania & 2 & $\mathbf{m} \mathbf{~ m}$ & limestone conglom. & Triassic & $\mathbf{F e}$ & & $6,9,21,26,32,37,49$ \\
\hline 79 & Bell mine & York & Pennsylvania & 2 & $\mathrm{~m} \mathrm{I}$ & limestone conglom. & Triassic & $\mathrm{Fe}$ & & $6,9,21,26,32,37,49$ \\
\hline 80 & Logan mine & York & Pennsylvania & 2 & $\mathrm{~m} \mathbf{m}$ & limestone conglom. & Triassic & $\mathrm{Fe}$ & & $6,9,21,26,32,37,49$ \\
\hline 81 & Cox mine & York & Pennsylvania & 2 & $\mathbf{m} \mathbf{m}$ & limestone conglom. & Triassic & $\mathrm{Fe}$ & & $6,9,21,26,32,37,49$ \\
\hline 82 & Grove mine & York & Pennsylvania & 2 & $\mathbf{m} \mathbf{m}$ & limestone conglom. & Triassic & $\mathrm{Fe}$ & & $6,9,21,26,32,37,49$ \\
\hline 83 & Bender mine & York & Pennsylvania & 2 & $\mathbf{m} \mathbf{n}$ & shale & Triassic & $\mathrm{Fe}$ & & $9,28,37,49$ \\
\hline 84 & Franklintown 1 & York & Pennsylvania & 2 & $\mathrm{p}$ & & Triassic & $\mathrm{Fe}$ & & $9,37,49$ \\
\hline 85 & Frankdintown 2 & York & Pennsylvania & 2 & p & & Triassic & $\mathrm{Fe}$ & & $9,37,49$ \\
\hline 86 & Franklintown 3 & York & Pennsylvania & 2 & $\mathrm{p}$ & & Triassic & $\mathrm{Fe}$ & & $9,37,49$ \\
\hline 87 & Franklintown 4 & York & Pennsylvania & 2 & p & & Triassic & $\mathrm{Fe}$ & & $9,37,49$ \\
\hline 88 & Lichte mine & York & Pennsylvania & 2 & m m & sandstone & Triassic & $\mathrm{Fe}$ & & 9,37 \\
\hline 90 & Center Mills 1 & Adams & Pennsylvania & 2 & $\mathrm{p}$ & & Triassic & $\mathrm{Fe}$ & & $37,51,54$ \\
\hline & Center Mills 2 & Adams & Pennsylvania & 2 & p & & Triassic & $\mathrm{Fe}$ & & $37,51,54$ \\
\hline 92 & Idaville & Adams & Pennsylvania & 2 & p & & Triassic & $\mathrm{Fe}$ & & 37,54 \\
\hline 98 & Cashtown 2 & Adams & Pennsylvania & 2 & p & & Triassic & $\mathrm{Fe}$ & & $33,37,51$ \\
\hline 99 & Cashtown 1 & Adams & Pennsylvania & 2 & p & & Triassic & $\mathrm{Fe}$ & & $33,37,51$ \\
\hline 100 & Orrtana & Adams & Pennsylvania & 2 & 0 & & Triassic & $\mathrm{Fe}$ & & 37,54 \\
\hline 101 & Carr Hill & Adams & Pennsylvania & 2 & p & & Triassic & $\mathrm{Fe}$ & & $37,51,54$ \\
\hline
\end{tabular}


Table $1 \boldsymbol{B}$. Listing by type of deposit for base- and precious-metal mines, prospects, and mineral occurrences associated with igneous and thermally altered rocks in the early Mesozoic basins of the Eastern United States-Continued

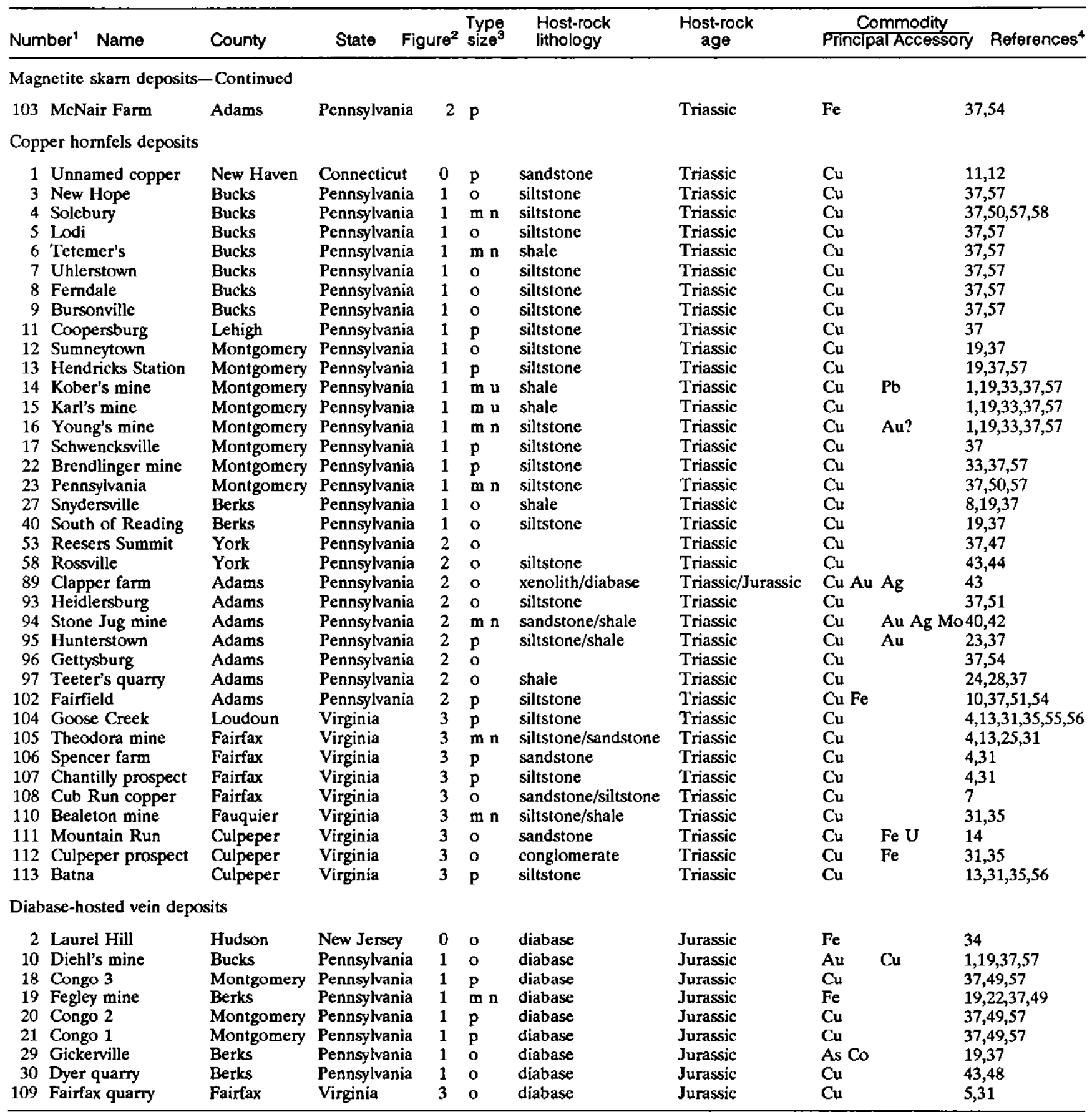

${ }^{1}$ Number of deposit as shown at location of deposit in figure $1 A, B$, or $C$.

${ }^{2}$ Number identifies subfigure of figure 1 that shows the location of the deposit: 0 indicates the deposit is not shown in figure $1 ; 1,2$, or 3 indicates the deposit is shown in figure $1 A, B$, or $C$, respectively.

${ }^{3}$ Type of occurrence. An $\mathrm{m}, \mathrm{p}$, or o indicates a mine, prospect, or mineral occurrence type. An l, $\mathrm{m}, \mathrm{n}$, or $\mathrm{u}$ following the mine (m) code indicates production greater than 100,000 tons, between 100,000 and 1,000 tons, less than 1,000 tons, or unknown (usually less than 1,000 tons), respectively.

4 Number of reference citation that is listed in table $1 C$ and fully described in "References Cited."

1950; Davidson and Wylie, 1968; Smith and Rose, 1972; Lapham and Gray, 1973; Eugster and Chou, 1979; Rose and others, 1985). The characteristic enrichment of these deposits in nickel and cobalt (Lapham and Gray, 1973), the evidence of late-stage leaching of iron in the associated diabase bodies (Davidson and Wylie, 1968), and the 
Table 1C. Listing of cited references for base- and precious-metal mines, prospects, and mineral occurrences associated with igneous and thermally altered rocks in the early Mesozoic basins of the Eastern United States

["Number" refers to "References" column in table $1 A$ and $B$; see "References Cited" section of this paper for further information]

\begin{tabular}{|c|c|}
\hline Number & Reference \\
\hline 1 & Bascom and others, 1931 \\
\hline 2 & Bascom and Stose, 1938 \\
\hline 3 & Basu, 1974 \\
\hline 4 & Bernstein, 1980 \\
\hline 5 & Dietrich, 1953 \\
\hline 6 & d'Invilliers, 1883 \\
\hline 7 & Eggleton, 1975 \\
\hline 8 & Eyerman, 1889 \\
\hline 9 & Frazer, 1877 \\
\hline 10 & Frazer, 1880 \\
\hline 11 & Fritts, 1962 \\
\hline 12 & Fritts, 1963 \\
\hline 13 & Froelich and Leavy, 1981 \\
\hline 14 & Froelich, A.J., 1984, personal commun. \\
\hline 15 & Gedde, 1965 \\
\hline 16 & Geyer and others, 1958 \\
\hline 17 & Geyer and others, 1976 \\
\hline 18 & Ghaffer-Adly, 1961 \\
\hline 19 & Gordon, 1922 \\
\hline 20 & Gray and Lapham, 1961 \\
\hline 21 & Harder, 1910 \\
\hline 22 & Hawkes and others, 1953 \\
\hline 23 & Hoff and Smith, 1985 \\
\hline 24 & Hoff, 1978 \\
\hline 25 & Hotchkiss, 1884 \\
\hline 26 & Hotz, 1950 \\
\hline 27 & Hunt, 1876 \\
\hline 28 & Lapham and Geyer, 1965 \\
\hline 29 & Lapham and Gray, 1973 \\
\hline 30 & Lapham, 1968 \\
\hline 31 & Luttrell, 1966 \\
\hline 32 & Neumann, 1947 \\
\hline 33 & Newhouse, 1933 \\
\hline 34 & Puffer and Peters, 1974 \\
\hline 35 & Roberts, 1928 \\
\hline 36 & Rogers, 1858 \\
\hline 37 & Rose, 1970 \\
\hline 38 & Ross, 1963 \\
\hline 39 & Shank, 1961 \\
\hline 40 & Sheely, 1886 \\
\hline 41 & Sims, 1968 \\
\hline 42 & Smith and Hoff, 1977 \\
\hline 43 & Smith and others, this volume \\
\hline 44 & Smith and O'Neill, 1973 \\
\hline 45 & Smith, 1931 \\
\hline 46 & Smith, 1973 \\
\hline 47 & Smith, 1977 \\
\hline 48 & Smith, 1978 \\
\hline 49 & Spencer, 1908 \\
\hline 50 & Stone, 1939 \\
\hline 51 & Stose and Bascom, 1929 \\
\hline 52 & Stose and Bascom, 1938 \\
\hline 53 & Stose and Jonas, 1939 \\
\hline 54 & Stose, 1932 \\
\hline 55 & Toewe, 1966 \\
\hline 56 & Weed, 1911 \\
\hline 57 & Wherry, 1908 \\
\hline 58 & Willard and others, 1959 \\
\hline
\end{tabular}

occurrence of similar $\mathrm{Au} / \mathrm{Cu}$ ratios $\left(3 \times 10^{-5}\right)$ in both ore and associated diabase bodies (Smith and others, this volume) imply that the intrusives themselves may be the principal source for these metals, as proposed by Hotz (1950), Smith and Rose (1972), and Puffer and Peters (1974). However, calculated sulfur and oxygen isotope compositions of the mineralizing fluids are not consistent with an igneous origin for these elements (Rose and others, 1985), and much of the iron and other trace metals in the skarn deposits may have been derived from sedimentary and metamorphic rocks along the fluid migration path of the hydrothermal system (Eugster and Chou, 1979; Rose and others, 1985). Apparently, a variety of sources, including both country rock and diabase, contributed components to the fluid.

\section{Genetic Model}

These deposits appear to be a variant of the calcic magnetite skarn type of Einaudi and others (1981). Lithostatic pressure, estimated from stratigraphy and phase relations of the mineral assemblages, was low, approximately 500 to 1,000 bars (Rose and others, 1985; Sims, 1968). The initial skarn alteration occurred at approximately 600 to $500^{\circ} \mathrm{C}$. The main period of oxideand sulfide-ore deposition probably occurred at lower temperatures $\left(500^{\circ} \mathrm{C}\right.$ or less) and was accompanied by hydrothermal alteration of both the diabase and early skarn minerals (Rose and others, 1985; Lapham and Gray, 1973). The ore-stage mineralization reflects higher oxidation and sulfidation potential and lower temperature than the early skarn assemblage. The extent of ore development is related to the degree that the early skarn assemblage is altered, which is in turn related to the existence and proximity of a long-lived hydrothermal system (Einaudi and others, 1981, p. 376). It has been interpreted that the skarn mineralization developed during the 4,000 to 5,000 years following intrusion, during which the solidified diabase sheet cooled from 600 to 350 ${ }^{\circ} \mathrm{C}$ (Rose and others, 1985; Lapham and Gray, 1973; Smith, 1973). Pre-ore fractures in diabase may have been important channels for the ore-forming hydrothermal fluids.

Eugster and Chou (1979) have developed a genetic model for the Cornwall-type magnetite skarn deposits that assumes a convective hydrothermal cell driven by heat from the newly intruded diabase sheet. The hydrothermal fluid probably was saline (chloride rich) to transport both dissolved iron and sulfur. These fluids probably were largely of connate origin, as indicated by sulfur and oxygen isotope studies (Rose and others, 1985), but a relatively small portion of the fluid may have come from late-stage diabase differentiates, such as ferrogabbro or granophyre (Smith and Rose, 1972; 
Table 2. Selected trace-element contents of ores, rocks, and sulfide concentrates from some representative base- and precious-metal occurrences associated with igneous and thermally altered rocks in the early Mesozoic basins of the Eastern United States

[Deposits listed by type and number from table $1 B$ ]

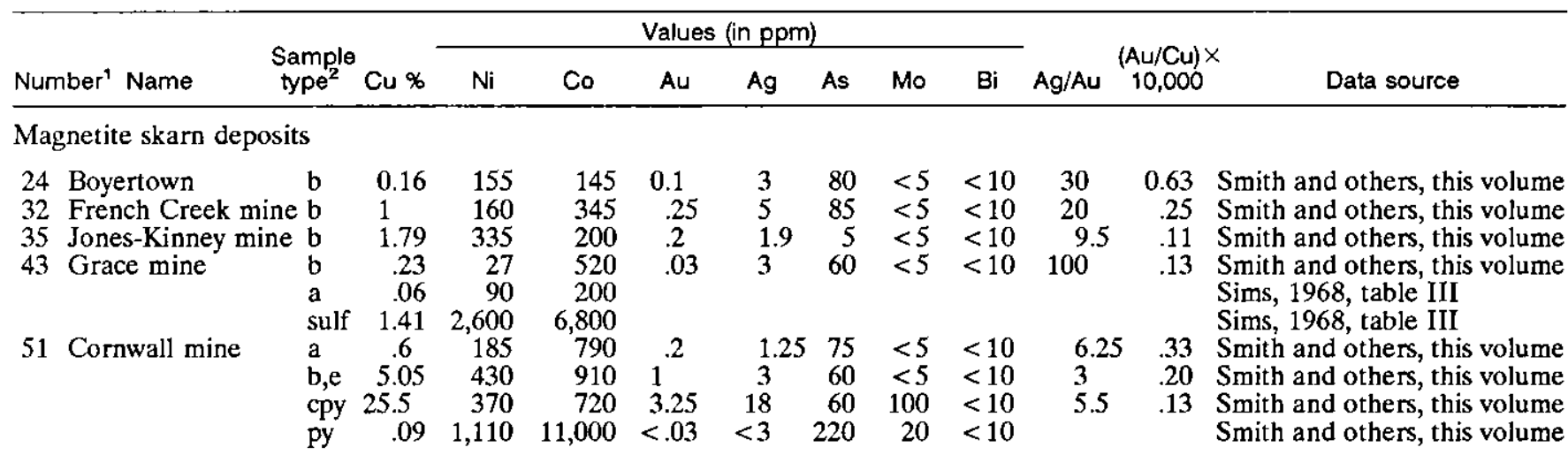

Copper hornfels deposits

\begin{tabular}{|c|c|c|c|c|c|c|c|c|c|c|c|c|c|}
\hline 58 & Rossville & $\mathrm{d}$ & 2.12 & 50 & 20 & .2 & 4 & $<5$ & $<5$ & 30 & 20 & .09 & Smith and others, this volume \\
\hline 89 & Clapper farm & c & 8 & 2 & $<5$ & 7 & 220 & $<5$ & $<5$ & 30 & 31.4 & .88 & Smith and others, this volume \\
\hline & & c & 4.15 & 5 & $<5$ & 4.5 & 90 & $<5$ & 2 & 18 & 20 & 1.08 & Smith and others, this volume \\
\hline 94 & Stone Jug & c & 6.65 & 15 & 10 & 1.75 & 51 & 20 & 100 & 100 & 29.1 & .26 & Smith and others, this volume \\
\hline & & c & $6_{53}$ & & & 1.5 & $\begin{array}{r}93 \\
3\end{array}$ & & 180 & $\begin{array}{r}300 \\
10\end{array}$ & 62 & .25 & Smith and Hoff, 1977 \\
\hline 95 & Hunterstown & $\begin{array}{l}c \\
c \\
b\end{array}$ & $\begin{array}{l}.52 \\
.54 \\
.1\end{array}$ & 20 & 15 & $\begin{array}{c}.25 \\
.38 \\
4.5\end{array}$ & $\begin{array}{l}3 \\
3\end{array}$ & 5 & $\begin{array}{r}<5 \\
2 \\
50\end{array}$ & $\begin{array}{l}10 \\
10 \\
30\end{array}$ & $\begin{array}{c}12 \\
7.9\end{array}$ & $\begin{array}{l}.48 \\
.70\end{array}$ & $\begin{array}{l}\text { Smith and others, this volume } \\
\text { Hoff and Smith, } 1985 \\
\text { Minard, J.P., 1968, 1969, } \\
\text { unpublished USGS notes }\end{array}$ \\
\hline
\end{tabular}

Igneous-hosted vein deposits

$\begin{array}{llllllllll}30 & \text { Dyer quarry } & c & .31 & 60 & 30<.001 & .03 & 10<5<10 \\ 53 & \text { Reesers Summit } & c & .28 & 35 & 40<.03<3 & 60<5<10\end{array}$

Smith and others, this volume Smith and others, this volume

\footnotetext{
${ }^{1}$ Deposit number, keyed to deposit numbers in tables $1 A$ and $B$.

${ }^{2}$ Sample type: a, average ore sample; $b$, an aggregate ore sample from dump or surface cut; $c$, a sample of rock chips showing at least a trace of mineralization; d, a channel sample; $e$, the east end of the open pit at the Cornwall mine; cpy, py, and sulf, are chalcopyrite, pyrite, and bulk sulfide mill concentrates, respectively.
}

Puffer and Peters, 1974). These moderately saline fluids produce magnetite-pyrite-pyrrhotite assemblages in calcareous rocks and feldspar-mica assemblages in quartzofeldspathic rocks (Lapham and Gray, 1973; Rose and others, 1985; Eugster and Chou, 1979). Saline fluids under the low pressures (500-1,000 bars) and high temperatures $\left(600-350^{\circ} \mathrm{C}\right)$ interpreted for these deposits (Rose and others, 1985) that are equilibrated with magnetite-pyrite-pyrrhotite-potassium feldspar-muscovite-quartz assemblages are capable of carrying significant amounts of iron and other metals (Hemley and others, 1986) as well as some reduced sulfur as $\mathrm{H}_{2} \mathrm{~S}$ (Gary Cygan, oral commun., 1986). Reaction of the fluid with calcite or dolomite (which raises fluid $\mathrm{pH}$ ), cooling of the fluid, and oxidation of the fluid can cause magnetite deposition.

Sulfide minerals postdate and replace earlier skarn minerals, and their deposition is probably related to cooling of the hydrothermal fluid. Another process leading to sulfide deposition is reaction of the hydrothermal fluid with calcite at the marble-skarn contact (Einaudi and others, 1981, p. 376) resulting in the preferential development of sulfide-rich zones at the periphery of the skarn along the marble contact (Umpleby, 1916). Monosulfides, such as pyrrhotite, sphalerite, and chalcopyrite may precipitate via coupled reactions such as

$$
\mathrm{CaCO}_{3}+2 \mathrm{H}^{+}=\mathrm{Ca}^{+2}+\mathrm{H}_{2} \mathrm{CO}_{3} \text { and }
$$

$\mathrm{M}^{+2}+\mathrm{H}_{2} \mathrm{~S}=\mathrm{MS}+2 \mathrm{H}^{+}$(where $\mathrm{M}^{+2}$ is a divalent metal cation)

leading to an overall reaction with the stoichiometry of

$$
\mathrm{CaCO}_{3}+\mathrm{M}^{+2}+\mathrm{H}_{2} \mathrm{~S}=\mathrm{MS}+\mathrm{Ca}^{+2}+\mathrm{H}_{2} \mathrm{CO}_{3}
$$

Precipitation of disulfides, such as pyrite, involves oxidation as well as neutralization, leading to an overall reaction with the stoichiometry of

$$
\mathrm{CaCO}_{3}+\mathrm{Fe}^{+2}+2 \mathrm{H}_{2} \mathrm{~S}+1 / 2 \mathrm{O}_{2}=\mathrm{FeS}_{2}+\mathrm{Ca}^{+2}+\mathrm{H}_{2} \mathrm{CO}_{3}+\mathrm{H}_{2} \mathrm{O}
$$

Reactions of this type may explain the sulfide enrichment in the Elizabeth pit of the Cornwall deposit (Lapham, 1968) and the sulfide-rich ores in the upper part of the French Creek deposit bordering calcite marble (Smith, 
1931). Sulfide enrichments (containing $\mathrm{Cu}, \mathrm{Au}, \mathrm{Ag}, \mathrm{Co}$, and $\mathrm{Ni}$ ) may be found peripheral to the main skarn mineralization elsewhere.

Critical features for the development of these deposits include:

1. Diabase sheets of sufficient thickness to set up hydrothermal circulation.

2. The presence of replaceable carbonate units in the proper geometry with respect to hydrothermal circulation to alter fluid $\mathrm{pH}$ and channel fluid flow.

An additional important feature may be syn- or early postcrystallization fracturing of diabase to focus fluid flow. Saturation of the hydrothermal fluid with a non-igneous reduced sulfur source (pyrite?) appears to be a general feature of these deposits (Rose and others, 1985) and may be important to supply sufficient sulfur to the system to develop an appreciable volume of sulfide minerals in the ores. If the $\mathrm{Au}$ and $\mathrm{Cu}$ values in these deposits are related to magmatic metal sources, then proximity to diabase differentiates enriched in those metals may result in skarn deposits enriched in $\mathrm{Cu}$ and $\mathrm{Au}$ (Smith and others, this volume).

\section{HORNFELS COPPER DEPOSITS}

Hornfels copper deposits are commonly associated with diabase sheets in the early Mesozoic basins of the Eastern United States but are insignificant in terms of historic metal production. Of the deposits of this type listed in table $1 B$, only two reportedly had production of nearly 1,000 tons of ore, and most are only mineralogical curiosities. These occurrences, however, are characteristically enriched in precious and other rare metals, which make them interesting from a geochemical perspective. The deposits appear to be metasomatic replacements of original calcareous siltstones and shales thermally metamorphosed to hornfels near diabase intrusive bodies.

\section{Commodities}

Copper is the principal metal at most of the deposits, and small amounts of $\mathrm{Au}$ and $\mathrm{Ag}$ are present in a few areas. This deposit type differs from the other deposit types discussed in this paper by being enriched in $\mathrm{Bi}, \mathrm{Mo}$, and sometimes Sn (table 2).

Chalcopyrite and bornite with, at places, magnetite, hematite, and chalcocite in the ore zone, are typically disseminated in dark-gray fine-grained hornfels. Unlike the magnetite skarn deposits, magnetite is generally not an abundant ore mineral. Chrysocolla and malachite, formed by supergene alteration of the copper minerals, commonly occur on fracture and weathered surfaces. Analyses of copper-bearing ore from the Clapper farm occurrence, Pennsylvania (no. 89 , table 1), show 4 to 8 percent $\mathrm{Cu}, 4.5$ to $7 \mathrm{ppm} \mathrm{Au,} 90$ to $220 \mathrm{ppm} \mathrm{Ag}$, and 18 to $30 \mathrm{ppm} \mathrm{Bi} \mathrm{(table} \mathrm{2;} \mathrm{Smith} \mathrm{and} \mathrm{others,} \mathrm{this} \mathrm{volume).}$ Analyses of copper-bearing ore from the Stone Jug mine, Pennsylvania (no. 94, table 1), show approximately 6 percent $\mathrm{Cu}, 1.5 \mathrm{ppm} \mathrm{Au}, 51$ to $93 \mathrm{ppm} \mathrm{Ag}, 20 \mathrm{ppm} \mathrm{As}$, 100 to $180 \mathrm{ppm} \mathrm{Mo}$, and 100 to $300 \mathrm{ppm} \mathrm{Bi} \mathrm{(table} \mathrm{2).}$ Analyses of rock chips from an open cut at the Hunterstown prospect, Pennsylvania (no. 95, table 1), show 0.1 percent $\mathrm{Cu}, 4.5 \mathrm{ppm} \mathrm{Au}, 50 \mathrm{ppm} \mathrm{Mo,} 30 \mathrm{ppm} \mathrm{Bi}$, and 150 ppm Sn (J.P. Minard, 1983, personal commun., and unpublished USGS fieldnotes, 1968-69).

\section{Geologic Setting}

The hornfels copper deposits either underlie or overlie the diabase sheets. Those with polymetallic metallization $(\mathrm{Cu}, \mathrm{Au}, \mathrm{Ag}, \mathrm{Mo}, \mathrm{Bi}, \mathrm{Sn})$, such as the Stone Jug mine (Smith and Hoff, 1977), appear to be associated with late-stage diabase differentiates (ferrogabbro and granophyre) enriched in volatiles and copper.

Ore is found in dark-colored, fine-grained, massive hornfels. The hornfels consists chiefly of epidote, chlorite, quartz, albite, alkali feldspar, and muscovite (Smith and Hoff, 1977). Heulandite and stilbite are present at many places, and andradite-grossular garnet at a few places. This suite of minerals indicates a metamorphic grade in the albite-epidote hornfels facies, although the grade may locally be as high as the lower hornblende facies. The primary ore occurs in small veins and replacements and consists chiefly of chalcopyrite and bornite; chalcocite has been reported at a few places. The secondary copper minerals chrysocolla and malachite are found in most deposits. Trace molybdenite and powellite have been reported from the Stone Jug mine (Smith and Hoff, 1977).

The copper minerals generally occur in the lower temperature facies of contact metamorphism, often just within the area of recognizable hornfels. Copper mineralization of this type associated with large diabase sheets may be separated from diabase by tens to hundreds of meters of unmineralized hornfels. The mineralized zones may be fractured, vuggy, or faulted.

\section{Genetic Model}

It is probable that many of the hornfels copper deposits are associated with late-stage diabase differentiates. Smith (1973, p. 53, table 7, sample D-39) has analyzed a late-stage quartzose ferrogabbro differentiate from Reesers Summit, Pennsylvania, that may be similar to the magmatic differentiates that produce the $\mathrm{Cu}$ and Au mineralization in hornfels. This ferrogabbro locally contains $2,800 \mathrm{ppm} \mathrm{Cl}, 242 \mathrm{ppm} \mathrm{Cu}, 170 \mathrm{ppm} \mathrm{S}$, and 7.2 
ppb Au. It also contains magnetite and trace amounts of chalcopyrite, bornite, and covellite. Associated quartz contains vapor-liquid fluid inclusions that indicate the presence of a separate fluid phase (Smith, 1973, p. 123). These fluid inclusions probably contain some of the $\mathrm{Cl}$ reported in the rock analysis, with apatite containing the balance. Using compositions of coexisting phases in the sample, Smith (1973, p. 128) calculated a solidus temperature of $780^{\circ} \mathrm{C}$ and a fugacity of $\mathrm{H}_{2} \mathrm{O}$ of 1,900 bars (which may be high because of uncertainties in the calculation). Therefore, at moderately low pressures, a chlorine-rich hydrothermal fluid capable of transporting $\mathrm{Cu}, \mathrm{Au}$, and other trace metals could have been liberated.

Large bodies of late-stage differentiates enriched in volatile and incompatible elements occur in local areas of much larger diabase sheets, apparently as a result of processes promoting both lateral and vertical migration of residual liquids (Smith, 1973; Gottfried and Froelich, 1985). Smith (1973, p. 122) speculatively describes the generation of the ferrogabbro body at Reesers Summit from the associated large York Haven sheet as:

"...the magma was of homogeneous, normal York Haven-type diabase composition when intruded but after crystallizing as fine-grained diabase at the contacts for a few hundred years (based on the heat flow data of Jaeger, 1967), the magma began to gravitationally settle out bronzite phenocrysts (density 3.4 ). The lighter residual magma then tended to migrate [laterally] up dip through the still liquid center of the sheet where it slowly cooled and produced a large volume of ferrogabbro...."

Near their solidus temperature these late-stage differentiates may have released a chloride-rich fluid from a magma enriched in $\mathrm{Cu}, \mathrm{Fe}, \mathrm{Au}$, and other trace metals from which the auriferous hornfels copper deposits formed. Ground-water hydrothermal cells set up by the cooling diabase sheet may also have provided additional copper and other metals.

Critical features for the development of these deposits include:

1. Diabase sheets of sufficient thickness to develop magmatic differentiation and set up hydrothermal circulation.

2. The presence of calcareous (dolomitic?) siltstones/ shales in proper geometry with respect to hydrothermal circulation.

Favorable factors for the development of these deposits include:

1. Development of hornfels overlying or adjacent to ferrogabbro and granophyre differentiates.

2. Fracturing of host rock to promote and focus fluid flow.
The mechanism and sources of the precious-metal enrichment in the hornfels copper deposits is a topic of interest, since the precious metals are the commodities that might make these deposits economic. $\mathrm{Au} / \mathrm{Cu}$ ratios in the hornfels $\mathrm{Cu}$ deposits generally are equal or greater than $0.3 \times 10^{-4}$ and are typically greater than the $\mathrm{Au} / \mathrm{Cu}$ ratios in the magnetite skarn deposits (table 2). Chemistry on representative diabase intrusive rocks in the Mesozoic basins yields $\mathrm{Au} / \mathrm{Cu}$ ratios near $0.3 \times 10^{-4}$ (Smith and others, this volume). This implies an equal or greater transport of gold relative to copper in the mineralizing fluids, if the metal sources are the diabase bodies. At temperatures representative of the albite-epidote hornfels facies $\left(300\right.$ to $400^{\circ} \mathrm{C}$ ), fluid transport of $\mathrm{Au}$ (Seward, 1984) and possibly $\mathrm{Cu}$ (Barnes, 1979, p. 444-445) will be most efficient as a sulfide complex. $\mathrm{Bi}$ and $\mathrm{As}$ behave similarly to $\mathrm{Au}$, and, at temperatures of $350^{\circ} \mathrm{C}$ or less, their solubilities are probably controlled by sulfide complexes. As the fugacity of oxygen decreases, transport of $\mathrm{Au}, \mathrm{Bi}, \mathrm{As}$, and $\mathrm{Cu}$ as sulfide complexes is enhanced, while the transport of $\mathrm{Fe}$ and other metals as chloride complexes is decreased (Barnes, 1979). Oxidation, cooling, and reaction of the fluid with carbonate minerals can lead to sulfide deposition and $\mathrm{Au}, \mathrm{Bi}, \mathrm{As}$, and $\mathrm{Cu}$ mineralization. The hornfels copper deposits appear to differ from the magnetite skarn deposits in being formed from lower oxygen fugacity and from lower temperature solutions.

\section{DIABASE-HOSTED VEIN AND SEGREGATION DEPOSITS}

The few diabase-hosted vein deposits listed in table 1 are largely mineralogical curiosities, and the amount of mineralized rock is small. Although the volume of metalenriched rock may be extremely small at most of these sites, the vein occurrences may have significance as indicators of important undiscovered mineralization of other types. Only one deposit of the diabase-hosted vein type listed in table 1 has been prospected and, perhaps, mined. However, vein occurrences of this type are not unusual in the diabase sheets, and the occurrences listed in table 1 are but a few examples of this deposit type.

Deposits of this type are near diabase pegmatite or segregation veins commonly found in the upper parts of large diabase sheets. Most veins occur in diabase and may either parallel or crosscut igneous layering (Shannon, 1926); some veins are in shear zones in diabase or rock adjacent to diabase. The veins appear to have been formed by hydrothermal fluids derived from late-stage diabase differentiates. The significance of this type of deposit is that it may be genetically linked to hornfels copper deposits, and the presence of diabasehosted veins may identify areas with potential for the more extensive auriferous hornfels copper deposits. 


\section{Commodities}

Most deposits have been prospected for $\mathrm{Au}, \mathrm{Ag}$, or $\mathrm{Cu}$. In most cases, $\mathrm{Au}$ and $\mathrm{Ag}$ concentrations are low (table 2); however, anomalous concentrations of $\mathrm{Au}, \mathrm{Ag}$, As, and Co have been reported. Chalcopyrite and pyrite are typically the most abundant sulfide minerals, but trace amounts of bornite, galena, native silver, arsenopyrite, and sphalerite have been reported. Erythrite and arsenopyrite have been found at the Gickerville, Pennsylvania, occurrence (Gordon, 1922). Gold, if present, is associated with $\mathrm{Cu}$ minerals, commonly chalcopyrite. A late-stage ferrogabbro zone in a diabase sheet at Reesers Summit, Pennsylvania (near occurrence 53, table 1), and similar zones in ferrodiorite of the Palisades sheet, New Jersey, show anomalous $\mathrm{Pd}$ concentrations as much as $208 \mathrm{ppb}$ (and as much as $31 \mathrm{ppb} \mathrm{Pt}$ ), which is an order of magnitude greater than the Pd concentrations in the other Jurassic diabase sheets sampled by Gottfried and Froelich (this volume). They interpret this Pd enrichment as possibly resulting from a late-stage hydrothermal event superimposed on a normal magmatic differentiation trend (Gottfried and Froelich, this volume).

\section{Geologic Setting}

Virtually no recent or detailed information exists on the vein deposits cited in table 1. Smith (1973, p. 50) visited Diehl's gold mine, as part of his study of diabase geochemistry, and noted that the prospect was developed in a large diabase pegmatite containing trace amounts of chalcopyrite. A sample of a late-stage hornblende syenite differentiate of the diabase sheet in the vicinity of the mine contains 385 ppm copper (Smith, 1973, p. 211, table 30 , sample D-66).

The vein deposits appear to be associated with pegmatitic phases of diabase that grade into ferrogabbro or granophyre. They commonly are near the periphery or upper part of diabase sheets but may occur in shear zones or fracture zones anywhere in the sheet. Mineralization may also be associated with miarolitic cavities developed from fluids evolved from the enclosing ferrogabbro or granophyre. Shannon (1926) describes miarolitic cavities from granophyre-rich diabase in the Old Goose Creek quarry, Manassas, Virginia, which contain chalcopyrite.

Diabase near the veins is bleached and shows alteration of hypersthene to chlorite and of intermediate plagioclase to pink albite. Common vein minerals such as chlorite, epidote, datolite, prehnite, calcite, and zeolites (particularly laumontite, stilbite, and chabazite) are characteristic of deuteric or low-temperature hydrothermal alteration of diabase. Alteration halos bordering the veins are zoned in texture and mineralogy; these zones, sequentially numbered from the exterior of the vein toward the interior of the vein, according to Simpson (1969) and Shannon (1926) are:

1. Hypersthene altered to chlorite; plagioclase altered and choked with inclusions. The texture of diabase is preserved.

2. Chlorite-prehnite-quartz or amphibole-quartzprehnite.

3. Quartz-epidote-datolite-zeolites ( \pm calcite).

Chalcopyrite appears abundant in the transition area between zone 1 and zones 2 or 3 , although chalcopyrite is also present in zones 2 and 3 . Other sulfides, such as bornite, sphalerite, and galena occur in zone 3 .

\section{Genetic Model}

The diabase-hosted veins are associated with segregations of late-stage diabase differentiates enriched in incompatible elements. The vein mineralization is apparently related to the evolution of hydrothermal fluids from these late-stage differentiates near their solidus temperature, as evidenced by mineralization occurring both in miarolitic cavities and cross-cutting veins. The deposition of sulfides is probably, related to cooling of the hydrothermal fluid. The source of metals and sulfur is presumably the residual diabase differentiate.

The genetic model for the development of diabasehosted vein occurrences is similar to the model developed for auriferous hornfels copper deposits. The presence of vein occurrences of this type may be an indicator of nearby hornfels copper mineralization, if suitable sedimentary host rocks are available. Critical features for the development of these deposits include:

1. Presence of late-stage differentiates of diabase enriched in incompatible elements with abundant chlorine and other volatiles.

2. Fracturing of host rock to promote and focus fluid flow and alteration.

\section{GEOLOGIC FACTORS FAVORABLE FOR MINERALIZATION}

The three igneous-associated deposit types discussed show many similar features of geology and mineralization. All are of hydrothermal origin, and all are associated with hydrothermal alteration zones bordering intrusions of diabase and its differentiates. Calcareous rocks are hosts for both skarn/replacement and hornfels deposits. These types of deposits typically contain magnetite and trace amounts of $\mathrm{Cu}, \mathrm{Ni}, \mathrm{Co}, \mathrm{Ag}, \mathrm{Au}, \mathrm{As}$, and at places Mo associated with sulfide minerals. Magnetite enrichment in the skarn deposits occurs in the ore zone, and magnetite in the hornfels deposits occurs in associ- 
ated ferrogabbro and granophyre. The $\mathrm{Cu}, \mathrm{Au}$, and $\mathrm{Ag}$ appear to have been deposited by hydrothermal fluids at temperatures less than $450^{\circ} \mathrm{C}$. In the skarn/replacement deposits, the sulfide minerals were deposited during retrograde alteration of earlier high-temperature skarn assemblages (Einaudi and others, 1981). In contrast, the sulfide minerals in the hornfels copper deposits were deposited during low-temperature prograde alteration.

Previous evaluation of geologic factors favorable for igneous-associated mineralization within the early Mesozoic basins of the Eastern United States is limited to the skarn/replacement type of deposits. Rose (1972) defined a number of geologic parameters favorable for skarn/replacement mineralization from a geological, geophysical, and geochemical data base covering Pennsylvania by using discriminant analysis. The favorable factors, listed in order of decreasing importance are:

1. Great extent of diabase-carbonate contacts,

2. High magnetic intensity,

3. Great thickness of diabase,

4. Various geochemical parameters.

Additional parameters, such as proximity to known skarn/replacement prospects or occurrences could be added to the list, since this factor logically defines areas favorable for mineralization.

Magnetic intensity may be useful in identifying favorable areas for copper hornfels development, as well as having proven success in locating favorable areas for magnetite skarn/replacement deposits. The concealed magnetite ore body of the Grace mine in the Morgantown, Pennsylvania, area was discovered through recognition of the circular magnetic anomaly over the site (Jensen, 1951). In addition, most of the known magnetite skarn deposits produce positive circular magnetic anomalies (Socolow, 1974). However, the large Cornwall ore bodies are characterized by relatively small magnetic anomalies, which have been attributed to strong remanent magnetism directed at right angles to the present geomagnetic field (Bromery and Griscom, 1967; Socolow, 1974). The early Mesozoic basin province is characterized by a mottled pattern of magnetic highs and lows. The pattern of magnetic contours generally corresponds closely to the outcrop of diabase and indicates that the present outcrop of the major diabase plutons is a fair indication of the three-dimensional distribution of some of the sheetlike intrusive bodies (Gettysburg basin, Pennsylvania: Phillips, 1985; Bromery and Griscom, 1967; Socolow, 1961; Culpeper basin, Virginia: Johnson and Froelich, 1982). Within the positive anomalies that represent the diabase outcrop and subcrop, local intense circular magnetic high closures are present. Bromery and Griscom (1967) suggested that the following three areas of anomalously high aeromagnetic intensities in the Gettysburg basin of Pennsylvania could represent mag- netite concentrations in either a skarn ore body, hornfels, or diabase differentiates: (1) south of Hopewell, (2) 3.2 $\mathrm{km}$ south of Heidlersburg, and (3) south-southwest of Gettysburg. Rose (1972) identified favorable areas for additional magnetite skarn bodies near Boyertown and Gettysburg. The pattern of magnetic highs in the Culpeper basin of Virginia represents contributions from both underlying pre-Mesozoic lithologies and Mesozoic diabase intrusions (Johnson and Froelich, 1982). The pattern of local magnetic highs within or adjacent to outcrop areas of some diabase sheets corresponds to areas of ferrogabbro and granophyre differentiates or to hornfels with high magnetite concentrations (Froelich, 1985, personal commun.). Since the hornfels copper and diabase-hosted vein deposits are associated with ferrogabbro and granophyre bodies, this high magnetic intensity may also indicate favorable areas for these deposit types. For example, Stone Jug hill, a diabase body near the Stone Jug prospect, a hornfels copper deposit in Pennsylvania, has a 1,280-gamma aeromagnetic anomaly above regional background (Bromery and Griscom, 1967). Cores from test holes drilled unsuccessfully in search of a magnetite skarn body suggested that the local magnetic high might be caused by accessory magnetite in the ferrogabbro and granophyre (Smith and Hoff, 1977).

In summary, a list of geologic factors favorable for the igneous-associated deposit types may be compiled from the above information:

1. Presence of extensive fractured and hydrothermally altered diabase-carbonate or diabase-calcareous siltstone contacts.

2. Presence of large ferrogabbro or granophyre bodies.

3. Positive magnetic anomalies associated with the margin of diabase bodies.

4. Great volume of diabase body.

\section{REFERENCES CITED}

Barnes, H.L., 1979, Solubilities of ore minerals, in, Barnes, H.L., ed., Geochemistry of hydrothermal ore deposits, second edition: New York, John Wiley and Sons, p. 404-460.

Bascom, F., and Stose, G.W., 1938, Geology and mineral resources of the Honeybrook and Phoenixville Quadrangles, Pennsylvania: U.S. Geological Survey Bulletin 891, 145 p.

Bascom, F., Wherry, E.T., Stose, G.W., and Jonas, A.I., 1931, Geology and mineral resources of the QuakertownDoylestown district, Pennsylvania and New Jersey: U.S. Geological Survey Bulletin 828, 62 p.

Basu, D., 1974, Genesis of the Grace Mine magnetite deposit; Morgantown, Berks County, southeastern Pennsylvania: unpublished Ph.D. thesis, Lehigh University, 317 p. 
Bernstein, L.R., 1980, Minerals of the Washington, D.C. area: Maryland Geological Survey, Education Series no. 5, $148 \mathrm{p}$.

Bromery, R.W., and Griscom, A., 1967, Aeromagnetic and generalized geologic map of southeastern Pennsylvania: U.S. Geological Survey Geophysical Investigations Map GP-577, scale $1 ; 125,000$.

Davidson, A., and Wylie, P.J., 1968, Opaque oxide minerals of some diabase-granophyre associations in Pennsylvania: Economic Geology, v. 63, p. 950-960.

Dietrich, R.V., 1953, Virginia mineral localities: Virginia Polytechnical Institute Bulletin, Engineering Experiment Station, Series 88, $57 \mathrm{p}$.

d'Invilliers, E.V., 1883, The geology of the South Mountain belt of Berks County: Pennsylvania Geological Survey (2d), Report DDD, 441 p.

Eggleton, R.E., 1975, Preliminary geologic map of the Herndon quadrangle: U.S. Geological Survey Open-File Report 75-386.

Einaudi, M.T., Meinert, L.D., and Newberry, R.J., 1981, Skarn deposits: Economic Geology, 75th Anniversary Volume, p. 317-391.

Eugster, H.P., and Chou, I-Ming, 1979, A model for the deposition of Cornwall-type magnetite deposits: Economic Geology, v. 74, p. 763-774.

Eyerman, J., 1889, Mineralogy of Pennsylvania, Part I: Easton, Pennsylvania, n.p.

Frazer, P., Jr., 1880, The geology of Lancaster County: Pennsylvania Geological Survey (2d), Report of Progress in 1877, Report CCC, 350 p.

1887, Regarđing some Mesozoic ores: American Philosophical Society, Proceedings, v. 16, p. 651-655.

Fritts, C.E., 1962, The barite mines of Cheshire: The Cheshire Historical Society, Cheshire, Connecticut.

1963, Bedrock geology of the Mount Carmel quadrangle, Connecticut: U.S. Geological Survey Geologic Quadrangle Map GQ-199, scale 1:24,000.

Froelich, A.J., and Gottfried, David, 1985, Early Jurassic diabase sheets of the Eastern United States-a preliminary overview, in Robinson, G.R., Jr., and Froelich, A.J., eds., Proceedings of the second U.S. Geological Survey workshop on the early Mesozoic basins of the Eastern United States: U.S. Geological Survey Circular 946, p. 79-86.

Froelich, A.J., and Leavy, B.D., 1981, Map showing mineral resources of the Culpeper basin, Northern Virginia and Maryland: Availability and planning for future needs: U.S. Geological Survey Miscellaneous Investigations Series Map I-1313-B, scale1:125,000.

Gedde, R.W., 1965, Geophysical investigation of a magnetite deposit, Chester County, Pennsylvania: unpub. M.S. thesis, The Pennsylvania State University, 59 p.

Geyer, A.R., Gray, Carlyle, McLaughlin, D.B., and Moseley, J.R., 1958, Geology of the Lebanon quadrangle: Pennsylvania Geological Survey, 4th series, Geologic Atlas $167 \mathrm{C}$.

Geyer, A.R., Smith, R.C., II, and Barnes, J.H., 1976, Mineral collecting in Pennsylvania: Pennsylvania Geological Survey, General Geology Report 33, 260 p.

Ghaffer-Adly, R., 1961, A detailed gravity survey in the Triassic basin, north Chester County, Pennsylvania: M.S. thesis, The Pennsylvania State University.
Gordon, S.G., 1922, The mineralogy of Pennsylvania: Special Publication No. 1, Academy of Natural Science, Philadelphia (reprinted 1973 by Friends of Mineralogy, Region III).

Gottfried, D., and Froelich, A.J., 1985, Geochemical and petrologic features of some Mesozoic diabase sheets in the northern Culpeper basin, in Robinson, G.R., Jr., and Froelich, A.J., eds., Proceedings of the second U.S. Geological Survey workshop on the early Mesozoic basins of the Eastern United States: U.S. Geological Survey Circular 946, p. 86-91.

Gray, C., and Lapham, D.M., 1961, Guide to the geology of Cornwall, Pennsylvania: Pennsylvania Geological Survey, Bulletin G-35, 18 p.

Harder, E.C., 1910, Structure and origin of the magnetite deposits near Dillsburg, York County, Pennsylvania: Economic Geology, v. 5, p. 599-622.

Hawkes, H.E., Wedow, Helmuth, and Balsley, J.R., 1953, Geologic investigations of the Boyertown magnetite deposits in Pennsylvania: U.S. Geological Survey Bulletin 995-D, p. 135-149.

Hemley, J.J., Cygan, G.L., and d'Angelo, W.M., 1986, Effect of pressure on ore mineral solubilities under hydrothermal conditions: Geology, v. 14, p. 377-379.

Hickok, W.O., 1933, The iron ore deposits at Cornwall, Pennsylvania: Economic Geology, v. 28, p. 193-255.

Hoff, D.T., 1978, Campbell's quarry, a complex mineral locality in Gettysburg, Pennsylvania: Rocks and Minerals, v. 53, no. 6 , p. 247-253.

Hoff, D.T., and Smith, R.C., II, 1985, An Adams County copper-gold mine, doomed to failure: Pennsylvania Geology, v. 16 , no. 6 , p. $13-16$.

Hotchkiss, J., 1884, The copper ores of Loudoun County, Virginia: The Virginias, v. 5, no. 12, p. 192.

Hotz, P.E., 1950, Diamond-drill exploration of the Dillsburg magnetite deposits, York County, Pennsylvania: U.S. Geological Survey Bulletin 969-A, 27 p.

1952, Form of diabase sheets in Southeastern Pennsylvania: American Joumal of Science, v. 250, p. 943-955.

Hunt, T.S., 1876, A new ore of copper and its metallurgy: American Institute of Mining Engineers, Transactions, v. 4, p. 325-328.

Jaeger, J.C., 1967, Cooling and solidification of igneous rocks, in, Hess, H.H., and Poldervaart, A., eds., Basalts: New York, John Wiley and Sons, Inc., v. 2, p. 503-536.

Jensen, H., 1951, Aeromagnetic survey helps find new Pennsylvania orebody: Engineering and Mining Journal, v. 152, no. 8 , p. $56-59$.

Johnson, S.S., and Froelich, A.J., 1982, Aeromagnetic contour map of the Culpeper basin and vicinity, Virginia: Virginia Division of Mineral Resources Publication 41, scale 1:125,000.

Lapham, D.M., 1968, Triassic magnetite and diabase at Comwall, Pennsylvania, in Ridge, J.D., ed., Ore deposits of the United States 1933-1967, v. 1: American Institute of Mining and Metallurgical Engineers, p. 73-94.

Lapham, D.M., and Geyer, A.R., 1965, Mineral collecting in Pennsylvania, second edition: Pennsylvania Geological Survey, 4th series, Bulletin G-33, 148 p. 
Lapham, D.M., and Gray, C., 1973, Geology and origin of the Triassic magnetite deposit and diabase at Cornwall, Pennsylvania: Pennsylvania Topographic and Geologic Survey, 4th series, Bulletin M-56.

Lindgren, W., 1933, Mineral deposits: New York, McGraw Hill Co., 4th edition, $930 \mathrm{p}$.

Luttrell, G.W., 1966, Base- and precious-metal and related ore deposits of Virginia: Virginia Division of Mineral Resources, Mineral Resource Report 7, 167 p.

Neumann, G.L., 1947, Investigation of the Dillsburg magnetite deposits, York County, Pennsylvania: U.S. Bureau of Mines Report of Investigations 4145, 7 p.

Newhouse, W.H., 1933, Mineral zoning in the New JerseyPennsylvania-Virginia Triassic area: Economic Geology, v. 28, p. 613-633.

Phillips, J.D., 1985, Aeromagnetic character and anomalies of the Gettysburg basin and vicinity-a preliminary appraisal, in Robinson, G.R., Jr., and Froelich, A.J., Proceedings of the second U.S. Geological Survey workshop on the early Mesozoic basins of the Eastern United States: U.S. Geological Survey Circular 946, p. 133-135.

Puffer, J.H., and Peters, J.J., 1974, Magnetite veins in diabase of Laurel Hill, New Jersey: Economic Geology, v. 69, p. 1294-1299.

Roberts, J.K., 1928, The geology of the Virginia Triassic: Virginia Geological Survey Bulletin 29, 205 p.

Rogers, H.D., 1858, The geology of Pennsylvania: Philadelphia, J.B. Lippincott and Company, 815 p.

Rose, A.W., 1970, Atlas of Pennsylvania's mineral resources, Part 3: Metal mines and occurrences in Pennsylvania: Pennsylvania Geological Survey, Bulletin M-50, 14 p.

1972, Favorability for Cornwall-type magnetite deposits in Pennsylvania using geological, geochemical, and geophysical data in a discriminant function: Journal of Geochemical Exploration, v. 1, p. 182-194.

Rose, A.W., Herrick, D.C., and Deines, P., 1985, An oxygen and sulfur isotope study of skarn-type magnetite deposits of the Cornwall type, southeastern Pennsylvania: Economic Geology, v. 80 , p. $418-443$.

Ross, H.P., 1963, Detailed electrical surveys in the Triassic [sic] basin, north Chester County, Pennsylvania: M.S. thesis, The Pennsylvania State University.

Seward, T.M., 1984, The transport and deposition of gold in hydrothermal systems, in Foster, R.P., ed., Gold '82: The geology, geochemistry, and genesis of gold deposits: Geological Society of Zimbabwe Special Publication No. 1, p. 165-181.

Shank, J.C., 1961, A detailed magnetic survey in the Triassic [sic] basin, North Chester County, Pennsylvania: M.S. thesis, The Pennsylvania State University.

Shannon, E.V., 1926, The mineralogy and petrology of intrusive Triassic [sic] diabase at Goose Creek, Loudoun County, Virginia: U.S. National Museum, Proceedings, v. 66, article 2,86 p.

Sheely, A., 1886, Natural history of Adams County: History of Cumberland and Adams Counties, Pennsylvania, part III, chapter X, p. 47, and chapter XIV, p. 333.

Simpson, D.R., 1969, Prehnite veins in Triassic [sic] diabase, Coopersburg, Pennsylvania: Geological Society of America Bulletin, v. 80, p. 1355-1362.
Sims, S.J., 1968, The Grace Mine magnetite deposit, Berks County, Pennsylvania, in Ridge, J.D., ed., Ore deposits of the United States 1933-1967, v. 1: American Institute of Mining and Metallurgical Engineers, p. 108-124.

Smith, L.L., 1931, Magnetite deposits of French Creek, Pennsylvania: Pennsylvania Geological Survey, 4th series, Bulletin $\mathrm{M}-14,52 \mathrm{p}$.

Smith, R.C., II, 1973, Geochemistry of Triassic [sic] diabase from southeastern Pennsylvania: Ph.D. thesis, The Pennsylvania State University, 262 p.

1977, Zinc and lead occurrences in Pennsylvania: Pennsylvania Geological Survey, Mineral Resource Report 72, 318 p.

1978, The mineralogy of Pennsylvania, 1966-1975: Friends of Mineralogy, Pennsylvania Chapter, Special Publication No. 1, 304 p.

Smith, R.C., II, and Hoff, D.T., 1977, Newly discovered minerals at Stone Jug Copper prospect, Adams County: Pennsylvania Geology, v. 8, no. 5, p. 14-16.

Smith, R.C., II, and O'Neill, B.J., 1973, A new Triassic copper occurrence at Rossville, Pa.: Pennsylvania Geology, v. 4, no. 1 , p. 6-7.

Smith, R.C., II, and Rose, A.W., Jr., 1972, Major and trace elements in differentiates of Triassic [sic] diabase and their relationship to Cornwall-type deposits: Geological Society of America Abstracts with Programs, v. 4, p. 671.

Smith, R.C., II, Rose, A.W., Jr., and Lanning, R.M., 1975, Geology and geochemistry of Triassic [sic] diabase in Pennsylvania: Geological Society of America Bulletin, v. 86 , p. 943-955.

Smitheringale, W.G., and Jensen, M.L., 1963, Sulfur isotopic composition of the Triassic [sic] igneous rocks of the Eastern United States: Geochimica et Cosmochimica Acta, v. 27, p. 1183-1207.

Socolow, A.W., 1961, Geologic interpretation of certain aeromagnetic maps of Lancaster, Berks and Lebanon Counties: Pennsylvania Geological Survey IC-41, 19 p.

1974 , Geologic interpretation of aeromagnetic maps of southeastern Pennsylvania: Pennsylvania Geological Survey Information Circular 77, 85 p.

Spencer, A.C., 1908, Magnetite deposits of the Cornwall-type in Pennsylvania: U.S. Geological Survey Bulletin 359, 102 p.

Stone, R.W., 1939, The minerals of Pennsylvania-non-metallic minerals: Pennsylvania Geological Survey, 4th series, Bulletin M-18-C, 49 p.

Stose, G.W., 1932, Geology and mineral resources of Adams County: Pennsylvania Geological Survey, 4th series, Bulletin $\mathrm{C}-1,153 \mathrm{p}$.

Stose, G.W., and Bascom, F., 1929, Fairfield-Gettysburg folio: U.S. Geological Survey Folio 225.

1938, Geology and mineral resources of the Honeybrook and Phoenixville quadrangles, Pennsylvania: U.S. Geological Survey Bulletin 891.

Stose, G.W., and Jonas, A.I., 1939, Geology and mineral resources of York County, Pennsylvania: Pennsylvania Geological Survey, 4th series, Bulletin C-67, 199 p.

Toewe, E.C., 1966, Geology of the Leesburg quadrangle, Virginia: Virginia Division of Mineral Resources, Report of Investigations $11,52 \mathrm{p}$. 
Umpleby, J.B., 1916, The occurrence of ore on the limestone side of garnet zones: University of California, Berkeley, Department of Geology Bulletin, v. 10, p. 25-37.

Weed, W.H., 1911, Copper deposits of the Appalachian States: U.S. Geological Survey Bulletin 455, 166 p.
Wherry, E.T., 1908, The Newark copper deposits of southeastern Pennsylvania: Economic Geology, v. 3, p. 726-738.

Willard, B., and others, 1959, Geology and mineral resources of Bucks County, Pennsylvania: Pennsylvania Geological Survey Bulletin C-9, 243 p.

\title{
LOCATIONS AND ANALYSES OF SELECTED EARLY MESOZOIC COPPER OCCURRENCES IN PENNSYLVANIA
}

\author{
R.C. Smith II, ${ }^{1}$ S.W. Berkheiser, Jr., ${ }^{1}$ and D.T. Hoff ${ }^{2}$
}

\begin{abstract}
Thirty composite samples from 21 different locations representing a wide variety of copper occurrences in the early Mesozoic basins of Pennsylvania have been analyzed for $\mathrm{Cu}, \mathrm{Au}, \mathrm{Ag}, \mathrm{Co}, \mathrm{Ni}, \mathrm{Mo}, \mathrm{As}$, and $\mathrm{Bi}$. Samples contain as much as 0.26 ounces per ton (oz/t) $\mathrm{Au}$ and $6.8 \mathrm{oz} / \mathrm{t} \mathrm{Ag}$. The samples having the highest gold contents are from low-iron contact skarns in the Heidlersburg area of the Gettysburg basin that are near intrusions of both York Haven-type diabase and later Rossville-type diabase.

A chalcopyrite concentrate from the Cornwall mill containing 25 percent $\mathrm{Cu}$ yielded $0.10 \mathrm{oz} / \mathrm{t} \mathrm{Au}$ and $0.6 \mathrm{oz} / \mathrm{t} \mathrm{Ag;} \mathrm{a}$ pyrite concentrate milled from the same iron ore yielded $<0.001 \mathrm{oz} / \mathrm{t} \mathrm{Au},<0.1 \mathrm{oz} / \mathrm{t} \mathrm{Ag}, 1.1$ percent $\mathrm{Co}$, and 0.1 percent Ni. The latter contains only $220 \mathrm{ppm} \mathrm{As,} \mathrm{suggesting}$ that most of the Co was not present as a cobaltite-like phase.
\end{abstract}

\section{INTRODUCTION}

Reconnaissance sampling of early Mesozoic basin copper occurrences in Pennsylvania was undertaken in an attempt to interpret their origin and to identify favorable targets for gold and cobalt. Previously collected composite samples were supplemented by additional sampling to broaden the variety of deposit types, sizes, and locations.

The Mesozoic basin of Pennsylvania is divided into a western portion known as the Gettysburg basin and an eastern portion known as the Newark basin. Both are filled with continental, primarily immature red-bed strata and are intruded by Jurassic and minor Triassic diabase (Van Houten, 1969). The two types of diabase that appear to be associated with the copper occurrences in this setting are (1) the Early Jurassic York Haven-type (or continental tholeiite) and (2) the slightly younger Rossville-type diabase (Smith and others, 1975) that

\footnotetext{
${ }^{1}$ Pennsylvania Geological Survey, Harrisburg, PA 17120.

${ }^{2}$ Pennsylvania State Museum, Harrisburg, PA 17108.
}

resembles island-arc tholeiites and is distinguished by the presence of plagioclase phenocrysts and lower $\mathrm{TiO}_{2}$ in the chilled margins.

The two known, large iron-copper skarn deposits (Cornwall and Grace mines) are located in the narrow east-west-trending area connecting the Gettysburg and Newark basins and are associated with York Haven-type diabase. Several very small $\mathrm{Cu} \pm \mathrm{Fe}$ skarn occurrences are located in the Gettysburg basin near Rossville-type diabase. Very small red-bed copper occurrences, deuteric(?) veinlets in diabase, and late diabase pegmatite differentiates occur throughout both basins.

\section{PAST PRODUCTION}

Occurrences of iron and copper have been known in the Cornwall area since colonial times (D'Invilliers, 1883 ). Some 500,000 tons of iron ore had been mined at the Jones mine, Cornwall area (fig. 1), by 1908 (Rogers, 1858; Rose, 1970), and several thousand tons of copper ore grading 6 to 7 percent copper was produced between 1870 and 1875 (Hunt, 1876). Numerous other copper occurrences are known in Pennsylvania (Evans, 1980). Production at copper-iron deposits has ranged from very little, such as at Hunterstown (fig. 2) (Hoff and Smith, 1985), to more than 100 million tons at Cornwall (Rose, 1970).

Mining at Cornwall began in 1742 and ceased on June 30, 1973. Precious-metal production for the 1908-73 period at Cornwall was approximately $67,000 \mathrm{oz}$ $\mathrm{Au}$ and 443,000 oz Ag (Pennsylvania Bureau of Statistics, 1944; U.S. Bureau of Mines, 1905-31, 1931-73; and Lapham, 1968). From data in U.S. Bureau of Mines "Yearbooks" for the period 1940 to 1950, it appears that the average recovered $\mathrm{Au}$ content of the iron ore was $0.001 \mathrm{oz} / \mathrm{t} \mathrm{Au}$ and $0.0062 \mathrm{oz} / \mathrm{t} \mathrm{Ag}$.

Mining at the Grace mine, Morgantown, began in 1958 and ceased in 1977. Production was probably on the 


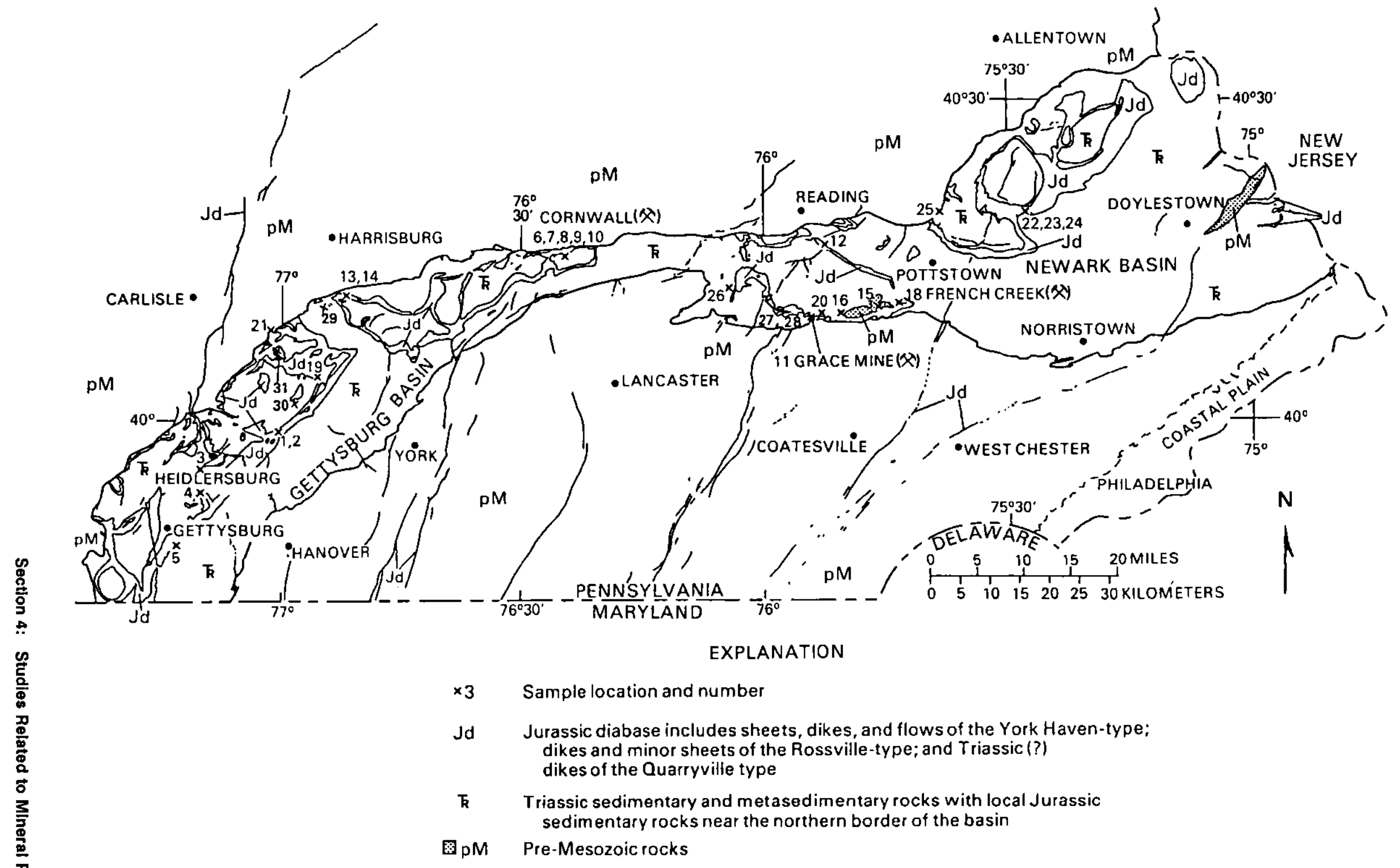

Figure 1. Locations of sampled early Mesozoic copper occurrences in southern Pennsylvania. Geology from Berg and others (1980). Numerals correspond with table 1. 


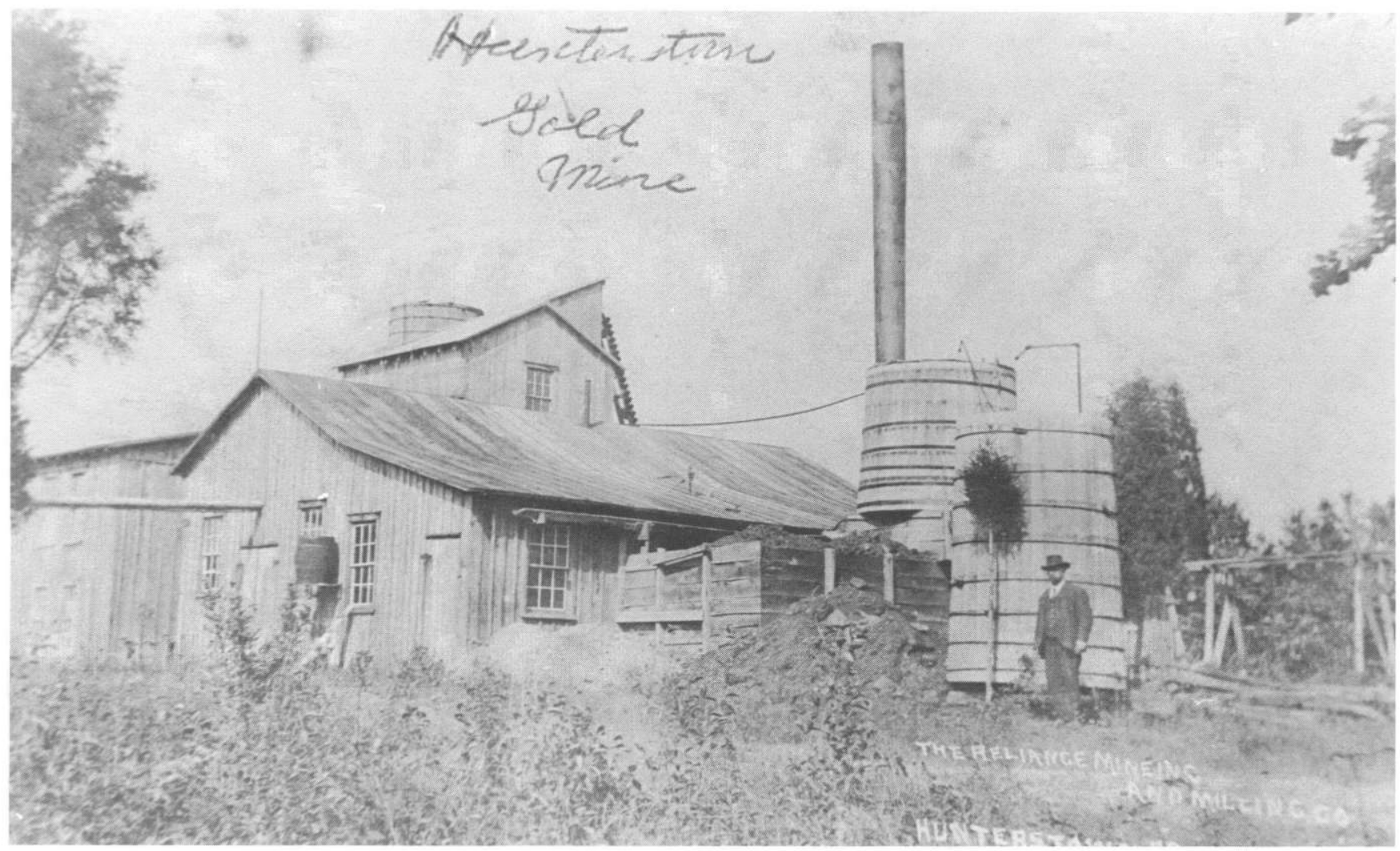

Figure 2. The Reliance Mining and Milling Company's Hunterstown mine around 1905. View to northeast shows Paris Erb and crusher building in rear and elevated railroad on right. (Courtesy of Edith Criswell.)

order of 45 million tons. Sims (1968) reported that ore from the Grace mine ran 43.7 percent $\mathrm{Fe}, 0.06$ percent $\mathrm{Cu}$, and 0.02 percent $\mathrm{Co}$ and that the pyrite averaged 0.51 percent Co. Smith (1977, p. 271) estimated a 60-millionton ore body on the basis of Sims' (1968) report of the dimensions prior to completion of drilling to the northeast. The ore body known in 1968 would have contained 40,000 tons of $\mathrm{Cu}$ and 10,000 tons of economically unrecoverable Co.

\section{SAMPLING AND ANALYSES}

Sample locations (fig. 1) are in both the Newark and Gettysburg basins. The types of occurrence sampled (table 1) include red-bed $\mathrm{Cu}$ (nos. 26 and 29); several Cornwall-type Fe-Cu skarns (nos. 6, 7, 8, 9, 10, 16, 18, 20, 25, 30, and 31); low-Fe skarns (nos. 1, 2, 3, 4, 5, 19, 22, and 23); veins in Mesozoic (no. 24) and pre-Mesozoic (no. 21) sedimentary rocks; veinlets in Jurassic diabase (nos. 11, 12, 13, and 28); and differentiates of diabase itself (nos. 14, 15, and 27). Sampling included both the large, well-known deposits (nos. 6, 7, 8, 9, 10, and 20) and those that are poorly known (nos. 1, 2, 21, 23, 26, and 30).

In sampling (table 1, fifth column) we attempted to obtain a representative composite of the copper and cobalt mineralization. Sample representativeness ranged from excellent (nos. 8, 9, 10, 19, 27, and 29) to only fair (no. 25). All analyses were performed by commercial laboratories (table 2).

\section{ORIGINS OF DEPOSITS}

The genetic end members of the types of copper deposits studied appear to have relatively clearcut origins. Occurrence nos. 26 and 29 seem to result from deposition by organic reduction of copper mobilized from red beds via a chloride-bearing pore fluid (Rose, 1976; Rose and others, 1986). Occurrences 14, 15, and 27 appear to be direct differentiates of the diabase. More problematic are the sources for the elements enriched in the "intermediate" types that have both sedimentary and igneous aspects. The model for generation of a chloriderich hydrothermal fluid from ferrogabbro (Smith, 1973, p. 122-129) still is a plausible one for Cornwall-type iron-copper and some related metasomatic deposits. However, this model does not eliminate the possibility of mobilization near diabase sheets of copper and other metals from normal sedimentary rocks or enriched redbed occurrences by convection of diabase-heated connate or other water (A.W. Rose, personal commun., 1972; Spencer, 1908). 


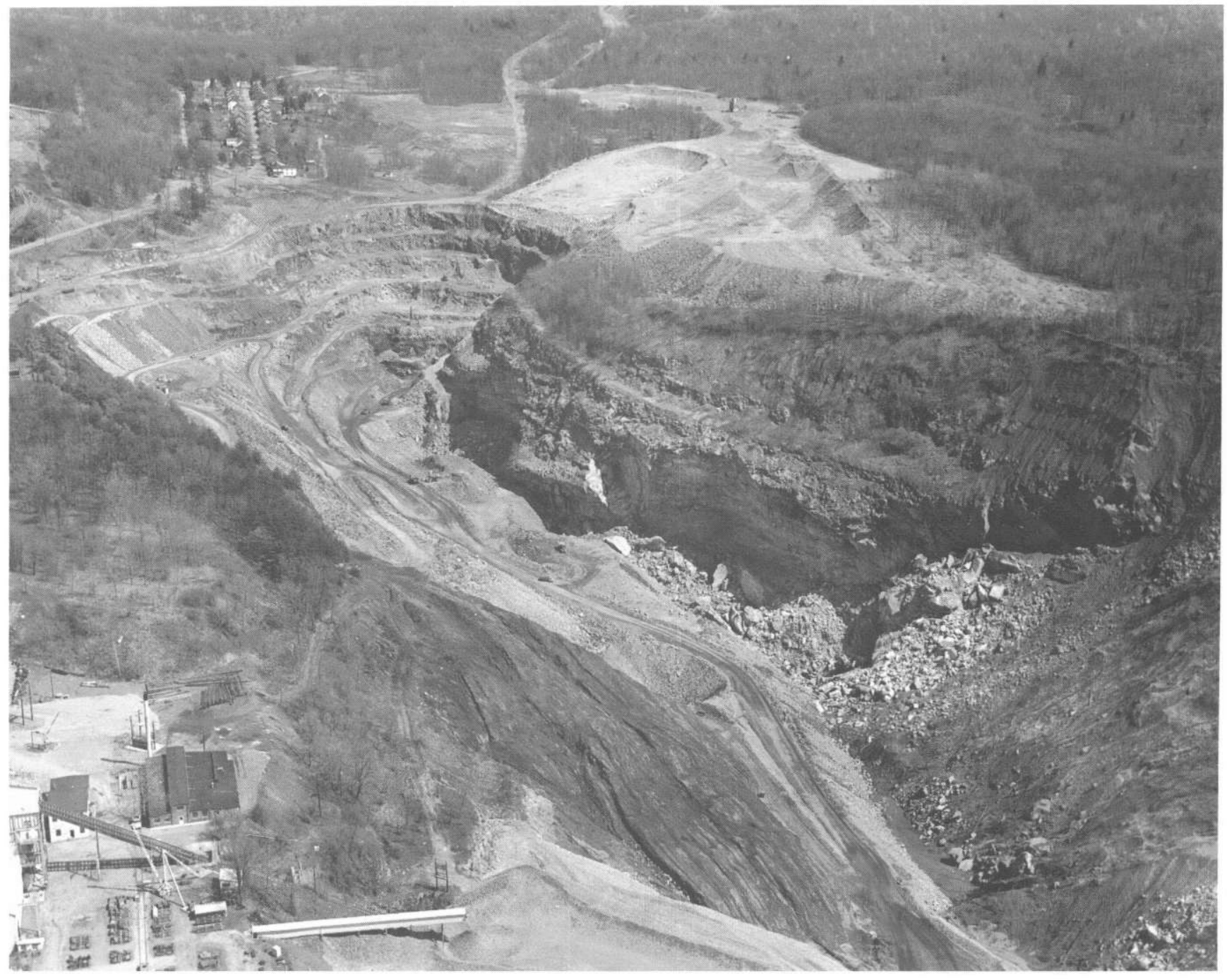

Figure 3. View of Cornwall mine east end open pit (looking east) on April 14, 1972. This part of the ore body was the richest in $\mathrm{Cu}$ and $\mathrm{Co}$ and perhaps Au. Inclined shaft leads to western ore body at lower left. (Courtesy of Bethlehem Steel Corporation.)

More recently, Eugster and Chou (1979) have combined the chloride and convection models; however, there is difficulty with the lack of the called-upon source pyrite in the country rock. Rose and others (1985) placed limits on the proportion of magmatic water from the observed ${ }^{18} \mathrm{O}$ and ${ }^{34} \mathrm{~S}$ enrichment of the 20 deposits they studied but do not rule out a magmatic source for copper and cobalt.

The association of the highest gold contents with areas known to contain intrusions of both York Havenand Rossville-type diabase is also problematic. On the basis of parent magma compositions (table 3 ), the York Haven magma is slightly favored as a source of metals and chloride for transport, whereas the Rossville seems to be more fertile with respect to sulfur. Note that the $\mathrm{Au} / \mathrm{Cu}$ ratio in both types of diabase $\left(\sim 0.3 \times 10^{-4}\right)$ is similar to that in many of the copper occurrences (table 2).

\section{DISCUSSION OF CORNWALL CONCENTRATES}

Samples 8, 9, and 10 (tables 1 and 2) are mid-1966 mill concentrates of chalcopyrite, pyrite, and magnetite from the productive Cornwall iron-copper deposit (fig. 3 ). Data from these samples agree moderately well with those for 1964 production reported by Lapham (1968). Lapham's values are 26.68 percent $\mathrm{Cu}$ and $460 \mathrm{ppm} \mathrm{Ni}$ for the chalcopyrite concentrates and 0.15 percent $\mathrm{Ni}$ and 1.37 percent $\mathrm{Co}$ for the pyrite concentrates. On the basis of the verification of millerite from the east end of the open pit (area of sample 7) as $0.1-\mathrm{mm}$ blebs in chalcopyrite associated with pyrite having 0.2 -mm-thick rims containing 4.47 percent $\mathrm{Ni}$ (Speer and Smith, 1981), the $\mathrm{Ni}$ in the concentrates is probably present as both a separate phase and in solid solution with the pyrite. On 
Table 1. Summary of the samples from early Mesozoic copper occurrences in southeastern Pennsylvania

\begin{tabular}{|c|c|c|c|c|c|}
\hline Numbe & Der Name & Location & $\begin{array}{l}\text { Latitude, } \\
\text { longitude }\end{array}$ & Sample size, type & Ore minerals in sample \\
\hline 1. $\mathrm{C}$ & Clapper farm & $\begin{array}{l}115 \mathrm{ft} . \mathrm{W} \text {. of Fish and } \\
\text { Game Rd., } 0.5 \mathrm{mi} \mathrm{N} \text {. by } \\
\text { route of int. with Baker's } \\
\text { Watering Trough Rd., } \\
\text { Adams Co. }\end{array}$ & $\begin{array}{l}39^{\circ} 59^{\prime} 24^{\prime \prime} \mathrm{N} \\
77^{\circ} 00^{\prime} 21^{\prime \prime} \mathrm{W}\end{array}$ & $\begin{array}{l}6.5 \mathrm{lb} \text { of chips } \\
\text { selected to show } \\
\text { at least trace } \mathrm{Cu}\end{array}$ & $\begin{array}{l}\text { Malachite, chrysocolla, bornite, azurite, } \\
\text { and "chalcocite" }\end{array}$ \\
\hline 2. $\mathrm{C}$ & Clapper farm & do. & do. & $\begin{array}{l}5.7 \text { lb composite } \\
\text { of } 84 \text { chips as } \\
\text { above }\end{array}$ & do. \\
\hline 3. $\mathrm{s}$ & $\begin{array}{l}\text { Stone Jug copper } \\
\text { prospect }\end{array}$ & $\begin{array}{l}150 \mathrm{ft} \mathrm{NW} \text {. of U.S. } 15,2.3 \\
\text { mi SW. of Heidlersburg } \\
\text { and } 0.75 \text { mi E. of Stone } \\
\text { Jug Hill, Adams Co. }\end{array}$ & $\begin{array}{l}39^{\circ} 55^{\prime} 11^{\prime \prime} \mathrm{N} \\
77^{\circ} 10^{\prime} 10^{\prime \prime} \mathrm{W}\end{array}$ & $\begin{array}{l}>1001 / 2-\text { to } 1- \\
\text { in. chips as } \\
\text { above }\end{array}$ & $\begin{array}{l}\text { Bornite, malachite chalcocite, djurleite, } \\
\text { chalcopyrite, molybdenite, powellite, } \\
\text { azurite, and chrysocolla }\end{array}$ \\
\hline 4. $\begin{array}{l}\mathrm{H} \\
\mathrm{m}\end{array}$ & $\begin{array}{l}\text { Hunterstown } \\
\text { mine }\end{array}$ & $\begin{array}{l}\text { - } 575 \mathrm{ft} \text { ESE. of Red } \\
\text { Bridge Rd. at a point } 0.42 \\
\text { mi N. of Hunterstown, } \\
\text { Adams Co. }\end{array}$ & $\begin{array}{l}39^{\circ} 53^{\prime} 18^{\prime \prime} \mathrm{N} \\
77^{\circ} 09^{\prime} 32^{\prime \prime} \mathrm{W}\end{array}$ & $\begin{array}{l}501 \text {-in. chips as } \\
\text { above, highgra- } \\
\text { ded from very } \\
\text { lean dump }\end{array}$ & Chrysocolla and malachite \\
\hline
\end{tabular}

S. Teeter-Campbell $2.2 \mathrm{mi} \mathrm{SE}$. of center of quarry

6. CEOP \#40

7. CEOP \#43

8. Cornwall chalcopyrite

9. Cornwall pyrite

10. Cornwall magnetite

11. I-176 Morgantown outcrop joints
Footwall ore body, Cornwall, Lebanon Co.

East end open pit, Cornwall, Lebanon Co.

Flotation concentrate from eastern and western mines

do.

Magnetic concentrate from eastern and western mines

NE. side of I-176 at footages 1,775 to $1,900 \mathrm{ft}$ from SE. end of cut and $0.4 \mathrm{mi}$ $\mathrm{NW}$. of $\mathrm{Pa}$. Turnpike, Berks Co.

\section{Gettysburg, Adams Co.}

$39^{\circ} 48^{\prime} 08^{\prime \prime} \mathrm{N} . \quad>501$ - to 2 -in. $77^{\circ} 12^{\prime} 44^{\prime \prime} \mathrm{W}$. chips

$\sim 40^{\circ} 15^{\prime} 58^{\prime \prime}$ N. 36 1-in.-long

$\sim 76^{\circ} 24^{\prime} 36^{\prime \prime} \mathrm{W}$. pieces of EX

(B.S. CO. core highgraded coordinates: to show at least S788 and a trace of visible E3100 for sulfide

hole collar at $144 \mathrm{ft}$ )

$40^{\circ} 15^{\prime} 58^{\prime \prime} \mathrm{N} . \quad 1051$-in. chips $76^{\circ} 24^{\prime} 15^{\prime \prime} \mathrm{W}$. highgraded for chalcopyrite from footwall to hanging wall

$40^{\circ} 15^{\prime} 54^{\prime \prime} \mathrm{N}$. $76^{\circ} 23^{\prime} 45^{\prime \prime} \mathrm{W}$.

do.

do.

$40^{\circ} 09^{\prime} 58^{\prime \prime} \mathrm{N} . \quad 6 \mathrm{lb}$ of chips, $75^{\circ} 54^{\prime} 09^{\prime \prime} \mathrm{W}$. most selected to show at least a trace of pyrite or chalcopyrite
Djurleite, chalcocite, bornite, idaite(?), chrysocolla, malachite, and cuprite

Chalcopyrite, pyrite, and magnetite

Chalcopyrite, pyrite, and magnetite

Chalcopyrite mill concentrate

Pyrite mill concentrate

Magnetite mill concentrate

Chalcopyrite and malachite 


\begin{tabular}{l} 
Gangue minerals \\
\hline Feldspar, pyroxene, mica, \\
and chlorite groups, \\
andradite-grossular, horn- \\
blende, quartz, epidote, \\
and actinolite(?); powder \\
yields slight fizz with dilute \\
$\mathrm{HCl}$
\end{tabular}

do.

Andradite-grossular, ep and stilbite

Epidote, chlorite group, and quartz
Hornfels xenolith(?) in Rossville diabase

\section{Size of} deposit

Comments

References

Occurrence with 20-200 Vegetation anomaly $23 \mathrm{ft}$ lb $\mathrm{Cu}$ ? diameter with "British Soldiers" lichen on rim; hornfels between diabase sheets good targets
Metallic Mineral

Files of Penn.

Geol. Survey, 8/14/86. do.

do.

Hornfels, presumably Prospect with at least above diabase

Bulk samples contain major feldspar such as albite; minor pyroxene such as diopside, mica; trace chlorite, quartz, actinolite(?); and $3 \mathrm{ppb} \mathbf{P d}$ and $<10 \mathrm{ppb} \mathrm{Pt}$

Stone Jug Hill drilled by Beth- Smith and Hoff lehem Steel in 1950 for Cornwall-type magnetite without success

Hornfels above York Haven diabase

cut; $1: \mathrm{Cu}$ ?

Mine with at least a pair of $30 \mathrm{ft}$ inclines and a

Do. (1977), Sheely (1978).

Hoff and Smith crosscut; depth $>245 \mathrm{ft}$; $1-10 \mathrm{t} \mathrm{Cu}$ ?

Calcareous hornfels; presumably would have been below York Haven diabase

Cornwall, calcareous xenolith in York Haven diabase; Lapham and Gray report possible replacement of diabase

$\sim 1.5 \mathrm{ft} \times>30 \mathrm{ft}$ exposed in 1976; $1-10 \mathrm{t}$ $\mathrm{Cu}$ ?

$>500 \mathrm{ft}$ long $\times 40 \mathrm{ft}$ $100,000 \mathrm{t}$ ? thick $x-40 \mathrm{ft}$ wide; pers. commun., 1982); mill area $375 \mathrm{ft} \mathrm{ESE}$. of Red Bridge Rd.; bulk sample contains major quartz, major to minor chlorite and epidote, and minor feldspar

Active aggregate quarry; magnetite in other lenses and stratiform, some with major chalcopyrite

Never mined, xenoliths in diabase considered favorable; strikes $\mathrm{N} .35^{\circ} \mathrm{W}$. and plunges $40^{\circ} \mathrm{NE}$; previous assay: 0.24 $\mathrm{oz} / \mathrm{t} \mathrm{Au}, 4.4 \mathrm{oz} / \mathrm{t} \mathrm{Ag}$, and 10 $\mathrm{ppb} \mathrm{Pd}$ and $12 \mathrm{ppb} \mathrm{Pt}$
Sparse gold flour in Beaverdam Run (D. Schmerling. (1886), Smith (1985), J.P. Minard (USGS upub. data, 1968), Sheely (1886).

Hoff (1978),

Smith (1978).

Lapham and Gray (1973, p. 111113), M.R. Metallic Mineral Files of Penn. Geol. Survey (1972), Herrick, (1973).
Cornwall, replacement of Buffalo Springs Formation above York Haven diabase sheet; sheet cut by small Rossville diabase dike

do.

do.

do.

do.

do.

Open pit, No. 3 and 4 mines yielded $106 \times 10^{6}$ $t$ ore; ore at bottom of E. end open pit was 70 $\mathrm{ft}$ thick on 300-ft level with ore-grade $\mathrm{Fe}$ down to $280 \mathrm{ft}$ and sub-oregrade to $250 \mathrm{ft}$ where only $30 \mathrm{ft}$ thick

do. joints in York Haven diabase
Deuteric mineralized
$\mathrm{Cu}$ grade in E. end of open pit ran 0.55 + 0.15 percent; $1,080 \mathrm{t}$ chalcopyrite recovered in Nov. 1972; overall deposit yielded $67,000 \mathrm{oz} \mathrm{Au}$ and $>440,000 \mathrm{oz} \mathrm{Ag}$

Millerite verified in chalcopyrite from the $E$. end of the open pit; tochilinite verified from hanging wall of west end of open pit

do.

do.

$1.2 \mathrm{mi}$ WSW. of shafts from Grace $\mathrm{Fe}-\mathrm{Cu}$ mine; Otc. ends at $1,900 \mathrm{ft}$; pure chalcopyrite previously reported to yield 85 ppm $\mathrm{Au}$ and $875 \mathrm{ppm} \mathrm{Ag}$
Lapham and Gray (1973), Herrick (1973), Field notebooks, R.C. Smith II.
Lapham and Gray (1973), Smith (1978).

Do.

Do.

Smith (1973). actinolite, and albite
Occurrence with $<20 \mathrm{lb}$ $\mathrm{Cu} ; \sim 0.5 \%$ sulfide in sample


Table 1. Summary of the samples from early Mesozoic copper occurrences in southeastern Pennsylvania-Continued

$\begin{array}{ll}\text { Number Name Location } & \text { Latitude, } \\ \text { longitude Sample size, type }\end{array}$

12. J.T. Dyer quarry SW. corner of lowest level of J.T. Dyer quarry, Berks Co.

13. I-83 Reesers Summit veinlets

14. I-83 Reesers Summit diabase pegmatite

15. D-169 Warwick pegmatite (Pine Swamp)

16. Jones mine

18. French Creek

19. Rossville roadcut

20. Grace Mine, dump/aggregate stockpile (Morgantown)

21. Strayer and Lefever quarry

22. Kibblehouse Quarry Co., highgrade

23. Kibblehouse quarry, new development

24. Kibblehouse quarry, $N$. face pyrite vein
NE. side of I-83525 ft along road NW. from upper contact, York Co.

NE. side of I-83 724 to

$738 \mathrm{ft}$ along road NW. from upper contact, York Co.

$7 \mathrm{ft}$ selected from 1,285 to $1,310 \mathrm{ft}$ of D.D.H. No. 26, $0.65 \mathrm{mi} \mathrm{SE}$. of Pine Swamp, Chester Co. intersection with $\mathrm{Pa}$. Route $82,1.3 \mathrm{mi} \mathrm{NW}$. of Elverson, Berks Co.

Dumps sampled are NW. and W. of P. Chonka house, which is located $1,200 \mathrm{ft}$ NE. of St. Peters and $2,200 \mathrm{ft}$ SW of Harmonyville, Chester Co.

NW. side of highway to Dillsburg, $0.7 \mathrm{mi} \mathrm{NW}$. of Rossville, York Co. mine headframes, Berks Co.

$0.5 \mathrm{mi} \mathrm{SE}$. of Williams Grove, York Co.

NW. face of quarry, 0.32 mi E. of Perkjomenville, Montgomery Co. Perkiomenville, Montgom-

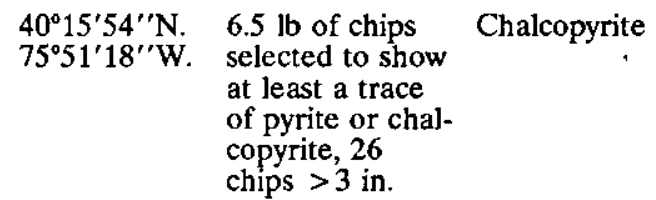

$40^{\circ} 15^{\prime} 54^{\prime \prime} \mathrm{N} . \quad 6.5 \mathrm{lb}$ of chips $75^{\circ} 51^{\prime} 18^{\prime \prime} \mathrm{W}$. selected to show at least a trace of pyrite or chalcopyrite, 26 chips $>3$ in.

\section{Chalcopyrite}

.

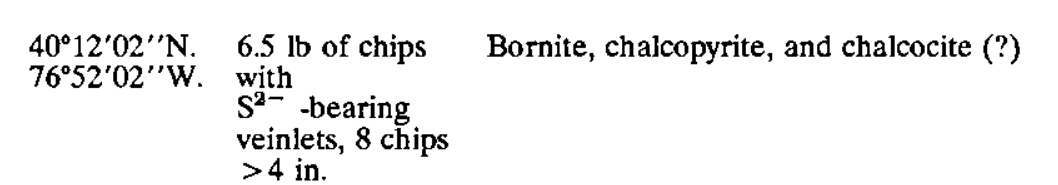

$40^{\circ} 12^{\prime} 03^{\prime \prime} \mathrm{N} . \quad 19 \mathrm{Jb}$ of chips Chalcopyrite

$76^{\circ} 52^{\prime} 04^{\prime \prime} \mathrm{W} . \quad>3$ in.

$40^{\circ} 10^{\prime} 50^{\prime \prime} \mathrm{N}$. Half of $7 \mathrm{ft}$ of

$75^{\circ} 46^{\prime} 25^{\prime \prime} \mathrm{W}$. 1.6-in.-diameter

Chalcopyrite core $\begin{array}{ll}\text { Dump sampled is on Red } 40^{\circ} 10^{\prime} 16^{\prime \prime} \mathrm{N} . & 18 \mathrm{lb} \text { of typical } \\ \text { Hill Rd. } 130 \text { to } 175 \mathrm{ft} \mathrm{N} \text {. of } 75^{\circ} 50^{\prime} 52^{\prime \prime} \mathrm{W} . & \text { ore from dump, }\end{array}$

$40^{\circ} 11^{\prime} 04^{\prime \prime} \mathrm{N} . \quad 19 \mathrm{lb}$ of typical $75^{\circ} 43^{\prime} 44^{\prime \prime} \mathrm{W}$. ore from dumps, 105 chips $>1 \frac{1}{2}$ in.

Chalcopyrite, magnetite, and "copper 117 chips $>1$ in. bloom"

$40^{\circ} 04^{\prime} 22^{\prime \prime} \mathrm{N} . \quad 10 \mathrm{lb}$ of 11.5 -in. $76^{\circ} 55^{\prime} 28^{\prime \prime} \mathrm{W}$. channel sample with 2.75 by 3.5 in. cross section

$1.3 \mathrm{mi}$. NNE. of Morgan- $\quad 40^{\circ} 10^{\prime} 27^{\prime \prime} \mathrm{N} . \quad 18 \mathrm{lb}$ of 120 town, $0.3 \mathrm{mi} \mathrm{NW}$. of Grace $75^{\circ} 53^{\prime} 12^{\prime \prime} \mathrm{W}$. chips $>2$ in.

$40^{\circ} 08^{\prime} 40^{\prime \prime} \mathrm{N} . \quad 1.3 \mathrm{lb}$ of $46 \mathrm{~min}-$ $77^{\circ} 01^{\prime} 22^{\prime \prime} \mathrm{W}$. eralized chips $>3 / 4$ in.

$40^{\circ} 19^{\prime} 27^{\prime \prime} \mathrm{N} . \quad 1.1 \mathrm{lb}$ consisting $75^{\circ} 28^{\prime} 21^{\prime \prime} \mathrm{W}$. of $13>1$-in. pieces highgraded to show visible cobaltite

Azurite, malachite chalcocite, and bornite

Magnetite, chalcopyrite, and hematite

Chalcopyrite, magnetite (octahedral and pseudomorphous after foliated specular hematite)

Malachite, chrysocolla, "copper pitch," chalcopyrite, and "chalcocite"(?)

Cobaltite as cuboctahedrons; Speer and other (1978) note that the crystals have cobaltian gersdorffite cores and cobalite rims; inclusions include safflorite and a joseite-like $\mathrm{Bi}$ sulfotelluride

Muck pile from S. face new $40^{\circ} 19^{\prime} 25^{\prime \prime}$ N. $\quad 6.8 \mathrm{lb}$ of $33>2$ development, Montgomery $75^{\circ} 28^{\prime} 12^{\prime \prime} \mathrm{W}$. in. chips selected Co.

N. face of main Kibblehouse quarry, $0.32 \mathrm{mi} \mathrm{E}$. of ery $\mathrm{Co}$.

(a) to show at least

trace $\mathrm{Cu}$

$40^{\circ} 19^{\prime} 29^{\prime \prime} \mathrm{N} . \quad 4 \mathrm{lb}$ of 55 chips None observed

$75^{\circ} 28^{\prime} 15^{\prime \prime} \mathrm{W}, \quad>1$ in., from

pyrite

Chalcopyrite, chrysocolla, and malachite 


\begin{tabular}{lllll}
\hline Gangue minerals & Type of deposit & $\begin{array}{l}\text { Size of } \\
\text { deposit }\end{array}$ & Comments & References \\
\hline
\end{tabular}

Hematite, pyrite, calcite, and chlorite group

Calcite and quartz var. chalcedony

Pyrite in slightly pinkish diabase pegmatite

Magnetite-ilnenite

Pyrite, chlorite group, talc, ferroan dolomite, and serpentine group

Pyrite (octahedral), calcite, actinolite, andradite, and stilpnomelane

Epidote and andraditegrossular

Pyrite, chlorite group, actinolite, serpentine group, pyrrhotite, and calcite

\section{Calcite and quartz (aci- cular)}

Calcite, actinolite, diopside, pumpellyite, axinite, and datolite

\author{
Cornwall-type \\ replacement of mar- \\ ble and gneiss
}

Deuteric mineralized veinlets in York Haven diabase

\section{lb $\mathrm{Cu}$}

Occurrence with $<20 \mathrm{lb}$ Cu. $\sim 0.5 \%$ sulfide in sample

Four 0.4-in.-thick veinlets over Smith (1978). $15 \mathrm{ft}$ trending $\sim \mathrm{N} .20^{\circ} \mathrm{E}$. were sampled; some samples slickenside; Co minerals described from similar veinlets; bulk sample $<10 \mathrm{ppb} \mathrm{Pd}$ and 11 ppb Pt

Disseminated sulfides in thin York Haven diabase pegmatite pod

Occurrence in York Haven-type diabase pegmatite

Cornwall type
Leakage(?) from Rossville-type diabase into calcareous hornfels

Cornwall-type replacement of Elbrook Formation above York Haven diabase

\section{Subvertical veins} below former base of N. Mesozoic margin

Porcelainlike, lightcolored hornfels near York Haven diabase
Sampled site is $360 \mathrm{ft}$ below upper contact; veinlets trend $\sim$ N. $10^{\circ} \mathrm{E}$.; bornite and "chalcocite" in calcite also at $900 \mathrm{ft}$ along road NW. of contact

Sampled site is $504 \mathrm{ft}$ below upper contact; assay yields $<10 \mathrm{ppb} \mathrm{Pd}$ and $6 \mathrm{ppb} \mathrm{Pt}$

Smith (1973).

Smith (1973), Gedde (1965).

$\mathrm{Cu}, 10.32 \% \mathrm{FeO}, 2.69 \%$

$\mathrm{Fe}_{2} \mathrm{O}_{3}, 1,420 \mathrm{ppm} \mathrm{Cl}$, and 315 ppm S; $383 \mathrm{ft}$ below upper contact of York Haven diabase

Smith and O'Neill development; no bleached zones

Perpendicular chlorite veining with associated bleached zone proximal Hunt (1876),

(1)

Smith (1973).
Smith (1978, p. 49-50,91-99, and 206-207); Speer and others (1978).
Calcite, "limonite," pyrite, and chlorite group

Pyrite (granular and cubic), "limonite" actinolite, calcite, and
Stratabound in dark hornfels near York Haven diabase

Pyrite vein perpendicular to bedding near stratabound $\mathrm{Co}$ and $\mathrm{Cu}$ occurrences; pyrite vein in quartzose hornfels
$>20 \mathrm{lb}$
Smith (1931), $\sim 200 \mathrm{lb} \mathrm{Cu} ?$

Rose (1970) estimates $500,000 \mathrm{t}$ and a few shipments of $6-7 \% \mathrm{Cu}$; mining ceased by 1908

Rose estimates $1,000,000 \mathrm{t}$

Probably $>100,000,000$ $\mathrm{t}$ of $\mathrm{Fe}$ ore produced

\section{$20-200 \mathrm{lb} \mathrm{Cu}$}

$$
>200 \mathrm{lb}
$$

(2)
Sampled dump may contain $500 \mathrm{t}$ of $\sim 2 \% \mathrm{Cu}$; assay yields $<10 \mathrm{ppb} \mathrm{Pd}$ and $6 \mathrm{ppb} \mathrm{Pt}$

Rare cobaltite (Smith, 1978) and erythrite were depleted from dump by mineral collectors by 1986

An overlying 65 in reported to average $0.19 \% \mathrm{Cu},<0.009$ $\mathrm{oz} / \mathrm{t} \mathrm{Au}$, and $0.32 \mathrm{oz} / \mathrm{t} \mathrm{Ag}$

Assayed sample probably represents subeconomic hanging wall of ore body; sample biased to include trace sulfides in each piece

Elsewhere in quarry, cobaltite in cross-cutting veins or with arsenopyrite and dark brown sphalerite; Speer and others (1978) report a cobaltitebearing metasedimentary layer $1 \mathrm{ft}$ thick and about $50 \mathrm{ft}$ long

Locally observed in place on $N$. face near entrance to new (1973).

\section{Sims (1968), Smith (1977, p. 271-275).} (1976).

(a)

Rogers (1858), Spencer (1908), Rose (1970).

$>200 \mathrm{lb} \mathrm{Cu}$ 
Table 1. Summary of the samples from early Mesozoic copper occurrences in southeastern Pennsylvania-Continued

\begin{tabular}{|c|c|c|c|c|c|}
\hline Numb & ber Name & Location & $\begin{array}{l}\text { Latitude, } \\
\text { longitude }\end{array}$ & Sample size, type & Ore minerals in sample \\
\hline 25. $\frac{\mathrm{I}}{\mathrm{i}}$ & $\begin{array}{l}\text { Boyertown area } \\
\text { iron mine dump }\end{array}$ & $\begin{array}{l}\text { Small dumps between } \mathrm{N} . \\
\text { end of Gabael Hill and } \\
\text { railroad, Berks Co. }\end{array}$ & $\begin{array}{l}40^{\circ} 19^{\prime} 42^{\prime \prime} \mathrm{N} \\
75^{\circ} 38^{\prime} 34^{\prime \prime} \mathrm{W}\end{array}$ & $\begin{array}{l}5 \mathrm{lb} \text { of } 34>1- \\
1 / 2 \text {-in. chips from } \\
\text { dumps, not very } \\
\text { representative }\end{array}$ & Magnetite, chalcopyrite, and malachite \\
\hline 26. I & Interchange 21 & $\begin{array}{l}\text { Roadcut on N. side of Exit } \\
21 \text { of } \mathrm{Pa} \text {. Turnpike, Lan- } \\
\text { caster } \mathrm{Co} \text {. }\end{array}$ & $\begin{array}{l}40^{\circ} 12^{\prime} 53^{\prime \prime} \mathrm{N} \\
76^{\circ} 04^{\prime} 46^{\prime \prime} \mathrm{W}\end{array}$ & $\begin{array}{l}4.6 \mathrm{ft} \text { vertical, } \\
\text { true channel } \\
\text { sample perpen- } \\
\text { dicular to bed- } \\
\text { ding }\end{array}$ & $\begin{array}{l}\text { Chrysocolla malachite, chalcocite(?), } \\
\text { digenite(?), brochantite, libethenite, } \\
\text { and cuprite(?) }\end{array}$ \\
\hline 27. 2 & $\begin{array}{l}\text { Turnpike, mile } \\
293 \text { (composite) }\end{array}$ & $\begin{array}{l}\text { S. side of Pa. Turnpike, E. } \\
\text { of mile marker post } 293.7 \text {, } \\
\text { Lancaster Co. }\end{array}$ & $\begin{array}{l}40^{\circ} 10^{\prime} 28^{\prime \prime} \mathrm{N} \\
75^{\circ} 57^{\prime} 57^{\prime \prime} \mathrm{W}\end{array}$ & $\begin{array}{l}19 \mathrm{lb} \text { of } 115 \\
\text { chips }>1 \text { in., } \\
\text { comp. along } 195 \\
\mathrm{ft} \text { horizontal }\end{array}$ & None \\
\hline 28. 7 & $\begin{array}{l}\text { Turnpike, mile } \\
293 \text { (E. satellite } \\
\text { vein) }\end{array}$ & $\begin{array}{l}\text { S. side of Pa. Turnpike } \\
\sim 135 \mathrm{ft} \mathrm{E} \text {. of mile marker } \\
\text { post } 293.7 \text {, Lancaster } \mathrm{Co} \text {. }\end{array}$ & $\begin{array}{l}40^{\circ} 10^{\prime} 28^{\prime \prime} \mathrm{N} \\
75^{\circ} 57^{\prime} 56^{\prime \prime} \mathrm{W}\end{array}$ & $\begin{array}{l}7 \mathrm{lb} \text { of } 110 \\
\text { chips }>2 \text { in., } \\
7 \text {-in.-wide chan- } \\
\text { nel sample }\end{array}$ & None \\
\hline 29. & $\begin{array}{l}\text { Fairview Bethel } \\
\text { Cemetery (Lis- } \\
\text { burn area) }\end{array}$ & $\begin{array}{l}1.2 \mathrm{mi} \mathrm{NNE} \text {. of Lisburn } \\
\text { and } 1.5 \mathrm{mi} \mathrm{NW} \text {. of } \\
\text { Bunches, York Co. }\end{array}$ & $\begin{array}{l}40^{\circ} 11^{\prime} 14^{\prime \prime} \mathrm{N} \\
76^{\circ} 54^{\prime} 52^{\prime \prime} \mathrm{W}\end{array}$ & $\begin{array}{l}\sim 5 \mathrm{lb} \text { of } 72 \\
\text { chips }>3 \text { in., } 1.4 \\
\text { ft. channel sam- } \\
\text { ple }\end{array}$ & Malachite \\
\hline 30. & $\begin{array}{l}\text { Wellsville area Fe } \\
\text { dump (Mine } \\
\text { Bank School- } \\
\text { house area) }\end{array}$ & $\begin{array}{l}1.8 \mathrm{mi} \mathrm{SW} \text {. of Wellsville } \\
\text { and } 1.5 \mathrm{mi} \text { NNE. of Krall- } \\
\text { town, York Co. }\end{array}$ & $\begin{array}{l}\sim 40^{\circ} 02^{\prime} 21^{\prime \prime} \mathrm{N} \\
\sim 76^{\circ} 58^{\prime} 11^{\prime \prime} \mathrm{W}\end{array}$ & $\begin{array}{l}7.5 \mathrm{lb} \text { of } 174 \\
\text { chips > } 2 \text { in., } \\
\text { composite of } \\
\text { only Cu-bearing } \\
\text { chips }\end{array}$ & $\begin{array}{l}\text { Platy magnetite, chrysocolla, malachite, } \\
\text { "copper pitch," and cuprite(?) }\end{array}$ \\
\hline 31. I & $\begin{array}{l}\text { Longnecker mine, } \\
\text { Dillsburg Dist. }\end{array}$ & $\begin{array}{l}1.1 \mathrm{mi} \mathrm{E} . \text { of Dillsburg, } \\
\text { York Co. }\end{array}$ & $\begin{array}{l}40^{\circ} 06^{\prime} 44^{\prime \prime} \mathrm{N} \\
77^{\circ} 00^{\prime} 52^{\prime \prime} \mathrm{W}\end{array}$ & $\begin{array}{l}7.5 \mathrm{lb} \text { of } 164 \\
\text { chips }>2 \text { in., } \\
\text { composite of } \\
\text { mine dump }\end{array}$ & $\begin{array}{l}\text { Octahedral magnetite, pyrite, rare chal- } \\
\text { copyrite, and "copper bloom" }\end{array}$ \\
\hline
\end{tabular}

the basis of the low As content of $220 \mathrm{ppm}$ in the pyrite concentrate (no. 9), it is suggested that most of the Co is not present as a separate arsenide phase.

From the analyses for the chalcopyrite concentrate (sample 8, tables 1 and 2) showing 25 percent $\mathrm{Cu}, 0.1 \mathrm{oz} / \mathrm{t}$ $\mathrm{Au}$, and $0.6 \mathrm{oz} / \mathrm{t} \mathrm{Ag}$, and the known production of $1.06 \times 10^{8}$ tons of recovered ore with an apparent grade of 0.4 percent $\mathrm{Cu}$, one can estimate a total precious metals potential (not recovered) from Cornwall ore bodies of 212,000 oz Au and 1,272,000 oz Ag. Average grades for this ore would have been $0.002 \mathrm{oz} / \mathrm{t} \mathrm{Au}$ and $0.012 \mathrm{oz} / \mathrm{t} \mathrm{Ag}$.

\section{CONCLUSIONS AND SUGGESTIONS FOR FUTURE STUDIES}

Spencer's (1908, p. 16) list of geologic suggestions for exploration for typical Cornwall-type magnetite deposits has stood the test of time very well. We suggest that the following of Spencer's conclusions be utilized:
(1) Cornwall-type ore bodies are to be sought in carbonate rocks near large bodies of diabase, and (2) particularly favorable intrusions are cross-cutting and steeply dipping. In addition, Rose (1972), using more recent geologic mapping, aeromagnetic data, regional streamsediment geochemical data, and discriminant analysis, identified favorable areas near Boyertown (general area of no. 25) and Gettysburg (general area of no. 5). Note that these are near the occurrences of the higher $\mathrm{Au} / \mathrm{Cu}$ ratio of the present study.

The new data (tables 1 and 2) suggest a possible association of occurrences containing moderate gold with multiple intrusions. Even if the apparent association is fortuitous, the fact remains that the northeastern Adams County area (occurrences 1 and 3 ) is a somewhat favorable area for gold exploration. The higher-than-typical $\mathrm{Au} / \mathrm{Cu}$ ratio (table 2 ) in this area suggests the possibility of an additional process that enriches gold. Hotz (1950) first studied multiple intrusions in the Dillsburg district of the Gettysburg basin, but he did not recognize the 


\begin{tabular}{|c|c|c|c|c|}
\hline Gangue minerals & Type of deposit & $\begin{array}{l}\text { Size of } \\
\text { deposit }\end{array}$ & Comments & References \\
\hline $\begin{array}{l}\text { Pyrite (octahedral), calcite, } \\
\text { chlorite, and orange garnet } \\
\text { on wall-rock contact }\end{array}$ & Cornwall type & $\begin{array}{l}\text { Rose estimates } \\
1,000,000 \mathrm{t} \text { for the } \\
\text { district production }\end{array}$ & $\begin{array}{l}\text { Ore resembles French Creek; } \\
\text { ore from Gable shaft(?) }\end{array}$ & $\begin{array}{l}\text { Spencer }(1908, p \text {. } \\
\text { 43), Rose }(1970) \text {. }\end{array}$ \\
\hline $\begin{array}{l}\text { Carbonaceous plant frag- } \\
\text { ments, barite, and } \\
\text { nontronite }\end{array}$ & $\begin{array}{l}\text { Red-bed reduced } \\
\text { channel }\end{array}$ & $>20 \mathrm{lb} \mathrm{Cu}$ & $\begin{array}{l}\text { Deposit resembles Upper } \\
\text { Devonian Cu occurrences in } \\
\mathrm{N} \text {.-central Penn.; host is } \\
\text { feldspathic gray sandstone }\end{array}$ & \\
\hline $\begin{array}{l}2 \pm \mathrm{mm} \text { honey- to smoky- } \\
\text { yellow orthopyroxene in a } \\
\text { coarse-grained diabase } \\
\text { matrix }\end{array}$ & $\begin{array}{l}\text { Orthopyroxene } \\
\text { cumulate zone at } \\
\text { base of York Haven- } \\
\text { type sheet }\end{array}$ & $>10,000 \mathrm{t}$ & $\begin{array}{l}\text { Well-developed cumulate; } \\
\text { alteration veinlets present, } \\
\text { see below }\end{array}$ & $\begin{array}{l}\text { Similar to sample } \\
\text { D-126 of Smith } \\
(1973) .\end{array}$ \\
\hline $\begin{array}{l}\text { Altered actinolite and } \\
\text { aplite }\end{array}$ & $\begin{array}{l}\text { Vein cutting ortho- } \\
\text { pyroxene cumulate } \\
\text { zone }\end{array}$ & $>1 t ?$ & $\begin{array}{l}\text { Vein trends } \mathrm{N} .20^{\circ} \mathrm{W} \text {. in a zone } \\
\text { of multiple veins, some up to } \\
1.6 \mathrm{ft} \text { thick, but other veins } \\
\text { found leaner for gold }\end{array}$ & \\
\hline None & $\begin{array}{l}\text { Red-bed reduced } \\
\text { channel }\end{array}$ & $>2 \mathrm{lb} \mathrm{Cu}$ & $\begin{array}{l}\text { Proximal to mapped border } \\
\text { faults and thin York Haven- } \\
\text { type diabase dikes }\end{array}$ & \\
\hline $\begin{array}{l}\text { Limonite, pink orthoclase, } \\
\text { chlorite, and fine-grained } \\
\text { mica }\end{array}$ & $\begin{array}{l}\text { Cornwall-type skarn } \\
\text { replacement }\end{array}$ & $\begin{array}{l}\text { Rose }(1970) \text { reports up } \\
\text { to } 4,000 \mathrm{t}\end{array}$ & $\begin{array}{l}\text { Nearby Rossville-type sheet; } \\
\text { also, Rossville-type diabase on } \\
\text { dumps }\end{array}$ & $\begin{array}{l}\text { Spencer }(1908) \text {, } \\
\text { Stose and Jonas } \\
(1939), \text { Rose } \\
(1970) \text {. }\end{array}$ \\
\hline $\begin{array}{l}\text { Actinolite, epidote, pink } \\
\text { orthoclase, ferroan dolo- } \\
\text { mite, calcite, and pink mica }\end{array}$ & do. & 1.5 metric $t$ from district & $\begin{array}{l}\text { Sheets of Rossville-type and } \\
\text { York Haven-type diabase in } \\
\text { area }\end{array}$ & $\begin{array}{l}\text { Spencer (1908), } \\
\text { Stose and Jonas } \\
(1939), \text { Rose } \\
(1970) .\end{array}$ \\
\hline
\end{tabular}

probability of an extensive layer of favorable carbonate host rock between a thin erosional remnant of a Rossville-type sheet at the surface and a thick York Haven-type sheet at depth (Smith, 1973, p. 176-177). As noted by Smith (1973, p. 177), magnetic anomalies unrelated to iron-rich diabase differentiates at the surface may warrant exploration for gold.

Smith (1973, p. 43-44) began reconnaissance mapping of the multiple intrusions, and Wood (1980) located additional sedimentary inliers along the contact. Most recently, reconnaissance mapping in the area of occurrence 1 suggests that it is located either in a xenolith in Rossville-type diabase or as a sediment inlier along the contact between the two diabase types. Mapping of the Rossville-York Haven diabase contact and associated hornfels inliers/xenoliths, together with geochemical sampling for copper and panning for gold, are strongly recommended.

Possible areas of reconnaissance for cobalt include (1) the bleached hornfels between the north face of the Kibblehouse quarry and the diabase sheet, (2) French
Creek-like marble- and gneiss-hosted deposits including the Pine Swamp prospect (Gedde, 1965), and (3) probable feeder zones for the larger known deposits such as Cornwall (beneath east end of open pit) and Morgantown (east-northeastern ore).

\section{ACKNOWLEDGMENTS}

Funding for the analyses and report preparation was provided by the Pennsylvania Bureau of Topographic and Geologic Survey. Reviews of a first draft were provided by A.W. Rose of The Pennsylvania State University, S.J. Sims of Bethlehem, Pennsylvania, and M. Foose and J.E. Gair of the U.S. Geological Survey. The second draft was reviewed by J.H. Barnes of the Pennsylvania Geological Survey and G.R. Robinson, Jr., of the U.S. Geological Survey. 
Table 2. Analyses of selected early Mesozoic copper occurrences from Pennsylvania

[Fire assays for $\mathrm{Au}$ and $\mathrm{Ag}$ were obtained on 35-g splits. $\mathrm{Co}, \mathrm{Ni}$, and $\mathrm{Cu}$ were determined by atomic absorption, As by a colorimetric analysis, and $\mathrm{Bi}$ and $\mathrm{Mo}$ by semiquantitative emission spectroscopy. Four samples were cross-checked for Au and Ag by a lead fire-assay concentration followed by a D.C. plasma determination. Analyses obtained prior to the present study are listed on the second lines, and analytical cross-checks for Au and $\mathrm{Ag}$ are in parentheses]

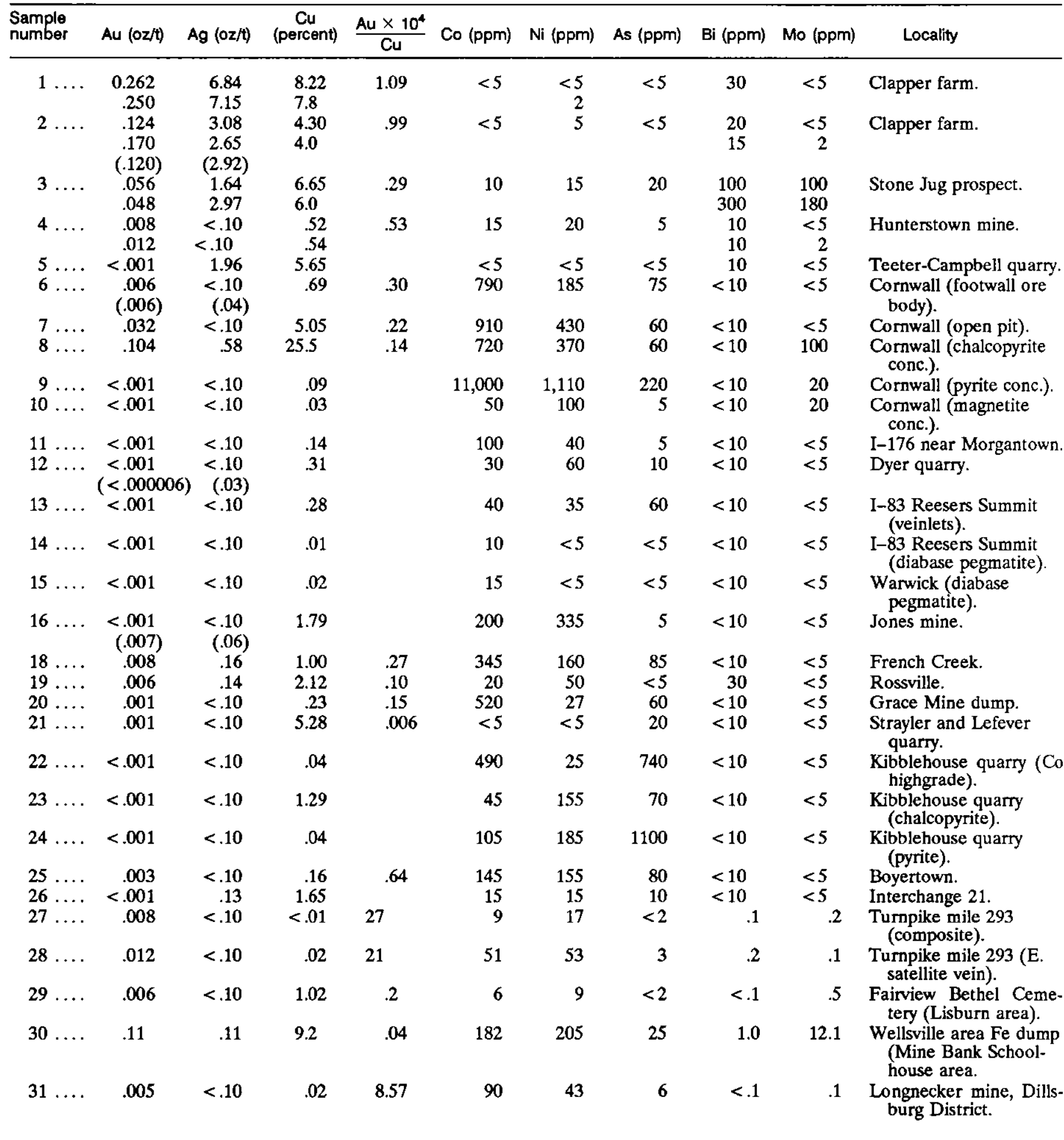


Table 3. Median composition of chilled margins of York Haven-type and Rossville-type diabase from Smith and others (1975)

[Au analyses courtesy of J.J. Rowe and David Gottfried, U.S. Geological Survey, personal commun., circa 1970]

\begin{tabular}{lcc}
\hline Element & Rossville type & York Haven type \\
\hline $\mathrm{Au}(\mathrm{ppm})$ & 0.0022 & 0.0035 \\
$\mathrm{Cl}(\mathrm{ppm})$ & 48 & 66 \\
$\mathrm{Co}(\mathrm{ppm})$ & 46 & 47 \\
$\mathrm{Cu}(\mathrm{ppm})$ & 66 & 121 \\
$\mathrm{Ni}(\mathrm{ppm})$ & 63 & 89 \\
$\mathrm{~S}(\mathrm{ppm})$ & 486 & 112 \\
$\mathrm{Au} \times 10^{4}$ & .33 & .29 \\
\hline $\mathrm{Cu}$ & .74 & 1.09 \\
Ti (percent) & &
\end{tabular}

\section{REFERENCES CITED}

Berg, T.M., and others, 1980, Geologic map of Pennsylvania: Pennsylvania Geological Survey, 4th series, Map 1.

D'Invilliers, E.V., 1883, The geology of the South Mountain belt of Berks County: Pennsylvania Geological Survey, 2d series, Report of Progress D3, v. II, 441 p.

Eugster, H.P., and Chou, I.-M., 1979, A model for deposition of Cornwall-type magnetite deposits: Economic Geology, v. 74 , p. $763-744$

Evans, F.H., 1980, Historical sketches of copper and lead mining in Montgomery County, Pennsylvania: Friends of Mineralogy, Pennsylvania Chapter, Special Publication No. 2, 36 p.

Gedde, R.W., 1965, Geophysical investigation of a magnetite deposit, Chester County, Pennsylvania: unpublished M.S. thesis, The Pennsylvania State University, University Park, Pennsylvania.

Geyer, A.R., and others, 1976, Mineral collecting in Pennsylvania: Pennsylvania Geological Survey, 4th series, General Geology Report 33, 260 p.

Herrick, D.C., 1973, An isotopic study of the magnetitechalcopyrite deposit of Cornwall, Pennsylvania: unpublished Ph.D. thesis, The Pennsylvania State University, 95 p.

Hoff, D.T., 1978, Campbell's quarry, a complex mineral locality in Gettysburg, Pennsylvania: Rocks and Minerals, v. 53, no. 6 , p. $247-253$.

Hoff, D.T., and Smith, R.C., II, 1985, An Adams County copper-gold mine, doomed to failure: Pennsylvania Geology, v. 16 , no. 6 , p. 13-16.

Hotz, P.E., 1950, Diamond-drill exploration of the Dillsburg magnetite deposits, York County, Pennsylvania: U.S. Geological Survey Bulletin 969-A, p. 1-27.

Hunt, T.S., 1876, A new ore of copper and its metallurgy: American Institute of Mining Engineers, Transaction 4, p. 325-328.

Lapham, D.M., 1968, Triassic magnetite and diabase at Cornwall, Pennsylvania, in Ore deposits of the United States: 1933-1967: New York, American Institute of Mining, Metallurgy, and Petroleum Engineers, v. 1, p. 72-94.

Lapham, D.M., and Gray, C., 1973, Geology and origin of the Triassic magnetite deposit and diabase at Cornwall, Pennsylvania: Pennsylvania Geological Survey, 4th series, Mineral Resources Report 56, 343 p.
Pennsylvania Bureau of Statistics, Pennsylvania Geological Survey, and Pennsylvania State College, 1944, Pennsylvania mineral heritage: Pennsylvania Department of Internal Affairs, $248 \mathrm{p}$.

Rogers, H.D., 1858, The geology of Pennsylvania: Pennsylvania Geological Survey, 1st series, v. 1, p. 182.

Rose, A.W., 1970, Atlas of Pennsylvania's mineral resources, Part 3, Metal mines and occurrences in Pennsylvania: Pennsylvania Geological Survey, 4th series, Mineral Resource Report 50.

1972, Favorability for Cornwall-type magnetite deposits in Pennsylvania using geological, geochemical, and geophysical data in a discriminant function: Journal of Geochemical Exploration, v. 1, p. 181-194.

1976, The effect of cuprous chloride complexes in the origin of red-bed copper and related deposits: Economic Geology, v. 71, p. 1036-1048.

Rose, A.W., Herrick, D.C., and Deines, P., 1985, An oxygen and sulfur isotope study of skam-type magnetite deposits of the Cornwall type, southeastern Pennsylvania: Economic Geology, v. 80, p. 418-443.

Rose, A.W., Smith, A.T., Lustwerk, R.L., Ohmoto, H., and Hoy, L.D., 1986, Geochemical aspects of stratiform and red-bed copper deposits in the Catskill Formation (Pennsylvania, USA) and Redstone area (Canada), sequence of mineralization in sediment-hosted copper deposits (Part 3), in Friedrich, G.H., and others, eds., Geology and Metallogeny of Copper Deposits: Berlin, Springer-Verlag, p. 413-421.

Sheely, A., 1886, Natural history of Adams County, history of Cumberland and Adams Counties, Pennsylvania, Part III, Chapters X and XLV: p. 47 and 333.

Sims, S.J., 1968, The Grace Mine magnetite deposit, Berks County, Pennsylvania, in Ore deposits of the United States: 1933-1967: New York, American Institute of Mining, Metallurgy, and Petroleum Engineers, v. 1, p. 108-124.

Smith, L.L., 1931, Magnetite deposits of French Creek, Pennsylvania: Pennsylvania Geological Survey, 4th series, Mineral Resource Report 14, 52 p.

Smith, R.C., II, 1973, Geochemistry of Triassic diabase from southeastem Pennsylvania: unpublished Ph.D. thesis, The Pennsylvania State University, University Park, Pennsylvania, $262 \mathrm{p}$.

1977, Zinc and lead occurrences in Pennsylvania: Pennsylvania Geological Survey, 4th series, Mineral Resource Report 72, p. 271-275.

-1978, The mineralogy of Pennsylvania, 1966-1975: Special Publication No. 1, Friends of Mineralogy, Pennsylvania Chapter, $304 \mathrm{p}$.

Smith, R.C., II, and Hoff, D.T., 1977, Newly discovered minerals at Stone Jug copper prospect, Adams County: Pennsylvania Geology, v. 8, no. 5, p. 14-16.

Smith, R.C., II, and O'Neill, B.J., 1973, A new Triassic copper occurrence at Rossville, $\mathrm{Pa}$.: Pennsylvania Geology, v. 4, no. 1, p. 6-7.

Smith, R.C., II, Rose, A.W., and Lanning, R.M., 1975, Geology and geochemistry of Triassic diabase in Pennsylvania: Geological Society of America Bulletin, v. 86, p. 943-955. 
Speer, J.A., and Smith, R.C., II, 1981, Nickelian pyrite and millerite from the Cornwall Iron Mine, Lebanon County: The Keystone Newsletter, v. 30, no. 10, p. 5-8.

Speer, J.A., Craig, J.R., and Hill, R.J., 1978, The "cobaltite" crystals from the Kibblehouse quarry: Rocks and Minerals, v. 53, no. 3, p. 130-134.

Spencer, A.C., 1908, Magnetite deposits of the Cornwall type in Pennsylvania: U.S. Geological Survey Bulletin 359, 102 p.

Stose, G.W., and Jonas, A.I., 1939, Geology and mineral resources of York County, Pennsylvania: Pennsylvania Geological Survey, 4th series, County Report 67, 199 p.

U.S. Bureau of Mines, 1905-31, Mineral resources of the United States: U.S. Bureau of Mines, U.S. Department of the Interior.

1932-73, Minerals Yearbook: U.S. Bureau of Mines, U.S. Department of the Interior.

Van Houten, F.B., 1969, Late Triassic Newark Group, northcentral New Jersey and adjacent Pennsylvania and New York, in Subitzky, S., ed., Geology of selected areas in New Jersey and eastern Pennsylvania: New Brunswick, New Jersey, Rutgers University Press, p. 314-347.

Wood, C.R., 1980, Groundwater resources of the Gettysburg and Hammer Creek Formations, southeastern Pennsylvania: Pennsylvania Geological Survey, 4th series, Water Resource Report 49, 87 p.

\section{VARIATIONS OF PALLADIUM AND PLATINUM CONTENTS AND RATIOS IN SELECTED EARLY MESOZOIC THOLEIITIC ROCK ASSOCIATIONS IN THE EASTERN UNITED STATES}

\section{David Gottried and Albert J. Froelich}

\begin{abstract}
Palladium $(\mathrm{Pd})$ and platinum $(\mathrm{Pt})$ contents from 170 samples of several varieties of early Mesozoic diabase in the Eastern United States have been analyzed in the course of a continuing regional study of rare metal distribution in magmatic rocks. Analytical results from systematic sampling of 12 representative quartz- and olivine-normative tholeiitic sheets and dikes indicate that absolute contents of Pd and Pt and $\mathrm{Pd} / \mathrm{Pt}$ ratios can be used to help characterize the three major magma types of the eastern North America tholeitic province. The low- $\mathrm{TiO}_{2}$ quartz-normative (LTQ) sheets and dikes consistently show lowest abundances ( $\mathrm{Pd}+\mathrm{Pt}$ ranging from $<1$ to $7.1 \mathrm{ppb}$ ) and $\mathrm{Pd} / \mathrm{Pt}$ ratios (averaging 0.35 ). Most high- $\mathrm{TiO}_{2}$ quartz-normative (HTQ) sheets and olivinenormative (ON) sheets and dikes have $\mathrm{Pd}+\mathrm{Pt}$ abundances that range from 8.6 to $51 \mathrm{ppb}$ and $\mathrm{Pd} / \mathrm{Pt}$ ratios that vary from 0.4 in cumulate-bearing sheets to more than 12 in late-stage granophyres. Furthermore, the distribution of $\mathrm{MgO}, \mathrm{Pt}$, and Pd in selected diabase sheets and dikes plotted against distance from intrusive contacts shows distinctive and consistent trends that define characteristic patterns of enrichment or depletion relative to chill-margin contents. During early differentiation of HTQ and ON tholeiites, Pt is enriched relative to $\mathbf{P d}$ in the cumulate layers, but in later differentiates $P d$ is enriched relative to Pt. A late-stage, iron-enriched zone in the HTQ diabase sheet at Reesers Summit, Pennsylvania, and a similar zone in the HTQ Palisades sill, New Jersey, show anomalous $\mathrm{Pd}$ abundances that are an order of magnitude (as much as $207 \mathrm{ppb}$ ) greater than in other diabase sheets thus far sampled.
\end{abstract}

\section{INTRODUCTION}

One of the objectives of this ongoing geochemical study is to determine the distribution of palladium (Pd) and platinum $(\mathrm{Pt})$ in early Mesozoic diabase of the eastern North America (ENA) tholeiitic province, and another is to establish baseline data for assessing the potential for the occurrence of strategic metals. This progress report documents the results of 170 new analyses and discusses analytical efforts to improve the consistency of results for $\mathrm{Pd}$ and $\mathrm{Pt}$ analyses in rocks where these results occur in the low parts-per-billion (ppb) range. Sampling across sheets and dikes inward from chill-margin contacts was done to determine whether $\mathrm{Pt}$ and $P d$ contents and ratios vary systematically and whether analytical results from nonmineralized igneous rocks are meaningful. Figure 1 shows the distribution of ENA tholeiitic sheets and dikes that were systematically sampled in this study. Knowledge of the behavior of $\mathbf{P d}$ and $\mathrm{Pt}$ in the course of differentiation of tholeiitic magmas is meager because of a previous lack of suitable analytical techniques. Reviews of the limited data available for these metals are found in Crocket (1979) and Barnes and others (1985).

\section{ANALYTICAL METHOD AND PRECISION}

$\mathrm{Pd}$ and Pt contents were determined by graphite furnace atomic absorption spectrometry after preconcentration by classical fire assay with lead collection. The analytical method has been described recently by Aruscavage and others (1984).

The precision of the analytical procedure can be estimated by the means and the standard deviation (sd) of replicate determinations of Pd and Pt in three U.S. Geological Survey reference samples, DNC-1, W-2, and BHVO-1. Two of these samples, DNC-1 and W-2, are medium-crystalline diabase; their compositions (Flanagan, 1984) nearly bracket the compositional range of magma types (olivine-normative to quartz-normative) 


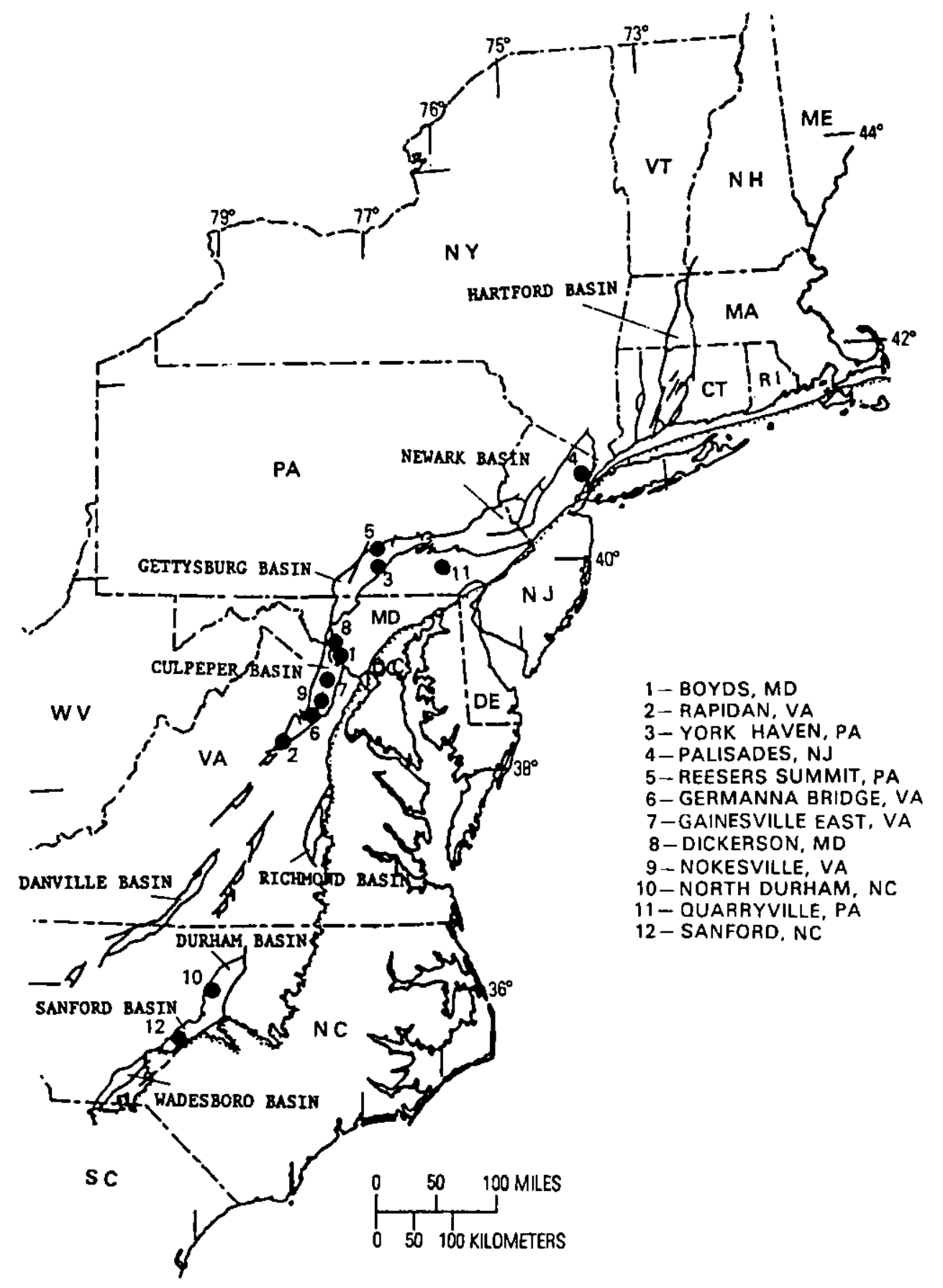

Figure 1. Index map of the Eastern United States showing the location of early Mesozoic tholeitic sheets and dikes analyzed for Pd and Pt.

found in the ENA Mesozoic tholeiitic province. The third sample, BHVO-1 (Flanagan and others, 1976), a Hawaiian tholeiitic basalt, is included in this evaluation because of the sample's relatively low Pd and Pt contents and its fine grain size. The range of Pd and Pt contents of these three reference samples is nearly the same as that of the samples analyzed in this study. The replicate determinations of Pd and Pt, using 10-g samples for the three rocks standards, are listed in table 1 . Our estimate of precision, expressed as relative deviation ( $\mathrm{rd}$ ), is

$$
\mathrm{rd}=\frac{\mathrm{sd} \times 100}{\bar{x}}
$$

where sd is the standard deviation and $\bar{x}$ is the mean value for $P d$ and $P t$ in samples DNC-1 and $W-2$, ranging from 19 to 16 percent; for BHVO-1, the precision for $\mathrm{Pd}$ 
Table 1. Replicate determinations of $P d$ and $P t$, in parts per billion (ppb), in USGS reference samples DNC-1, W-2, and BHVO-1

[Analyses by Norma Rait, Hezekiah Smith, and Leo Mei, 1984-86, U.S. Geological Survey]

\begin{tabular}{|c|c|c|c|c|c|c|c|c|c|}
\hline \multirow[b]{2}{*}{ Date of analysis } & \multicolumn{3}{|c|}{ DNC-1 } & \multicolumn{3}{|c|}{$W-2$} & \multicolumn{3}{|c|}{ BHVO-1 } \\
\hline & $\overline{P d}$ & Pt & $\overline{P d} / \mathrm{Pt}$ & $\mathrm{Pd}$ & $\mathrm{Pt}$ & $\mathrm{Pd} / \mathrm{Pt}$ & Pd & $\mathrm{Pt}$ & $\mathrm{Pd} / \mathrm{Pt}$ \\
\hline 1. $9-30-85$ to $1-9-86$ & 20.4 & 33.9 & 0.60 & 11 & 10.3 & 1.07 & & & \\
\hline 2. $9-30-85$ to $1-9-86$ & 11.6 & 23.4 & .50 & 10.6 & 7 & 1.51 & & & \\
\hline 3. $9-30-85$ to $1-9-86$ & 13.4 & 22.2 & .60 & 7.3 & 10.3 & .71 & & & \\
\hline 4. $9-30-85$ to $1-9-86$ & 21. & 27.6 & .76 & 6.4 & 7.6 & .84 & & & \\
\hline 5. $9-30-85$ to $1-9-86$ & 16.8 & 36 & .47 & 6.6 & 7.6 & .87 & 2.2 & 3.2 & 0.69 \\
\hline 6. $1-13-86$ & 16.6 & 31 & .54 & 9.8 & 10.8 & .91 & 2.6 & 2.6 & 1.00 \\
\hline 7. $2-12-86$ & 16.6 & 32 & .52 & 8.9 & 10.9 & .82 & 2.7 & 4.6 & .59 \\
\hline 8. $2-13-86$ & 12.8 & 28.5 & .45 & 8.7 & 9.6 & .91 & 2.4 & 4.2 & .57 \\
\hline 9. $4-24-86$ & 15.2 & 26.4 & .58 & 9.6 & 8.3 & 1.16 & 2.2 & 3.5 & .63 \\
\hline 10. $5-13-86$ & 14.4 & 23 & .63 & 7.1 & 12.5 & .57 & 2.5 & 3.7 & .68 \\
\hline 11. $7-14-86$ & 15.2 & 28.4 & .54 & 7.8 & 10.5 & .74 & 2.3 & 3.8 & .61 \\
\hline 12. $8-8-86$ & 14.4 & 30.4 & .47 & 8.0 & 12.1 & .66 & 2.4 & 3.3 & .73 \\
\hline 13. $9-10,11-86$ & 13.4 & 36 & .37 & 7.0 & 7.6 & .92 & 2.5 & 4.2 & .60 \\
\hline Mean & 15.5 & 29.1 & .54 & 8.4 & 9.6 & .90 & 2.4 & 3.7 & .68 \\
\hline Standard deviation & 2.77 & 4.65 & .098 & 1.5 & 1.8 & .24 & .17 & .61 & .13 \\
\hline $\begin{array}{l}\text { Relative deviation } \\
\text { (percent) }\end{array}$ & 18 & 16 & 18 & 18 & 19 & 27 & 7 & 17 & 19 \\
\hline
\end{tabular}

and $\mathrm{Pt}$ is 7 and 17 percent, respectively. Although one might anticipate greater homogeneity in sample BHVO-1, as indicated by a precision of 7 percent for Pd, the relative deviation for $\mathrm{Pt}$ ( 17 percent) is essentially the same as that found in the coarser grained samples DNC-1 and W-2.

These results imply that other factors affecting overall precision may be included in our simple statistical test. An important factor that cannot be evaluated now because of lack of data on particle size and mode of occurrence of Pd and Pt metals in our samples is the effect of variations in sample homogeneity (nugget effect) on the observed precision. However, we feel that differences greater than 20 percent in $\mathrm{Pd}$ and $\mathrm{Pt}$, and greater than 25 percent for $\mathrm{Pd} / \mathrm{Pt}$, probably represent geochemically significant variations at levels of $\mathrm{Pd}$ and $\mathrm{Pt}$ concentrations greater than $5.0 \mathrm{ppb}$. At concentrations less than $5.0 \mathrm{ppb}$, much greater deviations are likely, and relative deviations for concentrations from 0.5 to $2.0 \mathrm{ppb}$ may be on the order of 50 percent.

\section{DISTRIBUTION OF Pd AND Pt IN DIABASE SHEETS AND DIKES}

The distribution of Pd and Pt was determined in the three principal tholeiitic magma types of the ENA province-high-Ti, quartz-normative (HTQ); low-Ti, quartz-normative (LTQ); and olivine-normative (ON) (Weigand and Ragland, 1970). Cumulate rocks rich in olivine (Walker, 1969) and orthopyroxene (OPX) of HTQ or York Haven-type diabase sheets (Smith and others, 1975), and their granophyric and ferrogabbroic or ferrodioritic differentiates, were sampled in the Gettys- burg basin of Pennsylvania, the Newark basin of New Jersey, and the Culpeper basin of Maryland and Virginia (fig. 1 and table 2). An LTQ or Rossville-type diabase sheet (Smith and others, 1975) and an LTQ dike in the Culpeper basin of Virginia and Maryland were sampled (table 3). Samples from an ON cumulate gabbro sheet in the Durham basin and two ON dikes in the Sanford basin of North Carolina and from an ON or Quarryville-type (Smith and others, 1975) dike in the Piedmont of Pennsylvania were collected also (table 3 ).

The distribution of $\mathrm{MgO}, \mathrm{Pd}$, and $\mathrm{Pt}$ and $\mathrm{Pd} / \mathrm{Pt}$ ratios across selected diabase or gabbro bodies are plotted against distance from intrusive contacts in figures 2-6. Each of these three major magmatic suites has distinctive Pd+Pt abundances and ratios (see table 4), although some regional variations have been recognized.

\section{HTQ Cumulate-Bearing Sheets}

Large, thick (700-2,500 ft; 210-750 m) HTQ sheets in eastern North America commonly have layered OPX cumulate zones and less commonly have zones of cumulus olivine (Froelich and Gottfried, 1985, p. 80). The unroofed Boyds sheet is about 3 by $5 \mathrm{~km}$ in area, consists mainly of OPX-rich diabase, and is situated in the extreme northeast corner of the Culpeper basin in Maryland (fig. 1). Some of the petrochemical and trace element features of this sheet were described by Gottfried and Froelich (1985, p. 88-90), and the petrography and petrology are discussed by Ragland and Arthur (1985, p. 91-99). Results of $\mathrm{Pd}$ and $\mathrm{Pt}$ analyses and $\mathrm{Pd} / \mathrm{Pt}$ ratios for 26 samples across an interval of $450 \mathrm{ft}(135 \mathrm{~m})$ 
Table 2. Pd and Pt contents, total abundances, and ratios in high-Ti, quartz-normative (HTQ) cumulate- and latedifferentiate-bearing diabase in New Jersey, Pennsylvania, Maryland, and Virginia

[York Haven-Reesers Summit and Rapidan-Germanna Bridge are apparently cogenetic suites; that is, complementary fractions; (18), replicate analyses; analysts: Norma Rait, Hezekiah Smith, and Leo Mei, 1984-86, U.S. Geological Survey]

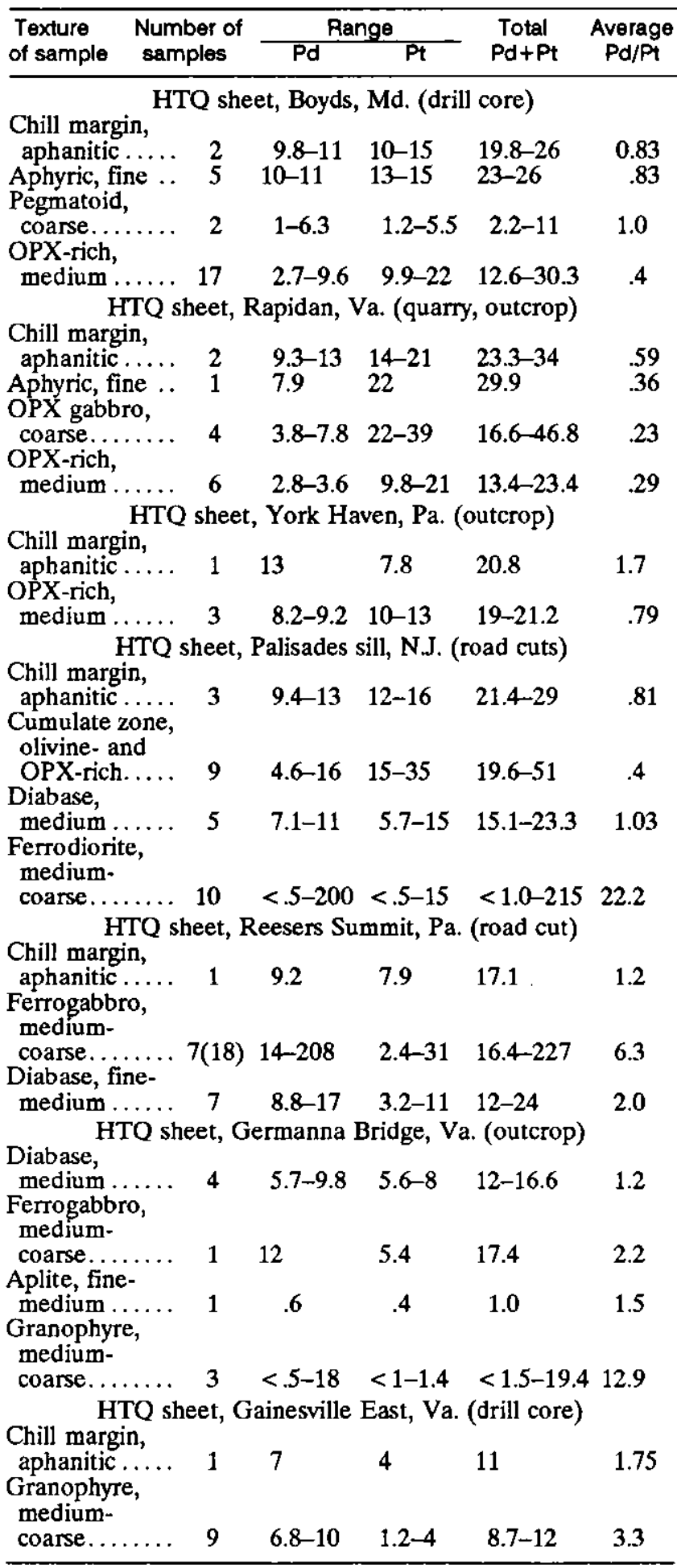

Table 3. Pd and Pt contents, total abundances, and ratios in low- $\mathrm{Ti}$, quartz-normative (LTQ) diabase and olivine-normative (ON) diabase and gabbro sheets and dikes in Pennsylvania, Maryland, Virginia, and North Carolina

[Analysts: Norma Rait, Hezekiah Smith, and Leo Mei, 1984-86, U.S. Geological Survey; -, not determined]

\begin{tabular}{|c|c|c|c|c|c|}
\hline \multirow{2}{*}{$\begin{array}{l}\text { Texture } \\
\text { of sample }\end{array}$} & \multirow{2}{*}{$\begin{array}{c}\text { Number of } \\
\text { samples }\end{array}$} & \multicolumn{2}{|c|}{ Range } & \multirow{2}{*}{$\begin{array}{l}\text { Total } \\
\mathrm{Pd}+\mathrm{Pt}\end{array}$} & \multirow{2}{*}{$\begin{array}{c}\text { Average } \\
\mathrm{Pd} / \mathrm{Pt}\end{array}$} \\
\hline & & Pd & Pt & & \\
\hline \multicolumn{6}{|c|}{ LTQ diabase dike, Dickerson, Md. (quarry) } \\
\hline \multirow{5}{*}{\multicolumn{2}{|c|}{$\begin{array}{l}\text { Chill margin, } \\
\text { aphanitic...... } \\
\text { Border zone, } \\
\text { fine ........... } \\
\text { Transitional, } \\
\text { fine-medium.. } \\
\text { Inner core, } \\
\text { medium ....... }\end{array}$}} & $0.5-0.6$ & $1.6-$ & 2 & 3 \\
\hline & & & & & \\
\hline & & & & & \\
\hline & & $.7-1.1$ & $2.7-3.3$ & $3.4-4.4$ & .3 \\
\hline & & $.5-1.0$ & $1.6-3.4$ & 2.1 & 3 \\
\hline \multicolumn{6}{|c|}{ LTQ diabase sheet, Nokesville, Va. (drill core) } \\
\hline \multirow{2}{*}{\multicolumn{2}{|c|}{$\begin{array}{l}\text { Chill margin, } \\
\text { aphanitic..... } \\
\text { Diabase, fine- } \\
\text { medium ...... }\end{array}$}} & $<.5-0.8$ & $.8-1.2$ & $<1$ & - \\
\hline & & $<.5-2.3$ & $.8-4.8$ & -7.1 & .4 \\
\hline \multicolumn{6}{|c|}{ ON sheet, North Durham, N.C. (quarry, outcrop) } \\
\hline \multirow{3}{*}{\multicolumn{2}{|c|}{$\begin{array}{l}\text { Chill margin, } \\
\text { aphanitic ..... } \\
\text { Pegmatoid, } \\
\text { coarse........ } \\
\text { Gabbro, } \\
\text { medium- } \\
\text { coarse........ } \\
\end{array}$}} & $4.1-8.9$ & $8-17$ & $12.2-$ & .5 \\
\hline & & 1.1 & 1.1 & 2. & 1 \\
\hline & & $.9-9.6$ & $9-29$ & 9.3 & .4 \\
\hline \multicolumn{6}{|c|}{ ON diabase dike, Quarryville, $\mathrm{Pa}$. (railroad cut) } \\
\hline \multirow{3}{*}{\multicolumn{2}{|c|}{$\begin{array}{l}\text { Chill margin, } \\
\text { aphanitic ..... } \\
\text { Transitional, } \\
\text { fine-medium.. } \\
\text { Inner core, } \\
\text { medium- } \\
\text { coarse........ }\end{array}$}} & $15-16$ & 11 & 26 & 1.4 \\
\hline & & $14-16$ & $11-12$ & $26-27$ & 1.4 \\
\hline & & $16-22$ & $12-14$ & $30-34$ & 1.5 \\
\hline \multicolumn{6}{|c|}{ ON diabase dikes, Sanford, N.C. (drill core) } \\
\hline Chi & 2 & $4.6-11$ & $4-8$ & $11.8-18.4$ & 1.3 \\
\hline
\end{tabular}

are summarized in table 2, and shown graphically, with $\mathrm{MgO}$ content, plotted in distance above the lower contact in figure 2.

$\mathrm{Pd}+\mathrm{Pt}$ content ranges from 19.8 to $26 \mathrm{ppb}$ in the aphanitic lower chill margin, to a low of $2.2 \mathrm{ppb}$ in pegmatoid veins, and to a maximum of $30.3 \mathrm{ppb}$ in an OPX-rich, cumulate-textured, medium crystalline diabase. $\mathrm{Pd} / \mathrm{Pt}$ for the sheet averages 0.57 ; this ratio indicates that $\mathrm{Pd}$ content is conspicuously less than $\mathrm{Pt}$ content. The bulk of the sheet is generally depleted in $\mathrm{Pd}$ relative to the chill margin, which has a $\mathrm{Pd} / \mathrm{Pt}$ of 0.83 . Some layers of OPX-rich diabase show an enrichment of $P t$ relative to the chill margin and the lower $75-\mathrm{ft}-(23 \mathrm{~m})$ thick aphyric zone. The pegmatoid zones have a $\mathrm{Pd} / \mathrm{Pt}$ ratio of 1.0 but low total abundances of $\mathrm{Pd}$ and $\mathrm{Pt}$.

The Rapidan sheet is a layered, OPX-rich diabase more than $1,200 \mathrm{ft}(360 \mathrm{~m})$ thick. The sheet occupies much of the southern Culpeper basin in Virginia and covers an area of $17 \mathrm{by} 7 \mathrm{~km}$. Both the base and roof of 

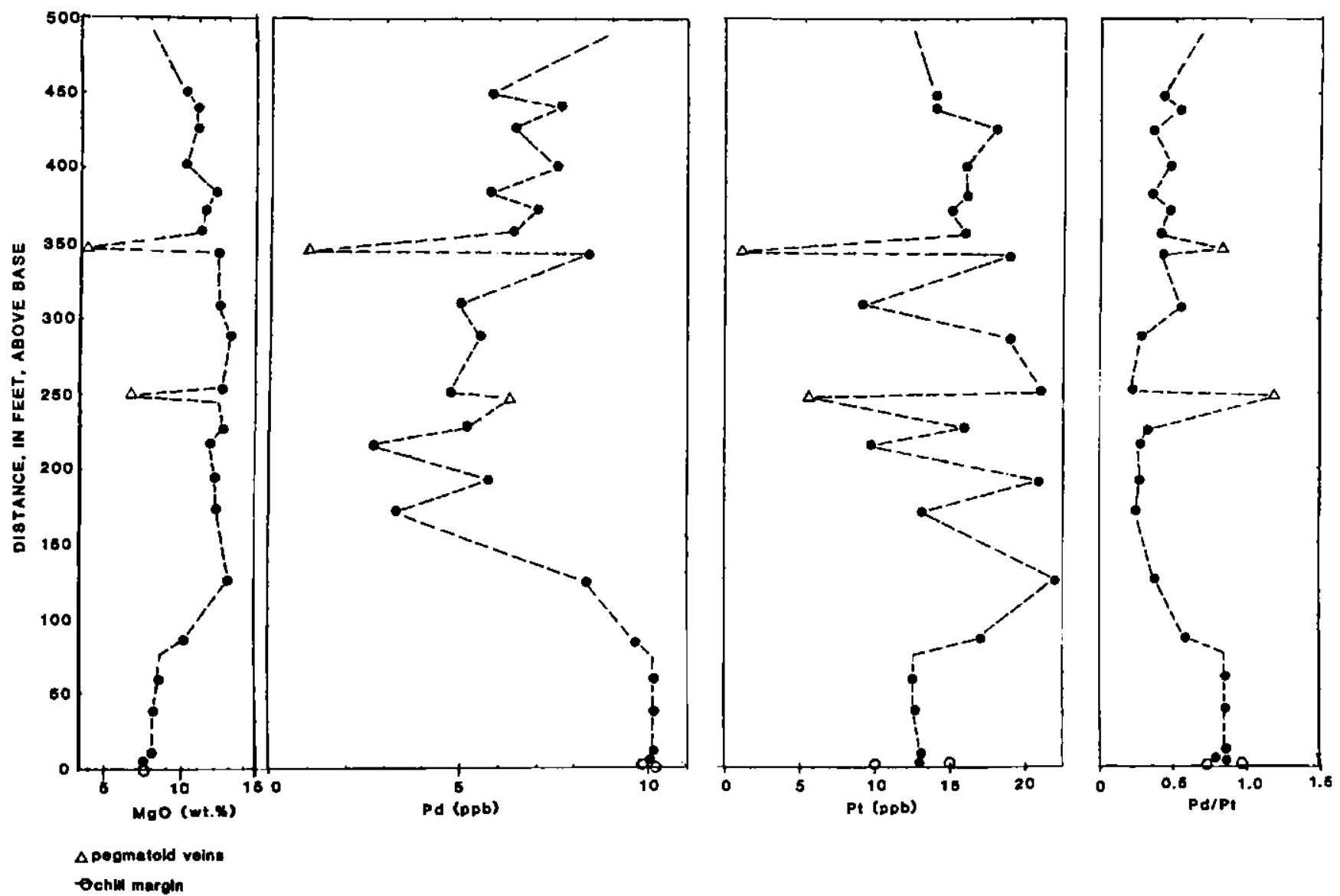

Figure 2. Distribution of $\mathrm{MgO}, \mathrm{Pd}$, and $\mathrm{Pt}$ in high-Ti, quartz-normative, orthopyroxene-bearing diabase sheet, Boyds, Maryland.

the sheet crop out along the upturned margins. Roadside samples were collected at about $200-\mathrm{ft}-(60 \mathrm{~m})$ intervals from outcrops across the southeast flank, which were studied petrographically by Keahey (1976). Other widely spaced samples were collected from quarries and outcrops. Results of 13 new $\mathrm{Pd}$ and $\mathrm{Pt}$ analyses and $\mathrm{Pd} / \mathrm{Pt}$ ratios are summarized in table 2 . Samples from the roadside traverse are shown graphically, with $\mathrm{MgO}$ content, plotted in distance above the lower contact in figure 3. Pd+Pt content ranges from $23.3 \mathrm{ppb}$ in the aphanitic lower chill margin to a maximum of $46.8 \mathrm{ppb}$ in a noritic gabbro cumulate layer; $\mathrm{Pd}+\mathrm{Pt}$ content decreases to a minimum of $13.4 \mathrm{ppb}$ in an OPX-bearing diabase. $\mathrm{Pd} / \mathrm{Pt}$ averages 0.35 , a value lower than the 0.59 found in the chill margin. Pd is depleted, whereas Pt is locally enriched in the noritic gabbro zone, which has the lowest average $\mathrm{Pd} / \mathrm{Pt}$ of 0.23 .

Only four samples from the lower part of the 2,500-ft- $(750 \mathrm{~m})$ thick York Haven sheet in the Gettysburg basin of Pennsylvania were analyzed (table 2). This is too few samples to determine significant trends; however, the OPX-rich layers again show depletion in Pd and slight enrichment in $\mathrm{Pt}$ relative to the chill margin in amounts comparable to those in the Boyds and Rapidan sheets.

The Palisades sill is a layered, differentiated HTQ diabase sheet approximately $1,000 \mathrm{ft}(300 \mathrm{~m})$ thick situated in the northeastern part of the Newark basin of New Jersey and New York. Immediately above the lower chill margin is a thin, distinctive zone of cumulus olivine overlain by a much thicker zone rich in orthopyroxene (Walker, 1969; Shirley, 1987). Pd+Pt content ranges from 21.4 to $29 \mathrm{ppb}$ in the chill margin to a maximum of $51 \mathrm{ppb}$ in the cumulate zone (table 2 ). $\mathrm{Pd} / \mathrm{Pt}$ ranges from 0.8 in the chill samples decreasing to 0.4 in the cumulates, indicating that $\mathrm{Pt}$ is enriched relative to $\mathrm{Pd}$ in the cumulate zone.

\section{Late Differentiate-Bearing Sheets}

Large, thick (1,000-1,800 ft; 300-540 m) HTQ sheets in eastern North America commonly enclose late-stage differentiated masses of ferrogabbro, ferrodiorite, pegmatite, granophyre, and aplite (Froelich and Gottfried, 1985, p. 80). The ferrogabbro-bearing section 

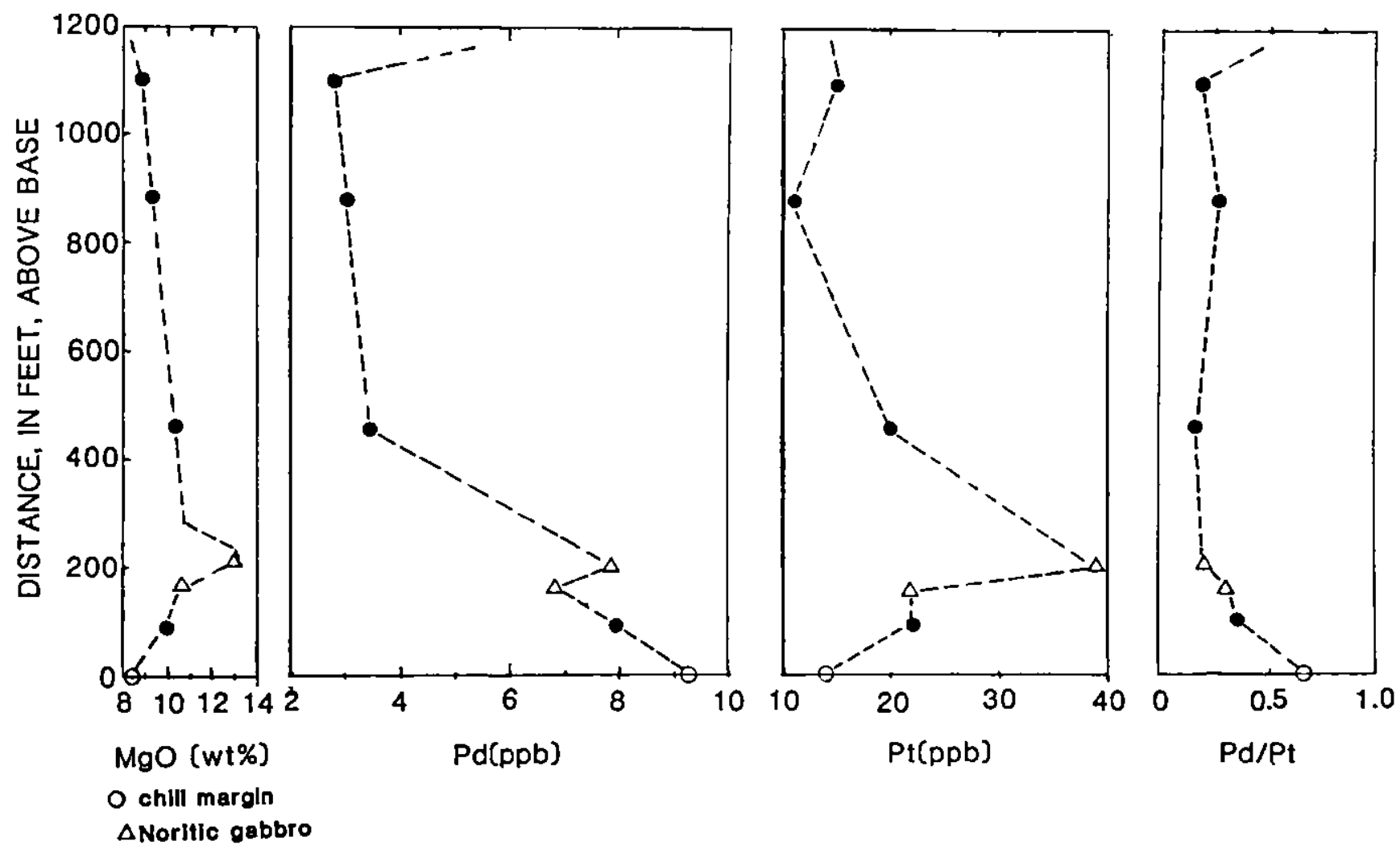

Figure 3. Distribution of $\mathrm{MgO}, \mathrm{Pd}$, and $\mathrm{Pt}$ in high-Ti, quartz-normative, orthopyroxene-bearing diabase sheet, Rapidan, Virginia.

exposed at Reesers Summit in the northern Gettysburg basin (Smith, 1973), about $1,675 \mathrm{ft}(507.5 \mathrm{~m})$ thick, is apparently physically continuous with the $2,500-\mathrm{ft}-(750$ m) thick York Haven OPX cumulate-bearing section about $10 \mathrm{mi}(16 \mathrm{~km})$ to the southeast (fig. 1). The upper two-thirds of the sheet at Reesers Summit is well exposed in the eastern roadcuts of Interstate Route 83, and 15 samples were collected at about $70-\mathrm{ft}-(21 \mathrm{~m})$ intervals. Results are summarized in table 2 and figure 4.

$\mathbf{P d}+\mathbf{P t}$ content ranges from $17.1 \mathrm{ppb}$ in the chill margin to $227 \mathrm{ppb}$ in some coarse crystalline ferrogabbro. Enrichment of Pd in these rocks is an order of magnitude greater than in most of the other rocks analyzed (table 2 ). $\mathrm{Pd} / \mathrm{Pt}$ ratios average 3.9 , with the chill margin about 1.2, and the ferrogabbro (7 samples) averaging 6.3; Pd contents show a distinct enrichment over Pt. The Pd enrichment and the Pd+Pt contents of the ferrogabbro contrast markedly with the complementary York Haven suite and with those of most other HTQ cumulate-bearing sheets. Preliminary petrographic, petrologic, and minor and trace element data from the ferrogabbro suggest the possibility of a late-stage hydrothermal enrichment event superimposed on the late magmatic iron enrichment trend. The Reesers Summit section is currently the subject of detailed geochemical and petrologic study.
The upper part of the Palisades sill contains two zones of late-stage differentiates several hundred feet (about $200 \mathrm{~m}$ ) above the basal cumulate zone of orthopyroxene and olivine (Shirley, 1987). The lower differentiated zone is a ferrodiorite with $\mathrm{Pd}+\mathrm{Pt}$ content of $215 \mathrm{ppb}$ locally, and $\mathrm{Pd} / \mathrm{Pt}$ averaging 22.2 (table 2). Furthermore, copper increases upward from the cumulate zone, indicating that silicate fractionation occurred without early sulfide fractionation (Talkington and others, 1987). The unusually high Pd content in the ferrodiorite generally has Pt values within the range of the average diabase, suggesting that the Pd enrichment here is also the result of very late (or post) magmatic hydrothermal processes.

Analytical data from other ferrogabbro samples and from several more highly fractionated HTQ rocks (principally granophyres, granophyric diabase, pegmatoids, and aplites) from the Germanna Bridge and Gainesville East sheets in the Culpeper basin show great variability but no comparable enrichment (table 2 ). $\mathrm{Pd}+\mathrm{Pt}$ content ranges from 1.0 to $19.4 \mathrm{ppb}$. $\mathrm{Pd} / \mathrm{Pt}$ ranges from 1.2 to 12.9 , and again shows Pd enriched relative to $\mathrm{Pt}$, consistent with the high $\mathrm{Pd} / \mathrm{Pt}$ ratios at Reesers Summit and the Palisades sill. The granophyres, representing the final stages of tholeiitic differentiation, have extremely low abundances of Pd and Pt; these low abundances suggest depletion of these elements. The 

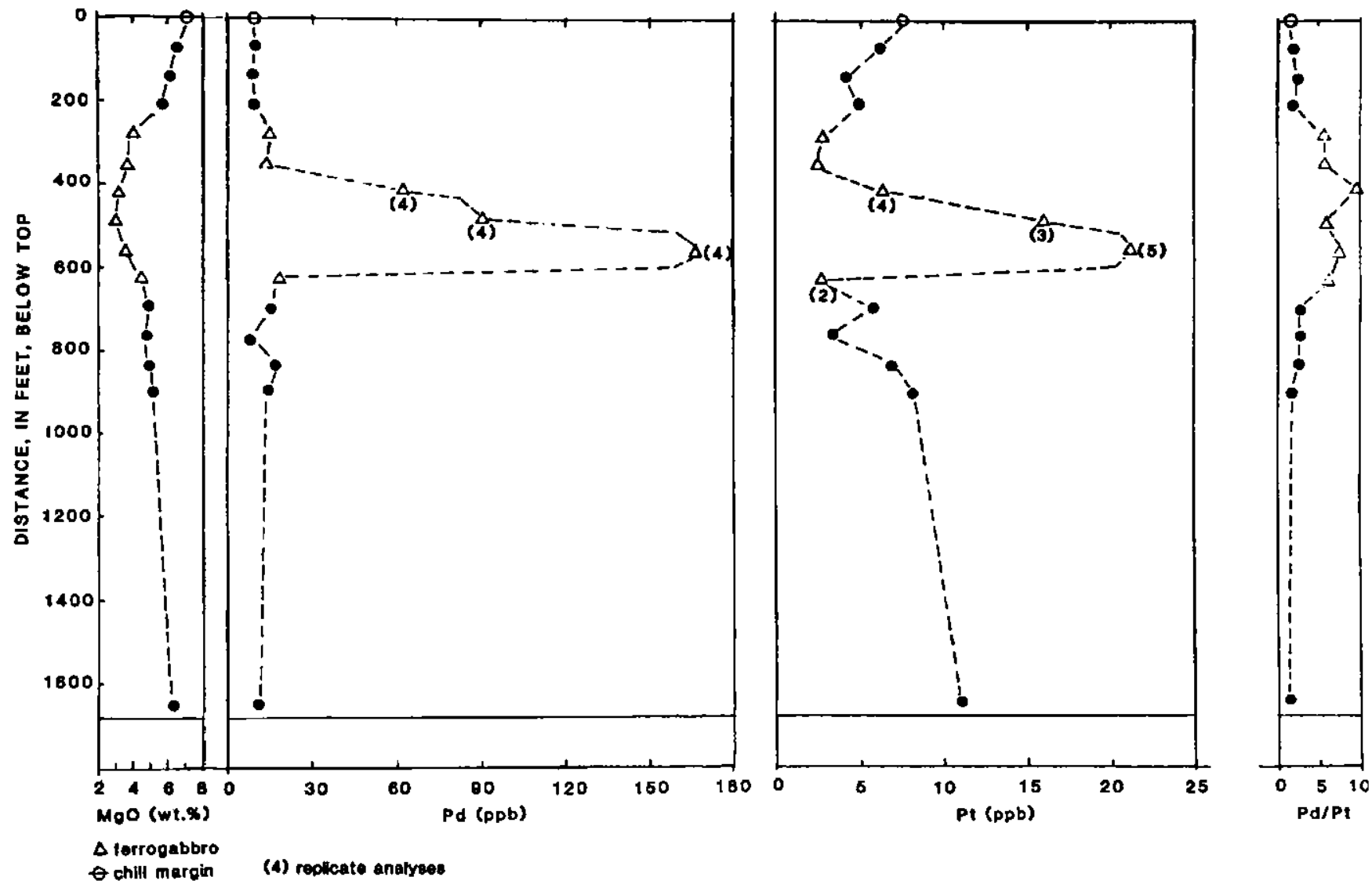

Figure 4. Distribution of $\mathrm{MgO}, \mathrm{Pd}$, and Pt in high-Ti, quartz-normative, ferrogabbro-bearing diabase sheet, Reesers Summit, Pennsylvania.

bulk of the sheet at Germanna Bridge that encloses the granophyres is sparsely OPX bearing (less than 10 percent) and can be traced southward into the OPX cumulate-bearing sheet at $\mathrm{Rapidan} . \mathrm{Pd} / \mathrm{Pt}$ ratios again differ markedly between these contrasting petrologic units, as was the case between Reesers Summit and the York Haven locality in the York Haven sheet, and between the basal cumulates and late-stage ferrodiorite differentiates of the Palisades sill. Geochemical data and field relationships suggest that, for the Rapidan and York Haven sheets, the ferrogabbro-granophyre bodies are complementary fractions to the orthopyroxene cumulates. These large bodies of differentiated rocks of contrasting compositions apparently are the result of lateral flow processes, rather than of simple vertical gravitational differentiation (Gottfried and others, 1985).

\section{Quartz-Normative LTQ Diabase Dikes and Sheets}

LTQ sheets are widespread in the Culpeper and Gettysburg basins, and LTQ dikes are common from Virginia to Connecticut. In every case of cross-cutting relationships seen, the LTQ bodies intrude the HTQ bodies. The Dickerson LTQ dike is completely exposed in an abandoned quarry in the northern Culpeper basin in Maryland (fig. 1). This dike is part of the northtrending Frederick dike system that extends for more than 150 miles $(240 \mathrm{~km})$ from northern Virginia, across western Maryland, and into east-central Pennsylvania. At the Dickerson locality, the dike is vertical, $172 \mathrm{ft}(52 \mathrm{~m})$ wide, and texturally zoned; 14 samples were collected across it at approximately 10-ft- $(3 \mathrm{~m})$ intervals. Pd and $\mathrm{Pt}$ analyses and $\mathrm{Pd} / \mathrm{Pt}$ are summarized in table 3 and shown graphically, with $\mathrm{MgO}$ contents, plotted in distance from the western contact in figure 5 . $P d+P t$ ranges from 1.6 to $4.6 \mathrm{ppb}$, and $\mathrm{Pd} / \mathrm{Pt}$ averages 0.3 , with only minor increases of the abundances and ratios in internal zones relative to chill margins (table 3 and fig. 5).

The Nokesville sheet, a sill about 30 by $1 \mathrm{~km}$ in area, averaging $700 \mathrm{ft}(210 \mathrm{~m})$ thick, is situated in the central part of the Culpeper basin, Virginia (fig. 1). Twenty-two samples were obtained from two core holes through the lower $400 \mathrm{ft}(120 \mathrm{~m})$ of the sheet. $\mathrm{Pd}$ and $\mathrm{Pt}$ analyses and $\mathrm{Pd} / \mathrm{Pt}$ are summarized in table $3 . \mathrm{Pd}+\mathrm{Pt}$ content ranges from less than $1 \mathrm{ppb}$ to $7.1 \mathrm{ppb}$. Typically $\mathrm{Pd}$ and $\mathrm{Pt}$ are below $5 \mathrm{ppb}$, and $\mathrm{Pd} / \mathrm{Pt}$ is relatively constant at about 0.4 . The consistent 7.5 to 8.5 percent 

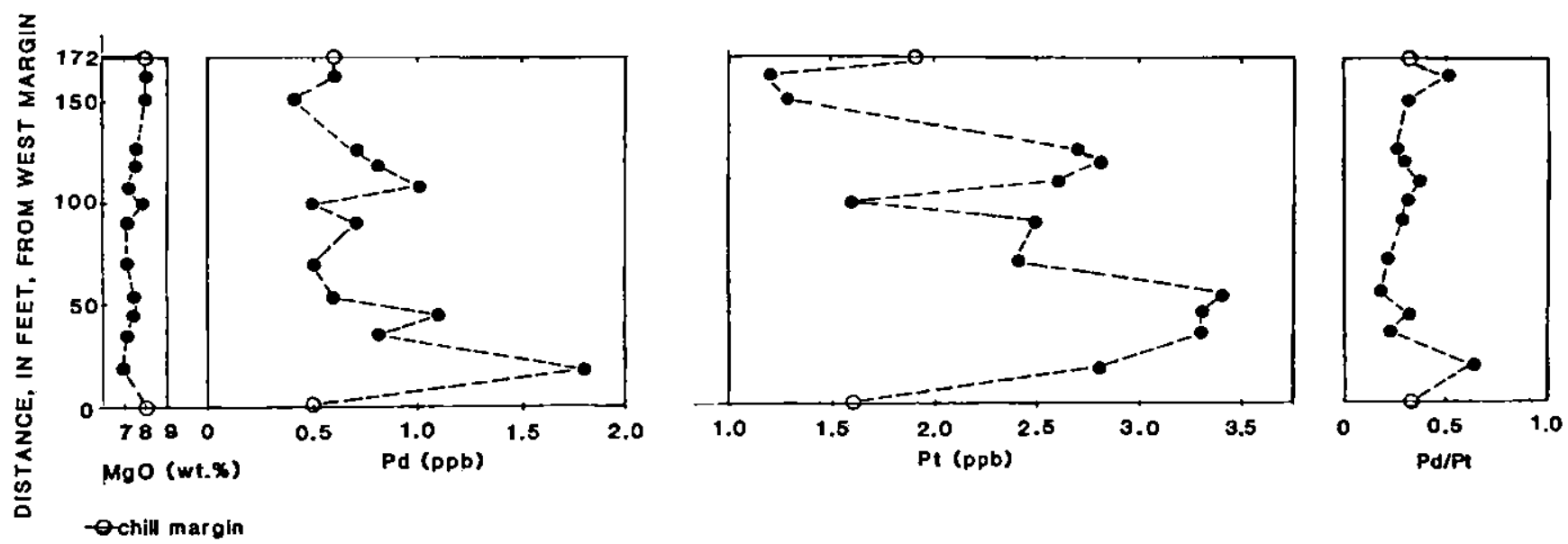

Figure 5. Distribution of $\mathrm{MgO}, \mathrm{Pd}$, and $\mathrm{Pt}$ in low-Ti, quartz-normative diabase dike, Dickerson, Maryland.

$\mathrm{MgO}$ content indicates a lack of significant fractionation or differentiation in this part of the sheet.

\section{Olivine-Normative Dikes and Sheets}

The North Durham sheets cover an area about 4 by $5 \mathrm{~km}$ in the northwestern part of the Durham basin, North Carolina (fig. 1). The upper part of a layered olivine- and troctolitic-gabbro sheet is well exposed at the Nello Teer quarry; other parts of the cumulate complex crop out along the Eno River north of the quarry. USGS reference sample DNC-1 is from the Braggtown quarry, a separate but related sheet along the southern margin of the same complex. The North Durham sheet averages about $350 \mathrm{ft}(115 \mathrm{~m})$ thick. The 24 samples analyzed for $\mathrm{Pd}$ and $\mathrm{Pt}$ are summarized in table 3 . Pd+Pt content ranges from $2.2 \mathrm{ppb}$ in pegmatoid to $36.8 \mathrm{ppb}$ in some layered cumulate zones. The Pd and Pt contents in the upper part of the sheet, exposed at Nello Teer quarry, are plotted, with $\mathrm{MgO}$ content, against distance below the upper contact in figure $6 . \mathrm{Pd} / \mathrm{Pt}$ averages 0.4 for the 22 samples, with a chill margin $\mathrm{Pd} / \mathrm{Pt}$ of 0.5 , pegmatoid at 1.0 , and the $\mathrm{Pd} / \mathrm{Pt}$ in layered gabbros varying widely between 0.1 and 0.96 but averaging 0.4 .

The Quarryville dike, about 35 to $40 \mathrm{ft}$ (11 to $12 \mathrm{~m}$ ) wide, is exposed in a railroad cut in Piedmont rocks several miles south of the Gettysburg and Newark basins in Pennsylvania (fig. 1). Five samples were collected from this steeply dipping zoned dike, and two samples from a 3- to 4-ft- (about $1 \mathrm{~m}$ ) thick related dike exposed about $700 \mathrm{ft}(210 \mathrm{~m})$ to the west. $\mathrm{Pd}$ and $\mathrm{Pt}$ analyses and $\mathrm{Pd} / \mathrm{Pt}$ are summarized in table 3 . $\mathrm{Pd}+\mathrm{Pt}$ content is consistently high, ranging from 26 to $34 \mathrm{ppb}$. Chill zones have a Pd/Pt of 1.4 , and this ratio increases slightly to 1.5 in the inner core.

Two core samples of chill margins of dikes in the Sanford basin of North Carolina show a much lower
$\mathrm{Pd}+\mathrm{Pt}$ content of 11.8 to $18.4 \mathrm{ppb}$, with $\mathrm{Pd} / \mathrm{Pt}$ of 1.3 , similar to that of the Quarryville dike. As more data from other sheets and particularly from dikes are obtained, the wide range of olivine-normative varieties already recognized in eastern North America on the basis of $\mathrm{Sr}$ and $\mathrm{Nd}$ isotope ratios and other trace elements (Gottfried and Arth, 1985; Gottfried and others, 1986) probably will be supported by contrasting Pd and Pt contents and ratios.

\section{SUMMARY AND DISCUSSION}

The relatively high precision of $\mathrm{Pd}$ and $\mathrm{Pt}$ analyses indicates that these elements may be used systematically to distinguish and to characterize different magma types. When used in conjunction with other trace elements and $\mathrm{Sr}$ isotopes, $\mathrm{Pd}$ and $\mathrm{Pt}$ analyses may facilitate identification of common or different source areas in the mantle.

Variations in $\mathrm{Pd}+\mathrm{Pt}$ abundances, and the $\mathrm{Pd} / \mathrm{Pt}$ ratios of cogenetic suites of rocks representing the various early Mesozoic HTQ, LTQ, and ON magma types, are summarized in table 4.

The data indicate that relative abundances of these elements and their ratios can be used for discriminating between the two quartz-normative magma types. The LTQ suites are characterized by unusually low Pd $+\mathrm{Pt}$ contents, generally less than $5 \mathrm{ppb}$, and by low $\mathrm{Pd} / \mathrm{Pt}$ ratios averaging 0.35 . In contrast, HTQ suites have higher abundances, averaging $20 \mathrm{ppb}$, and generally higher Pd/Pt ratios. Interestingly, the abundances of Pd and $\mathrm{Pt}$ in the LTQ suites are even lower than estimates of $\mathrm{Pd}$ and Pt contents in the mantle, 4.5 and $6.7 \mathrm{ppb}$, respectively (Barnes and others, 1985). These low abundances might be accounted for by early separation, during magmatic ascent, of an immiscible sulfide fraction containing platinum group elements (PGE's). Other possible causes are that PGE's were retained in a refrac- 

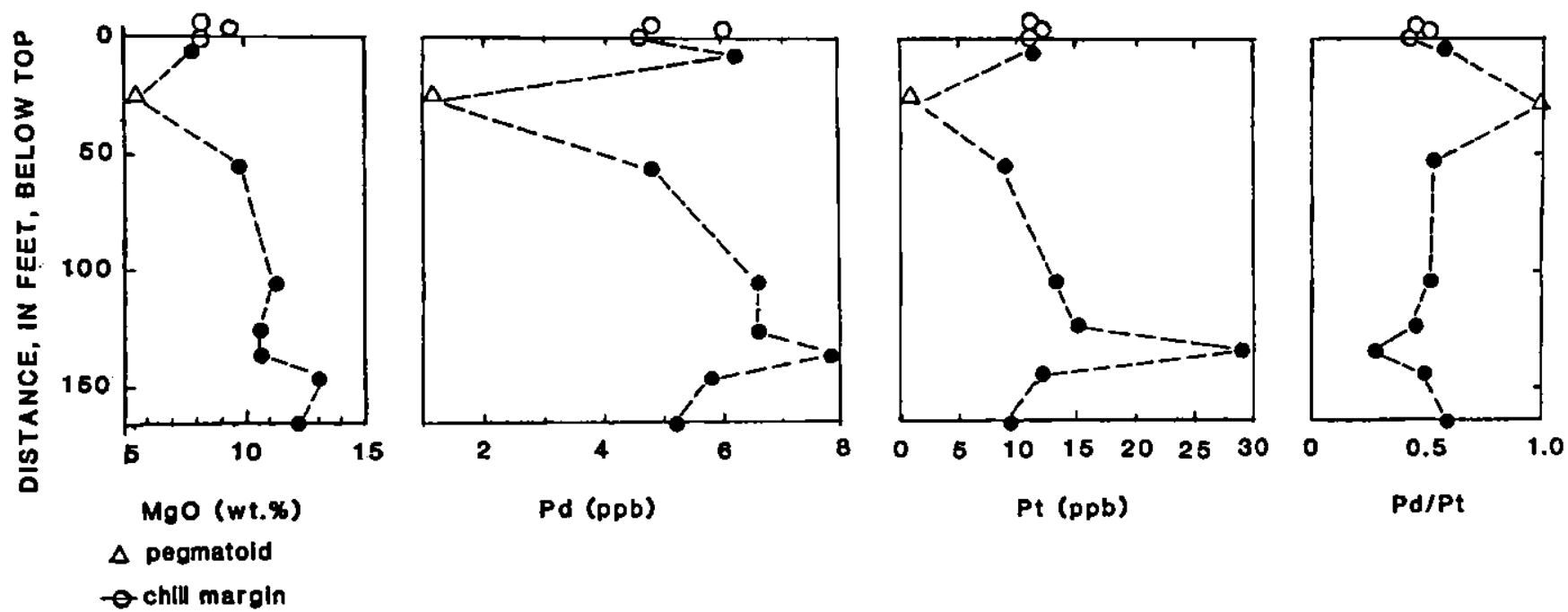

Figure 6. Distribution of $\mathrm{MgO}, \mathrm{Pd}$, and $\mathrm{Pt}$ in olivine-normative gabbro sheet, North Durham, North Carolina.

Table 4. Summary of Pd+Pt ranges and ratios from early Mesozoic tholeiites in the Eastern United States

[(2), number of samples; chill-margin samples included in totals]

\begin{tabular}{|c|c|c|c|c|}
\hline Variety of tholeiite & & $\begin{array}{l}\text { Mode of } \\
\text { occurrence }\end{array}$ & $\begin{array}{l}P d+P t \\
\text { range } \\
(p p b)\end{array}$ & $\begin{array}{c}\text { Average } \\
\mathrm{Pd} / \mathrm{Pt}\end{array}$ \\
\hline \multirow[t]{2}{*}{ Quartz-normative } & $\begin{array}{l}\text { High Ti } \\
\text { (HTQ) }\end{array}$ & $\begin{array}{l}\text { Chill margins }(10) \\
\text { Cumulate-bearing } \\
\text { sheets }{ }^{1}(57) \\
\text { Late differentiate- } \\
\text { bearing sheets } \\
\text { (45) }\end{array}$ & $\begin{array}{l}11-34 \\
16.3-51 \\
10-227 \\
\end{array}$ & $\begin{array}{r}0.96 \\
.75\end{array}$ \\
\hline & $\begin{array}{l}\text { Low Ti } \\
\text { (LTQ) }\end{array}$ & $\begin{array}{l}\text { Chill margins (2) } \\
\text { Dike (14) } \\
\text { Chill margins (2) } \\
\text { Sheet (22) }\end{array}$ & $\begin{array}{l}2.1-2.5 \\
2.5-4.6 \\
1.3-1.6 \\
<1-7.1\end{array}$ & $\begin{array}{l}.3 \\
.3 \\
.6 \\
.4\end{array}$ \\
\hline \multirow[t]{2}{*}{ Olivine-normative } & \multirow[t]{2}{*}{$(\mathrm{ON})$} & \multirow{2}{*}{$\begin{array}{l}\text { Chill margins (5) } \\
\text { Dikes (9) } \\
\text { Chill margins (8) } \\
\text { Cumulate-bearing } \\
\text { sheets }^{1}(24)\end{array}$} & $\begin{array}{c}11.8-29 \\
8.6-36 \\
12.2-25.9\end{array}$ & $\begin{array}{l}1.35 \\
1.4 \\
9 \quad .5\end{array}$ \\
\hline & & & $12-46$ & .4 \\
\hline
\end{tabular}

${ }^{1}$ Pegmatoid veins or pods in cumulate-bearing sheets generally have $\mathrm{Pd} / \mathrm{Pt}$ ratios greater than 1.0.

tory phase in the source area or that LTQ magmas were derived from source areas depleted in PGE's.

Fractionation of $\mathrm{Pd}$ from $\mathrm{Pt}$ has been found in each of the differentiated HTQ diabase sheets thus far studied. The cumulate zones, rich in OPX, are characterized by enrichment of $\mathrm{Pt}$ relative to $\mathrm{Pd}$ and by a $\mathrm{Pd} / \mathrm{Pt}$ ratio averaging 0.75 . In contrast, the later formed ferrogabbros are entiched in $\mathrm{Pd}$ relative to $\mathrm{Pt}$ and have $\mathrm{Pd} / \mathrm{Pt}$ ratios of 2.2 to 32.1 , averaging 6.8 . Granophyre, aplite, and pegmatoids, representing the final stages of differentiation, have extremely low abundances of Pd and Pt. These low abundances suggest that, in the normal course of tholeiitic differentiation, $\mathrm{Pd}$ is enriched relative to $\mathrm{Pt}$ in the later stages due to early extraction of Pt and that Pd and $\mathrm{Pt}$ are both depleted in the final stages of differentiation.

The highest abundances of Pd+Pt thus far determined, more than $225 \mathrm{ppb}$, occur in ferrogabbro and ferrodiorite and represent an order of magnitude enrichment over other rocks of similar composition in the ENA tholeiite province. These anomalous contents may be the result of concentration by later hydrothermal solutions. If so, the relatively high $\mathrm{Pd}$ contents and $\mathrm{Pd} / \mathrm{Pt}$ ratios in these rocks imply a greater mobility of Pd than of Pt during hydrothermal alteration, as noted by Barnes and others (1985).

Two suites of olivine-normative samples from widely separated areas have significantly different $\mathrm{Pd} / \mathrm{Pt}$ ratios. Dikes from Quarryville, Pennsylvania, have consistent $\mathrm{Pd} / \mathrm{Pt}$ ratios of 1.4 , whereas olivine-rich gabbro sheets from Durham, North Carolina, have Pd/Pt ratios of 0.4. These results and sparse data on other dikes in North Carolina and Virginia suggest important regional variations in the relative abundances of these elements. When used in conjunction with $\mathrm{Sr}$ and $\mathrm{Nd}$ isotope ratios and other trace elements, $\mathrm{Pd}$ and $\mathrm{Pt}$ abundances and ratios may also reflect fundamental differences in the mantle source areas of olivine-normative magmas.

\section{REFERENCES CITED}

Aruscavage, P.J., Simon, F.O., and Moore, R., 1984, Flameless atomic absorption determination of platinum, palladium, and rhodium in geologic materials: Geostandards Newsletter, v. 8 , no. 1 , p. $3-6$.

Barnes, S.-J., Naldrett, A.J., and Gorton, M.P., 1985, The origin of the fractionation of platinum-group elements in terrestrial magmas: Chemical Geology, v. 53, p. 303-323. 
Crocket, J.H., 1979, Platinum-group elements in mafic and ultramafic rocks: A survey: Canadian Mineralogist, v. 17, p. 391-402.

Flanagan, F.J., 1984, Three USGS mafic rock reference samples, W-2, DNC-1, and BIR-1: U.S. Geological Survey Bulletin 1623, $54 \mathrm{p}$.

Flanagan, F.J., Wright, T.L., Taylor, S.R., Annell, C.S., Christian, R.C., and Dinnin, J.I., 1976, Basalt, BHVO-1, from Kilauea crater, Hawaii, in Flanagan, F.J., ed., Descriptions and analyses of eight new USGS rock standards: U.S. Geological Survey Professional Paper 840, p. 33-39.

Froelich, A.J., and Gottfried, D., 1985, Early Jurassic diabase sheets of the Eastern United States-A preliminary overview, in Robinson, G.R., Jr., and Froelich, A.J., eds., Proceedings of the second U.S. Geological Survey workshop on the early Mesozoic basins of the Eastern United States: U.S. Geological Survey Circular 946, p. 79-86.

Gottfried, D., and Arth, J.G., 1985, Sr and Nd isotope ratios and geochemistry of Mesozoic diabase dikes from Georgia [abs.]: EOS, v. 66, no. 18, p. 399.

Gottfried, D., and Froelich, A.J., 1985, Geochemical and petrologic features of some Mesozoic diabase sheets in the northern Culpeper basin, in Robinson, G.R., Jr., and Froelich, A.J., eds., Proceedings of the second U.S. Geological Survey workshop on the early Mesozoic basins of the Eastern United States: U.S. Geological Survey Circular 946, p. 86-91.

Gottfried, D., Ragland, P.C., and Froelich, A.J., 1985, Styles of differentiation of some Mesozoic diabase sheets in the eastern United States: Geological Society of America Abstracts with Programs, v. 17, no. 7, p. 595.

Gottfried, D., Arth, J.G., and Ragland, P.C., 1986, Lowpartition coefficient trace elements and initial ${ }^{87} \mathrm{Sr} /{ }^{86} \mathrm{Sr}$ ratios in Mesozoic tholeiitic rocks from the southeastern United States: Geological Society of America Abstracts with Programs, v. 18, no. 3, p. 223.

Keahey, J.M., 1976, Triassic diabases of the Potomac basin, Virginia: University of Connecticut, Storrs, unpublished M.S. thesis, $72 \mathrm{p}$.

Ragland, P.C., and Arthur, J.D., 1985, Petrology of the Boyds diabase sheet, northern Culpeper basin, Maryland, in Robinson, G.R., Jr., and Froelich, A.J., eds., Proceedings of the second U.S. Geological Survey workshop on the early Mesozoic basins of the Eastern United States: U.S. Geological Survey Circular 946, p. 91-99.

Shirley, D.N., 1987, Differentiation and compaction in the Palisades sill, New Jersey: Journal of Petrology, v. 28, part 5 , p. $835-865$.

Smith, R.C., II, 1973, Geochemistry of Triassic diabase from southeastern Pennsylvania: University Park, The Pennsylvania State University, unpublished Ph.D. thesis, 262 p.

Smith, R.C., II, Rose, A.W., and Lanning, R.M., 1975, Geology and geochemistry of Triassic diabase in Pennsylvania: Geological Society of America Bulletin, v. 86, p. 943-955.

Talkington, R., Gottfried, D., Lipin, B.R., Rait, N., Puffer, J.H., and Shirley, D.N., 1987, The distribution of the platinum-group elements in the Palisades sill, New Jersey and New York, in Paper P-7, Abstracts, Geo-Platinum '87 Symposium: The Open University, Milton Keynes, United Kingdom.

Walker, K.R., 1969, The Palisades sill, New Jersey: A reinvestigation: Geological Society of America Special Paper 111, $178 \mathrm{p}$.

Weigand, P.W., and Ragland, P.C., 1970, Geochemistry of Mesozoic dolerite dikes from eastern North America: Contributions to Mineralogy and Petrology, v. 29, p. 195-214.

\title{
THE ORIGIN OF COPPER OCCURRENCES IN THE HARTFORD BASIN
}

\author{
Norman H. Gray ${ }^{1}$
}

\begin{abstract}
Significant copper occurrences in the Connecticut portion of the Mesozoic Hartford basin fall into three principal groups: (1) stratabound sulfide disseminations in gray sandstones and siltstones (for example, New-gate area mines), (2) gangue-poor solid sulfide veins (for example, Bristol and Higley mines) and (3) minor copper sulfides in quartzcarbonate-barite (QCB) veins (for example, mines in the Cheshire and New Britain areas). The stratabound disseminations are found almost exclusively in sedimentary rocks at or near the stratigraphic level of the Talcott Basalt.
\end{abstract}

\footnotetext{
${ }^{1}$ Department of Geology and Geophysics, The University of Connecticut, Storrs, CT 06268.
}

Wall-rock alteration associated with deposits is negligible in sedimentary rocks (minor silicification and dissolution of hematite) but extensive in basalt (albite-montmorilloniteferroan dolomite replacement). The gangue in all occurrences consists of minerals that were in equilibrium with diagenetic pore waters that developed within the sedimentary pile. These facts suggest the mineralizing fluids were the normal formation waters. Because these waters were apparently so far out of equilibrium with basalt, the source of the copper is likely to have been the sediments themselves. Detrital ilmenite and magnetite in the arkosic sediments broke down at the earliest stages of diagenesis and released their trace amounts of copper long before the pore fluids became saturated in other diagenetic minerals. This copper seems to have been deposited as stratabound dissemina- 
tions at local reducing sites in the near-surface environment when, during the cooling of Talcott-aged intrusives, the formation waters were flushed up open normal faults to the surface where they mixed with shallow ground waters. The gangue-poor vein deposits also formed at this time at favorable sites along the subsurface conduits used by the rising hydrothermal waters.

The gangue-rich QCB mineralization is much later and postdates the last volcanic event in the basin. A major episode of post-Hampden normal faulting tapped the mature, highly saline pore waters in the New Haven Arkose while the unit was still relatively permeable, permitting some of the waters to escape up open faults and deposit quartz, carbonate, barite, and copper en route to the surface.

\section{INTRODUCTION}

The Mesozoic red beds of the Hartford basin are host to a great number of small copper showings. Settlers, attracted by bright green weathering products, discovered many of these occurrences in the late 1600's and early 1700's (Harte, 1944). Others have been exposed in recent road cuts and quarries. The locations of all known occurrences of significant copper mineralization are shown on the accompanying map (fig. 1). A striking feature of the regional distribution is the number found at or near the stratigraphic level of the oldest lava flow in the basin, the Talcott Basalt.

Of the known deposits, New-gate and Bristol were the most productive (see table 1). New-gate was the first chartered copper mine in North America. The mine was actively worked for 30 years in the early 1700 's. The Bristol deposit was an important source of copper in the mid-19th century. Neither mine is presently economic, although the total quantity of low-grade copper ore remaining is substantial. The length of the mineralized zone at Bristol is more than $500 \mathrm{~m}$. At the New-gate deposit, copper mineralization can be traced for at least $2,000 \mathrm{~m}$ along strike.

This paper focuses on the relation between copper mineralization and volcanic activity in the Hartford basin and the regional geochemical implications of this activity.

\section{TYPES OF MINERALIZATION}

Although each occurrence of copper minerals in the Hartford basin is unique in many respects, the following general associations can be recognized.

\section{Stratabound}

\section{Organic-Debris Association}

This is the typical red-bed association but is not common in the Hartford basin. Small amounts of copper sulfides accompany and replace carbonized wood fragments in gray channel sands in the Portland Formation along the Connecticut and Farmington Rivers. In most occurrences the sulfide replacements (chalcocite, bornite, and chalcopyrite) preserve the cellular structure of original plant material and are interpreted to predate significant burial.

\section{Disseminated}

Disseminated copper sulfides are most common in sedimentary rocks at the stratigraphic level of the Talcott Basalt. Although this type of mineralization is found in both primarily and secondarily reduced gray sedimentary rocks, neither organic debris nor pyrite is directly associated with the copper minerals. In mineralized sandstones copper sulfides occur as concretions up to $1 \mathrm{~cm}$ in diameter. In the finer grained mineralized rocks, the sulfides are less concentrated and more widely dispersed throughout the original interstitial pore spaces.

\section{New-gate Mottled Ore}

Peculiar mottled chalcocite-impregnated sandstone forms the ore at the New-gate mine. It appears to be a secondary enrichment of earlier disseminated-type mineralization.

\section{Veins}

\section{Gangue-Rich}

Quartz-Carbonate-Barite ( \pm copper sulfides).Quartz-carbonate-barite (QCB) veins up to $1 \mathrm{~m}$ in width are common in the southern part of the Hartford basin. Barite is the most important economic constituent of these veins and was mined in the Cheshire area in the mid-1800's. Copper sulfides are ubiquitous, but the amount is typically small and none of the deposits was ever worked for its copper content alone.

Hematite-Siderite ( \pm copper sulfides). - This type of mineralization occurs in the Hartford basin at only one site, the "Wylls Copper Mine," Highland Park, Manchester. The copper is present in small amounts as sulfides in 1- to 4-cm-thick hematite-siderite veins in fractured crystalline rocks adjacent to the main Eastern Border Fault (Percival, 1842; Shepard, 1837).

Gangue-Poor Chalcocite-Bomite Veins. - The Bristol and Higley deposits are of this type. The mineralized stringers and veins worked in these mines consist almost entirely of chalcocite and bornite. Quartz is the only gangue mineral occurring in any abundance.

\section{Others}

Copper mineralization is also associated with the secondary minerals of the lava flows. Amygdules, partic- 


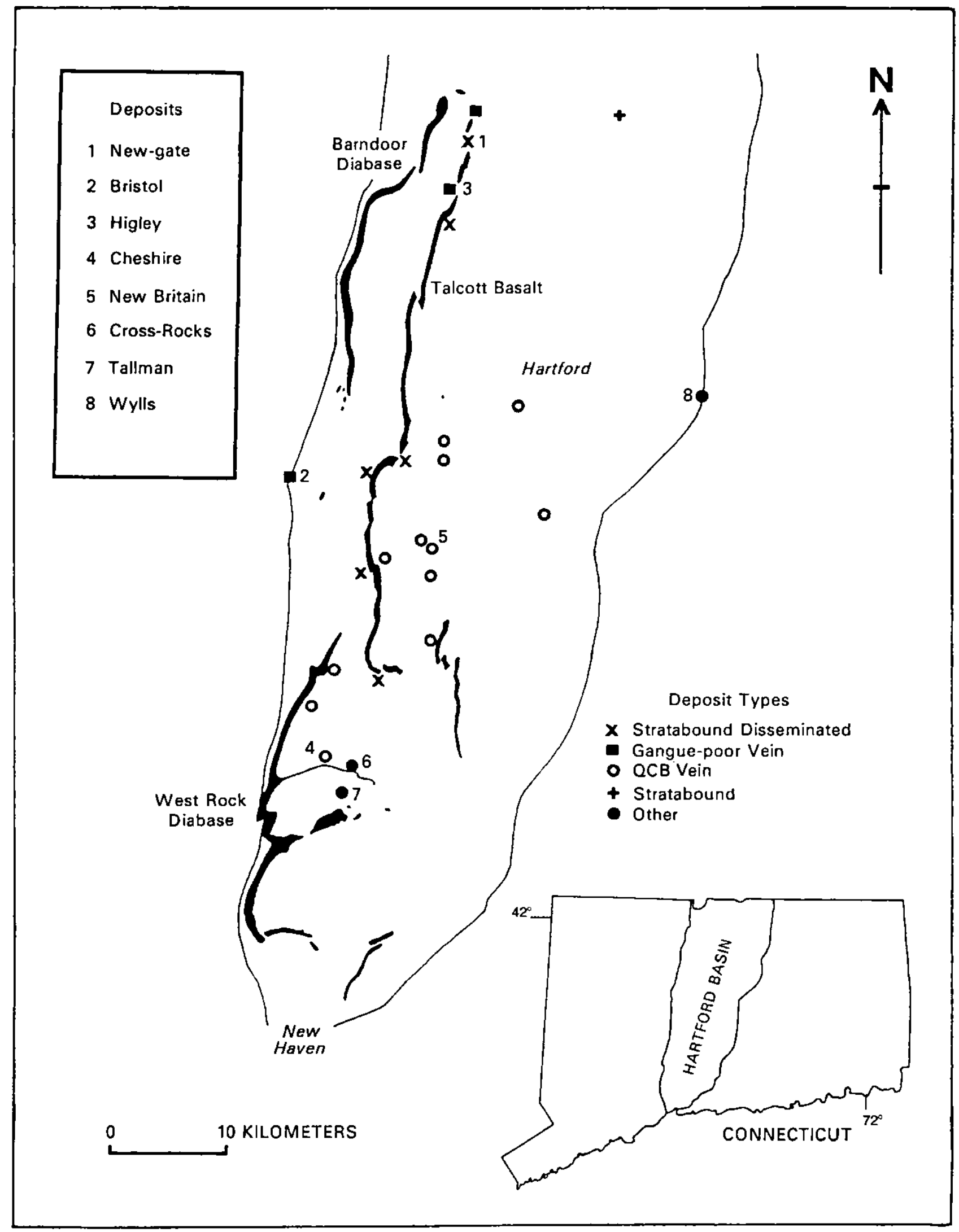

Figure 1. Regional distribution of known copper occurrences in the Hartford basin of Connecticut. 
Table 1. Copper deposits with known production and copper prospects in the Hanford basin

\begin{tabular}{|c|c|c|c|c|c|}
\hline Name & Location & Deposit type & Discovery & Production & Reference \\
\hline \multicolumn{6}{|c|}{ Copper deposits with known production } \\
\hline Bristol copper mine. ....... & Bristol & Gangue-poor vein & 1790 & $\begin{array}{l}1802-1810 \\
1836-1846 \\
1849-1858 \\
1888-1896\end{array}$ & Harte, 1944; Hulburt, 1897 \\
\hline New-gate area mines $\ldots \ldots \ldots$ & East Granby & Stratabound & 1707 & $\begin{array}{l}1707-1743 \\
1831-1836 \\
1855 \\
1901 ?\end{array}$ & $\begin{array}{l}\text { Richardson, } 1928 \\
\text { Harte, } 1944\end{array}$ \\
\hline Higley..$\ldots \ldots \ldots \ldots \ldots \ldots$ & East Granby & Gangue-poor vein & $1728 ?$ & $\begin{array}{l}1728-1737 \\
1832 ?\end{array}$ & Johnson, 1896 \\
\hline $\begin{array}{l}\text { Cross-Rocks mines } \ldots \ldots \ldots \ldots \\
\text { (also known as Copper } \\
\text { Valley, Gaylord, Parker } \\
\text { Mines) }\end{array}$ & Cheshire & Vein & 1711 & $\begin{array}{l}1711-1723 \\
1866-1874\end{array}$ & $\begin{array}{l}\text { Shepard, 1837; } \\
\text { Harte, } 1944\end{array}$ \\
\hline$? \ldots \ldots \ldots \ldots \ldots \ldots \ldots \ldots$ & Cheshire & $?$ & 1670 & $\begin{array}{l}1670-? \\
1880-1885\end{array}$ & Harte, 1944 \\
\hline Tallman's mine ........... & Hampden & Vein & pre- 1770 & $\begin{array}{l}1770 \text { 's } \\
1884-?\end{array}$ & Harte, 1944 \\
\hline \multicolumn{6}{|c|}{ Copper prospects } \\
\hline Wylls copper mine.. & Manchester & $\begin{array}{l}\text { Hematite-siderite } \\
\text { bornite veins }\end{array}$ & $1800 ?$ & early 1800 's & $\begin{array}{l}\text { Shepard, 1837; } \\
\text { Percival, 1842 }\end{array}$ \\
\hline Copper Ledges mine........ & Bristol & Gangue-poor veins & 1853 & 1850's & \\
\hline Mine Hollow ............ & Southington & Stratabound & $?$ & 1850 's & Hulbert, 1897 \\
\hline Golden-Parlor mine ....... & New Haven County? & $?$ & 1736 & $?$ & Harte, 1944 \\
\hline Copper mine . . . . . . . . . & New Britain & QCB veins ${ }^{1}$ & 1850 's & $?$ & Hulbert, 1897 \\
\hline Avon mine $\ldots \ldots \ldots \ldots \ldots$ & Avon & $?$ & $?$ & $?$ & Percival, 1842 \\
\hline Farmington mine .......... & Farmington & $?$ & $?$ & $1711-1720 ?$ & Richardson, 1928 \\
\hline
\end{tabular}

${ }^{1} \mathrm{QCB}$, Quartz-carbonate-barite.

ularly at flow tops, may contain minor amounts of chalcopyrite or native copper. Copper sulfides occur together with calcite, prehnite, and various zeolites in cooling-related fractures in the basalts. Chalcocite and bornite are found with calcite filling evaporite crystal casts. All of these occurrences are volumetrically minor. They are, however, convincing testimony to the widespread presence of copper in the Hartford basin.

\section{GEOLOGIC SETTING AND ORIGIN OF THE PRINCIPAL DEPOSITS}

The workings of most early Connecticut mines are now collapsed or flooded and the prospect pits are filled with debris. As a result, reliable information on the nature of the deposits and the mineralogy of the ore is difficult to obtain. Historical records provide only the crudest details and are generally of dubious accuracy. Old mine dumps and tailings piles must also be interpreted cautiously since the early "miners" were rarely obliging enough to leave samples of their hard-won "ore" lying around on the surface. Small, low-grade copper showings in outcrops and recent road cuts supply some insight into the nature of the copper deposits of the basin but are no substitute for the information that access to underground workings could provide. Thus, very little reliable information is available for most of the copper "mines" listed in table 1. Fortunately, the major exceptions happen to be the two largest copper deposits in Connecticut: New-gate and Bristol. Because of a "slough," or drainage tunnel, driven in 1720 , a portion of New-gate underground workings has always been accessible. The full extent of the workings was revealed in the summer of 1986 when the flooded section of the mine was temporarily dewatered. The Bristol mine has been flooded since 1898 , but the historic information about the deposit is unusually reliable. Benjamin Silliman, Jr., had a stake in the operation of the property from 1850-58 and published a geologic description of the deposit (Silliman and Whitney, 1855). Samples from Silliman's collection were the subject of a detailed mineralogic study by Bateman (1923).

\section{New-gate Area Mines}

Copper occurrences in the vicinity of the New-gate mine (fig. 2) are located along a major erosional unconformity, which truncates the Talcott Basalt (fig. 1) in northern Connecticut (Cornet and Traverse, 1975). The mineralized zone can be traced for at least $2 \mathrm{~km}$ along 


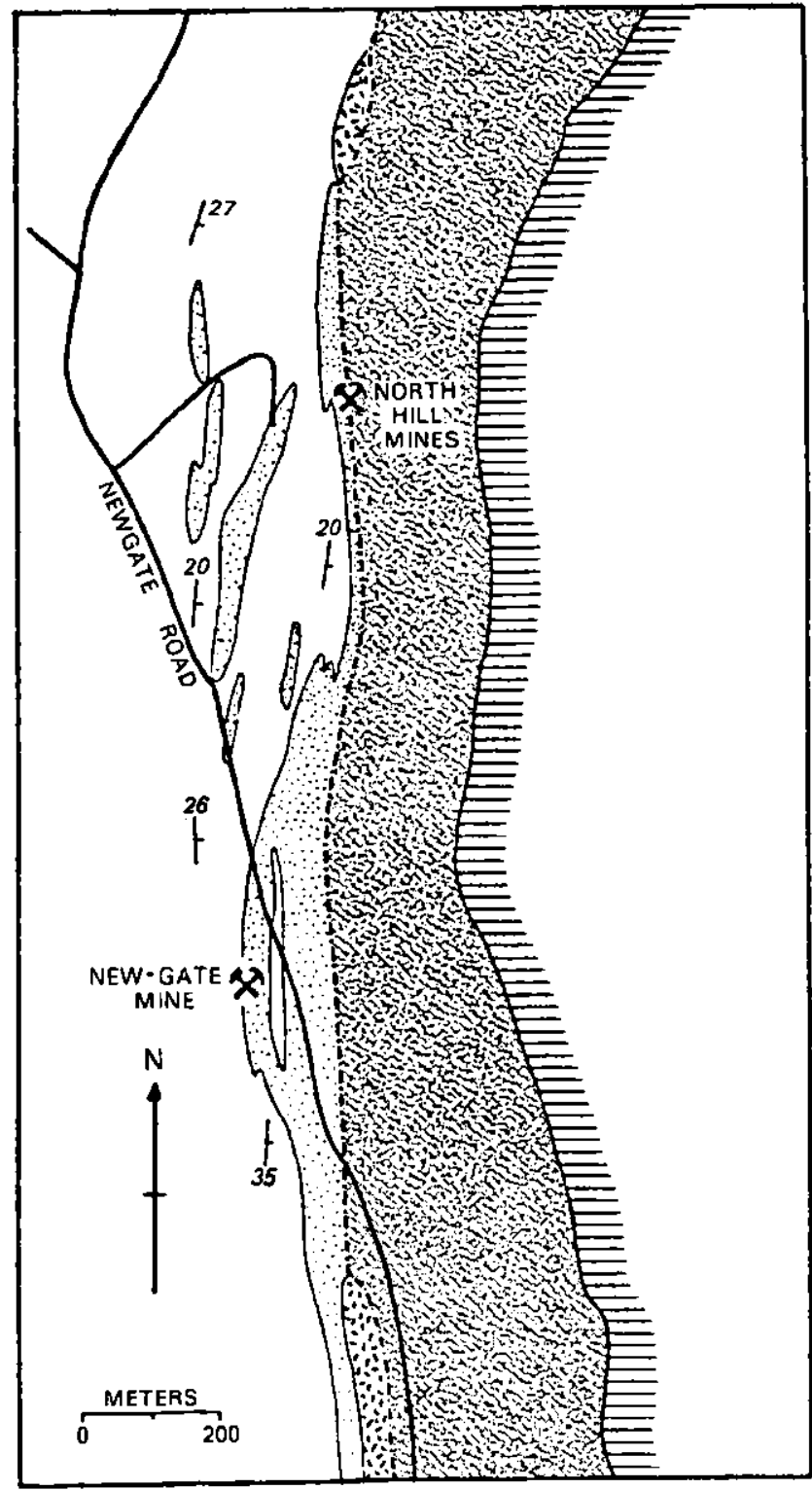

EXPLANATION

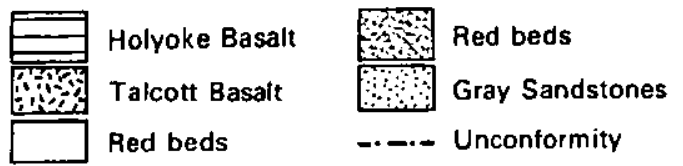

Figure 2. Generalized geology of the New-gate Prison area, East Granby, Connecticut (after Perrin, 1976).

strike. Copper was first noticed in the area in 1707 . The early miners quickly discovered and explored other copper occurrences along the entire length of the known mineralized belt. In the early 1700 's at least four separate "mines" produced ore in the New-gate area (Richardson, 1928).

The geologic setting of the New-gate deposits has been described in detail by Perrin (1976) and Gray (1982). Disseminated stratabound mineralization occurs exclusively in gray to black sedimentary rocks. The interbedded red-colored sandstones and shales are everywhere barren. Bornite and chalcopyrite fill the interstitial pores between detrital grains in the mineralized finegrained siltstones. In sandstones these same sulfides form nodular concretions as much as a centimeter in diameter. The concretions preferentially replace feldspar. Quartz grains in the sulfide nodules commonly exhibit euhedral overgrowths. Malachite and cuprite are conspicuous secondary replacements of the sulfides.

Gray sandstones less than $20 \mathrm{~m}$ below the unconformity that truncates the Talcott Basalt are the focus of the disseminated mineralization (fig. 2). Copper averages less than 1 percent in most of these beds, but near the North Hill mines the average grade is somewhat higher, 2 to 5 percent. The close relationship of the mineralization to the Talcott unconformity suggests copper-bearing solutions percolated into the sediments from the surface during the erosional interval responsible for the unconformity.

The main deposit at New-gate Prison is stratigraphically lower and texturally distinct from the disseminated ores. It is also higher grade. Copper averages 2.5 to 10 percent and silver up to 10 ounces per ton. The mineralized beds are part of sedimentary fill of a large north-south channel eroded into underlying red mudstones. Coarse, structureless sandstone at the north end of the mine was deposited in a small delta or sandbank along the edge of the channel. At the south end finely laminated gray siltstone grades upwards into a meterthick black mudstone, which suggests that the original channel became cut off from a larger stream and survived for a while as a small body of stagnant water. The edge of the coarse sand bank was partially cemented by ferroan dolomite prior to significant compaction. A zone of mixing between reduced waters below a stagnant pond and more aerated waters in the coarse sand may have localized carbonate precipitation.

The ferroan dolomite zones played a significant role in localizing the high-grade New-gate copper mineralization. The waters responsible for the disseminated mineralization just below the post-Talcott unconformity also precipitated copper sulfides in millimeter-size nodular concretions in the uncemented portions of the channel fill adjacent to the ferroan dolomite. Later, the initial nodular texture was modified when postcompaction, less-reduced solutions enriched the original ore and deposited additional chalcocite. Much of the channel fill was well compacted and impervious to these later solutions. Only the sandstones adjacent to the ferroan-dolomite-cemented zones, which had been shielded from compaction, retained some permeability. Chalcocite impregnates this sandstone as curious mottled patches surrounding centimeter-size porous areas within which the calcite and ferroan dolomite cements 
have been dissolved. The cause of the change in water chemistry responsible for the mottled ore is not obvious. Perhaps the cooling of the Holyoke sheet generated ground-water circulation that forced new waters through the old mineralized zone.

\section{Higley}

Although in the same stratigraphic zone and only $1.5 \mathrm{~km}$ from New-gate, the Higley mine is distinct from the other copper deposits in the New-gate area (Gray, 1982). Rather than filling pore spaces in sedimentary rocks, the Higley mineralization occupies fractures and vesicles in altered Talcott Basalt.

The vesicular upper surface of the lower Talcott flow is the focus of mineralization. Vesicles are lined by copper sulfides, calcite, and zeolites. The vesicular basalt is extensively replaced by ferroan dolomite, especially where heavily mineralized. Hematite-stained fractures filled with solid bornite and chalcopyrite, up to $2 \mathrm{~cm}$ wide, extend below the porous amygdaloidal zone. Unmineralized chloritized basalt caps the ore and is in turn overlain unconformably by a coarse breccia, which consists of angular fragments of chloritized basalt and bleached clay-rich hydrothermally altered basalt in a red sandstone matrix. Chalcopyrite-filled fractures crisscross the bleached basaltic clasts but do not extend into the matrix. These features demonstrate that both the hydrothermal alteration and the mineralization are later than the Talcott Basalt but earlier than the deposition of the Shuttle Meadow Formation. Similar copper-bearing hydrothermally altered basalt fragments occur in a mudflow breccia above the Talcott at the north end of the New-gate mineralized belt.

The bleached and altered volcanic fragments in sedimentary breccias imply extensive hydrothermal activity immediately after the Talcott event. Hot springs sited along the surface traces of the prominent northwesttrending normal faults may have been the source of the copper-bearing waters that deposited sulfides and ferroan dolomite in the permeable vesicular zone of the lower Talcott flow.

\section{Bristol}

The Bristol copper mine was discovered in 1790 and was Connecticut's only active copper mine between 1837 and 1896. Although the underground workings have long been flooded and are now inaccessible, the geology of the deposit was well documented by Silliman and Whitney (1855) and Bateman (1923). Bateman's especially thorough description, written several years after the mine closed, benefited from his use of ore samples collected by Silliman and from mine records obtained from one of Bristol's last superintendents. The mine is located on a major easterly dipping normal fault between Paleozoic metamorphic rocks of the Western Highlands and the Mesozoic sedimentary rocks of the basin. Copper mineralization occurs on both sides of the fault and is traceable for $700 \mathrm{~m}$ along strike. In the Paleozoic rocks of the footwall, the ore is an irregular stockwork of millimeter- to centimeter-thick chalcocitebornite-quartz veins. Gangue is a minor constituent of veins that in places consist entirely of copper sulfides. Mineralization in the Mesozoic hanging wall has an entirely different character. Copper sulfides there are disseminated through the interstices of two 6-m-thick gray sandstone beds. Ore values of between 1 to 3 percent copper are found in these gray beds as far as 50 $m$ from the fault. The other hanging wall sedimentary rocks are red and unmineralized right up to the fault surface. The early production of the mine was from the high-grade footwall veins. The lower grade disseminated mineralization was exploited only during the final years of operation.

The mineral paragenesis is similar to that at the New-gate and Higley deposits. Quartz was the first mineral deposited, followed in close succession by calcite, chalcocite, bornite, and chalcopyrite. Vein textures suggest open-space fillings. Indeed, the Bristol mine is world famous for its drusy cavities, which contained museumquality specimens of euhedral chalcocite crystals. The orthorhombic morphology of these crystals is convincing evidence for deposition from relatively cool $\left(<103{ }^{\circ} \mathrm{C}\right)$ solutions (Bateman, 1923).

The mineralizing solutions were probably close to equilibrium with the country rocks. Feldspars in both the crystalline gneisses and arkoses show no sign of alteration even where the rocks are highly mineralized. The one noticeable hydrothermal effect cited by Bateman (1923) is the gray color of the copper-bearing sandstone layers, which he inferred to be a consequence of the wholesale bleaching of initially red arkose. The mine maps show the lithological color boundaries to be parallel to bedding, suggesting a primary origin. Inasmuch as both primarily and secondarily reduced gray copperbearing sandstones are found at other sites in the Mesozoic basin, the origin of the Bristol gray sandstones remains an open question.

Most of the mineralization postdates the faulting. How much later is unknown. The fact that the sulfides filled open pores in sedimentary rocks suggests a shallow, early diagenetic origin. If the mineralizing solutions were derived from the basin, the lack of gangue minerals would point to immature formation waters containing relatively little dissolved material and thus a fairly early age for the deposit. On the basis of the similarity in mineralogy and depositional history of the Bristol and Higley deposits it is tempting to correlate the two and 
assign a Shuttle Meadow age to the Bristol mineralization. Bateman (1923) related the deposit to volcanic activity in the basin. Hydrothermal circulation driven by cooling Talcott intrusives would be a plausible source of the volume of warm waters necessary to form the Bristol deposit.

\section{New Britain Quartz-Carbonate-Barite (Copper Sulfide) Veins}

Quartz-carbonate-barite (QCB) veins up to a meter in width are common along normal faults between Cheshire and Hartford (Ryan, 1986). Copper sulfides are rarely more than minor constituents. Veins lying stratigraphically above the black shales of the Shuttle Meadow and East Berlin Formations contain, in addition to chalcopyrite and chalcocite, small quantities of galena, sphalerite, tennantite, and millimeter-size spheres of vitreous bitumen hydrocarbon. Veins containing ferroan dolomite occur only in rocks that are stratigraphically higher than the Shuttle Meadow and East Berlin Formations. In the early 1800 's a few of these veins in the New Britain area were prospected unsuccessfully for metals (Percival, 1842; Hulbert, 1897). Reportedly, some of the exploratory workings were $18 \mathrm{~m}$ deep and had horizontal drifts up to $30 \mathrm{~m}$ long (Hulbert, 1897). Similar veins in the Cheshire area were successfully mined for barite in the mid 1800's (Fritts, 1962).

The sequence of mineral deposition in the QCB veins is quartz, calcite, ferroan dolomite, and barite. The sulfides and hydrocarbons were deposited after the earliest quartz but before barite. Studies of fluid inclusions in the quartz (Ryan, 1986) indicate that the mineralizing fluids were moderately saline (10-13 weight percent $\mathrm{NaCl}$ equivalent), near $\mathrm{CO}_{2}$ saturation, and precipitated most minerals between 90 and $220^{\circ} \mathrm{C}$.

QCB veins cut both basalt and sedimentary rocks. Basalt is typically highly altered to an albite-montmorillonite assemblage where in contact with the veins, whereas the sedimentary wall rocks are only slightly silicified and bleached by the dissolution of hematite pigment.

The timing of the $\mathrm{QCB}$ veins coincides with postHampden normal faulting. In some veins early material is brecciated and recemented by later deposition. The hydrothermal solutions were probably derived from the interstitial brines of the New Haven, Shuttle Meadow, and East Berlin Formations. The New Haven Arkose appears to have contributed warm waters fully saturated in $\mathrm{CO}_{2}$, quartz, albite, calcite, and barite to the vein system. These minerals are all found as diagenetic cements in the New Haven Arkose. The upper stratigraphic units, including the lacustrine black shales, appear to have contributed vein waters saturated in only the earli- est diagenetic minerals-ferroan dolomite, hydrocarbons, and lead and zinc sulfides. Ferroan dolomite and the bitumen occur only in QCB veins cutting rocks above the Talcott Basalt.

Similar QCB veins occur sparingly in the Newark basins of New Jersey and Pennsylvania (Dombroski, 1980). The Gasswater Barite vein deposit of southern Scotland (Scott, 1967) and QCB veins in the Bantry area of Ireland (Schultz, 1971), which both cut Old Red Sandstone, are also similar to the Hartford veins in setting and mineralogy. $Q C B$ veins seem to be typical of red-bed sedimentary basins in which normal faults develop late enough to tap mature diagenetic brines but prior to significant loss of permeability due to cementation.

\section{COPPER AND THE EVOLUTION OF BASINAL DIAGENETIC FLUIDS}

Although economically of minor significance, the New-gate, Bristol, and QCB deposits record important events in the geochemical history of the Hartford basin. It is the theme of this paper that the mineralizing solutions responsible for these deposits are the normal diagenetic fluids that developed during the evolution of the basin. The exceptional aspect of these waters was not their composition but rather their volume and timing. Plumbing, more than water chemistry, was the principal factor responsible for concentrating of copper in these particular deposits. A number of lines of evidence, especially the timing of mineralization and the character of the wallrock alteration, support this hypothesis.

\section{Timing}

The Bristol, New-gate, and Higley deposits, as well as the smail stratabound copper occurrences, seem to be directly related to the basinwide thermal effects of Talcott age subvolcanic intrusives. On the basis of the petrography and trace-element chemistry, Philpotts and Martello (1986) have established that the principal intrusives in the Hartford basin, the Barndoor and West Rock "sills" (fig. 1), are related to and are the same age as the Talcott Basalt. Coincidentally, the Higley and New-gate mineralization is just slightly post-Talcott in age (see above). The cooling of large intrusive bodies within what must have been a poorly consolidated sedimentary sequence would have had a significant impact on the ground-water circulation in the basin. Thus, it is possible that the Higley and Bristol deposits were deposited by waters rising along the passageways offered by active normal faults during the cooling of these intrusive bodies. This deep-formation water would have reached the surface at hot springs along the traces of the active normal 
faults where it would have mixed with ground water and precipitated copper at favorable sites to form the numerous disseminated stratabound deposits associated with the Talcott Basalt.

The QCB copper sulfide veins appear to be unrelated to volcanic intrusives. Post-Hampden normal faults tapped New Haven formation waters late in their diagenetic evolution just prior to complete cementation. The diagenetic waters that poured up the conduits opened by this normal faulting were fully saturated in the complete suite of diagenetic minerals of the New Haven Arkose. Copper, although ubiquitous in these veins, is relatively minor compared to the nonmetallic gangue minerals. Presumably, most of the copper had been extracted from the formation waters and locked up in the disseminated stratabound occurrences during the earlier Talcott mineralization.

\section{Wall-Rock Alteration}

Regardless of age or paragenesis, all the copper mineralization in the Hartford basin has a common characteristic-its effect on the country rocks. Wall-rock alteration is minimal to nonexistent in the sedimentary rocks but extensive in basalt. Evidently, the mineralizing solutions were more nearly in equilibrium with the sedimentary rocks than with basalt. This fact alone suggests that the "hydrothermal" solutions that carried the copper were simply heated diagenetic pore fluids.

\section{Source of the Copper}

Red-bed formation waters are commonly saline enough to retain in solution any copper released by diagenesis of the sediments (Maynard, 1983). In the New Haven Arkose the bulk of the copper would have been originally tied up in detrital ilmenite and magnetite (Wedepohl, 1974). Hubert and Reed (1978) have shown that these oxides break down at the earliest stage of diagenesis. By the time of the Talcott event, most of the copper in the lower portion of the New Haven Arkose had probably been released to the interstitial waters. Hydrothermal circulation driven by the cooling Talcott intrusives would have brought some of this water to the surface where the dissolved copper could have been precipitated by decomposing organic material and bacteria. The Talcott event appears to have generated the first major overturning of the Hartford basin water, stripping it of most of its dissolved copper, leaving little to be extracted during the subsequent Holyoke and Hampden volcanic episodes.

The lack of stratabound copper occurrences associated with the later volcanic episodes is the strongest evidence for the diagenetic origin of the copper in those deposits closely associated with the Talcott event. It has often been suggested that copper in the Mesozoic basins is derived directly from the basalts by hydrothermal or metamorphic alteration (Weed, 1911; Puffer, 1984). The observed predominance of Talcott-age mineralization does not fit well with this scheme. Puffer (1984) noted that the Talcott and Hampden contain about the same amount of trace copper and, that on a regional scale, the two flows are equally altered. If the source of copper is basalts, where then are the deposits of Hampden age?

\section{COMPARISONS TO DEPOSITS OF THE NEWARK BASIN}

The similarity of the copper occurrences in the Newark basin of New Jersey and those in the Hartford basin is striking. Lewis (1907) called attention to the close association of the New Jersey deposits with the Orange Mountain Basalt and its intrusive equivalent, the Palisades sill. Mirroring the situation in Connecticut, the majority of the New Jersey stratabound occurrences are found either along the base of, or in the sedimentary rocks lying just above, the first flow in the basin.

\section{CONCLUSIONS}

The copper mineralization of the Connecticut Valley is an integral part of the geologic evolution of the Hartford basin. During the history of the basin a fortuitous combination of geological events twice resulted in basinwide copper mineralization. In both instances the "mineralizing solutions" were normal formation waters that developed in the sedimentary pile during diagenesis.

Copper was extracted from detrital magnetite and ilmenite early in the evolution of trapped pore waters. The thermal effects of the Barndoor and West Rock sills drove large volumes of this immature copper-bearing water up active faults into the near-surface hydrologic system. Wherever favorable reducing conditions were encountered, copper sulfides precipitated. Most of these sites were in the near-surface environment where the buried organic material was still actively being broken down by bacteria. Because the brines were immature, cool (probably $<100^{\circ} \mathrm{C}$ ), and of low salinity, the amount of gangue material associated with these deposits is small. The Bristol, New-gate, and Higley, along with a host of small stratabound deposits at roughly the stratigraphic level of the Talcott Basalt, formed during this episode of basinwide copper mineralization.

Much later, some time after the last volcanic activity in the Hartford basin, normal faulting once again opened pathways for deep-formation waters. This time the brines were much warmer $\left(100\right.$ to $\left.200{ }^{\circ} \mathrm{C}\right)$, more saline, and nearly fully saturated in the entire suite of 
diagenetic minerals now found in the sedimentary rocks: quartz, albite, calcite, ferroan dolomite, montmorillonite, barite, and minor copper sulfides. As the warm brines cooled during their rise to the surface, they deposited the minerals of the quartz-carbonate-barite (QCB) veins. Minor quantities of metallic sulfides precipitated where vein waters came into contact with hydrocarbons derived from adjacent lacustrine deposits. The waters in the QCB veins were nearly in equilibrium with the sedimentary rocks through which they passed. Minor silicification and hematite dissolution are the only noticeable wall-rock effects. These same waters, however, were well out of equilibrium with basalt, transforming it along vein walls into a fine-grained mixture of montmorillonite, albite, and ferroan dolomite.

\section{REFERENCES CITED}

Bateman, A.M., 1923, Primary chalcocite: Bristol copper mine: Economic Geology, v. 18, p. 122-126.

Cornet, B., and Traverse, A., 1975, Palynological contributions to the chronology and stratigraphy of the Hartford basin in Connecticut and Massachusetts: Geoscience and Man, v. 11, p. 1-33.

Dombroski, D.R., Jr., 1980, A geological and geophysical investigation of concealed contacts near an abandoned barite mine, Hopewell, N. J.: M.S. thesis, Rutgers University, New Brunswick, New Jersey, 33 p.

Fritts, C.E., 1962, The barite mines of Cheshire: The Cheshire Historical Society, Cheshire, Connecticut.

Gray, N.H., 1982, Copper occurrences in the Hartford Basin of Northern Connecticut, in New England Intercollegiate Geological Conference, 74th Annual Meeting Guidebook, Trip M-4: p. 1-17.

Harte, C.R., 1944, Connecticut's iron and copper: Connecticut Society of Engineers, 60th Annual Report, p. 130-166.

Hubert, J.F., and Reed, A.A., 1978, Red-bed diagenesis in the East Berlin formation, Newark Group, Connecticut Valley: Journal of Sedimentary Petrology, v. 48, p. 175-184.
Hulbert, E.M., 1897, Copper mining in Connecticut: The Connecticut Quarterly, v. 3, p. 23-32.

Johnson, Mrs. Mary (Coffin), 1896, The Higleys and their ancestry, an old colonial family: D. Appleton and Company, New York, 738 p.

Lewis, J.V., 1907, Copper deposits of the New Jersey Triassic: Economic Geology, v. 2, p. 244-257.

Maynard, J.B., 1983, Geochemistry of sedimentary ore deposits: Springer-Verlag, New York, 305 p.

Percival, J.G., 1842, Report on the geology of the State of Connecticut: Osorn and Baldwin, New Haven, Connecticut, $495 \mathrm{p}$.

Perrin, J., 1976, Geology of the Newgate Prison Mine, East Granby, Connecticut: M.S. thesis, The University of Connecticut, $90 \mathrm{p}$.

Philpotts, A.R., and Martello, A., 1986, Diabase feeder dikes for the Mesozoic basalts in Southern New England: Amerjcan Journal of Science, v. 286, p. 105-126.

Puffer, J.H., 1984, Copper mineralization of the Newark Basin, in 1st Annual Field Conference Guidebook: Geological Association of New Jersey, p. 127-136.

Richardson, C., 1928, A history of the Simsbury Copper Mines: M.A. thesis, Trinity College, Hartford, Connecticut, 100 p.

Ryan, S.S., 1986, Description and paragenetic interpretation of quartz-carbonate-barite veins of the Hartford Basin: M.S. thesis, The University of Connecticut, Storrs, Connecticut, $132 \mathrm{p}$.

Schultz, R.W., 1971, Mineral exploration practice in Ireland: Transactions of the Institution of Mining and Metallurgy, Section B (Applied Earth Science), v. 80, p. B238-258.

Scott, B., 1967, Barytes mineralization at Gasswater Mine, Ayrshire, Scotland: Transactions of the Institution of Mining and Metallurgy, Section B (Applied Earth Science), v. 76, p. B40-B51.

Shepard, C.U., 1837, A report on the Geological Survey of Connecticut: State of Connecticut, New Haven, $188 \mathrm{p}$.

Silliman, B., Jr., and Whitney, J.D., 1855, Notice of the geologic position and character of the copper mine at Bristol: American Journal of Science, v. 70, p. 361-368.

Wedepohl, K.H., 1974, Copper, abundance in rock-forming minerals, phase equilibria, copper minerals; Chapter 29-D, in Handbook of geochemistry: Springer-Verlag, New York.

Weed, W.H., 1911, Copper deposits of the Appalachian States: U.S. Geological Survey Bulletin 455, 166 p. 


\title{
A COMPARISON OF URANIUM-BEARING SEQUENCES IN THE NEWARK BASIN, PENNSYLVANIA AND NEW JERSEY, AND THE SAN JUAN BASIN, NEW MEXICO
}

\author{
Christine Turner-Peterson
}

\begin{abstract}
Triassic uranium-bearing sequences in the Newark basin of Pennsylvania and New Jersey are similar in many respects to Jurassic uranium-bearing sequences in the San Juan basin of New Mexico. Similarities include a transition upward from fluvial sandstone to closed-basin lacustrine mudstone and siltstone; a close spatial association between uranium in sandstone and interbeds of greenish-gray or dark-gray lacustrine mudstone; the tendency for uranium to be concentrated in tabular bodies that commonly follow scour surfaces marked by zones of clay rip-up clasts; the presence of organic matter, association of pyrite, and the enrichment of chlorite in uranium-bearing zones.

Significant differences between the two basins are also noteworthy. The San Juan basin was a broad foreland basin, in contrast to the Newark basin, which was a narrow, fault controlled rift basin. Other differences include (1) the uranium-bearing sandstones in the basins have different fluvial architectures; (2) uranium-enriched zones in the Newark basin have sparse organic matter compared to ubiquitous organic matter in uranium-enriched zones of the San Juan basin; and (3) the Newark basin uranium has a probable metamorphic source, while the San Juan basin is derived from synsedimentary airfall silicic volcanic ash.

It is unclear whether the differences in the uraniumbearing sequences in these two basins are fundamental or merely variations on a theme. If the relative paucity of organic matter in the uranium-bearing zones of the Newark basin compared to its relative abundance in the San Juan basin can be explained by replacement of organic matter by chlorite, it is more likely that a similar model for ore genesis could be applied to both basins.
\end{abstract}

\section{INTRODUCTION}

Uranium mineralization in sedimentary rocks is commonly confined to sandstones of fluvial origin (Finch, 1967), but the reasons for this selectivity in host rock are not well known. A model for mineralization has recently been proposed for uranium ore in fluvial sandstones of the Morrison Formation in the San Juan basin (TurnerPeterson, 1985), a region for which detailed sedimentologic and petrographic data are available. Uranium occurrences in fluvial sandstones of the Newark basin in Pennsylvania and New Jersey share some of the characteristics of uranium ore deposits in the San Juan basin. The tectonic settings of the the two basins contrast markedly; however, the Newark basin is a rift basin, and the San Juan basin is a foreland basin. A comparison of tectonic, lithologic, and facies characteristics of the two basins was undertaken to see if the model for ore genesis proposed for the San Juan basin has applicability to the Newark basin and thus possibly for other fluvial-hosted uranium deposits.

\section{BASIN SETTINGS}

\section{San Juan Basin}

During deposition of the Upper Jurassic Morrison Formation (fig. 1), the San Juan basin was a foreland basin located several hundred kilometers east of a volcanic arc (Santos and Turner-Peterson, 1986). Uplift in the arc region established the stream gradients necessary for delivering large amounts of arkosic sediment to the basin, resulting in the thick (as much as $110 \mathrm{~m}$ ) fluvial sandstones of the Westwater Canyon Member (TurnerPeterson, 1986). Individual lenses of sandstone that are separated by thin mudstone intervals contain numerous broad, shallow channel scours filled with flat lamination, low-angle inclined lamination, and trough crossbedding (Miall and Turner-Peterson, unpub. data), interpreted as shallow, low-sinuosity river channel complexes. Syndepositional folding and faulting caused thickness variations in the Westwater Canyon Member and appear to have controlled uranium mineralization trends (Kirk and Condon, 1986; Phelps and others, 1986; Santos and TurnerPeterson, 1986).

Extensive volcanic activity in the arc region is evidenced by several hundred meters of altered volcanic ash in the Brushy Basin Member (Bell, 1986), which overlies the Westwater Canyon Member. Concentric distribution patterns of authigenic minerals, including analcime and albite, are interpreted as the product of the alteration of ash in a hydrologically closed alkaline lake or playa (Turner-Peterson and others, 1986).

\section{Newark Basin}

Sedimentation in the Triassic-Jurassic Newark basin was the result of infilling of a rift basin that formed during incipient stages of continental breakup. It has been proposed that the overall structure of the basin was controlled by reactivation of Paleozoic ramps and thrusts in a Mesozoic extensional setting, resulting in curvilinear 


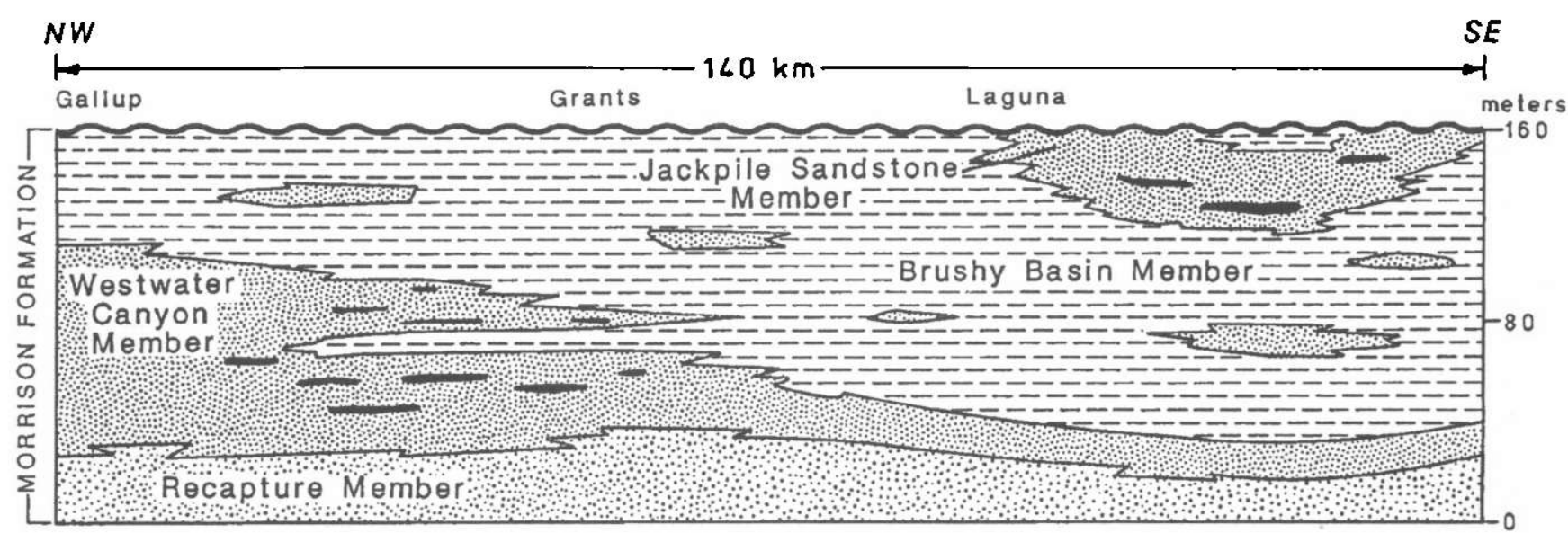

EXPLANATION

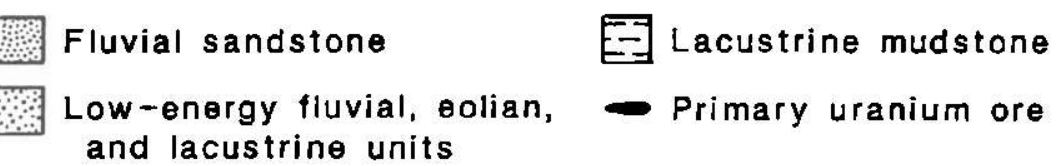

Figure 1. Schematic cross section of the Upper Jurassic Morrison Formation along the southern margin of the San Juan basin. Uranium ore occurs in fluvial sandstone, particularly in the the Westwater Canyon Member. The overlying Brushy Basin Member was deposited chiefly in a large playa-lake complex. (Modified slightly from Hilpert, 1963.)
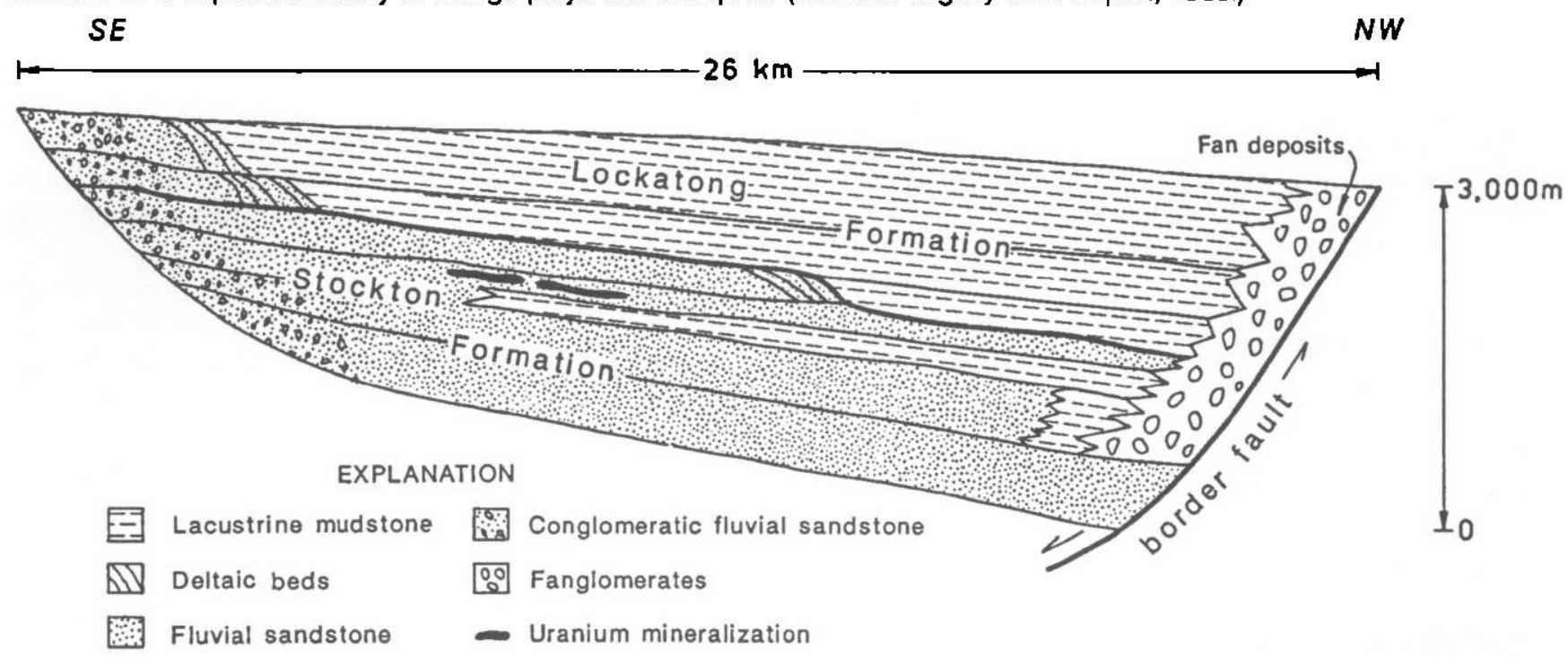

Figure 2. Schematic cross section of the Upper Triassic Stockton and Lockatong Formations in the Newark basin, Pennsylvania and New Jersey. Uranium enrichment occurs in fluvial sandstone of the Stockton Formation. (Modified from Turner-Peterson and Smoot, 1985.)

concave-upward fault geometries (Ratcliffe and Burton, 1985). Syndepositional tectonism apparently controlled facies distribution (Turner-Peterson, 1980): coarse, poorly bedded conglomerates interpreted as alluvial-fan deposits are restricted to the northwestern margin of the basin adjacent to border faults, whereas sheetlike fluvial deposits having abundant cross-stratification occur along the southeastern margin of the basin.

Fluvial sedimentation was dominant during the early history of the basin, accounting for lithologies in the
Stockton Formation (fig. 2). The abundance of low-angle inclined lamination in laterally extensive sandstone units is similar to that of the fluvial sandstone of the Westwater Canyon Member of the Morrison Formation in the San Juan basin.

The Stockton Formation is overlain by thousands of meters of lacustrine mudstone and siltstone of the Lockatong Formation. These lacustrine units extend across almost the entire width of the basin and reflect deposition in both deepwater and subaerial playa con- 
ditions (Olsen, 1984). A closed-basin hydrology is inferred for deposition of the lacustrine sequences, and some of the lacustrine beds contain analcime and albite. Lacustrine conditions probably existed before Lockatong deposition, as evidenced by deposits interpreted as small deltas in the upper part of the Stockton Formation (Turner-Peterson and Smoot, 1985). Thin beds of darkgray siltstone interbedded with Stockton sandstone near the top of the formation are also interpreted as lacustrine in origin, on the basis of the presence of fossil conchostracans.

\section{URANIUM MINERALIZATION}

\section{San Juan Basin}

Two distinct types of uranium ore that differ in age and in chemical and mineralogic characteristics occur in the Westwater Canyon Member of the Morrison Formation. The older uranium deposits-known as primary ore-are roughly tabular and typically are suspended within the host sandstone (fig. 1), cutting across sedimentary structures and bedding (Granger and others, 1961). These ore zones are several hundred meters long, several tens of meters wide, and commonly a meter or so thick. Uranium occurs chiefly as coffinite and as a uranoorganic compound. Mineralized zones show no preference for a specific grain size, sorting, or porosity in the host sandstone (Falkowski, 1980) but locally show a tendency to follow zones of clay rip-ups along the scour surfaces (Santos, 1963). Pyrite is commonly associated with ore zones (Granger and others, 1961), but more significant is the ubiquitous admixture of uranium with a postdepositionally introduced, noncellular organic matter identified as humin and interpreted to have originated from terrestrial plant material (Hatcher and others, 1986). The pore-filling humin is the main control on the location of primary ore. This humin is locally replaced by chlorite (Spirakis and Hansley, 1986).

A noteworthy attribute of primary ore is its exclusive occurrence in sandstones that are interbedded with or overlain by lacustrine green mudstone, which occurs either as interbeds in the Westwater Canyon Member or as intervals in the overlying Brushy Basin Member (Turner-Peterson, 1985).

A second type of uranium ore in the Westwater Canyon Member, which generally occurs in proximity to primary ore, is secondary or redistributed ore, so named because it formed by redistribution of primary ore (Granger and others, 1961). Redistributed ore lacks the pore-filling organic material that is intimately admixed with primary ore. Because primary ore genesis is related to depositional environments and secondary ore is not, only primary ore will be discussed in the remainder of the report.

\section{Newark Basin}

Uranium-enriched zones are in gray, arkosic, fluvial sandstone of the Stockton Formation (fig. 2), chiefly as tabular zones along scour surfaces in the sandstone. These zones are as much as a half meter in thickness and are commonly traceable for several hundred meters and possibly farther in outcrop. Clay rip-up clasts, which are red elsewhere in the Stockton, are light gray in and adjacent to mineralized zones. Uranium occurs with pods of pyrite that are intimately associated with the clay clasts (Turner-Peterson, 1980). No visible plant material occurs in the mineralized zones, but the zones do contain up to 0.23 percent organic carbon, compared to less than 0.01 percent in background samples (Turner-Peterson, 1980). In addition to organic carbon, pyrite, and light-gray clay clasts, the uraniumenriched zones contain chlorite (McCauley, 1961; Kunze, 1986). Uranium minerals include metatorbernite and metazeunerite (McCauley, 1961).

A dark-gray mudstone occurs a meter or so below a well-exposed zone of uranium concentration at one locality. Because lighter gray mudstone in the same interval contains numerous conchostracans, a lacustrine origin is suggested.

\section{Comparison of Mineralization in the Newark and San Juan Basins}

Similarities and differences between the nature of uranium mineralization in the two basins are summarized in table 1 . In both cases, although uranium mineralization is in fluvial sandstones, the mineralization is not restricted to any particular grain size, sorting, or porosity. This suggests that the depositional or hydrologic characteristics of the fluvial sandstones do not control the locus of mineralization and that other factors must play a role.

The stratigraphic settings of the mineralized zones in both basins show a remarkable similarity, in spite of contrasting tectonic settings. In both basins, uranium occurs in sandstone that is interbedded with or overlain by either greenish-gray or dark-gray lacustrine mudstones. The Westwater Canyon Member of the Morrison Formation in the San Juan basin is a fluvial sequence that extends across the basin and is overlain by and interfingers with alkaline lacustrine deposits of the equally extensive Brushy Basin Member. Similarly, in the Newark basin, the extensive fluvial Stockton Formation is overlain by the equally extensive lacustrine Lockatong Formation. Thus, deposition of fluvial rocks followed by 
Table 1. Comparison between uranium-bearing sequences in the Newark and San Juan basins

\begin{tabular}{|c|c|c|}
\hline Parameter & Newark basin & San Juan basin \\
\hline ectonjc & Rift basin & Foreland basin. \\
\hline Hydrologic setting. . & $\begin{array}{l}\text { Closed basin dur- } \\
\text { ing part of basin } \\
\text { history. }\end{array}$ & $\begin{array}{l}\text { Closed basin dur- } \\
\text { ing part of basin } \\
\text { history. }\end{array}$ \\
\hline Host rock. & Fluvial sandstone. & Fluvial sandstone. \\
\hline $\begin{array}{l}\text { Large-scale facies .. } \\
\text { association }\end{array}$ & $\begin{array}{l}\text { Fluvial sandstone } \\
\text { overlain by lacu- } \\
\text { strine sequence } \\
\text { (analcime in lake } \\
\text { beds). }\end{array}$ & $\begin{array}{l}\text { Fluvial sandstone } \\
\text { Fluvial sandstone } \\
\text { verlain by lacu- } \\
\text { strine sequence } \\
\text { (analcime in lake } \\
\text { beds). }\end{array}$ \\
\hline $\begin{array}{l}\text { Abundance of over- } \\
\text { bank material } \\
\text { associated with } \\
\text { fluvial rocks }\end{array}$ & Abundant & Minor. \\
\hline $\begin{array}{l}\text { Small-scale facies... } \\
\text { association }\end{array}$ & $\begin{array}{l}\text { Association with } \\
\text { lacustrine dark- } \\
\text { gray mudstone; } \\
\text { tendency of ura- } \\
\text { nium to follow } \\
\text { clay rip-up clasts } \\
\text { along scour sur- } \\
\text { faces in } \\
\text { sandstone. }\end{array}$ & $\begin{array}{l}\text { Association with } \\
\text { lacustrine } \\
\text { greenish-gray } \\
\text { mudstone; ten- } \\
\text { dency of uranium } \\
\text { to follow clay rip- } \\
\text { up clasts along } \\
\text { scour surfaces in } \\
\text { sandstone. }\end{array}$ \\
\hline $\begin{array}{l}\text { Geometry of miner- } \\
\text { alized zones }\end{array}$ & Tabular .. & Tabular. \\
\hline $\begin{array}{l}\text { Role of sandstone.. } \\
\text { texture in local- } \\
\text { izing mineraliza- } \\
\text { tion }\end{array}$ & None & None. \\
\hline $\begin{array}{l}\text { Presence of organic } \\
\text { matter in mineral- } \\
\text { ized zones }\end{array}$ & $\begin{array}{l}\text { Enriched, but not } \\
\text { visually abundant. }\end{array}$ & $\begin{array}{l}\text { Ubiquitous. } \\
\text { Ubiquitous. }\end{array}$ \\
\hline Pyrite..... & $\begin{array}{l}\text { Present in mineral- } \\
\text { ized zones. }\end{array}$ & $\begin{array}{l}\text { Present in mineral- } \\
\text { ized zones. }\end{array}$ \\
\hline Chlorite. & $\begin{array}{l}\text { Enriched in miner- } \\
\text { alized zones. }\end{array}$ & $\begin{array}{l}\text { Abundant in } \\
\text { organic-matter- } \\
\text { poor mineralized } \\
\text { zones. }\end{array}$ \\
\hline $\begin{array}{l}\text { Probable source of } \\
\text { uranium }\end{array}$ & $\begin{array}{l}\text { Metamorphic ter- } \\
\text { rane on south } \\
\text { flank of basin. }\end{array}$ & $\begin{array}{l}\text { Silicic volcanic ash } \\
\text { incorporated in } \\
\text { Morrison Forma- } \\
\text { tion. }\end{array}$ \\
\hline
\end{tabular}

deposition of thick lacustrine sequences appears to be a condition favorable for uranium mineralization.

Even though the overall stratigraphic succession of depositional environments is similar in both basins, the fluvial sequences that host the uranium differ in alluvial architecture. The Westwater Canyon Member consists of complexly cross-cutting channel fill sequences with little or no associated siltstone or mudstone, whereas the Stockton Formation consists of systematically graded sequences of sandstone to bioturbated siltstone that form sheetlike units separated by siltstone and mudstone intervals that are hundreds of meters thick. An additional difference is that deltaic beds occur in the Stockton
Formation, whereas no deltaic beds have been recognized in the Westwater Canyon Member of the Morrison Formation.

The lacustrine intervals in both basins are interpreted as alkaline closed-basin deposits, but they differ in detail. The Brushy Basin Member consists of altered volcanic ash that was deposited in a persistently shallow (and sometimes desiccated) alkaline lake, whereas the Lockatong Formation consists of highly cyclic alternations of deep-lake, shallow-lake, and desiccated playa mudflat deposits. It is interesting to note that, in spite of these differences, the lacustrine intervals in both basins contain authigenic analcime, a mineral indicative of highly alkaline conditions (Hay, 1966).

Individual mineralized zones in the fluvial sandstones of both basins show a close spatial association with greenish-gray or dark-gray lacustrine mudstones. In the San Juan basin, where excellent outcrops afford the opportunity to study the relationship in detail, a distinct one-to-one correlation exists between mineralized sandstone and greenish-gray mudstone (Turner-Peterson and others, 1980). Where the comparatively scarce outcrops permit, a similar relationship can be seen in the Newark basin (Turner-Peterson, 1980).

Mineralized zones in both basins show similarities as well. Mineralized zones in the Newark basin exhibit the tabular shape characteristic of primary ore bodies in the San Juan basin. The uranium-rich zones in both basins are suspended within the host sandstone and tend to follow zones of clay rip-up clasts along scour surfaces. The association with organic material is another characteristic the basins have in common, although the ubiquitous nature of humin in the San Juan basin ore bodies makes the link with organics more apparent here than in the Newark basin. The link with organic material in the Newark basin is based on chemical analyses rather than the presence of visible organic material. However, the abundance of pyrite in both basins is consistent with the former presence of organic matter. Presence of chlorite is another characteristic that mineralized zones in these two basins have in common.

The two uranium-bearing basins also differ significantly. On a large scale, the basins differ markedly in their tectonic setting: the Newark basin is a narrow, asymmetrical, fault-bordered basin that formed during incipient rifting of the continents in the Late Triassic and Early Jurassic, whereas the San Juan basin is a broad, symmetrical foreland basin that developed several hundred kilometers east of a large magmatic arc in the Late Jurassic.

Differences in tectonic setting probably contributed to differences in the type of volcanism in both basins; the type of volcanism is important in terms of the source of the uranium in the mineralized zones. West of the San Juan basin, explosive, silicic volcanism in the arc 
region probably provided the large quantities of airfall volcanic ash that became incorporated in the Morrison Formation. This ash became admixed with the fluvial sandstones of the Westwater Canyon Member and also formed discrete tuff beds in the Brushy Basin Member. This silicic volcanic ash was the most likely source for the uranium that became concentrated in ore zones.

Volcanism in the Newark basin differed in that no silicic volcanic ash erupted. Instead, basalt flows issued onto the surface in the Early Jurassic (Froelich and Gottfried, 1985). Basaltic igneous rocks are not enriched in uranium and thus are an unlikely source for the uranium in mineralized zones in the Newark basin. The most likely source for uranium in the Newark basin is the uranium-enriched metamorphic complex that flanks the southern margin of the basin. Significant concentrations of uranium occur in these metamorphic rocks in a variety of lithologies (Grauch and Zarinski, 1976). The fact that clasts of these rocks occur in the Stockton Formation indicates that the uranium-enriched metamorphic rocks were exposed to erosion in the highlands that bordered the basin during deposition of the Stockton.

\section{Implications for Genetic Modeling of Uranium Mineralization}

The similarity in the uranium-mineralized zones in both basins suggests that similar processes may account for the uranium enrichment. The ore zones are similar in shape, in the association with clay clasts along scour surfaces, and in the association with organic material and chlorite. A major difference is the lack of abundant interstitial organic carbon in uranium-bearing Stockton rocks in contrast to the ubiquitous humin in the uraniummineralized zones in the San Juan basin. A similar situation exists for the Salt Wash Member of the Morrison Formation in Utah and Colorado in comparison to the Westwater Canyon Member of the Morrison Formation: the uranium ores are similar in their facies association (Peterson, 1980; Turner-Peterson and others, 1980), but ore in the Salt Wash Member lacks abundant interstitial organic material. Recent observations suggest that chlorite has diagenetically replaced organic carbon in the Salt Wash ores (Z. Wong, written commun., 1982; Spirakis and Hansley, 1986). A gradation between organic-matter-rich, chlorite-poor, and organic-matterpoor, chlorite-rich ores in the Westwater Canyon Member lends credence to this idea and is interpreted to represent the degree of postmineralization diagenesis (Spirakis and Hansley, 1986). This replacement may explain the lack of abundant organic carbon in ores that are otherwise similar to the organic-matter-rich ores in the Westwater Canyon Member. The chlorite associated with the Stockton mineralized zones may also be a replacement of organic carbon.

Ore genesis in the organic-matter-rich ores of the Westwater Canyon Member of the Morrison Formation is constrained by detailed sedimentologic and alteration studies and is presently understood better than mineralization in the Stockton Formation of the Newark basin. Petrographic studies in the Westwater Canyon Member indicate that ore-related, organic-matter-rich pore fluids that passed through the fluvial sandstones on their way to sites of mineralization within the sandstones can be traced to an origin in lacustrine mudstones that are interbedded with and overlie the ore-bearing intervals (Reynolds and others, 1986; Turner-Peterson and Fishman, 1986). The relatively organic-matter-poor, chloriterich ores in the Newark basin are reminiscent of Salt Wash ores and may also represent altered organicmatter-rich mineralized zones.

In modeling uranium ore genesis, observations at every scale are necessary to evaluate those factors that are critical to ore genesis and those that are incidental. In the two basins, some of the large-scale features are similar and some dissimilar. Important differences include the tectonic setting, the source of uranium, and the details of the fluvial styles. A unifying factor, however, is the superposition of alkaline lacustrine deposits over extensive fluvial sandstone deposits. Furthermore, the transition may signal a change from throughgoing drainage to closed-basin conditions in both basins. The resulting chemical and hydrologic setting may be critical for mineralization because alkaline conditions (indicated by analcime in the lacustrine units of both basins) cause mobilization of the humic-type organic matter associated with uranium ore. In addition, a permeable sandstone must be spatially associated with the lacustrine intervals to provide the conduit for the organic-matter-bearing fluids. Upon precipitation in the fluvial sandstone (facilitated by clay-organic reactions in the clay clast zones), the organics may then concentrate the uranium.

\section{CONCLUSIONS}

Similarities in uranium-bearing rocks in the Newark basin and the San Juan basin are sufficient to suggest that they have a similar origin. Although the uraniumbearing intervals have significant gross similarities, especially in a striking facies association, they differ in some of the details of mineralization, particularly with respect to the possible role of organic carbon. Thus, the question remains whether the differences are first order or second order, requiring in the first case different models of ore genesis or, in the second case, merely variations on a theme. At the present time, the model that is constrained by abundant data in the San Juan basin cannot be 
extended unreservedly to the Newark basin because of the lack of detailed petrographic studies in the uraniumbearing rocks of the Newark basin. However, the close association of uranium-bearing rocks with lacustrine deposits in two markedly different tectonic settings enhances the usefulness of this criterion as a guide to exploration.

\section{REFERENCES CITED}

Bell, T.E., 1986, Deposition and diagenesis in the Brushy Basin and upper part of the Westwater Canyon Member of the Morrison Formation, San Juan Basin, New Mexico, in Turner-Peterson, C.E., Santos, E.S., and Fishman, N.S., eds., A basin analysis case study-The Morrison Formation, Grants uranium region, New Mexico: American Association of Petroleum Geologists Studies in Geology 22, p. 77-91.

Falkowski, S.K., 1980, Geology and ore deposits of the Johnny M Mine, Ambrosia Lake district, New Mexico, in Rautman, C.A., compiler, Geology and mineral technology of the Grants uranium region 1979: New Mexico Bureau of Mines and Mineral Resources Memoir 38, p. 230-239.

Finch, W.I., 1967, Geology of epigenetic uranium deposits in sandstone in the United States: U.S. Geological Survey Professional Paper 538, 121 p.

Froelich, A.J., and Gottfried, D., 1985, Early Jurassic diabase sheets of the Eastern United States-A preliminary overview, in Robinson, G.R., Jr., and Froelich, A.J., eds., Proceedings of the second U.S. Geological Survey workshop on the early Mesozoic basins of the Eastern United States: U.S. Geological Survey Circular 946, p. 79-86.

Granger, H.C., Santos, E.S., Dean, B.G., and Moore, F.B., 1961, Sandstone-type uranium deposits at Ambrosia Lake, New Mexico-An interim report: Economic Geology, v. 56, p. 1179-1210.

Grauch, R.I., and Zarinski, Katrin, 1976, Generalized descriptions of uranium-bearing veins, pegmatites, and disseminations in non-sedimentary rocks, Eastern United States: U.S. Geological Survey Open-File Report 76-582, 114 p.

Hatcher, P.G., Spiker, E.C., Orem, W.H., Romankiw, L.A., Szeverenyi, N.M., and Maciel, G.E., 1986, Organic geochemical studies of uranium-associated organic matter from the San Juan basin-A new approach using solidstate ${ }^{19} \mathrm{C}$ nuclear magnetic resonance, in Turner-Peterson, C.E., Santos, E.S., and Fishman, N.S., eds., A basin analysis case study-The Morrison Formation, Grants uranium region, New Mexico: American Association of Petroleum Geologists Studies in Geology 22, p. 171-184.

Hay, R.L., 1966, Zeolites and zeolitic reactions in sedimentary rocks: Geological Society of America Special Paper 85, $130 \mathrm{p}$.

Hilpert, L.S., 1963, Regional and local stratigraphy of uraniumbearing rocks, in Kelley, V.C., ed., Geology and technology of the Grants uranium region: New Mexico Bureau of Mines and Mineral Resources Memoir 15, p. 6-18.

Kirk, A.R., and Condon, S.M., 1986, Structural control of sedimentation patterns and the distribution of uranium deposits in the Westwater Canyon Member of the Morrison Formation, northwestern New Mexico-A subsurface study, in Turner-Peterson, C.E., Santos, E.S., and Fishman, N.S., eds., A basin analysis case study-The Morrison Formation, Grants uranium region, New Mexico: American Association of Petroleum Geologists Studies in Geology 22, p. 105-143.

Kunze, C., 1986, Diagenesis of the Upper Triassic Stockton Formation, Pennsylvania and New Jersey: Unpublished senior thesis, Bryn Mawr College, Bryn Mawr, Pennsylvania, $136 \mathrm{p}$.

McCauley, J.F., 1961, Uranium in Pennsylvania: Pennsylvania Geological Survey Bulletin M-43, 71 p.

Olsen, P.E., 1984, Comparative paleolimnology of the Newark Supergroup-A study of ecosystem evolution: New Haven, Connecticut, Yale University, unpublished $\mathrm{Ph} . \mathrm{D}$. thesis, $726 \mathrm{p}$.

Peterson, F., 1980, Sedimentology as a strategy for uranium exploration-Concepts gained from analysis of a uraniumbearing depositional sequence in the Morrison Formation of south-central Utah, in Turner-Peterson, C.E., ed., Uranium in sedimentary rocks-Application of the facies concept to exploration: Society of Economic Paleontologists and Mineralogists Short Course Notes, Rocky Mountain Section, p. 65-126.

Phelps, W.T., Zech, R.S., and Huffman, A.C., 1986, Seismic studies in the Church Rock uranium district, southwest San Juan Basin, New Mexico, in Tumer-Peterson, C.E., Santos, E.S., and Fishman, N.S., eds., A basin analysis case studyThe Morrison Formation, Grants uranium region, New Mexico: American Association of Petroleum Geologists Studies in Geology 22, p. 145-159.

Ratcliffe, N.M., and Burton, W.C., 1985, Fault reactivation models for origin of the Newark basin and studies related to eastern U. S. seismicity, in Robinson, G.R., Jr., and Froelich, A.J., eds., Proceedings of the second U.S. Geological Survey workshop on the early Mesozoic basins of the Eastern United States: U.S. Geological Survey Circular 946 , p. $36-45$.

Reynolds, R.L., Fishman, N.S., Scott, J.H., and Hudson, M.R., 1986, Iron-titanium oxide minerals and magnetic susceptibility anomalies in the Mariano Lake-Lake Valley coresConstraints on conditions of uranium mineralization in the Morrison Formation, San Juan Basin, New Mexico, in Turner-Peterson, C.E., Santos, E.S., and Fishman, N.S., eds., A basin analysis case study-The Morrison Formation, Grants uranium region, New Mexico: American Association of Petroleum Geologists Studies in Geology 22, p. 303-313.

Santos, E.S., 1963, Relation of ore deposits to the stratigraphy of the Ambrosia Lake area, in Kelly, V.C., ed., Geology and technology of the Grants uranium region: New Mexico Bureau of Mines and Mineral Resources Memoir 15, p. 53-59.

Santos, E.S., and Turner-Peterson, C.E., 1986, Tectonic setting of the San Juan Basin and vicinity, in Turner-Peterson, C.E., Santos, E.S., and Fishman, N.S., eds., A basin analysis case study-The Morrison Formation, Grants uranium region, New Mexico: American Association of Petroleum Geologists Studies in Geology 22, p. 27-33. 
Spirakis, C.S., and Hansley, P.L., 1986, The formation and alteration of tabular-type uranium-vanadium deposits as a variant of normal diagenetic processes in organic-rich sediments, in Carter, L.M.H., ed., U.S. Geological Survey research on energy resources-1986, program and abstracts: U.S. Geological Survey Circular 974, p. 64-65.

Tumer-Peterson, C.E., 1980, Sedimentology and uranium mineralization in the Triassic-Jurassic Newark basin, Pennsylvania and New Jersey, in Turner-Peterson, C.E., ed., Uranium in sedimentary rocks-Application of the facies concept to exploration: Society of Economic Paleontologists and Mineralogists Short Course Notes, Rocky Mountain Section, p. 149-175.

-1985, Lacustrine-humate model for primary uranium ore deposits, Grants uranium region, New Mexico: American Association of Petroleum Geologists Bulletin, v. 69, p. 1999-2020.

-1986, Fluvial sedimentology of a major uranium-bearing sandstone - A study of the Westwater Canyon Member of the Morrison Formation, San Juan Basin, New Mexico, in Turner-Peterson, C.E., Santos, E.S., and Fishman, N.S., eds., A basin analysis case study-The Morrison Formation, Grants uranium region, New Mexico: American Association of Petroleum Geologists Studies in Geology 22 , p. $47-75$.

Turner-Peterson, C.E., and Fishman, N.S., 1986, Geologic synthesis and genetic models for uranium mineralization in the Morrison Formation, Grants uranium region, New
Mexico, in Turner-Peterson, C.E., Santos, E.S., and Fishman, N.S., eds., A basin analysis case study-The Morrison Formation, Grants uranium region, New Mexico: American Association of Petroleum Geologists Studies in Geology 22, p. 357-388.

Turner-Peterson, C.E., and Smoot, J.P., 1985, New thoughts on facies relationships in the Triassic Stockton and Lockatong Formations, Pennsylvania and New Jersey, in Robinson, G.R., Jr., and Froelich, A.J., eds., Proceedings of the second U.S. Geological Survey workshop on the early Mesozoic basins of the Eastern United States: U.S. Geological Survey Circular 946, p. 10-17.

Turner-Peterson, C.E., Gundersen, L.C., Francis, D.S., and Aubrey, W.M., 1980, Fluvio-lacustrine sequences in the Upper Jurassic Morrison Formation and the relationship of facies to tabular uranium ore deposits in the Poison Canyon area, Grants mineral belt, New Mexico, in TurnerPeterson, C.E., ed., Uranium in sedimentary rocks-Application of the facies concept to exploration: Society of Economic Paleontologists and Mineralogists Short Course Notes, Rocky Mountain Section, p. 177-211.

Turner-Peterson, C.E., Fishman, N.S., and Hay, R.L., 1986, Recognition of an extensive Jurassic playa-lake complexThe Brushy Basin Member of the Morrison Formation, Colorado Plateau: Society of Economic Paleontologists and Mineralogists Annual Midyear Meeting Abstracts, v. 3, Raleigh, North Carolina, p. 111.

\title{
SEDIMENTOLOGY OF STRATABOUND BASE-METAL OCCURRENCES IN THE NEWARK SUPERGROUP
}

\author{
Joseph P. Smoot and Gilpin R. Robinson, Jr.
}

\begin{abstract}
Stratabound base metals in the Newark Supergroup occur in fluvial sandstones and lacustrine mudstones. Copper minerals in the sandstones are associated with organic material or root structures within trough cross-beds with silty mudstone drapes. The sandstones are interpreted as deposits of meandering and possibly anastomosing rivers that had high suspended loads. Copper, zinc, and lead enrichment occurs in lacustrine sandy mudstones with abundant root structures immediately underlying black laminated shales. The sandy mudstones represent muddy, vegetated lake shoreline deposits overlain by deep-lake deposits. Mineralization in both cases appears to be associated with depositional conditions that favor preservation of organic material within permeable strata. The origin of the mineralizing fluids and the timing of their introduction are unknown, but the distribution of mineralized zones can be constrained by depositional facies models reflecting the sedimentary controls.
\end{abstract}

Although the known stratabound base-metal occurrences in the Newark Supergroup are subeconomic, they are linked by common tectonic and sedimentary environments with an important class of copper, lead, and zinc deposits classified as sediment-hosted stratiform sulfide deposits. In particular, the copper, zinc, and lead enrichment in the black lacustrine mudstones of the Newark Supergroup identifies these rocks as a potential host for more extensive and economically significant base-metal deposits.

\section{INTRODUCTION}

Numerous occurrences of stratabound base metals in the Newark Supergroup were noted and prospected during the eighteenth and early nineteenth centuries (Cook, 1883; Lewis, 1907a; Weed, 1903; Wherry, 1908). Table 1 lists a number of sediment-hosted stratabound base-metal occurrences whose locations in the early 
Mesozoic basins of the Eastern United States are shown in figure 1. Most of the base-metal occurrences listed are copper rich, and this encouraged Kummel (1901) to make an optimistic evaluation of the potential for copper production. In fact, only a few of these occurrences produced significant quantities of ore (New-gate Prison mine, Connecticut, and the Glen Ridge, Dod, Schuyler, and Stony Brook mines in New Jersey; Lewis, 1907a; Gray, 1982), and the copper industry in the Newark Supergroup was nearly nonexistent by the early 1900's (Lewis, 1907b). Zinc-rich occurrences are largely unrecognized; however, a few references to sphalerite-bearing shales occur (for example, Gray, 1982, p. 207).

Although the known stratabound base-metal occurrences in the Newark Supergroup are subeconomic, they are linked by common tectonic and sedimentary environments with an important class of copper, lead, and zinc deposits elsewhere, the sediment-hosted stratiform deposits of Gustafson and Williams (1981). Deposits in this class are characterized by essentially stratiform sulfide mineralization developed in sediments deposited in tectonically active intracratonic basins. Mineralization appears to be associated with the transport of metalbearing brines from within the basin to shallow sites of sulfide development, which may be expressed as either epigenetic replacement or syngenetic precipitation. This report is a preliminary description of the sedimentary features and interpreted depositional environments of certain stratabound, sediment-hosted, copper- and zincmineralized zones in the Hartford, Newark, and Culpeper basins (fig. 1) of the early Mesozoic Newark Supergroup. The specific associations of sedimentary features that appear to control the distribution and extent of sulfide mineralization may be used in models of sedimentation for these Mesozoic basins to identify areas favorable for more extensive mineralization. The mineralized occurrences discussed fall into two general categories: fluvial sandstones with disseminated copper, and lacustrine siltstones and mudstones with disseminated copper, zinc, and lead.

\section{COPPER-MINERALIZED FLUVIAL SANDSTONE DEPOSITS}

Most of the base-metal occurrences listed in table 1 are in fluvial sandstones and are copper rich. These copper occurrences, and many others having similar or slightly different characteristics, are generally classified as "red-bed copper deposits" by various workers (Rose, 1976), on the basis of their common features of sedimentary and tectonic environment, redox interface control on ore distribution, and mineralogy. Summaries of "red-bed copper deposits" are given in Lindgren (1933, p. 403-409) and Bastin (1933), and the geologic setting and genesis of these deposits are discussed by Rose (1976). These copper deposits occur within thick sequences of reddish sandstone, siltstone, and mudstone deposited in terrestrial basins that are typically developed in extensional or rift-tectonic settings. The copper-rich zones are stratabound but lenticular and may cut across sedimentary layering. The mineralized zones are typically in gray, green, or tan sandstone, in contrast to the surrounding reddish, hematite-bearing rocks, or are hosted by altered basalts within the sedimentary sequence. The mineralized zones are characteristically associated with redox interfaces in the sedimentary sections, with typical reductants being fossil plant debris and sometimes pyrite, basalt, or thermally metamorphosed rocks.

The major primary base-metal sulfide minerals of red-bed copper deposits are chalcocite and pyrite. In some places bornite, chalcopyrite, native copper, or covellite may be primary or secondary minerals. Native silver, acanthite, galena, sphalerite, and various arsenic, cobalt, nickel, and molybdenum minerals may also occur in small amounts (Gann and Hagni, 1974; Woodward and others, 1974; Broderick, 1929; Ljunggren and Meyer, 1964). The uranium minerals uraninite, coffinite, and cuprosklodowskite occur in the New-gate Prison mine deposit (occurrence 2, table 1; John Windolph, 1972, USGS CRIB file records). Introduced co-depositional gangue minerals are rare but, where present, include minor calcite, gypsum, and barite accompanied by quartz, feldspar, chlorite, and illite (Woodward and others, 1974; Kidwell and Bower, 1974). Secondary supergene malachite, azurite, and chrysocolla are common and sometimes coat weathered surfaces or impregnate fractures with conspicuous color. Base-metal minerals in the fluvial sandstones from surface outcrops of the Newark Supergroup consist mainly of malachite and chrysocolla filling intergranular spaces or coating carbonized wood. These minerals are interpreted as the weathering products of copper sulfides that replaced woody debris and partially filled intergranular spaces. Table 2 lists representative chemical analyses of a few sandstone-hosted copper ores from deposits in the Hartford, Newark, and Culpeper basins. These ores have extreme copper enrichment (as much as a few weight percent). They are also enriched in silver and barium, slightly enriched in strontium, but not enriched in zinc and lead relative to the representative unmineralized sandstones (table 2). Copper-silver ratios in the ore samples are high and variable relative to average sedimentary rocks, implying that some geochemical separation of copper from silver occurred during mineralization.

For the copper-rich sandstone-hosted deposits, the critical feature controlling mineralization appears to be a reductant such as organic matter or basalt and hornfels adjacent to or within the permeable rocks at the time 
Table 1A. Listing by location of sediment-hosted stratabound base-metal occurrences in the early Mesozoic basins of the Eastern United States

[Numerals in the first column correspond with locations shown in figure 1; reference numbers in the last column correspond with citations in table $1 B$; the first letters in the "type" column are: $\mathrm{m}$, mine; $\mathrm{p}$, prospect; $\mathrm{o}$, mineral occurrence; subsequent letters in the "type" column are: m, mine ore production between 1,000 and 100,000 tons; $n$, production less than 1,000 tons; $u$, production unknown (usually less than 1,000 tons)]

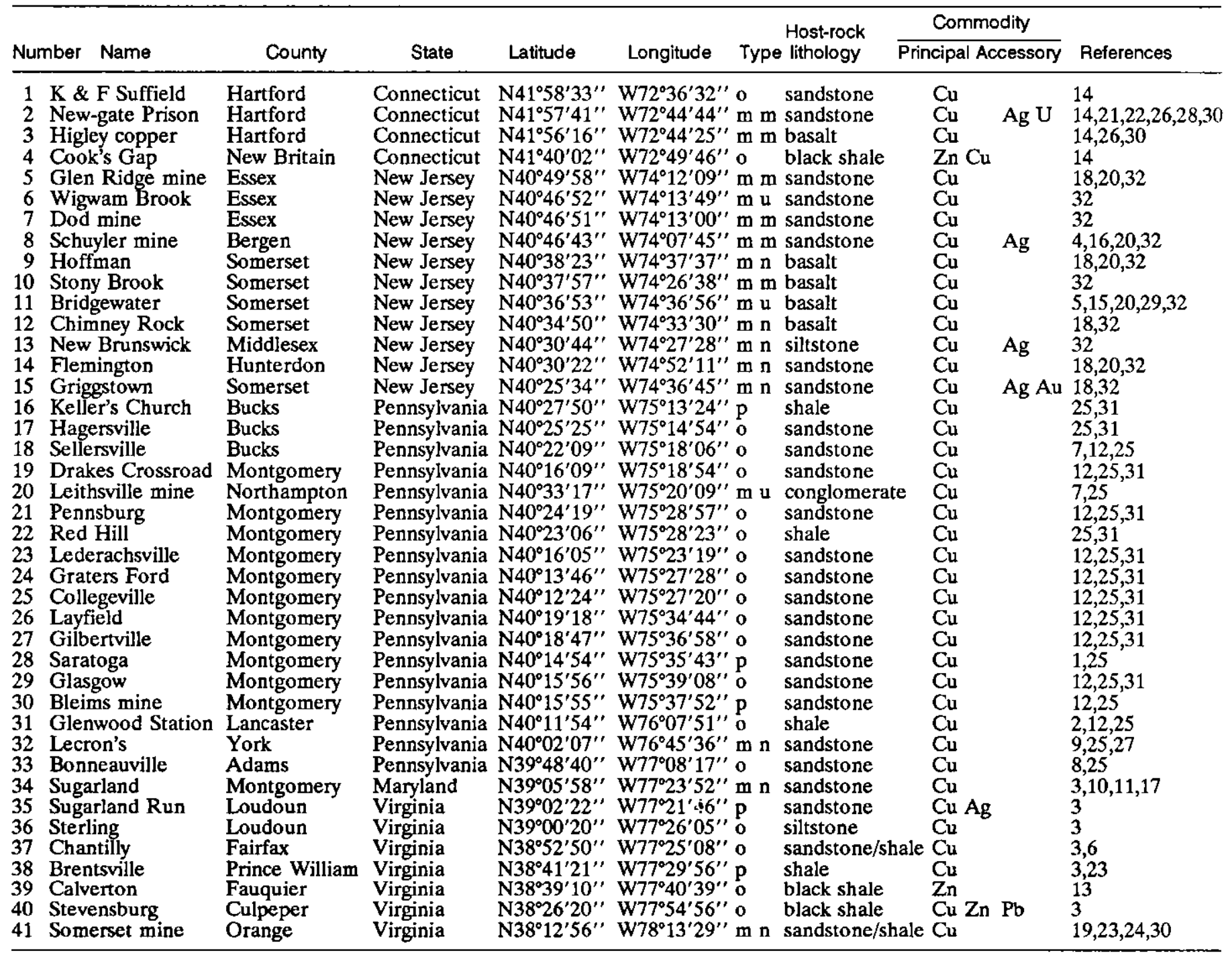

Table 1B. References cited in table $1 A$, listed by number

[Complete citations listed at end of paper]

\begin{tabular}{|c|c|c|c|}
\hline \multicolumn{2}{|c|}{ Number } & Number & Reference \\
\hline 1 & Bascom and Stose, 1938 & $17 \mathrm{I}$ & Lee, 1979 \\
\hline 2 & Beck, 1952 & $18 \mathrm{I}$ & Lewis, $1907 \mathrm{a}$ \\
\hline 3 & Bernstein, 1980 & $19 \mathrm{I}$ & Luttrell, 1966 \\
\hline 4 & Cornwall, 1945 & 201 & Newhouse, 1933 \\
\hline 5 & Darton, 1885 & $21 \mathrm{P}$ & Perrin, 1976 \\
\hline 6 & D'Agostino and Hanshaw, 1970 & $22 \mathrm{~F}$ & Potisat, 1978 \\
\hline 7 & Eyerman, 1889 & $23 \mathrm{~F}$ & Roberts, 1928 \\
\hline 8 & Frazer, 1880 & $24 \mathrm{~F}$ & Rogers, 1884 \\
\hline 9 & Frazer, 1886 & $25 \mathrm{~F}$ & Rose, 1970 \\
\hline 10 & Froelich, 1975 & $26 \mathrm{~S}$ & Schairer, 1931 \\
\hline 11 & Froelich and Leavy, 1981 & $27 \mathrm{~S}$ & Stose and Jonas, 1939 \\
\hline 12 & Gordon, 1922 & $28 \mathrm{~V}$ & Webster, 1978 \\
\hline 13 & P. Gore, 1983, pers commun. & $29 \mathrm{~V}$ & Weed, 1903 \\
\hline 14 & Gray, 1982 & $30 \mathrm{~V}$ & Weed, 1911 \\
\hline 15 & Hayes, 1949 & $31 v$ & Wherry, 1908 \\
\hline 16 & Lee, 1937 & $32 \mathrm{~V}$ & Woodward, 1944 \\
\hline
\end{tabular}

metal-bearing fluids are moving through the units. In the fluvial sequences, therefore, important variables are those that control the distribution and preservation of reductants and the transport of fluids. The following section discusses the sedimentary setting and characteristics of fluvial sandstones that host copper minerals in the Newark Supergroup.

\section{Sedimentology of Fluvial Sandstone-Hosted Copper Deposits in the Newark Supergroup}

Sandstone deposits containing disseminated copper were examined at several localities in the Culpeper, 


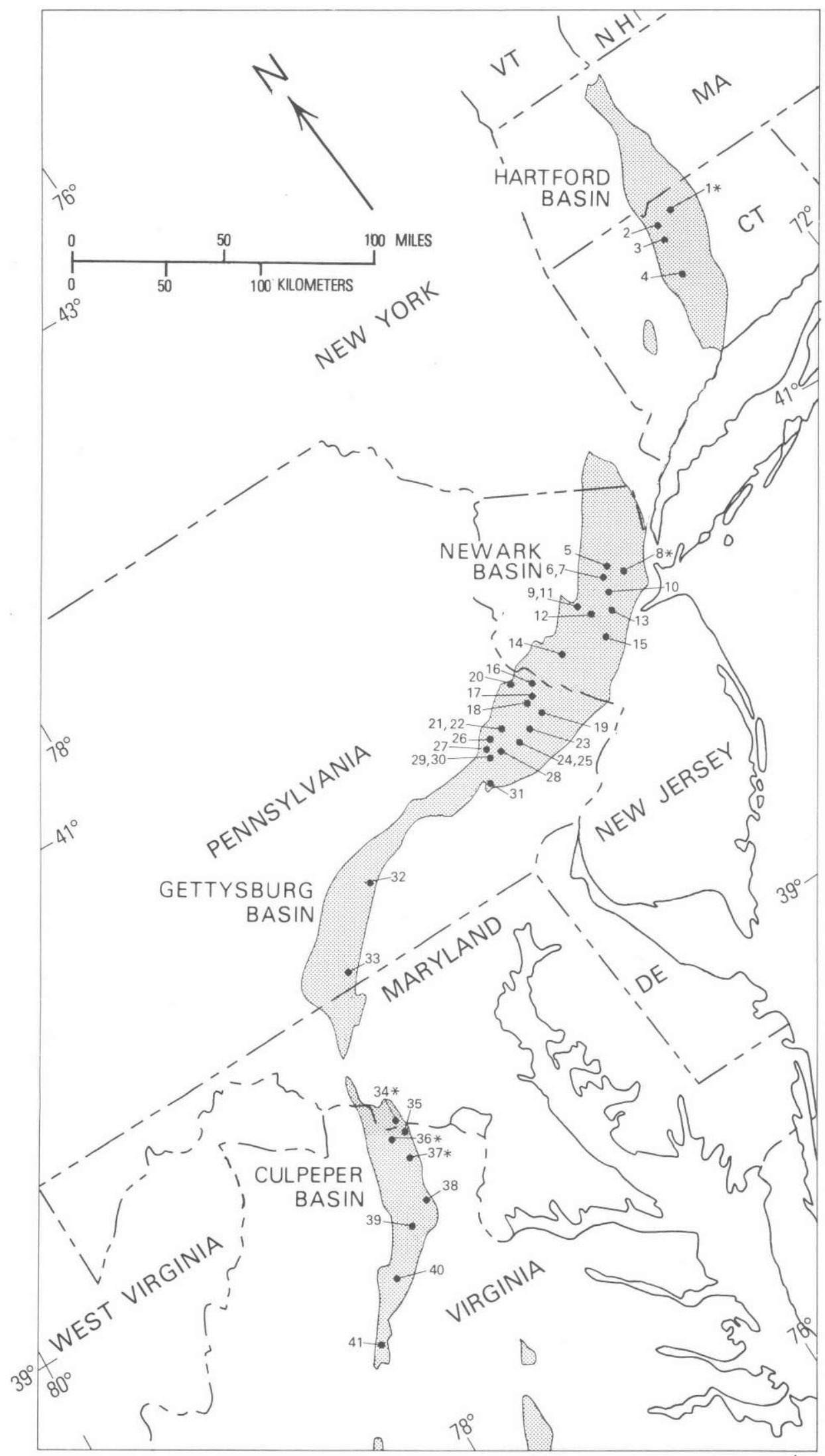

Figure 1. Map showing approximate locations of base-metal occurrences in the Newark Supergroup given in table 1. Asterisks mark localities at which detailed sedimentary studies were made. 
Table 2. Geochemistry of selected mineralized and unmineralized sedimentary rocks from the Hartford, Newark, and Culpeper basins

[- indicates not determined; numerals in the "Source" column are 1, Potisat, 1978 (unpublished data of Tortochaux, 1979, in appendix C); 2 , Robinson, 1987, unpublished data; 3, Lee and Froelich, 1985; 4, Dean, this volume (sample locations in Olsen, 1984)]

\begin{tabular}{|c|c|c|c|c|c|c|c|c|c|c|c|c|}
\hline Sample & $\underset{(\mathrm{ppm})}{\mathrm{Cu}}$ & $\begin{array}{c}\mathrm{Pb} \\
(\mathrm{ppm})\end{array}$ & $\underset{(p p m)}{Z n}$ & $\underset{(p p m)}{A g}$ & $\begin{array}{c}\text { As } \\
\text { (ppm) }\end{array}$ & $\begin{array}{c}\mathrm{B} \\
(\mathrm{ppm})\end{array}$ & $\begin{array}{c}\mathrm{Ba} \\
(\mathrm{ppm})\end{array}$ & $\begin{array}{c}\mathrm{Sr} \\
\text { (ppm) }\end{array}$ & $\mathrm{Ba} / \mathrm{Sr}$ & $\mathrm{Cu} / \mathrm{Ag}$ & Sourc & Remarks \\
\hline \multicolumn{13}{|c|}{ Sandstone-hosted copper occurrences } \\
\hline M684 & 73,000 & 30 & 67 & 139 & - & 38 & 1,998 & 357 & 5.6 & 525 & $1 s$ & Sandstone, New-gate Prison mine, north adit \\
\hline CN-N6-1 & 28,000 & 18 & 35 & 16 & - & 120 & 670 & 360 & 1.9 & 1750 & $2 s$ & Sandstone, New-gate Prison mine ore, Hartford basin \\
\hline M721 & 2,000 & 101 & 51 & 62 & - & 149 & 1,348 & 83 & 16.2 & 32 & $1 s$ & Sandstone, mineralized, Hartford basin \\
\hline NJ-SM-1a & 15,000 & 18 & 71 & 65 & 150 & 37 & 19,000 & 1,100 & 17.3 & 231 & $2 s$ & Sandstone, Schuyler mine ore, Newark basin \\
\hline NJ-SM-1b & 82,000 & 11 & 75 & 54 & $<100$ & 37 & 17,000 & 1,100 & 15.5 & 1519 & $2 s$ & Sandstone, Schuyler mine ore, Newark basin \\
\hline \multicolumn{13}{|c|}{ Unmineralized sandstone occurrences } \\
\hline VA-C-146 & 9.5 & 6.1 & 25.8 & .1 & - & 62 & 209 & 94 & 2.2 & 95 & $3 s$ & Sandstone, unmineralized, Culpeper basin \\
\hline $\mathrm{VA}-\mathrm{C}-152$ & 25.4 & 6.2 & 70.6 & .1 & - & 47 & 360 & 126 & 2.9 & 254 & 35 & Sandstone, unmineralized, Culpeper basin \\
\hline \multicolumn{13}{|c|}{ Mineralized lacustrine mudstone occurrences } \\
\hline VA-CDR-1 & 130 & 99 & 6,200 & 2.6 & - & 16 & 220 & 570 & 0.4 & 50 & 20 & Gray limestone, mineralized, Culpeper basin \\
\hline $\mathrm{CC}-37$ & 4,900 & 1,000 & 6,000 & 16 & 93 & 340 & 540 & 730 & 0.7 & 306 & 21 & Black mudstone, mineralized, Culpeper basin \\
\hline $\mathrm{CC}-38$ & 170 & 920 & 1,800 & 2.5 & 79 & 390 & 490 & 1,100 & 0.4 & 68 & 21 & Black mudstone, mineralized, Culpeper basin \\
\hline $\mathrm{CC}-41$ & 28,000 & 43 & 64 & 40 & 76 & 98 & 240 & 930 & 0.3 & 700 & 21 & Black mudstone, mineralized, Culpeper basin \\
\hline $\mathrm{CC}-75$ & 7,900 & 30 & 430 & 1 & 20 & 70 & 470 & 450 & 1.0 & 7900 & $2 \mathrm{I}$ & Black mudstone, mineralized, Culpeper basin \\
\hline \multicolumn{13}{|c|}{ Unmineralized lacustrine mudstone occurrences } \\
\hline $\mathrm{CC}-21$ & 10 & 13 & 140 & 6 & - & 190 & 440 & 880 & 0.5 & 17 & 21 & Black mudstone, unmineralized, Culpeper basin \\
\hline CC-29 & 35 & 9 & 280 & .9 & - & 67 & 360 & 190 & 1.9 & 39 & 21 & Black mudstone, unmineralized, Culpeper basin \\
\hline $\mathrm{CC}-35$ & 13 & 26 & 100 & .5 & - & 250 & 760 & 850 & 0.9 & 26 & 21 & Black mudstone, unmineralized, Culpeper basin \\
\hline E-11 & 92 & 28 & 92 & .26 & - & 170 & 870 & 360 & 2.4 & 354 & 2,4 & Black mudstone, unmineralized, Newark basin \\
\hline E-15 & 86 & 26 & 98 & .28 & - & 45 & 450 & 320 & 1.4 & 307 & $2,4 \quad$ & Black mudstone, unmineralized, Newark basin \\
\hline$E-23$ & 53 & 25 & 100 & .16 & $\ldots$ & 59 & 350 & 390 & 0.9 & 331 & 2,4 & Black mudstone, unmineralized, Newark basin \\
\hline
\end{tabular}

Newark, and Hartford basins (fig. 1). The mineralized zones occur in gray- to buff-colored, medium- to coarsegrained, arkosic sandstones surrounded by red, finegrained sandstone and mudstone. The sandstones occur as lenticular fining-upward sequences, which are typically 2 to $5 \mathrm{~m}$ thick. Each fining-upward sequence has a basal scour overlain by trough cross-bedded sandstones in which the cross-beds become progressively thinner and finer grained upward. The fining-upward sequences are capped by thin beds of ripple cross-laminated sandstone overlain by heavily bioturbated siltstone and mudstone. The sandstone lenses are commonly inclined and rhythmically imbricated (fig. 2) but may also fill isolated channel forms surrounded by bioturbated mudstone and siltstone.

The coarsest portion of each fining-upward sequence consists of trough cross-beds, 25 to $50 \mathrm{~cm}$ thick, each internally graded with mud clasts, carbonate intraclasts, and small pebbles at the base. The carbonate intraclasts are locally abundant enough to make the lower portions of troughs calcarenites. Foresets commonly exhibit soft-sediment fold structures and are penetrated by sandstone-filled or calcite cement-filled root structures. Trough cross-beds that have relatively flat basal scours commonly exhibit 1 - to $3-\mathrm{cm}$-thick basal mudstone-siltstone lenses, which may also drape foresets (fig. 2). The mudstone-siltstone lenses commonly contain abundant mica and carbonized wood and plant frag- ments. Thicker mudstone-siltstone lenses commonly exhibit ripple cross-lamination with flow directions that may be parallel to those of the trough cross-beds or opposite them. In some cases oscillatory ripple crosslamination is also present in mudstone-siltstone lenses. Load structures occur at the contacts between some coarse sandstone foresets and the underlying mudstonesiltstone lenses. Carbonized root structures are locally abundant in the cross-bed sets that have thick mudstoncsiltstone lenses.

The mudstone-siltstone lenses are more abundant in small, fine-grained cross-bed sets but are thicker and more continuous where present in larger, coarser grained sets. The mudstone-siltstone lenses are very thin or absent in some fining-upward sequences but in others may reach thicknesses of $20 \mathrm{~cm}$ and occur throughout the sequence. Mudstone-siltstone layers continuous for the length of the outcrop were observed at the Schuyler mine (occurrence 8, fig. 1) and described at the New-gate Prison mine (occurrence 2, fig. 1) by Perrin (1976), Potisat (1978), and Turner-Peterson (1980).

The upper portions of the fining-upward sequences consist of thin beds of fine-grained, red sandstone having low-angle, climbing ripple cross-lamination and horizontal lamination alternating with thin beds of mudstone and siltstone that have abundant mudcracks and bioturbation features, including root structures and burrows. The fining-upward sequences are capped by massive mud- 


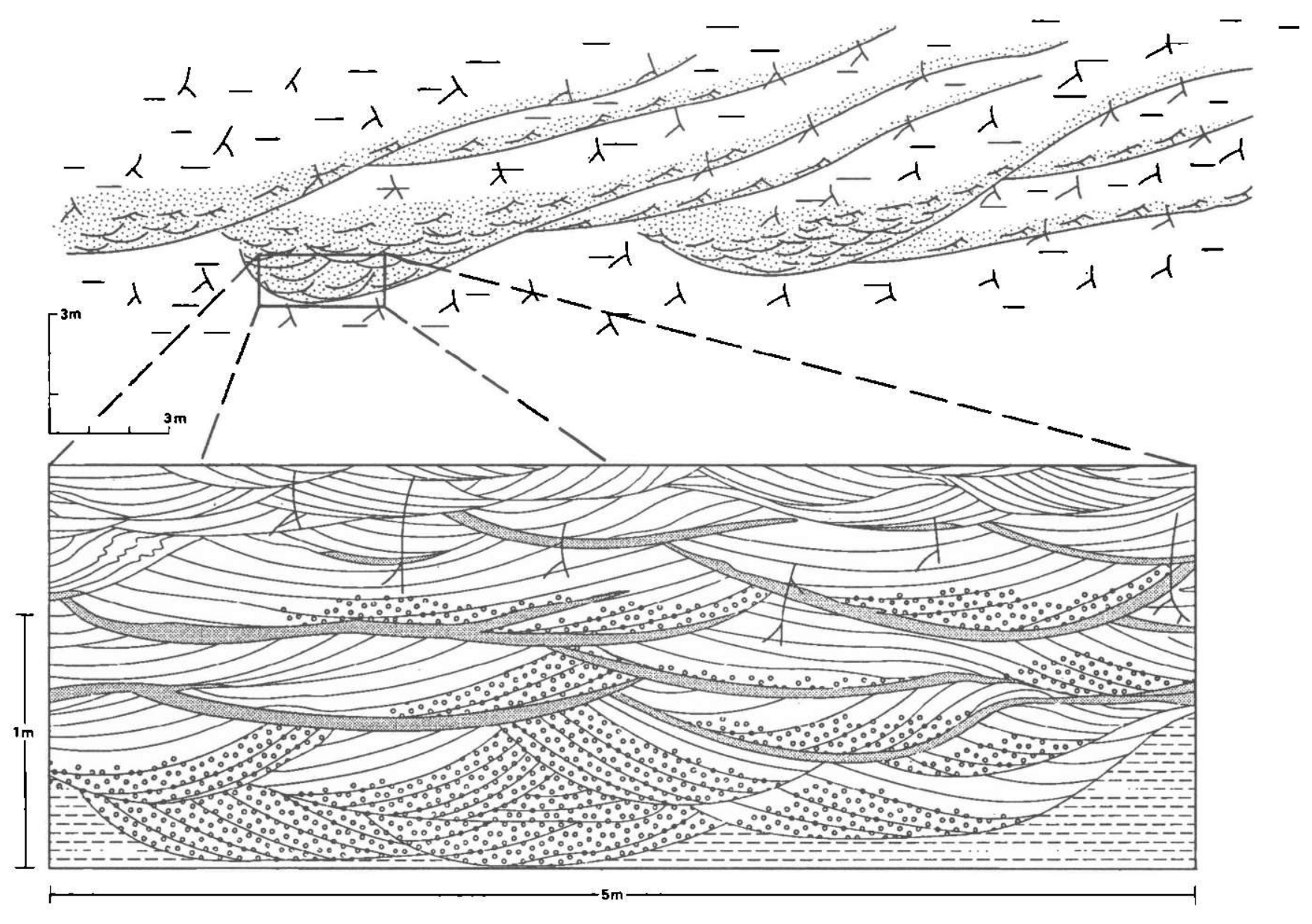

EXPLANATION

Siltstone and mudstone

Figure 2. Idealized sketch showing sedimentary features of copper-bearing fluvial sandstones. Top, imbricated lenses of sandstone with fining-upward sequences of trough crossbedding grading upward to ripple cross-lamination and bioturbated siltstone. Bottom, detail of the trough crossbedding that shows the distribution of mudstone-siltstone lenses at the bases of troughs. Cross-beds in the middle portion of the fining-upward sequence contain the highest copper enrichment. Views in both sketches are perpendicular to paleocurrent direction. Sketches were developed from field observations at occurrence 36 (table 1, fig. 1). 
stone with abundant root structures, burrows, and common carbonate nodules. The most common burrows are similar to Scoyenia. The carbonate nodules appear to be the source of the carbonate intraclasts contained in the trough cross-beds.

The fining-upward sequences comprising these sandstone bodies are interpreted as fluvial deposits of meandering and possibly anastomosing streams. The imbricated lenses are similar to lateral accretion sets of meandering rivers (see Cant, 1982), whereas the isolated channel-form lenses are more similar to those of anastomosing rivers (Smith, 1983; Rust and Legun, 1983). In both cases the large trough sets were formed by dunescale bedforms in the channels, while the overlying rippled sandstones and bioturbated mudstones were deposited as upper point bar, levee, and overbank deposits. The root structures and burrows indicate a moist area with abundant vegetation surrounding the channels. Olsen (1977) noted the similarity between Scoyenia and modern crayfish burrows and suggested that a similar organism made the Triassic structures. Crayfish burrows are abundant in modern swampy floodplains of the Southern United States (Wells, 1977). The carbonate nodules are interpreted as soil caliche glaebules similar to those described by Mermut and Dasog (1986) formed in monsoonal conditions in India. These nodules do not resemble those found in soil profiles in the more arid conditions of the Southwestern United States (Giles and others, 1966).

The Newark Supergroup fluvial sandstones are interpreted as the deposits of rivers and streams that had very high suspended loads. The mudstone partings between successive sandstone lateral accretion units are very similar to the point-bar and bench deposits of the modern Barwon River in Australia (Taylor and Woodyer, 1978; Woodyer and others, 1979). The presence of mudstone-siltstone lenses within the trough cross-beds is also consistent with high suspended loads. The basal mudstone-siltstone lenses are partly the result of deposition of suspended fine-grained sediment due to separation backflow on the lee sides of the dunes (Jopling, 1967). This is supported by the presence of ripple cross-lamination locally with flow directions opposing the dune foresets (Boersma and others, 1968; Allen, 1980). The mudstone-siltstone lenses are also probably partially due to deposition during waning flow. Flooding in the Barwon River is followed by periods of sluggish flow, during which mud and silt suspended by the flood is deposited in the channel and on the adjacent banks. This could produce ripple cross-laminae with flow directions parallel to the dune foresets and also clay-rich layers that drape foresets, like those seen in the Newark Supergroup deposits. The presence of soft-sediment deformation structures in the dune foresets, loading of foreset sandstone into the mudstone-siltstone lenses, and the absence of desiccation features in the mudstone-siltstone lenses indicate that the channel-fill sandstones were continuously subaqueous and not deposits of ephemeral streams. This is also supported by the abundance of Scoyenia burrows, if they were formed by organisms with habits similar to crayfish. The oscillatory ripple crosslamination suggests that the fine-grained material was reworked by wind-generated waves in standing water during periods of slack flow. Examples of analogous ancient mudstone-rich meandering rivers are provided by Stewart (1983) and Gibling and Rust (1987). The isolated channel-form lenses in the Newark Supergroup are interpreted as deposits of anastomosing streams that carried high suspended loads. However, we are unaware of any descriptions of modern or ancient examples of this type of fluvial deposit.

The variability in the thickness, abundance, and continuity of mudstone-siltstone lenses within the crossbedded sandstones may be due to exposure of different cross-sections of parts of the channels or may be due to actual changes in the depositional environment. Thicker deposits of intercalated fine-grained material would be expected on the lee sides of tight meander bends or downstream of large channel bars where flow velocities would be lower. The amount of fine-grained sediment deposited in the channel by a river would change if lake level were to rise and drown the channel, thus decreasing stream velocity. Rapid rise and fall of lake levels and drowning of fluvial systems are common in closed-basin drainages (Smoot, 1985), and closed-basin conditions are envisioned for most of the Newark Supergroup basins for at least part of the time of their filling. Perrin (1976) and Turner-Peterson (1980) interpreted the New-gate Prison mine deposit (occurrence 2, fig. 1) as transitional between fluvial and lacustrine because of the continuity of the organic-matter-rich mudstone-siltstone layers and the absence of large-scale cross-bedding in the sandstone layers. Olsen (pers. commun., 1986) found fish fossils and conchostracans, which he interprets as lacustrine, in mudstone layers associated with isolated channel lenses in the Portland Formation at occurrence 1 (fig. 1). Sandstone beds intercalated with continuous mudstonesiltstone layers at the Schuyler mine (occurrence 8, fig. 1) have cross-beds that are difficult to see because of the thick intercalations of ripple cross-laminated sandstone. These would be difficult to recognize in the New-gate Prison mine deposit because of the overprint of mineralization and the lack of surface weathering to accentuate parting. The continuous mudstone-siltstone layers may also be interpreted as channel-fill deposits of larger rivers (see Bridge and others, 1986). Perrin (1976) mentions outcrop ridges of sandstone 20 to $50 \mathrm{~m}$ wide and 60 to $300 \mathrm{~m}$ long in the vicinity of the New-gate Prison mine, which he interprets as channel lenses. 
The most mineralized portions of the sandstones are at the base of trough cross-beds that contain abundant plant material and that have thick mudstonesiltstone lenses at their base or draping the foresets. Pebbly cross-beds that lack mudstone-siltstone lenses are generally not mineralized, even though they often have impressions of woody material in sandy layers. Root structures and sandstone-filled root casts within the cross-beds that have mudstone-siltstone lenses are also commonly mineralized. Perrin (1976) and Potisat (1978) noted that base-metal minerals in the New-gate Prison mine deposit (occurrence 2, fig. 1) are concentrated in a mottled zone that has tubular shapes containing unidentified organic material. The tube structures are probably root structures. Red sedimentary rocks in all of the known Newark Supergroup occurrences are never mineralized, even where they contain pieces of carbonized wood.

Copper enrichment of the Newark Supergroup fluvial deposits appears to have been controlled by organic material in the medium- to coarse-grained sandstones. Similar controls elsewhere in the world have been cited for significant copper and silver occurrences (Creta, Oklahoma: Smith, 1976; Boleo, Baja California, Mexico: Wilson, 1955; Corocoro, Bolivia: Entwistle and Gouin, 1955; Nacimiento, New Mexico: LaPoint, 1976). The sandstones presumably acted as conduits for metalbearing fluids, while organic material helped to fix the metals by providing local reducing conditions. Basemetal enrichment in the Newark Supergroup sandstones does not appear to be related to the contact between the red rocks and the buff or gray rocks, so there is no clear evidence that reduction of former hematitic sediments was important to mineralization.

The organic-matter-rich mudstone-siltstone lenses overlying trough cross-bed scours in the Newark Supergroup apparently offered the proper conditions for preservation of organic material long enough for it to be mineralized. Most of the strata in the fluvial deposits are now red and were apparently oxidized early, aided by the intense bioturbation, with most of the organic material apparently removed before mineralizing fluids passed through. Cross-bedded sandstones that are not red, but also do not have mudstone-siltstone lenses, are presently not mineralized, even though many had organic debris, as evidenced by the woody impressions. Apparently the wood in these sandstones decayed and was removed before the mineralizing fluids entered or the wood and all traces of copper mineralization were subsequently removed by weathering. The mudstone-siltstone lenses in the cross-bedded sandstones may have restricted circulation of outside fluids enough to allow the decay of organic material to produce local reducing conditions. These conditions would favor the preservation of woody material, including roots that penetrated the sands, until mineralizing fluids passed through the still relatively permeable deposits. The timing of this mineralization could have been long after deposition of the fluvial deposits and even following some lithification. The mudstone-siltstone lenses may also have acted as barriers to much later fluids that have removed woody material and copper, thus allowing for their preferential preservation.

The exact source of the metal-bearing fluids is unclear, but there appears to be an association of the mineralized fluvial deposits with basalt flows, diabase intrusives, and areas with thermal alteration in some cases. Possibly, circulation of mineralizing fluids was initiated by Jurassic igneous activity. Saline fluids may have been involved in the mineralization, as hypothesized by Rose (1976). Evaporite pseudomorphs after gypsum(?) are associated with the Schuyler mine (occurrence 8, fig. 1) and are found in nearby strata in all other Newark Supergroup occurrences, suggesting evaporitic conditions. Flint $(1985,1986)$ described mineralized fluvial deposits, containing gypsum crystals and nodules, that have sedimentary features similar to some of the Newark Supergroup examples.

\section{COPPER-, ZINC-, AND LEAD-MINERALIZED LACUSTRINE MUDSTONE DEPOSITS}

Three of the base-metal occurrences listed in table 1 are in black and gray lacustrine siltstone and mudstone. Base metals in the lacustrine mudstones are inconspicuous in outcrop or hand sample. This may account for the limited number of reported base-metal occurrences of this type. Important deposits of stratabound base metals in lacustrine deposits in similar rift-basin settings are the copper deposits in the Nonesuch Shale of the Keweenaw basin, Michigan (Daniels, 1982) and the lead-zinc-copper deposits in the McArthur basin, Northern Territory, Australia, and the Urquhart Shale, Queensland, Australia (Muir, 1981; Neudert, 1986). Other minor occurrences of base-metal enrichment in lacustrine rocks include Triassic rift basins in East Greenland (Clemmensen, 1980) and Morocco (Brown, 1980), and pullapart basins along the margin of the Kalahari Craton in southern Africa (Maiden and others, 1986; Ruxton, 1986) and the Lomagundi basin in Zimbabwe (Maiden and others, 1986; Newham, 1986). In contrast to coppermineralized sandstone deposits, most of the major basemetal mineralized lacustrine mudstone deposits occur in strata that are apparently impermeable, and the ore distribution does not appear to have been controlled by the interface between oxidizing and reducing conditions.

The major primary sulfide minerals of the copper-, zinc-, and lead-mineralized lacustrine mudstone class are chalcopyrite, sphalerite, and galena (Mathias and Clark, 
1975; Brown, 1971). Pyrite is present but is usually a minor constituent. Zoning and separation of copper from zinc and lead enrichment is common (Gustafson and Williams, 1981). At the White Pine copper deposit, for example, chalcocite, chalcopyrite, and djurleite are common copper minerals, while small amounts of bornite, digenite, native copper, and native silver are present. Trace amounts of greenockite, galena, wurtzite, covellite, and molybdenite also occur (Brown, 1971). Organicmatter-poor sandstone adjacent to mineralized mudstone may also be cemented by native copper and hematite (Brown, 1971).

Table 2 shows a few representative chemical analyses of base-metal-enriched lacustrine mudstone samples from the Culpeper basin, Virginia. Small amounts of chalcopyrite, bornite, covellite (supergene), sphalerite, galena, and wurtzite occur in these mudstones and, in some places, partially replace pyrite. A similar style of base-metal occurrence replacing epigenetic pyrite has been observed at the White Pine (Nonesuch Shale) deposit, Keweenaw basin, Michigan (Brown, 1971), the Creta deposit, Oklahoma (Hagni and Gann, 1976), the Kupferschiefer, Germany-Poland (Love, 1962), and the Mount Isa deposit, Queensland, Australia (Love and Zimmerman, 1961). The mineralized lacustrine mudstone samples listed in table 2 are enriched in copper (as much as 2.8 weight percent $\mathrm{Cu}$ ), zinc, lead, and silver relative to representative unmineralized lacustrine mudstones. Copper-silver ratios are high relative to unmineralized lacustrine mudstones and show a range of values similar to the sandstone-hosted copper occurrences. Copper, lead, zinc, and silver values for the mineralized lacustrine mudstones do not appear to correlate, implying that the base-metal enrichments may be spatially zoned.

The controlling factors on base-metal mineralization in lacustrine mudstones are poorly understood. A syngenetic origin for the lead-zinc ores of the Mount Isa deposit and the copper ores of the White Pine deposit is supported by (1) the extreme conformity of the basemetal mineralization to the bedding, (2) the occurrence of base metals in impermeable strata, and (3) the lack of control on mineralization by fractures or the rock mineralogy (Finlow-Bates, 1979; Gustafson and Williams, 1981, p. 157-160). Finlow-Bates (1979) interpreted the Mount Isa deposit as an exhalative accumulation of base metals related to hydrothermal fluids entering a water body.

White $(1968,1971)$ developed an epigenetic model for the White Pine deposit based on the textural evidence of the replacement of pyrite by copper sulfides (Brown, 1971) and on his recognition of a regional stratigraphic discordance in copper mineralization. The fine-grained carbonate rocks of the White Pine and Mount Isa deposits contain mineral assemblages that were probably not syndepositional, indicating that the rocks or their precursor sediments were not always impermeable. Calcite pseudomorphs after gypsum and broad zoning patterns of iron enrichment in dolomite surrounding the Mount Isa ore bodies (Van den Heuvel, 1969) suggest extensive introduction and removal of components either before appreciable compaction and cementation of the sediments or following dissolution of relatively soluble minerals, thereby producing sufficient permeability. The regional distribution of chemical zoning and the variability of isotopic signatures in the McArthur River basemetal deposits led Williams (1979) and Rye and Williams (1981) to conclude an epigenetic origin for them. Muir (1983) and Neudert (1986) used the sedimentological characteristics of the McArthur River and Mount Isa deposits to infer an epigenetic origin for that mineralization. They argued that base-metal mineralization resulted from the transport and reaction of metal-bearing brines with diagenetic pyrite and favorable lithologies.

The lack of detailed evidence for the timing of mineralization and for the chemical zoning patterns in many of the lacustrine-hosted base-metal deposits limits our ability to develop a well-constrained genetic model. The following section discusses the sedimentary characteristics of a Newark Supergroup lacustrine sequence containing stratabound base metals. The distribution of the base metals suggests that, as with the sandstonehosted deposits, preservation of organic material and depositional porosity were important controls on basemetal mineralization.

\section{Sedimentology of a Lacustrine Mudstone-Hosted Base-Metal Deposit in the Newark Supergroup}

Anomalous concentrations of zinc sulfides, copper sulfides, and lead sulfides appear to be associated with specific beds of dark-gray to black lacustrine mudstone in the Balls Bluff Siltstone at the Culpeper Crushed Stone quarry (occurrence 40, fig. 1; fig. 3). Base-metal sulfides occur as disseminations and fracture fillings within rootdisrupted mudstones that underlie black, organic-matterrich shales as parts of rhythmic, asymmetric cycles (figs. 4-6).

Twenty-three cycles were observed in the Culpeper Crushed Stone quarry, ranging from 3 to $7 \mathrm{~m}$ in thickness (fig. 4). Each cycle shows a consistent vertical change from well-bedded mudstone to massive mudstone, and a range of sedimentary structures that, with a few minor exceptions, can be grouped within eight lithologic types that are repeated throughout the section.

Lithology 1 is a black, finely laminated shale. Desiccation features are rare; where present, they consist 
of mudcracks that extend down from overlying lithologies. Lamination in lithology 1 consists of alternations of siltstone with organic-matter-rich mudstone. The laminae increase in thickness and waviness upward in each unit within a cycle, as the siltstone layers become coarser and more lenticular. Lithology 1 is interpreted as the deposit of a relatively deep lake that became shallower with time.

Lithology 2 is a laminated to thin-bedded mudstone with interbeds of siltstone and fine-grained sandstone that have pinch-and-swell lamination or oscillatory ripple cross-lamination. Mudcracks are common and systematically change in character upward in each unit within a cycle. Mudcracks near the base are 10 to $20 \mathrm{~cm}$ deep and define polygons 30 to $40 \mathrm{~cm}$ in diameter, but mudcracks near the top of each unit are 5 to $6 \mathrm{~cm}$ deep and define polygons 10 to $15 \mathrm{~cm}$ in diameter. Oscillatory ripples near the top of some units are asymmetric, indicating net propagation to the east or southeast. Lithology 2 is interpreted as shallow-lake deposits that were intermittently exposed to desiccation. The vertical changes in sedimentary structures indicate a change to shallower conditions of deposition and more frequent periods of desiccation. The orientation of the oscillatory ripple cross-lamination indicates that deeper water was to the west or northwest.

Lithology 3 consists of a breccia-like fabric of angular mudstone blocks separated by narrow, jagged, polygonal crack fillings of muddy siltstone. The mudstone blocks show no evidence of transportation or rotation and may have internal stratification similar to lithology 2. The size of the breccia blocks decreases upward in each unit within a cycle as the number of siltstone-filled polygons increases. The breccia-like fabric in lithology 3 was probably formed as a shallow-lake deposit was disrupted by prolonged desiccation and repeated episodes of wetting and drying (see Smoot, 1981; Smoot and Katz, 1982). The lake deposits were cracked and recracked while sediment accumulation was restricted to crack fillings. Mud-block breccias similar to lithology 3 are found at the upper contacts of Pleistocene pluvial lake deposits in the Mojave region, where lake clays grade upward into modern playa mudflat deposits (Smoot, 1981).

Lithology 4 consists of thin beds of tan-weathering siltstone broken into polygonal lenses by vertical crack fillings of muddy siltstone. The tan siltstone lenses curl upward and alternate with thin beds of silty mudstone similar to the polygonal crack fillings. The muddy siltstones have abundant small, angular polygonal cracks and irregular submillimeter vugs that are filled with mudstone and void-filling cement textures. The tan siltstone beds have internal horizontal lamination, oscillatory ripple cross-lamination, and small scours. The oscillatory ripple cross-laminae are commonly asymmetrical and show a similar east or southeast sense of propagation to the oscillatory ripple cross-laminae in lithology 2 . The tan siltstone lenses are smaller, more widely spaced, and more brecciated upward in each lithology 4 unit within a cycle and laterally from west to east in each unit within the quarry exposure. The tan siltstone layers are interpreted as the deposits of shallow ephemeral lakes or sheetfloods on a playa surface. These layers are transitional in character to lithology 2 , which they gradationally overlie in some cycles. The siltstone layers were disrupted by desiccation, curling away from the hard, dry underlying material during prolonged periods of subaerial exposure. The curling may have been partially due to algal mats binding the surface of the silt layers. The vertical change in character in lithology 4 is interpreted as the result of superimposed desiccation features, in a manner similar to those in lithology 3 . The muddy siltstone interbeds are interpreted as playa mudflat deposits. The oscillatory ripple cross-lamination and the lateral change in the disruption of the silt layers suggest that deeper water was to the west or northwest.

Lithology 5 is a massive silty mudstone having abundant narrow, jagged polygonal cracks and submillimeter vugs with pore-filling cements. The cracks are filled with mudstone and are generally less than $10 \mathrm{~cm}$ deep. Crack polygons are 2 to $10 \mathrm{~cm}$ in diameter. Lithology 5 is interpreted as deposits analogous to modern aggrading playa mudflats in the Mojave region (Smoot, 1981; Smoot and Katz, 1982; Katz, 1983). The cracks are similar to those formed on modern playa flats by repeated wetting and drying, and the vugs are similar to vesicles in the modern playa muds. Vesicles are air bubbles trapped in the wet mud during flooding of the playa flats. The amount of sediment that was deposited by each flood is very small, most of it having been deposited in open cracks. Subsequent desiccation and volume change by the opening of new cracks allowed the accumulation of a massive mud deposit. Most commonly lithology 5 gradationally overlies lithology 3 or lithology 4 in a cycle.

Lithologies 6 and 7 are massive silty mudstones with abundant cement- and sediment-filled tubes that taper and branch. Lithology 6 contains polygonal cracks similar to those in lithology 5 , and the tubes appear to be concentrated within the crack fillings (Smoot and Olsen, in press). Lithology 7 contains narrow cracks that are deeper than those of lithology $6(15$ to $30 \mathrm{~cm}$ ) and have larger polygons (20 to $40 \mathrm{~cm}$ in diameter). Lithology 7 also has more dolomitic cement in tubes and cracks, and contains carbonate nodules in the uppermost part of some occurrences. The tubes in these lithologies are interpreted as root casts and the deposits are interpreted as vegetated mudflats (Smoot and Olsen, 1985, in press). Lithology 6 was probably deposited under dry conditions that were gradational with the playa conditions of lithol- 


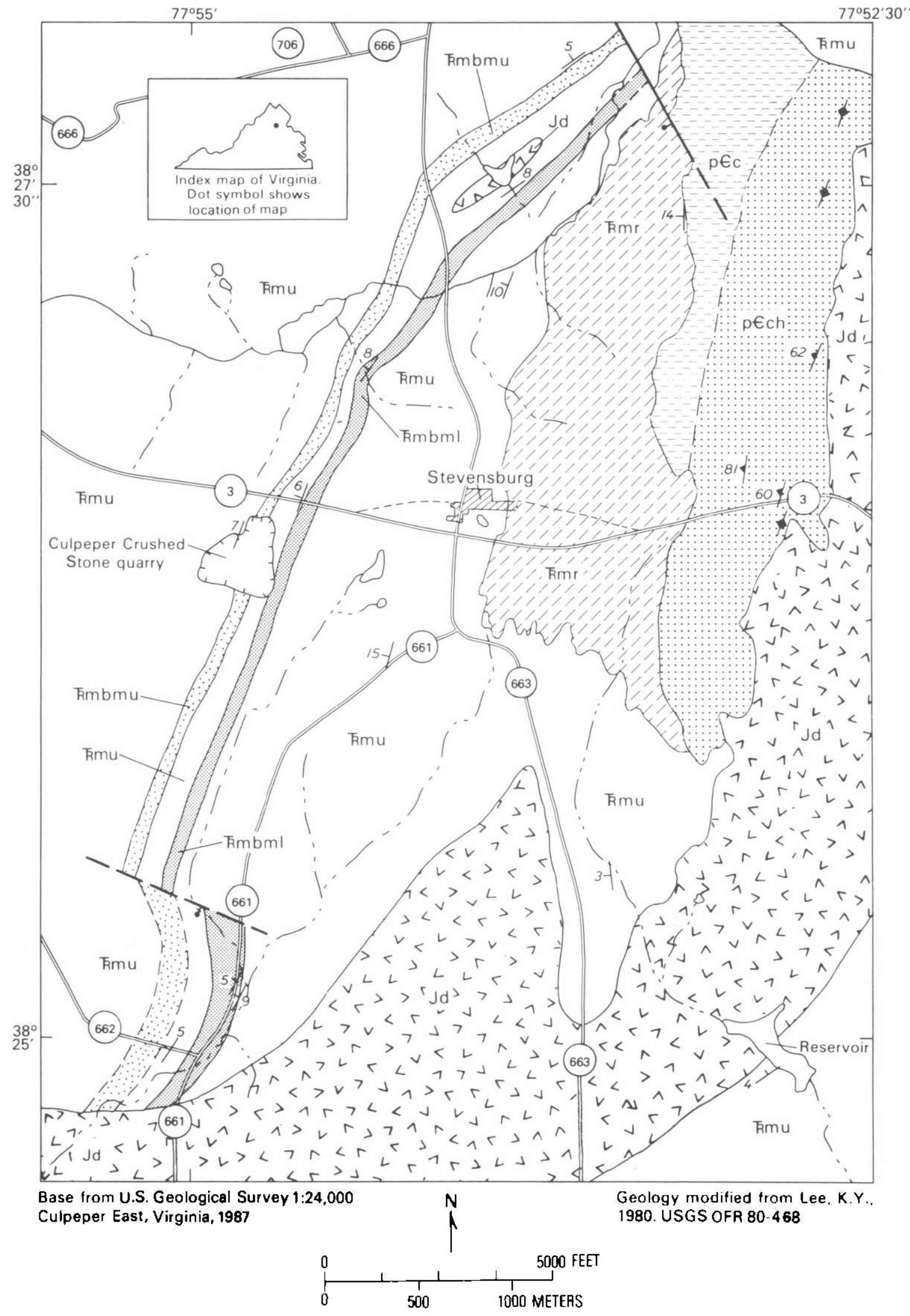

Figure 3. Geologic map of the Stevensburg, Virginia, area showing the location of the Culpeper Crushed Stone quarry and the distribution of the two gray intervals shown in figure 4. 


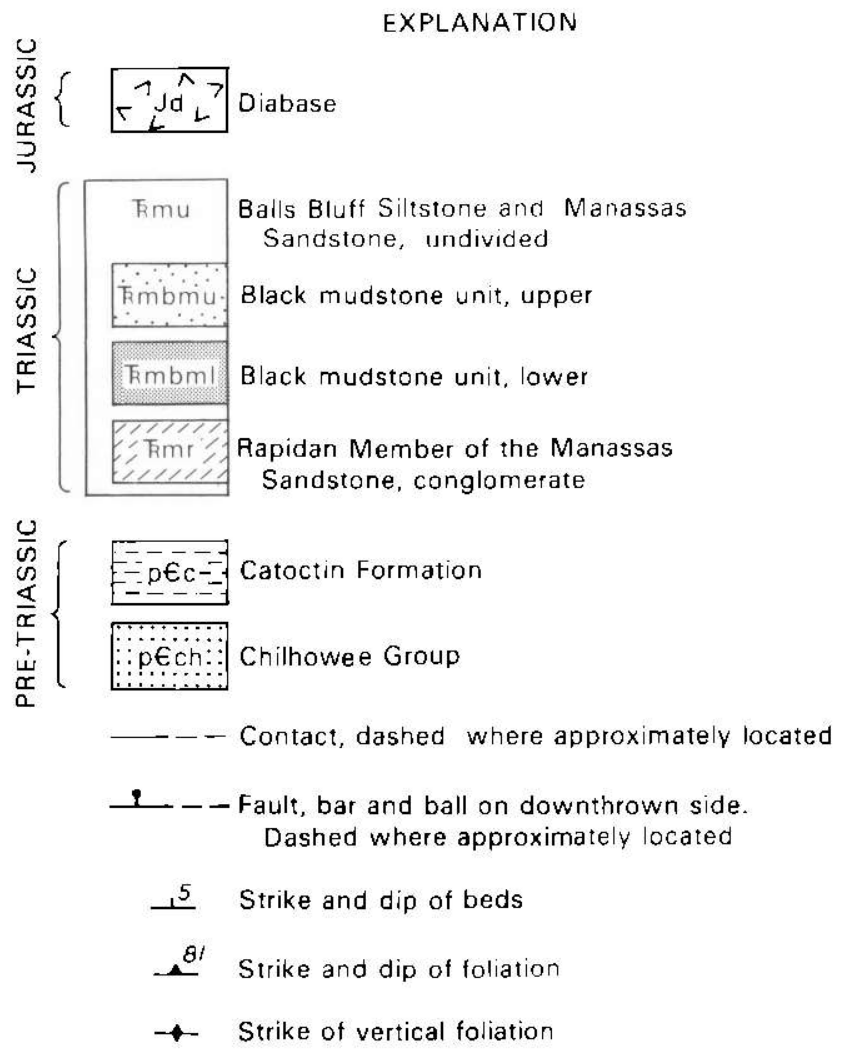

Figure 3. Continued.

ogy 5. Plants may have preferred to grow in cracks for more moisture or their roots may have followed cracks, unable to penetrate the hard playa mud. Lithology 7 was deposited during wetter conditions, as indicated by the larger, deeper mudcracks. The carbonate nodules in lithology 7 suggest soil development, and the combination of lithologies 6 and 7 may represent a soil profile superimposed on the playa deposits of lithology 5 .

Lithology 8 is a massive sandy mudstone having root structures and mudcracks similar to lithology 7 , although the cracks are locally less abundant. It also contains patches of remnant sandstone beds and large carbonate nodules in some occurrences. The upper bedding surface of lithology 8 in one cycle has abundant dinosaur tracks. The alignment of trackways and changes in the preservation of tracks indicate they were made under standing water with a shoreline orientation that is consistent with the oscillatory ripple cross-laminae in lithologies 2 and 4 (Weems, 1987). Lithology 8 is interpreted as the muddy shoreline deposits of a vegetated lake margin. Different portions of this lithology were probably subaqueous or subaerial during deposition in each cycle, as indicated by the dinosaur tracks and by lateral changes in the size and abundance of mudcracks. Lithology 8 invariably directly underlies lithology 1 at the quarry.

Other lithologic types that occur within the section include a lenticular peloidal sandstone near the base of a

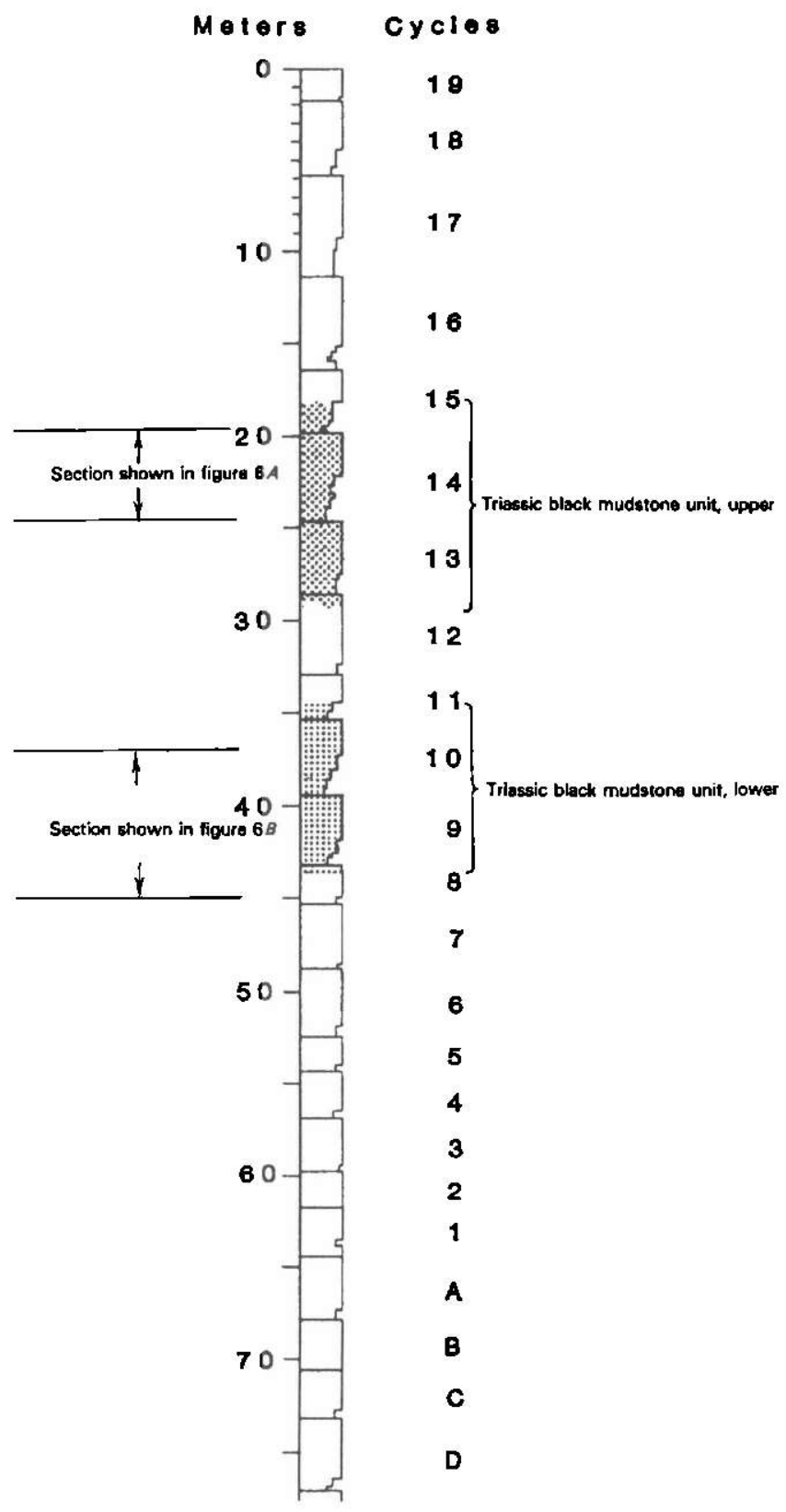

Figure 4. Stratigraphic section exposed in the Culpeper Crushed Stone quarry that shows the cycle boundaries. The two gray intervals (patterned) are equivalent to the units mapped in figure 3.

lithology 1 shale, an oolitic limestone that forms lenses as much as $20 \mathrm{~cm}$ thick along the contact between lithology 8 and lithology 1 , and a rippled sandstone unit with mudcracked mud partings that overlies lithology 4 and underlies lithology 7. Several portions of the quarry could be viewed only through binoculars and the different massive mudstone types could not be distinguished. These mudstones were referred to as lithology 9 , which is undifferentiated massive mudstone. 
The lithologic types are organized into cycles that have sharp boundaries between them and internal gradational boundaries. There are two end-member varieties of cycles (fig. 5): long cycles (5 to $7 \mathrm{~m}$ thick) and short cycles ( 3 to $5 \mathrm{~m}$ thick). The sequence of lithologic types in each cycle indicates the transgression and regression of lakes, probably in response to climatic changes (see Olsen, 1986). In the long cycles, deeper lake conditions (lithologies 1 and 2) were followed by playa-like conditions and ephemeral-lake deposition (lithologies 3 and 4). In contrast, short cycles begin with ephemeral-lake deposits (lithology 4) and are followed by playa mudflat deposits (lithology 5). This suggests that the short cycles represent generally drier conditions than the long cycles. The upper portions of both cycle types consist of rootdisrupted mudstone, indicating progressively wetter conditions (lithologies 6 and 7). The sandy mudstone at the tops of some long cycles (lithology 8 ) is interpreted as a shoreline deposit formed during a lake transgression under conditions of low sedimentation.

Most of the quarry section is red, with the exception of two gray intervals that are associated with long cycles containing the organic-matter-rich lithology 1 (fig. 4). The zones of base-metal enrichment are restricted to these gray intervals, primarily within lithology 8 or the lithologic units immediately underlying or overlying it (fig. 6). The gray intervals were traced north for about 3.5 $\mathrm{km}$ and south for about $3 \mathrm{~km}$ before striking into a diabase sheet (fig. 3). Another pair of closely spaced gray intervals occurs approximately $200 \mathrm{~m}$ above the quarry section. These stratigraphically higher gray intervals have not yet been examined in detail.

Small aggregates of intergrown sphalerite, chalcopyrite, bornite, and minor galena occur disseminated throughout root-disrupted mudstones (mostly lithology 8 and to a lesser degree lithology 7), preferentially concentrated in cement-filled root tubes (fig. 7) and siltstonefilled mudcracks. Chalcopyrite, pyrite, and minor sphalerite coat and replace wall rock adjacent to thin, near-vertical, calcite-filled fractures and veins. These sulfides are preferentially developed where the veins and fractures cut lithology 8 and to a lesser degree lithology 7 , but also occur in other lithologies immediately above and below them. Concentrations of chalcopyrite, sphalerite, and minor galena appear to replace coarse carbonate cements in silty mudcrack and root fillings within a few inches of sulfide-bearing veins, apparently by reactions with vein fluids. Covellite occurs locally as supergene alteration of bornite and chalcopyrite. Black shales (lithology 1) do not appear to contain elevated basemetal or sulfide content except for occasional lenses or mudcrack fillings of sandstone and siltstone, especially in areas where sulfide-bearing veins are present.

Lithology 8 is interpreted as the most favorable host lithology for base-metal concentrations. The associ- ation may be due to the position of lithology 8 units below black shales of lithology 1 that kept the root-filled muds of lithology 8 in reducing conditions and preserved reactive organic material in the woody root tissues. Reducing conditions cannot be the only control on the localization of sulfide mineralization, however, as the organic-matter-rich black shales of lithology 1 are not mineralized. The preferential base-metal enrichment of lithology 8 may also be because of its slightly sandier and, therefore, more permeable nature that would allow passage of metal-bearing fluids. The metal-bearing fluids may have been introduced long after lithification along fractures, and sulfide dissemination occurred by their reaction with and dissolution of carbonate cements. The observations on the reaction rims around veins and fractures in other lithologies support this hypothesis, but it is not known whether the metals were introduced by fluids along the fractures or if the metals were remobilized from their initial accumulation in lithology 8 .

Features other than the specific sedimentological characteristics of the quarry section may have been important in the development of base-metal enrichment in these rocks. Saline fluids may have been important for the transport of base metals. However, there is no evidence of saline conditions in the quarry sequence, such as evaporite pseudomorphs. The apparent absence of fossils in the black shales may be due to saline depositional conditions, but no detailed studies have been made. Evaporite casts are found in stratigraphically higher intervals of the Balls Bluff Siltstone. These evaporites may have produced metal-bearing brines that mineralized the older deposits. A Jurassic diabase intrusive that occurs near the quarry may have affected the movement of fluids that transported the metals. A fault along the east side of the Precambrian basement inlier east of the quarry (fig. 3) appears to have been a conduit for diabase intrusion and could have carried hydrothermal brines to the sediments before and during intrusion.

Although the mechanism and timing of base-metal mineralization in the Culpeper Crushed Stone quarry occurrence is poorly understood, the lithologically selective mineralization within cyclic mudstones provides a model for further exploration in the Newark Supergroup. Cyclic mudstones with similar lithologic sequences to the Culpeper Crushed Stone quarry cycles occur in the Lockatong Formation and the lower Passaic Formation in the Newark basin and in the Gettysburg Formation in the Gettysburg basin. A sample of sandy mudstone similar to lithology 8 within a cycle in the informal Skunk Hollow member of Olsen (1984b) of the Lockatong Formation near Chalfont, Pennsylvania, contains 1,500 ppm copper, whereas samples from adjacent mudstones and shales all contain around $100 \mathrm{ppm}$ copper. The sandy mudstone similar to lithology 8 was overlain by a black 


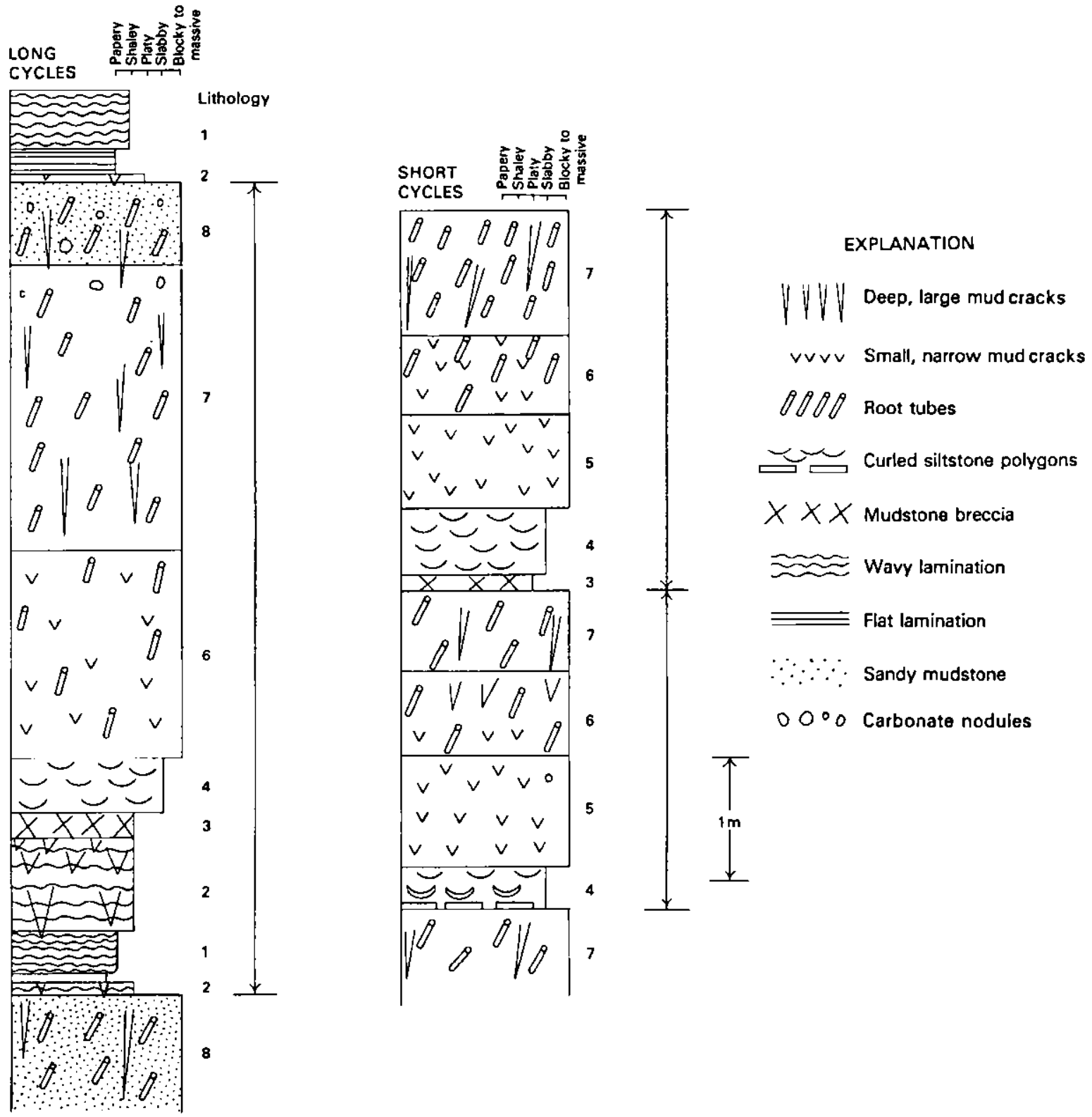

Figure 5. Sketches showing vertical cross sections of the distribution of lithologies in the two end-member varieties of cycles in the Culpeper Crushed Stone quarry. The lithologic types (numbered) are described in the text. The amount of indentation represents the parting character of the rock.

shale similar to lithology 1 . Cycles similar to those of the Culpeper Crushed Stone quarry have not been reported outside of the Newark Supergroup, and similar relationships of depositional facies to mineralization are not known to have been mentioned in the literature on lacustrine base-metal deposits.

\section{DISCUSSION}

Both varieties of sedimentary stratabound basemetal mineral occurrences in the Newark Supergroup are small and are not presently of economic significance.
The lacustrine-hosted deposits may have economic potential, if bulk mining techniques are feasible. It is useful to postulate the variables that may control larger, richer deposits. In the case of the fluvial sandstones, the depositional features to consider are the size of the channel, the amount of organic material, and the presence of reducing conditions.

Figure 8 illustrates a possible channel pattern for axial meandering streams entering a closed basin (Langbein, 1961), a situation that could explain the distribution of fluvial deposits in several of the Newark Supergroup basins. A complex meandering pattern extends from 


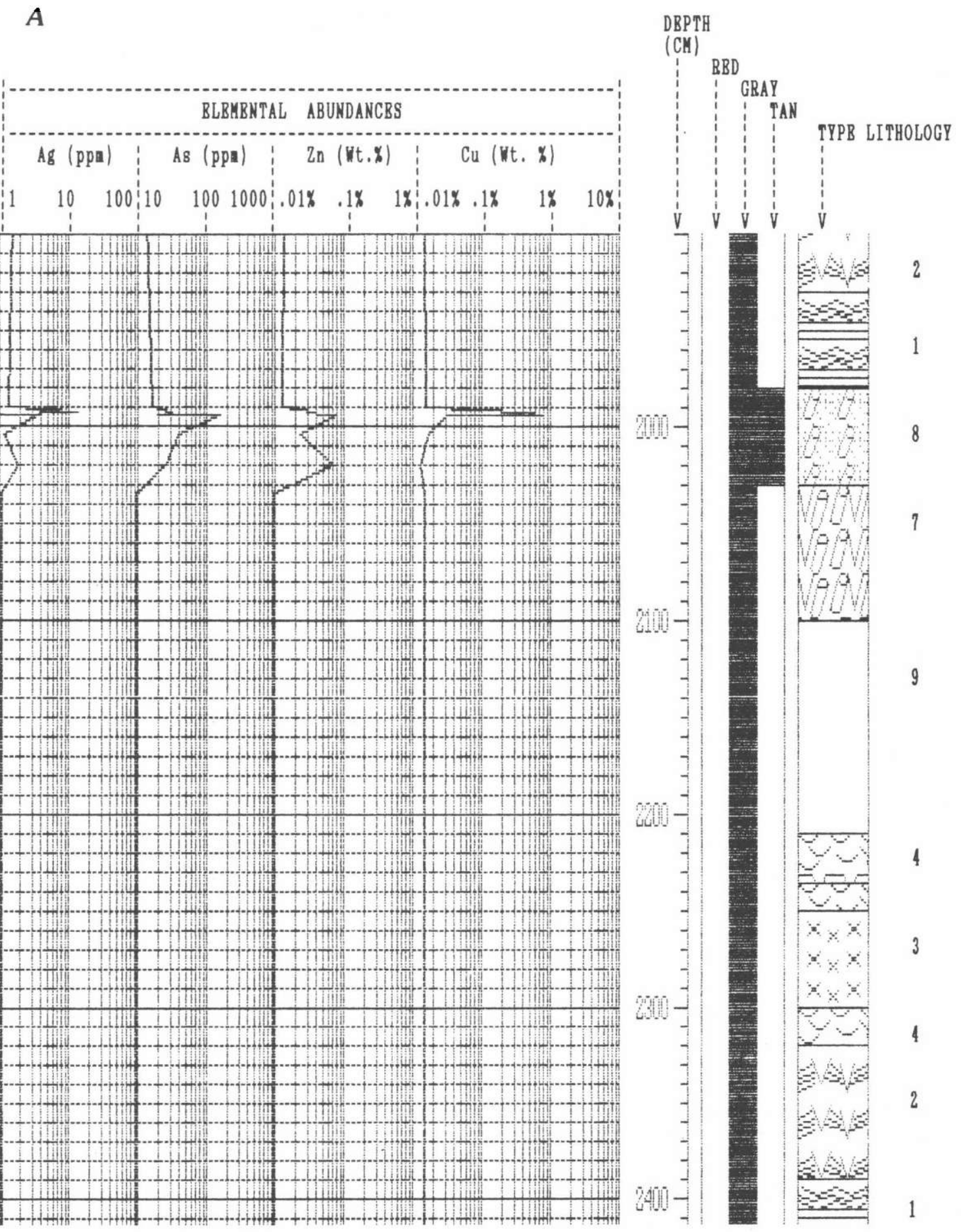

Figure 6. Plots of the distribution of elemental abundances in two vertical sequences within the Culpeper Crushed Stone quarry are shown in $A_{1} 5.1 \mathrm{~m}$ of section, and $B, 7 \mathrm{~m}$ of section. The location of these sequences in the stratigraphic section is shown in figure 4. Type lithology is equivalent to lithologic types described in the text and illustrated in figure 5. Lithologic type 9 is undifferentiated massive mudstone.

several large trunk streams. One exploration goal would be to look for the trunk channels near the axial margin of the basin. The larger channels would have larger bedforms, which could be draped by thicker and more continuous clay layers, thus providing larger potential reservoirs for mineralization. High-gradient streams along other margins would probably not have clay drapes and therefore would not be good targets. If the basin ground-water system were saline, larger plants would grow at the edges of the basin as opposed to the central 


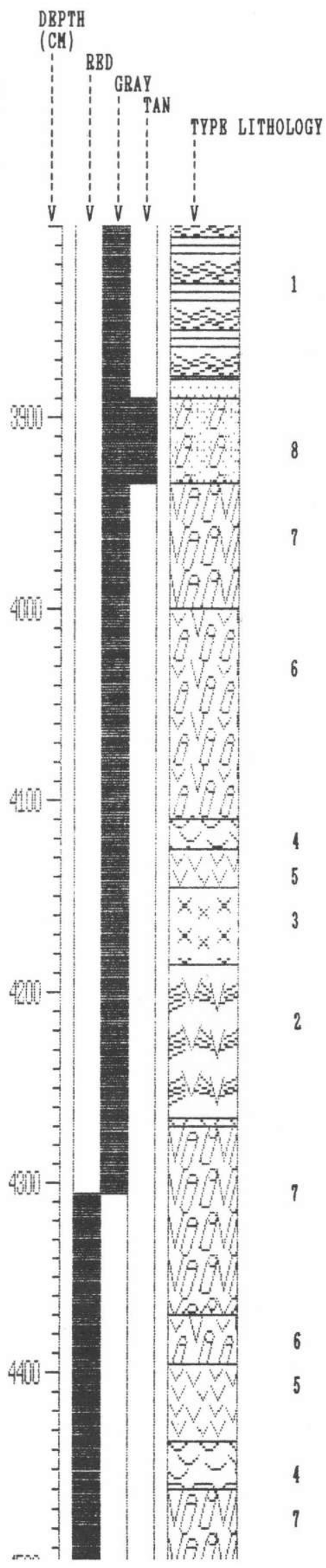

Figure 6. Continued. 


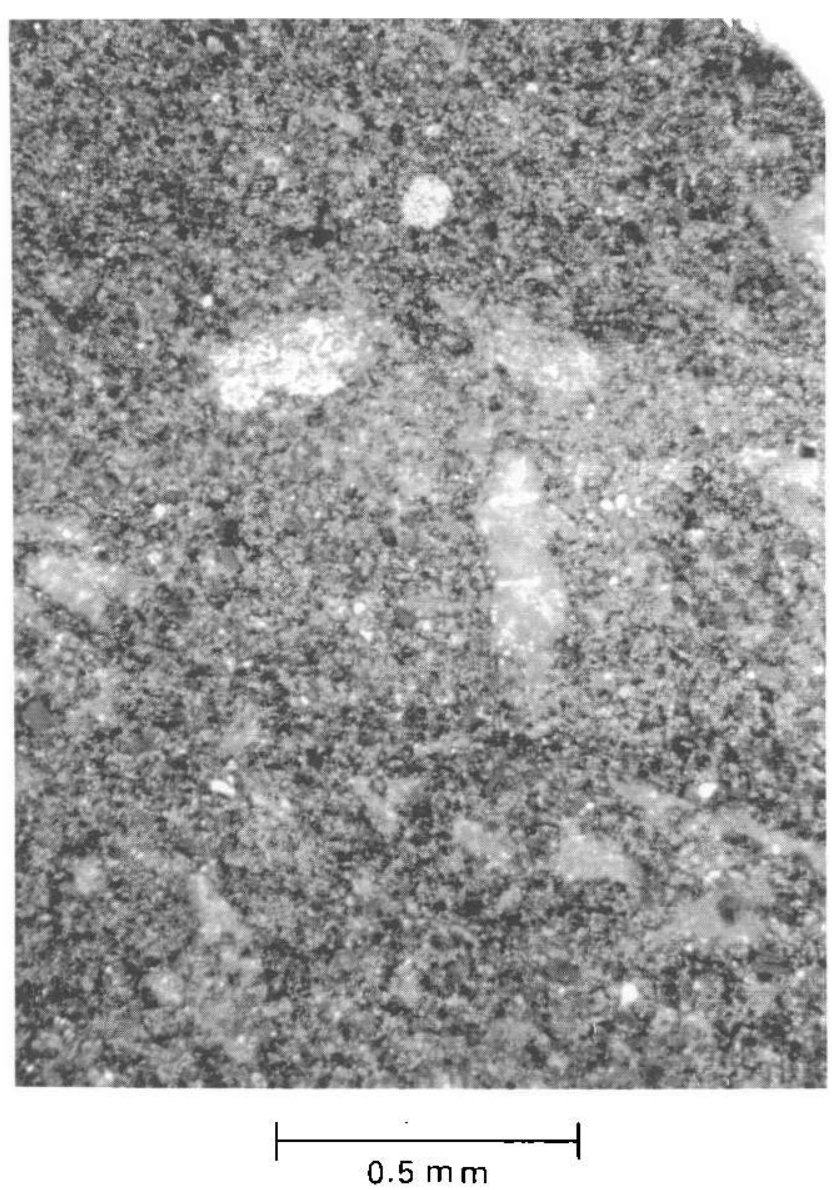

Figure 7. Reflected-light photomicrograph of lithology 8 sandy mudstone containing base metals. Note the porefilling cement textures in light-colored tubes (root casts). Lightest patches are aggregates of sulfides within tube structures.

parts. Therefore, even the small streams that are near the margins may be preferred sites for mineralization. Large logs are documented sites of mineralization in the Nacimiento deposits (Woodward and others, 1974). The presence of logs need not be the only necessary ingredient for mineralization, however, as large logs in fluvial sandstones in the Taylorsville and Richmond basins of Virginia show no evidence of mineralization. Further, Flint (1986) makes no mention of woody material associated with the copper minerals of the San Bartolo copper deposit in Chile. If intermittent drowning of the fluvial system by transgressing lakes is important for producing thick mudstone-siltstone lenses within the fluvial sandstone, it would be important to know the maximum extent of lake transgression. The best localities for mineralization in this scenario would consist of a compromise between the maximum extent of lake transgression, where the thickest channel sands would occur, and areas most frequently covered by transgressions, where there would be more chances of developing reducing conditions. The more basinward deposits would also be closer to sources for saline fluids that could be the source of metals.

The lacustrine mudstone mineralization appears to be controlled by the immediate superposition of organicrich, deep-water lacustrine shale over sandy, root-rich mudstone. Thicker lake deposits may lead to larger or richer mineralized zones in the underlying mudstone. The sedimentary structures in the Culpeper Crushed Stone quarry suggest that the lakes deepened to the west or northwest, so that thicker black shales may occur in that direction. Cyclic mudstones with black shales much thicker than the Culpeper Crushed Stone quarry examples, however, are not known to be associated with base-metal minerals. In these deposits a thick sequence of transgressive mudstone or sandstone lies between the black shale and the root-disrupted mudstone. This suggests that an environment is required where sedimentation rates were low with respect to the rate of lake transgression. An exploration strategy under these constraints would avoid areas of deltaic accumulation and search for thick lacustrine shales formed during arid periods, during which sedimentation rates are generally low. Arid conditions may also provide saline fluids to mobilize the base metals.

The base-metal mineral occurrences in both types of deposits in the Newark Supergroup appear to be postdepositional, so the overprint of diagenetic conditions may be critical for mineral enrichment. Magnitude of enrichment may vary with the proximity of intrusives or large faults or the depth of sediment burial during the mineralization. Patterns of fluid circulation induced by diabase intrusion would be concentrated in more porous and permeable layers, such as uncemented near-surface sediments. Faults may act as conduits for hydrothermal brines and carry the fluids to the more porous layers. Another variable may be the structural-stratigraphic relationship of the fluvial deposits to evaporite-bearing strata. If evaporites are located in sediments down-dip from the sandstones, it is possible that they provided warm brines as they were compacted during burial. 


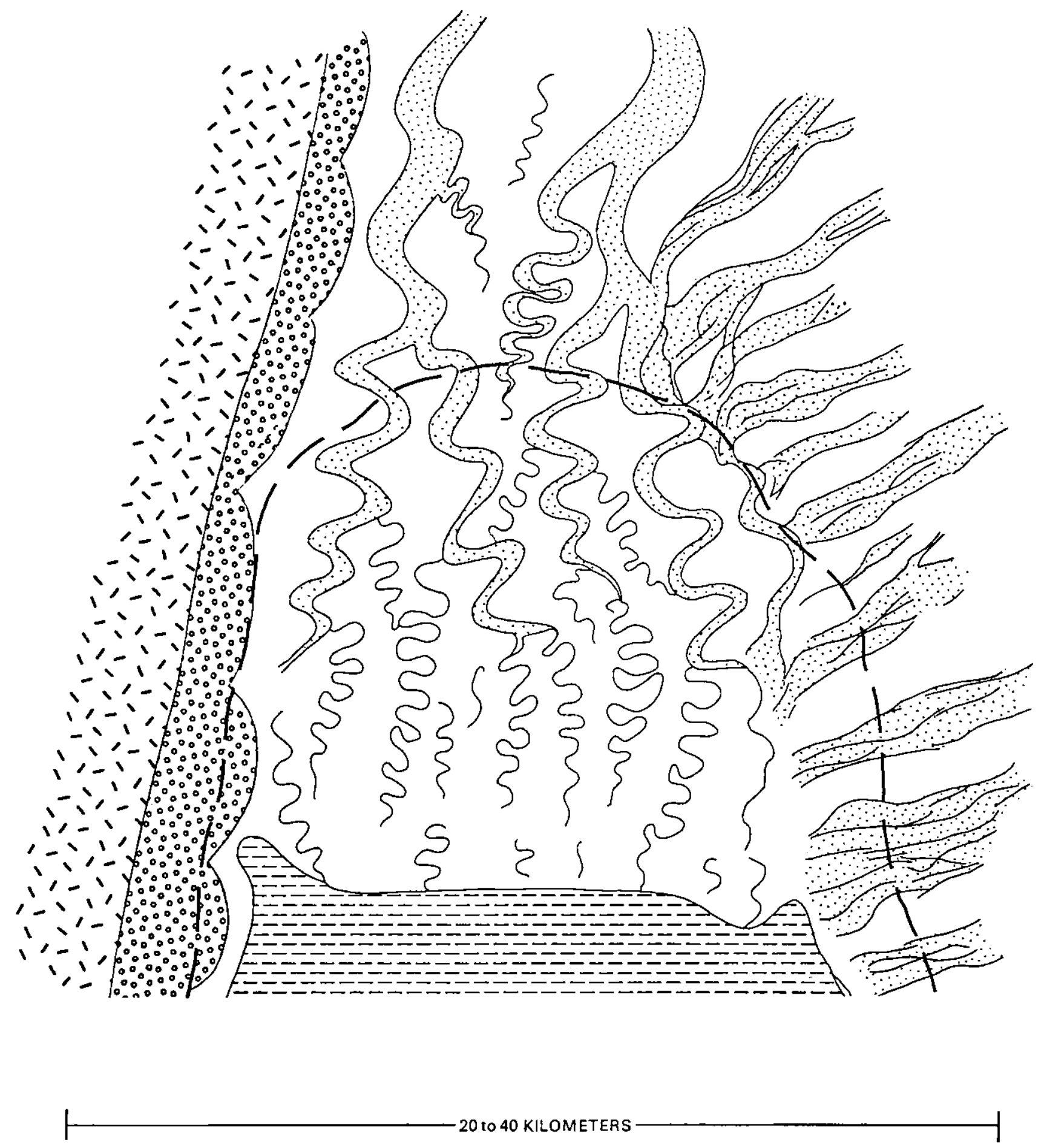

Figure 8. Sketch showing hypothetical distribution of channel sands (map view) in a closed basin during deposition. Thick dashed line represents the limits of lake transgression over the fluvial system. Dashed pattern covers the area of little or no fluvial deposition. The channel patterns on the right side are high-gradient braided streams and the patterns on the left side are alluvial fans. 


\section{REFERENCES CITED}

Allen, J.R.L., 1980, Sand waves: A model of origin and internal structure: Sedimentary Geology, v. 26, p. 281-328.

Bascom, F., and Stose, G.W., 1938, Geology and mineral resources of the Honeybrook and Phoenixville quadrangles, Pennsylvania: U.S. Geological Survey Bulletin 891, $145 \mathrm{p}$.

Bastin, E.S., 1933, The chalcocite and native copper types of ore deposits: Economic Geology, v. 28, p. 407-446.

Beck, H.H., 1952, The minerals of Lancaster County, 3rd edition: Linnaean Society of Lancaster County, Lancaster, Pennsylvania, $13 \mathrm{p}$.

Bernstein, L.R., 1980, Minerals of the Washington D.C. area: Maryland Geological Survey, Education Series, no. 5, 148 p.

Boersma, J.R., Van de Meene, E.A., and Tjalsma, R.C., 1968, Intricated cross-stratification due to interaction of a megaripple with its lee-side system of backflow ripples (upperpoint bar deposits, lower Rhine): Sedimentology, v. 11, p. 147-162.

Bridge, J.S., Smith, N.D., Trent, F., Gabel, S.L., and Bernstein, P., 1986, Sedimentology and morphology of a low-sinuosity river: Calamus River, Nebraska Sand Hills: Sedimentology, v. 33, p. 851-870.

Broderick, T.M., 1929, Zoning in Michigan copper deposits and its significance, Part II: Economic Geology, v. 24, p. 311-326.

Brown, A.C., 1971, Zoning in the White Pine copper deposit, Ontonagon County, Michigan: Economic Geology, v. 66, p. 543-573.

Brown, R.H., 1980, Triassic rocks of Argana Valley, southern Morocco, and their regional structural implications: American Association of Petroleum Geologists Bulletin, v. 64, p. 988-1003.

Cant, D.J., 1982, Fluvial facies models and their application, in Scholle, P.A., and Spearing, D., eds., Sandstone depositional environments: American Association of Petroleum Geologists Memoir 31, p. 115-137.

Clemmensen, L.B., 1980, Triassic rift sedimentation and paleogeography of central East Greenland: Gronlands Geologiske Undersogelse, Bulletin 136, 72 p.

Cook, G.H., 1883, Miscellaneous-Copper ores: New Jersey Geological Survey, Annual Report of the State Geologist, 1883 , p. $164-166$.

Cornwall, H.R., 1945, The Arlington copper mine, North Arlington, New Jersey: U.S. Geological Survey Strategic Minerals Investigation Report (unnumbered, 1943), 6 p.

D'Agostino, J.P., and Hanshaw, P.M., 1970, Malachite- and specularite-bearing Triassic sandstone localities near Chantilly, Virginia: U.S. Geological Survey Professional Paper 700-C, p. C103-C106.

Daniels, P.A., Jr., 1982, Upper Precambrian rocks: Oronto Group, Michigan-Wisconsin, in Wold, P.J., and Hinze, W.J., eds., Geology and tectonics of the Lake Superior Basin: Geological Society of America Memoir 156, p. 107-133.

Darton, N.H., 1885, On the occurrence of native silver in New Jersey: American Journal of Science, 3d series, v. 30, p. $80-81$.
Entwistle, L.B., and Gouin, L.O., 1955, The chalcocite-ore deposits at Corocoro, Bolivia: Economic Geology, v. 50, p. 555-570.

Eyerman, J., 1889, Mineralogy of Pennsylvania, Part I: Easton, Pennsylvania, (n.p.).

Finlow-Bates, T., 1979, Cyclicity in the lead-zinc-silver-bearing sediments at Mount Isa Mine, Queensland, Australia, and rates of sulfide accumulation: Economic Geology, v. 74, p. 1408-1419.

Flint, S., 1985, Alluvial fan and playa sedimentation in an Andean arid closed basin: The Pacencia Group, Antofagasta Province, Chile: Journal of the Geological Society of London, v. 142, p. 533-546.

1986, Sedimentary and diagenetic controls on red-bed ore genesis: The Middle Tertiary San Bartolo copper deposit, Antofagasta Province, Chile: Economic Geology, v. 81, p. $761-778$.

Frazer, P., 1880, The geology of Lancaster County: Pennsylvania Geological Survey (2d), Report of Progress in 1877, Report CCC, 350 p.

1886, Sketch on the geology of York County, Pennsylvania: American Philosophical Society Proceedings, v. 16, p. $651-655$.

Froelich, A.J., 1975, Map showing mineral resources of Montgomery County, Maryland: U.S. Geological Survey Miscellaneous Investigations, Series Map I-920-E.

Froelich, A.J., and Leavy, B.D., 1981, Map showing mineral resources of the Culpeper basin, Northern Virginia and Maryland: U.S. Geological Survey Miscellaneous Investigations, Series Map I-1313-B.

Gann, D.E., and Hagni, R.D., 1974, Ore microscopy of copper ore at the Creta Mine, southern Oklahoma: Geological Society of America Abstracts with Programs, v. 5, p. 104.

Gibling, M.R., and Rust, B.R., 1987, Evolution of a mud-rich meander belt in the Carboniferous Morien Group, Nova Scotia, Canada: Bulletin of Canadian Petroleum Geology, v. 35 , p. $24-33$.

Giles, L.H., Peterson, F.F., and Grossman, R.B., 1966, Morphological and genetic sequences of carbonate accumulation in desert soils: Soil Science, v. 101, p. 347-360.

Gordon, S.G., 1922, The mineralogy of Pennsylvania: Special Publication No. 1, Academy of Natural Science, Philadelphia (reprinted 1973 by Friends of Mineralogy, Region III), $255 \mathrm{p}$.

Gray, N.H., 1982, Copper occurrences in the Hartford basin of northern Connecticut, in Joesten, Raymond, and Quarrier, S.S., eds., Guidebook for Fieldtrips in Connecticut and South Central Massachusetts: New England Intercollegiate Geological Conference, 74th Annual Meeting, p. 195-211.

Gustafson, L.B., and Williams, Neil, 1981, Sediment-hosted stratiform deposits of copper, lead, and zinc: Economic Geology, 75th Anniversary Volume, p. 139-178.

Hagni, R.D., and Gann, D.E., 1976, Microscopy of copper ores at the Creta Mine, southwestern Oklahoma: Oklahoma Geological Survey Circular 77, p. 40-50.

Hayes, W.H., 1949, The Bridgewater Copper Mine from the collector's point of view: Rocks and Minerals, v. 24, p. 27-29. 
Jopling, A.V., 1967, Origin of laminae produced by the movement of ripples along a streambed: A laboratory study: Journal of Geology, v. 75, p. 287-305.

Katz, S.B., 1983, Sedimentary features and soil-like fabrics in chemical cycles of the Lockatong Formation, Newark Supergroup (Late Triassic), New Jersey and Pennsylvania: Stony Brook, State University of New York at Stony Brook, unpublished M.S. thesis, 134 p.

Kidwell, A.L., and Bower, R.R., 1974, Mineralogy and microtextures of sulfides in the Flowerpot Shale of Oklahoma and Texas: Geological Society of America Abstracts with Programs, v. 5, p. 110.

Kummel, H.S., 1901, Mining industry of New Jersey: New Jersey Geological Survey, Annual Report of the State Geologist, 1901, p. 150-156.

Langbein, N.B., 1961, Salinity and hydrology of closed lakes: U.S. Geological Survey Professional Paper 412, 20 p.

LaPoint, D.J., 1976, A comparison of selected sandstone copper deposits in New Mexico: Oklahoma Geological Survey Circular 77, p. 80-96.

Lee, K.Y., 1979, Triassic-Jurassic geology of the northern part of the Culpeper basin, Virginia and Maryland: U.S. Geological Survey Bulletin 1422-C, 17 p.

1980, Triassic-Jurassic geology of the southern part of the Culpeper basin and the Barboursville basin, Virginia: U.S. Geological Survey Open-File Report 80-468, 19 p., scale $1: 24,000$.

Lee, K.Y., and Froelich, A.J., 1985, Geochemical data for Triassic sedimentary and thermally metamorphosed rocks of the northern Culpeper basin, Virginia: U.S. Geological Survey Open File Report 85-215, 17 p.

Lee, O.I., 1937, Ye ancient copper mine of Arent Schuyler: Rocks and Minerals, v. 12, p. 99-109.

Lewis, J.V., 1907a, Copper deposits of the New Jersey Triassic: Economic Geology, v. 2, p. 242-257.

1907b, The Newark (Triassic) copper ores of New Jersey: New Jersey Geological Survey, Annual Report of the State Geologist, 1906, p. 131-164.

Lindgren, W., 1933, Mineral deposits, 4th edition: New York, McGraw Hill Book Company, Inc., 930 p.

Ljunggren, P., and Meyer, H.C., 1964, The copper mineralization in the Corocoro basin, Bolivia: Economic Geology, v. 59 , p. 110-125.

Love, L.G., 1962, Biogenic primary sulfides of the Permian Kupferschiefer and Marl Slate: Economic Geology, v. 57, p. 350-366.

Love, L.G., and Zimmerman, D.O., 1961, Bedded pyrite and micro-organisms from the Mount Isa Shale: Economic Geology, v. 56, p. 873-896.

Luttrell, G.W., 1966, Base- and precious-metal and related ore deposits of Virginia: Virginia Division of Mineral Resources, Mineral Resource Report 7,167 p.

Maiden, K., Master, S., and Borg, G., 1986, Rift-related stratabound copper-precious metal deposits in southern Africa: Abstracts for the 12th International Sedimentological Congress, Canberra, Australia, p. 197.

Mathias, B.V., and Clark, G.J., 1975, Mount Isa copper and silver-lead-zinc orebodies-Isa and Hilton mines, in Knight, C.L., ed., Economic geology of Australia and
Papua New Guinea, I. Metals: Australian Institute of Mining Metallurgy Monograph 5, p. 351-372.

Mermut, A.R., and Dasog, G.S., 1986, Nature and morphology of carbonate glaebules in some vertisols of India: Soil Science of America Journal, v. 50, p. 382-391.

Muir, M.D., 1981, The microfossils from the Proterozoic Urquhart Shale, Mount Isa, Queensland, and their significance in relation to the depositional environment, diagenesis, and mineralization: Mineralium Deposita, v. 16, p. 51-58.

1983, Depositional environments of host rocks to northem Australian lead-zinc deposits, with special reference to McArthur River, in Sangster, D.F., ed., Sediment-hosted stratiform lead-zinc deposits: Mineralogical Association of Canada Short Course Handbook, v. 8, p. 141-174.

Neudert, M.K., 1986, Sedimentology of the Middle Proterozoic Mount Isa Group, Queensland, Australia: Abstracts for the 12th International Sedimentological Congress, Canberra, Australia, p. 229.

Newham, W.D.N. (compiled by F. Mendelsohn), 1986, The Lomagundi and Sabi metallogenic provinces of Zimbabwe, in Anhaeusser, C.R., and Maske, S., eds., Mineral deposits of Southern Africa, volume II: Johannesburg, South Africa, Geological Society of South Africa, p. 1351-1393.

Newhouse, W.H., 1933, Mineral zoning in the New JerseyPennsylvania-Virginia Triassic area: Economic Geology, v. 28, p. 613-633.

Olsen, P.E., 1977, Stop 11-Triangle Brick Quarry, in Bain, G.L., and Harvey, B.W., eds., Field guide to the geology of the Durham Basin: Carolina Geological Society, Fortieth Anniversary Meeting, p. 59-60.

1984a, Comparative paleolimnology of the Newark Supergroup: A study of ecosystem evolution: New Haven, Connecticut, Yale University, unpublished Ph.D. thesis, $726 \mathrm{p}$.

1984b, Periodicity of lake-level cycles in the Late Triassic Lockatong Formation of the Newark basin (Newark Supergroup), New Jersey and Pennsylvania, in Berger and others, eds., Milankovitch and climate: D. Reidel Publishing Co., Pt. 1, p. 129-146.

1986, A 40-million-year lake record of Early Mesozoic orbital climatic forcing: Science, v. 234, p. 842-848.

Perrin, J.D., 1976, Geology of the Newgate Prison Mine, East Granby, Connecticut: Storrs, Connecticut, The University of Connecticut, unpublished M.S. thesis, $93 \mathrm{p}$.

Potisat, S., 1978, Copper and uranium deposits in red beds of the Connecticut Valley: Middletown, Connecticut, Wesleyan University, unpublished M.S. thesis, $123 \mathrm{p}$.

Roberts, J.K., 1928, The Geology of the Virginia Triassic: Virginia Geological Survey, Bulletin 29, 205 p.

Rogers, W.B., 1884, A reprint of annual reports and other papers on the geology of the Virginias: New York, D. Appleton and Company, $832 \mathrm{p}$.

Rose, A.W., 1970, Atlas of Pennsylvania's mineral resources, Part 3: Metal mines and occurrences in Pennsylvania: Pennsylvania Geological Survey, Bulletin M-50, 14 p.

1976, The effect of cuprous chloride complexes in the origin of red-bed copper and related deposits: Economic Geology, v. 71, p. 1036-1048.

Rust, B.R., and Legun, A.S., 1983, Modern anastomosingfluvial deposits in arid Central Australia, and a Carboni- 
ferous analogue in New Brunswick, Canada, in Collinson, J.D., and Lewin, J., eds., Modern and ancient fluvial systems: International Association of Sedimentologists Special Publication 6, p. 385-392.

Ruxton, P.A., 1986, Sedimentology, isotopic signature and ore genesis of the Klein Aub copper mine, South-west Africa/ Namibia, in Anhaeusser, C.R., and Maske, S., eds., Mineral deposits of Southern Africa, volume II: Johannesburg, South Africa, Geological Society of South Africa, p. 1725-1738.

Rye, D.M., and Williams, N., 1981, Studies of the base-metal sulfide deposits at McArthur River, Northern Territory, Australia, III, The stable isotope geochemistry of the H.Y.C., Ridge, and Cooley deposits: Economic Geology, v. 76, p. $1-26$.

Schairer, J.F., 1931, The minerals of Connecticut: Connecticut Geological and Natural History Survey, Bulletin 51.

Smith, D.G., 1983, Anastomosed fluvial deposits: Modern examples from western Canada, in Collinson, J.D., and Lewin, J., eds., Modern and ancient fluvial systems: International Association of Sedimentologists Special Publication 6, p. 155-168.

Smith, G.E., 1976, Sabkha and tidal-flat facies control of stratiform copper deposits in north Texas: Oklahoma Geological Survey Circular 77, p. 25-39.

Smoot, J.P., 1981, Subaerial exposure criteria as seen in modern playa mudcracks: American Association of Petroleum Geologists Bulletin, v. 65 , p. 530.

-1985, The closed-basin hypothesis and its use in facies analysis of the Newark Supergroup, in Robinson, G.R., Jr., and Froelich, A.J., eds., Proceedings of the second U.S. Geological Survey workshop on the early Mesozoic basins of the Eastern United States: U.S. Geological Survey Circular 946, p. 4-10.

Smoot, J.P., and Katz, S.B., 1982, Comparison of modern playa mudflat fabrics to cycles in the Triassic Lockatong Formation of New Jersey: Northeastern-Southeastern Sections, Geological Society of America Abstracts with Programs, v. 14 , p. 83.

Smoot, J.P., and Olsen, P.E., 1985, Massive mudstones in basin analysis and paleoclimatic interpretation of the Newark Supergroup, in Robinson, G.R., Jr., and Froelich, A.J., eds., Proceedings of the second U.S. Geological Survey workshop on the early Mesozoic basins of the Eastem United States: U.S. Geological Survey Circular 946, p. 29-33.

-in press, Massive mudstones in basin analysis and paleoclimatic interpretation of the Newark Supergroup, in Manspeizer, Warren, ed., Triassic-Jurassic rifting and the opening of the Atlantic Ocean: Elsevier Publishers, The Netherlands.

Stewart, D.J., 1983, Possible suspended-load channel deposits from the Wealdon Group (Lower Cretaceous) of southern England, in Collinson, J.D., and Lewin, J., eds., Modern and ancient fluvial systems: International Association of Sedimentologists Special Publication 6, p. 369-384.

Stose, G.W., and Jonas, A.I., 1939, Geology and mineral resources of the Honeybrook-Phoenixville quadrangles, Pennsylvania: Pennsylvania Geological Survey, 4th series, Bulletin C-67, 199 p.

Taylor, G. and Woodyer, K.D., 1978, Bank deposition in suspended-load streams, in Collinson, J.D., and Lewin, J., eds., Modern and ancient fluvial systems: International Association of Sedimentologists Special Publication 6, p. 155-168.

Turner-Peterson, C.E., 1980, Sedimentology and uranium mineralization in the Triassic-Jurassic Newark basin, Pennsylvania and New Jersey, in Turner-Peterson, C.E., ed., Uranium in sedimentary rocks-Application of the facies concept to exploration: Rocky Mountain Section, Socicty of Economic Paleontologists and Mineralogists Short Course Notes, p. 149-175.

Van den Heuvel, H.B., 1969, Sedimentation, stratigraphy, and post-depositional changes in the sediments of the upper formations of the Mount Isa Group, northwest Queensland: University of Queensland, unpublished Ph.D. thesis.

Webster, B., 1978, Mineral collector's field guide, Connecticut: E.R. Webster, Jr.

Weed, W.H., 1903, Copper deposits of New Jersey: New Jersey Geological Survey, Annual Report of the State Geologist, 1902, p. 125-140.

1911, Copper deposits of the Appalachian States: U.S. Geological Survey Bulletin 455, 166 p.

Weems, R.E., 1987, A Late Triassic footprint fauna from the Culpeper basin, northern Virginia (U.S.A.): Transactions of the American Philosophical Society, v. 77, part 1, 79 p.

Wells, R.F., 1977, Freshwater invertebrate living traces of the Mississippi alluvial valley near Baton Rouge, Louisiana: Baton Rouge, Louisiana State University, unpublished Ph.D. thesis, $254 \mathrm{p}$.

Wherry, E.T., 1908, The Newark copper deposits of southeastern Pennsylvania: Economic Geology, v. 3, p. 726-738.

White, D.E., 1968, Environments of generation of some basemetal ore deposits: Economic Geology, v. 63, p. 301-335. 1971, A paleohydrologic model for mineralization of the White Pine copper deposit, northern Michigan: Economic Geology, v. 66, p. 1-13.

Williams, N., 1979, Studies of the base-metal sulfide deposits at McArthur River, Northern Territory, Australia, II, The sulfide-S and organic-C relationships of the concordant deposits and their significance-A reply: Economic Geology, v. 74, p. 1699-1702.

Wilson, I.F., 1955, Geology and mineral deposits of the Boleo Copper District, Baja California, Mexico: U.S. Geological Survey Professional Paper 273, 133 p.

Woodward, H.P., 1944, Copper mines and mining in New Jersey: New Jersey Department of Conservation and Development, Geologic Series, Bulletin 57, $156 \mathrm{p}$.

Woodward, L.A., Kaufman, W.H., Schumacher, O.L., and Talbott, L.W., 1974, Strata-bound copper deposits in Triassic sandstones of Sierra Nacimiento, New Mexico: Economic Geology, v. 69, p. 108-120.

Woodyer, K.D., Taylor, G., and Crook, K.A.W., 1979, Sedimentation and benches in a very low gradient suspended-load stream: The Barwon River, New South Wales: Sedimentary Geology, v. 22, p. 97-120. 


\title{
CHARACTERISTICS OF BASE-METAL AND BARITE VEIN DEPOSITS ASSOCIATED WITH RIFT BASINS, WITH EXAMPLES FROM SOME EARLY MESOZOIC BASINS OF EASTERN NORTH AMERICA
}

\author{
Gilpin R. Robinson, Jr., and Laurel G. Woodruff
}

\begin{abstract}
Epithermal base-metal and barite vein deposits are common within or near the margins of rift basins in continental settings. A number of vein deposits of this type are associated with the Fundy, Deerfield-Hartford, Newark, and Culpeper early Mesozoic basins of eastern North America. Mineralized veins occur as open-space fillings in high-angle faults or fractures in sedimentary rocks of the basins and in adjacent crystalline rocks. Fluid inclusion data from sphalerite and quartz, and sulfur isotope fractionation between coexisting galena and sphalerite indicate that the veins crystallized in the range of 100 to $250^{\circ} \mathrm{C}$. The source fluids are inferred to have been brines of moderate salinity (10 to 16 equivalent weight percent $\mathrm{NaCl}$ ).

The vein deposits appear to be associated with the transport of moderate-temperature $\left(100\right.$ to $\left.250{ }^{\circ} \mathrm{C}\right)$ brines from within the basins and adjacent "basement" rocks to shallow sites of mineral precipitation. Preexisting fractures and faults are apparently important in localizing vein development. Sulfate reduction, cooling, wall-rock reaction, and (or) fluid mixing may be important mechanisms of sulfide deposition in these vein deposits. Multiple periods of mineralization, possibly more than one fluid source, and many pulses of fluid migration are evident in many of the vein systems. Fluid migration may be due to a seismic pumping process that was active in Middle Jurassic time as result of the changing stress regime developed during the separation of North America from Africa.
\end{abstract}

\section{INTRODUCTION}

Base-metal and barite vein deposits occur within and bordering the Fundy (Nova Scotia-New Brunswick, Canada), Deerfield-Hartford (Massachusetts-Connecticut), Newark (New York-New Jersey-Pennsylvania), and Culpeper (Maryland-Virginia) early Mesozoic basins of eastern North America. The locations of 14 districts containing 92 vein deposits in the Eastern United States are shown in figure 1, and summary information on 96 deposits is given in table 1 . The largest base-metal and barite vein deposit associated with the early Mesozoic basins of eastern North America is the Magnet Cove barite-sulfide deposit near Walton, Nova Scotia, bordering the eastern margin of the Fundy basin (Boyle, 1962; Boyle and Jambor, 1966). As of 1964, mining of this deposit yielded approximately 3.3 million tons of barite and 16.7 thousand tons of sulfide concentrates with a total metal content of 1.3 million pounds of $\mathrm{Cu}, 9$ million pounds of $\mathrm{Pb}, 4.3$ million pounds of $\mathrm{Zn}$, and 1.3 million ounces of $\mathrm{Ag}$ (Boyle and Jambor, 1966, p. 396).
Base-metal and barite vein deposits are generally situated near the margins of rift basins of many ages in continental settings. Vein deposits of this type can be found within and bordering Late Proterozoic rift basins in the Lake Superior region of Ontario, Canada (Franklin and Mitchell, 1977); the Cretaceous Benue trough, Nigeria (Olade and Morton, 1985; Maurin and Lancelot, 1987); the Paleozoic Midland Valley, Scotland, (Jassim and others, 1983; Pattrick and others, 1983); rift basins associated with the Rhine Graben system, Federal Republic of Germany (Hoffmann and Baumann, 1984); and pull-apart basins and linear fault zones along the Grenville front, Scandinavia (Andreasson and others, 1987), and south of the Rhodesian craton, South Africa (Reimer, 1986).

In general, these deposits contain $\mathrm{Pb}, \mathrm{Zn}$, and $\mathrm{Cu}$ sulfide minerals and are characterized by high $\mathrm{Ag}$ contents. The silver is typically present as a minor component in abundant sulfide minerals, such as galena, and in some cases is present as trace sulfosalts and sulfides, such as tetrahedrite and acanthite. Representative analyses of silver and other rare metals in bulk ore and sulfide concentrates from selected vein deposits given in table 1 are presented in table 2. High silver contents make these veins attractive exploration targets and indicate that precious- and base-metal-bearing fluids were transported through these basins. Rocks in the vicinity of these vein deposits may also host other types of base-metal deposits formed by the transport of metal-bearing fluids in similar extensional basins, such as lacustrine mudstonehosted stratabound base-metal sulfides (Smoot and Robinson, this volume) and stratabound sandstonehosted Cu-Ag deposits similar to those of the Revett-type in the Belt Supergroup, Montana-Idaho (Lange and Sherry, 1983). In fact, these base-metal and barite vein deposits share a similar geologic setting and geochemical association with a number of silver vein districts, such as Cobalt-Gowganda and Thunder Bay, Canada (Andrews, 1986), and Coeur d'Alene, Montana-Idaho (Fryklund, 1964; Landis and others, 1984). In this broad class of deposits, a consistent set of geologic features includes:

1. A tectonic environment characterized by basinal subsidence and crustal extension in a continental setting,

2. Spatial association of the vein deposits with regional faults, and 


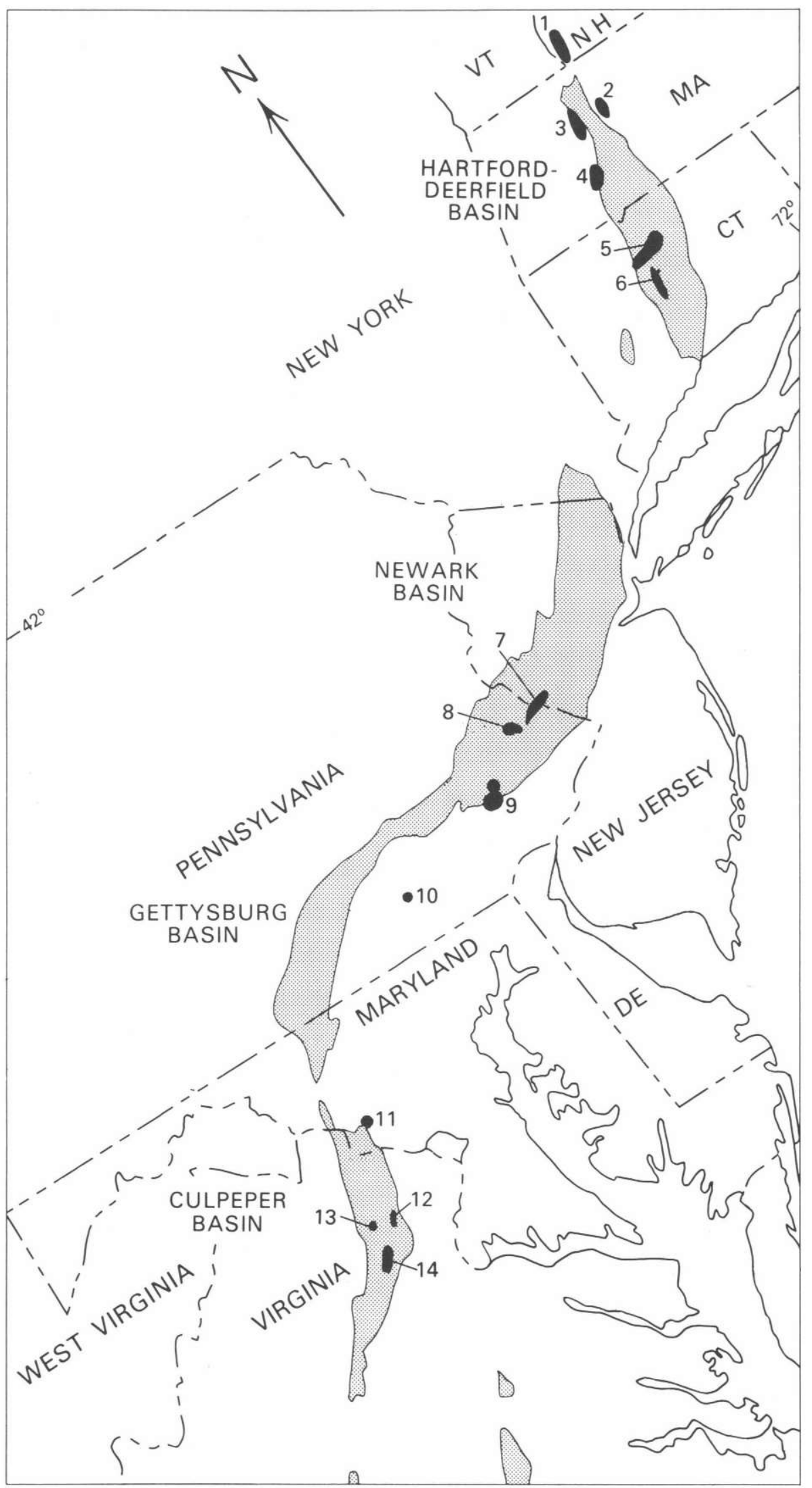


- Figure 1. Map showing the distribution of mine districts containing base-metal and barite vein deposits associated with the early Mesozoic basins of Massachusetts, Connecticut, New York, New Jersey, Pennsylvania, Maryland, and Virginia. The early Mesozoic basins are indicated by the stippled pattern. The distribution of mine districts and deposits is indicated by the solid black pattern, with identifying number. New Hampshire: 1, Cheshire district (deposits 1-10, table 1); Massachusetts: 2, Leverett district (deposits 13-17, table 1); 3 , Whatley-Hatfield district (deposits 18-25, table 1); 4, Loudville district (deposits 26-33, table 1); Connecticut: 5. New Britain district (deposits 34-45, table 1); 6, Cheshire-Jinny Hill district (deposits 46-57, table 1); New Jersey-Pennsylvania: 7, Hopewell-Solebury district (deposits 59-63, table 1); Pennsylvania: 8, New Galena deposit (deposit 64, table 1); 9, Audubon (north) and Phoenixville (south) districts (deposits 66-84, table 1); 10, Safe Harbor deposit (deposit 85, table 1); Maryland: 11, Boyds barite occurrence (deposit 86, table 1); Virginia: 12, Cedar Run district (deposits 87-88, table 1); 13, St. Stephens deposit (deposit 89, table 1); and 14, Gear-Kemper district (deposits 90-92, table 1). Map scale approximately $1: 3,250,000$.

3. Fluid inclusion evidence indicating moderately saline brines with a temperature range generally of 100 to $250^{\circ} \mathrm{C}$ during mineralization.

\section{VEINS ASSOCIATED WITH THE EARLY MESOZOIC BASINS OF EASTERN NORTH AMERICA}

Individual veins associated with the early Mesozoic basins of eastern North America vary widely in size and extent. They range from a few centimeters to $10 \mathrm{~m}$ in width. Groups of veins may extend along strike for several kilometers, such as some of the veins in the Audubon district (deposits 68-71, table 1), Pennsylvania (Smith, 1977, p. 247-262), and the Wheatley-BrookdalePhoenix vein (deposits 77, 81, 82), Phoenixville district, Pennsylvania (Smith, 1977, p. 263-270). The mineralized intervals may also extend over considerable depths, such as in the Magnet Cove deposit bordering the Fundy basin, Nova Scotia, where sulfide and barite mineralization extends over a depth of more than $500 \mathrm{~m}$ (Boyle and Jambor, 1966).

Vein mineralogy typically consists of quartz, galena, sphalerite, and (or) chalcopyrite, with minor pyrite and tetrahedrite and local barite, fluorite, and (or) carbonate minerals. Sulfide minerals in the veins characteristically have high $\mathrm{Ag}$ content, and sphalerite may contain high $\mathrm{Cd}, \mathrm{Ge}$, and $\mathrm{Ga}$ concentrations (table 2). Some veins contain minor bitumen, such as those in the New Britain district, Connecticut (Ryan, 1984, 1986; Gray, 1982), and the Magnet Cove deposit, Nova Scotia (Boyle, 1962, p. 23). Quartz-carbonate veins from the New Britain area of Connecticut, which parallel the metal-bearing veins, also contain liquid hydrocarbons as well as bitumen in fluid inclusions (Pratt and Burruss, this volume).

On the basis of dominant mineralogy, three varieties of the veins can be defined. One variant contains quartz and sulfide minerals with or without minor barite and (or) carbonate minerals. Some examples of this type are the Cheshire mine, New Hampshire (deposit 1, table 1), the Manhan deposits, Massachusetts (deposits 27-31, table 1), the New Galena mines, (deposit 64, table 1), deposits in the Audubon district (deposits 66-72, table 1), and Phoenixville district, Pennsylvania (deposits 73-84, table 1). A second variant consists of intergrown barite, sulfides, and carbonate minerals with minor quartz, such as at the Hatfield deposit, Massachusetts (deposit 24, table 1) and some deposits in the New Britain district, Connecticut (deposits 34-42, table 1). The third variant consists largely of barite with minor quartz and only trace accessory sulfides, as at some deposits in the Cheshire-Jinny Hill district, Connecticut (deposits 47-53, table 1), the Hopewell-Solebury district, New Jersey-Pennsylvania (deposits 59-63, table 1), and deposits in Maryland and Virginia (deposits 86-92, table 1). More than one type of vein may be present at individual deposits.

The quartz, barite, fluorite, and sulfide minerals occupy open-space fillings in high-angle faults or fractures. The veins show a variety of features that are interpreted to have formed from multiple periods of mineralization. Granulation of early vein material and cutting by later veins indicate the veins were successively reopened and mineralized. Multiple generations of minerals are present, as exemplified by growth-banded quartz and zones of sphalerite with differing color and iron content. The relative proportion of minerals varies both vertically and lateraliy in a pattern of mineralogical zoning interpreted to represent multiple mineral-growth events. A schematic vertical zoning of metals and minerals in the Wheatley-Brookdale-Phoenix vein, Phoenixville district, Pennsylvania (deposits $77,81,82$, table 1) is adapted by Smith (1977, p. 269, fig. 105) from Smith (1855) and Hoofstetten (1855), and the zoning and separation of barite-rich zones from sulfide-rich zones in the Magnet Cove deposit, Nova Scotia, is illustrated by Boyle and Jambor (1966, p. 397, fig. 3). A schematic lateral zoning of metals and minerals in similar basemetal and barite veins from the Dorian area, Ontario, is given by Franklin and Mitchell (1977). In general, the veins are mineralogically zoned such that sulfide-rich areas (locally lacking barite) are surrounded both vertically and laterally by a barite-rich zone (which is nearly devoid of sulfides, in some cases). Fluorite is typically late in the paragenetic sequence of mineral deposition and occurs with barite and quartz. 
There is no direct association of the veins with igneous activity, although some veins are located on or near the flanks of Jurassic diabase sheets or dikes. Vein deposits in the Cheshire-Jinny Hill district, Connecticut (deposits 46-57, table 1) are all located near the West Rock diabase body. The Hopewell barite deposit, New Jersey (deposit 59, table 1), the Boyds, Maryland, barite occurrence (deposit 86, table 1), and the barite deposits in the Gear-Kemper district, Virginia (deposits 90-92, table 1) are all located near diabase bodies. The St. Stephens mine, Virginia (deposit 89 , table 1 ), and minor barite veins at the Harrisville barite locality, North Carolina (deposit 98, table 1), cut Jurassic diabase dikes. In all of these cases, the veins are barite rich and are younger than the crystallization of the diabase bodies. Veins in the New Britain district, Connecticut (except the Bristol copper deposit, no. 35, table 1), and in the Audubon and Phoenixville districts, Pennsylvania, occur in or parallel to fracture systems intruded by or parallel to Jurassic diabase dikes.

The veins occur in a variety of rock types that have the following range:

1. Quartzofeldspathic gneisses, which may contain biotite, chlorite, pyrite, and (or) hornblende as the principal ferromagnesian minerals;

2. Schistose rocks with abundant chlorite and (or) muscovite;

3. Red to gray Triassic siltstone and sandstone containing plagioclase, quartz, and minor muscovite, potassium feldspar, chlorite, hematite, and (or) carbonate minerals;

4. Gray hornfels of Triassic siltstone containing plagioclase, quartz, chlorite, and mica minerals;

5. Gray to black Triassic-Jurassic mudstones containing chlorite, albite, quartz, carbonate minerals, and as much as a few weight percent of organic material; and

6. Basalt or diabase containing plagioclase and clinopyroxene in a fine-grained chlorite-rich matrix.

Alteration of wall rocks near the veins is not evident where the host rocks are quartzofeldspathic gneiss, sandstone, siltstone, or mudstone. These wall rocks do not appear to be discolored or altered, but subtle modal increases in albite, chlorite, muscovite, and (or) other layer silicates may be present in the immediate vicinity of the vein. Chemical analyses of a Jurassic red siltstone bordering and at some distance from a vein in the East Berlin Formation at Trinity College, Hartford, Connecticut (Ryan, 1986, Appendix B, p. 118) indicate subtle chemical changes as much as $20 \mathrm{~cm}$ from the vein contact. Either a constant volume reference frame (Gresens, 1967) or an element ratio reference frame, with $\mathrm{Ti}$ assumed to be an immobile element, indicates that the red siltstone bordering the vein has lost $\mathrm{Fe}, \mathrm{Ca}$, and some $\mathrm{Na}$ and gained $\mathrm{Si}, \mathrm{K}$, and $\mathrm{Mg}$. The relative magnitude of
MESOZOIC BASE-METAL VEINS

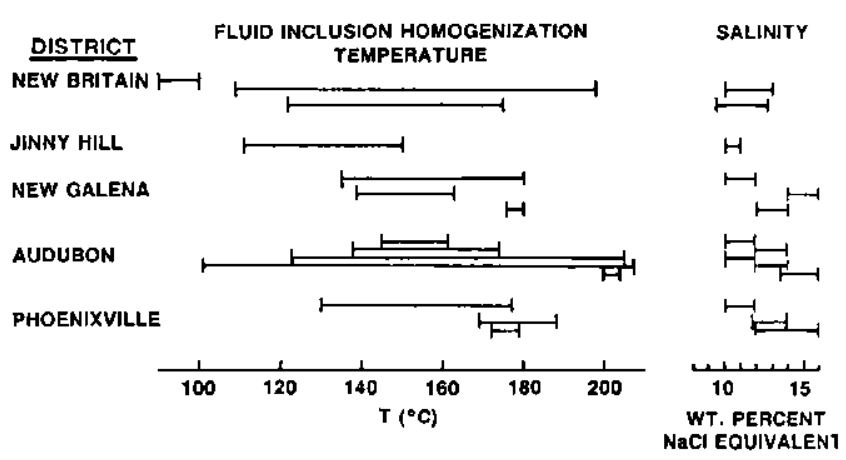

Figure 2. The range of fluid-inclusion homogenization temperatures and fluid salinity determined by freezing temperature from inclusions in quartz and sphalerite from vein deposits associated with the early Mesozoic basins of the Eastern United States (indicated by the barred lines). Data are shown from three deposits in the New Britain district and from the Jinny Hill deposit, Connecticut, three dump areas from the New Galena deposit, five mines from the Audubon district, and three mines from the Phoenixville district, Pennsylvania. Fluid inclusion data for the Connecticut deposits are from Ryan (1986). Fluid inclusion data for the Pennsylvania deposits are from Lawler (1981).

the gains and losses requires a small degree of proton metasomatism to preserve charge balance.

Wall-rock alteration is intense and evident only where the host rocks of the veins are basalt or diabase. These wall rocks are bleached and mineralogically altered as much as $120 \mathrm{~cm}$ from the vein walls, although alteration halos of 5 to $10 \mathrm{~cm}$ are more typical (Ryan, 1986). Albite, chlorite, and (or) montmorillonite are the principal alteration minerals. Chemical analyses of basalt and diabase along profiles from altered to unaltered material bordering veins in the New Britain, Connecticut, district are presented by Ryan (1986, Appendix B). Results are similar from a constant volume reference frame or from an element ratio reference frame, assuming $\mathrm{Ti}$ and $\mathrm{Al}$ to be immobile elements, with the altered wall rocks losing $\mathrm{Fe}, \mathrm{Mg}$, and $\mathrm{Ca}$ and gaining $\mathrm{Na}$ and $\mathrm{K}$ relative to unaltered basalt or diabase. Silica may be enriched in the altered wall rock immediately adjacent to the vein but is depleted in altered material farther from the vein contact. In all cases, a slight to moderate degree of proton metasomatism is required to preserve charge balance in the altered material, and the intensity of proton metasomatism generally increases toward the vein contact.

Fluid inclusions in quartz, sphalerite, and carbonates from veins in the New Britain district and the Jinny Hill deposit, Connecticut (Ryan, 1984, 1986), and the Audubon district, Phoenixville district, and New Galena deposit, Pennsylvania (Lawler, 1981), have fluidinclusion homogenization temperatures in the range of 90 to $210^{\circ} \mathrm{C}$ (fig. 2). The source fluids are brines of 
Table 1A. Geographic listing of base-metal and barite veins associated with the early Mesozoic basins of the Eastern United States

[An m, p, or o under the "Deposit type" heading indicates either a mine, prospect, or mineral occurrence deposit type, respectively; numbers next to the mine category type indicate estimated ore production or reserves: 4, greater than 100,000 tons; 3 , between 100,000 and 1,000 tons; 2 , less than 1,000 tons; and 1, unknown production or reserves; in the "References" column, the numbers are the reference citations as listed in table $1 B$; no entry in the "Host-rock lithology" column means lithology unknown]

\begin{tabular}{|c|c|c|c|c|c|c|c|c|c|c|c|}
\hline \multirow[b]{2}{*}{ Number } & \multirow[b]{2}{*}{ Name } & \multirow[b]{2}{*}{ County } & \multirow[b]{2}{*}{ State } & \multirow[b]{2}{*}{ Latitude } & \multirow[b]{2}{*}{ Longitude } & \multirow{2}{*}{$\begin{array}{c}\text { Deposit } \\
\text { type }\end{array}$} & \multirow{2}{*}{$\begin{array}{l}\text { Host-rock } \\
\text { lithology }\end{array}$} & \multirow{2}{*}{$\begin{array}{c}\text { Host-rock } \\
\text { age }\end{array}$} & \multicolumn{2}{|c|}{ Commodity } & \multirow[b]{2}{*}{ References } \\
\hline & & & & & & & & & Principal & Accessory & \\
\hline
\end{tabular}

I. Hartford-Deerfield basin and vicinity, New Hampshire, Massachusetts, and Connecticut

A. Cheshire, New Hampshire, district

1 E. Surry Mtn. mine Cheshire NH

2 Will Wise mine

3 Stoddard mine 1

4 Stoddard mine 2

5 Springer mine

6 Fluorite prospect

7 Pierce mine

8 Streeter Hill

9 Galena occurrence

10 Winchester mine

11 Tumers Falls 1

12 Tumers Falls 2 B. Leverett district

13 Leverett

14 Unnamed $\mathrm{Pb}-\mathrm{Ba} 1$ Franklin

Franklin

16 Unnamed Pb-Ba 3 Franklin

17 Unnamed Pb-Ba 4 Franklin C. Whatley-Hatfield district

18 Deerfield Franklin

19 Unnamed Pb-Ba 5 Franklin

20 Mt. Esther Franklin MS

21 Whatley-Wm. 1 Franklin MS

22 Whatley-Wm. 2 Franklin MS

23 Whatley-Wm. 3 Franklin MS

24 Hatfield Lead Hampshire MS

25 Unnamed $\mathrm{Pb}-\mathrm{Ba} 6$ Hampshire MS D. Loudville district

26 Unnamed $\mathrm{Pb}-\mathrm{Ba} 7$ Hampshire MS

27 Manhan Lead 1 Hampshire MS

28 Manhan Lead 2 Hampshire MS

29 Manhan Lead 3 Hampshire MS

30 Manhan Lead 4 Hampshire MS

31 Manhan Lead 5 Hampshire MS

32 Southampton

33 New Mine vein E. New Britain district

35 Bristol copper

36 Farmington

37 Basalt quarry

38 Plainfield quarry

39 Columbus Blvd.

40 Ellis Street

41 Bitumen vein

Hampshire MS

Hampshire MS

42 Mattabesset River

43 Berlin Moores Mill Hartford

44 Limestone quarry Hartford

Middlesex

F. Cheshire-Jinny Hill district

46 Middletown lead Middlesex CI

47 Barite vein

48 New Haven mine

49 Cheshire Mine 3

50 Cheshire Mine 2

51 Booth and Hinman New Haven CI

52 Cheshire Mine 1 New Haven CT

53 Jinny Hill

54 Cross Rock

55 Gaylord

56 Tallman's mine

57 Copper Valley Hartford
$\mathrm{N} 43^{\circ} 02^{\prime} 01^{\prime \prime} \mathrm{W} 72^{\circ} 18^{\prime} 26^{\prime \prime} \mathrm{m} 1$ gneiss $\mathrm{N} 42^{\circ} 56^{\prime} 55^{\prime \prime} \mathrm{W} 72^{\circ} 29^{\prime} 10^{\prime \prime} \mathrm{m} 2$ gneiss N42 $56^{\prime} 01^{\prime \prime} W 72^{\circ} 27^{\prime} 56^{\prime \prime}$ ' 3 gneiss N42 $56^{\prime} 00^{\prime \prime}$ W72 $28^{\prime} 03^{\prime \prime}$ im 3 gneiss $\mathrm{N} 42^{\circ} 55^{\prime} 50^{\prime \prime} \mathrm{W} 72^{\circ} 28^{\prime} 32^{\prime \prime}$ ' $\mathrm{m} 3$ gneiss $\mathrm{N} 42^{\circ} 55^{\prime} 45^{\prime \prime} \mathrm{W} 72^{\circ} 28^{\prime} 18^{\prime \prime} \mathrm{P}$ gneiss $\mathrm{N} 42^{\circ} 55^{\prime} 44^{\prime \prime} \mathrm{W} 72^{\circ} 27^{\prime} 55^{\prime \prime}$ m 3 gneiss $\mathrm{N} 42^{\circ} 55^{\prime} 21^{\prime \prime} \mathrm{W} 72^{\circ} 29^{\prime} 51^{\prime \prime}$ o gneiss $\mathrm{N} 42^{\circ} 49^{\prime} 17^{\prime \prime} \mathrm{W} 72^{\circ} 23^{\prime} 24^{\prime \prime}$ o gneiss $\mathrm{N} 42^{\circ} 43^{\prime} 42^{\prime \prime} \mathrm{W} 72^{\circ} 26^{\prime} 30^{\prime \prime} \mathrm{m} 2$ gneiss $\mathrm{N} 42^{\circ} 36^{\prime} 54^{\prime \prime} \mathrm{W} 72^{\circ} 34^{\prime} 09^{\prime \prime}$ o sandstone $\mathrm{N} 42^{\circ} 36^{\prime} 49^{\prime \prime} \mathrm{W} 72^{\circ} 34^{\prime} 01^{\prime \prime}$ o sandstone

N42 $27^{\prime} 28^{\prime \prime} \mathrm{W} 72^{\circ} 31^{\prime} 06^{\prime \prime}$ in 3 granite $\mathrm{N} 42^{\circ} 27^{\prime} 26^{\prime \prime}$ 'W72 $31^{\prime} 30^{\prime \prime}$ $\mathrm{N} 42^{\circ} 26^{\prime} 29^{\prime \prime} \mathrm{W} 72^{\circ} 31^{\prime} 30^{\prime \prime} \mathrm{O}$ Silurian-Devonian $\mathrm{Pb}$ schist/granite Silurian-Devonian $\mathrm{Pb}$ $\mathrm{N} 42^{\circ} 26^{\prime} 15^{\prime \prime}$ 'W72 $31^{\prime} 32^{\prime \prime}$ o
$\mathrm{N}^{\circ} 22^{\prime}$
schist/granite Silurian-Devonian $\mathrm{Pb}$

$\mathrm{N} 42^{\circ} 26^{\prime} 14^{\prime \prime} \mathrm{W} 72^{\circ} 31^{\prime} 28^{\prime \prime}$ "

N42 $29^{\prime} 03^{\prime \prime}$ 'W $72^{\circ} 39^{\prime} 21^{\prime \prime}$ o schist

N42 $28^{\prime} 10^{\prime \prime} \mathrm{W} 72^{\circ} 39^{\prime} 19^{\prime \prime}$ o schist

$\mathrm{N} 42^{\circ} 27^{\prime} 28^{\prime \prime} \mathrm{W} 72^{\circ} 40^{\prime} 06^{\prime \prime}$ o schist

N42 $27^{\prime} 17^{\prime \prime}$ 'W72 $42^{\prime} 01^{\prime \prime}$ m 1 schist/granite Silurian -Devonian $\mathrm{Pb}$

$\mathrm{N} 42^{\circ} 26^{\prime} 58^{\prime \prime} \mathrm{W} 72^{\circ} 40^{\prime} 55^{\prime \prime} \mathrm{m} 1$ schist/granite Silurian-Devonian $\mathrm{Pb}$

$\mathrm{N} 42^{\circ} 25^{\prime} 46^{\prime \prime} \mathrm{W} 72^{\circ} 40^{\prime} 15^{\prime \prime} \mathrm{m} 1$ schist/granite Silurian-Devonian $\mathrm{Pb}$

$\mathrm{N} 42^{\circ} 23^{\prime} 18^{\prime \prime} \mathrm{W} 72^{\circ} 38^{\prime} 07^{\prime \prime} \mathrm{m}$ '

N42 $21^{\prime} 35^{\prime \prime}$ 'W72 $72^{\circ} 44^{\prime} 48^{\prime \prime}$ ' m 3 granite

$\mathrm{N} 42^{\circ} 17^{\prime} 34^{\prime \prime} \mathrm{W} 72^{\circ} 43^{\prime} 50^{\prime \prime}$ m 3 granite $\mathrm{N} 42^{\circ} 17^{\prime} 02^{\prime \prime} \mathrm{W} 72^{\circ} 43^{\prime} 55^{\prime \prime} \mathrm{m} 3$ granite $\mathrm{N} 42^{\circ} 16^{\prime} 54^{\prime \prime} \mathrm{W} 73^{\circ} 43^{\prime} 58^{\prime \prime}$ 'm 3 granite N42 $16^{\prime} 49^{\prime \prime}$ 'W72 $43^{\prime} 58^{\prime \prime}$ m 3 granite $\mathrm{N} 42^{\circ} 16^{\prime} 36^{\prime \prime} \mathrm{W} 72^{\circ} 44^{\prime} 02^{\prime \prime} \mathrm{m} 3$ granite $\mathrm{N} 42^{\circ} 16^{\prime} 30^{\prime \prime} \mathrm{W} 72^{\circ} 44^{\prime} 00^{\prime \prime} \mathrm{m} 3$ granite $\mathrm{N} 42^{\circ} 15^{\prime} 51^{\prime \prime} \mathrm{W} 72^{\circ} 44^{\prime} 18^{\prime \prime} \mathrm{m} 2$ granite $\mathrm{N} 42^{\circ} 12^{\prime} 45^{\prime \prime} \mathrm{W} 72^{\circ} 46^{\prime} 50^{\prime \prime} \mathrm{m} 1$ granite

CT N41 $45^{\prime} 04^{\prime \prime} \mathrm{W} 72^{\circ} 44^{\prime} 05^{\prime \prime}$ o siltstone

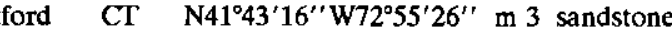
CT N41 $42^{\prime} 26^{\prime \prime}$ W72 $42^{\circ} 48^{\prime \prime}$ o sandstone N41 $40^{\prime} 27^{\prime \prime}$ 'W72 $42^{\circ} 25^{\prime}$ "' o basalt $\mathrm{N} 41^{\circ} 40^{\prime} 17^{\prime \prime} \mathrm{W} 72^{\circ} 49^{\prime} 43^{\prime \prime}$ o

$\mathrm{N} 41^{\circ} 39^{\prime} 51^{\prime \prime} \mathrm{W} 72^{\circ} 48^{\prime} 05^{\prime \prime}$ o basalt basalt N41 ${ }^{\circ} 39^{\prime} 28^{\prime \prime}$ 'W72 $46^{\prime} 23^{\prime \prime}$ o basalt N41 $37^{\prime} 33^{\prime \prime}$ 'W72 $47^{\circ} 05^{\prime \prime}$ o $\begin{aligned} & \text { sandstone/ } \\ & \text { siltstone }\end{aligned}$

N41 $37^{\prime} 16^{\prime \prime} \mathrm{W} 72^{\circ} 47^{\prime} 30^{\prime \prime}$ m 2 basalt N41 $37^{\prime} 09^{\prime \prime} \mathrm{W} 72^{\circ} 47^{\prime} 40^{\prime \prime}$ m 2 basalt N41 $37^{\prime} 09^{\prime \prime}$ 'W $72^{\circ} 49^{\prime} 51^{\prime \prime}$ o limestone N41 $36^{\prime} 53^{\prime \prime}$ W $72^{\circ} 43^{\prime} 34^{\prime \prime}$ o basalt

N413' $33^{\prime \prime} \mathrm{W} 73^{\circ} 36^{\prime} 41^{\prime \prime} \mathrm{m} 2$ gneiss N41 $33^{\prime} 05^{\prime \prime} \mathrm{W} 72^{\circ} 53^{\prime} 58^{\prime \prime}$ ' o sandstone $\mathrm{N} 41^{\circ} 33^{\prime} 01^{\prime \prime} \mathrm{W} 72^{\circ} 53^{\prime} 42^{\prime \prime} \mathrm{m} 2$ sandstone N41 $32^{\prime} 57^{\prime \prime} W 72^{\circ} 53^{\prime} 41^{\prime \prime}$ 'm 1 sandstone $\mathrm{N} 41^{\circ} 32^{\prime} 43^{\prime \prime} \mathrm{W} 72^{\circ} 54^{\prime} 18^{\prime \prime}$ 'm 1 sandstone $\mathrm{N} 41^{\circ} 32^{\prime} 07^{\prime \prime} \mathrm{W} 72^{\circ} 54^{\prime} 25^{\prime \prime} \mathrm{m} 2$ sandstone N41 31' $11^{\prime \prime}$ 'W72 $54^{\prime} 47^{\prime \prime}$ m 1 sandstone $\mathrm{N} 41^{\circ} 28^{\prime} 49^{\prime \prime} \mathrm{W} 72^{\circ} 53^{\prime} 49^{\prime \prime}$ m 4 sandstone $\mathrm{N} 41^{\circ} 28^{\prime} 11^{\prime \prime} \mathrm{W} 72^{\circ} 52^{\prime} 39^{\prime \prime} \mathrm{m} 2$ sandstone N41 $27^{\prime} 43^{\prime \prime} W 72^{\circ} 53^{\prime} 37^{\prime \prime}$ p sandstone N41 $26^{\prime} 31^{\prime \prime}$ W72 $54^{\prime} 02^{\prime \prime}$ m 3 sandstone $\mathrm{N} 41^{\circ} 26^{\prime} 15^{\prime \prime} \mathrm{W} 72^{\circ} 54^{\prime} 03^{\prime \prime} \mathrm{p}$ sandstone

$\begin{array}{lll}\text { Paleozoic } & \mathrm{Pb} & \mathrm{Cu} \\ \text { Paleozoic } & \mathrm{F} & \mathrm{Ba} \mathrm{Pb} \\ \text { Paleozoic } & \mathrm{F} & \mathrm{Ba} \mathrm{Pb} \\ \text { Paleozoic } & \mathrm{F} & \mathrm{Ba} \mathrm{Pb} \\ \text { Paleozoic } & \mathrm{F} & \mathrm{Ba} \mathrm{Pb} \mathrm{Cu} \\ \text { Paleozoic } & \mathrm{F} & \mathrm{Ba} \mathrm{Pb} \\ \text { Paleozoic } & \mathrm{F} & \mathrm{Pb} \\ \text { Paleozoic } & \mathrm{F} & \mathrm{Pb} \\ \text { Paleozoic } & \mathrm{Pb} & \mathrm{Ag} \\ \text { Paleozoic } & \mathrm{Pb} & \mathrm{Bg} \\ \text { Jurassic } & \mathrm{Cu} & \mathrm{Ba} \\ \text { Jurassic } & \mathrm{Cu} & \mathrm{Ba}\end{array}$

41
1
1
1
1
1
1
1
41
41
$13,22,29,31,68$
$13,22,29,31,68$

$\mathrm{Ba} \mathrm{Cu} \quad 13,22,27,31,33,45$ $\mathrm{Ba} \mathrm{Cu} 13$ $\mathrm{Ba} \mathrm{Cu} 13$ $\mathrm{Ba} \mathrm{Cu} 13$ $\mathrm{BaCu} 13$

$\begin{array}{ll}\text { Ba } & 13,29,31 \\ \text { Ba } & 13,29,31 \\ \text { Ba } & 22,29,31 \\ & 13,22,29,31,69 \\ & 13,22,29,31,69 \\ & 13,22,29,31,69 \\ \text { Ba Cu } & 13,22,28,31,69 \\ \text { Ba } & 13,29,31\end{array}$

$\mathrm{Ba}$

$13,29,31$

Devonian $\quad$ Pb $\quad$ Ba $13,29,31$

Devonian $\quad \mathrm{Pb} \mathrm{Ba}$ Ag Zn Cu 13,29

Devonian $\quad \mathrm{Pb} \mathrm{Ba} \mathrm{Ag} \mathrm{Zn} \mathrm{Cu} \mathrm{13,29}$

Devonian $\quad \mathrm{Pb} \mathrm{Ba} \mathrm{Ag} \mathrm{Zn} \mathrm{Cu} 13,29$

Devonian $\quad \mathrm{Pb} \mathrm{Ba} \mathrm{Ag} \mathrm{Zn} \mathrm{Cu} \mathrm{13,29}$

Devonian $\quad \mathrm{Pb} \mathrm{Ba} \mathrm{Ag} \mathrm{Zn} \mathrm{Cu} \mathrm{13,29}$

Devonian $\quad \mathrm{Pb} \mathrm{Cu} \mathrm{Ag} \mathrm{Zn} \mathrm{Ba} \mathrm{22,29,31}$

Devonian $\quad \mathrm{Pb} \quad \mathrm{Ag}, 42$

\begin{tabular}{|c|c|c|c|}
\hline $\begin{array}{l}\text { Jurassic } \\
\text { Triassic } \\
\text { Jurassic } \\
\text { Jurassic } \\
\text { Jurassic } \\
\text { Jurassic } \\
\text { Jurassic } \\
\text { Jurassic }\end{array}$ & $\begin{array}{l}\mathrm{Cu} \\
\mathrm{Cu} \\
\mathrm{Zn} \\
\mathrm{Zn} \mathrm{Pb} \\
\mathrm{Cu}\end{array}$ & $\begin{array}{l}\mathrm{Ba} \\
\mathrm{Ag} \mathrm{U} \\
\mathrm{Ba} \\
\mathrm{Cu} \mathrm{Zn} \\
\mathrm{Cu} \mathrm{Ba} \\
\mathrm{Ba}\end{array}$ & $\begin{array}{l}55 \\
3,34,56,58 \\
59 \\
59 \\
59 \\
24 \\
24 \\
59\end{array}$ \\
\hline $\begin{array}{l}\text { Jurassic } \\
\text { Jurassic } \\
\text { Jurassic } \\
\text { Jurassic }\end{array}$ & $\begin{array}{l}\mathrm{Pb} \\
\mathrm{Ba}\end{array}$ & $\begin{array}{l}\mathrm{Zn} \mathrm{Ba} \\
\mathrm{F} \\
\mathrm{Ba}\end{array}$ & $\begin{array}{l}25,46,57 \\
25,46,57 \\
25 \\
36\end{array}$ \\
\hline $\begin{array}{l}\text { Paleozoic } \\
\text { Triassic } \\
\text { Triassic } \\
\text { Triassic } \\
\text { Triassic } \\
\text { Triassic } \\
\text { Triassic } \\
\text { Triassic } \\
\text { Triassic } \\
\text { Triassic } \\
\text { Triassic } \\
\text { Triassic }\end{array}$ & $\begin{array}{l}\mathrm{Pb} \\
\mathrm{Ba} \\
\mathrm{Ba} \\
\mathrm{Ba} \\
\mathrm{Ba} \\
\mathrm{Ba} \\
\mathrm{Ba} \\
\mathrm{Ba} \\
\mathrm{Cu} \\
\mathrm{Cu} \\
\mathrm{Cu} \\
\mathrm{Cu}\end{array}$ & $\begin{array}{l}\mathrm{Cu} \mathrm{Ag} \\
\mathrm{Ba} \\
\mathrm{Ba} \mathrm{Ag} \\
\mathrm{Ba} \mathrm{Ag} \\
\mathrm{Ag}\end{array}$ & $\begin{array}{l}49 \\
18 \\
16,18 \\
16 \\
16 \\
16 \\
16 \\
16,17 \\
17 \\
16,17,57 \\
17,47,57 \\
16,17\end{array}$ \\
\hline
\end{tabular}


Table 1A. Geographic listing of base-metal and barite veins associated with the early Mesozoic basins of the Eastern United States-Continued

[An $\mathrm{m}, \mathrm{p}$, or o under the "Deposit type" heading indicates either a mine, prospect, or mineral occurrence deposit type, respectively; numbers next to the mine category type indicate estimated ore production or reserves: 4 , greater than 100,000 tons; 3 , between 100,000 and 1,000 tons; 2 , less than 1,000 tons; and 1, unknown production or reserves; in the "References" column, the numbers are the reference citations as listed in table $1 B$; no entry in the "Host-rock lithology" column means lithology unknown]

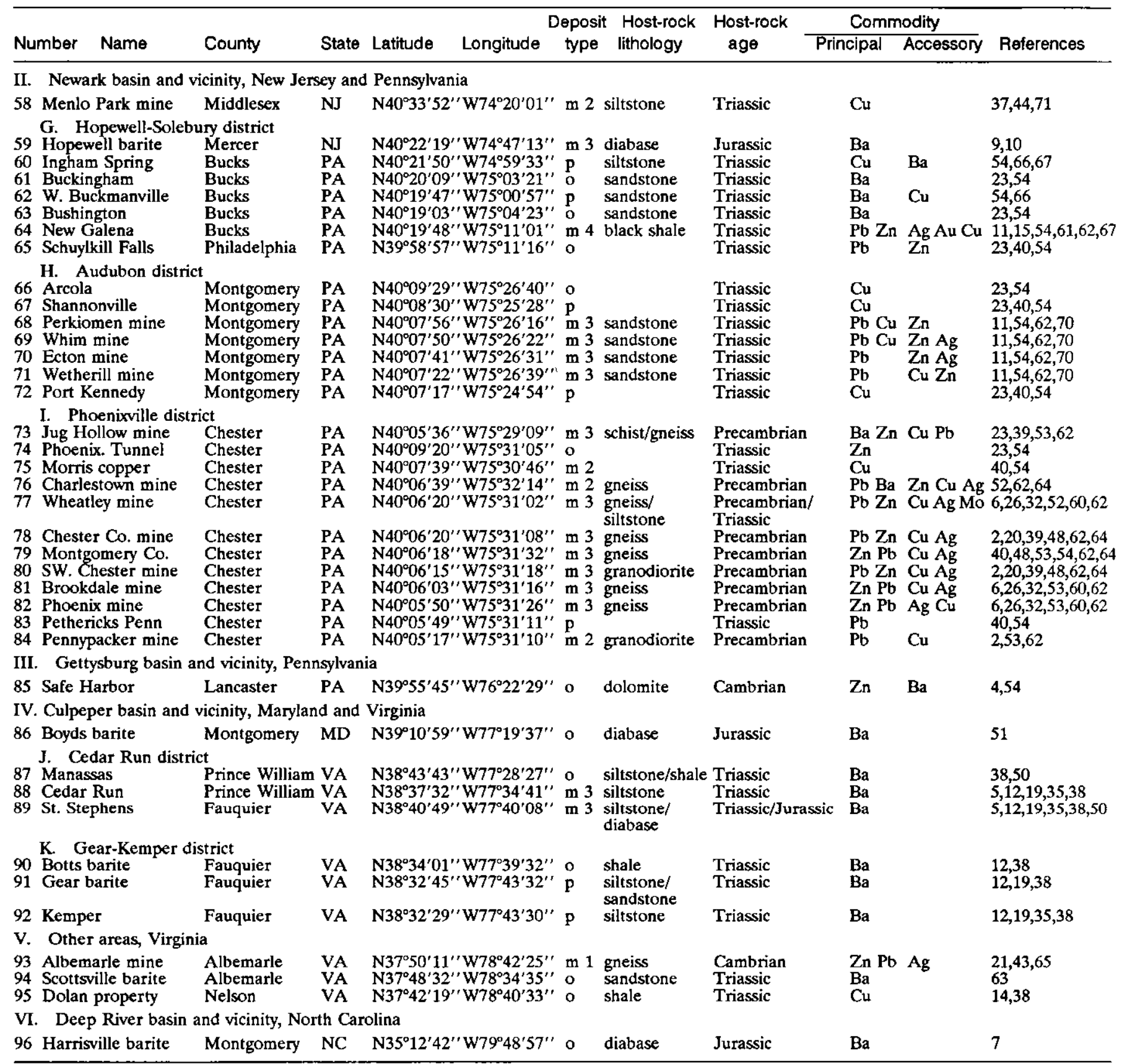

moderate salinity (10 to 16 equivalent weight percent $\mathrm{NaCl}$; approximately 2 molar $\mathrm{NaCl}$ solutions). Some fluid inclusions in one vein in Connecticut have a high $\mathrm{CO}_{2}$ content (Ryan, 1986), but this is not typical of most of the veins. A pressure correction of approximately 10 to $11^{\circ} \mathrm{C}$ per 100 bars trapping pressure for fluids in this salinity range (Potter and Brown, 1977; Haas, 1976) must be applied to the fluid-inclusion homogenization temperatures to determine the trapping temperature (Roedder and Bodnar, 1980). The fluid-trapping pressure is probably somewhere between lithostatic and hydrostatic in these types of veins (Roedder and Bodnar, 1980), and for shallow, open-vein development, trapping pressures are probably close to hydrostatic pressure. The depths of 
Table 1B. References cited in table $1 A$.

[Refer to the "References Cited" section of the text for complete citations]

\begin{tabular}{|c|c|c|c|c|c|}
\hline $\begin{array}{l}\text { Reference } \\
\text { number }\end{array}$ & Citation & $\begin{array}{l}\text { Ref } \\
\text { num }\end{array}$ & Citation & & Citation \\
\hline $\begin{array}{l}1 \\
2 \\
3 \\
4 \\
5 \\
6 \\
7 \\
\\
9 \\
10 \\
11 \\
12 \\
13 \\
14 \\
15 \\
16 \\
17 \\
18 \\
19 \\
20 \\
21 \\
22 \\
23 \\
24 \\
25\end{array}$ & $\begin{array}{l}\text { Bannerman, } 1941 \\
\text { Bascom and Stose, } 1938 \\
\text { Bateman, 1923 } \\
\text { Bates, 1959 } \\
\text { Bernstein, } 1980 \\
\text { Blake, 1860 } \\
\text { Burt, 1985, N.C. Geol. Survey, } \\
\text { oral commun. } \\
\text { Cook, 1868 } \\
\text { Dombroski, 1980 } \\
\text { Earl, 1950 } \\
\text { Edmundson, 1938 } \\
\text { Emerson, 1898a,b } \\
\text { Espenshade, 1954 } \\
\text { Faill, 1973 } \\
\text { Fritts, 1962 } \\
\text { Fritts, 1963a } \\
\text { Fritts, 1963b } \\
\text { Froelich and Leavy, } 1981 \\
\text { Genth, 1851 } \\
\text { Giannini, 1959 } \\
\text { Gleba, 1978 } \\
\text { Gordon, 1922 } \\
\text { Gray, 1982 } \\
\text { Hanshaw, 1968 }\end{array}$ & $\begin{array}{l}26 \\
27 \\
28 \\
29 \\
30 \\
31 \\
32 \\
33 \\
34 \\
35 \\
36 \\
37 \\
38 \\
39 \\
40 \\
41 \\
42 \\
43 \\
44 \\
45 \\
46 \\
47 \\
48 \\
49\end{array}$ & $\begin{array}{l}\text { Harvey, 1865 } \\
\text { Hiller, 1974 } \\
\text { Hiller, 1975 } \\
\text { Hitchcock, } 1823 \\
\text { Hitchcock, 1832 } \\
\text { Hitchcock, 1835 } \\
\text { Hoofstetten, 1855 } \\
\text { Jahns, 1951 } \\
\text { Januzzi, 1959 } \\
\text { Lee, 1979 } \\
\text { Lehmann, 1959 } \\
\text { Lewis, 1907 } \\
\text { Luttrell, 1966 } \\
\text { Miller, 1923 } \\
\text { Miller, 1924 } \\
\text { Morrill, 1960 } \\
\text { Nash, 1827 } \\
\text { Nelson, 1962 } \\
\text { Newhouse, 1933 } \\
\text { Pearre, 1956 } \\
\text { Percival, 1842 } \\
\text { Potisat, 1978 } \\
\text { Reed, 1949 } \\
\text { Rice and Foye, } 1927\end{array}$ & $\begin{array}{l}50 \\
51 \\
52 \\
53 \\
54 \\
55 \\
56 \\
57 \\
58 \\
59 \\
60 \\
61 \\
62 \\
63 \\
64 \\
65 \\
66 \\
67 \\
68 \\
69 \\
70 \\
71\end{array}$ & $\begin{array}{l}\text { Roberts, } 1928 \\
\text { Rockville Crushed Stone, Inc., } \\
\text { 1984, written information } \\
\text { Rogers, } 1853 \\
\text { Rogers, } 1858 \\
\text { Rose, } 1970 \\
\text { Ryan, S., 1985, U. Connecticut, } \\
\text { written commun. } \\
\text { Schairer, } 1931 \\
\text { Shepard, } 1837 \\
\text { Silliman and Whitney, } 1855 \\
\text { Simpson, } 1966 \\
\text { Smith, } 1855 \\
\text { Smith, 1973 } \\
\text { Smith, 1977 } \\
\text { Sunderman, } 1958 \\
\text { Turnbull, } 1854 \\
\text { Watson, } 1907 \\
\text { Wherry, 1908 } \\
\text { Willard and others, } 1959 \\
\text { Willard, } 1952 \\
\text { Willard, } 1956 \\
\text { Williams, } 1863 \\
\text { Woodward, } 1944\end{array}$ \\
\hline
\end{tabular}

emplacement of veins in the New Galena, Audubon, and Phoenixville districts of Pennsylvania are estimated as approximately 3,000 to $4,000 \mathrm{~m}$ on the basis of observations of Smith (1977) on the stratigraphic location of the veins, and the stratigraphic thickness estimates of Glaeser (1966) and Bascom and Stose (1938) (see Lawler, 1981, p. 47-49), although the overburden thickness could be less either because of pre-vein erosion or uncertainty in the thickness of the stratigraphic section. Using an average fluid density of approximately 1 $\mathrm{gm} / \mathrm{cm}^{3}$, which is appropriate for these temperature and salinity conditions, yields an estimated hydrostatic pressure of 300 to 400 bars for the Pennsylvania deposits. Using similar stratigraphic arguments, Ryan (1986, p. 29-30) estimates the hydrostatic trapping pressure of the New Britain veins and the Jinny Hill deposit to be equal to or less than 250 bars. Boiling is not observed in the fluid-inclusion studies, and in order to prevent boiling, the trapping pressure must have exceeded approximately 20 bars for the $210^{\circ} \mathrm{C}$ fluids and approximately 40 bars for $250^{\circ} \mathrm{C}$ fluids in this salinity range (Haas, 1976). When using generous uncertainty estimates regarding fluidinclusion trapping pressures, one needs to apply a correction of +10 to $+40^{\circ} \mathrm{C}$ (corresponding to hydrostatic pressures of 100 to 400 bars) to the fluid-inclusion homogenization temperatures to estimate trapping temperature. Such a correction allows for fluid-inclusion trapping temperatures ranging from 100 to $250^{\circ} \mathrm{C}$ for these vein deposits.
Limited lead isotope data from galenas in some of the veins in the Hartford basin (Parnell, 1986) indicate that the lead in these galenas is moderately radiogenic, with isotope ratios of $18.5-18.6$ for ${ }^{206} \mathrm{~Pb} /{ }^{204} \mathrm{~Pb}, 15.64$ 15.66 for ${ }^{207} \mathrm{~Pb} /{ }^{204} \mathrm{~Pb}$, and $38.4-38.6$ for ${ }^{208} \mathrm{~Pb} /{ }^{204} \mathrm{~Pb}$. The moderately high ratios of ${ }^{207} \mathrm{~Pb} /{ }^{204} \mathrm{~Pb}$ suggest lead derivation predominantly from continental sources, with an enrichment in $U$ and $U / T h$ relative to deep crustal or mantle sources. Model lead ages fall in the range of 150 $\pm 20 \mathrm{Ma}$, which is consistent with the veins being younger than sedimentation, intrusion, tilting, and some faulting in these basins. The easily mobilized nature of $U$ and much of its daughter $\mathrm{Pb}$ in the first-cycle red-bed sediments of continental basins (Doe and Zartman, 1979) implies that the model $\mathrm{Pb}$ ages of galenas in these Mesozoic vein deposits may be younger than the age of deposition. However, the vein-hosted galenas are only slightly anomalously radiogenic (J-type lead) relative to the composition of the average orogene of Doe and Zartman (1979), and the model ages are broadly correlative with a 175 -Ma thermal event reported by Sutter (this volume) based on ${ }^{40} \mathrm{Ar} /{ }^{39} \mathrm{Ar}$ isotopic analysis of potassium feldspar from Early Jurassic intrusives in the Culpeper basin of Virginia and Maryland and the Newark basin of New Jersey. Sutter (this volume) interprets the 175-Ma apparent ages of these feldspars as being due to a moderate-temperature heating event (approximately $200^{\circ} \mathrm{C}$ ) caused by the migration of hydrothermal fluids. Interestingly, this $175-\mathrm{Ma}$ age is broadly correlative with the age of the Mesozoic magnetic lineaments and of 
Table 2. Rare metals in bulk ore and mineral concentrates from base-metal and barite veins associated with the early Mesozoic basins of the Eastern United States

[The type of analyzed sample, metal and measured analytical range, and data source are indicated for individual deposits; error in values is due to rounding]

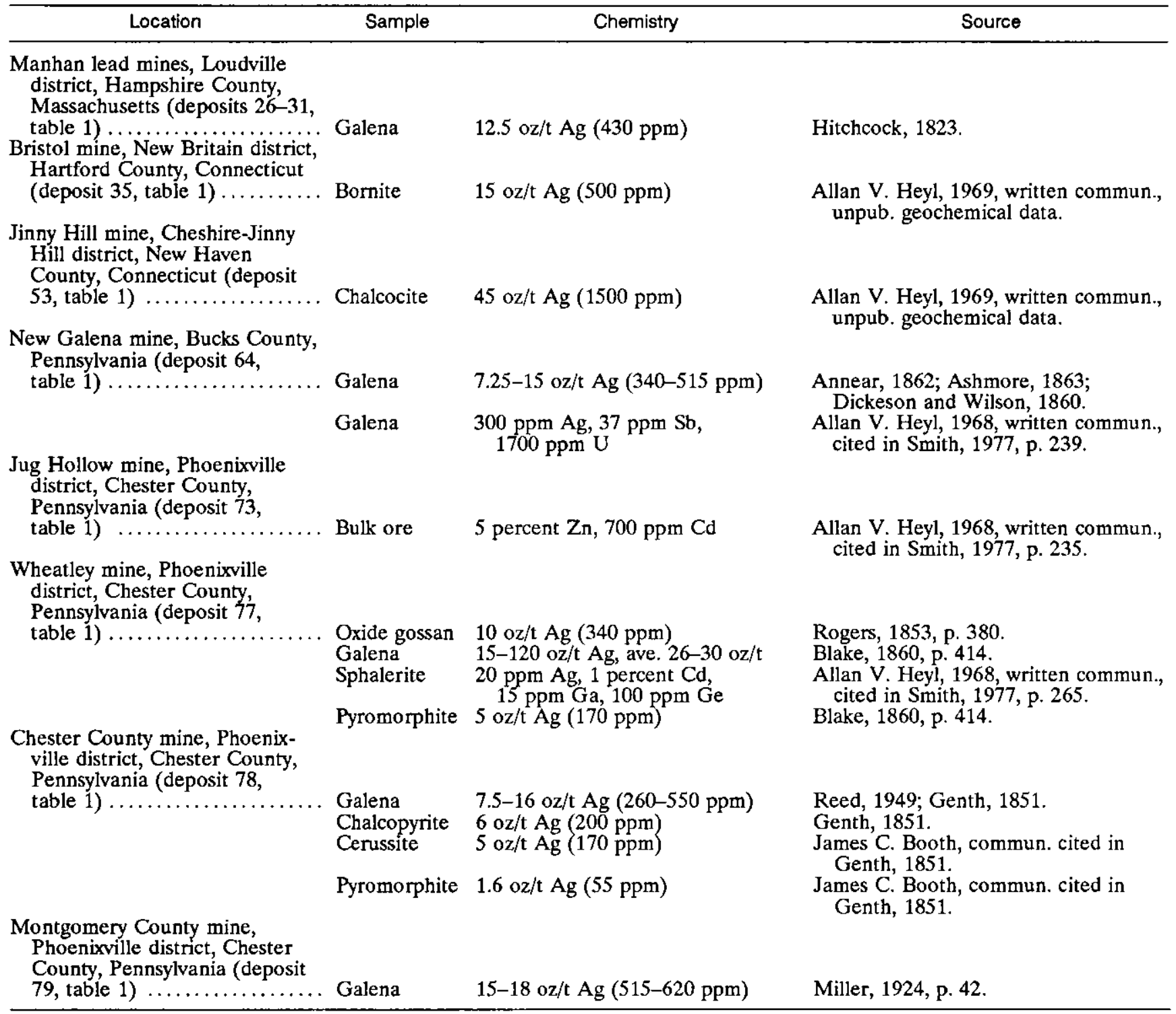

sedimentation during the initial opening of the Atlantic Ocean, which resulted from the physical separation of North America from Africa (Klitgord and Schouten, 1986, p. 364).

\section{SULFUR ISOTOPE STUDY}

Suites of coexisting minerals (in physical contact or in proximity) were collected for sulfur isotope analysis from a number of base-metal and barite vein localities associated with the early Mesozoic basins of the Eastern United States. Eighty-six sulfide and barite separates were prepared from samples from 20 deposits in the
Leverett and Whatley-Hatfield districts, Massachusetts; the New Britain district, Connecticut; the Jinny Hill deposit, Connecticut; the New Galena deposit, Pennsylvania; the Audubon and Phoenixville districts, Pennsylvania; and various barite deposits in the Culpeper basin of Virginia. Robert C. Smith II (Pennsylvania Geological Survey) supplied splits of samples used by Lawler (1981) in her fluid-inclusion study of the Pennsylvania deposits, and Scott Ryan provided splits of the Connecticut vein samples used in his fluid inclusion studies (Ryan, 1986).

The sulfide and sulfate minerals separated for isotopic analysis were hand picked under a binocular microscope from lightly crushed material. Pure sulfide mineral separates were converted to $\mathrm{SO}_{2}$ by roasting with 
$\mathrm{Cu}_{2} \mathrm{O}$ at $1025^{\circ} \mathrm{C}$ for 10 minutes. Barite was converted to $\mathrm{SO}_{2}$ by mixing with $\mathrm{Cu}_{2} \mathrm{O}$ and ground $\mathrm{SiO}_{2}$ and roasting at $1125^{\circ} \mathrm{C}$ for 15 minutes. The $\mathrm{SO}_{2}$ produced from both extraction techniques was routinely purified by use of a glass vacuum distillation line. Ratio measurements were made on a Nuclide 6-60-RMS mass spectrometer at the U.S. Geological Survey in Reston, Virginia. To avoid problems of oxygen correction, the McMaster University $\mathrm{Ag}_{2} \mathrm{~S}$ reference standards (Rees, 1978) were used to determine $\delta{ }^{34} \mathrm{~S}_{\mathrm{CD} \text { T }}$. Analytical precision, based on duplicate runs of samples, is $0.1 \%$ ( 1 standard deviation).

The results of the sulfur isotope study are schematically portrayed in figure 3 . The range of sulfur isotope variation of individual mineral samples from the various deposits or districts is shown in intervals of $1 \%$. Sulfur isotope variation in barites from all deposits from Massachusetts to Virginia lies within the relatively small range of $\delta{ }^{34} \mathrm{~S}$ values between +9 and $+20 \%$. In deposits where barite is an abundant mineral, such as Hatfield, Massachusetts, Jinny Hill, Connecticut, and the deposits in Virginia, the $\delta{ }^{34} \mathrm{~S}$ values for barite, in general, fall in the lower end of the range of variation $(+9$ to +15 $\%$ ); in deposits where barite is a minor or paragenetically late mineral, such as Audubon and Phoenixville, Pennsylvania, the $\delta{ }^{34} S$ values for barite lie at the higher end of the range $(+15$ to $+20 \%$ ). Proximal districts (Leverett-Hatfield, Massachusetts, New Britain-Jinny Hill, Connecticut, and Audubon-Phoenixville, Pennsylvania) have similar and overlapping $\delta^{34} \mathrm{~S}$ values for barite. At temperatures greater than $100^{\circ} \mathrm{C}$, it is believed that little or no isotope fractionation takes place between aqueous sulfate and coexisting sulfate minerals (Ohmoto and Rye, 1979); therefore, sulfur isotope values for mineral sulfates are taken to represent aqueous sulfate values. These results imply a relatively uniform regional fluid source for sulfate, at least on the scale of individual basins.

In contrast, the sulfur isotope values for coexisting sulfides from the vein deposits show a considerable range in $\delta{ }^{34} \mathrm{~S}$ values $(-17$ to $+19 \%)$. For most of the deposits, the range in $\delta{ }^{34} S$ values for individual sulfide minerals is more than $5 \%$. In the New Galena deposit of Pennsylvania, for example, the range of galena $\delta{ }^{34} \mathrm{~S}$ values is $23 \%\left(-4\right.$ to $+19 \%$. This type of $\delta{ }^{34} \mathrm{~S}$ variation in sulfides is characteristic of systems that have undergone sulfate reduction, received fluids from multiple sources, or both (Ohmoto and Lasaga, 1982).

Sulfur isotope values for sulfides in some of these vein deposits differ significantly from the isotopic composition of sulfides in the adjacent host rocks, implying that sulfide phases in the host rocks were not the dominant source of sulfur for vein mineralization. For example, a sample of diagenetic pyrite from black shale at the New Galena deposit, Pennsylvania, has a $\delta{ }^{34} S$ value of -19.3 (fig. 3), which differs significantly from the sulfur
MESOZOIC BASE-METAL VEINS

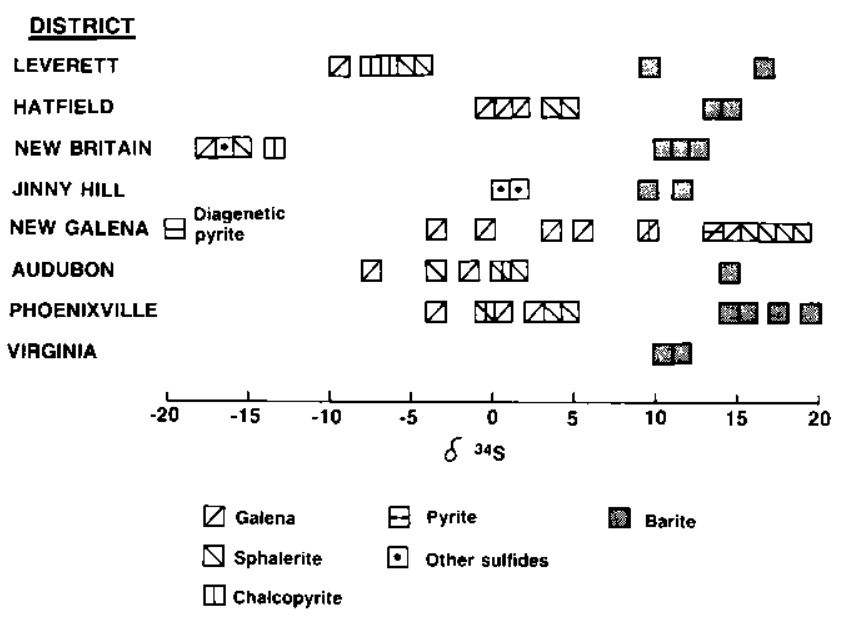

Figure 3. Sulfur isotope values of pure mineral separates from a total of 20 deposits in the Leverett and WhatleyHatfield districts, Massachusetts; New Britain district and Jinny Hill deposit, Connecticut; New Galena deposit, Pennsylvania; Audubon and Phoenixville districts, Pennsylvania; and various barite deposits in Virginia are shown by symbol, in 1-per-mil intervals.

isotope composition of the vein-hosted sulfides there. If this diagenetic pyrite had formed by bacterial reduction of sulfate-bearing aqueous fluids, and a biogenic isotopic fractionation of $+45 \pm 20 \%$ exists between fluid sulfate and biogenetic sulfides (Ohmoto and others, in press), then the aqueous sulfate source at the New Galena locality would have had a value of $+25 \pm 20 \% \delta^{34} \mathrm{~S}$. This range of aqueous sulfate values overlaps the measured range of barite sulfate values, in general agreement with a regional aqueous sulfate source of +10 to $-20 \%$.

Sulfur isotope fractionation temperatures for coexisting sulfides in the vein samples were calculated from the equations of Ohmoto and Rye (1979, tables 10-1, $10-2)$. The calculated temperatures $\left(90\right.$ to $280^{\circ} \mathrm{C}$ ) are consistent with the temperatures indicated from the fluid inclusion studies (fig. 4), with the exception of two sphalerite-galena pairs from the New Galena deposit, Pennsylvania. However, fractionation temperatures calculated for coexisting sulfate-sulfide mineral pairs by use of the equations of Ohmoto and Rye (1979), modified with the revised aqueous sulfate-aqueous sulfide fractionation curve of Ohmoto and Lasaga (1982), are generally inconsistent with the crystallization temperatures indicated by sulfide mineral pairs and fluid-inclusion studies, and typically give values of 300 to more than 600 ${ }^{\circ} \mathrm{C}$. This type of nonequilibrium sulfide-sulfate fractionation is common in low-temperature veins (Ohmoto and Lasaga, 1982). Three important processes that may produce this relationship are (1) inheritance of higher temperature fractionation signatures from deeper parts of the hydrothermal system, (2) mixing of sulfide-rich solu- 
tions with sulfate-rich solutions near the deposition site, and (3) partial oxidation or reduction of the fluid near the deposition site (Ohmoto and Lasaga, 1982). The sulfur isotope data indicate that one or more of these processes may have occurred during deposition of the vein minerals.

Simple cooling of a fluid results in deposition of quartz, sulfide minerals, and (or) barite because of their prograde solubility in 2 molar $\mathrm{NaCl}$ solutions (Holland and Malinin, 1979). Districts where sulfate-sulfide fractionation is not greatly in disequilibrium, delineated by sulfate-sulfide temperatures of $400^{\circ} \mathrm{C}$ or less, such as New Britain, Connecticut, and Audubon and Phoenixville, Pennsylvania (fig. 4), have sulfur isotope values that may reflect inheritance of fossil high-temperature aqueous sulfate-sulfide fractionation. The spread of sulfatesulfide fractionation values for these deposits (New Britain, $\delta_{\text {SO }_{4} \text {-Mes }}=27 \%$; Audubon, $\delta_{\mathrm{SO}_{4}-\mathrm{Mes}}=20 \%$; Phoenixville, $\delta_{\mathrm{SO}_{4} \text {-Mes }}=17 \%$ ) may be the result of variable cooling rates for the different vein systems. Alteration of wall rock at the New Britain, Connecticut, veins produces increasing modal abundances of chlorite, albite, and montmorillonite, and leaches cations through proton metasomatism (Ryan, 1986). This type of alteration is consistent with wall rock reaction with source fluids equilibrated with feldspar-mica-chlorite assemblages at higher temperatures.

Mixing of sulfide-rich and sulfate-rich solutions, particularly where there is a contrast in the temperatures of the solutions, is an effective mechanism to deposit barite and (or) sulfide minerals without much silica gangue (Ohmoto and Rye, 1979). Sulfide- and (or) sulfate-rich veins are found in the Whatley-Hatfield district, Massachusetts; the New Britain and CheshireJinny Hill districts, Connecticut; the Hopewell-Solebury district, New Jersey-Pennsylvania; and barite deposits in the Culpeper basin, Maryland-Virginia. The large disequilibrium fractionation between sulfate and sulfide for the Hatfield and Jinny Hill deposits (figs. 3 and 4) may be a result of mixing of two or more fluids. However, the narrow range of salinities reported from these vein systems implies that if fluid mixing occurred, the mixed fluids may have been partially reduced and nonreduced fluids from the same source area.

Partial oxidation of reduced sulfur or partial reduction of oxidized sulfur in the fluid near the site of deposition can lead to nonequilibrium sulfate-sulfide fractionation in co-precipitated minerals (Ohmoto and Lasaga, 1982). Oxidation of reduced sulfur in the fluid can lead to barite deposition, but this process should cause dissolution, not precipitation, of sulfide minerals. In addition, fluid oxidation is not consistent with the restricted and regionally consistent range of $\delta{ }^{34} S$ values for barite sulfate from these vein deposits.

\section{MESOZOIC BASE-METAL VEINS}

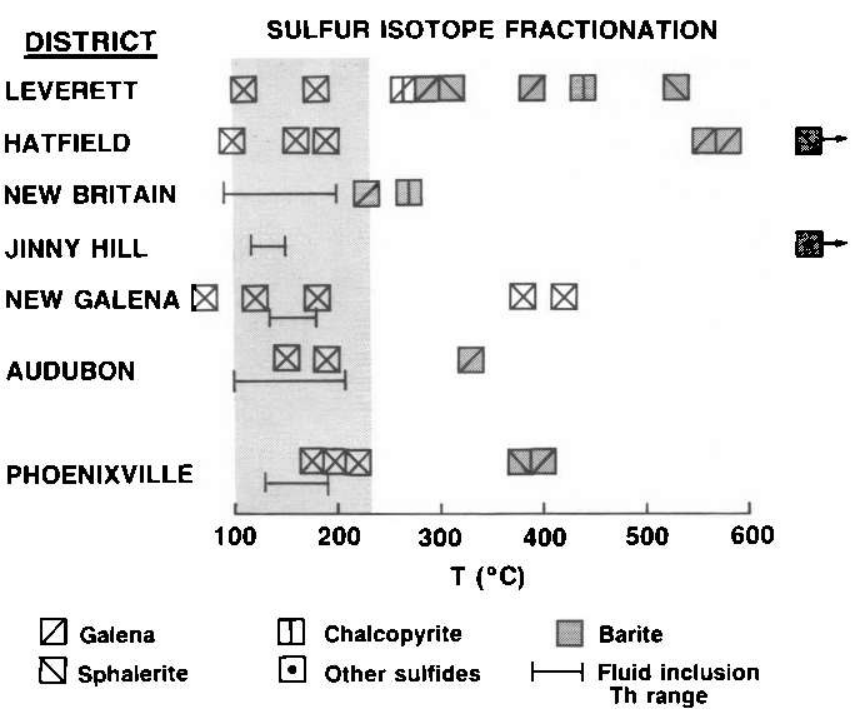

Figure 4. Sulfur isotope fractionation temperatures for coexisting sulfur-bearing minerals calculated from the equations of Ohmoto and Rye (1979, tables 10-1, 10-2), modified with the revised aqueous sulfate-aqueous sulfide fractionation curve of Ohmoto and Lasaga (1982). Mineral pairs are indicated by symbol. The sulfur isotope data shown were measured by Laurel Woodruff in U.S. Geological Survey laboratories. Fluid-inclusion homogenization temperatures (Th) for corresponding samples are indicated by barred lines. Shaded area indicates range of fluid-inclusion filling temperatures as described in text.

Reduction of oxidized sulfur in the fluid can lead to sulfide precipitation. The large range in $\delta{ }^{34} S$ values from -4 to $19 \%$ for galena and sphalerite, which overlaps the range of barite sulfate values from other districts, and the absence of sulfate minerals at the New Galena, Pennsylvania, deposit suggest that sulfate reduction was an important deposition mechanism at the New Galena locality. This interpretation is supported by the presence of organic-matter-rich shales in the mineralized area, which could act as a reductant. The large range in sulfide $\delta{ }^{34} \mathrm{~S}$ and the variable barite-sulfate values in the heavy range of $\delta^{34} \mathrm{~S}$ values from deposits in the Audubon and Phoenixville districts, Pennsylvania, suggest that a sulfate reduction process may be important in the formation of these deposits as well, even though reductants are not evident. Hydrocarbons are present in veins in the New Britain district, Connecticut (Ryan, 1986; Pratt and Burruss, this volume), and at the Magnet Cove deposit, Nova Scotia (Boyle, 1962, p. 23), and may be involved in the mineralization process as reducing agents, as hypothesized by Hayes and Einaudi (1986) for the stratabound and replacement Spar Lake deposits in the Coeur d'Alene district, Idaho-Montana.

Sulfate reduction can lead to significant deposition of quartz from solutions at temperatures greater than $150{ }^{\circ} \mathrm{C}$ if silicic acid-sulfate complexes are present in the 
fluid (Marshall and Chen, 1982; Fournier and Marshall, 1983). However, sulfate reduction is unlikely to result in barite deposition unless fluids cool and (or) react with wall rock. In the deposits where sulfate reduction coupled with cooling and (or) wall-rock reaction are probable mineralization processes, sulfide mineralization should occur dominantly with quartz gangue, and barite should be either (1) a minor, paragenetically late phase or (2) largely restricted to sulfide-free portions of the vein system where no sulfate reduction took place. Deposits with these features are located at Magnet Cove, Nova Scotia; New Galena, Audubon, and Phoenixville, Pennsylvania; and possibly the Whatley and Manhan deposits, Massachusetts. For these deposits, sulfate reduction coupled with cooling of the fluid and (or) fluid reaction with wall rock were the probable depositional processes.

Reaction of the hydrothermal fluids with wall rocks along the vein system may be an additional process that caused mineral precipitation. The wall-rock alteration described earlier can be explained by reactions involving cation exchange and proton metasomatism under conditions of constant volume. Under conditions where the dominant carbonate species and reduced sulfur species in the fluid are either $\mathrm{H}_{2} \mathrm{CO}_{3}$ and $\mathrm{H}_{2} \mathrm{~S}$ or $\mathrm{HCO}_{3}{ }^{-}$and $\mathrm{HS}^{-}$, the loss of $\mathrm{H}^{+}$moves the hydrothermal fluid towards saturation with carbonates and metal sulfides by reactions of the type:

$\mathrm{Ca}^{+2}+\mathrm{H}_{2} \mathrm{CO}_{3}=\mathrm{CaCO}_{3}+2 \mathrm{H}^{+}$and $\mathrm{M}^{+2}+\mathrm{H}_{2} \mathrm{~S}=\mathrm{MS}+2 \mathrm{H}^{+}$, or $\mathrm{Ca}^{+2}+\mathrm{HCO}_{3}{ }^{-}=\mathrm{CaCO}_{3}+\mathrm{H}^{+}$and $\mathrm{M}^{+2}+\mathrm{HS}^{-}=\mathrm{MS}+\mathrm{H}^{+}$

The gains of $\mathrm{Ca}^{+2}$ and other cations in the fluid may move the fluid to saturation with respect to a sulfate mineral, such as barite (Holland and Malinin, 1979, p. 502 ). Although the extent of wall-rock alteration does not appear to be great at many of the vein occurrences, these fluid-rock reactions may be responsible for some portion of the metal sulfides, carbonate minerals, and possibly barite in these vein systems.

\section{INTERPRETATION}

Barite and base-metal vein deposits appear to be associated with the transport of moderate-temperature $\left(100-250^{\circ} \mathrm{C}\right)$ brines from within the basins and adjacent basement rocks to shallow sites of mineral precipitation. The principal mechanisms of mineral deposition appear to be cooling, sulfate reduction, wall-rock reaction, and possibly fluid mixing, with the relative importance of these processes varying in different deposits. Preexisting fractures and faults are apparently important in localizing vein development, and a seismic pumping mechanism (Sibson and others, 1975) may be an important process driving fluid migration. According to this model, consid- erable volumes of fluid are rapidly moved in the crust following faulting as a consequence of the dilatancy/fluiddiffusion mechanism for shallow earthquakes. Prior to fault failure, a large region around the focus of the subsequent earthquake dilates in response to rising tectonic stress by opening extension cracks.

Fluid infiltration is promoted because the developing fracture porosity reduces fluid pressure in the dilatant zone. Faulting partially reduces stress levels, allowing the dilatant cracks to collapse, and the fluids they contain are rapidly expelled into the fault system. Sibson and others (1975) estimate that a moderate-intensity earthquake (with a mean slip of 10 to $100 \mathrm{~cm}$ over a $10-\mathrm{km}$ interval) may expel approximately $5 \times 10^{9} \mathrm{~L}$ of fluid, and a fault with a finite displacement of $1 \mathrm{~km}$ could have produced 1,000 to 10,000 such pulses of fluid per each $10 \mathrm{~km}$ of fault length. This seismic pumping mechanism is consistent with the multiple periods of mineralization, fluid sources, and pulses of fluid migration evident in many of the vein systems. In addition, the seismic pumping mechanism can drive significant quantities of hot, deep-seated fluids into the upper crust, perhaps from depths as great as $10 \mathrm{~km}$, and provides a mechanism for the rapid mixing of different fluids. Saline fluids of appropriate chemistry and temperature to form vein deposits fill microfractures in granitoid rocks underlying sedimentary basins (for example, in granitoid rocks underlying the Illinois basin: Couture and Seitz, 1986), and the early Mesozoic basins containing red-bed sediments may be important as recharge areas of saline brines and leachable metals (Zielinski and others, 1983) that ultimately form deep-seated fluids of this type. Fluid migration may be the result of the dynamic and changing stresses that developed during the Middle Jurassic during the separation of North America from Africa.

\section{REFERENCES CITED}

Andreasson, P.-G., Solyom, Z. and Johansson, I., 1987, Geotectonic significance of $\mathrm{Mn}-\mathrm{Fe}-\mathrm{Ba}$ and $\mathrm{Pb}-\mathrm{Zn}-\mathrm{Cu}-\mathrm{Ag}$ mineralizations along the Sveconorwegian-Grenville front in Scandinavia: Economic Geology, v. 82, p. 201-207.

Andrews, A.J., 1986, Silver vein deposits: Summary of recent research: Canadian Journal of Earth Sciences, v. 23, p. 1459-1462.

Annear, J., 1862, Report of the New Britain Lead Mine, Bucks County, Pennsylvania: Philadelphia, no publisher.

Ashmore, S., 1863, Bucks County Lead Company: New York, no publisher.

Bannerman, H.M., 1941, The fluorite deposits of Cheshire County, N.H.: New Hampshire State Planning and Development Commission, New Hampshire Mineral Resource Survey, Part V, 11 p. 
Bascom, F., and Stose, G.W., 1938, Geology and mineral resources of the Honeybrook and Phoenixville quadrangles, Pennsylvania: U.S. Geological Survey Bulletin 891, $145 \mathrm{p}$.

Bateman, A.M., 1923, Primary chalcocite: Bristol Copper Mine, Connecticut: Economic Geology, v. 18, no. 2, p. 122-166.

Bates, R.O., 1959, An application of statistical analysis to exploration for uranium on the Colorado Plateau: Economic Geology, v. 54 , p. $449-466$.

Bernstein, L.R., 1980, Minerals of the Washington, D.C. area: Maryland Geological Survey, Education Series No. 5, 148 p.

Blake, W.P., 1860, The Wheatley silver lead mines: Mining Magazine and Journal of Geology, second series, v. 1, p. 411-418.

Boyle, R.W., 1962, Geology of the barite, gypsum, manganese, and lead-zinc-copper-silver deposits of the WaltonCheverie area, Nova Scotia: Geological Survey of Canada Paper 62-25, 26 p.

Boyle, R.W., and Jambor, J.L., 1966, Mineralogy, geochemistry and origin of the Magnet Cove barite-sulphide deposit, Walton, Nova Scotia: Canadian Institute of Mining and Metallurgy Transactions, v. 69, p. 394-413.

Cook, G.H., 1868, Geology of New Jersey: New Jersey Geological Survey, $900 \mathrm{p}$.

Couture, R.A., and Seitz, M.G., 1986, Movement of fossil pore fluids in granite basement, Illinois: Geology, v. 14, p. 831-834.

Dickeson, M., and Wilson, M.D., 1860, Report of the geological survey of the Dickeson Lead Mine, Bucks County, Pennsylvania: Philadelphia, no publisher.

Doe, B.R., and Zartman, R.E., 1979, Plumbotectonics, the Phanerozoic, in Barnes, H.L., ed., Geochemistry of hydrothermal ore deposits, second edition: New York, WileyInterscience Publication, p. 22-70.

Dombroski, D.R., Jr., 1980, A geological and geophysical investigation of concealed contacts near an abandoned barite mine, Hopewell, New Jersey: unpublished M.S. thesis, Rutgers University, New Jersey, 33 p.

Earl, K.M., 1950, Investigation of Perkiomen Creek copper deposits, Montgomery County, Pennsylvania: U.S. Bureau of Mines, Report of Investigations 4666, $13 \mathrm{p}$.

Edmundson, R.S., 1938, Barite deposits of Virginia: Virginia Division of Mineral Resources, Bulletin 53, 85 p.

Emerson, B.K., 1898a, Holyoke Folio: U.S. Geological Survey Geologic Atlas No. 50, 13 p.

-1898b, Geology of old Hampshire County, Massachusetts, comprising Franklin, Hampshire, and Hampden Counties: U.S. Geological Survey Monograph 29, 790 p.

Espenshade, G.H., 1954, Geology and mineral deposits of the James River-Roanoke River manganese district, Virginia: U.S. Geological Survey Bulletin 1008, 155 p.

Faill, R.T., 1973, Tectonic development of the Triassic NewarkGettysburg Basin in Pennsylvania: Geological Society of America Bulletin, v. 84, p. 725-740.

Fournier, R.O., and Marshall, W.L., 1983, Calculation of amorphous silica solubilities at $25^{\circ}$ to $300^{\circ} \mathrm{C}$ and apparent hydration numbers in aqueous salt solutions using the concept of effective density of water: Geochimica et Cosmochimica Acta, v. 47, p. 587-596.
Franklin, J.M., and Mitchell, R.H., 1977, Lead-zinc-barite veins of the Dorian area, Thunder Bay district, Ontario: Canadian Journal of Earth Sciences, v. 14, no. 9, p. 1963-1979.

Fritts, C.E., 1962, The barite mines of Cheshire: The Cheshire Historical Society, Cheshire, Connecticut.

1963a, Bedrock geology of the Mount Carmel quadrangle, Connecticut: U.S. Geological Survey Geologic Quadrangle Map GQ-199, scale 1:24,000.

1963b, Geologic map of the Southington quadrangle, Connecticut: U.S. Geological Survey Geologic Quadrangle Map GQ-200, scale 1:24,000.

Froelich, A.J., and Leavy, B.D., 1981, Map showing mineral resources of the Culpeper basin, Virginia and Maryland: Availability and planning for future needs: U.S. Geological Survey Miscellaneous Investigations Series Map I-1313-B, scale 1:125,000.

Fryklund, V.C., Jr., 1964, Ore deposits of the Coeur d'Alene district, Shoshone County, Idaho: U.S. Geological Survey Professional Paper 445, 103 p.

Genth, F.A.L.K.W., 1851, Geological report, in First report of the board of directors and the superintendent of the Chester County Mining Company: Philadelphia, King and Baird Publishers, p. 19-28.

Giannini, W.F., 1959, A study of the lead-zinc deposit near Faber, Virginia: unpublished M.S. thesis, University of Virginia.

Glaeser, J.D., 1966, Provenance, dispersal, and depositional environments of Triassic sediments in the Newark-Gettysburg basin: Pennsylvania Geological Survey Bulletin G-43, 4th Series, $168 \mathrm{p}$.

Gleba, P., 1978, Massachusetts mineral and fossil localities: Cambridge, Massachusetts, Krueger Enterprises, Inc.

Gordon, S.G., 1922, The mineralogy of Pennsylvania: Special Publication No. 1, Academy of Natural Science, Philadelphia (reprinted 1973 by Friends of Mineralogy, Region III).

Gray, N.H., 1982, Copper occurrences in the Hartford Basin of northern Connecticut, in Joesten, R., and Quarrier, S.S., eds., Guidebook for fieldtrips in Connecticut and southcentral Massachusetts: New England Intercollegiate Geological Conference, 74th Annual Meeting, p. 195-211.

Gresens, R.L., 1967, Composition-volume relationships of metasomatism: Chemical Geology, v. 2, p. 47-65.

Haas, J.L., Jr., 1976, Physical properties of the coexisting phases and thermochemical properties of the $\mathrm{H}_{2} \mathrm{O}$ component in boiling $\mathrm{NaCl}$ solutions: U.S. Geological Survey Bulletin 1421-A, 73 p.

Hanshaw, P.M., 1968, Bedrock geology of the Meriden quadrangle: U.S. Geological Survey Geologic Quadrangle Map GQ-738, scale 2:24,000.

Harvey, James, 1865, First annual report of the New York and Boston Silver Lead Mining Company: New York, A.A. Moser, stationer.

Hayes, T.S., and Einaudi, M.T., 1986, Genesis of the Spar Lake strata-bound copper-silver deposit, Montana: Part I, Controls inherited from sedimentation and preore diagenesis: Economic Geology, v. 81, p. 1899-1931.

Hiller, John, 1974, Connecticut mines and minerals: Waterbury, Connecticut, no publisher, $61 \mathrm{p}$. 
1975, Massachusetts mines and minerals: Stratford, Connecticut, no publisher, $51 \mathrm{p}$.

Hitchcock, Edward, 1823, A sketch of the geology, mineralogy, and scenery of the regions contiguous to the River Connecticut; with a geological map and drawings of organic remains; and occasional botanical notices, Part II, Simple minerals: American Journal of Science, v. 6, p. 201-236.

-1832, Report on the geology of Massachusetts: American Journal of Science and Arts, v. 22, no. 1, p. 1-70.

-1835 , Report on the geology, mineralogy, botany and zoology of Massachusetts: Amherst, p. 68-74.

Hoffmann, R., and Baumann, A., 1984, Preliminary report on the $\mathrm{Sr}$ isotopic composition of hydrothermal vein barites in the Federal Republic of Germany: Mineralum Deposita, v. 19, p. 166-169.

Holland, H.D., and Malinin, S.D., 1979, The solubility and occurrence of non-ore minerals, in Barnes, H.L., ed., Geochemistry of hydrothermal ore deposits, second edition: New York, Wiley-Interscience Publication, p. 461-508.

Hoofstetten, Charles, 1855, in Wheatley, C.M., ed., Statement of the Pennsylvania Land Company: Philadelphia, T.K. and P.G. Collins, publishers.

Jahns, R.H., 1951, Surficial geology of the Mount Toby quadrangle, Massachusetts: U.S. Geological Survey Geologic Quadrangle Map GQ-9, scale 1:31,680.

Januzzi, R.E., 1959, The minerals of westem Connecticut and southeastem New York State: Danbury, Connecticut, The Mineralogical Press.

Jassim, R.Z., Pattrick, R.A.D., and Russell, M.J., 1983, On the origin of the silver + copper + cobalt + baryte mineralization of Ochil Hills, Scotland: A sulphur isotope study: Institution of Mining and Metallurgy Transactions, Section B, v. 92, p. B213-B216.

Klitgord, K.D., and Schouten, Hans, 1986, Plate kinematics of the central Atlantic, in Vogt, P.R., and Tucholke, B.E., eds., The geology of North America, Volume M, The western North Atlantic region: Geological Society of America, p. 351-378.

Landis, G.P., Leach, D.L., and Hofstra, A.H., 1984, Silver-base metal mineralization as a product of metamorphismCoeur d'Alene district, Shoshone County, Idaho: Concepts of genesis: Montana Bureau of Mines and Geology Special Publication 90, p. 68.

Lange, I.M., and Sherry, R.A., 1983, Genesis of the sandstone (Revett) type of copper-silver occurrences in the Belt Supergroup in northwestern Montana and northeastern Idaho: Geology, v. 11, p. 643-646.

Lawler, J.P., 1981, Fluid inclusion evidence for ore-forming solutions: Phoenixville, Audubon and New Galena Mine districts, Pa.: unpublished M.A. thesis, Bryn Mawr College, Bryn Mawr, Pennsylvania, 74 p.

Lee, K.Y., 1979, Triassic stratigraphy in the northern part of the Culpeper basin, Virginia and Maryland: U.S. Geological Survey Bulletin 1422-C, p. C1-C17.

Lehmann, E.P., 1959, Bedrock geology of the Middletown quadrangle: Connecticut Geological Survey Quadrangle Report No. 8, 34 p.

Lewis, J.V., 1907, Copper deposits of the New Jersey Triassic: Economic Geology, v. 2, p. 242-257.
Luttrell, G.W., 1966, Base- and precious-metal and related ore deposits of Virginia: Virginia Division of Mineral Resources, Mineral Resource Report 7, 167 p.

Marshall, W.L., and Chen, C.T.A., 1982, Amorphous silica solubilities, VI, Postulated sulfate-silicic acid solution complex: Geochimica et Cosmochimica Acta, v. 46, p. 367-370.

Maurin, J.-C., and Lancelot, J.R., 1987, Origine des mineralisations de $\mathrm{Pb}-\mathrm{Zn}$ de la Vallee de la Benoue (Nigeria) d'apres la composition en $\mathrm{Pb}$ des galenas et de l'encaissant: Mineralium Deposita, v. 22, p. 99-108.

Miller, B.L., 1923, Lead and zinc ores near Phoenixville, Chester County, Pennsylvania: Pennsylvania Geological Survey, 4th series, Progress Report 67.

1924, Lead and zinc ores of Pennsylvania: Pennsylvania Geological Survey, 4th series, Bulletin M-5, 91 p.

Morrill, Philip, 1960, New Hampshire mines and mineral localities, second edition: Hanover, New Hampshire, Dartmouth College Museum, $46 \mathrm{p}$.

Nash, Allanson, 1827, Notices of lead mines and veins of Hampshire County, Massachusetts and the geology and mineralogy of that region: American Journal of Science and Arts, v. XII, Article IX, p. 258.

Nelson, W.A., 1962, Geology and mineral resources of Albemarle County: Virginia Division of Mineral Resources, Bulletin 77, $92 \mathrm{p}$.

Newhouse, W.H., 1933, Mineral zoning in the New JerseyPennsylvania-Virginia Triassic area: Economic Geology, v. 28, p. 613-633.

Ohmoto, Hiroshi, Kaiser, C.J., and Geer, K.A., in press, Systematics of sulphur isotopes in recent marine sediments and ancient sediment-hosted base metal deposits, in International Conference on Stable Isotopes and Fluid Processes in Mineralization: Geological Society of Australia, Special Publication, 114 manuscript pages.

Ohmoto, Hiroshi, and Lasaga, A.C., 1982, Kinetics of reactions between aqueous sulfates and sulfides in hydrothermal systems: Geochimica et Cosmochimica Acta, v. 46, p. 1727-1745.

Ohmoto, Hiroshi, and Rye, R.O., 1979, Isotopes of sulfur and carbon, in Barnes, H.L., ed., Geochemistry of hydrothermal ore deposits, second edition: New York, WileyInterscience Publication, p. 509-567.

Olade, M.A., and Morton, R.D., 1985, Origin of lead-zinc mineralization in the southern Benue Trough, NigeriaFluid inclusion and trace element studies: Mineralium Deposita, v. 20 , no. 2 , p. $76-80$.

Parnell, J., 1986, Hydrocarbons and metalliferous mineralization in a lacustrine rift basin: The Hartford-Deerfield Basin, Connecticut Valley: Neues Jahrbuch fur Mineralogie, Abhandlungen, v. 145, no. 1, p. 93-110.

Pattrick, R.A.D., Coleman, M.L., and Russell, M.J., 1983, Sulphur isotopic investigation of vein lead-zinc mineralization at Tyndrum, Scotland: Mineralium Deposita, v. 18, p. $477-485$.

Pearre, N.C., 1956, Mineral deposits and occurrences in Massachusetts and Rhode Island, exclusive of clay, sand and gravel, and peat: U.S. Geological Survey Mineral Investigations Resource Map MR-4, scale 1:500,000. 
Percival, J.G., 1842, Report on the geology of the state of Connecticut: New Haven, Connecticut, Osborn and Baldwin, 495 p.

Potisat, S., 1978, Copper and uranium deposits in red beds of the Connecticut Valley: unpublished M.S. thesis, Wesleyan University, $123 \mathrm{p}$.

Potter, R.W., II, and Brown, D.L., 1977, The volumetric properties of aqueous sodium chloride solutions from $0^{\circ}$ to $500^{\circ}$ $\mathrm{C}$ at pressures up to 2000 bars based on a regression of available data in the literature: U.S. Geological Survey Bulletin 1421-C, p. C1-C36.

Reed, D.F., 1949, Investigation of Pickering Creek lead-zinc deposits, Chester County, Pennsylvania: U.S. Bureau of Mines Report of Investigations 4451, 11 p.

Rees, C.E., 1978, Sulfur isotope measurements using $\mathrm{SO}_{2}$ and $\mathrm{SF}_{\mathrm{B}}$ : Geochimica et Cosmochimica Acta, v. 42, p. 383-389.

Reimer, T.O., 1986, Phanerozoic barite deposits of South Africa and Zimbabwe, in Anhaeusser, C.R., and Maske, S., eds., Mineral deposits of southem Africa: Johannesburg, South Africa, Geological Society of South Africa, v. 2, p. 1351-1393.

Rice, W.N., and Foye, W.G., 1927, Geology of Middletown, Connecticut and vicinity: Connecticut Geological and Natural History Survey, Bulletin 41, 137 p.

Roberts, J.K., 1928, The geology of the Virginia Triassic: Virginia Geological Survey Bulletin 29, 205 p.

Roedder, E., and Bodnar, R.J., 1980, Geologic pressure determinations from fluid inclusion studies: Annual Review of Earth and Planetary Sciences, v. 8, p. 263-301.

Rogers, H.D., 1853, Report on the Wheatley and Brookdale Mines, Chester County, Pennsylvania: Mining Magazine, v. 1, p. $375-387$.

1858, The geology of Pennsylvania: Philadelphia, J.B. Lippincott and Company, $815 \mathrm{p}$.

Rose, A.W., 1970, Atlas of Pennsylvania's mineral resources, Part 3: Metal mines and occurrences in Pennsylvania: Pennsylvania Geological Survey Bulletin M-50, 14 p.

Ryan, S.S., 1984, Carbonate-quartz-barite veins of the Hartford basin: Geological Society of America Abstracts with Programs, v. 16 , no. 1, p. 61 .

__ 1986, Description and paragenetic interpretation of quartz-carbonate-barite veins of the Hartford basin: unpublished M.S. thesis, The University of Connecticut, Storrs, $132 \mathrm{p}$.

Schairer, J.F., 1931, The minerals of Connecticut: Connecticut Geological and Natural History Survey Bulletin 51 .

Shepard, C.U., 1837, A report on the geological survey of Connecticut: Connecticut Geological Survey Report, New Haven, Connecticut, 188 p.
Sibson, R.H., Moore, J.M., and Rankin, A.H., 1975, Seismic pumping-a hydrothermal fluid transport mechanism: Journal of the Geological Society of London, v. 131, p. 653-659.

Silliman, Benjamin, Jr., and Whitney, J.D., 1855, Notice of the geological position and character of the copper mines at Bristol, Connecticut: American Journal of Science, v. 20, p. 361-368.

Simpson, H.E., 1966, Bedrock geologic map of the New Britain quadrangle, Connecticut: U.S. Geological Survey Geologic Quadrangle Map GQ-494, scale 1:24,000.

Smith, J.L., 1855, Re-examination of American minerals, Part $\mathrm{V}$-The minerals of the Wheatley mine in Pennsylvania: American Journal of Science and Arts, second series, v. 20, p. 242-253.

Smith, R.C., II, 1973, Geochemistry of Triassic diabase from southeastern Pennsylvania: Ph.D. thesis, The Pennsylvania State University, $262 \mathrm{p}$.

1977, Zinc and lead occurrences in Pennsylvania: Pennsylvania Geological Survey, Mineral Resource Report 72, $318 \mathrm{p}$.

Sunderman, H.C., 1958, Geology and mineral resources of the Scottsville Triassic basin, Virginia: Virginia Division of Mineral Resources, Open-File Report, 58 p.

Tumbull, L., 1854, A visit to the lead and copper mines of Chester County, Pennsylvania: Journal of the Franklin Institute, 3rd series, v. 27, p. 52-54.

Watson, T.L., 1907, Mineral resources of Virginia: Lynchburg, Virginia, Virginia Jamestown Exposition Commission.

Wherry, E.T., 1908, The Newark copper deposits of southeastern Pennsylvania: Economic Geology, v. 3, p. 726-738.

Willard, B., and others, 1959, Geology and mineral resources of Bucks County, Pennsylvania: Pennsylvania Geological Survey, Bulletin C-9, 243 p.

Willard, M.E., 1952, Bedrock geology of the Greenfield quadrangle, Massachusetts: U.S. Geological Survey Geologic Quadrangle Map GQ-20, scale 1:31,680.

1956, Bedrock geology of the Williamsburg quadrangle, Massachusetts: U.S. Geological Survey Geologic Quadrangle Map GQ-85, scale 1:31,680.

Williams, C.P., 1863, A stock prospectus of the Perkiomen Mining Company, Philadelphia: no publisher.

Woodward, H.P., 1944, Copper mines and mining in New Jersey: New Jersey Department of Conservation and Development, Geologic Series, Bulletin 57, 156 p.

Zielinski, R.A., Black, S., and Walker, T.R., 1983, The mobility and distribution of heavy metals during the formation of first cycle red beds: Economic Geology, v. 78, p. 1574-1589. 


\title{
FIELD GUIDE TO THE IGNEOUS ROCKS OF THE SOUTHERN CULPEPER BASIN, VIRGINIA
}

\author{
Richard P. Tollo', David Gottfried, and Albert J. Froelich
}

\section{INTRODUCTION}

Igneous rocks of the Culpeper basin include (1) two extensive systems of diabase sheets, (2) three systems of chemically distinct diabase dikes, and (3) three series of multiple basalt flows. The diabase intrudes both Upper Triassic and Lower Jurassic strata and the sheets are bordered by extensive contact aureoles. Froelich and Gottfried (this volume) have subdivided the sheets on the basis of chill margin geochemistry into high-titanium, quartz normative (HTQ) and low-titanium, quartz normative (LTQ) tholeiite subtypes, correlating these to the bimodal populations of diabase dike compositions originally defined for the eastern North America (ENA) province by Weigand and Ragland (1970). These compositions are chemically similar to those of the York Haven (HTQ) and Rossville (LTQ) diabase sheets of the Gettysburg basin in Pennsylvania (Smith and others, 1975). ${ }^{40} \mathrm{Ar} /{ }^{39} \mathrm{Ar}$ age spectra yielding a mean age of $198.4 \pm 2.1 \mathrm{Ma}$ (Sutter, 1985) supported by paleomagnetic data (Raymond and others, 1982) suggest that the intrusion of HTQ and LTQ diabase was essentially contemporaneous, approximately concurrent with basalt extrusion, and restricted to a relatively short interval within the Early Jurassic. Local field relations, however, indicate that at least some of the LTQ diabase intruded after emplacement of the HTQ sheets (Froelich and Gottfried, this volume). The individual HTQ sheets, enclosing extensive orthopyroxene-cumulate zones and (or) evolved granophyre or ferrogabbro sections, appear to have fractionated as systems in which lateral migration and flow differentiation were important. The petrologic systematics of the LTQ sheets show little evidence for differentiation and are generally less well defined. Initial data suggest that these magmas are not part of a direct lineage involving the HTQ diabase.

Dike rocks within the Culpeper basin are divisible into three petrologic subtypes on the basis of geochemistry and orientation. The Seneca dike system trends north-northeast along the eastern margin of the basin but occurs primarily in the Paleozoic metamorphic rocks

\footnotetext{
${ }^{1}$ George Washington University, Washington, DC 20052.
}

adjacent to the northeastern edge of the basin (Leavy and others, 1983). These dikes are characterized by HTQ compositions and may form part of a petrologic suite defined by several HTQ diabase sheets and transverse dikes in the east-central portion of the basin (Froelich and Gottfried, this volume). The Ashburn-Dickerson dike system, occurring 7-9 $\mathrm{mi}(11-15 \mathrm{~km})$ west of the Seneca dikes and also striking north-northeast, forms part of the throughgoing Frederick dike system and is characterized by LTQ compositions. These dikes extend through the central portion of the basin (Leavy and others, 1983) and form part of a suite encompassing the LTQ diabase sheets located in that area (Froelich and Gottfried, this volume). A series of north- and northwesttrending olivine-bearing dikes compose a third distinct system and, together with several poorly exposed olivinebearing plugs, may constitute an olivine normative magmatic suite (Froelich and Gottfried, this volume).

A sequence of at least 13 basalt flows is intercalated with Lower Jurassic strata in the west-central portion of the Culpeper basin (Lee, 1979, 1980). These flows comprise three series mapped (from oldest to youngest) as the Mount Zion Church (2 flows), Hickory Grove (2 flows), and Sander (9 flows) Basalts (Lee, 1979, 1980; Lee and Froelich, in press). These basalts include both HTQ and LTQ lavas, although the latter is volumetrically rare and probably restricted to the third flow of the Sander Basalt in the central and northern portions of the basalt outcrop belt (Tollo, this volume). The Mount Zion Church and Hickory Grove Basalts and the first flow of the Sander Basalt represent chemically distinct HTQ subtypes that can be correlated throughout the length of the outcrop belt. All overlying flows within the Sander Basalt are locally variable in composition. The stratigraphy of basalt petrochemical types indicates that the composition of succeeding lavas was not controlled simply by tholeiitic fractionation. Correlation of the basalt types along strike suggests that volcanic activity in the basin was initially areally extensive, possibly with significant ponding of lava in the south, but later involved more local and chemically distinct eruptions (Tollo, this volume). 
This field trip is an introduction to the igneous rocks of the southern Culpeper basin. The first three stops are located within the basalt sequence near Casanova, Virginia, and will provide an opportunity to examine flows assigned to each of the three extrusive series. Stop 1 is located at the base of the volcanic sequence where two flows of the Mount Zion Church Basalt are separated by a thin lens of intercalated strata. Stop 2 provides a cross section through part of the Hickory Grove Basalt at a locality where distinct zones of brittle fracture deformation and subsequent hydrothermal mineral activity are present. Stop 3 is located in Sander quarry where part of a thick ponded sequence comprising the lowermost portion of the Sander Basalt is exposed. Exceptional examples of chemically evolved, coarsegrained differentiates of the basalt will also be examined at this locality. The last three stops are located in the southern part of the Culpeper basin and have been chosen as representative of the lithologic variation characterizing the HTQ diabase sheets in this area. Stops $4 a-4 c$ represent a traverse through the eastern flank of the Rapidan sheet and provide a composite cross section of the diabase stratigraphy including the upper and lower chill margins, noritic gabbro cumulates, and leucocratic orthopyroxene diabase. Stop 5 provides a further opportunity to examine the textural characteristics of the orthopyroxene cumulates of this sheet located at the Virginia Granite quarry at nearby Buena. Thin late-stage veins composed of tourmaline + potassic feldspar + chlorite cut the diabase at this locality. Stop 6, located 15 $\mathrm{mi}(24 \mathrm{~km})$ northeast of Buena at Berry Hill, contiguous to the Rapidan diabase sheet, includes exposures of granophyre and ferrogabbro that may represent the evolved products of typical HTQ differentiation in the Culpeper basin.

\section{Road Log}

The field trip begins in the visitors' parking lot at the U.S. Geological Survey in Reston, Virginia. Measured mileage begins at the entrance to this lot at the intersection with South Lakes Drive. Incremental mileage is given in parentheses. The individual stop locations are located on a generalized map of the igneous geology of the Culpeper basin in figure 1 .

$0.0(0.0)$ Exit lot by turning left onto South Lakes Drive.

0.5 (0.5) Turn right onto Reston Avenue (Route 602).

3.1 (2.6) Reston Avenue becomes West Ox Road (Route 608); continue south.

6.4 (3.3) Intersection of Routes 608 and 50, continue south on Route 608 .
}

7.3 (0.9) Cross over Interstate 66 (I-66), continue south on Route 608.

8.2 (0.9) Turn right onto Route 29, Lee Highway, proceed west.

11.5 (3.3) Turn left onto Route 28, proceed south.

19.5 (8.0) Fork in road, bear left to continue on Nokesville Road.

26.2 (6.7) Intersection of Routes 28 and 652, continue south on Route 28 .

31.0 (4.8) Entering Catlett.

33.5 (2.5) Turn right onto Route 616, proceed northwest.

35.4 (1.9) STOP 1: Turn left off of highway, park on unpaved road. Exposures are located along the railway across Route 616 and to the left.

\section{STOP 1: MOUNT ZION CHURCH BASALT (CATLETT QUADRANGLE)}

The exposures at this stop provide a partial cross section through two flows forming the base of the volcanic sequence in the Culpeper basin (fig. 2). The first rocks exposed as we proceed northwest along the railway are thin-bedded to finely laminated red sandstones and interbedded siltstones of the Catharpin Creek Formation (Lee and Froelich, in press). Palynological evidence indicates that these strata are Early Jurassic in age with the Triassic-Jurassic boundary located approximately $200 \mathrm{ft}(60 \mathrm{~m})$ southeast along Route 616 (Cornet, 1977). The lowermost flow of the Mount Zion Church Basalt is approximately $23 \mathrm{ft}(7 \mathrm{~m})$ thick and is composed of dark-gray, fine-grained, sparsely porphyritic basalt. The lower contact with the underlying sedimentary rocks can be located within several feet, and it is important to note the lack of obvious contact metamorphism. This is characteristic of the basalt flows in the basin and helps to distinguish the volcanics from fine-grained intrusive counterparts. The two flows exposed at this locality are separated by a thin lens of thin-bedded red sandstone with local silty interbeds. Such intercalated strata are not continuous along strike within the formation. The upper flow at this locality is approximately $75 \mathrm{ft}(23 \mathrm{~m})$ thick and is composed of pale-green, generally fine-grained, sparsely porphyritic basalt that is considerably more altered than the lower flow. The upper contact of this flow with the overlying strata of the Midland Formation (Lee and Froelich, in press) is not exposed here, but is interpreted to be located approximately $200 \mathrm{ft}(60 \mathrm{~m})$ southeast of the railroad bridge on the tracks between stops 1 and 2 (Lee, 1980).

The basalt comprising both flows at this locality is characterized in thin section by a distinctly glomeroporphyritic texture defined by clusters of subhedral to euhedral augite phenocrysts locally intergrown with relatively rare, generally finer grained, subhedral plagioclase. The groundmass consists primarily of abundant, finely granular augite and microlitic plagioclase locally intergrown with brown serpentine that is probably pseu- 

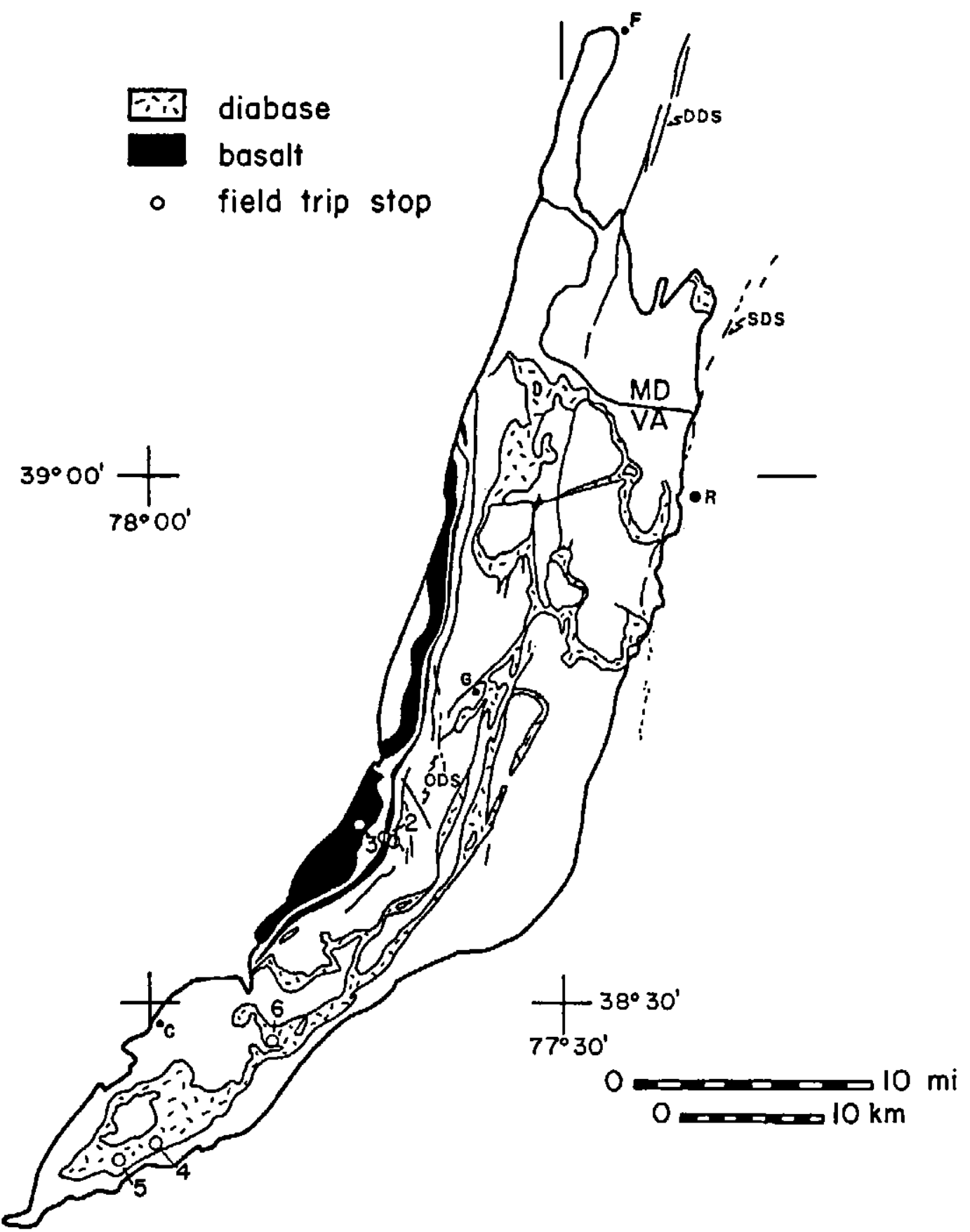

Figure 1. Geologic map showing the distribution of major igneous units within the Culpeper basin. Numbers refer to field trip stops and are keyed to the text. DDS, Dickerson dike system; SDS, Seneca dike system; ODS, olivine-bearing dike system; F, Frederick; G, Gainesville; C, Culpeper; R, Reston.

domorphic after original olivine. Brown intersertal glass (mostly devitrified) is present throughout the groundmass and typically contains abundant skeletal magnetite. Secondary alteration of all phases is considerably more widespread in the upper flow.

The chemical compositions (table 1) of samples from each of the flows exposed at this locality are typical of the range characterizing the Mount Zion Church Basalt and reflect the relative degree of alteration observed in thin section. Values for 10 selected elements from the lower flow sample (MZ-13-86) correspond closely to the average concentrations in two relatively unaltered samples from the geochemical type locality (fig. 3). This close correspondence indicates that these 


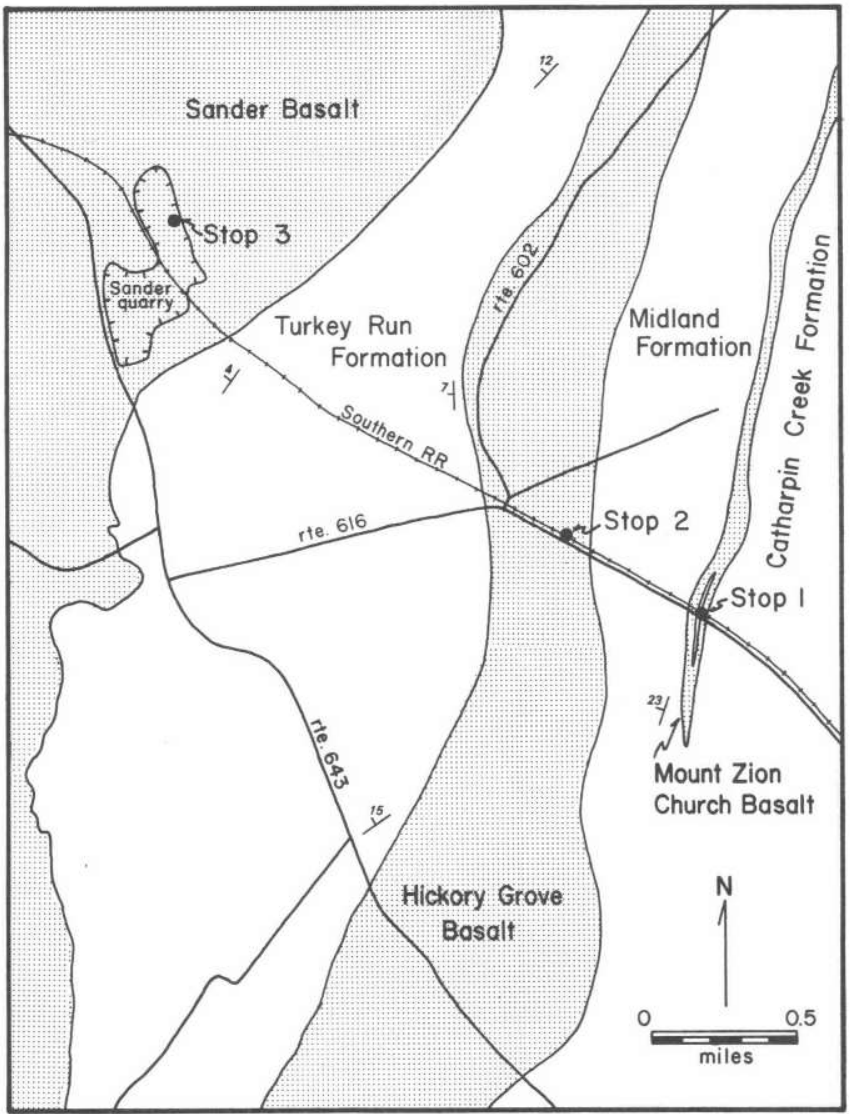

Figure 2. Geologic map of part of the Catlett Quadrangle in the area of Casanova, Virginia, showing the location of field trip stops 1-3. Map modified after Lee (1980).

compositions approximate that of the original lava. Values for the highly altered upper flow sample diverge widely from those of the geochemical type locality for $\mathrm{K}$, $\mathrm{Sr}, \mathrm{Ca}$, and $\mathrm{Na}$, indicating that these elements are mobile during alteration. These data are generally consistent with the observations of Gottfried and others (1978), except for the radical decoupling of $\mathrm{Ca}$ and $\mathrm{Sr}$, which show pronounced depletion and enrichment, respectively. Values for elements of smaller ionic radii, including $\mathrm{Mg}, \mathrm{Zr}, \mathrm{Ti}, \mathrm{Nb}, \mathrm{V}$, and $\mathrm{P}$, exhibit very limited ranges throughout the Mount Zion Church flow series, indicating that alteration has little effect on the concentrations. This characteristic immobility indicates that the concentrations of these elements may be used as indicators of magmatic evolution. It is instructive to note that the enrichment of sodium due to alteration is sufficient to yield a spurious olivine normative composition for the altered sample (table 2).

The Mount Zion Church Basalt, like the initial flow series in both the Newark and Hartford basins (Orange Mountain and Talcott Basalts, respectively), is the least chemically evolved of the tholeiitic volcanic sequence, as
Table 1. Major- and trace-element compositions of samples from field trip stops 1 and 2

[Major-element analyses are normalized to 100 weight percent (anhydrous); trace-element concentrations are expressed in parts per million (ppm); analytical methods for all geochemical data are described in appendix $A ; n$, number of analyses; - , not analyzed]

\begin{tabular}{|c|c|c|c|}
\hline & \multicolumn{2}{|c|}{ Stop 1: Mount Zlon Church Basalt } & \multirow{2}{*}{$\begin{array}{c}\text { Stop 2: Hickory } \\
\text { Grove Basalt } \\
\text { HG-16-86 }\end{array}$} \\
\hline & $\begin{array}{l}\text { lower flow, } \\
\text { MZ-13-86 }\end{array}$ & $\begin{array}{l}\text { upper flow. } \\
M Z-12-86\end{array}$ & \\
\hline $\mathrm{SiO}_{2} \ldots \ldots \ldots \ldots$ & 51.89 & 52.29 & 53.26 \\
\hline $\mathrm{TiO}_{2} \ldots \ldots \ldots \ldots$ & 1.15 & 1.15 & 1.09 \\
\hline $\mathrm{Al}_{2} \mathrm{O}_{3} \ldots \ldots \ldots$ & 14.30 & 14.52 & 14.09 \\
\hline $\begin{array}{l}\mathrm{Fe}_{2} \mathrm{O}_{3} * \ldots \ldots \ldots \ldots \\
\mathrm{FeO} \ldots \ldots \ldots \ldots\end{array}$ & 11.14 & 11.24 & 13.43 \\
\hline $\mathrm{MnO} \ldots \ldots \ldots \ldots$ & .18 & .20 & .22 \\
\hline $\mathrm{MgO} \ldots \ldots \ldots \ldots$ & 7.65 & 7.72 & 5.15 \\
\hline $\mathrm{CaO} \ldots \ldots \ldots \ldots$ & 11.41 & 7.77 & 9.22 \\
\hline $\mathrm{Na}_{2} \mathrm{O} \ldots \ldots \ldots \ldots$ & 2.00 & 4.91 & 2.62 \\
\hline $\mathrm{K}_{2} \mathrm{O} \ldots \ldots \ldots \ldots$ & .15 & .07 & .74 \\
\hline $\mathrm{P}_{2} \mathrm{O}_{5} \ldots \ldots \ldots \ldots$ & .13 & .13 & .18 \\
\hline Total ......... & 100 & 100 & 100 \\
\hline n.............. & 2 & 2 & 2 \\
\hline $\mathrm{Nb} \ldots \ldots \ldots \ldots$ & 7.2 & 6.9 & 4.3 \\
\hline $\mathrm{Zr} \ldots \ldots \ldots \ldots$ & 101 & 101 & 96 \\
\hline Sr $\ldots \ldots \ldots$ & 233 & 838 & 260 \\
\hline $\mathrm{Zn} \ldots \ldots \ldots \ldots$ & 84 & 84 & 95 \\
\hline $\mathrm{Ni} \ldots \ldots \ldots \ldots \ldots$ & 96 & 87 & 17 \\
\hline $\mathrm{Cr} \ldots \ldots \ldots \ldots \ldots$ & 295 & 264 & 14 \\
\hline$V \ldots \ldots \ldots \ldots \ldots$ & 241 & 240 & 268 \\
\hline $\mathrm{Ce} \ldots \ldots \ldots \ldots \ldots$ & 14 & - & - \\
\hline Ba............ & 182 & - & - \\
\hline
\end{tabular}

* Total iron expressed as $\mathrm{Fe}_{2} \mathrm{O}_{3}$.

demonstrated by high values of $\mathrm{MgO}, \mathrm{Cr}$, and $\mathrm{Ni}$ (Puffer and others, 1981; Philpotts and Martello, 1986; Tollo, this volume). Abundances of the trace elements $\mathrm{Y}$ and $\mathrm{V}$ are consistent with this trend, but values for $\mathrm{Ba}$ and $\mathrm{Zr}$ are anomalously high in these initial flows, exceeding the levels characterizing the overlying extrusives in each basin. The composition of the Mount Zion Church Basalt closely resembles the median composition of York Haven diabase chilled margins reported by Smith and others (1975). Within the Culpeper basin, the closest analog to the composition of the Mount Zion Church Basalt is represented by the chilled margin of the HTQ Boyds sheet (Froelich and Gottfried, this volume), although the major-element compositions of the chilled margins from nearly all of the HTQ sheets are similar.

Return to the vehicles. Tum around on the unpaved road and carefully turn left onto Route 616. Proceed northwest.

36.3 (0.9) STOP 2: Turn right onto Route 747 and immediately park on the left across from the abandoned store. The exposures are located along the railway approximately $1,200 \mathrm{ft}(360$ m) to the southeast. 
Table 2. Normative compositions of samples from field trip stops 1 and 2

[Measured in weight percent]

\begin{tabular}{|c|c|c|c|}
\hline Mineral & $M Z-13-86$ & $M Z-12-86$ & $H G-16-86$ \\
\hline Quartz. & 3.36 & 0 & 4.62 \\
\hline Orthoclase.......... & 1.11 & .56 & 4.45 \\
\hline Albite..$\ldots \ldots \ldots$ & 16.77 & 41.40 & 22.01 \\
\hline Anorthite.... & 29.47 & 17.24 & 24.46 \\
\hline Diopside. . . . . . . . . & 21.61 & 16.81 & 17.20 \\
\hline Hypersthene . . . . . . & 22.64 & 1.79 & 21.74 \\
\hline Olivine $\ldots \ldots \ldots \ldots$ & 0 & 16.90 & 0 \\
\hline Magnetite ........ & 1.62 & 1.62 & 1.86 \\
\hline Ilmenite .......... & 2.13 & 2.13 & 2.13 \\
\hline Apatite.$\ldots \ldots \ldots \ldots$ & .34 & .34 & .34 \\
\hline
\end{tabular}

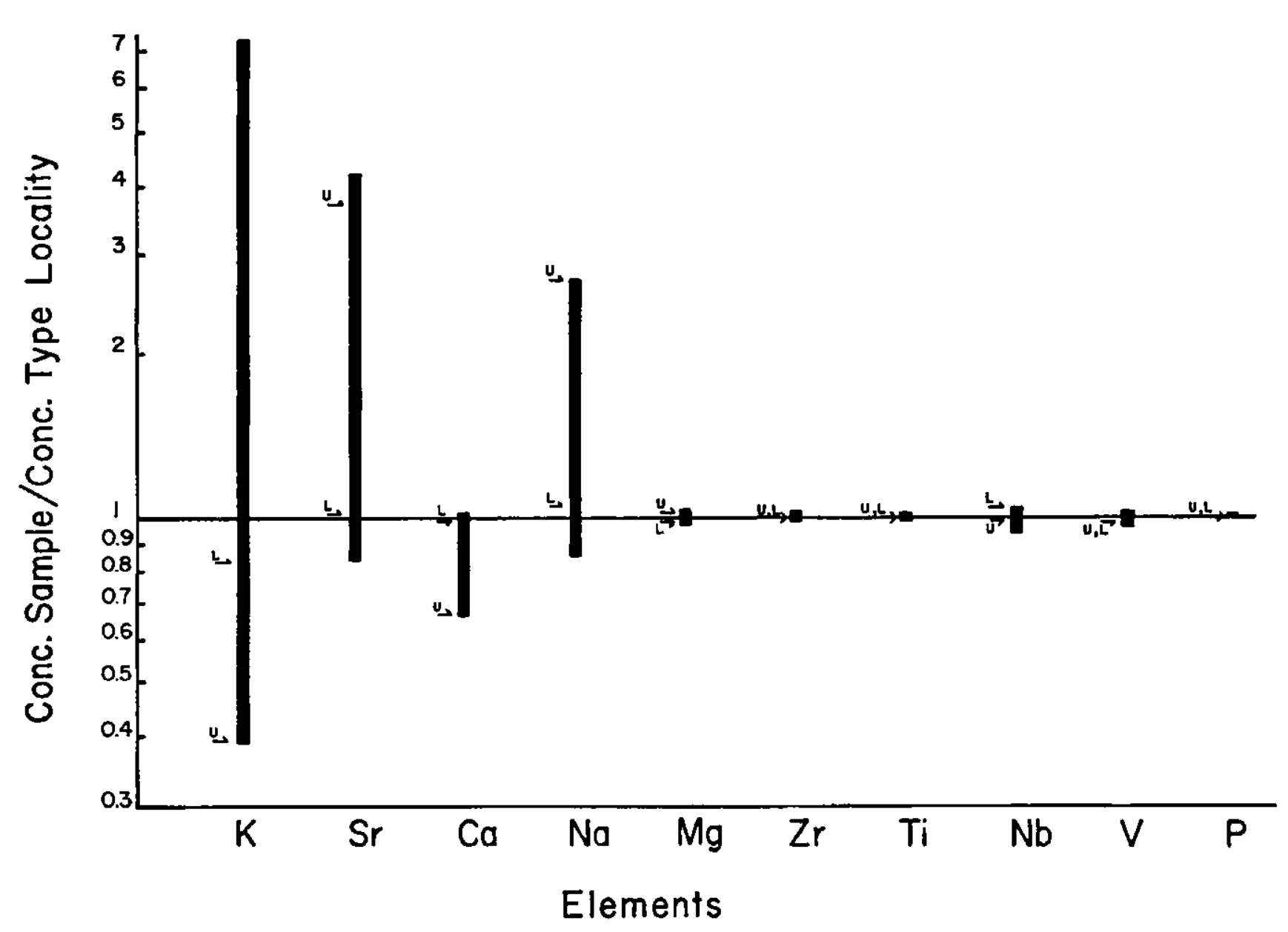

\section{STOP 2: HICKORY GROVE BASALT} (CATLETT QUADRANGLE)

The exposures at this stop are located within the central portion of the Hickory Grove Basalt (fig. 2). The contact between this flow and the overlying strata of the Turkey Run Formation (Lee and Froelich, in press) is located approximately $300 \mathrm{ft}(91 \mathrm{~m})$ west of the intersection of Routes 616 and 747 (Lee, 1980). The exposures at this locality are composed of fine-grained, locally porphyritic basalt characterized by pale reddish-gray weathered surfaces typical of the Hickory Grove throughout the basin. Several zones of brittle fractures, which probably represent nearly vertical, minor faults, occur at the eastern end of the roadcut. The largest of these is approximately $6 \mathrm{ft}(2 \mathrm{~m})$ wide and strikes $\mathrm{N} .14^{\circ} \mathrm{W}$, parallel to two larger faults mapped in the quadrangle by Lee (1980). The angular basalt fragments contained within these zones are cemented primarily by calcite and quartz. Numerous cavities are present and are partially

Figure 3. Plot showing the range of values for selected elements from samples of the Mount Zion Church Basalt expressed as a ratio relative to the average concentration of each element in samples from the geochemical type locality (see Tollo, this volume, for location). Values for samples from the upper (U) and lower (L) flows at stop 1 are indicated by arrows. 
or wholly filled either with these minerals or with banded gray agate. Slickensided surfaces are abundant throughout the exposure.

A sample collected from the central portion of this exposure is characterized in thin section by an overall fine-grained, intergranular texture comprised of randomly oriented, subhedral plagioclase laths and granular augite intergrown with relatively sparse, generally altered pigeonite. Relatively rare plagioclase crystals exceeding 1 $\mathrm{mm}$ in length may represent phenocrysts. This lack of clear definition between phenocrysts and groundmass is a characteristic distinction between the basalt of this flow series and the first flow of the overlying Sander Basalt, in which both plagioclase and augite form distinct phenocrysts, together composing as much as 14 modal percent of the rock in this part of the basin. The oxide minerals in this basalt are typically blocky in form and locally approach $0.5 \mathrm{~mm}$ in diameter, contrasting sharply with the exclusively very fine-grained, skeletal types that characterize the underlying Mount Zion Church Basalt. Turbid, light-colored mesostasis is present in small amounts in the interstices between grains but is typically too altered to analyze adequately.

The chemical composition of the sample collected from this roadcut (table 1) is typical of the Hickory Grove Basalt and corresponds to the high-iron, quartz normative (HFQ) subdivision of the HTQ magma type, as originally proposed by Weigand and Ragland (1970). Like the second flow series in both the Hartford and Newark basins, the Hickory Grove Basalt is characterized by a composition that is lower in $\mathrm{MgO}$ and higher in iron, at nearly constant $\mathrm{TiO}_{2}$ content, than the underlying volcanic unit. Relative to the Preakness and Holyoke Basalts (Newark and Hartford basins, respectively), the Hickory Grove is the most chemically evolved of the "middle" series, as indicated by the characteristically high values of $72-73$ for 100 times the mafic index (Tollo, this volume). Trace-element evidence bearing on the possible derivation of Hickory Grove type basalt from Mount Zion Church type magma is contradictory. Some elements show predicted enrichment $(\mathrm{V})$ or depletion $(\mathrm{Ni}$, $\mathrm{Cr}$ ), but others remain essentially constant ( $\mathrm{Zr}$ ) (Puffer and others, 1981; Philpotts and Martello, 1986; Tollo, this volume).

Gottfried and others (1978) have demonstrated that the concentrations of rare-earth elements (REE) in ENA lavas remain essentially unchanged by the effects of alteration and low-grade metamorphism. Normalized REE patterns of selected samples from the Mount Zion Church and Hickory Grove Basalts (fig. 4) support this observation and show the light-REE enrichment and slight negative Eu anomaly typical of HTQ magma types in the ENA province (Ragland and others, 1971). The curves for these basalts show considerable overlap for the light REE but diverge for the heavy elements, with the

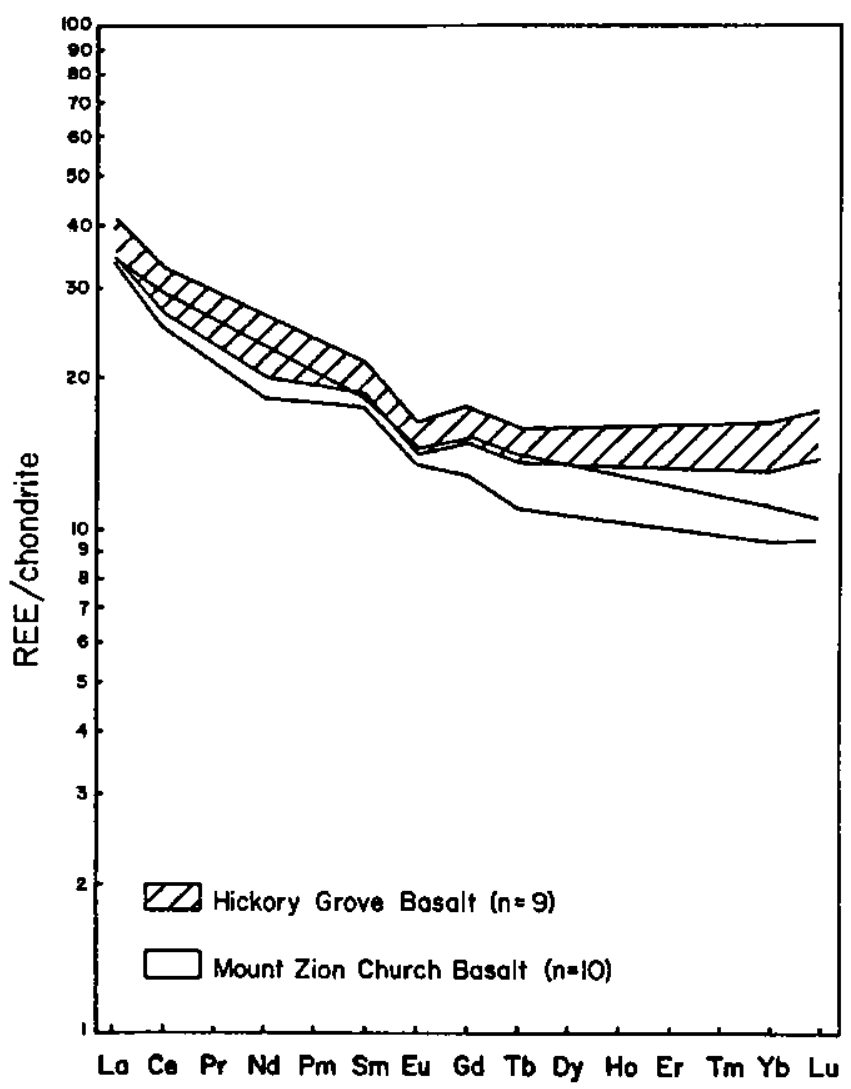

Figure 4. Plot of abundances of rare-earth elements (REE) in selected samples of the Mount Zion Church and Hickory Grove Basalts ( $n$, number of samples analyzed). Data are normalized to average REE abundances in chondrites (Anders and Ebihara, 1982).

Mount Zion Church values $(\mathrm{La} / \mathrm{Yb}=3.2)$ somewhat lower relative to the Hickory Grove $(\mathrm{La} / \mathrm{Yb}=2.6)$. These data suggest that these basalts were derived either from the same or similar undepleted source materials and have experienced different degrees of heavy-REE (clinopyroxene) fractionation or are derivatives of somewhat different sources.

Return to the vehicles. Turn right onto Route 616 and proceed west.

37.5 (1.2) Tum right onto Route 643. Proceed north.

38.7 (1.2) Stop 3: Turn right into entrance to Sander quarry. Proceed cautiously and beware of heavy truck traffic. The exposures to be examined are located along the eastern wall of the northem pit.

\section{STOP 3: SANDER BASALT (CATLETT QUADRANGLE)}

Sander quarry provides an important cross section through the lower portion of the Sander Basalt in the southern Culpeper basin. Assuming an orientation conformable with the underlying Turkey Run Formation which is exposed $300 \mathrm{ft}(91 \mathrm{~m})$ southeast of the south- 
ernmost quarry wall, a minimum stratigraphic thickness of approximately $181 \mathrm{ft}(55 \mathrm{~m})$ of basalt is present in nearly continuous exposure. The rocks to be examined at this stop extend from approximately the midpoint of the eastern wall northward to the northwest corner of the quarry and constitute the upper half of the exposed sequence. The basalt at this location is generally greenish- to reddish-gray, fine- to medium-grained, and characteristically porphyritic. The rocks show a moderately developed colonnade-style columnar jointing oriented approximately perpendicular to the regional dip throughout most of the section, except near the northwest corner of the quarry where curvicolumnar entablature is developed. The transition between the two types of columnar jointing is relatively abrupt, occurring over an interval of less than $10 \mathrm{ft}(3 \mathrm{~m})$. Medium- to coarsegrained gabbroid veins crosscut the basalt at three locations along the eastern quarry wall (McFall, 1985). These gabbroids form an irregular network of meter-scale veins, are characterized by both sharp and gradational contacts with the surrounding basalt, and, in at least one case, extend across the full width of the quarry floor. The veins are locally associated with abundant sulfides occurring as joint coatings.

The basalt in this portion of the quarry is characterized in thin section by an overall fine-grained inequigranular to sparsely porphyritic texture comprised of randomly oriented grains of plagioclase + augite + pigeonite + oxide with Iocal areas of highly altered mesostasis. Plagioclase is generally coarser grained than the predominantly granular pyroxene and, where locally exceeding $1 \mathrm{~mm}$ in length, may represent phenocrysts. Augite and pigeonite are present in subequal amounts and may be distinguished by the typically more altered nature and characteristic herringbone twinning of the former. The mesostasis is typically highly altered, although local patches of identifiable granophyre are present. The oxide phase is dominantly magnetite and ranges from blocky to irregular in habit and from very fine-grained to approximately $0.5 \mathrm{~mm}$ in diameter. The medium- to coarse-grained gabbroic veins contain the same plagioclase + augite + pigeonite + oxide assemblage as the enclosing basalt. Elongate augite prisms are typically prominent and locally sufficiently coarsegrained to show herringbone twinning in hand specimen. Oxide minerals occur as both coarse, blocky grains and as very fine-grained overgrowths nucleated on subhedral silicates. Although the overall texture of the rock is medium to coarse grained, a considerable amount of very fine-grained mesostasis occurs in the interstices. Typically highly altered and replaced, this mesostasis locally contains abundant apatite(?) needles. Plagioclase and pyroxene crystals extend into such areas with euhedral outlines.
Table 3. Major- and trace-element compositions of selected samples from Sander quarry

[a, average of ten samples (analyzed in duplicate) from a 74-ft $(22.5-\mathrm{m})$ vertical traverse near the base of the basalt in the southern pit; $b$, sample collected from entablature unit near top of exposed sequence approximately 120 feet $(36 \mathrm{~m})$ southeast of the northern comer of the northem pit; $c$, sample collected from colonnade unit approximately midway along the eastern wall of the northern pit; $d$, average of two samples collected from gabbroid veins in central portion of northern pit. All data are from McFall (1985). Major-element analyses are normalized to 100 weight percent (anhydrous); trace-element analyses are expressed in parts per million (ppm); n, number of analyses; n.d., not detected]

\begin{tabular}{|c|c|c|c|c|}
\hline & $a: V T$ & b: $2-4 A-84$ & c: $2-7 A-84$ & d: $2-9 / 14 A-84$ \\
\hline $\mathrm{SiO}_{2} \ldots \ldots \ldots$ & 52.58 & 51.34 & 53.30 & 54.06 \\
\hline $\mathrm{TiO}_{2} \ldots \ldots$ & 1.09 & 1.10 & 1.31 & 1.82 \\
\hline $\mathrm{Al}_{2} \mathrm{O}_{3} \ldots \ldots$ & 13.84 & 13.82 & 13.60 & 11.95 \\
\hline $\begin{array}{l}\mathrm{Fe}_{2} \mathrm{O}_{9}{ }^{*} \ldots \ldots \ldots \\
\mathrm{FeO} \ldots \ldots \ldots\end{array}$ & 13.73 & 13.86 & 13.98 & 16.36 \\
\hline $\mathrm{MnO} \ldots \ldots \ldots$ & .21 & .22 & .21 & .25 \\
\hline $\mathrm{MgO} \ldots \ldots \ldots$ & 5.56 & 5.74 & 4.82 & 3.42 \\
\hline $\mathrm{CaO} \ldots \ldots \ldots$ & 9.71 & 8.70 & 8.97 & 8.12 \\
\hline $\mathrm{Na}_{3} \mathrm{O} \ldots \ldots \ldots$ & 2.54 & 4.76 & 2.96 & 2.77 \\
\hline $\mathrm{K}_{2} \mathrm{O} \ldots \ldots \ldots$ & .59 & .29 & .67 & 1.03 \\
\hline $\mathrm{P}_{2} \mathrm{O}_{5} \ldots \ldots \ldots$ & .15 & .17 & .18 & .22 \\
\hline Total. ........ & 100 & 100 & 100 & 100 \\
\hline $\begin{array}{l}\text { index }{ }^{* *} \\
(\times 100) \ldots\end{array}$ & 71 & 71 & 74 & 83 \\
\hline$n \ldots \ldots \ldots$ & 20 & 2 & 2 & 4 \\
\hline$\ldots \ldots$ & 28 & 28 & 30 & 39 \\
\hline Sr . . . . . . . & 143 & 190 & 229 & 179 \\
\hline Rb $\ldots \ldots \ldots \ldots$ & 18 & 9 & 23 & 32 \\
\hline $\mathrm{Pb} \ldots \ldots \ldots \ldots$ & 6 & 5 & 7 & 10 \\
\hline $\mathrm{Ga} \ldots \ldots \ldots \ldots$ & 19 & 18 & 20 & 21 \\
\hline $\mathrm{Nb} \ldots \ldots \ldots \ldots$ & 5.2 & 4.6 & 5.5 & 7.9 \\
\hline Zr......... & 91 & 88 & 107 & 140 \\
\hline $\mathrm{Zn} \ldots \ldots \ldots \ldots$ & 109 & 110 & 121 & 116 \\
\hline $\mathrm{Ni} \ldots \ldots \ldots \ldots$ & 30 & 34 & 16 & 11 \\
\hline Cr.... & 20 & 19 & 17 & n.d. \\
\hline$\ldots$. & 343 & 330 & 394 & 416 \\
\hline $\mathrm{Ce} \ldots \ldots \ldots \ldots$ & 21 & 20 & 22 & 31 \\
\hline $\mathrm{Ba} \ldots \ldots \ldots \ldots$ & 150 & 151 & 158 & 195 \\
\hline
\end{tabular}

* Total iron expressed as $\mathrm{Fe}_{2} \mathrm{O}_{3}$.

** Mafic index $-\left(\mathrm{FeO}+\mathrm{Fe}_{2} \mathrm{O}_{3} / \mathrm{FeO}+\mathrm{Fe}_{2} \mathrm{O}_{3}+\mathrm{MgO}\right)$.

Analyses of samples from near both the top and the base of the exposed sequence (table 3 , analyses a and $b$, respectively) indicate that the basalt in this quarry is dominantly of the type A variety typical of the lowermost Sander flow throughout the Culpeper basin (McFall, 1985; Tollo, this volume). This basalt corresponds to the HFQ magma type of Weigand and Ragland (1970). The composition is considerably lower in $\mathrm{TiO}_{2}$ than those of the uppermost flow units in the Newark (Hook Mountain Basalt) and Hartford (Hampden Basalt) basins but is quite similar to the average compositions of the "middle" flow units (Puffer and others, 1981; Philpotts and Martello, 1986). This compositional trend underscores the uniqueness of the Culpeper volcanic sequence. Analyses $a$ and $b$ in table 3 also offer further evidence for the 


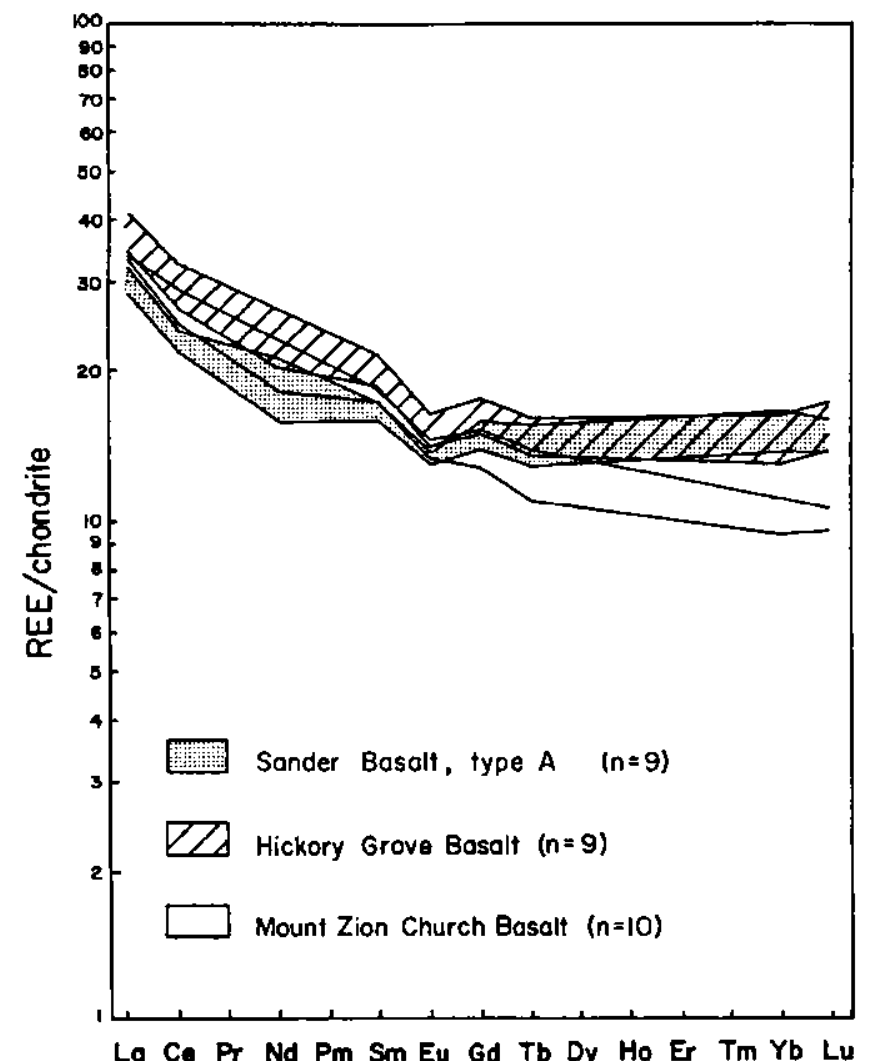

Figure 5. Plot of abundances of rare-earth elements (REE) in nine samples of type A Sander Basalt from the lowermost Sander flow (n, number of samples analyzed). REE patterns of Mount Zion Church and Hickory Grove Basalts from figure 4 are plotted for comparison. Data are normalized to average REE abundances in chondrites (Anders and Ebihara, 1982).

mobility of $\mathrm{Ca}, \mathrm{Na}, \mathrm{K}, \mathrm{Sr}$, and $\mathrm{Rb}$ during alteration and serve to demonstrate the immobility of $\mathrm{Ti}, \mathrm{Y}, \mathrm{Ga}, \mathrm{Nb}, \mathrm{Zr}$, and $\mathrm{V}$ under the same conditions. The REE pattern for such basalt is also, as stated previously, relatively insensitive to the effects of alteration. Data for 9 samples of type A Sander Basalt (fig. 5) show a subdued $(\mathrm{La} / \mathrm{Yb}=$ 2.0) light-REE enrichment pattern in which the data overlap those of the Hickory Grove for the heavy REE and are generally more depleted in the light REE than either of the underlying flow series. The data suggest that these basalts may share the same or similar source materials but indicate that they are unlikely to be related by any simple fractionation mechanism.

The basalt in the central and southern portions of the northern pit is considerably more chemically evolved than that exposed elsewhere and corresponds to the type E category of Tollo (this volume). Sample 2-7A-84 (table 3, analysis c) was collected approximately midway along the eastern wall and is characterized by marked enrichment in $\mathrm{Si}, \mathrm{Ti}, \mathrm{P}, \mathrm{Zr}$, and $\mathrm{V}$, slight enrichment in $\mathrm{Fe}, \mathrm{Y}$, and $\mathrm{Nb}$, and depletion in $\mathrm{Mg}$ and $\mathrm{Cr}$. All of these

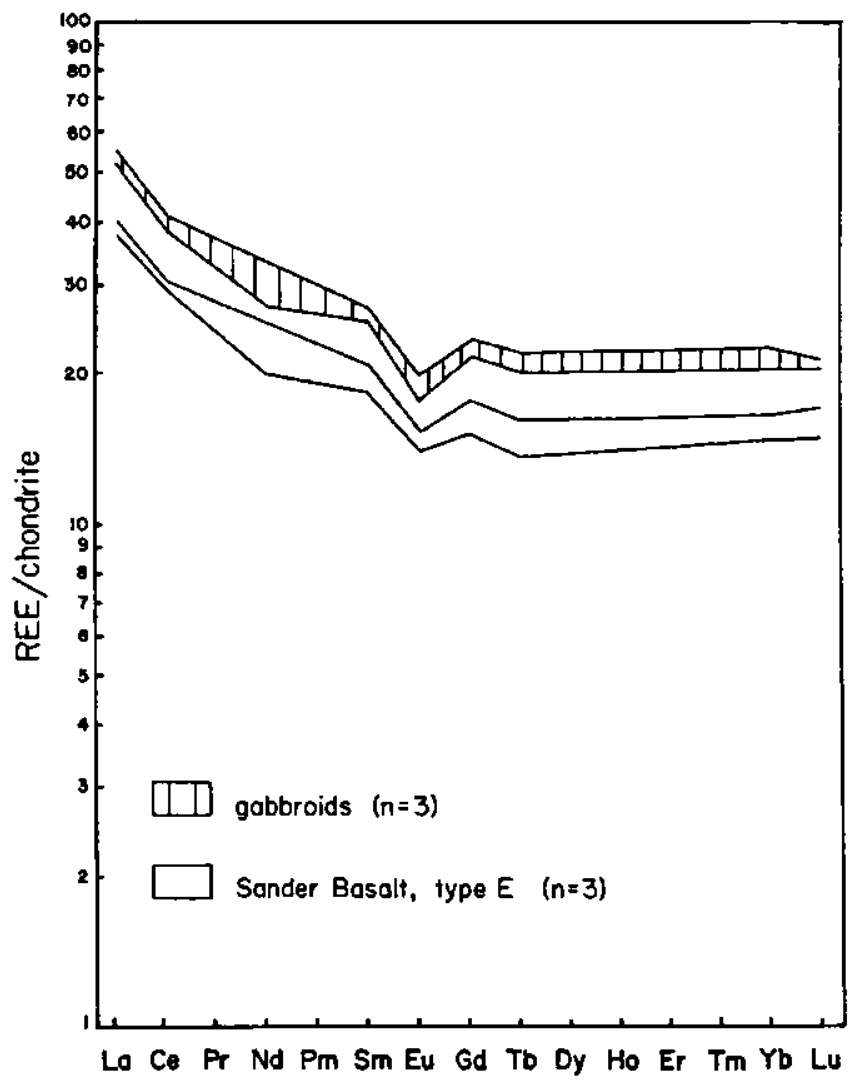

Figure 6. Plot of abundances of rare-earth elements (REE) in type $E$ basalt and associated segregation gabbroids from Sander quarry ( $n$, number of samples analyzed). Data are normalized to average REE abundances in chondrites (Anders and Ebihara, 1982).

elemental trends are consistent with the development of type $\mathrm{E}$ basalt by tholeiitic fractionation of type A. The type $\mathrm{E}$ basalt is associated with coarse-grained gabbroids that occur as irregular, anastomosing veins and dikelets cutting the basalt. Chemical analyses of two samples from such veins (table 3 , analysis $d$ ) indicate further enrichment in $\mathrm{Si}, \mathrm{Ti}, \mathrm{Fe}, \mathrm{P}, \mathrm{Zr}, \mathrm{V}, \mathrm{Y}$, and $\mathrm{Nb}$ accompanied by depletion in both $\mathrm{Mg}$ and $\mathrm{Cr}$ relative to the enclosing type $\mathrm{E}$ basalt. These data strongly suggest that these are segregation gabbroids formed by tholeiitic fractionation of type $E$ basalt. Such fractionation would be consistent with the parallel REE patterns showing enrichment by the gabbroids in all elements relative to the surrounding type $\mathrm{E}$ basalt (fig. 6). These veins are somewhat similar in scope to those reported from lava lakes on Kilauea (Wright and Okamura, 1977; Helz, 1980) but in this case do not occur as subhorizontal sheets. As at Kilauea, the mode of origin and mechanism of emplacement of such large volumes remain problematical, although textural evidence indicates that the segregation material was (1) probably relatively rich in volatile content, (2) emplaced into an at least semirigid basalt host, and (3) not quenched along the margins. The 
marked increase in iron with only slight increase in $\mathrm{SiO}_{2}$ is similar to that observed in basalt-segregation vein pairs by Kuno (1965), who interpreted the trend as indicative of crystallization under conditions of relatively low oxygen fugacity.

$42.5 \quad(3.8)$

$48.9 \quad(6.4)$

$49.6(0.7)$

60.3 (10.7) Intersection with Route 663 near Brandy Station. Continue west-southwest on Route $15 / 29$.

67.3 (0.7) Turn right onto Route 522. Proceed south.

70.7 (3.4) Intersection with Route 615. Bear left to continue on Route 522.

74.6 (3.9) Turn right onto Route 647. Proceed southwest.

75.4 (0.8) STOP 4a: Turn right onto Route 655 and park along the right shoulder. The exposures are located along Route 655 on both sides of the intersection with Route 647.

\section{STOP 4A: RAPIDAN DIABASE SHEET (UNIONVILLE QUADRANGLE)}

Stops $4 \mathrm{a}-4 \mathrm{c}$ represent a cross section through the eastern flank of the Rapidan sheet and provide an opportunity to examine the variety of diabase lithologies which comprise this HTQ layered intrusion. The chemical compositions of samples collected along a traverse across the sheet are presented in table 4 . At this location, the sheet dips gently toward the northwest and is approximately $1,200 \mathrm{ft}(360 \mathrm{~m})$ thick. The basal contact of the diabase in this area strikes approximately northeast and is located adjacent to Route 647 for several miles east and west of this intersection. Fine-grained hornfels at the base of the sheet is present in the field south of the intersection and along the adjacent Route 655. Darkcolored, fine-grained to aphanitic diabase in the ditch along Route 655 on the north side of the intersection represents part of the chilled margin of the sheet. Boulders and outcrops located within approximately $50 \mathrm{ft}(15$ $\mathrm{m})$ of the intersection northwest along Route 655 are composed of dark-colored, medium-grained, orthopyroxene-bearing diabase (sample K-6, table 4) that contrasts sharply with the fine-grained diabase of the chilled margin. Farther northwest, medium-grained diabase locally contains prominent phenocrysts of golden-

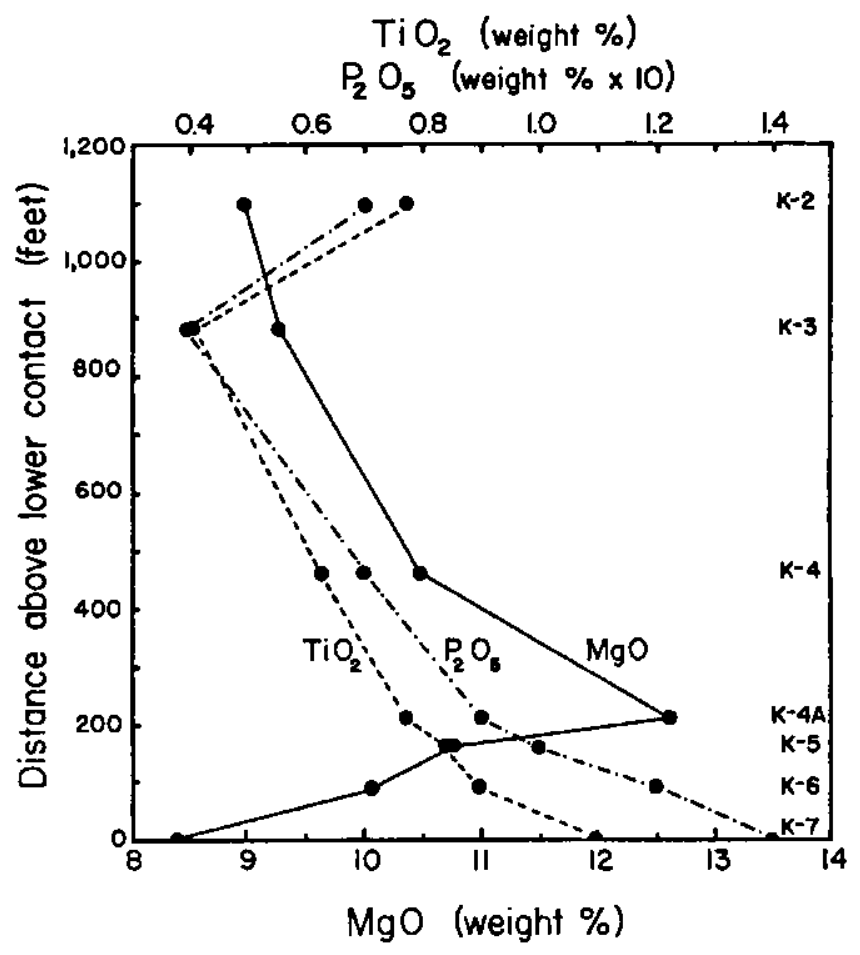

Figure 7. Abundances of selected elements plotted as a function of distance above the lower contact of the Rapidan diabase sheet. Data are from samples collected along the Route 655 traverse (stops $4 a-c$ ) described in the text and table 4. All data were normalized to 100 weight percent (anhydrous) before plotting.

colored orthopyroxene and is interpreted to represent the base of a cumulate zone within the intrusion.

A sample (K-7, table 4) collected from the chilled margin zone contains 1.1 weight percent $\mathrm{TiO}_{2}$ and 8.3 weight percent $\mathrm{MgO}$ (fig. 7), values similar to those characterizing the chilled margins of other HTQ sheets in the Culpeper basin (Froelich and Gottfried, this volume). Contents of the incompatible elements $\mathrm{P}, \mathrm{Nb}$, $\mathrm{Zr}$, and $\mathrm{Y}$ are correspondingly high, indicating enrichment relative to the main body of the sheet and reflecting the nature of the magma chilled near the contact. It is important to note that all of the other samples collected along this traverse have higher $\mathrm{MgO}$ contents than the chilled margin (fig. 7), suggesting that all are cumulate in origin. Gottfried and Froelich (1985) have described a similar pattern in the Boyds HTQ diabase sheet. Chondrite-normalized REE patterns of the sample suite representing a traverse through the Rapidan sheet (fig. 8) support the cumulate interpretation because the chilled margin samples show maximum values for both light and heavy REE.

Return to the vehicles and proceed northwest on Route 655 .

75.9 (0.5) STOP 4b: Park along the right shoulder. The exposures are located along the road and in the woods to the southeast and northwest. 


\section{STOP 4B: RAPIDAN DIABASE SHEET (UNIONVILLE QUADRANGLE)}

The rocks at this locality are within the lower part of the sheet and are typical of the noritic gabbro cumulate zone characterizing the intrusion in this area. Outcrops and boulders located along the road and in the woods toward the southeast are composed of darkcolored, medium- to coarse-grained, orthopyroxene(opx-) rich diabase represented by samples $\mathrm{K}-4 \mathrm{~A}$ and $\mathrm{K}-5$. This diabase differs texturally from that exposed farther southeast primarily in the coarse equigranular texture and abundant opx phenocrysts. The high $\mathrm{MgO}$ content (fig. 7) of a sample from this cumulate zone reflects the abundance and composition of the constituent opx. Values for $\mathrm{TiO}_{2}$ and $\mathrm{P}_{2} \mathrm{O}_{5}$ are predictably lower relative to the chilled margin, consistent with the REE patterns (fig. 8). Toward the northwest, the diabase is characterized by an overall medium-grained, granular texture and a marked increase in modal plagioclase. This plagioclase-rich, leucocratic diabase is a locally significant lithology within the upper cumulate zones of this intrusion where it occurs interlayered with darker colored, opx-rich diabase. The mesoscale textural features of such layering are well exposed in the Virginia Granite quarry at stop 5 .

Retum to the vehicles and proceed northwest on Route 655.

76.3 (0.4) STOP 4c: Park along the right shoulder. The exposures are located along the road and in the woods to the southeast and northwest.

\section{STOP 4C: RAPIDAN DIABASE SHEET (UNIONVILLE QUADRANGLE)}

The rocks in this area are in the upper portion of the sheet. Exposures within and around a small abandoned pit south of the road approximately $0.1 \mathrm{mi}(160 \mathrm{~m})$ southeast are principally medium-gray to dark-colored, medium-grained, opx-bearing diabase locally interlayered with a leucocratic, plagioclase-rich variety. The chemical composition of a sample from this leucocratic variety is characterized by lower $\mathrm{MgO}$ contents ( 9.3 weight percent) and increased $\mathrm{Al}_{2} \mathrm{O}_{3}$ (15.6 weight percent), relative to the opx-cumulate, reflecting the increased modal abundance of plagioclase. The REE pattern for sample $\mathrm{K}-3$ shows the lowest relative abundances and a distinct Eu anomaly indicative of the cumulate plagioclase (fig. 8). Lee (1980) has mapped the upper contact of the sheet approximately $0.25 \mathrm{mi}(400 \mathrm{~m})$ toward the northwest just east of well-bedded, finegrained hornfels of the roof rocks. Precise location of the contact is difficult, however, because of the zone of fine-grained, hybrid lithologies resulting from interaction between the diabase and hornfels (sample $\mathrm{K}-1$, table 4 ).

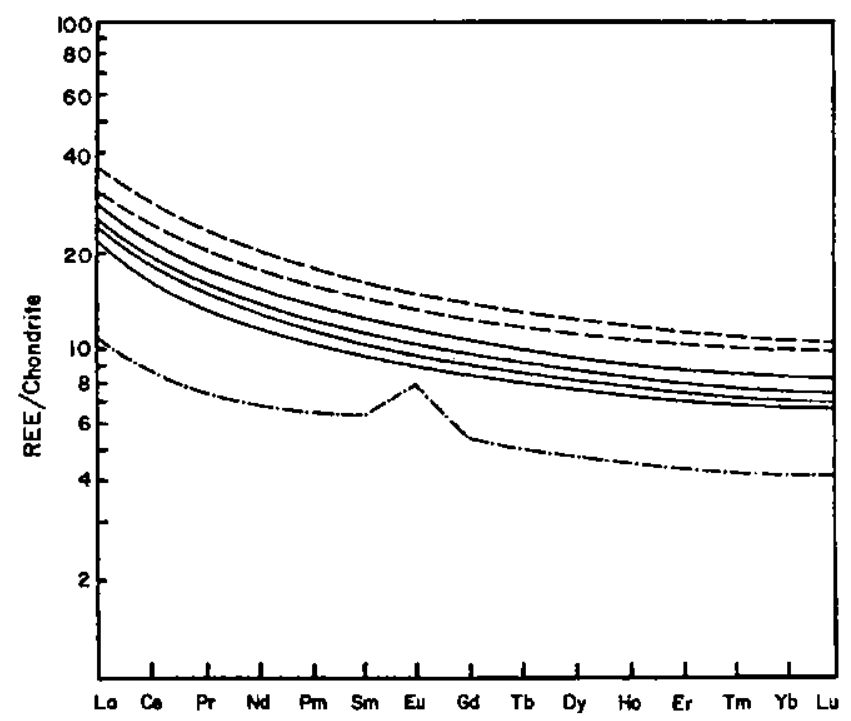

Figure 8. Rare-earth element (REE) patterns of the Rapidan HTQ diabase sheet along the Route 655 traverse. Data are normalized to average REE abundances in chondrites (Anders and Ebihara, 1982). Data include one additional sample of the chilled margin collected nearby along strike. Petrologic types include (1) fine-grained diabase of chilled margin (dashed), (2) orthopyroxene-bearing diabase (solid), and (3) plagioclase-rich diabase (alternating dash-dot).

Rocks typical of this hybridized zone are exposed along Route 655 approximately $0.2 \mathrm{mi}(320 \mathrm{~m})$ northwest of the pit. The upper chilled contact is exposed, however, in roadcuts along Route 522 , west of the intersection with Route 655 .

$77.7 \quad(1.4)$

$78.9(1.2)$

$81.1(2.2)$

Return to the vehicles and proceed northwest on Route 655.

Turn left onto Route 652 . Proceed southwest.

Turn left onto Route 615. Proceed south.

STOP 5: Turn left into entrance to the Virginia Granite Company quarry. Proceed cautiously and beware of heavy truck traffic. The exposures to be examined are located in the pit north of the office.

\section{STOP 5: RAPIDAN DIABASE SHEET (RAPIDAN QUADRANGLE)}

The rocks exposed in this quarry provide an indication of the dynamic events that characterized the crystallization history of the Rapidan magma. The quarry is located within the lower portion of the sheet and correlates approximately with the opx-rich zone at stop 4b. The dominant lithology is a medium-grained, sparsely porphyritic to equigranular, opx-rich diabase that is locally interlayered with a light-colored, plagioclase-rich anorthositic variety. Geochemical data for sample RA-A1, opx-cumulate diabase from this locality, presented in table 4, indicate close similarity in $\mathrm{MgO}$ content 
Table 4. Major- and trace-element compositions of selected samples from the Rapidan diabase sheet (field trip stops 4 and 5 , except $\mathrm{K}-1$, a hornfels from the Triassic roof rocks)

[Major-element analyses are expressed in weight percent; trace-element analyses are expressed in parts per million (ppm). Sample RA-A1 analyzed by X-ray fluorescence spectroscopy by B.D. Leavy, New Mexico Institute of Mining and Technology, Socorro; all other samples by inductively coupled plasma source spectroscopy (ICP), USGS analysts, Reston, Virginia. Sample K-1, hybridized hornfels; all other samples diabase. Major elements analyzed by Hezekiah Smith and Norma Rait, 1986; trace elements analyzed by G.A. Wandless, J.S. Kane, J.D. Fletcher, S.L. Fleming, R.G. Johnson, and M.W. Doughten. n.d., not determined]

\begin{tabular}{|c|c|c|c|c|c|c|c|c|c|}
\hline & $\mathrm{K}-1$ & $\mathrm{~K}-2$ & $\mathrm{~K}-3$ & $\mathrm{~K}-4$ & $K-4 A$ & $\mathrm{~K}-5$ & $k-6$ & $\mathrm{~K}-7$ & RA-A1 \\
\hline $\mathrm{SiO}_{2} \ldots \ldots \ldots \ldots \ldots$ & 48.9 & 52.0 & 51.9 & 52.2 & 50.8 & 50.9 & 51.1 & 52.0 & 52.05 \\
\hline $\mathrm{TiO}_{2} \ldots \ldots \ldots \ldots \ldots$ & .90 & .76 & .41 & .63 & .76 & .83 & .88 & 1.1 & .48 \\
\hline $\mathrm{Al}_{2} \stackrel{\mathrm{O}}{9}_{3} \ldots \ldots \ldots \ldots \ldots$ & 19.5 & 13.6 & 15.6 & 13.1 & 11.6 & 13.0 & 13.0 & 13.6 & 12.17 \\
\hline $\mathrm{Fe}_{2} \mathrm{O}_{3} \ldots \ldots \ldots \ldots \ldots$ & 7.3 & 2.0 & 1.6 & 1.9 & 2 & 1.9 & 2.0 & 2.2 & $11.89^{*}$ \\
\hline $\mathrm{FeO} \ldots \ldots \ldots \ldots \ldots$ & 2.2 & 8.2 & 6.3 & 7.2 & 8 & 7.9 & 7.8 & 8.2 & \\
\hline $\mathrm{MnO} \ldots \ldots \ldots \ldots \ldots$ & .20 & .19 & .16 & .18 & .18 & .17 & .17 & .18 & .16 \\
\hline $\operatorname{MgO} \ldots \ldots \ldots \ldots \ldots$ & 4.7 & 8.9 & 9.3 & 10.4 & 12.4 & 10.6 & 9.9 & 8.3 & 13.20 \\
\hline $\mathrm{CaO} \ldots \ldots \ldots \ldots \ldots \ldots$ & 6.0 & 11.7 & 12.7 & 12.0 & 10.4 & 10.9 & 11.0 & 10.6 & 9.31 \\
\hline $\mathrm{Na}_{2} \mathrm{O} \ldots \ldots \ldots \ldots \ldots$ & 3.7 & 1.8 & 1.7 & 1.5 & 1.5 & 1.7 & 1.7 & 1.9 & 1.56 \\
\hline $\mathrm{K}_{2} \mathrm{O} \ldots \ldots \ldots \ldots \ldots$ & 4.3 & .38 & .26 & .29 & .40 & .45 & .56 & .64 & .20 \\
\hline $\mathrm{P}_{2} \mathrm{O}_{5} \ldots \ldots \ldots \ldots \ldots$ & .30 & .07 & .04 & .07 & .09 & .10 & .12 & .14 & .04 \\
\hline $\mathrm{H}_{2} \mathrm{O}+\ldots \ldots \ldots \ldots \ldots$ & 1.5 & .66 & .46 & .61 & .68 & .49 & .62 & .89 & $.30^{\prime}$ \\
\hline $\mathrm{H}_{2} \mathrm{O}^{-} \ldots \ldots \ldots \ldots \ldots$ & .18 & .15 & .16 & .16 & .23 & .24 & .29 & .31 & n.d.' \\
\hline $\mathrm{CO}_{2} \ldots \ldots \ldots \ldots \ldots \ldots$ & .01 & .02 & .01 & .01 & .02 & .02 & .02 & .01 & n.d.' \\
\hline Total .............. & 99.69 & 100.43 & 100.60 & 100.25 & 99.06 & 99.20 & 99.16 & 100.07 & 101.36 \\
\hline$\ldots \ldots$ & 19 & 4.5 & $<2.0$ & 3.8 & 5.1 & 5.3 & 6.5 & 6.8 & n.d. \\
\hline $\mathrm{Rb} \ldots \ldots \ldots \ldots \ldots \ldots$ & 248 & 9 & 6 & 8 & 16 & 13 & 21 & 29 & 8.1 \\
\hline $\mathrm{Sr} \ldots \ldots \ldots \ldots \ldots \ldots$ & 811 & 172 & 189 & 149 & 140 & 154 & 159 & 179 & 128.8 \\
\hline $\mathrm{Z}_{\mathrm{r}} \ldots \ldots \ldots \ldots \ldots \ldots$ & 141 & 66 & 35 & 55 & 81 & 81 & 86 & 104 & 37.6 \\
\hline $\mathrm{V} \ldots \ldots \ldots \ldots \ldots \ldots$ & 110 & 200 & 180 & 200 & 190 & 180 & 180 & 190 & 9.8 \\
\hline $\mathrm{Y} \ldots \ldots \ldots \ldots \ldots \ldots \ldots$ & 38 & 21 & 12 & 17 & 21 & 20 & 19 & 30 & n.d. \\
\hline $\mathrm{Ba} \ldots \ldots \ldots \ldots \ldots \ldots$ & 627 & 119 & 90 & 112 & 111 & 112 & 126 & 171 & n.d. \\
\hline $\mathrm{Cr} \ldots \ldots \ldots \ldots \ldots \ldots$ & 110 & 310 & 420 & 450 & 810 & 660 & 620 & 400 & n.d. \\
\hline $\mathrm{Cu} \ldots \ldots \ldots \ldots \ldots \ldots$ & 4 & 87 & 37 & 58 & 76 & 84 & 92 & 110 & n.d. \\
\hline $\mathrm{Ni} \ldots \ldots \ldots$ & 45 & 86 & 100 & 110 & 190 & 150 & 130 & 91 & n.d. \\
\hline $\mathrm{Zn} \ldots \ldots \ldots$ & 166 & 70 & 63 & 68 & 72 & 78 & 70 & 81 & n.d. \\
\hline Co $\ldots \ldots \ldots \ldots \ldots \ldots$ & 31 & 46 & 45 & 42 & 52 & 45 & 52 & 52 & n.d. \\
\hline
\end{tabular}

* Total iron expressed as $\mathrm{Fe}_{2} \mathrm{O}_{3}$.

' Loss on ignition.

with opx-rich diabase from stop $4 \mathrm{~b}$ on the Route 655 traverse. The subparallel layering and local scour and fill features of the diabase in this quarry provide evidence for magma currents during emplacement and crystallization of the diabase. Anastomosing veinlets of leucocratic diabase cutting the darker variety are a further indication of the complex magma mechanics. A conspicuous vein, several inches in width, cuts the diabase in the pit directly north of the office. The vein, part of a local network, is composed of tourmaline + chlorite + potassic feldspar and appears to have recrystallized the diabase within a narrow zone adjacent to the contacts.

Return to the vehicles and carefully drive along the access road from the quarry. Beware of heavy truck traffic. Turn right onto Route 615 and proceed northward.

85.6 (4.5) Turn left onto Route 522. Proceed north.

89.1 (3.5) Turn right onto Route 3. Proceed east.

96.5 (7.4) Tum left onto Route 669. Proceed north.

98.9 (2.4) STOP 6: Turn right and proceed cautiously up the hill on the private road. The rocks to be examined are exposed in two locations along the road.

\section{STOP 6: BERRY HILL, GERMANNA BRIDGE DIABASE SHEET (GERMANNA BRIDGE QUADRANGLE)}

The rocks at this locality are typical of the highly fractionated lithologies composing a significant portion of the Germanna Bridge diabase sheet. The main volume of this sheet is composed of very sparse opx-bearing HTQ diabase generally similar in composition to the upper part of the Rapidan sheet. Sparse opx-bearing diabase has been traced from the northeast end of the Rapidan sheet through the diabase offshoot east of "The Ridge" in the Culpeper East Quadrangle and into the Germanna Bridge diabase sheet. The geochemical similarity and general map relations (fig. 1) indicate that the Germanna Bridge sheet probably represents a northeast extension of the Rapidan sheet. Medium- to coarsegrained, syenitic granophyre is exposed along the road in front of the barn where it is associated with fine-grained granophyre and diabase. Medium- to coarse-grained, 


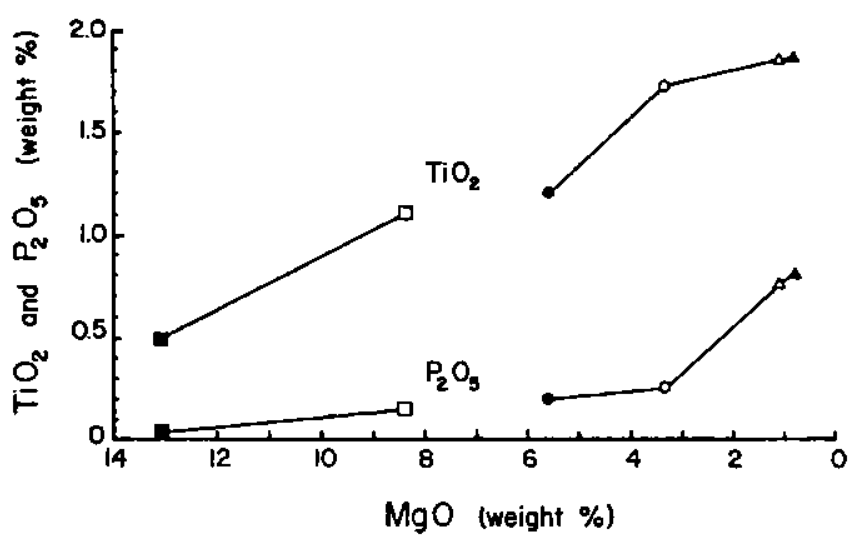

Figure 9. Plot of $\mathrm{TiO}_{2}$ and $\mathrm{P}_{2} \mathrm{O}_{3}$ versus $\mathrm{MgO}$ for four samples from the area of Berry Hill (stop 6): gray, mediumgrained diabase (filled circles), ferrogabbro (open circles), syenite (open triangles), and pink syenite granophyre (filled triangles). Data for the chilled margin (open squares) and opx-cumulate diabase (filled squares) of the Rapidan sheet are plotted for comparison. All data were normalized to 100 weight percent (anhydrous) before plotting.

Table 5. Major- and trace-element compositions of selected samples from the Germanna Bridge diabase sheet (field trip stop 6)

[Major-element analyses are expressed in weight percent; trace-element analyses are expressed in parts per million (ppm). FG-84-20B, ferrogabbro; FG-84-20A1 and A2, pink granophyre; FG-84-20A3, diabase, medium grained. Major elements analyzed by Hezekiah Smith, J.W. Marinenko, and Norma Rait, USGS, Reston, Virginia, 1986; trace elements analyzed by G.A. Wandless, USGS, Reston, Virginia, 1986]

\begin{tabular}{|c|c|c|c|c|}
\hline & $F G-84-20 A 1$ & $G-84-20 A 2$ & FG-84-20A3 & $F G-84-20 B$ \\
\hline $\mathrm{SiO}_{2} \ldots \ldots \ldots$ & 57.8 & 59.0 & 52.5 & 52.2 \\
\hline $\mathrm{TiO}_{2} \ldots \ldots \ldots$ & 1.8 & 1.8 & 1.2 & 1.7 \\
\hline $\mathrm{Al}_{9} \mathrm{O}_{3} \ldots \ldots \ldots$ & 12.5 & 13.7 & 15.4 & 16.0 \\
\hline $\mathrm{Fe}_{2} \mathrm{O}_{3} \ldots \ldots \ldots$ & 4.4 & 5.3 & 3.0 & 3.7 \\
\hline $\mathrm{FeO} \ldots \ldots \ldots$ & 6.8 & 3.6 & 7.5 & 8.5 \\
\hline $\mathrm{MnO} \ldots \ldots \ldots$ & .18 & .14 & .22 & .16 \\
\hline $\mathrm{MgO} \ldots \ldots \ldots$ & 1.1 & .77 & 5.5 & 3.3 \\
\hline $\mathrm{CaO} \ldots \ldots \ldots$ & 5.7 & 4.0 & 9.9 & 5.9 \\
\hline $\mathrm{Na}_{2} \mathrm{O} \ldots \ldots \ldots$ & 4.9 & 5.2 & 2.6 & 4.3 \\
\hline $\mathrm{K}_{2} \mathrm{O} \ldots \ldots \ldots \ldots$ & 2.2 & 2.5 & .83 & 2.7 \\
\hline $\mathrm{P}_{2} \mathrm{O}_{5} \ldots \ldots \ldots$ & .76 & .77 & .2 & .24 \\
\hline $\mathrm{H}_{2} \mathrm{O}+\ldots \ldots \ldots$ & .98 & 1.8 & 1.1 & 2.0 \\
\hline $\mathrm{H}_{2} \mathrm{O}^{-} \ldots \ldots \ldots$ & .72 & .98 & .34 & .54 \\
\hline $\mathrm{CO}_{3} \ldots \ldots \ldots$ & .02 & 01 & .01 & .03 \\
\hline Total........ & 99.86 & 99.57 & 100.30 & 101.27 \\
\hline $\mathrm{Nb} \ldots \ldots \ldots \ldots$ & 24 & 29 & 8.4 & 10 \\
\hline $\mathrm{Rb} \ldots \ldots \ldots$ & 66 & 75 & 43 & 112 \\
\hline Sr $\ldots \ldots \ldots \ldots$ & . 146 & 120 & 213 & 407 \\
\hline Zr. $\ldots \ldots \ldots \ldots$ & 322 & 386 & 110 & 158 \\
\hline$\ldots \ldots \ldots$ & . 131 & 121 & 30 & 42 \\
\hline Ba $\ldots \ldots \ldots \ldots$ & 390 & 405 & 265 & 373 \\
\hline $\mathrm{Cr} \ldots \ldots \ldots \ldots$ & . $<8$ & $<5$ & 61 & $<20$ \\
\hline $\mathrm{Cu} \ldots \ldots \ldots \ldots$ & 120 & 33 & 140 & 170 \\
\hline $\mathrm{Ni} \ldots \ldots \ldots \ldots$ &.$<5$ & 59 & 59 & 35 \\
\hline $\mathrm{Zn} \ldots \ldots \ldots$ & . 52 & 48 & 82 & 122 \\
\hline Co $\ldots \ldots \ldots \ldots$ & . 26 & 13 & 42 & 39 \\
\hline
\end{tabular}

magnetite-bearing ferrogabbro is exposed behind the barn. The chemically evolved nature of these rocks is apparent from the low $\mathrm{MgO}$ contents and marked enrichment in $\mathrm{TiO}_{2}$ and $\mathrm{P}_{2} \mathrm{O}_{5}$ shown in table 5 and figure 9. This locality represents the closest occurrence of such fractionated lithologies to the opx-bearing diabase examined at stops 4 and 5. Therefore, these rocks may represent part of the geochemical complementary fraction that is apparently missing within the Rapidan sheet. This would suggest considerable migration and fractionation of magma by lateral flow differentiation (Gottfried and others, 1985).

\begin{abstract}
Return to the vehicles and cautiously proceed down the driveway. Turn right onto Route 669 and proceed northwest. Follow Route 669 to Brandy Station. Route $15 / 29$, accessible via Route 663, is located north of Brandy Station and provides access to Reston and other destinations.
\end{abstract}

\section{APPENDIX A: ANALYTICAL METHODS}

Major- and trace-element analyses for the basalts (tables 1 and 3 ) were performed by R.P. Tollo and students using X-ray fluorescence spectrometry at the Analytical Geochemistry Laboratory of the University of Massachusetts in Amherst. Majorand trace-element analyses for the hornfels and most of the diabases (tables 4 and 5) were performed by analysts at the U.S. Geological Survey analytical laboratories in Reston, Virginia, using inductively coupled plasma source spectroscopy (ICP) and atomic absorption spectrophotometry (AA). Rare-earth analyses for all samples were performed at the USGS facility using instrumental neutron activation analysis techniques (INAA).

\section{REFERENCES CITED}

Anders, E., and Ebihara, M., 1982, Solar-system abundances of the elements: Geochimica et Cosmochimica Acta, v. 46, p. 2363-2380.

Cornet, B., 1977, The palynostratigraphy and age of the Newark Supergroup: University Park, The Pennsylvania State Unjversity, unpublished Ph.D. thesis, 506 p.

Gottfried, D., and Froelich, A.J., 1985, Geochemical and petrologic features of some Mesozoic diabase sheets in the northern Culpeper basin, in Robinson, G.R., Jr., and Froelich, A.J., eds., Proceedings of the second U.S. Geological Survey workshop on the early Mesozoic basins of the Eastern United States: U.S. Geological Survey Circular 946, p. 86-91.

Gottfried, D., Annell, C.S., and Schwarz, L.J., 1978, Geochemistry of subsurface basalt from the deep corehole (Clubhouse Crossroads Corehole 1) near Charleston, South Carolina; magma type and tectonic implications, in Rankin, D.W., Studies related to the Charleston, South Carolina, earthquake of 1886; a preliminary report: U.S. Geological Survey Professional Paper 1028-G, p. 91-113. 
Gottfried, D., Ragland, P.A., and Froelich, A.J., 1985, Styles of differentiation of some Mesozoic diabase sheets in the eastern United States: Geological Society of America Abstracts with Programs, v. 17, p. 595.

Helz, R.T., 1980, Crystallization history of Kilauea Iki lava lake as seen in drill core recovered in 1967-1979: Bulletin Volcanologique, v. 43 , p. $657-701$.

Kuno, H., 1965, Fractionation trends of basalt magmas in lava flows: Journal of Petrology, v. 6, p. 302-321.

Leavy, B.D., Froelich, A.J., and Abram, E.C., 1983, Bedrock map and geotechnical properties of rocks of the Culpeper basin and vicinity, Virginia and Maryland: U.S. Geological Survey Miscellaneous Investigations Series Map I-1313-C, scale 1:125,000.

Lee, K.Y., 1979, Triassic-Jurassic geology of the northern part of the Culpeper basin, Virginia and Maryland: U.S. Geological Survey Open-File Report 79-1557, 29 p., 16 pl., scale $1: 24,000$.

1980, Triassic-Jurassic geology of the southern portion of the Culpeper basin and the Barboursville basin, Virginia: U.S. Geological Survey Open-File Report 80-468, 19 p., 18 pl., scale $1: 24,000$.

Lee, K.Y., and Froelich, A.J., in press, Triassic-Jurassic stratigraphy of the Culpeper and Barboursville basins, Virginia and Maryland: U.S. Geological Survey Professional Paper 1472.

Philpotts, A.R., and Martello, A., 1986, Diabase feeder dikes for the Mesozoic basalts in southern New England: American Journal of Science, v. 286, p. 105-126.

Puffer, J.H., Hurtubise, D.O., Geiger, F.J., Lechler, P., 1981, Chemical composition and stratigraphic correlation of Mesozoic basalt units of the Newark basin, New Jersey, and the Hartford basin, Connecticut: Geological Society of America Bulletin, Part II, v. 92, p. 515-553.

McFall, K.S., 1985, Petrography and geochemistry of the constituent flows of the Sander Basalt, Culpeper basin, Virginia: unpublished senjor thesis, The George Washington University, $36 \mathrm{p}$.

Ragland, P.C., Brunfelt, A.O., and Weigand, P.W., 1971, Rareearth abundances in Mesozoic dolerite dikes from eastern United States, in Brunfelt, A.O., and Steinnes, E., eds., Activation analysis in geochemistry and cosmochemistry: Oslo, Universitetsfarlaget, p. 227-235.

Raymond, C.A., Ellwood, B.B., Chaves, L., and Leavy, B.D., 1982, Paleomagnetic analyses of lower Mesozoic diabase and basalt from the central and southern Appalachians: Geological Society of America Abstracts with Programs, v. 14, p. 76.

Smith, R.C., II, Rose, A.W., and Lanning, R.M., 1975, Geology and geochemistry of Triassic diabase in Pennsylvania: Geological Society of America Bulletin, v. 86, p. 943-955.

Sutter, J.F., 1985, Progress on geochronology of Mesozoic diabases and basalts, in Robinson, G.R., Jr., and Froelich, A.J., eds., Proceedings of the second U.S. Geological Survey workshop on the early Mesozoic basins of the Eastern United States: U.S. Geological Survey Circular 946, p. 110-114.

Weigand, P.W., and Ragland, P.A., 1970, Geochemistry of Mesozoic dolerite dikes from eastern North America:Contributions to Mineralogy and Petrology, v. 29, p. 195-214.

Wright, T.L., and Okamura, R., 1977, Cooling and crystallization of tholeiitic basalt, 1965 Makaopuhi Lava Lake, Hawaii: U.S. Geological Survey Professional Paper 1004, $78 \mathrm{p}$.

\section{BASE- AND PRECIOUS-METAL OCCURRENCES IN THE CULPEPER BASIN, NORTHERN VIRGINIA}

Joseph P. Smoot and Gilpin R. Robinson, Jr.

\section{INTRODUCTION}

During the eighteenth and nineteenth centuries, base and precious metals were actively prospected in, and locally produced from, "red beds" of the early Mesozoic basins in the Eastern United States. Numerous small base- and precious-metal occurrences were discovered during this period (see table 1 for a list of occurrences in the Culpeper basin), and a few occurrences were developed into mines that produced significant amounts of ore, such as Cornwall, Pennsylvania, and New-gate and Bristol, Connecticut. The Culpeper basin in northern Virginia is typical of these early Mesozoic basins occur- ring near the east coast (fig. 1) of the United States and contains a representative sampling of various types of base- and precious-metal occurrences.

Most of the large abandoned mine sites in these early Mesozoic basins are not located in the Culpeper basin. Therefore, we will not be able to visit any of the large mine sites during this trip, but we will visit a few small occurrences that illustrate the nature and diversity of mineralization associated with these Mesozoic basins. In general, the base- and precious-metal occurrences tend to group into three broad deposit categories (with some overlap). The first category is deposits associated with igneous intrusions or the thermal aureole bordering 
Table 1. Inventory of mines, prospects, and mineral occurrences in the Culpeper basin, Virginia

\begin{tabular}{|c|c|c|c|c|c|c|c|c|c|c|c|}
\hline Name & County & State & Quadrangle & $\begin{array}{l}\text { Latitude } \\
\text { (north) }\end{array}$ & $\begin{array}{l}\text { Longhtude } \\
\text { (west) }\end{array}$ & $\begin{array}{c}\text { Occurrence } \\
\text { type }\end{array}$ & $\begin{array}{c}\text { Deposth } \\
\text { type }\end{array}$ & $\begin{array}{l}\text { Host-rock } \\
\text { itthology }\end{array}$ & $\begin{array}{l}\text { Most-rock } \\
\text { age }\end{array}$ & \multicolumn{2}{|c|}{$\frac{\text { Commodity }}{\text { Principal Accessory }}$} \\
\hline Boyds barite & Montgomery & Maryland & Germantown & $39^{\circ} 10^{\prime} 59^{\prime \prime}$ & ' $77^{\circ} 19^{\prime} 37^{\prime}$ & occurrence & vein & diabase & Jurassic & $\mathrm{Ba}$ & \\
\hline Dawsonville 1 & Montgomery & Maryland & Germantown & $39^{\circ} 07^{\prime} 54^{\prime \prime}$ & ' $77^{\circ} 20^{\prime} 06^{\prime \prime}$ & occurrence & placer & gravel & Quatemary & $\mathrm{Au}$ & \\
\hline Dawsonville 2 & Montgomery & Maryland & 1 Germantown & $39^{\circ} 07^{\prime} 42^{\prime \prime}$ & ' $77^{\circ} 20^{\prime} 07^{\prime \prime}$ & occurrence & placer & gravel & Quatemary & Au & \\
\hline Seneca Creek & Montgomery & Maryland & Seneca & $39^{\circ} 06^{\prime} 11^{\prime \prime}$ & $77^{\circ} 20^{\prime} 38^{\prime \prime}$ & occurrence & placer & gravel & Quaternary & $\mathrm{Hg}$ & \\
\hline Sugarland & Montgomery & Maryland & Sterling & $39^{\circ} 05^{\prime} 58^{\prime \prime}$ & $77^{\circ} 23^{\prime} 52^{\prime \prime}$ & $\operatorname{mine}$ & stratabound/replacement & sandstone & Triassic & $\mathrm{Cu}$ & \\
\hline Waterford gold & Loudoun & Virginia & Waterford & $39^{\circ} 07^{\prime} 57^{\prime \prime}$ & ' $77^{\circ} 33^{\prime} 05^{\prime \prime}$ & occurrence & placer & gravel & Quaternary & Au & \\
\hline Goose Creek & Loudoun & Virginia & Leesburg & $39^{\circ} 05^{\prime} 53^{\prime \prime}$ & $77^{\circ} 30^{\prime} 01^{\prime \prime}$ & prospect & hornfels/replacement & siltstone & Triassic & $\mathrm{Cu}$ & \\
\hline Sugarland Run & Loudoun & Virginia & Seneca & $39^{\circ} 02^{\prime} 22^{\prime \prime}$ & $77^{\circ} 21^{\prime} 46^{\prime \prime}$ & prospect & stratabound/replacement & sandstone & Triassic & $\mathrm{Cu}, \mathrm{Ag}$ & \\
\hline Sterling & Loudoun & Virginia & Sterling & $39^{\circ} 00^{\prime} 20^{\prime \prime}$ & $77^{\circ} 26^{\prime} 05^{\prime \prime}$ & occurrence & stratabound/replacement & siltstone & Triassic & $\mathrm{Cu}$ & \\
\hline Theodora & Fairfax & Virginia & Herndon & $38^{\circ} 56^{\prime} 59^{\prime \prime}$ & $77^{\circ} 25^{\prime} 23^{\prime \prime}$ & mine & hornfels & siltstone/sandstone & Triassic & $\mathrm{Cu}$ & \\
\hline Spencer farm & Fairfax & Virginia & Hemdon & $38^{\circ} 54^{\prime} 17^{\prime \prime}$ & $77^{\circ} 28^{\prime} 35^{\prime \prime}$ & prospect & homfels/replacement & sandstone & Triassic & $\mathrm{Cu}$ & \\
\hline Chantilly prospect & Fairfax & Virginia & Hemdon & $38^{\circ} 53^{\prime} 20^{\prime \prime}$ & $77^{\circ} 25^{\prime} 10^{\prime \prime}$ & prospect & homfels/replacement & siltstone & Triassic & $\mathrm{Cu}$ & \\
\hline Cub Run copper & Fairfax & Virginia & Herndon & $38^{\circ} 52^{\prime} 54^{\prime \prime}$ & $77^{\circ} 28^{\prime} 15^{\prime \prime}$ & occurrence & homfels/replacement & sandstone/siltstone & Triassic & $\mathrm{Cu}$ & \\
\hline Chantilly & Fairfax & Virginia & Herndon & $38^{\circ} 52^{\prime} 50^{\prime \prime}$ & $77^{\circ} 25^{\prime} 08^{\prime \prime}$ & occurrence & stratabound/replacement & sandstone/shale & Triassic & $\mathrm{Cu}$ & \\
\hline Fairfax quarry & Fairfax & Virginia & Manassas & $38^{\circ} 49^{\prime} 33^{\prime \prime}$ & $77^{\circ} 29^{\prime} 19^{\prime \prime}$ & occurrence & diabase host/vein & diabase & Jurassic & $\mathrm{Cu}$ & \\
\hline Bull Run & Fairfax & Virginia & Manassas & $38^{\circ} 48^{\prime} 27^{\prime \prime}$ & $77^{\circ} 29^{\prime} 23^{\prime \prime}$ & occurrence & placer & gravel & Quaternary & Au & \\
\hline Manassas & Prince William & Virginia & Independent Hill & $38^{\circ} 43^{\prime} 43^{\prime \prime}$ & ' $77^{\circ} 28^{\prime} 27^{\prime \prime}$ & occurrence & vein & siltstone/shale & Triassic & $\mathrm{Ba}$ & \\
\hline Brentsville & Prince William & Virginia & Independent Hill & $38^{\circ} 41^{\prime} 21^{\prime \prime}$ & $77^{\circ} 29^{\prime} 56^{\prime \prime}$ & prospect & sediment host & shale & Triassic & $\mathrm{Cu}$ & \\
\hline St. Stephens & Fauquier & Virginia & Catlett & $38^{\circ} 40^{\prime} 49^{\prime \prime}$ & $77^{\circ} 40^{\prime} 08^{\prime \prime}$ & mine & vein & siltstone/diabase & Triassic/Jurassic & $\mathrm{Ba}$ & \\
\hline Calverton & Fauquier & Virginia & Catlett & $38^{\circ} 39^{\prime} 10^{\prime \prime}$ & $77^{\circ} 40^{\prime} 39^{\prime \prime}$ & occurrence & stratabound/replacement & black shale & Triassic & $\mathrm{Zn}$ & \\
\hline Cedar Run & Prince William & Virginia & Nokesville & $38^{\circ} 37^{\prime} 32^{\prime \prime}$ & $77^{\circ} 34^{\prime} 41^{\prime \prime}$ & mine & vein/fault zone & siltstone & Triassic & $\mathrm{Ba}$ & \\
\hline Botts barite & Fauquier & Virginia & Midland & $38^{\circ} 34^{\prime} 01^{\prime \prime}$ & $77^{\circ} 39^{\prime} 32^{\prime \prime}$ & occurrence & vein & shale & Triassic & $\mathbf{B a}$ & \\
\hline Elk Run mine & Fauquier & Virginia & Midland & $38^{\circ} 33^{\prime} 21^{\prime \prime}$ & $77^{\circ} 40^{\prime} 12^{\prime \prime}$ & prospect & fault zone/vein & siltstone/shale & Triassic & $\mathrm{Cu}$ & \\
\hline Bealeton mine & Fauquier & Virginia & Midland & $38^{\circ} 33^{\prime} 15^{\prime \prime}$ & $77^{\circ} 43^{\prime} 54^{\prime \prime}$ & mine & hornfels/replacement & siltstone/shale & Triassic & $\mathrm{Cu}$ & \\
\hline Gear barite & Fauquier & Virginia & Midland & $38^{\circ} 32^{\prime} 45^{\prime \prime}$ & $77^{\circ} 43^{\prime} 32^{\prime \prime}$ & prospect & vein & siltstone/sandstone & Triassic & $\mathbf{B a}$ & \\
\hline Kemper & Fauquier & Virginia & Midland & $38^{\circ} 32^{\prime} 29^{\prime \prime}$ & $77^{\circ} 43^{\prime} 30^{\prime \prime}$ & prospect & vein & siltstone & Triassic & $\mathrm{Ba}$ & \\
\hline Mountain Run & Culpeper & Virginia & Culpeper East & $38^{\circ} 27^{\prime} 09^{\prime \prime}$ & $77^{\circ} 54^{\prime} 09^{\prime \prime}$ & occurrence & homfels/replacement & sandstone & Triassic & $\mathrm{Cu}$ & $\mathrm{Fe}, \mathrm{U}$ \\
\hline Stevensburg & Culpeper & Virginia & Culpeper East & $38^{\circ} 26^{\prime} 20^{\prime \prime}$ & $77^{\circ} 54^{\prime} 56^{\prime \prime}$ & occurrence & stratabound/replacement & black shale & Triassic & $\mathrm{Zn}, \mathrm{Cu}$ & \\
\hline Culpeper prospect & Culpeper & Virginia & Culpeper East & $38^{\circ} 26^{\prime} 08^{\prime \prime}$ & $77^{\circ} 59^{\prime} 44^{\prime \prime}$ & occurrence & hornfels/skam & limestone conglomerate & Triassic & $\mathrm{Cu}$ & $\mathrm{Fe}$ \\
\hline Batna & Culpeper & Virginia & Culpeper East & $38^{\circ} 23^{\prime} 50^{\prime \prime}$ & $77^{\circ} 53^{\prime} 29^{\prime \prime}$ & prospect & homfels & siltstone & Triassic & $\mathrm{Cu}$ & \\
\hline Somerset mine & Orange & Virginia & Gordonsville & $38^{\circ} 12^{\prime} 56^{\prime \prime}$ & $78^{\circ} 13^{\prime} 29^{\prime \prime}$ & mine & stratabound/replacement & sandstone/shale & Triassic & $\mathrm{Cu}$ & \\
\hline
\end{tabular}




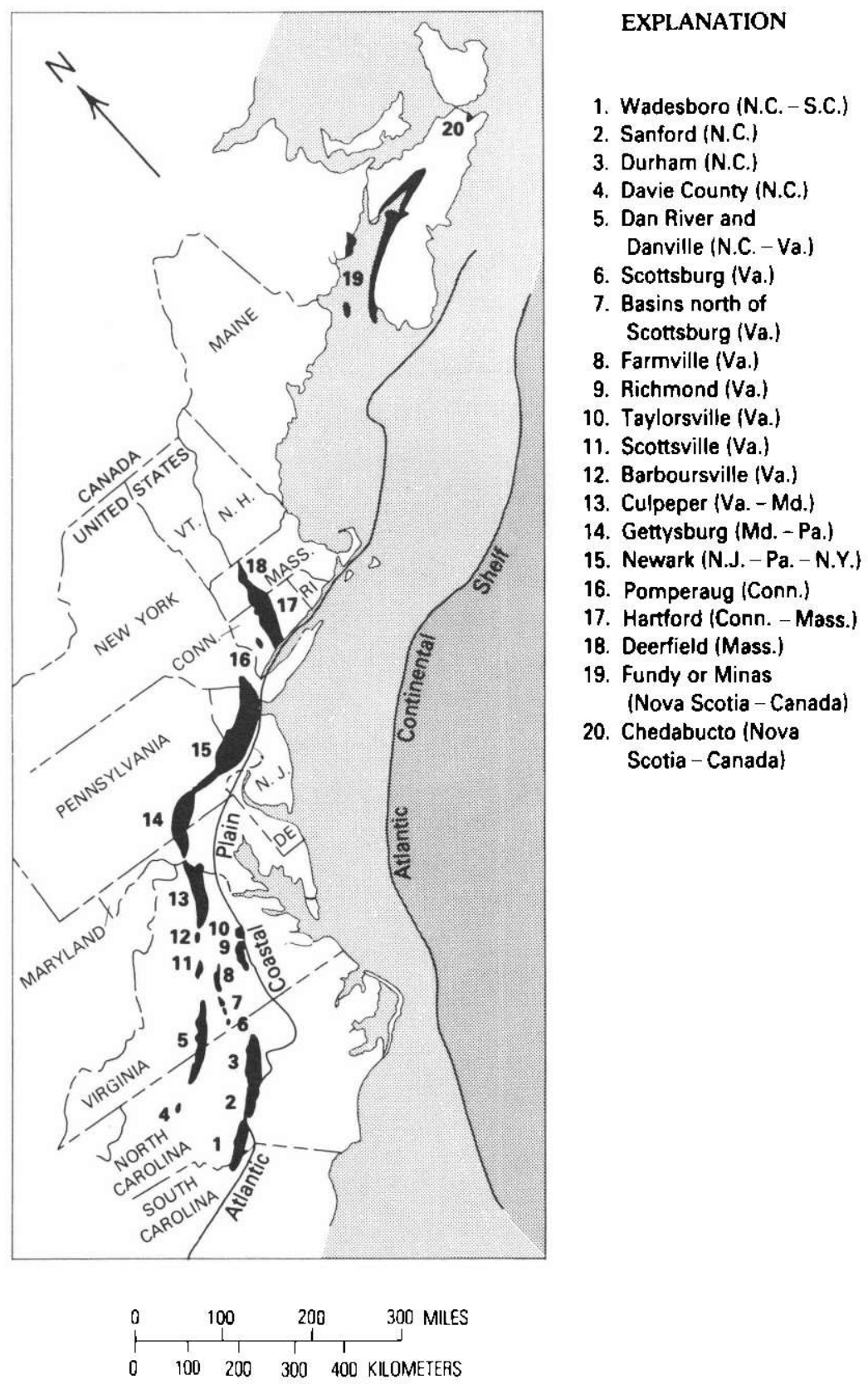

Figure 1. Exposed early Mesozoic basins in eastern North America.

igneous intrusions. Deposit types associated with this category include:

1. Magnetite skarn/replacement deposits in carbonate rocks bordering diabase sheets. These deposits, such as the Cornwall deposit in Pennsylvania, contain significant $\mathrm{Fe}$ and are enriched in $\mathrm{Cu}, \mathrm{Co}, \mathrm{Ni}, \mathrm{Au}$, and $\mathrm{Ag}$.

2. Copper-rich hornfels bordering granophyre and ferrogabbro bodies. The hornfels is enriched in $\mathrm{Cu}$ or $\mathrm{Cu}$ and $\mathrm{Fe}$ and locally contains anomalous $\mathrm{Au}, \mathrm{Mo}$, and other trace metals.
3. Late-stage segregations and veins, enriched in copper and locally in precious metals, associated with diabase bodies.

The second category is deposits associated with the migration of connate brines within the basin, apparently unrelated to igneous intrusion. Deposit types in this category include:

1. Sandstone-hosted copper-rich occurrences, commonly associated with organic debris. These deposits contain significant $\mathrm{Cu}$, are commonly enriched in $\mathrm{Ag}$, and are enriched in $U$ in some places. 


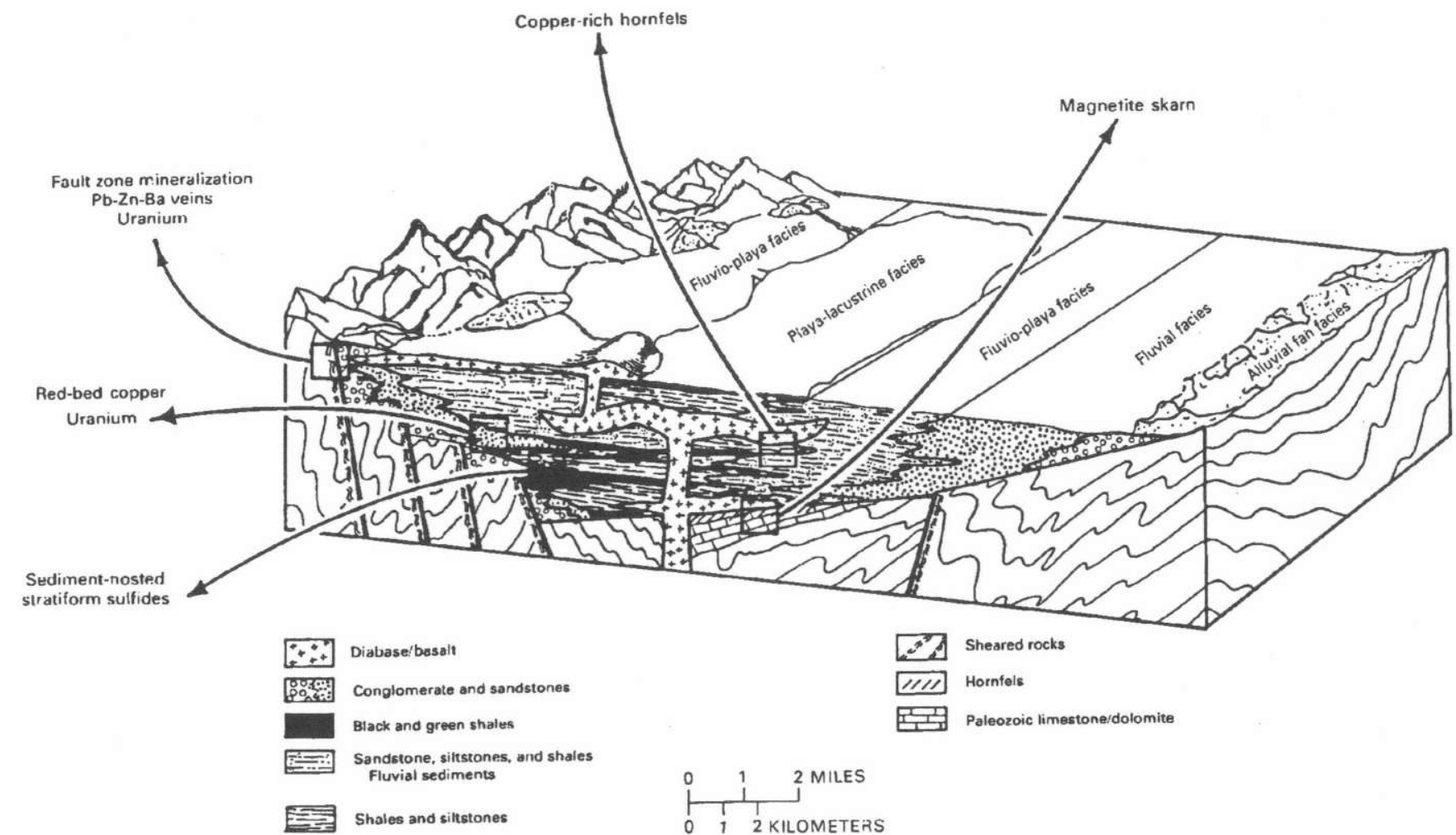

Figure 2. Schematic distribution of facies in the early Mesozoic basins in the Eastern United States showing some potential mineral resources. (Modified from Turner-Peterson, 1980.)

2. Black mudstone-hosted disseminated sulfide occurrences. This deposit type appears restricted to a particular sedimentological facies of mudstone, with enrichment in $\mathrm{Zn}, \mathrm{Cu}$, and locally $\mathrm{Pb}$ and $\mathrm{Mo}$.

3. Base-metal barite vein/replacement bodies, locally enriched in $\mathrm{Pb}, \mathrm{Zn}, \mathrm{Cu}$, and $\mathrm{Ag}$, as well as barite.

The third category is syngenetic deposits associated with basin sedimentation, such as placer gold deposits derived from detritus of pre-Mesozoic igneous and metamorphic rocks bordering the basins. The setting of most of these deposit types in a typical early Mesozoic basin is shown schematically in figure 2 .

We will visit mineralized occurrences representative of the sandstone-hosted copper mineralization (Stop 1, type 2.1), black-mudstone-hosted disseminated sulfides (Stop 3, type 2.2), and base-metal barite veins (Stop 5 , type 2.3). In addition, we will visit rock types associated with some of the other deposit types, such as skarn/hornfels (Stop 2), which is related to magnetite skarn/replacement bodies (type 1.1) and granophyre/ferrogabbro (Stop 4) which, in some cases, is associated with copperrich hornfels (type 1.2) and segregation and vein occurrences in diabase (type 1.3). The locations of field trip stops 1 through 5 are shown in figure 3.
We have planned approximately 30 minutes at each stop. The trip runs 8 hours as planned. All participants who wish to enter the Culpeper quarry must have hard hats and sturdy shoes (preferably field boots) and sign liability releases.

\section{OVERVIEW OF THE GEOLOGY OF THE CULPEPER BASIN}

The Culpeper basin of northern Virginia and adjacent Maryland is an elongate, north-northeast-trending, fault-bounded trough containing a thick sequence of Upper Triassic to Lower Jurassic nonmarine sedimentary rocks. The basin is centrally located in a belt of related lower Mesozoic troughs (fig. 1) extending discontinuously from South Carolina to Canada. These basins formed during the initial stages of continental fragmentation that ultimately developed the framework of the modern western Atlantic margin.

The term Culpeper Group of the Newark Supergroup is herein used for the lower Mesozoic strata and intercalated basalt flows in the Culpeper basin, following the usage of Lee and Froelich (in press) (fig. 4). The lower Culpeper Group, mostly of Late Triassic age, is 


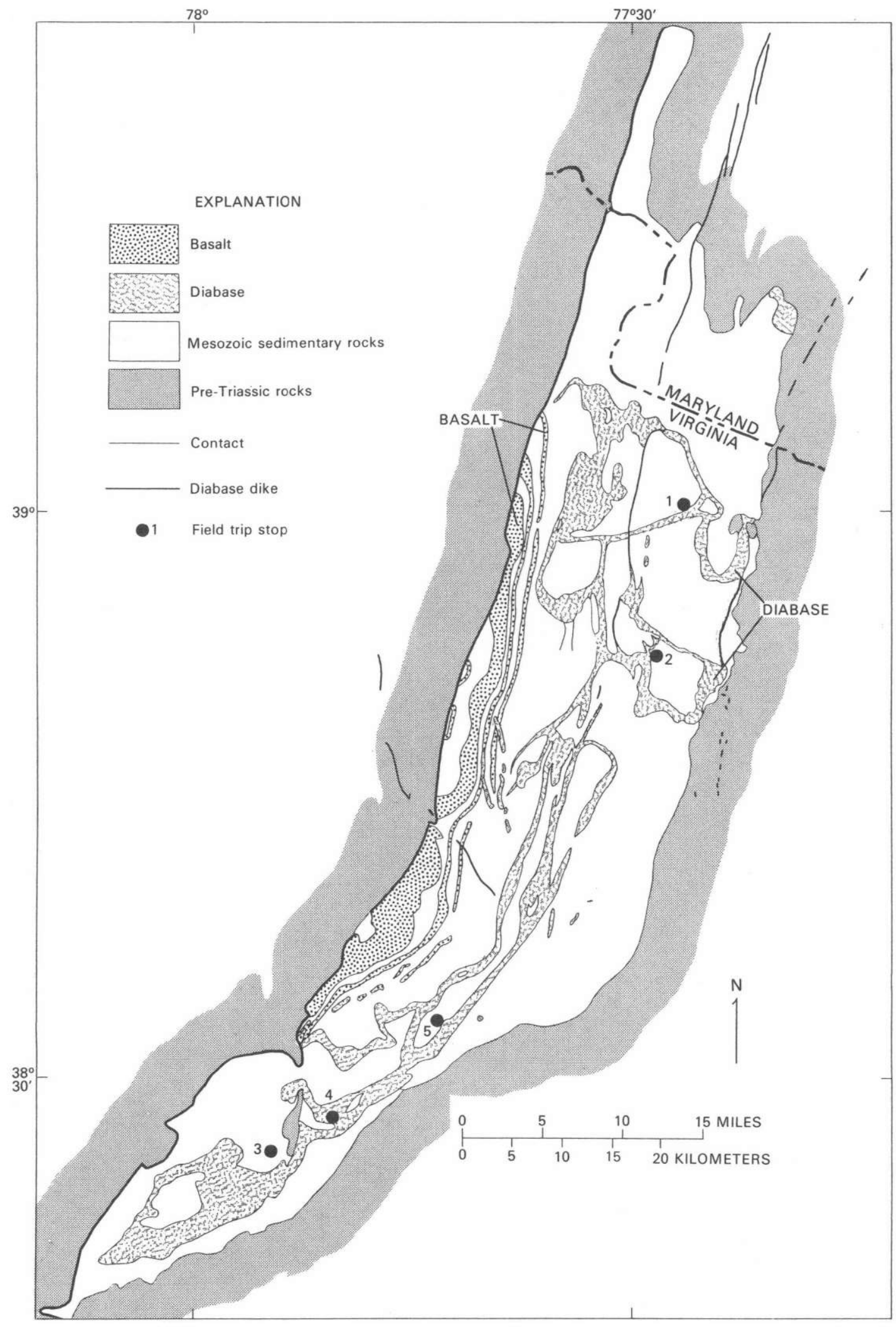

Figure 3. Field trip stops in the Culpeper basin. 


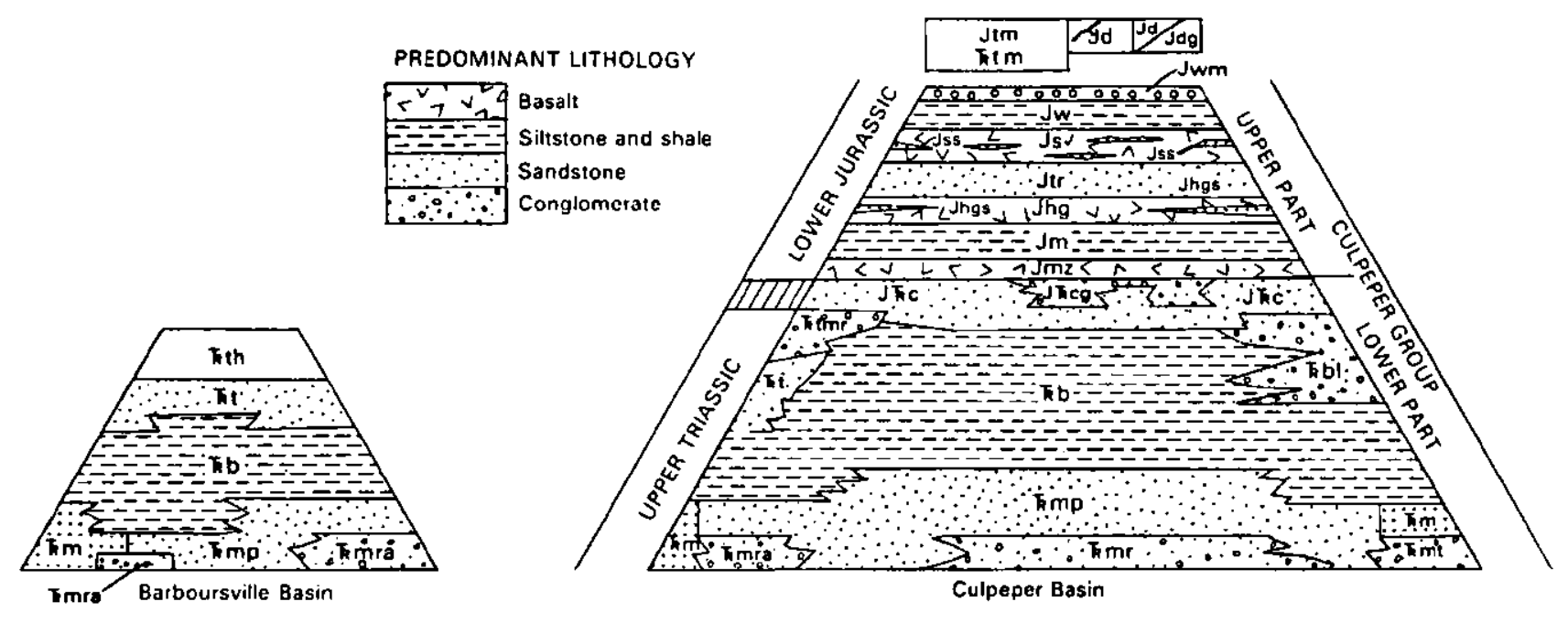

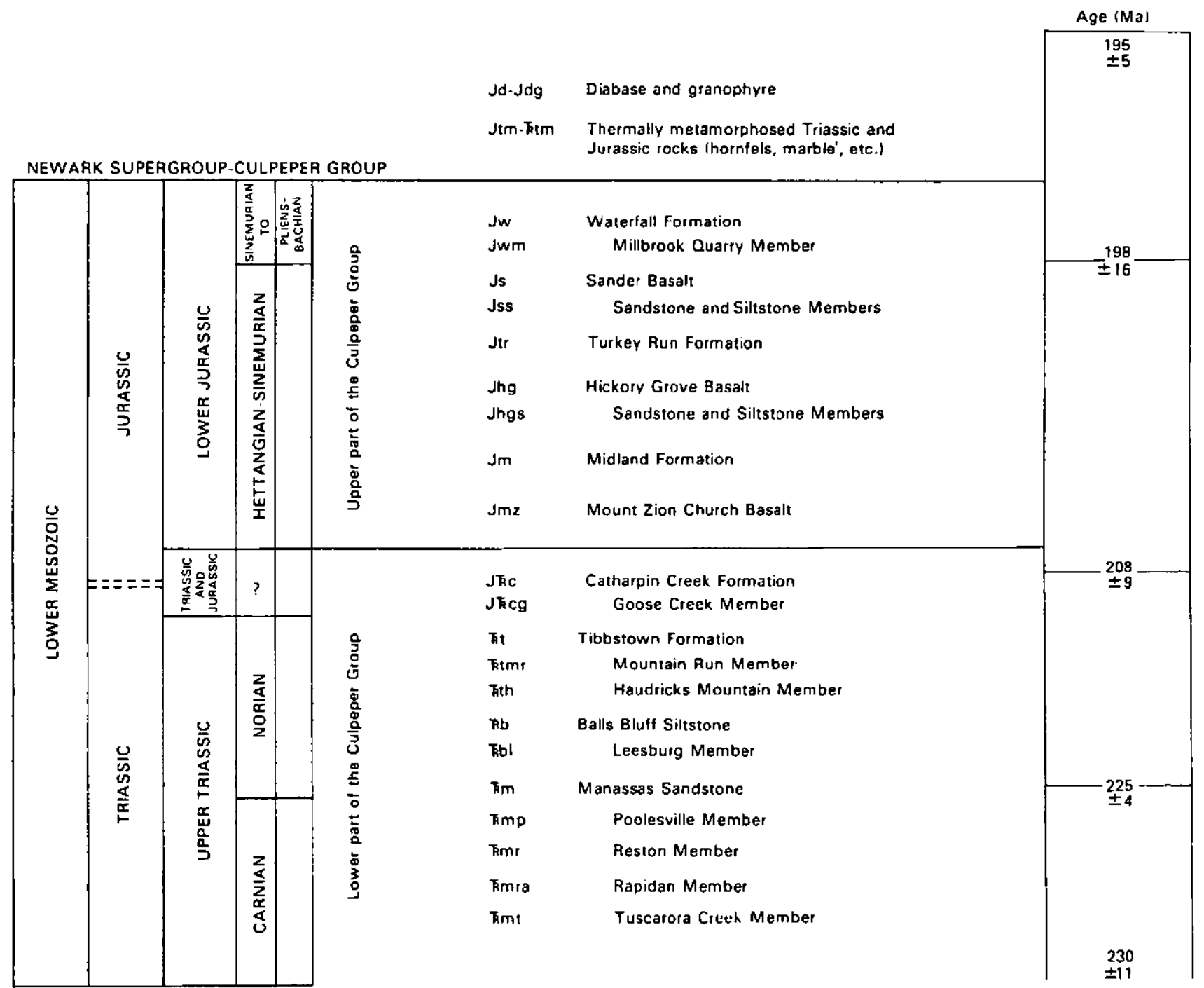

Figure 4. Simplified stratigraphic correlation diagram summarizing age and lithology of the Culpeper Group in the Culpeper and Barboursville basins, Virginia. 
subdivided into four formations: the Manassas Sandstone, the Balls Bluff Siltstone, the Tibbstown Formation, and the Catharpin Creek Formation. The Manassas Sandstone contains three conglomerate members that lie at the base of the Culpeper Group in different areas along the eastern margin of the basin. These members all grade upward and laterally into the main arkosic red sandstone (Poolesville Member) of the Manassas. The Balls Bluff Siltstone conformably overlies, grades into, and intertongues with sandstone of the Manassas. It occupies the medial part of the basin and is predominately red-brown siltstone and sandstone intercalated with green-gray fossiliferous mudstone. The Balls Bluff Siltstone is conformably overlain by sandstones and conglomerates of the Tibbstown Formation in the southern Culpeper basin and the Catharpin Creek Formation in the central Culpeper basin. The conglomerates occur as lenses at the top of these formations and are the youngest sedimentary rocks in the southern Culpeper basin.

The upper Culpeper Group of Early Jurassic age consists of a series of intercalated basalt flows and sedimentary rocks. The lowermost unit, the Mount Zion Church Basalt, consists of two or more individual basalt flows. The Mount Zion Church Basalt is overlain by red-brown sandstone, siltstone, and gray mudstone of the Midland Formation, which in turn is succeeded by the Hickory Grove Basalt. The Hickory Grove consists of at least two or, more flows that locally are separated by lenticular sandstone and siltstone bodies. The Hickory Grove Basalt is overlain by sandstone and interbedded with red-brown and gray-green siltstone of the Turkey Run Formation, which is capped by the Sander Basalt. The Sander Basalt comprises the thickest series of flows and contains the most extensive lenticular sandstone and siltstone intercalations. The overlying Waterfall Formation consists of interbedded sandstone, siltstone, conglomerate, and several thin calcareous shale zones.

Fossil flora and fauna are present but generally sparse in the red beds typical of the Culpeper basin; however, conchostracans, ostracods, fish scales, insect parts, and diagnostic spores and pollen are present and locally abundant in some of the dark-gray shales and siltstones of the Culpeper Group. The presence of diagnostic Late Triassic and Early Jurassic spores and pollen distributed throughout the stratigraphic section has enabled the systematic palynofloral zonation of the entire Culpeper Group to be determined. This zonation is supported in places by diagnostic fish fossil zones. Strata of the Culpeper Group range in age from at least the late Carnian stage of the Late Triassic (about $225 \mathrm{Ma}$ ) to the late Sinemurian or possibly early Pliensbachian stage of the Early Jurassic (about $198 \mathrm{Ma}$ ) with the TriassicJurassic boundary (about $208 \mathrm{Ma}$ ) a short distance below the Mount Zion Church Basalt.
Most published depositional models of the Culpeper basin (for instance, Lindholm, 1979; Froelich and others, 1982; Gore, 1984) suggest a closed-basin setting and arid to semiarid conditions. Conglomerates restricted to the basin margins contain structures indicative of debris flow and shallow, flash-flooding stream deposition and are interpreted as alluvial-fan deposits. Poorly sorted, pebbly sandstones dominated by horizontal lamination and numerous cut-and-fill structures are believed to represent the distal fan deposits. Many sandstone outcrops, however, are made up of channel-form, 3- to 6-m-thick, fining-upward sequences dominated by large-scale cross-bedding and ripple-scale crosslamination. These are intercalated with lenses of thin, rippled sandstones and siltstones with abundant burrow and root structures. This type of sandstone is interpreted as the deposits of perennial meandering or anastomosing rivers that flowed over heavily vegetated flood plains. These rivers may represent basin-axial drainages coeval with the alluvial fans or they may reflect more pluvial periods with higher river discharges. The fine-grained sedimentary rocks of the Culpeper Group were deposited in both fluvial and lacustrine environments. The fine-grained fluvial deposits are dominated by red siltstones with abundant burrow and root structures and carbonate nodules indicative of vegetated flood plains with soil development. The siltstones are cut by $2-$ to 4-m-thick fining-upward sandstone sequences that are interpreted as deposits of small, flash-flooding, meandering streams. The lacustrine deposits typically form 3- to 10-m-thick cycles consisting of gray to black laminated shale grading upward into red siltstone or fine-grained sandstone. The shales commonly contain aquatic fossils, including conchostracans and fish, and are interpreted as the deposits of shallow to deep lakes. The red siltstones have desiccation and root structures indicating subaerial conditions. The lacustrine cycles are interpreted as the transgression and regression of closed-basin lakes in response to long-term climatic changes.

During the early stages of Jurassic deposition (about $200 \mathrm{Ma}$ ), tholeiitic diabase stocks, sills, and dikes extensively intruded and metamorphosed the sedimentary rocks and generated local areas of basalt flows. The strata were regionally tilted to the west, particularly along the active western border faults.

\section{STOP 1-SANDSTONE-HOSTED COPPER MINERALIZATION, ROUTE 28, STERLING, VIRGINIA}

\section{Introduction}

The small copper occurrence in weathered sandstone at Stop 1 (fig. 5) is representative of the class of 


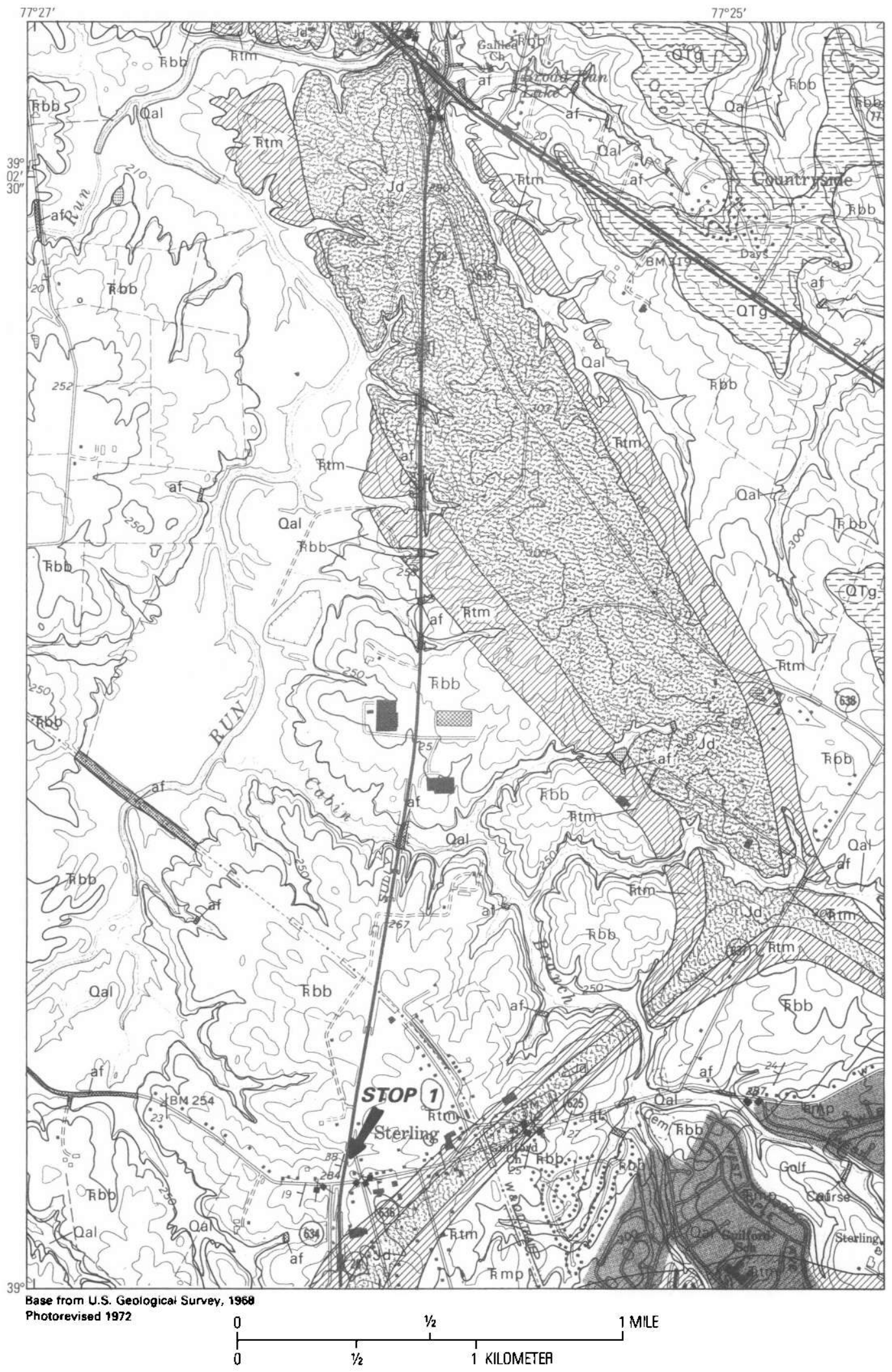

Figure 5. Geologic map of Stop 1 and vicinity. (Geology modified from Lee, 1979.) 


\begin{tabular}{|c|c|}
\hline af & Artificial fill and stripped land surface \\
\hline Qal & Alluvium (Holocene) \\
\hline QTg & Terrace deposits (Pleistocene and Upper Tertiary?) \\
\hline Jd & Diabase (Lower Jurassic\}) \\
\hline ntm & Thermally metamorphosed rocks (Upper Triassic) \\
\hline Kabb & Balls Bluff Siltstone (Upper Triassic) \\
\hline Rmp & Poolesville Member of the Manassas Sandstone (Upper Triassic) \\
\hline & Contact-Approximately located \\
\hline 고. & Strike and dip of bedding \\
\hline$\rightarrow$ & $\begin{array}{l}\text { Strike of vertical joint--For multiple joints, point of observation } \\
\text { is at intersection of symbols }\end{array}$ \\
\hline
\end{tabular}

Figure 5. Continued.

sandstone-hosted copper deposits. The geologic setting and genesis of this deposit type are discussed by Rose (1976). The copper occurrence at Stop 1 illustrates the association of copper mineralization with local reducing areas in an otherwise "oxidized" sedimentary sequence. Copper mineralization is commonly associated with organic material, often plant fragments, root zones, hydrocarbons, and, less often, black-shale lenses, in permeable sandstone units deposited in tectonically active intracratonic basins. In some areas of pervasive mineralization, the association with organic material is not readily apparent because of reaction with mineralizing fluids and flushing of organic constituents. In other areas, basalt and hornfels act as reductants, as, for example, in the numerous occurrences of copper mineralization located at the base of the Orange Mountain Basalt in the Newark basin of New Jersey.

Most of the known copper deposits of this type in the world are relatively small, although some larger and more significant deposits occur, such as the White Pine district, Michigan (White, 1971), and Corocoro, Bolivia (Ljunggren and Meyer, 1964). Some of the Zambian copper belt deposits may belong in this category as well (particularly Chibuluma). Unweathered sandstonehosted copper deposits are characterized by copper sulfide minerals replacing and coating organic material and also precipitating as a cement in the sandstone. Mineralization commonly follows a copper enrichment sequence, with early diagenetic pyrite replaced or followed by chalcopyrite, then bornite, chalcocite, and locally native copper (in some localities with native silver). The copper mineralization is commonly enriched in precious metals, such as Ag and Au. A grab sample from the dump of the abandoned Schuyler mine in the Newark basin in New
Jersey, running approximately 1.5 percent $\mathrm{Cu}$, contained $65 \mathrm{ppm} \mathrm{Ag}$ and $0.4 \mathrm{ppm} \mathrm{Au}$. Similar samples from other Newark Supergroup occurrences, such as New-gate and Meriden, in the Hartford basin in Connecticut, run from $<1$ percent to 7 percent $\mathrm{Cu}$, and contained 60 to 140 ppm $\mathrm{Ag}$. $\mathrm{Pb}$ and $\mathrm{Zn}$ are typically low in these mineralized areas, with concentrations in the range of 30 to $80 \mathrm{ppm}$. Enrichment of $\mathrm{Ba}$ and $\mathrm{Sr}$ is typical, with values in the range of 1,000 to $20,000 \mathrm{ppm} \mathrm{Ba}$ and 100 to $1,000 \mathrm{ppm}$ Sr.

Copper mineralization in red-bed deposits apparently formed relatively early in the diagenetic history of the enclosing sediments from fluids (brines?) derived from within the basin. The information summarized in Rose (1976) indicates that the copper occurrences of this type probably formed from $\operatorname{cool}\left(<150^{\circ} \mathrm{C}\right)$ sulfate-rich brines migrating updip along preferentially permeable zones to reducing sites of deposition. The mineralizing fluids are apparently equilibrated with quartz, feldspar, illite, and carbonates. The fluids are in the hematite stability field but are often undersaturated with respect to hematite. As a result, many of the mineralized sandstones appear "bleached" and have lost much of their hematite/goethite pigmentation. The fluids were not in equilibrium with gypsum, anhydrite, or barite, although some of the mineralized rocks are enriched in barium. Redox interfaces appear to control copper mineralization, with deposits occurring at sites where sulfate is reduced.

\section{Description}

This exposure of the Balls Bluff Siltstone is part of the fluvial facies transitional to the underlying Manassas Sandstone. The gray sandstone exposed in a trench in the hill contains a typical example of stratabound copper mineralization in the Culpeper Group. The sandstone is about $2 \mathrm{~m}$ thick with a sharp basal contact that dips more steeply $\left(40^{\circ}\right)$ than the underlying strata $\left(25-30^{\circ}\right)$, suggesting a channel scour. The sandstone is made up of 20 - to 30 -cm-thick lenses that are interpreted as trough crossbedding. Each cross-bed set consists of punky weathering carbonate granules grading into medium- to coarsegrained arkosic sandstone with a lenticular silty shale parting at the base. Abundant plant debris mixed with the carbonate granules in the silty shale localized most of the copper as surficial coatings of malachite and chrysocolla. Coarse-grained cross-beds immediately above the basal contact of the sandstone do not show any evidence of copper mineralization. They also lack the silty shale partings and have only poorly preserved wood fragments. A ripple cross-laminated, fine-grained sandstone overlies the gray sandstone in a small exposure north of the trenches. Across Route 28 to the west, the overlying red 

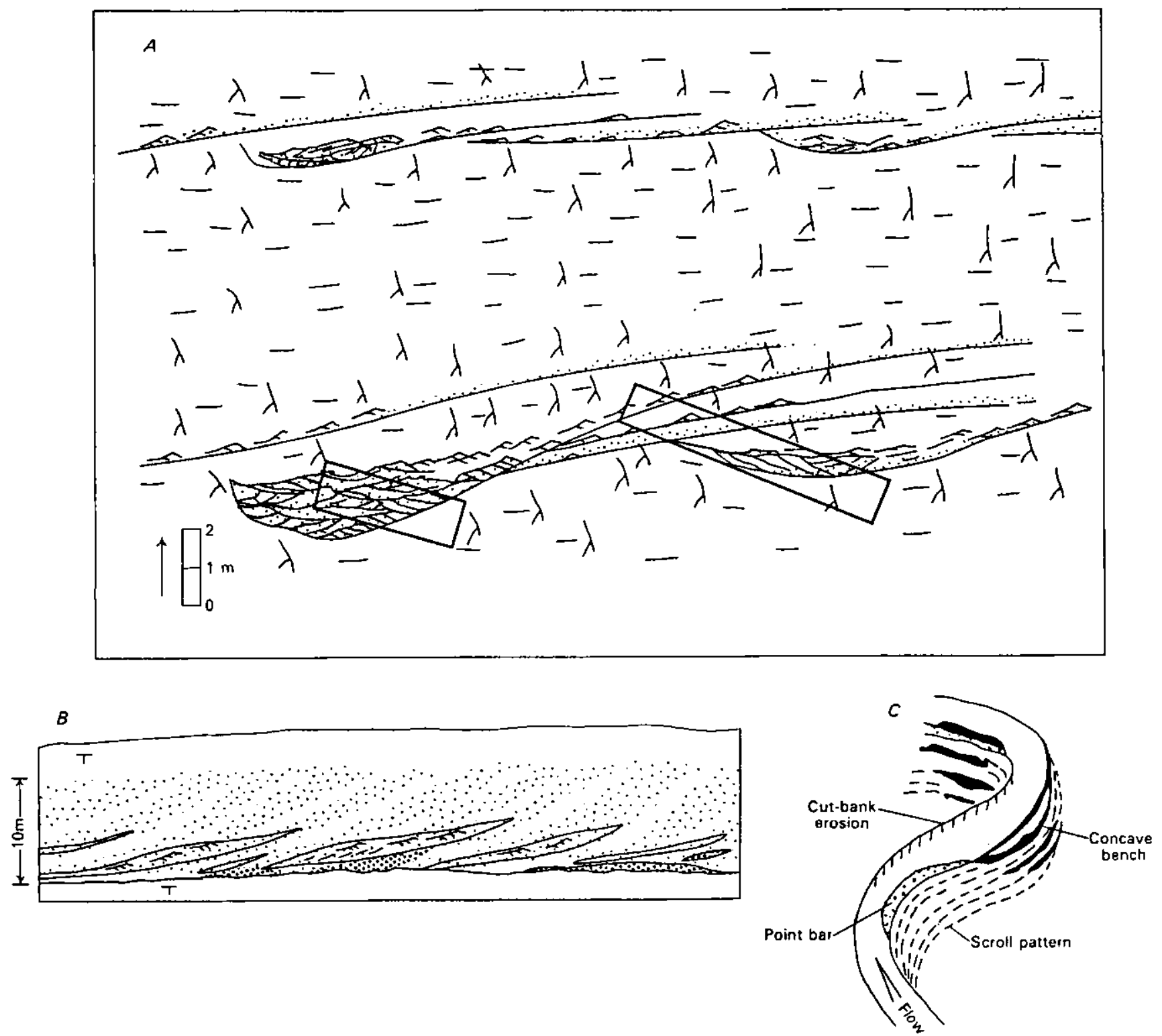

Figure 6. $A$, Schematic cross section illustrating the lithologic setting of Stops 1 and 2. Heavy boxes show sections at Stop 1. The sequence in the upper portion of the figure is more like the section at Stop 2. B, Cretaceous sandstone in Wealdon Group, England, showing lateral

siltstone exhibits little internal bedding and contains burrow and root structures and weathered carbonate nodules. Beneath the scour contact of the gray sandstone, a sequence of four 20- to $50-\mathrm{cm}$-thick beds of gray to buff sandstone each grade upward into red shaly siltstone. The sandstone beds contain ripple cross-lamination and the siltstones exhibit flat lamination or ripple crosslamination. Both the sandstone and siltstone layers are disrupted by root and burrow structures. The lowest sandstone layer exposed at this outcrop contains mudclasts and plant debris and shows some copper mineral- accretion sets in a setting similar to setting of Stops 1 and 2 . $C$, Plan view of a meandering river that would produce deposits similar to those in $A$ and $B$. Dark areas show the distribution of best deposits for copper mineralization.

ization in silty partings, presumably analogous to those in the upper gray sandstone.

Figure 6 shows a reconstruction of the sedimentary relationships at Stop 1 by comparison to more complete exposures in the Culpeper and other Newark Supergroup basins. This reconstruction is interpreted as the deposits of a small meandering river on a heavily vegetated flood plain. The gray sandstone at Stop 1 represents channel thalweg deposits, while the interbedded sandstone and shaly siltstone represent lateral accretion sets of a point bar or a concave bench. The trough cross-beds are the 
deposits of sinuous-crested dunes that migrated during floods, trapping wood, silt, and other debris on the lee sides, and that were draped with mud and silt during intervening slack water. Most of the mud was eroded during subsequent floods, except for the mud trapped in the deepest troughs in front of the dunes. High-energy dunes near the cut bank of the channel apparently eroded all of the mud drapes, reworking them as mudclasts. Low-velocity ripples migrated across the upper portions of point bars during floods and were draped with mud during the waning stages of the floods. During slack water this portion of the point bar was subaerially exposed and colonized by vegetation. The flood plain surrounding the meandering rivers was probably inundated with water only during floods. The carbonate nodules are interpreted to have originated as soil features. They provided the carbonate granules in the trough cross-beds when soils were eroded during floods.

Modern examples of small, muddy, sinuous rivers with analogous suites of sedimentary structures have been described in the literature, such as the Barwon River in New South Wales, Australia (Taylor and Woodyer, 1978; Woodyer and others, 1979). The Barwon River is part of a fluvial system that drains into the sea. The Balls Bluff example may represent part of an internal drainage, such as a distal facies of a large fluvial system that drains into a large lake. The Balls Bluff deposits at this stop should be laterally equivalent to lake deposits, if the Culpeper basin was a closed basin. The cyclic lake deposits that crop out south of this locality may be related to these fluvial deposits. Lake transgressions may be due to increased flooding of the rivers, producing point-bar sandstones, and the lake regressions may be equivalent to long periods of low channel activity, causing intense soil carbonate development.

The copper mineralization at this outcrop is clearly related to the occurrences of well-preserved woody material. The localization of this mineralization in the trough cross-beds may be the result of preservation of organic material in the reducing environment created locally by mud drapes over trapped woody debris. The mud drapes on the upper portions of the point bars did not preserve organic material because they were subaerially exposed following deposition, while the lower point bars were continuously subaqueous. Diagenetic fluids that carried copper probably reached the woody debris because of the permeability of the sandstone. Woody material is preserved only in the thick channel deposits, as woody material in thinner deposits would have been oxidized by subsequent burrowing and root penetration. The resulting patterns of mineralized deposits would be expected to be lenticular in shape as shown in figures $6 B, C$. The mineralized sandstone units should be in the direction of net flow and form broad areas of narrow lenses perpendicular to that direction.

\section{STOP 2-HORNFELS, ROUTE 661, CHANTILLY, VIRGINIA}

\section{Introduction}

Stop 2 (fig. 7), a thermally metamorphosed suite of lithologies nearly identical to those at Stop 1, illustrates the style of textural and mineralogical changes associated with the baked zone surrounding diabase sheets. In what were once calcareous sandstones, these metamorphic rocks show some slight enrichment in iron and copper. However, other areas show extreme enrichment in $\mathrm{Fe}$ with accessory $\mathrm{Cu}, \mathrm{Co}, \mathrm{Au}$, and $\mathrm{Ni}$ associated with magnetite-rich skarns developed in calcareous rocks bordering diabase sheets.

Magnetite-rich skarns, such as those at Cornwall and Morgantown, Pennsylvania, are enriched in base and precious metals (other than iron) carried in associated sulfides. The sulfide contents of these ores averaged less than 5 weight percent; however, mining operations at that time were designed to minimize the sulfide content of the magnetite ore. Sulfide-rich areas may occur in the skarn mineralization, often at the periphery of the skarn along the marble contact. Sulfide concentrates (approximately 63 percent pyrite and 37 percent chalcopyrite) from the Cornwall deposit contain approximately 9.9 percent $\mathrm{Cu}$, 0.11 percent $\mathrm{Ni}, 0.87$ percent $\mathrm{Co}$, and about $1 \mathrm{ppm} \mathrm{Au}$, and 9 ppm Ag (Lapham, 1968, table II; Smith and others, this volume). Byproduct recovery of cobalt from these sulfide concentrates was a major domestic source of cobalt for a number of years. Sulfide concentrates (approximately 92 percent pyrite, 4.5 percent chalcopyrite, and 3.5 percent pyrrhotite) from the Grace mine at Morgantown contain approximately 1.4 percent $\mathrm{Cu}, 0.26$ percent $\mathrm{Ni}$, and 0.68 percent Co (Sims, 1968). Although the magnetite skarn ores are now considered uneconomic as iron ores, the enrichments in $\mathrm{Co}, \mathrm{Ni}, \mathrm{Cu}, \mathrm{Au}$, and $\mathrm{Ag}$ associated with local segregations of sulfides probably warrant further investigation.

\section{Description}

This sequence of thermally metamorphosed Triassic rocks is roughly at the same stratigraphic level in the Balls Bluff Siltstone as that at Stop 1. Here a 30-cm-thick layer of medium-to coarse-grained meta-arkose, in part recrystallized and replaced with medium-grained pink feldspar and minor quartz, is impregnated with abundant specular hematite, minor malachite, and epidote. This porous, coarse-grained layer is sandwiched between beds of dense, spotted hornfels. Tholeiitic Early Jurassic diabase with granophyre crops out in the ridge approximately $250 \mathrm{~m}$ to the northwest. The mineralized sand- 


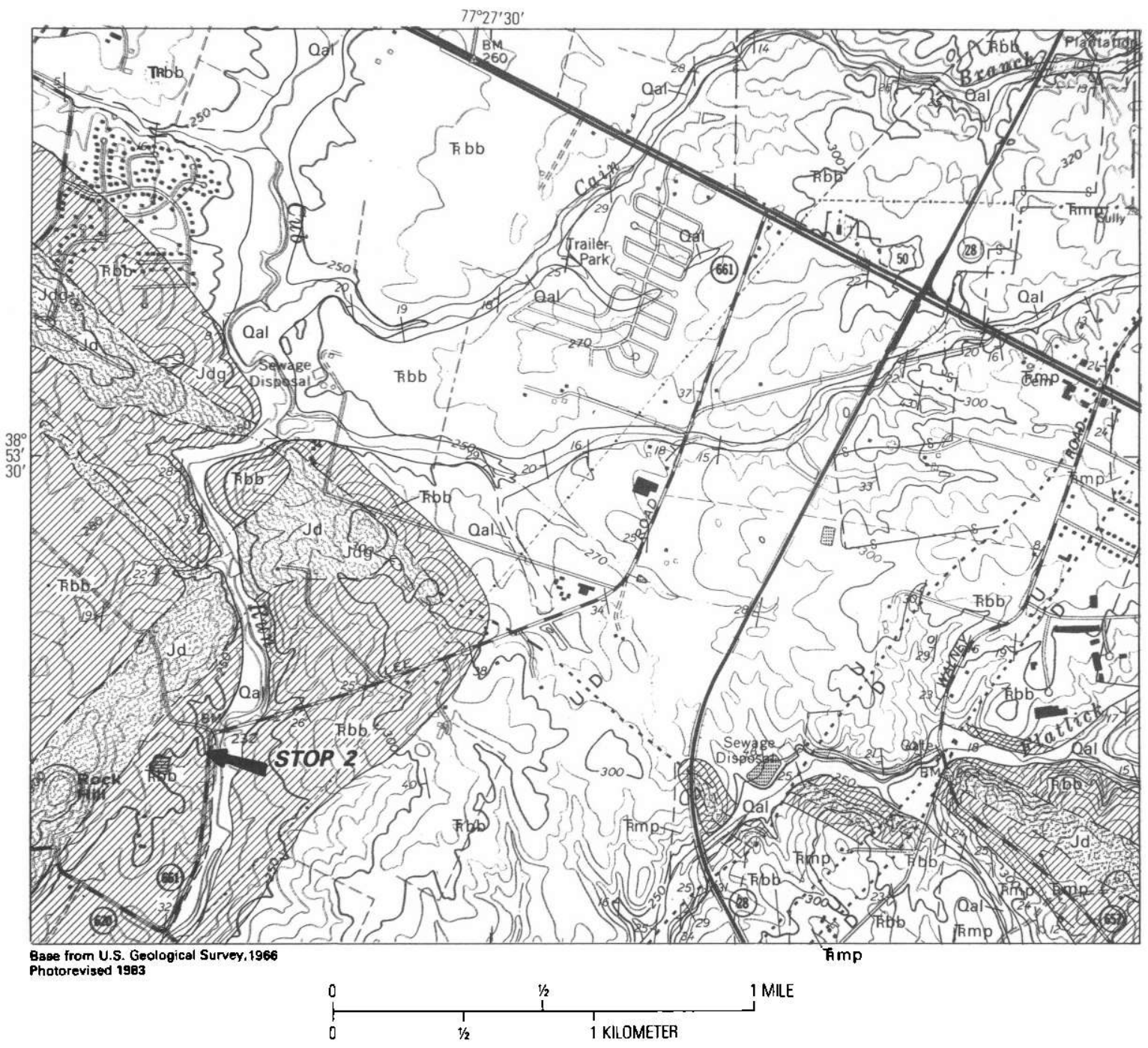

EXPLANATION

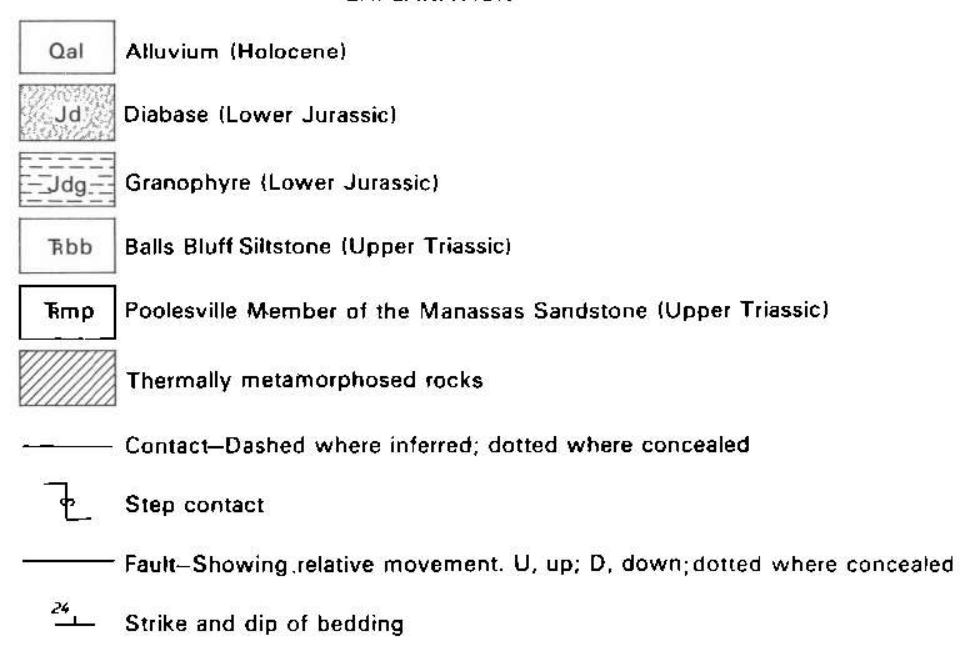

Figure 7. Geologic map of Stop 2 and vicinity. (Geology modified from Eggleton, 1975.) 
stone layer appears to be a lens that can be traced for about $20 \mathrm{~m}$. A series of lenses at about the same stratigraphic level can be traced for about $150 \mathrm{~m}$ to the west.

The coarse-textured meta-arkose probably once contained abundant carbonate granules and woody debris, analogous to the coarse-grained sandstone beds at Stop 1. The meta-arkose is cross-bedded with a paleocurrent orientation to the west, so the roadcut exposure is normal to flow. It overlies a hornfels of silty mudstone with a distinctive nodular texture. Similar hornfels elsewhere in the basin contains nodules of metamorphic minerals, such as epidote, chlorite, and biotite, which have replaced synsedimentary carbonate nodules that followed roots or that were scattered in the sediment. Overlying the meta-arkose is a metasiltstone with ripple cross-lamination. The ripples show a paleocurrent direction of $\mathrm{N} .40^{\circ} \mathrm{W}$. The meta-arkose thins northward and becomes finer grained. A rippled metasiltstone directly overlies the hornfels of silty mudstone lateral to the meta-arkose.

These deposits are interpreted as meandering river deposits similar to those of Stop 1, but smaller in scale. The meta-arkose was deposited as a channel thalweg, while the rippled metasiltstone beds are the upper point-bar deposits. The hornfels of silty mudstones are the flood-plain deposits, and the epidote nodules are altered carbonate nodules. The smaller channels may be laterally equivalent to the larger channels, or they could have been formed by downflow bifurcation of larger channels.

The thermal alteration of this outcrop has recrystallized and possibly introduced hematite and feldspar and flushed carbonate from the unit. The minor copper mineralization here postdates the intrusion and was introduced by supergene fluids.

\section{STOP 3-CULPEPER CRUSHED STONE QUARRY, STEVENSBURG, VIRGINIA}

\section{Introduction}

Sediment-hosted stratabound base-metal occurrences, enriched in $\mathrm{Cu}, \mathrm{Zn}$, or $\mathrm{Pb}$, occur in black mudstone sequences in some places. Within the cyclic sequence of lacustrine-siltstone-hornfels exposed in the Culpeper Crushed Stone quarry (fig. 8) are a few black calcareous siltstone layers enriched in base and precious metals. The anomalous $\mathrm{Zn}, \mathrm{Cu}$, and $\mathrm{Pb}$ enrichment appears restricted to a particular sedimentological unit in the cyclic sequences. In this unit, sphalerite and chalcopyrite occur within root casts in the siltstone and partially replace diagenetic pyrite. In fresh samples, the mineral- ized siltstones typically run from 1,000 to $7,000 \mathrm{ppm} \mathrm{Zn}$, 200 to $28,000 \mathrm{ppm} \mathrm{Cu}$, and as much as $200 \mathrm{ppm} \mathrm{Mo,}$ $1,000 \mathrm{ppm} \mathrm{Pb}$, and 17,000 ppm Mn. The metal-rich zones are found laterally for $3.5 \mathrm{~km}$ north of the quarry and 3 $\mathrm{km}$ south of it. One unusual feature of the lacustrine section exposed at the quarry is that it appears to lack fossils, in contrast to many other fossiliferous lacustrine sections in the early Mesozoic basins. One possible explanation is that here the lake waters were toxic as result of high sulfate content or salinity.

\section{Description}

Stop 3 is a quarry exposure of about $80 \mathrm{~m}$ of slightly thermally altered mudstone and siltstone. These deposits are divided into nine lithologic types, which are shown in the stratigraphic column (fig. 9). (1) Dark-gray to black, laminated shaley mudstone without mudcracks. This lithology is interpreted as the deposits of a deep, perennial lake. (2) Dark-gray or purplish-red, platy mudstone with internal pinch-and-swell layering, reflecting oscillatory ripples, and large sinuous mudcracks. This lithology is interpreted as shallow-lake deposits that were intermittently subaerially exposed. (3) Gray or purplish-red mudstone with layering similar to lithology 2 , but broken into breccialike blocks by numerous polygonal mudcracks. This lithology is interpreted as a subaerially exposed lake deposit that was wetted then dried repeatedly without net sediment accumulation. (4) Thin beds of tan-weathering siltstone with mudstone partings that are disrupted into polygonal, concave-upward curls. This lithology is interpreted as shallow lake or sheetflood deposits that are desiccated, causing the coarser material to curl away from the finer grained sediments. The silt layers may have been bound by algal mats. (5) Massive, red or gray mudstone with abundant narrow, jagged mudcracks and spheroidal to flattened, dolomite- or calcite-filled vugs. This lithology is interpreted as the deposits of an aggrading playalike mudflat. The vugs are interpreted as vesicles formed from air trapped during flooding events that brought in the sediments. (6) Massive, red or gray mudstone similar to lithology 5 but also containing abundant cement-filled tubes (root structures). This lithology is interpreted as playalike mudflat deposits disrupted by roots. The plants may be growing on the playa, preferentially following crack patterns for more moisture, or the rooting may be much younger and following cracks rather than penetrating the hard, dry playa mud. (7) Massive, red or gray mudstone with abundant millimeter-scale to centimeter-scale, dolomiteor mud-filled tubes (root structures) and deep, narrow, sinuous mudcracks. This lithology is interpreted as the deposits of a vegetated mudflat. The deeper cracks suggest that the surface was wetter than that of litholo- 


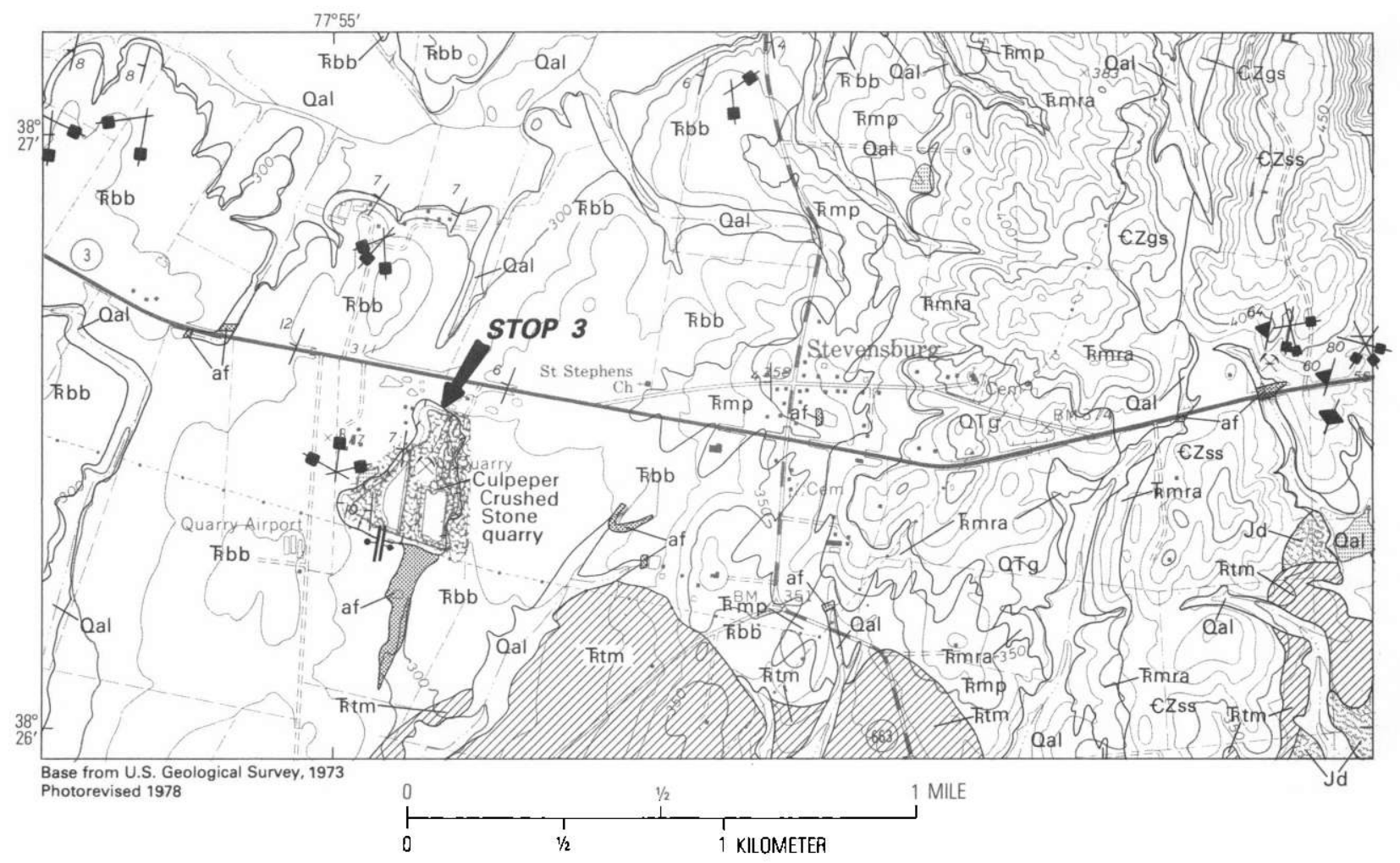

EXPLANATION

\begin{tabular}{|c|c|}
\hline af & Artificial fill and stripped land surface \\
\hline Qal & Alluvium (Holocene) \\
\hline QTg & Terrace deposits (Pleistocene and Upper Tertiary?) \\
\hline Jd & Diabase (Lower Jurassic) \\
\hline Kti & Thermally metamorphosed rocks (Upper Triassic) \\
\hline Rbb & Balls Bluff Siltstone (Upper Triassic\} \\
\hline Rmp & $\begin{array}{l}\text { Poolesville Member of the Manassas Sandstone } \\
\text { (Upper Triassic) }\end{array}$ \\
\hline Fimra & $\begin{array}{l}\text { Reston Member of the Manassas Sandstone } \\
\text { Upper Triassic) }\end{array}$ \\
\hline €Zgs & Greenstone (Cambrian and (or) Late Proterozoic) \\
\hline €Zss & $\begin{array}{l}\text { Sandstone and quartzite (Cambrian and (ar) } \\
\text { Late Proterozoic) }\end{array}$ \\
\hline
\end{tabular}

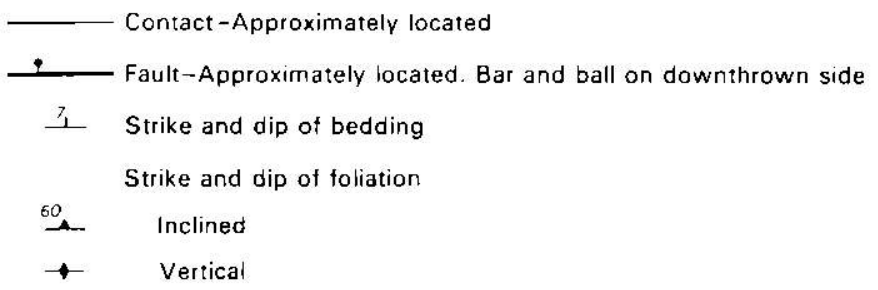

Figure 8. Geologic map of Stop 3 and vicinity. (Geology modified from Lee, 1980.)

gies 5 and 6, although the cracks may be narrow due to the roots binding the surface. (8) Massive, gray to black sandy mudstone or siltstone with abundant dolomite- and calcite-filled tubes (root structures), some deep, narrow, sinuous mudcracks, large dolomite or epidote nodules, and sulfide mineralization. This lithology is interpreted as a vegetated shallow-water shoreline deposit that was intermittently subaerially exposed. (9) Massive red or gray mudstone, undifferentiated because of inaccessibility for examination except by binoculars. The mudstones are mostly combinations of lithologies 5, 6, and 7 . Another important lithologic type is marked "c" on the stratigraphic column. It is a lenticular oolitic limestone with stromatolitic micrite lamination and abundant sulfide minerals. This is interpreted as a shoreline tufa deposit probably related to spring activity. 


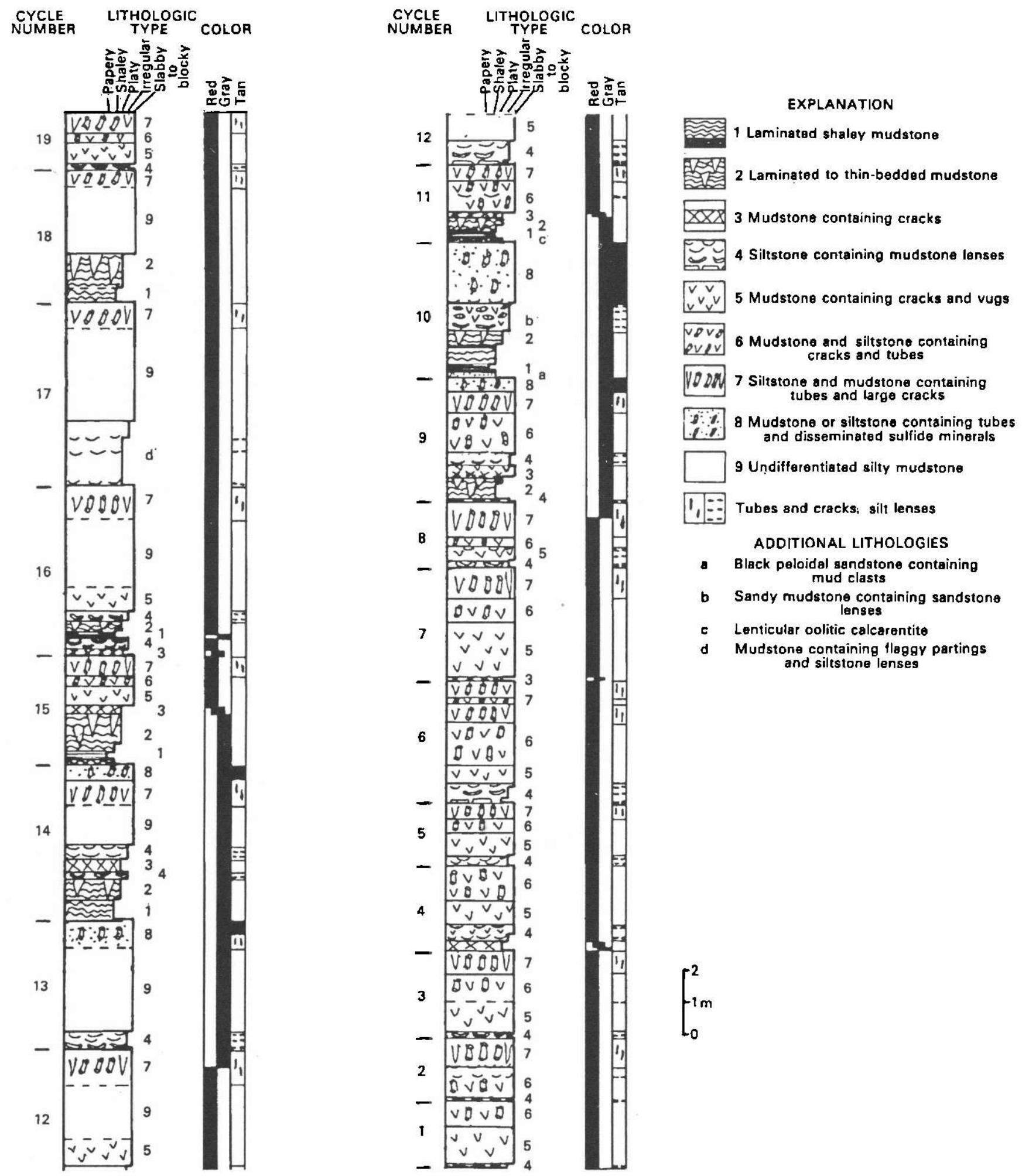

Figure 9. Stratigraphic column illustrating lithologic types at the Culpeper Crushed Stone quarry, Stevensburg, Virginia. Zinc and copper mineralization is associated with the gray siltstones of lithology 8. 
The lithologies are organized into cyclic patterns of rocks with layering that grades into massive rocks. Nineteen cycles are shown on the stratigraphic column with two end-member types: 2-1-2-3-4-6-7-8 and 4-5-6-7. The contacts between cycles are abrupt, while the boundaries between lithologic types within cycles are gradational. The cycles are interpreted as representing the transgression and regression of a lake, probably because of climatic changes (see Olsen, 1986). The shorter, red cycles represent dryer conditions and a shallower lake than the longer, gray cycles. This type of cyclic sedimentary rock in the Balls Bluff Siltstone appears restricted to the southern part of the Culpeper basin. The cycles seen here are generally thinner and have much more evidence of prolonged desiccation than the deposits to the north. The lacustrine deposits at Stop 3 may represent the sediment-starved margin of the lakes forming cycles to the north, or they may represent a different climatic setting in a subbasin of the Culpeper. These lake deposits are older than any exposed to the north in the Culpeper basin and the style of sedimentation is similar to upper Carnian and lower Norian mudstones in the Newark basin of Pennsylvania, New Jersey, and New York.

Zinc and copper mineralization as sphalerite and chalcopyrite, respectively, is restricted to lithology 8 at this exposure. This lithology was probably mineralized, because (1) it contained woody material in the roots, (2) the water-saturated conditions of accumulation and the burial beneath organic-matter-rich lake deposits were conducive to preservation of the wood (in a similar deposit, carbonized remnants of tree stumps project up into the overlying laminite), and (3) the sandy mudstone is slightly more porous than the overlying and underlying rocks, allowing diagenetic fluids to pass through. The copper and zinc sulfides appear to be replacing pyrite and (or) carbonate cements that grew around the roots during their decay. It is not clear what role, if any, the thermal alteration of the mudstone had on the mineralization; however, chalcopyrite and pyrite also occur in high-angle fractures that cut the mudstone hornfels.

\section{STOP 4-GRANOPHYRE AND FERROGABBRO, GERMANNA BRIDGE, VIRGINIA}

\section{Introduction}

Hornfels enriched in copper and other metals (Au, $\mathrm{Ag}, \mathrm{Mo}, \mathrm{Bi}, \mathrm{Sn}$ ), examples of which occur at the Stone Jug mine and Hunterstown prospect in Pennsylvania (Smith and others, this volume) appear to be associated with and overlie late-stage diabase differentiates (ferrogabbro and granophyre) enriched in volatiles, copper, and other trace metals. Stop 4 (fig. 10) illustrates representative granophyre and ferrogabbro differentiates that are similar to those near copper-rich hornfels elsewhere.

R.C. Smith II (1973) analyzed a late-stage ferrogabbro differentiate from Reesers Summit, Pennsylvania, which is similar to the differentiates that result in copper and gold mineralization in hornfels. This ferrogabbro contains $2,800 \mathrm{ppm} \mathrm{Cl,} 242 \mathrm{ppm} \mathrm{Cu}, 170 \mathrm{ppm} \mathrm{S}$, and $7.2 \mathrm{ppb} \mathrm{Au}$. It also contains magnetite and trace amounts of chalcopyrite, bornite, and covellite. Associated quartz contains vapor-liquid fluid inclusions that indicate the presence of a separate fluid phase and that contain some of the chlorine reported in the analysis. Using compositions of coexisting phases in the sample, he calculated a solidus temperature of $780{ }^{\circ} \mathrm{C}$ and a fugacity of $\mathrm{H}_{2} \mathrm{O}$ of 1,900 bars. Therefore, at total pressures slightly less than 2 kilobars, a chlorine-rich hydrothermal fluid capable of transporting copper, gold, and other trace metals could have been liberated.

The copper mineralization in hornfels occurs as small veins and replacements in dark-gray, fine-grained hornfels, similar in appearance to that in Stop 2. Primary sulfide and oxide minerals are chalcopyrite, bornite, and, at places, magnetite, hematite, and chalcocite. Malachite and chrysocolla, formed by supergene alteration of the copper sulfides, commonly occur on fracture and weathered surfaces. At the Stone Jug mine, Pennsylvania, trace amounts of molybdenum are present in the minerals molybdenite and powellite. Analysis of copper-bearing ore from the Stone Jug mine shows 6 percent $\mathrm{Cu}, 100$ ppm Ag, $1.6 \mathrm{ppm} \mathrm{Au}$, and $180 \mathrm{ppm}$ Mo. Analysis of material from an open cut at the Hunterstown prospect, Pennsylvania, shows 0.1 percent $\mathrm{Cu}, 4.5 \mathrm{ppm} \mathrm{Au}, 50 \mathrm{ppm}$ Mo, $150 \mathrm{ppm}$ Sn, and $30 \mathrm{ppm}$ Bi (J.P. Minard, 1984, personal commun., based on unpublished U.S. Geological Survey field notes for Pennsylvania, 1968-69).

\section{Description}

The ridge trending N. $60^{\circ} \mathrm{E}$. is underlain by syenitic granophyre with abundant pink feldspar intergrown with large, bladed hornblende crystals. The granophyre is in contact with gray, medium-grained ferrogabbro, locally pegmatitic, with coarse plagioclase, pyroxene, and magnetite. The granophyre-ferrogabbro suite is enclosed within an orthopyroxene-bearing (sparse) diabase sheet indistinguishable from the upper leucocratic part of the large Rapidan sheet of high-TiO ${ }_{2}$ quartz-normative diabase to the south that has voluminous orthopyroxene cumulates. From this area, the granophyre-ferrogabbro ridges can be traced for more than $24 \mathrm{~km}$. The association of bronzite-norite cumulate zones and ferrogabbro differentiates is similar to that in other sheets, notably the York Haven Sheet and the Reesers Summit ferrogabbro 


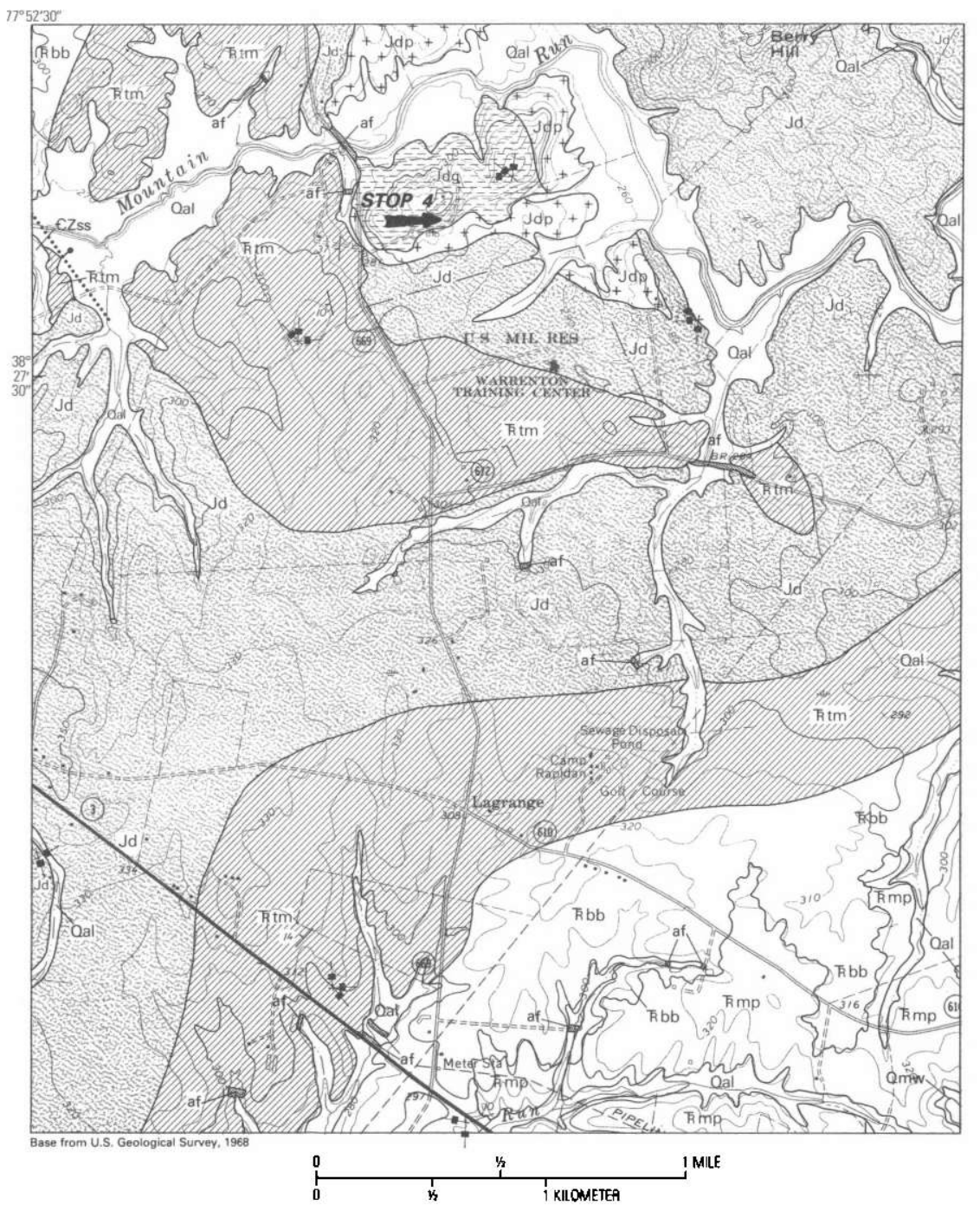

EXPLANATION

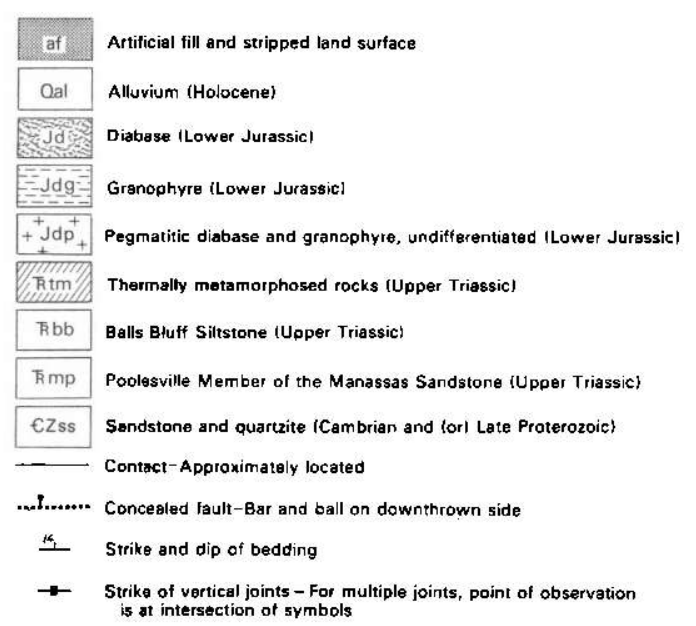

Figure 10. Geologic map of Stop 4 and vicinity. (Geology modified from Lee, 1980.) 


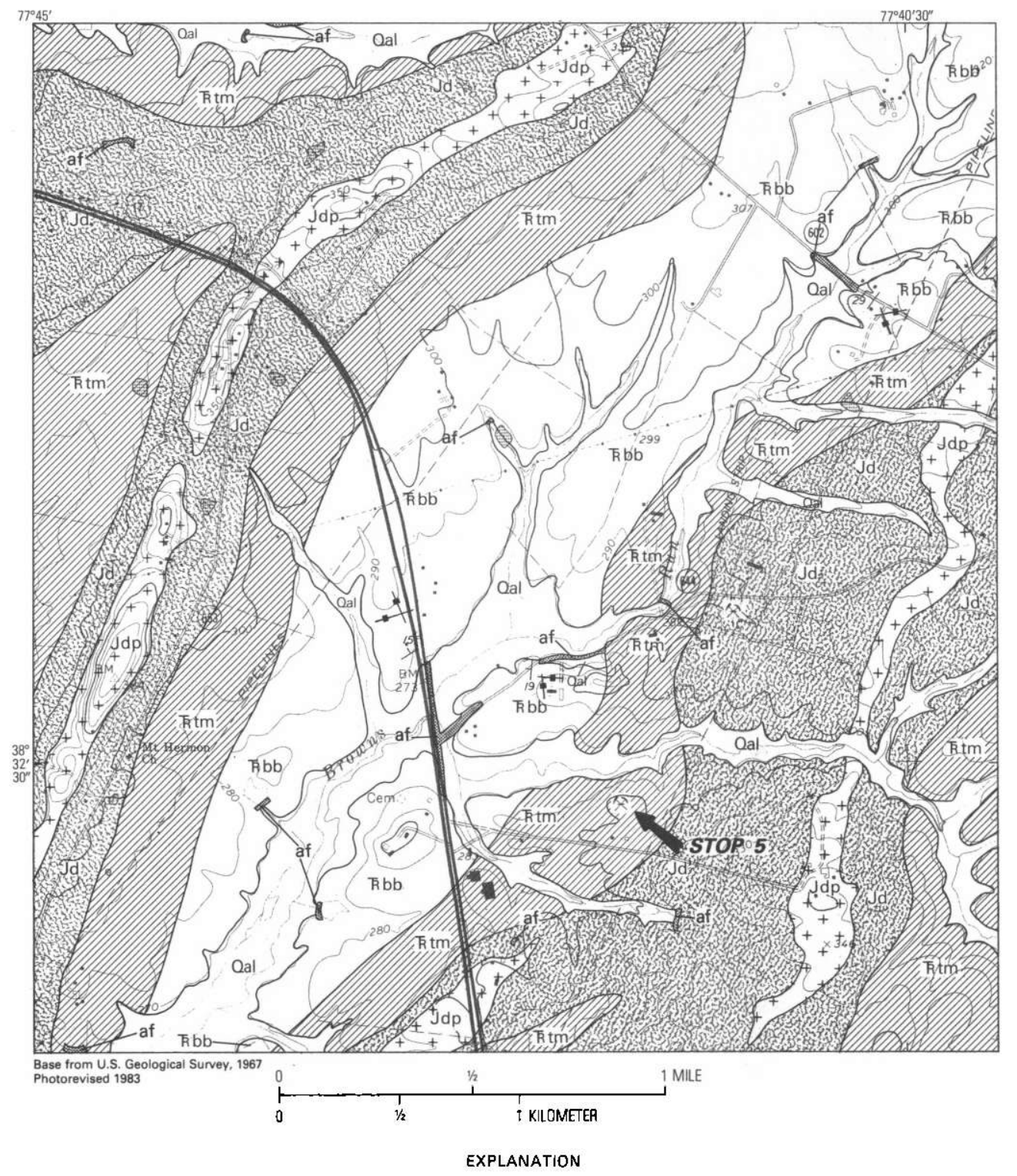

\begin{tabular}{|c|c|}
\hline af & Artificial fill and stripped land surface \\
\hline Qal & Alluvium (Holocene) \\
\hline Ifd J & Diabase (Lower Jurassic) \\
\hline$+\underset{+}{+}+\mathrm{dp}_{+}^{+}$ & $\begin{array}{l}\text { Pegmatitic diabase and granophyre, } \\
\text { undifferentiated (Lower Jurassic) }\end{array}$ \\
\hline tim & Thermally metamorphosed rocks (Upper Triassic) \\
\hline R bb & Balls Bluff Siltstone (Upper Triassic \\
\hline & Contact-Approximately located \\
\hline 15, & Strike and dip of bedding \\
\hline$\rightarrow-$ & $\begin{array}{l}\text { Strike of vertical joints - For multiple joints, point of } \\
\text { observation is at intersection of symbols }\end{array}$ \\
\hline s. & Abandoned quarry, mine, or prospect \\
\hline
\end{tabular}

Figure 11. Geologic map of Stop 5 and vicinity. (Geology modified from Lee, 1980.) 
section in the Gettysburg basin studied by R.C. Smith II in 1973. Major- and trace-element chemistry and field relationships suggest that for both sheets, the ferrogabbro bodies are complementary fractions to the orthopyroxene cumulates. These large bodies of differentiated rocks apparently are segregated by lateral flow processes, in contrast with the style of vertical gravitational differentiation seen in the Palisades sill.

\section{STOP 5-KEMPER BARITE MINE (ABANDONED), MIDLAND, VIRGINIA}

\section{Introduction}

Epithermal veins containing quartz and commonly barite, galena, sphalerite, and chalcopyrite occur in or near the margins of the early Mesozoic Culpeper, Gettysburg, Newark, Hartford, and Fundy basins. Individual veins range from a few centimeters to $10 \mathrm{~m}$ in width, and base-metal mineralization is known to occur over an interval of up to $500 \mathrm{~m}$ in depth. The barite and sulfide mineralization occurs as open-vein filling within highangle fault or fracture zones exhibiting multiple periods of brecciation. Mineral textures and sulfur isotope analyses indicate that multiple pulses of fluids with differing chemistry passed through the vein systems. The veins are sometimes zoned, with barite-rich caps and margins overlying and surrounding sulfide-rich cores. Where cross-cutting relationships are present, the veins are younger than Early Jurassic diabase dikes and basalt flows. There is no obvious association with igneous activity, although the veins are occasionally sited at the flanks of diabase sheets and dikes. Fluid migration responsible for the vein formation may have been caused by the changing stress regime developed during the Middle Jurassic as North America separated from Africa.

Barite veins were mined extensively in the midnineteenth century when Virginia was the largest barite producer in the United States (Edmundson, 1938). At that time the Culpeper basin had three or more large active mines. The large barite vein deposits in the Culpeper basin appear to be generally devoid of sulfides; however, minor chalcopyrite, galena, and pyrite have been reported from the Cedar Run barite mine. Similar vein systems in Pennsylvania, Connecticut, and Massachusetts were worked as lead and zinc mines during the nineteenth century. Sulfide mineralization in the vein systems is silver rich, with galena carrying approximately $300 \mathrm{ppm} \mathrm{Ag}$, chalcocite $1,000 \mathrm{ppm} \mathrm{Ag}$, and bornite 500 ppm Ag. In addition, the copper-rich sulfides carry up to $20 \mathrm{ppm} \mathrm{Bi}$. Some of the vein deposits are zoned, with barite-rich and sulfide-poor zones surrounding central sulfide-rich portions of the veins. The zoning of barite and sulfides is particularly evident at the Magnet Cove mine bordering the Fundy basin in Nova Scotia where a silver-rich base-metal sulfide deposit was discovered accidentally during routine drilling to expand a barite quarry operation.

Studies on fluid inclusions in quartz and sphalerite from some of the vein systems give filling temperatures of 90 to $210^{\circ} \mathrm{C}$. The fluids are sodium rich with moderate salinity (10 to 16 equivalent weight percent $\mathrm{NaCl}$ ). The sulfur isotopic signature of sulfides and sulfates is variable. Temperatures of equilibration calculated from sulfur isotopic fractionation between coexisting sulfides generally agree with the fluid-inclusion filling temperatures, indicating equilibrium fractionation. However, sulfate-sulfide isotopic fractionation is not in equilibrium.

\section{Description}

Veins containing barite and quartz at the site of the abandoned Kemper barite mine (fig. 11) occur in thermally altered purple to gray, fractured siltstones and sandstones of the Balls Bluff Siltstone. Relict bedding in the hornfels has a northeast strike and dips approximately $15^{\circ} \mathrm{W}$. Diabase is exposed in the drainage a few hundred meters northeast of the barite pits. The barite prospect pits trend roughly north-northeast. The large barite veins in the Culpeper basin are sited in or near fault zones. The Kemper, Gear, and Cedar Run barite mines are roughly aligned along the projected subsurface trend of the Mountain Run fault zone, near the eastern border of the Culpeper basin. This fault zone, with its recurrent history of displacement from the Paleozoic to the Holocene, may have provided a conduit for the fluids responsible for mineralization.

Mineral paragenesis in the veins typically indicates multiple periods of vein opening, brecciation, and mineralization. A generalized paragenesis for mineralization at the Kemper mine is as follows (from oldest to youngest):

1. fracturing of siltstone hornfels,

2. local silicification and oxidation of hornfels,

3. barite filling open space in fractures and veins,

4. drusy quartz filling open vug spaces in the veins,

5. ferroan dolomite (mostly altered to yellow ochre),

6. clear barite crystals in open vug spaces.

\section{REFERENCES CITED}

Edmundson, R.S., 1938, Barite deposits of Virginia: Virginia Geological Survey Bulletin 53, 85 p. 
Eggleton, R.E., Preliminary geologic map of the Herndon quadrangle, Virginia: U.S. Geological Survey Open-File Report 75-386, 8 p., 1 sheet, scale 1:24,000.

Froelich, A.J., Leavy, B.D., and Lindholm, R.C., 1982, Geologic traverse across the Culpeper basin (Triassic-Jurassic) of northern Virginia, in Lyttle, P.T., ed., Central Appalachian geology-Joint Northeastern-Southeastern Sections, Geological Society of America Fieldtrip Guidebooks: American Geological Institute, Falls Church, Virginia, p. $55-81$.

Gore, P.J.W., 1984, Triassic and Jurassic lacustrine sequences in the Culpeper basin, northern Virginia: Geological Society of America Abstracts with Programs, v. 16, p. 141.

Lapham, D.M., 1968, Triassic magnetite and diabase at Cornwall, Pennsylvania, in Ridge, J.D., ed., Ore deposits of the United States 1933-1967, v. 1: American Institute of Mining and Metallurgical Engineers, p. 73-94.

Lee, K.Y., 1979, Triassic-Jurassic geology of the northern part of the Culpeper basin, Virginia and Maryland: U.S. Geological Survey Open-File Report 79-1557, 10 p.

1980, Triassic-Jurassic geology of the southern part of the Culpeper basin and the Barboursville basin, Virginia: U.S. Geological Survey Open-File Report 80-468, 19 p.

Lee, K.Y., and Froelich, A.J., in press, Triassic-Jurassic stratigraphy of the Culpeper and Barboursville basins, Virginia and Maryland, U.S. Geological Survey Professional Paper 1472.

Lindholm, R.C., 1979, Geologic history and stratigraphy of the Triassic-Jurassic Culpeper basin, Virginia: Geological Society of America Bulletin, v. 90, p. 1702-1736.

Ljunggren, P., and Meyer, H.C., 1964, The copper mineralization in the Corocoro basin, Bolivia: Economic Geology, v. 59 , p. 110-125.

Olsen, P.E., 1986, A 40-million-year-lake record of early Mesozoic orbital climatic forcing: Science, v. 234, p. 842-848.
Rose, A.W., 1976, The effect of cuprous chloride complexes in the origin of red-bed copper and related deposits: Economic Geology, v. 71, p. 1036-1048.Sims, S.J., 1968, The Grace mine magnetite deposit, Berks County, Pennsylvania, in Ridge, J.D., ed., Ore deposits of the United States 1933-1967, v. 1: American Institute of Mining and Metallurgical Engineers, p. 108-124.

Smith, R.C., II, 1973, Geochemistry of Triassic diabase from southeastern Pennsylvania: Ph.D. thesis, The Pennsylvania State University, $262 \mathrm{p}$.

Taylor, G., and Woodyer, K.D., 1978, Bank deposition in suspended-load streams, in Collinson, J.D., and Lewin, J., eds., Modern and ancient fluvial systems: International Association of Sedimentologists Special Publication 6, p. 155-168.

Turner-Peterson, C.E., 1980, Short course notes: Rocky Mountain Section of the Society of Economic Paleontologists and Mineralogists, p. 149-175.

White, D.E., 1971, A paleohydrologic model for mineralization of the White Pine copper deposit, northern Michigan: Economic Geology, v. 66, p. 1-13.

Woodyer, K.D., Taylor, G., and Crook, K.A.W., 1979, Sedimentation and benches in a very low gradient suspended-load stream: The Barwon River, New South Wales: Sedimentary Geology, v. 22, p. 97-120.

\section{ROAD LOG}

$71 \frac{1}{2}$-minute quadrangles traversed: Vienna, Sterling (Stop 1), Herndon (Stop 2), Arcola, Thoroughfare Gap, Warrenton, Remington, Culpeper East (Stop 3), Germanna Bridge (Stop 4), Midland (Stop 5), Gainesville, Manassas.

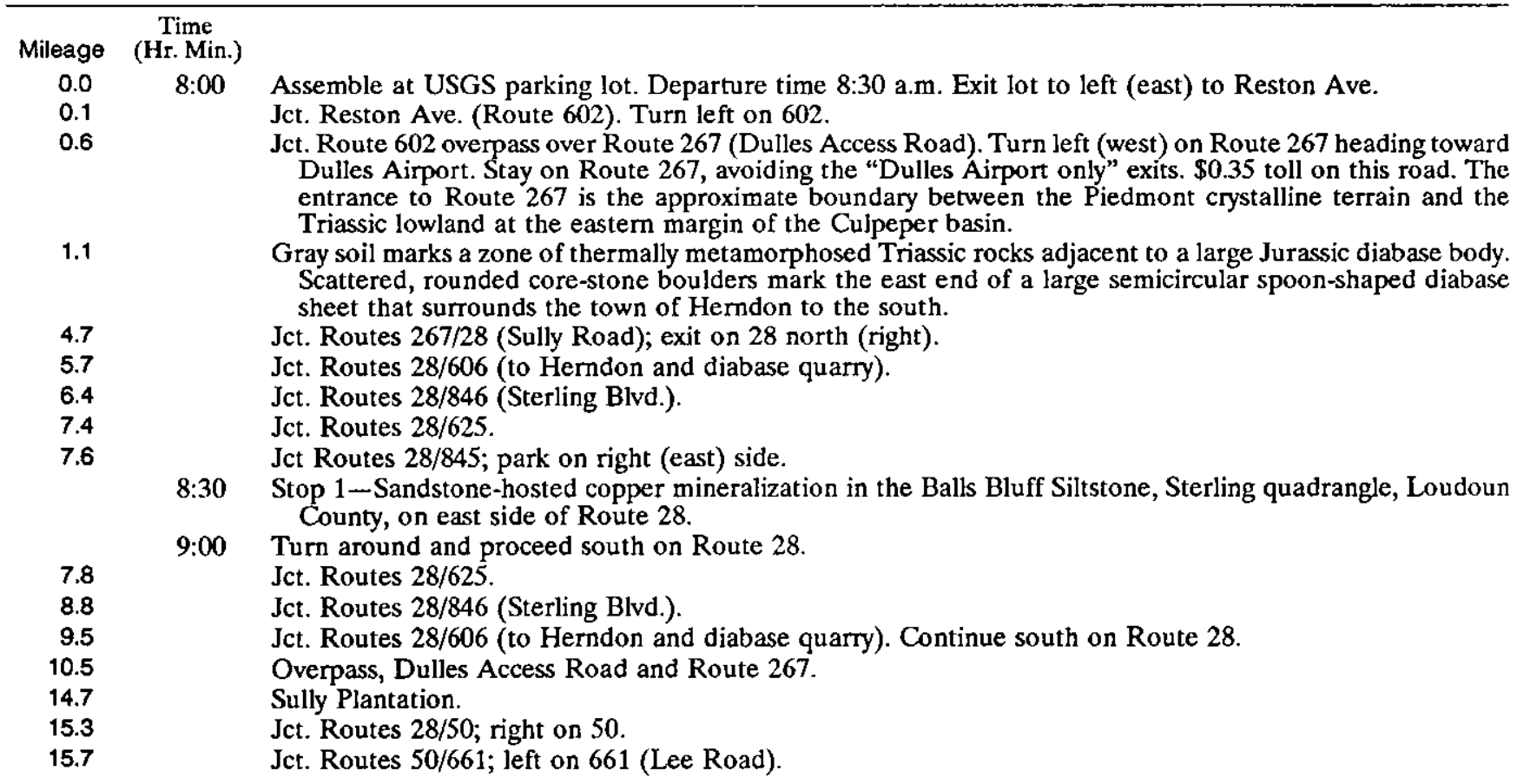




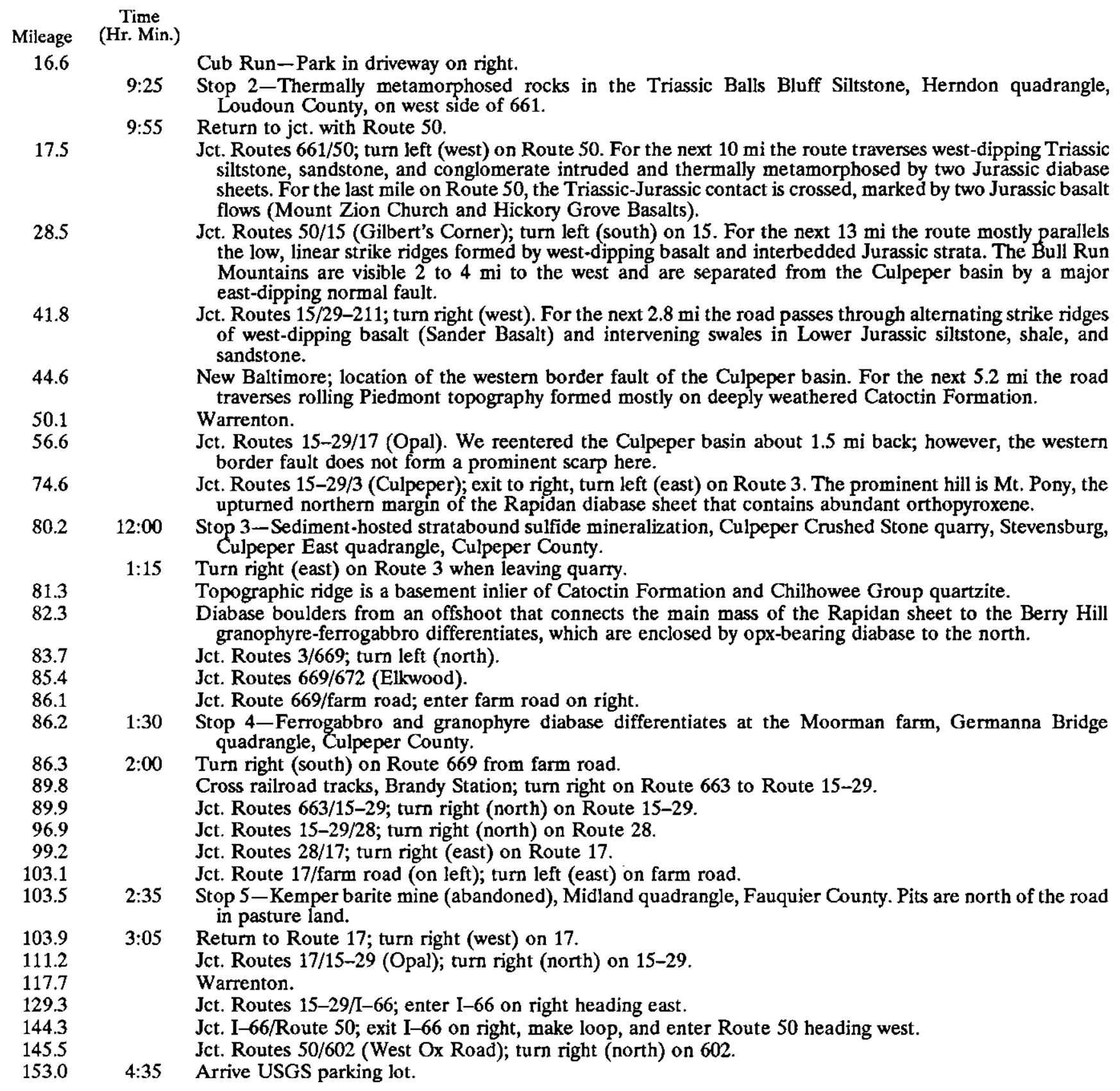





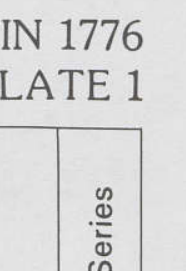

EXPLANATION

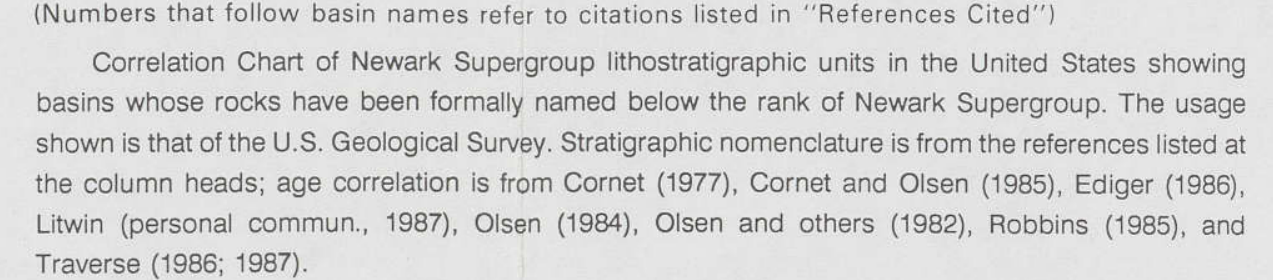

REFERENCES CITED

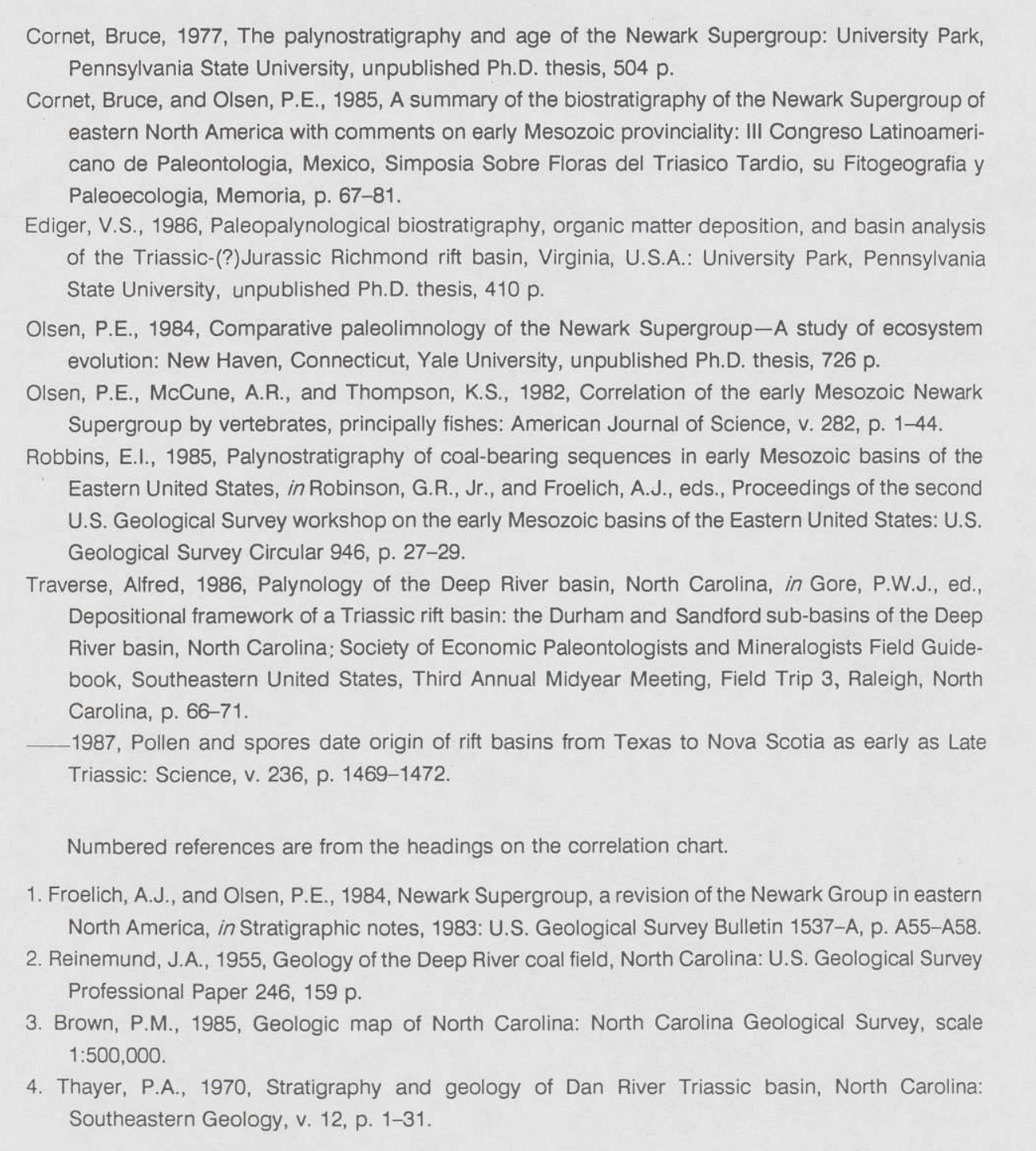




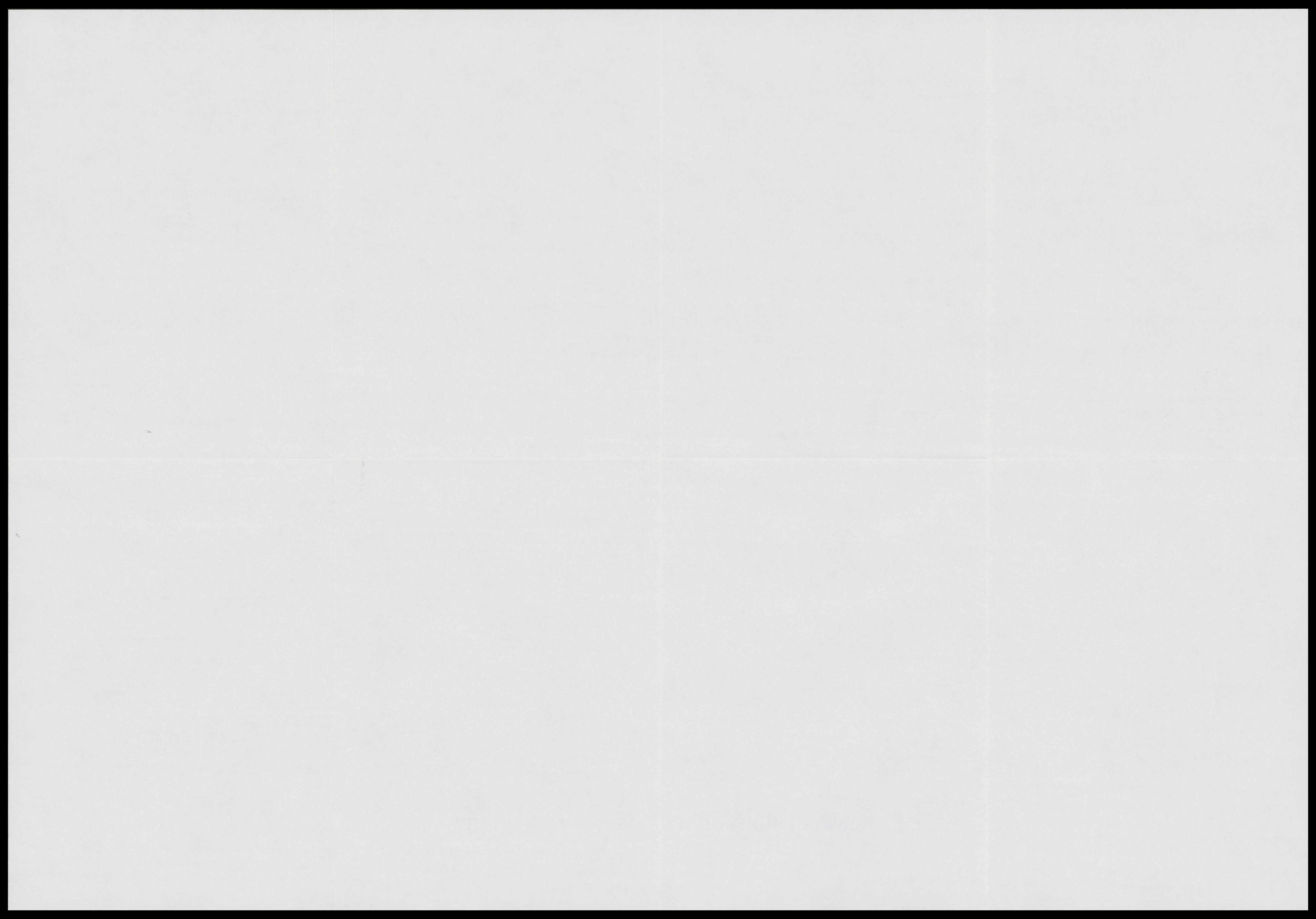

